\title{
Waste Isolation Pilot Plant 2001 Site Environmental Report
}

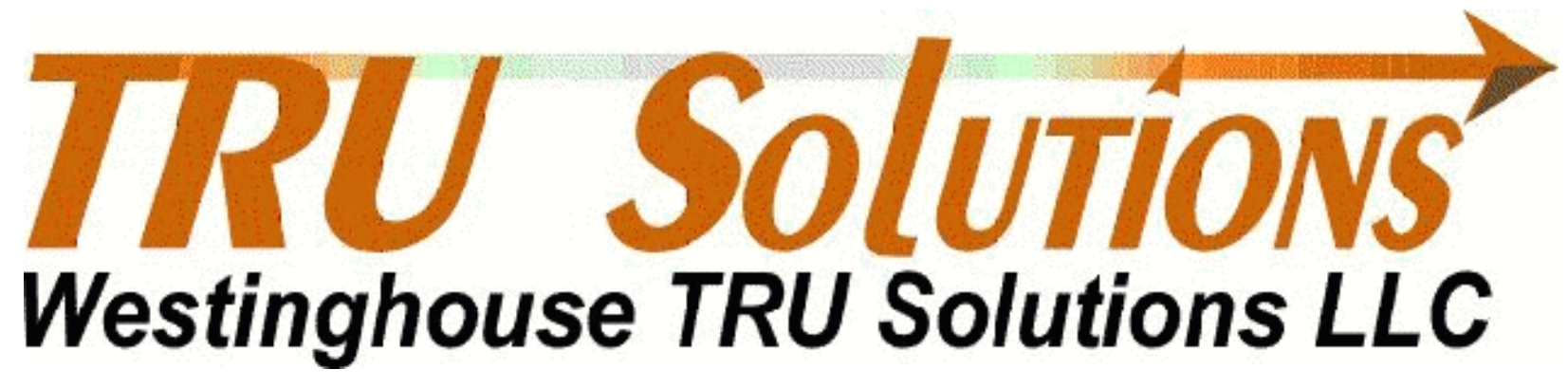


This document has been reproduced directly from the best possible copy. It is available to DOE and DOE contractors from the following address:

Office of Scientific and Technical Information

P.O. Box 62

Oak Ridge, TN 37831

Prices available from (615) 576-8401

Available to the public from the National Technical Information Services

United States Department of Commerce 5285 Port Royal Road Springfield, Virginia 22161

Processing and final preparation of this report was performed by the Waste Isolation Pilot Plant Management and Operating Contractor for the U.S. Department of Energy under Contract No. DE-AC04-01AL66444. 


\section{ACKNOWLEDGMENTS}

We appreciate the reviews by Harold Johnson of the United States Department of Energy Carlsbad Field Office, the Carlsbad Field Office Technical Assistance Contractor, and Candice Jierree, Joe Harvill, Marsha Beekman, and Jeff Knox of Westinghouse TRU Solutions LLC.

Don Gray of the Environmental Evaluation Group provided radiological data for scientific comparisons in advance of releasing the data in their own report.

Many WTS groups contributed to this report, which would not have been complete and accurate without their assistance. Dirk Roberson provided advice and assistance with the color figures and designed the cover. Steve Offner produced the meteorological graphs.

The WTS Laboratory Group: Mansour Akbarzadeh, Okka Maung, Raymond Neuman, Joseph Ortiz, Randy Randolph, Ginny Waymire, Russ Whiteley, and Ying-Hua Xue provided the gross alpha and gross beta results for the ambient air filters.

The Authorization Basis Group: Anne Strait, Koreen Guillermo, Jim Hollen, Patty Hollen, Steve Travis, and Cindy Woodin, was very helpful throughout the writing of this report.

The WTS Radiation Safety and Emergency Management Group: Dave Kump, Marsha Beekman, Ted Sleeman, and Linda Frank-Supka, provided radiological and dosimetry data.

The WTS Environmental Monitoring Group: Stewart Jones, Mel Balderrama, Wes Boatwright, Mark Crawley, Walter Daszczyszak, Bill Foster, Oscar Garcia, Don Gilbert, Jack Hayes, Dave Hughes, Doug Lynn, Morgan Nail, Ron Richardson, Aurelio Rivas, and Roger Simmons collected samples and provided help when needed. Luann Underwood and Mak Walker reviewed and proofread the entire document. Irene Quintana was invaluable compiling all radiological data and was quick to respond to all queries. Wesley Nance edited and coordinated the writing of this report.

Formatting and editing were performed by Vivian Allen of L\&M Technologies, Document Services. 
This page intentionally left blank 


\section{EXECUTIVE SUMMARY}

The United States (U.S.) Department of Energy's (DOE) Carlsbad Field Office (CBFO) and Westinghouse TRU Solutions LLC (WTS) are dedicated to maintaining high quality management of Waste Isolation Pilot Plant (WIPP) environmental resources. DOE Order 5400.1, General Environmental Protection Program, and DOE Order 231.1, Environmental, Safety, and Health Reporting, require that the environment at and near DOE facilities be monitored to ensure the safety and health of the public and the environment. This Waste Isolation Pilot Plant 2001 Site Environmental Report summarizes environmental data from calendar year (CY) 2001 that characterize environmental management performance and demonstrate compliance with federal and state regulations.

This report was prepared in accordance with DOE Order 5400.1, DOE Order 231.1, the Environmental Regulatory Guide for Radiological Effluent Monitoring and Environmental Surveillance (DOE/EH- 0173T), and the Waste Isolation Pilot Plant Environmental Protection Implementation Plan (DOE/WIPP 96-2199). The above Orders and guidance documents require that DOE facilities submit an annual site environmental report to DOE Headquarters, Office of the Assistant Secretary for Environment, Safety, and Health; and the New Mexico Environment Department (NMED). The purpose of this report is to provide a comprehensive description of operational environmental monitoring activities, to provide an abstract of environmental activities conducted to characterize site environmental management performance to confirm compliance with environmental standards and requirements, and to highlight significant programs and efforts of environmental merit at WIPP during CY 2001.

WIPP received its first shipment of waste on March 26, 1999. In 2001, no evidence was found of any adverse effects from WIPP on the surrounding environment.

\section{Introduction}

Located in southeastern New Mexico, WIPP is the world's first underground repository permitted to safely and permanently dispose of transuranic (TRU) radioactive and mixed waste generated through the research and production of nuclear weapons and other activities related to the national defense of the United States. TRU mixed waste is TRU waste mixed with hazardous waste regulated under the Resource Conservation and Recovery Act (RCRA). TRU waste consists of material contaminated with more than $3.7 \times 10^{3} \mathrm{~Bq} / \mathrm{g}$ (becquerels per gram) $(100 \mathrm{nCi} / \mathrm{g})$ of alpha-emitting elements having atomic numbers greater than uranium, the heaviest natural element. Most TRU waste is contaminated industrial trash, such as rags, old tools, sludges from solidified liquids; and glass, metal, and other materials from dismantled buildings.

WIPP's legislative mandate is to demonstrate the safe disposal of TRU wastes from national defense activities and programs. To fulfill this mandate, WIPP has been designed to safely handle, store, and dispose of TRU waste in a fully operational disposal facility. When waste arrives at WIPP, it is placed in excavated storage rooms, carved from rock salt, $655 \mathrm{~m}(2,150 \mathrm{ft})$ below the earth's surface. The nature of the salt 


\section{Waste Isolation Pilot Plant 2001 Site Environmental Report DOE/WIPP 02-2225}

is such that after a storage room has been filled, the salt will slowly fill the remaining spaces, thus isolating the waste for thousands of years.

\section{Environmental Program Information}

It is the DOE's policy to conduct its operations at WIPP in compliance with all applicable environmental laws and regulations, and to safeguard the integrity of the southeastern New Mexico environment. This is accomplished through a comprehensive management system consisting of radiological and nonradiological environmental monitoring, environmental compliance, and land management programs, which include wildlife monitoring and the WIPP Raptor Program (WRP). The purpose of these programs is to obtain land use permits, implement selected compliance functions such as National Environmental Policy Act (NEPA) compliance, collect data needed to detect and quantify possible impacts WIPP may have on the surrounding environment and to provide technical support to the DOE's Carlsbad Field Office in the fields of environmental science and land management.

Environmental activities at WIPP generally fall into four categories: collecting environmental samples and analyzing them for a variety of contaminants, preparing and publishing documents showing compliance with federal and state regulations, evaluating whether WIPP activities cause any environmental impacts, and taking corrective action when an adverse effect on the environment is identified.

The WIPP Environmental Monitoring Plan (EMP) (DOE/WIPP 99-2194) outlines the programs that monitor the environment on, and immediately surrounding, the WIPP site. It discusses major environmental monitoring and surveillance activities at WIPP and WIPP's quality assurance/quality control (QA/QC) program as it relates to environmental monitoring.

WIPP's effluent monitoring and environmental surveillance programs are designed to determine adequate protection of the public and the environment during DOE operations, and to ensure that operations comply with the DOE and other applicable federal and state radiation standards and requirements. The Environmental Monitoring Program monitors the pathways that radionuclides and other contaminants could take to reach the environment surrounding WIPP. Pathways monitored include air, groundwater, surface water, soils, sediments, vegetation, and game animals. Groundwater quality and wildlife populations are also monitored. The goal of the program is to determine if the local ecosystem has been impacted during the predisposal and disposal phases of WIPP, and, if so, to evaluate the severity, geographic extent, and environmental significance of those impacts. The Environmental Monitoring Program is conducted in compliance with DOE Orders 5400.1 and 5400.5.

Southeastern New Mexico is home to an abundant array of wildlife. Wildlife species are monitored on the WIPP site to document any population changes that may occur as a result of WIPP activities. Species of special concern, including federally listed threatened and endangered species, receive special consideration when planning WIPP activities that may impact wildlife habitat. 


\section{Waste Isolation Pilot Plant 2001 Site Environmental Report DOE/WIPP 02-2225}

WIPP's Land Management Plan (LMP) was created in accordance with the WIPP Land Withdrawal Act of 1992. This plan identifies resource values, promotes multiple-use management, and identifies long-term goals for the management of WIPP lands. In accordance with its LMP, WIPP follows a land reclamation program and a long-range reclamation plan. WIPP also conducts oil and gas surveillance in the region surrounding the WIPP site to identify new activities associated with oil and gas exploration and production.

\section{Environmental Compliance}

WIPP is required to comply with applicable federal and state laws and DOE Orders.

\section{Comprehensive Environmental Response, Compensation, and Liability Act}

The Comprehensive Environmental Response, Compensation, and Liability Act (CERCLA) (42 U.S.C. 9601 et seq) establishes a comprehensive federal strategy for responding to, and establishing liability for, releases of hazardous substances from a facility to the environment. Through December 2001, no release sites have been identified at WIPP that would require cleanup under provisions of CERCLA.

WIPP submitted the Annual Tier II Emergency and Hazardous Chemical inventory form, required by the Superfund Amendments and Reauthorization Act, on February 22, 2002. The Tier II is submitted to the State Emergency Response Commission (SERC), the Local Emergency Planning Committee (LEPC), and the fire departments with which the CBFO maintains a Memorandum of Understanding (MOU).

\section{Federal Acquisition, Recycling, and Pollution Prevention}

In 1995, WIPP adopted a systematic and cost-effective affirmative procurement plan (APP) for the promotion and procurement of products containing recovered materials. Affirmative procurement is designed to "close the loop" in the waste minimization recycling process by supporting the market for materials collected through recycling and salvage operations.

WIPP continued its recycling program in 2001. Noteworthy pollution prevention (P2) activities completed:

- $\quad$ Chemical Use Reduction

- $\quad$ Reduction of Office Supplies

- Improvements in the Recycling Center 


\section{Resource Conservation and Recovery Act}

The RCRA ensures that hazardous wastes are managed from the point of generation through ultimate disposal in a manner that is protective of human health and the environment. The state of New Mexico is authorized by U.S. Environmental Protection Agency (EPA) to implement the provisions of the RCRA in accordance with the New Mexico Hazardous Waste Act. WIPP has a Hazardous Waste Facility Permit (HWFP) from the NMED in accordance with 20.4.1.500 NMAC [New Mexico Administrative Code] and 20.4.1.900 NMAC. The HWFP authorizes the storage of contact-handled $(\mathrm{CH})$ TRU waste in two locations (the Parking Area Unit and Waste Handling Building) and the disposal of $\mathrm{CH}$ TRU waste in the three underground Hazardous Waste Disposal Units.

\section{National Environmental Policy Act}

The NEPA requires the federal government to use all practicable means to consider potential environmental impacts of proposed federal projects as part of the decision-making process. The NEPA dictates the public shall be allowed to review and comment on proposed projects that have the potential to significantly affect the environment. The NEPA also directs the federal government to use all practicable means to improve and coordinate federal plans, functions, programs, and resources relating to human health and the environment.

Title 10 Code of Federal Regulations (CFR) §1021.331 requires, following completion of each Environmental Impact Statement (EIS) and its associated Record of Decision (ROD), that the DOE prepare a mitigation action plan addressing mitigation commitments expressed in the ROD. DOE Order 451.1B requires DOE facilities to track and annually report progress in implementing a commitment for environmental impact mitigation. To fulfill this DOE Order requirement, the CBFO issued the 2001 Annual Mitigation Report for the Waste Isolation Pilot Plant on July 2001.

\section{Clean Air Act}

The Clean Air Act provides for the preservation, protection, and enhancement of air quality. Under Section 109 of the Clean Air Act, the EPA established the National Ambient Air Quality Standards for six "criteria" pollutants. The initial WIPP emissions inventory was developed as a baseline document to calculate maximum potential hourly and annual emissions of both hazardous and criteria pollutants. The air emissions inventory is conducted biennially and compared to baseline data to identify trends and potential emissions problems. The biennial inventory scheduled for CY 1998 was postponed because conditions at the site were unchanged from the previous inventory. The air emissions inventory for CY 1999 was conducted in 2000. Based on the 1999 air emissions inventory, WIPP operations do not exceed the 10-ton-per-year emission limit for any individual pollutant or the 25 -ton-per-year limit for any combination of pollutants.

Based on emission estimates generated in the air emissions inventory, the WIPP site is not required to obtain federal Clean Air Act permits. 
WIPP was required to obtain a New Mexico Air Quality Construction Permit for two primary backup diesel generators. During 2001, the generators were operated for approximately 28 of the 480 hours allowed by the permit. There were no malfunctions or abnormal conditions of operations that would cause a violation of the permit.

\section{Clean Water Act}

Section 402 of the Clean Water Act established provisions for the issuance of permits for discharges into waters of the United States. WIPP has no pollutant discharges from point sources and is currently exempt from obtaining a National Pollutant Discharge Elimination System (NPDES) permit.

A permit for Storm Water Discharge Associated with Industrial Activity was issued in 1998. No sampling is required to demonstrate compliance with this permit unless a release occurs. Operational permit compliance activities are limited to quarterly inspections of retention basins, spill containment devices, reclamations sites, and site housekeeping practices.

Quarterly discharge monitoring reports are submitted to the NMED to demonstrate compliance with inspection, monitoring, and reporting requirements as identified in the WIPP Discharge Plan (DP-831) issued by the NMED. Refer to Section 3.2.6 for detailed information.

\section{Safe Drinking Water Act}

The Safe Drinking Water Act of 1974 (SDWA) provides the regulatory strategy for protecting public water supply systems and sources of drinking water. The WIPP water supply is categorized as a nontransient, noncommunity system for reporting and testing requirements. The water supply is sampled ten times every three years for various chemical constituents. Samples were collected in July 2001, and the results were submitted to the NMED. All samples were below action levels as specified by New Mexico monitoring requirements for lead and copper in tap water. The next lead and copper sampling period will be July 2004. Bacterial samples were collected and reported monthly throughout 2001 . All results were below SDWA regulatory limits.

\section{National Historic Preservation Act}

The National Historic Preservation Act (NHPA) was enacted to protect the nation's cultural resources and establish the National Register of Historic Places. Federal agencies are required to ensure that historic and cultural properties are given proper consideration in the preparation of NEPA-related documents. No new archeological sites were discovered in 2001. 


\section{Hazardous Materials Transportation Act}

The Hazardous Materials Transportation Act is one of the major transportation-related statutes that affects WIPP operations. It provides for the safe transportation of hazardous materials, including radioactive materials. DOE Orders establish packaging and transportation criteria and require DOE field offices to conduct their operations in accordance with all applicable international, federal, state, local, and tribal laws, rules, and regulations governing materials transportation. These DOE Orders also require the development of a transportation plan and use of the DOE TRANSCOM (transportation and tracking communications) system to monitor shipments.

\section{Packaging and Transporting Radioactive Materials}

The WIPP Land Withdrawal Act requires TRU waste containers destined for WIPP to be shipped using specification packagings certified by the Nuclear Regulatory Commission (NRC). Certified shipping containers tor TRU waste satisfy NRC QA requirements. Contact-handled TRU waste will be shipped in TRUPACT-II (Transuranic Package Transporter Model II) and HalfPACT (short Transuranic Package Transporter) containers. Containers for remote-handled waste were certified in 2001.

\section{Environmental Compliance Assessment Program}

The Environmental Compliance Assessment Program plays a major role in the overall program for environmental protection activities at WIPP. The program was developed to determine if facility activities protect human health and the environment and if these activities are in compliance with applicable federal, state, and local requirements; with permit conditions and requirements; and with best management practices. During 2001, WTS environmental compliance assessments identified and implemented a number of improvements.

\section{Environmental Management System}

The WTS Environmental Management System (EMS) received International Organization for Standardization (ISO) 14001 third-party registration on August 5, 1997. Two third-party surveillance audits were conducted in 2001. No nonconformance or findings were identified during the 2001 surveillance period. The EMS registrar recommended continued registration of the WTS EMS.

\section{Pollution Prevention Committee}

WIPP's P2 Committee was formed in 1993. The primary purpose of this committee is to foster recycling activities at WIPP. The committee sponsored activities to raise employee awareness of waste minimization on Earth Day, National America Recycles Day, and during Energy Month (October). 


\section{Environmental Training}

Environmental training was provided to personnel associated with environmental operations at WIPP. The WIPP training program has been designed to ensure that personnel performing work are capable of performing their assigned task proficiently. Personnel who perform work that requires special skills or abilities are required to meet the qualification requirements for that specific task unless directly supervised by a qualified person. The WTS Technical Training Section maintains a total of fifteen qualification cards, which are reviewed and updated biennially. This insures that proper adequate training is performed regularly.

\section{Environmental Radiological Program Information}

Radionuclides present in the environment, whether naturally-occurring or from human-made sources, contribute to radiation doses to humans. Therefore, environmental monitoring around nuclear facilities is imperative for characterizing radiological conditions, and for detecting releases and determining their effects, should they occur. The WIPP Environmental Monitoring Program monitors air, surface and groundwater, soils, and biota to characterize the radiation environment and to detect potential releases from WIPP activities. Plutonium-238, ${ }^{239+240} \mathrm{Pu},{ }^{241} \mathrm{Am},{ }^{60} \mathrm{Co},{ }^{90} \mathrm{Sr}$, ${ }^{137} \mathrm{Cs},{ }^{234} \mathrm{U},{ }^{235} \mathrm{U}$, and ${ }^{238} \mathrm{U}$ are monitored because they are components of TRU waste. Potassium- 40 is monitored because of possible enhancement in southeastern New Mexico due to potash mining.

\section{Effluent Monitoring}

If radionuclides are released into the environment from WIPP, they would first be detected in airborne effluents. Therefore, WIPP monitors airborne effluents from the facility at three locations. Station A samples unfiltered underground exhaust air, Station $B$ samples unfiltered underground exhaust air in maintenance mode and high efficiency particulate air (HEPA) filtered exhaust air in filtration mode, and Station C samples HEPA filtered air from the Waste Handling Building. Samples were composited monthly or quarterly, in accordance with the Periodic Confirmatory Measurement Protocol for the Waste Isolation Pilot Plant, and analyzed for ${ }^{241} \mathrm{Am},{ }^{238} \mathrm{Pu}$, and ${ }^{239+240} \mathrm{Pu}$.

\section{Airborne Gross Alpha/Beta}

Gross alpha and beta measurements in airborne particulates are used as screening techniques to provide timely information on levels of radioactivity in the environment around the WIPP site. Airborne particulate samples were collected from seven locations around WIPP on a weekly basis. Analysis of Variance (ANOVA) indicated no statistically significant differences between sampling years 2000 and 2001. 


\section{Airborne Particulates}

Inhalation of dust particles is the major pathway for the intake of plutonium. Accordingly, plutonium and other radionuclides of interest were determined in air particulate samples around WIPP. There were no statistically significant differences between sampling years 2000 and 2001 for the concentration of any radionuclide in composite air filters.

\section{Groundwater}

Groundwater samples, collected twice in 2001 from seven wells around WIPP, were analyzed for gamma-emitting radionuclides, ${ }^{90} \mathrm{Sr}$, and isotopes of uranium, plutonium, and americium. Isotopes of naturally-occurring uranium were detected in every well. The results for the concentrations of uranium isotopes in water samples collected in 2001 were compared with the results from 2000 . There was a notable difference in concentrations of uranium isotopes between groundwater samples collected in 2000 and 2001 because of the laboratory's analytical method and counting duration.

\section{Surface Water}

Surface water samples were collected once from each of ten locations around WIPP in 2001. There were no significant differences in concentration of uranium isotopes between years. Large spatial variations in uranium concentrations in surface water are expected because of the different characteristics of the water bodies and the underlying sediments.

\section{Soil Samples}

Soil samples were collected from six locations surrounding WIPP. Samples from each location were collected at three different depths. Measurements of radionuclides in depth profiles provide information about their vertical movements in soil systems. There were no statistically significant differences between sampling years for the concentration of any radionuclide.

\section{Sediments}

Sediment samples were collected from 12 locations around the WIPP site, mostly from the same water bodies from which the surface water samples were collected. There were no statistically significant differences between sampling years 2000 and 2001 for the concentration of any radionuclide.

\section{Biota}

The concentration of radionuclides in plants is an important factor in estimating the intake of individual radionuclides by humans through ingestion. Therefore, rangeland vegetation samples were collected from the same six locations where soil samples were collected. Also collected were muscle tissues from three road-killed deer, two quail, and 
one rabbit; species commonly consumed by humans. Fish samples were taken from three different locations on the Pecos River. The whole fish and the muscle tissue from the deer, quail, and rabbit were analyzed for radionuclides (see Section 4.8).

\section{Environmental Nonradiological Program Information}

Nonradiological environmental surveillance programs at WIPP include land management programs (including reclamation of disturbed lands, oil and gas surveillance, and wildlife population monitoring) and meteorological monitoring. In addition to nonradiological environmental surveillance programs, volatile organic compounds (VOCs) were monitored to comply with provisions of WIPP's HWFP, and liquid effluent monitoring was conducted in accordance to WIPP Discharge Plan criteria.

\section{WIPP Raptor Program}

The WRP was established in the early 1990s to monitor and protect raptors on the WIPP site, and to educate site workers and the public about these birds. The program presently serves four functions: wildlife monitoring, scientific research, community outreach, and interagency cooperation.

\section{Meteorology}

The main function of the WIPP meteorological station is to provide data for atmospheric dispersion modeling. The station measures and records wind speed, wind direction, and temperature at elevations of 2,10 , and $50 \mathrm{~m}(6.5,33$, and $165 \mathrm{ft})$. The station records ground-level measurements of barometric pressure, relative humidity, precipitation, and solar radiation.

\section{Volatile Organic Compound Monitoring}

The VOC monitoring program is designed to measure VOC concentrations attributable to hazardous waste disposal units (panels), which are either open and are in the process of being filled or which are full and have been closed. This Confirmatory VOC Monitoring Program was implemented as a requirement of the HWFP, Module IV, Section D and Attachment N, and is intended to demonstrate that regulated VOCs are not being emitted by the waste at concentrations in excess of concentrations of concern (see Table 5.7) as prescribed in the permit.

\section{Seismic Activity}

Currently, seismicity within $300 \mathrm{~km}$ (186 mi) of the WIPP site is being monitored by the New Mexico Institute of Mining and Technology (NMIMT), in Socorro, New Mexico, using data from a seven-station network approximately centered on the site (Figure 5.8). Station signals are transmitted to the NMIMT Seismological Observatory in Socorro. When appropriate, readings from the WIPP network stations are combined with readings from an additional NMIMT network in the central Rio Grande Rift. 
Occasionally, data are also exchanged with the University of Texas at El Paso and Texas Tech University in Lubbock, both of which operate stations in west Texas.

\section{Liquid Effluent Monitoring}

The WIPP sewage lagoon system is a zero-discharge facility. The entire facility is lined with 30-mil synthetic liners and is designed to dispose of domestic sewage as well as site-generated brine waters. The facility is operated under the conditions of DP-831, and is managed in accordance with EPA sewage sludge regulations, New Mexico Water Quality Control Regulations, and applicable WIPP controlled procedures.

\section{Groundwater Monitoring}

Current groundwater monitoring activities at WIPP are outlined in the WIPP Groundwater Monitoring Program Plan. Data obtained by the WIPP Groundwater Monitoring Program supports two major programs at WIPP: (1) the RCRA Detection Monitoring Program, and (2) performance assessments supporting the Compliance Certification Application.

Groundwater monitoring activities during 2001 included groundwater quality sampling and groundwater level monitoring. Groundwater quality data were gathered from six wells in the Culebra member of the Rustler Formation and one well in the Dewey Lake Formation.

\section{Radiological Dose Assessment}

The potential radiation dose to members of the public from WIPP operations was calculated to demonstrate compliance with federal regulations and the DOE's policies and objectives of keeping this dose as low as possible.

\section{Dose Limits}

For more than 50 years, extensive research has been conducted on the effects of radiation on humans and the environment. Much of this research used standard epidemiological and toxicological approaches to characterize the response of populations and individuals to high radiation doses. From this, a good understanding of the risks associated with high radiation doses was achieved. However, there is still uncertainty as to what risks are incurred from low radiation dose and dose rates, so models are used to predict these risks.

\section{Background Radiation}

Radiation is a naturally-occurring phenomenon that has been in the environment since the beginning of time. There are several sources of natural radiation: cosmic and cosmogenic radiation (from outer space and the earth's atmosphere), terrestrial radiation (from the earth's crust), and internal radiation (naturally-occurring radiation in our bodies). In addition to natural radioactivity, small amounts of radioactivity from the 


\section{Waste Isolation Pilot Plant 2001 Site Environmental Report DOE/WIPP 02-2225}

1986 Chernobyl nuclear accident and above-ground nuclear weapons tests that occurred from 1945 to 1980 are also present in the environment. Together, these sources of radiation are called "background" radiation. Every human is constantly exposed to background radiation. Exposure to radioactivity from weapons testing fallout is quite small compared to natural radioactivity and continually gets smaller as radionuclides decay. The average annual dose received by a member of the public from naturally-occurring radionuclides is about $3 \mathrm{mSv}$ (millisievert) (300 mrem) (NCRP [National Council on Radiation Protection and Measurements], 1987).

\section{Dose from Air Emissions}

The National Emission Standards for Hazardous Air Pollutants (NESHAP) issued by the EPA set limits for doses due to radionuclide emissions to air. To determine the potential radiation dose received by members of the public from WIPP, WTS used the computer model CAP88-PC, version 2.0. CAP88 dose calculations are based on the assumption that exposed persons remain at home during the entire year and all vegetables, milk, and meat consumed are home produced. Thus, this dose calculation is a maximum potential dose which encompasses dose from inhalation, plume submersion, deposition, and ingestion of air emitted radionuclides.

\section{Total Potential Dose from WIPP Operations}

The potential dose to an individual from the ingestion of WIPP-related radionuclides transported in water is estimated to be nonexistent. Drinking water for communities near WIPP comes from groundwater sources which are too far away to be affected by potential WIPP contaminants. Groundwater and surface water samples collected around WIPP during 2001 did not contain radionuclide concentrations different from those in samples collected prior to WIPP receiving waste.

Game animals sampled during 2001 were mule deer, quail, fish, and rabbit. The only radionuclides detected, were not different from background levels measured prior to commencement of waste shipments to WIPP. Therefore, no dose from WIPP related radionuclides is estimated to have been received by any individual from this pathway during 2001.

The only pathway for which a dose could be estimated was that of air emissions. Air emissions from WIPP were not considered above background ambient air levels. Estimated concentrations of radionuclides in air emissions accounted for the calculable dose from WIPP operations during 2001.

\section{Dose to Nonhuman Biota}

DOE Order 5400.5 lists the environmental radiation protection requirements that WIPP must meet to protect aquatic animals. In addition, dose limits below which no deleterious effects on populations of aquatic and terrestrial organisms have been observed, have been discussed by the National Council on Radiation Protection and 
Measurements and the International Atomic Energy Agency. Those absorbed dose limits are:

- $\quad$ Aquatic Animals $10 \mathrm{mGy} / \mathrm{d}(1 \mathrm{rad} / \mathrm{d})$

- Terrestrial Plants $10 \mathrm{mGy} / \mathrm{d}(1 \mathrm{rad} / \mathrm{d})$

- $\quad$ Terrestrial Animals $1 \mathrm{mGy} / \mathrm{d}(0.1 \mathrm{rad} / \mathrm{d})$

The DOE requires discussion of radiation doses to non-human biota in the Annual Site Environmental Report using the DOE Interim Technical Standard, DOE-STD-XXXX-YR, A Graded Approach for Evaluating Radiation Doses to Aquatic and Terrestrial Biota. The Interim Technical Standard uses a multiphase approach, including an initial screening phase with conservative assumptions.

This guidance was used to screen radionuclide concentrations observed around WIPP during 2001. The sum of fractions was less than one for all media, demonstrating compliance with the proposed rule. Radiation in the environment surrounding WIPP does not have a deleterious effect on populations of plants and animals.

\section{Quality Assurance}

The fundamental objective of a QA program is to ensure high-quality measurements are produced and reported from the analytical laboratory. The defensibility of data generated by laboratories must be based on sound scientific principles, method evaluations, and data verification and validation. Wastren, of Grand Junction, Colorado; Air Toxics, Ltd. of Folsom, California; and Trace Analysis, of Lubbock, Texas, were the contract laboratories that performed the radiological and nonradiological analyses for WIPP environmental samples. WIPP Laboratories performed the radiological analyses on the environmental monitoring samples.

WTS performed assessments and audits to ensure that the quality of the systems, processes, and deliverables was maintained or improved in 2001. 


\section{TABLE OF CONTENTS}

ACKNOWLEDGMENTS $\ldots \ldots \ldots \ldots \ldots \ldots \ldots \ldots \ldots \ldots \ldots \ldots \ldots \ldots \ldots \ldots$ iii

EXECUTIVE SUMMARY $\ldots \ldots \ldots \ldots \ldots \ldots \ldots \ldots \ldots \ldots \ldots \ldots \ldots$

LIST OF TABLES $\ldots \ldots \ldots \ldots \ldots \ldots \ldots \ldots \ldots \ldots \ldots \ldots \ldots \ldots \ldots \ldots \ldots \ldots \ldots$

LIST OF FIGURES $\ldots \ldots \ldots \ldots \ldots \ldots \ldots \ldots \ldots \ldots \ldots \ldots \ldots \ldots \ldots \ldots$

CHAPTER 1 - INTRODUCTION $\ldots \ldots \ldots \ldots \ldots \ldots \ldots \ldots \ldots \ldots \ldots \ldots \ldots \ldots \ldots \ldots$

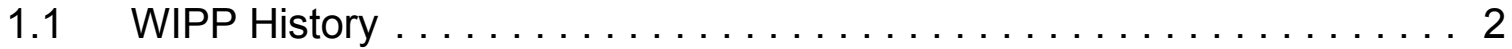

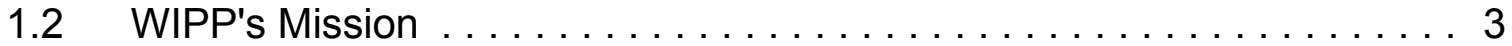

$1.3 \quad$ WIPP Location $\ldots \ldots \ldots \ldots \ldots \ldots \ldots \ldots \ldots \ldots \ldots \ldots$

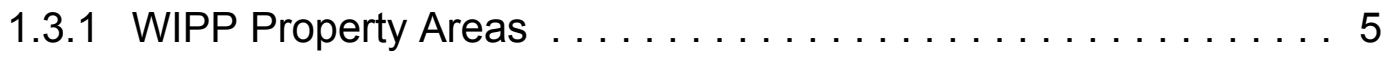

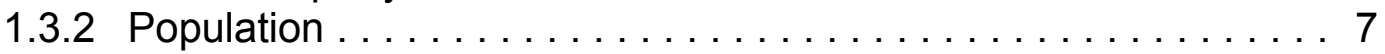

1.4 Environmental Performance $\ldots \ldots \ldots \ldots \ldots \ldots \ldots \ldots \ldots \ldots$

CHAPTER 2 - ENVIRONMENTAL PROGRAM INFORMATION ........... 9

$2.1 \quad$ Environmental Monitoring Plan $\ldots \ldots \ldots \ldots \ldots \ldots \ldots \ldots$

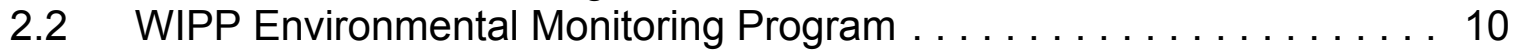

2.3 Land Management Programs $\ldots \ldots \ldots \ldots \ldots \ldots \ldots \ldots \ldots \ldots \ldots \ldots$

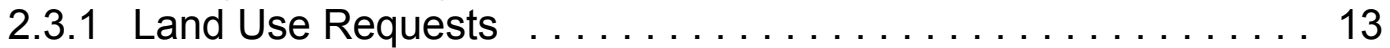

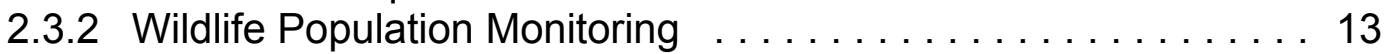

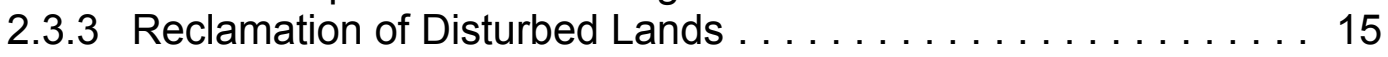

2.3.4 Oil and Gas Surveillance $\ldots \ldots \ldots \ldots \ldots \ldots \ldots \ldots$

CHAPTER 3 - COMPLIANCE SUMMARY . . . . . . . . . . . . . . . . . 19

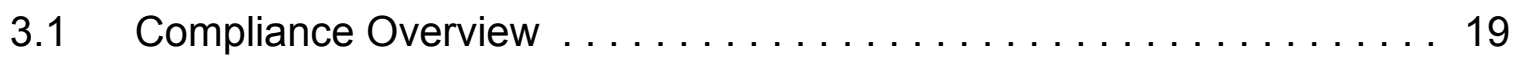

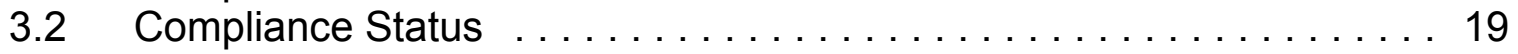

3.2.1 Comprehensive Environmental Response, Compensation, and Liability Act . .................... 19

3.2.2 Federal Acquisition, Recycling, and Pollution Prevention . . . . 20

3.2.3 Resource Conservation and Recovery Act . . . . . . . . . . 22

3.2.4 National Environmental Policy Act $\ldots \ldots \ldots \ldots \ldots \ldots \ldots .26$

3.2 .5 Clean Air Act . . . . . . . . . . . . . . . . . . . . . . . 26

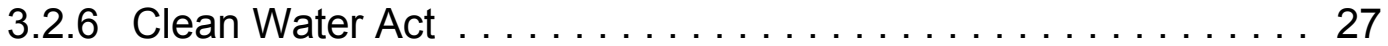

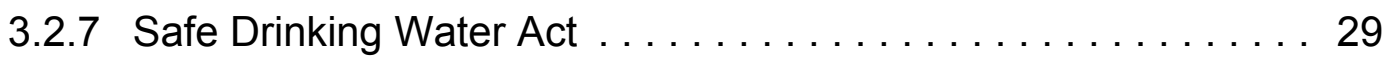

3.2.8 National Historic Preservation Act . . . . . . . . . . . . . 29

3.2.9 Hazardous Materials Transportation Act . . . . . . . . . 30

3.2.10 Packaging and Transporting Radioactive Materials ........ 30

3.3 Other Significant Accomplishments and Ongoing Compliance Activities ......................... 32

3.3.1 Environmental Compliance Assessment Program . . . . . . . 32

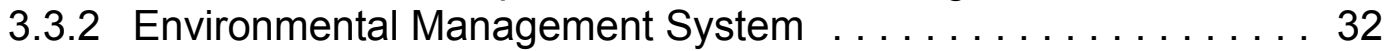

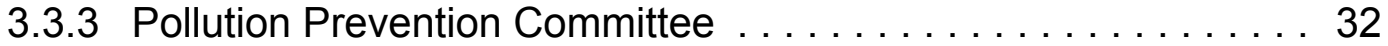

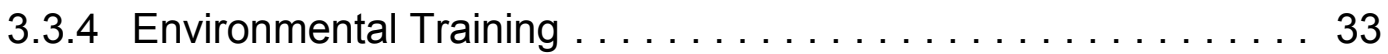


CHAPTER 4 - ENVIRONMENTAL RADIOLOGICAL PROGRAM INFORMATION . . 47

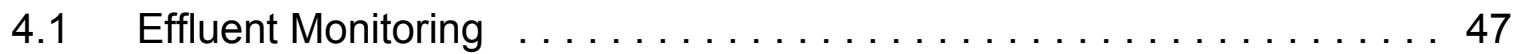

4.2 Airborne Gross Alpha/Beta . . . . . . . . . . . . . . . . . . . . 49

4.3 Airborne Particulates . . . . . . . . . . . . . . . . . 54

4.3.1 Sample Preparation ... . . . . . . . . . . . . . . . 54

4.3.2 Determination of Individual Radionuclides . . . . . . . . . . 55

4.3 .3 Results and Discussions . . . . . . . . . . . . . . . . 55

4.4 Groundwater ... . . . . . . . . . . . . . . . . . . . . . . . 60

4.4.1 Sample Collection . . . . . . . . . . . . . . . . . . 60

4.4.2 Determination of Individual Radionuclides . . . . . . . . . . 60

4.4 .3 Results and Discussions . . . . . . . . . . . . . . . . 60

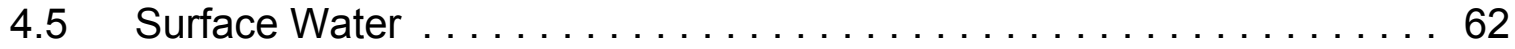

4.5 .1 Sample Collection . . . . . . . . . . . . . . . . . . 62

4.5.2 Determination of Individual Radionuclides . . . . . . . . . . . 63

4.5 .3 Results and Discussions . . . . . . . . . . . . . . . . . . . 64

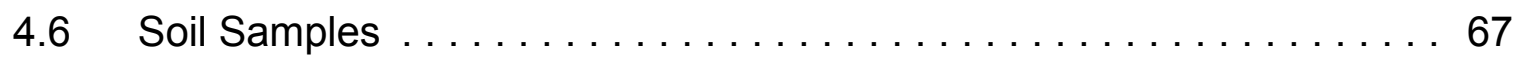

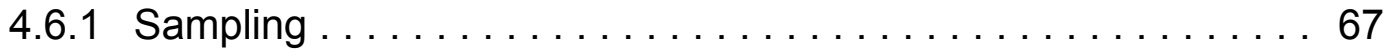

4.6 .2 Sample Preparation ... . . . . . . . . . . . . . . 67

4.6.3 Determination of Individual Radionuclides . . . . . . . . . . 67

4.6 .4 Results and Discussions . . . . . . . . . . . . . . . . 68

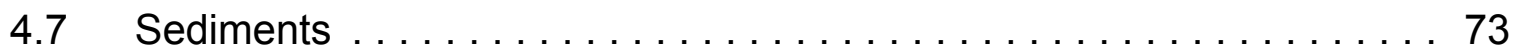

4.7 .1 Sample Collection . . . . . . . . . . . . . . . . . . 73

4.7 .2 Sample Preparation . . . . . . . . . . . . . . . . . 74

4.7.3 Determination of Individual Radionuclides . . . . . . . . . . . 74

4.7 .4 Results and Discussions . . . . . . . . . . . . . . . 74

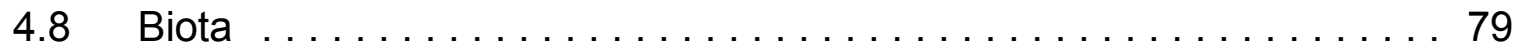

4.8 .1 Sample Collection . . . . . . . . . . . . . . . . . . . 79

4.8 .2 Sample Preparation . . . . . . . . . . . . . . . . . . . 79

4.8 .3 Results and Discussions . . . . . . . . . . . . . . . . . 79

4.9 Summary and Conclusion . . . . . . . . . . . . . . 82

CHAPTER 5 - ENVIRONMENTAL NONRADIOLOGICAL PROGRAM

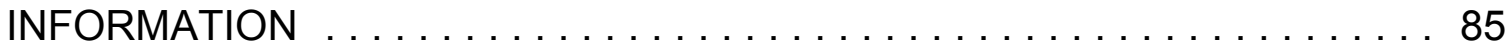

5.1 Principal Functions of Nonradiological Sampling . . . . . . . . . 85

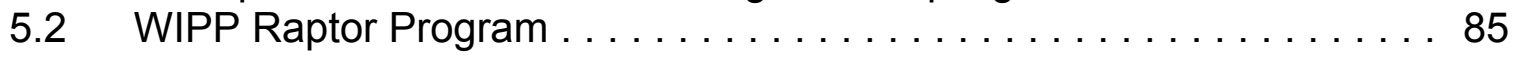

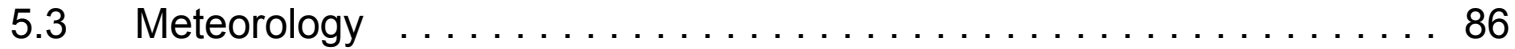

5.3 .1 Climatic Data . . . . . . . . . . . . . . . . . . 87

5.3 .2 Wind Direction and Wind Speed . . . . . . . . . . . . . . . 87

5.4 Volatile Organic Compound Monitoring . . . . . . . . . . . . . 87

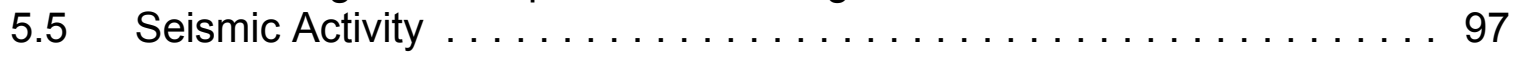

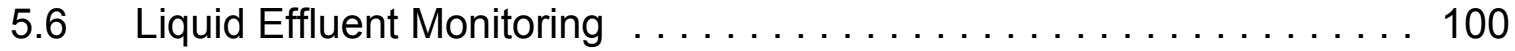

CHAPTER 6 - GROUNDWATER MONITORING . . . . . . . . . . . . . . . . . . 101

6.1 Groundwater Quality Sampling . . . . . . . . . . . . . . . . . . . . . . . . . . . . . . . . . . . . . . . . .

6.2 Groundwater Level Surveillance . . . . . . . . . . . . . . . . . . . 106

6.3 Well Maintenance Activities . . . . . . . . . . . . . . . . . 108 


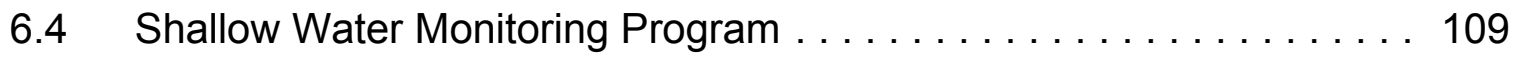

6.4 .1 Groundwater Quality Sampling . . . . . . . . . . . . . . . 109

6.4.2 Shallow Water Level Surveillance .................. 109

CHAPTER 7 - RADIOLOGICAL DOSE ASSESSMENT . . . . . . . . . . . 153

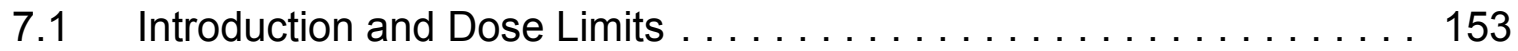

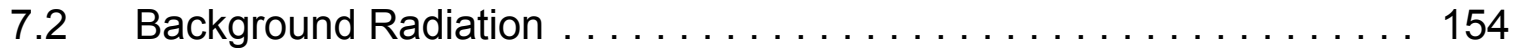

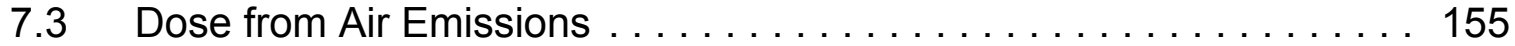

7.4 Total Potential Dose from WIPP Operations . . . . . . . . . . 155

7.4.1 Potential Dose from Water Ingestion Pathway . . . . . . . 156

7.4.2 Potential Dose from Wild Game Ingestion ........... 156

7.4.3 Total Potential Dose from All Pathways . . . . . . . . . . . 156

7.5 Dose to Nonhuman Biota $\ldots \ldots \ldots \ldots \ldots \ldots \ldots \ldots \ldots \ldots$

CHAPTER 8 - QUALITY ASSURANCE . . . . . . . . . . . . . . . . . 159

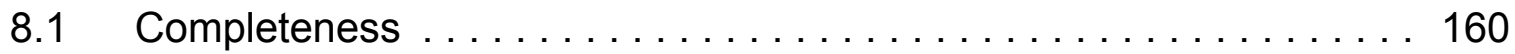

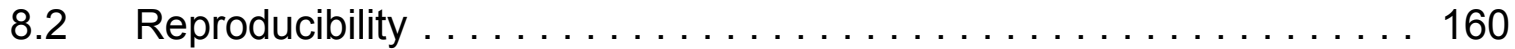

$8.3 \quad$ Accuracy and Comparability . . . . . . . . . . . . . . 161

8.4 Representativeness ......................... 163 
This page intentionally left blank 


\section{LIST OF TABLES}

Table 2.1 The Environmental Monitoring Plan Outlines the Sampling Schedule

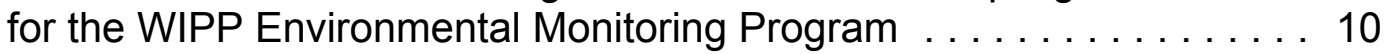

Table $3.1 \quad$ Materials Recycled at WIPP in $2001 \ldots \ldots \ldots \ldots \ldots \ldots \ldots \ldots \ldots$

Table 3.2 WIPP's Key RCRA ${ }^{a}$ Permit Deliverables and Due Dates $\ldots \ldots \ldots .25$

Table 3.3 Activities Associated with Major Environmental Regulations

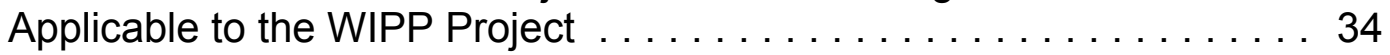

Table 3.4 Primary DOE Orders Affecting the WIPP Environmental Program . . . 36

Table 3.5 Active Environmental Permits and Approvals for the Waste Isolation

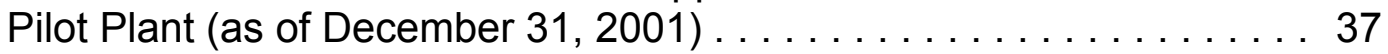

Table 4.1 Activity (Bq) of Quarterly Composite Air Samples from Effluent Monitoring Stations A, B, and C ................ 50

Table 4.2 Annual Mean Gross Alpha and Gross Beta Activity Concentrations $\left(\mathrm{Bq} / \mathrm{m}^{3}\right)$ Found in Weekly Air Particulate Samples .......... 53

Table 4.3 Minimum, Maximum and Average Radionuclide Concentrations $\left(\mathrm{Bq} / \mathrm{m}^{3}\right)$ in Air Filter Composites from Stations Surrounding the WIPP Site

Table 4.4 Results of Duplicate Composite Air Filter Sampling . . . . . . . . . 59

Table 4.5 Preliminary Quarterly Average Radionuclide Concentrations $\left(\mathrm{Bq} / \mathrm{m}^{3}\right)$ Measured in Air Particulate Samples by the Environmental Evaluation Group in $2001 \ldots \ldots \ldots \ldots$. . . . . . . . . . . . . 60

Table 4.6 Average Annual Radionuclide Concentrations (Bq/l) in Groundwater from Wells at the WIPP Site

Table 4.7 Uranium Concentrations $(\mathrm{Bq} / \mathrm{l})$ in Surface Water Near the WIPP Site

Table 4.8 Americium and Plutonium Concentrations $(\mathrm{Bq} / \mathrm{l})$ in Surface Water Near the WIPP Site

Table 4.9 Selected Radionuclide Concentrations $(\mathrm{Bq} / \mathrm{l})$ in Surface Water near the WIPP Site 66

Table 4.10 Results of Duplicate Surface Water Sample Analysis 67 
Table 4.11 Uranium Concentrations $(\mathrm{Bq} / \mathrm{g})$ in Soil Near the WIPP Site . . . . . . 69

Table 4.12 Americium and Plutonium Concentrations (Bq/g) in Soil Near the WIPP Site ......................... 70

Table 4.13 Selected Radionuclide Concentrations $(\mathrm{Bq} / \mathrm{g})$ in Soil Near the WIPP Site

Table 4.14 Results of Duplicate Soil Sample Analysis $\ldots \ldots \ldots \ldots \ldots \ldots$

Table 4.15 Uranium Concentrations (Bq/g) in Sediment Near the WIPP Site . . . . 75

Table 4.16 Americium and Plutonium Concentrations $(\mathrm{Bq} / \mathrm{g})$ in Sediment Near the WIPP Site . . . . . . . . . . . . . . . . . . 76

Table 4.17 Selected Radionuclide Concentrations $(\mathrm{Bq} / \mathrm{g})$ in Sediment Near the

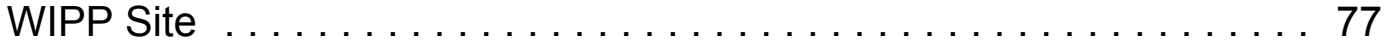

Table 4.18 Results of Duplicate Sediment Sample Analysis . . . . . . . . . . . 78

Table 4.19 Radionuclide Concentrations (Bq/g Wet Mass) in Vegetation Near

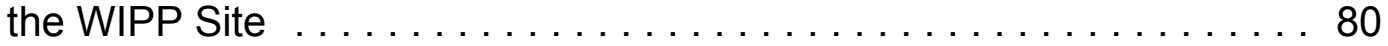

Table 4.20 Results of Duplicate Vegetation Sample Analysis . . . . . . . . . . . 81

Table 4.21 Radionuclide Concentrations (Bq/g Wet Mass) in Deer and Quail Near the WIPP Site . . . . . . . . . . . . . . . . . . . 81

Table 4.22 Radionuclide Concentrations (Bq/g Wet Mass) in Fish Near the WIPP Site

Table 5.1 A Summary of 2001 Temperature Observations at 2-Meter Height _. . 89

Table 5.2 A Summary of 2001 Temperature Observations at 10-Meter Height . . 90

Table 5.3 A Summary of 2001 Temperature Observations at 50-Meter Height . . 91

Table 5.4 2001 Wind Frequencies at 2-Meter Height, Stratified by Direction and Speed $(\%) \ldots \ldots \ldots \ldots \ldots \ldots \ldots \ldots \ldots \ldots \ldots \ldots \ldots \ldots \ldots \ldots$

Table 5.5 2001 Wind Frequencies at 10-Meter Height, Stratified by Direction

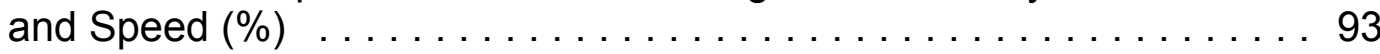

Table 5.6 2001 Wind Frequencies at 50-Meter Height, Stratified by Direction

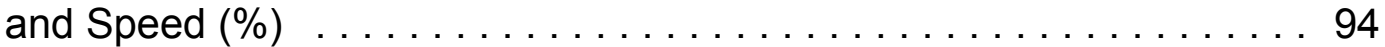


Table 5.7 Concentrations of Concern for Volatile Organic Compounds, from Attachment $\mathrm{N}$ of the HWFP . . . . . . . . . . . . . . . 95

Table 5.8 Volatile Organic Compound Sample Pair Differences Measured at

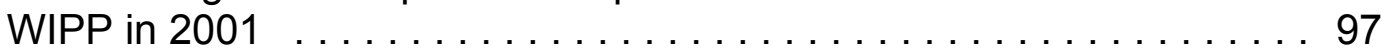

Table 6.1 Analytical Parameters for Which Groundwater Was Analyzed . . . . 105

Table 6.2 Analytical Results for Groundwater Sampled from Well WQSP-1 . . 116

Table 6.3 Analytical Results for Groundwater Sampled from Well WQSP-2 . . . 118

Table 6.4 Analytical Results for Groundwater Sampled from Well WQSP-3 . . . 120

Table 6.5 Analytical Results for Groundwater Sampled from Well WQSP-4 . . . 122

Table 6.6 Analytical Results for Groundwater Sampled from Well WQSP-5 . . . 124

Table 6.7 Analytical Results for Groundwater Sampled from Well WQSP-6 . . . 126

Table 6.8 Analytical Results for Groundwater Sampled from Well WQSP-6A . 128

Table 6.9 Groundwater Level Measurement Results for $2001 \ldots \ldots$. . . . . . . 130

Table 6.10 Analytical Results for Shallow Groundwater Program . . . . . . . . . 151

Table 7.1 Annual Estimated Average Radiation Dose Received by a Member of the Population of the United States from Naturally Occurring Radiation Sources . . . . . . . . . . . . . . . . . 155

Table 7.2 General Screening Results for Potential Radiation Dose to Nonhuman Biota from Radionuclide Concentrations in Surface Water $(\mathrm{Bq} / \mathrm{l})$, Sediment $(\mathrm{Bq} / \mathrm{g})$, and Soil $(\mathrm{Bq} / \mathrm{g})$ near the WIPP Site . . 158

Table 8.1 Comparison of Duplicate Air Monitoring Results (First Quarter of 2001) from WIPP Laboratories Data from WIPP East (WEE) Sampling Location . . . . . . . . . . . . . . . . . . . 165

Table 8.2 Comparison of Duplicate Air Monitoring Results (Second Quarter of 2001) from WIPP Laboratories Data from WIPP South (WSS) Sampling Location . . . . . . . . . . . . . . . . . . . . 166

Table 8.3 Comparison of Duplicate Air Monitoring Results (Third Quarter of 2001) from WIPP Laboratories Data from Mills Ranch (MLR) Sampling Location . . . . . . . . . . . . . . . . . . 167 
Table 8.4 Comparison of Duplicate Air Monitoring Results (Fourth Quarter of 2001) from WIPP Laboratories Data from Smith Ranch (SMR) Sampling Location . . . . . . . . . . . . . . . . . . . . . 168

Table 8.5 Environmental Measurements Laboratory Assessments for

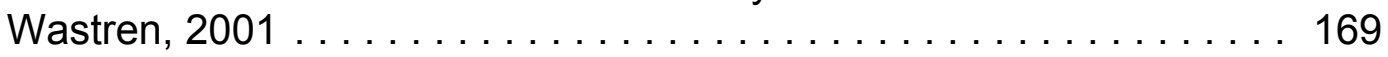

Table 8.6 Environmental Measurements Laboratory Assessments for Wastren, 2001 . . . . . . . . . . . . . . . . . . . . . . . . . . . . . 169

Table 8.7 Environmental Measurements Laboratory Assessments for Wastren, $2001 \ldots \ldots \ldots \ldots \ldots$. . . . . . . . . . . . . . . . 170

Table 8.8 Environmental Measurements Laboratory Assessments for

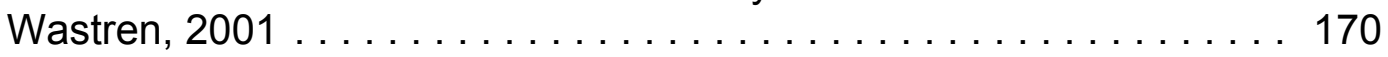

Table 8.9 Environmental Resource Associates $®$ for Wastren, $2001 \ldots \ldots \ldots .171$

Table 8.10 NRIP for WIPP Laboratories, $2001 \ldots \ldots \ldots \ldots \ldots \ldots \ldots \ldots$

Table 8.11 Environmental Measurements Laboratory Assessments for WIPP Laboratories, 2001 . . . . . . . . . . . . . . . . . . . . . . 171

Table 8.12 Environmental Measurements Laboratory Assessments for WIPP Laboratories, $2001 \ldots \ldots \ldots \ldots \ldots \ldots \ldots \ldots \ldots \ldots \ldots \ldots$

Table 8.13 Environmental Measurements Laboratory Assessments for WIPP Laboratories, $2001 \ldots \ldots \ldots \ldots$. . . . . . . . . . . . . . . . . 172

Table 8.14 Environmental Measurements Laboratory Assessments for WIPP Laboratories, 2001

Table 8.15 Environmental Resource Associates $®$ Assessment of Air Toxics, Ltd., WP-75, June 14, 2001, for Volatile Organic Compounds . . . . . 173

Table 8.16 Environmental Resource Associates $®$ Assessment of Trace Analysis, Inc., WP-76, July 19, 2001 . . . . . . . . . . . . . . . 174

Table 8.17 Environmental Resource Associates $®$ Assessment of Trace Analysis, Inc., UST-34, June 15, 2001

Table 8.18 Environmental Resource Associates $₫$ Pesticides assessment Trace Analysis, Inc., QuiK ${ }^{\top \mathrm{M}}$ Response, March 8, 2001 . . . . . . . . 180

Table 8.19 Environmental Resource Associates $\AA$ Assessment of Wastren,

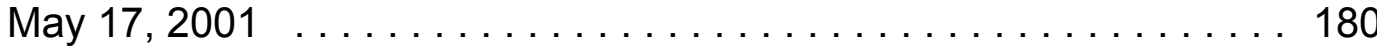




\section{LIST OF FIGURES}

Figure $1.1 \quad$ WIPP Stratigraph $\ldots \ldots \ldots \ldots \ldots \ldots \ldots \ldots \ldots \ldots \ldots \ldots \ldots$

Figure 1.2 WIPP Location $\ldots \ldots \ldots \ldots \ldots \ldots \ldots \ldots \ldots \ldots \ldots \ldots \ldots \ldots \ldots \ldots \ldots \ldots$

Figure 1.3 WIPP Property Areas $\ldots \ldots \ldots \ldots \ldots \ldots \ldots \ldots \ldots \ldots \ldots$

Figure 4.1 Air Sampling Locations on and Near the WIPP Facility . . . . . . . 52

Figure 4.2 Gross Alpha Activity Concentration Measured in Air Particulates

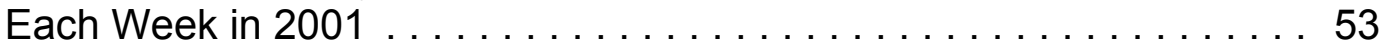

Figure 4.3 Gross Beta Activity Concentration Measured in Air Particulates

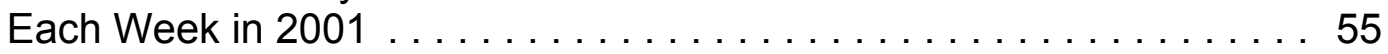

Figure 4.4 Average Gross Alpha and Beta Activity Concentrations Measured in Air Particulates in Four Consecutive Years . . . . . . . . . . . 56

Figure 4.5 Surface Water Sampling Locations in $2001 \ldots \ldots \ldots \ldots \ldots$

Figure 4.6 Soil and Vegetation Sampling Areas in $2001 \ldots \ldots \ldots$

Figure 4.7 Sediment Sampling Sites $\ldots \ldots \ldots \ldots \ldots \ldots \ldots \ldots \ldots \ldots \ldots$

Figure 5.12001 Precipitation at WIPP $\ldots \ldots \ldots \ldots \ldots \ldots \ldots \ldots \ldots \ldots$

Figure 5.22001 WIPP Site Temperature at 2-Meter Height . . . . . . . . . . . . 89

Figure 5.32001 WIPP Site Temperature at 10-Meter Height . . . . . . . . . . . . 90

Figure 5.42001 WIPP Site Temperature at 50-Meter Height . . . . . . . . . . . . 91

Figure 5.52001 WIPP Site Wind Rose at 2-Meter Height $\ldots \ldots \ldots \ldots \ldots \ldots$

Figure 5.62001 WIPP Site Wind Rose at 10-Meter Height $\ldots \ldots \ldots \ldots \ldots$. . . . 93

Figure $5.7 \quad 2001$ WIPP Site Wind Rose at 50-Meter Height $\ldots \ldots \ldots \ldots \ldots$.

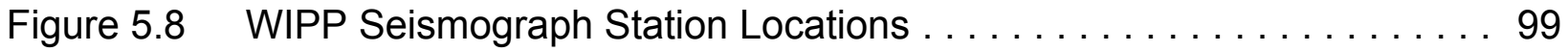

Figure 6.1 Water Quality Sampling Program Wells . . . . . . . . . . . . . 102

Figure 6.2 Groundwater Level Surveillance Wells . . . . . . . . . . . . . . 103 
Figure 6.3 Potentiometric Surface, Adjusted to Equivalent Freshwater Head, of the Culebra Dolomite Member of the Rustler Formation near the

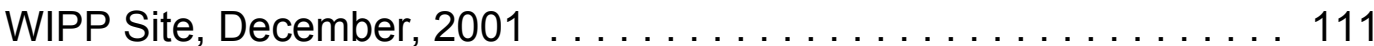

Figure 6.4 Flow Rate and Direction of Groundwater Flowing Across the WIPP Site from the Culebra Formation, December $2001 \ldots \ldots \ldots \ldots . .112$

Figure 6.5 Units Commonly Encountered During Shallow Drilling at WIPP . . . . 113

Figure 6.6 Locations of Piezometers PZ-1 and C-2811, and Wells C-2505,

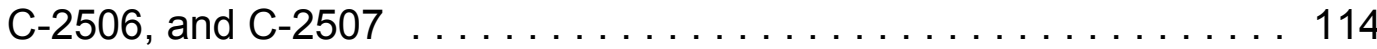

Figure 6.7 Contour Plot of the Potentiometric Surface in the Santa Rosa Formation at the Dewey Lake Contract: December 2001 . . . . . . 115 


\section{CHAPTER 1 - INTRODUCTION}

WIPP is the world's first underground repository with the necessary permits and certifications for safe and permanent disposal of TRU radioactive and mixed waste generated by defense-related activities. A TRU waste is eligible for disposal at WIPP if it has been generated in whole or in part by one or more of the activities listed in the Nuclear Waste Policy Act of 1982 (41 United States Code [U.S.C.] 10101[3]), including naval reactors development, weapons activities, verification and control technology, defense nuclear materials production, defense nuclear waste and materials by-products management, defense nuclear materials security and safeguards and security investigations, and defense research and development.

TRU waste is defined in the WIPP Land Withdrawal Act of 1992 (Public Law [Pub. L.] 102-579) as radioactive waste containing more than 100 nanocuries (3,700 becquerels $[\mathrm{Bq}])$ of alpha-emitting TRU isotopes per gram of waste, with half-lives greater than 20 years. A TRU isotope is an isotope of an element with an atomic number greater than uranium (92). There are certain exceptions to the WIPP Land Withdrawal Act definition, including high-level radioactive waste; waste that the Secretary of Energy has determined, with the concurrence of the Administrator of the EPA, does not need the degree of isolation required by 40 CFR Part 191 disposal regulations; or waste that the NRC has approved for disposal on a case-by-case basis in accordance with 10 CFR Part 61. Most TRU waste is contaminated industrial trash, including used protective clothing, rags, tools and equipment, sludges from solidified liquids, and glass, metal, and other materials from dismantled buildings.

The WIPP Project is authorized by the DOE National Security and Military Applications of Nuclear Energy Authorization Act of 1980 (Pub. L. 96-164). WIPP's legislative mandate is to demonstrate the safe disposal of TRU wastes from national defense activities and programs. To fulfill this mandate, WIPP has been designed to safely handle, store, and dispose of TRU waste in a fully operational disposal facility. After more than 20 years of scientific study, public input, and regulatory struggles, WIPP received its first shipment of waste on March 26, 1999.

When TRU waste arrives at WIPP, it is transported into the Waste Handling Building. The waste containers are removed from the shipping containers, placed on the waste hoist, and lowered to the repository level of $655 \mathrm{~m}(2,150 \mathrm{ft}$; approximately $0.5 \mathrm{mi})$ below the surface. During the disposal phase, the containers of waste are removed from the hoist and placed in excavated storage rooms in the Salado Formation, a thick sequence of salt beds deposited approximately 250 million years ago (Figure 1.1). Once a disposal area has been filled with waste, specially designed closures will be placed in the excavated disposal rooms, and seals will be placed in the shafts. Salt under pressure is relatively plastic, and mine openings will be allowed to creep closed for final disposal, encapsulating and isolating the waste. 


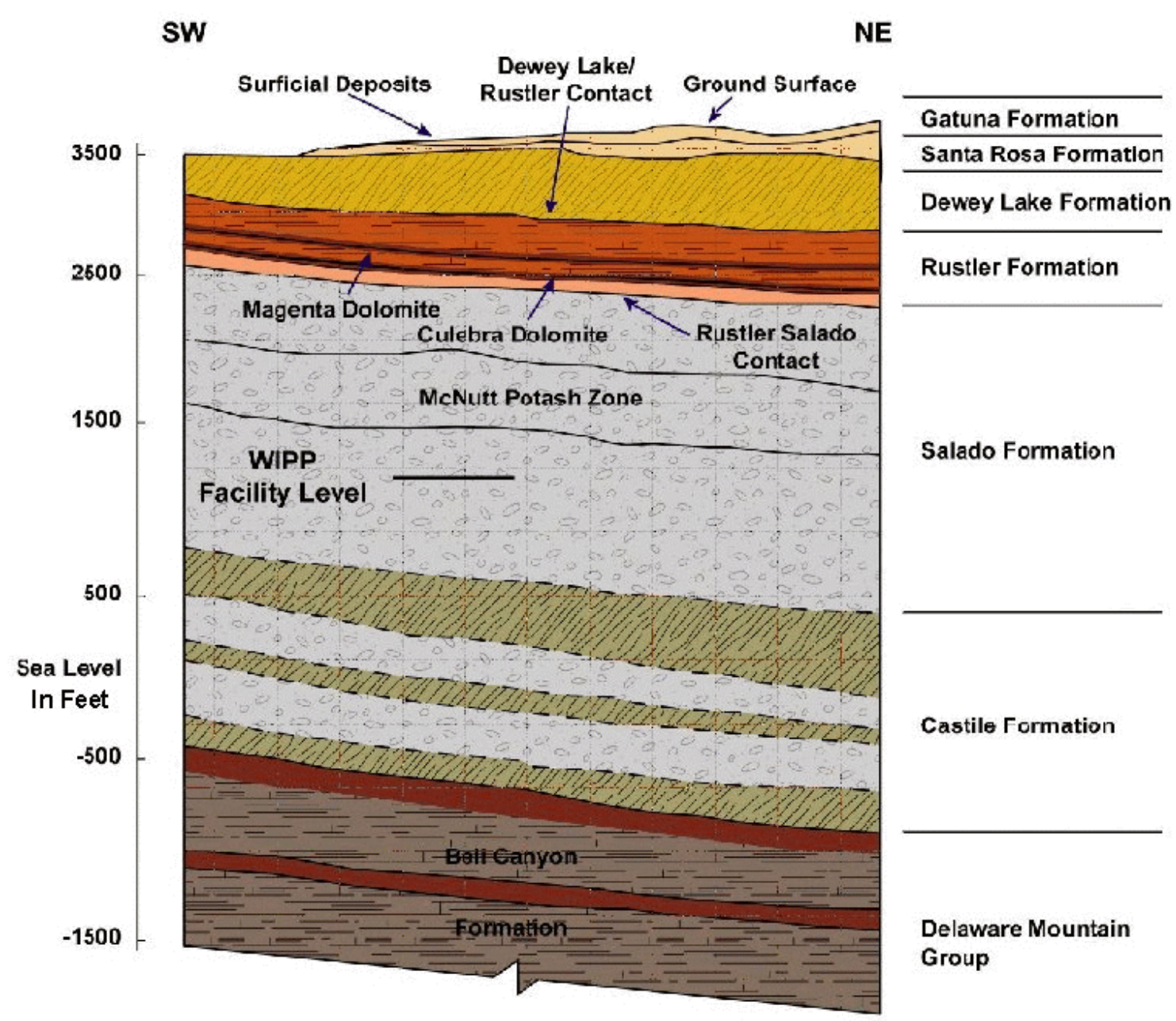

Figure 1.1 - WIPP Stratigraph

\section{$1.1 \quad$ WIPP History}

Government officials and scientists initiated the WIPP site selection process in the 1950s. At that time, the National Academy of Sciences conducted a nationwide search for stable geological formations to contain wastes for thousands of years. In 1955, after extensive study, salt deposits were recommended as a promising medium for the disposal of radioactive waste.

Salt was chosen as the material for the planned disposal of nuclear waste for several reasons. Most deposits of salt are found in stable geological areas with very little earthquake activity, assuring the stability of a waste repository. Salt deposits also demonstrate the absence of flowing fresh water that could move waste to the surface. Water, if it had been or were present, would have dissolved the salt beds. In addition, 


\section{Waste Isolation Pilot Plant 2001 Site Environmental Report DOE/WIPP 02-2225}

salt is relatively easy to mine. Finally, rock salt heals its own fractures because it is relatively plastic. This means salt formations will slowly and progressively move in to fill mined areas and will safely seal radioactive waste from the environment.

Government scientists searched for an appropriate site for the disposal of radioactive waste throughout the 1960s, and finally tested the area of southeastern New Mexico in the early 1970s. Salt formations at WIPP were deposited in thick beds during the evaporation of an ancient ocean, the Permian Sea. These geologic formations consist mainly of sodium chloride, the same substance as table salt. However, at WIPP, the salt is not granular, but is in the form of solid rock. The main salt formation at WIPP is

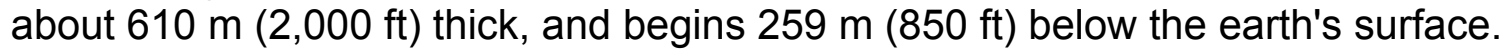
Formed about 225 million years ago during the Permian Age, the large expanses of uninterrupted salt beds provide a repository that has been stable and free from the disturbances of large earthquakes for more than 200 million years. This proven stability over such a long time span offers the predictability that the salt will remain stable for the comparatively short 10,000 -year period that WIPP is mandated to isolate the waste from the human environment.

In 1979, Congress authorized the construction of WIPP, and the DOE constructed the facility during the 1980s. In late 1993, the DOE created the CBFO to lead the TRU waste disposal efforts. The CBFO coordinates the TRU program at waste-generating sites and national laboratories.

In 1999, WIPP received its first waste shipment. On March 25, the first waste bound for WIPP departed Los Alamos National Laboratory in New Mexico; it arrived at WIPP the following morning, and the first wastes were placed underground later that day. On April 17, WIPP celebrated its official grand opening. Ten days later, on April 27, the first out-of-state shipment arrived at WIPP, from the Idaho National Engineering and Environmental Laboratory. Later in the year, on October 27, the Secretary of the NMED issued a WIPP HWFP, which allows WIPP to manage, store, and dispose of contact-handled TRU mixed waste. Mixed waste is waste contaminated by both hazardous and radioactive substances. "Contact-handled mixed waste" is TRU mixed waste with a surface dose rate less than 200 millirem per hour.

\subsection{WIPP's Mission}

Current temporary radioactive waste storage facilities at 23 locations across the United States were never intended to provide permanent disposal. WIPP is the nation's first operating underground repository for defense-generated TRU waste and is a critical step toward solving the nation's nuclear waste disposal problem. Its mission is to provide for the safe, permanent, and environmentally sound disposal of TRU radioactive waste left from research, development, and production of nuclear weapons. Over the next 35 years, WIPP is expected to receive about 37,000 shipments of waste from locations across the United States. 
The mission of the CBFO is to protect human health and the environment by opening and operating WIPP for safe disposal of TRU waste and by establishing an effective system for management of TRU waste from generation to disposal.

\section{$1.3 \quad$ WIPP Location}

Located in Eddy County in the remote Chihuahuan Desert of southeastern New Mexico (Figure 1.2), the WIPP site encompasses approximately $41.1 \mathrm{~km}^{2}$, or $16 \mathrm{mi}^{2}$. The site is $42 \mathrm{~km}$ (26 mi) east of Carlsbad in a region known as Los Medaños. This part of New Mexico is relatively flat and is sparsely inhabited, with little surface water. The WIPP site boundary extends a minimum of $1.6 \mathrm{~km}(1 \mathrm{mi})$ beyond any of the WIPP underground developments. The WIPP Land Withdrawal Act was signed into law on October 30, 1992, transferring the land from the Department of the Interior to the DOE. With the exception of facilities within the boundaries of the posted $5.7 \mathrm{~km}^{2}\left(2.2 \mathrm{mi}^{2}\right)$ Off-Limits Area, the surface land uses remain largely unchanged from pre-1992 uses, and are managed in accordance with accepted practices for multiple land use. However, mining and drilling for purposes other than those which support WIPP are prohibited within the WIPP site.

The majority of the lands in the immediate vicinity of WIPP are managed by the Department of the Interior's Bureau of Land Management (BLM). Land uses in the surrounding area include livestock grazing; potash mining; oil and gas exploration and production; and recreational activities such as hunting, camping, hiking, and bird watching. The region is home to diverse populations of animals and plants. 


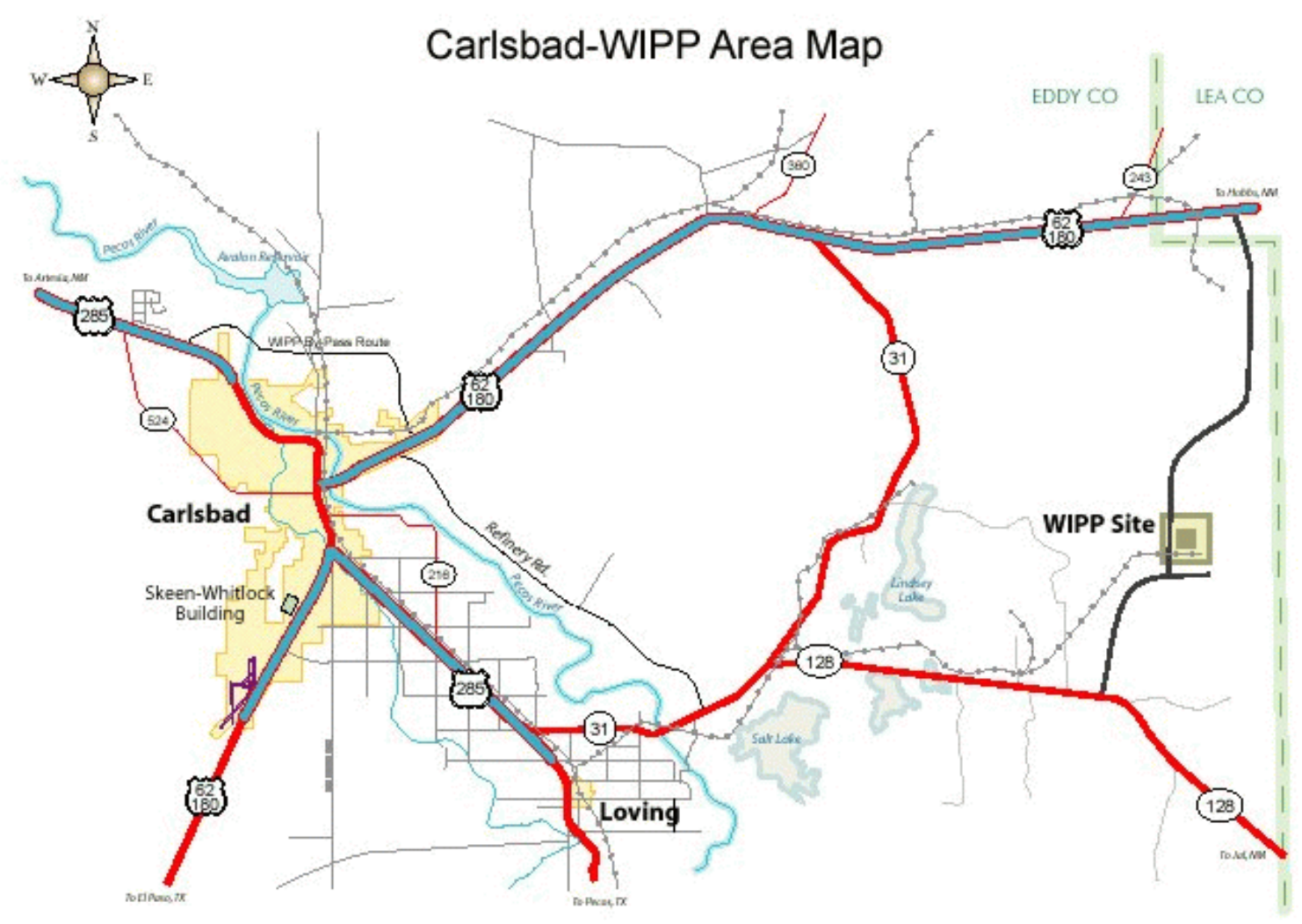

Figure 1.2 - WIPP Location

\subsubsection{WIPP Property Areas}

Five types of property areas are found within WIPP's boundary (Figure 1.3).

\section{Property Protection Area}

The interior core of the facility encompasses approximately $0.129 \mathrm{~km}^{2}\left(0.05 \mathrm{mi}^{2}\right)$ surrounded by a chain link fence. This area is under tight security and uniformed security personnel are on duty 24 hours a day.

\section{Exclusive Use Area}

The Exclusive Use Area comprises $1.12 \mathrm{~km}^{2}\left(0.432 \mathrm{mi}^{2}\right)$. It is surrounded by a five-strand barbed wire fence and is restricted exclusively for the use of the DOE and its contractors and subcontractors in support of the project. In addition, this area is defined as the point of closest public access for the purpose of analyzing accident consequences to the general public in the WIPP Safety Analysis Report (DOE/WIPP 95-2065). This area is marked by DOE warning (e.g., "no trespassing") 
signs and is patrolled by WIPP security personnel to prevent unauthorized activities or uses.

\section{$\underline{\text { Off-Limits Area }}$}

Managed as an area where unauthorized entry and introduction of weapons and/or dangerous materials is prohibited, the Off-Limits Area includes 5.7 square kilometers $\left(\mathrm{km}^{2}\right)$ (2.2 square miles $\left[\mathrm{mi}^{2}\right]$ ). Pertinent prohibitions are posted at consistent intervals along the perimeter. Grazing and public thoroughfare will continue in this area until such time that these activities present a threat to the security, safety, or environmental quality of WIPP. This sector is patrolled by WIPP security personnel to prevent unauthorized activity or use.

\section{WIPP Land Withdrawal Area}

The WIPP site boundary delineates the perimeter of the $41.4 \mathrm{~km}^{2}\left(16 \mathrm{mi}^{2}\right)$ WIPP Land Withdrawal Area. This tract includes properties outlying the Property Protection Area, the Exclusive Use Area, and the Off-Limits Area. This sector is designated as a Multiple Land Use Area, and is managed accordingly.

\section{$\underline{\text { Special Management Areas }}$}

Certain properties used in the operation of WIPP (e.g., reclamation sites, well pads, roads) are, or may be, identified as Special Management Areas (SMA). A SMA designation is made due to values, resources, and/or circumstances that meet criteria for protection and management under special management designations. Unique resources of value that are in danger of being lost or damaged, areas where ongoing construction is occurring, fragile plant and/or animal communities, sites of archaeological significance, locations containing safety hazards, or sectors that may receive an unanticipated elevated security status would be suitable for designation as a SMA. Accordingly, the subject sector would receive special management emphasis under this stipulation. Special Management Areas will be posted against trespass and will be safeguarded commensurate with applicable laws governing property protection. WIPP security personnel will patrol these areas to prevent unauthorized access or use. 


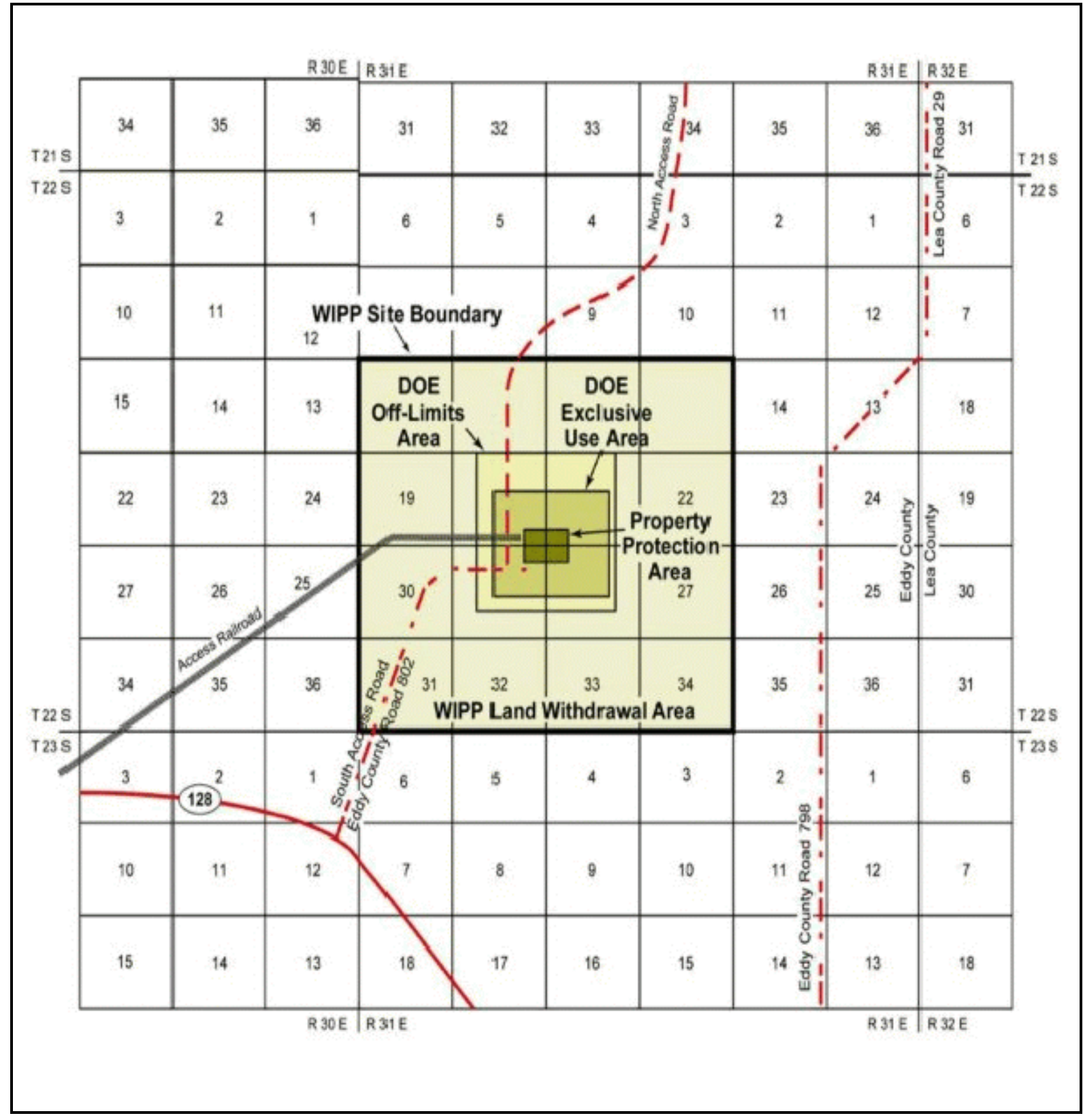

Figure 1.3 - WIPP Property Areas

\subsubsection{Population}

Approximately 26 residents live within $16 \mathrm{~km}$ (10 mi) of the WIPP site. The majority of the local population within $80.5 \mathrm{~km}(50 \mathrm{mi})$ of WIPP is concentrated in and around the communities of Carlsbad, Hobbs, Eunice, Loving, Jal, and Artesia, New Mexico. The nearest community is the village of Loving (current estimated population 1,326), $29 \mathrm{~km}$ $(18 \mathrm{mi})$ west-southwest of WIPP. The nearest major populated area is Carlsbad, $42 \mathrm{~km}$ (26 mi) west of WIPP. The current estimated population of Carlsbad is approximately 25,625 . The population within $16 \mathrm{~km}(10 \mathrm{mi})$ of WIPP is associated with ranching, oil 


\section{Waste Isolation Pilot Plant 2001 Site Environmental Report DOE/WIPP 02-2225}

and gas exploration/production, and potash mining. There are two nearby ranch residences (Smith Ranch and Mills Ranch) which are continuously monitored as part of the EMP.

\subsection{Environmental Performance}

The DOE's Environmental Policy Statement (DOE, 1986) describes the DOE's commitment to environmental protection and pledges to conduct operations "in an environmentally safe and sound manner. . . in compliance with the letter and spirit of applicable environmental statutes, regulations, and standards" (DOE, 1986). The Statement also affirms the DOE's commitment to "good environmental management in all of its programs and at all of its facilities in order to correct existing environmental problems and to anticipate and address potential environmental problems before they pose a threat to the quality of the environment or public welfare." Additionally, it states, "It is DOE's policy that efforts to meet environmental obligations be carried out consistently across all operations and among all field organizations and programs. . ." (DOE, 1986).

The DOE used laboratory tests, field tests, and computer models to demonstrate WIPP's expected 10,000 year performance as a permanent disposal site. The EPA certified, in May 1998, WIPP's ability to protect the environment and human health, while assuring continued compliance through periodic recertification.

WTS conducted the Environmental Monitoring Program at WIPP in CY 2001 to monitor for any potential radiological effects of WIPP on people and the environment. Other organizations oversee the WIPP program, including the EPA, which is responsible for certifying whether radioactive material disposal requirements are met; the state of New Mexico, which regulates the handling of the hazardous components of mixed wastes; and the Environmental Evaluation Group (EEG), an independent technical oversight group that participates in and comments on various WIPP issues and activities. The Carlsbad Environmental Monitoring and Research Center conducts a supplementary environmental monitoring program around WIPP. Several other agencies, committees, and panels monitor progress at WIPP and contribute to the project's development through regulation, review, and comment at the state and federal levels.

This Waste Isolation Pilot Plant 2001 Site Environmental Report was prepared in accordance with DOE Order 231.1. This report documents WIPP's radiological, nonradiological, and groundwater monitoring programs and their results for CY 2001. 


\section{Waste Isolation Pilot Plant 2001 Site Environmental Report DOE/WIPP 02-2225}

\section{CHAPTER 2 - ENVIRONMENTAL PROGRAM INFORMATION}

The DOE's policy for the management of WIPP is to conduct its operations in a manner commensurate with applicable environmental laws and regulations, and to safeguard the integrity of the southeastern New Mexico environment. This is accomplished through radiological and nonradiological environmental monitoring, environmental compliance, and land management programs, which include monitoring wildlife populations, the WRP, and reclamation of disturbed lands. The purpose of these programs is to obtain land use permits, implement selected compliance functions such as NEPA compliance, collect data needed to detect and quantify possible impacts WIPP may have on the surrounding ecosystem and, when necessary, provide technical support in the disciplines of environmental science and land management to the DOE's CBFO.

Environmental monitoring activities at WIPP generally fall into four categories: collecting environmental samples from various matrices and analyzing them for specific radionuclides; preparing and publishing documents showing compliance with federal, state, and local regulations; evaluating whether WIPP activities cause any environmental impacts; and taking corrective action when an adverse effect on the environment is identified.

\subsection{Environmental Monitoring Plan}

WIPP's EMP outlines the programs that monitor the environment on, and immediately surrounding, the WIPP site. It discusses major environmental monitoring and surveillance activities at WIPP and reflects the importance of monitoring as a critical element of an effective environmental protection program. The EMP also discusses the WIPP QA/QC program as it relates to environmental monitoring. The purpose of the EMP is to outline the programs that evaluate WIPP's effect on the local ecosystem. Effluent and environmental monitoring also provide the data necessary to demonstrate compliance with applicable environmental protection regulations. The EMP sampling schedule is provided in Table 2.1.

The EMP describes the monitoring of naturally-occurring and specific anthropogenic (human-made) radionuclides. This surveillance includes monitoring worldwide fallout from historic nuclear weapons tests. The geographic scope of radiological sampling is based on projections of potential release pathways from the waste stored at WIPP. Airborne radioactivity is also monitored at Carlsbad, New Mexico, and local ranches.

The EMP also describes monitoring of VOCs, wildlife populations, meteorology, groundwater chemistry, and other nonradiological environmental parameters. In general nonradiological monitoring is conducted within or near the WIPP boundary.

Results and discussions pertaining to the monitoring programs prescribed by the EMP are provided in Chapter 4, "Environmental Radiological Program Information," and Chapter 5, "Environmental Nonradiological Program Information." DOE Order 5400.1 


\section{Waste Isolation Pilot Plant 2001 Site Environmental Report DOE/WIPP 02-2225}

requires the EMP to be reviewed internally every year and updated every three years. The EMP will be updated in September 2002.

Table 2.1 - The Environmental Monitoring Plan Outlines the Sampling Schedule for the WIPP Environmental Monitoring Program

\begin{tabular}{lcc}
\hline \multicolumn{1}{c}{ Type of Sample } & $\begin{array}{c}\text { Number of Sampling } \\
\text { Locations }\end{array}$ & Sampling Frequency \\
\hline Liquid effluent & 1 & Semiannual (oversight) \\
Liquid effluent & 1 & Quarterly (DP 831 permit ${ }^{\mathrm{a}}$ ) \\
Airborne effluent & 3 & Periodic/Confirmatory \\
Meteorology & 2 & Continuous \\
Atmospheric particulate & 7 & Weekly \\
Vegetation & 6 & Annual \\
Beef/Deer/Game Birds/Rabbits & Sitewide & Annual \\
Soil & 6 & Annual \\
Surface water & 14 & Annual \\
Groundwater & 7 & Semiannual \\
Fish & 3 & Annual \\
Sediment & 12 & Annual \\
Aerial photography & Sitewide & As needed \\
Volatile organic compounds (VOCs) & 2 & Semiweekly
\end{tabular}

${ }^{a}$ Monitoring compliance with the Discharge Plan, DP-831.

\subsection{WIPP Environmental Monitoring Program}

It is the policy of the DOE to conduct effluent monitoring and environmental surveillance programs that are appropriate for determining adequate protection of the public and the environment during WIPP operations, and to ensure operations comply with DOE and other applicable federal or state radiation standards and requirements. It is the DOE's objective that all DOE operations properly and accurately measure radionuclides in effluent streams and in the ambient environmental media. The goal of the WIPP Environmental Monitoring Program is to determine if the local ecosystem has been impacted during the predisposal and disposal phases of WIPP, and, if so, to evaluate the severity, geographic extent, and environmental significance of those impacts. The program fulfills DOE Orders 5400.1 (General Environmental Protection Program) and 5400.5 (Radiation Protection of the Public and the Environment).

The Environmental Monitoring Program monitors pathways by which WIPP-related radionuclides and other contaminants could reach the environment surrounding the WIPP site. The pathways measured include air, surface water, groundwater, sediments, soils, and biota (e.g., vegetation, game birds, and fish). In addition, the program monitors groundwater quality and the overall health of the local environment. Nonradiological portions of the program focus on the area immediately surrounding the site while radiological surveillance generally covers a broader geographical area. 
In addition to monitoring for radionuclides contained in WIPP wastes, background radiation (naturally-occurring radioactivity and radioactivity associated with worldwide fallout from historic weapons testing) is also monitored. The geographic scope of radiological sampling is based on projections of potential release pathways for the types of radionuclides in WIPP wastes. Also, Carlsbad, New Mexico, and local ranches are monitored, even though release scenarios involving radiation doses to residents of these population centers are improbable.

The atmospheric pathway, which can lead to the inhalation of radionuclides, has been determined to be the most likely exposure pathway to the public from WIPP. Therefore, airborne particulate sampling for alpha-emitting radionuclides is emphasized. Air sampling results are used to trend environmental radiological levels and determine if there has been a deviation from established baseline concentrations.

Nonradiological environmental monitoring activities at WIPP consist of a comprehensive set of sampling programs designed to detect and quantify impacts of construction and operational activities. The ecological monitoring program focuses on nonradiological effects of WIPP, such as habitat disturbance.

WIPP has collected preoperational radiological and nonradiological environmental data. Baseline conditions were initially characterized by the Radiological Baseline Program. When the first shipment of waste arrived at WIPP, this program became an operational monitoring program.

Preoperational studies must be considered during environmental evaluations. These assessments have contributed to baseline data gathered during the construction phase and provided much of the foundation for long-term monitoring programs. Below are listed examples of such investigations.

- $\quad$ The WIPP Site Characterization Program was instituted in 1976 by Sandia National Laboratories to monitor air quality, background radiation levels, and groundwater quality.

- $\quad$ The WIPP Biology Program began in 1975 with site characterization studies of climate, soils, vegetation, arthropods, and vertebrates.

- $\quad$ Investigations of site geohydrology were conducted by the U.S. Geological Survey at the request of the DOE. In addition, the NRC issued a contract to Columbia University to perform a study of radionuclide mobility in the highly saline groundwaters of the Delaware Basin.

- $\quad$ Radiological monitoring of air, water, and biological media was conducted by the U.S. Atomic Energy Commission before and after the Project Gnome nuclear detonation in 1961. 


\section{Waste Isolation Pilot Plant 2001 Site Environmental Report DOE/WIPP 02-2225}

\subsection{Land Management Programs}

On October 30, 1992, the WIPP Land Withdrawal Act (Pub. L. 109-579) became law. This act transferred the responsibility for the management of the WIPP Land Withdrawal Area from the Secretary of the Interior to the Secretary of Energy. In accordance with Sections $3(a)(1)$ and (3) of the act, these lands:
... are withdrawn from all forms of entry, appropriation, and disposal under the public land laws . . . and are reserved for the use of the Secretary of Energy ... for the construction, experimentation, operation, repair and maintenance, disposal, shutdown, monitoring, decommissioning, and other activities associated with the purposes of WIPP as set forth in Section 213 of the DOE National Security and Military Application of the Nuclear Energy Act of 1980 (Pub. L. 96-164); 93 Stat. 1259, 1265, and this Act.

The DOE developed the LMP (DOE/WIPP 93-004) as required by Section 4 of the Land Withdrawal Act. The LMP was developed to identify resource values, promote multiple-use management, and identify long-term goals for the management of WIPP lands until the culmination of the decommissioning phase. This plan was developed in consultation and cooperation with the BLM and the state of New Mexico. Changes or amendments to the plan require the involvement of the BLM, the state of New Mexico, and affected stakeholders, as appropriate.

Guidelines in the LMP provide for the management and oversight of WIPP lands under the jurisdiction of the DOE. Lands outside the WIPP boundary used in the operation of WIPP (e.g., groundwater surveillance well pads outside the withdrawal area) are also included in the plan. Furthermore, the plan provides for multi-agency involvement in the administration of the DOE land management actions. For example, the BLM is responsible for administering grazing leases through an MOU. The LMP is available to anyone desiring to conduct activities on lands under the jurisdiction of WIPP in addition to those involved in developing or amending existing land management actions.

The LMP encourages direct communication among stakeholders, including federal and state agencies, involved in managing the resources within, or activities impacting the areas adjacent to, the WIPP Land Withdrawal Area. It sets forth cooperative arrangements and protocols for addressing WIPP-related land management actions. Commitments contained in current permits, agreements, or concurrent MOUs with other agencies will be respected when addressing and evaluating land use management activities and future amendments that affect the management of WIPP lands.

The LMP was last reviewed in 2001. It is reviewed on a biennial basis to assess the adequacy and effectiveness of the document, or as may be necessary to address emerging issues potentially affecting WIPP lands. Affected agencies, groups, and individuals may be involved in the review process. Components of the LMP emphasize management protocols for the following issues: administration of the plan, environmental compliance, wildlife, cultural resources, grazing, recreation, energy and 
mineral resources, lands/realty, reclamation, security, industrial safety, emergency management, maintenance, and work control.

\subsubsection{Land Use Requests}

Parties who wish to conduct activities that may impact lands under the jurisdiction of WIPP, but outside the secured fence area of the facility designated as the Property Protection Area, are required by the LMP to prepare a Land Use Request (LUR). A LUR consists of a narrative description of the project, a completed environmental review, and a map depicting the location of the proposed activity. The LUR, and associated NEPA checklists, are used to determine if applicable regulatory requirements have been met prior to the approval of a proposed project. A LUR may be submitted to the land use coordinator by any WIPP organization or outside entity wishing to complete any construction, right-of-way, pipeline easement, or similar action within the WIPP boundary or on lands used in the operation of WIPP, under the jurisdiction of the DOE. During 2001, six LURs were submitted for review and approval; all met applicable criteria and were approved.

\subsubsection{Wildlife Population Monitoring}

Southeastern New Mexico is home to diverse populations of plants and wildlife. Shrubs and grasses are the most prominent components of the local flora. Dominant trees include shinnery oak (Quercus havardii), honey mesquite (Prosopis glandulosa), and western soapberry (Sapindus drummondii). Much of the area is composed of combined dune and grassland habitats that include perennial grasses and shrubs.

According to the BLM's Resource Management Plan, 15 percent of the wildlife species identified in the area use the shinnery oak habitat, while 30 percent occupy areas consisting primarily of grasses. The juxtaposition of shinnery oak/dune habitat with grassland habitat has resulted in a diverse wildlife population.

This portion of New Mexico supports an abundant and diverse population of mammals, including black-tailed jackrabbits (Lepus californicus), desert cottontails (Sylvilagus audoboni), desert mule deer (Odocoileus hemionus), coyotes (Canis latrans), gray foxes (Urocyon cinereoargenteus), badgers (Taxidea taxis), and striped skunks (Mephitis mephitis).

The habitat heterogeneity of the Los Medaños region also accounts for a wide assortment of bird species. Scaled quail (Callipepla squamata), mourning doves (Zenaida macroura), loggerhead shrikes (Lanius ludovicianus), black-throated sparrows (Amphispiza bilineata), Chihuahuan ravens (Corvus cryptoleucus), and a unique desert subspecies of the northern bobwhite (Colinus virginianus) are but a few examples of the array of avian inhabitants. Due to a scarcity of surface waters in the immediate vicinity of WIPP, migrating or breeding waterfowl are not common.

In addition, this area supports a particularly abundant and diverse population of raptors, or birds of prey. Harris' hawks (Parabuteo unicinctus), Swainson's hawks (Buteo 


\section{Waste Isolation Pilot Plant 2001 Site Environmental Report DOE/WIPP 02-2225}

swainsoni), and great horned owls (Bubo virginianus) are species commonly found nesting in the area. Northern harriers (Cicus cyaneus), burrowing owls (Athene cunicularia), barn owls (Tyto alba), and American kestrels (Falco sparverius) are also found around the site.

Reptiles and amphibians are also found in great numbers in southeastern New Mexico. Representative of the no fewer than ten native amphibians are the tiger salamander (Ambystoma tigrinum), green toad (Bufo debilis), plain's spadefoot toad (Spea bombifrons), red-spotted toad (Bufo punctatus), and New Mexico spadefoot toad (Spea muliplicata). Their significance is seldom recognized until spring or summer rains, at which time they appear in extraordinary numbers.

Reptiles are more conspicuous due to their diurnal nature. Characteristic reptiles in the region include the ornate box turtles (Terrapene ornata), side-blotched lizards (Uta stansburiana), western whiptails (Cnemidophorus tigris), bullsnakes (Pituophis melanoleucus), prairie rattlesnakes (Crotalus viridis), and Texas horned lizards (Phrynosoma cornutum), a federal notice-of-review species listed under the Endangered Species Act (16 U.S.C. 1531-1544).

Birds and mammals compose the upper levels of the food chain in the natural ecosystem around WIPP. These organisms may be affected by noise and human presence as well as by changes in habitat structure due to salt impacts. Population densities are monitored annually to define normal cycles of abundance and to detect major changes in populations or communities which may be due to activities at WIPP.

Beginning in 1985, population density measurements of birds and small nocturnal mammals were performed annually to assess the effects of WIPP surface activities (e.g., construction, salt piles) on wildlife populations. Customary protocol involved comparative data analyses between two outlying or "control" plots and two experimental plots near WIPP operations. No consistent differences were found between the control and experimental plots. A Hantavirus investigation during 1994 prompted the temporary postponement of small nocturnal mammal surveys. Previous years' investigations revealed no detectable detrimental impacts from salt encroachment on the peripheral environment; therefore, annual appraisals of small mammal populations were discontinued indefinitely.

WTS personnel manage several wildlife research projects and conduct a number of general wildlife management activities. Specific wildlife populations are monitored and researched in accordance with applicable laws, agreements, and regulations. Each activity is mandated and/or supported by state and federal guidelines or by way of commitments created through interagency agreements and MOUs. Wildlife within the WIPP Land Withdrawal Area are given consideration by way of the WIPP LUR process during planning stages of projects that may disturb or encroach on wildlife habitat.

In 1979, the DOE consulted with the U.S. Fish and Wildlife Service (USF\&WS) and was informed of the presence of threatened or endangered species at or near the WIPP site. However, no critical habitats for endangered species were identified at WIPP. In 1989, 


\section{Waste Isolation Pilot Plant 2001 Site Environmental Report DOE/WIPP 02-2225}

the DOE again consulted with the USF\&WS and was advised of no status changes since 1979.

During 1989, the DOE consulted with the New Mexico Department of Game and Fish (NMDG\&F) regarding state-listed endangered species in the vicinity of WIPP. NMDG\&F Regulation 657, dated January 9, 1988, listed seven birds and one reptile in one of two endangerment categories that may be present at the site.

In 1995, the USF\&WS provided an updated list of threatened and endangered species for Eddy and Lea Counties, New Mexico. Included were 18 species that may be present on WIPP lands. A comprehensive evaluation in support of the second Supplemental Environmental Impact Statement (SEIS-II) (DOE/EIS-0026-S-2) was conducted in 1996 to determine the presence or absence of threatened or endangered species in the vicinity of WIPP and WIPP's effect on these species. Results indicated that activities associated with the operation of WIPP had no impact on any threatened or endangered species. The protection of threatened and endangered species is taken into consideration when planning and administering projects on WIPP lands.

WIPP, and the region surrounding it, is widely recognized for its concentration and diversity of raptors. The area is home to several raptor species of special concern, including Harris' hawks, Swainson's hawks, burrowing owls, and barn owls, as well as other species.

The DOE, the BLM, and other government agencies are keenly aware of the value and importance of protecting and monitoring raptor populations. To assist in this effort at WIPP, the BLM and the DOE established the WRP in the early 1990s to monitor, protect, and educate about raptors on the WIPP site. The WRP is administered by the WIPP Environmental Monitoring Program with input from the BLM and others. Scientific consultation, research direction, and field operations are conducted by scientists from Rocky Mountain College in Billings, Montana.

In CY 2001, research continued on long term studies of productivity and population demographics of the raptor community in and around WIPP. These studies are described in greater detail in Chapter 5.

\subsubsection{Reclamation of Disturbed Lands}

The DOE recognizes its responsibility pursuant to federal, state, and local environmental regulations to enhance and restore areas affected by WIPP activities, including disturbed lands accepted as part of the land transfer from the BLM.

WIPP reclamation activities are conducted in accordance with DOE Order 5400.1 ; the DOE Organization Act (42 U.S.C. 7112); the Federal Land Policy and Management Act of 1976 (43 U.S.C. 1751); the WIPP Disposal Phase SEIS-II; the SEIS-I (DOE/EIS-0026-FS); the Final Environmental Impact Statement (FEIS) (DOE/EIS-0026); and all applicable reclamation requirements by federal laws and regulations, Executive Orders, MOUs, DOE Orders, and state and local laws. 
Without an active reclamation program for disturbed areas, the establishment of stable ecological conditions in arid environments may require decades or centuries to achieve stability, depending on the disturbances and environmental conditions present. Reclamation activities are intended to reduce soil erosion, increase the rate of plant colonization and succession, and provide habitat for wildlife in disturbed areas. Reclamation ultimately serves to mitigate the effects of WIPP-related activities on affected plant and animal communities. The objective of the reclamation program is to reclaim lands used in the operation of WIPP that are no longer commissioned for WIPP operations. The DOE will also establish reclamation guidelines for land use requesters on a case-by-case basis.

In accordance with the LMP, WIPP follows a reclamation program and a long-range reclamation plan. As locations are identified for reclamation, WIPP personnel reclaim these areas by using the best acceptable reclamation practices. Seed mixes used reflect those species indigenous to the area with priority given to those plant species which are conducive to soil stabilization, wildlife, and livestock needs.

\subsubsection{Oil and Gas Surveillance}

The oil and gas industry is well established in southeastern New Mexico. Nearly all phases of oil and gas activities have occurred in the vicinity of WIPP, including seismic exploration, exploratory drilling, field development (comprised of production and injection wells), and other activities associated with hydrocarbon extraction.

The Los Medaños region, where WIPP is located, is part of the Delaware Basin. Although the Delaware Basin accounts for approximately 32 percent of lands in Eddy County, approximately 20 percent of the oil and gas wells are located within its boundaries. During 1995, oil and gas reserves in the immediate vicinity of the WIPP Land Withdrawal Area were evaluated by the New Mexico Bureau of Mines and Mineral Resources. Results from this evaluation were compiled in a report, Evaluation of Mineral Resources at the Waste Isolation Pilot Plant Site, March 31, 1996.

One aspect of the WIPP land withdrawal, unique to most DOE facilities, was the intent to maintain a multiple land use concept in the management of the property. However, an exception to a global multiple use strategy was required to reduce likelihood of inadvertent intrusion on the repository and to safeguard the surface infrastructure. Accordingly, all drilling and mining on the WIPP site has been prohibited. Oil and gas activities within $1.6 \mathrm{~km}(1 \mathrm{mi})$ of the WIPP boundary are monitored twice monthly to identify new activities associated with oil and gas exploration and production, including:

- $\quad$ Drilling

- $\quad$ Survey staking

- Geophysical exploration

- Pipeline construction

- Work-overs

- $\quad$ Changes in well status

- Anomalous occurrences (e.g., leaks, spills, accidents, etc.) 
During CY 2001, WIPP surveillance teams conducted 24 scheduled surveillances with more than 100 cursory field inspections.

One exception to the prohibition of mining and drilling on the WIPP site involved two mineral leases. Under a provision contained in the Land Withdrawal Act (Public Law 102-579), these two mineral leases, consisting of 129 ha (320 ac) each, were not appropriated in the proceedings. Both tracts, located in Township 22 South, Range 31 East, Section 31, prohibit drilling within the first 1,830 m $(6,000 \mathrm{ft})$ of the surface. In accordance with the WIPP Land Withdrawal Act, existing rights under these leases were not affected unless the Administrator of EPA determined, after consultation with the Secretary of Energy, that the area in question should have been purchased.

This determination was made because of the presence of an existing gas well that had been drilled directionally from the adjacent Section 6 of Township 23 South, Range 31 East. During deliberations, it was determined the DOE would condemn (withdraw from public use) the upper $1,830 \mathrm{~m}(6,000 \mathrm{ft})$ of Section 31. This action would require operators interested in accessing minerals under the section to stage drilling operations outside the WIPP boundary and directionally drill under Section 31. The condemnation of the upper $1,830 \mathrm{~m}(6,000 \mathrm{ft})$ would provide an adequate protective zone for DOE operations while still allowing the legal owner of the minerals to access the reserves. Section 4(b)(5) of the Land Withdrawal Act describes this action as follows:

(5) Mining:

(A) In general. Except as provided in subparagraph (B), no surface or subsurface mining, or oil or gas production, including slant drilling from outside the boundaries of the Withdrawal, shall be permitted at any time (including after decommissioning) on lands on or under the Withdrawal.

(B) Exception. Existing rights under Federal Oil and Gas Leases No. NMNM 02953 and No. NMNM 02953 shall not be affected unless the Administrator determines, after consultation with the Secretary and the Secretary of the Interior, that the acquisition of such leases by the Secretary is required to comply with the final disposal regulations. 
This page intentionally left blank 


\section{CHAPTER 3 - COMPLIANCE SUMMARY}

WIPP is required to comply with applicable federal and state laws and DOE Orders. Documentation of requisite federal and state permits, notifications, and applications for approval is maintained by the WTS Environment, Safety, and Health Department. Regulatory requirements are incorporated in facility plans and implementing procedures.

\subsection{Compliance Overview}

In 2001, WIPP maintained compliance with applicable federal and state environmental regulations. Section 3.2 contains a listing of environmental statutes/regulations applicable to WIPP. Section 3.3 describes significant accomplishments and ongoing compliance activities relative to the regulations most pertinent to WIPP's development. A detailed breakdown of WIPP's compliance with environmental regulations is available in the WIPP Biennial Environmental Compliance Report (DOE/WIPP 99-2171).

\subsection{Compliance Status}

A summary of WIPP's compliance with major environmental regulations is presented in Table 3.3. Applicable DOE Orders are found in Table 3.4, and a list of WIPP permits appears in Table 3.5.

\subsubsection{Comprehensive Environmental Response, Compensation, and Liability Act}

No release sites have been identified at WIPP that would require cleanup under the provisions of the CERCLA. CERCLA establishes a comprehensive federal strategy for responding to, and establishing liability for, releases of hazardous substances from a facility to the environment. Any spills of hazardous substances that exceed a reportable quantity must be reported to the National Response Center under the provisions of Section 103 of CERCLA and 40 CFR Part 302. Hazardous substance cleanup procedures are specified in the National Oil and Hazardous Substances Pollution Contingency Plan (40 CFR Part 300).

In May 2001, a release of lead was reported to the National Response Center, the SERC, and the Eddy County Local Emergency Planning Committee (Follow-On Notification for Reportable Release, dated May 30, 2001). Subsequent analysis of the release determined that it was not reportable under CERCLA, or any other regulations, due to the lead particle size and the containment of the release to the WIPP property. Appropriate remediation of the release was completed. Soil samples showed no elevated lead levels and confirmed completion of clean-up activities. Follow-on reports sent to the three agencies explained the actions taken at the release location and the basis for the nonreportable determination. No further actions are required at this location. 


\section{Waste Isolation Pilot Plant 2001 Site Environmental Report DOE/WIPP 02-2225}

Superfund Amendments and Reauthorization Act of 1986

WIPP is required by Sections 311 and 312 of the Superfund Amendments and Reauthorization Act (SARA) Title III (also known as the Emergency Planning and Community Right-to-Know Act) to submit (1) a list of chemicals for which a material safety data sheet (MSDS) is required, and (2) an Emergency and Hazardous Chemical Inventory Form (Tier II Form) to the State Emergency Response Commission, the Local Emergency Planning Committee, and the fire departments with jurisdiction over the facility.

The list of chemicals provides external emergency responders with information they may need when responding to a hazardous chemical emergency at WIPP. The Tier II Form, due on March 1 of each year, provides information to the public about hazardous chemicals that a facility has on site at any time during the year above threshold planning quantities. WIPP submits the list of chemicals and the Tier II Form to each fire department with which the CBFO maintains an MOU. WIPP also provides the list of chemicals and the Tier II Form to the LEPC and SERC, as well as the fire departments that have MOUs with WIPP.

\section{Accidental Releases of Reportable Quantities of Hazardous Substances}

During 2001, there were no releases of hazardous substances exceeding the reportable quantity limits. The driver for accidental release reporting is Section 304 of SARA (or Section 304 of the Emergency Planning and Community Right-to-Know Act).

\subsubsection{Federal Acquisition, Recycling, and Pollution Prevention}

In July 1995, WIPP adopted a systematic and cost-effective APP for the promotion and procurement of products containing recovered materials. Affirmative procurement is designed to "close a loop" in the waste minimization and recycling processes by supporting the market for materials collected through recycling and salvage operations.

Affirmative procurement programs are mandated by the RCRA, Section 6002(i), which requires federal procuring departments to establish material preference programs targeted to purchase recycled materials. Executive Order 13101 and the EPA guidelines in 40 CFR Part 247 provides additional guidance for implementing affirmative procurement programs at federal facilities.

Affirmative procurement programs must include four elements: (1) a preference program, (2) a promotion program, (3) an estimation, certification, and verification procedure, and (4) annual review and monitoring procedures. The purchase and use of recycled products at WIPP will help foster markets for recovered materials and reduce the amount of solid waste requiring disposal.

WIPP's Affirmative Procurement Program Plan is defined WP 02-EC.07. In 2001, WTS purchased 99.99 percent of the items identified in the EPA guidelines through this 
program. WTS also purchased numerous items which were not required by the EPA program but, nevertheless, contained recovered materials.

\section{Pollution Prevention Programs}

Pollution prevention activities during 2001 included the following Pollution Prevention Opportunity Assessment (PPOA) activities:

- $\quad$ PPOA 2000-01 - Chemical Use Reduction. An assessment was performed in 2001 to evaluate (1) concerns of using similar chemicals for the same tasks, (2) benefits of implementing and expanding an online, electronic MSDS system at WIPP, (3) developing an approved chemicals list, and (4) increasing product substitution. This project was accepted and is currently in progress. Thirty-four hazardous products have been replaced/eliminated by nonhazardous products. Of these 34 products, 25 products were replaced with one product.

- $\quad$ PPOA 2001-02 - Office Supplies. It was determined that implementation of changes to the office supply program, either by an on-site store or a closed book ordering system would reduce costs and the amount of items purchased, ensure only Affirmative Procurement items would be ordered, thus bringing the site in to full compliance with Executive Order 13101, and provide easier tracking of APP items.

Noteworthy P2 activities during 2001 included the following:

- $\quad$ WTS will continue to promote affirmative procurement strategies in the following ways: evaluate ways to improve data collection of affirmative program items online, complete bench marking of all successful programs at other DOE sites, and revise the WTS APP to include the 18 additional new items that were added in January 2001.

- $\quad$ Recycling - WIPP continued its mandatory recycling program (Table 3.1). 
Table 3.1 - Materials Recycled at WIPP in 2001

\begin{tabular}{lr}
\hline & \multicolumn{1}{c}{ Mass } \\
\cline { 2 - 2 } \multicolumn{1}{c}{ Material } & Metric Tons \\
\hline Office and mixed paper & 11.33 \\
Aluminum cans & 0.37 \\
Cardboard & 5.56 \\
Batteries & 2.45 \\
Oil & 3.17 \\
Scrap metal & 132.50 \\
Plastic & 0.18 \\
Toner Cartridges & 0.85 \\
Ethylene glycol & 2.69 \\
Computer equipment & 4.71 \\
Fluorescent bulbs and debris & 0.11 \\
Solvent (RCRA) & 0.16 \\
Miscellaneous items sold at & $\mathrm{N} / \mathrm{A}$ \\
auction 257, avoiding landfill disposal & \\
\hline
\end{tabular}

\subsubsection{Resource Conservation and Recovery Act}

The RCRA (42 U.S.C. 321 et seq.) was enacted in 1976. Implementing regulations were promulgated in May 1980. This body of regulations ensures that hazardous wastes are managed and disposed of in a way that protects human health and the environment. The Hazardous and Solid Waste Amendments of 1984 prohibit land disposal of hazardous wastes unless treatment standards are met. The amendments also place increased emphasis on waste minimization activities and serve as a mechanism to enforce RCRA cleanup requirements.

Title 40 CFR Parts 280 and 281 address USTs containing petroleum products or hazardous chemicals. Requirements for UST management pertain to the design, construction, installation, and operation of USTs as well as notification and corrective action requirements in the event of a release and actions required for out-of-service USTs. The NMED was authorized by the EPA to regulate USTs. The annual registration fee for two USTs is submitted by July 1 of each year.

The NMED is authorized by the EPA to implement the RCRA program in New Mexico pursuant to the New Mexico Hazardous Waste Act. The technical standards for treatment storage and disposal facilities are outlined in 20.4.1.500 NMAC (incorporating 40 CFR Part 264). The hazardous waste management permitting program is 


\section{Waste Isolation Pilot Plant 2001 Site Environmental Report DOE/WIPP 02-2225}

administered through 20.4.1.900 NMAC (incorporating 40 CFR Part 270), which outlines the administrative aspects for processing permit applications and modifications.

WIPP was issued the HWFP on October 27, 1999. The operating conditions set forth in the permit were effective November 26, 1999. The HWFP authorized WIPP to receive, store, and dispose of $\mathrm{CH}$ TRU waste. Specifically, two storage units (the Parking Area and Waste Handling Building) and three underground Hazardous Waste Disposal Units are permitted for the management of $\mathrm{CH}$ TRU waste.

In the CY 2001, ten groups of HWFP Modifications were submitted to the NMED in accordance with 20.4.1.900 NMAC proposing approximately 27 changes to the HWFP. These modifications were processed to support economic and operational efficiencies at, not only the WIPP facility; but also to facilitate innovative technologies and simplify waste characterization and reduce employee exposure at the DOE TRU waste generator sites.

The NMED conducted an inspection at the WIPP facility on August 10, 2001, focusing on operational procedures for the receipt, management and storage of TRU waste. The inspectors observed no violations and concluded that the facility was in compliance with applicable regulations and permit conditions.

\section{Hazardous Waste Generator Compliance}

Nonradioactive hazardous waste is currently generated through normal facility operations, and is managed in Satellite Accumulation Areas and a "less-than-90-day" storage area. In addition, hazardous waste generated at WIPP is characterized, packaged, labeled, and manifested to an off-site treatment, storage, and disposal facilities in accordance with the requirements codified in 40 CFR Part 262.

\section{WIPP Solid Waste Management Units and Areas of Concerns}

The NMED issued the WIPP HWFP on October 27, 1999. Module VII of the permit contains the requirements for corrective action for the WIPP Solid Waste Management Units (SWMUs) and Areas of Concern (AOCs). The permit identified fifteen SWMUs requiring a RCRA Facility Investigation (RFI), three SWMUs not requiring a RFI (the Hazardous Waste Management Units), and eight AOCs in the 4,146 hectares (16 $\mathrm{mi}^{2}$ ) WIPP Land Withdrawal Area.

\section{Solid Waste Management Units}

The 15 SWMUs included in the permit that require a RFI are listed below:

SWMU $001 \mathrm{~g}(\mathrm{H}-14 / \mathrm{P}-1$ Mud Pits)

SWMU 001h (H-15/P-2 Mud Pits)

SWMU001j (P-3 Mud Pit)

SWMU 001k (P-4 Mud Pit)

SWMU 001I (WIPP-12/P-5 Drilling Mud Pits) 
SWMU 001m (P-6 Mud Pit)

SWMU 001n (P-15 Mud Pit)

SWMU 0010 (Badger Unit Drilling Mud Pits)

SWMU 001p (Cotton Baby Drilling Mud Pits)

SWMU 001q (DOE-1 Drilling Mud Pits)

SWMU 001s (ERDA 9 Mud Pit)

SWMU 001t (IMC 347 Mud Pit)

SWMU 001x (WIPP-13 Drilling Mud Pits)

SWMU 004a (Portacamp Storage Yard, West Side)

SWMU 007b (SW Evaporation Pond)

\section{Areas of Concern}

Following are the eight AOCs included in the permit.

AOC 001r (D-123 Mud Pit)

AOC 001u (IMC-376 Mud Pit)

AOC 001v (IMC-456 Mud Pit)

AOC 001w (IMC-457 Mud Pit)

AOC 001ac (DSP-207 Mud Pit)

AOC 001ae (IMC-377 Mud Pit)

AOC 010b (Waste Handling Shaft Sump)

AOC 010c (Exhaust Shaft Sump

The SWMU program at WIPP began in 1994 under EPA regulatory authority. The NMED subsequently received regulatory authority from the EPA. A Phase 1 RFI was completed at WIPP during 1996 as part of a Voluntary Release Assessment.

The fifteen SWMUs and eight AOCs identified in the permit are associated with natural resource exploration activities prior to the development of the WIPP, early WIPP mineral assessment and geologic studies to support facility, or facility construction.

Samples were collected at some of the SWMUs as part of a RCRA Facility Assessment performed by WTS Environmental Compliance (NMED/DOE/AIP 94/1 1994). WIPP conducted three rounds of soil sampling at selected SWMUs one in 1995, a second in 1996 , and a third in 2001. In the summer of 1995, soil samples were collected for initial characterization by the toxicity characteristic leaching procedure (TCLP). A second round of sampling at the same SWMUs was conducted in the summer of 1996 and involved collecting soil samples for total constituent analyses. A third round of sampling was requested by the NMED in 2001 . This sampling event included collecting soil samples for total constituent analyses. SWMUs 0011, 001q, 001x, and 004a were sampled for barium, chromium, lead, and nickel. The NMED sent a representative to the site during soil sampling. He split samples with the sampling team and indicated that sampling was conducted according to the Sampling and Analysis Plan. The sampling event was concluded in August. 


\section{Waste Isolation Pilot Plant 2001 Site Environmental Report}

DOE/WIPP 02-2225

The total constituent analysis data were collected based on a request from the NMED to support the TCLP data collected in the initial sampling round. The NMED reviewed the sampling conducted by WIPP at the SWMUs and defined a list of SWMUs with constituents of concern and AOCs to be included in the permit. These SWMUs/AOCs and constituents of concern for the SWMUs were described in the Technical Support Document, Exclusion/Inclusion of SWMUs and Areas of Concern, Permit Module VII Correction Action for Solid Waste Management Units (NMED 1999).

\section{Program Deliverables and Schedule}

As required by Module VII, Table $1 \mathrm{RFI} / \mathrm{CMS}$ (Corrective Measures Study) Schedule of Compliance, WIPP is in compliance with the Permit reporting requirements. The key Permit deliverables and their dates of submittal as contained in Module VII, Table 1, include: (1) the first initiating activity occurred in August of 2001; and (2) the first Quarterly Report was submitted in November 2001.

Table 3.2 - WIPP's Key RCRA ${ }^{a}$ Permit Deliverables and Due Dates

\begin{tabular}{ll}
\hline \multicolumn{1}{c}{ Due Date } & \multicolumn{1}{c}{ Deliverable(s) } \\
\hline August 2001 & $\begin{array}{l}\text { The NMED approved soil sampling activities. This initiated } \\
\text { submittal of quarterly progress reports. }\end{array}$ \\
November & Quarterly progress report for SWMU activities was submitted. \\
2001 &
\end{tabular}

The Sampling and Analysis Plan addresses the current permit requirements for an RFI of SWMUs and AOCs. It uses the results of previous investigations performed at WIPP and expands the investigations as required by the permit. As an alternative to the RFI specified in Module VII of the permit, current NMED guidance identifies an Accelerated Corrective Action Approach (ACAA) that may be used for any SWMU or AOC. This ACAA is used to replace the standard RFI Work Plan and Report sequence with a more flexible decision-making approach. The ACAA process allows a facility to proceed on an accelerated time line. The ACAA process can be entered either before or after an RFI Work Plan. According to the NMED's guidance, a facility can prepare an RFI Work Plan or ACAA for any SWMU or AOC. The NMED recognized that the facility was using the ACAA in lieu of the standard RFI in 2001.

The Sampling and Analysis Plan has two primary objectives: to define the extent of concentrations of hazardous constituents that exceed background concentrations in soil at specific SWMUs, and to perform a release assessment at specific AOCs to determine if hazardous constituents are present above background concentrations. The scope of this investigation is limited to the SWMUs and AOCs identified in the permit. 


\subsubsection{National Environmental Policy Act}

The NEPA requires the federal government to use all practicable means to consider potential environmental impacts of proposed projects as part of the decision-making process. The NEPA dictates the public shall be allowed to review and comment on proposed projects that have the potential to significantly affect the environment. The NEPA also directs the federal government to use all practicable means to improve and coordinate federal plans, functions, programs, and resources relating to human health and the environment.

NEPA procedural objectives and public involvement requirements are detailed in the Council on Environmental Quality regulations implementing NEPA in 40 CFR Parts 1500 through 1508. The DOE codified its requirements for implementing the council's regulations in $10 \mathrm{CFR}$ Part 1021. Further procedural NEPA compliance guidance is provided in DOE Order 451.1B. Title 10 CFR $\S 1021.331$ requires that, following completion of each EIS and its associated ROD, the DOE shall prepare a mitigation action plan that addresses mitigation commitments expressed in the ROD.

Day-to-day operational compliance with NEPA at WIPP is achieved through implementation of the CBFO/WTS National Environmental Policy Act Compliance Plan and the WIPP NEPA compliance procedure. These documents describe the roles and responsibilities of both the DOE NEPA Compliance Officer and the WTS NEPA Coordinator to evaluate the impacts of proposed projects at the site.

On January 29, 2001, the DOE issued an Environmental Assessment and a Finding of No Significant Impact for the proposal to conduct astrophysics and other basic science experiments at the WIPP site (DOE/EA-1340). The experiments would be conducted primarily in the WIPP underground, where the low background radiation would enhance the ability of detectors to identify some of the basic particles that are believed to make up the universe.

\subsubsection{Clean Air Act}

The Clean Air Act (42 U.S.C. 7401 et seq.) provides for the preservation, protection, and enhancement of air quality, particularly at locations of special interest such as areas of natural, recreational, scenic, or historic value.

Under Section 109 of the Clean Air Act, the EPA established the National Ambient Air Quality Standards for six "criteria" pollutants: sulfur dioxide, total suspended particulates, carbon monoxide, ozone, nitrogen oxides, and lead. These standards establish primary and secondary criteria for ambient air quality that the EPA considers necessary to protect public health and welfare.

The initial 1993 WIPP air emissions inventory was developed as a baseline document to calculate maximum potential hourly and annual emissions of both hazardous and criteria pollutants. Based on the current air emissions inventory, WIPP operations do not exceed the 10-ton-per-year emission limit for any individual hazardous air pollutant 


\section{Waste Isolation Pilot Plant 2001 Site Environmental Report DOE/WIPP 02-2225}

or the 25-ton-per-year limit for any combination of hazardous air pollutant emissions established in Subpart A of NESHAP.

Based on the initial 1993 air emissions inventory, the WIPP site is not required to obtain federal Clean Air Act permits. WIPP, in consultation with the NMED Air Quality Bureau, working in concert with data provided in the first air emissions inventory, was required to obtain a New Mexico Air Quality Control Regulation 702, Operating Permit (recodified in 1997 as 20.2.72 NMAC, "Construction Permits") for two primary backup diesel generators at the site. The only emission points where the WIPP site exceeds state threshold criteria requiring a permit are the backup diesel generators. WIPP completed all necessary requirements for emissions monitoring and sampling required by New Mexico Air Quality Permit 310-M-2. During 2001, the backup diesel generators were operated for approximately 28 of the 480 hours allowed by the permit. There were no malfunctions or abnormal conditions of operation that would cause a violation of the permit. Proposed facility modifications are reviewed to determine if they caused new air emissions and require permit applications.

WIPP's normal operations do not involve or entail any planned or expected releases of airborne radioactive materials to the workplace or the environment. Waste containers accepted for disposal at WIPP are required to meet the 10 CFR Part 835 external contamination limits. To ensure compliance, the containers are surveyed both prior to release from the generator sites and as the TRUPACT-II containers are opened at WIPP.

Since radioactive material remains in the waste containers, there are no emissions of radionuclides to the ambient air from DOE facilities during normal WIPP waste handling, and the public is not subjected to radioactivity from the WIPP facility. The WIPP 2001 NESHAP report concluded that WIPP was operated in compliance with the release standards of 40 CFR Part 191, Subpart A, and 40 CFR Part 61, Subpart H.

External doses to workers from the handling of contact-handled waste containers were estimated to be well within the DOE's "as low as reasonably achievable" goals and well below regulatory limits. Similarly, consequences to the public and workers as a result of the release of VOCs during disposal phase normal operations were shown to be many orders of magnitude below health-based limits.

\subsubsection{Clean Water Act}

Section 402 of the Clean Water Act (33 U.S.C. 1251 through 1376) establishes provisions for the issuance of permits for discharges into waters of the United States. The regulation defining the scope of the permitting process is contained in 40 CFR Part 122, Subpart A, Section (b)(1), and states that ". . . National Pollutant Discharge Elimination System (NPDES) program requires permits for the discharge of 'pollutants' from any 'point source' into waters of the United States."

In August 1997, WIPP submitted to the EPA a Notice of Intent (NOI) for Storm Water Discharges Associated with Industrial Activity under a NPDES Multi-Sector General 


\section{Waste Isolation Pilot Plant 2001 Site Environmental Report DOE/WIPP 02-2225}

Permit. Permit NMR05A823 was issued February 23, 1998. This permit expired on October 30, 2000, and a NOI was submitted to the EPA on January 29, 2001, for coverage under NPDES Storm Water Multi-Sector General Permit for Industrial Activities.

As a condition of the multi-sector general permit, a P2 plan has been developed and implemented. The plan describes how the Best Management Practices and other requirements of the NPDES storm water regulations are being implemented at WIPP.

No sampling is required to demonstrate compliance with the WIPP Storm Water Permit unless a release occurs. Operational permit compliance activities are limited to quarterly inspections of retention basins, spill containment devices, reclamation sites, and site housekeeping practices. All requirements of the NPDES storm water regulations applicable to WIPP were met during 2001.

The NPDES sewage sludge regulations promulgated in 40 CFR $\S 122.21$ require all facilities that generate or dispose of sewage sludge to submit an information package describing sewage sludge management and disposal practices. This information is reviewed by the EPA to determine if a NPDES permit will be required for the disposal of sewage sludge at a facility.

Another implementing regulation under the Clean Water Act applicable to the WIPP project is 40 CFR Part 112, "Oil Pollution Prevention," which includes criteria and guidelines for the preparation and implementation of a facility's Spill Prevention, Control, and Countermeasures (SPCC) Plan (WP 02-EC.09). The WIPP SPCC Plan undergoes and annual review and is revised as needed to reflect changes in facility activities and emergency equipment. The WIPP SPCC Plan was issued in November 1988. The revised plan was issued in June 1999.

On February 14, 1994, the DOE submitted an information package to the EPA Water Management Division and requested a written determination of whether a NPDES permit would be required for sewage sludge generated at WIPP. On March 31, 1994, the EPA Region VI Permits Issuance Section notified the DOE that they had received the information package. The agency determined that the information package was complete and, at a future date, would notify the DOE if a full and complete sewage sludge permit application would be required. To date this notification has not been made, indicating an application is not yet required.

On January 16, 1992, the NMED issued the original discharge plan (DP-831) for the WIPP sewage facility. DP-831, as amended through December 2001, allows the disposal of 23,000 gallons per day (gpd) of sewage effluent to the five lagoons; $2,000 \mathrm{gpd}$ of nonhazardous brine water to the north evaporation cell; $8,000 \mathrm{gpd}$ of nonhazardous brine water to the $\mathrm{H}-19$ evaporation pond; and 100 gallons per year of neutralized acid to the domestic wastewater lagoons. Characterization samples are collected to appropriately disposition brines prior to discharge. 
The DOE submits quarterly discharge monitoring reports to the NMED to demonstrate compliance with the inspection, monitoring, and reporting requirements identified in the plan.

DP-831 requires quarterly sampling and analysis of the sewage system influent for nitrate, total Kjeldahl nitrogen, total dissolved solids (TDS), ${ }^{238} \mathrm{Pu},{ }^{239+240} \mathrm{Pu},{ }^{241} \mathrm{Am},{ }^{234} \mathrm{U}$, ${ }^{235} \mathrm{U},{ }^{238} \mathrm{U}$, and ${ }^{90} \mathrm{Sr}$.

\subsubsection{Safe Drinking Water Act}

The SDWA (42 U.S.C. 300f, et seq.) provides the regulatory strategy for protecting public water supply systems and underground sources of drinking water. The NMED notified WIPP in a September 9, 1992, letter that the WIPP public water supply was categorized as a nontransient, noncommunity system for reporting and testing requirements.

New Mexico water supply regulations mandate that when a public water supply system supplements other systems, that water system is treated as a single system for compliance sampling purposes. The Carlsbad municipal water supply system is contracted to provide raw water to WIPP from city-owned wells $50 \mathrm{~km}(31 \mathrm{mi})$ north of the site. Because of this contractual agreement, the city of Carlsbad completes the source, or point-of-entry, samples for the various chemical constituents at each well field source.

In a letter dated August 28, 1996, the NMED set the frequency for sampling lead and copper in the drinking water supply at ten samples every three years. The required samples were collected in July 1999 and the results were submitted to the NMED. All samples were below action levels as specified by New Mexico monitoring requirements for lead and copper in tap water. The next lead and copper sampling period will be in July 2002.

Bacterial samples were collected and reported monthly throughout 2001. All bacteriological/analytical results were below the SDWA regulatory limits.

\subsubsection{National Historic Preservation Act}

The NHPA (16 U.S.C. 470 et seq.) was enacted to protect the nation's cultural resources and establish the National Register of Historic Places. Federal agencies are required to coordinate NEPA compliance with the responsibilities of the NHPA to ensure that historic and cultural properties are given proper consideration in the preparation of NEPA documentation. Agency obligations under the NHPA, however, are independent from NEPA and must be complied with even when no additional NEPA documentation is required (i.e., for proposed projects not classified as major federal actions with significant environmental impacts, the DOE must still consider impacts to historic properties and sites). Where both NEPA and the NHPA are applicable, Environmental Assessments and EISs must integrate NHPA considerations along with other environmental impact analyses and studies (see 40 CFR §1502.25). 
During 2001, one archaeological investigation was conducted to assess cultural resources in an area proposed for a range improvement. No artifacts were encountered.

\subsubsection{Hazardous Materials Transportation Act}

The Hazardous Materials Transportation Act (49 App. U.S.C.A. 1801 et seq; 49 CFR Parts 106 through 178) is one of the major transportation-related statutes that affects the DOE at WIPP. It provides for safe transportation of hazardous materials, including radioactive materials. The DOE complies with applicable U.S. Department of Transportation (DOT) regulations, corresponding NRC regulations, and DOE Orders for the transportation of hazardous materials. DOE Orders require the development of a transportation plan, and implementing procedures to ensure that the DOT regulations and requirements of each NRC-certified package is met. DOE Orders also require the use of the DOE TRANSCOM system to monitor shipments, shipment inspections, and preshipment notifications to the states.

Other federal transportation regulations applicable to WIPP include:

- $\quad$ Title 10 CFR Part 71, NRC requirements for packaging, preparing, and transporting licensed material,

- $\quad$ Title 40 CFR Part 262, Subpart B, requirements for use of the hazardous waste manifest., and

- $\quad$ Title 49 CFR Part 397, Subpart D, requirements for routing of radioactive materials.

The WTS Shipping Coordination Section implements applicable DOT and EPA regulations and DOE Orders for the transport of hazardous waste and hazardous materials from WIPP through the use of a transportation plan and implementing procedures. These implementing procedures address the classification, labeling, marking, placarding, and the shipping documentation needed to transport these materials in a safe and regulatory compliant manner. In a similar manner, shipping sites implement applicable DOT and EPA regulations and DOE Orders for the transport of TRU waste to WIPP.

\subsubsection{Packaging and Transporting Radioactive Materials}

Regulations for transportation of radioactive materials, under the authority of the DOT, are found in 49 CFR Parts 171 through 178. If the quantity of radioactive material exceeds certain limits, as determined by 49 CFR $\$ 173.431$, a Type B shipping container (packaging) must be used. The specific requirements for the shipment of radioactive materials and requirements applicable to the Type B packages to be used to transport waste to the WIPP facility are detailed in 49 CFR Parts 171 through 173, 40 CFR Part 262, and the NRC Certificate of Compliance (C of C) for the package. Regulations for Type B packaging, under the authority of the NRC, are found in 


\section{Waste Isolation Pilot Plant 2001 Site Environmental Report DOE/WIPP 02-2225}

10 CFR Part 71, "Packaging and Transportation of Radioactive Materials." The WIPP Land Withdrawal Act requires that TRU waste containers shipped to WIPP shall be transported using packages which have had the design certified by the NRC and which have been determined by the NRC to satisfy its QA requirements.

Additional transportation requirements for the mixed waste shipments (i.e., TRU mixed wastes) are detailed in 40 CFR Part 262. The appendix to Part 262 provides an example of a uniform hazardous waste manifest and instructions to waste generators and shippers of hazardous wastes.

Contact-handled TRU waste is shipped in the TRUPACT-II and the HalfPACT. The HalfPACT is a shorter version of the TRUPACT-II; it was designed to transport heavier contact-handled TRU waste containers. The NRC certified the TRUPACT-II container on August 30,1989. Since 1989, expansion of the TRUPACT-II payload envelope has been accomplished through applications to the NRC for revisions of the TRUPACT-II Safety Analysis Report for Packaging and the $\mathrm{C}$ of $\mathrm{C}$, when applicable. The current revision of the TRUPACT-II C of C, No. 11, expires June 30, 2004. The current revision of the HalfPACT C of C, No. 9279, expires October 30, 2005.

Remote handled waste will be shipped in the RH-72B and the CNS 10-160B casks. The current $\mathrm{C}$ of $\mathrm{C}$ for the $\mathrm{RH}-72 \mathrm{~B}$ cask expires February 8,2005 . The current revision of the $\mathrm{C}$ of $\mathrm{C}$ for the 10-160B expires October 31, 2005.

For the transportation of TRU waste emergency response is addressed by defense in depth. The first line of defense is the packaging itself. The NRC-certified packagings are able to survive "hypothetical" accident conditions without loss of contents. The testing process subjects the package to forces that are more severe than those that would be experienced in a vehicular accident.

The second line of defense rests with the driver. The qualifications for the drivers is set at a high mark. The driver's record is reviewed for at least five years. The driver must be accident free and moving violation free in this time period. In addition to prior skills, the driver must attend and pass WIPP-specified training. To date, WIPP drivers have traveled over miles without a vehicle accident.

In the event an incident should occur, the DOE has trained emergency responders and hospital personnel along the routes in the actions to mitigate the incident. In addition, to the training provided to the first responders, the DOE and the states have conducted "WIPPTREXes" (training exercises) to provide the emergency response personnel the opportunity to put into practice the training they receive. In addition to the training the DOE has an Incident/Accident Response Team that is on standby to respond to an incident to assist the on-scene Incident Commander in the mitigation of the incident. 


\subsection{Other Significant Accomplishments and Ongoing Compliance Activities}

\subsubsection{Environmental Compliance Assessment Program}

The Environmental Compliance Assessment Program plays a major role in the overall program for environmental protection activities at WIPP. The program was developed to determine if impactive or potentially impactive facility activities protect human health and the environment and if these activities are in compliance with applicable federal, state, and local requirements; with permit conditions and requirements; and with best management practices.

\subsubsection{Environmental Management System}

WTS has implemented an EMS that conforms to the requirements of ISO 14001. ISO 14001 is the specific standard within the ISO 14000 family of standards that provides specifications for EMSs. The WTS EMS received third-party registration on August 5, 1997, following a comprehensive audit by Advanced Waste Management Systems, Inc. This recognition provided independent verification of the disciplined and systematic approach WTS applies to achieve excellent environmental performance while operating WIPP. The EMS, including environmental aspects, objectives, and targets, is reviewed and updated by WTS senior management at least annually.

Advanced Waste Management Systems, Inc. performed two surveillance audits of the WTS EMS in 2001. There were no nonconformance issues identified during the 2001 surveillance period. Two third-party surveillance audits are scheduled during 2002 as required for continued ISO 14001 registration.

Integration of WIPP's EMS with other WTS, DOE, and EPA programs, such as the Voluntary Protection Program, the Integrated Safety Management System, and the National Environmental Performance Track, is under way. WTS also shares its EMS experience with other interested organizations in both the public and private sectors to achieve even broader positive environmental results.

Additional information, including the WTS Environmental Management Policy, is available to the public via the world-wide-web or by calling the information line at 1-800-336-WIPP.

\subsubsection{Pollution Prevention Committee}

The P2 Committee was formed in 1993 with a representative from each department. The primary purpose of this committee is to foster recycling activities at WIPP. The committee prepared a waste minimization charter, which outlines the committee's responsibilities.

On Earth Day, 2001, the committee conducted activities to heighten employee awareness of the dangers of household chemicals. Information was also provided to 
WIPP employees on nonhazardous substitutions for hazardous household cleaning products.

The WIPP P2 Committee celebrated America Recycles Day in November 2001, using a display describing the "Trail of Trash." This display demonstrated how much trash is generated by the average New Mexico family, how it is disposed of either in the landfill or by recycling, and how the items that are recycled are made into useable products.

During October 2001, Energy Month was celebrated with posters being hung around site emphasizing the importance of saving energy.

\subsubsection{Environmental Training}

Environmental training was provided to personnel associated with environmental operations at WIPP. Training courses included technical topics (e.g., RCRA sampling), EMS, basic environmental safety and health training, and general sitewide training such as the required General Employee Training module. These courses were conducted both on-site by WIPP personnel and off-site by various contractors. 


\section{Waste Isolation Pilot Plant 2001 Site Environmental Report}

\section{DOE/WIPP 02-2225}

Table 3.3 - Activities Associated with Major Environmental Regulations Applicable to the WIPP Project

\begin{tabular}{|c|c|}
\hline Statute/Regulation & Related Activity \\
\hline $\begin{array}{l}\text { Atomic Energy Act of } 1954 \text { (42 U.S.C. 2278a) and } \\
40 \text { CFR Part 191, Subpart A }\end{array}$ & $\begin{array}{l}\text { WIPP was authorized by the DOE and the EPA to open. Monitoring/reporting began upon first } \\
\text { receipt of waste, March 26, } 1999 \text {. }\end{array}$ \\
\hline Clean Air Act & Monitoring/reporting began upon first receipt of waste, March 26, 1999. \\
\hline Clean Water Act & $\begin{array}{l}\text { Quarterly inspections of best management practices to comply with (storm water retention } \\
\text { basins) NPDES storm water general permit (NMR05A823). }\end{array}$ \\
\hline $\begin{array}{l}\text { Comprehensive Environmental Response, } \\
\text { Compensation, and Liability Act/SARA }\end{array}$ & $\begin{array}{l}\text { No CERCLA site cleanup required. Reports filed as required under SARA for hazardous } \\
\text { substances are maintained on site. }\end{array}$ \\
\hline Endangered Species Act of 1973 & $\begin{array}{l}\text { In November 1996, WIPP completed the } 1996 \text { Threatened and Endangered Species Survey. } \\
\text { The survey is part of the analysis required for the SEIS-II. There were no threatened or } \\
\text { endangered species located on WIPP land. Individual permits to collect biological samples and } \\
\text { to band nonendangered species of raptors are maintained. Consultation with federal and state } \\
\text { agencies is not required. }\end{array}$ \\
\hline Federal Land Policy and Management Act & $\begin{array}{l}\text { An MOU between the DOE and the BLM was issued in July } 1994 \text {. This MOU outlines the } \\
\text { responsibilities the BLM and the DOE have with regard to land use management for the } \\
\text { withdrawal area. }\end{array}$ \\
\hline $\begin{array}{l}\text { Federal Insecticide, Fungicide, and Rodenticide Act } \\
\text { (7 U.S.C. 136-136y) }\end{array}$ & All pesticides must be approved by Industrial Safety and Hygiene. \\
\hline Hazardous Materials Transportation Act & $\begin{array}{l}\text { Appropriate shipping papers accompany hazardous materials and hazardous wastes shipped off- } \\
\text { site to ensure compliance with the act. }\end{array}$ \\
\hline \multirow[t]{2}{*}{$\begin{array}{l}\text { National Environmental Policy Act (as supplemented } \\
\text { by DOE Order 451.1B, and } 10 \text { CFR Part 1021) }\end{array}$} & $\begin{array}{l}\text { The } 2001 \text { Annual Mitigation Report for the Waste Isolation Pilot Plant (NEPA ID\# WIP:00:001) } \\
\text { was issued July 2001, in accordance with the requirement of DOE Order 451.1B, National } \\
\text { Environmental Policy Act Compliance Program. This order requires DOE facilities to track and } \\
\text { annually report progress in implementing a commitment for environmental impact mitigation that } \\
\text { is essential to render the impacts of a proposed action nonsignificant or that is made in the ROD. }\end{array}$ \\
\hline & $\begin{array}{l}\text { The Environmental Assessment for Conducting Astrophysics and Other Basic Science } \\
\text { Experiments at the WIPP Site (DOE/EA-1340) was issued in January 2001. This Environmental } \\
\text { Assessment was required to support a congressional directive to make maximum use of existing } \\
\text { WIPP facilities to further the scientific missions assigned to the DOE by Congress. }\end{array}$ \\
\hline
\end{tabular}




\section{Waste Isolation Pilot Plant 2001 Site Environmental Report}

\section{DOE/WIPP 02-2225}

Table 3.3 - Activities Associated with Major Environmental Regulations Applicable to the WIPP Project

\begin{tabular}{|c|c|}
\hline Statute/Regulation & Related Activity \\
\hline National Historic Preservation Act & $\begin{array}{l}\text { Activities requiring excavation in previously undisturbed areas are surveyed by licensed, } \\
\text { permitted archaeologists. Required reports are submitted to the New Mexico State Historic } \\
\text { Preservation Officer. }\end{array}$ \\
\hline $\begin{array}{l}\text { New Mexico Air Quality Control Act (NMSA } 1978 \\
\S 74-2)\end{array}$ & $\begin{array}{l}\text { During } 2001 \text {, the backup diesel generators were operated for approximately } 28 \text { of the } 480 \text { hours } \\
\text { allowed by the permit. There were no malfunctions or abnormal conditions of operation that } \\
\text { would cause a violation of the permit. }\end{array}$ \\
\hline New Mexico Water Quality Act & $\begin{array}{l}\text { The NMED has issued a ground water discharge plan (DP-831) to WIPP for the disposal of site } \\
\text { generated wastewater. The DOE submits quarterly discharge monitoring reports to the NMED } \\
\text { Groundwater Quality Bureau to comply with the requirements of DP-831. }\end{array}$ \\
\hline New Mexico Wildlife Conservation Act & See "Endangered Species Act." \\
\hline Resource Conservation and Recovery Act & $\begin{array}{l}\text { Hazardous-waste generator compliance: All site generated hazardous wastes were transported } \\
\text { offsite within the 90-day accumulation period. Permit compliance: NMED granted RCRA permit } \\
\text { NM4890139088 effective November 26, 1999. Underground Storage Tanks: Annual registration } \\
\text { fee paid. }\end{array}$ \\
\hline $\begin{array}{l}\text { Toxic Substances Control Act (15 U.S.C. } 2301 \\
\text { et seq) }\end{array}$ & $\begin{array}{l}\text { Procurement of asbestos- or PCB-containing materials not allowed. Other portions of the Toxic } \\
\text { Substances Control Act are not applicable. }\end{array}$ \\
\hline Safe Drinking Water Act & $\begin{array}{l}\text { The WIPP public water system is characterized as a nontransient, noncommunity system } \\
\text { (NMED, September 9, 1992). Drinking water is piped from the Carlsbad, New Mexico, municipal } \\
\text { system and the city of Carlsbad is responsible for compliance. }\end{array}$ \\
\hline
\end{tabular}




\section{Waste Isolation Pilot Plant 2001 Site Environmental Report}

\section{DOE/WIPP 02-2225}

Table 3.4 - Primary DOE Orders Affecting the WIPP Environmental Program

\begin{tabular}{|c|c|c|}
\hline Order No. & Title & Annotation \\
\hline $\begin{array}{l}\text { DOE Order } 5400.1 \text { Paragraphs } 2 \mathrm{~B}, \\
4 \mathrm{~B}, \text { and } 4 \mathrm{C} \text { of Chapter II, and } 2 \mathrm{D} \\
\text { and } 3 \mathrm{~B} \text { of Chapter III were canceled } \\
\text { and replaced by DOE O } 231.1\end{array}$ & $\begin{array}{l}\text { General Environmental } \\
\text { Protection Program }\end{array}$ & $\begin{array}{l}\text { Establishes environmental protection program requirements, authorities, and responsibilities for } \\
\text { DOE operations for ensuring compliance with federal and state environmental protection laws } \\
\text { and regulations, federal executive orders, and internal department policies. }\end{array}$ \\
\hline $\begin{array}{l}\text { DOE Order } 5400.5 \\
\text { Paragraph } 1 \mathrm{~A}(3)(\mathrm{A}) \text { of Chapter II is } \\
\text { canceled by DOE O } 231.1\end{array}$ & $\begin{array}{l}\text { Radiation Protection of } \\
\text { the Public and the } \\
\text { Environment }\end{array}$ & $\begin{array}{l}\text { Establishes standards and requirements for operations of the DOE and DOE contractors with } \\
\text { respect to protection of the public and the environment against undue risk from radiation. }\end{array}$ \\
\hline DOE O 231.1, Change 2 & $\begin{array}{l}\text { Environmental, Safety, and } \\
\text { Health Reporting }\end{array}$ & Ensures collecting and reporting on environment, safety, and health information. \\
\hline $\begin{array}{l}\text { DOE O } 225.1 \mathrm{~A} \text {, cancels } \\
\text { DOE O } 225.1\end{array}$ & Accident Investigation & $\begin{array}{l}\text { Prescribes requirements for conducting investigations of accidents and preventing recurrence of } \\
\text { such accidents. }\end{array}$ \\
\hline DOE O 414.1A & Quality Assurance & Promotes effective management through performance requirements and technical standards. \\
\hline DOE O 435.1 & $\begin{array}{l}\text { Radioactive Waste } \\
\text { Management }\end{array}$ & $\begin{array}{l}\text { Promotes radioactive waste management in a manner that is protective of workers, public health } \\
\text { and safety, and the environment. }\end{array}$ \\
\hline DOE O 451.1B & $\begin{array}{l}\text { National Environmental Policy } \\
\text { Act Compliance Program }\end{array}$ & Establishes DOE policy for implementation of the NEPA of 1969 (Pub. L. 91-190). \\
\hline DOE O 460.1A & $\begin{array}{l}\text { Packaging and Transportation } \\
\text { Safety }\end{array}$ & $\begin{array}{l}\text { Establishes safety requirements for the proper packaging and transporting of DOE offsite } \\
\text { shipments and onsite transfers of hazardous materials and for model transportation. }\end{array}$ \\
\hline DOE 5480.23 & $\begin{array}{l}\text { Nuclear Safety Analysis } \\
\text { Reports }\end{array}$ & $\begin{array}{l}\text { Establishes uniform requirements for the preparation and review of safety analyses of DOE } \\
\text { operations that include the following: identification of hazards, their elimination or control, } \\
\text { assessment of risk, and documented management authorization of their operation. }\end{array}$ \\
\hline DOE O 151.1 & $\begin{array}{l}\text { Comprehensive Emergency } \\
\text { Management System }\end{array}$ & $\begin{array}{l}\text { Establishes requirements for comprehensive planning, preparedness, response, and recovery } \\
\text { activities of emergency management programs for the DOE and for programs requiring DOE } \\
\text { assistance. }\end{array}$ \\
\hline DOE O 430.1A & $\begin{array}{l}\text { Life-Cycle Assessment } \\
\text { Management }\end{array}$ & $\begin{array}{l}\text { Establishes procedures to plan, acquire, operate, maintain, and dispose of physical assets as } \\
\text { valuable national resources. }\end{array}$ \\
\hline
\end{tabular}




\section{Waste Isolation Pilot Plant 2001 Site Environmental Report}

DOE/WIPP 02-2225

Table 3.5 - Active Environmental Permits and Approvals for the Waste Isolation Pilot Plant (as of December 31, 2001)

(Does Not Include RCRA Permits)

\begin{tabular}{|c|c|c|c|c|c|c|c|c|}
\hline Granting Agency & Type of Permit & Permit Number & $\begin{array}{l}\text { Granted/ } \\
\text { Submitted }\end{array}$ & Expiration & $\begin{array}{l}\text { Current Permit } \\
\text { Status }\end{array}$ & WTS Owner & Signed By/Title & Signed For \\
\hline $\begin{array}{l}\text { Department of the } \\
\text { Interior, BLM }\end{array}$ & $\begin{array}{l}\text { Right-of-Way for Water } \\
\text { Pipeline }\end{array}$ & NM53809 & $08 / 17 / 83$ & $\begin{array}{c}\text { In } \\
\text { Perpetuity }\end{array}$ & Active & $\begin{array}{l}\text { Environmental } \\
\text { Monitoring }\end{array}$ & $\begin{array}{l}\text { Issued by BLM - WIPP } \\
\text { signature not required }\end{array}$ & DOE \\
\hline $\begin{array}{l}\text { Department of the } \\
\text { Interior, BLM }\end{array}$ & $\begin{array}{l}\text { Right-of-Way for the North } \\
\text { Access Road }\end{array}$ & NM55676 & $08 / 24 / 83$ & None & Active & $\begin{array}{l}\text { Environmental } \\
\text { Monitoring }\end{array}$ & $\begin{array}{l}\text { Issued by BLM - WIPP } \\
\text { signature not required }\end{array}$ & $\overline{\mathrm{DOE}}$ \\
\hline $\begin{array}{l}\text { Department of the } \\
\text { Interior, BLM }\end{array}$ & Right-of-Way for Railroad & NM55699 & $09 / 27 / 83$ & None & Active & $\begin{array}{l}\text { Environmental } \\
\text { Monitoring }\end{array}$ & $\begin{array}{l}\text { Issued by BLM - WIPP } \\
\text { signature not required }\end{array}$ & $\overline{\mathrm{DOE}}$ \\
\hline $\begin{array}{l}\text { Department of the } \\
\text { Interior, BLM }\end{array}$ & $\begin{array}{l}\text { Right-of-Way for Dosimetry } \\
\text { and Aerosol Sampling Sites }\end{array}$ & NM63136 & $07 / 31 / 86$ & $07 / 31 / 11$ & Active & $\begin{array}{l}\text { Environmental } \\
\text { Monitoring }\end{array}$ & $\begin{array}{l}\text { Issued by BLM - WIPP } \\
\text { signature not required }\end{array}$ & $\mathrm{DOE}$ \\
\hline $\begin{array}{l}\text { Department of the } \\
\text { Interior, BLM }\end{array}$ & \begin{tabular}{|l|} 
Right-of-Way for Seven \\
Subsidence Monuments \\
\end{tabular} & NM65801 & $11 / 07 / 86$ & None & Active & \begin{tabular}{|l|} 
Environmental \\
Monitoring \\
\end{tabular} & \begin{tabular}{|l|} 
Issued by BLM - WIPP \\
signature not required \\
\end{tabular} & $\mathrm{DOE}$ \\
\hline $\begin{array}{l}\text { Department of the } \\
\text { Interior, BLM }\end{array}$ & $\begin{array}{l}\text { Right-of-Way for Aerosol } \\
\text { Sampling Site }\end{array}$ & NM77921 & $08 / 18 / 89$ & $08 / 18 / 19$ & Active & $\begin{array}{l}\text { Environmental } \\
\text { Monitoring }\end{array}$ & $\begin{array}{l}\text { Issued by BLM - WIPP } \\
\text { signature not required }\end{array}$ & $\overline{\mathrm{DOE}}$ \\
\hline $\begin{array}{l}\text { Department of the } \\
\text { Interior, BLM }\end{array}$ & $\begin{array}{l}\text { Right-of-Way for Two Survey } \\
\text { Monuments }\end{array}$ & NM82245 & $12 / 13 / 89$ & $12 / 13 / 19$ & Active & $\begin{array}{l}\text { Environmental } \\
\text { Monitoring }\end{array}$ & $\begin{array}{l}\text { Issued by BLM - WIPP } \\
\text { signature not required }\end{array}$ & $\mathrm{DOE}$ \\
\hline $\begin{array}{l}\text { Department of the } \\
\text { Interior, BLM }\end{array}$ & $\begin{array}{l}\text { Right-of-Way for Telephone } \\
\text { Cable }\end{array}$ & NM46029 & $07 / 03 / 90$ & $09 / 04 / 11$ & Active & \begin{tabular}{|l} 
Environmental \\
Monitoring \\
\end{tabular} & $\begin{array}{l}\text { Issued by BLM - WIPP } \\
\text { signature not required }\end{array}$ & $\mathrm{DOE}$ \\
\hline $\begin{array}{l}\text { Department of the } \\
\text { Interior, BLM }\end{array}$ & $\begin{array}{l}\text { Right-of-Way for SPS } \\
\text { Powerline }\end{array}$ & NM43203 & $02 / 20 / 96$ & $10 / 19 / 11$ & Active & $\begin{array}{l}\text { Environmental } \\
\text { Monitoring }\end{array}$ & $\begin{array}{l}\text { Issued by BLM - WIPP } \\
\text { signature not required }\end{array}$ & $\mathrm{DOE}$ \\
\hline $\begin{array}{l}\text { Department of the } \\
\text { Interior, BLM }\end{array}$ & $\begin{array}{l}\text { Right-of-Way for South } \\
\text { Access Road }\end{array}$ & NM46130 & $09 / 26 / 94$ & $08 / 17 / 31$ & Active & $\begin{array}{l}\text { Environmental } \\
\text { Monitoring } \\
\end{array}$ & $\begin{array}{l}\text { Issued by BLM - WIPP } \\
\text { signature not required }\end{array}$ & $\mathrm{DOE}$ \\
\hline $\begin{array}{l}\text { Department of the } \\
\text { Interior, BLM }\end{array}$ & $\begin{array}{l}\text { Right-of-Way for Duval } \\
\text { Telephone Line }\end{array}$ & NM60174 & $11 / 06 / 96$ & $03 / 08 / 15$ & Active & \begin{tabular}{|l|} 
Environmental \\
Monitoring \\
\end{tabular} & $\begin{array}{l}\text { Issued by BLM - WIPP } \\
\text { signature not required }\end{array}$ & $\mathrm{DOE}$ \\
\hline $\begin{array}{l}\text { Department of the } \\
\text { Interior, BLM }\end{array}$ & $\begin{array}{l}\text { Right-of-Way for Wells AEC-7 } \\
\text { and AEC-8 }\end{array}$ & NM300603-SLU-12 & $07 / 23 / 75$ & None & Active & \begin{tabular}{|l|} 
Environmental \\
Monitoring \\
\end{tabular} & \begin{tabular}{|l|} 
Issued by BLM - WIPP \\
signature not required \\
\end{tabular} & $\overline{\mathrm{DOE}}$ \\
\hline $\begin{array}{l}\text { Department of the } \\
\text { Interior, BLM }\end{array}$ & Right-of-Way for ERDA-6 & \begin{tabular}{|l|} 
NM300605-SLU-29 \\
\end{tabular} & $05 / 12 / 75$ & None & Active & \begin{tabular}{|l|} 
Environmental \\
Monitoring \\
\end{tabular} & $\begin{array}{l}\text { Issued by BLM - WIPP } \\
\text { signature not required }\end{array}$ & $\overline{\mathrm{DOE}}$ \\
\hline $\begin{array}{l}\text { Department of the } \\
\text { Interior, BLM }\end{array}$ & $\begin{array}{l}\text { Right-of-Way for Monitoring } \\
\text { Wells C-2752 (ERDA-9) and } \\
\text { C-2765 (H-1) }\end{array}$ & NM0606-SLU-34 & $03 / 31 / 76$ & None & Active & $\begin{array}{l}\text { Environmental } \\
\text { Monitoring }\end{array}$ & $\begin{array}{l}\text { Issued by BLM - WIPP } \\
\text { signature not required }\end{array}$ & DOE \\
\hline $\begin{array}{l}\text { Department of the } \\
\text { Interior, BLM }\end{array}$ & Right-of-Way for ERDA 11 & NM0607-LUP-63 & $08 / 19 / 77$ & None & Active & $\begin{array}{l}\text { Environmental } \\
\text { Monitoring }\end{array}$ & $\begin{array}{l}\text { Issued by BLM - WIPP } \\
\text { signature not required }\end{array}$ & $\overline{\mathrm{DOE}}$ \\
\hline $\begin{array}{l}\text { Department of the } \\
\text { Interior, BLM }\end{array}$ & Right-of-Way for ERDA-13 & NM0606-SLU-38 & $07 / 15 / 77$ & None & Active & $\begin{array}{l}\text { Environmental } \\
\text { Monitoring }\end{array}$ & $\begin{array}{l}\text { Issued by BLM - WIPP } \\
\text { signature not required }\end{array}$ & $\mathrm{DOE}$ \\
\hline $\begin{array}{l}\text { Department of the } \\
\text { Interior, BLM }\end{array}$ & Right-of-Way for ERDA-14 & NM0607-TUP-62 & $06 / 29 / 77$ & None & Active & $\begin{array}{l}\text { Environmental } \\
\text { Monitoring }\end{array}$ & $\begin{array}{l}\text { Issued by BLM - WIPP } \\
\text { signature not required }\end{array}$ & $\overline{\mathrm{DOE}}$ \\
\hline
\end{tabular}


Waste Isolation Pilot Plant 2001 Site Environmental Report DOE/WIPP 02-2225

Table 3.5 - Active Environmental Permits and Approvals for the Waste Isolation Pilot Plant (as of December 31, 2001)

(Does Not Include RCRA Permits)

\begin{tabular}{|c|c|c|c|c|c|c|c|c|}
\hline Granting Agency & Type of Permit & Permit Number & $\begin{array}{l}\text { Granted/ } \\
\text { Submitted }\end{array}$ & Expiration & $\begin{array}{l}\text { Current Permit } \\
\text { Status }\end{array}$ & WTS Owner & Signed By/Title & Signed For \\
\hline $\begin{array}{l}\text { Department of the } \\
\text { Interior, BLM }\end{array}$ & $\begin{array}{l}\text { Right-of-Way for Monitoring } \\
\text { Wells C-2762 (H-2) and } \\
\text { C-2764 (H-3) }\end{array}$ & NM0606-SLU-41 & $07 / 14 / 77$ & None & Active & $\begin{array}{l}\text { Environmental } \\
\text { Monitoring }\end{array}$ & $\begin{array}{l}\text { Issued by BLM - WIPP } \\
\text { signature not required }\end{array}$ & DOE \\
\hline $\begin{array}{l}\text { Department of the } \\
\text { Interior, BLM }\end{array}$ & $\begin{array}{l}\text { Right-of-Way for Wells } \mathrm{P}-1 \text {, } \\
\mathrm{P}-2, \mathrm{P}-3 \text {, and } \mathrm{P}-4\end{array}$ & NM060-SLU-48 & $05 / 16 / 77$ & None & Active & \begin{tabular}{|l|} 
Environmental \\
Monitoring \\
\end{tabular} & $\begin{array}{l}\text { Issued by BLM - WIPP } \\
\text { signature not required }\end{array}$ & DOE \\
\hline $\begin{array}{l}\text { Department of the } \\
\text { Interior, BLM }\end{array}$ & $\begin{array}{l}\text { Right-of-Way for Wells P-5, } \\
\text { P-6, and P-7 }\end{array}$ & NM060-SLU-50 & $05 / 16 / 77$ & None & Active & $\begin{array}{l}\text { Environmental } \\
\text { Monitoring }\end{array}$ & $\begin{array}{l}\text { Issued by BLM - WIPP } \\
\text { signature not required }\end{array}$ & $\overline{D O E}$ \\
\hline $\begin{array}{l}\text { Department of the } \\
\text { Interior, BLM }\end{array}$ & $\begin{array}{l}\text { Right-of-Way for Wells P-8, } \\
\text { P-9, P-12, P-13, P-20, and } \\
\text { Monitoring Wells C-2637 } \\
\text { (P-14), C-2686 (P-15), } \\
\text { C-2756 (P-18) }\end{array}$ & NM060-SLU-52 & $05 / 16 / 77$ & None & Active & $\begin{array}{l}\text { Environmental } \\
\text { Monitoring }\end{array}$ & $\begin{array}{l}\text { Issued by BLM - WIPP } \\
\text { signature not required }\end{array}$ & $\mathrm{DOE}$ \\
\hline $\begin{array}{l}\text { Department of the } \\
\text { Interior, BLM }\end{array}$ & $\begin{array}{l}\text { Right-of-Way for Wells P-10, } \\
\text { P-11, P-16, P-19, P-21, and } \\
\text { Monitoring Well C-2774 } \\
\text { (P-17) }\end{array}$ & NM0606-SLU-54 & $11 / 08 / 76$ & None & Active & $\begin{array}{l}\text { Environmental } \\
\text { Monitoring }\end{array}$ & $\begin{array}{l}\text { Issued by BLM - WIPP } \\
\text { signature not required }\end{array}$ & $\mathrm{DOE}$ \\
\hline $\begin{array}{l}\text { Department of the } \\
\text { Interior, BLM }\end{array}$ & $\begin{array}{l}\text { Right-of-Way for } \\
\text { Archaeological Clearance for } \\
\text { Wells P-5 - P-21 }\end{array}$ & $\begin{array}{c}\text { NM-6-5 } \\
\text { Cooperative } \\
\text { Agreement }\end{array}$ & $05 / 19 / 81$ & None & Active & $\begin{array}{l}\text { Environmental } \\
\text { Monitoring }\end{array}$ & $\begin{array}{l}\text { Issued by BLM - WIPP } \\
\text { signature not required }\end{array}$ & $\mathrm{DOE}$ \\
\hline $\begin{array}{l}\text { Department of the } \\
\text { Interior, BLM }\end{array}$ & $\begin{array}{l}\text { Right-of-Way for Access } \\
\text { Road for Monitoring Wells } \\
\text { C-2639 (WIPP-12) and } \\
\text { C-2748 (WIPP-13) }\end{array}$ & $\begin{array}{c}\text { NM-6-5 } \\
\text { Cooperative } \\
\text { Agreement }\end{array}$ & $04 / 19 / 78$ & None & Active & $\begin{array}{l}\text { Environmental } \\
\text { Monitoring }\end{array}$ & $\begin{array}{l}\text { Issued by BLM - WIPP } \\
\text { signature not required }\end{array}$ & $\overline{D O E}$ \\
\hline $\begin{array}{l}\text { Department of the } \\
\text { Interior, BLM }\end{array}$ & \begin{tabular}{|l} 
Right-of-Way for \\
Meteorological Tower
\end{tabular} & NM060-SLU-43 & $02 / 04 / 77$ & None & Active & \begin{tabular}{|l|} 
Environmental \\
Monitoring \\
\end{tabular} & $\begin{array}{l}\begin{array}{l}\text { Issued by BLM - WIPP } \\
\text { signature not required }\end{array} \\
\end{array}$ & $\overline{D O E}$ \\
\hline $\begin{array}{l}\text { Department of the } \\
\text { Interior, BLM }\end{array}$ & $\begin{array}{l}\text { Right-of-Way for Aerosol } \\
\text { Sampler }\end{array}$ & NM067-LUP-221 & $05 / 25 / 85$ & None & Active & \begin{tabular}{|l} 
Environmental \\
Monitoring \\
\end{tabular} & $\begin{array}{l}\text { Issued by BLM - WIPP } \\
\text { signature not required }\end{array}$ & $\mathrm{DOE}$ \\
\hline $\begin{array}{l}\text { Department of the } \\
\text { Interior, BLM }\end{array}$ & $\begin{array}{l}\text { Right-of-Way for North } \\
\text { Access Road Batch Plant }\end{array}$ & NM060-LUP-212 & $10 / 09 / 84$ & None & Active & \begin{tabular}{|l} 
Environmental \\
Monitoring \\
\end{tabular} & $\begin{array}{l}\text { Issued by BLM - WIPP } \\
\text { signature not required }\end{array}$ & $\mathrm{DOE}$ \\
\hline $\begin{array}{l}\text { Department of the } \\
\text { Interior, BLM }\end{array}$ & $\begin{array}{l}\text { Right-of-Way for Construction } \\
\text { Landfill }\end{array}$ & NM067-LUP-219 & $12 / 08 / 95$ & None & Active & \begin{tabular}{|l|} 
Environmental \\
Monitoring \\
\end{tabular} & $\begin{array}{l}\text { Issued by BLM - WIPP } \\
\text { signature not required }\end{array}$ & $\mathrm{DOE}$ \\
\hline $\begin{array}{l}\text { Department of the } \\
\text { Interior, BLM }\end{array}$ & \begin{tabular}{|l} 
Right-of-Way for Monitoring \\
Well C-2664 (Cabin Baby)
\end{tabular} & NM0606-SLU-40 & $07 / 14 / 76$ & None & Active & \begin{tabular}{|l|} 
Environmental \\
Monitoring \\
\end{tabular} & $\begin{array}{l}\text { Issued by BLM - WIPP } \\
\text { signature not required }\end{array}$ & $\overline{\mathrm{DOE}}$ \\
\hline $\begin{array}{l}\text { Department of the } \\
\text { Interior, BLM }\end{array}$ & \begin{tabular}{|l|} 
Right-of-Way for Seismic \\
Monitoring Station
\end{tabular} & NM85426 & $09 / 23 / 91$ & None & Active & $\begin{array}{l}\text { Environmental } \\
\text { Monitoring }\end{array}$ & $\begin{array}{l}\text { Issued by BLM - WIPP } \\
\text { signature not required }\end{array}$ & DOE \\
\hline
\end{tabular}




\section{Waste Isolation Pilot Plant 2001 Site Environmental Report}

DOE/WIPP 02-2225

Table 3.5 - Active Environmental Permits and Approvals for the Waste Isolation Pilot Plant (as of December 31, 2001)

(Does Not Include RCRA Permits)

\begin{tabular}{|c|c|c|c|c|c|c|c|c|}
\hline Granting Agency & Type of Permit & Permit Number & $\begin{array}{l}\text { Granted/ } \\
\text { Submitted }\end{array}$ & Expiration & $\begin{array}{l}\text { Current Permit } \\
\text { Status }\end{array}$ & WTS Owner & Signed By/Title & Signed For \\
\hline $\begin{array}{l}\text { Department of the } \\
\text { Interior, BLM }\end{array}$ & $\begin{array}{l}\text { Right-of-Way for Monitoring } \\
\text { Wells C-2684 (WIPP-18), } \\
\text { C-2755 (WIPP-19), C-2754 } \\
\text { (WIPP-21) and Well WIPP-22 }\end{array}$ & $\begin{array}{c}\text { NM-6-5 } \\
\text { Cooperative } \\
\text { Agreement }\end{array}$ & $03 / 02 / 78$ & None & Active & $\begin{array}{l}\text { Environmental } \\
\text { Monitoring }\end{array}$ & $\begin{array}{l}\text { Issued by BLM - WIPP } \\
\text { signature not required }\end{array}$ & DOE \\
\hline $\begin{array}{l}\text { Department of the } \\
\text { Interior, BLM }\end{array}$ & $\begin{array}{l}\text { Right-of-Way for Well } \\
\text { WIPP-15 }\end{array}$ & $\begin{array}{c}\text { NM-6-5 } \\
\text { Cooperative } \\
\text { Agreement }\end{array}$ & $01 / 19 / 78$ & None & Active & $\begin{array}{l}\text { Environmental } \\
\text { Monitoring }\end{array}$ & $\begin{array}{l}\text { Issued by BLM - WIPP } \\
\text { signature not required }\end{array}$ & $\mathrm{DOE}$ \\
\hline $\begin{array}{l}\text { Department of the } \\
\text { Interior, BLM }\end{array}$ & \begin{tabular}{|l} 
Right-of-Way for Wells \\
C-2725 (H-4A), C-2775 \\
$(\mathrm{H}-4 \mathrm{~B})$, and C-2776 (H-4C)
\end{tabular} & $\begin{array}{c}\text { NM-6-5 } \\
\text { Cooperative } \\
\text { Agreement }\end{array}$ & $04 / 27 / 78$ & None & Active & $\begin{array}{l}\text { Environmental } \\
\text { Monitoring }\end{array}$ & $\begin{array}{l}\text { Issued by BLM - WIPP } \\
\text { signature not required }\end{array}$ & $\mathrm{DOE}$ \\
\hline $\begin{array}{l}\text { Department of the } \\
\text { Interior, BLM }\end{array}$ & $\begin{array}{l}\text { Right-of-Way for Monitoring } \\
\text { Wells C-2723 (WIPP-25), } \\
\text { C-2724 (WIPP-26), C-2722 } \\
\text { (WIPP-27), C-2636 } \\
\text { (WIPP-28), C-2743 } \\
\text { (WIPP-29), and C-2727 } \\
\text { (WIPP-30) }\end{array}$ & $\begin{array}{c}\text { NM-6-5 } \\
\text { Cooperative } \\
\text { Agreement }\end{array}$ & $06 / 14 / 78$ & None & Active & $\begin{array}{l}\text { Environmental } \\
\text { Monitoring }\end{array}$ & $\begin{array}{l}\text { Issued by BLM - WIPP } \\
\text { signature not required }\end{array}$ & $\mathrm{DOE}$ \\
\hline $\begin{array}{l}\text { Department of the } \\
\text { Interior, BLM }\end{array}$ & \begin{tabular}{|l} 
Right-of-Way for Monitoring \\
Well C-2748 (WIPP13)
\end{tabular} & $\begin{array}{c}\text { NM-6-5 } \\
\text { Cooperative } \\
\text { Agreement }\end{array}$ & $05 / 03 / 78$ & None & Active & $\begin{array}{l}\text { Environmental } \\
\text { Monitoring }\end{array}$ & $\begin{array}{l}\text { Issued by BLM - WIPP } \\
\text { signature not required }\end{array}$ & $\mathrm{DOE}$ \\
\hline $\begin{array}{l}\text { Department of the } \\
\text { Interior, BLM }\end{array}$ & $\begin{array}{l}\text { Right-of-Way for Well } \\
\text { WIPP-11 }\end{array}$ & $\begin{array}{c}\text { NM-6-5 } \\
\text { Cooperative } \\
\text { Agreement }\end{array}$ & $12 / 19 / 77$ & None & Active & $\begin{array}{l}\text { Environmental } \\
\text { Monitoring }\end{array}$ & $\begin{array}{l}\text { Issued by BLM - WIPP } \\
\text { signature not required }\end{array}$ & DOE \\
\hline $\begin{array}{l}\text { Department of the } \\
\text { Interior, BLM }\end{array}$ & $\begin{array}{l}\text { Right-of-Way for Dosimetry } \\
\text { and Aerosol Sampling Sites }\end{array}$ & NM63136 & $07 / 31 / 86$ & $07 / 31 / 11$ & Active & $\begin{array}{l}\text { Environmental } \\
\text { Monitoring }\end{array}$ & $\begin{array}{l}\text { Issued by BLM - WIPP } \\
\text { signature not required }\end{array}$ & $\overline{D O E}$ \\
\hline $\begin{array}{l}\text { Department of the } \\
\text { Interior, BLM }\end{array}$ & $\begin{array}{l}\text { Right-of-Way for Aerosol } \\
\text { Sampling Sites }\end{array}$ & NM77921 & $10 / 03 / 89$ & $08 / 18 / 19$ & Active & $\begin{array}{l}\text { Environmental } \\
\text { Monitoring }\end{array}$ & $\begin{array}{l}\text { Issued by BLM - WIPP } \\
\text { signature not required }\end{array}$ & $\mathrm{DOE}$ \\
\hline $\begin{array}{l}\text { Department of the } \\
\text { Interior, BLM }\end{array}$ & $\begin{array}{l}\text { Right-of-Way easement for } \\
\text { accessing state trust lands in } \\
\text { Eddy and Lea Counties } \\
\end{array}$ & NM25430 & $02 / 29 / 00$ & $09 / 28 / 04$ & Active & $\begin{array}{l}\text { Environmental } \\
\text { Monitoring }\end{array}$ & $\begin{array}{l}\text { Issued by BLM - WIPP } \\
\text { signature not required }\end{array}$ & $\mathrm{DOE}$ \\
\hline $\begin{array}{l}\text { Department of the } \\
\text { Interior, BLM }\end{array}$ & $\begin{array}{l}\text { Free-Use Caliche Extraction } \\
\text { Permit }\end{array}$ & NM105004 & $10 / 12 / 00$ & $10 / 12 / 01$ & $\begin{array}{l}\text { Inactive Will be } \\
\text { renewed when } \\
\text { required }\end{array}$ & $\begin{array}{l}\text { Environmental } \\
\text { Monitoring }\end{array}$ & $\begin{array}{l}\text { Issued by BLM - WIPP } \\
\text { signature not required }\end{array}$ & $\mathrm{DOE}$ \\
\hline
\end{tabular}




\section{Waste Isolation Pilot Plant 2001 Site Environmental Report}

DOE/WIPP 02-2225

Table 3.5 - Active Environmental Permits and Approvals for the Waste Isolation Pilot Plant (as of December 31, 2001)

(Does Not Include RCRA Permits)

\begin{tabular}{|c|c|c|c|c|c|c|c|c|}
\hline Granting Agency & Type of Permit & Permit Number & $\begin{array}{l}\text { Granted/ } \\
\text { Submitted }\end{array}$ & Expiration & $\begin{array}{l}\text { Current Permit } \\
\text { Status }\end{array}$ & WTS Owner & Signed By/Title & Signed For \\
\hline $\begin{array}{l}\text { U.S. Department of } \\
\text { the Interior, Fish and } \\
\text { Wildlife Service }\end{array}$ & $\begin{array}{l}\text { Concurrence that WIPP } \\
\text { construction activities will } \\
\text { have no significant impact on } \\
\text { federally listed threatened or } \\
\text { endangered species }\end{array}$ & None & $05 / 29 / 80$ & None & Active & $\begin{array}{l}\text { Environmental } \\
\text { Monitoring }\end{array}$ & $\mathrm{N} / \mathrm{A}$ & $\mathrm{N} / \mathrm{A}$ \\
\hline $\begin{array}{l}\text { U.S. DOT Research } \\
\text { and Special Programs } \\
\text { Administration }\end{array}$ & $\begin{array}{l}\text { Hazardous materials } \\
\text { transporter registration }\end{array}$ & $082801002021 \mathrm{~J}$ & $8 / 31 / 01$ & $6 / 30 / 02$ & Active & Shipping Coordination & $\begin{array}{l}\text { R. White, Transportation } \\
\text { Engineer } \\
6 / 5 / 01\end{array}$ & WTS \\
\hline U.S. EPA & $\begin{array}{l}\text { National Pollutant Discharge } \\
\text { Elimination System (NPDES) } \\
\text { Storm Water Multi-Sector } \\
\text { General Permit issued for use } \\
\text { in the State of New Mexico }\end{array}$ & NMR05A823 & $01 / 29 / 01$ & $09 / 29 / 05$ & Active & $\begin{array}{l}\text { Environmental } \\
\text { Compliance }\end{array}$ & $\begin{array}{l}\text { Ines Triay, Manager, } \\
\text { DOE/CBFO }\end{array}$ & DOE/CBFO \\
\hline $\begin{array}{l}\text { New Mexico } \\
\text { Commissioner of } \\
\text { Public Lands }\end{array}$ & $\begin{array}{l}\text { Right-of-Way for High } \\
\text { Volume Air Sampler }\end{array}$ & RW-22789 & $10 / 03 / 85$ & $10 / 03 / 20$ & Active & $\begin{array}{l}\text { Environmental } \\
\text { Monitoring }\end{array}$ & $\begin{array}{l}\text { Stewart Jones, Manager } \\
\text { Environmental Monitoring }\end{array}$ & WTS \\
\hline $\begin{array}{l}\text { NMED Groundwater } \\
\text { Bureau }\end{array}$ & Discharge Permit & $\mathrm{DP}-831$ & $07 / 03 / 97$ & $07 / 03 / 02$ & Active & \begin{tabular}{|l} 
Environmental \\
Compliance and \\
Facility Operations
\end{tabular} & $\begin{array}{l}\text { G. E. Dials, Manager } \\
12 / 16 / 96\end{array}$ & $\mathrm{DOE}$ \\
\hline $\begin{array}{l}\text { NMED Air Quality } \\
\text { Bureau }\end{array}$ & $\begin{array}{l}\text { Operating Permit for two } \\
\text { backup diesel generators }\end{array}$ & $310-\mathrm{M}-2$ & $12 / 07 / 93$ & None & Active & $\begin{array}{l}\text { Environmental } \\
\text { Compliance and } \\
\text { Facility Operations }\end{array}$ & $\begin{array}{l}\text { A. E. Hunt Project Manager } \\
06 / 18 / 93\end{array}$ & $\mathrm{DOE}$ \\
\hline NMDG\&F & $\begin{array}{l}\text { Concurrence that WIPP } \\
\text { construction activities will } \\
\text { have no significant impact on } \\
\text { state-listed threatened or } \\
\text { endangered species }\end{array}$ & $\begin{array}{c}\text { None } \\
07 / 25 / 83\end{array}$ & $05 / 26 / 89$ & None & Active & $\begin{array}{l}\text { Environmental } \\
\text { Monitoring }\end{array}$ & $\mathrm{N} / \mathrm{A}$ & $\mathrm{N} / \mathrm{A}$ \\
\hline NMED UST Bureau & Underground Storage Tanks & $\begin{array}{c}\text { NMED1198 } \\
\text { (Number changes } \\
\text { annually) }\end{array}$ & $07 / 01 / 01$ & $06 / 30 / 02$ & Active & \begin{tabular}{|l} 
Environmental \\
Compliance and \\
Facility Operations
\end{tabular} & $\begin{array}{l}\text { V. Daub, } \\
\text { Deputy Project Site } \\
\text { Manager } \\
06 / 18 / 92\end{array}$ & $\mathrm{DOE}$ \\
\hline $\begin{array}{l}\text { NMED Solid Waste } \\
\text { Bureau }\end{array}$ & $\begin{array}{l}\text { Solid Waste Hauler } \\
\text { Registration }\end{array}$ & 006655 & $12 / 01 / 99$ & None & Active & \begin{tabular}{|l|} 
N/A - Issued to Cast \\
Trucking and Tri-State \\
Motor Transit
\end{tabular} & $\mathrm{N} / \mathrm{A}$ & $\mathrm{N} / \mathrm{A}$ \\
\hline $\begin{array}{l}\text { NMED Solid Waste } \\
\text { Bureau }\end{array}$ & $\begin{array}{l}\text { Solid Waste Hauler } \\
\text { Registration }\end{array}$ & 040889 & $01 / 16 / 01$ & None & Active & $\begin{array}{l}\text { N/A - Issued to } \\
\text { Tri-State Motor } \\
\text { Transit Co. } \\
\end{array}$ & $\mathrm{N} / \mathrm{A}$ & $\mathrm{N} / \mathrm{A}$ \\
\hline
\end{tabular}




\section{Waste Isolation Pilot Plant 2001 Site Environmental Report}

DOE/WIPP 02-2225

Table 3.5 - Active Environmental Permits and Approvals for the Waste Isolation Pilot Plant (as of December 31, 2001)

(Does Not Include RCRA Permits)

\begin{tabular}{|c|c|c|c|c|c|c|c|c|}
\hline Granting Agency & Type of Permit & Permit Number & $\begin{array}{l}\text { Granted/ } \\
\text { Submitted }\end{array}$ & Expiration & $\begin{array}{l}\text { Current Permit } \\
\text { Status }\end{array}$ & WTS Owner & Signed By/Title & Signed For \\
\hline $\begin{array}{l}\text { New Mexico State } \\
\text { Engineer Office }\end{array}$ & $\begin{array}{l}\text { Monitoring Well Exhaust } \\
\text { Shaft Exploratory Borehole }\end{array}$ & C-2801 & $02 / 23 / 01$ & None & Active & $\begin{array}{l}\text { Environmental } \\
\text { Compliance and } \\
\text { Geotechnical } \\
\text { Engineering }\end{array}$ & H. E. Johnson, DOE & $\mathrm{DOE}$ \\
\hline $\begin{array}{l}\text { New Mexico State } \\
\text { Engineer Office }\end{array}$ & \begin{tabular}{|l|} 
Monitoring Well Exhaust \\
Shaft Exploratory Borehole
\end{tabular} & C-2802 & $02 / 23 / 01$ & None & Active & $\begin{array}{l}\text { Environmental } \\
\text { Compliance and } \\
\text { Geotechnical } \\
\text { Engineering }\end{array}$ & $\begin{array}{l}\text { E. K. Hunter, Asst. Manager } \\
\text { ONTWO } \\
09 / 10 / 97\end{array}$ & $\overline{\mathrm{DOE}}$ \\
\hline $\begin{array}{l}\text { New Mexico State } \\
\text { Engineer Office }\end{array}$ & \begin{tabular}{|l|} 
Monitoring Well Exhaust \\
Shaft Exploratory Borehole
\end{tabular} & C-2803 & $02 / 23 / 01$ & None & Active & $\begin{array}{l}\text { Environmental } \\
\text { Compliance and } \\
\text { Geotechnical } \\
\text { Engineering }\end{array}$ & $\begin{array}{l}\text { E. K. Hunter, Asst. Manager } \\
\text { ONTWO } \\
09 / 10 / 97\end{array}$ & $\overline{\mathrm{DOE}}$ \\
\hline $\begin{array}{l}\text { New Mexico State } \\
\text { Engineer Office }\end{array}$ & Appropriation: WQSP-1 Well & C-2413 & $10 / 21 / 96$ & None & Active & $\begin{array}{l}\text { Environmental } \\
\text { Compliance and } \\
\text { Environmental } \\
\text { Monitoring } \\
\end{array}$ & $\begin{array}{l}\text { E. K. Hunter, Asst. Manager } \\
\text { ONTWO } \\
\text { 07/03/96 DOE }\end{array}$ & $\overline{\mathrm{DOE}}$ \\
\hline $\begin{array}{l}\text { New Mexico State } \\
\text { Engineer Office }\end{array}$ & Appropriation: WQSP-2 Well & C-2414 & $10 / 21 / 96$ & None & Active & $\begin{array}{l}\text { Environmental } \\
\text { Compliance and } \\
\text { Environmental } \\
\text { Monitoring } \\
\end{array}$ & $\begin{array}{l}\text { E. K. Hunter, Asst. Manager } \\
\text { ONTWO } \\
07 / 03 / 96\end{array}$ & $\overline{\mathrm{DOE}}$ \\
\hline $\begin{array}{l}\text { New Mexico State } \\
\text { Engineer Office }\end{array}$ & Appropriation: WQSP-3 Well & $\mathrm{C}-2415$ & $10 / 21 / 96$ & None & Active & $\begin{array}{l}\text { Environmental } \\
\text { Compliance and } \\
\text { Environmental } \\
\text { Monitoring }\end{array}$ & $\begin{array}{l}\text { E. K. Hunter, Asst. Manager } \\
\text { ONTWO } \\
\text { 07/03/96 }\end{array}$ & $\overline{\mathrm{DOE}}$ \\
\hline $\begin{array}{l}\text { New Mexico State } \\
\text { Engineer Office }\end{array}$ & Appropriation: WQSP-4 Well & $\mathrm{C}-2416$ & $10 / 21 / 96$ & None & Active & $\begin{array}{l}\text { Environmental } \\
\text { Compliance and } \\
\text { Environmental } \\
\text { Monitoring }\end{array}$ & $\begin{array}{l}\text { E. K. Hunter, Asst. Manager } \\
\text { ONTWO } \\
07 / 03 / 96\end{array}$ & $\overline{\mathrm{DOE}}$ \\
\hline $\begin{array}{l}\text { New Mexico State } \\
\text { Engineer Office }\end{array}$ & Appropriation: WQSP-5 Well & C-2417 & $10 / 21 / 96$ & None & Active & $\begin{array}{l}\text { Environmental } \\
\text { Compliance and } \\
\text { Environmental } \\
\text { Monitoring } \\
\end{array}$ & $\begin{array}{l}\text { E. K. Hunter, Asst. Manager } \\
\text { ONTWO } \\
07 / 03 / 96\end{array}$ & $\overline{\mathrm{DOE}}$ \\
\hline $\begin{array}{l}\text { New Mexico State } \\
\text { Engineer Office }\end{array}$ & Appropriation: WQSP-6 Well & C-2418 & $10 / 21 / 96$ & None & Active & $\begin{array}{l}\text { Environmental } \\
\text { Compliance and } \\
\text { Environmental } \\
\text { Monitoring } \\
\end{array}$ & $\begin{array}{l}\text { E. K. Hunter, Asst. Manager } \\
\text { ONTWO } \\
07 / 03 / 96\end{array}$ & $\overline{\mathrm{DOE}}$ \\
\hline
\end{tabular}




\section{Waste Isolation Pilot Plant 2001 Site Environmental Report}

DOE/WIPP 02-2225

Table 3.5 - Active Environmental Permits and Approvals for the Waste Isolation Pilot Plant (as of December 31, 2001)

(Does Not Include RCRA Permits)

\begin{tabular}{|c|c|c|c|c|c|c|c|c|}
\hline Granting Agency & Type of Permit & Permit Number & $\begin{array}{l}\text { Granted/ } \\
\text { Submitted }\end{array}$ & Expiration & $\begin{array}{l}\text { Current Permit } \\
\text { Status }\end{array}$ & WTS Owner & Signed By/Title & Signed For \\
\hline $\begin{array}{l}\text { New Mexico State } \\
\text { Engineer Office }\end{array}$ & $\begin{array}{l}\text { Appropriation: WQSP-6a } \\
\text { Well }\end{array}$ & C-2419 & $10 / 21 / 96$ & None & Active & $\begin{array}{l}\text { Environmental } \\
\text { Compliance and } \\
\text { Environmental } \\
\text { Monitoring } \\
\end{array}$ & $\begin{array}{l}\text { E. K. Hunter, Asst. } \\
\text { Manager ONTWO } \\
\text { 07/03/96 }\end{array}$ & $\mathrm{DOE}$ \\
\hline $\begin{array}{l}\text { New Mexico State } \\
\text { Engineer Office }\end{array}$ & Monitoring Well AEC-7 & C-2742 & $11 / 06 / 00$ & None & Active & $\begin{array}{l}\text { Environmental } \\
\text { Monitoring }\end{array}$ & $\begin{array}{l}\text { D. C. Lynn, WTS Land Use } \\
\text { Coordinator, 10/23/00 }\end{array}$ & DOE \\
\hline $\begin{array}{l}\text { New Mexico State } \\
\text { Engineer Office }\end{array}$ & Monitoring Well AEC-8 & C-2744 & $11 / 06 / 00$ & None & Active & $\begin{array}{l}\text { Environmental } \\
\text { Monitoring } \\
\end{array}$ & \begin{tabular}{|l|} 
D. C. Lynn, WTS Land Use \\
Coordinator, $10 / 23 / 00$ \\
\end{tabular} & $\mathrm{DOE}$ \\
\hline $\begin{array}{l}\text { New Mexico State } \\
\text { Engineer Office }\end{array}$ & Monitoring Well Cabin Baby & C-2664 & $07 / 30 / 99$ & None & Active & $\begin{array}{l}\text { Environmental } \\
\text { Monitoring } \\
\end{array}$ & $\begin{array}{l}\text { Richard A. Jepson, SNL } \\
\text { 07/29/99 }\end{array}$ & $\mathrm{DOE}$ \\
\hline $\begin{array}{l}\text { New Mexico State } \\
\text { Engineer Office }\end{array}$ & Monitoring Well D-268 & C-2638 & $01 / 12 / 99$ & None & Active & $\begin{array}{l}\text { Environmental } \\
\text { Monitoring } \\
\end{array}$ & $\begin{array}{l}\text { G. T. Basabilvaso, DOE } \\
\text { 12/10/98 }\end{array}$ & $\mathrm{DOE}$ \\
\hline $\begin{array}{l}\text { New Mexico State } \\
\text { Engineer Office }\end{array}$ & Monitoring Well DOE-1 & C-2757 & $11 / 06 / 00$ & None & Active & $\begin{array}{l}\text { Environmental } \\
\text { Monitoring } \\
\end{array}$ & \begin{tabular}{|l|} 
D. C. Lynn, WTS Land Use \\
Coordinator, $10 / 23 / 00$
\end{tabular} & $\mathrm{DOE}$ \\
\hline $\begin{array}{l}\text { New Mexico State } \\
\text { Engineer Office }\end{array}$ & Monitoring Well DOE-2 & C-2682 & $04 / 17 / 00$ & None & Active & $\begin{array}{l}\text { Environmental } \\
\text { Monitoring }\end{array}$ & \begin{tabular}{|l|} 
D. C. Lynn, WTS Land Use \\
Coordinator, $10 / 23 / 00$
\end{tabular} & $\mathrm{DOE}$ \\
\hline $\begin{array}{l}\text { New Mexico State } \\
\text { Engineer Office }\end{array}$ & Monitoring Well ERDA-9 & C-2752 & $11 / 06 / 00$ & None & Active & $\begin{array}{l}\text { Environmental } \\
\text { Monitoring } \\
\end{array}$ & $\begin{array}{l}\text { D. C. Lynn, WTS Land Use } \\
\text { Coordinator, } 10 / 23 / 00\end{array}$ & $\mathrm{DOE}$ \\
\hline $\begin{array}{l}\text { New Mexico State } \\
\text { Engineer Office }\end{array}$ & Monitoring Well H-1 & C-2765 & $11 / 06 / 00$ & None & Active & $\begin{array}{l}\text { Environmental } \\
\text { Monitoring } \\
\end{array}$ & $\begin{array}{l}\text { D. C. Lynn, WTS Land Use } \\
\text { Coordinator, } 10 / 23 / 00\end{array}$ & $\mathrm{DOE}$ \\
\hline $\begin{array}{l}\text { New Mexico State } \\
\text { Engineer Office }\end{array}$ & Monitoring Well $\mathrm{H}-2 \mathrm{~A}$ & C-2762 & $11 / 06 / 00$ & None & Active & $\begin{array}{l}\text { Environmental } \\
\text { Monitoring }\end{array}$ & $\begin{array}{l}\text { D. C. Lynn, WTS Land Use } \\
\text { Coordinator, } 10 / 23 / 00\end{array}$ & $\mathrm{DOE}$ \\
\hline $\begin{array}{l}\text { New Mexico State } \\
\text { Engineer Office }\end{array}$ & Monitoring Well H-2B1 & C-2758 & $11 / 06 / 00$ & None & Active & $\begin{array}{l}\text { Environmental } \\
\text { Monitoring }\end{array}$ & \begin{tabular}{|l|} 
D. C. Lynn, WTS Land Use \\
Coordinator, $10 / 23 / 00$ \\
\end{tabular} & DOE \\
\hline $\begin{array}{l}\text { New Mexico State } \\
\text { Engineer Office }\end{array}$ & Monitoring Well H-2B2 & C-2763 & $11 / 06 / 00$ & None & Active & $\begin{array}{l}\text { Environmental } \\
\text { Monitoring }\end{array}$ & $\begin{array}{l}\text { D. C. Lynn, WTS Land Use } \\
\text { Coordinator, 10/23/00 }\end{array}$ & $\mathrm{DOE}$ \\
\hline $\begin{array}{l}\text { New Mexico State } \\
\text { Engineer Office }\end{array}$ & Monitoring Well $\mathrm{H}-2 \mathrm{C}$ & C-2759 & $11 / 06 / 00$ & None & Active & $\begin{array}{l}\text { Environmental } \\
\text { Monitoring } \\
\end{array}$ & \begin{tabular}{|l|} 
D. C. Lynn, WTS Land Use \\
Coordinator, $10 / 23 / 00$ \\
\end{tabular} & $\mathrm{DOE}$ \\
\hline $\begin{array}{l}\text { New Mexico State } \\
\text { Engineer Office }\end{array}$ & Monitoring Well H-3B1 & C-2764 & $11 / 06 / 00$ & None & Active & \begin{tabular}{|l|} 
Environmental \\
Monitoring \\
\end{tabular} & \begin{tabular}{|l|} 
D. C. Lynn, WTS Land Use \\
Coordinator, 10/23/00 \\
\end{tabular} & $\mathrm{DOE}$ \\
\hline $\begin{array}{l}\text { New Mexico State } \\
\text { Engineer Office }\end{array}$ & Monitoring Well H-3B2 & C-2760 & $11 / 06 / 00$ & None & Active & $\begin{array}{l}\text { Environmental } \\
\text { Monitoring } \\
\end{array}$ & \begin{tabular}{|l|} 
D. C. Lynn, WTS Land Use \\
Coordinator, 10/23/00 \\
\end{tabular} & $\mathrm{DOE}$ \\
\hline $\begin{array}{l}\text { New Mexico State } \\
\text { Engineer Office }\end{array}$ & Monitoring Well H-3B3 & C-2761 & $11 / 06 / 00$ & None & Active & $\begin{array}{l}\text { Environmental } \\
\text { Monitoring } \\
\end{array}$ & \begin{tabular}{|l|} 
D. C. Lynn, WTS Land Use \\
Coordinator, $10 / 23 / 00$ \\
\end{tabular} & $\mathrm{DOE}$ \\
\hline $\begin{array}{l}\text { New Mexico State } \\
\text { Engineer Office }\end{array}$ & Monitoring Well H-3D & pending & $11 / 06 / 00$ & None & Active & $\begin{array}{l}\text { Environmental } \\
\text { Monitoring }\end{array}$ & $\begin{array}{l}\text { D. C. Lynn, WTS Land Use } \\
\text { Coordinator, 10/23/00 }\end{array}$ & $\mathrm{DOE}$ \\
\hline
\end{tabular}


Waste Isolation Pilot Plant 2001 Site Environmental Report DOE/WIPP 02-2225

Table 3.5 - Active Environmental Permits and Approvals for the Waste Isolation Pilot Plant (as of December 31, 2001)

(Does Not Include RCRA Permits)

\begin{tabular}{|c|c|c|c|c|c|c|c|c|}
\hline Granting Agency & Type of Permit & Permit Number & $\begin{array}{l}\text { Granted/ } \\
\text { Submitted }\end{array}$ & Expiration & $\begin{array}{l}\text { Current Permit } \\
\text { Status }\end{array}$ & WTS Owner & Signed By/Title & Signed For \\
\hline $\begin{array}{l}\text { New Mexico State } \\
\text { Engineer Office }\end{array}$ & Monitoring Well H-4A & C-2725 & $11 / 06 / 00$ & None & Active & $\begin{array}{l}\text { Environmental } \\
\text { Monitoring }\end{array}$ & $\begin{array}{l}\text { D. C. Lynn, WTS Land Use } \\
\text { Coordinator, 10/23/00 }\end{array}$ & DOE \\
\hline $\begin{array}{l}\text { New Mexico State } \\
\text { Engineer Office }\end{array}$ & Monitoring Well H-4B & $\mathrm{C}-2775$ & $11 / 06 / 00$ & None & Active & $\begin{array}{l}\text { Environmental } \\
\text { Monitoring } \\
\end{array}$ & $\begin{array}{l}\text { D. C. Lynn, WTS Land Use } \\
\text { Coordinator, 10/23/00 } \\
\end{array}$ & DOE \\
\hline $\begin{array}{l}\text { New Mexico State } \\
\text { Engineer Office }\end{array}$ & Monitoring Well $\mathrm{H}-4 \mathrm{C}$ & C-2776 & $11 / 06 / 00$ & None & Active & \begin{tabular}{|l|} 
Environmental \\
Monitoring \\
\end{tabular} & $\begin{array}{l}\text { D. C. Lynn, WTS Land Use } \\
\text { Coordinator, 10/23/00 } \\
\end{array}$ & DOE \\
\hline $\begin{array}{l}\text { New Mexico State } \\
\text { Engineer Office }\end{array}$ & Monitoring Well H-5A & C-2746 & $11 / 06 / 00$ & None & Active & \begin{tabular}{|l|} 
Environmental \\
Monitoring \\
\end{tabular} & $\begin{array}{l}\text { D. C. Lynn, WTS Land Use } \\
\text { Coordinator, 10/23/00 } \\
\end{array}$ & $\mathrm{DOE}$ \\
\hline $\begin{array}{l}\text { New Mexico State } \\
\text { Engineer Office }\end{array}$ & Monitoring Well H-5B & C-2745 & $11 / 06 / 00$ & None & Active & \begin{tabular}{|l|} 
Environmental \\
Monitoring \\
\end{tabular} & $\begin{array}{l}\text { D. C. Lynn, WTS Land Use } \\
\text { Coordinator, 10/23/00 } \\
\end{array}$ & DOE \\
\hline $\begin{array}{l}\text { New Mexico State } \\
\text { Engineer Office }\end{array}$ & Monitoring Well H-5C & C-2747 & $11 / 06 / 00$ & None & Active & $\begin{array}{l}\text { Environmental } \\
\text { Monitoring } \\
\end{array}$ & $\begin{array}{l}\text { D. C. Lynn, WTS Land Use } \\
\text { Coordinator, 10/23/00 }\end{array}$ & $\mathrm{DOE}$ \\
\hline $\begin{array}{l}\text { New Mexico State } \\
\text { Engineer Office }\end{array}$ & Monitoring Well H-6A & C-2751 & $11 / 06 / 00$ & None & Active & \begin{tabular}{|l|} 
Environmental \\
Monitoring \\
\end{tabular} & $\begin{array}{l}\text { D. C. Lynn, WTS Land Use } \\
\text { Coordinator, 10/23/00 } \\
\end{array}$ & DOE \\
\hline $\begin{array}{l}\text { New Mexico State } \\
\text { Engineer Office }\end{array}$ & Monitoring Well H-6B & C-2749 & $11 / 06 / 00$ & None & Active & $\begin{array}{l}\text { Environmental } \\
\text { Monitoring }\end{array}$ & $\begin{array}{l}\text { D. C. Lynn, WTS Land Use } \\
\text { Coordinator, } 10 / 23 / 00\end{array}$ & DOE \\
\hline $\begin{array}{l}\text { New Mexico State } \\
\text { Engineer Office }\end{array}$ & Monitoring Well H-6C & C-2750 & $11 / 06 / 00$ & None & Active & $\begin{array}{l}\text { Environmental } \\
\text { Monitoring }\end{array}$ & $\begin{array}{l}\text { D. C. Lynn, WTS Land Use } \\
\text { Coordinator, 10/23/00 }\end{array}$ & DOE \\
\hline $\begin{array}{l}\text { New Mexico State } \\
\text { Engineer Office }\end{array}$ & Monitoring Well H-7A & C-2694 & $04 / 17 / 00$ & None & Active & \begin{tabular}{|l|} 
Environmental \\
Monitoring \\
\end{tabular} & $\begin{array}{l}\text { D. C. Lynn, WTS Land Use } \\
\text { Coordinator, 10/23/00 } \\
\end{array}$ & DOE \\
\hline $\begin{array}{l}\text { New Mexico State } \\
\text { Engineer Office }\end{array}$ & Monitoring Well H-7B1 & $\mathrm{C}-2770$ & $11 / 06 / 00$ & None & Active & \begin{tabular}{|l|} 
Environmental \\
Monitoring \\
\end{tabular} & \begin{tabular}{|l|} 
D. C. Lynn, WTS Land Use \\
Coordinator, $10 / 23 / 00$ \\
\end{tabular} & $\overline{D O E}$ \\
\hline $\begin{array}{l}\text { New Mexico State } \\
\text { Engineer Office }\end{array}$ & Monitoring Well H-7B2 & C-2771 & $11 / 06 / 00$ & None & Active & \begin{tabular}{|l|} 
Environmental \\
Monitoring \\
\end{tabular} & $\begin{array}{l}\text { D. C. Lynn, WTS Land Use } \\
\text { Coordinator, 10/23/00 } \\
\end{array}$ & DOE \\
\hline $\begin{array}{l}\text { New Mexico State } \\
\text { Engineer Office }\end{array}$ & Monitoring Well H-7C & C-2772 & $11 / 06 / 00$ & None & Active & $\begin{array}{l}\text { Environmental } \\
\text { Monitoring } \\
\end{array}$ & $\begin{array}{l}\text { D. C. Lynn, WTS Land Use } \\
\text { Coordinator, 10/23/00 } \\
\end{array}$ & $\mathrm{DOE}$ \\
\hline $\begin{array}{l}\text { New Mexico State } \\
\text { Engineer Office }\end{array}$ & Monitoring Well H-8A & C-2780 & $11 / 06 / 00$ & None & Active & \begin{tabular}{|l|} 
Environmental \\
Monitoring \\
\end{tabular} & $\begin{array}{l}\text { D. C. Lynn, WTS Land Use } \\
\text { Coordinator, 10/23/00 } \\
\end{array}$ & $\overline{\mathrm{DOE}}$ \\
\hline $\begin{array}{l}\text { New Mexico State } \\
\text { Engineer Office }\end{array}$ & Monitoring Well H-8B & C-2781 & $11 / 06 / 00$ & None & Active & \begin{tabular}{|l|} 
Environmental \\
Monitoring \\
\end{tabular} & $\begin{array}{l}\text { D. C. Lynn, WTS Land Use } \\
\text { Coordinator, 10/23/00 } \\
\end{array}$ & DOE \\
\hline $\begin{array}{l}\text { New Mexico State } \\
\text { Engineer Office }\end{array}$ & Monitoring Well H-8C & C-2782 & $11 / 06 / 00$ & None & Active & \begin{tabular}{|l} 
Environmental \\
Monitoring \\
\end{tabular} & $\begin{array}{l}\text { D. C. Lynn, WTS Land Use } \\
\text { Coordinator, 10/23/00 } \\
\end{array}$ & DOE \\
\hline $\begin{array}{l}\text { New Mexico State } \\
\text { Engineer Office }\end{array}$ & Monitoring Well H-9A & C-2785 & $11 / 06 / 00$ & None & Active & \begin{tabular}{|l|} 
Environmental \\
Monitoring \\
\end{tabular} & $\begin{array}{l}\text { D. C. Lynn, WTS Land Use } \\
\text { Coordinator, 10/23/00 } \\
\end{array}$ & DOE \\
\hline $\begin{array}{l}\text { New Mexico State } \\
\text { Engineer Office }\end{array}$ & Monitoring Well H-9B & C-2783 & $11 / 06 / 00$ & None & Active & $\begin{array}{l}\text { Environmental } \\
\text { Monitoring } \\
\end{array}$ & $\begin{array}{l}\text { D. C. Lynn, WTS Land Use } \\
\text { Coordinator, } 10 / 23 / 00\end{array}$ & $\overline{\mathrm{DOE}}$ \\
\hline
\end{tabular}




\section{Waste Isolation Pilot Plant 2001 Site Environmental Report}

DOE/WIPP 02-2225

Table 3.5 - Active Environmental Permits and Approvals for the Waste Isolation Pilot Plant (as of December 31, 2001)

(Does Not Include RCRA Permits)

\begin{tabular}{|c|c|c|c|c|c|c|c|c|}
\hline Granting Agency & Type of Permit & Permit Number & $\begin{array}{l}\text { Granted/ } \\
\text { Submitted }\end{array}$ & Expiration & $\begin{array}{l}\text { Current Permit } \\
\text { Status }\end{array}$ & WTS Owner & Signed By/Title & Signed For \\
\hline $\begin{array}{l}\text { New Mexico State } \\
\text { Engineer Office }\end{array}$ & Monitoring Well H-9C & C-2784 & $11 / 06 / 00$ & None & Active & $\begin{array}{l}\text { Environmental } \\
\text { Monitoring }\end{array}$ & $\begin{array}{l}\text { D. C. Lynn, WTS Land Use } \\
\text { Coordinator, } 10 / 23 / 00\end{array}$ & $\mathrm{DOE}$ \\
\hline $\begin{array}{l}\text { New Mexico State } \\
\text { Engineer Office }\end{array}$ & Monitoring Well $\mathrm{H}-10 \mathrm{~A}$ & C-2779 & $11 / 06 / 00$ & None & Active & $\begin{array}{l}\text { Environmental } \\
\text { Monitoring }\end{array}$ & $\begin{array}{l}\text { D. C. Lynn, WTS Land Use } \\
\text { Coordinator, } 10 / 23 / 00\end{array}$ & DOE \\
\hline $\begin{array}{l}\text { New Mexico State } \\
\text { Engineer Office }\end{array}$ & Monitoring Well $\mathrm{H}-10 \mathrm{~B}$ & C-2778 & $11 / 06 / 00$ & None & Active & $\begin{array}{l}\text { Environmental } \\
\text { Monitoring }\end{array}$ & $\begin{array}{l}\text { D. C. Lynn, WTS Land Use } \\
\text { Coordinator, } 10 / 23 / 00\end{array}$ & DOE \\
\hline $\begin{array}{l}\text { New Mexico State } \\
\text { Engineer Office }\end{array}$ & Monitoring Well $\mathrm{H}-10 \mathrm{C}$ & C-2695 & $04 / 17 / 00$ & None & Active & $\begin{array}{l}\text { Environmental } \\
\text { Monitoring }\end{array}$ & $\begin{array}{l}\text { D. C. Lynn, WTS Land Use } \\
\text { Coordinator, } 10 / 23 / 00\end{array}$ & DOE \\
\hline $\begin{array}{l}\text { New Mexico State } \\
\text { Engineer Office }\end{array}$ & Monitoring Well H-11B1 & C-2767 & $11 / 06 / 00$ & None & Active & $\begin{array}{l}\text { Environmental } \\
\text { Monitoring } \\
\end{array}$ & $\begin{array}{l}\text { D. C. Lynn, WTS Land Use } \\
\text { Coordinator, 10/23/00 }\end{array}$ & $\mathrm{DOE}$ \\
\hline $\begin{array}{l}\text { New Mexico State } \\
\text { Engineer Office }\end{array}$ & Monitoring Well H-11B2 & C-2687 & $04 / 17 / 00$ & None & Active & $\begin{array}{l}\text { Environmental } \\
\text { Monitoring } \\
\end{array}$ & $\begin{array}{l}\text { D. C. Lynn, WTS Land Use } \\
\text { Coordinator, 10/23/00 }\end{array}$ & $\mathrm{DOE}$ \\
\hline $\begin{array}{l}\text { New Mexico State } \\
\text { Engineer Office }\end{array}$ & Monitoring Well H-11B3 & C-2768 & $11 / 06 / 00$ & None & Active & $\begin{array}{l}\text { Environmental } \\
\text { Monitoring } \\
\end{array}$ & $\begin{array}{l}\text { D. C. Lynn, WTS Land Use } \\
\text { Coordinator, } 10 / 23 / 00\end{array}$ & $\mathrm{DOE}$ \\
\hline $\begin{array}{l}\text { New Mexico State } \\
\text { Engineer Office }\end{array}$ & Monitoring Well H-11B4 & C-2769 & $11 / 06 / 00$ & None & Active & $\begin{array}{l}\text { Environmental } \\
\text { Monitoring }\end{array}$ & $\begin{array}{l}\text { D. C. Lynn, WTS Land Use } \\
\text { Coordinator, } 10 / 23 / 00\end{array}$ & $\mathrm{DOE}$ \\
\hline $\begin{array}{l}\text { New Mexico State } \\
\text { Engineer Office }\end{array}$ & Monitoring Well $\mathrm{H}-12$ & C-2777 & $11 / 06 / 00$ & None & Active & $\begin{array}{l}\text { Environmental } \\
\text { Monitoring } \\
\end{array}$ & $\begin{array}{l}\text { D. C. Lynn, WTS Land Use } \\
\text { Coordinator, } 10 / 23 / 00\end{array}$ & $\mathrm{DOE}$ \\
\hline $\begin{array}{l}\text { New Mexico State } \\
\text { Engineer Office }\end{array}$ & Monitoring Well $\mathrm{H}-14$ & C-2766 & $11 / 06 / 00$ & None & Active & $\begin{array}{l}\text { Environmental } \\
\text { Monitoring } \\
\end{array}$ & $\begin{array}{l}\text { D. C. Lynn, WTS Land Use } \\
\text { Coordinator, } 10 / 23 / 00\end{array}$ & $\mathrm{DOE}$ \\
\hline $\begin{array}{l}\text { New Mexico State } \\
\text { Engineer Office }\end{array}$ & Monitoring Well $\mathrm{H}-15$ & C-2685 & $04 / 17 / 00$ & None & Active & $\begin{array}{l}\text { Environmental } \\
\text { Monitoring }\end{array}$ & $\begin{array}{l}\text { D. C. Lynn, WTS Land Use } \\
\text { Coordinator, } 10 / 23 / 00\end{array}$ & $\mathrm{DOE}$ \\
\hline $\begin{array}{l}\text { New Mexico State } \\
\text { Engineer Office }\end{array}$ & Monitoring Well H-16 & C-2753 & $11 / 06 / 00$ & None & Active & \begin{tabular}{|l|} 
Environmental \\
Monitoring \\
\end{tabular} & $\begin{array}{l}\text { D. C. Lynn, WTS Land Use } \\
\text { Coordinator, 10/23/00 }\end{array}$ & $\mathrm{DOE}$ \\
\hline $\begin{array}{l}\text { New Mexico State } \\
\text { Engineer Office }\end{array}$ & Monitoring Well H-17 & C-2773 & $11 / 06 / 00$ & None & Active & $\begin{array}{l}\text { Environmental } \\
\text { Monitoring }\end{array}$ & $\begin{array}{l}\text { D. C. Lynn, WTS Land Use } \\
\text { Coordinator, } 10 / 23 / 00\end{array}$ & $\mathrm{DOE}$ \\
\hline $\begin{array}{l}\text { New Mexico State } \\
\text { Engineer Office }\end{array}$ & Monitoring Well $\mathrm{H}-18$ & C-2683 & $04 / 17 / 00$ & None & Active & $\begin{array}{l}\text { Environmental } \\
\text { Monitoring } \\
\end{array}$ & $\begin{array}{l}\text { D. C. Lynn, WTS Land Use } \\
\text { Coordinator, 10/23/00 }\end{array}$ & $\mathrm{DOE}$ \\
\hline $\begin{array}{l}\text { New Mexico State } \\
\text { Engineer Office }\end{array}$ & Monitoring Well H-19B0 & C-2420 & $01 / 25 / 95$ & $01 / 31 / 98$ & $\begin{array}{c}\text { Inactive } \\
\text { Renew when } \\
\text { necessary }\end{array}$ & $\begin{array}{l}\text { Environmental } \\
\text { Monitoring }\end{array}$ & $\begin{array}{l}\text { Harold F. Klaus, Jr. } \\
\text { DOE 11/09/94 }\end{array}$ & DOE \\
\hline $\begin{array}{l}\text { New Mexico State } \\
\text { Engineer Office }\end{array}$ & Monitoring Well H-19B1 & C-2420 & $01 / 25 / 95$ & $01 / 31 / 98$ & $\begin{array}{c}\text { Inactive } \\
\text { Renew when } \\
\text { necessary }\end{array}$ & \begin{tabular}{|l|} 
Environmental \\
Monitoring
\end{tabular} & $\begin{array}{l}\text { Harold F. Klaus, Jr. } \\
\text { DOE 11/09/94 }\end{array}$ & $\overline{\mathrm{DOE}}$ \\
\hline $\begin{array}{l}\text { New Mexico State } \\
\text { Engineer Office }\end{array}$ & Monitoring Well H-19B2 & C-2421 & $01 / 25 / 95$ & $01 / 31 / 98$ & $\begin{array}{c}\text { Inactive } \\
\text { Renew when } \\
\text { necessary }\end{array}$ & $\begin{array}{l}\text { Environmental } \\
\text { Monitoring }\end{array}$ & $\begin{array}{l}\text { Harold F. Klaus, Jr. } \\
\text { DOE 11/09/94 }\end{array}$ & $\mathrm{DOE}$ \\
\hline
\end{tabular}




\section{Waste Isolation Pilot Plant 2001 Site Environmental Report}

DOE/WIPP 02-2225

Table 3.5 - Active Environmental Permits and Approvals for the Waste Isolation Pilot Plant (as of December 31, 2001)

(Does Not Include RCRA Permits)

\begin{tabular}{|c|c|c|c|c|c|c|c|c|}
\hline Granting Agency & Type of Permit & Permit Number & $\begin{array}{l}\text { Granted/ } \\
\text { Submitted }\end{array}$ & Expiration & $\begin{array}{l}\text { Current Permit } \\
\text { Status }\end{array}$ & WTS Owner & Signed By/Title & Signed For \\
\hline $\begin{array}{l}\text { New Mexico State } \\
\text { Engineer Office }\end{array}$ & Monitoring Well H-19B3 & C-2422 & $01 / 25 / 95$ & $01 / 31 / 98$ & $\begin{array}{c}\text { Inactive } \\
\text { Renew when } \\
\text { necessary }\end{array}$ & $\begin{array}{l}\text { Environmental } \\
\text { Monitoring }\end{array}$ & $\begin{array}{l}\text { Harold F. Klaus, Jr. } \\
\text { DOE 11/09/94 }\end{array}$ & $\mathrm{DOE}$ \\
\hline $\begin{array}{l}\text { New Mexico State } \\
\text { Engineer Office }\end{array}$ & Monitoring Well H-19B4 & C-2423 & $01 / 25 / 95$ & $01 / 31 / 98$ & $\begin{array}{c}\text { Inactive } \\
\text { Renew when } \\
\text { necessary }\end{array}$ & $\begin{array}{l}\text { Environmental } \\
\text { Monitoring }\end{array}$ & $\begin{array}{l}\text { Harold F. Klaus, Jr. } \\
\text { DOE 11/09/94 }\end{array}$ & $\mathrm{DOE}$ \\
\hline $\begin{array}{l}\text { New Mexico State } \\
\text { Engineer Office }\end{array}$ & Monitoring Well H-19B5 & C-2424 & $01 / 25 / 95$ & $01 / 31 / 98$ & $\begin{array}{c}\text { Inactive } \\
\text { Renew when } \\
\text { necessary }\end{array}$ & $\begin{array}{l}\text { Environmental } \\
\text { Monitoring }\end{array}$ & $\begin{array}{l}\text { Harold F. Klaus, Jr. } \\
\text { DOE 11/09/94 }\end{array}$ & $\mathrm{DOE}$ \\
\hline $\begin{array}{l}\text { New Mexico State } \\
\text { Engineer Office }\end{array}$ & Monitoring Well H-19B6 & C-2425 & $01 / 25 / 95$ & $01 / 31 / 98$ & $\begin{array}{c}\text { Inactive } \\
\text { Renew when } \\
\text { necessary }\end{array}$ & $\begin{array}{l}\text { Environmental } \\
\text { Monitoring }\end{array}$ & $\begin{array}{l}\text { Harold F. Klaus, Jr. } \\
\text { DOE 11/09/94 }\end{array}$ & $\mathrm{DOE}$ \\
\hline $\begin{array}{l}\text { New Mexico State } \\
\text { Engineer Office }\end{array}$ & Monitoring Well H-19B7 & C-2426 & $01 / 25 / 95$ & $01 / 31 / 98$ & $\begin{array}{c}\text { Inactive } \\
\text { Renew when } \\
\text { necessary }\end{array}$ & \begin{tabular}{|l} 
Environmental \\
Monitoring
\end{tabular} & $\begin{array}{l}\text { Harold F. Klaus, Jr. } \\
\text { DOE 11/09/94 }\end{array}$ & $\mathrm{DOE}$ \\
\hline $\begin{array}{l}\text { New Mexico State } \\
\text { Engineer Office }\end{array}$ & Monitoring Well P-14 & C-2637 & $01 / 02 / 99$ & None & Active & $\begin{array}{l}\text { Environmental } \\
\text { Monitoring }\end{array}$ & $\begin{array}{l}\text { G. T. Basabilvaso, DOE } \\
11 / 17 / 98\end{array}$ & DOE \\
\hline $\begin{array}{l}\text { New Mexico State } \\
\text { Engineer Office }\end{array}$ & Monitoring Well P-15 & C-2686 & $04 / 17 / 00$ & None & Active & $\begin{array}{l}\text { Environmental } \\
\text { Monitoring } \\
\end{array}$ & \begin{tabular}{|l|} 
D. C. Lynn, WTS Land Use \\
Coordinator, 10/23/00
\end{tabular} & $\mathrm{DOE}$ \\
\hline $\begin{array}{l}\text { New Mexico State } \\
\text { Engineer Office }\end{array}$ & Monitoring Well P-17 & C-2774 & $11 / 06 / 00$ & None & Active & $\begin{array}{l}\text { Environmental } \\
\text { Monitoring } \\
\end{array}$ & \begin{tabular}{|l|} 
D. C. Lynn, WTS Land Use \\
Coordinator, 10/23/00 \\
\end{tabular} & $\overline{D O E}$ \\
\hline $\begin{array}{l}\text { New Mexico State } \\
\text { Engineer Office }\end{array}$ & Monitoring Well P-18 & C-2756 & $11 / 06 / 00$ & None & Active & $\begin{array}{l}\text { Environmental } \\
\text { Monitoring } \\
\end{array}$ & \begin{tabular}{|l|} 
D. C. Lynn, WTS Land Use \\
Coordinator, 10/23/00
\end{tabular} & $\overline{\mathrm{DOE}}$ \\
\hline $\begin{array}{l}\text { New Mexico State } \\
\text { Engineer Office }\end{array}$ & Monitoring Well WIPP-12 & C-2639 & $01 / 12 / 99$ & None & Active & \begin{tabular}{|l|} 
Environmental \\
Monitoring \\
\end{tabular} & $\begin{array}{l}\text { G. T. Basabilvaso, DOE } \\
11 / 17 / 98\end{array}$ & $\mathrm{DOE}$ \\
\hline $\begin{array}{l}\text { New Mexico State } \\
\text { Engineer Office }\end{array}$ & Monitoring Well WIPP-13 & C-2748 & $11 / 06 / 00$ & None & Active & $\begin{array}{l}\text { Environmental } \\
\text { Monitoring } \\
\end{array}$ & $\begin{array}{l}\text { D. C. Lynn, WTS Land Use } \\
\text { Coordinator, } 10 / 23 / 00\end{array}$ & $\mathrm{DOE}$ \\
\hline $\begin{array}{l}\text { New Mexico State } \\
\text { Engineer Office }\end{array}$ & Monitoring Well WIPP-18 & C-2684 & $04 / 17 / 00$ & None & Active & $\begin{array}{l}\text { Environmental } \\
\text { Monitoring } \\
\end{array}$ & \begin{tabular}{|l|} 
D. C. Lynn, WTS Land Use \\
Coordinator, $10 / 23 / 00$
\end{tabular} & $\overline{\mathrm{DOE}}$ \\
\hline $\begin{array}{l}\text { New Mexico State } \\
\text { Engineer Office }\end{array}$ & Monitoring Well WIPP-19 & C-2755 & $11 / 06 / 00$ & None & Active & $\begin{array}{l}\text { Environmental } \\
\text { Monitoring }\end{array}$ & \begin{tabular}{|l|} 
D. C. Lynn, WTS Land Use \\
Coordinator, 10/23/00
\end{tabular} & $\mathrm{DOE}$ \\
\hline $\begin{array}{l}\text { New Mexico State } \\
\text { Engineer Office }\end{array}$ & Monitoring Well WIPP-21 & C-2754 & $11 / 06 / 00$ & None & Active & $\begin{array}{l}\text { Environmental } \\
\text { Monitoring }\end{array}$ & $\begin{array}{l}\text { D. C. Lynn, WTS Land Use } \\
\text { Coordinator, } 10 / 23 / 00\end{array}$ & DOE \\
\hline $\begin{array}{l}\text { New Mexico State } \\
\text { Engineer Office }\end{array}$ & Monitoring Well WIPP-25 & C-2723 & $07 / 26 / 00$ & None & Active & $\begin{array}{l}\text { Environmental } \\
\text { Monitoring }\end{array}$ & $\begin{array}{l}\text { D. C. Lynn, WTS Land Use } \\
\text { Coordinator, } 10 / 23 / 00\end{array}$ & $\mathrm{DOE}$ \\
\hline $\begin{array}{l}\text { New Mexico State } \\
\text { Engineer Office }\end{array}$ & Monitoring Well WIPP-26 & C-2724 & $11 / 06 / 00$ & None & Active & $\begin{array}{l}\text { Environmental } \\
\text { Monitoring } \\
\end{array}$ & $\begin{array}{l}\text { D. C. Lynn, WTS Land Use } \\
\text { Coordinator, } 10 / 23 / 00 \\
\end{array}$ & $\mathrm{DOE}$ \\
\hline
\end{tabular}




\section{Waste Isolation Pilot Plant 2001 Site Environmental Report}

$$
\text { DOE/WIPP 02-2225 }
$$

Table 3.5 - Active Environmental Permits and Approvals for the Waste Isolation Pilot Plant (as of December 31, 2001) (Does Not Include RCRA Permits)

\begin{tabular}{|c|c|c|c|c|c|c|c|c|}
\hline Granting Agency & Type of Permit & Permit Number & $\begin{array}{l}\text { Granted/ } \\
\text { Submitted }\end{array}$ & Expiration & $\begin{array}{l}\text { Current Permit } \\
\text { Status }\end{array}$ & WTS Owner & Signed By/Title & Signed For \\
\hline $\begin{array}{l}\text { New Mexico State } \\
\text { Engineer Office }\end{array}$ & Monitoring Well WIPP-27 & C-2722 & $11 / 06 / 00$ & None & Active & $\begin{array}{l}\text { Environmental } \\
\text { Monitoring }\end{array}$ & $\begin{array}{l}\text { D. C. Lynn, WTS Land Use } \\
\text { Coordinator, } 07 / 24 / 00\end{array}$ & $\mathrm{DOE}$ \\
\hline $\begin{array}{l}\text { New Mexico State } \\
\text { Engineer Office }\end{array}$ & Monitoring Well WIPP28 & C-2636 & $01 / 12 / 99$ & None & Active & $\begin{array}{l}\text { Environmental } \\
\text { Monitoring }\end{array}$ & $\begin{array}{l}\text { G. T. Basabilvaso, DOE } \\
11 / 17 / 98\end{array}$ & $\mathrm{DOE}$ \\
\hline $\begin{array}{l}\text { New Mexico State } \\
\text { Engineer Office }\end{array}$ & Monitoring Well WIPP-29 & C-2743 & $11 / 06 / 00$ & None & Active & \begin{tabular}{|l|} 
Environmental \\
Monitoring
\end{tabular} & $\begin{array}{l}\text { D. C. Lynn, WTS Land Use } \\
\text { Coordinator, } 10 / 23 / 00\end{array}$ & $\mathrm{DOE}$ \\
\hline $\begin{array}{l}\text { New Mexico State } \\
\text { Engineer Office }\end{array}$ & Monitoring Well WIPP-30 & C-2727 & $08 / 04 / 00$ & None & Active & $\begin{array}{l}\text { Environmental } \\
\text { Monitoring }\end{array}$ & $\begin{array}{l}\text { G. T. Basabilvaso, DOE } \\
07 / 31 / 00\end{array}$ & $\mathrm{DOE}$ \\
\hline
\end{tabular}




\section{Waste Isolation Pilot Plant 2001 Site Environmental Report}

DOE/WIPP 02-2225

\section{CHAPTER 4 - ENVIRONMENTAL RADIOLOGICAL PROGRAM INFORMATION}

Radionuclides present in the environment, whether naturally-occurring or human-made, contribute to radiation doses to humans. Therefore, environmental monitoring around nuclear facilities is imperative to characterize radiological conditions, detect releases, and determine their effects, should they occur. Because of this, the DOE requires an environmental monitoring program for nuclear facilities (DOE Order 5400.1).

The WIPP Environmental Monitoring Program monitors air, surface and groundwater, soils, and biota to characterize the radiation environment and to detect potential releases from WIPP activities. This program is carried out in accordance with the EMP. This chapter summarizes the results of radiological monitoring during CY 2001.

The radiological environment near WIPP includes natural radioactivity, global fallout and, potentially, radioactive contamination from the Project Gnome. A nuclear device was detonated underground in bedded salt on December 10, 1961. The test site for Project Gnome was located about $20 \mathrm{~km}$ (13 miles) southwest of the WIPP site. The Project Gnome shot vented into the drift and up the shaft to the atmosphere. Therefore, most environmental samples are expected to contain small amounts of natural radioactivity and fission products.

Throughout this chapter, radionuclides were considered "detected" in a sample if the measured concentration or activity minus $2 \times$ total propagated uncertainty (TPU) exceeded the minimum detectable concentration (MDC). The MDC was determined by the different analytical laboratories based on the natural background radiation, the analytical technique, and inherent characteristics of the analytical equipment. The MDC represents the minimum concentration of a radionuclide detectable in a given sample using the given equipment and techniques.

Total propagated uncertainty is an estimate of the uncertainty in the measurement due to all sources, including counting error, measurement error, chemical recovery error, detector efficiency, randomness of radioactive decay and any other sources of uncertainty.

Comparisons of radionuclide concentrations were made between years and locations using the statistical procedure, ANOVA. When this, or another statistical test, was used, the value of $p$, the probability of obtaining the value of the test statistic by chance alone, was reported. In many cases, scientists have accepted a value of $p<0.05$ as indicative of a difference between samples. However, interpretation of $p$ requires some judgment on the part of the reader; individual readers may choose to defend higher or lower values of $p$ as their cutoff value. For this report, $p<0.05$ was used.

\subsection{Effluent Monitoring}

If radionuclides are released into the environment from WIPP, they would first be detected in airborne effluents. Thus, WIPP monitors airborne effluents at three locations, effluent monitoring Stations A, B, and C. Station A samples the unfiltered 


\section{Waste Isolation Pilot Plant 2001 Site Environmental Report DOE/WIPP 02-2225}

underground exhaust air. Station B samples the underground exhaust air after HEPA filtration and, sometimes, nonfiltered air during maintenance. Station $\mathrm{C}$ samples the air from the Waste Handling Building after HEPA filtration. Each station employs one or more fixed air samplers, collecting particulates from effluent air stream and a Versapore filter.

During 2001, 411 samples were collected from Station A for a total air volume sampled of $26,697.5 \mathrm{~m}^{3}\left(942,707 \mathrm{ft}^{3}\right)$. Because only a small fraction of the air released through Station $A$ is sampled, the activity on the filter is normalized to the total air flow through Station A using an EPA-approved methodology. Fifty-six samples were collected from Station B for a total air volume sampled of $29,735.8 \mathrm{~m}^{3}\left(1,049,994 \mathrm{ft}^{3}\right)$, and 53 samples were collected from Station $C$ for a total air volume sampled of 8,312.9 $\mathrm{m}^{3}\left(293,533 \mathrm{ft}^{3}\right)$. Samples were composited each quarter for stations $B$ and $C$. Because of the large number of samples from Station $A$, these samples were composited monthly. Samples were analyzed radiochemically for ${ }^{241} \mathrm{Am},{ }^{238} \mathrm{Pu}$, and ${ }^{239+240} \mathrm{Pu}$, the components of the contact handled waste at WIPP expected to produce 98 percent of the potential dose to humans.

Out of 60 total composite samples, only one sample had detectable radioactivity (Table 4.1). For the remaining 59 samples WIPP Laboratories reported an activity less than the MDC. For the 59 composite samples where there was no activity detected, it was conservatively assumed that the actual activity was equal to the MDC for the WIPP 2001 Annual Periodic Confirmatory Measurement Compliance Report (40 CFR Part 61, Subpart $\mathrm{H}$ ), and for other effluent reporting requirements.

The sample filter containing the detectable radioactivity, ${ }^{241} \mathrm{Am}$, was collected from Station A during October 2001 (Table 4.1). In addition, during February 2001 at Station $A$, and during the third quarter at Station B, the reported activity of ${ }^{241} \mathrm{Am}$ was greater than the MDC. However, in both of these cases, the reported activities were less than two times the TPU, indicating the samples did not likely contained ${ }^{241} \mathrm{Am}$.

In reference to Table 4.1, the WIPP Laboratories reports the radionuclide results in units of picoCurie/sample ( $\mathrm{pCi} / \mathrm{sample).} \mathrm{The} \mathrm{laboratory} \mathrm{results} \mathrm{are} \mathrm{converted} \mathrm{from}$ $\mathrm{pCi} /$ sample to becquerels $(\mathrm{Bq})$. The laboratory results are converted to $\mathrm{Bq}$ by multiplying the laboratory results by 0.037 .

There was no significant difference in the concentration of any radionuclide at Stations B and C between the years 2000 and 2001. It was not possible to compare results from Station $A$ across years, because the composition frequency changed from quarterly to monthly from year 2000 to year 2001.

Results from Stations A, B, and C were used as input for the dose assessment presented in Chapter 7.

Additional sampling was routinely performed in the underground using fixed air samplers and continuous air monitors. Evaluation of the samples from both indicate there were no detectable releases above background activity from the WIPP facility. 


\subsection{Airborne Gross Alpha/Beta}

Gross alpha and beta measurements in airborne particulates are used as a screening technique to provide timely information on levels of radioactivity in the environment around the WIPP site. Airborne particulate samples were collected from seven different locations around WIPP: Southeast Control (SEC), Carlsbad (CBD), J. C. Mills Ranch (MLR), Smith Ranch (SMR), WIPP East (WEE), WIPP South (WSS), and WIPP Far Field (WFF) (Figure 4.1).

Each week at each station, approximately $600 \mathrm{~m}^{3}\left(21,200 \mathrm{ft}^{3}\right)$ of air was filtered through a $4.7-\mathrm{cm}$ (1.85-in) diameter glass microfiber filter using a low-volume continuous air sampler. The samples were collected at a height of $1.5-2 \mathrm{~m}(5-6.5 \mathrm{ft})$ to closely match the height at which air is inhaled by humans. Filters were counted for gross alpha and beta only after being stored for five to seven days in the laboratory to make sure the short-lived radon progeny had decayed.

Blank filters were also counted for gross alpha and beta activities so that background corrections (activities present in the blank filters) could be made in the gross alpha and beta measurements of the air samples. Blanks were counted weekly along with the samples. The gross alpha and beta activities per cubic meter of air were then determined by dividing the total activity of gross alpha and beta found in each weekly sample by the amount of air pulled through each sample. The results are given in Appendix D. The mass and volume of air collected each week are reported in Appendix E.

As expected, weekly gross alpha activity concentrations measured in 2001 varied by an order of magnitude throughout the year at each location (Figure 4.2). Measured concentrations ranged from a minimum of $1.15 \times 10^{-5} \pm 1.72 \times 10^{-5} \mathrm{~Bq} / \mathrm{m}^{3}\left(3.11 \times 10^{-4} \pm\right.$ $\left.4.65 \times 10^{-4} \mathrm{pCi} / \mathrm{m}^{3}\right)$ to a maximum of $1.52 \times 10^{-4} \pm 4.27 \times 10^{-5} \mathrm{~Bq} / \mathrm{m}^{3}\left(4.11 \times 10^{-3} \pm\right.$ $\left.1.15 \times 10^{-3} \mathrm{pCi} / \mathrm{m}^{3}\right)($ Table 4.2). However, the annual mean concentrations of gross alpha activities found at all locations were similar, ranging from $5.26 \times 10^{-5} \pm 3.97 \times 10^{-5}$ to $6.16 \times 10^{-5} \pm 5.28 \times 10^{-5} \mathrm{~Bq} / \mathrm{m}^{3}\left(1.42 \times 10^{-3} \pm 1.07 \times 10^{-3}\right.$ to $\left.1.66 \times 10^{-3} \pm 1.43 \times 10^{-3} \mathrm{pCi} / \mathrm{m}^{3}\right)$. ANOVA indicated no statistically significant difference between sampling stations $(p=0.989)$. 
Table 4.1 - Activity (Bq) of Quarterly Composite Air Samples from

Effluent Monitoring Stations A, B, and C

\begin{tabular}{|c|c|c|c|c|c|c|c|c|c|}
\hline Nuclide & Activity & $2 \times \mathrm{TPU}^{\mathrm{a}}$ & $\mathrm{MDC}^{\mathrm{b}}$ & Activity & $2 \times$ TPU & MDC & Activity & $2 \times$ TPU & MDC \\
\hline & & Station A & & \multicolumn{3}{|c|}{ Station B } & \multicolumn{3}{|c|}{ Station C } \\
\hline \multicolumn{10}{|c|}{$1^{\text {st }}$ Quarter } \\
\hline${ }^{241} \mathrm{Am}$ & & & & $3.11 \times 10^{-4}$ & $7.62 \times 10^{-4}$ & $1.45 \times 10^{-3}$ & $0.00 \times 10^{0}$ & $0.00 \times 10^{0}$ & $5.03 \times 10^{-4}$ \\
\hline${ }^{238} \mathrm{Pu}$ & & See below ${ }^{c}$ & & $0.00 \times 10^{0}$ & $0.00 \times 10^{0}$ & $1.07 \times 10^{-3}$ & $1.05 \times 10^{-4}$ & $3.65 \times 10^{-4}$ & $7.70 \times 10^{-4}$ \\
\hline${ }^{239+240} \mathrm{Pu}$ & & & & $1.15 \times 10^{-4}$ & $2.31 \times 10^{-4}$ & $3.11 \times 10^{-4}$ & $1.05 \times 10^{-4}$ & $2.10 \times 10^{-4}$ & $2.83 \times 10^{-4}$ \\
\hline \multicolumn{10}{|c|}{$2^{\text {nd }}$ Quarter } \\
\hline${ }^{241} \mathrm{Am}$ & & & & $0.00 \times 10^{0}$ & $0.00 \times 10^{0}$ & $5.07 \times 10^{-4}$ & $-3.63 \times 10^{-4}$ & $5.22 \times 10^{-4}$ & $1.69 \times 10^{-3}$ \\
\hline${ }^{238} \mathrm{Pu}$ & & See below & & $6.07 \times 10^{-5}$ & $2.11 \times 10^{-4}$ & $4.44 \times 10^{-4}$ & $0.00 \times 10^{0}$ & $0.00 \times 10^{-4}$ & $4.88 \times 10^{-4}$ \\
\hline${ }^{239+240} \mathrm{Pu}$ & & & & $0.00 \times 10^{0}$ & $0.00 \times 10^{0}$ & $1.64 \times 10^{-4}$ & $6.62 \times 10^{-5}$ & $1.33 \times 10^{-4}$ & $1.79 \times 10^{-4}$ \\
\hline \multicolumn{10}{|c|}{$3^{\text {rd }}$ Quarter } \\
\hline${ }^{241} \mathrm{Am}$ & & & & $1.21 \times 10^{-3}$ & $1.42 \times 10^{-3}$ & $1.09 \times 10^{-3}$ & $1.10 \times 10^{-4}$ & $6.59 \times 10^{-4}$ & $1.32 \times 10^{-3}$ \\
\hline${ }^{238} \mathrm{Pu}$ & & See below & & $-1.09 \times 10^{-4}$ & $2.19 \times 10^{-4}$ & $7.99 \times 10^{-4}$ & $-2.11 \times 10^{-4}$ & $4.26 \times 10^{-4}$ & $1.13 \times 10^{-3}$ \\
\hline${ }^{239+240} \mathrm{Pu}$ & & & & $1.08 \times 10^{-4}$ & $2.18 \times 10^{-4}$ & $2.94 \times 10^{-4}$ & $2.10 \times 10^{-4}$ & $2.99 \times 10^{-4}$ & $2.85 \times 10^{-4}$ \\
\hline \multicolumn{10}{|c|}{$4^{\text {th }}$ Quarter } \\
\hline${ }^{241} \mathrm{Am}$ & & & & $0.00 \times 10^{0}$ & $0.00 \times 10^{0}$ & $1.39 \times 10^{-3}$ & $2.18 \times 10^{-4}$ & $4.37 \times 10^{-4}$ & $8.03 \times 10^{-4}$ \\
\hline${ }^{238} \mathrm{Pu}$ & & See below & & $0.00 \times 10^{0}$ & $0.00 \times 10^{0}$ & $1.03 \times 10^{-3}$ & $0.00 \times 10^{0}$ & $0.00 \times 10^{0}$ & $7.62 \times 10^{-4}$ \\
\hline \multirow[t]{3}{*}{${ }^{239+240} \mathrm{Pu}$} & & & & $0.00 \times 10^{0}$ & $0.00 \times 10^{0}$ & $3.77 \times 10^{-4}$ & $2.07 \times 10^{-4}$ & $2.95 \times 10^{-4}$ & $2.81 \times 10^{-4}$ \\
\hline & \multirow{2}{*}{\multicolumn{3}{|c|}{ Station A }} & \multicolumn{2}{|c|}{$1^{\text {st }}$ Quarter } & Monthly $^{c}$ & & & \\
\hline & & & & & February & & \multicolumn{3}{|c|}{ March } \\
\hline${ }^{241} \mathrm{Am}$ & $5.88 \times 10^{-4}$ & $7.25 \times 10^{-4}$ & $1.08 \times 10^{-3}$ & $6.07 \times 10^{-4}$ & $6.18 \times 10^{-4}$ & $4.11 \times 10^{-4}$ & $0.00 \times 10^{0}$ & $0.00 \times 10^{0}$ & $1.50 \times 10^{-3}$ \\
\hline${ }^{238} \mathrm{Pu}$ & $1.34 \times 10^{-4}$ & $2.69 \times 10^{-4}$ & $3.61 \times 10^{-4}$ & $0.00 \times 10^{0}$ & $0.00 \times 10^{0}$ & $7.51 \times 10^{-4}$ & $-1.22 \times 10^{-4}$ & $4.26 \times 10^{-4}$ & $1.13 \times 10^{-3}$ \\
\hline \multirow[t]{3}{*}{${ }^{239+240} \mathrm{Pu}$} & $4.00 \times 10^{-4}$ & $5.99 \times 10^{-4}$ & $9.81 \times 10^{-4}$ & $0.00 \times 10^{0}$ & $0.00 \times 10^{0}$ & $2.76 \times 10^{-4}$ & $0.00 \times 10^{0}$ & $0.00 \times 10^{0}$ & $3.30 \times 10^{-4}$ \\
\hline & \multirow{2}{*}{\multicolumn{3}{|c|}{ Station A }} & \multicolumn{2}{|c|}{$2^{\text {nd }}$ Quarter } & Monthly & & & \\
\hline & & & & & May & & \multicolumn{3}{|c|}{ June } \\
\hline${ }^{241} \mathrm{Am}$ & $1.51 \times 10^{-4}$ & $3.02 \times 10^{-4}$ & $5.55 \times 10^{-4}$ & $-3.10 \times 10^{-4}$ & $3.85 \times 10^{-4}$ & $1.02 \times 10^{-3}$ & $6.40 \times 10^{-4}$ & $8.07 \times 10^{-4}$ & $1.28 \times 10^{-3}$ \\
\hline${ }^{238} \mathrm{Pu}$ & $0.00 \times 10^{0}$ & $0.00 \times 10^{0}$ & $4.33 \times 10^{-4}$ & $-6.07 \times 10^{-5}$ & $1.22 \times 10^{-4}$ & $4.44 \times 10^{-4}$ & $0.00 \times 10^{0}$ & $0.00 \times 10^{0}$ & $4.81 \times 10^{-4}$ \\
\hline \multirow[t]{3}{*}{${ }^{239+240} \mathrm{Pu}$} & $5.88 \times 10^{-5}$ & $2.04 \times 10^{-4}$ & $4.33 \times 10^{-4}$ & $-6.03 \times 10^{-5}$ & $1.21 \times 10^{-4}$ & $4.44 \times 10^{-4}$ & $6.55 \times 10^{-5}$ & $1.31 \times 10^{-4}$ & $1.77 \times 10^{-4}$ \\
\hline & \multirow{2}{*}{\multicolumn{3}{|c|}{ Station A }} & \multicolumn{2}{|c|}{$3^{\text {rd }}$ Quarter } & Monthly & & & \\
\hline & & & & & August & & \multicolumn{3}{|c|}{ September } \\
\hline${ }^{241} \mathrm{Am}$ & $3.29 \times 10^{-4}$ & $4.70 \times 10^{-4}$ & $4.44 \times 10^{-4}$ & $2.21 \times 10^{-4}$ & $6.25 \times 10^{-4}$ & $1.19 \times 10^{-3}$ & $7.22 \times 10^{-4}$ & $6.29 \times 10^{-4}$ & $7.59 \times 10^{-4}$ \\
\hline${ }^{238} \mathrm{Pu}$ & $0.00 \times 10^{0}$ & $0.00 \times 10^{0}$ & $3.43 \times 10^{-4}$ & $0.00 \times 10^{0}$ & $0.00 \times 10^{0}$ & $2.99 \times 10^{-4}$ & $0.00 \times 10^{0}$ & $0.00 \times 10^{0}$ & $3.10 \times 10^{-4}$ \\
\hline \multirow[t]{3}{*}{${ }^{239+240} \mathrm{Pu}$} & $0.00 \times 10^{0}$ & $0.00 \times 10^{0}$ & $9.32 \times 10^{-4}$ & $2.21 \times 10^{-4}$ & $3.14 \times 10^{-4}$ & $2.99 \times 10^{-4}$ & $-2.29 \times 10^{-4}$ & $3.26 \times 10^{-4}$ & $1.06 \times 10^{-3}$ \\
\hline & \multirow{2}{*}{\multicolumn{3}{|c|}{ Station A }} & \multicolumn{2}{|c|}{$4^{\text {th }}$ Quarter } & Monthly & & & \\
\hline & & & & & November & & \multicolumn{3}{|c|}{ December } \\
\hline${ }^{241} \mathrm{Am}$ & $1.86 \times 10^{-3}$ & $1.41 \times 10^{-3}$ & $1.52 \times 10^{-3}$ & $-2.39 \times 10^{-2}$ & $4.81 \times 10^{-4}$ & $1.29 \times 10^{-3}$ & $2.71 \times 10^{-4}$ & $3.85 \times 10^{-4}$ & $3.67 \times 10^{-4}$ \\
\hline${ }^{238} \mathrm{Pu}$ & $2.20 \times 10^{-4}$ & $4.40 \times 10^{-4}$ & $8.07 \times 10^{-4}$ & $-2.78 \times 10^{-4}$ & $5.59 \times 10^{-4}$ & $1.49 \times 10^{-3}$ & $1.37 \times 10^{-4}$ & $2.74 \times 10^{-4}$ & $3.69 \times 10^{-4}$ \\
\hline${ }^{239+240} \mathrm{Pu}$ & $1.10 \times 10^{-4}$ & $2.19 \times 10^{-4}$ & $2.97 \times 10^{-4}$ & $0.00 \times 10^{0}$ & $0.00 \times 10^{0}$ & $1.02 \times 10^{-3}$ & $-1.36 \times 10^{-4}$ & $2.73 \times 10^{-4}$ & $1.00 \times 10^{-3}$ \\
\hline
\end{tabular}

In 2001, the weekly gross beta concentrations also varied throughout the year at each station (Figure 4.3). Stations tended to vary together, showing a strong annual pattern. 
Concentrations ranged over almost an order of magnitude, from a minimum of $4.71 \times 10^{-4}$ $\pm 7.88 \times 10^{-5} \mathrm{~Bq} / \mathrm{m}^{3}\left(1.27 \times 10^{-2} \pm 2.13 \times 10^{-3} \mathrm{pCi} / \mathrm{m}^{3}\right)$ to a maximum of $1.70 \times 10^{-3} \pm$ $2.04 \times 10^{-4} \mathrm{~Bq} / \mathrm{m}^{3}\left(4.59 \times 10^{-2} \pm 5.51 \times 10^{-3} \mathrm{pCi} / \mathrm{m}^{3}\right)($ Table 4.2$)$. However, the annual mean concentrations of gross beta activities found at all locations were similar, ranging from $8.37 \times 10^{-4} \pm 4.17 \times 10^{-4}$ to $9.28 \times 10^{-4} \pm 1.86 \times 10^{-3} \mathrm{~Bq} / \mathrm{m}^{3}\left(2.26 \times 10^{-2} \pm 1.13 \times 10^{-2}\right.$ to $2.51 \times 10^{-2}$ $\pm 5.03 \times 10^{-2} \mathrm{pCi} / \mathrm{m}^{3}$ ). There was no significant difference between sampling stations (ANOVA, $p=0.565$ ).

Gross alpha and gross beta activity concentrations in 2000 and 2001 were compared using ANOVA to determine whether they had increased since waste began to be received at WIPP (Figure 4.4). There was no significant difference in measured gross alpha $(p=0.241)$ or gross beta $(p=0.094)$ activity concentration between years. 


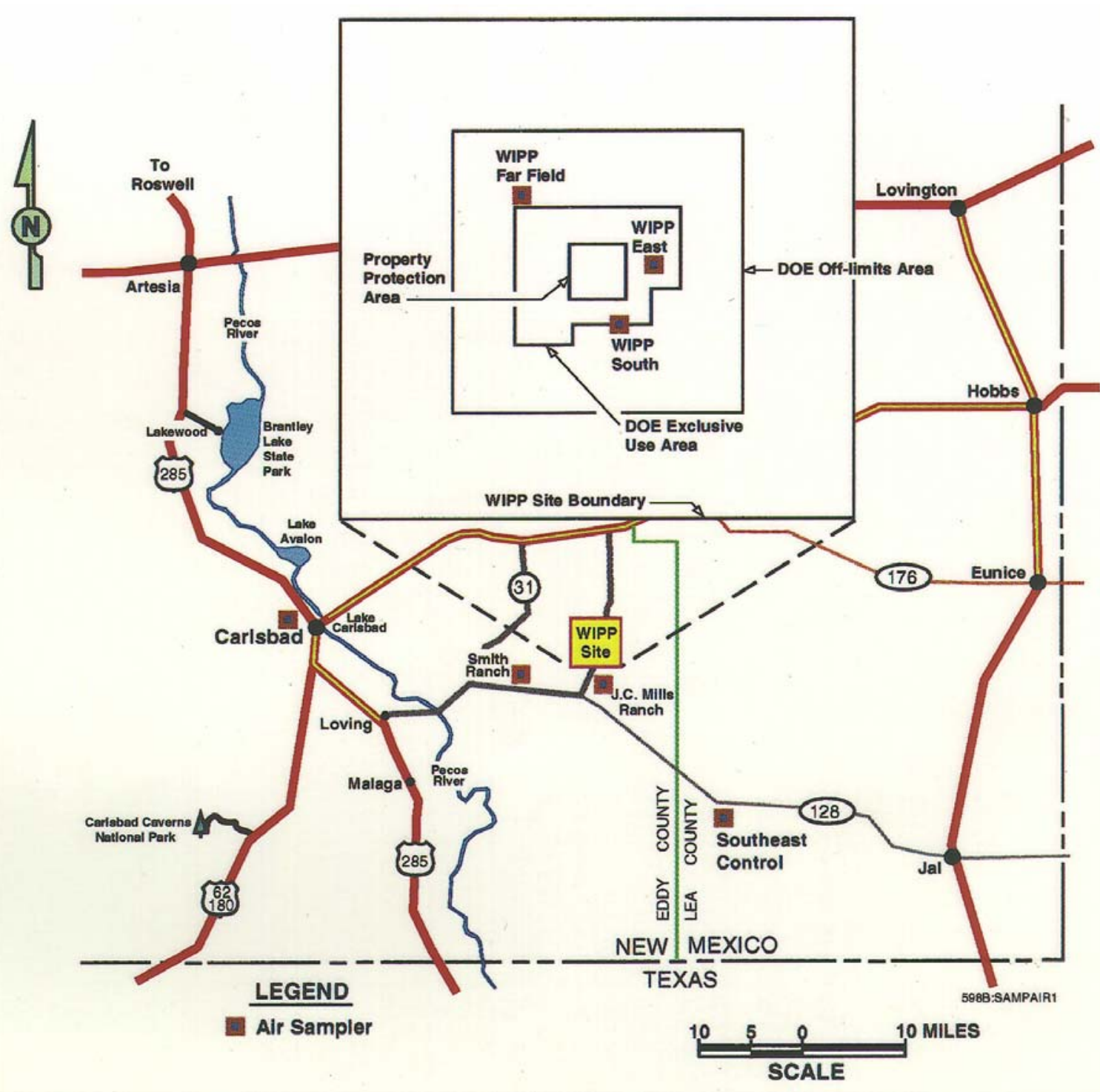

Figure 4.1 - Air Sampling Locations on and Near the WIPP Facility

One duplicate sample was collected every quarter by rotating the portable sampler from one location to another: WEE in the first quarter, WSS in the second quarter, MLR in the third quarter, and SMR in the fourth quarter. The samples were collected by both samplers in identical conditions at all four locations. Duplicate samples were collected and analyzed for the QC of (1) air sampling technique, (2) determination of gross alpha and beta activities, and (3) analysis of the individual radionuclides in airborne particulate. Relative Error Ratios (RER) (see Appendix C) was exceeded once in the weekly gross alpha (RER value 1.03) and were less than one in all of the weekly gross beta measurements. An RER less than one indicates good agreement between duplicates. The duplicate data are provided in Appendix D. 


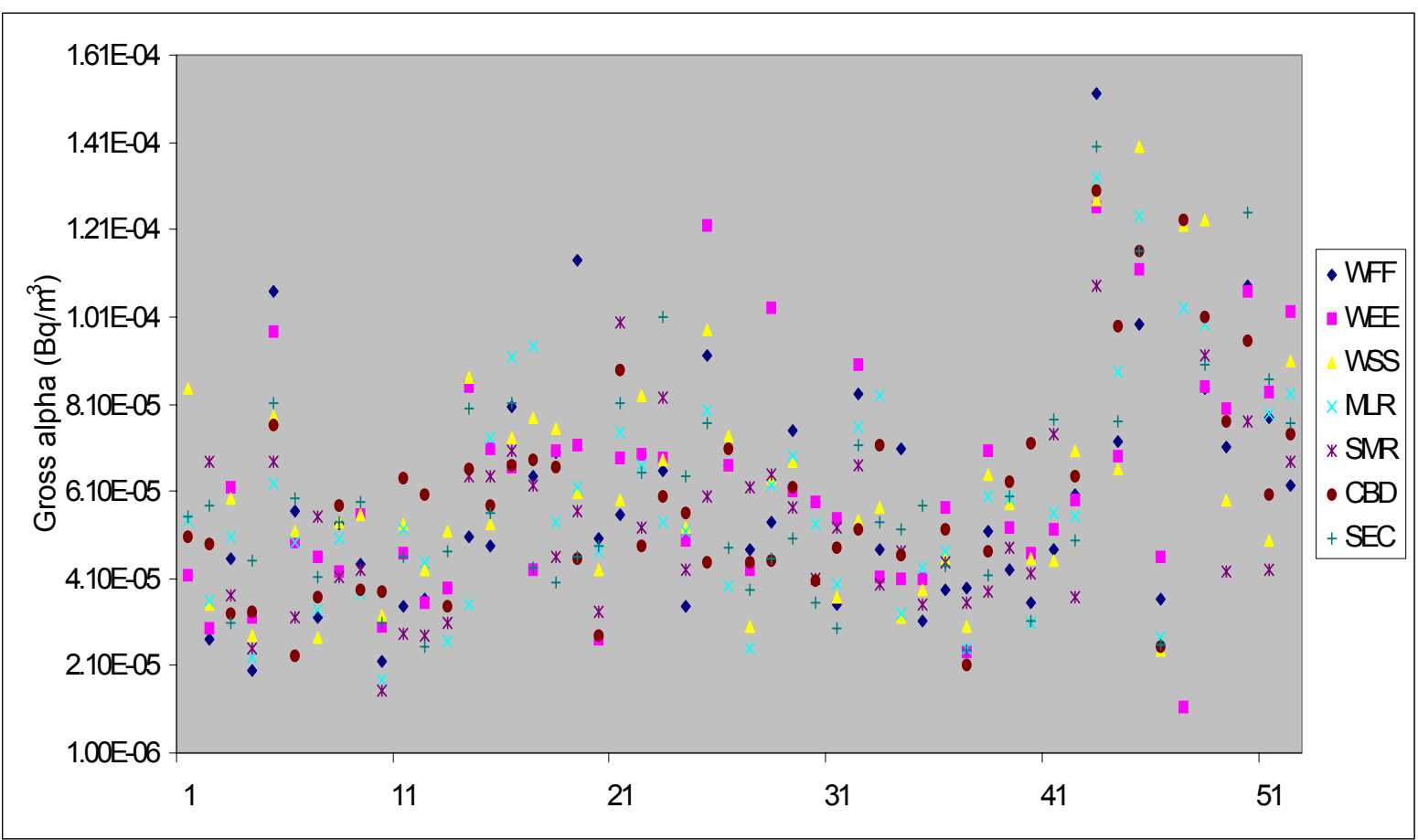

Figure 4.2 - Gross Alpha Activity Concentration Measured in Air Particulates Each Week in 2001. See text for sampling station locations.

Table 4.2 - Annual Mean Gross Alpha and Gross Beta Activity Concentrations (Bq/ $\left.\mathrm{m}^{3}\right)$ Found in Weekly Air Particulate Samples

(See Appendix B for sample locations.)

\begin{tabular}{|c|c|c|c|c|c|c|}
\hline Location & Minimum & $2 \times \mathrm{TPU}^{\mathrm{a}}$ & Maximum & $2 \times$ TPU & Mean & $2 \times S^{b}$ \\
\hline \multicolumn{7}{|c|}{ Gross Alpha } \\
\hline CBD & $2.11 \times 10^{-5}$ & $1.57 \times 10^{-5}$ & $1.30 \times 10^{-4}$ & $3.87 \times 10^{-5}$ & $5.98 \times 10^{-5}$ & $4.92 \times 10^{-5}$ \\
\hline MLR & $1.77 \times 10^{-5}$ & $1.45 \times 10^{-5}$ & $1.33 \times 10^{-4}$ & $4.03 \times 10^{-5}$ & $5.83 \times 10^{-5}$ & $5.13 \times 10^{-5}$ \\
\hline SEC & $2.46 \times 10^{-5}$ & $1.71 \times 10^{-5}$ & $1.40 \times 10^{-4}$ & $4.11 \times 10^{-5}$ & $5.93 \times 10^{-5}$ & $5.07 \times 10^{-5}$ \\
\hline SMR & $1.52 \times 10^{-5}$ & $1.37 \times 10^{-5}$ & $1.08 \times 10^{-4}$ & $3.68 \times 10^{-5}$ & $5.26 \times 10^{-5}$ & $3.97 \times 10^{-5}$ \\
\hline WEE & $1.15 \times 10^{-5}$ & $1.72 \times 10^{-5}$ & $1.26 \times 10^{-4}$ & $3.92 \times 10^{-5}$ & $6.16 \times 10^{-5}$ & $5.15 \times 10^{-5}$ \\
\hline WFF & $1.99 \times 10^{-5}$ & $1.55 \times 10^{-5}$ & $1.52 \times 10^{-4}$ & $4.27 \times 10^{-5}$ & $5.90 \times 10^{-5}$ & $1.18 \times 10^{-4}$ \\
\hline WSS & $2.47 \times 10^{-5}$ & $1.69 \times 10^{-5}$ & $1.40 \times 10^{-4}$ & $4.08 \times 10^{-5}$ & $6.16 \times 10^{-5}$ & $5.28 \times 10^{-5}$ \\
\hline \multicolumn{7}{|c|}{ Gross Beta } \\
\hline CBD & $5.59 \times 10^{-4}$ & $8.38 \times 10^{-5}$ & $1.70 \times 10^{-3}$ & $2.04 \times 10^{-4}$ & $8.83 \times 10^{-4}$ & $4.63 \times 10^{-4}$ \\
\hline MLR & $5.77 \times 10^{-4}$ & $8.99 \times 10^{-5}$ & $1.56 \times 10^{-3}$ & $1.91 \times 10^{-4}$ & $8.76 \times 10^{-4}$ & $4.33 \times 10^{-4}$ \\
\hline SEC & $6.13 \times 10^{-4}$ & $9.12 \times 10^{-5}$ & $1.62 \times 10^{-3}$ & $1.93 \times 10^{-4}$ & $9.04 \times 10^{-4}$ & $4.13 \times 10^{-4}$ \\
\hline SMR & $4.71 \times 10^{-4}$ & $7.88 \times 10^{-5}$ & $1.39 \times 10^{-3}$ & $1.73 \times 10^{-4}$ & $8.37 \times 10^{-4}$ & $4.17 \times 10^{-4}$ \\
\hline WEE & $5.54 \times 10^{-4}$ & $8.61 \times 10^{-5}$ & $1.64 \times 10^{-3}$ & $1.95 \times 10^{-4}$ & $8.90 \times 10^{-4}$ & $4.58 \times 10^{-4}$ \\
\hline WFF & $5.87 \times 10^{-4}$ & $8.92 \times 10^{-5}$ & $1.66 \times 10^{-3}$ & $1.98 \times 10^{-4}$ & $9.28 \times 10^{-4}$ & $1.86 \times 10^{-3}$ \\
\hline WSS & $6.05 \times 10^{-4}$ & $8.86 \times 10^{-5}$ & $1.51 \times 10^{-3}$ & $1.83 \times 10^{-4}$ & $8.67 \times 10^{-4}$ & $4.31 \times 10^{-4}$ \\
\hline
\end{tabular}

a Total propagated uncertainty

${ }^{\mathrm{b}}$ Standard deviation of the mean 


\subsection{Airborne Particulates}

The major pathways for the intake of radioactive materials into the human body are from the inhalation of dust particles and the ingestion of food and drinking water. Plutonium is the major constituent of the TRU wastes to be disposed at the WIPP site. Accordingly, plutonium and other radionuclides of interest were determined in air particulate samples around the WIPP site.

Isotopes of plutonium and americium were analyzed because they are the most significant alpha-emitting radionuclides among the constituents of TRU wastes received at the WIPP site. Uranium isotopes were analyzed because they are prominent alpha-emitting radionuclides in the natural environment.

WIPP analyzed samples for ${ }^{90} \mathrm{Sr},{ }^{60} \mathrm{Co}$, and ${ }^{137} \mathrm{Cs}$ in order to demonstrate the ability to quantify these beta and gamma-emitting contaminants should they appear in the TRU waste stream. These radionuclides have been the subject of background studies at WIPP prior to 1999 and continue to be monitored. Potassium-40, a natural gammaemitting radionuclide which is ubiquitous in the earth's crust, was also monitored because of its possible enhancement in southeastern New Mexico due to potash mining.

Gross alpha and gross beta measurements are used as a screening technique and to identify any seasonal trends. The results are compared to historical values. Any result above the $2 \sigma$ warning limit is investigated for sampling error, instrument problems, and any other steps involved in the gross alpha and gross beta analysis. If the abovementioned were ruled out as a contribution to the high result, a destructive analysis is performed to identify the specific nuclide contributing to the activity.

\subsubsection{Sample Preparation}

Weekly air particulate samples were collected as described in Section 4.2 and composited for each quarter. The composites were transferred into a Pyrex beaker, spiked with appropriate tracers, and heated in a Muffle furnace at $250^{\circ} \mathrm{C}\left(482^{\circ} \mathrm{F}\right)$ for two hours, followed by two hours at $375^{\circ} \mathrm{C}\left(707^{\circ} \mathrm{F}\right)$ and six hours at $525^{\circ} \mathrm{C}\left(977^{\circ} \mathrm{F}\right)$.

The ash was cooled, transferred quantitatively into a Teflon beaker by rinsing with concentrated nitric acid, and heated with concentrated hydrofluoric acid until completely dissolved. Hydrofluoric acid was removed by evaporating to dryness.

Approximately $25 \mathrm{ml}$ ( $0.845 \mathrm{oz}$ [ounce]) of concentrated nitric acid and one gram ( $0.0353 \mathrm{oz})$ of boric acid were added, heated, and finally evaporated to dryness. The residue was dissolved in $8 \mathrm{M}$ (molar) nitric acid for gamma spectrometry and determinations of ${ }^{90} \mathrm{Sr}$ and alpha-emitting radionuclides. 


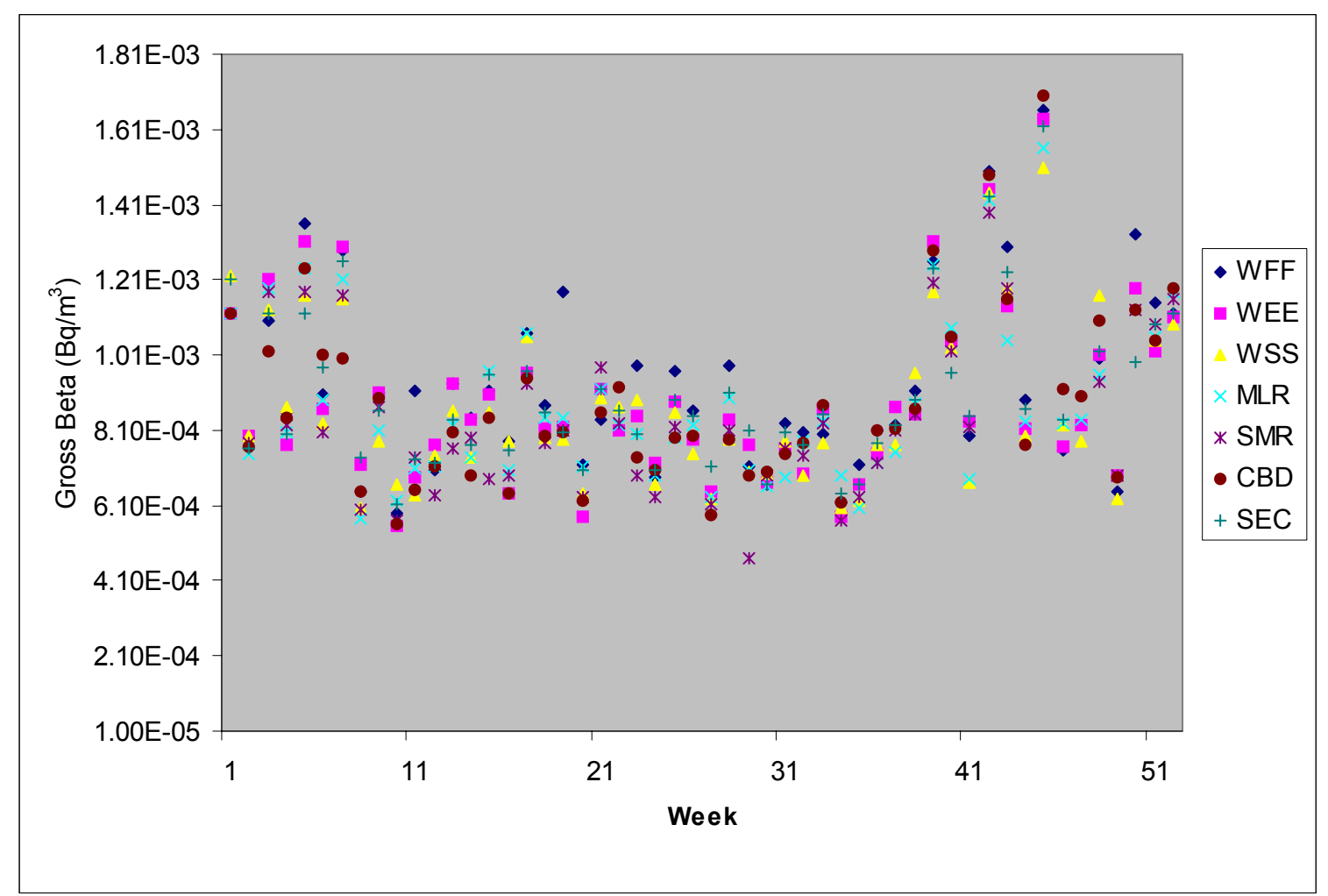

Figure 4.3 - Gross Beta Activity Concentration Measured in Air Particulates Each Week in 2001. See text for sampling station locations.

\subsubsection{Determination of Individual Radionuclides}

Gamma-emitting radionuclides were measured in the air filters by gamma spectrometry. Strontium-90 and alpha-emitting radionuclides were determined by sequential separation and counting. Determination of actinides involved co-precipitation, ion exchange separation, and alpha spectrometry.

\subsubsection{Results and Discussions}

The minima, maxima, and means for all stations combined are reported in Table 4.3. Detailed data for each station are reported in Appendix G (Table G.1). Natural uranium isotopes were detected in every composite sample. Concentrations of ${ }^{234} \mathrm{U}$ ranged from $2.01 \times 10^{-6} \pm 4.48 \times 10^{-7} \mathrm{~Bq} / \mathrm{m}^{3}\left(5.43 \times 10^{-5} \pm 1.21 \times 10^{-5} \mathrm{pCi} / \mathrm{m}^{3}\right)$ at WSS in the first quarter to $4.59 \times 10^{-6} \pm 8.51 \times 10^{-7} \mathrm{~Bq} / \mathrm{m}^{3}\left(1.24 \times 10^{-4} \pm 2.30 \times 10^{-5} \mathrm{pCi} / \mathrm{m}^{3}\right)$ at WFF in the second quarter (Appendix G, Table G.1). There was no significant difference between concentrations measured in 2000 and 2001 (ANOVA, $p=0.345$ ). 

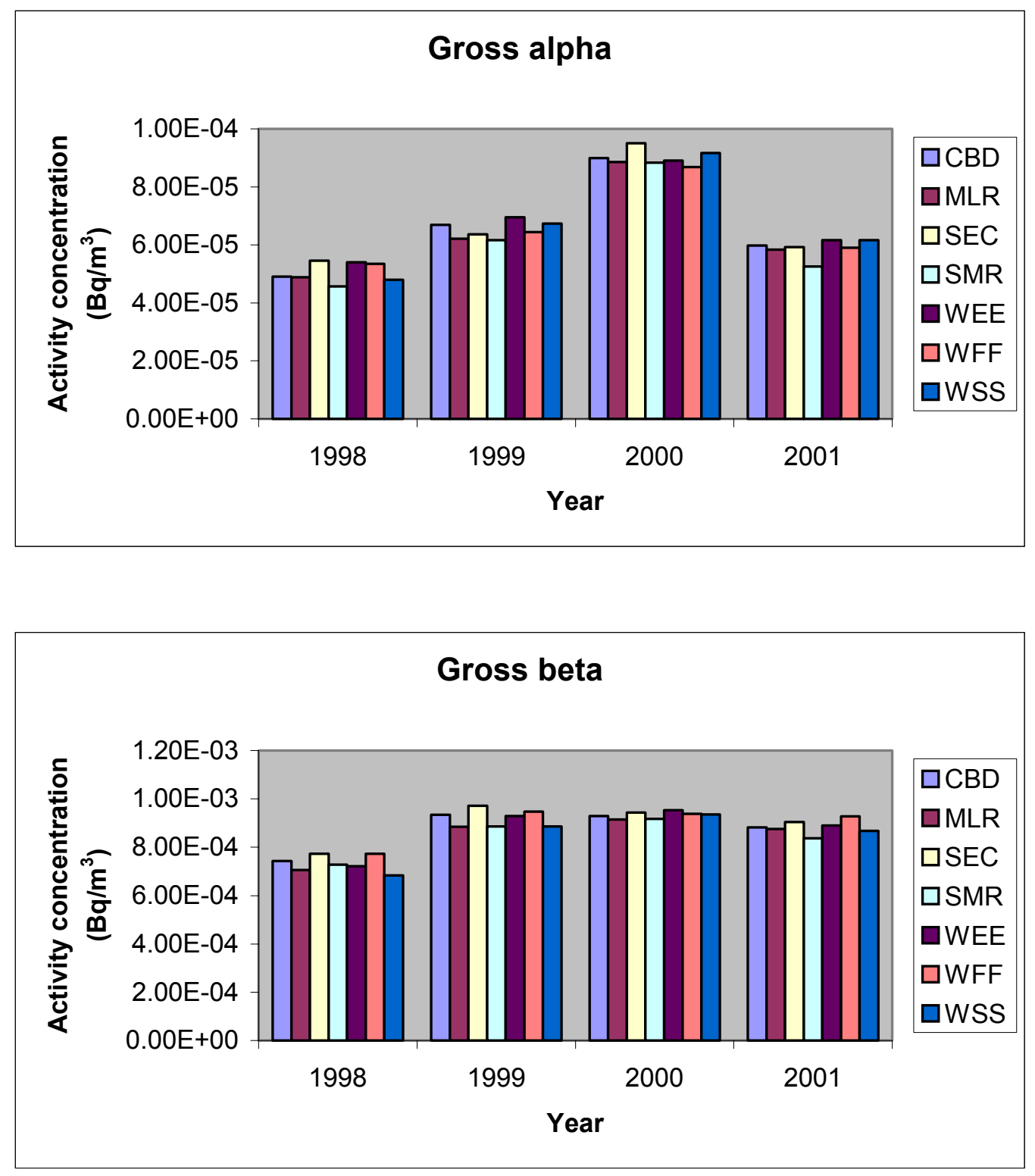

Figure 4.4 - Average Gross Alpha and Beta Activity Concentrations Measured in Air Particulates in Four Consecutive Years. The year 1999 was the first year in which radioactivity was stored in WIPP. See text for sampling station locations. 
Table 4.3 - Minimum, Maximum and Average Radionuclide Concentrations $\left(\mathrm{Bq} / \mathrm{m}^{3}\right)$ in Air Filter Composites from Stations Surrounding the WIPP Site. See Appendix B for locations. See Appendix $\mathbf{G}$ for supporting data.

\begin{tabular}{|c|c|c|c|c|}
\hline \multicolumn{2}{|c|}{ Radionuclide } & \multirow{2}{*}{$\begin{array}{c}{[\mathrm{RN}]^{\mathrm{a}}} \\
-4.26 \times 10^{-8}\end{array}$} & \multirow{2}{*}{$\frac{\mathbf{2 \times T _ { P U }}}{6.40 \times 10^{-8}}$} & \multirow{2}{*}{$\begin{array}{c}\text { MDC }^{\mathbf{c}} \\
3.81 \times 10^{-8}\end{array}$} \\
\hline${ }^{241} \mathrm{Am}$ & Minimum & & & \\
\hline & Maximum & $6.03 \times 10^{-8}$ & $6.11 \times 10^{-8}$ & $2.17 \times 10^{-7}$ \\
\hline & Average & $1.87 \times 10^{-8}$ & $4.88 \times 10^{-8}$ & $8.58 \times 10^{-8}$ \\
\hline \multirow[t]{3}{*}{${ }^{238} \mathrm{Pu}$} & Minimum & $-3.36 \times 10^{-8}$ & $6.73 \times 10^{-8}$ & $3.92 \times 10^{-8}$ \\
\hline & Maximum & $2.07 \times 10^{-7}$ & $2.23 \times 10^{-7}$ & $3.05 \times 10^{-7}$ \\
\hline & Average & $2.23 \times 10^{-8}$ & $9.37 \times 10^{-8}$ & $1.43 \times 10^{-7}$ \\
\hline \multirow[t]{3}{*}{${ }^{239+240} \mathrm{Pu}$} & Minimum & $-2.96 \times 10^{-8}$ & $5.96 \times 10^{-8}$ & $3.52 \times 10^{-8}$ \\
\hline & Maximum & $1.08 \times 10^{-7}$ & $1.34 \times 10^{-7}$ & $2.18 \times 10^{-7}$ \\
\hline & Average & $1.62 \times 10^{-8}$ & $5.36 \times 10^{-8}$ & $7.84 \times 10^{-8}$ \\
\hline \multirow[t]{3}{*}{${ }^{234} U$} & Minimum & $2.01 \times 10^{-6}$ & $4.48 \times 10^{-7}$ & $3.52 \times 10^{-8}$ \\
\hline & Maximum & $4.59 \times 10^{-6}$ & $8.51 \times 10^{-7}$ & $1.29 \times 10^{-7}$ \\
\hline & Average & $2.96 \times 10^{-6}$ & $1.66 \times 10^{-6}$ & $5.80 \times 10^{-8}$ \\
\hline \multirow[t]{3}{*}{${ }^{235} \mathrm{U}$} & Minimum & $0.00 \times 10^{0}$ & $0.00 \times 10^{0}$ & $4.44 \times 10^{-8}$ \\
\hline & Maximum & $8.18 \times 10^{-7}$ & $9.29 \times 10^{-8}$ & $2.10 \times 10^{-7}$ \\
\hline & Average & $1.69 \times 10^{-7}$ & $2.82 \times 10^{-7}$ & $7.74 \times 10^{-8}$ \\
\hline \multirow[t]{3}{*}{${ }^{238} \mathrm{U}$} & Minimum & $1.75 \times 10^{-6}$ & $4.18 \times 10^{-7}$ & $3.51 \times 10^{-8}$ \\
\hline & Maximum & $4.81 \times 10^{-6}$ & $9.55 \times 10^{-7}$ & $1.82 \times 10^{-7}$ \\
\hline & Average & $2.90 \times 10^{-6}$ & $1.63 \times 10^{-6}$ & $6.42 \times 10^{-8}$ \\
\hline \multirow[t]{3}{*}{${ }^{40} \mathrm{~K}$} & Minimum & $-5.29 \times 10^{-5}$ & $2.37 \times 10^{-4}$ & $1.27 \times 10^{-4}$ \\
\hline & Maximum & $6.44 \times 10^{-3}$ & $2.46 \times 10^{-4}$ & $8.84 \times 10^{-4}$ \\
\hline & Average & $6.90 \times 10^{-4}$ & $3.11 \times 10^{-3}$ & $3.31 \times 10^{-4}$ \\
\hline \multirow[t]{3}{*}{${ }^{60} \mathrm{Co}$} & Minimum & $-1.32 \times 10^{-5}$ & $2.94 \times 10^{-5}$ & $1.98 \times 10^{-5}$ \\
\hline & Maximum & $3.96 \times 10^{-5}$ & $4.00 \times 10^{-5}$ & $5.07 \times 10^{-5}$ \\
\hline & Average & $6.32 \times 10^{-6}$ & $2.72 \times 10^{-5}$ & $2.89 \times 10^{-5}$ \\
\hline \multirow[t]{3}{*}{${ }^{90} \mathrm{Sr}$} & Minimum & $-7.47 \times 10^{-6}$ & $5.66 \times 10^{-6}$ & $6.99 \times 10^{-6}$ \\
\hline & Maximum & $6.33 \times 10^{-6}$ & $4.40 \times 10^{-6}$ & $1.44 \times 10^{-5}$ \\
\hline & Average & $2.01 \times 10^{-7}$ & $7.08 \times 10^{-6}$ & $8.77 \times 10^{-6}$ \\
\hline \multirow[t]{3}{*}{${ }^{137} \mathrm{Cs}$} & Minimum & $-3.81 \times 10^{-5}$ & $3.28 \times 10^{-5}$ & $1.69 \times 10^{-5}$ \\
\hline & Maximum & $3.70 \times 10^{-5}$ & $3.70 \times 10^{-5}$ & $4.88 \times 10^{-5}$ \\
\hline & Average & $-7.71 \times 10^{-7}$ & $3.35 \times 10^{-5}$ & $2.62 \times 10^{-5}$ \\
\hline
\end{tabular}

a $[\mathrm{RN}]=$ Radionuclide concentration

${ }^{b}$ Total Propagated Uncertainty (Standard Deviation, in the case of the mean)

${ }^{\mathrm{c}}$ Minimum Detectable Concentration

The activity concentration of ${ }^{235} \mathrm{U}$ in the natural environment is very low compared to the concentrations of ${ }^{234} \mathrm{U}$ and ${ }^{238} \mathrm{U}(1 \mu \mathrm{g}$ of natural uranium contains $12.2 \mathrm{mBq}$ [millibecquerel] [0.33 pCi] of ${ }^{238} \mathrm{U}, 0.56 \mathrm{mBq}$ [0.01 pCi] of ${ }^{235} \mathrm{U}$, and $12.8 \mathrm{mBq}$ [0.35 pCi] of ${ }^{234} \mathrm{U}$ ); therefore, the amount of ${ }^{235} \mathrm{U}$ in air particulate samples is expected to be lower. Uranium-235 was detected in approximately 75 percent of the quarterly composite samples. The lowest concentration $\left(0.00 \times 10^{0} \pm 0.00 \times 10^{0} \mathrm{~Bq} / \mathrm{m}^{3}\left[0.00 \times 10^{0} \pm 0.00 \times 10^{0}\right.\right.$ $\left.\mathrm{pCi} / \mathrm{m}^{3}\right]$ ) was measured at WFF in the fourth quarter and the highest concentration $\left(8.18 \times 10^{-7} \pm 9.29 \times 10^{-8} \mathrm{~Bq} / \mathrm{m}^{3}\left[2.21 \times 10^{-5} \pm 2.51 \times 10^{-6} \mathrm{pCi} / \mathrm{m}^{3}\right]\right)$ was found at MLR in the first quarter (Table G.1). 


\section{Waste Isolation Pilot Plant 2001 Site Environmental Report DOE/WIPP 02-2225}

Uranium-238 was also, as expected, detected in 100 percent of the composite air filters. Concentrations ranged from $1.75 \times 10^{-6} \pm 4.18 \times 10^{-7} \mathrm{~Bq} / \mathrm{m}^{3}\left(4.73 \times 10^{-5} \pm 1.13 \times 10^{-5} \mathrm{pCi} / \mathrm{m}^{3}\right)$ at WFF in the first quarter to $4.81 \times 10^{-6} \pm 9.55 \times 10^{-7} \mathrm{~Bq} / \mathrm{m}^{3}\left(1.30 \times 10^{-4} \pm 2.58 \times 10^{-5} \mathrm{pCi} / \mathrm{m}^{3}\right)$ at CBD in the second quarter (Table G.1).

Neither ${ }^{238} \mathrm{Pu}$ nor ${ }^{239+240} \mathrm{Pu}$ were detected in any sample in 2001 . Americium-241 was also not detected in any of the quarterly composites.

Concentrations of ${ }^{40} \mathrm{~K}$ (Table G.1) were detected in approximately 50 percent of the samples. The minimum $\left(-5.29 \times 10^{-5} \pm 2.37 \times 10^{-4} \mathrm{~Bq} / \mathrm{m}^{3}\left[1.43 \times 10^{-3} \pm 6.41 \times 10^{-3} \mathrm{pCi} / \mathrm{m}^{3}\right]\right)$ was found at WFF in the second quarter, while the maximum $\left(6.44 \times 10^{-3} \pm 2.46 \times 10^{-4}\right.$ $\left.\mathrm{Bq} / \mathrm{m}^{3}\left[1.74 \times 10^{-1} \pm 6.65 \times 10^{-3} \mathrm{pCi} / \mathrm{m}^{3}\right]\right)$ was found at WEE in the second quarter.

Cesium-137 was not detected in any of the quarterly composite samples. Cobalt-60 was detected in one sample. Strontium-90 was never detected in a quarterly composite air filter in 2001.

Duplicate air particulate samples were collected by rotating the portable sampler from one location to another every quarter: WEE in the first quarter, WSS in the second quarter, MLR in the third quarter, and SMR in the fourth quarter. The samples were collected by both samplers in identical conditions at all four locations. The duplicate samples were analyzed to check the reproducibility of the data. The results are given in Table 4.4. The original and duplicate results for ${ }^{234} \mathrm{U},{ }^{238} \mathrm{U}$, and ${ }^{40} \mathrm{~K}$ were compared using the RER. The results for all other radionuclides were excluded because of insufficient detections for a meaningful test. Relative Error Ratios were less than one for all results except ${ }^{234} U$ and ${ }^{238} U$ at SMR fourth quarter due to the non-homogenous deposit of airborne particulates on the filter. Sample WSS in the second quarter failed to meet RER criteria for ${ }^{40} \mathrm{~K}$ because the gamma software had a problem calculating the activity. The problem was isolated to this incidence. The sample could not be reanalyzed since the aliquot was used for actinide analysis.

The results obtained for the concentrations of ${ }^{238} \mathrm{Pu},{ }^{239+240} \mathrm{Pu}$, and ${ }^{241} \mathrm{Am}$ in air particulates compared favorably with those measured by the EEG (Table 4.5). The annual mean concentrations of these radionuclides were very low, and most samples collected by either WIPP or EEG did not contain detectable concentrations. 


\section{Waste Isolation Pilot Plant 2001 Site Environmental Report DOE/WIPP 02-2225}

Table 4.4 - Results of Duplicate Composite Air Filter Sampling. Units are Bq/m $\mathbf{m}^{3}$. See Appendix B for sampling stations.

\begin{tabular}{|c|c|c|c|c|c|}
\hline \multirow[b]{2}{*}{ Location } & \multirow[b]{2}{*}{ Quarter } & {$[R N]^{a}$} & $2 \times T_{P U}^{b}$ & $M^{\prime} C^{c}$ & RER $^{d}$ \\
\hline & & \multicolumn{4}{|c|}{${ }^{40} \mathrm{~K}$} \\
\hline$\overline{\text { WEE }}$ & 1 & $2.46 \times 10^{-4}$ & $2.43 \times 10^{-4}$ & $3.06 \times 10^{-4}$ & 0.155 \\
\hline WEE Dup. & 1 & $2.93 \times 10^{-4}$ & $1.85 \times 10^{-4}$ & $2.40 \times 10^{-4}$ & \\
\hline WSS & 2 & $2.93 \times 10^{-4}$ & $1.84 \times 10^{-4}$ & $2.41 \times 10^{-4}$ & 64.70 \\
\hline WSS Dup. & 2 & $7.47 \times 10^{-2}$ & $1.14 \times 10^{-3}$ & $7.96 \times 10^{-4}$ & \\
\hline MLR & 3 & $2.26 \times 10^{-4}$ & $1.04 \times 10^{-4}$ & $1.36 \times 10^{-4}$ & 0.035 \\
\hline MLR Dup. & 3 & $2.21 \times 10^{-4}$ & $9.55 \times 10^{-5}$ & $1.22 \times 10^{-4}$ & \\
\hline SMR & 4 & $4.29 \times 10^{-4}$ & $3.64 \times 10^{-4}$ & $5.74 \times 10^{-4}$ & 0.607 \\
\hline \multirow[t]{2}{*}{ SMR Dup. } & 4 & $1.56 \times 10^{-4}$ & $2.64 \times 10^{-4}$ & $3.23 \times 10^{-4}$ & \\
\hline & & \multicolumn{4}{|c|}{${ }^{234} \mathrm{U}$} \\
\hline WEE & 1 & $2.34 \times 10^{-6}$ & $5.40 \times 10^{-7}$ & $1.29 \times 10^{-7}$ & 0.172 \\
\hline WEE Dup. & 1 & $2.47 \times 10^{-6}$ & $5.39 \times 10^{-7}$ & $4.01 \times 10^{-8}$ & \\
\hline WSS & 2 & $4.29 \times 10^{-6}$ & $8.62 \times 10^{-7}$ & $4.18 \times 10^{-8}$ & 0.025 \\
\hline WSS Dup. & 2 & $4.26 \times 10^{-6}$ & $8.29 \times 10^{-7}$ & $3.99 \times 10^{-8}$ & \\
\hline MLR & 3 & $2.91 \times 10^{-6}$ & $6.33 \times 10^{-7}$ & $4.26 \times 10^{-8}$ & 0.369 \\
\hline MLR Dup. & 3 & $2.60 \times 10^{-6}$ & $5.51 \times 10^{-7}$ & $3.81 \times 10^{-8}$ & \\
\hline SMR & 4 & $2.58 \times 10^{-6}$ & $5.99 \times 10^{-7}$ & $5.33 \times 10^{-8}$ & 2.760 \\
\hline \multirow[t]{2}{*}{ SMR Dup. } & 4 & $3.33 \times 10^{-7}$ & $5.51 \times 10^{-7}$ & $1.09 \times 10^{-7}$ & \\
\hline & & \multicolumn{4}{|c|}{${ }^{238} \mathrm{U}$} \\
\hline WEE & 1 & $2.35 \times 10^{-6}$ & $5.40 \times 10^{-7}$ & $4.29 \times 10^{-8}$ & 0.288 \\
\hline WEE Dup. & 1 & $2.14 \times 10^{-6}$ & $4.85 \times 10^{-7}$ & $9.59 \times 10^{-7}$ & \\
\hline WSS & 2 & $4.37 \times 10^{-6}$ & $8.73 \times 10^{-7}$ & $4.14 \times 10^{-8}$ & 0.113 \\
\hline WSS Dup. & 2 & $4.51 \times 10^{-6}$ & $8.73 \times 10^{-7}$ & $3.96 \times 10^{-8}$ & \\
\hline MLR & 3 & $2.53 \times 10^{-6}$ & $5.70 \times 10^{-7}$ & $1.15 \times 10^{-7}$ & 0.000 \\
\hline MLR Dup. & 3 & $2.53 \times 10^{-6}$ & $5.40 \times 10^{-7}$ & $1.03 \times 10^{-8}$ & \\
\hline SMR & 4 & $2.56 \times 10^{-6}$ & $6.03 \times 10^{-7}$ & $1.82 \times 10^{-7}$ & 2.797 \\
\hline SMR Dup. & 4 & $2.60 \times 10^{-7}$ & $5.59 \times 10^{-7}$ & $1.08 \times 10^{-7}$ & \\
\hline
\end{tabular}


Table 4.5 - Preliminary Quarterly Average Radionuclide Concentrations $\left(\mathrm{Bq} / \mathrm{m}^{3}\right)$ Measured in Air Particulate Samples by the Environmental Evaluation Group in 2001

\begin{tabular}{|c|c|c|c|c|}
\hline & & & & \\
\hline & 1 & 2 & 3 & 4 \\
\hline & & & & \\
\hline Concentration & $2.99 \times 10^{-8}$ & $2.52 \times 10^{-8}$ & $9.59 \times 10^{-9}$ & $\mathrm{NR}^{\mathrm{b}}$ \\
\hline $2 \times S D^{a}$ & $3.53 \times 10^{-8}$ & $3.49 \times 10^{-8}$ & $3.50 \times 10^{-8}$ & NR \\
\hline & & & & \\
\hline Concentration & $-1.51 \times 10^{-9}$ & $1.28 \times 10^{-8}$ & $-8.32 \times 10^{-9}$ & NR \\
\hline $2 \times S D$ & $4.20 \times 10^{-8}$ & $4.46 \times 10^{-8}$ & $-4.29 \times 10^{-8}$ & NR \\
\hline & & & & \\
\hline Concentration & $6.21 \times 10^{-9}$ & $2.46 \times 10^{-8}$ & $8.42 \times 10^{-9}$ & NR \\
\hline $2 \times S D$ & $2.05 \times 10^{-8}$ & $2.29 \times 10^{-8}$ & $1.97 \times 10^{-8}$ & NR \\
\hline
\end{tabular}

\subsection{Groundwater}

\subsubsection{Sample Collection}

Groundwater samples were collected from seven different wells around the WIPP site as shown in Figure 6.1. Approximately three bore volumes (approximately 3,800 I $[1,000 \mathrm{gal}])$ of water were pumped out of these wells before collecting approximately 38 I (10 gal) of water samples. The water samples were collected from depths ranging from 180-270 $\mathrm{m}$ (600-900 ft) from six wells (WQSP-1 to WQSP-6), and from a depth of $69 \mathrm{~m}(225 \mathrm{ft})$ from WQSP-6A. Samples were collected twice in 2001. Approximately 8 ( $2 \mathrm{gal}$ ) of water were sent to the laboratory for the determination of radionuclides of interest. The rest of the samples were used to analyze for nonradiological parameters or were put into storage. The samples were acidified to $\mathrm{pH} \leq 2$ by adding concentrated nitric acid drop by drop.

\subsubsection{Determination of Individual Radionuclides}

The acidified water samples were used for the determination of gamma-emitting radionuclides, such as ${ }^{40} \mathrm{~K},{ }^{60} \mathrm{Co}$, and ${ }^{137} \mathrm{Cs}$, by gamma-spectrometry. An aliquot of approximately $0.5 \mathrm{I}(16.9 \mathrm{oz})$ was used for the determination of ${ }^{90} \mathrm{Sr}$. Another aliquot was used for the sequential determinations of the uranium isotopes, the plutonium isotopes, and ${ }^{241} \mathrm{Am}$ by alpha spectrometry, which involved the co-precipitation of actinides with iron carrier, ion exchange chromatographic separation of individual radionuclides, source preparation by micro-precipitating, and alpha spectrometry.

\subsubsection{Results and Discussions}

Isotopes of naturally-occurring uranium were detected in every well in 2001 (Table 4.6). The mean concentrations of ${ }^{234} \mathrm{U}$ ranged from $2.53 \times 10^{-1} \pm 7.69 \times 10^{-3} \mathrm{~Bq} / \mathrm{l}$ (becquerels per liter) $\left(6.84 \times 10^{0} \pm 2.08 \times 10^{-1} \mathrm{pCi} / \mathrm{l}\right)$ (picoCuries per liter) in WQSP-6A to $1.29 \times 10^{0} \pm$ $1.90 \times 10^{-1} \mathrm{~Bq} / \mathrm{l}\left(3.49 \times 10^{1} \pm 5.14 \times 10^{0} \mathrm{pCi} / \mathrm{l}\right)$ in WQSP-1. Uranium-235 ranged from 
$5.88 \times 10^{-3} \pm 1.13 \times 10^{-3} \mathrm{~Bq} / \mathrm{l}\left(1.59 \times 10^{-1} \pm 3.05 \times 10^{-2} \mathrm{pCi} / \mathrm{l}\right)$ in WQSP-3 to $3.34 \times 10^{-2} \pm$ $2.95 \times 10^{-2} \mathrm{~Bq} / \mathrm{l}\left(9.02 \times 10^{-1} \pm 7.97 \times 10^{-1} \mathrm{pCi} / \mathrm{l}\right)$ in WQSP-1. The mean concentration of ${ }^{238} \mathrm{U}$ ranged from $4.14 \times 10^{-2} \pm 1.13 \times 10^{-3} \mathrm{~Bq} / \mathrm{l}\left(1.12 \times 10^{0} \pm 3.05 \times 10^{-1} \mathrm{pCi} / \mathrm{l}\right)$ in WQSP-3 to $2.11 \times 10^{-1} \pm 2.15 \times 10^{-2} \mathrm{~Bq} / \mathrm{l}\left(5.70 \times 10^{0} \pm 5.81 \times 10^{-1} \mathrm{pCi} / \mathrm{l}\right)$ in WQSP-1.

Table 4.6 - Average Annual Radionuclide Concentrations (Bq/l) in Groundwater from Wells at the WIPP Site. See Chapter 6 for the sampling locations.

\begin{tabular}{|c|c|c|c|c|c|c|c|c|c|}
\hline \multirow[b]{2}{*}{ Location } & 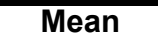 & $\times \mathrm{SD}^{\mathrm{a}}$ & $M D^{b}$ & IV & $2 \times S D$ & MDC & Me & $2 \times S D$ & MDC \\
\hline & \multicolumn{3}{|c|}{${ }^{241} \mathrm{Am}$} & \multicolumn{3}{|c|}{${ }^{238} \mathrm{Pu}$} & \multicolumn{3}{|c|}{${ }^{239+240} \mathrm{Pu}$} \\
\hline QSP-1 & & $7.00 \times 10^{-4}$ & $7.59 \times 10^{-4}$ & $.93 \times 10^{-4}$ & $1.53 \times 10^{-4}$ & $9.45 \times 10^{-4}$ & $10^{-5}$ & $1.61 \times 10^{-4}$ & $10^{-4}$ \\
\hline ○-2 & $0.00 \times 10^{0}$ & $.00 \times 10^{0}$ & $1.41 \times 10^{-3}$ & $2.19 \times 10^{-4}$ & $1.36 \times 10^{-4}$ & $8.82 \times 10^{-4}$ & $-2.19 \times 10^{-4}$ & $1.35 \times 10^{-4}$ & $1.44 \times 10^{-3}$ \\
\hline-3 & $5.20 \times 10^{-4}$ & $.39 \times 10^{-4}$ & $1.91 \times 10^{-3}$ & $-9.56 \times 10^{-5}$ & $2.65 \times 10^{-4}$ & $2.28 \times 10^{-3}$ & $0.00 \times 10^{0}$ & $0.00 \times 10^{0}$ & $6.64 \times 10^{-4}$ \\
\hline$P-4$ & $3.00 \times 10^{-4}$ & $29 \times 10^{-4}$ & $8.55 \times 10^{-4}$ & $2.15 \times 10^{-4}$ & $.52 \times 10^{-4}$ & $3.75 \times 10^{-4}$ & $1.44 \times 10^{-5}$ & $3.84 \times 10^{-4}$ & $6.64 \times 10^{-4}$ \\
\hline-5 & $-9.62 \times 10^{-5}$ & $2.67 \times 10^{-4}$ & $1.39 \times 10^{-3}$ & $1.08 \times 10^{-4}$ & $2.99 \times 10^{-4}$ & $7.01 \times 10^{-4}$ & $5.40 \times 10^{-5}$ & $1.50 \times 10^{-4}$ & $6.01 \times 10^{-4}$ \\
\hline QSP-6 & $-1.46 \times 10^{-4}$ & $8.56 \times 10^{-5}$ & $1.07 \times 10^{-3}$ & $5.22 \times 10^{-4}$ & $2.39 \times 10^{-3}$ & $1.82 \times 10^{-3}$ & $-9.29 \times 10^{-5}$ & $6.83 \times 10^{-4}$ & $1.46 \times 10^{-3}$ \\
\hline \multirow[t]{2}{*}{ WQSP-6A } & $2.11 \times 10^{-4}$ & $7.08 \times 10^{-5}$ & $1.12 \times 10^{-3}$ & $.40 \times 10^{-4}$ & $5.33 \times 10^{-5}$ & $1.03 \times 10^{-3}$ & $5.98 \times 10^{-5}$ & $1.66 \times 10^{-4}$ & $6.57 \times 10^{-4}$ \\
\hline & \multicolumn{3}{|c|}{${ }^{234} \mathrm{U}$} & \multicolumn{3}{|c|}{${ }^{235} U$} & \multicolumn{3}{|c|}{${ }^{238} \mathrm{U}$} \\
\hline 1 & $1.29 \times 10^{-1}$ & $1.90 \times 10^{-1}$ & $6.44 \times 10^{-4}$ & $3.34 \times 10^{-2}$ & $2.95 \times 10^{-2}$ & $1.32 \times 10^{-3}$ & $2.11 \times 10^{-1}$ & $2.15 \times 10^{-2}$ & $6.40 \times 10^{-4}$ \\
\hline-2 & $1.15 \times 10^{0}$ & $1.54 \times 10^{-1}$ & $3.86 \times 10^{-4}$ & $1.76 \times 10^{-2}$ & $1.26 \times 10^{-2}$ & $4.75 \times 10^{-4}$ & $1.88 \times 10^{-1}$ & $1.79 \times 10^{-2}$ & $6.62 \times 10^{-4}$ \\
\hline D-3 & $2.71 \times 10^{-1}$ & $4.05 \times 10^{-2}$ & $9.18 \times 10^{-4}$ & $5.88 \times 10^{-3}$ & $1.13 \times 10^{-3}$ & $6.42 \times 10^{-4}$ & $4.14 \times 10^{-2}$ & $1.13 \times 10^{-2}$ & $5.18 \times 10^{-4}$ \\
\hline 4 & $5.31 \times 10^{-1}$ & $1.54 \times 10^{-2}$ & $2.26 \times 10^{-3}$ & $8.20 \times 10^{-3}$ & $5.13 \times 10^{-5}$ & $6.48 \times 10^{-4}$ & $8.90 \times 10^{-2}$ & $1.18 \times 10^{-2}$ & $5.22 \times 10^{-4}$ \\
\hline-5 & $5.75 \times 10^{-1}$ & $1.28 \times 10^{-1}$ & $1.17 \times 10^{-3}$ & $8.10 \times 10^{-3}$ & $1.33 \times 10^{-3}$ & $1.55 \times 10^{-3}$ & $8.33 \times 10^{-2}$ & $1.33 \times 10^{-2}$ & $5.28 \times 10^{-4}$ \\
\hline VQSP-6 & $5.48 \times 10^{-1}$ & $7.18 \times 10^{-3}$ & $1.44 \times 10^{-3}$ & $1.22 \times 10^{-2}$ & $1.44 \times 10^{-2}$ & $9.03 \times 10^{-4}$ & $7.47 \times 10^{-2}$ & $1.64 \times 10^{-2}$ & $7.29 \times 10^{-3}$ \\
\hline \multirow[t]{2}{*}{ WQSP-6A } & $53 \times 10^{-1}$ & $.69 \times 10^{-3}$ & $10^{-4}$ & $10 \times 10^{-3}$ & $2.05 \times 10^{-3}$ & $8.81 \times 10^{-4}$ & $33 \times 10^{-1}$ & $3.59 \times 10^{-3}$ & $10^{-4}$ \\
\hline & \multicolumn{3}{|c|}{${ }^{137} \mathrm{Cs}$} & \multicolumn{3}{|c|}{${ }^{60} \mathrm{Co}$} & \multicolumn{3}{|c|}{${ }^{40} \mathrm{~K}$} \\
\hline-1 & $-1.13 \times 10^{2}$ & $9.29 \times 10^{-2}$ & $4.40 \times 10^{-1}$ & $1.51 \times 10^{-1}$ & $1.68 \times 10$ & $4.02 \times 10$ & $.15 \times 10$ & $2.91 \times 10$ & $5.55 \times 10^{0}$ \\
\hline 2 & $-2.52 \times 10^{-1}$ & $5.03 \times 10^{-1}$ & $5.68 \times 10^{-1}$ & $5.22 \times 10^{-1}$ & $2.56 \times 10^{-1}$ & $5.81 \times 10^{-1}$ & $1.57 \times 10^{1}$ & $5.64 \times 10^{1}$ & $8.97 \times 10^{0}$ \\
\hline-3 & $-4.81 \times 10^{-3}$ & $4.89 \times 10^{-1}$ & $4.55 \times 10^{-1}$ & $1.09 \times 10^{-1}$ & $2.72 \times 10^{-2}$ & $4.96 \times 10^{-1}$ & $5.20 \times 10^{1}$ & $1.59 \times 10^{1}$ & $6.08 \times 10^{0}$ \\
\hline D-4 & $-1.27 \times 10^{-1}$ & $4.56 \times 10^{-1}$ & $3.62 \times 10^{-1}$ & $6.44 \times 10^{-2}$ & $3.59 \times 10^{-1}$ & $4.16 \times 10^{-1}$ & $2.57 \times 10^{1}$ & $8.20 \times 10^{1}$ & $3.52 \times 10^{0}$ \\
\hline-5 & $-8.57 \times 10^{-2}$ & $7.14 \times 10^{-1}$ & $4.09 \times 10^{-1}$ & $3.68 \times 10^{-2}$ & $4.32 \times 10^{-1}$ & $4.44 \times 10^{-1}$ & $1.02 \times 10^{1}$ & $4.00 \times 10^{0}$ & $4.31 \times 10^{0}$ \\
\hline & $-3.86 \times 10^{-1}$ & $4.78 \times 10^{-1}$ & $3.82 \times 10^{-1}$ & $1.73 \times 10^{-1}$ & $4.91 \times 10^{-1}$ & $4.28 \times 10^{-1}$ & $6.14 \times 10^{0}$ & $5.13 \times 10^{1}$ & $4.01 \times 10^{0}$ \\
\hline \multirow[t]{2}{*}{ WQSP-6A } & $8.29 \times 10^{-2}$ & $5.23 \times 10^{-2}$ & $3.90 \times 10^{-1}$ & $1.44 \times 10^{-1}$ & $7.28 \times 10^{-2}$ & $4.18 \times 10^{-1}$ & $6.08 \times 10^{0}$ & $7.34 \times 10^{0}$ & $4.52 \times 10^{0}$ \\
\hline & \multicolumn{3}{|c|}{${ }^{90} \mathrm{Sr}$} & \multicolumn{3}{|c|}{${ }^{226} \mathrm{Ra}$} & \multicolumn{3}{|c|}{${ }^{228} \mathrm{Ra}$} \\
\hline$P-1$ & $-1.13 \times 10^{-2}$ & $2.93 \times 10^{-2}$ & $4.37 \times 10^{-2}$ & $5.52 \times 10^{0}$ & $5.49 \times 10^{-1}$ & $3.59 \times 10^{-2}$ & $1.04 \times 10^{0}$ & $1.36 \times 10^{-1}$ & $1.38 \times 10^{-1}$ \\
\hline-2 & $-5.16 \times 10^{-3}$ & $1.45 \times 10^{-2}$ & $2.93 \times 10^{-2}$ & $3.88 \times 10^{0}$ & $8.61 \times 10^{-2}$ & $2.57 \times 10^{-2}$ & $5.14 \times 10^{-1}$ & $1.26 \times 10^{-1}$ & $1.25 \times 10^{-1}$ \\
\hline 3 & $-9.23 \times 10^{-3}$ & $6.28 \times 10^{-2}$ & $4.43 \times 10^{-2}$ & $6.75 \times 10^{0}$ & $6.54 \times 10^{-1}$ & $3.16 \times 10^{-2}$ & $1.10 \times 10^{0}$ & $1.84 \times 10^{-1}$ & $1.25 \times 10^{-1}$ \\
\hline$V Q O r-4$ & $1.60 \times 10^{-2}$ & $1.16 \times 10^{-1}$ & $3.25 \times 10^{-2}$ & $8.86 \times 10^{0}$ & $1.04 \times 10^{0}$ & $3.53 \times 10^{-2}$ & $1.36 \times 10^{0}$ & $2.60 \times 10^{-1}$ & $1.49 \times 10^{-1}$ \\
\hline VQS & $9.84 \times 10^{-3}$ & $8.14 \times 10^{-2}$ & $6.11 \times 10^{-2}$ & $2.71 \times 10^{0}$ & $1.22 \times 10^{-1}$ & $2.35 \times 10^{-2}$ & $3.83 \times 10^{-1}$ & $3.08 \times 10^{-3}$ & $1.18 \times 10^{-1}$ \\
\hline-6 & $1.65 \times 10^{-3}$ & $8.10 \times 10^{-2}$ & $5.57 \times 10^{-2}$ & $1.26 \times 10^{0}$ & $7.69 \times 10^{2}$ & $1.81 \times 10^{2}$ & $1.70 \times 10^{-1}$ & $1.27 \times 10^{-1}$ & $1.11 \times 10^{-1}$ \\
\hline$-6 A$ & $1.21 \times 10^{-2}$ & $6.72 \times 10^{-2}$ & $5.70 \times 10^{-2}$ & $4.07 \times 10^{3}$ & $3.08 \times 10^{3}$ & $1.37 \times 10^{2}$ & $-6.48 \times 10^{-3}$ & $9.38 \times 10^{-2}$ & $1.06 \times 10^{-1}$ \\
\hline
\end{tabular}

a Standard deviation of the mean

${ }^{\mathrm{b}}$ Minimum detectable concentration

The concentrations of uranium isotopes in water samples collected from these wells were compared between the years 2000 and 2001. There was a significant difference in the concentration of uranium isotopes (ANOVA, ${ }^{234} U p=0.008,{ }^{238} \cup p=0.009$ ). The average concentration for both nuclides was approximately two times higher in 2001. Two different laboratories performed the analysis in years 2000 and 2001, and 


\section{Waste Isolation Pilot Plant 2001 Site Environmental Report DOE/WIPP 02-2225}

employed two different methods. The groundwater had a high content of total dissolved solids, which caused the average chemical recovery of the samples to be less in 2001. The lower chemical recovery causes the activity to be higher. The 2001 values are within the $2 \sigma$ limit.

Plutonium-238, ${ }^{239+240} \mathrm{Pu}$, and ${ }^{241} \mathrm{Am}$ were also analyzed in these groundwater samples (Table 4.6). Neither ${ }^{239+240} \mathrm{Pu}$ nor ${ }^{241} \mathrm{Am}$ were detected in any sample. The concentration of ${ }^{238} \mathrm{Pu}$ was greater than the MDC in one sample from well WQSP-6 during the spring sampling $\left(1.38 \times 10^{-3} \pm 1.05 \times 10^{-3} \mathrm{~Bq} / \mathrm{l} ; \mathrm{MDC}=1.13 \times 10^{-3} \mathrm{~Bq} / \mathrm{l}\left[3.73 \times 10^{-2}\right.\right.$ $\left.\left.\pm 2.84 \times 10^{-2} \mathrm{pCi} / \mathrm{l} ; \mathrm{MDC}=3.05 \times 10^{-2} \mathrm{pCi} / \mathrm{l}\right]\right)$. However, this result was very close to the MDC. All wells' sample results and means were below the detection limit for ${ }^{239+240} \mathrm{Pu}$. Analysis of variance did not show differences in ${ }^{238} \mathrm{Pu},{ }^{239+240} \mathrm{Pu}$, or ${ }^{241} \mathrm{Am}$ (ANOVA ${ }^{238} \mathrm{Pu}$ $p=0.619,{ }^{239+240} \mathrm{Pu} p=0.520,{ }^{241} \mathrm{Am} \mathrm{p}=0.423$ ) between years 2000 and 2001.

As discussed in last year's annual Site Environmental Report (DOE/WIPP 01-2225), groundwater results from wells WQSP-1, WQSP-3, and WQSP-4 have exhibited a pattern of activity above the MDC for ${ }^{238} \mathrm{Pu}$ and ${ }^{241} \mathrm{Am}$. In order to help explain these apparently above background concentrations, WIPP began analyzing groundwater for

${ }^{226} \mathrm{Ra}$ and ${ }^{228} \mathrm{Ra}$ during the fall sampling of 2000 . Radium-226 and ${ }^{228} \mathrm{Ra}$ were detected in 100 percent of the samples. The mean concentrations were all above the mean detection limits (Table 4.6). However, the concentrations of ${ }^{226} \mathrm{Ra}$ in water from wells WQSP-1, WQSP-3, and WQSP-4 were all lower than those reported in the 1995 Annual Site Environmental Report $(6.0 \pm 0.06 \mathrm{~Bq} / \mathrm{l}, 7.8 \pm 0.06 \mathrm{~Bq} / \mathrm{l}$, and $9.1 \pm 0.07 \mathrm{~Bq} / \mathrm{l}$, respectively).

These results are important because one decay product of ${ }^{226} \mathrm{Ra},{ }^{222} \mathrm{Rn}$, emits alpha particles with an energy of $5.489 \mathrm{MeV}$, very close to the most abundant alpha energy of ${ }^{241} \mathrm{Am}(5.486 \mathrm{MeV})$ and ${ }^{238} \mathrm{Pu}(5.499 \mathrm{MeV})$. Because these energies are close, the region of interest in the alpha spectrum from the groundwater samples likely contained counts originating from ${ }^{222} \mathrm{Rn}$ that were identified as ${ }^{238} \mathrm{Pu}$ or ${ }^{241} \mathrm{Am}$. Additional ${ }^{226} \mathrm{Ra}$ progeny were also likely present. The solubility of the components can vary causing the ${ }^{222} \mathrm{Rn}$ activity and associated ${ }^{226} \mathrm{Ra}$ progeny to appear in some analyses, but not all. This phenomenon may explain the trend of seemingly high concentrations of ${ }^{238} \mathrm{Pu}$ and ${ }^{241} \mathrm{Am}$ observed in some groundwater samples over time. These patterns will become more apparent as more samples are analyzed for ${ }^{226} \mathrm{Ra}$.

Cesium-137 and ${ }^{60} \mathrm{Co}$ were not detected in any of the samples. Potassium-40 was detected in all the wells except for the spring sampling round WQSP-6A. Strontium-90 was not detectable in any of the wells.

\subsection{Surface Water}

\subsubsection{Sample Collection}

Fourteen different locations around the WIPP site, as shown in Figure 4.5, were identified for collecting the surface water samples (see Appendix B for location codes). Samples were collected once in 2001 from ten sampling locations. If the surface water 
collection location was dry, sediment was collected. Sediment results are described in Section 4.7.

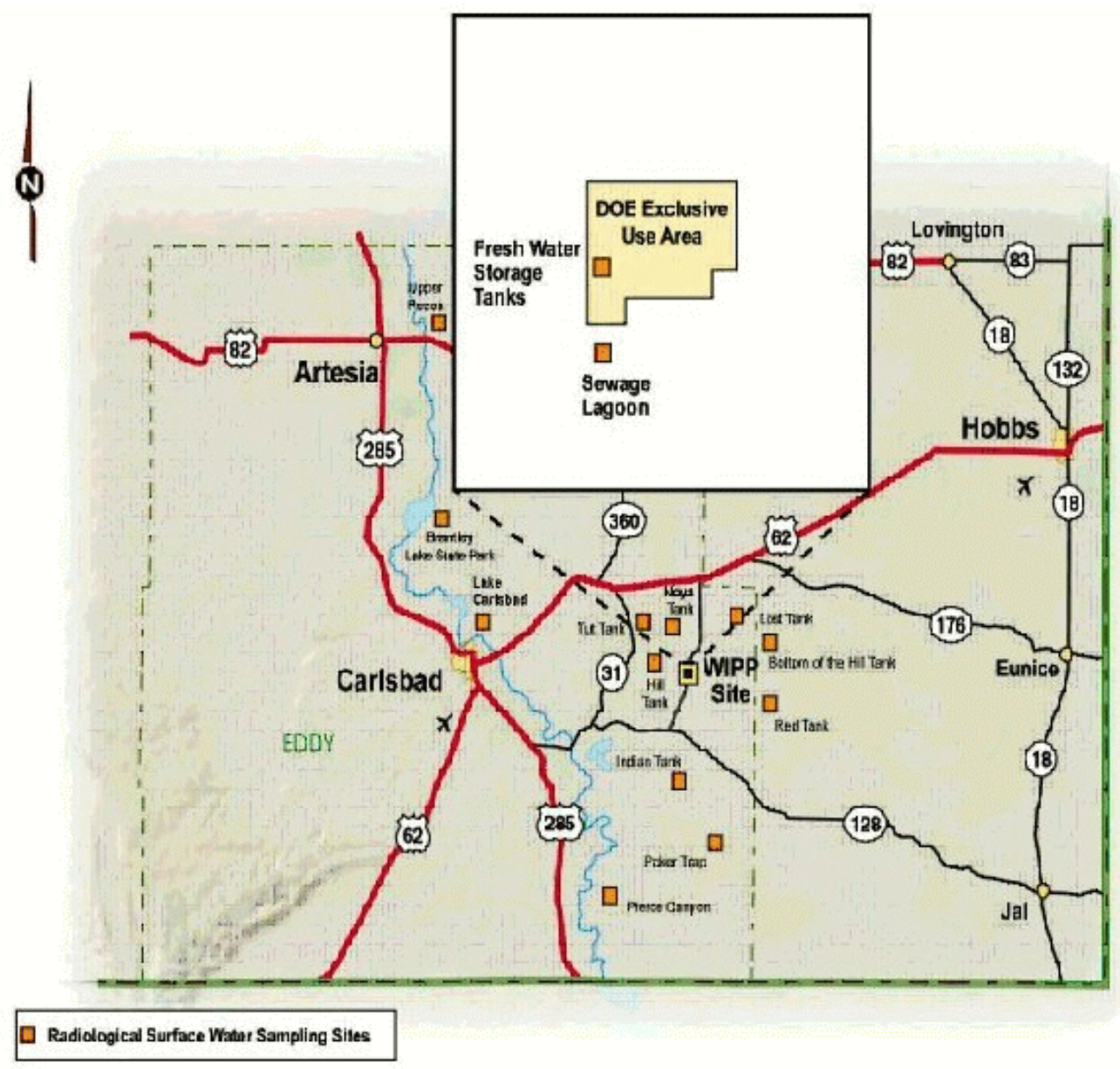

Figure 4.5 - Surface Water Sampling Locations in 2001

Water from the sampling location was used to rinse 3.78-I (1-gal) polyethylene containers several times. Approximately $3.78 \mathrm{I}(1 \mathrm{gal})$ of water was collected from each location. The samples were acidified immediately after collection with concentrated nitric acid to $\mathrm{pH} \leq 2$. Later, the samples were shipped to the laboratory for analysis. Chain of custody was maintained throughout the process.

\subsubsection{Determination of Individual Radionuclides}

Gamma-spectrometry was used for the determination of ${ }^{40} \mathrm{~K},{ }^{60} \mathrm{Co}$, and ${ }^{137} \mathrm{Cs}$. Strontium-90, a beta-emitting radionuclide, was determined by chemical separation and counting it on the gas proportional counter. Uranium, plutonium, and americium were determined by alpha spectrometry. These alpha-emitting radionuclides were separated from the bulk of water samples by co-precipitation with an iron carrier. Ion-exchange 


\section{Waste Isolation Pilot Plant 2001 Site Environmental Report DOE/WIPP 02-2225}

chromatography was used for the separation of individual radionuclides. Finally, the samples were counted by alpha spectrometry.

\subsubsection{Results and Discussions}

Isotopes of natural uranium were detected in surface water at every sampling location (Table 4.7). Uranium-234 was lowest at Coyote Well (COW) $\left(4.14 \times 10^{-4} \pm 5.11 \times 10^{-4} \mathrm{~Bq} / \mathrm{l}\right.$ $\left.\left[1.12 \times 10^{-2} \pm 1.38 \times 10^{-2} \mathrm{pCi} / \mathrm{l}\right]\right)$ and highest at Pierce Canyon (PCN) $\left(2.18 \times 10^{-1} \pm\right.$ $\left.3.42 \times 10^{-2} \mathrm{~Bq} / \mathrm{l}\left[5.89 \times 10^{0} \pm 9.24 \times 10^{-1} \mathrm{pCi} / \mathrm{l}\right]\right)$. Uranium-235 was detected in 54 percent of the samples. Concentrations ranged from $1.28 \times 10^{-4} \pm 2.56 \times 10^{-4} \mathrm{~Bq} / \mathrm{l}\left(3.46 \times 10^{-3} \pm\right.$ $\left.6.92 \times 10^{-2} \mathrm{pCi} / \mathrm{l}\right)$ at COW to $6.51 \times 10^{-3} \pm 2.06 \times 10^{-3} \mathrm{~Bq} / \mathrm{l}\left(1.76 \times 10^{-1} \pm 5.57 \times 10^{-2} \mathrm{pCi} / \mathrm{l}\right)$ at $\mathrm{PCN}$. Concentrations of ${ }^{238} \mathrm{U}$, detected in all samples, ranged from $0.00 \times 10^{0} \pm 0.00 \times 10^{0}$ $\mathrm{Bq} / \mathrm{l}\left(0.00 \times 10^{0} \pm 0.00 \times 10^{0} \mathrm{pCi} / \mathrm{l}\right)$ at $\mathrm{PCN}$ to $1.08 \times 10^{-1} \pm 1.75 \times 10^{-2} \mathrm{~Bq} / \mathrm{l}\left(2.92 \times 10^{0} \pm\right.$ $\left.4.73 \times 10^{-1} \mathrm{pCi} / \mathrm{l}\right)$ at $\mathrm{PCN}$.

Results for uranium concentrations in 2001 samples were compared with the uranium concentrations in 2000 samples. There was no significant difference in the concentration of any uranium isotope between years (ANOVA, ${ }^{234} \mathrm{U} p=0.227,{ }^{235} \mathrm{U}$ $\left.p=0.869,{ }^{238} \cup p=0.817\right)$.

Table 4.7 - Uranium Concentrations (Bq/l) in Surface Water Near the WIPP Site.

See Appendix $B$ for the sampling locations.

\begin{tabular}{|c|c|c|c|c|c|c|c|c|c|}
\hline \multirow{2}{*}{ Location } & $\overline{\mathrm{N}}]^{\mathrm{a}}$ & $\times \mathrm{TPU}^{\mathrm{b}}$ & $\overline{\mathrm{DC}}$ & [RN] & $2 \times$ TPU & $\overline{M D C}$ & [RN] & $2 \times$ TPU & $\overline{M D C}$ \\
\hline & & ${ }^{234} \mathrm{U}$ & & \multicolumn{3}{|c|}{${ }^{235} \mathrm{U}$} & \multicolumn{3}{|c|}{${ }^{238} \mathrm{U}$} \\
\hline$\overline{\mathrm{RA}}$ & $07 \times 10^{-1}$ & $1.79 \times 10^{-2}$ & $92 \times 10$ & & $1.44 \times 10^{-3}$ & 5.01 & U & $9.69 \times 10^{-3}$ & $.92 \times 10$ \\
\hline $3 \mathrm{D}$ & 1.32 & $25 \times 10^{-2}$ & $96 \times 10^{-4}$ & -3 & $1.52 \times 10^{-3}$ & $3.66 \times 10^{-4}$ & J & $1.11 x$ & $95 \times 10^{-4}$ \\
\hline T & $5.29 x$ & $36 \times 10^{-3}$ & $77 \times 10^{-4}$ & $39 \times 10^{-3}$ & $9.36 \times 10^{-4}$ & $9.29 \times 10^{-4}$ & $.28 \times 10^{-2}$ & $4.66 \times 10^{-3}$ & $2.76 \times 10^{-4}$ \\
\hline L & $219 x$ & $4.96 \times 10^{-3}$ & $.59 \times 10^{-4}$ & $81 \times 10^{-4}$ & $8.18 \times 10^{-4}$ & $4.44 \times 10^{-4}$ & $1.85 \times 10^{-2}$ & $4.37 \times 10^{-3}$ & $3.58 \times 10^{-4}$ \\
\hline N & $21 x$ & $3.00 \times 10^{-3}$ & $7.99 \times 10^{-4}$ & $.36 \times 10^{-4}$ & $8.14 \times 10^{-4}$ & $9.84 \times 10^{-4}$ & $1.22 \times 10^{-2}$ & $3.00 \times 10^{-3}$ & $2.92 \times 10^{-4}$ \\
\hline DY & $1.10 \times 10^{-2}$ & $3.22 \times 10^{-3}$ & $4.14 \times 10^{-4}$ & $5.66 \times 10^{-4}$ & $6.59 \times 10^{-4}$ & $5.11 \times 10^{-4}$ & $8.21 \times 10^{-3}$ & $2.65 \times 10^{-3}$ & $4.11 \times 10^{-4}$ \\
\hline $\mathrm{CN}$ & $2.18 x$ & $3.42 \times 10^{-2}$ & $7.62 \times 10$ & 6.51 & $2.06 \times 10^{-3}$ & $3.45 \times 10^{-4}$ & $1.08 x$ & $1.75 \times 10^{-2}$ & $2.79 \times 10^{-4}$ \\
\hline & $4.48 x$ & $9.51 \times 10^{-3}$ & $4.22 \times 10^{-4}$ & $92 x$ & $6.66 \times 10^{-4}$ & $1.42 \times 10^{-}$ & 1.63 & $4.29 \times 10^{-3}$ & $4.22 \times 10^{-4}$ \\
\hline 01 & $66 \times$ & $2.49 \times 10^{-3}$ & $2.76 \times 10^{-4}$ & $03 x$ & $5.07 \times 10^{-4}$ & $3.40 \times 10^{-1}$ & 7.81 & $2.15 \times 10^{-3}$ & $2.75 \times 10^{-4}$ \\
\hline PR & $8.14 \times 10^{-2}$ & $1.42 \times 10^{-2}$ & $3.03 \times 10^{-4}$ & $3.59 \times 10^{-3}$ & $1.52 \times 10^{-3}$ & $3.74 \times 10^{-4}$ & $4.51 \times 10^{-2}$ & $8.36 \times 10^{-3}$ & $3.02 \times 10^{-4}$ \\
\hline
\end{tabular}

${ }^{a}[\mathrm{RN}]=$ Radionuclide concentration

${ }^{\mathrm{b}}$ Total propagated uncertainty

${ }^{\mathrm{C}}$ Minimum detectable concentration

Analysis of variance was also used to test for differences in uranium concentration between sampling locations. Differences were detected for each uranium isotope $(p<0.001)$. Pierce Canyon had the highest concentrations, with other locations along the Pecos River (Brantley Lake [BRA], Carlsbad [CBD], and Upper Pecos River [UPR]) in another homogeneous subset of the data. All of the surface tanks were in another homogeneous subset having the lowest concentrations. Large spatial variations in uranium concentration in surface water are expected because of the different characteristics of the water bodies and the underlying sediments. For example, the PCN site drains a large surface area and leaches uranium from the sediments. The Tut Tank (TUT) is mostly rainwater and has relatively little contact with sediments. 


\section{Waste Isolation Pilot Plant 2001 Site Environmental Report DOE/WIPP 02-2225}

These water samples were also analyzed for ${ }^{238} \mathrm{Pu},{ }^{239+240} \mathrm{Pu}$, and ${ }^{241} \mathrm{Am}$ (Table 4.8). Concentrations of ${ }^{241} \mathrm{Am},{ }^{238} \mathrm{Pu}$ and ${ }^{239+240} \mathrm{Pu}$ were below the MDC in every sample.

Potassium-40, ${ }^{60} \mathrm{Co},{ }^{90} \mathrm{Sr}$, and ${ }^{137} \mathrm{Cs}$ are ubiquitous in soils and might reasonably be expected in surface water samples due to leaching from sediments. As expected, ${ }^{40} \mathrm{~K}$ was detected in 70 percent of the surface water samples (Table 4.9). Its concentration ranged from $-2.87 \times 10^{0} \pm 3.85 \times 10^{0} \mathrm{~Bq} / \mathrm{l}\left(-7.76 \times 10^{1} \pm 1.04 \times 10^{2} \mathrm{pCi} / \mathrm{l}\right)$ at Noya Tank (NOY) to $1.02 \times 10^{2} \pm 1.57 \times 10^{1} \mathrm{~Bq} / \mathrm{l}\left(2.76 \times 10^{3} \pm 4.54 \times 10^{2} \mathrm{pCi} / \mathrm{l}\right)$ at PCN. Cobalt-60, ${ }^{137} \mathrm{Cs}$, and ${ }^{90} \mathrm{Sr}$ were not detected in the samples.

Table 4.8 - Americium and Plutonium Concentrations (Bq/l) in Surface Water Near the WIPP Site. See Appendix $B$ for the sampling locations.

\begin{tabular}{|c|c|c|c|c|c|c|c|c|c|}
\hline & {$[\mathrm{RN}]^{\mathrm{a}}$} & $2 \times$ TPU $^{b}$ & $M^{\prime} C^{c}$ & [RN] & $2 \times \mathrm{TPU}$ & MDC & [RN] & $2 \times$ TPU & MDC \\
\hline Location & & ${ }^{241} \mathrm{Am}$ & & & ${ }^{238} \mathrm{Pu}$ & & & ${ }^{239+240} \mathrm{Pu}$ & \\
\hline$\overline{\mathrm{BRA}}$ & $2.41 \times 10^{-4}$ & $5.92 \times 10^{-4}$ & $1.12 \times 10^{-3}$ & $1.05 \times 10^{-4}$ & $2.11 \times 10^{-4}$ & $2.84 \times 10^{-4}$ & $1.05 \times 10^{-4}$ & $2.10 \times 10^{-4}$ & $2.84 \times 10^{-4}$ \\
\hline CBD & $1.13 \times 10^{-4}$ & $2.26 \times 10^{-4}$ & $3.05 \times 10^{-4}$ & $0.00 \times 10^{0}$ & $0.00 \times 10^{0}$ & $8.25 \times 10^{-4}$ & $0.00 \times 10^{0}$ & $0.00 \times 10^{0}$ & $3.03 \times 10^{-4}$ \\
\hline FWT & $2.21 \times 10^{-4}$ & $7.66 \times 10^{-4}$ & $1.62 \times 10^{-3}$ & $0.00 \times 10^{0}$ & $0.00 \times 10^{0}$ & $9.25 \times 10^{-4}$ & $1.26 \times 10^{-4}$ & $2.52 \times 10^{-4}$ & $3.41 \times 10^{-4}$ \\
\hline HIL & $-1.18 \times 10^{-4}$ & $2.38 \times 10^{-4}$ & $8.73 \times 10^{-4}$ & $2.11 \times 10^{-4}$ & $3.00 \times 10^{-4}$ & $2.86 \times 10^{-4}$ & $3.16 \times 10^{-4}$ & $5.59 \times 10^{-4}$ & $9.81 \times 10^{-4}$ \\
\hline IDN & $3.05 \times 10^{-4}$ & $7.47 \times 10^{-4}$ & $1.42 \times 10^{-4}$ & $0.00 \times 10^{0}$ & $0.00 \times 10^{0}$ & $7.59 \times 10^{-4}$ & $4.11 \times 10^{-4}$ & $4.18 \times 10^{-4}$ & $2.79 \times 10^{-4}$ \\
\hline NOY & $4.81 \times 10^{-4}$ & $5.92 \times 10^{-4}$ & $8.84 \times 10^{-4}$ & $1.37 \times 10^{-4}$ & $2.74 \times 10^{-4}$ & $3.70 \times 10^{-4}$ & $4.11 \times 10^{-5}$ & $6.14 \times 10^{-4}$ & $1.01 \times 10^{-3}$ \\
\hline $\mathrm{PCN}$ & $3.81 \times 10^{-4}$ & $4.44 \times 10^{-4}$ & $3.44 \times 10^{-4}$ & $-1.05 \times 10^{-4}$ & $2.12 \times 10^{-4}$ & $7.77 \times 10^{-4}$ & $0.00 \times 10^{0}$ & $0.00 \times 10^{0}$ & $2.86 \times 10^{-4}$ \\
\hline SWL & $6.51 \times 10^{-4}$ & $6.62 \times 10^{-4}$ & $4.40 \times 10^{-4}$ & $2.56 \times 10^{-4}$ & $3.64 \times 10^{-4}$ & $3.46 \times 10^{-4}$ & $0.00 \times 10^{0}$ & $0.00 \times 10^{0}$ & $3.46 \times 10^{-4}$ \\
\hline TUT & $1.22 \times 10^{-4}$ & $5.48 \times 10^{-4}$ & $1.14 \times 10^{-3}$ & $2.13 \times 10^{-4}$ & $3.03 \times 10^{-4}$ & $2.88 \times 10^{-4}$ & $1.06 \times 10^{-4}$ & $2.13 \times 10^{-4}$ & $2.88 \times 10^{-4}$ \\
\hline UPR & $0.00 \times 10^{0}$ & $0.00 \times 10^{0}$ & $1.25 \times 10^{-3}$ & $3.64 \times 10^{-4}$ & $4.26 \times 10^{-4}$ & $3.28 \times 10^{-4}$ & $1.21 \times 10^{-4}$ & $4.22 \times 10^{-4}$ & $8.92 \times 10^{-4}$ \\
\hline
\end{tabular}




\section{Waste Isolation Pilot Plant 2001 Site Environmental Report DOE/WIPP 02-2225}

Table 4.9 - Selected Radionuclide Concentrations (Bq/l) in Surface Water near the WIPP Site. See Appendix $B$ for the sampling locations.

\begin{tabular}{|c|c|c|c|c|c|c|}
\hline \multirow[b]{2}{*}{ Location } & {$[\mathrm{RN}]^{\mathrm{a}}$} & $2 \times \mathrm{TPU}^{\mathrm{b}}$ & $\mathrm{MDC}^{\mathrm{c}}$ & [RN] & $2 \times \mathrm{TPU}$ & MDC \\
\hline & \multicolumn{3}{|c|}{${ }^{137} \mathrm{Cs}$} & \multicolumn{3}{|c|}{${ }^{60} \mathrm{Co}$} \\
\hline$\overline{\mathrm{BRA}}$ & $1.21 \times 10^{-1}$ & $4.51 \times 10^{-1}$ & $5.07 \times 10^{-1}$ & $4.66 \times 10^{-1}$ & $4.51 \times 10^{-1}$ & $5.37 \times 10^{-1}$ \\
\hline CBD & $3.23 \times 10^{-1}$ & $3.15 \times 10^{-1}$ & $3.74 \times 10^{-1}$ & $-9.88 \times 10^{-3}$ & $3.17 \times 10^{-1}$ & $3.74 \times 10^{-1}$ \\
\hline FWT & $-8.33 \times 10^{-1}$ & $5.11 \times 10^{-1}$ & $4.92 \times 10^{-1}$ & $3.05 \times 10^{-2}$ & $4.44 \times 10^{-1}$ & $5.07 \times 10^{-1}$ \\
\hline HIL & $2.05 \times 10^{-1}$ & $2.13 \times 10^{-1}$ & $2.65 \times 10^{-1}$ & $7.18 \times 10^{-2}$ & $2.79 \times 10^{-1}$ & $3.26 \times 10^{-1}$ \\
\hline IDN & $2.03 \times 10^{-1}$ & $3.25 \times 10^{-1}$ & $3.77 \times 10^{-1}$ & $7.55 \times 10^{-3}$ & $3.44 \times 10^{-1}$ & $4.07 \times 10^{-1}$ \\
\hline NOY & $1.99 \times 10^{-2}$ & $3.23 \times 10^{-1}$ & $3.66 \times 10^{-1}$ & $2.16 \times 10^{-2}$ & $3.37 \times 10^{-1}$ & $4.00 \times 10^{-1}$ \\
\hline $\mathrm{PCN}$ & $2.54 \times 10^{-1}$ & $5.29 \times 10^{-1}$ & $6.18 \times 10^{-1}$ & $-2.43 \times 10^{-1}$ & $5.66 \times 10^{-1}$ & $5.92 \times 10^{-1}$ \\
\hline SWL & $-4.29 \times 10^{-2}$ & $2.23 \times 10^{-1}$ & $2.58 \times 10^{-1}$ & $-1.47 \times 10^{-1}$ & $3.00 \times 10^{-1}$ & $3.19 \times 10^{-1}$ \\
\hline TUT & $-4.59 \times 10^{-1}$ & $4.88 \times 10^{-1}$ & $5.00 \times 10^{-1}$ & $-3.06 \times 10^{-1}$ & $4.77 \times 10^{-1}$ & $5.11 \times 10^{-1}$ \\
\hline \multirow[t]{2}{*}{ UPR } & $7.40 \times 10^{-2}$ & $2.13 \times 10^{-1}$ & $2.56 \times 10^{-1}$ & $1.74 \times 10^{-1}$ & $2.92 \times 10^{-1}$ & $3.50 \times 10^{-1}$ \\
\hline & \multicolumn{3}{|c|}{${ }^{90} \mathrm{Sr}$} & \multicolumn{3}{|c|}{${ }^{40} \mathrm{~K}$} \\
\hline BRA & $-1.90 \times 10^{-2}$ & $3.74 \times 10^{-2}$ & $6.29 \times 10^{-2}$ & $7.36 \times 10^{0}$ & $4.37 \times 10^{0}$ & $5.22 \times 10^{0}$ \\
\hline CBD & $2.95 \times 10^{-3}$ & $4.00 \times 10^{-2}$ & $6.55 \times 10^{-2}$ & $4.29 \times 10^{0}$ & $3.20 \times 10^{0}$ & $4.22 \times 10^{0}$ \\
\hline FWT & $1.19 \times 10^{-2}$ & $3.62 \times 10^{-2}$ & $6.03 \times 10^{-2}$ & $4.81 \times 10^{0}$ & $2.22 \times 10^{0}$ & $3.13 \times 10^{0}$ \\
\hline HIL & $2.32 \times 10^{-2}$ & $3.42 \times 10^{-2}$ & $5.62 \times 10^{-2}$ & $3.92 \times 10^{0}$ & $2.75 \times 10^{0}$ & $3.52 \times 10^{0}$ \\
\hline IDN & $-1.84 \times 10^{-2}$ & $4.14 \times 10^{-2}$ & $6.96 \times 10^{-2}$ & $-1.24 \times 10^{0}$ & $3.74 \times 10^{0}$ & $4.07 \times 10^{0}$ \\
\hline NOY & $3.54 \times 10^{-2}$ & $4.14 \times 10^{-2}$ & $6.55 \times 10^{-2}$ & $-2.87 \times 10^{0}$ & $3.85 \times 10^{0}$ & $3.92 \times 10^{0}$ \\
\hline $\mathrm{PCN}$ & $1.40 \times 10^{-2}$ & $4.51 \times 10^{-2}$ & $7.36 \times 10^{-2}$ & $1.02 \times 10^{2}$ & $1.57 \times 10^{1}$ & $1.10 \times 10^{1}$ \\
\hline SWL & $-2.67 \times 10^{-2}$ & $4.40 \times 10^{-2}$ & $7.51 \times 10^{-2}$ & $2.19 \times 10^{1}$ & $4.81 \times 10^{0}$ & $4.81 \times 10^{0}$ \\
\hline TUT & $4.81 \times 10^{-3}$ & $4.14 \times 10^{-2}$ & $6.77 \times 10^{-2}$ & $5.66 \times 10^{0}$ & $2.45 \times 10^{0}$ & $3.41 \times 10^{0}$ \\
\hline UPR & $-1.63 \times 10^{-2}$ & $3.33 \times 10^{-2}$ & $5.77 \times 10^{-2}$ & $3.20 \times 10^{0}$ & $2.68 \times 10^{0}$ & $3.40 \times 10^{0}$ \\
\hline
\end{tabular}

${ }^{\mathrm{a}}[\mathrm{RN}]=$ Radionuclide concentration

${ }^{\mathrm{b}}$ Total propagated uncertainty

${ }^{\mathrm{C}}$ Minimum detectable concentration

Duplicate samples were collected from two locations (Indian Tank [IDN] and TUT) to check the reproducibility of the sampling and the measurement techniques (Table 4.10). The RER values for ${ }^{241} \mathrm{Am}$, plutonium, and the uranium isotopes in these samples were all less than one, indicating no difference between duplicate samples. 
Table 4.10 - Results of Duplicate Surface Water Sample Analysis. Units are Bq/l. See Appendix $B$ for the sampling locations.

\begin{tabular}{|c|c|c|c|c|c|c|c|c|}
\hline \multirow[b]{2}{*}{ Location } & {$[\mathrm{RN}]^{\mathrm{a}}$} & $2 \times T^{\prime b} U^{b}$ & $M{ }^{c}$ & RER $^{\text {d }}$ & [RN] & $2 \times$ TPU & MDC & RER \\
\hline & \multicolumn{4}{|c|}{${ }^{241} \mathrm{Am}$} & \multicolumn{4}{|c|}{${ }^{238} \mathrm{Pu}$} \\
\hline IDN & $3.05 \times 10^{-4}$ & $7.47 \times 10^{-4}$ & $1.42 \times 10^{-4}$ & 0.050 & $0.00 \times 10^{0}$ & $0.00 \times 10^{0}$ & $7.59 \times 10^{-4}$ & 0.500 \\
\hline IDN Dup. & $2.63 \times 10^{-4}$ & $3.74 \times 10^{-4}$ & $3.57 \times 10^{-4}$ & & $1.96 \times 10^{-4}$ & $3.92 \times 10^{-4}$ & $5.29 \times 10^{-4}$ & \\
\hline TUT & $1.22 \times 10^{-4}$ & $5.48 \times 10^{-4}$ & $1.14 \times 10^{-3}$ & 0.495 & $2.13 \times 10^{-4}$ & $3.03 \times 10^{-4}$ & $2.88 \times 10^{-4}$ & 0.407 \\
\hline \multirow[t]{2}{*}{ TUT Dup. } & $4.85 \times 10^{-4}$ & $4.88 \times 10^{-4}$ & $3.28 \times 10^{-4}$ & & $5.62 \times 10^{-4}$ & $8.03 \times 10^{-4}$ & $7.62 \times 10^{-4}$ & \\
\hline & \multicolumn{4}{|c|}{${ }^{239+240} \mathrm{Pu}$} & \multicolumn{4}{|c|}{${ }^{234} \mathrm{U}$} \\
\hline IDN & $4.11 \times 10^{-4}$ & $4.18 \times 10^{-4}$ & $2.79 \times 10^{-4}$ & 0.983 & $1.21 \times 10^{-2}$ & $3.00 \times 10^{-3}$ & $7.99 \times 10^{-4}$ & 0.355 \\
\hline IDN Dup. & $0.00 \times 10^{0}$ & $0.00 \times 10^{0}$ & $5.29 \times 10^{-4}$ & & $1.37 \times 10^{-2}$ & $3.36 \times 10^{-3}$ & $3.16 \times 10^{-4}$ & \\
\hline TUT & $1.06 \times 10^{-4}$ & $2.13 \times 10^{-4}$ & $2.88 \times 10^{-4}$ & 0.288 & $9.66 \times 10^{-3}$ & $2.49 \times 10^{-3}$ & $2.76 \times 10^{-4}$ & 0.818 \\
\hline \multirow[t]{2}{*}{ TUT Dup. } & $2.80 \times 10^{-4}$ & $5.66 \times 10^{-4}$ & $7.62 \times 10^{-4}$ & & $1.45 \times 10^{-2}$ & $5.37 \times 10^{-3}$ & $8.55 \times 10^{-4}$ & \\
\hline & \multicolumn{4}{|c|}{${ }^{235} \mathrm{U}$} & \multicolumn{4}{|c|}{${ }^{238} U$} \\
\hline IDN & $9.36 \times 10^{-4}$ & $8.14 \times 10^{-4}$ & $9.84 \times 10^{-4}$ & 0.066 & $1.22 \times 10^{-2}$ & $3.00 \times 10^{-3}$ & $2.92 \times 10^{-4}$ & 0.693 \\
\hline IDN Dup. & $1.01 \times 10^{-3}$ & $7.81 \times 10^{-4}$ & $3.89 \times 10^{-4}$ & & $9.40 \times 10^{-3}$ & $2.61 \times 10^{-3}$ & $8.55 \times 10^{-4}$ & \\
\hline TUT & $5.03 \times 10^{-4}$ & $5.07 \times 10^{-4}$ & $3.40 \times 10^{-4}$ & 0.122 & $7.81 \times 10^{-3}$ & $2.15 \times 10^{-3}$ & $2.75 \times 10^{-4}$ & 0.704 \\
\hline TUT Dup. & $3.89 \times 10^{-4}$ & $7.84 \times 10^{-4}$ & $1.05 \times 10^{-3}$ & & $5.33 \times 10^{-3}$ & $2.86 \times 10^{-3}$ & $8.51 \times 10^{-4}$ & \\
\hline
\end{tabular}

${ }^{a}[\mathrm{RN}]=$ Radionuclide concentration

${ }^{b}$ Total propagated uncertainty

${ }^{\mathrm{C}}$ Minimum detectable concentration

${ }^{\mathrm{d}}$ Relative Error Ratio

\subsection{Soil Samples}

\subsubsection{Sampling}

Soil samples were collected from near the low-volume air samplers at six different locations around the WIPP site: MLR, SEC, SMR, WEE, WFF, and WSS (Figure 4.6). Samples were collected from each location in three incremental profiles: surface soil (SS, 0-2 cm [0-0.8 in.]), intermediate soil (SI, $2-5 \mathrm{~cm}$ [0.8-2 in.]), and deep soil (SD, $5-10 \mathrm{~cm}[2-4 \mathrm{in}]$.$) . Measurements of radionuclides in depth profiles provide information$ about their vertical movements in the soil systems.

\subsubsection{Sample Preparation}

Soil samples were dried at $110^{\circ} \mathrm{C}\left(230^{\circ} \mathrm{F}\right)$ for several hours and homogenized by grinding to small particle sizes. One gram $(0.04 \mathrm{oz})$ of soil was dissolved by heating it with a mixture of nitric, hydrochloric, and hydrofluoric acids. Finally, it was heated with nitric and boric acids, and the residue was dissolved in hydrochloric acid for the determination of individual radionuclides.

\subsubsection{Determination of Individual Radionuclides}

Gamma-emitting radionuclides $\left({ }^{40} \mathrm{~K},{ }^{60} \mathrm{Co}\right.$, and $\left.{ }^{137} \mathrm{Cs}\right)$ were determined by counting an aliquot of well-homogenized ground soil samples by gamma-spectrometry. Strontium-90 was analyzed from an aliquot of the sample solution by separating it from other stable and radioactive elements using radiochemical techniques and beta 


\section{Waste Isolation Pilot Plant 2001 Site Environmental Report DOE/WIPP 02-2225}

counting. Another aliquot of the sample solution was used for the sequential determinations of alpha-emitting radionuclides, such as ${ }^{234} \mathrm{U},{ }^{235} \mathrm{U}$, and ${ }^{238} \mathrm{U} ;{ }^{238} \mathrm{Pu}$ and ${ }^{239+240} \mathrm{Pu}$; and ${ }^{241} \mathrm{Am}$. These radionuclides were separated from the bulk of the inorganic materials present in the soil samples and from one another by radiochemical separations including co-precipitation and ion-exchange chromatography. Finally, the samples were micro-precipitated, filtered onto micro-filters, and counted on the alpha spectrometer.

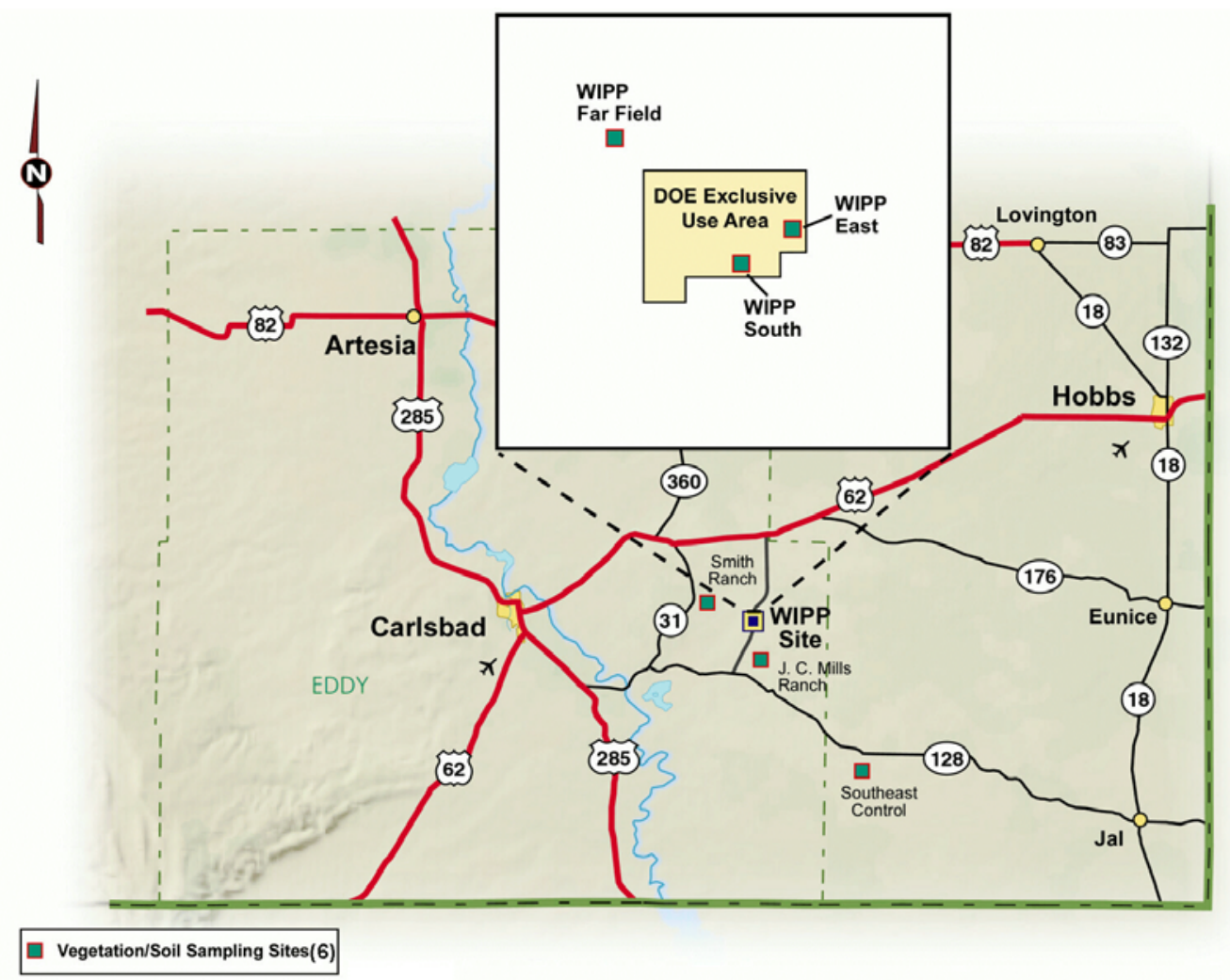

Figure 4.6 - Soil and Vegetation Sampling Areas in 2001

\subsubsection{Results and Discussions}

Uranium-234 and ${ }^{238} U$ were detected in every soil sample in 2001 and ${ }^{235} U$ was detected in all but one. Concentrations of ${ }^{234} \mathrm{U}$ in surface soils $(0-2 \mathrm{~cm})$ ranged from a minimum of $5.66 \times 10^{-3} \pm 1.35 \times 10^{-3} \mathrm{~Bq} / \mathrm{g}\left(1.53 \times 10^{-1} \pm 3.65 \times 10^{-2} \mathrm{pCi} / \mathrm{g}\right)$ at WEE to a maximum of $1.25 \times 10^{-2} \pm 2.48 \times 10^{-3} \mathrm{~Bq} / \mathrm{g}\left(3.38 \times 10^{-1} \pm 6.70 \times 10^{-2} \mathrm{pCi} / \mathrm{g}\right)$ at SEC (Table 4.11). Concentrations of ${ }^{235} \mathrm{U}$ in the same samples ranged from $2.83 \times 10^{-4} \pm$ $2.72 \times 10^{-4} \mathrm{~Bq} / \mathrm{g}\left(7.65 \times 10^{-3} \pm 7.35 \times 10^{-3} \mathrm{pCi} / \mathrm{g}\right)$ at WFF to $2.32 \times 10^{-3} \pm 2.48 \times 10^{-4} \mathrm{~Bq} / \mathrm{g}$ $\left(6.27 \times 10^{-2} \pm 6.70 \times 10^{-3} \mathrm{pCi} / \mathrm{g}\right)$ at WEE. The concentration of ${ }^{238} \mathrm{U}$ in surface soils ranged from $6.85 \times 10^{-3} \pm 1.57 \times 10^{-3} \mathrm{~Bq} / \mathrm{g}\left(1.85 \times 10^{-1} \pm 4.24 \times 10^{-2} \mathrm{pCi} / \mathrm{g}\right)$ at WEE to $1.28 \times 10^{-2} \pm$ $2.63 \times 10^{-3} \mathrm{~Bq} / \mathrm{g}\left(3.46 \times 10^{-1} \pm 7.11 \times 10^{-1} \mathrm{pCi} / \mathrm{g}\right)$ at WFF.

The results for uranium in intermediate depth $(2-5 \mathrm{~cm})$ soil samples are also given in Table 4.11. The concentration of ${ }^{234} U$ ranged from $6.73 \times 10^{-3} \pm 1.38 \times 10^{-3} \mathrm{~Bq} / \mathrm{g}$ $\left(1.82 \times 10^{-1} \pm 3.73 \times 10^{-2} \mathrm{pCi} / \mathrm{g}\right)$ at WEE to $2.03 \times 10^{-2} \pm 3.92 \times 10^{-3} \mathrm{~Bq} / \mathrm{g}\left(5.49 \times 10^{-1} \pm\right.$ 


\section{Waste Isolation Pilot Plant 2001 Site Environmental Report DOE/WIPP 02-2225}

$\left.1.06 \times 10^{-1} \mathrm{pCi} / \mathrm{g}\right)$ at SEC. Uranium-235 in these soils was lowest at WEE $\left(3.92 \times 10^{-4} \pm\right.$ $\left.2.43 \times 10^{-4} \mathrm{~Bq} / \mathrm{g}\left[1.06 \times 10^{-2} \pm 6.57 \times 10^{-3} \mathrm{pCi} / \mathrm{g}\right]\right)$ and highest at SEC $\left(1.11 \times 10^{-3} \pm 4.92 \times 10^{-4}\right.$ $\left.\mathrm{Bq} / \mathrm{g}\left[3.00 \times 10^{-2} \pm 1.16 \times 10^{-2} \mathrm{pCi} / \mathrm{g}\right]\right)$. The concentration of ${ }^{238} \mathrm{U}$ ranged from $7.33 \times 10^{-3} \pm$ $1.48 \times 10^{-3} \mathrm{~Bq} / \mathrm{g}\left(1.98 \times 10^{-1} \pm 4.00 \times 10^{-2} \mathrm{pCi} / \mathrm{g}\right)$ at WEE to $2.27 \times 10^{-2} \pm 4.33 \times 10^{-3} \mathrm{~Bq} / \mathrm{g}$ $\left(6.14 \times 10^{-1} \pm 1.17 \times 10^{-1} \mathrm{pCi} / \mathrm{g}\right)$ at SEC.

Table 4.11 - Uranium Concentrations (Bq/g) in Soil Near the WIPP Site.

See Appendix $B$ for the sampling locations.

\begin{tabular}{|c|c|c|c|c|c|c|c|c|c|c|}
\hline \multirow[b]{2}{*}{ Location } & \multirow{2}{*}{$\begin{array}{c}\text { Depth } \\
\text { (cm) }\end{array}$} & $\mathrm{RN}]^{\mathrm{a}}$ & $2 \times$ TPU $^{6}$ & $\mathrm{MDC}^{\mathrm{C}}$ & [RN] & $2 \times \mathrm{TPU}$ & MDC & [RN] & $2 \times$ TPU & MDC \\
\hline & & \multicolumn{3}{|c|}{${ }^{234} U$} & \multicolumn{3}{|c|}{${ }^{235} U$} & \multicolumn{3}{|c|}{${ }^{238} \mathrm{U}$} \\
\hline ILR & ?-O & $1.20 \times 10^{-2}$ & $2.22 \times 10^{-3}$ & $2.19 \times 10^{-4}$ & 年 & $75 \times 1$ & & $1.13 \times 10^{-2}$ & $2.10 \times 10^{-3}$ & $3 \times 10^{-5}$ \\
\hline ILR & $2-5$ & $1.41 \times 10^{-2}$ & $2.45 \times 10^{-3}$ & $7.22 \times 10^{-5}$ & $4.92 \times 10^{-4}$ & $2.66 \times 10^{-4}$ & $8.92 \times 10^{-2}$ & $1.32 \times 10^{-2}$ & $2.32 \times 10^{-3}$ & $2.47 \times 10^{-4}$ \\
\hline ALR & $v$ & $1.18 \times 10^{-2}$ & $2.13 \times 10^{-3}$ & $6.99 \times 10^{-5}$ & $6.36 \times 10^{-4}$ & $3.00 \times 10^{-4}$ & $8.62 \times 10^{-5}$ & $1.17 \times 10^{-2}$ & $2.11 \times 10^{-3}$ & $6.96 \times 10^{-5}$ \\
\hline EC & 2 & $1.25 \times 10^{-2}$ & $2.48 \times 10^{-3}$ & $2.47 \times 10^{-4}$ & $1.03 \times 10^{-3}$ & $4.48 \times 10^{-4}$ & $1.12 \times 10^{-4}$ & $1.28 \times 10^{-2}$ & $2.52 \times 10^{-3}$ & $9.03 \times 10^{-5}$ \\
\hline SEC & 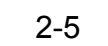 & $2.03 \times 10^{-2}$ & $3.92 \times 10^{-3}$ & $2.77 \times 10^{-4}$ & $1.11 \times 10^{-3}$ & $4.92 \times 10^{-4}$ & $1.25 \times 10^{-4}$ & $2.27 \times 10^{-2}$ & $4.33 \times 10^{-3}$ & $1.01 \times 10^{-4}$ \\
\hline $\mathrm{EC}$ & $5-10$ & $1.90 \times 10^{-2}$ & $3.50 \times 10^{-3}$ & $8.77 \times 10^{-5}$ & $8.40 \times 10^{-4}$ & $4.07 \times 10^{-4}$ & $2.95 \times 10^{-4}$ & $1.61 \times 10^{-2}$ & $3.02 \times 10^{-3}$ & $2.38 \times 10^{-4}$ \\
\hline MR & -2 & $1.04 \times 10^{-2}$ & $1.92 \times 10^{-3}$ & $7.18 \times 10^{-5}$ & $4.59 \times 10^{-4}$ & $2.55 \times 10^{-4}$ & $8.84 \times 10^{-5}$ & $1.09 \times 10^{-2}$ & $2.00 \times 10^{-3}$ & $7.14 \times 10^{-5}$ \\
\hline MR & $2-5$ & $1.11 \times 10^{-2}$ & $2.02 \times 10^{-3}$ & $7.22 \times 10^{-5}$ & $7.22 \times 10^{-4}$ & $3.27 \times 10^{-3}$ & $8.88 \times 10^{-5}$ & $1.14 \times 10^{-2}$ & $2.06 \times 10^{-3}$ & $7.18 \times 10^{-5}$ \\
\hline MR & 0 & $2.09 \times 10^{-2}$ & $3.74 \times 10^{-3}$ & $8.51 \times 10^{-5}$ & $8.92 \times 10^{-4}$ & $4.00 \times 10^{-4}$ & $1.05 \times 10^{-4}$ & $2.09 \times 10^{-2}$ & $3.74 \times 10^{-3}$ & $8.47 \times 10^{-5}$ \\
\hline /EE & $0-2$ & $5.66 \times 10^{-3}$ & $1.35 \times 10^{-3}$ & $1.02 \times 10^{-4}$ & $2.32 \times 10^{-5}$ & $2.48 \times 10^{-4}$ & $3.41 \times 10^{-4}$ & $6.85 \times 10^{-3}$ & $1.57 \times 10^{-3}$ & $1.01 \times 10^{-4}$ \\
\hline VEE & & $6.73 \times 10^{-3}$ & $1.38 \times 10^{-3}$ & $7.81 \times 10^{-5}$ & $3.92 \times 10^{-4}$ & $2.43 \times 10^{-4}$ & $9.62 \times 10^{-5}$ & $7.33 \times 10^{-3}$ & $1.48 \times 10^{-3}$ & $7.77 \times 10^{-5}$ \\
\hline JEE & $5-10$ & $1.84 \times 10^{-2}$ & $3.68 \times 10^{-3}$ & $2.83 \times 10^{-4}$ & $4.74 \times 10^{-4}$ & $3.11 \times 10^{-4}$ & $1.28 \times 10^{-4}$ & $2.00 \times 10^{-2}$ & $3.96 \times 10^{-3}$ & $1.04 \times 10^{-4}$ \\
\hline NFF & & $1.17 \times 10^{-2}$ & $2.45 \times 10^{-3}$ & $1.04 \times 10^{-4}$ & $2.83 \times 10^{-4}$ & $2.72 \times 10^{-4}$ & $3.48 \times 10^{-4}$ & $1.28 \times 10^{-2}$ & $2.63 \times 10^{-3}$ & $2.80 \times 10^{-4}$ \\
\hline NFF & & $1.22 \times 10^{-2}$ & $2.62 \times 10^{-3}$ & $3.56 \times 10^{-4}$ & $6.62 \times 10^{-4}$ & $3.74 \times 10^{-4}$ & $1.28 \times 10^{-4}$ & $1.23 \times 10^{-2}$ & $2.62 \times 10^{-3}$ & $2.81 \times 10^{-4}$ \\
\hline WFF & $5-10$ & $1.00 \times 10^{-2}$ & $2.18 \times 10^{-3}$ & $1.08 \times 10^{-4}$ & $2.96 \times 10^{-4}$ & $2.47 \times 10^{-4}$ & $1.34 \times 10^{-4}$ & $9.36 \times 10^{-3}$ & $2.05 \times 10^{-3}$ & $1.08 \times 10^{-4}$ \\
\hline SS & 02 & $1.24 \times 10^{-2}$ & $2.37 \times 10^{-3}$ & $2.92 \times 10^{-4}$ & $4.26 \times 10^{-4}$ & $2.66 \times 10^{-4}$ & $1.05 \times 10^{-4}$ & $1.25 \times 10^{-2}$ & $2.39 \times 10^{-3}$ & $2.30 \times 10^{-4}$ \\
\hline WSS & $2-5$ & $9.58 \times 10^{-3}$ & $1.97 \times 10^{-3}$ & $9.25 \times 10^{-5}$ & $7.99 \times 10^{-4}$ & $3.92 \times 10^{-4}$ & $1.14 \times 10^{-4}$ & $9.18 \times 10^{-3}$ & $1.53 \times 10^{-3}$ & $9.18 \times 10^{-5}$ \\
\hline WSS & -10 & $8.73 \times 10^{-3}$ & $1.86 \times 10^{-3}$ & $9.77 \times 10^{-5}$ & $1.78 \times 10^{-4}$ & $1.81 \times 10^{-4}$ & $1.21 \times 10^{-4}$ & $8.51 \times 10^{-3}$ & $1.82 \times 10^{-3}$ & $9.73 \times 10^{-5}$ \\
\hline
\end{tabular}

${ }^{\mathrm{a}}[\mathrm{RN}]=$ Radionuclide concentration

b Total propagated uncertainty

${ }^{\mathrm{c}}$ Minimum detectable concentration

Concentrations of ${ }^{234} U,{ }^{235} U$, and ${ }^{238} U$ were also measured in deep soils $(5-10 \mathrm{~cm})$ (Table 4.11). Concentrations of ${ }^{234} \mathrm{U}$ varied from $8.73 \times 10^{-3} \pm 1.86 \times 10^{-3} \mathrm{~Bq} / \mathrm{g}\left(2.36 \times 10^{-1}\right.$ $\left.\pm 5.03 \times 10^{-2} \mathrm{pCi} / \mathrm{g}\right)$ at WSS to $2.09 \times 10^{-2} \pm 3.74 \times 10^{-3} \mathrm{~Bq} / \mathrm{g}\left(5.65 \times 10^{-1} \pm 1.01 \times 10^{-1} \mathrm{pCi} / \mathrm{g}\right)$ at SMR. The lowest concentration of ${ }^{235} \mathrm{U}$ in deep soils was found at WSS $\left(1.78 \times 10^{-4} \pm\right.$ $\left.1.81 \times 10^{-4} \mathrm{~Bq} / \mathrm{g}\left[4.81 \times 10^{-3} \pm 4.89 \times 10^{-3} \mathrm{pCi} / \mathrm{g}\right]\right)$ and the highest concentration was found at SMR $\left(8.92 \times 10^{-4} \pm 4.00 \times 10^{-4} \mathrm{~Bq} / \mathrm{g}\left[2.41 \times 10^{-2} \pm 1.08 \times 10^{-2} \mathrm{pCi} / \mathrm{g}\right]\right)$. Uranium-238 lowest concentration was $8.51 \times 10^{-3} \pm 1.82 \times 10^{-3} \mathrm{~Bq} / \mathrm{g}\left(2.30 \times 10^{-1} \pm 4.92 \times 10^{-2} \mathrm{pCi} / \mathrm{g}\right)$ at WSS and the highest was found $2.09 \times 10^{-2} \pm 3.74 \times 10^{-3} \mathrm{~Bq} / \mathrm{g}\left(5.65 \times 10^{-1} \pm 1.01 \times 10^{-1} \mathrm{pCi} / \mathrm{g}\right)$ at SMR.

No uranium isotope varied significantly with year 2001 (ANOVA, ${ }^{234} \cup p=0.105$, ${ }^{238} \mathrm{U} p=0.722$ ). All maximum measured concentrations fell within the range of natural concentrations of uranium found in soils throughout the world (Pais and Jones 1997). All these results suggest a pattern of natural variability consistent with the existence of natural uranium, without amendment from artificial sources. 


\section{Waste Isolation Pilot Plant 2001 Site Environmental Report DOE/WIPP 02-2225}

Plutonium-238, ${ }^{239+240} \mathrm{Pu}$, and ${ }^{241} \mathrm{Am}$ were also analyzed in these soil samples (Table 4.12). Plutonium-238 was not detected in any samples. The measured concentration of ${ }^{239+240} \mathrm{Pu}$ was greater than the MDC at location MLR at all three depths. The ${ }^{241} \mathrm{Am}$ concentration was greater than the MDC at MLR, 0-2 cm and $2-5 \mathrm{~cm}$, SEC, $5-10 \mathrm{~cm}$, and WEE, $5-10 \mathrm{~cm}$. Historically, soil samples collected in the same locations have shown positive results on numerous occasions. Since 1997, soil samples collected by the Environmental Monitoring group at WEE, SEC, and MLR have shown levels of ${ }^{241} \mathrm{Am}$ and ${ }^{239 / 240} \mathrm{Pu}$ slightly above background. During this time period, three different analytical laboratories were used; all had similar results. The source of activity in WIPP samples could be due to natural transport of contaminated soil from the Gnome Site via wind. The Gnome Site lies about $9 \mathrm{~km}$ southwest of the WIPP boundary and was contaminated with fission products in 1961 when an underground test of a 3-kiloton ${ }^{239} \mathrm{Pu}$ device vented to the surface. Because there are elevated levels of radionuclides in the soil near the Gnome Site, there is potential for contamination of WIPP environmental samples. The measurable levels of radionuclides remains relatively high around the Gnome Site despite remediation efforts.

Table 4.12 - Americium and Plutonium Concentrations (Bq/g) in Soil Near the WIPP Site. See Appendix B for the sampling locations.

\begin{tabular}{|c|c|c|c|c|c|c|c|c|c|c|}
\hline \multirow[b]{2}{*}{ Location } & \multirow{2}{*}{$\begin{array}{l}\text { Depth } \\
\text { (cm) }\end{array}$} & & $\times$ & MI & RN] & $\times$ TPU & MDC & ] & $2 \times$ TPU & MDC \\
\hline & & \multicolumn{3}{|c|}{${ }^{241} \mathrm{Am}$} & \multicolumn{3}{|c|}{${ }^{238} \mathrm{Pu}$} & \multicolumn{3}{|c|}{${ }^{239+240} \mathrm{Pu}$} \\
\hline$R$ & -2 & $1.79 \times 10^{-4}$ & $1.49 \times 10^{-4}$ & $8.07 \times 10^{-5}$ & & $6.88 \times 10^{-5}$ & $2.52 \times 10^{-4}$ & & $2.23 \times 10^{-4}$ & \\
\hline LR & 5 & $4.18 \times 10^{-4}$ & $2.29 \times 10^{-4}$ & $8.10 \times 10^{-5}$ & $0.00 \times 10^{0}$ & $0.00 \times 10^{0}$ & $1.28 \times 10^{-4}$ & $6.59 \times 10^{-4}$ & $3.70 \times 1$ & $1.28 \times 10^{-4}$ \\
\hline LR & & $2.41 \times 10^{-4}$ & $2.31 \times 10^{-4}$ & $3.19 \times 10^{-4}$ & $-4.88 \times 10^{-5}$ & $9.84 \times 10^{-5}$ & $3.60 \times 10^{-4}$ & $5.85 \times 10^{-4}$ & $3.55 \times 10^{-4}$ & $1.32 \times 10^{-4}$ \\
\hline$E C$ & 2 & $3.23 \times 10^{-5}$ & $1.45 \times 10^{-4}$ & $3.00 \times 10^{-4}$ & $4.44 \times 10^{-5}$ & $8.92 \times 10^{-5}$ & $1.20 \times 10^{-4}$ & $1.77 \times 10^{-4}$ & & $1.20 \times 10^{-4}$ \\
\hline$E C$ & -5 & $8.95 \times 10^{-5}$ & $1.34 \times 10^{-4}$ & $2.20 \times 10^{-4}$ & $1.70 \times 10^{-4}$ & $2.10 \times 10^{-4}$ & $3.13 \times 10^{-4}$ & $1.70 \times 10^{-4}$ & $1.72 \times 10^{-4}$ & $1.15 \times 10^{-4}$ \\
\hline C & 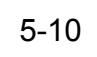 & $1.37 \times 10^{-4}$ & $1.16 \times 10^{-4}$ & $8.99 \times 10^{-4}$ & $6.29 \times 10^{-5}$ & $1.26 \times 10^{-4}$ & $2.31 \times 10^{-4}$ & $6.25 \times 10^{-5}$ & $1.26 \times 10^{-4}$ & $2.31 \times 10^{-4}$ \\
\hline $\mathrm{IR}$ & & $0.00 \times 10^{0}$ & $0.00 \times 10^{0}$ & $2.21 \times 10^{-4}$ & $-4.07 \times 10^{-5}$ & $8.14 \times 10^{-5}$ & $2.99 \times 10^{-4}$ & $0.00 \times 10^{0}$ & $0.00 \times 10^{0}$ & $2.99 \times 10^{-4}$ \\
\hline MR & -5 & $8.03 \times 10^{-5}$ & $1.15 \times 10^{-4}$ & $1.09 \times 10^{-4}$ & $0.00 \times 10^{0}$ & $0.00 \times 10^{0}$ & $1.30 \times 10^{-4}$ & $.00 \times 10^{0}$ & $.00 \times 10^{0}$ & $3.52 \times 10^{-4}$ \\
\hline $\mathrm{R}$ & & & & & & & & & & \\
\hline EE & $0-2$ & $6.33 \times 10^{-5}$ & $9.03 \times 10^{-5}$ & $8.58 \times 10^{-5}$ & $0.00 \times 10^{0}$ & $0.00 \times 10^{0}$ & $9.81 \times 10^{-5}$ & $3.61 \times 10^{-5}$ & $\times 10^{-5}$ & $10^{-5}$ \\
\hline EE & 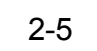 & $0.00 \times 10^{0}$ & $0.00 \times 10^{0}$ & $3.47 \times 10^{-4}$ & $3.96 \times 10^{-5}$ & $7.92 \times 10^{-5}$ & $1.07 \times 10^{-4}$ & $1.58 \times 10^{-4}$ & $1.60 \times 10^{-4}$ & $1.07 \times 10^{-4}$ \\
\hline IEE & -10 & $1.32 \times 10^{-4}$ & $1.54 \times 10^{-4}$ & $1.19 \times 10^{-4}$ & $10^{0}$ & $0.00 \times 10^{0}$ & $2.25 \times 10^{-4}$ & $10^{-5}$ & & $8.29 \times 10^{-5}$ \\
\hline JFF & -2 & $1.68 \times 10^{-4}$ & $1.71 \times 10^{-4}$ & $1.14 \times 10^{-4}$ & $4.14 \times 10^{-5}$ & $8.29 \times 10^{-5}$ & $1.12 \times 10^{-4}$ & $1.65 \times 10^{-4}$ & $1.67 \times 10^{-4}$ & $1.12 \times 10^{-4}$ \\
\hline 5 & $2-5$ & $1.96 \times 10^{-4}$ & $2.09 \times 10^{-4}$ & $3.03 \times 10^{-4}$ & & & $6.25 \times 10^{-4}$ & & & $2.30 \times 10^{-4}$ \\
\hline $\mathrm{FF}$ & 10 & $5.62 \times 10^{-5}$ & $1.95 \times 10^{-4}$ & $4.14 \times 10^{-4}$ & $1.18 \times 10^{-4}$ & $1.77 \times 10^{-4}$ & $2.89 \times 10^{-4}$ & $7.84 \times 10^{-5}$ & $1.12 \times 10^{-4}$ & $1.06 \times 10^{-4}$ \\
\hline is & 2 & $-3.25 \times 10^{-5}$ & $1.45 \times 10^{-4}$ & $3.50 \times 10^{-4}$ & $0.00 \times 10^{0}$ & $0.00 \times 10^{0}$ & $9.21 \times 10^{-5}$ & $1.36 \times 10^{-4}$ & $1.38 \times 10^{-4}$ & $9.21 \times 10^{-5}$ \\
\hline SS & 5 & $7.29 \times 10^{-5}$ & $1.04 \times 10^{-4}$ & $9.48 \times 10^{-5}$ & $-3.53 \times 10^{-5}$ & $1.22 \times 10^{-4}$ & $3.27 \times 10^{-4}$ & $7.03 \times 10^{-5}$ & $1.00 \times 10^{-4}$ & $9.55 \times 10^{-5}$ \\
\hline SS & 10 & $1.21 \times 10^{-4}$ & $1.73 \times 10^{-4}$ & $2.82 \times 10^{-4}$ & $9.62 \times 10^{-5}$ & $1.37 \times 10^{-4}$ & $1.30 \times 10^{-4}$ & $4.81 \times 10^{-5}$ & $1.67 \times 10^{-4}$ & $3.54 \times 10^{-4}$ \\
\hline
\end{tabular}

${ }^{\mathrm{a}}[\mathrm{RN}]=$ Radionuclide concentration

b Total propagated uncertainty

${ }^{\mathrm{c}}$ Minimum detectable concentration

Potassium-40, as expected, was detected in every sample (Table 4.13). This naturally-occurring gamma-emitting radionuclide is ubiquitous in soils. Concentrations in surface soils ranged from $2.24 \times 10^{-1} \pm 3.05 \times 10^{-2} \mathrm{~Bq} / \mathrm{g}\left(6.05 \times 10^{0} \pm 8.24 \times 10^{-1} \mathrm{pCi} / \mathrm{g}\right)$ at SEC to $4.74 \times 10^{-1} \pm 6.18 \times 10^{-2} \mathrm{~Bq} / \mathrm{g}\left(1.28 \times 10^{1} \pm 1.67 \times 10^{0} \mathrm{pCi} / \mathrm{g}\right)$ at SMR. In intermediate 
depth soils, concentrations of ${ }^{40} \mathrm{~K}$ varied from $2.32 \times 10^{-1} \pm 3.15 \times 10^{-2} \mathrm{~Bq} / \mathrm{g}\left(6.27 \times 10^{0} \pm\right.$ $\left.8.51 \times 10^{-1} \mathrm{pCi} / \mathrm{g}\right)$ at SEC to $5.11 \times 10^{-1} \pm 6.73 \times 10^{-2} \mathrm{~Bq} / \mathrm{g}\left(1.38 \times 10^{1} \pm 1.82 \times 10^{0} \mathrm{pCi} / \mathrm{g}\right)$ at SMR. Potassium-40 concentrations in deep soils were lowest at WFF $\left(2.09 \times 10^{-1} \pm\right.$ $2.76 \times 10^{-2} \mathrm{~Bq} / \mathrm{g}\left(5.65 \times 10^{0} \pm 7.46 \times 10^{-1} \mathrm{pCi} / \mathrm{g}\right)$ and highest at SMR $\left(5.62 \times 10^{-1} \pm 7.29 \times 10^{-2}\right.$ $\mathrm{Bq} / \mathrm{g}\left(1.52 \times 10^{1} \pm 1.97 \times 10^{0} \mathrm{pCi} / \mathrm{g}\right)$.

The concentration of ${ }^{40} \mathrm{~K}$ was not significantly different between depths or between years. The range of concentrations observed is consistent with the average natural ${ }^{40} \mathrm{~K}$ concentration in soils around the world $\left(4.00 \times 10^{-1} \mathrm{~Bq} / \mathrm{g}\left[1.08 \times 10^{1} \mathrm{pCi} / \mathrm{g}\right]\right.$; NCRP, 1994).

Cesium-137 was detected in 17 of the 18 soil samples (Table 4.13). In surface soils, concentrations ranged from $9.29 \times 10^{-4} \pm 5.14 \times 10^{-4} \mathrm{~Bq} / \mathrm{g}\left(2.51 \times 10^{-2} \pm 1.39 \times 10^{-2} \mathrm{pCi} / \mathrm{g}\right)$ at SMR to $8.88 \times 10^{-3} \pm 1.22 \times 10^{-3} \mathrm{~Bq} / \mathrm{g}\left(2.40 \times 10^{-1} \pm 3.30 \times 10^{-2} \mathrm{pCi} / \mathrm{g}\right)$ at MLR. The concentration in intermediate depth soils ranged from $1.16 \times 10^{-3} \pm 4.33 \times 10^{-4} \mathrm{~Bq} / \mathrm{g}$ $\left(3.14 \times 10^{-2} \pm 1.17 \times 10^{-2} \mathrm{pCi} / \mathrm{g}\right)$ at SMR to $1.65 \times 10^{-2} \pm 2.16 \times 10^{-3} \mathrm{~Bq} / \mathrm{g}\left(4.46 \times 10^{-1} \pm\right.$ $\left.5.84 \times 10^{-2} \mathrm{pCi} / \mathrm{g}\right)$ at MLR. In deep soils, the lowest concentrations of ${ }^{137} \mathrm{Cs}$ were found at $\operatorname{SMR}\left(7.55 \times 10^{-4} \pm 5.00 \times 10^{-4} \mathrm{~Bq} / \mathrm{g}\left[2.04 \times 10^{-2} \pm 1.35 \times 10^{-2} \mathrm{pCi} / \mathrm{g}\right]\right)$ and the highest concentrations were found at MLR $\left(1.48 \times 10^{-2} \pm 2.01 \times 10^{-3} \mathrm{~Bq} / \mathrm{g}\left[4.00 \times 10^{-1} \pm\right.\right.$ $\left.\left.5.43 \times 10^{-2} \mathrm{pCi} / \mathrm{g}\right]\right)$. 
Table 4.13 - Selected Radionuclide Concentrations (Bq/g) in Soil Near the WIPP Site. See Appendix B for the sampling locations.

\begin{tabular}{|c|c|c|c|c|c|c|c|}
\hline \multirow[b]{2}{*}{ Location } & \multirow{2}{*}{$\begin{array}{c}\text { Depth } \\
\text { (cm) }\end{array}$} & {$[R N]^{a}$} & $2 \times$ TPU $^{b}$ & $M^{\prime} C^{c}$ & [RN] & $2 \times$ TPU & MDC \\
\hline & & \multicolumn{3}{|c|}{${ }^{137} \mathrm{Cs}$} & \multicolumn{3}{|c|}{${ }^{60} \mathrm{Co}$} \\
\hline$\overline{M L R}$ & $0-2$ & $8.88 \times 10^{-3}$ & $1.22 \times 10^{-3}$ & $4.29 \times 10^{-4}$ & $2.97 \times 10^{-4}$ & $3.03 \times 10^{-4}$ & $4.81 \times 10^{-4}$ \\
\hline MLR & $2-5$ & $1.65 \times 10^{-2}$ & $2.16 \times 10^{-3}$ & $5.81 \times 10^{-4}$ & $-1.72 \times 10^{-4}$ & $4.88 \times 10^{-4}$ & $8.25 \times 10^{-4}$ \\
\hline MLR & $5-10$ & $1.48 \times 10^{-2}$ & $2.01 \times 10^{-3}$ & $8.07 \times 10^{-4}$ & $2.20 \times 10^{-6}$ & $4.33 \times 10^{-4}$ & $7.33 \times 10^{-4}$ \\
\hline SEC & $0-2$ & $2.82 \times 10^{-3}$ & $5.48 \times 10^{-4}$ & $5.14 \times 10^{-4}$ & $2.28 \times 10^{-4}$ & $2.34 \times 10^{-4}$ & $3.68 \times 10^{-4}$ \\
\hline SEC & $2-5$ & $2.15 \times 10^{-3}$ & $4.51 \times 10^{-4}$ & $4.51 \times 10^{-4}$ & $7.22 \times 10^{-5}$ & $2.48 \times 10^{-4}$ & $4.22 \times 10^{-4}$ \\
\hline SEC & $5-10$ & $9.44 \times 10^{-4}$ & $3.77 \times 10^{-4}$ & $5.29 \times 10^{-4}$ & $8.55 \times 10^{-5}$ & $2.80 \times 10^{-4}$ & $4.74 \times 10^{-4}$ \\
\hline SMR & $0-2$ & $9.29 \times 10^{-4}$ & $5.14 \times 10^{-4}$ & $7.81 \times 10^{-4}$ & $3.66 \times 10^{-4}$ & $4.29 \times 10^{-4}$ & $6.92 \times 10^{-4}$ \\
\hline SMR & $2-5$ & $1.16 \times 10^{-3}$ & $4.33 \times 10^{-4}$ & $6.03 \times 10^{-4}$ & $1.82 \times 10^{-4}$ & $3.20 \times 10^{-4}$ & $5.25 \times 10^{-4}$ \\
\hline SMR & $5-10$ & $7.55 \times 10^{-4}$ & $5.00 \times 10^{-4}$ & $7.73 \times 10^{-4}$ & $2.11 \times 10^{-4}$ & $4.63 \times 10^{-4}$ & $7.59 \times 10^{-4}$ \\
\hline WEE & $0-2$ & $2.21 \times 10^{-3}$ & $5.48 \times 10^{-4}$ & $6.55 \times 10^{-4}$ & $8.29 \times 10^{-5}$ & $2.48 \times 10^{-4}$ & $4.22 \times 10^{-4}$ \\
\hline WEE & $2-5$ & $3.13 \times 10^{-3}$ & $5.33 \times 10^{-4}$ & $5.62 \times 10^{-4}$ & $-3.74 \times 10^{-4}$ & $4.14 \times 10^{-4}$ & $7.10 \times 10^{-4}$ \\
\hline WEE & $5-10$ & $2.49 \times 10^{-3}$ & $6.22 \times 10^{-4}$ & $7.62 \times 10^{-4}$ & $-5.03 \times 10^{-4}$ & $4.63 \times 10^{-4}$ & $7.88 \times 10^{-4}$ \\
\hline WFF & $0-2$ & $3.57 \times 10^{-3}$ & $5.40 \times 10^{-4}$ & $3.59 \times 10^{-4}$ & $-6.99 \times 10^{-5}$ & $1.75 \times 10^{-4}$ & $3.40 \times 10^{-4}$ \\
\hline WFF & $2-5$ & $4.48 \times 10^{-3}$ & $6.22 \times 10^{-4}$ & $3.89 \times 10^{-4}$ & $-1.96 \times 10^{-5}$ & $2.76 \times 10^{-4}$ & $4.66 \times 10^{-4}$ \\
\hline WFF & $5-10$ & $3.30 \times 10^{-3}$ & $4.88 \times 10^{-4}$ & $2.63 \times 10^{-4}$ & $2.13 \times 10^{-4}$ & $1.61 \times 10^{-4}$ & $2.46 \times 10^{-4}$ \\
\hline WSS & $0-2$ & $1.95 \times 10^{-3}$ & $4.11 \times 10^{-4}$ & $3.96 \times 10^{-4}$ & $5.85 \times 10^{-5}$ & $2.42 \times 10^{-4}$ & $4.14 \times 10^{-4}$ \\
\hline WSS & $2-5$ & $1.78 \times 10^{-3}$ & $5.07 \times 10^{-4}$ & $6.51 \times 10^{-4}$ & $-3.08 \times 10^{-4}$ & $4.22 \times 10^{-4}$ & $7.18 \times 10^{-4}$ \\
\hline \multirow[t]{2}{*}{ WSS } & $5-10$ & $1.10 \times 10^{-3}$ & $3.29 \times 10^{-4}$ & $4.07 \times 10^{-4}$ & $2.24 \times 10^{-4}$ & $2.49 \times 10^{-4}$ & $3.96 \times 10^{-4}$ \\
\hline & & \multicolumn{3}{|c|}{${ }^{90} \mathrm{Sr}$} & \multicolumn{3}{|c|}{${ }^{40} \mathrm{~K}$} \\
\hline MLR & $0-2$ & $-2.81 \times 10^{-3}$ & $1.14 \times 10^{-2}$ & $1.89 \times 10^{-2}$ & $4.51 \times 10^{-1}$ & $5.96 \times 10^{-2}$ & $9.14 \times 10^{-3}$ \\
\hline MLR & $2-5$ & $9.62 \times 10^{-3}$ & $1.27 \times 10^{-2}$ & $2.00 \times 10^{-2}$ & $4.77 \times 10^{-1}$ & $6.25 \times 10^{-2}$ & $1.38 \times 10^{-2}$ \\
\hline MLR & $5-10$ & $-3.96 \times 10^{-4}$ & $1.04 \times 10^{-2}$ & $1.72 \times 10^{-2}$ & $4.29 \times 10^{-1}$ & $5.66 \times 10^{-2}$ & $1.37 \times 10^{-2}$ \\
\hline SEC & $0-2$ & $4.37 \times 10^{-3}$ & $1.21 \times 10^{-2}$ & $2.05 \times 10^{-2}$ & $2.24 \times 10^{-1}$ & $3.05 \times 10^{-2}$ & $5.62 \times 10^{-3}$ \\
\hline SEC & $2-5$ & $1.29 \times 10^{-2}$ & $1.21 \times 10^{-2}$ & $1.97 \times 10^{-2}$ & $2.32 \times 10^{-1}$ & $3.15 \times 10^{-2}$ & $5.85 \times 10^{-3}$ \\
\hline SEC & $5-10$ & $1.17 \times 10^{-2}$ & $1.33 \times 10^{-2}$ & $2.18 \times 10^{-2}$ & $2.51 \times 10^{-1}$ & $3.39 \times 10^{-2}$ & $5.48 \times 10^{-3}$ \\
\hline SMR & $0-2$ & $-1.34 \times 10^{-3}$ & $1.26 \times 10^{-2}$ & $2.07 \times 10^{-2}$ & $4.74 \times 10^{-1}$ & $6.18 \times 10^{-2}$ & $1.34 \times 10^{-2}$ \\
\hline SMR & $2-5$ & $-2.93 \times 10^{-3}$ & $1.17 \times 10^{-2}$ & $1.94 \times 10^{-2}$ & $5.11 \times 10^{-1}$ & $6.73 \times 10^{-2}$ & $9.47 \times 10^{-3}$ \\
\hline SMR & $5-10$ & $3.37 \times 10^{-3}$ & $1.25 \times 10^{-2}$ & $2.13 \times 10^{-2}$ & $5.62 \times 10^{-1}$ & $7.29 \times 10^{-2}$ & $1.37 \times 10^{-2}$ \\
\hline WEE & $0-2$ & $1.79 \times 10^{-2}$ & $9.55 \times 10^{-3}$ & $1.60 \times 10^{-2}$ & $2.25 \times 10^{-1}$ & $3.07 \times 10^{-2}$ & $7.36 \times 10^{-3}$ \\
\hline WEE & $2-5$ & $-8.70 \times 10^{-3}$ & $9.07 \times 10^{-3}$ & $1.60 \times 10^{-2}$ & $2.50 \times 10^{-1}$ & $3.41 \times 10^{-2}$ & $1.33 \times 10^{-2}$ \\
\hline WEE & $5-10$ & $-3.15 \times 10^{-3}$ & $9.47 \times 10^{-3}$ & $1.63 \times 10^{-2}$ & $2.62 \times 10^{-1}$ & $3.55 \times 10^{-2}$ & $1.32 \times 10^{-2}$ \\
\hline WFF & $0-2$ & $-3.40 \times 10^{-3}$ & $9.32 \times 10^{-3}$ & $1.61 \times 10^{-2}$ & $2.53 \times 10^{-1}$ & $3.31 \times 10^{-2}$ & $4.33 \times 10^{-3}$ \\
\hline WFF & $2-5$ & $-4.22 \times 10^{-3}$ & $9.14 \times 10^{-3}$ & $1.58 \times 10^{-2}$ & $2.58 \times 10^{-1}$ & $3.40 \times 10^{-2}$ & $1.06 \times 10^{-2}$ \\
\hline WFF & $5-10$ & $-4.22 \times 10^{-3}$ & $9.51 \times 10^{-3}$ & $1.65 \times 10^{-2}$ & $2.09 \times 10^{-1}$ & $2.76 \times 10^{-2}$ & $4.63 \times 10^{-3}$ \\
\hline WSS & $0-2$ & $9.62 \times 10^{-3}$ & $1.25 \times 10^{-2}$ & $2.07 \times 10^{-2}$ & $2.29 \times 10^{-1}$ & $3.12 \times 10^{-2}$ & $6.96 \times 10^{-3}$ \\
\hline WSS & $2-5$ & $7.92 \times 10^{-3}$ & $1.24 \times 10^{-2}$ & $2.06 \times 10^{-2}$ & $2.44 \times 10^{-1}$ & $3.34 \times 10^{-2}$ & $1.33 \times 10^{-2}$ \\
\hline WSS & $5-10$ & $4.07 \times 10^{-3}$ & $1.20 \times 10^{-2}$ & $2.03 \times 10^{-2}$ & $2.35 \times 10^{-1}$ & $3.20 \times 10^{-2}$ & $5.74 \times 10^{-3}$ \\
\hline
\end{tabular}

${ }^{a}[R N]=$ Radionuclide concentration

b Total propagated uncertainty

${ }^{\mathrm{C}}$ Minimum detectable concentration

Although ${ }^{137} \mathrm{Cs}$ is a fission product, it is ubiquitous in soils because of global fallout from atmospheric nuclear weapons testing. In 1998, prior to WIPP accepting any waste, the average concentration of ${ }^{137} \mathrm{Cs}$ in soils around WIPP was $4.3 \times 10^{-3} \mathrm{~Bq} / \mathrm{g}$ $\left(1.16 \times 10^{-1} \mathrm{pCi} / \mathrm{g}\right)$. There was no statistically significant difference between concentrations measured in 2000 and 2001 (ANOVA, $p=0.519$ ). 


\section{Waste Isolation Pilot Plant 2001 Site Environmental Report DOE/WIPP 02-2225}

Strontium-90 was only detected at WEE, depth 0-2cm, slightly above the MDC (Table 4.13). However, ${ }^{60} \mathrm{Co}$ was not detected in any of the soil samples. There was nonsignificant difference in ${ }^{60}$ Co concentrations between years $(p=0.421)$.

Soil samples collected from one location (WEE) were divided into two parts and analyzed separately (Table 4.14). Uranium-234, ${ }^{238} \mathrm{U},{ }^{40} \mathrm{~K}$, and ${ }^{137} \mathrm{Cs}$ were compared between the duplicates. Other radionuclides of interest had insufficient detections to allow a reasonable comparison. The RER was greater than one for ${ }^{234} U$ and ${ }^{238} U$ in all samples. However, it was less than one in one for ${ }^{40} \mathrm{~K}$ analyses and ${ }^{137} \mathrm{Cs}$ analyses. A paired t-test indicated no significant difference between ${ }^{234} U$ duplicates $(p=0.624)$ and between ${ }^{238} U$ duplicates $(p=0.666)$. This circumstance indicates a lack of precision in these analyses, primarily due to the non-homogeneous distribution of radionuclides in soils. Because of small-scale differences in topography, soil type and structure, soil moisture, and other microenvironmental conditions, radionuclides are rarely homogeneously distributed in soils, and good agreement between duplicate samples is difficult to achieve. However, all the measurements were low, within the range of natural concentrations, and did not differ in time or space in such a way as to suggest WIPP-related contamination of the environment.

Table 4.14 - Results of Duplicate Soil Sample Analysis. Units are Bq/g. See Appendix $B$ for the sampling locations.

\begin{tabular}{|c|c|c|c|c|c|c|c|c|c|}
\hline \multirow[b]{2}{*}{ Location } & \multirow{2}{*}{$\begin{array}{c}\text { Depth } \\
\text { (cm) }\end{array}$} & {$[\mathrm{RN}]^{\mathrm{a}}$} & $2 \times T_{P U}^{b}$ & $\mathrm{MDC}^{\mathrm{C}}$ & RER $^{\mathrm{d}}$ & [RN] & $2 \times T_{P U^{a}}$ & $M C^{b}$ & RER $^{c}$ \\
\hline & & \multicolumn{4}{|c|}{${ }^{234} U$} & \multicolumn{4}{|c|}{${ }^{238} U$} \\
\hline WEE & $0-2$ & $5.66 \times 10^{-3}$ & $1.35 \times 10^{-3}$ & $1.02 \times 10^{-4}$ & 2.94 & $6.85 \times 10^{-3}$ & $1.57 \times 10^{-3}$ & $1.01 \times 10^{-4}$ & 2.26 \\
\hline WEE De & $0-2$ & $1.50 \times 10^{-2}$ & $2.88 \times 10^{-3}$ & $8.92 \times 10^{-4}$ & & $1.39 \times 10^{-2}$ & $2.70 \times 10^{-3}$ & $8.88 \times 10^{-5}$ & \\
\hline WEE & $2-5$ & $6.73 \times 10^{-3}$ & $1.38 \times 10^{-3}$ & $7.81 \times 10^{-5}$ & 2.63 & $7.33 \times 10^{-3}$ & $1.48 \times 10^{-3}$ & $7.77 \times 10^{-5}$ & 2.81 \\
\hline WEE D & $2-5$ & $1.57 \times 10^{-2}$ & $3.12 \times 10^{-3}$ & $9.99 \times 10^{-5}$ & & $1.81 \times 10^{-2}$ & $3.53 \times 10^{-3}$ & $9.92 \times 10^{-5}$ & \\
\hline WEE & $5-10$ & $1.84 \times 10^{-2}$ & $3.68 \times 10^{-3}$ & $2.83 \times 10^{-4}$ & 1.94 & $2.00 \times 10^{-2}$ & $3.96 \times 10^{-3}$ & $1.04 \times 10^{-4}$ & 1.90 \\
\hline \multirow[t]{2}{*}{ WEE D } & $5-10$ & $1.01 \times 10^{-2}$ & $2.20 \times 10^{-3}$ & $3.00 \times 10^{-4}$ & & $1.12 \times 10^{-2}$ & $2.39 \times 10^{-3}$ & $3.77 \times 10^{-4}$ & \\
\hline & & \multicolumn{4}{|c|}{${ }^{40} \mathrm{~K}$} & \multicolumn{4}{|c|}{${ }^{137} \mathrm{Cs}$} \\
\hline WEE & $0-2$ & $2.25 \times 10^{-1}$ & $3.07 \times 10^{-2}$ & $7.36 \times 10^{-3}$ & $\overline{0.40}$ & $2.21 \times 10^{-3}$ & $5.48 \times 10^{-4}$ & $6.55 \times 10^{-4}$ & 0.25 \\
\hline WEE $D^{\mathrm{e}}$ & $0-2$ & $2.43 \times 10^{-1}$ & $3.30 \times 10^{-2}$ & $6.29 \times 10^{-3}$ & & $2.40 \times 10^{-3}$ & $5.22 \times 10^{-4}$ & $5.55 \times 10^{-4}$ & \\
\hline WEE & $2-5$ & $2.62 \times 10^{-1}$ & $3.55 \times 10^{-2}$ & $1.32 \times 10^{-2}$ & 0.41 & $2.49 \times 10^{-3}$ & $6.22 \times 10^{-4}$ & $7.62 \times 10^{-4}$ & 0.18 \\
\hline WEE $D^{\mathrm{e}}$ & $2-5$ & $2.42 \times 10^{-1}$ & $3.28 \times 10^{-2}$ & $6.36 \times 10^{-3}$ & & $2.35 \times 10^{-3}$ & $4.74 \times 10^{-4}$ & $4.55 \times 10^{-4}$ & \\
\hline WEE & $5-10$ & $2.62 \times 10^{-1}$ & $3.55 \times 10^{-2}$ & $1.32 \times 10^{-2}$ & 0.22 & $2.49 \times 10^{-3}$ & $6.22 \times 10^{-4}$ & $7.62 \times 10^{-4}$ & 0.50 \\
\hline WEE $D^{\mathrm{e}}$ & $5-10$ & $2.51 \times 10^{-1}$ & $3.42 \times 10^{-2}$ & $1.34 \times 10^{-2}$ & & $2.12 \times 10^{-3}$ & $4.07 \times 10^{-4}$ & $5.14 \times 10^{-4}$ & \\
\hline
\end{tabular}

${ }^{\mathrm{a}}[\mathrm{RN}]=$ Radionuclide concentration

b Total propagated uncertainty

${ }^{\mathrm{c}}$ Minimum detectable concentration

${ }^{d}$ Relative Error Ratio

e Duplicate

\section{7 $\quad$ Sediments}

\subsubsection{Sample Collection}

Sediment samples were collected from 12 locations around the WIPP site, mostly from the same water bodies from which the surface water samples were collected (Figure 4.7, see Appendix B for location codes). The samples were collected in $1 \mathrm{I}$ 


\section{Waste Isolation Pilot Plant 2001 Site Environmental Report DOE/WIPP 02-2225}

plastic containers from the top $15 \mathrm{~cm}$ (6 in) of the sediments of the water bodies and shipped to the laboratory for the determination of individual radionuclides.

\subsubsection{Sample Preparation}

Sediment samples were dried at $110^{\circ} \mathrm{C}\left(230^{\circ} \mathrm{F}\right)$ for several hours and homogenized by grinding to smaller particle sizes. A $0.75-\mathrm{g}(0.04-\mathrm{Oz})$ aliquot was dissolved by heating it with a mixture of nitric, hydrochloric, and hydrofluoric acids. The residue was heated with nitric and boric acids to remove hydrofluoric acid quantitatively. Finally, the residue was dissolved in hydrochloric acid for the determination of individual radionuclides.

\subsubsection{Determination of Individual Radionuclides}

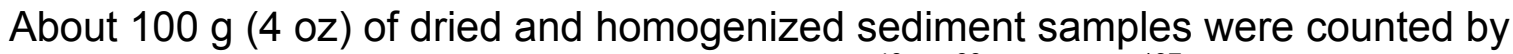
gamma-spectrometry for the determinations of ${ }^{40} \mathrm{~K},{ }^{60} \mathrm{Co}$, and ${ }^{137} \mathrm{Cs}$. Strontium-90 was determined from an aliquot of dissolved sediment samples by chemical separation and beta counting. Uranium, plutonium, and americium were determined by alpha spectrometry after chemical separations, micro-precipitating, and filtering onto micro filter papers.

\subsubsection{Results and Discussions}

Uranium-234, ${ }^{235} \mathrm{U}$, and ${ }^{238} \mathrm{U}$ were detected in every sediment sample in (Table 4.15). The concentration of ${ }^{234} \mathrm{U}$ ranged from $1.73 \times 10^{-2} \pm 3.10 \times 10^{-3} \mathrm{~Bq} / \mathrm{g}\left(4.68 \times 10^{-1} \pm\right.$ $\left.8.38 \times 10^{-2} \mathrm{pCi} / \mathrm{g}\right)$ at LST to $4.96 \times 10^{-2} \pm 8.33 \times 10^{-3} \mathrm{~Bq} / \mathrm{g}\left(1.34 \times 10^{0} \pm 2.25 \times 10^{-1} \mathrm{pCi} / \mathrm{g}\right)$ at CBD. The concentration of ${ }^{235} \mathrm{U}$ ranged from $9.32 \times 10^{-4} \pm 3.60 \times 10^{-4} \mathrm{~Bq} / \mathrm{g}\left(2.52 \times 10^{-2} \pm\right.$ $\left.9.73 \times 10^{-3} \mathrm{pCi} / \mathrm{g}\right)$ at RED to $2.12 \times 10^{-3} \pm 6.25 \times 10^{-4} \mathrm{~Bq} / \mathrm{g}\left(5.73 \times 10^{-2} \pm 1.69 \times 10^{-2} \mathrm{pCi} / \mathrm{g}\right)$ at CBD. The concentration of ${ }^{238} \mathrm{U}$ was lowest at LST $\left(1.84 \times 10^{-2} \pm 3.27 \times 10^{-3} \mathrm{~Bq} / \mathrm{g}\right.$ $\left.\left[4.97 \times 10^{-1} \pm 8.84 \times 10^{-2} \mathrm{pCi} / \mathrm{g}\right]\right)$ and highest at CBD $\left(3.35 \times 10^{-2} \pm 5.74 \times 10^{-4} \mathrm{~Bq} / \mathrm{g}\right.$ $\left.\left[9.05 \times 10^{-1} \pm 1.55 \times 10^{-2} \mathrm{pCi} / \mathrm{g}\right]\right)$. As expected, the ${ }^{235} \mathrm{U}$ concentration was much lower than the concentrations of ${ }^{234} U$ and ${ }^{238} U$. There was not a significant difference between sampling years (ANOVA ${ }^{234} U p=0.526,{ }^{235} U p=0.399,{ }^{238} \mathrm{U} p=0.315$ ).

Plutonium-238 was not detected in any sediment sample in 2001 (Table 4.16). Americium-241 was measured above the MDC at BRA. Plutonium-239+240 concentration was greater than the MDC at BRA, IDN, and Poker Trap [PKT]. These samples were processed several times in the laboratory due to interference in the spectra. The samples showed concentration barely above the MDC for two out of three analysis. The apparent lack of homogeneity of the samples caused the different results. Sample location BRA indicated ${ }^{241} \mathrm{Am}$ concentration above the MDC. This sample was also reprocessed for spectral interference. The radionuclide concentrations in Table 4.16 are the reprocessed results.

Cesium-137 was detected in all the sediment samples, ranging from $4.14 \times 10^{-4} \pm$ $1.60 \times 10^{-4} \mathrm{~Bq} / \mathrm{g}\left(1.12 \times 10^{-2} \pm 4.32 \times 10^{-3} \mathrm{pCi} / \mathrm{g}\right)$ at UPR to $4.59 \times 10^{-2} \pm 5.77 \times 10^{-3} \mathrm{~Bq} / \mathrm{g}$ $\left(1.24 \times 10^{0} \pm 1.56 \times 10^{-1} \mathrm{pCi} / \mathrm{g}\right)$ at BRA (Table 4.17). Cesium-137 did not differ statistically between sampling years 2000 and 2001 (ANOVA $p=0.397$ ). 


\section{Waste Isolation Pilot Plant 2001 Site Environmental Report DOE/WIPP 02-2225}

Strontium-90 was not detected in any sediment samples and Cobalt-60 was detected in one sediment sample (BRA). None of these radionuclides had sufficient detections to justify statistical comparisons between locations or years.

Potassium-40 was detected, as expected, in all sediment samples (Table 4.17). Its lowest concentration was found at CBD $\left(2.49 \times 10^{-1} \pm 3.25 \times 10^{-2} \mathrm{~Bq} / \mathrm{g}\left[6.73 \times 10^{0} \pm\right.\right.$ $\left.\left.8.78 \times 10^{-1} \mathrm{pCi} / \mathrm{g}\right]\right)$ and its highest concentration was found at TUT $\left(1.04 \times 10^{0} \pm 1.34 \times 10^{-1}\right.$ $\left.\mathrm{Bq} / \mathrm{g}\left[2.81 \times 10^{1} \pm 3.62 \times 10^{-1} \mathrm{pCi} / \mathrm{g}\right]\right)$. Potassium-40 did not vary significantly between years (ANOVA, $p=0.977$ ). Overall, the concentrations measured in 2001 were similar to the average concentration of ${ }^{40} \mathrm{~K}$ found in soils throughout the United States $\left(4.00 \times 10^{-1} \mathrm{~Bq} / \mathrm{g}\left[1.08 \times 10^{1} \mathrm{pCi} / \mathrm{g}\right] ; \mathrm{NCRP}, 1994\right)$.

Duplicate analyses were performed for all the radionuclides in sediment samples IDN and TUT (Table 4.18). The RER was less than one for ${ }^{241} \mathrm{Am}$ and all uranium isotopes, indicating acceptable correspondence between the original and the duplicate samples. For ${ }^{137} \mathrm{Cs}$ and ${ }^{40} \mathrm{~K}$, it was greater than one for location TUT. However, a t-test indicated no significant difference between any of these duplicate measurements for ${ }^{40} \mathrm{~K}$ $(p=0.613)$ and ${ }^{137} \mathrm{Cs}(p=0.723)$.

Table 4.15 - Uranium Concentrations (Bq/g) in Sediment Near the WIPP Site. See Appendix $B$ for the sampling locations.

\begin{tabular}{|c|c|c|c|c|c|c|c|c|c|}
\hline \multirow[b]{2}{*}{ Location } & $\overline{\mathrm{N}}]^{\mathrm{a}}$ & $2 \times T^{2} U^{b}$ & $\mathrm{MDC}^{\mathrm{C}}$ & [RN] & $2 \times$ TPU & MDC & $\overline{\text { [RN] }}$ & $2 \times$ TPU & MDC \\
\hline & \multicolumn{3}{|c|}{${ }^{234} \mathrm{U}$} & \multicolumn{3}{|c|}{${ }^{235} \mathrm{U}$} & \multicolumn{3}{|c|}{${ }^{238} \mathrm{U}$} \\
\hline RA & $2.82 \times 10^{-2}$ & $81 \times 10^{-3}$ & $6.25 \times 10^{-5}$ & $0^{-3}$ & $81 \times 10^{-4}$ & $7.73 \times 10^{-5}$ & $2.61 \times 10^{-2}$ & $48 \times 10^{-3}$ & $5 \times 10^{-5}$ \\
\hline HT & $2.15 \times 10^{-2}$ & $3.67 \times 10^{-3}$ & $5.99 \times 10^{-5}$ & $1.25 \times 10^{-3}$ & $4.18 \times 10^{-4}$ & $7.40 \times 10^{-5}$ & $2.32 \times 10^{-2}$ & $3.96 \times 10^{-3}$ & $.62 \times 10^{-4}$ \\
\hline CBD & $4.96 \times 10^{-2}$ & $8.33 \times 10^{-3}$ & $7.07 \times 10^{-5}$ & $2.12 \times 10^{-3}$ & $6.25 \times 10^{-4}$ & $8.70 \times 10^{-5}$ & $3.35 \times 10^{-2}$ & $5.74 \times 10^{-3}$ & $1.91 \times 10^{-4}$ \\
\hline HIL & $1.92 \times 10^{-2}$ & $3.51 \times 10^{-3}$ & $7.18 \times 10^{-5}$ & $1.50 \times 10^{-3}$ & $5.11 \times 10^{-4}$ & $8.84 \times 10^{-5}$ & $2.09 \times 10^{-2}$ & $3.77 \times 10^{-3}$ & $1.94 \times 10^{-4}$ \\
\hline IV & $2.33 \times 10^{-2}$ & $3.89 \times 10^{-3}$ & $5.40 \times 10^{-5}$ & $1.23 \times 10^{-3}$ & $4.03 \times 10^{-4}$ & $1.81 \times 10^{-4}$ & $2.30 \times 10^{-2}$ & $3.85 \times 10^{-3}$ & $5.37 \times 10^{-5}$ \\
\hline ד & $1.73 \times 10^{-2}$ & $3.10 \times 10^{-3}$ & $2.21 \times 10^{-4}$ & $1.15 \times 10^{-3}$ & $4.11 \times 10^{-4}$ & $7.96 \times 10^{-5}$ & $1.84 \times 10^{-2}$ & $3.27 \times 10^{-3}$ & $6.44 \times 10^{-5}$ \\
\hline OY & $2.32 \times 10^{-2}$ & $3.89 \times 10^{-3}$ & $5.81 \times 10^{-5}$ & $1.21 \times 10^{-3}$ & $4.07 \times 10^{-4}$ & $7.14 \times 10^{-5}$ & $2.43 \times 10^{-2}$ & $4.07 \times 10^{-3}$ & $5.77 \times 10^{-5}$ \\
\hline 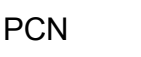 & $3.56 \times 10^{-2}$ & $6.29 \times 10^{-3}$ & $2.00 \times 10^{-4}$ & $1.91 \times 10^{-3}$ & $5.99 \times 10^{-4}$ & $9.07 \times 10^{-5}$ & $3.20 \times 10^{-2}$ & $5.66 \times 10^{-3}$ & $7.33 \times 10^{-5}$ \\
\hline KT & $2.55 \times 10^{-2}$ & $4.18 \times 10^{-3}$ & $1.53 \times 10^{-4}$ & $1.94 \times 10^{-3}$ & $5.37 \times 10^{-4}$ & $6.92 \times 10^{-5}$ & $2.70 \times 10^{-2}$ & $4.40 \times 10^{-3}$ & $5.59 \times 10^{-5}$ \\
\hline Lப & $1.94 \times 10^{-2}$ & $3.34 \times 10^{-3}$ & $1.74 \times 10^{-4}$ & $9.32 \times 10^{-4}$ & $3.60 \times 10^{-4}$ & $7.88 \times 10^{-5}$ & $1.92 \times 10^{-2}$ & $3.30 \times 10^{-4}$ & $6.36 \times 10^{-5}$ \\
\hline TUT & $2.32 \times 10^{-2}$ & $3.89 \times 10^{-3}$ & $6.62 \times 10^{-5}$ & $1.63 \times 10^{-3}$ & $5.07 \times 10^{-4}$ & $8.18 \times 10^{-5}$ & $2.53 \times 10^{-2}$ & $4.18 \times 10^{-3}$ & $6.59 \times 10^{-5}$ \\
\hline JPR & $2.60 \times 10^{-2}$ & $4.48 \times 10^{-3}$ & $6.40 \times 10^{-5}$ & $1.31 \times 10^{-3}$ & $4.51 \times 10^{-4}$ & $2.15 \times 10^{-4}$ & $2.69 \times 10^{-2}$ & $4.63 \times 10^{-3}$ & $6.36 \times 10^{-5}$ \\
\hline
\end{tabular}

${ }^{\mathrm{a}}[\mathrm{RN}]=$ Radionuclide concentration

b Total propagated uncertainty

${ }^{\mathrm{c}}$ Minimum detectable concentration 
Table 4.16 - Americium and Plutonium Concentrations (Bq/g) in Sediment Near the WIPP Site. See Appendix $B$ for the sampling locations.

\begin{tabular}{|c|c|c|c|c|c|c|c|c|c|}
\hline \multirow{2}{*}{ Location } & $N]^{a}$ & $2 \times 7$ & $\overline{\mathrm{ADC}^{\mathrm{c}}}$ & RN] & $2 \times \mathrm{TPU}$ & $\overline{M D C}$ & [RN] & $2 \times$ TPU & $\overline{M D C}$ \\
\hline & \multicolumn{3}{|c|}{${ }^{241} \mathrm{Am}$} & \multicolumn{3}{|c|}{${ }^{238} \mathrm{Pu}$} & \multicolumn{3}{|c|}{${ }^{239+240} \mathrm{Pu}$} \\
\hline BRA & $7.10 \times 10^{-4}$ & $4.03 \times 10^{-4}$ & $1.37 \times 10^{-4}$ & $1.20 \times 10$ & $1.25 \times 10^{-4}$ & $0.00 x^{2}$ & $2.46 \times 10^{-3}$ & $6.85 \times 10^{-4}$ & 0.001 \\
\hline HT & $2.04 \times 10^{-4}$ & $2.18 \times 10^{-4}$ & $3.16 \times 10^{-4}$ & $0.00 \times 10^{0}$ & $0.00 \times 10^{0}$ & $3.03 \times 10^{-4}$ & $1.64 \times 10^{-4}$ & $1.67 \times 10^{-4}$ & \\
\hline$B D$ & $3.06 \times 10^{-5}$ & $1.37 \times 10^{-4}$ & $2.84 \times 10^{-4}$ & $1.02 \times 10^{-4}$ & $1.04 \times 10^{-4}$ & $6.96 \times 10^{-5}$ & $7.70 \times 10^{-5}$ & $8.95 \times 10^{-5}$ & $6.96 \times 10^{-5}$ \\
\hline L & $1.51 \times 10^{-4}$ & $1.62 \times 10^{-4}$ & $2.22 \times 10^{-4}$ & $-8.14 \times 10^{-5}$ & $1.16 \times 10^{-4}$ & $3.77 \times 10^{-4}$ & $1.62 \times 10^{-4}$ & $1.65 \times 10^{-4}$ & $1.10 \times 10^{-4}$ \\
\hline $\mathrm{N}$ & $0.00 \times 10^{0}$ & $0.00 \times 10^{0}$ & $2.30 \times 10^{-4}$ & $-3.96 \times 10^{-5}$ & $1.38 \times 10^{-4}$ & $3.68 \times 10^{-4}$ & $7.92 \times 10^{-4}$ & $3.85 \times 10^{-4}$ & $1.07 \times 10^{-4}$ \\
\hline ST & $1.10 \times 10^{-4}$ & $1.57 \times 10^{-4}$ & $2.55 \times 10^{-4}$ & $6.85 \times 10^{-5}$ & $1.37 \times 10^{-4}$ & $2.51 \times 10^{-4}$ & $1.36 \times 10^{-4}$ & $1.38 \times 10^{-4}$ & $9.25 \times 10^{-5}$ \\
\hline OY & $1.43 \times 10^{-4}$ & $1.74 \times 10^{-4}$ & $2.66 \times 10^{-4}$ & $3.89 \times 10^{-5}$ & $1.35 \times 10^{-4}$ & $2.87 \times 10^{-4}$ & $1.95 \times 10^{-4}$ & $2.08 \times 10^{-4}$ & $2.87 \times 10^{-4}$ \\
\hline $\mathrm{CN}$ & $0.00 \times 10^{0}$ & $0.00 \times 10^{0}$ & $2.19 \times 10^{-4}$ & $0.00 \times 10^{0}$ & $0.00 \times 10^{0}$ & $5.03 \times 10^{-4}$ & $0.00 \times 10^{0}$ & $0.00 \times 10^{0}$ & $1.47 \times 10^{-4}$ \\
\hline KT & $7.73 \times 10^{-5}$ & $1.10 \times 10^{-4}$ & $1.05 \times 10^{-4}$ & $7.88 \times 10^{-5}$ & $1.58 \times 10^{-4}$ & $2.90 \times 10^{-4}$ & $7.07 \times 10^{-4}$ & $3.74 \times 10^{-4}$ & $2.90 \times 10^{-4}$ \\
\hline ED & $8.25 \times 10^{-5}$ & $1.24 \times 10^{-4}$ & $2.02 \times 10^{-4}$ & $7.77 \times 10^{-5}$ & $1.16 \times 10^{-4}$ & $1.90 \times 10^{-4}$ & $7.73 \times 10^{-5}$ & $9.03 \times 10^{-5}$ & $6.99 \times 10^{-5}$ \\
\hline UT & $3.05 \times 10^{-5}$ & $1.06 \times 10^{-4}$ & $2.25 \times 10^{-4}$ & $-2.51 \times 10^{-5}$ & $5.03 \times 10^{-5}$ & $1.85 \times 10^{-4}$ & $1.25 \times 10^{-4}$ & $1.34 \times 10^{-4}$ & $1.85 \times 10^{-4}$ \\
\hline JPR & $0.00 \times 10^{0}$ & $0.00 \times 10^{0}$ & $7.10 \times 10^{-5}$ & $-5.22 \times 10^{-5}$ & $1.05 \times 10^{-4}$ & $2.81 \times 10^{-4}$ & $7.81 \times 10^{-5}$ & $9.10 \times 10^{-5}$ & $7.07 \times 10^{-5}$ \\
\hline
\end{tabular}

${ }^{\mathrm{a}}[\mathrm{RN}]=$ Radionuclide concentration

${ }^{\mathrm{b}}$ Total propagated uncertainty

${ }^{\mathrm{C}}$ Minimum detectable concentration 
Table 4.17 - Selected Radionuclide Concentrations (Bq/g) in Sediment Near the WIPP Site. See Appendix $B$ for the sampling locations.

\begin{tabular}{|c|c|c|c|c|c|c|}
\hline \multirow[b]{2}{*}{ Location } & {$[R N]^{a}$} & $2 \times \mathrm{TPU}^{\mathrm{b}}$ & $M C^{c}$ & [RN] & $2 \times \mathrm{TPU}$ & MDC \\
\hline & \multicolumn{3}{|c|}{${ }^{137} \mathrm{Cs}$} & \multicolumn{3}{|c|}{${ }^{60} \mathrm{Co}$} \\
\hline BRA & $4.59 \times 10^{-2}$ & $5.77 \times 10^{-3}$ & $4.22 \times 10^{-4}$ & $6.85 \times 10^{-4}$ & $5.85 \times 10^{-4}$ & $6.73 \times 10^{-4}$ \\
\hline BHT & $6.77 \times 10^{-3}$ & $9.03 \times 10^{-4}$ & $3.58 \times 10^{-4}$ & $4.14 \times 10^{-5}$ & $5.88 \times 10^{-4}$ & $6.59 \times 10^{-4}$ \\
\hline CBD & $2.51 \times 10^{-3}$ & $4.74 \times 10^{-4}$ & $4.77 \times 10^{-4}$ & $2.60 \times 10^{-4}$ & $5.07 \times 10^{-4}$ & $5.85 \times 10^{-4}$ \\
\hline HIL & $7.99 \times 10^{-3}$ & $1.10 \times 10^{-3}$ & $5.14 \times 10^{-4}$ & $8.40 \times 10^{-5}$ & $6.25 \times 10^{-4}$ & $7.10 \times 10^{-4}$ \\
\hline IDN & $5.85 \times 10^{-3}$ & $7.84 \times 10^{-4}$ & $3.36 \times 10^{-4}$ & $-1.18 \times 10^{-4}$ & $2.50 \times 10^{-4}$ & $2.74 \times 10^{-4}$ \\
\hline LST & $1.73 \times 10^{-3}$ & $4.14 \times 10^{-4}$ & $5.11 \times 10^{-4}$ & $5.40 \times 10^{-4}$ & $5.07 \times 10^{-4}$ & $5.88 \times 10^{-4}$ \\
\hline NOY & $8.92 \times 10^{-4}$ & $2.64 \times 10^{-4}$ & $3.47 \times 10^{-4}$ & $2.36 \times 10^{-4}$ & $4.85 \times 10^{-4}$ & $5.55 \times 10^{-4}$ \\
\hline $\mathrm{PCN}$ & $7.62 \times 10^{-4}$ & $1.69 \times 10^{-4}$ & $2.55 \times 10^{-4}$ & $1.55 \times 10^{-4}$ & $4.51 \times 10^{-4}$ & $5.18 \times 10^{-4}$ \\
\hline PKT & $1.61 \times 10^{-2}$ & $2.03 \times 10^{-3}$ & $4.26 \times 10^{-4}$ & $3.42 \times 10^{-4}$ & $7.07 \times 10^{-4}$ & $7.99 \times 10^{-4}$ \\
\hline RED & $4.07 \times 10^{-3}$ & $5.77 \times 10^{-4}$ & $3.70 \times 10^{-4}$ & $5.00 \times 10^{-4}$ & $5.48 \times 10^{-4}$ & $6.33 \times 10^{-4}$ \\
\hline \multirow[t]{2}{*}{$\begin{array}{l}\text { TUT } \\
\text { UPR }\end{array}$} & $\begin{array}{l}3.81 \times 10^{-3} \\
4.14 \times 10^{-4}\end{array}$ & $\begin{array}{l}5.62 \times 10^{-4} \\
1.60 \times 10^{-4}\end{array}$ & $\begin{array}{l}4.44 \times 10^{-4} \\
3.57 \times 10^{-4}\end{array}$ & $\begin{array}{l}3.81 \times 10^{-4} \\
5.37 \times 10^{-4}\end{array}$ & $\begin{array}{l}7.29 \times 10^{-4} \\
5.33 \times 10^{-4}\end{array}$ & $\begin{array}{l}8.25 \times 10^{-4} \\
6.18 \times 10^{-4}\end{array}$ \\
\hline & \multicolumn{3}{|c|}{${ }^{90} \mathrm{Sr}$} & \multicolumn{3}{|c|}{${ }^{40} \mathrm{~K}$} \\
\hline BRA & $1.70 \times 10^{-2}$ & $1.55 \times 10^{-2}$ & $2.49 \times 10^{-2}$ & $5.51 \times 10^{-1}$ & $7.10 \times 10^{-2}$ & $6.51 \times 10^{-3}$ \\
\hline BHT & $1.45 \times 10^{-2}$ & $1.16 \times 10^{-2}$ & $1.80 \times 10^{-2}$ & $6.66 \times 10^{-1}$ & $8.55 \times 10^{-2}$ & $5.96 \times 10^{-3}$ \\
\hline CBD & $1.79 \times 10^{-3}$ & $6.59 \times 10^{-3}$ & $1.11 \times 10^{-2}$ & $2.49 \times 10^{-1}$ & $3.25 \times 10^{-2}$ & $5.59 \times 10^{-3}$ \\
\hline HIL & $6.85 \times 10^{-3}$ & $7.59 \times 10^{-3}$ & $1.20 \times 10^{-2}$ & $8.66 \times 10^{-1}$ & $1.11 \times 10^{-1}$ & $6.55 \times 10^{-3}$ \\
\hline IDN & $-5.48 \times 10^{-4}$ & $8.03 \times 10^{-3}$ & $1.35 \times 10^{-2}$ & $4.81 \times 10^{-1}$ & $6.18 \times 10^{-2}$ & $6.07 \times 10^{-3}$ \\
\hline LST & $-3.07 \times 10^{-3}$ & $6.44 \times 10^{-3}$ & $1.10 \times 10^{-2}$ & $3.89 \times 10^{-1}$ & $5.03 \times 10^{-2}$ & $6.03 \times 10^{-3}$ \\
\hline NOY & $-7.22 \times 10^{-4}$ & $6.07 \times 10^{-3}$ & $1.02 \times 10^{-2}$ & $4.77 \times 10^{-1}$ & $6.18 \times 10^{-2}$ & $6.25 \times 10^{-3}$ \\
\hline $\mathrm{PCN}$ & $1.54 \times 10^{-3}$ & $6.66 \times 10^{-3}$ & $1.10 \times 10^{-2}$ & $3.27 \times 10^{-1}$ & $4.26 \times 10^{-2}$ & $5.33 \times 10^{-3}$ \\
\hline PKT & $2.16 \times 10^{-3}$ & $7.07 \times 10^{-3}$ & $1.16 \times 10^{-2}$ & $8.70 \times 10^{-1}$ & $1.10 \times 10^{-1}$ & $6.99 \times 10^{-3}$ \\
\hline RED & $1.32 \times 10^{-3}$ & $6.92 \times 10^{-3}$ & $1.15 \times 10^{-2}$ & $4.85 \times 10^{-1}$ & $6.25 \times 10^{-2}$ & $6.18 \times 10^{-3}$ \\
\hline $\begin{array}{l}\text { TUT } \\
\text { UPR }\end{array}$ & $\begin{array}{c}2.52 \times 10^{-3} \\
-2.64 \times 10^{-4}\end{array}$ & $\begin{array}{l}7.14 \times 10^{-3} \\
6.99 \times 10^{-3}\end{array}$ & $\begin{array}{l}1.20 \times 10^{-2} \\
1.20 \times 10^{-2}\end{array}$ & $\begin{array}{r}1.04 \times 10^{0} \\
4.81 \times 10^{-1}\end{array}$ & $\begin{array}{l}1.34 \times 10^{-1} \\
6.22 \times 10^{-2}\end{array}$ & $\begin{array}{l}7.77 \times 10^{-3} \\
6.07 \times 10^{-3}\end{array}$ \\
\hline
\end{tabular}

a $[\mathrm{RN}]=$ Radionuclide concentration

${ }^{b}$ Total propagated uncertainty

${ }^{\mathrm{C}}$ Minimum detectable concentration 
Table 4.18 - Results of Duplicate Sediment Sample Analysis. Units are Bq/g.

See Appendix B for the sampling locations.

\begin{tabular}{|c|c|c|c|c|c|c|c|c|}
\hline \multirow[b]{2}{*}{ Location } & {$[\mathrm{RN}]^{\mathrm{a}}$} & $2 \times T^{\prime} U^{b}$ & $\mathrm{MDC}^{\mathrm{c}}$ & RER $^{d}$ & [RN] & $2 \times T_{P U^{a}}$ & $\mathrm{MDC}^{\mathrm{b}}$ & RER $^{c}$ \\
\hline & \multicolumn{4}{|c|}{${ }^{241} \mathrm{Am}$} & \multicolumn{4}{|c|}{${ }^{137} \mathrm{Cs}$} \\
\hline$\overline{I D N}$ & $0.00 \times 10^{0}$ & $0.00 \times 10^{0}$ & $2.30 \times 10^{-4}$ & 0.811 & $5.85 \times 10^{-3}$ & $7.84 \times 10^{-4}$ & $3.36 \times 10^{-4}$ & 0.324 \\
\hline IDN Dup. & $1.20 \times 10^{-4}$ & $1.48 \times 10^{-4}$ & $2.20 \times 10^{-4}$ & & $6.22 \times 10^{-3}$ & $8.29 \times 10^{-4}$ & $3.24 \times 10^{-4}$ & \\
\hline TUT & $3.05 \times 10^{-5}$ & $1.06 \times 10^{-4}$ & $2.25 \times 10^{-4}$ & 0.492 & $3.81 \times 10^{-3}$ & $5.62 \times 10^{-4}$ & $4.44 \times 10^{-4}$ & 1.419 \\
\hline \multirow[t]{2}{*}{ TUT Dup. } & $6.59 \times 10^{-5}$ & $9.40 \times 10^{-5}$ & $8.92 \times 10^{-5}$ & & $2.80 \times 10^{-3}$ & $4.37 \times 10^{-4}$ & $4.22 \times 10^{-4}$ & \\
\hline & \multicolumn{4}{|c|}{${ }^{40} \mathrm{~K}$} & \multicolumn{4}{|c|}{${ }^{234} U$} \\
\hline IDN & $4.81 \times 10^{-1}$ & $6.18 \times 10^{-2}$ & $6.07 \times 10^{-3}$ & 0.520 & $2.33 \times 10^{-2}$ & $3.89 \times 10^{-3}$ & $5.40 \times 10^{-5}$ & 0.261 \\
\hline IDN Dup. & $5.29 \times 10^{-1}$ & $6.85 \times 10^{-2}$ & $5.18 \times 10^{-3}$ & & $2.19 \times 10^{-2}$ & $3.69 \times 10^{-3}$ & $5.55 \times 10^{-5}$ & \\
\hline TUT & $1.04 \times 10^{0}$ & $1.34 \times 10^{-1}$ & $7.77 \times 10^{-3}$ & 1.604 & $2.32 \times 10^{-2}$ & $3.89 \times 10^{-3}$ & $6.62 \times 10^{-5}$ & 0.247 \\
\hline \multirow[t]{2}{*}{ TUT Dup. } & $7.73 \times 10^{-1}$ & $9.88 \times 10^{-2}$ & $6.66 \times 10^{-3}$ & & $2.46 \times 10^{-2}$ & $4.11 \times 10^{-3}$ & $1.67 \times 10^{-4}$ & \\
\hline & \multicolumn{4}{|c|}{${ }^{235} \mathrm{U}$} & \multicolumn{4}{|c|}{${ }^{238} \mathrm{U}$} \\
\hline IDN & $1.23 \times 10^{-3}$ & $4.03 \times 10^{-4}$ & $1.81 \times 10^{-4}$ & 0.252 & $2.30 \times 10^{-2}$ & $3.85 \times 10^{-3}$ & $5.37 \times 10^{-5}$ & 0.161 \\
\hline IDN Dup. & $1.09 \times 10^{-3}$ & $3.81 \times 10^{-4}$ & $1.86 \times 10^{-4}$ & & $2.39 \times 10^{-2}$ & $4.03 \times 10^{-3}$ & $5.55 \times 10^{-5}$ & \\
\hline TUT & $1.63 \times 10^{-3}$ & $5.07 \times 10^{-4}$ & $8.18 \times 10^{-5}$ & 0.292 & $2.53 \times 10^{-2}$ & $4.18 \times 10^{-3}$ & $6.59 \times 10^{-5}$ & 0.261 \\
\hline TUT Dup. & $1.43 \times 10^{-3}$ & $4.59 \times 10^{-4}$ & $7.59 \times 10^{-5}$ & & $2.69 \times 10^{-2}$ & $4.48 \times 10^{-3}$ & $6.14 \times 10^{-5}$ & \\
\hline
\end{tabular}

${ }^{\mathrm{a}}[\mathrm{RN}]=$ Radionuclide concentration

${ }^{\mathrm{b}}$ Total propagated uncertainty

${ }^{\mathrm{C}}$ Minimum detectable concentration

${ }^{d}$ Relative Error Ratio

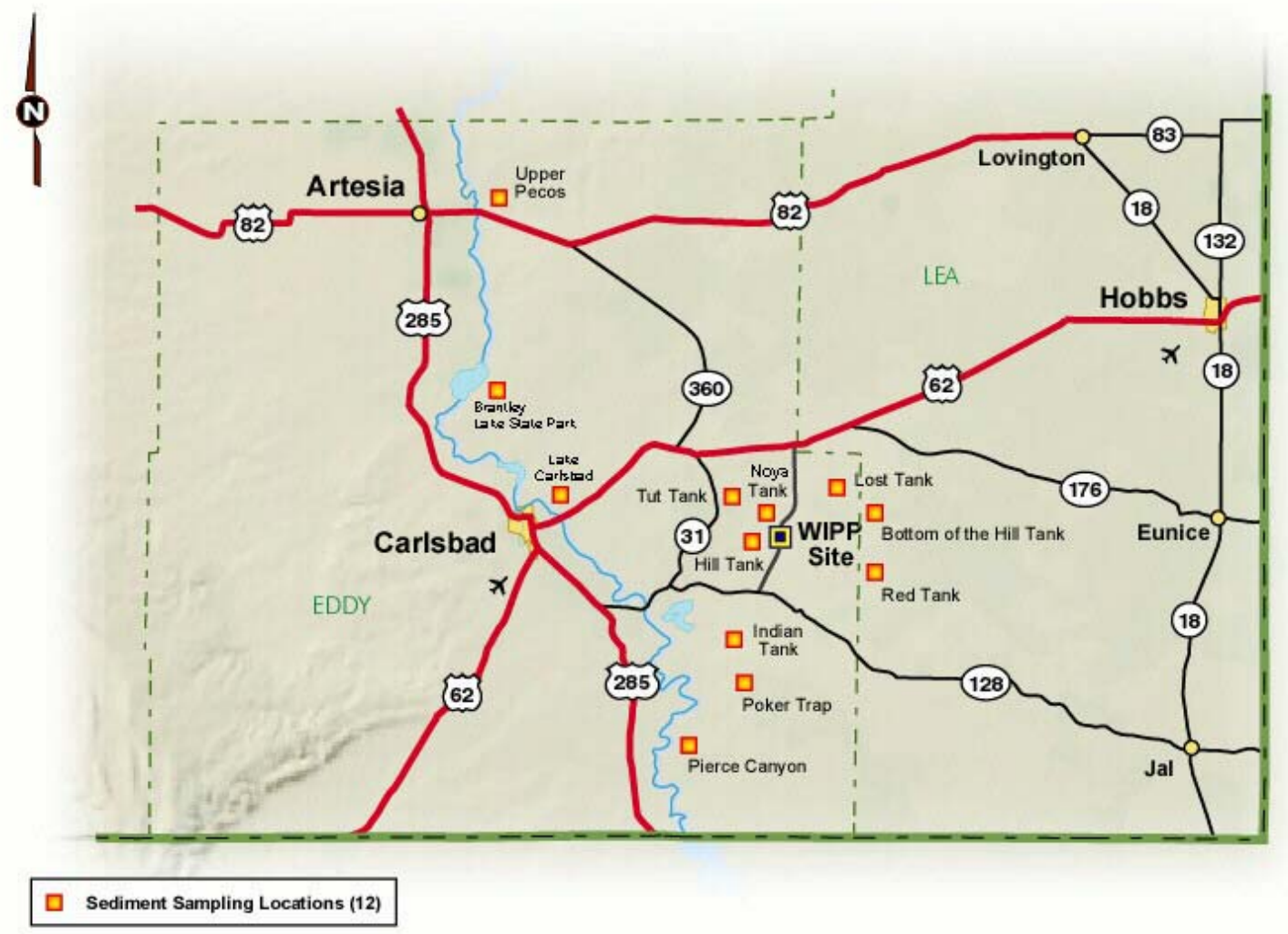

Figure 4.7 - Sediment Sampling Sites 


\subsection{Biota}

\subsubsection{Sample Collection}

The concentration of radionuclides in plants is an important factor in estimating the intake of individual radionuclides by humans through ingestion. Therefore, rangeland vegetation samples were collected from the same six locations from where the soil samples were collected (Figure 4.6). The vegetation samples were chopped into 2.5-5-cm (1-2-in)-pieces, mixed together well, air dried at room temperature, and sent to the contract laboratory for analysis. Also collected were muscle tissues from two road-killed deer and one quail, both species commonly consumed by humans. Fish is also consumed in large amounts; therefore, fish samples from PCN, PEC, and BRA (three different locations on the Pecos River) were collected. The muscle tissues from the deer, quail, rabbit, and fish were sent to the laboratory for analysis.

\subsubsection{Sample Preparation}

Weighed aliquots were taken from the bulk of the chopped vegetation samples and animal tissue samples from each location. The aliquots were transferred into separate containers and dried at $100^{\circ} \mathrm{C}\left(212^{\circ} \mathrm{F}\right)$. Gamma spectrometric determinations of ${ }^{40} \mathrm{~K}$, ${ }^{60} \mathrm{Co}$, and ${ }^{137} \mathrm{Cs}$ were performed directly from these aliquots. The samples were then dry-ashed, followed by wet-ashing and dissolution in $8 \mathrm{M}$ nitric acid. Aliquots from the dissolved samples were taken for the determinations of ${ }^{90} \mathrm{Sr},{ }^{233+234} \mathrm{U},{ }^{235} \mathrm{U},{ }^{238} \mathrm{U},{ }^{238} \mathrm{Pu}$, ${ }^{239+240} \mathrm{Pu}$, and ${ }^{241} \mathrm{Am}$.

\subsubsection{Results and Discussions}

\section{$\underline{\text { Vegetation }}$}

Uranium-234 was detected in all vegetation samples; because of its naturally low concentration, ${ }^{235} \mathrm{U}$ was not detected in any vegetation sample (Table 4.19). Concentrations of ${ }^{234} \mathrm{U}$ ranged from $4.18 \times 10^{-4} \pm 3.34 \times 10^{-4} \mathrm{~Bq} / \mathrm{g}\left(1.13 \times 10^{-2} \pm 9.03 \times 10^{-3}\right.$ $\mathrm{pCi} / \mathrm{g})$ at WSS to $8.21 \times 10^{-4} \pm 2.75 \times 10^{-4} \mathrm{~Bq} / \mathrm{g}\left(2.22 \times 10^{-2} \pm 7.43 \times 10^{-2} \mathrm{pCi} / \mathrm{g}\right)$ at WEE. Uranium-238 was detected all but one sample, WSS and varied between $2.54 \times 10^{-4} \pm$ $1.32 \times 10^{-4} \mathrm{~Bq} / \mathrm{g}\left(6.86 \times 10^{-3} \pm 3.57 \times 10^{-3} \mathrm{pCi} / \mathrm{g}\right)$ at MLR to $5.03 \times 10^{-4} \pm 2.05 \times 10^{-4} \mathrm{~Bq} / \mathrm{g}$ $\left(1.36 \times 10^{-2} \pm 5.54 \times 10^{-3} \mathrm{pCi} / \mathrm{g}\right)$ at WEE. The concentration of ${ }^{234} \mathrm{U}$ and ${ }^{238} \mathrm{U}$ did not vary significantly between locations (ANOVA, ${ }^{234} \mathrm{U} p=0.548,{ }^{238} \mathrm{U} p=0.527$ ). The primary source for uranium in plant tissues is the soil, so this difference from the uranium results for soils may seem counterintuitive. However, uptake of radionuclides and contamination by resuspension are highly species dependent. Because of small-scale differences in soil type, shading, water availability, and other microenvironmental conditions, plants of the same species collected adjacent to one another will often have very different radionuclide concentrations.

Concentrations of ${ }^{238} \mathrm{Pu},{ }^{239+240} \mathrm{Pu}$, and ${ }^{241} \mathrm{Am}$ were less than the minimum detectable concentrations in every vegetation sample (Table 4.19). 


\section{Waste Isolation Pilot Plant 2001 Site Environmental Report DOE/WIPP 02-2225}

Potassium-40 was detected in every vegetation sample (Table 4.19), ranging from $1.64 \times 10^{-1} \pm 2.75 \times 10^{-2} \mathrm{~Bq} / \mathrm{g}\left(4.43 \times 10^{0} \pm 7.43 \times 10^{-1} \mathrm{pCi} / \mathrm{g}\right)$ at WEE to $4.29 \times 10^{-1} \pm$ $6.48 \times 10^{-2} \mathrm{~Bq} / \mathrm{g}\left(1.16 \times 10^{1} \pm 1.75 \times 10^{0} \mathrm{pCi} / \mathrm{g}\right)$ at SMR. The concentration of ${ }^{40} \mathrm{~K}$ in vegetation was not significantly different between years (ANOVA, $p=0.348$ ). Like uranium, the primary source for potassium in plant tissues is the soil, and this difference from the ${ }^{40} \mathrm{~K}$ results for soil is probably due to the same factors. Cesium-137 was not detected in vegetation samples. Cobalt-60 was detected in sample location SEC. Strontium-90 was not detected in any of the vegetation samples.

Table 4.19 - Radionuclide Concentrations (Bq/g Wet Mass) in Vegetation Near the WIPP Site. See Appendix B for the sampling locations.

\begin{tabular}{|c|c|c|c|c|c|c|c|c|c|}
\hline \multirow[b]{2}{*}{ Location } & {$[\mathrm{RN}]^{\mathrm{a}}$} & $2 \times T_{P U}^{b}$ & $M^{\prime} C^{c}$ & [RN] & $2 \times T P U$ & MDC & [RN] & $2 \times T P U$ & MDC \\
\hline & \multicolumn{3}{|c|}{${ }^{241} \mathrm{Am}$} & \multicolumn{3}{|c|}{${ }^{238} \mathrm{Pu}$} & \multicolumn{3}{|c|}{${ }^{239} \mathrm{Pu}$} \\
\hline$\overline{M L R}$ & $4.48 \times 10^{-5}$ & $7.92 \times 10^{-5}$ & $1.38 \times 10^{-4}$ & $-1.59 \times 10^{-5}$ & $5.51 \times 10^{-5}$ & $1.47 \times 10^{-4}$ & $-1.58 \times 10^{-5}$ & $3.17 \times 10^{-5}$ & $1.17 \times 10^{-4}$ \\
\hline SEC & $0.00 \times 10^{0}$ & $0.00 \times 10^{0}$ & $1.53 \times 10^{-4}$ & $1.31 \times 10^{-5}$ & $6.92 \times 10^{-5}$ & $1.40 \times 10^{-4}$ & $0.00 \times 10^{0}$ & $0.00 \times 10^{0}$ & $3.53 \times 10^{-5}$ \\
\hline SMR & $1.05 \times 10^{-4}$ & $1.12 \times 10^{-4}$ & $1.64 \times 10^{-4}$ & $-6.48 \times 10^{-5}$ & $2.25 \times 10^{-4}$ & $5.99 \times 10^{-4}$ & $0.00 \times 10^{0}$ & $0.00 \times 10^{0}$ & $1.75 \times 10^{-4}$ \\
\hline WEE & $1.49 \times 10^{-5}$ & $6.66 \times 10^{-5}$ & $1.39 \times 10^{-4}$ & $1.43 \times 10^{-5}$ & $6.40 \times 10^{-5}$ & $1.33 \times 10^{-4}$ & $1.43 \times 10^{-5}$ & $2.86 \times 10^{-5}$ & $3.89 \times 10^{-5}$ \\
\hline WFF & $9.99 \times 10^{-5}$ & $9.77 \times 10^{-5}$ & $1.34 \times 10^{-4}$ & $2.80 \times 10^{-5}$ & $5.62 \times 10^{-5}$ & $1.03 \times 10^{-4}$ & $0.00 \times 10^{0}$ & $0.00 \times 10^{0}$ & $1.03 \times 10^{-4}$ \\
\hline \multirow[t]{2}{*}{ WSS } & $3.22 \times 10^{-5}$ & $6.48 \times 10^{-5}$ & $1.19 \times 10^{-4}$ & $4.55 \times 10^{-5}$ & $6.81 \times 10^{-5}$ & $1.11 \times 10^{-4}$ & $0.00 \times 10^{0}$ & $0.00 \times 10^{0}$ & $4.11 \times 10^{-5}$ \\
\hline & \multicolumn{3}{|c|}{${ }^{234} U$} & \multicolumn{3}{|c|}{${ }^{235} U$} & \multicolumn{3}{|c|}{${ }^{238} U$} \\
\hline MLR & $4.66 \times 10^{-4}$ & $1.79 \times 10^{-4}$ & $3.85 \times 10^{-5}$ & $0.00 \times 10^{0}$ & $0.00 \times 10^{0}$ & $1.62 \times 10^{-4}$ & $2.54 \times 10^{-4}$ & $1.32 \times 10^{-4}$ & $1.04 \times 10^{-4}$ \\
\hline SEC & $6.25 \times 10^{-4}$ & $2.78 \times 10^{-4}$ & $1.77 \times 10^{-4}$ & $2.96 \times 10^{-5}$ & $5.96 \times 10^{-5}$ & $8.03 \times 10^{-5}$ & $4.55 \times 10^{-4}$ & $2.24 \times 10^{-4}$ & $6.48 \times 10^{-5}$ \\
\hline SMR & $7.33 \times 10^{-4}$ & $2.67 \times 10^{-4}$ & $1.32 \times 10^{-4}$ & $6.62 \times 10^{-5}$ & $7.73 \times 10^{-5}$ & $5.99 \times 10^{-5}$ & $4.63 \times 10^{-4}$ & $1.99 \times 10^{-4}$ & $4.85 \times 10^{-5}$ \\
\hline WEE & $8.21 \times 10^{-4}$ & $2.75 \times 10^{-4}$ & $4.74 \times 10^{-5}$ & $2.15 \times 10^{-5}$ & $7.47 \times 10^{-5}$ & $1.59 \times 10^{-4}$ & $5.03 \times 10^{-4}$ & $2.05 \times 10^{-4}$ & $4.70 \times 10^{-5}$ \\
\hline WFF & $4.63 \times 10^{-4}$ & $1.84 \times 10^{-4}$ & $4.18 \times 10^{-5}$ & $1.90 \times 10^{-5}$ & $3.81 \times 10^{-5}$ & $5.14 \times 10^{-5}$ & $3.53 \times 10^{-4}$ & $1.58 \times 10^{-4}$ & $4.14 \times 10^{-5}$ \\
\hline \multirow[t]{2}{*}{ WSS } & $4.18 \times 10^{-4}$ & $3.34 \times 10^{-4}$ & $1.62 \times 10^{-4}$ & $0.00 \times 10^{0}$ & $0.00 \times 10^{0}$ & $2.00 \times 10^{-4}$ & $4.18 \times 10^{-4}$ & $3.74 \times 10^{-4}$ & $4.40 \times 10^{-4}$ \\
\hline & \multicolumn{3}{|c|}{${ }^{137} \mathrm{Cs}$} & \multicolumn{3}{|c|}{${ }^{60} \mathrm{Co}$} & & & \\
\hline MLR & $6.77 \times 10^{-4}$ & $1.15 \times 10^{-3}$ & $1.39 \times 10^{-3}$ & $1.19 \times 10^{-3}$ & $1.54 \times 10^{-3}$ & $1.87 \times 10^{-3}$ & & & \\
\hline SEC & $1.18 \times 10^{-3}$ & $2.73 \times 10^{-3}$ & $3.07 \times 10^{-3}$ & $4.44 \times 10^{-3}$ & $2.72 \times 10^{-3}$ & $3.08 \times 10^{-3}$ & & & \\
\hline SMR & $6.14 \times 10^{-4}$ & $2.64 \times 10^{-3}$ & $2.96 \times 10^{-3}$ & $1.68 \times 10^{-3}$ & $2.71 \times 10^{-3}$ & $3.01 \times 10^{-3}$ & & & \\
\hline WEE & $-2.75 \times 10^{-6}$ & $1.17 \times 10^{-3}$ & $1.37 \times 10^{-3}$ & $3.14 \times 10^{-5}$ & $1.53 \times 10^{-3}$ & $1.78 \times 10^{-3}$ & & & \\
\hline WFF & $1.69 \times 10^{-4}$ & $1.18 \times 10^{-3}$ & $1.40 \times 10^{-3}$ & $6.73 \times 10^{-4}$ & $1.59 \times 10^{-3}$ & $1.88 \times 10^{-3}$ & & & \\
\hline \multirow[t]{2}{*}{ WSS } & $9.66 \times 10^{-4}$ & $1.68 \times 10^{-3}$ & $1.95 \times 10^{-3}$ & $9.73 \times 10^{-4}$ & $1.86 \times 10^{-3}$ & $2.29 \times 10^{-3}$ & & & \\
\hline & \multicolumn{3}{|c|}{${ }^{90} \mathrm{Sr}$} & \multicolumn{3}{|c|}{${ }^{40} \mathrm{~K}$} & & & \\
\hline MLR & $3.28 \times 10^{-4}$ & $4.39 \times 10^{-3}$ & $6.60 \times 10^{-3}$ & 2.16E-01 & $3.53 \times 10^{-2}$ & $1.78 \times 10^{-2}$ & & & \\
\hline SEC & $1.94 \times 10^{-3}$ & $4.17 \times 10^{-3}$ & $6.15 \times 10^{-3}$ & 4.18E-01 & $6.36 \times 10^{-2}$ & $3.05 \times 10^{-2}$ & & & \\
\hline SMR & $3.75 \times 10^{-3}$ & $4.11 \times 10^{-3}$ & $5.96 \times 10^{-3}$ & 4.29E-01 & $6.48 \times 10^{-2}$ & $2.76 \times 10^{-2}$ & & & \\
\hline WEE & $-4.23 \times 10^{-4}$ & $4.42 \times 10^{-3}$ & $6.69 \times 10^{-3}$ & $1.64 \mathrm{E}-01$ & $2.75 \times 10^{-2}$ & $1.36 \times 10^{-2}$ & & & \\
\hline WFF & $-5.29 \times 10^{-3}$ & $4.20 \times 10^{-3}$ & $6.67 \times 10^{-3}$ & 2.93E-01 & $4.55 \times 10^{-2}$ & $1.72 \times 10^{-2}$ & & & \\
\hline WSS & $1.47 \times 10^{-3}$ & $4.41 \times 10^{-3}$ & $6.54 \times 10^{-3}$ & $2.56 \mathrm{E}-01$ & $4.22 \times 10^{-2}$ & $2.00 \times 10^{-2}$ & & & \\
\hline
\end{tabular}

${ }^{\mathrm{a}}[\mathrm{RN}]=$ Radionuclide concentration

b Total propagated uncertainty

${ }^{c}$ Minimum detectable concentration

A duplicate analysis of the vegetation sample from WEE was performed for all the radionuclides of interest (Table 4.20). Concentrations of ${ }^{234} \mathrm{U},{ }^{238} \mathrm{U}$, and ${ }^{40} \mathrm{~K}$ were above detection limits in the duplicate sample. Relative Error Ratio values exceeded one for ${ }^{234} \mathrm{U},{ }^{238} \mathrm{U}$, and ${ }^{40} \mathrm{~K}$, indicating a nonhomogenous sample. 


\section{Waste Isolation Pilot Plant 2001 Site Environmental Report DOE/WIPP 02-2225}

\section{$\underline{\text { Animals }}$}

Of the radionuclides of interest, ${ }^{234} \mathrm{U},{ }^{238} \mathrm{U}$, and ${ }^{40} \mathrm{~K}$ were detected in deer, rabbit, and quail tissue (Table 4.21). The mean concentrations did not differ from year 2000.

These results can be used only as a gross indication of uptakes, as the sample sizes are too small to provide a robust analysis.

Table 4.20 - Results of Duplicate Vegetation Sample Analysis. Units are Bq/g. See Appendix $B$ for the sampling locations.

\begin{tabular}{|c|c|c|c|c|c|c|c|c|}
\hline \multirow[b]{2}{*}{ Location } & {$[\mathrm{RN}]^{\mathrm{a}}$} & $2 \times T^{\prime b}{ }^{b}$ & MDC $^{c}$ & RER $^{d}$ & [RN] & $2 \times$ TPU & MDC & RER \\
\hline & \multicolumn{4}{|c|}{${ }^{234} \mathrm{U}$} & \multicolumn{4}{|c|}{${ }^{40} \mathrm{~K}$} \\
\hline WEE & $8.21 \times 10^{-4}$ & $2.75 \times 10^{-4}$ & $4.74 \times 10^{-5}$ & 1.839 & $1.64 \times 10^{-1}$ & $2.75 \times 10^{-2}$ & $1.36 \times 10^{-2}$ & 3.778 \\
\hline \multirow[t]{2}{*}{ WEE Dup. } & $2.43 \times 10^{-4}$ & $1.52 \times 10^{-4}$ & $1.61 \times 10^{-4}$ & & $4.22 \times 10^{-1}$ & $6.25 \times 10^{-2}$ & $1.79 \times 10^{-2}$ & \\
\hline & \multicolumn{4}{|c|}{${ }^{238} U$} & & & & \\
\hline WEE & $5.03 \times 10^{-4}$ & $2.05 \times 10^{-4}$ & $4.70 \times 10^{-5}$ & 1.14 & & & & \\
\hline WEE Dup. & $2.25 \times 10^{-4}$ & $1.30 \times 10^{-4}$ & $4.70 \times 10^{-5}$ & & & & & \\
\hline
\end{tabular}

a $[\mathrm{RN}]=$ Radionuclide concentration

b Total propagated uncertainty

${ }^{\mathrm{c}}$ Minimum detectable concentration

${ }^{\mathrm{d}}$ Relative Error Ratio

Table 4.21 - Radionuclide Concentrations (Bq/g Wet Mass) in Deer and Quail Near the WIPP Site

\begin{tabular}{|c|c|c|c|c|c|c|c|c|c|}
\hline \multirow[b]{2}{*}{$\begin{array}{l}\text { Sample } \\
\text { Type }\end{array}$} & {$[\mathrm{RN}]^{\mathrm{a}}$} & $2 \times T_{P U}^{b}$ & MDC $^{c}$ & [RN] & $2 \times$ TPU & MDC & [RN] & $2 \times$ TPU & MDC \\
\hline & \multicolumn{3}{|c|}{${ }^{241} \mathrm{Am}$} & \multicolumn{3}{|c|}{${ }^{238} \mathrm{Pu}$} & \multicolumn{3}{|c|}{${ }^{239} \mathrm{Pu}$} \\
\hline Deer $^{d}$ & $3.14 \times 10^{-7}$ & $1.42 \times 10^{-6}$ & $1.32 \times 10^{-6}$ & $2.74 \times 10^{-7}$ & $1.04 \times 10^{-6}$ & $1.59 \times 10^{-6}$ & $-2.05 \times 10^{-8}$ & $6.95 \times 10^{-8}$ & $1.56 \times 10^{-6}$ \\
\hline Quail $^{\mathrm{e}}$ & $1.23 \times 10^{-6}$ & $3.40 \times 10^{-6}$ & $3.03 \times 10^{-5}$ & $-1.01 \times 10^{-4}$ & $2.79 \times 10^{-4}$ & $2.87 \times 10^{-5}$ & $0.00 \times 10^{0}$ & $0.00 \times 10^{0}$ & $8.35 \times 10^{-6}$ \\
\hline \multirow[t]{2}{*}{ Rabbit $^{f}$} & $1.84 \times 10^{-6}$ & $2.13 \times 10^{-6}$ & $1.65 \times 10^{-6}$ & $0.00 \times 10^{0}$ & $0.00 \times 10^{0}$ & $1.67 \times 10^{-6}$ & $-6.18 \times 10^{-7}$ & $1.24 \times 10^{-6}$ & $4.55 \times 10^{-6}$ \\
\hline & \multicolumn{3}{|c|}{${ }^{234} U$} & \multicolumn{3}{|c|}{${ }^{235} U$} & \multicolumn{3}{|c|}{${ }^{238} U$} \\
\hline Deer & $1.07 \times 10^{-5}$ & $2.62 \times 10^{-5}$ & $5.51 \times 10^{-7}$ & $1.44 \times 10^{-7}$ & $3.74 \times 10^{-7}$ & $6.80 \times 10^{-7}$ & $7.92 \times 10^{-6}$ & $1.93 \times 10^{-5}$ & $5.49 \times 10^{-7}$ \\
\hline Quail & $1.07 \times 10^{-3}$ & $2.93 \times 10^{-3}$ & $8.93 \times 10^{-6}$ & $3.69 \times 10^{-5}$ & $1.06 \times 10^{-4}$ & $1.41 \times 10^{-5}$ & $1.20 \times 10^{-3}$ & $3.32 \times 10^{-3}$ & $2.18 \times 10^{-5}$ \\
\hline \multirow[t]{2}{*}{ Rabbit } & $4.81 \times 10^{-5}$ & $1.31 \times 10^{-5}$ & $1.61 \times 10^{-6}$ & $5.11 \times 10^{-6}$ & $3.96 \times 10^{-6}$ & $1.98 \times 10^{-7}$ & $3.89 \times 10^{-5}$ & $1.14 \times 10^{-5}$ & $1.60 \times 10^{-6}$ \\
\hline & \multicolumn{3}{|c|}{${ }^{137} \mathrm{Cs}$} & \multicolumn{3}{|c|}{${ }^{60} \mathrm{Co}$} & & & \\
\hline Deer & $-1.76 \times 10^{-4}$ & $7.60 \times 10^{-4}$ & $3.49 \times 10^{-4}$ & $2.06 \times 10^{-4}$ & $2.43 \times 10^{-4}$ & $3.85 \times 10^{-4}$ & & & \\
\hline Quail & $2.09 \times 10^{-4}$ & $2.02 \times 10^{-3}$ & $3.95 \times 10^{-3}$ & $1.77 \times 10^{-3}$ & $2.04 \times 10^{-3}$ & $5.16 \times 10^{-3}$ & & & \\
\hline \multirow[t]{2}{*}{ Rabbit } & $-1.59 \times 10^{-4}$ & $5.59 \times 10^{-4}$ & $6.40 \times 10^{-4}$ & $-4.85 \times 10^{-4}$ & $7.70 \times 10^{-4}$ & $8.21 \times 10^{-4}$ & & & \\
\hline & \multicolumn{3}{|c|}{${ }^{90} \mathrm{Sr}$} & \multicolumn{3}{|c|}{${ }^{40} \mathrm{~K}$} & & & \\
\hline Deer & $-9.77 \times 10^{-6}$ & $3.03 \times 10^{-5}$ & $7.29 \times 10^{-5}$ & $9.34 \times 10^{-2}$ & $3.85 \times 10^{-2}$ & $3.22 \times 10^{-3}$ & & & \\
\hline Quail & $1.55 \times 10^{-3}$ & $2.16 \times 10^{-3}$ & $1.54 \times 10^{-3}$ & $1.41 \times 10^{-1}$ & $3.66 \times 10^{-1}$ & $4.23 \times 10^{-2}$ & & & \\
\hline Rabbit & $-9.95 \times 10^{-5}$ & $1.38 \times 10^{-4}$ & $2.33 \times 10^{-4}$ & $1.07 \times 10^{-1}$ & $1.74 \times 10^{-2}$ & $9.29 \times 10^{-3}$ & & & \\
\hline \multicolumn{10}{|c|}{ 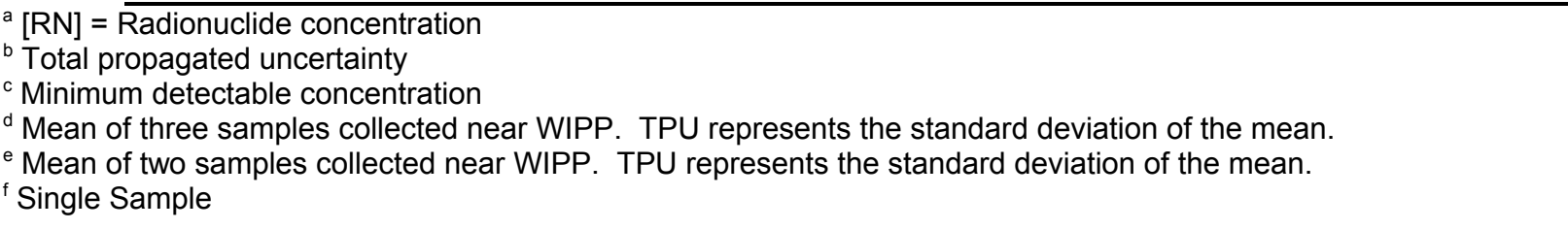 } \\
\hline
\end{tabular}

Uranium-234 and ${ }^{238} \mathrm{U}$ were detected in all the fish samples. Uranium-235 was detected in 67 percent of the fish samples (Table 4.22). Neither plutonium or ${ }^{241} \mathrm{Am}$ isotope was detected in fish. 


\section{Waste Isolation Pilot Plant 2001 Site Environmental Report DOE/WIPP 02-2225}

Cesium-137, ${ }^{60} \mathrm{Co}$, and ${ }^{90} \mathrm{Sr}$ were not detected in any of the fish samples (Table 4.22). Potassium -40 was detected in all fish (Table 4.22). It was lowest in the sample from BRA $\left(5.66 \times 10^{-2} \pm 9.40 \times 10^{-3} \mathrm{~Bq} / \mathrm{g}\left[1.53 \times 10^{0} \pm 2.54 \times 10^{-1} \mathrm{pCi} / \mathrm{g}\right]\right)$, and highest in the sample from PCN $\left(1.03 \times 10^{-1} \pm 1.55 \times 10^{-2} \mathrm{~Bq} / \mathrm{g}\left[2.78 \times 10^{1} \pm 4.19 \times 10^{-1} \mathrm{pCi} / \mathrm{g}\right]\right)$.

Table 4.22 - Radionuclide Concentrations (Bq/g Wet Mass) in Fish Near the WIPP Site. See Appendix $B$ for the sampling locations.

\begin{tabular}{|c|c|c|c|c|c|c|c|c|c|}
\hline \multirow[b]{2}{*}{ Location } & ${ }[\mathrm{RN}]^{\mathrm{a}}$ & $2 \times T_{P U}^{b}$ & $M^{\prime} C^{c}$ & [RN] & $2 \times T P U$ & MDC & [RN] & $2 \times$ TPU & MDC \\
\hline & \multicolumn{3}{|c|}{${ }^{241} \mathrm{Am}$} & \multicolumn{3}{|c|}{${ }^{238} \mathrm{Pu}$} & \multicolumn{3}{|c|}{${ }^{239} \mathrm{Pu}$} \\
\hline$\overline{B R A}$ & $1.65 \times 10^{-6}$ & $1.93 \times 10^{-6}$ & $1.49 \times 10^{-6}$ & $9.95 \times 10^{-7}$ & $1.42 \times 10^{-6}$ & $1.35 \times 10^{-6}$ & $4.96 \times 10^{-7}$ & $9.99 \times 10^{-7}$ & $1.35 \times 10^{-6}$ \\
\hline BRA & $1.03 \times 10^{-6}$ & $1.20 \times 10^{-6}$ & $9.29 \times 10^{-7}$ & $1.10 \times 10^{-6}$ & $1.57 \times 10^{-6}$ & $1.49 \times 10^{-6}$ & $0.00 \times 10^{0}$ & $0.00 \times 10^{0}$ & $1.49 \times 10^{-6}$ \\
\hline $\mathrm{PCN}$ & $6.48 \times 10^{-7}$ & $1.30 \times 10^{-6}$ & $1.75 \times 10^{-6}$ & $5.96 \times 10^{-7}$ & $1.20 \times 10^{-6}$ & $1.61 \times 10^{-6}$ & $5.92 \times 10^{-7}$ & $1.19 \times 10^{-6}$ & $1.61 \times 10^{-6}$ \\
\hline $\mathrm{PCN}$ & $1.28 \times 10^{-6}$ & $1.82 \times 10^{-6}$ & $1.73 \times 10^{-6}$ & $1.26 \times 10^{-6}$ & $1.47 \times 10^{-6}$ & $1.14 \times 10^{-6}$ & $0.00 \times 10^{0}$ & $0.00 \times 10^{0}$ & $3.09 \times 10^{-6}$ \\
\hline PEC & $7.03 \times 10^{-7}$ & $2.44 \times 10^{-6}$ & $5.18 \times 10^{-6}$ & $3.50 \times 10^{-6}$ & $5.25 \times 10^{-6}$ & $8.58 \times 10^{-6}$ & $0.00 \times 10^{0}$ & $0.00 \times 10^{0}$ & $8.58 \times 10^{-6}$ \\
\hline \multirow[t]{2}{*}{ PEC } & $0.00 \times 10^{0}$ & $0.00 \times 10^{0}$ & $4.92 \times 10^{-6}$ & $-1.22 \times 10^{-6}$ & $1.74 \times 10^{-6}$ & $5.67 \times 10^{-6}$ & $0.00 \times 10^{0}$ & $0.00 \times 10^{0}$ & $4.48 \times 10^{-6}$ \\
\hline & \multicolumn{3}{|c|}{${ }^{234} \mathrm{U}$} & \multicolumn{3}{|c|}{${ }^{235} \mathrm{U}$} & \multicolumn{3}{|c|}{${ }^{238} U$} \\
\hline BRA & $8.70 \times 10^{-5}$ & $1.68 \times 10^{-5}$ & $8.29 \times 10^{-7}$ & $3.02 \times 10^{-6}$ & $2.18 \times 10^{-6}$ & $1.02 \times 10^{-6}$ & $3.77 \times 10^{-5}$ & $8.92 \times 10^{-6}$ & $8.25 \times 10^{-7}$ \\
\hline BRA & $5.48 \times 10^{-5}$ & $1.08 \times 10^{-5}$ & $5.88 \times 10^{-7}$ & $1.07 \times 10^{-6}$ & $1.08 \times 10^{-6}$ & $7.25 \times 10^{-7}$ & $3.26 \times 10^{-5}$ & $7.29 \times 10^{-6}$ & $5.85 \times 10^{-7}$ \\
\hline $\mathrm{PCN}$ & $1.03 \times 10^{-4}$ & $2.19 \times 10^{-5}$ & $4.33 \times 10^{-6}$ & $4.00 \times 10^{-6}$ & $3.10 \times 10^{-6}$ & $1.55 \times 10^{-6}$ & $5.37 \times 10^{-5}$ & $1.32 \times 10^{-5}$ & $1.25 \times 10^{-6}$ \\
\hline $\mathrm{PCN}$ & $1.58 \times 10^{-4}$ & $2.99 \times 10^{-5}$ & $9.88 \times 10^{-7}$ & $3.59 \times 10^{-6}$ & $2.60 \times 10^{-6}$ & $1.22 \times 10^{-6}$ & $8.51 \times 10^{-5}$ & $1.79 \times 10^{-5}$ & $2.67 \times 10^{-6}$ \\
\hline PEC & $1.32 \times 10^{-4}$ & $2.70 \times 10^{-5}$ & $1.65 \times 10^{-6}$ & $2.25 \times 10^{-6}$ & $2.62 \times 10^{-6}$ & $2.04 \times 10^{-6}$ & $6.73 \times 10^{-5}$ & $1.64 \times 10^{-5}$ & $1.64 \times 10^{-6}$ \\
\hline \multirow[t]{2}{*}{ PEC } & $1.96 \times 10^{-4}$ & $3.63 \times 10^{-5}$ & $1.11 \times 10^{-6}$ & $5.07 \times 10^{-6}$ & $3.31 \times 10^{-6}$ & $1.37 \times 10^{-6}$ & $9.62 \times 10^{-5}$ & $2.00 \times 10^{-5}$ & $3.81 \times 10^{-6}$ \\
\hline & \multicolumn{3}{|c|}{${ }^{137} \mathrm{Cs}$} & \multicolumn{3}{|c|}{${ }^{60} \mathrm{Co}$} & & & \\
\hline BRA & $9.99 \times 10^{-5}$ & $6.55 \times 10^{-4}$ & $7.62 \times 10^{-4}$ & $-1.65 \times 10^{-4}$ & $7.33 \times 10^{-4}$ & $7.81 \times 10^{-4}$ & & & \\
\hline BRA & $-4.29 \times 10^{-4}$ & $5.33 \times 10^{-4}$ & $5.59 \times 10^{-4}$ & $1.66 \times 10^{-4}$ & $5.00 \times 10^{-4}$ & $5.77 \times 10^{-4}$ & & & \\
\hline $\mathrm{PCN}$ & $3.92 \times 10^{-4}$ & $1.01 \times 10^{-3}$ & $1.18 \times 10^{-3}$ & $-5.07 \times 10^{-4}$ & $1.13 \times 10^{-3}$ & $1.18 \times 10^{-3}$ & & & \\
\hline $\begin{array}{l}\mathrm{PCN} \\
2.37 \times 10^{-3}\end{array}$ & $-3.45 \times 10^{-4}$ & $5.44 \times 10^{-4}$ & $5.77 \times 10^{-4}$ & $2.06 \times 10^{-4}$ & $5.25 \times 10^{-4}$ & $6.07 \times 10^{-4}$ & & & \\
\hline PEC & $1.47 \times 10^{-3}$ & $1.39 \times 10^{-3}$ & $1.63 \times 10^{-3}$ & $3.89 \times 10^{-5}$ & $1.49 \times 10^{-3}$ & $1.62 \times 10^{-3}$ & & & \\
\hline \multirow[t]{2}{*}{ PEC } & $2.12 \times 10^{-4}$ & $5.29 \times 10^{-4}$ & $6.03 \times 10^{-4}$ & $-2.85 \times 10^{-4}$ & $6.29 \times 10^{-4}$ & $6.85 \times 10^{-4}$ & & & \\
\hline & \multicolumn{3}{|c|}{${ }^{90} \mathrm{Sr}$} & \multicolumn{3}{|c|}{${ }^{40} \mathrm{~K}$} & & & \\
\hline BRA & $1.45 \times 10^{-5}$ & $9.40 \times 10^{-5}$ & $1.54 \times 10^{-4}$ & $9.51 \times 10^{-2}$ & $1.69 \times 10^{-2}$ & $1.51 \times 10^{-2}$ & & & \\
\hline BRA & $3.35 \times 10^{-5}$ & $7.84 \times 10^{-5}$ & $1.26 \times 10^{-4}$ & $5.66 \times 10^{-2}$ & $9.40 \times 10^{-3}$ & $6.29 \times 10^{-3}$ & & & \\
\hline $\mathrm{PCN}$ & $2.20 \times 10^{-4}$ & $1.69 \times 10^{-4}$ & $2.60 \times 10^{-4}$ & $8.88 \times 10^{-2}$ & $1.98 \times 10^{-2}$ & $2.29 \times 10^{-2}$ & & & \\
\hline $\mathrm{PCN}$ & $8.55 \times 10^{-5}$ & $7.29 \times 10^{-5}$ & $1.13 \times 10^{-4}$ & $1.03 \times 10^{-1}$ & $1.55 \times 10^{-2}$ & $6.66 \times 10^{-3}$ & & & \\
\hline PEC & $7.03 \times 10^{-5}$ & $1.76 \times 10^{-4}$ & $2.83 \times 10^{-4}$ & $9.14 \times 10^{-2}$ & $2.46 \times 10^{-2}$ & $3.18 \times 10^{-2}$ & & & \\
\hline PEC & $-2.73 \times 10^{-5}$ & $1.02 \times 10^{-4}$ & $1.70 \times 10^{-4}$ & $8.81 \times 10^{-2}$ & $1.47 \times 10^{-2}$ & $8.62 \times 10^{-3}$ & & & \\
\hline
\end{tabular}

a $[\mathrm{RN}]=$ Radionuclide concentration

b Total propagated uncertainty

${ }^{\mathrm{c}}$ Minimum detectable concentration

Neither ${ }^{241} \mathrm{Am}$ nor any plutonium isotopes were detected in fish.

\subsection{Summary and Conclusion}

The Environmental Monitoring Program collected samples of air particulates, soil, sediment, groundwater, surface water, and biota and analyzed them for radionuclides considered to be indicators of potential contamination from the WIPP facility, as well as other radionuclides of potential interest. Measured concentrations were examined for evidence of WIPP-related contamination, such as higher concentrations of TRU 
radionuclides after 1998, or higher concentrations in downwind or down gradient directions. Radionuclide concentrations observed were highly variable in space and time and between media. However, no time or space relationships related to WIPP were observed, and concentrations were consistent with background levels. In no case, could environmental concentrations be attributed to WIPP releases. In addition, no events occurred at WIPP, which would lead one to suspect that a release had occurred. 
This page intentionally left blank 


\section{CHAPTER 5 - ENVIRONMENTAL NONRADIOLOGICAL PROGRAM INFORMATION}

This chapter discusses nonradiological environmental surveillance data collected between January 1 and December 31, 2001. Nonradiological programs at WIPP include wildlife population monitoring, meteorological monitoring, and seismic monitoring. In addition, VOCs were monitored to comply with the provisions of WIPP's hazardous waste permit, and liquid effluent monitoring was conducted in accordance with WIPP's Discharge Plan (DP-831).

\subsection{Principal Functions of Nonradiological Sampling}

The principal functions of the nonradiological environmental surveillance program are to:

- $\quad$ Assess the impacts of WIPP operations on the surrounding ecosystem;

- Monitor ecological conditions in the Los Medaños region;

- Investigate unusual or unexpected elements in the ecological databases;

- $\quad$ Provide environmental data which are important to the mission of the WIPP project, but which have not or will not be acquired by other programs; and

- $\quad$ Comply with applicable commitments identified with existing agreements (e.g., BLM/DOE MOU, Interagency Agreements, Agreements in Principle, etc.).

\subsection{WIPP Raptor Program}

WIPP, and the region surrounding it, is widely recognized for its concentration and diversity of raptors. The area is home to several raptor species of special concern, including Harris' hawks, Swainson's hawks, burrowing owls, and barn owls, as well as other species.

The DOE, the BLM, and other government agencies are aware of the value and importance of protecting and monitoring raptor populations. To assist in this effort at WIPP, the BLM and the DOE established the WRP in the early 1990s to monitor and protect raptors on the WIPP site, and to educate site workers and the public about these birds. The WRP is administrated by the WIPP Environmental Monitoring Program with input from the BLM and others. Scientific consultation, research direction, and field operations are conducted by scientists from the Department of Biology at Rocky Mountain College (Restani, 2001).

Raptor research at WIPP began in 1981 when the DOE initiated a study of the social behavior of Harris' hawks conducted by the University of New Mexico. Research results revealed the extent of the overall raptor population, and provided new information about raptor species in the area. In the late 1980s, the BLM designated the Los Medaños Raptor Area, which included the WIPP site, as a National Key Raptor Area. This 


\section{Waste Isolation Pilot Plant 2001 Site Environmental Report DOE/WIPP 02-2225}

designation served as a catalyst for the development of the WRP. Simultaneously, the DOE reorganized its program to encompass expanded objectives.

The WRP presently serves four significant functions:

- Wildlife Monitoring. The WRP provides the DOE, the BLM, and other agencies with current information about the status of raptor populations in and around WIPP.

- $\quad$ Scientific Research. WRP staff conduct research on topics that contribute to the understanding of raptors in the desert southwest.

- Interagency Cooperation. The WRP is funded by the DOE, but works closely with several other federal and state agencies.

In 2001, long-term studies of productivity and population demographics of the raptor community in and around WIPP continued. The primary objective for the 2001 nesting season was to locate all raptor and raven nests within the $3000 \mathrm{~km}^{2}$ study area, centered on WIPP. Secondary objectives were to estimate raptor productivity in the area and to determine causes of raptor mortality.

Research ornithologists located 98 raptor territories in 2001. As in CY 2000, the number of nests far surpassed those found in previous years' studies.

Electrocution by power poles continues to be an important cause of raptor mortality and is predicted to increase as oil and gas exploration increases in the area. In one case, however, a nest was deliberately destroyed by an unknown person or persons. For more information on the WRP, see the Waste Isolation Pilot Plant WIPP Raptor Program 2001 Annual Report (Restani, 2001).

\subsection{Meteorology}

The primary WIPP meteorological station is located $600 \mathrm{~m}(1,970 \mathrm{ft})$ northeast of the Waste Handling Building. The main function of the station is to provide data for atmospheric dispersion modeling. The station measures and records wind speed, wind direction, and temperature at elevations of 2,10, and $50 \mathrm{~m}(6.5,33$, and $165 \mathrm{ft})$. The station records ground-level measurements of barometric pressure, relative humidity, precipitation, and solar radiation.

In addition to the primary meteorological station, the WIPP Far Field Station is located $1,000 \mathrm{~m}(3,300 \mathrm{ft})$ northwest of the Waste Handling Building. At the WIPP Far Field Station, a secondary meteorological station measures and records temperature and

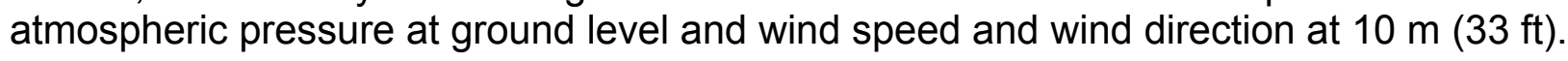




\section{Waste Isolation Pilot Plant 2001 Site Environmental Report DOE/WIPP 02-2225}

\subsubsection{Climatic Data}

The annual precipitation at the WIPP site for 2001 was $240 \mathrm{~mm}$ (9.5 in), which was 65 $\mathrm{mm}(2.5 \mathrm{in})$ less than the previous year's rainfall. Figure 5.1 displays the monthly precipitation at WIPP.

The mean annual temperature for the WIPP area in 2001 was $17^{\circ} \mathrm{C}\left(64^{\circ} \mathrm{F}\right)$. The mean monthly temperatures for the WIPP area ranged from $10^{\circ} \mathrm{C}\left(50^{\circ} \mathrm{F}\right)$ during December to $25^{\circ} \mathrm{C}\left(78^{\circ} \mathrm{F}\right)$ in July. Generally, maximum temperatures occurred from May through September, while minimum temperatures occurred in January, November, and December, as illustrated in Figures 5.2, 5.3, and 5.4 and Tables 5.1, 5.2, and 5.3. The lowest recorded temperature was $-9^{\circ} \mathrm{C}\left(16^{\circ} \mathrm{F}\right)$ in January. The maximum recorded temperature was $40^{\circ} \mathrm{C}\left(105^{\circ} \mathrm{F}\right)$ in May.

\subsubsection{Wind Direction and Wind Speed}

Winds in the WIPP area in 2001 blew predominantly from the southeast $\left(135^{\circ}\right)$. Seasonal weather systems move through this area, briefly altering the predominant southeasterly winds and sometimes resulting in violent convectional storms. Wind speed measured at the 10-m (33-ft) level were calm (less than 0.5 meters per second $[\mathrm{m} / \mathrm{s}])(1.1 \mathrm{miles}$ per hour [mph]) about 0.5 percent of the time. At the $10-\mathrm{m}$ level, winds of 3.7 through $6.3 \mathrm{~m} / \mathrm{s}$ ( 8.3 to $14.1 \mathrm{mph}$ ) were the most prevalent over 2001, occurring 40 percent of the time. Figures 5.5, 5.6, and 5.7 and Tables 5.4, 5.5, and 5.6 display the annual wind data at WIPP for 2001.

\subsection{Volatile Organic Compound Monitoring}

Volatile organic compound monitoring was implemented on April 21, 1997, in accordance with WP12-VC.01, Confirmatory Volatile Organic Compound Monitoring Program. This program was implemented as a requirement of the HWFP, Module IV, Section D and Attachment N, and is intended to demonstrate that regulated VOCs are not being emitted by the waste at concentrations in excess of concentrations of concern as prescribed in the permit.

Nine target compounds, which contribute approximately 99 percent of the calculated human health risks from RCRA constituents, were chosen for monitoring. These target compounds are 1,1-dichloroethylene, methylene chloride, chloroform, 1,1,1-trichloroethane, carbon tetrachloride, 1,2-dichloroethane, toluene, chlorobenzene, and 1,1,2,2-tetrachloroethane.

Sampling for target compounds is done at two air monitoring stations. The stations are identified as VOC-A, located downstream from hazardous waste disposal unit Panel 1 in Drift E300, and VOC-B, located upstream from Panel 1. In 2001, VOC-B was located in Drift S1950. As waste is placed in new panels, VOC-B will be relocated to ensure that it samples underground air before it passes the waste panels. The location of VOC-A is not anticipated to change. 
Waste Isolation Pilot Plant 2001 Site Environmental Report DOE/WIPP 02-2225

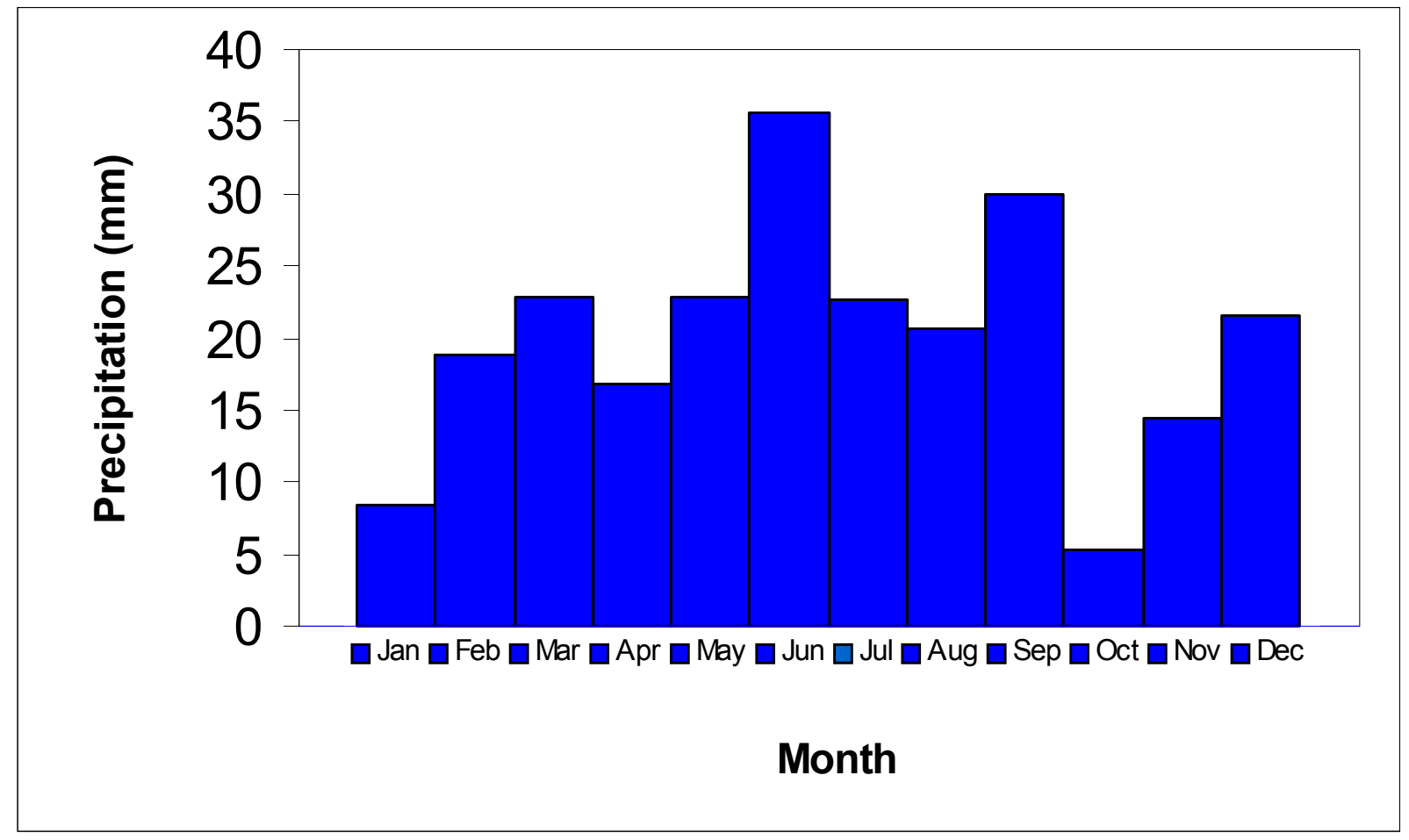

Figure 5.1 - 2001 Precipitation at WIPP 


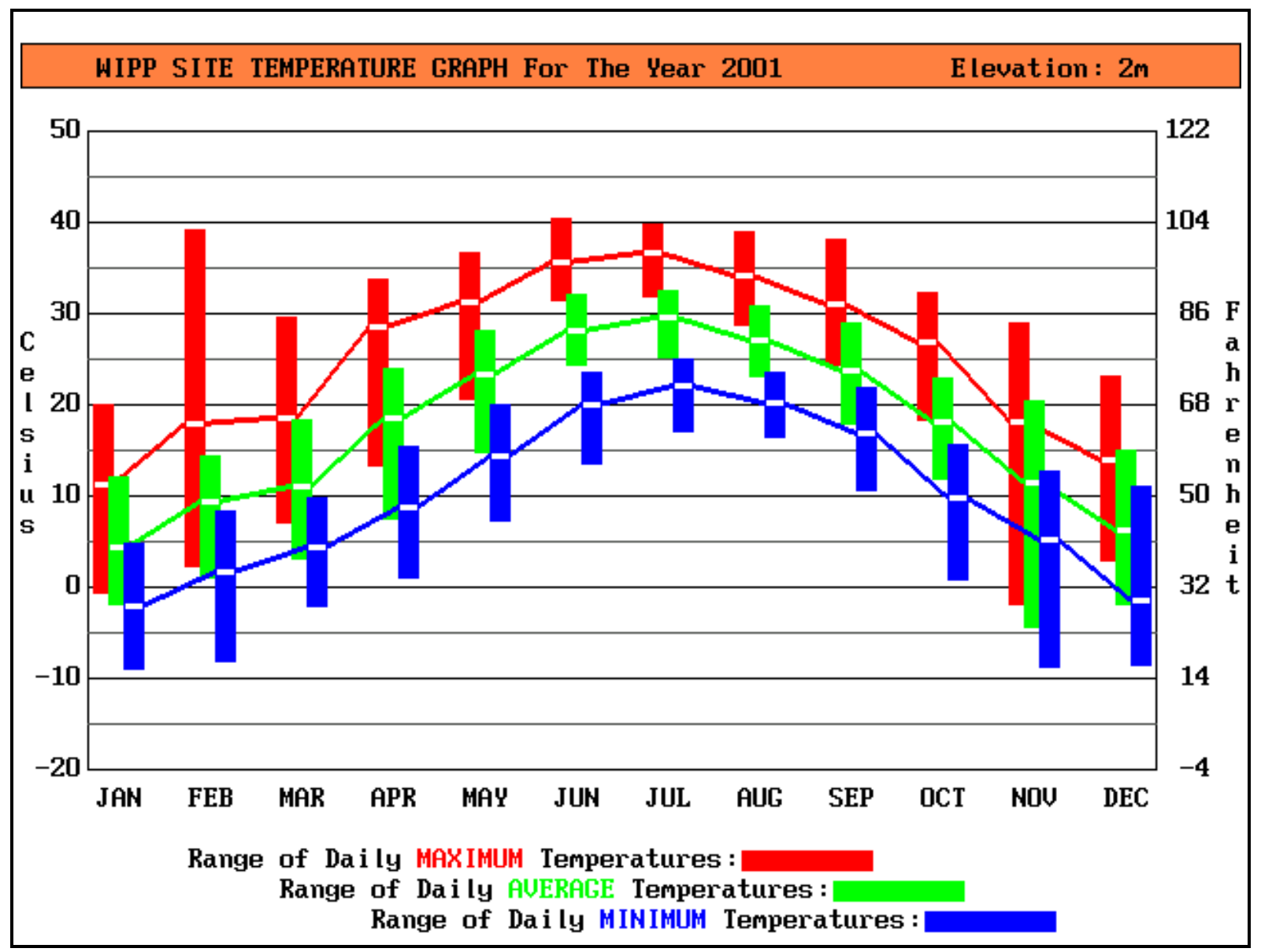

Figure 5.2 - 2001 WIPP Site Temperature at 2-Meter Height

Table 5.1 - A Summary of 2001 Temperature Observations at 2-Meter Height

\begin{tabular}{lccccccccc}
\hline Month & $\begin{array}{c}\text { Max of } \\
\text { Daily } \\
\text { ighs } \\
\left({ }^{\circ} \mathbf{C}\right)\end{array}$ & $\begin{array}{c}\text { Avg of } \\
\text { Daily } \\
\text { Highs } \\
\left({ }^{\circ} \mathbf{C}\right)\end{array}$ & $\begin{array}{c}\text { Min of } \\
\text { Daily } \\
\text { Highs } \\
\left({ }^{\circ} \mathbf{C}\right)\end{array}$ & $\begin{array}{c}\text { Max } \\
\text { of Daily } \\
\text { Averages } \\
\left({ }^{\circ} \mathbf{C}\right)\end{array}$ & $\begin{array}{c}\text { Avg of } \\
\text { Daily } \\
\text { Averages } \\
\left({ }^{\circ} \mathbf{C}\right)\end{array}$ & $\begin{array}{c}\text { Min of } \\
\text { Daily } \\
\text { Averages } \\
\left({ }^{\circ} \mathbf{C}\right)\end{array}$ & $\begin{array}{c}\text { Max of } \\
\text { Daily } \\
\text { Lows } \\
\left({ }^{\circ} \mathbf{C}\right)\end{array}$ & $\begin{array}{c}\text { Avg of } \\
\text { Daily } \\
\text { Lows } \\
\left({ }^{\circ} \mathbf{C}\right)\end{array}$ & $\begin{array}{c}\text { Min of } \\
\text { Daily } \\
\text { Lows } \\
\left({ }^{\circ} \mathbf{C}\right)\end{array}$ \\
\hline Jan & 19.97 & 11.24 & -0.68 & 12.15 & 4.43 & -1.96 & 4.81 & -2.08 & -8.93 \\
Feb & 39.15 & 17.99 & 2.34 & 14.47 & 9.28 & 0.95 & 8.24 & 1.69 & -8.16 \\
Mar & 29.51 & 18.63 & 7.04 & 18.30 & 11.13 & 3.14 & 9.87 & 4.44 & -2.06 \\
Apr & 33.77 & 28.50 & 13.40 & 23.87 & 18.63 & 7.56 & 15.39 & 8.83 & 0.94 \\
May & 36.76 & 31.29 & 20.56 & 28.10 & 23.23 & 14.84 & 19.98 & 14.31 & 7.22 \\
Jun & 40.47 & 35.58 & 31.53 & 32.02 & 28.14 & 24.36 & 23.51 & 19.98 & 13.49 \\
Jul & 39.85 & 36.66 & 31.88 & 32.47 & 29.68 & 25.23 & 25.09 & 22.17 & 17.17 \\
Aug & 39.04 & 34.23 & 28.66 & 30.84 & 27.09 & 23.15 & 23.49 & 20.16 & 16.56 \\
Sep & 38.20 & 31.08 & 24.28 & 28.87 & 23.74 & 17.89 & 21.79 & 16.84 & 10.65 \\
Oct & 32.20 & 26.79 & 18.23 & 22.86 & 18.18 & 11.82 & 15.67 & 9.81 & 0.87 \\
Nov & 28.96 & 18.16 & -1.84 & 20.35 & 11.49 & -4.39 & 12.81 & 5.18 & -8.69 \\
Dec & 23.20 & 14.00 & 2.94 & 15.02 & 6.17 & -1.97 & 10.95 & -1.47 & -8.60 \\
\hline Annual & 40.47 & 25.35 & -1.84 & 32.47 & 17.60 & -4.39 & 25.09 & 9.99 & -8.93 \\
\hline
\end{tabular}


Waste Isolation Pilot Plant 2001 Site Environmental Report DOE/WIPP 02-2225

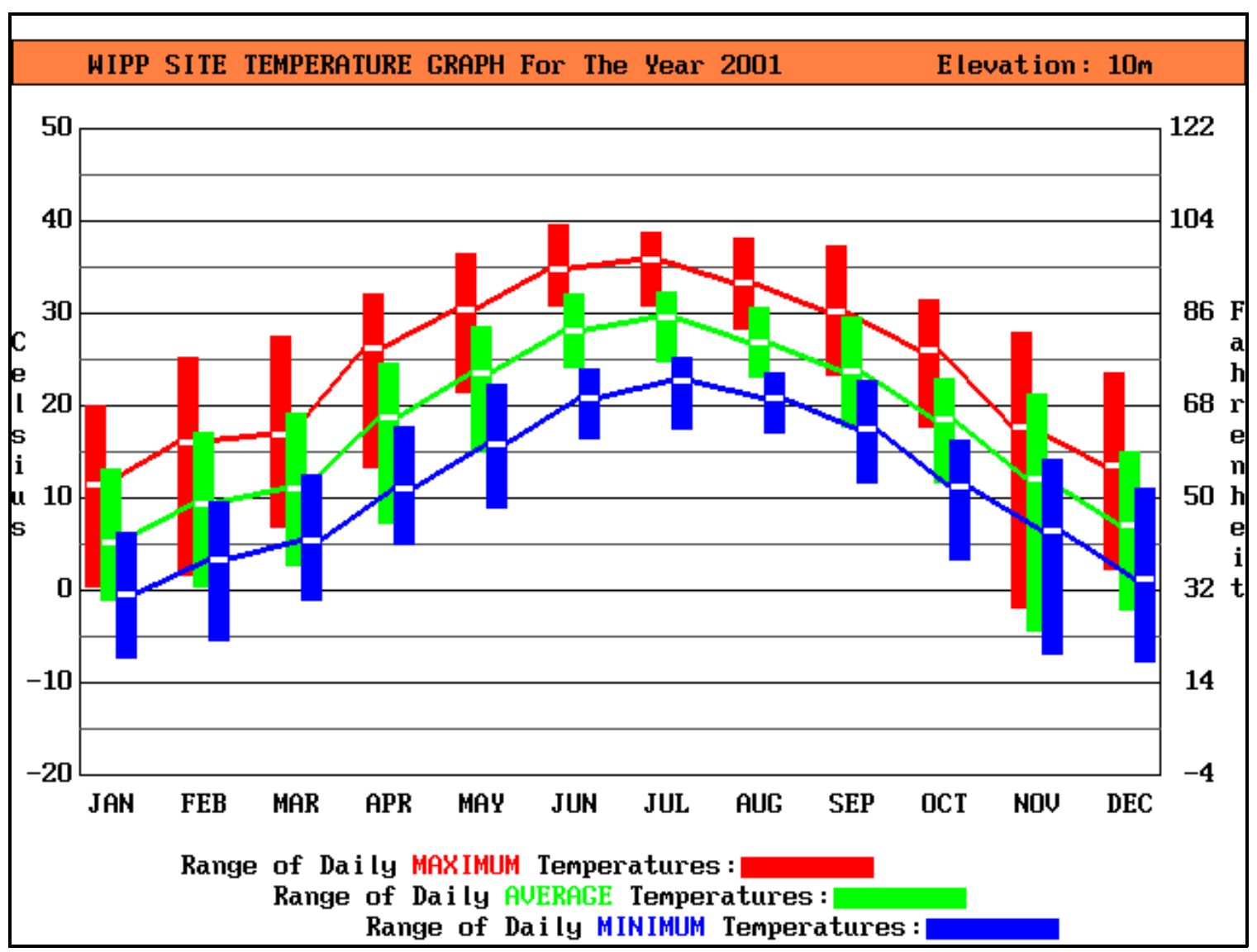

Figure 5.3 - 2001 WIPP Site Temperature at 10-Meter Height

Table 5.2 - A Summary of 2001 Temperature Observations at 10-Meter Height

\begin{tabular}{lccccccccc}
\hline Month & $\begin{array}{c}\text { Max of } \\
\text { Daily } \\
\text { Highs } \\
\left({ }^{\circ} \mathbf{C}\right)\end{array}$ & $\begin{array}{c}\text { Avg of } \\
\text { Daily } \\
\text { Highs } \\
\left({ }^{\circ} \mathbf{C}\right)\end{array}$ & $\begin{array}{c}\text { Min of } \\
\text { Daily } \\
\text { Highs } \\
\left({ }^{\circ} \mathbf{C}\right)\end{array}$ & $\begin{array}{c}\text { Max of } \\
\text { Daily } \\
\text { Averages } \\
\left({ }^{\circ} \mathbf{C}\right)\end{array}$ & $\begin{array}{c}\text { Avg of } \\
\text { Daily } \\
\text { Averages } \\
\left({ }^{\circ} \mathbf{C}\right)\end{array}$ & $\begin{array}{c}\text { Min of } \\
\text { Daily } \\
\text { Averages } \\
\left({ }^{\circ} \mathbf{C}\right)\end{array}$ & $\begin{array}{c}\text { Max of } \\
\text { Daily } \\
\text { Lows } \\
\left({ }^{\circ} \mathbf{C}\right)\end{array}$ & $\begin{array}{c}\text { Avg of } \\
\text { Daily } \\
\text { Lows } \\
\left({ }^{\circ} \mathbf{C}\right)\end{array}$ & $\begin{array}{c}\text { Min of } \\
\text { Daily } \\
\text { Lows } \\
\left({ }^{\circ} \mathbf{C}\right)\end{array}$ \\
\hline Jan & 20.02 & 11.43 & 0.37 & 13.10 & 5.20 & -1.02 & 6.28 & -.36 & -7.32 \\
Feb & 25.19 & 16.00 & 1.71 & 17.11 & 9.42 & 0.52 & 9.51 & 3.23 & -5.42 \\
Mar & 27.55 & 16.88 & 6.90 & 19.18 & 11.01 & 2.64 & 12.46 & 5.47 & -1.10 \\
Apr & 32.16 & 26.31 & 13.27 & 24.67 & 18.79 & 7.26 & 17.77 & 10.95 & 4.99 \\
May & 36.41 & 30.50 & 21.55 & 28.60 & 23.55 & 14.98 & 22.23 & 15.82 & 9.03 \\
Jun & 39.53 & 34.74 & 30.75 & 32.02 & 28.09 & 24.26 & 24.05 & 20.76 & 16.38 \\
Jul & 38.77 & 35.80 & 30.90 & 32.29 & 29.54 & 24.78 & 25.30 & 22.81 & 17.54 \\
Aug & 38.14 & 33.34 & 28.42 & 30.53 & 26.97 & 23.06 & 23.62 & 20.88 & 17.11 \\
Sep & 37.27 & 30.27 & 23.40 & 29.50 & 23.74 & 17.81 & 22.72 & 17.42 & 11.62 \\
Oct & 31.37 & 25.98 & 17.79 & 22.82 & 18.51 & 11.66 & 16.19 & 11.26 & 3.34 \\
Nov & 27.89 & 17.80 & -.92 & 21.18 & 12.04 & -.37 & 14.10 & 6.45 & -6.84 \\
Dec & 23.59 & 13.56 & 2.21 & 14.95 & 7.18 & -2.08 & 10.97 & 1.23 & -7.77 \\
\hline Annual & 39.53 & 24.38 & -1.92 & 32.29 & 17.84 & -4.37 & 25.30 & 11.33 & -7.77 \\
\hline
\end{tabular}


Waste Isolation Pilot Plant 2001 Site Environmental Report DOE/WIPP 02-2225

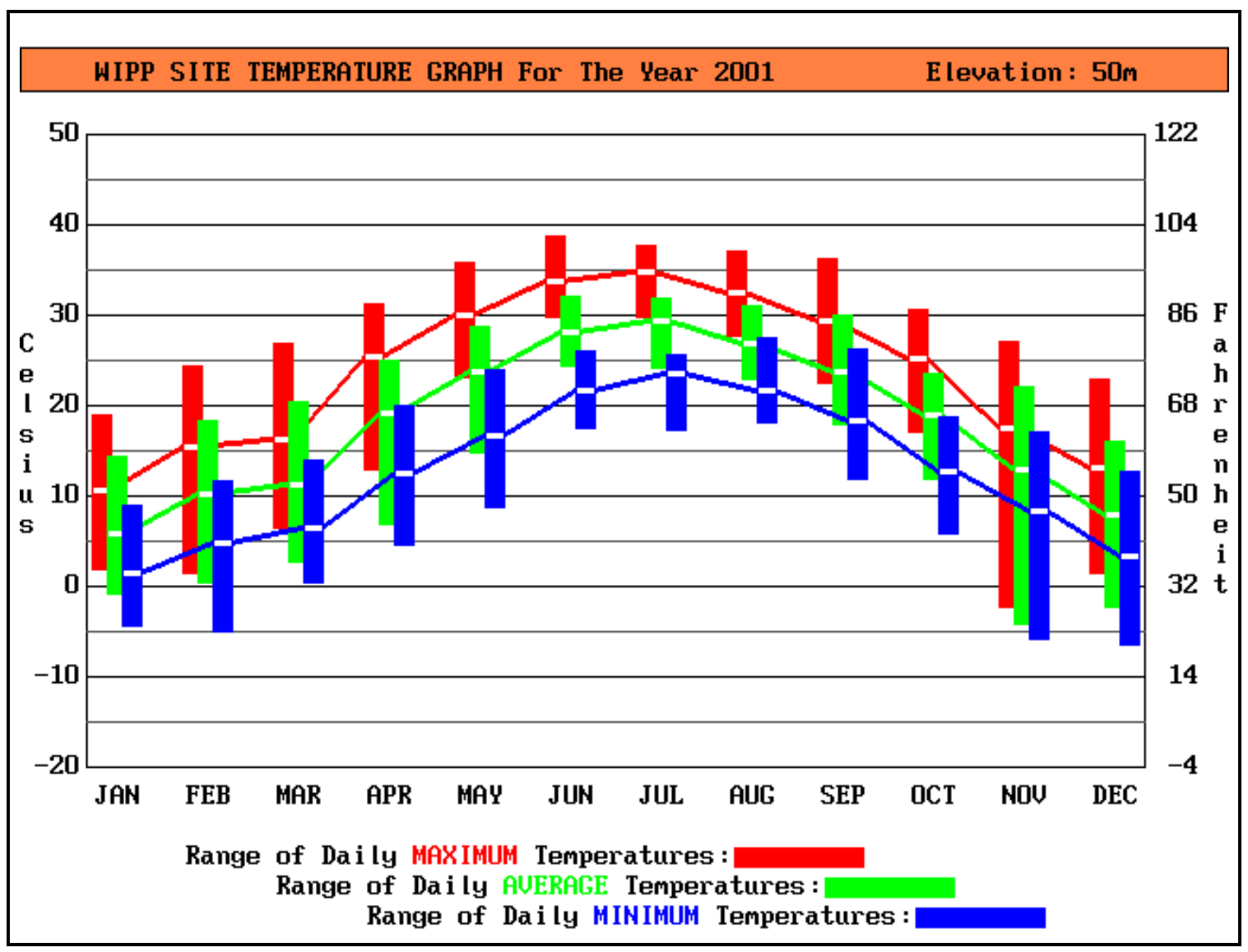

Figure 5.4 - 2001 WIPP Site Temperature at 50-Meter Height

Table 5.3 - A Summary of 2001 Temperature Observations at 50-Meter Height

\begin{tabular}{|c|c|c|c|c|c|c|c|c|c|}
\hline Month & $\begin{array}{l}\text { Max of } \\
\text { Daily } \\
\text { Highs } \\
\left({ }^{\circ} \mathrm{C}\right) \\
\end{array}$ & $\begin{array}{l}\text { Avg of } \\
\text { Daily } \\
\text { Highs } \\
\left({ }^{\circ} \mathrm{C}\right) \\
\end{array}$ & $\begin{array}{c}\text { Min of } \\
\text { Daily } \\
\text { Highs } \\
\left({ }^{\circ} \mathrm{C}\right)\end{array}$ & $\begin{array}{c}\text { Max of } \\
\text { Daily } \\
\text { Averages } \\
\left({ }^{\circ} \mathrm{C}\right) \\
\end{array}$ & $\begin{array}{c}\text { Avg of } \\
\text { Daily } \\
\text { Averages } \\
\left({ }^{\circ} \mathrm{C}\right) \\
\end{array}$ & $\begin{array}{c}\text { Min of } \\
\text { Daily } \\
\text { Averages } \\
\left({ }^{\circ} \mathrm{C}\right) \\
\end{array}$ & $\begin{array}{l}\text { Max of } \\
\text { Daily } \\
\text { Lows } \\
\left({ }^{\circ} \mathrm{C}\right) \\
\end{array}$ & $\begin{array}{l}\text { Avg of } \\
\text { Daily } \\
\text { Lows } \\
\left({ }^{\circ} \mathrm{C}\right) \\
\end{array}$ & $\begin{array}{c}\text { Min of } \\
\text { Daily } \\
\text { Lows } \\
\left({ }^{\circ} \mathrm{C}\right) \\
\end{array}$ \\
\hline Jan & 19.02 & 10.60 & 1.93 & 14.37 & 5.82 & -0.88 & 8.89 & 1.42 & -4.45 \\
\hline Feb & 24.38 & 15.43 & 1.45 & 18.33 & 10.12 & 0.43 & 11.75 & 4.76 & -4.98 \\
\hline Mar & 26.87 & 16.31 & 6.50 & 20.45 & 11.21 & 2.61 & 14.06 & 6.44 & 0.42 \\
\hline Apr & 31.29 & 25.51 & 12.82 & 24.95 & 19.12 & 6.83 & 19.93 & 12.57 & 4.64 \\
\hline May & 35.83 & 29.91 & 23.20 & 28.84 & 23.69 & 14.79 & 23.93 & 16.67 & 8.68 \\
\hline Jun & 38.65 & 33.79 & 29.87 & 32.02 & 28.03 & 24.46 & 26.03 & 21.64 & 17.53 \\
\hline Jul & 37.70 & 34.79 & 29.85 & 31.93 & 29.36 & 24.23 & 25.67 & 23.50 & 17.35 \\
\hline Aug & 37.16 & 32.42 & 27.79 & 31.05 & 26.91 & 22.87 & 27.40 & 21.68 & 18.04 \\
\hline Sep & 36.27 & 29.42 & 22.58 & 30.09 & 23.82 & 17.88 & 26.18 & 18.37 & 11.96 \\
\hline Oct & 30.63 & 25.26 & 17.00 & 23.53 & 18.95 & 11.97 & 18.82 & 12.79 & 5.86 \\
\hline Nov & 27.01 & 17.44 & -2.26 & 22.10 & 12.91 & -4.16 & 17.00 & 8.41 & -5.73 \\
\hline Dec & 22.98 & 13.13 & 1.44 & 16.00 & 7.99 & -2.35 & 12.79 & 3.29 & -6.43 \\
\hline Annual & 38.65 & 23.67 & -2.26 & 32.02 & 18.16 & -4.16 & 27.40 & 12.63 & -6.43 \\
\hline
\end{tabular}




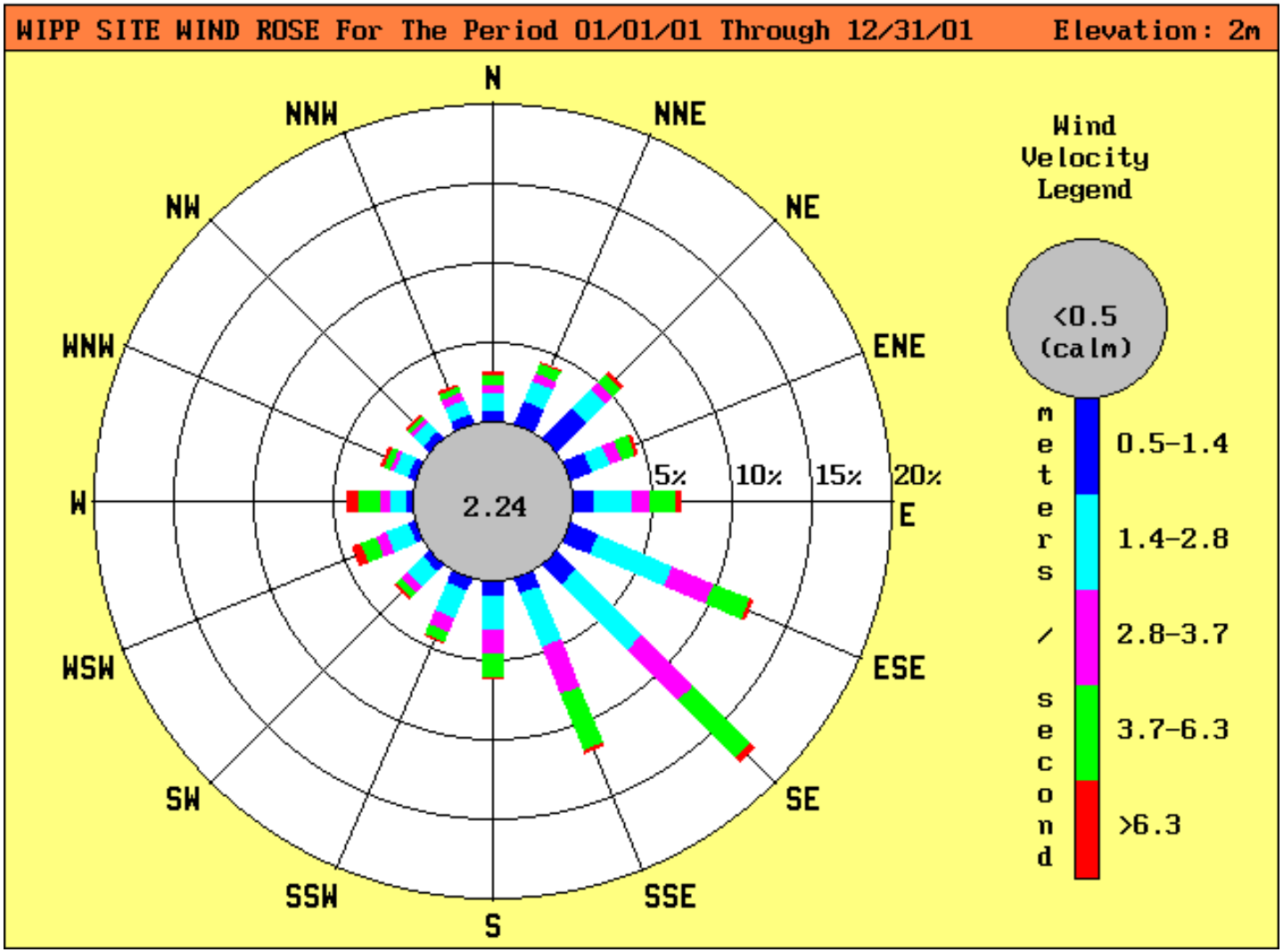

Figure 5.5 - 2001 WIPP Site Wind Rose at 2-Meter Height

Table 5.4 - 2001 Wind Frequencies at 2-Meter Height, Stratified by Direction and Speed (\%)

\begin{tabular}{|c|c|c|c|c|c|c|c|}
\hline \multirow[b]{2}{*}{ Direction } & \multicolumn{6}{|c|}{ Wind Speed Range, Meters/Second } & \multirow[b]{2}{*}{ Totals } \\
\hline & $<0.5$ & $0.5-1.4$ & $1.4-2.8$ & $2.8-3.7$ & $3.7-6.3$ & $>6.3$ & \\
\hline$\overline{\mathrm{N}}$ & $0.123^{a}$ & 0.679 & 1.224 & 0.557 & 0.722 & 0.243 & 3.547 \\
\hline NNE & 0.171 & 1.590 & 1.404 & 0.517 & 0.779 & 0.103 & 4.563 \\
\hline NE & 0.217 & 2.506 & 1.784 & 0.659 & 0.811 & 0.228 & 6.204 \\
\hline ENE & 0.268 & 1.393 & 1.370 & 0.759 & 0.962 & 0.168 & 4.920 \\
\hline$E$ & 0.297 & 1.310 & 2.392 & 1.233 & 1.681 & 0.288 & 7.200 \\
\hline ESE & 0.265 & 1.809 & 5.186 & 2.780 & 2.551 & 0.223 & 12.814 \\
\hline SE & 0.231 & 1.652 & 5.965 & 4.566 & 5.126 & 0.251 & 17.791 \\
\hline SSE & 0.166 & 1.082 & 3.647 & 3.193 & 3.981 & 0.245 & 12.314 \\
\hline$S$ & 0.091 & 0.885 & 2.178 & 1.530 & 1.612 & 0.111 & 6.407 \\
\hline SSW & 0.083 & 0.788 & 1.895 & 1.005 & 0.674 & 0.054 & 4.498 \\
\hline SW & 0.057 & 0.517 & 1.484 & 0.591 & 0.545 & 0.154 & 3.348 \\
\hline WSW & 0.026 & 0.494 & 1.601 & 0.759 & 1.110 & 0.511 & 4.501 \\
\hline W & 0.071 & 0.491 & 1.124 & 0.628 & 1.416 & 0.625 & 4.355 \\
\hline WNW & 0.049 & 0.534 & 0.933 & 0.283 & 0.502 & 0.160 & 2.460 \\
\hline NW & 0.051 & 0.531 & 0.876 & 0.342 & 0.371 & 0.051 & 2.223 \\
\hline NNW & 0.071 & 0.537 & 1.053 & 0.531 & 0.497 & 0.166 & 2.854 \\
\hline Total & 2.237 & 16.795 & 34.115 & 19.932 & 23.339 & 3.582 & 100.000 \\
\hline
\end{tabular}

${ }^{a}$ Percentage of time in which wind blew from this direction at this speed 


\section{Waste Isolation Pilot Plant 2001 Site Environmental Report DOE/WIPP 02-2225}

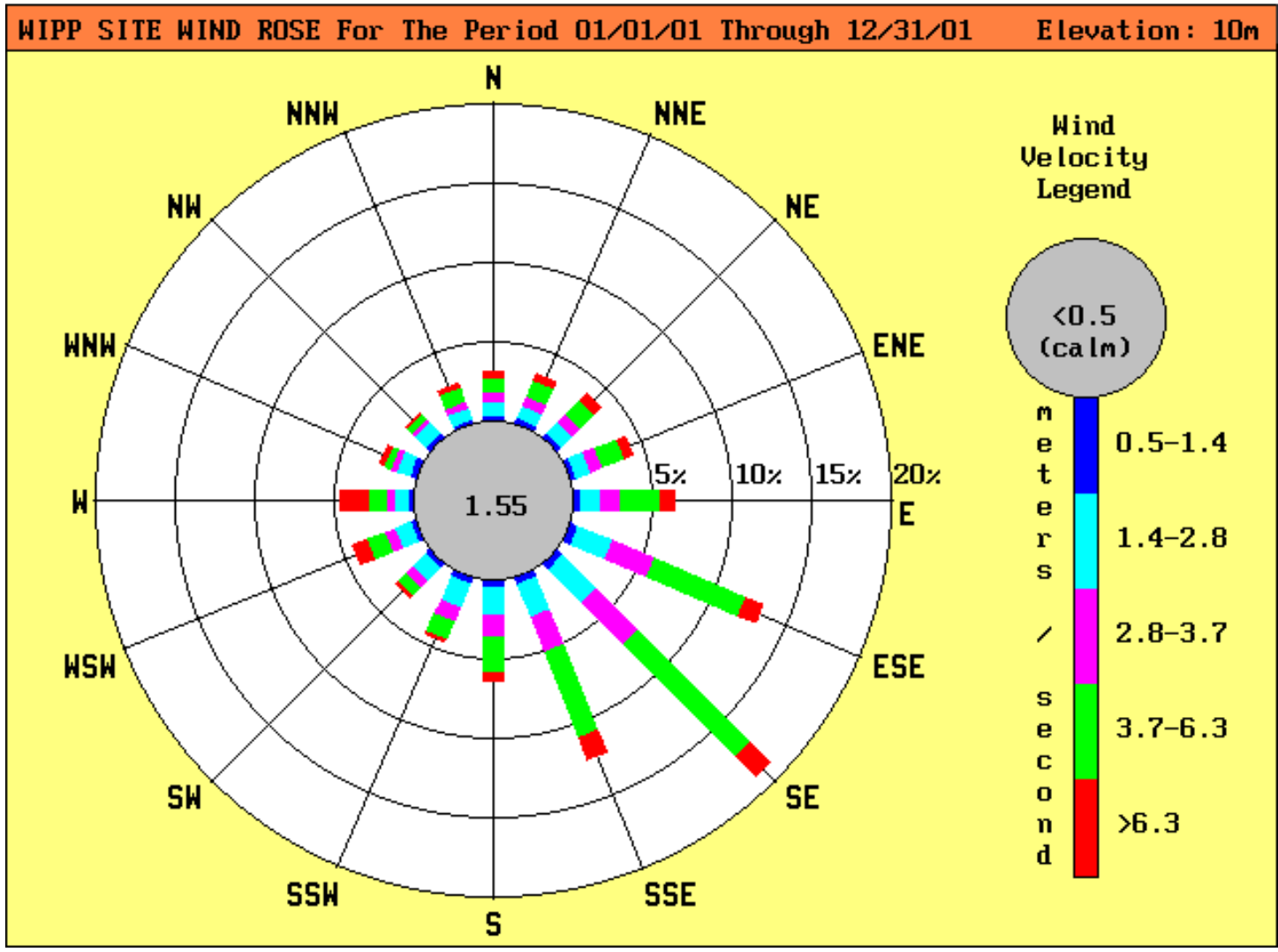

Figure 5.6 - 2001 WIPP Site Wind Rose at 10-Meter Height

Table 5.5 - 2001 Wind Frequencies at 10-Meter Height, Stratified by Direction and Speed (\%)

\begin{tabular}{|c|c|c|c|c|c|c|c|}
\hline \multirow[b]{2}{*}{ Direction } & \multicolumn{6}{|c|}{ Wind Speed Range, Meters/Second } & \multirow[b]{2}{*}{ Totals } \\
\hline & $<0.5$ & $0.5-1.4$ & 1.4-2.8 & 2.8-3.7 & 3.7-6.3 & $>6.3$ & \\
\hline $\mathrm{N}$ & 0.037 & 0.263 & 0.928 & 0.645 & 0.902 & 0.454 & 3.228 \\
\hline NNE & 0.108 & 0.342 & 0.962 & 0.736 & 1.150 & 0.411 & 3.710 \\
\hline NE & 0.108 & 0.311 & 1.119 & 0.773 & 1.264 & 0.585 & 4.161 \\
\hline ENE & 0.057 & 0.365 & 1.124 & 0.839 & 1.564 & 0.528 & 4.478 \\
\hline $\mathrm{E}$ & 0.180 & 0.425 & 1.327 & 1.293 & 2.566 & 0.993 & 6.784 \\
\hline ESE & 0.154 & 0.454 & 2.417 & 2.897 & 6.318 & 1.236 & 13.476 \\
\hline SE & 0.214 & 0.491 & 3.045 & 3.776 & 10.017 & 1.718 & 19.261 \\
\hline SSE & 0.205 & 0.494 & 2.266 & 2.397 & 5.796 & 1.581 & 12.740 \\
\hline$S$ & 0.077 & 0.471 & 1.818 & 1.413 & 2.334 & 0.594 & 6.707 \\
\hline SSW & 0.054 & 0.368 & 1.630 & 1.005 & 1.341 & 0.228 & 4.626 \\
\hline SW & 0.040 & 0.317 & 1.247 & 0.748 & 0.868 & 0.294 & 3.513 \\
\hline WSW & 0.063 & 0.311 & 1.144 & 0.722 & 1.341 & 0.970 & 4.552 \\
\hline W & 0.051 & 0.317 & 0.910 & 0.531 & 1.233 & 1.781 & 4.823 \\
\hline WNW & 0.103 & 0.408 & 0.930 & 0.414 & 0.591 & 0.348 & 2.794 \\
\hline NW & 0.071 & 0.357 & 1.005 & 0.340 & 0.557 & 0.097 & 2.426 \\
\hline NNW & 0.031 & 0.237 & 0.762 & 0.528 & 0.905 & 0.260 & 2.723 \\
\hline Total & 1.555 & 5.930 & 22.634 & 19.055 & 38.747 & 12.078 & 100.000 \\
\hline
\end{tabular}

${ }^{\text {a }}$ Percentage of time in which wind blew from this direction at this speed 


\section{Waste Isolation Pilot Plant 2001 Site Environmental Report DOE/WIPP 02-2225}

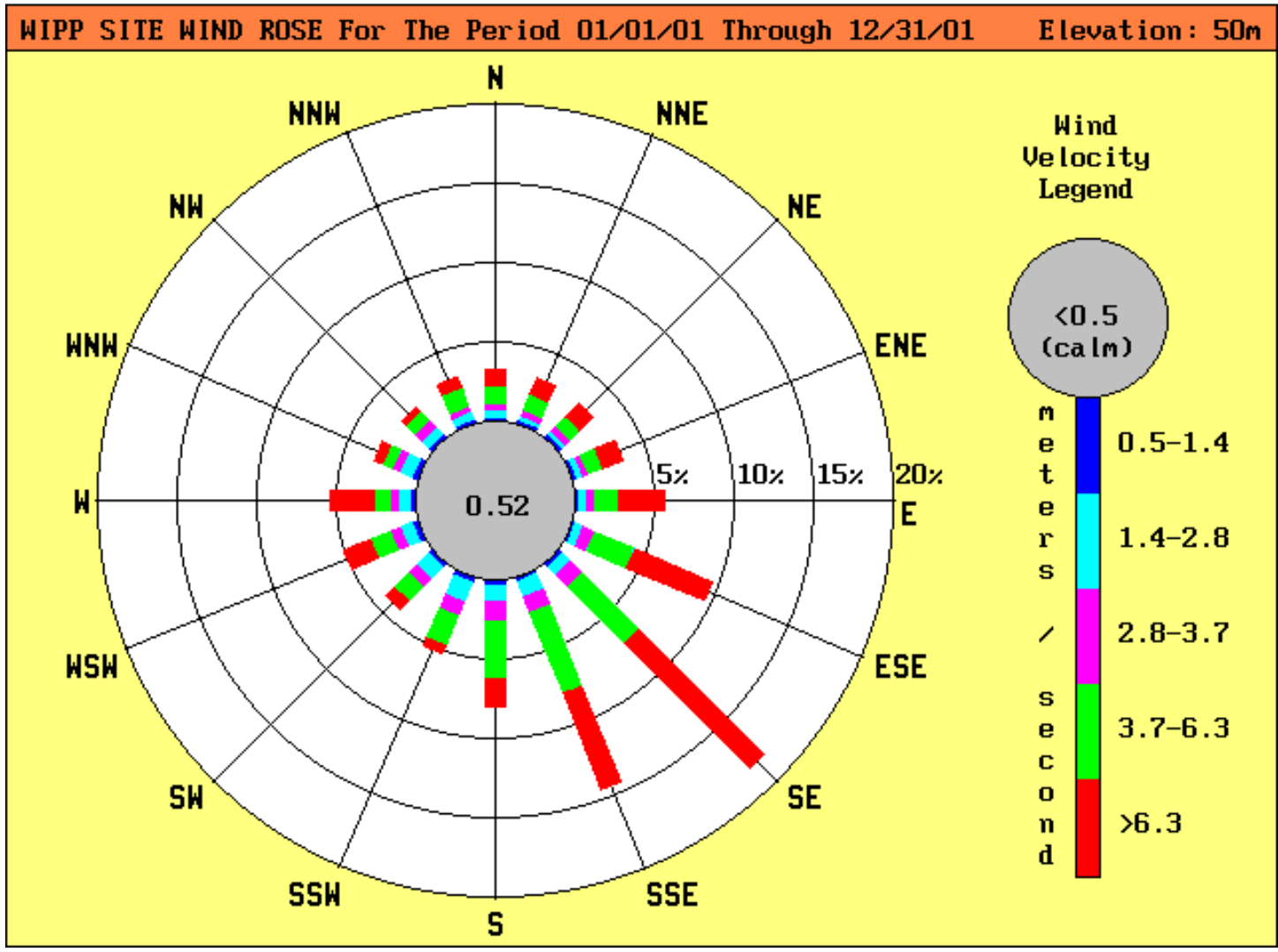

Figure 5.7 - 2001 WIPP Site Wind Rose at 50-Meter Height

Table 5.6 - 2001 Wind Frequencies at 50-Meter Height, Stratified by Direction and Speed (\%)

\begin{tabular}{|c|c|c|c|c|c|c|c|}
\hline \multirow[b]{2}{*}{ Direction } & \multicolumn{6}{|c|}{ Wind Speed Range, Meters/Second } & \multirow[b]{2}{*}{ Totals } \\
\hline & $<0.5$ & $0.5-1.4$ & 1.4-2.8 & 2.8-3.7 & $3.7-6.3$ & $>6.3$ & \\
\hline $\mathrm{N}$ & 0.023 & 0.188 & 0.554 & 0.471 & 1.224 & 1.025 & 3.485 \\
\hline NNE & 0.014 & 0.134 & 0.431 & 0.422 & 1.093 & 1.144 & 3.239 \\
\hline NE & 0.006 & 0.171 & 0.442 & 0.385 & 0.965 & 1.273 & 3.242 \\
\hline ENE & 0.026 & 0.151 & 0.411 & 0.328 & 1.142 & 1.444 & 3.502 \\
\hline E & 0.014 & 0.137 & 0.548 & 0.568 & 1.535 & 2.894 & 5.696 \\
\hline ESE & 0.063 & 0.103 & 0.696 & 0.773 & 2.837 & 5.283 & 9.755 \\
\hline SE & 0.111 & 0.163 & 0.816 & 1.053 & 5.186 & 11.184 & 18.513 \\
\hline SSE & 0.091 & 0.191 & 1.130 & 1.110 & 5.562 & 6.501 & 14.586 \\
\hline$S$ & 0.031 & 0.263 & 1.062 & 1.284 & 3.627 & 1.809 & 8.076 \\
\hline SSW & 0.026 & 0.300 & 1.318 & 1.062 & 2.103 & 0.585 & 5.394 \\
\hline SW & 0.009 & 0.254 & 1.019 & 0.671 & 1.473 & 0.848 & 4.272 \\
\hline WSW & 0.020 & 0.280 & 0.890 & 0.628 & 1.464 & 1.835 & 5.117 \\
\hline W & 0.031 & 0.305 & 0.848 & 0.539 & 1.093 & 2.768 & 5.585 \\
\hline WNW & 0.023 & 0.277 & 0.953 & 0.545 & 0.819 & 0.611 & 3.228 \\
\hline NW & 0.034 & 0.191 & 0.865 & 0.508 & 0.928 & 0.445 & 2.971 \\
\hline NNW & 0.003 & 0.148 & 0.594 & 0.468 & 1.267 & 0.859 & 3.339 \\
\hline Total & 0.525 & 3.256 & 12.577 & 10.816 & 32.317 & 40.508 & 100.000 \\
\hline
\end{tabular}

${ }^{a}$ Percentage of time in which wind blew from this direction at this speed 


\section{Waste Isolation Pilot Plant 2001 Site Environmental Report DOE/WIPP 02-2225}

Target compounds found in VOC-B represent air found in the underground before the air passes through the panels containing waste. The VOC concentrations measured at this location are the sum of background concentrations entering the mine through the air intake shaft plus additional concentrations contributed by facility operations upstream of the waste panels. Concentrations measured at VOC-A will be equal to those found at VOC-B plus any contributions from the waste panels. Differences measured between the two stations will then represent any VOC contributions from the waste panels. Any concentration differences between the two stations must be less than the concentrations of concern listed in Attachment $\mathrm{N}$ of the HWFP (Table 5.7).

Table 5.7 - Concentrations of Concern for Volatile Organic Compounds, from Attachment $\mathrm{N}$ of the HWFP

(No. NM4890139088)

\begin{tabular}{lc}
\hline \multicolumn{1}{c}{ Compound } & $\begin{array}{c}\text { Concentration of Concern } \\
\text { ppbv }^{\mathbf{a}}\end{array}$ \\
\hline 1,1,1-Trichloroethane & 590 \\
1,1,2,2-Tetrachloroethane & 50 \\
1,1-Dichloroethylene & 100 \\
1,2-Dichloroethane & 45 \\
Carbon tetrachloride & 165 \\
Chlorobenzene & 220 \\
Chloroform & 180 \\
Methylene chloride & 1,930 \\
Toluene & 190 \\
\hline a Parts per billion by volume &
\end{tabular}

Sample pair differences are calculated by subtracting the concentration of a compound of interest observed at VOC-B from that measured at VOC-A for the given sampling period (Table 5.8). Negative values indicate ambient air concentrations of a compound (VOC-B) were greater than concentrations in the air passing out of the panel (VOC-A). Negative values could be caused by emissions from normal mining activities near VOC-B which quickly dispersed in the mine ventilation flow and were not detected at VOC-A. The annual averages shown in Table 5.8 were calculated by averaging all sample pair differences from January 1, 2001, to December 31, 2001. Samples in which a compound of interest was non-detectable (less than the 0.5 parts per billion by volume [ppbv] minimum detection limit [MDL]) were assigned a value of zero for the purposes of computing this average.

During 2001, four of the nine target compounds (1,2-dichloroethane, chloroform, methylene chloride, and toluene) were measured above the $0.5 \mathrm{ppbv}$ MDL. For each of the detected target compounds, the annual average was less than 0.5 percent of the respective concentration of concern listed in Table 5.7 and were, therefore, at insignificant levels with respect to human health and the environment. 


\section{Waste Isolation Pilot Plant 2001 Site Environmental Report DOE/WIPP 02-2225}

Positive sample pair differences for methylene chloride were found in 16 of 103 sample pairs. The 2001 annual average sample pair difference for methylene chloride was $0.0 \mathrm{ppbv}$, with a minimum difference value of $-2.76 \mathrm{ppbv}$ and a maximum value of $5.23 \mathrm{ppbv}$. Methylene chloride, a common laboratory contaminant, can also be found in paint remover, aerosol propellant, degreasing and metal cleaning agents, and adhesives.

Positive sample pair differences for toluene were found in 31 of the 103 sample pairs. The overall 2001 average for toluene sample pair differences was $0.97 \mathrm{ppbv}$, with a minimum difference value of -1.45 and a maximum difference value of $75.16 \mathrm{ppbv}$. Possible sources of toluene contamination could be products of incomplete combustion of diesel fuel, cleaning solvents, or paint. The maximum toluene concentration measured in 2001 occurred on August 14. On that day, Underground Operations was painting some equipment located in Panel II, Room 7, using a paint with a very high toluene concentration. The painting location is upstream in the ventilation air flow from VOC Sampling Station A.

One negative sample pair difference for 1,2-dichloroethane was found out of 103 sample pairs in 2001. The overall 2001 average for 1,2-dichloroethane sample differences was $0.00 \mathrm{ppbv}$, with a minimum difference of -0.78 and a maximum difference value of $0.00 \mathrm{ppbv}$. This compound has not been detected previously. The 1,2-dichloroethane can be found as a tar and grease remover in cleaning and degreasing operations and is used in paint and varnish removers.

One positive sample pair difference was observed for chloroform in 2001. The overall 2001 average sample difference for this compound was $0.00 \mathrm{ppbv}$, with a minimum difference of $0.00 \mathrm{ppbv}$, and a maximum difference of $0.94 \mathrm{ppbv}$. Chloroform was not detected in 2000. This compound can be found in electronics and metals cleaning solvent solutions and insecticides.

The routine laboratory reporting limit was $5.0 \mathrm{ppbv}$ for 1,1,1-trichloroethane, 1,1-dichloroethylene, methylene chloride, and toluene and $2.0 \mathrm{ppbv}$ for 1,1,2,2-tetrachloroethane, 1,2-dichloroethane, carbon tetrachloride, chlorobenzene, and chloroform. For dilution factors greater than one, the $5.0 \mathrm{ppbv}$ and $2.0 \mathrm{ppbv}$ values are multiplied by the dilution factor to calculate the laboratory reporting limits for the diluted sample.

The MDL is defined as the minimum concentration of a substance that can be measured and reported with a 99 percent confidence to be greater than zero. Values were estimated for constituents detected at concentrations less than the laboratory reporting limits but above the $0.5 \mathrm{ppbv} \mathrm{MDL}$.

Volatile organic compound sampling reported in this section was performed using guidance included in Compendium Method TO-14A, Determination of Volatile Organic Compounds (Volatile organic compounds) in Ambient Air Using Specially Prepared Canisters with Subsequent Analysis By Gas Chromatography (EPA 1997). The samples were analyzed using gas chromatography/mass spectrometry under an 


\section{Waste Isolation Pilot Plant 2001 Site Environmental Report DOE/WIPP 02-2225}

established QA/QC program. Laboratory analytical procedures were developed based on the concepts contained in both TO-14A and the draft EPA Contract Laboratory Program Volatile Organics Analysis of Ambient Air in Canisters (EPA 1994). The results of year 2001 VOC monitoring did not indicate a noticeable increase in VOCs in air downstream of Panel I. The only measurement of significance occurred on August 14 for toluene, the same day that a high toluene spray paint was being used in the underground. Thus, waste stored at WIPP did not release significant amounts of VOCs.

Table 5.8 - Volatile Organic Compound Sample Pair Differences Measured at WIPP in 2001

\begin{tabular}{|c|c|c|c|c|}
\hline Compound & $\begin{array}{c}\text { No. of Sample } \\
\text { Pairs } \\
\text { (A and B) }\end{array}$ & $\begin{array}{c}2001 \text { Annual } \\
\text { Average of } \\
\text { Sample Pair } \\
\text { Differences } \\
\left(p_{p b v}\right)\end{array}$ & $\begin{array}{c}\text { Minimum of } \\
\text { Sample Pair } \\
\text { Differences } \\
\left(p_{p b v}\right)^{a}\end{array}$ & $\begin{array}{c}\text { Maximum of } \\
\text { Sample Pair } \\
\text { Differences } \\
\left(p_{p b v}\right)^{2}\end{array}$ \\
\hline 1,1,1-Trichloroethane & 103 & 0 & 0 & 0 \\
\hline 1,1,2,2-Tetrachloroethane & 103 & 0 & 0 & 0 \\
\hline 1,1-Dichloroethylene & 103 & 0 & 0 & 0 \\
\hline 1,2-Dichloroethane & 103 & 0 & -0.78 & 0 \\
\hline Carbon Tetrachloride & 103 & 0 & 0 & 0 \\
\hline Chlorobenzene & 103 & 0 & 0 & 0 \\
\hline Chloroform & 103 & 0 & 0 & 0.94 \\
\hline Methylene Chloride & 103 & 0 & -2.76 & 5.23 \\
\hline Toluene & 103 & 0.97 & -1.45 & 75.16 \\
\hline
\end{tabular}

${ }^{\text {a }}$ Parts per billion by volume

\subsection{Seismic Activity}

WIPP is located about 60 miles east of the western margin of the Permian Basin. The geologic structure and tectonic pattern of the Permian Basin are chiefly the result of large-scale subsidence and uplift during the Paleozoic era. The broad basin is divided into a series of sub-basins which passed through their last stage of significant subsidence during the Late Permian age. The Delaware sub-basin occupies the southwestern portion of the Permian Basin and hosts the WIPP site. It is bordered by the Roosevelt Uplift to the north, the Marathon Thrust Belt to the south, the Central (Permian) Basin Platform to the east, and the Sierra Diablo Platform and Guadalupe and Sacramento Mountains to the west. The Delaware Basin contains a thick sequence of evaporite layers.

All major tectonic elements of the Delaware Basin were essentially formed before deposition of the Permian evaporites, and the region has been relatively stable since then. Deep-seated faults are rare, except along the western and eastern basin margins, and there is no evidence of young, deep-seated faults inside the basin.

Researchers suspect that some low-magnitude earthquakes may result from secondary oil recovery (water flooding). Their foci are about as deep as the bottom of relatively shallow hydrocarbon wells. 
Significant recent seismic events near WIPP on January 2, 1992, and April 14, 1995, had magnitudes of 5.0 and 5.3 respectively. The January 2, 1992, Rattlesnake Canyon earthquake had an epicenter $60 \mathrm{~km}$ (36 mi) east-southeast of the WIPP site, while an April 14, 1995, event's epicenter was located about $240 \mathrm{~km}$ (144 mi) southwest of WIPP, near Alpine, Texas. Neither earthquake had any effect on WIPP structures, as documented by post-event inspections by WIPP staff and the NMED. The magnitudes of both events were within the parameters used to develop the seismic risk assessment of the WIPP structures.

Seismic information for the WIPP region before 1962 was derived from chronicles of the effects of those tremors on people, structures, and surface features. Seismicity in New Mexico reported prior to 1962 was mostly limited to the corridor between Albuquerque and Socorro, part of a structure known as the Rio Grande Rift. Since 1962, most seismic information has been based on instrumental data recorded at various seismograph stations.

Currently, seismicity within $300 \mathrm{~km}$ (186 mi) of the WIPP site is being monitored by the New Mexico Institute of Mining and Technology (NMIMT), in Socorro, New Mexico, using data from a seven-station network approximately centered on the site (Figure 5.8). Station signals are transmitted to the NMIMT Seismological Observatory in Socorro. When appropriate, readings from the WIPP network stations are combined with readings from an additional NMIMT network in the central Rio Grande Rift. Occasionally, data are also exchanged with the University of Texas at El Paso and Texas Tech University in Lubbock, both of which operate stations in west Texas.

The mean operational efficiency of the WIPP seismic monitoring stations during 2001 was approximately 96.2 percent. From January 1 through December 31, 2001, locations for 129 seismic events were recorded within $300 \mathrm{~km}(186 \mathrm{mi})$ of WIPP. These data included origin times, epicenter coordinates, and magnitudes. The strongest recorded event (magnitude 3.1) occurred on June 2 and was located approximately $65 \mathrm{~km}$ (40 mi) east of the site. The event closest to the site occurred on September 21, and was probably an aftershock of the June 2 event. This event had a magnitude of 1.6 and was located about $61 \mathrm{~km}(38 \mathrm{mi})$ east of the site. These events had no effect on WIPP structures. 


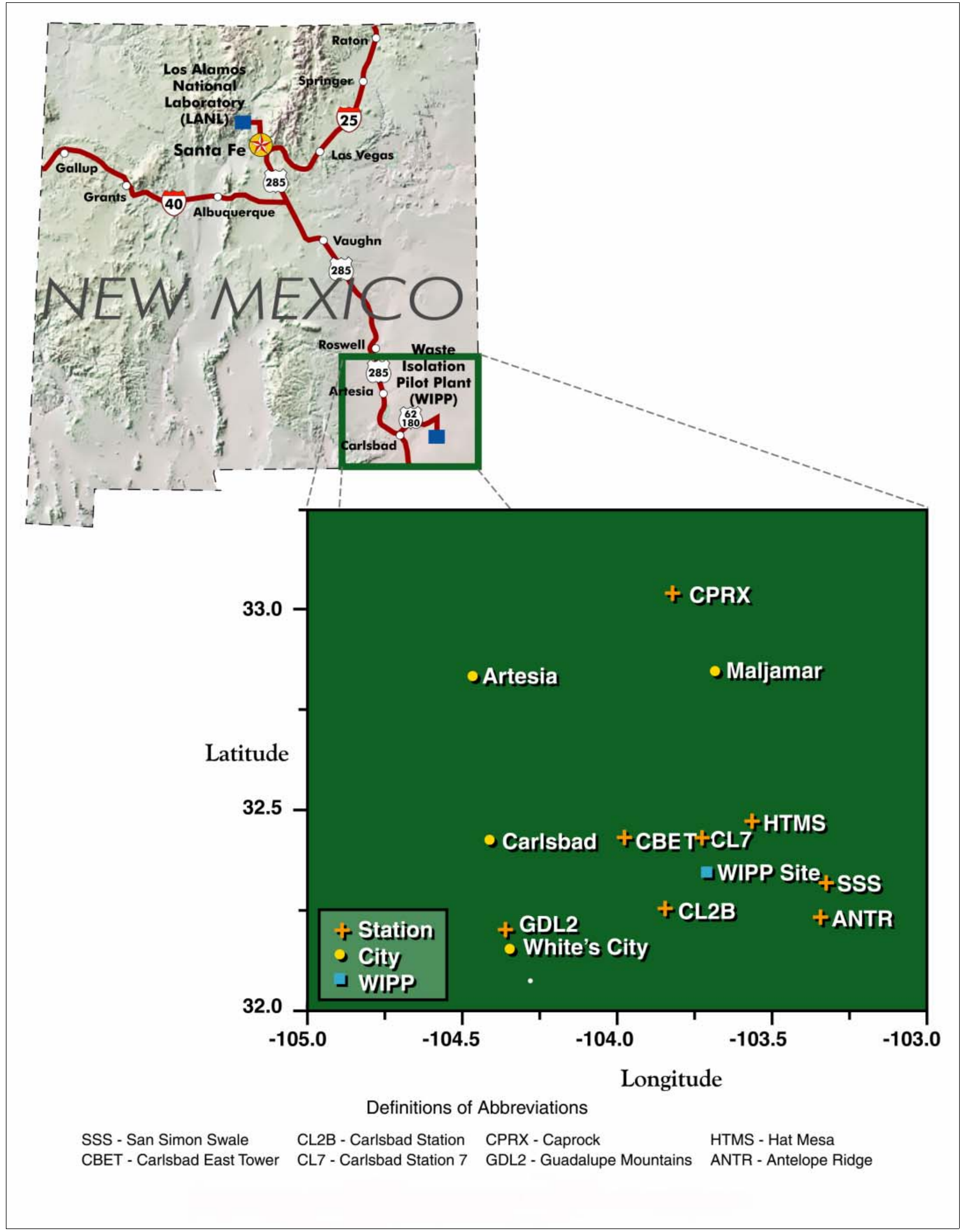

Figure 5.8 - WIPP Seismograph Station Locations 


\subsection{Liquid Effluent Monitoring}

The WIPP sewage lagoon system is a zero-discharge facility consisting of two primary settling lagoons, two polishing lagoons, a chlorination system, and three evaporation basins. The entire facility is lined with 30-mil synthetic liners and is designed to dispose of domestic sewage as well as site-generated brine waters from observation well pumping and underground dewatering activities at the site.

The WIPP sewage facility is operated under Discharge Permit No. 831 (DP-831), issued by the state of New Mexico in accordance with the Clean Water Act, and is managed in accordance with EPA sewage sludge regulations (40 CFR Part 503), New Mexico Water Quality Control Regulations (20.6.2.3 NMAC), and applicable WIPP controlled procedures. These requirements provide the framework for disposal of domestic sewage, site-generated brine waters, and non-hazardous waste waters.

DP-831 allows for the disposal of 7,570 I (2,000 gal) per day of nonhazardous brines to $\mathrm{H}-19$ pond. Nonhazardous brines are discharged only to Evaporation Pond B of the Sewage Lagoon System. The DOE submits quarterly discharge monitoring reports to NMED to demonstrate compliance with the inspection, monitoring, and reporting requirements identified in the plan. Because effluent is not discharged from the facility, no effluent limits were established in DP-831. The NMED Groundwater Protection and Remediation Bureau established a list of analytes to be sampled on a quarterly basis as indicators of sewage system performance. 


\section{CHAPTER 6 - GROUNDWATER MONITORING}

Current groundwater monitoring activities at WIPP are outlined in the WIPP Groundwater Monitoring Program Plan (WP 02-1). This is a QA document containing program plans for each activity performed by groundwater monitoring personnel. In addition, WIPP has detailed procedures for performing specific activities, such as pumping system installations, field parameter analyses and documentation, and QA records management. Groundwater monitoring activities are also defined in the EMP.

The objectives of the Groundwater Monitoring Program are to:

- $\quad$ Determine the physical and chemical characteristics of groundwater;

- Maintain surveillance of groundwater levels surrounding the WIPP facility, both before and throughout the operational lifetime of the facility;

- Document and identify effects, if any, of WIPP operations on groundwater parameters; and

- $\quad$ Fulfill the requirements of the RCRA Operating Permit, the EPA Compliance Certification Application (CCA) and DOE Order 5400.1.

The data obtained by the WIPP Groundwater Monitoring Program supported two major programs at WIPP: (1) the RCRA Detection Monitoring Program supporting the RCRA Part B Permit in compliance with 40 CFR Part 264 and 20.4.1 NMAC, and

(2) performance assessment supporting the Compliance Certification (DOE/CAO 96-2184) in compliance with 40 CFR Part 191 and 40 CFR Part 194. Each of these programs requires a unique set of analyses and data. Particular sample needs are defined by each program.

Background data were collected from 1995 through 1997 and reported in the Waste Isolation Pilot Plant RCRA Background Groundwater Quality Baseline Report (DOE/WIPP 98-2285). The Background data were expanded in 2000 to include ten rounds of sampling instead of five. The data were published in Addendum 1 Waste Isolation Pilot Plant RCRA Background Groundwater Quality Baseline Update Report. These background data will be compared to water quality data collected throughout the operational life of the facility.

Groundwater monitoring activities during 2001 included groundwater quality sampling and groundwater level surveillance. Groundwater quality data were gathered from six wells completed in the Culebra Member of the Rustler Formation (wells WQSP-1 through WQSP-6) and one well completed in the Dewey Lake Formation (well WQSP-6A; Figure 6.1). Groundwater surface elevation data were gathered from 70 well bores, five of which were equipped with production-inflated packers to allow groundwater level surveillance of more than one producing zone through the same well bore (Figure 6.2). 


\subsection{Groundwater Quality Sampling}

The RCRA Permit Module $\mathrm{V}$ requires groundwater quality sampling twice a year, from March through May (Round 12 for 2001) and, again, from September through November (Round 13 for 2001). Sampling for groundwater quality was performed at seven well sites during 2001 (Figure 6.1). Field analysis for Eh (Intensity Factor: an indicator of oxidation or reduction of chemical species), specific gravity, specific conductance, acidity or alkalinity, chloride, divalent cations, and total iron were performed periodically during the sampling.

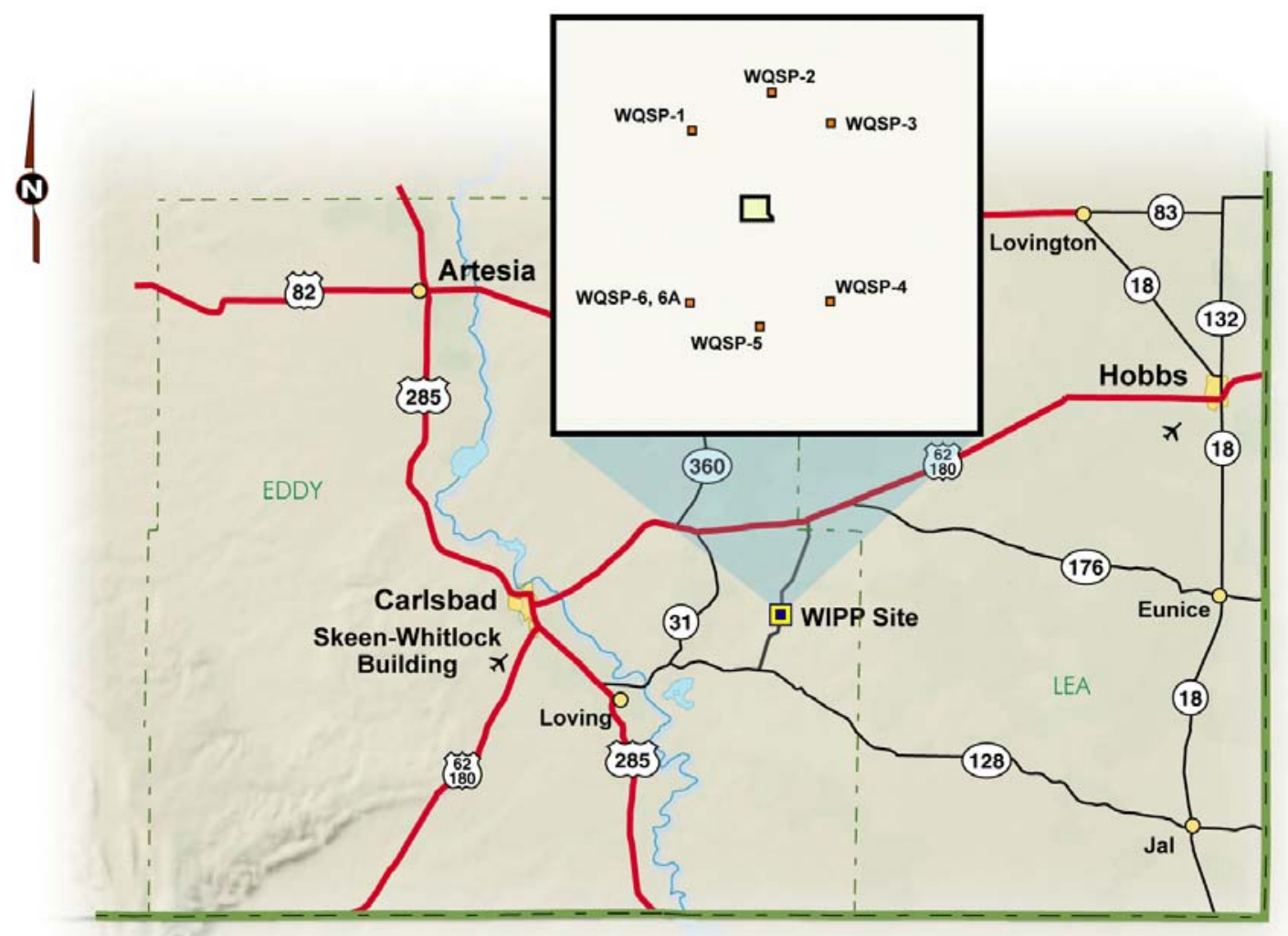

Figure 6.1 - Water Quality Sampling Program Wells 


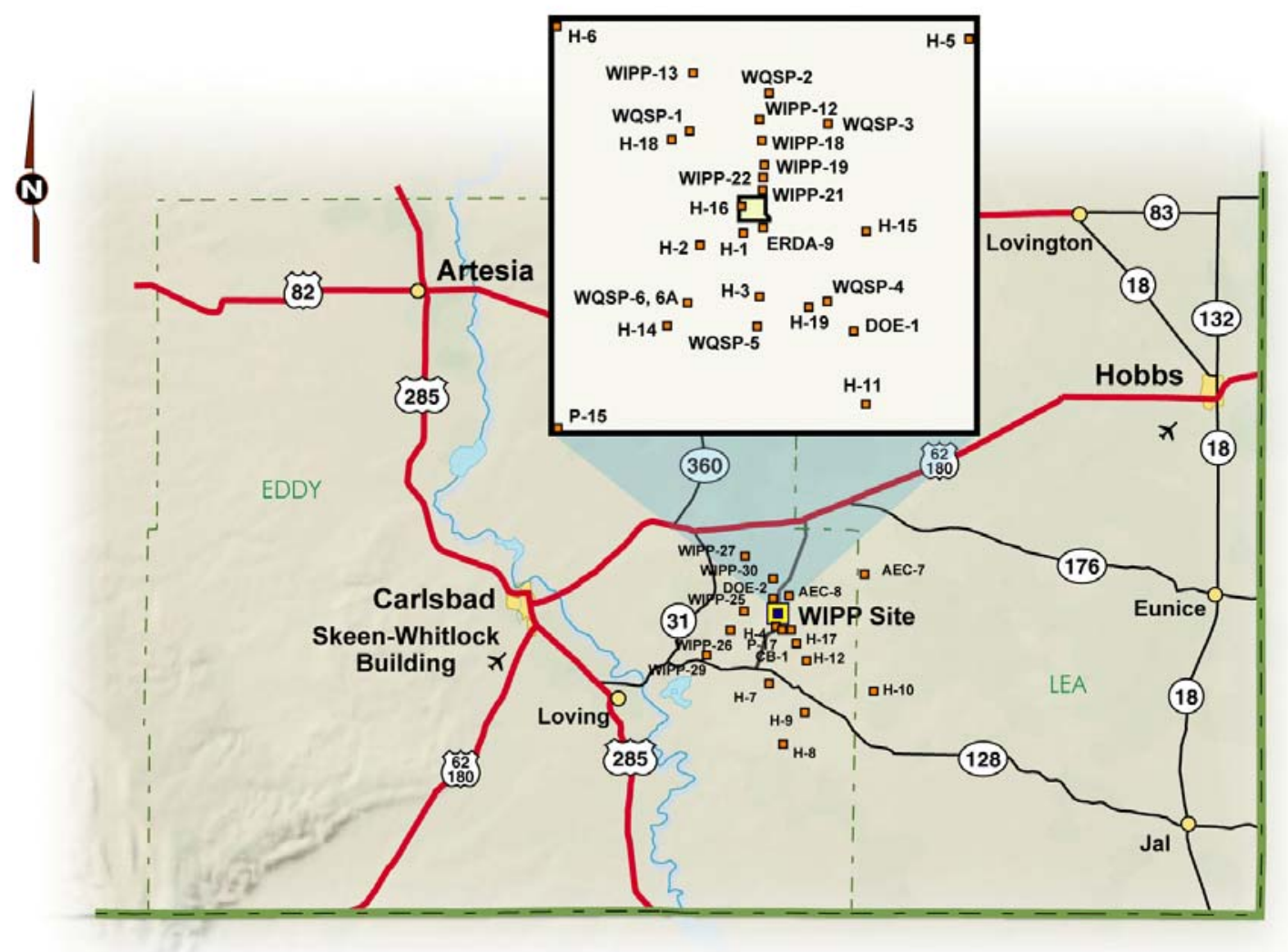

Figure 6.2 - Groundwater Level Surveillance Wells

Table 6.1 lists the analytical parameters included in the year 2001 groundwater sampling program.

During 2001, groundwater surveillance activities removed approximately 77,166 I $(20,385 \mathrm{gal})$ of water from the Culebra member of the Rustler Formation and 18,571 I $(4,906 \mathrm{gal})$ from the Dewey Lake Formation. The quality of the Culebra water sampled near WIPP is naturally poor and not suitable for human consumption or for agricultural purposes. Historically TDS concentrations measured in the Culebra ranged from 17,000 to over $280,000 \mathrm{mg} / \mathrm{l}$. The groundwater of the Culebra is considered to be Class III water by EPA guidelines.

Water quality measurements performed in the Dewey Lake Formation indicate the waters are considerably better quality than the Culebra water. The TDS values were below $10,000 \mathrm{mg} / \mathrm{l}$. The water is suitable for livestock consumption, and classified as Class II water according to EPA guidance. Saturation of the Dewey Lake Formation in the area of WIPP is discontinuous. No hydrologic connection has been established that would indicate WIPP activities would have a potential impact on the Dewey Lake Formation. 
Because of the highly variable transmissivity and TDS values within the Culebra, baseline groundwater quality was defined for each individual well. Tables 6.2 through 6.8 summarize the results of analyses for each parameter or constituent for the two sampling sessions in 2001 (rounds 12 and 13).

In these tables, either the $95^{\text {th }}$ upper tolerance limit value (UTLV) or the $95^{\text {th }}$ percentile value is presented depending on the type of distribution exhibited by the parameter. Both values represent the value beneath which 95 percent of the values in a population are expected to occur. The UTLVs were calculated for data that exhibited a normal or a lognormal distribution. The $95^{\text {th }}$ percentile was determined for data that were considered nonparametric; having neither a normal nor a lognormal distribution. Due to the large number of nondetectable concentrations of organic compounds, the limits for organic compounds were considered nonparametric and based on the method detection limit reported by the laboratory. These values have been recomputed after baseline sampling was completed in 2000, and were used for sampling rounds 12 and 13 to evaluate potential contamination of the groundwater wells.

As stated above, TDS, measured as filterable residue, of the Culebra Member in the WIPP area ranged from 17,000 to over $280,000 \mathrm{mg} / \mathrm{l}$. High TDS samples require dilution prior to analysis. The dilution factors have varied between sampling rounds and wells. Historically, three different contract laboratories have been employing EPA methods to perform the groundwater chemistry analyses. Due to the variability in dilution factors and sensitivity of instruments, the concentrations and method detection limits from different laboratories were also different.

The analytical results for detectable constituents are plotted as Time Trend Plots compared to the baseline established prior to 2000 (Appendix F, Figures F.1 through F.126).

In a few isolated cases, reported concentrations of some parameters, such as potassium, magnesium, and lithium, slightly exceeded the calculated $95^{\text {th }}$ percentile or the $95^{\text {th }}$ UTLV. Such exceedences do not indicate the presence of contamination. The $95^{\text {th }}$ UTLV or percentile is a value representing where 5 percent of the concentration in the population will be greater than the UTLV or percentile. WIPP groundwater in the Culebra Dolomite Member of the Rustler Formation has very high concentrations of dissolved solids. The contract analytical laboratory has had some difficulty performing the analyses for some of the cations found in the highly concentrated brines. 
Waste Isolation Pilot Plant 2001 Site Environmental Report DOE/WIPP 02-2225

Table 6.1- Analytical Parameters for Which Groundwater Was Analyzed

\begin{tabular}{|c|c|c|c|c|c|}
\hline CAS No. ${ }^{a}$ & Parameter & $\begin{array}{c}\text { EPA } \\
\text { Method } \\
\text { Number } \\
\end{array}$ & CAS No. & Parameter & $\begin{array}{c}\text { EPA } \\
\text { Method } \\
\text { Number } \\
\end{array}$ \\
\hline $71-55-6$ & 1,1,1-Trichloroethane & $8260 \mathrm{~B}$ & $7727-37-9$ & Nitrate (as N) & 300.0 \\
\hline $79-34-5$ & 1,1,2,2-Tetrachloroethane & $8260 B$ & & Orthophosphate (as $\mathrm{P}$ ) & 365.2 \\
\hline $79-00-5$ & 1,1,2-Trichloroethane & $8260 B$ & & $\mathrm{pH}$ & 150.1 \\
\hline $75-34-3$ & 1,1-Dichloroethane & $8260 B$ & & Specific conductance & 120.1 \\
\hline $75-35-4$ & 1,1-Dichloroethylene & $8260 B$ & & Sulfate & 300.0 \\
\hline $107-06-2$ & 1,2-Dichloroethane & $8260 \mathrm{~B}$ & & Total dissolved solids (TDS) & 160.1 \\
\hline $56-23-5$ & Carbon tetrachloride & $8260 B$ & & Total organic carbon (TOC) & 415.1 \\
\hline $108-90-7$ & Chlorobenzene & $8260 \mathrm{~B}$ & & Total organic halogen $(\mathrm{TOH})$ & $9020 \mathrm{~B}$ \\
\hline $67-66-3$ & Chloroform & $8260 \mathrm{~B}$ & & Total phenols & 420.1 \\
\hline $540-59-0$ & cis-1,2-Dichloroethylene & $8260 B$ & & Total suspended solids (TSS) & 160.2 \\
\hline 78-93-3 & Methyl ethyl ketone & $8260 \mathrm{~B}$ & & & \\
\hline 75-09-2 & Methylene chloride & $8260 \mathrm{~B}$ & & & \\
\hline $127-18-4$ & Tetrachloroethylene & 8260B & $7440-36-0$ & Antimony & $6010 \mathrm{~B}$ \\
\hline $108-88-3$ & Toluene & $8260 \mathrm{~B}$ & $7440-38-2$ & Arsenic & $6010 B$ \\
\hline 79-01-6 & Trichloroethylene & $8260 \mathrm{~B}$ & $7440-39-3$ & Barium & $6010 B$ \\
\hline $75-69-4$ & Trichlorofluoromethane & $8260 \mathrm{~B}$ & $7440-41-7$ & Beryllium & $6010 \mathrm{~B}$ \\
\hline 75-01-4 & Vinyl chloride & $8260 \mathrm{~B}$ & $7440-42-8$ & Boron & $6010 \mathrm{~B}$ \\
\hline $1330-20-7$ & Xylene & $8260 B$ & $7440-43-9$ & Cadmium & $6010 \mathrm{~B}$ \\
\hline $95-50-1$ & 1,2-Dichlorobenzene & $8270 \mathrm{C}$ & $7440-70-2$ & Calcium & $6010 \mathrm{~B}$ \\
\hline $106-46-7$ & 1,4-Dichlorobenzene & $8270 \mathrm{C}$ & $7440-47-3$ & Chromium & $6010 \mathrm{~B}$ \\
\hline $51-28-5$ & 2,4-Dinitrophenol & $8270 \mathrm{C}$ & $7440-48-4$ & Cobalt & $6010 B$ \\
\hline $121-14-2$ & 2,4-Dinitrotoluene & $8270 \mathrm{C}$ & $7440-50-8$ & Copper & $6010 \mathrm{~B}$ \\
\hline $95-48-7$ & 2-Methylphenol & $8270 \mathrm{C}$ & $7439-89-6$ & Iron & $6010 \mathrm{~B}$ \\
\hline \multirow[t]{2}{*}{$\begin{array}{l}108-39-4 / \\
106-44-5\end{array}$} & $\begin{array}{l}\text { 3-Methylphenol/ } \\
\text { 4-Methylphenol }\end{array}$ & $8270 \mathrm{C}$ & $7439-92-1$ & Lead & $6010 \mathrm{~B}$ \\
\hline & & & 7439-93-2 & Lithium & $6010 \mathrm{~B}$ \\
\hline $118-74-1$ & Hexachlorobenzene & $8270 \mathrm{C}$ & 7439-95-4 & Magnesium & $6010 \mathrm{~B}$ \\
\hline $67-72-1$ & Hexachloroethane & $8270 \mathrm{C}$ & $7439-97-6$ & Mercury & $7470 \mathrm{~A}$ \\
\hline 98-95-3 & Nitrobenzene & $8270 \mathrm{C}$ & $7440-02-0$ & Nickel & $6010 \mathrm{~B}$ \\
\hline 87-86-5 & Pentachlorophenol & $8270 \mathrm{C}$ & $7440-09-7$ & Potassium & $6010 \mathrm{~B}$ \\
\hline 110-86-1 & Pyridine & $8270 \mathrm{C}$ & $7782-49-2$ & Selenium & $6010 \mathrm{~B}$ \\
\hline \multirow[t]{2}{*}{ 78-83-1 } & Isobutanol & $8015 B$ & $7631-86-9$ & Silica & $6010 \mathrm{~B}$ \\
\hline & Alkalinity & 310.1 & $7440-22-4$ & Silver & $6010 \mathrm{~B}$ \\
\hline $7726-95-6$ & Bromide & 300.0 & $7440-23-5$ & Sodium & $6010 \mathrm{~B}$ \\
\hline \multirow[t]{4}{*}{$7782-50-5$} & Chloride & 300.0 & $7440-28-0$ & Thallium & $6010 \mathrm{~B}$ \\
\hline & Density $^{b}$ & & $7440-31-5$ & Tin & $6010 \mathrm{~B}$ \\
\hline & Fluoride & 300.0 & $7440-62-2$ & Vanadium & $6010 \mathrm{~B}$ \\
\hline & lodide & 345.1 & $7440-66-6$ & Zinc & $6010 \mathrm{~B}$ \\
\hline
\end{tabular}

${ }^{a}$ Chemical Abstract Service Registry Number

${ }^{\mathrm{b}}$ Analysis method was ASTM (American Society for Testing and Materials) D854-92 


\section{Waste Isolation Pilot Plant 2001 Site Environmental Report DOE/WIPP 02-2225}

\subsection{Groundwater Level Surveillance}

Groundwater surface elevations in the vicinity of WIPP may be influenced by site activities, such as pumping tests for site characterization, water quality sampling, or shaft sealing. Other influences on groundwater surface elevations may be caused by natural groundwater level fluctuations and industrial influences from agriculture, mining, and resource exploration.

In October 1988, WIPP was tasked with conducting a Groundwater Level Surveillance Program. Seventy well bores were used to perform surveillance of seven water-bearing zones in the WIPP area (Figure 6.2). The two zones of primary interest were the Culebra and Magenta members of the Rustler Formation (see Figure 1.1). Fifty-eight measurements were taken in the Culebra and ten in the Magenta. Three measurements were taken in the Dewey Lake Formation. One measurement each was taken in the Bell Canyon formation, Forty-niner, Rustler/Salado contact and an unnamed lower member of the Rustler formation. In 2001, groundwater level measurements were taken monthly in at least one accessible well bore at each well site for each available formation. Redundant well bores at each well site were measured on a quarterly basis.

Five well bores (WIPP-30 Culebra/Magenta, H-01 Culebra/Magenta, H-03d Dewey Lake/Forty-niner, Cabin Baby Culebra/Bell Canyon, and WIPP-25 Culebra/Magenta) were completed at multiple depths. By using packers, these well bores may be monitored in more than one formation.

Groundwater elevation measurements in the Culebra member indicated the generalized directional flow of groundwater was north to south in the vicinity of WIPP (Figure 6.3). Regional groundwater levels taken in Culebra observation wells with four or more data points for the year showed rising trends in water levels in 43 wells and falling trends in eight wells.

Total fluctuations of more than $0.6 \mathrm{~m}(2 \mathrm{ft})$ in groundwater levels occurred in nine wells completed to the Culebra. Two wells with fluctuations of more than $0.6 \mathrm{~m}(2 \mathrm{ft})$ (WQSP-3 and WQSP-6) may have been influenced by groundwater sampling activities. One well $(\mathrm{H}-9 \mathrm{~b})$ experienced water-level fluctuations due to maintenance activities. Two wells (ERDA-9 and WIPP-21) may have been influenced by plant activities, each of these wells is located in close proximity to the site property protection fence. C-2737 is a newly completed well. Fluctuations in C-2737 were caused by development activities. Two wells (WIPP-25 and WIPP-30) are recovering to previous water levels established prior to maintenance activities in August and September of 2000. One well with fluctuations more than $0.6 \mathrm{~m}$ (2 ft) (WIPP-27) is unexplained; however, WIPP-27 is located near local potash mining institutions and may be influenced by mining activities.

Groundwater level data were transmitted on a monthly basis to the NMED, EEG, Sandia National Laboratories, the Carlsbad Field Office Technical Assistance Contractor, and technical subcontractors as requested by the CBFO. A copy of the data was placed in the operating record for inspection by authorized agencies. 


\section{Waste Isolation Pilot Plant 2001 Site Environmental Report DOE/WIPP 02-2225}

Calculated Culebra flow rates across the Land Withdrawal Area range from $2.6 \times 10^{-5}$ feet per day (ft/d) in the northern section of the eastern third of the Land Withdrawal Area to $1.7 \times 10^{-3} \mathrm{ft} / \mathrm{d}$ in the western and central sections of the WIPP site. Calculated flow rates in the southeastern section of the WIPP site was $1.1 \times 10^{-3} \mathrm{ft} / \mathrm{d}$ (Figure 6.4).

The interpretation of groundwater data collected in 2001 are similar to previous years. To date there is no indication WIPP operations have had a measurable or significant impact on either the elevation or the quality of groundwater underlying WIPP.

Culebra groundwater in the vicinity of WIPP exhibits highly variable TDS concentrations. These variable TDS concentrations are reflected in a commensurate variability in groundwater density. Each year the WIPP conducts a program to measure the density of well-bore fluids in water level monitoring wells. Due to the high concentration of TDS in WIPP groundwater, density must be taken into account to accurately determine relative water levels between wells. Measured water levels are adjusted to equivalent fresh-water head values, considering fluid density differences between measuring points.

For the year 2001, the Pressure-Density Survey measured well-bore fluid density in eighteen wells. The following wells have had Pressure-Density Surveys completed.

\begin{tabular}{|l|l|l|l|}
\hline \multicolumn{1}{|c|}{ WELL NAME } & \multicolumn{1}{c|}{ DATE } & \multicolumn{1}{c|}{ FORMATION } & \multicolumn{1}{c|}{ DENSITY } \\
\hline $\mathrm{H}-06 \mathrm{~b}$ & $5 / 16 / 01$ & Culebra & $1.0371 \mathrm{~g} / \mathrm{cc}$ \\
\hline $\mathrm{DOE}-1$ & $5 / 18 / 01$ & Culebra & $1.093 \mathrm{~g} / \mathrm{cc}$ \\
\hline $\mathrm{H}-11 \mathrm{~b} 2$ & $5 / 31 / 01$ & Magenta & $1.070 \mathrm{~g} / \mathrm{cc}$ \\
\hline $\mathrm{H}-04 \mathrm{~b}$ & $6 / 4 / 01$ & Culebra & $1.0154 \mathrm{~g} / \mathrm{cc}$ \\
\hline $\mathrm{H}-03 \mathrm{~b} 2$ & $6 / 4 / 01$ & Culebra & $1.0334 \mathrm{~g} / \mathrm{cc}$ \\
\hline $\mathrm{H}-19 \mathrm{~b} 0$ & $6 / 5 / 01$ & Culebra & $1.0620 \mathrm{~g} / \mathrm{cc}$ \\
\hline $\mathrm{H}-11 \mathrm{~b} 4$ & $6 / 11 / 01$ & Culebra & $1.061 \mathrm{~g} / \mathrm{cc}$ \\
\hline $\mathrm{H}-17$ & $6 / 11 / 01$ & Culebra & $1.140 \mathrm{~g} / \mathrm{cc}$ \\
\hline $\mathrm{H}-09 \mathrm{~b}$ & $6 / 13 / 01$ & Culebra & $1.000 \mathrm{~g} / \mathrm{cc}$ \\
\hline $\mathrm{H}-14$ & $7 / 9 / 01$ & Magenta & $1.0294 \mathrm{~g} / \mathrm{cc}$ \\
\hline $\mathrm{H}-15$ & $7 / 9 / 01$ & Magenta & $1.0294 \mathrm{~g} / \mathrm{cc}$ \\
\hline $\mathrm{H}-18$ & $7 / 11 / 01$ & Magenta & $1.0294 \mathrm{~g} / \mathrm{cc}$ \\
\hline $\mathrm{DOE}-2$ & $7 / 11 / 01$ & Magenta & $1.0553 \mathrm{~g} / \mathrm{cc}$ \\
\hline $\mathrm{WIPP}-18$ & $7 / 12 / 01$ & Magenta & $1.0423 \mathrm{~g} / \mathrm{cc}$ \\
\hline $\mathrm{H}-06 \mathrm{cc}$ & $9 / 26 / 01$ & Magenta & $1.003 \mathrm{~g} / \mathrm{cc}$ \\
\hline $\mathrm{H}-05 \mathrm{~b}$ & $10 / 8 / 01$ & Culebra & $1.0981 \mathrm{~g} / \mathrm{cc}$ \\
\hline $\mathrm{H}-05 \mathrm{c}$ & $10 / 8 / 01$ & Magenta & $1.0045 \mathrm{~g} / \mathrm{cc}$ \\
\hline $\mathrm{H}-03 \mathrm{~b} 1$ & $10 / 9 / 01$ & Magenta & $1.0051 \mathrm{~g} / \mathrm{cc}$ \\
\hline
\end{tabular}




\subsection{Well Maintenance Activities}

Maintenance activities were performed on nine wells in CY 2001. Maintenance is performed to prepare wells for future experiments, repair nonfunctioning wells, recomplete wells to monitor additional zones of interest, and plugging and abandonment of wells that were no longer useful.

In 2001, SNL recompleted six Culebra wells (DOE-2, H-11b2, H-15, H-18, WIPP-18, and $\mathrm{H}-14$ ) as Magenta wells to support the compliance monitoring program for the CCA.

During the month of January well casings were brushed to clean scale off the side of the casing in wells DOE-2, $\mathrm{H}-11 \mathrm{~b} 2, \mathrm{H}-15, \mathrm{H}-18$, WIPP-18, and $\mathrm{P}-15$. P-15 well casing was discovered to have holes in the casing near the surface. As a result, $\mathrm{P}-15$ has been moved to the plugging and abandonment priority list.

In March 2001, the well casing at $\mathrm{H}-14$ was brushed to remove scale from the casing wall. Bridge plugs were set below the Magenta at DOE-2 (736 ft), H-11b2 (663 ft), H-14 (459 ft), $\mathrm{H}-15$ (792 ft), $\mathrm{H}-18$ (613 ft), and WIPP-18 (713 ft). All measurements are to the top of the bridge plug below land surface (BLS).

The well casings at $\mathrm{H}-7 \mathrm{~b} 1$ and $\mathrm{H}-7 \mathrm{c}$ were brushed and circulated in an attempt to remove obstructions in the well casings. The operations were successful in $\mathrm{H}-7 \mathrm{~b} 1$, however, $\mathrm{H}-7 \mathrm{c}$ remains obstructed, thus preventing groundwater level measurements.

During April 2001, Natural Gamma logs were run on wells DOE-2, $\mathrm{H}-11 \mathrm{~b} 2, \mathrm{H}-15, \mathrm{H}-18$, WIPP-18, and $\mathrm{H}-14$. After the gamma logs were completed each of the wells were jet perforated across the Magenta member of the Rustler formation.

Perforation depths in each of the wells are as follows:

$\begin{array}{ll}\text { DOE -2 } & 702-728 \mathrm{ft} \mathrm{BLS} \\ \text { H-11b2 } & 622-650 \mathrm{ft} \mathrm{BLS} \\ \text { H-15 } & 751-780 \mathrm{ft} \mathrm{BLS} \\ \text { H-18 } & 575-601 \mathrm{ft} \mathrm{BLS} \\ \text { WIPP-18 } & 676-702 \mathrm{ft} \mathrm{BLS} \\ \text { H-14 } & 428-455 \mathrm{ft} \mathrm{BLS}\end{array}$

After perforation was completed one well bore volume was bailed from each well.

Plugging and abandonment activities took place at $\mathrm{H}-1$ in February 2001. After cleaning and logging the well bore, $175 \mathrm{ft}$ of casing were removed from the well bore. The well was then cemented from the bottom of the well to the surface and a monument was placed at the surface in the top of the well bore.

New well construction was completed at C-2737 from February 14 through March 8, 2001. Well C-2737 is located in Southeastern Eddy County Section 29, T22S, R31E, $527 \mathrm{ft}$ from the east section line and 1,513 ft from the north section line. Well C-2737 
was drilled to provide hydrological monitoring of the Culebra and Magenta members of the Rustler Formation. Well C-2737 is a replacement for $\mathrm{H}-1$, which was plugged and abandoned as C-2737 was being completed. Well C-2737 was drilled to a total depth of $710 \mathrm{ft}$ BLS. Two screens were placed in the borehole one across the Magenta from 561 to $584 \mathrm{ft} \mathrm{BLS}$ and the second across the Culebra from 675 to $698 \mathrm{ft} \mathrm{BLS}$. Full details on the C-2737 well are available in DOE/WIPP 01-3210, Basic Data Report for Drillhole C-2737.

\subsection{Shallow Water Monitoring Program}

A third program included in this year's Site Environmental Report, is the Shallow Water Monitoring Program formerly titled the Exhaust Shaft Hydraulic Assessment Program. Investigations were conducted in 1996 and 1997 and described in DOE/WIPP 97-2119 and DOE/WIPP 97-2278 establishing a monitoring network for a shallow perched waterbearing horizon located at the base of the Santa Rosa Formation at the Dewey Lake contact (Figure 6.5). Additional background data has been presented in DOE/WIPP 99-2302, 99-3120, 00-2013, 01-3177 and 02-3177.

Groundwater monitoring activities during 2001 included groundwater quality sampling and groundwater level surveillance. Data were gathered from 16 wells and piezometers (Figure 6.6) completed through the Santa Rosa into the upper few feet of the Dewey Lake Formation.

\subsubsection{Groundwater Quality Sampling}

One round of water-quality samples involving the sampling of fifteen wells/piezometers was collected in year 2001 from the Shallow Water Monitoring Program. During groundwater surveillance activities removed less than twenty gallons per well/piezometer from the Santa Rosa Formation at the Dewey Lake contact. The waterbearing horizon in the Santa Rosa is transient (limited in areal extent). Wells are poor producers with flow rates of less than $2.0 \mathrm{gpm}$. The quality of the shallow water system sampled near the WIPP is poor and not suitable for human consumption. TDS concentrations measured in the Santa Rosa range from 2,300 mg/l to $134,000 \mathrm{mg} / \mathrm{l}$ (Tables 6.2 through 6.8). Three locations have TDS values of less than $10,000 \mathrm{mg} / \mathrm{l}$ : C-2507, PZ-10 and C-2811; all other locations have TDS values in excess of $10,000 \mathrm{mg} / \mathrm{l}$.

\subsubsection{Shallow Water Level Surveillance}

Sixteen wells were used to perform surveillance of the shallow perched water-bearing horizon in the Santa Rosa at the Dewey Lake contact. Water-level measurements were collected monthly. Fluctuations varied by less than 1.5 feet, with only PZ-12 and PZ-10 changing by more than one foot. Changes in the fluid levels appear to be in response decreased precipitation resulting in less recharge to the perched water-bearing horizon through surface runoff. 
Groundwater elevation measurements in the Santa Rosa at the Dewey Lake contact indicate that flow moves radially away from a potentiometric high located near PZ-7 adjacent to the Salt Water Evaporation Pond (Figure 6.7). A potentiometric low is located near PZ-12 between two retention ponds. A second low is PZ-8 located east of the site, which is presently a dry hole. Data from piezometer C-2811 located approximately 2,500 feet south of the site is not included in the contour plots because of a lack of sufficient data characterize the hydrology to the south. Projected work in year 2003 is intended to investigate the conditions to the south of the site. 


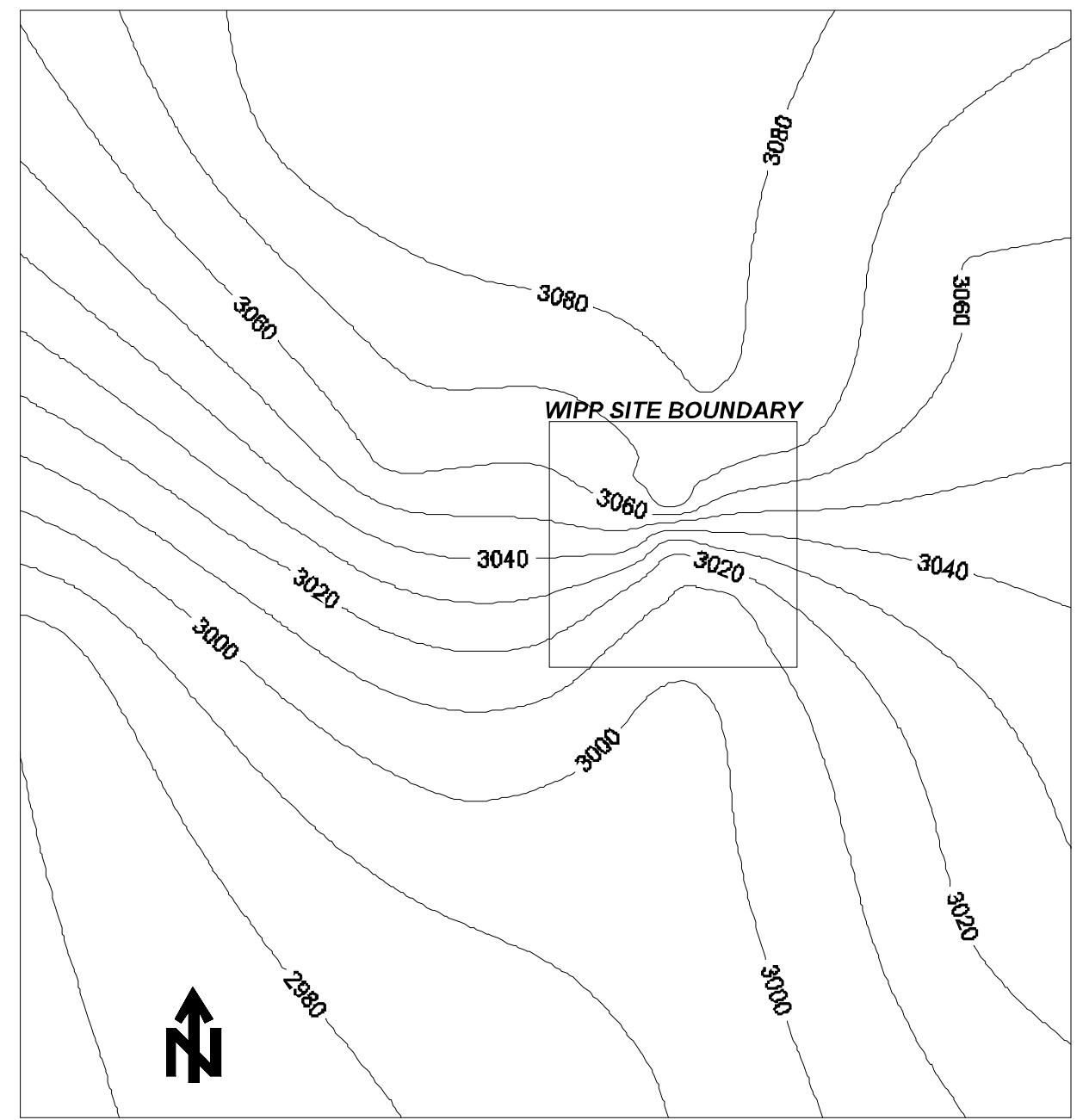

Note: Contour elevations are in feet above mean sea level.

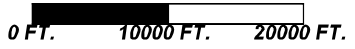

Figure 6.3 - Potentiometric Surface, Adjusted to Equivalent Freshwater Head, of the Culebra Dolomite Member of the Rustler Formation near the WIPP Site, December, 2001 


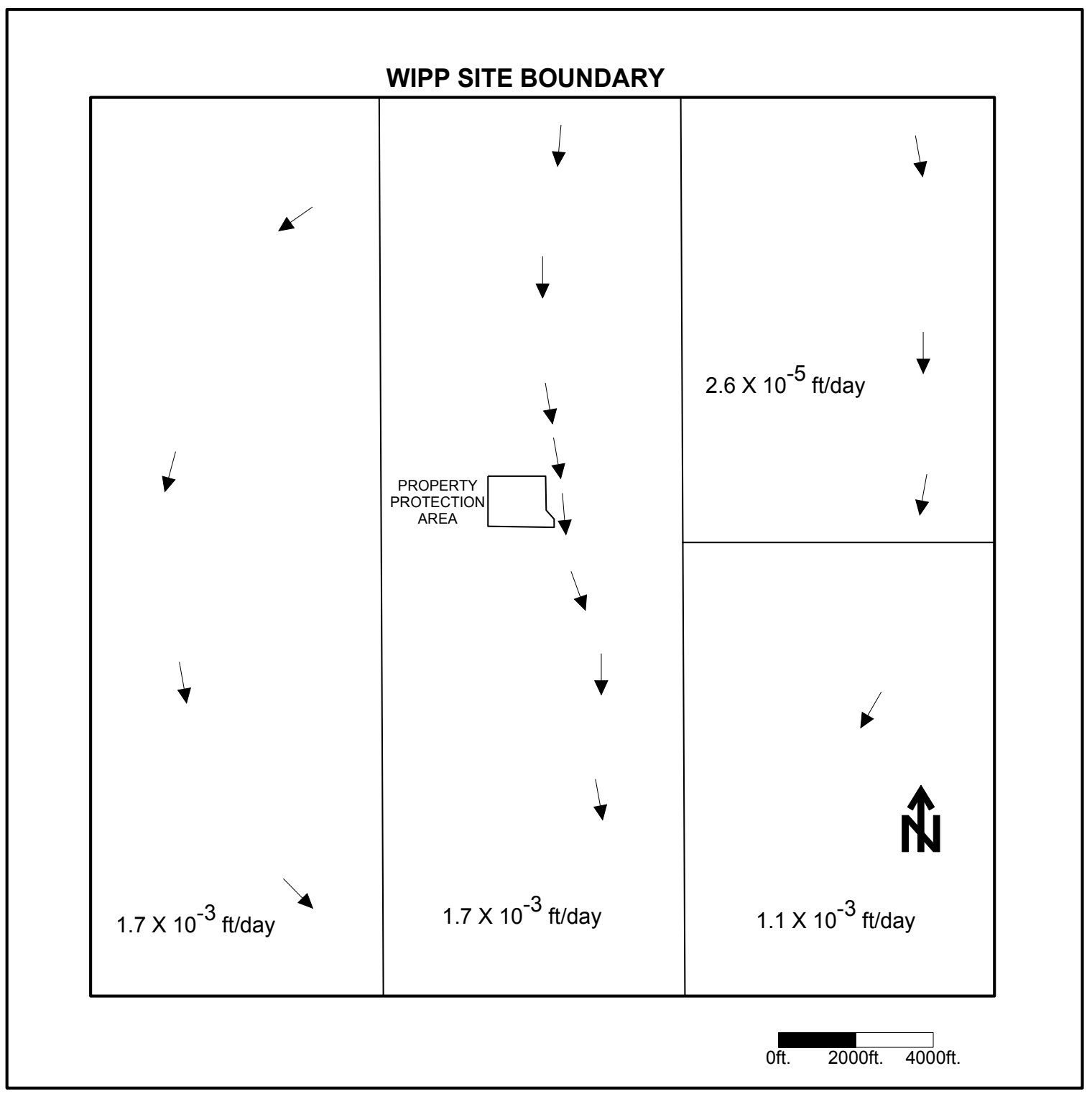

Figure 6.4 - Flow Rate and Direction of Groundwater Flowing Across the WIPP Site from the Culebra Formation, December 2001 
Waste Isolation Pilot Plant 2001 Site Environmental Report

DOE/WIPP 02-2225

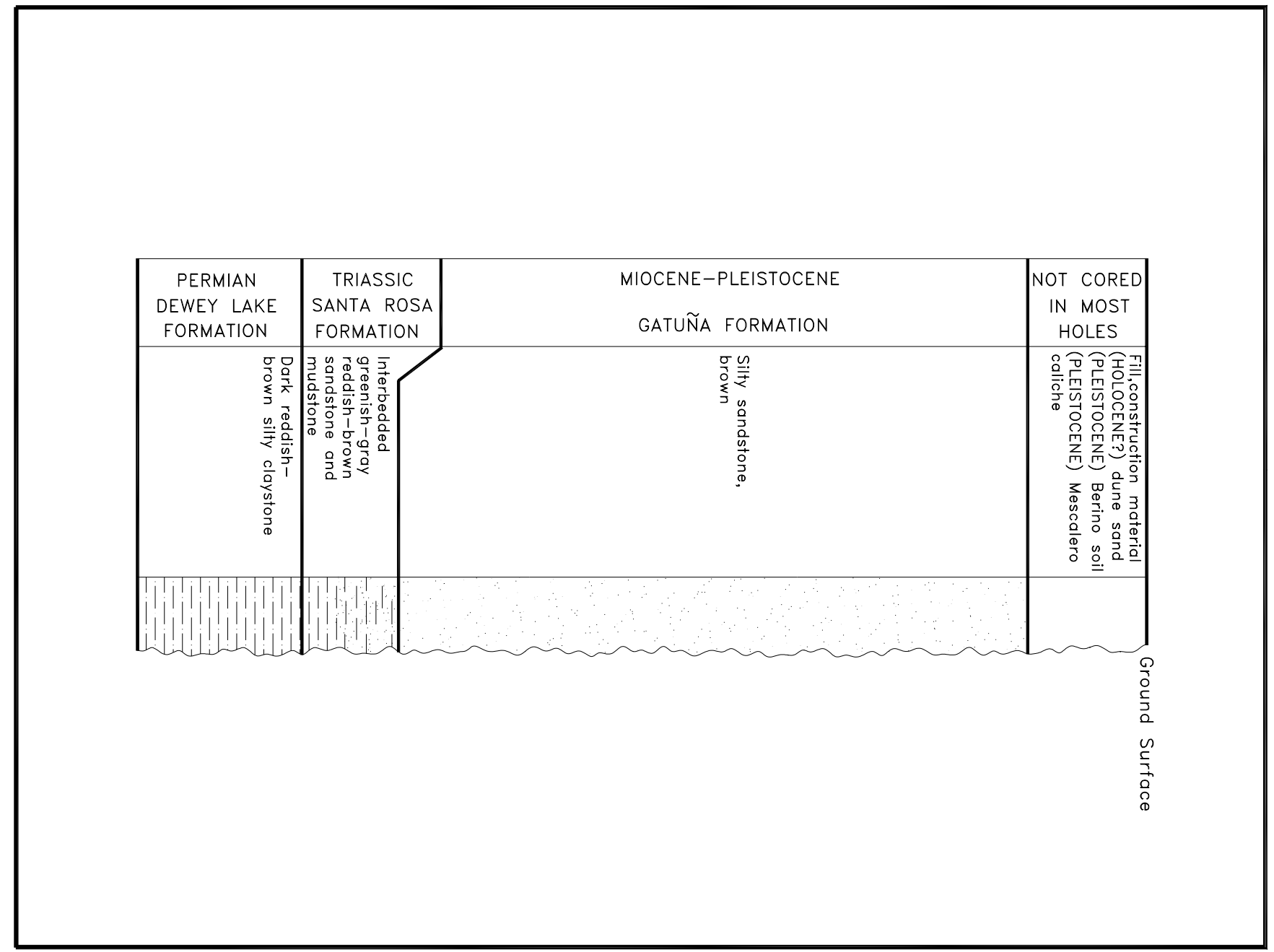

Figure 6.5 - Units Commonly Encountered During Shallow Drilling at WIPP 
Waste Isolation Pilot Plant 2001 Site Environmental Report DOE/WIPP 02-2225

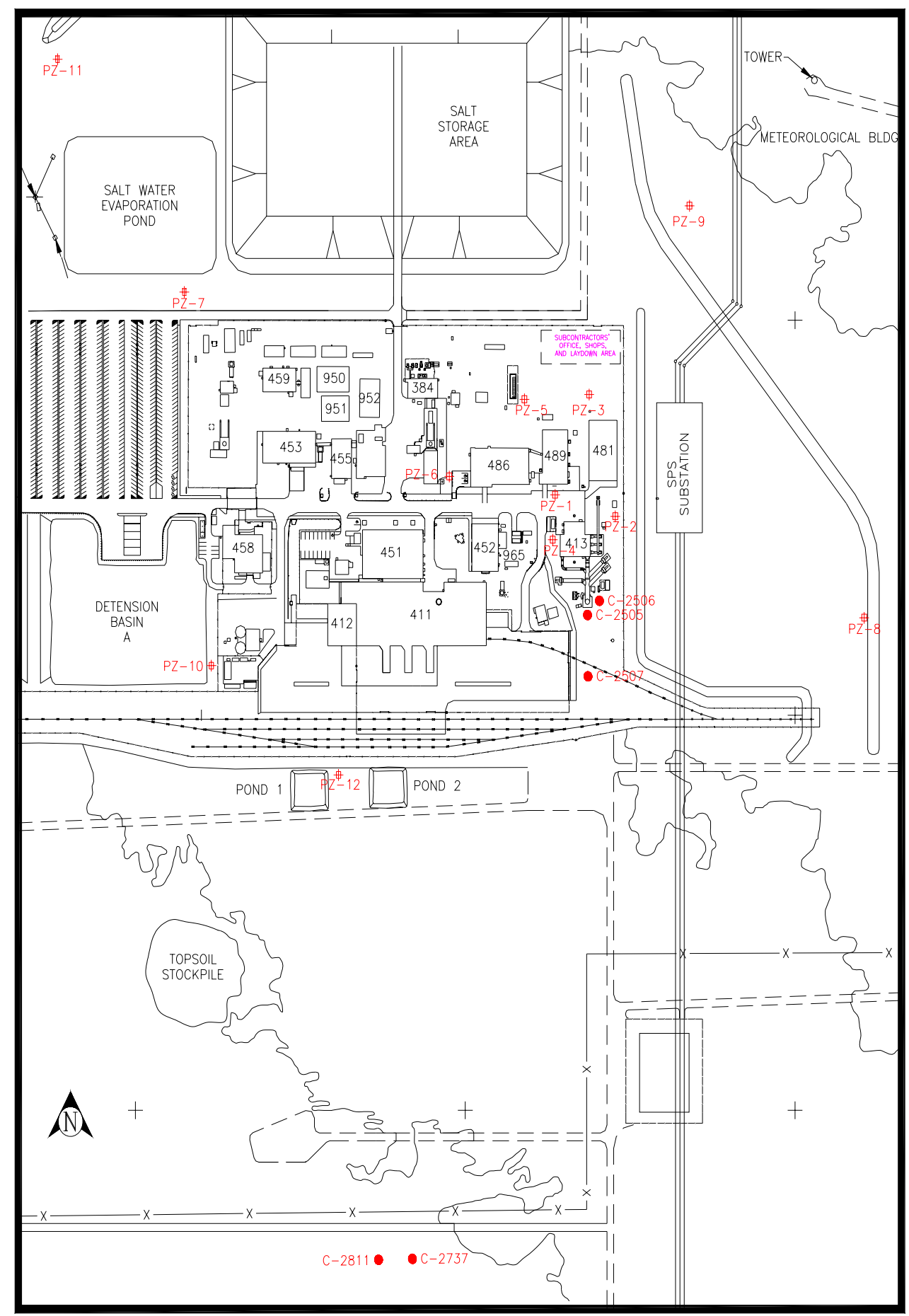

Figure 6.6 - Locations of Piezometers PZ-1 and C-2811, and Wells C-2505, C-2506, and C-2507 
Waste Isolation Pilot Plant 2001 Site Environmental Report DOE/WIPP 02-2225

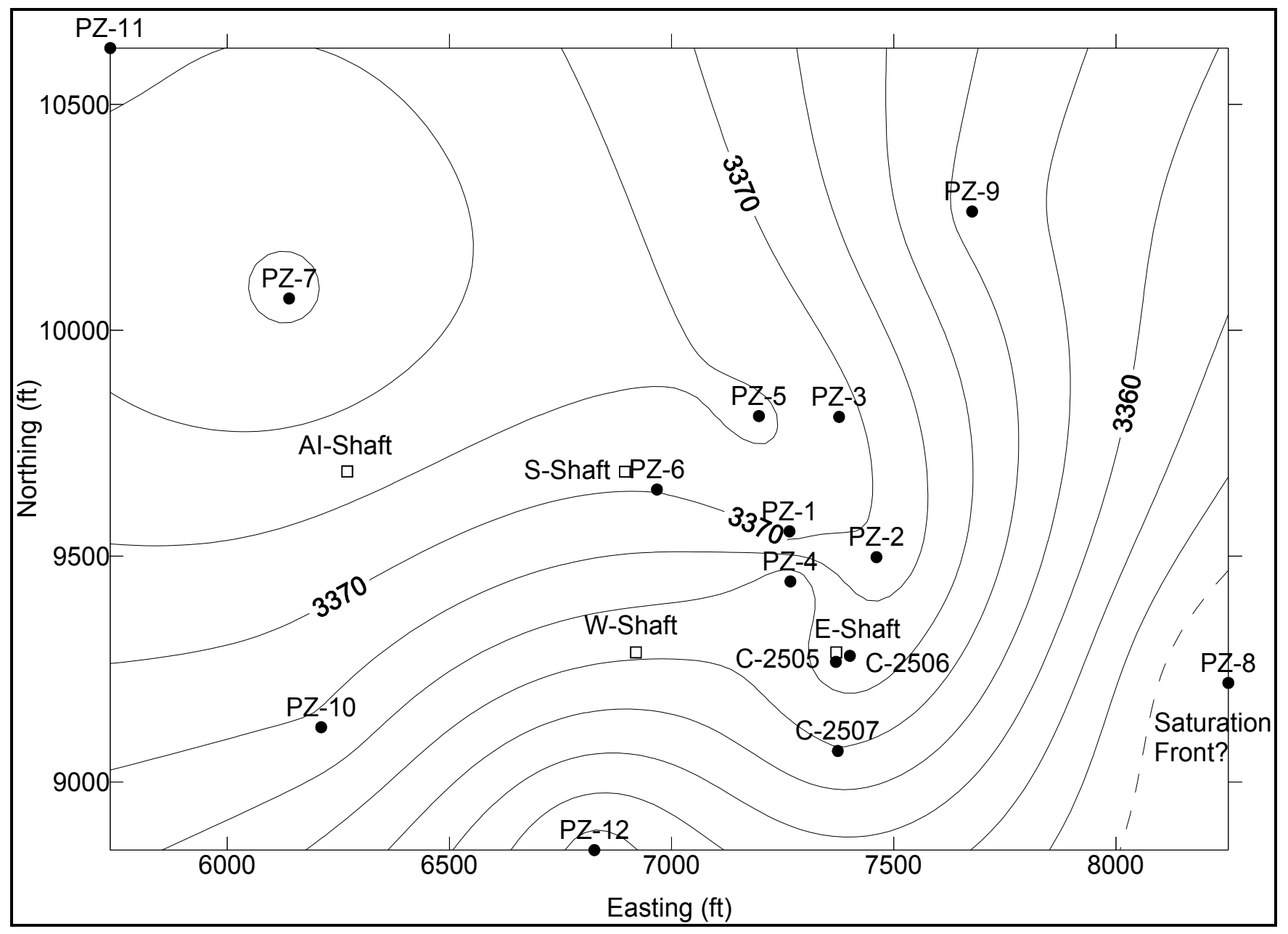

Figure 6.7 - Contour Plot of the Potentiometric Surface in the Santa Rosa Formation at the Dewey Lake Contract: December 2001 
Table 6.2 - Analytical Results for Groundwater Sampled from Well WQSP-1

\begin{tabular}{|c|c|c|c|c|c|c|c|c|}
\hline \multirow[b]{3}{*}{ Parameter } & \multicolumn{7}{|c|}{ Concentration } & \multirow[b]{3}{*}{$\begin{array}{c}95^{\text {th }} \\
\text { UTLV }^{\text {a }}\end{array}$} \\
\hline & \multicolumn{2}{|c|}{ Round 12} & \multicolumn{2}{|c|}{ Round 13} & \multirow[b]{2}{*}{ Units } & \multicolumn{2}{|c|}{ Reporting Limit } & \\
\hline & Sample & Dup. & Sample & Dup. & & $\begin{array}{c}\text { Round } \\
12\end{array}$ & $\begin{array}{c}\text { Round } \\
13\end{array}$ & \\
\hline 1,1,1-Trichloroethane & $<1$ & $<1$ & $<1$ & $<1$ & $\mu g / l$ & 1 & 1 & $<R L^{b}$ \\
\hline 1,1,2,2-Tetrachloroethane & $<1$ & $<1$ & $<1$ & $<1$ & $\mu g / l$ & 1 & 1 & $<R L$ \\
\hline 1,1,2-Trichloroethane & $<1$ & $<1$ & $<1$ & $<1$ & $\mu g / l$ & 1 & 1 & $<R L$ \\
\hline 1,1-Dichloroethane & $<1$ & $<1$ & $<1$ & $<1$ & $\mu g / l$ & 1 & 1 & $<R L$ \\
\hline 1,1-Dichloroethylene & $<1$ & $<1$ & $<1$ & $<1$ & $\mu g / l$ & 1 & 1 & $<\mathrm{RL}$ \\
\hline 1,2-Dichloroethane & $<1$ & $<1$ & $<1$ & $<1$ & $\mu g / l$ & 1 & 1 & $<\mathrm{RL}$ \\
\hline Carbon tetrachloride & $<1$ & $<1$ & $<1$ & $<1$ & $\mu g / l$ & 1 & 1 & $<\mathrm{RL}$ \\
\hline Chlorobenzene & $<1$ & $<1$ & $<1$ & $<1$ & $\mu g / l$ & 1 & 1 & $<\mathrm{RL}$ \\
\hline Chloroform & $<1$ & $<1$ & $<1$ & $<1$ & $\mu g / l$ & 1 & 1 & $<\mathrm{RL}$ \\
\hline cis-1,2-Dichloroethylene & $<1$ & $<1$ & $<1$ & $<1$ & $\mu g / l$ & 1 & 1 & $<\mathrm{RL}$ \\
\hline Methyl ethyl ketone & $<5$ & $<5$ & $<5$ & $<5$ & $\mu g / l$ & 5 & 5 & $<\mathrm{RL}$ \\
\hline Methylene chloride & $<5$ & $<5$ & $<5$ & $<5$ & $\mu g / l$ & 5 & 5 & $<\mathrm{RL}$ \\
\hline Tetrachloroethylene & $<1$ & $<1$ & $<1$ & $<1$ & $\mu g / l$ & 1 & 1 & $<\mathrm{RL}$ \\
\hline Toluene & $<1$ & $<1$ & $<1$ & $<1$ & $\mu g / l$ & 1 & 1 & $<\mathrm{RL}$ \\
\hline Trichloroethylene & $<1$ & $<1$ & $<1$ & $<1$ & $\mu g / l$ & 1 & 1 & $<\mathrm{RL}$ \\
\hline Trichlorofluoromethane & $<1$ & $<1$ & $<1$ & $<1$ & $\mu g / l$ & 1 & 1 & $<\mathrm{RL}$ \\
\hline Vinyl chloride & $<1$ & $<1$ & $<1$ & $<1$ & $\mu g / l$ & 1 & 1 & $<\mathrm{RL}$ \\
\hline Xylene & $<1$ & $<1$ & $<1$ & $<1$ & $\mu g / l$ & 1 & 1 & $<\mathrm{RL}$ \\
\hline 1,2-Dichlorobenzene & $<5$ & $<5$ & $<5$ & $<5$ & $\mu g / l$ & 5 & 5 & $<\mathrm{RL}$ \\
\hline 1,4-Dichlorobenzene & $<5$ & $<5$ & $<5$ & $<5$ & $\mu g / l$ & 5 & 5 & $<\mathrm{RL}$ \\
\hline 2,4-Dinitrophenol & $<5$ & $<5$ & $<5$ & $<5$ & $\mu g / l$ & 5 & 5 & $<\mathrm{RL}$ \\
\hline 2,4-Dinitrotoluene & $<5$ & $<5$ & $<5$ & $<5$ & $\mu g / l$ & 5 & 5 & $<\mathrm{RL}$ \\
\hline 2-Methylphenol & $<5$ & $<5$ & $<5$ & $<5$ & $\mu g / l$ & 5 & 5 & $<\mathrm{RL}$ \\
\hline $\begin{array}{l}\text { 3-Methylphenol/ } \\
\text { 4-Methylphenol }\end{array}$ & $<5$ & $<5$ & $<5$ & $<5$ & $\mu \mathrm{g} / \mathrm{l}$ & 5 & 5 & $<\mathrm{RL}$ \\
\hline Hexachlorobenzene & $<5$ & $<5$ & $<5$ & $<5$ & $\mu g / l$ & 5 & 5 & $<\mathrm{RL}$ \\
\hline Hexachloroethane & $<5$ & $<5$ & $<5$ & $<5$ & $\mu g / l$ & 5 & 5 & $<\mathrm{RL}$ \\
\hline Nitrobenzene & $<5$ & $<5$ & $<5$ & $<5$ & $\mu \mathrm{g} / \mathrm{l}$ & 5 & 5 & $<\mathrm{RL}$ \\
\hline Pentachlorophenol & $<5$ & $<5$ & $<5$ & $<5$ & $\mu g / l$ & 5 & 5 & $<\mathrm{RL}$ \\
\hline Pyridine & $<5$ & $<5$ & $<5$ & $<5$ & $\mu g / l$ & 5 & 5 & $<\mathrm{RL}$ \\
\hline Isobutanol & $<2$ & $<2$ & $<2$ & $<2$ & $\mathrm{mg} / \mathrm{l}$ & 2 & 2 & $<\mathrm{RL}$ \\
\hline Alkalinity & 51 & 52 & 50 & 52 & $\mathrm{mg} / \mathrm{l}$ & 4 & 4 & 55.7 \\
\hline Bromide & 33 & 30 & 26.8 & 25.8 & $\mathrm{mg} / \mathrm{l}$ & 1 & 1 & 51.8 \\
\hline Chloride & 37000 & 36000 & 35900 & 36100 & $\mathrm{mg} / \mathrm{l}$ & 0.5 & 0.5 & 39105 \\
\hline Density & 1.05 & 1.051 & 1.042 & 1.047 & $\mathrm{~g} / \mathrm{ml}$ & $N / A^{c}$ & $\mathrm{~N} / \mathrm{A}$ & 1.072 \\
\hline Fluoride & 1.5 & 1.4 & 1.09 & 1.08 & $\mathrm{mg} / \mathrm{l}$ & 0.2 & 0.1 & 4.36 \\
\hline lodide & $<2.0$ & $<2.0$ & $<2.0$ & $<2.0$ & $\mathrm{mg} / \mathrm{l}$ & 2 & 2 & 2 \\
\hline Nitrate (as N) & $<.10$ & $<.10$ & $<.10$ & $<.10$ & $\mathrm{mg} / \mathrm{l}$ & 0.1 & 0.1 & $<10$ \\
\hline Orthophosphate (as P) & $<0.04$ & $<0.04$ & $<0.040$ & 0.04 & $\mathrm{mg} / \mathrm{l}$ & 0.04 & 0.04 & 0.1 \\
\hline
\end{tabular}


Table 6.2 - Analytical Results for Groundwater Sampled from Well WQSP-1

\begin{tabular}{|c|c|c|c|c|c|c|c|c|}
\hline \multirow[b]{3}{*}{ Parameter } & \multicolumn{7}{|c|}{ Concentration } & \multirow[b]{3}{*}{$\begin{array}{c}95^{\text {th }} \\
\text { UTLV }^{\mathrm{a}}\end{array}$} \\
\hline & \multicolumn{2}{|c|}{ Round 12} & \multicolumn{2}{|c|}{ Round 13} & \multirow[b]{2}{*}{ Units } & \multicolumn{2}{|c|}{ Reporting Limit } & \\
\hline & Sample & Dup. & Sample & Dup. & & $\begin{array}{c}\text { Round } \\
12 \\
\end{array}$ & $\begin{array}{c}\text { Round } \\
13 \\
\end{array}$ & \\
\hline $\mathrm{pH}$ & 7.1 & 7.1 & 7.31 & 7.33 & $S U^{d}$ & $\mathrm{~N} / \mathrm{A}$ & $\mathrm{N} / \mathrm{A}$ & $6.89-7.65$ \\
\hline Specific conductance & 80000 & 81000 & 83800 & 83100 & $\mu \mathrm{mhos} / \mathrm{cm}$ & N/A & $\mathrm{N} / \mathrm{A}$ & 175000 \\
\hline Sulfate & 4900 & 4800 & 4730 & 4720 & $\mathrm{mg} / \mathrm{l}$ & 0.5 & 0.5 & 5757 \\
\hline Total dissolved solids & 63000 & 63000 & 68300 & 65700 & $\mathrm{mg} / \mathrm{l}$ & 10 & 10 & 80700 \\
\hline Total organic carbon & 1.15 & $<1.0$ & $<1.0$ & $<1.0$ & $\mathrm{mg} / \mathrm{l}$ & 1 & 1 & $<5.0$ \\
\hline Total organic halogen & 9.7 & 11.4 & 1.6 & 2.9 & $\mathrm{mg} / \mathrm{l}$ & $N / A$ & $N / A$ & 14.6 \\
\hline Total phenols & $<0.10$ & $<0.10$ & $<0.10$ & $<0.10$ & $\mathrm{mg} / \mathrm{l}$ & 0.1 & 0.1 & $<0.10$ \\
\hline Total suspended solids & $<1.0$ & $<1.0$ & $<1.0$ & $<1.0$ & $\mathrm{mg} / \mathrm{l}$ & 1 & 1 & 33.5 \\
\hline Antimony & $<0.025$ & $<0.025$ & $<0.025$ & $<0.025$ & $\mathrm{mg} / \mathrm{l}$ & 0.025 & 0.025 & 0.33 \\
\hline Arsenic & $<0.05$ & $<0.05$ & $<0.05$ & $<0.05$ & $\mathrm{mg} / \mathrm{l}$ & 0.05 & 0.05 & $<0.1$ \\
\hline Barium & $<0.10$ & $<0.10$ & $<0.10$ & $<0.10$ & $\mathrm{mg} / \mathrm{l}$ & 0.1 & 0.1 & $<1.0$ \\
\hline Beryllium & $<0.0025$ & $<0.0025$ & $<0.003$ & $<0.003$ & $\mathrm{mg} / \mathrm{l}$ & 0.003 & 0.003 & $<0.02$ \\
\hline Boron & 13.43 & 13.42 & 14.1 & 13.5 & $\mathrm{mg} / \mathrm{l}$ & 0.005 & 0.05 & 19.3 \\
\hline Cadmium & $<0.025$ & $<0.025$ & $<0.025$ & $<0.025$ & $\mathrm{mg} / \mathrm{l}$ & 0.025 & 0.025 & $<0.2$ \\
\hline Calcium & 1854 & 1794 & 1828 & $1 / 795$ & $\mathrm{mg} / \mathrm{l}$ & 0.5 & 0.2 & 2,087 \\
\hline Chromium & $<0.01$ & $<0.01$ & $<0.01$ & $<0.01$ & $\mathrm{mg} / \mathrm{l}$ & 0.01 & 0.01 & $<0.5$ \\
\hline Cobalt & $<0.025$ & $<0.025$ & $<0.025$ & $<0.025$ & $\mathrm{mg} / \mathrm{l}$ & 0.025 & 0.025 & 0.11 \\
\hline Copper & $<0.0125$ & $<0.0125$ & $<0.013$ & $<0.013$ & $\mathrm{mg} / \mathrm{l}$ & 0.0125 & 0.013 & $<1.0$ \\
\hline Iron & $<0.05$ & $<0.05$ & 0.08 & $<0.05$ & $\mathrm{mg} / \mathrm{l}$ & 0.05 & 0.05 & 1.32 \\
\hline Lead & 0.0124 & $<0.010$ & 0.013 & 0.01 & $\mathrm{mg} / \mathrm{l}$ & 0.01 & 0.01 & 0.105 \\
\hline Lithium & 0.719 & 0.693 & 0.88 & 0.841 & $\mathrm{mg} / \mathrm{l}$ & 0.005 & 0.01 & 0.547 \\
\hline Magnesium & 1255 & 1180 & 1262 & 1270 & $\mathrm{mg} / \mathrm{l}$ & 0.5 & 0.2 & 1,247 \\
\hline Mercury & $<0.0002$ & $<0.0002$ & $<0.0002$ & $<0.0002$ & $\mathrm{mg} / \mathrm{l}$ & 0 & 0 & $<0.002$ \\
\hline Nickel & $<0.025$ & $<0.025$ & $<0.025$ & $<0.025$ & $\mathrm{mg} / \mathrm{l}$ & 0.025 & 0.025 & 0.490 \\
\hline Potassium & 767 & 745 & 896 & 871 & $\mathrm{mg} / \mathrm{l}$ & 0.5 & 0.2 & 799 \\
\hline Selenium & $<0.05$ & $<0.05$ & $<0.05$ & $<0.05$ & $\mathrm{mg} / \mathrm{l}$ & 0.05 & 0.05 & 0.15 \\
\hline Silica & 6.39 & 6 & 4.75 & 4.61 & $\mathrm{mg} / \mathrm{l}$ & 0.05 & 0.05 & 17.9 \\
\hline Silver & $<0.0125$ & $<0.0125$ & $<0.013$ & $<0.013$ & $\mathrm{mg} / \mathrm{l}$ & 0.0125 & 0.013 & $<0.50$ \\
\hline Sodium & 19170 & 17460 & 18450 & 17430 & $\mathrm{mg} / \mathrm{l}$ & 0.5 & 0.2 & 22,090 \\
\hline Thallium & $<0.05$ & $<0.05$ & $<0.05$ & $<0.050$ & $\mathrm{mg} / \mathrm{l}$ & 0.05 & 0.05 & 0.98 \\
\hline Tin & $<0.025$ & $<0.025$ & $<0.025$ & $<0.025$ & $\mathrm{mg} / \mathrm{l}$ & 0.025 & 0.025 & 0.46 \\
\hline Vanadium & $<0.025$ & $<0.025$ & $<0.025$ & $<0.025$ & $\mathrm{mg} / \mathrm{l}$ & 0.025 & 0.025 & $<0.1$ \\
\hline Zinc & $<0.025$ & $<0.025$ & $<0.025$ & 0.037 & $\mathrm{mg} / \mathrm{l}$ & 0.025 & 0.025 & $<5.0$ \\
\hline
\end{tabular}


Table 6.3 - Analytical Results for Groundwater Sampled from Well WQSP-2

\begin{tabular}{|c|c|c|c|c|c|c|c|c|}
\hline \multirow[b]{3}{*}{ Parameter } & \multicolumn{7}{|c|}{ Concentration } & \multirow[b]{3}{*}{$\begin{array}{l}9^{\text {th }} \\
\text { UTLV }^{\mathrm{a}}\end{array}$} \\
\hline & \multicolumn{2}{|c|}{ Round 12} & \multicolumn{2}{|c|}{ Round 13} & \multirow[b]{2}{*}{ Units } & \multicolumn{2}{|c|}{ Reporting Limit } & \\
\hline & Sample & Dup. & Sample & Dup. & & $\begin{array}{c}\text { Round } \\
12\end{array}$ & $\begin{array}{c}\text { Round } \\
13\end{array}$ & \\
\hline 1,1,1-Trichloroethane & $<1$ & $<1$ & $<1$ & $<1$ & $\mu g / l$ & 1 & 1 & $<\mathrm{RL}^{\mathrm{b}}$ \\
\hline 1,1,2,2-Tetrachloroethane & $<1$ & $<1$ & $<1$ & $<1$ & $\mu \mathrm{g} / \mathrm{l}$ & 1 & 1 & $<\mathrm{RL}$ \\
\hline 1,1,2-Trichloroethane & $<1$ & $<1$ & $<1$ & $<1$ & $\mu \mathrm{g} / \mathrm{l}$ & 1 & 1 & $<\mathrm{RL}$ \\
\hline 1,1-Dichloroethane & $<1$ & $<1$ & $<1$ & $<1$ & $\mu g / l$ & 1 & 1 & $<\mathrm{RL}$ \\
\hline 1,1-Dichloroethylene & $<1$ & $<1$ & $<1$ & $<1$ & $\mu \mathrm{g} / \mathrm{l}$ & 1 & 1 & $<\mathrm{RL}$ \\
\hline 1,2-Dichloroethane & $<1$ & $<1$ & $<1$ & $<1$ & $\mu \mathrm{g} / \mathrm{l}$ & 1 & 1 & $<\mathrm{RL}$ \\
\hline Carbon tetrachloride & $<1$ & $<1$ & $<1$ & $<1$ & $\mu g / l$ & 1 & 1 & $<\mathrm{RL}$ \\
\hline Chlorobenzene & $<1$ & $<1$ & $<1$ & $<1$ & $\mu \mathrm{g} / \mathrm{l}$ & 1 & 1 & $<\mathrm{RL}$ \\
\hline Chloroform & $<1$ & $<1$ & $<1$ & $<1$ & $\mu g / l$ & 1 & 1 & $<\mathrm{RL}$ \\
\hline cis-1,2-Dichloroethylene & $<1$ & $<1$ & $<1$ & $<1$ & $\mu g / l$ & 1 & 1 & $<\mathrm{RL}$ \\
\hline Methyl ethyl ketone & $<5$ & $<5$ & $<5$ & $<5$ & $\mu \mathrm{g} / \mathrm{l}$ & 5 & 5 & $<\mathrm{RL}$ \\
\hline Methylene chloride & $<5$ & $<5$ & $<5$ & $<5$ & $\mu \mathrm{g} / \mathrm{l}$ & 5 & 5 & $<\mathrm{RL}$ \\
\hline Tetrachloroethylene & $<1$ & $<1$ & $<1$ & $<1$ & $\mu g / l$ & 1 & 1 & $<\mathrm{RL}$ \\
\hline Toluene & $<1$ & $<1$ & $<1$ & $<1$ & $\mu \mathrm{g} / \mathrm{l}$ & 1 & 1 & $<\mathrm{RL}$ \\
\hline Trichloroethylene & $<1$ & $<1$ & $<1$ & $<1$ & $\mu g / l$ & 1 & 1 & $<\mathrm{RL}$ \\
\hline Trichlorofluoromethane & $<1$ & $<1$ & $<1$ & $<1$ & $\mu g / l$ & 1 & 1 & $<\mathrm{RL}$ \\
\hline Vinyl chloride & $<1$ & $<1$ & $<1$ & $<1$ & $\mu \mathrm{g} / \mathrm{l}$ & 1 & 1 & $<\mathrm{RL}$ \\
\hline Xylene & $<1$ & $<1$ & $<1$ & $<1$ & $\mu \mathrm{g} / \mathrm{l}$ & 1 & 1 & $<\mathrm{RL}$ \\
\hline 1,2-Dichlorobenzene & $<5$ & $<5$ & $<5$ & $<5$ & $\mu g / l$ & 5 & 5 & $<\mathrm{RL}$ \\
\hline 1,4-Dichlorobenzene & $<5$ & $<5$ & $<5$ & $<5$ & $\mu g / l$ & 5 & 5 & $<\mathrm{RL}$ \\
\hline 2,4-Dinitrophenol & $<5$ & $<5$ & $<5$ & $<5$ & $\mu g / l$ & 5 & 5 & $<\mathrm{RL}$ \\
\hline 2,4-Dinitrotoluene & $<5$ & $<5$ & $<5$ & $<5$ & $\mu g / l$ & 5 & 5 & $<\mathrm{RL}$ \\
\hline 2-Methylphenol & $<5$ & $<5$ & $<5$ & $<5$ & $\mu g / l$ & 5 & 5 & $<\mathrm{RL}$ \\
\hline $\begin{array}{l}\text { 3-Methylphenol/ } \\
\text { 4-Methylphenol }\end{array}$ & $<5$ & $<5$ & $<5$ & $<5$ & $\mu g / l$ & 5 & 5 & $<\mathrm{RL}$ \\
\hline Hexachlorobenzene & $<5$ & $<5$ & $<5$ & $<5$ & $\mu \mathrm{g} / \mathrm{l}$ & 5 & 5 & $<\mathrm{RL}$ \\
\hline Hexachloroethane & $<5$ & $<5$ & $<5$ & $<5$ & $\mu g / l$ & 5 & 5 & $<\mathrm{RL}$ \\
\hline Nitrobenzene & $<5$ & $<5$ & $<5$ & $<5$ & $\mu g / l$ & 5 & 5 & $<\mathrm{RL}$ \\
\hline Pentachlorophenol & $<5$ & $<5$ & $<5$ & $<5$ & $\mu g / l$ & 5 & 5 & $<\mathrm{RL}$ \\
\hline Pyridine & $<5$ & $<5$ & $<5$ & $<5$ & $\mu g / l$ & 5 & 5 & $<\mathrm{RL}$ \\
\hline Isobutanol & $<2$ & $<2$ & $<2$ & $<2$ & $\mathrm{mg} / \mathrm{l}$ & 2 & 2 & $<\mathrm{RL}$ \\
\hline Alkalinity & 28 & 50 & 46 & 48 & $\mathrm{mg} / \mathrm{l}$ & 4 & 4 & 70.3 \\
\hline Bromide & 42 & 38 & 55.8 & 60.8 & $\mathrm{mg} / \mathrm{l}$ & 1 & 0.2 & 63.7 \\
\hline Chloride & 35000 & 36000 & 34900 & 34800 & $\mathrm{mg} / \mathrm{l}$ & 0.5 & 2 & 39670 \\
\hline Density & 1.0479 & 1.0449 & 1.0496 & 1.0364 & $\mathrm{~g} / \mathrm{ml}$ & $N / A^{d}$ & $\mathrm{~N} / \mathrm{A}$ & 1.06 \\
\hline Fluoride & 1.7 & 1.7 & 1.066 & 1.022 & $\mathrm{mg} / \mathrm{l}$ & 0.2 & 0.1 & 20 \\
\hline lodide & $<2.0$ & $<2.0$ & $<2.0$ & $<2.0$ & $\mathrm{mg} / \mathrm{l}$ & 2 & 2 & 2 \\
\hline Nitrate (as N) & $<0.1$ & $<0.1$ & $<0.1$ & $<0.1$ & $\mathrm{mg} / \mathrm{l}$ & 0.1 & 0.1 & $<10$ \\
\hline Orthophosphate (as $\mathrm{P}$ ) & $<0.04$ & $<0.04$ & $<0.040$ & $<0.04$ & $\mathrm{mg} / \mathrm{l}$ & 0.04 & 0.04 & 0.33 \\
\hline
\end{tabular}




\section{Waste Isolation Pilot Plant 2001 Site Environmental Report}

DOE/WIPP 02-2225

Table 6.3 - Analytical Results for Groundwater Sampled from Well WQSP-2

\begin{tabular}{|c|c|c|c|c|c|c|c|c|}
\hline \multirow[b]{3}{*}{ Parameter } & \multicolumn{7}{|c|}{ Concentration } & \multirow[b]{3}{*}{$\begin{array}{c}95^{\text {th }} \\
\text { UTLV }^{\text {a }}\end{array}$} \\
\hline & \multicolumn{2}{|c|}{ Round 12} & \multicolumn{2}{|c|}{ Round 13} & \multirow[b]{2}{*}{ Units } & \multicolumn{2}{|c|}{ Reporting Limit } & \\
\hline & Sample & Dup. & Sample & Dup. & & $\begin{array}{c}\text { Round } \\
12 \\
\end{array}$ & $\begin{array}{c}\text { Round } \\
13 \\
\end{array}$ & \\
\hline $\mathrm{pH}$ & 7.2 & 7.2 & 7.2 & 7.2 & $S U^{e}$ & N/A & $\mathrm{N} / \mathrm{A}$ & $7.00-7.60$ \\
\hline Specific conductance & 79000 & 80000 & 85200 & 85000 & $\mu \mathrm{mhos} / \mathrm{cm}$ & N/A & $N / A$ & 124000 \\
\hline Sulfate & 5200 & 5600 & 5160 & 5060 & $\mathrm{mg} / \mathrm{l}$ & 0.5 & 2 & 6590 \\
\hline Total dissolved solids & 62000 & 61000 & 62800 & 62800 & $\mathrm{mg} / \mathrm{l}$ & 10 & 10 & 80500 \\
\hline Total organic carbon & $<1.0$ & $<1.0$ & 2.91 & $<1.0$ & $\mathrm{mg} / \mathrm{l}$ & 1 & 1 & 7.97 \\
\hline Total organic halogen & 6.5 & 2.7 & 2 & 3 & $\mathrm{mg} / \mathrm{l}$ & 0.005 & 0.005 & 63.8 \\
\hline Total phenols & $<0.10$ & $<0.10$ & $<0.10$ & $<0.10$ & $\mathrm{mg} / \mathrm{l}$ & 0.1 & 0.1 & 0.16 \\
\hline Total suspended solids & $<1.0$ & $<1.0$ & $<1.0$ & $<1.0$ & $\mathrm{mg} / \mathrm{l}$ & 1 & 1 & 43 \\
\hline Antimony & $<0.025$ & $<0.025$ & $<0.025$ & $<0.025$ & $\mathrm{mg} / \mathrm{l}$ & 0.025 & 0.025 & $<0.50$ \\
\hline Arsenic & $<0.05$ & $<0.05$ & $<0.05$ & $<0.05$ & $\mathrm{mg} / \mathrm{l}$ & 0.05 & 0.05 & $<0.1$ \\
\hline Barium & $<0.10$ & $<0.10$ & $<0.10$ & $<0.10$ & $\mathrm{mg} / \mathrm{l}$ & 0.1 & 0.1 & $<1.0$ \\
\hline Beryllium & $<0.0025$ & $<0.0025$ & $<0.0025$ & $<0.0025$ & $\mathrm{mg} / \mathrm{l}$ & 0.003 & 0.003 & $<1.0$ \\
\hline Boron & 17.21 & 16.65 & 16.3 & 16 & $\mathrm{mg} / \mathrm{l}$ & 0.005 & 0.05 & 19.4 \\
\hline Cadmium & $<0.025$ & $<0.025$ & $<0.025$ & $<0.025$ & $\mathrm{mg} / \mathrm{l}$ & 0.025 & 0.025 & $<0.5$ \\
\hline Calcium & 1651 & 1715 & 1689 & 1676 & $\mathrm{mg} / \mathrm{l}$ & 0.5 & 0.2 & 1,827 \\
\hline Chromium & 0.01 & 0.01 & 0.01 & 0.01 & $\mathrm{mg} / \mathrm{l}$ & 0.01 & 0.01 & $<0.5$ \\
\hline Cobalt & $<0.025$ & $<0.025$ & $<0.025$ & $<0.025$ & $\mathrm{mg} / \mathrm{l}$ & 0.025 & 0.025 & 0.11 \\
\hline Copper & $<0.0125$ & $<0.0125$ & $<0.0125$ & $<0.0125$ & $\mathrm{mg} / \mathrm{l}$ & 0.0125 & 0.0125 & $<1.0$ \\
\hline Iron & $<0.50$ & $<0.50$ & $<0.05$ & $<0.05$ & $\mathrm{mg} / \mathrm{l}$ & 0.5 & 0.05 & 1.32 \\
\hline Lead & $<0.01$ & $<0.01$ & $<0.01$ & $<0.01$ & $\mathrm{mg} / \mathrm{l}$ & 0.01 & 0.01 & 0.163 \\
\hline Lithium & 0.727 & 0.681 & 0.92 & 0.913 & $\mathrm{mg} / \mathrm{l}$ & 0.005 & 0.01 & 0.493 \\
\hline Magnesium & 1199 & 1188 & 1175 & 1193 & $\mathrm{mg} / \mathrm{l}$ & 0.5 & 0.2 & 1,310 \\
\hline Mercury & $<0.0002$ & $<0.0002$ & $<0.0002$ & $<0.0002$ & $\mathrm{mg} / \mathrm{l}$ & 0 & 0 & $<0.002$ \\
\hline Nickel & $<0.025$ & $<0.025$ & $<0.025$ & $<0.025$ & $\mathrm{mg} / \mathrm{l}$ & 0.025 & 0.025 & 0.490 \\
\hline Potassium & 706 & 768 & 841 & 856 & $\mathrm{mg} / \mathrm{l}$ & 0.5 & 0.2 & 845 \\
\hline Selenium & $<0.05$ & $<0.05$ & $<0.05$ & $<0.05$ & $\mathrm{mg} / \mathrm{l}$ & 0.05 & 0.05 & 0.150 \\
\hline Silica & 5.67 & 5.47 & 4.72 & 4.41 & $\mathrm{mg} / \mathrm{l}$ & 0.05 & 0.5 & 24.0 \\
\hline Silver & $<0.0125$ & $<0.0125$ & $<0.0125$ & $<0.0125$ & $\mathrm{mg} / \mathrm{l}$ & 0.0125 & 0.0125 & $<0.50$ \\
\hline Sodium & 19790 & 21340 & 20910 & 21060 & $\mathrm{mg} / \mathrm{l}$ & 0.5 & 0.2 & 21,900 \\
\hline Thallium & $<0.05$ & $<0.05$ & $<0.05$ & $<0.05$ & $\mathrm{mg} / \mathrm{l}$ & 0.05 & 0.05 & 0.98 \\
\hline Tin & $<0.025$ & $<0.025$ & $<0.025$ & $<0.025$ & $\mathrm{mg} / \mathrm{l}$ & 0.025 & 0.025 & 0.46 \\
\hline Vanadium & $<0.025$ & $<0.025$ & $<0.025$ & $<0.025$ & $\mathrm{mg} / \mathrm{l}$ & 0.025 & 0.025 & $<0.1$ \\
\hline Zinc & $<0.025$ & $<0.025$ & $<0.025$ & $<0.025$ & $\mathrm{mg} / \mathrm{l}$ & 0.025 & 0.025 & $<5.0$ \\
\hline
\end{tabular}


Table 6.4 - Analytical Results for Groundwater Sampled from Well WQSP-3

\begin{tabular}{|c|c|c|c|c|c|c|c|c|}
\hline \multirow[b]{3}{*}{ Parameter } & \multicolumn{7}{|c|}{ Concentration } & \multirow[b]{3}{*}{$\begin{array}{l}95^{\text {th }} \\
\text { UTLV }^{\mathrm{a}}\end{array}$} \\
\hline & \multicolumn{2}{|c|}{ Round 12} & \multicolumn{2}{|c|}{ Round 13} & \multirow[b]{2}{*}{ Units } & \multicolumn{2}{|c|}{ Reporting Limit } & \\
\hline & Sample & Dup. & Sample & Dup. & & $\begin{array}{c}\text { Round } \\
12\end{array}$ & $\begin{array}{c}\text { Round } \\
13\end{array}$ & \\
\hline 1,1,1-Trichloroethane & $<1$ & $<1$ & $<1$ & $<1$ & $\mu \mathrm{g} / \mathrm{l}$ & 1 & 1 & $<\mathrm{RL}^{\mathrm{b}}$ \\
\hline 1,1,2,2-Tetrachloroethane & $<1$ & $<1$ & $<1$ & $<1$ & $\mu g / l$ & 1 & 1 & $<\mathrm{RL}$ \\
\hline 1,1,2-Trichloroethane & $<1$ & $<1$ & $<1$ & $<1$ & $\mu \mathrm{g} / \mathrm{l}$ & 1 & 1 & $<\mathrm{RL}$ \\
\hline 1,1-Dichloroethane & $<1$ & $<1$ & $<1$ & $<1$ & $\mu \mathrm{g} / \mathrm{l}$ & 1 & 1 & $<R L$ \\
\hline 1,1-Dichloroethylene & $<1$ & $<1$ & $<1$ & $<1$ & $\mu \mathrm{g} / \mathrm{l}$ & 1 & 1 & $<R L$ \\
\hline 1,2-Dichloroethane & $<1$ & $<1$ & $<1$ & $<1$ & $\mu \mathrm{g} / \mathrm{l}$ & 1 & 1 & $<\mathrm{RL}$ \\
\hline Carbon tetrachloride & $<1$ & $<1$ & $<1$ & $<1$ & $\mu \mathrm{g} / \mathrm{l}$ & 1 & 1 & $<R L$ \\
\hline Chlorobenzene & $<1$ & $<1$ & $<1$ & $<1$ & $\mu g / l$ & 1 & 1 & $<R L$ \\
\hline Chloroform & $<1$ & $<1$ & $<1$ & $<1$ & $\mu \mathrm{g} / \mathrm{l}$ & 1 & 1 & $<\mathrm{RL}$ \\
\hline cis-1,2-Dichloroethylene & $<1$ & $<1$ & $<1$ & $<1$ & $\mu \mathrm{g} / \mathrm{l}$ & 1 & 1 & $<\mathrm{RL}$ \\
\hline Methyl ethyl ketone & $<5$ & $<5$ & $<5$ & $<5$ & $\mu \mathrm{g} / \mathrm{l}$ & 5 & 5 & $<\mathrm{RL}$ \\
\hline Methylene chloride & $<5$ & $<5$ & $<5$ & $<5$ & $\mu \mathrm{g} / \mathrm{l}$ & 5 & 5 & $<R L$ \\
\hline Tetrachloroethylene & $<1$ & $<1$ & $<1$ & $<1$ & $\mu \mathrm{g} / \mathrm{l}$ & 1 & 1 & $<\mathrm{RL}$ \\
\hline Toluene & $<1$ & $<1$ & $<1$ & $<1$ & $\mu g / l$ & 1 & 1 & $<\mathrm{RL}$ \\
\hline Trichloroethylene & $<1$ & $<1$ & $<1$ & $<1$ & $\mu \mathrm{g} / \mathrm{l}$ & 1 & 1 & $<R L$ \\
\hline Trichlorofluoromethane & $<1$ & $<1$ & $<1$ & $<1$ & $\mu \mathrm{g} / \mathrm{l}$ & 1 & 1 & $<R L$ \\
\hline Vinyl chloride & $<1$ & $<1$ & $<1$ & $<1$ & $\mu g / l$ & 1 & 1 & $<\mathrm{RL}$ \\
\hline Xylene & $<1$ & $<1$ & $<1$ & $<1$ & $\mu \mathrm{g} / \mathrm{l}$ & 1 & 1 & $<R L$ \\
\hline 1,2-Dichlorobenzene & $<5$ & $<5$ & $<5$ & $<5$ & $\mu \mathrm{g} / \mathrm{l}$ & 5 & 5 & $<R L$ \\
\hline 1,4-Dichlorobenzene & $<5$ & $<5$ & $<5$ & $<5$ & $\mu \mathrm{g} / \mathrm{l}$ & 5 & 5 & $<R L$ \\
\hline 2,4-Dinitrophenol & $<5$ & $<5$ & $<5$ & $<5$ & $\mu \mathrm{g} / \mathrm{l}$ & 5 & 5 & $<R L$ \\
\hline 2,4-Dinitrotoluene & $<5$ & $<5$ & $<5$ & $<5$ & $\mu \mathrm{g} / \mathrm{l}$ & 5 & 5 & $<\mathrm{RL}$ \\
\hline 2-Methylphenol & $<5$ & $<5$ & $<5$ & $<5$ & $\mu \mathrm{g} / \mathrm{l}$ & 5 & 5 & $<\mathrm{RL}$ \\
\hline $\begin{array}{l}\text { 3-Methylphenol/ } \\
\text { 4-Methylphenol }\end{array}$ & $<5$ & $<5$ & $<5$ & $<5$ & $\mu g / l$ & 5 & 5 & $<\mathrm{RL}$ \\
\hline Hexachlorobenzene & $<5$ & $<5$ & $<5$ & $<5$ & $\mu g / l$ & 5 & 5 & $<R L$ \\
\hline Hexachloroethane & $<5$ & $<5$ & $<5$ & $<5$ & $\mu \mathrm{g} / \mathrm{l}$ & 5 & 5 & $<R L$ \\
\hline Nitrobenzene & $<5$ & $<5$ & $<5$ & $<5$ & $\mu g / l$ & 5 & 5 & $<\mathrm{RL}$ \\
\hline Pentachlorophenol & $<5$ & $<5$ & $<5$ & $<5$ & $\mu g / l$ & 5 & 5 & $<R L$ \\
\hline Pyridine & $<5$ & $<5$ & $<5$ & $<5$ & $\mu g / l$ & 5 & 5 & $<R L$ \\
\hline Isobutanol & $<2$ & $<2$ & $<2$ & $<2$ & $\mathrm{mg} / \mathrm{l}$ & 2 & 2 & $<\mathrm{RL}$ \\
\hline Alkalinity & 34 & 32 & 32 & 34 & $\mathrm{mg} / \mathrm{l}$ & 4 & 4 & 54.5 \\
\hline Bromide & 80 & 78 & 127 & 122 & $\mathrm{mg} / \mathrm{l}$ & 1 & 0.2 & 137 \\
\hline Chloride & 130000 & 130000 & 131000 & 129000 & $\mathrm{mg} / \mathrm{l}$ & 0.5 & 2 & 149100 \\
\hline Density & 1.131 & 1.132 & 1.152 & 1.146 & $\mathrm{~g} / \mathrm{ml}$ & $N / A^{d}$ & $\mathrm{~N} / \mathrm{A}$ & 1.17 \\
\hline Fluoride & 0.71 & 0.69 & 0.938 & 0.92 & $\mathrm{mg} / \mathrm{l}$ & 0.1 & 0.1 & $<10.0$ \\
\hline lodide & $<2.0$ & $<2.0$ & $<2.0$ & $<2.0$ & $\mathrm{mg} / \mathrm{l}$ & 2 & 2 & 2.18 \\
\hline Nitrate (as N) & $<0.10$ & $<0.10$ & $<0.10$ & $<0.10$ & $\mathrm{mg} / \mathrm{l}$ & 0.1 & 0.1 & 12 \\
\hline Orthophosphate (as $\mathrm{P}$ ) & $<0.04$ & $<0.04$ & 0.118 & 0.0923 & $\mathrm{mg} / \mathrm{l}$ & 0.04 & 0.04 & 0.41 \\
\hline
\end{tabular}


Waste Isolation Pilot Plant 2001 Site Environmental Report DOE/WIPP 02-2225

Table 6.4 - Analytical Results for Groundwater Sampled from Well WQSP-3

\begin{tabular}{|c|c|c|c|c|c|c|c|c|}
\hline \multirow[b]{3}{*}{ Parameter } & \multicolumn{5}{|c|}{ Concentration } & & & \multirow[b]{3}{*}{$\begin{array}{l}95^{\text {th }} \\
\text { UTLV }^{\mathrm{a}}\end{array}$} \\
\hline & \multicolumn{2}{|c|}{ Round 12} & \multicolumn{2}{|c|}{ Round 13} & \multirow[b]{2}{*}{ Units } & \multicolumn{2}{|c|}{ Reporting Limit } & \\
\hline & Sample & Dup. & Sample & Dup. & & $\begin{array}{c}\text { Round } \\
12 \\
\end{array}$ & $\begin{array}{c}\text { Round } \\
13\end{array}$ & \\
\hline $\mathrm{pH}$ & 6.6 & 6.6 & 6.77 & 6.79 & $S U^{e}$ & $\mathrm{~N} / \mathrm{A}$ & $\mathrm{N} / \mathrm{A}$ & $\begin{array}{c}6.60-7.2 \\
0\end{array}$ \\
\hline Specific conductance & 194000 & 205000 & 195000 & 197000 & $\mu \mathrm{mhos} / \mathrm{cm}$ & $\mathrm{N} / \mathrm{A}$ & $N / A$ & 517000 \\
\hline Sulfate & 7200 & 7200 & 7460 & 7190 & $\mathrm{mg} / \mathrm{l}$ & 0.5 & 2 & 8015 \\
\hline Total dissolved solids & 204000 & 210000 & 234000 & 215000 & $\mathrm{mg} / \mathrm{l}$ & 10 & 10 & 261000 \\
\hline Total organic carbon & $<1.0$ & $<1.0$ & $<1.0$ & $<1.0$ & $\mathrm{mg} / \mathrm{l}$ & 1 & 1 & $<5.0$ \\
\hline Total organic halogen & 10 & 5.3 & 5.8 & 6.2 & $\mathrm{mg} / \mathrm{l}$ & NR & 0.005 & 55 \\
\hline Total phenols & $<0.10$ & $<0.10$ & 0.153 & 0.162 & $\mathrm{mg} / \mathrm{l}$ & 0.1 & 0.1 & 0.26 \\
\hline Total suspended solids & $<1.0$ & $<1.0$ & 82 & 92 & $\mathrm{mg} / \mathrm{l}$ & 1 & 1 & 107 \\
\hline Antimony & $<0.013$ & $<0.013$ & $<0.125$ & $<0.125$ & $\mathrm{mg} / \mathrm{l}$ & 0.013 & 0.125 & $<1.0$ \\
\hline Arsenic & $<0.05$ & $<0.05$ & $<0.05$ & $<0.05$ & $\mathrm{mg} / \mathrm{l}$ & 0.05 & 0.05 & 0.207 \\
\hline Barium & $<0.02$ & $<0.02$ & $<0.50$ & $<0.50$ & $\mathrm{mg} / \mathrm{l}$ & 0.02 & 0.5 & $<1.0$ \\
\hline Beryllium & $<0.01$ & $<0.01$ & $<0.0125$ & $<0.0125$ & $\mathrm{mg} / \mathrm{l}$ & 0.01 & 0.0125 & $<0.1$ \\
\hline Boron & 44 & 51.4 & 78.8 & 59.5 & $\mathrm{mg} / \mathrm{l}$ & 0.05 & 0.05 & 55.9 \\
\hline Cadmium & $<0.01$ & $<0.01$ & $<0.05$ & $<0.05$ & $\mathrm{mg} / \mathrm{l}$ & 0.01 & 0.05 & $<0.5$ \\
\hline Calcium & 1310 & 1300 & 1537 & 1430 & $\mathrm{mg} / \mathrm{l}$ & 0.5 & 0.2 & 1,680 \\
\hline Chromium & $<0.025$ & $<0.025$ & $<0.050$ & 0.05 & $\mathrm{mg} / \mathrm{l}$ & 0.025 & 0.05 & $<2.0$ \\
\hline Cobalt & $<0.013$ & $<0.013$ & $<0.125$ & $<0.125$ & $\mathrm{mg} / \mathrm{l}$ & 0.013 & 0.125 & $<5.0$ \\
\hline Copper & $<0.050$ & $<0.050$ & $<0.0625$ & $<0.0625$ & $\mathrm{mg} / \mathrm{l}$ & 0.05 & 0.0625 & $<1.0$ \\
\hline Iron & $<0.50$ & $<0.50$ & $<0.25$ & $<0.25$ & $\mathrm{mg} / \mathrm{l}$ & 0.5 & 0.25 & $<1.0$ \\
\hline Lead & $<0.02$ & $<0.02$ & $<0.10$ & $<0.10$ & $\mathrm{mg} / \mathrm{l}$ & 0.02 & 0.1 & 0.80 \\
\hline Lithium & 0.527 & 0.492 & 1.28 & 1.28 & $\mathrm{mg} / \mathrm{l}$ & 0.01 & 0.01 & 2.76 \\
\hline Magnesium & 2120 & 2040 & 2455 & 2312 & $\mathrm{mg} / \mathrm{l}$ & 0.5 & 0.2 & 2,625 \\
\hline Mercury & $<0.0002$ & $<0.0002$ & $<0.0002$ & $<0.0002$ & $\mathrm{mg} / \mathrm{l}$ & 0 & 0 & $<0.002$ \\
\hline Nickel & $<0.025$ & $<0.025$ & $<0.05$ & $<0.05$ & $\mathrm{mg} / \mathrm{l}$ & 0.025 & 0.05 & $<5.00$ \\
\hline Potassium & 2180 & 2190 & 3035 & 2862 & $\mathrm{mg} / \mathrm{l}$ & .0 .50 & 0.2 & 3,438 \\
\hline Selenium & 0.033 & 0.041 & $<0.250$ & $<0.250$ & $\mathrm{mg} / \mathrm{l}$ & 0.013 & 0.25 & $<2.00$ \\
\hline Silica & 1.84 & 1.82 & 2 & 1.62 & $\mathrm{mg} / \mathrm{l}$ & 0.5 & 0.5 & 7.20 \\
\hline Silver & $<0.013$ & $<0.013$ & $<0.0625$ & $<0.0625$ & $\mathrm{mg} / \mathrm{l}$ & 0.013 & 0.0625 & 0.31 \\
\hline Sodium & 68300 & 71100 & 81600 & 74400 & $\mathrm{mg} / \mathrm{l}$ & 0.5 & 0.2 & 140,400 \\
\hline Thallium & $<0.013$ & $<0.010$ & $<0.100$ & $<0.100$ & $\mathrm{mg} / \mathrm{l}$ & 0.013 & 0.1 & 5.800 \\
\hline Tin & $<0.025$ & $<0.025$ & $<0.125$ & $<0.125$ & $\mathrm{mg} / \mathrm{l}$ & 0.025 & 0.125 & $<5.00$ \\
\hline Vanadium & $<0.025$ & $<0.025$ & $<0.125$ & $<0.125$ & $\mathrm{mg} / \mathrm{l}$ & 0.025 & 0.125 & $<5.00$ \\
\hline Zinc & $<0.050$ & $<0.050$ & $<0.125$ & $<0.125$ & $\mathrm{mg} / \mathrm{l}$ & 0.05 & 0.125 & 2.70 \\
\hline
\end{tabular}


Table 6.5 - Analytical Results for Groundwater Sampled from Well WQSP-4

\begin{tabular}{|c|c|c|c|c|c|c|c|c|}
\hline \multirow[b]{3}{*}{ Parameter } & \multicolumn{7}{|c|}{ Concentration } & \multirow[b]{3}{*}{$\begin{array}{l}95^{\text {th }} \\
\text { UTLV }^{\text {a }}\end{array}$} \\
\hline & \multicolumn{2}{|c|}{ Round 12} & \multicolumn{2}{|c|}{ Round 13} & \multirow[b]{2}{*}{ Units } & \multicolumn{2}{|c|}{ Reporting Limit } & \\
\hline & Sample & Dup. & Sample & Dup. & & $\begin{array}{c}\text { Round } \\
12\end{array}$ & $\begin{array}{c}\text { Round } \\
13\end{array}$ & \\
\hline 1,1,1-Trichloroethane & $<1$ & $<1$ & $<1$ & $<1$ & $\mu \mathrm{g} / \mathrm{l}$ & 1 & 1 & $<\mathrm{RL}^{\mathrm{b}}$ \\
\hline 1,1,2,2-Tetrachloroethane & $<1$ & $<1$ & $<1$ & $<1$ & $\mu \mathrm{g} / \mathrm{l}$ & 1 & 1 & $<\mathrm{RL}$ \\
\hline 1,1,2-Trichloroethane & $<1$ & $<1$ & $<1$ & $<1$ & $\mu \mathrm{g} / \mathrm{l}$ & 1 & 1 & $<\mathrm{RL}$ \\
\hline 1,1-Dichloroethane & $<1$ & $<1$ & $<1$ & $<1$ & $\mu \mathrm{g} / \mathrm{l}$ & 1 & 1 & $<\mathrm{RL}$ \\
\hline 1,1-Dichloroethylene & $<1$ & $<1$ & $<1$ & $<1$ & $\mu g / l$ & 1 & 1 & $<\mathrm{RL}$ \\
\hline 1,2-Dichloroethane & $<1$ & $<1$ & $<1$ & $<1$ & $\mu \mathrm{g} / \mathrm{l}$ & 1 & 1 & $<\mathrm{RL}$ \\
\hline Carbon tetrachloride & $<1$ & $<1$ & $<1$ & $<1$ & $\mu \mathrm{g} / \mathrm{l}$ & 1 & 1 & $<\mathrm{RL}$ \\
\hline Chlorobenzene & $<1$ & $<1$ & $<1$ & $<1$ & $\mu g / l$ & 1 & 1 & $<\mathrm{RL}$ \\
\hline Chloroform & $<1$ & $<1$ & $<1$ & $<1$ & $\mu g / l$ & 1 & 1 & $<\mathrm{RL}$ \\
\hline cis-1,2-Dichloroethylene & $<1$ & $<1$ & $<1$ & $<1$ & $\mu \mathrm{g} / \mathrm{l}$ & 1 & 1 & $<\mathrm{RL}$ \\
\hline Methyl ethyl ketone & $<5$ & $<5$ & $<5$ & $<5$ & $\mu g / l$ & 5 & 5 & $<\mathrm{RL}$ \\
\hline Methylene chloride & $<5$ & $<5$ & $<5$ & $<5$ & $\mu g / l$ & 5 & 5 & $<\mathrm{RL}$ \\
\hline Tetrachloroethylene & $<1$ & $<1$ & $<1$ & $<1$ & $\mu \mathrm{g} / \mathrm{l}$ & 1 & 1 & $<\mathrm{RL}$ \\
\hline Toluene & $<1$ & $<1$ & $<1$ & $<1$ & $\mu \mathrm{g} / \mathrm{l}$ & 1 & 1 & $<\mathrm{RL}$ \\
\hline Trichloroethylene & $<1$ & $<1$ & $<1$ & $<1$ & $\mu g / l$ & 1 & 1 & $<\mathrm{RL}$ \\
\hline Trichlorofluoromethane & $<1$ & $<1$ & $<1$ & $<1$ & $\mu \mathrm{g} / \mathrm{l}$ & 1 & 1 & $<\mathrm{RL}$ \\
\hline Vinyl chloride & $<1$ & $<1$ & $<1$ & $<1$ & $\mu g / l$ & 1 & 1 & $<\mathrm{RL}$ \\
\hline Xylene & $<1$ & $<1$ & $<1$ & $<1$ & $\mu \mathrm{g} / \mathrm{l}$ & 1 & 1 & $<\mathrm{RL}$ \\
\hline 1,2-Dichlorobenzene & $<5$ & $<5$ & $<5$ & $<5$ & $\mu \mathrm{g} / \mathrm{l}$ & 5 & 5 & $<\mathrm{RL}$ \\
\hline 1,4-Dichlorobenzene & $<5$ & $<5$ & $<5$ & $<5$ & $\mu \mathrm{g} / \mathrm{l}$ & 5 & 5 & $<\mathrm{RL}$ \\
\hline 2,4-Dinitrophenol & $<5$ & $<5$ & $<5$ & $<5$ & $\mu \mathrm{g} / \mathrm{l}$ & 5 & 5 & $<\mathrm{RL}$ \\
\hline 2,4-Dinitrotoluene & $<5$ & $<5$ & $<5$ & $<5$ & $\mu \mathrm{g} / \mathrm{l}$ & 5 & 5 & $<\mathrm{RL}$ \\
\hline 2-Methylphenol & $<5$ & $<5$ & $<5$ & $<5$ & $\mu \mathrm{g} / \mathrm{l}$ & 5 & 5 & $<\mathrm{RL}$ \\
\hline $\begin{array}{l}\text { 3-Methylphenol/ } \\
\text { 4-Methylphenol }\end{array}$ & $<5$ & $<5$ & $<5$ & $<5$ & $\mu \mathrm{g} / \mathrm{l}$ & 5 & 5 & $<\mathrm{RL}$ \\
\hline Hexachlorobenzene & $<5$ & $<5$ & $<5$ & $<5$ & $\mu \mathrm{g} / \mathrm{l}$ & 5 & 5 & $<\mathrm{RL}$ \\
\hline Hexachloroethane & $<5$ & $<5$ & $<5$ & $<5$ & $\mu \mathrm{g} / \mathrm{l}$ & 5 & 5 & $<\mathrm{RL}$ \\
\hline Nitrobenzene & $<5$ & $<5$ & $<5$ & $<5$ & $\mu \mathrm{g} / \mathrm{l}$ & 5 & 5 & $<\mathrm{RL}$ \\
\hline Pentachlorophenol & $<5$ & $<5$ & $<5$ & $<5$ & $\mu \mathrm{g} / \mathrm{l}$ & 5 & 5 & $<\mathrm{RL}$ \\
\hline Pyridine & $<5$ & $<5$ & $<5$ & $<5$ & $\mu \mathrm{g} / \mathrm{l}$ & 5 & 5 & $<\mathrm{RL}$ \\
\hline Isobutanol & $<2$ & $<2$ & $<2$ & $<2$ & $\mathrm{mg} / \mathrm{l}$ & 2 & 2 & $<\mathrm{RL}$ \\
\hline Alkalinity & 40 & 38 & 36 & 34 & $\mathrm{mg} / \mathrm{l}$ & 4 & 4 & 47.1 \\
\hline Bromide & 53.2 & 54.2 & 82 & 80 & $\mathrm{mg} / \mathrm{l}$ & 0.1 & 0.2 & $<200$ \\
\hline Chloride & 54900 & 52100 & 55300 & 55000 & $\mathrm{mg} / \mathrm{l}$ & 0.5 & 2 & 63960 \\
\hline Density & 1.074 & 1.075 & 1.0764 & 1.0777 & $\mathrm{~g} / \mathrm{ml}$ & $N / A^{c}$ & $N / A$ & 1.1 \\
\hline Fluoride & 1.26 & 1.3 & 1.64 & 1.62 & $\mathrm{mg} / \mathrm{l}$ & 0.1 & 0.1 & 2.73 \\
\hline lodide & $<2.0$ & $<2.0$ & $<2.0$ & $<2.0$ & $\mathrm{mg} / \mathrm{l}$ & 2 & 2 & $<2.0$ \\
\hline Nitrate (as N) & $<0.10$ & $<0.10$ & $<0.10$ & $<0.10$ & $\mathrm{mg} / \mathrm{l}$ & 0.1 & 0.1 & $<10$ \\
\hline Orthophosphate (as $\mathrm{P}$ ) & $<0.04$ & $<0.04$ & $<0.04$ & $<0.04$ & $\mathrm{mg} / \mathrm{l}$ & 0.04 & 0.04 & 0.54 \\
\hline
\end{tabular}


Table 6.5 - Analytical Results for Groundwater Sampled from Well WQSP-4

\begin{tabular}{|c|c|c|c|c|c|c|c|c|}
\hline \multirow[b]{3}{*}{ Parameter } & \multicolumn{7}{|c|}{ Concentration } & \multirow[b]{3}{*}{$\begin{array}{c}95^{\text {th }} \\
\text { UTLV }\end{array}$} \\
\hline & \multicolumn{2}{|c|}{ Round 12} & \multicolumn{2}{|c|}{ Round 13} & \multirow[b]{2}{*}{ Units } & \multicolumn{2}{|c|}{ Reporting Limit } & \\
\hline & Sample & Dup. & Sample & Dup. & & $\begin{array}{c}\text { Round } \\
12 \\
\end{array}$ & $\begin{array}{c}\text { Round } \\
13 \\
\end{array}$ & \\
\hline $\mathrm{pH}$ & 7.3 & 7.31 & 7.1 & 7.1 & $S U^{d}$ & $\mathrm{~N} / \mathrm{A}$ & $\mathrm{N} / \mathrm{A}$ & $6.80-7.61$ \\
\hline Specific conductance & 116000 & 124000 & 116000 & 121000 & $\mu \mathrm{mhos} / \mathrm{cm}$ & $\mathrm{N} / \mathrm{A}$ & $\mathrm{N} / \mathrm{A}$ & 319800 \\
\hline Sulfate & 6470 & 6380 & 6300 & 6130 & $\mathrm{mg} / \mathrm{l}$ & 0.5 & 2 & 7927 \\
\hline Total dissolved solids & 108000 & 109000 & 102000 & 104000 & $\mathrm{mg} / \mathrm{l}$ & 10 & 10 & 123500 \\
\hline Total organic carbon & 1.1 & 1.22 & $<1.0$ & $<1.0$ & $\mathrm{mg} / \mathrm{l}$ & 1 & 1 & $<5.0$ \\
\hline Total organic halogen & 10 & 10 & 4 & 7.2 & $\mathrm{mg} / \mathrm{l}$ & $N R^{e}$ & NR & 17 \\
\hline Total phenols & $<0.10$ & $<0.10$ & $<0.10$ & $<0.10$ & $\mathrm{mg} / \mathrm{l}$ & 0.1 & 0.1 & 0.27 \\
\hline Total suspended solids & $<1.0$ & $<1.0$ & $<1.0$ & $<1.0$ & $\mathrm{mg} / \mathrm{l}$ & 1 & 1 & 57 \\
\hline Antimony & $<0.013$ & $<0.013$ & $<0.250$ & $<0.250$ & $\mathrm{mg} / \mathrm{l}$ & 0.013 & 0.25 & 0.8 \\
\hline Arsenic & $<0.05$ & $<0.05$ & $<0.10$ & $<0.10$ & $\mathrm{mg} / \mathrm{l}$ & 0.05 & 0.1 & $<0.50$ \\
\hline Barium & $<0.02$ & $<0.02$ & 0.106 & 0.106 & $\mathrm{mg} / \mathrm{l}$ & 0.02 & 0.02 & $<1.0$ \\
\hline Beryllium & $<0.010$ & $<0.010$ & $<0.025$ & $<0.025$ & $\mathrm{mg} / \mathrm{l}$ & 0.01 & 0.01 & 0.25 \\
\hline Boron & 34.7 & 34.7 & 39.3 & 36 & $\mathrm{mg} / \mathrm{l}$ & 0.05 & 0.5 & 36.8 \\
\hline Cadmium & $<0.010$ & $<0.010$ & $<0.050$ & $<0.050$ & $\mathrm{mg} / \mathrm{l}$ & 0.01 & 0.05 & $<0.50$ \\
\hline Calcium & 1520 & 1650 & 1470 & 1505 & $\mathrm{mg} / \mathrm{l}$ & 0.5 & 0.2 & 1,834 \\
\hline Chromium & $<0.025$ & $<0.025$ & 0.011 & 0.012 & $\mathrm{mg} / \mathrm{l}$ & 0.025 & 0.025 & $<2.0$ \\
\hline Cobalt & $<0.013$ & $<0.013$ & $<0.250$ & $<0.250$ & $\mathrm{mg} / \mathrm{l}$ & 0.013 & 0.25 & $<0.50$ \\
\hline Copper & $<0.050$ & $<0.050$ & $<0.125$ & $<0.125$ & $\mathrm{mg} / \mathrm{l}$ & 0.05 & 0.125 & $<0.50$ \\
\hline Iron & 0.056 & $<0.50$ & $<0.50$ & $<0.50$ & $\mathrm{mg} / \mathrm{l}$ & 0.5 & 0.5 & $<4.0$ \\
\hline Lead & $<0.02$ & $<0.02$ & $<0.10$ & $<0.10$ & $\mathrm{mg} / \mathrm{l}$ & 0.02 & 0.02 & 0.525 \\
\hline Lithium & 0.381 & 0.424 & 0.829 & 0.849 & $\mathrm{mg} / \mathrm{l}$ & 0.01 & 0.01 & 1.380 \\
\hline Magnesium & 1050 & 1060 & 1093 & 1134 & $\mathrm{mg} / \mathrm{l}$ & 0.5 & 0.2 & 1,472 \\
\hline Mercury & $<0.0002$ & $<0.0002$ & $<0.0002$ & $<0.0002$ & $\mathrm{mg} / \mathrm{l}$ & 0 & 0 & $<0.002$ \\
\hline Nickel & $<0.025$ & $<0.025$ & $<0.250$ & $<0.250$ & $\mathrm{mg} / \mathrm{l}$ & 0.025 & 0.25 & $<5.00$ \\
\hline Potassium & 1020 & 1090 & 1221 & 1245 & $\mathrm{mg} / \mathrm{l}$ & 0.5 & 0.2 & 1,648 \\
\hline Selenium & 0.033 & 0.041 & $<0.500$ & $<0.500$ & $\mathrm{mg} / \mathrm{l}$ & 0.013 & 0.5 & 2.009 \\
\hline Silica & 2.96 & 3.28 & 3.58 & 3.51 & $\mathrm{mg} / \mathrm{l}$ & 0.5 & 0.5 & 11.40 \\
\hline Silver & $<0.013$ & $<0.013$ & $<0.125$ & $<0.125$ & $\mathrm{mg} / \mathrm{l}$ & 0.013 & 0.125 & 0.519 \\
\hline Sodium & 35000 & 34200 & 34100 & 33170 & $\mathrm{mg} / \mathrm{l}$ & 0.5 & 0.2 & 38,790 \\
\hline Thallium & $<0.013$ & $<0.010$ & $<0.500$ & $<0.500$ & $\mathrm{mg} / \mathrm{l}$ & 0.01 & 0.5 & 1.00 \\
\hline Tin & $<0.025$ & $<0.025$ & $<0.250$ & $<0.250$ & $\mathrm{mg} / \mathrm{l}$ & 0.025 & 0.25 & 5.00 \\
\hline Vanadium & $<0.025$ & $<0.025$ & $<0.250$ & $<0.250$ & $\mathrm{mg} / \mathrm{l}$ & 0.025 & 0.25 & $<5.00$ \\
\hline Zinc & $<0.050$ & $<0.050$ & $<0.250$ & $<0.250$ & $\mathrm{mg} / \mathrm{l}$ & 0.05 & 0.25 & $<5.00$ \\
\hline
\end{tabular}


Table 6.6 - Analytical Results for Groundwater Sampled from Well WQSP-5

\begin{tabular}{|c|c|c|c|c|c|c|c|c|}
\hline \multirow[b]{3}{*}{ Parameter } & \multicolumn{7}{|c|}{ Concentration } & \multirow[b]{3}{*}{$\begin{array}{l}95^{\text {th }} \\
\text { UTLV }^{\text {a }}\end{array}$} \\
\hline & \multicolumn{2}{|c|}{ Round 12} & \multicolumn{2}{|c|}{ Round 13} & \multirow[b]{2}{*}{ Units } & \multicolumn{2}{|c|}{ Reporting Limit } & \\
\hline & Sample & Dup. & Sample & Dup. & & $\begin{array}{c}\text { Round } \\
12\end{array}$ & $\begin{array}{c}\text { Round } \\
13\end{array}$ & \\
\hline 1,1,1-Trichloroethane & $<1$ & $<1$ & $<1$ & $<1$ & $\mu \mathrm{g} / \mathrm{l}$ & 1 & 1 & $<R L^{\mathrm{b}}$ \\
\hline 1,1,2,2-Tetrachloroethane & $<1$ & $<1$ & $<1$ & $<1$ & $\mu g / l$ & 1 & 1 & $<\mathrm{RL}$ \\
\hline 1,1,2-Trichloroethane & $<1$ & $<1$ & $<1$ & $<1$ & $\mu g / l$ & 1 & 1 & $<\mathrm{RL}$ \\
\hline 1,1-Dichloroethane & $<1$ & $<1$ & $<1$ & $<1$ & $\mu g / l$ & 1 & 1 & $<\mathrm{RL}$ \\
\hline 1,1-Dichloroethylene & $<1$ & $<1$ & $<1$ & $<1$ & $\mu g / l$ & 1 & 1 & $<\mathrm{RL}$ \\
\hline 1,2-Dichloroethane & $<1$ & $<1$ & $<1$ & $<1$ & $\mu g / l$ & 1 & 1 & $<\mathrm{RL}$ \\
\hline Carbon tetrachloride & $<1$ & $<1$ & $<1$ & $<1$ & $\mu g / l$ & 1 & 1 & $<\mathrm{RL}$ \\
\hline Chlorobenzene & $<1$ & $<1$ & $<1$ & $<1$ & $\mu g / l$ & 1 & 1 & $<\mathrm{RL}$ \\
\hline Chloroform & $<1$ & $<1$ & $<1$ & $<1$ & $\mu g / l$ & 1 & 1 & $<\mathrm{RL}$ \\
\hline cis-1,2-Dichloroethylene & $<1$ & $<1$ & $<1$ & $<1$ & $\mu g / l$ & 1 & 1 & $<\mathrm{RL}$ \\
\hline Methyl ethyl ketone & $<5$ & $<5$ & $<5$ & $<5$ & $\mu g / l$ & 5 & 5 & $<\mathrm{RL}$ \\
\hline Methylene chloride & $<5$ & $<5$ & $<5$ & $<5$ & $\mu g / l$ & 5 & 5 & $<\mathrm{RL}$ \\
\hline Tetrachloroethylene & $<1$ & $<1$ & $<1$ & $<1$ & $\mu \mathrm{g} / \mathrm{l}$ & 1 & 1 & $<\mathrm{RL}$ \\
\hline Toluene & $<1$ & $<1$ & $<1$ & $<1$ & $\mu g / l$ & 1 & 1 & $<\mathrm{RL}$ \\
\hline Trichloroethylene & $<1$ & $<1$ & $<1$ & $<1$ & $\mu g / l$ & 1 & 1 & $<\mathrm{RL}$ \\
\hline Trichlorofluoromethane & $<1$ & $<1$ & $<1$ & $<1$ & $\mu g / l$ & 1 & 1 & $<\mathrm{RL}$ \\
\hline Vinyl chloride & $<1$ & $<1$ & $<1$ & $<1$ & $\mu g / l$ & 1 & 1 & $<\mathrm{RL}$ \\
\hline Xylene & $<1$ & $<1$ & $<1$ & $<1$ & $\mu g / l$ & 1 & 1 & $<\mathrm{RL}$ \\
\hline 1,2-Dichlorobenzene & $<5$ & $<5$ & $<5$ & $<5$ & $\mu g / l$ & 5 & 5 & $<\mathrm{RL}$ \\
\hline 1,4-Dichlorobenzene & $<5$ & $<5$ & $<5$ & $<5$ & $\mu \mathrm{g} / \mathrm{l}$ & 5 & 5 & $<\mathrm{RL}$ \\
\hline 2,4-Dinitrophenol & $<5$ & $<5$ & $<5$ & $<5$ & $\mu g / l$ & 5 & 5 & $<\mathrm{RL}$ \\
\hline 2,4-Dinitrotoluene & $<5$ & $<5$ & $<5$ & $<5$ & $\mu \mathrm{g} / \mathrm{l}$ & 5 & 5 & $<\mathrm{RL}$ \\
\hline 2-Methylphenol & $<5$ & $<5$ & $<5$ & $<5$ & $\mu \mathrm{g} / \mathrm{l}$ & 5 & 5 & $<\mathrm{RL}$ \\
\hline $\begin{array}{l}\text { 3-Methylphenol/ } \\
\text { 4-Methylphenol }\end{array}$ & $<5$ & $<5$ & $<5$ & $<5$ & $\mu g / l$ & 5 & 5 & $<\mathrm{RL}$ \\
\hline Hexachlorobenzene & $<5$ & $<5$ & $<5$ & $<5$ & $\mu \mathrm{g} / \mathrm{l}$ & 5 & 5 & $<\mathrm{RL}$ \\
\hline Hexachloroethane & $<5$ & $<5$ & $<5$ & $<5$ & $\mu \mathrm{g} / \mathrm{l}$ & 5 & 5 & $<\mathrm{RL}$ \\
\hline Nitrobenzene & $<5$ & $<5$ & $<5$ & $<5$ & $\mu \mathrm{g} / \mathrm{l}$ & 5 & 5 & $<\mathrm{RL}$ \\
\hline Pentachlorophenol & $<5$ & $<5$ & $<5$ & $<5$ & $\mu \mathrm{g} / \mathrm{l}$ & 5 & 5 & $<\mathrm{RL}$ \\
\hline Pyridine & $<5$ & $<5$ & $<5$ & $<5$ & $\mu g / l$ & 5 & 5 & $<\mathrm{RL}$ \\
\hline Isobutanol & $<2$ & $<2$ & $<2$ & $<2$ & mg/l & 2 & 2 & $<\mathrm{RL}$ \\
\hline Alkalinity & 46 & 46 & 46 & 44 & mg/l & 4 & 4 & 56 \\
\hline Bromide & 27.8 & 25.7 & 21.8 & 18.4 & mg/l & 1 & 0.2 & 59.4 \\
\hline Chloride & 16100 & 15700 & 15600 & 14800 & mg/l & 0.5 & 2 & 18100 \\
\hline Density & 1.027 & 1.023 & 1.0277 & 1.021 & $\mathrm{~g} / \mathrm{ml}$ & $N / A^{d}$ & $\mathrm{~N} / \mathrm{A}$ & 1.04 \\
\hline Fluoride & 2.21 & 2 & 2.05 & 2.13 & mg/l & 0.1 & 0.1 & 3 \\
\hline lodide & $<2.0$ & $<2.0$ & $<2.0$ & $<2.0$ & mg/l & 2 & 2 & $<2.0$ \\
\hline Nitrate (as N) & $<0.1$ & $<0.1$ & $<0.10$ & $<0.10$ & mg/l & 0.1 & 0.1 & $<10$ \\
\hline Orthophosphate (as $\mathrm{P}$ ) & $<0.04$ & $<0.04$ & $<0.04$ & $<0.04$ & mg/l & 0.04 & 0.04 & $<5.0$ \\
\hline
\end{tabular}


Waste Isolation Pilot Plant 2001 Site Environmental Report

DOE/WIPP 02-2225

Table 6.6 - Analytical Results for Groundwater Sampled from Well WQSP-5

\begin{tabular}{|c|c|c|c|c|c|c|c|c|}
\hline \multirow[b]{3}{*}{ Parameter } & \multicolumn{7}{|c|}{ Concentration } & \multirow[b]{3}{*}{$\begin{array}{c}95^{\text {th }} \\
\text { UTLV }^{\text {a }}\end{array}$} \\
\hline & \multicolumn{2}{|c|}{ Round 12} & \multicolumn{2}{|c|}{ Round 13} & \multirow[b]{2}{*}{ Units } & \multicolumn{2}{|c|}{ Reporting Limit } & \\
\hline & Sample & Dup. & Sample & Dup. & & $\begin{array}{c}\text { Round } \\
12 \\
\end{array}$ & $\begin{array}{c}\text { Round } \\
13\end{array}$ & \\
\hline $\mathrm{pH}$ & 7.58 & 7.57 & 7.6 & 7.6 & $S U^{e}$ & N/A & N/A & $7.40-7.90$ \\
\hline Specific conductance & 44200 & 43800 & 35400 & 36600 & $\mu \mathrm{mhos} / \mathrm{cm}$ & $\mathrm{N} / \mathrm{A}$ & $\mathrm{N} / \mathrm{A}$ & 67700 \\
\hline Sulfate & 4890 & 4800 & 4690 & 4470 & $\mathrm{mg} / \mathrm{l}$ & 0.5 & 2 & 6129 \\
\hline Total dissolved solids & 32200 & 31300 & 31000 & 30800 & $\mathrm{mg} / \mathrm{l}$ & 10 & 10 & 43950 \\
\hline Total organic carbon & 1.97 & $<1.0$ & $<1.0$ & $<1.0$ & $\mathrm{mg} / \mathrm{l}$ & 1 & 1 & $<5.0$ \\
\hline Total organic halogen & 8.7 & 5.3 & 4.26 & 2.19 & $\mathrm{mg} / \mathrm{l}$ & 0.005 & 0.005 & 8.37 \\
\hline Total phenols & $<0.10$ & $<0.10$ & $<0.10$ & $<0.10$ & $\mathrm{mg} / \mathrm{l}$ & 0.1 & 0.1 & $<0.10$ \\
\hline Total suspended solids & $<1.0$ & $<1.0$ & $<1.0$ & $<1.0$ & $\mathrm{mg} / \mathrm{l}$ & 1 & 1 & $<10.0$ \\
\hline Antimony & $<0.013$ & $<0.013$ & $<0.125$ & $<0.125$ & $\mathrm{mg} / \mathrm{l}$ & 0.013 & 0.125 & 0.073 \\
\hline Arsenic & $<0.05$ & $<0.05$ & $<0.05$ & $<0.05$ & $\mathrm{mg} / \mathrm{l}$ & 0.05 & 0.05 & $<0.50$ \\
\hline Barium & $<0.02$ & $<0.02$ & $<0.50$ & $<0.50$ & $\mathrm{mg} / \mathrm{l}$ & 0.02 & 0.02 & $<1.0$ \\
\hline Beryllium & $<0.01$ & $<0.01$ & $<0.0125$ & $<0.0125$ & $\mathrm{mg} / \mathrm{l}$ & 0.01 & 0.01 & 0.02 \\
\hline Boron & 29 & 31.8 & 37.1 & 36.3 & $\mathrm{mg} / \mathrm{l}$ & 0.05 & 0.05 & 40 \\
\hline Cadmium & $<0.010$ & $<0.010$ & $<0.025$ & $<0.025$ & $\mathrm{mg} / \mathrm{l}$ & 0.01 & 0.01 & $<0.050$ \\
\hline Calcium & 1011 & 1029 & 1090 & 1080 & $\mathrm{mg} / \mathrm{l}$ & 5 & 0.2 & 1,303 \\
\hline Chromium & $<0.025$ & $<0.025$ & $<0.050$ & $<0.050$ & $\mathrm{mg} / \mathrm{l}$ & 0.025 & 0.025 & $<0.50$ \\
\hline Cobalt & $<0.013$ & $<0.013$ & $<0.125$ & $<0.125$ & $\mathrm{mg} / \mathrm{l}$ & 0.013 & 0.125 & $<0.50$ \\
\hline Copper & $<0.05$ & $<0.05$ & $<0.0625$ & $<0.0625$ & $\mathrm{mg} / \mathrm{l}$ & 0.05 & 0.05 & $<1.0$ \\
\hline Iron & 0.0684 & 0.0671 & $<0.250$ & 0.49 & $\mathrm{mg} / \mathrm{l}$ & 0.5 & 0.5 & 0.795 \\
\hline Lead & $<0.02$ & $<0.02$ & $<0.05$ & $<0.05$ & $\mathrm{mg} / \mathrm{l}$ & 0.02 & 0.05 & $<0.05$ \\
\hline Lithium & 0.376 & 0.368 & 0.603 & 0.602 & $\mathrm{mg} / \mathrm{l}$ & 0.01 & 0.01 & 0.74 \\
\hline Magnesium & 425 & 437 & 545 & 545 & $\mathrm{mg} / \mathrm{l}$ & 5 & 0.2 & 547.0 \\
\hline Mercury & $<0.0002$ & $<0.0002$ & $<0.0002$ & $<0.0002$ & $\mathrm{mg} / \mathrm{l}$ & 0 & 0 & $<0.002$ \\
\hline Nickel & $<0.025$ & $<0.025$ & $<0.125$ & $<0.125$ & $\mathrm{mg} / \mathrm{l}$ & 0.025 & 0.125 & $<0.10$ \\
\hline Potassium & 474 & 505 & 452 & 454 & $\mathrm{mg} / \mathrm{l}$ & 5 & 0.2 & 622.0 \\
\hline Selenium & 0.033 & 0.041 & $<0.250$ & $<0.250$ & $\mathrm{mg} / \mathrm{l}$ & 0.013 & 0.25 & $<0.10$ \\
\hline Silica & 4.23 & 4.11 & 4.26 & 4.36 & $\mathrm{mg} / \mathrm{l}$ & 0.5 & 0.5 & 16.3 \\
\hline Silver & $<0.013$ & $<0.013$ & $<0.0625$ & $<0.0625$ & $\mathrm{mg} / \mathrm{l}$ & 0.013 & 0.0625 & $<0.50$ \\
\hline Sodium & 9756 & 9712 & 10600 & 10200 & $\mathrm{mg} / \mathrm{l}$ & 5 & 0.2 & 11,190 \\
\hline Thallium & $<0.013$ & $<0.013$ & $<0.250$ & $<0.250$ & $\mathrm{mg} / \mathrm{l}$ & 0.01 & 0.25 & 0.209 \\
\hline Tin & $<0.025$ & $<0.025$ & $<0.125$ & $<0.125$ & $\mathrm{mg} / \mathrm{l}$ & 0.025 & 0.125 & $<0.10$ \\
\hline Vanadium & $<0.025$ & $<0.025$ & $<0.125$ & $<0.125$ & $\mathrm{mg} / \mathrm{l}$ & 0.025 & 0.125 & 2.70 \\
\hline Zinc & $<0.050$ & $<0.050$ & $<0.125$ & $<0.125$ & $\mathrm{mg} / \mathrm{l}$ & 0.05 & 0.15 & $<5.00$ \\
\hline
\end{tabular}


Table 6.7 - Analytical Results for Groundwater Sampled from Well WQSP-6

\begin{tabular}{|c|c|c|c|c|c|c|c|c|}
\hline \multirow[b]{3}{*}{ Parameter } & \multicolumn{7}{|c|}{ Concentration } & \multirow[b]{3}{*}{$\begin{array}{l}9^{\text {th }} \\
\text { UTLV }\end{array}$} \\
\hline & \multicolumn{2}{|c|}{ Round 12} & \multicolumn{2}{|c|}{ Round 13} & \multirow[b]{2}{*}{ Units } & \multicolumn{2}{|c|}{ Reporting } & \\
\hline & Sample & Dup. & Sample & Dup. & & $\begin{array}{c}\text { Round } \\
12\end{array}$ & $\begin{array}{c}\text { Round } \\
13\end{array}$ & \\
\hline 1,1,1-Trichloroethane & $<1$ & $<1$ & $<1$ & $<1$ & $\mu \mathrm{g} / \mathrm{l}$ & 1 & 1 & $<\mathrm{RL}^{\mathrm{b}}$ \\
\hline 1,1,2,2-Tetrachloroethane & $<1$ & $<1$ & $<1$ & $<1$ & $\mu \mathrm{g} / \mathrm{l}$ & 1 & 1 & $<\mathrm{RL}$ \\
\hline 1,1,2-Trichloroethane & $<1$ & $<1$ & $<1$ & $<1$ & $\mu \mathrm{g} / \mathrm{l}$ & 1 & 1 & $<\mathrm{RL}$ \\
\hline 1,1-Dichloroethane & $<1$ & $<1$ & $<1$ & $<1$ & $\mu \mathrm{g} / \mathrm{l}$ & 1 & 1 & $<\mathrm{RL}$ \\
\hline 1,1-Dichloroethylene & $<1$ & $<1$ & $<1$ & $<1$ & $\mu \mathrm{g} / \mathrm{l}$ & 1 & 1 & $<\mathrm{RL}$ \\
\hline 1,2-Dichloroethane & $<1$ & $<1$ & $<1$ & $<1$ & $\mu \mathrm{g} / \mathrm{l}$ & 1 & 1 & $<\mathrm{RL}$ \\
\hline Carbon tetrachloride & $<1$ & $<1$ & $<1$ & $<1$ & $\mu \mathrm{g} / \mathrm{l}$ & 1 & 1 & $<\mathrm{RL}$ \\
\hline Chlorobenzene & $<1$ & $<1$ & $<1$ & $<1$ & $\mu \mathrm{g} / \mathrm{l}$ & 1 & 1 & $<\mathrm{RL}$ \\
\hline Chloroform & $<1$ & $<1$ & $<1$ & $<1$ & $\mu \mathrm{g} / \mathrm{l}$ & 1 & 1 & $<\mathrm{RL}$ \\
\hline cis-1,2-Dichloroethylene & $<1$ & $<1$ & $<1$ & $<1$ & $\mu \mathrm{g} / \mathrm{l}$ & 1 & 1 & $<\mathrm{RL}$ \\
\hline Methyl ethyl ketone & $<5$ & $<5$ & $<5$ & $<5$ & $\mu \mathrm{g} / \mathrm{l}$ & 5 & 5 & $<\mathrm{RL}$ \\
\hline Methylene chloride & $<5$ & $<5$ & $<5$ & $<5$ & $\mu \mathrm{g} / \mathrm{l}$ & 5 & 5 & $<\mathrm{RL}$ \\
\hline Tetrachloroethylene & $<1$ & $<1$ & $<1$ & $<1$ & $\mu \mathrm{g} / \mathrm{l}$ & 1 & 1 & $<\mathrm{RL}$ \\
\hline Toluene & $<1$ & $<1$ & $<1$ & $<1$ & $\mu \mathrm{g} / \mathrm{l}$ & 1 & 1 & $<\mathrm{RL}$ \\
\hline Trichloroethylene & $<1$ & $<1$ & $<1$ & $<1$ & $\mu \mathrm{g} / \mathrm{l}$ & 1 & 1 & $<R L$ \\
\hline Trichlorofluoromethane & $<1$ & $<1$ & $<1$ & $<1$ & $\mu \mathrm{g} / \mathrm{l}$ & 1 & 1 & $<\mathrm{RL}$ \\
\hline Vinyl chloride & $<1$ & $<1$ & $<1$ & $<1$ & $\mu \mathrm{g} / \mathrm{l}$ & 1 & 1 & $<\mathrm{RL}$ \\
\hline Xylene & $<1$ & $<1$ & $<1$ & $<1$ & $\mu \mathrm{g} / \mathrm{l}$ & 1 & 1 & $<\mathrm{RL}$ \\
\hline 1,2-Dichlorobenzene & $<5$ & $<5$ & $<5$ & $<5$ & $\mu \mathrm{g} / \mathrm{l}$ & 5 & 5 & $<R L$ \\
\hline 1,4-Dichlorobenzene & $<5$ & $<5$ & $<5$ & $<5$ & $\mu \mathrm{g} / \mathrm{l}$ & 5 & 5 & $<\mathrm{RL}$ \\
\hline 2,4-Dinitrophenol & $<5$ & $<5$ & $<5$ & $<5$ & $\mu \mathrm{g} / \mathrm{l}$ & 5 & 5 & $<\mathrm{RL}$ \\
\hline 2,4-Dinitrotoluene & $<5$ & $<5$ & $<5$ & $<5$ & $\mu \mathrm{g} / \mathrm{l}$ & 5 & 5 & $<R L$ \\
\hline 2-Methylphenol & $<5$ & $<5$ & $<5$ & $<5$ & $\mu \mathrm{g} / \mathrm{l}$ & 5 & 5 & $<\mathrm{RL}$ \\
\hline $\begin{array}{l}\text { 3-Methylphenol/ } \\
\text { 4-Methylphenol }\end{array}$ & $<5$ & $<5$ & $<5$ & $<5$ & $\mu \mathrm{g} / \mathrm{l}$ & 5 & 5 & $<\mathrm{RL}$ \\
\hline Hexachlorobenzene & $<5$ & $<5$ & $<5$ & $<5$ & $\mu \mathrm{g} / \mathrm{l}$ & 5 & 5 & $<\mathrm{RL}$ \\
\hline Hexachloroethane & $<5$ & $<5$ & $<5$ & $<5$ & $\mu \mathrm{g} / \mathrm{l}$ & 5 & 5 & $<R L$ \\
\hline Nitrobenzene & $<5$ & $<5$ & $<5$ & $<5$ & $\mu \mathrm{g} / \mathrm{l}$ & 5 & 5 & $<R L$ \\
\hline Pentachlorophenol & $<5$ & $<5$ & $<5$ & $<5$ & $\mu \mathrm{g} / \mathrm{l}$ & 5 & 5 & $<\mathrm{RL}$ \\
\hline Pyridine & $<5$ & $<5$ & $<5$ & $<5$ & $\mu \mathrm{g} / \mathrm{l}$ & 5 & 5 & $<R L$ \\
\hline Isobutanol & $<2$ & $<2$ & $<2$ & $<2$ & $\mathrm{mg} / \mathrm{l}$ & 2 & 2 & $<R L$ \\
\hline Alkalinity & 42 & 42 & 46 & 44 & $\mathrm{mg} / \mathrm{l}$ & 4 & 4 & 55.8 \\
\hline Bromide & 6.04 & 5.22 & 6.36 & 6.51 & $\mathrm{mg} / \mathrm{l}$ & 1 & 0.2 & 14.1 \\
\hline Chloride & 5140 & 5170 & 4970 & 4820 & $\mathrm{mg} / \mathrm{l}$ & 0.5 & 2 & 6200 \\
\hline Density & 1.011 & 1.011 & 1.009 & 1.009 & $\mathrm{~g} / \mathrm{ml}$ & $N / A^{d}$ & $N / A$ & 1.02 \\
\hline Fluoride & 2.2 & 2.15 & 2.44 & 2.42 & $\mathrm{mg} / \mathrm{l}$ & 0.1 & 0.1 & 4.85 \\
\hline lodide & $<2.0$ & $<2.0$ & $<2.0$ & $<2.0$ & $\mathrm{mg} / \mathrm{l}$ & 2 & 2 & $<2.0$ \\
\hline Nitrate (as N) & $<0.10$ & $<0.10$ & $<0.10$ & $<0.10$ & $\mathrm{mg} / \mathrm{l}$ & 0.1 & 2 & 7.45 \\
\hline Orthophosphate (as $\mathrm{P}$ ) & $<0.04$ & $<0.04$ & $<0.04$ & $<0.04$ & $\mathrm{mg} / \mathrm{l}$ & 0.04 & 0.04 & 0.34 \\
\hline
\end{tabular}


Table 6.7 - Analytical Results for Groundwater Sampled from Well WQSP-6

\begin{tabular}{|c|c|c|c|c|c|c|c|c|}
\hline \multirow[b]{3}{*}{ Parameter } & \multicolumn{7}{|c|}{ Concentration } & \multirow[b]{3}{*}{$\begin{array}{c}9^{\text {th }} \\
\text { UTLV }^{\text {a }}\end{array}$} \\
\hline & \multicolumn{2}{|c|}{ Round 12} & \multicolumn{2}{|c|}{ Round 13} & \multirow[b]{2}{*}{ Units } & \multicolumn{2}{|c|}{ Reporting } & \\
\hline & Sample & Dup. & Sample & Dup. & & $\begin{array}{c}\text { Round } \\
12 \\
\end{array}$ & $\begin{array}{c}\text { Round } \\
13 \\
\end{array}$ & \\
\hline $\mathrm{pH}$ & 7.71 & 7.74 & 7.8 & 7.8 & $S U^{e}$ & $\mathrm{~N} / \mathrm{A}$ & $\mathrm{N} / \mathrm{A}$ & $7.50-7.90$ \\
\hline Specific conductance & 20100 & 20400 & 16600 & 16500 & $\mu \mathrm{mhos} / \mathrm{cm}$ & $\mathrm{N} / \mathrm{A}$ & N/A & 27660 \\
\hline Sulfate & 4600 & 4720 & 4500 & 4510 & $\mathrm{mg} / \mathrm{l}$ & 0.5 & 2 & 5557 \\
\hline Total dissolved solids & 16800 & 16300 & 16000 & 15600 & $\mathrm{mg} / \mathrm{l}$ & 10 & 10 & 22500 \\
\hline Total organic carbon & 1.57 & $<1.0$ & 1.14 & $<1.0$ & $\mathrm{mg} / \mathrm{l}$ & 1 & 1 & 10.14 \\
\hline Total organic halogen & 2.1 & 2.1 & 2.2 & 2.25 & $\mathrm{mg} / \mathrm{l}$ & NR & 0.005 & 1.54 \\
\hline Total phenols & $<0.10$ & $<0.10$ & $<0.10$ & $<0.10$ & $\mathrm{mg} / \mathrm{l}$ & 0.1 & 0.1 & $<0.10$ \\
\hline Total suspended solids & $<1.0$ & $<1.0$ & $<1.0$ & $<1.0$ & $\mathrm{mg} / \mathrm{l}$ & 1 & 1 & 14.8 \\
\hline Antimony & $<0.013$ & $<0.013$ & $<0.025$ & $<0.025$ & $\mathrm{mg} / \mathrm{l}$ & 0.013 & 0.025 & 0.14 \\
\hline Arsenic & $<0.05$ & $<0.05$ & $<0.01$ & $<0.01$ & $\mathrm{mg} / \mathrm{l}$ & 0.05 & 0.01 & $<0.50$ \\
\hline Barium & $<0.020$ & $<0.020$ & $<0.100$ & $<0.100$ & $\mathrm{mg} / \mathrm{l}$ & 0.02 & 0.1 & $<1.0$ \\
\hline Beryllium & $<0.010$ & $<0.010$ & $<0.0025$ & $<0.025$ & $\mathrm{mg} / \mathrm{l}$ & 0.01 & 0.003 & $<0.020$ \\
\hline Boron & 11.1 & 13.9 & 20.3 & 17.6 & $\mathrm{mg} / \mathrm{l}$ & 0.5 & 0.5 & 17.5 \\
\hline Cadmium & $<0.010$ & $<0.010$ & $<0.005$ & $<0.005$ & $\mathrm{mg} / \mathrm{l}$ & 0.01 & 0.01 & $<0.050$ \\
\hline Calcium & 663 & 687 & 672 & 688 & $\mathrm{mg} / \mathrm{l}$ & 0.5 & 0.2 & 796 \\
\hline Chromium & $<0.025$ & $<0.025$ & $<0.010$ & $<0.010$ & $\mathrm{mg} / \mathrm{l}$ & 0.025 & 0.01 & $<0.50$ \\
\hline Cobalt & $<0.013$ & $<0.013$ & $<0.025$ & $<0.025$ & $\mathrm{mg} / \mathrm{l}$ & 0.013 & 0.025 & $<0.50$ \\
\hline Copper & $<0.050$ & $<0.050$ & $<0.125$ & $<0.125$ & $\mathrm{mg} / \mathrm{l}$ & 0.05 & 0.125 & $<1.0$ \\
\hline Iron & 0.0886 & 0.131 & $<0.050$ & $<0.050$ & $\mathrm{mg} / \mathrm{l}$ & 0.05 & 0.05 & 3.105 \\
\hline Lead & 0.0113 & 0.0132 & $<0.010$ & $<0.010$ & $\mathrm{mg} / \mathrm{l}$ & 0.02 & 0.01 & 0.150 \\
\hline Lithium & 0.99 & 1.08 & 0.369 & 0.369 & $\mathrm{mg} / \mathrm{l}$ & 0.01 & 0.01 & 0.468 \\
\hline Magnesium & 212 & 231 & 234 & 236 & $\mathrm{mg} / \mathrm{l}$ & 0.5 & 0.2 & 255 \\
\hline Mercury & $<0.0002$ & $<0.0002$ & $<0.0002$ & $<0.0002$ & $\mathrm{mg} / \mathrm{l}$ & 0 & 0 & $<0.002$ \\
\hline Nickel & $<0.025$ & $<0.025$ & $<0.025$ & $<0.025$ & $\mathrm{mg} / \mathrm{l}$ & 0.025 & 0.025 & $<0.50$ \\
\hline Potassium & 208 & 204 & 278 & 282 & $\mathrm{mg} / \mathrm{l}$ & 0.5 & 0.2 & 270 \\
\hline Selenium & 0.0188 & 0.019 & $<0.050$ & $<0.050$ & $\mathrm{mg} / \mathrm{l}$ & 0.13 & 0.05 & $<0.10$ \\
\hline Silica & 4.58 & 5.8 & 4.15 & 4.16 & $\mathrm{mg} / \mathrm{l}$ & 0.5 & 0.5 & 18.2 \\
\hline Silver & $<0.013$ & $<0.013$ & $<0.0125$ & $<0.0125$ & $\mathrm{mg} / \mathrm{l}$ & 0.013 & 0.013 & $<0.50$ \\
\hline Sodium & 4320 & 4330 & 4090 & 4230 & $\mathrm{mg} / \mathrm{l}$ & 0.5 & 0.2 & 6,290 \\
\hline Thallium & 0.013 & $<0.013$ & $<0.050$ & $<0.050$ & $\mathrm{mg} / \mathrm{l}$ & 0.013 & 0.05 & 0.560 \\
\hline Tin & $<0.025$ & $<0.025$ & $<0.025$ & $<0.025$ & $\mathrm{mg} / \mathrm{l}$ & 0.025 & 0.025 & $<0.10$ \\
\hline Vanadium & $<0.025$ & $<0.025$ & $<0.025$ & $<0.025$ & $\mathrm{mg} / \mathrm{l}$ & 0.025 & 0.025 & $<0.10$ \\
\hline Zinc & $<0.050$ & $<0.050$ & 0.025 & $<0.025$ & $\mathrm{mg} / \mathrm{l}$ & 0.05 & 0.025 & $<5.00$ \\
\hline
\end{tabular}




\section{Waste Isolation Pilot Plant 2001 Site Environmental Report \\ DOE/WIPP 02-2225}

Table 6.8 - Analytical Results for Groundwater Sampled from Well WQSP-6A

\begin{tabular}{|c|c|c|c|c|c|c|c|c|}
\hline \multirow[b]{3}{*}{ Parameter } & \multicolumn{7}{|c|}{ Concentration } & \multirow[b]{3}{*}{$\begin{array}{l}95^{\text {th }} \\
\text { UTLV }\end{array}$} \\
\hline & \multicolumn{2}{|c|}{ Round 12} & \multicolumn{2}{|c|}{ Round 13} & \multirow[b]{2}{*}{ Units } & \multicolumn{2}{|c|}{ Reporting } & \\
\hline & Sample & Dup. & Sample & Dup. & & $\begin{array}{c}\text { Round } \\
12\end{array}$ & $\begin{array}{c}\text { Round } \\
13\end{array}$ & \\
\hline 1,1,1-Trichloroethane & $<1$ & $<1$ & $<1$ & $<1$ & $\mu \mathrm{g} / \mathrm{l}$ & 1 & 1 & $<R^{L^{b}}$ \\
\hline 1,1,2,2-Tetrachloroethane & $<1$ & $<1$ & $<1$ & $<1$ & $\mu g / l$ & 1 & 1 & $<R L$ \\
\hline 1,1,2-Trichloroethane & $<1$ & $<1$ & $<1$ & $<1$ & $\mu \mathrm{g} / \mathrm{l}$ & 1 & 1 & $<R L$ \\
\hline 1,1-Dichloroethane & $<1$ & $<1$ & $<1$ & $<1$ & $\mu \mathrm{g} / \mathrm{l}$ & 1 & 1 & $<\mathrm{RL}$ \\
\hline 1,1-Dichloroethylene & $<1$ & $<1$ & $<1$ & $<1$ & $\mu g / l$ & 1 & 1 & $<R L$ \\
\hline 1,2-Dichloroethane & $<1$ & $<1$ & $<1$ & $<1$ & $\mu \mathrm{g} / \mathrm{l}$ & 1 & 1 & $<R L$ \\
\hline Carbon tetrachloride & $<1$ & $<1$ & $<1$ & $<1$ & $\mu g / l$ & 1 & 1 & $<\mathrm{RL}$ \\
\hline Chlorobenzene & $<1$ & $<1$ & $<1$ & $<1$ & $\mu g / l$ & 1 & 1 & $<R L$ \\
\hline Chloroform & $<1$ & $<1$ & $<1$ & $<1$ & $\mu g / l$ & 1 & 1 & $<\mathrm{RL}$ \\
\hline cis-1,2-Dichloroethylene & $<1$ & $<1$ & $<1$ & $<1$ & $\mu g / l$ & 1 & 1 & $<R L$ \\
\hline Methyl ethyl ketone & $<5$ & $<5$ & $<5$ & $<5$ & $\mu g / l$ & 5 & 5 & $<R L$ \\
\hline Methylene chloride & $<5$ & $<5$ & $<5$ & $<5$ & $\mu g / l$ & 5 & 5 & $<R L$ \\
\hline Tetrachloroethylene & $<1$ & $<1$ & $<1$ & $<1$ & $\mu g / l$ & 1 & 1 & $<\mathrm{RL}$ \\
\hline Toluene & $<1$ & $<1$ & $<1$ & $<1$ & $\mu g / l$ & 1 & 1 & $<R L$ \\
\hline Trichloroethylene & $<1$ & $<1$ & $<1$ & $<1$ & $\mu g / l$ & 1 & 1 & $<R L$ \\
\hline Trichlorofluoromethane & $<1$ & $<1$ & $<1$ & $<1$ & $\mu g / l$ & 1 & 1 & $<R L$ \\
\hline Vinyl chloride & $<1$ & $<1$ & $<1$ & $<1$ & $\mu \mathrm{g} / \mathrm{l}$ & 1 & 1 & $<R L$ \\
\hline Xylene & $<1$ & $<1$ & $<1$ & $<1$ & $\mu g / l$ & 1 & 1 & $<R L$ \\
\hline 1,2-Dichlorobenzene & $<5$ & $<5$ & $<5$ & $<5$ & $\mu \mathrm{g} / \mathrm{l}$ & 5 & 5 & $<R L$ \\
\hline 1,4-Dichlorobenzene & $<5$ & $<5$ & $<5$ & $<5$ & $\mu \mathrm{g} / \mathrm{l}$ & 5 & 5 & $<R L$ \\
\hline 2,4-Dinitrophenol & $<5$ & $<5$ & $<5$ & $<5$ & $\mu g / l$ & 5 & 5 & $<R L$ \\
\hline 2,4-Dinitrotoluene & $<5$ & $<5$ & $<5$ & $<5$ & $\mu \mathrm{g} / \mathrm{l}$ & 5 & 5 & $<\mathrm{RL}$ \\
\hline 2-Methylphenol & $<5$ & $<5$ & $<5$ & $<5$ & $\mu g / l$ & 5 & 5 & $<R L$ \\
\hline $\begin{array}{l}\text { 3-Methylphenol/ } \\
\text { 4-Methylphenol }\end{array}$ & $<5$ & $<5$ & $<5$ & $<5$ & $\mu \mathrm{g} / \mathrm{l}$ & 5 & 5 & $<\mathrm{RL}$ \\
\hline Hexachlorobenzene & $<5$ & $<5$ & $<5$ & $<5$ & $\mu g / l$ & 5 & 5 & $<R L$ \\
\hline Hexachloroethane & $<5$ & $<5$ & $<5$ & $<5$ & $\mu g / l$ & 5 & 5 & $<\mathrm{RL}$ \\
\hline Nitrobenzene & $<5$ & $<5$ & $<5$ & $<5$ & $\mu g / l$ & 5 & 5 & $<\mathrm{RL}$ \\
\hline Pentachlorophenol & $<5$ & $<5$ & $<5$ & $<5$ & $\mu g / l$ & 5 & 5 & $<R L$ \\
\hline Pyridine & $<5$ & $<5$ & $<5$ & $<5$ & $\mu \mathrm{g} / \mathrm{l}$ & 5 & 5 & $<\mathrm{RL}$ \\
\hline Isobutanol & $<2$ & $<2$ & $<2$ & $<2$ & $\mathrm{mg} / \mathrm{l}$ & 2 & 2 & $<R L$ \\
\hline Alkalinity & 104 & 106 & 102 & 102 & $\mathrm{mg} / \mathrm{l}$ & 4 & 4 & 113 \\
\hline Bromide & 1.23 & 1.23 & 1.14 & $<1.11$ & $\mathrm{mg} / \mathrm{l}$ & 1 & 0.2 & 14.5 \\
\hline Chloride & 536 & 505 & 414 & 411 & $\mathrm{mg} / \mathrm{l}$ & 0.5 & 2 & 1040 \\
\hline Density & 1.005 & 1.005 & 1.005 & 1.005 & $\mathrm{~g} / \mathrm{ml}$ & $N / A^{c}$ & $N / A$ & 1.01 \\
\hline Fluoride & 1.91 & 1.91 & 1.39 & 1.44 & $\mathrm{mg} / \mathrm{l}$ & 0.1 & 0.1 & 2.95 \\
\hline lodide & $<2.0$ & $<2.0$ & $<2.0$ & $<2.0$ & $\mathrm{mg} / \mathrm{l}$ & 2 & 2 & $<2.0$ \\
\hline Nitrate (as N) & 6.37 & 6.37 & 3.67 & 3.82 & $\mathrm{mg} / \mathrm{l}$ & 0.1 & 0.1 & 12.2 \\
\hline Orthophosphate (as $\mathrm{P}$ ) & $<0.04$ & $<0.04$ & $<0.04$ & $<0.04$ & $\mathrm{mg} / \mathrm{l}$ & 0.04 & 0.04 & 0.11 \\
\hline
\end{tabular}




\section{Waste Isolation Pilot Plant 2001 Site Environmental Report}

DOE/WIPP 02-2225

Table 6.8 - Analytical Results for Groundwater Sampled from Well WQSP-6A

\begin{tabular}{|c|c|c|c|c|c|c|c|c|}
\hline $\mathrm{pH}$ & 7.4 & 7.3 & 7.52 & 7.51 & $S U^{d}$ & $\mathrm{~N} / \mathrm{A}$ & $\mathrm{N} / \mathrm{A}$ & $6.80-8.00$ \\
\hline Specific conductance & 4400 & 4370 & 4160 & 4050 & $\mu \mathrm{mhos} / \mathrm{cm}$ & $\mathrm{N} / \mathrm{A}$ & $\mathrm{N} / \mathrm{A}$ & 5192 \\
\hline Sulfate & 1900 & 1830 & 1900 & 1870 & $\mathrm{mg} / \mathrm{l}$ & 0.5 & 2 & 2543 \\
\hline Total dissolved solids & 3680 & 3670 & 4600 & 4550 & $\mathrm{mg} / \mathrm{l}$ & 10 & 10 & 11000 \\
\hline Total organic carbon & 1.28 & $<1.0$ & $<1.0$ & $<1.0$ & $\mathrm{mg} / \mathrm{l}$ & 1 & 1 & 15.45 \\
\hline Total organic halogen & 0.029 & 0.041 & 0.039 & 0.039 & $\mathrm{mg} / \mathrm{l}$ & NR & 0.005 & 0.19 \\
\hline Total phenols & $<0.10$ & $<0.10$ & $<0.10$ & $<0.10$ & $\mathrm{mg} / \mathrm{l}$ & 0.1 & 0.1 & $<0.28$ \\
\hline Total suspended solids & $<1.0$ & $<1.0$ & $<1.0$ & $<1.0$ & $\mathrm{mg} / \mathrm{l}$ & 1 & 1 & 91 \\
\hline Antimony & $<0.013$ & $<0.013$ & $<0.025$ & $<0.025$ & $\mathrm{mg} / \mathrm{l}$ & 0.013 & 0.025 & 0.48 \\
\hline Arsenic & $<0.050$ & $<0.050$ & $<0.010$ & $<0.010$ & $\mathrm{mg} / \mathrm{l}$ & 0.05 & 0.01 & $<0.50$ \\
\hline Barium & $<0.020$ & $<0.020$ & $<0.100$ & $<0.100$ & $\mathrm{mg} / \mathrm{l}$ & 0.02 & 0.1 & $<0.10$ \\
\hline Beryllium & $<0.010$ & $<0.010$ & $<0.0025$ & $<0.0025$ & $\mathrm{mg} / \mathrm{l}$ & 0.01 & 0.003 & $<0.01$ \\
\hline Boron & 0.38 & 0.362 & 0.397 & 0.376 & $\mathrm{mg} / \mathrm{l}$ & 0.05 & 0.05 & $<0.75$ \\
\hline Cadmium & $<0.010$ & $<0.010$ & $<0.005$ & $<0.005$ & $\mathrm{mg} / \mathrm{l}$ & 0.01 & 0.005 & $<0.05$ \\
\hline Calcium & 570 & 540 & 622 & 620 & $\mathrm{mg} / \mathrm{l}$ & 0.5 & 0.5 & 733 \\
\hline Chromium & $<0.025$ & $<0.025$ & $<0.010$ & $<0.010$ & $\mathrm{mg} / \mathrm{l}$ & 0.025 & 0.01 & $<0.50$ \\
\hline Cobalt & $<0.013$ & $<0.013$ & $<0.025$ & $<0.025$ & $\mathrm{mg} / \mathrm{l}$ & 0.013 & 0.025 & $<0.50$ \\
\hline Copper & $<0.050$ & $<0.050$ & $<0.0125$ & $<0.0125$ & $\mathrm{mg} / \mathrm{l}$ & 0.05 & 0.0125 & $<1.0$ \\
\hline Iron & $<0.500$ & $<0.500$ & $<0.050$ & $<0.050$ & $\mathrm{mg} / \mathrm{l}$ & 0.5 & 0.05 & $<1.0$ \\
\hline Lead & $<0.020$ & 0.013 & $<0.010$ & $<0.010$ & $\mathrm{mg} / \mathrm{l}$ & 0.02 & 0.01 & $<0.05$ \\
\hline Lithium & 0.204 & 0.205 & 0.135 & 0.142 & $\mathrm{mg} / \mathrm{l}$ & 0.01 & 0.01 & $<0.50$ \\
\hline Magnesium & 150 & 146 & 186 & 169 & $\mathrm{mg} / \mathrm{l}$ & 0.5 & 5 & 188 \\
\hline Mercury & $<0.0002$ & $<0.0002$ & $<0.0002$ & $<0.0002$ & $\mathrm{mg} / \mathrm{l}$ & 0 & 0 & $<0.002$ \\
\hline Nickel & $<0.025$ & $<0.025$ & $<0.025$ & $<0.025$ & $\mathrm{mg} / \mathrm{l}$ & 0.025 & 0.025 & 0.284 \\
\hline Potassium & 7.2 & 7.5 & 7.55 & 7.59 & $\mathrm{mg} / \mathrm{l}$ & 0.5 & 0.5 & 10.1 \\
\hline Selenium & 0.0385 & 0.0222 & $<0.050$ & $<0.050$ & $\mathrm{mg} / \mathrm{l}$ & 0.013 & 0.05 & 0.220 \\
\hline Silica & 10.6 & 11.2 & 10.2 & 9.65 & $\mathrm{mg} / \mathrm{l}$ & 0.5 & 0.5 & 40.10 \\
\hline Silver & $<0.013$ & $<0.013$ & $<0.0125$ & $<0.0125$ & $\mathrm{mg} / \mathrm{l}$ & 0.013 & 0.0125 & $<0.50$ \\
\hline Sodium & 260 & 255 & 302 & 267 & $\mathrm{mg} / \mathrm{l}$ & 0.5 & 0.5 & 369.0 \\
\hline Thallium & $<0.013$ & $<0.013$ & $<0.050$ & $<0.050$ & $\mathrm{mg} / \mathrm{l}$ & 0.013 & 0.05 & 0.058 \\
\hline Tin & $<0.025$ & $<0.025$ & $<0.025$ & $<0.025$ & $\mathrm{mg} / \mathrm{l}$ & 0.025 & 0.025 & 0.230 \\
\hline Vanadium & 0.052 & 0.051 & 0.046 & 0.0465 & $\mathrm{mg} / \mathrm{l}$ & 0.025 & 0.025 & $<0.50$ \\
\hline Zinc & $<0.050$ & $<0.050$ & 0.025 & $<0.025$ & $\mathrm{mg} / \mathrm{l}$ & 0.05 & 0.025 & $<5.00$ \\
\hline
\end{tabular}

${ }^{A} 95^{\text {th }}$ Upper Tolerance Limit Value, equivalent to $95 \%$ Confidence Limit

${ }^{\mathrm{b}}$ Reporting Limit

${ }^{c}$ Not Applicable

${ }^{\mathrm{d}}$ Standard Unit

${ }^{\mathrm{e}}$ Not reported by the laboratory 
Waste Isolation Pilot Plant 2001 Site Environmental Report DOE/WIPP 02-2225

Table 6.9 - Groundwater Level Measurement Results for 2001

\begin{tabular}{|c|c|c|c|c|c|c|c|c|c|c|c|}
\hline WELL_NO & ZONE & TOC_AMSL* & DATE & TIME & TP_FT_TOC & ADJ_FT & WL_FT & WL_METERS & WL_MSL_FT & WL_MSL_M & Adj_Fr_Hd_amsI \\
\hline AEC-7 & CUL & 3657.25 & $1 / 9 / 01$ & $07: 23$ & 619.94 & 0.98 & 618.96 & 188.66 & 3038.29 & 926.07 & 3061.25 \\
\hline AEC-7 & CUL & 3657.25 & $2 / 6 / 01$ & $07: 15$ & 620.01 & 0.98 & 619.03 & 188.68 & 3038.22 & 926.05 & 3061.17 \\
\hline AEC-7 & CUL & 3657.25 & $3 / 6 / 01$ & $14: 18$ & 619.90 & 0.98 & 618.92 & 188.65 & 3038.33 & 926.08 & 3061.29 \\
\hline AEC-7 & CUL & 3657.25 & $4 / 4 / 01$ & $11: 19$ & 619.75 & 0.98 & 618.77 & 188.60 & 3038.48 & 926.13 & 3061.45 \\
\hline AEC-7 & CUL & 3657.25 & $5 / 8 / 01$ & $07: 37$ & 620.01 & 0.98 & 619.03 & 188.68 & 3038.22 & 926.05 & 3061.17 \\
\hline AEC-7 & CUL & 3657.25 & $6 / 7 / 01$ & $09: 49$ & 619.87 & 0.98 & 618.89 & 188.64 & 3038.36 & 926.09 & 3061.32 \\
\hline AEC-7 & CUL & 3657.25 & $7 / 10 / 01$ & $08: 30$ & 619.97 & 0.98 & 618.99 & 188.67 & 3038.26 & 926.06 & 3061.21 \\
\hline AEC-7 & CUL & 3657.25 & $8 / 8 / 01$ & $14: 11$ & 620.11 & 0.98 & 619.13 & 188.71 & 3038.12 & 926.02 & 3061.06 \\
\hline AEC-7 & CUL & 3657.25 & 9/7/01 & $13: 35$ & 619.73 & 0.98 & 618.75 & 188.60 & 3038.50 & 926.13 & 3061.48 \\
\hline AEC-7 & CUL & 3657.25 & $10 / 8 / 01$ & $12: 43$ & 620.00 & 0.98 & 619.02 & 188.68 & 3038.23 & 926.05 & 3061.18 \\
\hline AEC-7 & CUL & 3657.25 & $11 / 13 / 01$ & $12: 53$ & 619.94 & 0.98 & 618.96 & 188.66 & 3038.29 & 926.07 & 3061.25 \\
\hline AEC-7 & CUL & 3657.25 & $12 / 4 / 01$ & $11: 58$ & 619.94 & 0.98 & 618.96 & 188.66 & 3038.29 & 926.07 & 3061.25 \\
\hline AEC-8 & $B / C$ & 3537.10 & $1 / 9 / 01$ & 07:52 & 510.58 & 0.00 & 510.58 & 155.62 & 3026.52 & 922.48 & \\
\hline AEC-8 & $\mathrm{B} / \mathrm{C}$ & 3537.10 & $2 / 6 / 01$ & $07: 43$ & 508.38 & 0.00 & 508.38 & 154.95 & 3028.72 & 923.15 & \\
\hline AEC-8 & $\mathrm{B} / \mathrm{C}$ & 3537.10 & $3 / 6 / 01$ & $14: 48$ & 506.92 & 0.00 & 506.92 & 154.51 & 3030.18 & 923.60 & \\
\hline AEC-8 & $\mathrm{B} / \mathrm{C}$ & 3537.10 & $4 / 4 / 01$ & $11: 41$ & 506.06 & 0.00 & 506.06 & 154.25 & 3031.04 & 923.86 & \\
\hline AEC-8 & $\mathrm{B} / \mathrm{C}$ & 3537.10 & $5 / 8 / 01$ & 08:02 & 504.13 & 0.00 & 504.13 & 153.66 & 3032.97 & 924.45 & \\
\hline AEC-8 & $B / C$ & 3537.10 & $6 / 7 / 01$ & $10: 14$ & 502.53 & 0.00 & 502.53 & 153.17 & 3034.57 & 924.94 & \\
\hline AEC-8 & $B / C$ & 3537.10 & 7/10/01 & $08: 55$ & 500.82 & 0.00 & 500.82 & 152.65 & 3036.28 & 925.46 & \\
\hline AEC-8 & $B / C$ & 3537.10 & $8 / 8 / 01$ & $14: 29$ & 499.31 & 0.00 & 499.31 & 152.19 & 3037.79 & 925.92 & \\
\hline AEC-8 & $B / C$ & 3537.10 & 9/7/01 & 13:50 & 497.69 & 0.00 & 497.69 & 151.70 & 3039.41 & 926.41 & \\
\hline AEC-8 & $B / C$ & 3537.10 & $10 / 8 / 01$ & 13:06 & 496.15 & 0.00 & 496.15 & 151.23 & 3040.95 & 926.88 & \\
\hline AEC-8 & $\mathrm{B} / \mathrm{C}$ & 3537.10 & $11 / 12 / 01$ & $11: 12$ & 494.44 & 0.00 & 494.44 & 150.71 & 3042.66 & 927.40 & \\
\hline AEC-8 & $\mathrm{B} / \mathrm{C}$ & 3537.10 & $12 / 3 / 01$ & $11: 45$ & 493.40 & 0.00 & 493.40 & 150.39 & 3043.70 & 927.72 & \\
\hline C-2737 (ANNULUS) & MAG & 3399.30 & $4 / 5 / 01$ & $10: 49$ & 257.83 & 0.00 & 257.83 & 78.59 & 3141.47 & 957.52 & \\
\hline C-2737 (ANNULUS) & MAG & 3399.30 & $5 / 8 / 01$ & $13: 43$ & 253.96 & 0.00 & 253.96 & 77.41 & 3145.34 & 958.70 & \\
\hline C-2737 (ANNULUS) & MAG & 3399.30 & $6 / 6 / 01$ & $06: 57$ & 253.44 & 0.00 & 253.44 & 77.25 & 3145.86 & 958.86 & \\
\hline C-2737 (ANNULUS) & MAG & 3399.30 & $7 / 9 / 01$ & 09:25 & 253.58 & 0.00 & 253.58 & 77.29 & 3145.72 & 958.82 & \\
\hline C-2737 (ANNULUS) & MAG & 3399.30 & $8 / 7 / 01$ & $13: 13$ & 253.77 & 0.00 & 253.77 & 77.35 & 3145.53 & 958.76 & \\
\hline C-2737 (ANNULUS) & MAG & 3399.30 & 9/6/01 & $12: 45$ & 253.79 & 0.00 & 253.79 & 77.36 & 3145.51 & 958.75 & \\
\hline C-2737 (ANNULUS) & MAG & 3399.30 & 10/10/01 & $07: 55$ & 254.00 & 0.00 & 254.00 & 77.42 & 3145.30 & 958.69 & \\
\hline C-2737 (ANNULUS) & MAG & 3399.30 & $11 / 14 / 01$ & 10:53 & 254.90 & 0.00 & 254.90 & 77.69 & 3144.40 & 958.41 & \\
\hline C-2737 (ANNULUS) & MAG & 3399.30 & $12 / 5 / 01$ & $10: 15$ & 254.34 & 0.00 & 254.34 & 77.52 & 3144.96 & 958.58 & \\
\hline C-2737 (PIP) & CUL & 3399.30 & $4 / 5 / 01$ & 10:43 & 386.07 & 0.75 & 385.32 & 117.45 & 3013.98 & 918.66 & \\
\hline $\mathrm{C}-2737$ (PIP) & CUL & 3399.30 & $5 / 8 / 01$ & 13:39 & 376.04 & 0.75 & 375.29 & 114.39 & 3024.01 & 921.72 & \\
\hline $\mathrm{C}-2737$ (PIP) & CUL & 3399.30 & $6 / 6 / 01$ & $06: 51$ & 385.94 & 0.75 & 385.19 & 117.41 & 3014.11 & 918.70 & \\
\hline $\mathrm{C}-2737$ (PIP) & CUL & 3399.30 & $7 / 9 / 01$ & $09: 14$ & 385.82 & 0.75 & 385.07 & 117.37 & 3014.23 & 918.74 & \\
\hline
\end{tabular}


Waste Isolation Pilot Plant 2001 Site Environmental Report DOE/WIPP 02-2225

Table 6.9 - Groundwater Level Measurement Results for 2001

\begin{tabular}{|c|c|c|c|c|c|c|c|c|c|c|c|}
\hline WELL_NO & ZONE & TOC_AMSL* & DATE & TIME & TP_FT_TOC & ADJ_FT & WL_FT & WL_METERS & WL_MSL_FT & WL_MSL_M & Adj_Fr_Hd_amsI \\
\hline C-2737 (PIP) & CUL & 3399.30 & $8 / 7 / 01$ & 13:08 & 385.75 & 0.75 & 385.00 & 117.35 & 3014.30 & 918.76 & \\
\hline C-2737 (PIP) & CUL & 3399.30 & 9/6/01 & $12: 40$ & 385.42 & 0.75 & 384.67 & 117.25 & 3014.63 & 918.86 & \\
\hline C-2737 (PIP) & CUL & 3399.30 & 10/10/01 & 07:48 & 385.43 & 0.75 & 384.68 & 117.25 & 3014.62 & 918.86 & \\
\hline $\mathrm{C}-2737$ (PIP) & CUL & 3399.30 & $11 / 14 / 01$ & $10: 49$ & 385.55 & 0.75 & 384.80 & 117.29 & 3014.50 & 918.82 & \\
\hline $\mathrm{C}-2737$ (PIP) & CUL & 3399.30 & $12 / 5 / 01$ & $10: 11$ & 385.78 & 0.75 & 385.03 & 117.36 & 3014.27 & 918.75 & \\
\hline CB-1 & CUL & 3328.38 & $1 / 10 / 01$ & $12: 49$ & 84.76 & 0.69 & 84.07 & 25.62 & 3244.31 & 988.87 & 3256.31 \\
\hline CB-1 & CUL & 3328.38 & $2 / 5 / 01$ & 13:05 & 83.66 & 0.69 & 82.97 & 25.29 & 3245.41 & 989.20 & 3257.44 \\
\hline CB-1 & CUL & 3328.38 & $4 / 5 / 01$ & $08: 36$ & 77.98 & 0.69 & 77.29 & 23.56 & 3251.09 & 990.93 & 3263.30 \\
\hline CB-1 & CUL & 3328.38 & $5 / 9 / 01$ & $10: 26$ & 73.15 & 0.69 & 72.46 & 22.09 & 3255.92 & 992.40 & 3268.28 \\
\hline CB-1 & CUL & 3328.38 & $7 / 11 / 01$ & $10: 50$ & 76.21 & 0.69 & 75.52 & 23.02 & 3252.86 & 991.47 & 3265.12 \\
\hline CB-1 & CUL & 3328.38 & $8 / 7 / 01$ & $09: 15$ & 72.55 & 0.69 & 71.86 & 21.90 & 3256.52 & 992.59 & 3268.90 \\
\hline CB-1 & CUL & 3328.38 & $10 / 9 / 01$ & $12: 31$ & 62.84 & 0.69 & 62.15 & 18.94 & 3266.23 & 995.55 & 3278.91 \\
\hline CB-1 & CUL & 3328.38 & $11 / 12 / 01$ & $10: 11$ & 57.79 & 0.69 & 57.10 & 17.40 & 3271.28 & 997.09 & 3284.11 \\
\hline CB-1 & CUL & 3328.38 & $3 / 7 / 01$ & $11: 51$ & 81.88 & 0.69 & 81.19 & 24.75 & 3247.19 & 989.74 & 3259.28 \\
\hline CB-1 & CUL & 3328.38 & $6 / 6 / 01$ & $12: 17$ & 75.63 & 0.69 & 74.94 & 22.84 & 3253.44 & 991.65 & 3265.72 \\
\hline CB-1 & CUL & 3328.38 & $9 / 5 / 01$ & $14: 45$ & 68.11 & 0.69 & 67.42 & 20.55 & 3260.96 & 993.94 & 3273.47 \\
\hline CB-1 & CUL & 3328.38 & $12 / 3 / 01$ & $10: 19$ & 54.79 & 0.69 & 54.10 & 16.49 & 3274.28 & 998.00 & 3287.21 \\
\hline CB-1 (PIP) & $B / C$ & 3328.38 & $1 / 10 / 01$ & $12: 45$ & 314.36 & 0.76 & 313.60 & 95.59 & 3014.78 & 918.90 & \\
\hline CB-1 (PIP) & $B / C$ & 3328.38 & 2/5/01 & $12: 53$ & 314.46 & 0.76 & 313.70 & 95.62 & 3014.68 & 918.87 & \\
\hline CB-1 (PIP) & $B / C$ & 3328.38 & $3 / 7 / 01$ & $11: 47$ & 314.42 & 0.76 & 313.66 & 95.60 & 3014.72 & 918.89 & \\
\hline CB-1 (PIP) & $B / C$ & 3328.38 & $4 / 5 / 01$ & $08: 28$ & 314.29 & 0.76 & 313.53 & 95.56 & 3014.85 & 918.93 & \\
\hline CB-1 (PIP) & $\mathrm{B} / \mathrm{C}$ & 3328.38 & $5 / 9 / 01$ & $10: 29$ & 314.43 & 0.76 & 313.67 & 95.61 & 3014.71 & 918.88 & \\
\hline CB-1 (PIP) & $\mathrm{B} / \mathrm{C}$ & 3328.38 & $6 / 6 / 01$ & $12: 14$ & 314.37 & 0.76 & 313.61 & 95.59 & 3014.77 & 918.90 & \\
\hline CB-1 (PIP) & $\mathrm{B} / \mathrm{C}$ & 3328.38 & $7 / 11 / 01$ & $10: 40$ & 314.00 & 0.76 & 313.24 & 95.48 & 3015.14 & 919.01 & \\
\hline CB-1 (PIP) & $\mathrm{B} / \mathrm{C}$ & 3328.38 & $8 / 7 / 01$ & 09:08 & 314.50 & 0.76 & 313.74 & 95.63 & 3014.64 & 918.86 & \\
\hline CB-1 (PIP) & $\mathrm{B} / \mathrm{C}$ & 3328.38 & $9 / 5 / 01$ & $14: 40$ & 314.48 & 0.76 & 313.72 & 95.62 & 3014.66 & 918.87 & \\
\hline CB-1 (PIP) & $B / C$ & 3328.38 & $10 / 9 / 01$ & $12: 28$ & 314.40 & 0.76 & 313.64 & 95.60 & 3014.74 & 918.89 & \\
\hline CB-1 (PIP) & $B / C$ & 3328.38 & $11 / 12 / 01$ & 10:03 & 314.58 & 0.76 & 313.82 & 95.65 & 3014.56 & 918.84 & \\
\hline CB-1 (PIP) & $B / C$ & 3328.38 & $12 / 3 / 01$ & $10: 14$ & 314.48 & 0.76 & 313.72 & 95.62 & 3014.66 & 918.87 & \\
\hline DOE-1 & CUL & 3466.04 & $1 / 10 / 01$ & $13: 20$ & 490.85 & 0.00 & 490.85 & 149.61 & 2975.19 & 906.84 & 3003.54 \\
\hline DOE-1 & CUL & 3466.04 & 2/5/01 & $13: 31$ & 490.79 & 0.00 & 490.79 & 149.59 & 2975.25 & 906.86 & 3003.61 \\
\hline DOE-1 & CUL & 3466.04 & $3 / 8 / 01$ & 07:34 & 490.42 & 0.00 & 490.42 & 149.48 & 2975.62 & 906.97 & 3004.01 \\
\hline DOE-1 & CUL & 3466.04 & $4 / 5 / 01$ & 09:05 & 490.12 & 0.00 & 490.12 & 149.39 & 2975.92 & 907.06 & 3004.33 \\
\hline DOE-1 & CUL & 3466.04 & $5 / 9 / 01$ & 09:27 & 489.95 & 0.00 & 489.95 & 149.34 & 2976.09 & 907.11 & 3004.52 \\
\hline DOE-1 & CUL & 3466.04 & $6 / 6 / 01$ & $10: 25$ & 489.79 & 0.00 & 489.79 & 149.29 & 2976.25 & 907.16 & 3004.69 \\
\hline DOE-1 & CUL & 3466.04 & $7 / 10 / 01$ & $10: 45$ & 489.64 & 0.00 & 489.64 & 149.24 & 2976.40 & 907.21 & 3004.85 \\
\hline DOE-1 & CUL & 3466.04 & $8 / 7 / 01$ & $07: 18$ & 489.40 & 0.00 & 489.40 & 149.17 & 2976.64 & 907.28 & 3005.11 \\
\hline
\end{tabular}


Waste Isolation Pilot Plant 2001 Site Environmental Report DOE/WIPP 02-2225

Table 6.9 - Groundwater Level Measurement Results for 2001

\begin{tabular}{|c|c|c|c|c|c|c|c|c|c|c|c|}
\hline WELL_NO & ZONE & TOC_AMSL* & DATE & TIME & TP_FT_TOC & ADJ_FT & WL_FT & WL_METERS & WL_MSL_FT & WL_MSL_M & Adj_Fr_Hd_amsI \\
\hline DOE-1 & CUL & 3466.04 & $9 / 7 / 01$ & $13: 15$ & 489.43 & 0.00 & 489.43 & 149.18 & 2976.61 & 907.27 & 3005.08 \\
\hline DOE-1 & CUL & 3466.04 & $10 / 9 / 01$ & $12: 51$ & 489.35 & 0.00 & 489.35 & 149.15 & 2976.69 & 907.30 & 3005.17 \\
\hline DOE-1 & CUL & 3466.04 & $11 / 13 / 01$ & $14: 30$ & 489.39 & 0.00 & 489.39 & 149.17 & 2976.65 & 907.28 & 3005.12 \\
\hline DOE-1 & CUL & 3466.04 & $12 / 5 / 01$ & $12: 38$ & 489.33 & 0.00 & 489.33 & 149.15 & 2976.71 & 907.30 & 3005.19 \\
\hline DOE-2 & CUL & 3419.09 & $1 / 8 / 01$ & $14: 00$ & 378.24 & 0.00 & 378.24 & 115.29 & 3040.85 & 926.85 & 3053.63 \\
\hline DOE-2 & CUL & 3419.09 & $2 / 6 / 01$ & $11: 56$ & 378.35 & 0.00 & 378.35 & 115.32 & 3040.74 & 926.82 & 3053.52 \\
\hline DOE-2 & CUL & 3419.09 & $3 / 6 / 01$ & $12: 48$ & 378.31 & 0.00 & 378.31 & 115.31 & 3040.78 & 926.83 & 3053.56 \\
\hline DOE-2 & MAG & 3419.09 & $4 / 4 / 01$ & $13: 32$ & 476.75 & 0.00 & 476.75 & 145.31 & 2942.34 & 896.83 & \\
\hline DOE-2 & MAG & 3419.09 & $5 / 8 / 01$ & 09:34 & 371.51 & 0.00 & 371.51 & 113.24 & 3047.58 & 928.90 & \\
\hline DOE-2 & MAG & 3419.09 & $6 / 5 / 01$ & $12: 46$ & 370.65 & 0.00 & 370.65 & 112.97 & 3048.44 & 929.16 & \\
\hline DOE-2 & MAG & 3419.09 & $7 / 9 / 01$ & 07:40 & 369.85 & 0.00 & 369.85 & 112.73 & 3049.24 & 929.41 & \\
\hline DOE-2 & MAG & 3419.09 & $9 / 12 / 01$ & $08: 30$ & 365.98 & 0.00 & 365.98 & 111.55 & 3053.11 & 930.59 & \\
\hline DOE-2 & MAG & 3419.09 & $10 / 23 / 01$ & 09:44 & 362.54 & 0.00 & 362.54 & 110.50 & 3056.55 & 931.64 & \\
\hline DOE-2 & MAG & 3419.09 & $11 / 12 / 01$ & $14: 52$ & 361.90 & 0.00 & 361.90 & 110.31 & 3057.19 & 931.83 & \\
\hline DOE-2 & MAG & 3419.09 & $12 / 3 / 01$ & $12: 14$ & 360.97 & 0.00 & 360.97 & 110.02 & 3058.12 & 932.11 & \\
\hline ERDA-9 & CUL & 3410.10 & $1 / 9 / 01$ & 13:05 & 403.46 & 0.65 & 402.81 & 122.78 & 3007.29 & 916.62 & 3022.68 \\
\hline ERDA-9 & CUL & 3410.10 & $2 / 5 / 01$ & $10: 07$ & 404.10 & 0.65 & 403.45 & 122.97 & 3006.65 & 916.43 & 3022.00 \\
\hline ERDA-9 & CUL & 3410.10 & $3 / 7 / 01$ & $14: 24$ & 403.47 & 0.65 & 402.82 & 122.78 & 3007.28 & 916.62 & 3022.66 \\
\hline ERDA-9 & CUL & 3410.10 & $4 / 5 / 01$ & 13:15 & 403.00 & 0.65 & 402.35 & 122.64 & 3007.75 & 916.76 & 3023.16 \\
\hline ERDA-9 & CUL & 3410.10 & $5 / 8 / 01$ & $13: 25$ & 402.86 & 0.65 & 402.21 & 122.59 & 3007.89 & 916.80 & 3023.30 \\
\hline ERDA-9 & CUL & 3410.10 & $6 / 6 / 01$ & $06: 42$ & 402.47 & 0.65 & 401.82 & 122.47 & 3008.28 & 916.92 & 3023.71 \\
\hline ERDA-9 & CUL & 3410.10 & $7 / 11 / 01$ & $07: 35$ & 402.30 & 0.65 & 401.65 & 122.42 & 3008.45 & 916.98 & 3023.89 \\
\hline ERDA-9 & CUL & 3410.10 & $8 / 7 / 01$ & $13: 48$ & 402.16 & 0.65 & 401.51 & 122.38 & 3008.59 & 917.02 & 3024.04 \\
\hline ERDA-9 & CUL & 3410.10 & $9 / 6 / 01$ & $13: 45$ & 401.96 & 0.65 & 401.31 & 122.32 & 3008.79 & 917.08 & 3024.25 \\
\hline ERDA-9 & CUL & 3410.10 & 10/10/01 & 08:04 & 401.91 & 0.65 & 401.26 & 122.30 & 3008.84 & 917.09 & 3024.30 \\
\hline ERDA-9 & CUL & 3410.10 & $11 / 14 / 01$ & $10: 40$ & 402.05 & 0.65 & 401.40 & 122.35 & 3008.70 & 917.05 & 3024.15 \\
\hline ERDA-9 & CUL & 3410.10 & $12 / 5 / 01$ & $10: 22$ & 402.15 & 0.65 & 401.50 & 122.38 & 3008.60 & 917.02 & 3024.05 \\
\hline H-01 (ANNULUS) & MAG & 3399.84 & $1 / 9 / 01$ & $13: 18$ & 168.27 & 0.00 & 168.27 & 51.29 & 3231.57 & 984.98 & \\
\hline H-01 (ANNULUS) & MAG & 3399.84 & $2 / 5 / 01$ & $08: 51$ & 169.95 & 0.00 & 169.95 & 51.80 & 3229.89 & 984.47 & \\
\hline $\mathrm{H}-01$ (PIP) & CUL & 3399.84 & $1 / 9 / 01$ & $13: 13$ & 365.00 & 0.66 & 364.34 & 111.05 & 3035.50 & 925.22 & 3036.15 \\
\hline $\mathrm{H}-01$ (PIP) & CUL & 3399.84 & $2 / 5 / 01$ & $08: 40$ & 365.17 & 0.66 & 364.51 & 111.10 & 3035.33 & 925.17 & 3035.98 \\
\hline $\mathrm{H}-02 \mathrm{a}$ & CUL & 3378.09 & $3 / 8 / 01$ & 10:06 & 341.03 & 0.00 & 341.03 & 103.95 & 3037.06 & 925.70 & 3040.58 \\
\hline $\mathrm{H}-02 \mathrm{a}$ & CUL & 3378.09 & $6 / 6 / 01$ & $10: 10$ & 340.75 & 0.00 & 340.75 & 103.86 & 3037.34 & 925.78 & 3040.86 \\
\hline $\mathrm{H}-02 \mathrm{a}$ & CUL & 3378.09 & 9/6/01 & $12: 15$ & 340.50 & 0.00 & 340.50 & 103.78 & 3037.59 & 925.86 & 3041.12 \\
\hline $\mathrm{H}-02 \mathrm{a}$ & CUL & 3378.09 & $12 / 5 / 01$ & $13: 42$ & 340.32 & 0.00 & 340.32 & 103.73 & 3037.77 & 925.91 & 3041.30 \\
\hline $\mathrm{H}-02 \mathrm{~b} 1$ & MAG & 3378.46 & $1 / 9 / 01$ & 13:33 & 231.90 & 0.00 & 231.90 & 70.68 & 3146.56 & 959.07 & \\
\hline $\mathrm{H}-02 \mathrm{~b} 1$ & MAG & 3378.46 & 2/6/01 & $13: 45$ & 231.98 & 0.00 & 231.98 & 70.71 & 3146.48 & 959.05 & \\
\hline
\end{tabular}


Waste Isolation Pilot Plant 2001 Site Environmental Report DOE/WIPP 02-2225

Table 6.9 - Groundwater Level Measurement Results for 2001

\begin{tabular}{|c|c|c|c|c|c|c|c|c|c|c|c|}
\hline WELL_NO & ZONE & TOC_AMSL* & DATE & TIME & TP_FT_TOC & ADJ_FT & WL_FT & WL_METERS & WL_MSL_FT & WL_MSL_M & Adj_Fr_Hd_amsl \\
\hline $\mathrm{H}-02 \mathrm{~b} 1$ & MAG & 3378.46 & $3 / 8 / 01$ & $10: 10$ & 231.88 & 0.00 & 231.88 & 70.68 & 3146.58 & 959.08 & \\
\hline $\mathrm{H}-02 \mathrm{~b} 1$ & MAG & 3378.46 & $4 / 5 / 01$ & $14: 43$ & 231.74 & 0.00 & 231.74 & 70.63 & 3146.72 & 959.12 & \\
\hline $\mathrm{H}-02 \mathrm{~b} 1$ & MAG & 3378.46 & $5 / 8 / 01$ & 14:06 & 231.61 & 0.00 & 231.61 & 70.59 & 3146.85 & 959.16 & \\
\hline $\mathrm{H}-02 \mathrm{~b} 1$ & MAG & 3378.46 & $6 / 6 / 01$ & 09:56 & 231.51 & 0.00 & 231.51 & 70.56 & 3146.95 & 959.19 & \\
\hline $\mathrm{H}-02 \mathrm{~b} 1$ & MAG & 3378.46 & $7 / 11 / 01$ & 14:05 & 231.42 & 0.00 & 231.42 & 70.54 & 3147.04 & 959.22 & \\
\hline $\mathrm{H}-02 \mathrm{~b} 1$ & MAG & 3378.46 & $8 / 7 / 01$ & 11:57 & 231.34 & 0.00 & 231.34 & 70.51 & 3147.12 & 959.24 & \\
\hline $\mathrm{H}-02 \mathrm{~b} 1$ & MAG & 3378.46 & 9/6/01 & $12: 25$ & 231.23 & 0.00 & 231.23 & 70.48 & 3147.23 & 959.28 & \\
\hline $\mathrm{H}-02 \mathrm{~b} 1$ & MAG & 3378.46 & 10/10/01 & $07: 28$ & 231.23 & 0.00 & 231.23 & 70.48 & 3147.23 & 959.28 & \\
\hline $\mathrm{H}-02 \mathrm{~b} 1$ & MAG & 3378.46 & $11 / 14 / 01$ & 11:01 & 231.26 & 0.00 & 231.26 & 70.49 & 3147.20 & 959.27 & \\
\hline $\mathrm{H}-02 \mathrm{~b} 1$ & MAG & 3378.46 & $12 / 5 / 01$ & $13: 34$ & 231.27 & 0.00 & 231.27 & 70.49 & 3147.19 & 959.26 & \\
\hline $\mathrm{H}-02 \mathrm{~b} 2$ & CUL & 3378.31 & $1 / 9 / 01$ & $13: 29$ & 341.46 & 0.00 & 341.46 & 104.08 & 3036.85 & 925.63 & 3039.20 \\
\hline $\mathrm{H}-02 \mathrm{~b} 2$ & CUL & 3378.31 & $2 / 6 / 01$ & 13:52 & 341.40 & 0.00 & 341.40 & 104.06 & 3036.91 & 925.65 & 3039.26 \\
\hline $\mathrm{H}-02 \mathrm{~b} 2$ & CUL & 3378.31 & $3 / 8 / 01$ & 10:02 & 341.19 & 0.00 & 341.19 & 103.99 & 3037.12 & 925.71 & 3039.47 \\
\hline $\mathrm{H}-02 \mathrm{~b} 2$ & CUL & 3378.31 & $4 / 5 / 01$ & $14: 45$ & 341.15 & 0.00 & 341.15 & 103.98 & 3037.16 & 925.73 & 3039.51 \\
\hline $\mathrm{H}-02 \mathrm{~b} 2$ & CUL & 3378.31 & $5 / 8 / 01$ & $14: 11$ & 341.32 & 0.00 & 341.32 & 104.03 & 3036.99 & 925.67 & 3039.34 \\
\hline $\mathrm{H}-02 \mathrm{~b} 2$ & CUL & 3378.31 & $6 / 6 / 01$ & 10:05 & 341.03 & 0.00 & 341.03 & 103.95 & 3037.28 & 925.76 & 3039.63 \\
\hline $\mathrm{H}-02 \mathrm{~b} 2$ & CUL & 3378.31 & $7 / 11 / 01$ & $14: 14$ & 341.04 & 0.00 & 341.04 & 103.95 & 3037.27 & 925.76 & 3039.62 \\
\hline $\mathrm{H}-02 \mathrm{~b} 2$ & CUL & 3378.31 & $8 / 7 / 01$ & 12:51 & 341.01 & 0.00 & 341.01 & 103.94 & 3037.30 & 925.77 & 3039.65 \\
\hline $\mathrm{H}-02 \mathrm{~b} 2$ & CUL & 3378.31 & $9 / 6 / 01$ & $12: 10$ & 340.70 & 0.00 & 340.70 & 103.85 & 3037.61 & 925.86 & 3039.96 \\
\hline $\mathrm{H}-02 \mathrm{~b} 2$ & CUL & 3378.31 & $10 / 10 / 01$ & 07:33 & 340.69 & 0.00 & 340.69 & 103.84 & 3037.62 & 925.87 & 3039.97 \\
\hline $\mathrm{H}-02 \mathrm{~b} 2$ & CUL & 3378.31 & $11 / 14 / 01$ & 11:05 & 340.52 & 0.00 & 340.52 & 103.79 & 3037.79 & 925.92 & 3040.14 \\
\hline $\mathrm{H}-02 \mathrm{~b} 2$ & CUL & 3378.31 & $12 / 5 / 01$ & $13: 38$ & 340.71 & 0.00 & 340.71 & 103.85 & 3037.60 & 925.86 & 3039.95 \\
\hline $\mathrm{H}-02 \mathrm{c}$ & CUL & 3378.41 & $3 / 8 / 01$ & 09:56 & 341.39 & 0.00 & 341.39 & 104.06 & 3037.02 & 925.68 & 3049.88 \\
\hline $\mathrm{H}-02 \mathrm{c}$ & CUL & 3378.41 & $6 / 6 / 01$ & 09:50 & 341.00 & 0.00 & 341.00 & 103.94 & 3037.41 & 925.80 & 3050.29 \\
\hline $\mathrm{H}-02 \mathrm{c}$ & CUL & 3378.41 & 9/6/01 & 12:04 & 340.77 & 0.00 & 340.77 & 103.87 & 3037.64 & 925.87 & 3050.53 \\
\hline $\mathrm{H}-02 \mathrm{c}$ & CUL & 3378.41 & $12 / 5 / 01$ & $13: 29$ & 339.70 & 0.00 & 339.70 & 103.54 & 3038.71 & 926.20 & 3051.65 \\
\hline $\mathrm{H}-03 \mathrm{~b} 1$ & MAG & 3390.64 & $1 / 9 / 01$ & 13:45 & 238.76 & 0.00 & 238.76 & 72.77 & 3151.88 & 960.69 & \\
\hline $\mathrm{H}-03 \mathrm{~b} 1$ & MAG & 3390.64 & $2 / 6 / 01$ & 14:04 & 238.69 & 0.00 & 238.69 & 72.75 & 3151.95 & 960.71 & \\
\hline $\mathrm{H}-03 \mathrm{~b} 1$ & MAG & 3390.64 & $3 / 8 / 01$ & $10: 26$ & 238.45 & 0.00 & 238.45 & 72.68 & 3152.19 & 960.79 & \\
\hline $\mathrm{H}-03 \mathrm{~b} 1$ & MAG & 3390.64 & $4 / 5 / 01$ & $13: 45$ & 239.38 & 0.00 & 239.38 & 72.96 & 3151.26 & 960.50 & \\
\hline $\mathrm{H}-03 \mathrm{~b} 1$ & MAG & 3390.64 & $5 / 9 / 01$ & 11:14 & 239.66 & 0.00 & 239.66 & 73.05 & 3150.98 & 960.42 & \\
\hline $\mathrm{H}-03 \mathrm{~b} 1$ & MAG & 3390.64 & 6/6/01 & 07:10 & 239.47 & 0.00 & 239.47 & 72.99 & 3151.17 & 960.48 & \\
\hline $\mathrm{H}-03 \mathrm{~b} 1$ & MAG & 3390.64 & $7 / 10 / 01$ & $12: 45$ & 239.63 & 0.00 & 239.63 & 73.04 & 3151.01 & 960.43 & \\
\hline $\mathrm{H}-03 \mathrm{~b} 1$ & MAG & 3390.64 & $8 / 7 / 01$ & 13:24 & 239.76 & 0.00 & 239.76 & 73.08 & 3150.88 & 960.39 & \\
\hline $\mathrm{H}-03 \mathrm{~b} 1$ & MAG & 3390.64 & 9/6/01 & 13:00 & 239.73 & 0.00 & 239.73 & 73.07 & 3150.91 & 960.40 & \\
\hline $\mathrm{H}-03 \mathrm{~b} 1$ & MAG & 3390.64 & $10 / 10 / 01$ & 08:17 & 239.87 & 0.00 & 239.87 & 73.11 & 3150.77 & 960.35 & \\
\hline $\mathrm{H}-03 \mathrm{~b} 1$ & MAG & 3390.64 & $11 / 14 / 01$ & $10: 29$ & 240.01 & 0.00 & 240.01 & 73.16 & 3150.63 & 960.31 & \\
\hline
\end{tabular}


Waste Isolation Pilot Plant 2001 Site Environmental Report DOE/WIPP 02-2225

Table 6.9 - Groundwater Level Measurement Results for 2001

\begin{tabular}{|c|c|c|c|c|c|c|c|c|c|c|c|}
\hline WELL_NO & ZONE & TOC_AMSL* & DATE & TIME & TP_FT_TOC & ADJ_FT & WL_FT & WL_METERS & WL_MSL_FT & WL_MSL_M & Adj_Fr_Hd_amsI \\
\hline $\mathrm{H}-03 \mathrm{~b} 1$ & MAG & 3390.64 & $12 / 5 / 01$ & 10:32 & 240.09 & 0.00 & 240.09 & 73.18 & 3150.55 & 960.29 & \\
\hline $\mathrm{H}-03 \mathrm{~b} 2$ & CUL & 3390.03 & $1 / 9 / 01$ & $14: 01$ & 391.80 & 0.00 & 391.80 & 119.42 & 2998.23 & 913.86 & 3009.55 \\
\hline $\mathrm{H}-03 \mathrm{~b} 2$ & CUL & 3390.03 & $2 / 6 / 01$ & $14: 20$ & 391.68 & 0.00 & 391.68 & 119.38 & 2998.35 & 913.90 & 3009.67 \\
\hline $\mathrm{H}-03 \mathrm{~b} 2$ & CUL & 3390.03 & $3 / 8 / 01$ & $10: 52$ & 391.45 & 0.00 & 391.45 & 119.31 & 2998.58 & 913.97 & 3009.91 \\
\hline $\mathrm{H}-03 \mathrm{~b} 2$ & CUL & 3390.03 & $4 / 5 / 01$ & $13: 56$ & 391.36 & 0.00 & 391.36 & 119.29 & 2998.67 & 913.99 & 3010.01 \\
\hline $\mathrm{H}-03 \mathrm{~b} 2$ & CUL & 3390.03 & $5 / 9 / 01$ & $10: 56$ & 392.14 & 0.00 & 392.14 & 119.52 & 2997.89 & 913.76 & 3009.20 \\
\hline $\mathrm{H}-03 \mathrm{~b} 2$ & CUL & 3390.03 & $6 / 6 / 01$ & $07: 36$ & 391.40 & 0.00 & 391.40 & 119.30 & 2998.63 & 913.98 & 3009.97 \\
\hline $\mathrm{H}-03 \mathrm{~b} 2$ & CUL & 3390.03 & $7 / 10 / 01$ & $12: 50$ & 391.15 & 0.00 & 391.15 & 119.22 & 2998.88 & 914.06 & 3010.22 \\
\hline $\mathrm{H}-03 \mathrm{~b} 2$ & CUL & 3390.03 & $8 / 7 / 01$ & $13: 33$ & 391.15 & 0.00 & 391.15 & 119.22 & 2998.88 & 914.06 & 3010.22 \\
\hline $\mathrm{H}-03 \mathrm{~b} 2$ & CUL & 3390.03 & 9/6/01 & $13: 30$ & 390.74 & 0.00 & 390.74 & 119.10 & 2999.29 & 914.18 & 3010.65 \\
\hline $\mathrm{H}-03 \mathrm{~b} 2$ & CUL & 3390.03 & 10/10/01 & $08: 34$ & 390.79 & 0.00 & 390.79 & 119.11 & 2999.24 & 914.17 & 3010.60 \\
\hline $\mathrm{H}-03 \mathrm{~b} 2$ & CUL & 3390.03 & $11 / 14 / 01$ & 09:19 & 391.18 & 0.00 & 391.18 & 119.23 & 2998.85 & 914.05 & 3010.19 \\
\hline $\mathrm{H}-03 \mathrm{~b} 2$ & CUL & 3390.03 & $12 / 5 / 01$ & $10: 54$ & 391.09 & 0.00 & 391.09 & 119.20 & 2998.94 & 914.08 & 3010.29 \\
\hline $\mathrm{H}-03 \mathrm{~b} 3$ & CUL & 3388.67 & $3 / 8 / 01$ & $10: 43$ & 390.34 & 0.00 & 390.34 & 118.98 & 2998.33 & 913.89 & 3008.01 \\
\hline $\mathrm{H}-03 \mathrm{~b} 3$ & CUL & 3388.67 & $6 / 6 / 01$ & $07: 30$ & 389.85 & 0.00 & 389.85 & 118.83 & 2998.82 & 914.04 & 3008.52 \\
\hline $\mathrm{H}-03 \mathrm{~b} 3$ & CUL & 3388.67 & 9/6/01 & $13: 25$ & 389.20 & 0.00 & 389.20 & 118.63 & 2999.47 & 914.24 & 3009.19 \\
\hline $\mathrm{H}-03 \mathrm{~b} 3$ & CUL & 3388.67 & $12 / 5 / 01$ & $10: 47$ & 389.67 & 0.00 & 389.67 & 118.77 & 2999.00 & 914.10 & 3008.70 \\
\hline $\mathrm{H}-03 \mathrm{~d} / 49$ (PIP) & 49ER & 3390.01 & $1 / 9 / 01$ & $13: 50$ & 302.52 & 2.22 & 300.30 & 91.53 & 3089.71 & 941.74 & \\
\hline $\mathrm{H}-03 \mathrm{~d} / 49$ (PIP) & 49ER & 3390.01 & $2 / 6 / 01$ & $14: 07$ & 302.37 & 2.22 & 300.15 & 91.49 & 3089.86 & 941.79 & \\
\hline $\mathrm{H}-03 \mathrm{~d} / 49$ (PIP) & 49ER & 3390.01 & $3 / 8 / 01$ & $10: 31$ & 302.05 & 2.22 & 299.83 & 91.39 & 3090.18 & 941.89 & \\
\hline $\mathrm{H}-03 \mathrm{~d} / 49$ (PIP) & 49ER & 3390.01 & $4 / 5 / 01$ & 13:48 & 301.81 & 2.22 & 299.59 & 91.32 & 3090.42 & 941.96 & \\
\hline $\mathrm{H}-03 \mathrm{~d} / 49$ (PIP) & 49ER & 3390.01 & $5 / 9 / 01$ & $11: 03$ & 301.50 & 2.22 & 299.28 & 91.22 & 3090.73 & 942.05 & \\
\hline $\mathrm{H}-03 \mathrm{~d} / 49$ (PIP) & 49ER & 3390.01 & $6 / 6 / 01$ & $07: 19$ & 301.34 & 2.22 & 299.12 & 91.17 & 3090.89 & 942.10 & \\
\hline $\mathrm{H}-03 \mathrm{~d} / 49$ (PIP) & 49ER & 3390.01 & 7/10/01 & $12: 35$ & 301.23 & 2.22 & 299.01 & 91.14 & 3091.00 & 942.14 & \\
\hline $\mathrm{H}-03 \mathrm{~d} / 49(\mathrm{PIP})$ & 49ER & 3390.01 & $8 / 7 / 01$ & 13:29 & 301.26 & 2.22 & 299.04 & 91.15 & 3090.97 & 942.13 & \\
\hline $\mathrm{H}-03 \mathrm{~d} / 49$ (PIP) & 49ER & 3390.01 & $9 / 6 / 01$ & 13:05 & 301.00 & 2.22 & 298.78 & 91.07 & 3091.23 & 942.21 & \\
\hline $\mathrm{H}-03 \mathrm{~d} / 49$ (PIP) & 49ER & 3390.01 & 10/10/01 & $08: 22$ & 300.84 & 2.22 & 298.62 & 91.02 & 3091.39 & 942.26 & \\
\hline $\mathrm{H}-03 \mathrm{~d} / 49$ (PIP) & 49ER & 3390.01 & $11 / 14 / 01$ & $10: 23$ & 300.62 & 2.22 & 298.40 & 90.95 & 3091.61 & 942.32 & \\
\hline $\mathrm{H}-03 \mathrm{~d} / 49$ (PIP) & 49ER & 3390.01 & $12 / 5 / 01$ & $10: 37$ & 300.59 & 2.22 & 298.37 & 90.94 & 3091.64 & 942.33 & \\
\hline $\mathrm{H}-03 \mathrm{~d} / \mathrm{DL}$ (PVC) & $\mathrm{DL}$ & 3390.01 & $1 / 9 / 01$ & 13:54 & 319.13 & 2.22 & 316.91 & 96.59 & 3073.10 & 936.68 & \\
\hline $\mathrm{H}-03 \mathrm{~d} / \mathrm{DL}$ (PVC) & $\mathrm{DL}$ & 3390.01 & $2 / 6 / 01$ & $14: 13$ & 319.14 & 2.22 & 316.92 & 96.60 & 3073.09 & 936.68 & \\
\hline $\mathrm{H}-03 \mathrm{~d} / \mathrm{DL}(\mathrm{PVC})$ & $\mathrm{DL}$ & 3390.01 & $3 / 8 / 01$ & 10:34 & 318.98 & 2.22 & 316.76 & 96.55 & 3073.25 & 936.73 & \\
\hline $\mathrm{H}-03 \mathrm{~d} / \mathrm{DL}$ (PVC) & $\mathrm{DL}$ & 3390.01 & $4 / 5 / 01$ & $13: 52$ & 318.91 & 2.22 & 316.69 & 96.53 & 3073.32 & 936.75 & \\
\hline $\mathrm{H}-03 \mathrm{~d} / \mathrm{DL}(\mathrm{PVC})$ & $\mathrm{DL}$ & 3390.01 & $5 / 9 / 01$ & $11: 10$ & 318.77 & 2.22 & 316.55 & 96.48 & 3073.46 & 936.79 & \\
\hline $\mathrm{H}-03 \mathrm{~d} / \mathrm{DL}$ (PVC) & $\mathrm{DL}$ & 3390.01 & $6 / 6 / 01$ & $07: 24$ & 318.70 & 2.22 & 316.48 & 96.46 & 3073.53 & 936.81 & \\
\hline $\mathrm{H}-03 \mathrm{~d} / \mathrm{DL}$ (PVC) & $\mathrm{DL}$ & 3390.01 & $7 / 10 / 01$ & $12: 40$ & 318.58 & 2.22 & 316.36 & 96.43 & 3073.65 & 936.85 & \\
\hline $\mathrm{H}-03 \mathrm{~d} / \mathrm{DL}(\mathrm{PVC})$ & $\mathrm{DL}$ & 3390.01 & $8 / 7 / 01$ & $13: 38$ & 318.53 & 2.22 & 316.31 & 96.41 & 3073.70 & 936.86 & \\
\hline
\end{tabular}


Waste Isolation Pilot Plant 2001 Site Environmental Report DOE/WIPP 02-2225

Table 6.9 - Groundwater Level Measurement Results for 2001

\begin{tabular}{|c|c|c|c|c|c|c|c|c|c|c|c|}
\hline WELL_NO & ZONE & TOC_AMSL* & DATE & TIME & TP_FT_TOC & ADJ_FT & WL_FT & WL_METERS & WL_MSL_FT & WL_MSL_M & Adj_Fr_Hd_amsI \\
\hline $\mathrm{H}-03 \mathrm{~d} / \mathrm{DL}$ (PVC) & $\mathrm{DL}$ & 3390.01 & $9 / 4 / 01$ & $13: 15$ & 318.44 & 2.22 & 316.22 & 96.38 & 3073.79 & 936.89 & \\
\hline $\mathrm{H}-03 \mathrm{~d} / \mathrm{DL}$ (PVC) & $\mathrm{DL}$ & 3390.01 & 10/10/01 & $08: 27$ & 318.37 & 2.22 & 316.15 & 96.36 & 3073.86 & 936.91 & \\
\hline $\mathrm{H}-03 \mathrm{~d} / \mathrm{DL}$ (PVC) & $\mathrm{DL}$ & 3390.01 & $11 / 14 / 01$ & $10: 20$ & 318.29 & 2.22 & 316.07 & 96.34 & 3073.94 & 936.94 & \\
\hline $\mathrm{H}-03 \mathrm{~d} / \mathrm{DL}$ (PVC) & $\mathrm{DL}$ & 3390.01 & $12 / 5 / 01$ & $10: 41$ & 318.27 & 2.22 & 316.05 & 96.33 & 3073.96 & 936.94 & \\
\hline $\mathrm{H}-04 \mathrm{~b}$ & CUL & 3333.35 & $1 / 9 / 01$ & $14: 16$ & 332.85 & 0.00 & 332.85 & 101.45 & 3000.50 & 914.55 & 3004.07 \\
\hline $\mathrm{H}-04 \mathrm{~b}$ & CUL & 3333.35 & $2 / 7 / 01$ & $12: 00$ & 332.60 & 0.00 & 332.60 & 101.38 & 3000.75 & 914.63 & 3004.33 \\
\hline $\mathrm{H}-04 \mathrm{~b}$ & CUL & 3333.35 & $3 / 8 / 01$ & $09: 23$ & 332.40 & 0.00 & 332.40 & 101.32 & 3000.95 & 914.69 & 3004.53 \\
\hline $\mathrm{H}-04 \mathrm{~b}$ & CUL & 3333.35 & $4 / 5 / 01$ & $14: 19$ & 332.29 & 0.00 & 332.29 & 101.28 & 3001.06 & 914.72 & 3004.64 \\
\hline $\mathrm{H}-04 \mathrm{~b}$ & CUL & 3333.35 & $5 / 9 / 01$ & 07:47 & 332.25 & 0.00 & 332.25 & 101.27 & 3001.10 & 914.74 & 3004.69 \\
\hline $\mathrm{H}-04 \mathrm{~b}$ & CUL & 3333.35 & $6 / 6 / 01$ & $09: 26$ & 331.97 & 0.00 & 331.97 & 101.18 & 3001.38 & 914.82 & 3004.97 \\
\hline $\mathrm{H}-04 \mathrm{~b}$ & CUL & 3333.35 & 7/11/01 & $08: 54$ & 332.19 & 0.00 & 332.19 & 101.25 & 3001.16 & 914.75 & 3004.75 \\
\hline $\mathrm{H}-04 \mathrm{~b}$ & CUL & 3333.35 & 8/7/01 & 10:39 & 332.36 & 0.00 & 332.36 & 101.30 & 3000.99 & 914.70 & 3004.57 \\
\hline $\mathrm{H}-04 \mathrm{~b}$ & CUL & 3333.35 & 9/6/01 & $14: 12$ & 332.24 & 0.00 & 332.24 & 101.27 & 3001.11 & 914.74 & 3004.70 \\
\hline $\mathrm{H}-04 \mathrm{~b}$ & CUL & 3333.35 & 10/10/01 & 09:04 & 332.31 & 0.00 & 332.31 & 101.29 & 3001.04 & 914.72 & 3004.62 \\
\hline $\mathrm{H}-04 \mathrm{~b}$ & CUL & 3333.35 & $11 / 14 / 01$ & 10:03 & 332.18 & 0.00 & 332.18 & 101.25 & 3001.17 & 914.76 & 3004.76 \\
\hline $\mathrm{H}-04 \mathrm{~b}$ & CUL & 3333.35 & $12 / 5 / 01$ & $13: 13$ & 332.28 & 0.00 & 332.28 & 101.28 & 3001.07 & 914.73 & 3004.66 \\
\hline $\mathrm{H}-04 \mathrm{c}$ & MAG & 3334.04 & $1 / 9 / 01$ & $14: 24$ & 190.06 & 0.00 & 190.06 & 57.93 & 3143.98 & 958.29 & \\
\hline $\mathrm{H}-04 \mathrm{c}$ & MAG & 3334.04 & $2 / 7 / 01$ & $12: 12$ & 190.00 & 0.00 & 190.00 & 57.91 & 3144.04 & 958.30 & \\
\hline $\mathrm{H}-04 \mathrm{c}$ & MAG & 3334.04 & $3 / 8 / 01$ & $09: 27$ & 189.88 & 0.00 & 189.88 & 57.88 & 3144.16 & 958.34 & \\
\hline $\mathrm{H}-04 \mathrm{c}$ & MAG & 3334.04 & $4 / 5 / 01$ & $14: 22$ & 189.74 & 0.00 & 189.74 & 57.83 & 3144.30 & 958.38 & \\
\hline $\mathrm{H}-04 \mathrm{c}$ & MAG & 3334.04 & $5 / 9 / 01$ & $07: 52$ & 189.86 & 0.00 & 189.86 & 57.87 & 3144.18 & 958.35 & \\
\hline $\mathrm{H}-04 \mathrm{c}$ & MAG & 3334.04 & $6 / 6 / 01$ & 09:33 & 189.72 & 0.00 & 189.72 & 57.83 & 3144.32 & 958.39 & \\
\hline $\mathrm{H}-04 \mathrm{c}$ & MAG & 3334.04 & $7 / 11 / 01$ & 09:02 & 189.85 & 0.00 & 189.85 & 57.87 & 3144.19 & 958.35 & \\
\hline $\mathrm{H}-04 \mathrm{c}$ & MAG & 3334.04 & $8 / 7 / 01$ & $10: 52$ & 189.85 & 0.00 & 189.85 & 57.87 & 3144.19 & 958.35 & \\
\hline $\mathrm{H}-04 \mathrm{c}$ & MAG & 3334.04 & 9/6/01 & $14: 05$ & 189.71 & 0.00 & 189.71 & 57.82 & 3144.33 & 958.39 & \\
\hline $\mathrm{H}-04 \mathrm{c}$ & MAG & 3334.04 & $10 / 10 / 01$ & $08: 51$ & 189.76 & 0.00 & 189.76 & 57.84 & 3144.28 & 958.38 & \\
\hline $\mathrm{H}-04 \mathrm{c}$ & MAG & 3334.04 & $11 / 14 / 01$ & $10: 00$ & 189.82 & 0.00 & 189.82 & 57.86 & 3144.22 & 958.36 & \\
\hline $\mathrm{H}-04 \mathrm{c}$ & MAG & 3334.04 & $12 / 5 / 01$ & 13:09 & 189.71 & 0.00 & 189.71 & 57.82 & 3144.33 & 958.39 & \\
\hline $\mathrm{H}-05 a$ & CUL & 3506.24 & $3 / 7 / 01$ & $08: 50$ & 475.09 & 0.00 & 475.09 & 144.81 & 3031.15 & 923.89 & 3071.09 \\
\hline $\mathrm{H}-05 a$ & CUL & 3506.24 & $6 / 7 / 01$ & $10: 47$ & 475.05 & 0.00 & 475.05 & 144.80 & 3031.19 & 923.91 & 3071.13 \\
\hline $\mathrm{H}-05 a$ & CUL & 3506.24 & $9 / 10 / 01$ & 07:00 & 475.23 & 0.00 & 475.23 & 144.85 & 3031.01 & 923.85 & 3070.93 \\
\hline $\mathrm{H}-05 \mathrm{a}$ & CUL & 3506.24 & $12 / 4 / 01$ & $11: 18$ & 474.94 & 0.00 & 474.94 & 144.76 & 3031.30 & 923.94 & 3071.25 \\
\hline $\mathrm{H}-05 \mathrm{~b}$ & CUL & 3506.04 & $1 / 9 / 01$ & $08: 16$ & 477.67 & 0.00 & 477.67 & 145.59 & 3028.37 & 923.05 & 3073.24 \\
\hline $\mathrm{H}-05 \mathrm{~b}$ & CUL & 3506.04 & $2 / 6 / 01$ & 08:00 & 477.71 & 0.00 & 477.71 & 145.61 & 3028.33 & 923.03 & 3073.20 \\
\hline $\mathrm{H}-05 \mathrm{~b}$ & CUL & 3506.04 & $3 / 7 / 01$ & $08: 44$ & 477.59 & 0.00 & 477.59 & 145.57 & 3028.45 & 923.07 & 3073.33 \\
\hline $\mathrm{H}-05 \mathrm{~b}$ & CUL & 3506.04 & $4 / 4 / 01$ & $11: 58$ & 477.40 & 0.00 & 477.40 & 145.51 & 3028.64 & 923.13 & 3073.54 \\
\hline $\mathrm{H}-05 \mathrm{~b}$ & CUL & 3506.04 & $5 / 8 / 01$ & $10: 29$ & 477.62 & 0.00 & 477.62 & 145.58 & 3028.42 & 923.06 & 3073.30 \\
\hline
\end{tabular}


Waste Isolation Pilot Plant 2001 Site Environmental Report DOE/WIPP 02-2225

Table 6.9 - Groundwater Level Measurement Results for 2001

\begin{tabular}{|c|c|c|c|c|c|c|c|c|c|c|c|}
\hline WELL_NO & ZONE & TOC_AMSL* & DATE & TIME & TP_FT_TOC & ADJ_FT & WL_FT & WL_METERS & WL_MSL_FT & WL_MSL_M & Adj_Fr_Hd_amsI \\
\hline $\mathrm{H}-05 \mathrm{~b}$ & CUL & 3506.04 & $6 / 7 / 01$ & 10:35 & 477.50 & 0.00 & 477.50 & 145.54 & 3028.54 & 923.10 & 3073.43 \\
\hline $\mathrm{H}-05 \mathrm{~b}$ & CUL & 3506.04 & 7/10/01 & 09:11 & 477.56 & 0.00 & 477.56 & 145.56 & 3028.48 & 923.08 & 3073.37 \\
\hline $\mathrm{H}-05 \mathrm{~b}$ & CUL & 3506.04 & $8 / 8 / 01$ & $14: 46$ & 477.60 & 0.00 & 477.60 & 145.57 & 3028.44 & 923.07 & 3073.32 \\
\hline $\mathrm{H}-05 \mathrm{~b}$ & CUL & 3506.04 & $9 / 10 / 01$ & $06: 50$ & 477.62 & 0.00 & 477.62 & 145.58 & 3028.42 & 923.06 & 3073.30 \\
\hline $\mathrm{H}-05 \mathrm{~b}$ & CUL & 3506.04 & 10/10/01 & $12: 06$ & 477.49 & 0.00 & 477.49 & 145.54 & 3028.55 & 923.10 & 3073.44 \\
\hline $\mathrm{H}-05 \mathrm{~b}$ & CUL & 3506.04 & $11 / 13 / 01$ & $13: 23$ & 477.55 & 0.00 & 477.55 & 145.56 & 3028.49 & 923.08 & 3073.38 \\
\hline $\mathrm{H}-05 \mathrm{~b}$ & CUL & 3506.04 & $12 / 4 / 01$ & 11:11 & 477.47 & 0.00 & 477.47 & 145.53 & 3028.57 & 923.11 & 3073.47 \\
\hline $\mathrm{H}-05 \mathrm{c}$ & MAG & 3506.04 & $1 / 9 / 01$ & $08: 22$ & 349.08 & 0.00 & 349.08 & 106.40 & 3156.96 & 962.24 & \\
\hline $\mathrm{H}-05 \mathrm{c}$ & MAG & 3506.04 & $2 / 6 / 01$ & 08:07 & 349.00 & 0.00 & 349.00 & 106.38 & 3157.04 & 962.27 & \\
\hline $\mathrm{H}-05 \mathrm{c}$ & MAG & 3506.04 & $3 / 7 / 01$ & $08: 49$ & 348.95 & 0.00 & 348.95 & 106.36 & 3157.09 & 962.28 & \\
\hline $\mathrm{H}-05 \mathrm{c}$ & MAG & 3506.04 & $4 / 4 / 01$ & 12:07 & 348.71 & 0.00 & 348.71 & 106.29 & 3157.33 & 962.35 & \\
\hline $\mathrm{H}-05 \mathrm{c}$ & MAG & 3506.04 & $5 / 8 / 01$ & $10: 35$ & 348.92 & 0.00 & 348.92 & 106.35 & 3157.12 & 962.29 & \\
\hline $\mathrm{H}-05 \mathrm{c}$ & MAG & 3506.04 & $6 / 7 / 01$ & $10: 55$ & 348.65 & 0.00 & 348.65 & 106.27 & 3157.39 & 962.37 & \\
\hline $\mathrm{H}-05 \mathrm{c}$ & MAG & 3506.04 & $7 / 10 / 01$ & $09: 20$ & 348.83 & 0.00 & 348.83 & 106.32 & 3157.21 & 962.32 & \\
\hline $\mathrm{H}-05 \mathrm{c}$ & MAG & 3506.04 & $8 / 8 / 01$ & $15: 00$ & 348.84 & 0.00 & 348.84 & 106.33 & 3157.20 & 962.31 & \\
\hline $\mathrm{H}-05 \mathrm{c}$ & MAG & 3506.04 & 9/10/01 & 07:05 & 348.89 & 0.00 & 348.89 & 106.34 & 3157.15 & 962.30 & \\
\hline $\mathrm{H}-05 \mathrm{c}$ & MAG & 3506.04 & 10/10/01 & $12: 14$ & 348.75 & 0.00 & 348.75 & 106.30 & 3157.29 & 962.34 & \\
\hline $\mathrm{H}-05 \mathrm{c}$ & MAG & 3506.04 & $11 / 13 / 01$ & 13:31 & 348.85 & 0.00 & 348.85 & 106.33 & 3157.19 & 962.31 & \\
\hline $\mathrm{H}-05 \mathrm{c}$ & MAG & 3506.04 & $12 / 4 / 01$ & $11: 27$ & 348.75 & 0.00 & 348.75 & 106.30 & 3157.29 & 962.34 & \\
\hline $\mathrm{H}-06 \mathrm{a}$ & CUL & 3348.11 & $3 / 6 / 01$ & $10: 42$ & 295.54 & 0.00 & 295.54 & 90.08 & 3052.57 & 930.42 & 3064.76 \\
\hline $\mathrm{H}-06 \mathrm{a}$ & CUL & 3348.11 & $6 / 5 / 01$ & 11:39 & 295.16 & 0.00 & 295.16 & 89.96 & 3052.95 & 930.54 & 3065.16 \\
\hline $\mathrm{H}-06 \mathrm{a}$ & CUL & 3348.11 & $9 / 4 / 01$ & 07:19 & 295.10 & 0.00 & 295.10 & 89.95 & 3053.01 & 930.56 & 3065.22 \\
\hline $\mathrm{H}-06 \mathrm{a}$ & CUL & 3348.11 & $12 / 4 / 01$ & $14: 10$ & 294.97 & 0.00 & 294.97 & 89.91 & 3053.14 & 930.60 & 3065.35 \\
\hline $\mathrm{H}-06 \mathrm{~b}$ & CUL & 3348.25 & $1 / 9 / 01$ & 09:54 & 296.45 & 0.00 & 296.45 & 90.36 & 3051.80 & 930.19 & 3063.95 \\
\hline $\mathrm{H}-06 \mathrm{~b}$ & CUL & 3348.25 & 2/6/01 & 09:08 & 296.32 & 0.00 & 296.32 & 90.32 & 3051.93 & 930.23 & 3064.08 \\
\hline $\mathrm{H}-06 \mathrm{~b}$ & CUL & 3348.25 & $3 / 6 / 01$ & $10: 51$ & 296.33 & 0.00 & 296.33 & 90.32 & 3051.92 & 930.23 & 3064.07 \\
\hline $\mathrm{H}-06 \mathrm{~b}$ & CUL & 3348.25 & $4 / 4 / 01$ & $14: 23$ & 296.04 & 0.00 & 296.04 & 90.23 & 3052.21 & 930.31 & 3064.38 \\
\hline $\mathrm{H}-06 \mathrm{~b}$ & CUL & 3348.25 & $5 / 8 / 01$ & 11:51 & 296.25 & 0.00 & 296.25 & 90.30 & 3052.00 & 930.25 & 3064.16 \\
\hline $\mathrm{H}-06 \mathrm{~b}$ & CUL & 3348.25 & $6 / 5 / 01$ & 11:45 & 295.97 & 0.00 & 295.97 & 90.21 & 3052.28 & 930.33 & 3064.45 \\
\hline $\mathrm{H}-06 \mathrm{~b}$ & CUL & 3348.25 & $7 / 9 / 01$ & $08: 50$ & 295.94 & 0.00 & 295.94 & 90.20 & 3052.31 & 930.34 & 3064.48 \\
\hline $\mathrm{H}-06 \mathrm{~b}$ & CUL & 3348.25 & $8 / 7 / 01$ & $14: 18$ & 295.99 & 0.00 & 295.99 & 90.22 & 3052.26 & 930.33 & 3064.43 \\
\hline $\mathrm{H}-06 \mathrm{~b}$ & CUL & 3348.25 & $9 / 4 / 01$ & 07:34 & 295.88 & 0.00 & 295.88 & 90.18 & 3052.37 & 930.36 & 3064.54 \\
\hline $\mathrm{H}-06 \mathrm{~b}$ & CUL & 3348.25 & $10 / 10 / 01$ & $11: 25$ & 295.83 & 0.00 & 295.83 & 90.17 & 3052.42 & 930.38 & 3064.59 \\
\hline $\mathrm{H}-06 \mathrm{~b}$ & CUL & 3348.25 & $11 / 14 / 01$ & 07:19 & 295.62 & 0.00 & 295.62 & 90.10 & 3052.63 & 930.44 & 3064.81 \\
\hline $\mathrm{H}-06 \mathrm{~b}$ & CUL & 3348.25 & $12 / 5 / 01$ & $14: 05$ & 295.75 & 0.00 & 295.75 & 90.14 & 3052.50 & 930.40 & 3064.68 \\
\hline $\mathrm{H}-06 \mathrm{c}$ & MAG & 3348.52 & $1 / 9 / 01$ & 09:48 & 284.09 & 0.00 & 284.09 & 86.59 & 3064.43 & 934.04 & \\
\hline $\mathrm{H}-06 \mathrm{C}$ & MAG & 3348.52 & 2/6/01 & 09:00 & 283.98 & 0.00 & 283.98 & 86.56 & 3064.54 & 934.07 & \\
\hline
\end{tabular}


Waste Isolation Pilot Plant 2001 Site Environmental Report DOE/WIPP 02-2225

Table 6.9 - Groundwater Level Measurement Results for 2001

\begin{tabular}{|c|c|c|c|c|c|c|c|c|c|c|c|}
\hline WELL_NO & ZONE & TOC_AMSL* & DATE & TIME & TP_FT_TOC & ADJ_FT & WL_FT & WL_METERS & WL_MSL_FT & WL_MSL_M & Adj_Fr_Hd_amsl \\
\hline $\mathrm{H}-06 \mathrm{c}$ & MAG & 3348.52 & $3 / 6 / 01$ & $10: 46$ & 283.98 & 0.00 & 283.98 & 86.56 & 3064.54 & 934.07 & \\
\hline $\mathrm{H}-06 \mathrm{c}$ & MAG & 3348.52 & $4 / 4 / 01$ & $14: 15$ & 283.77 & 0.00 & 283.77 & 86.49 & 3064.75 & 934.14 & \\
\hline $\mathrm{H}-06 \mathrm{c}$ & MAG & 3348.52 & $5 / 8 / 01$ & 11:45 & 284.02 & 0.00 & 284.02 & 86.57 & 3064.50 & 934.06 & \\
\hline $\mathrm{H}-06 \mathrm{c}$ & MAG & 3348.52 & $6 / 5 / 01$ & $11: 34$ & 283.71 & 0.00 & 283.71 & 86.47 & 3064.81 & 934.15 & \\
\hline $\mathrm{H}-06 \mathrm{c}$ & MAG & 3348.52 & $7 / 9 / 01$ & 08:45 & 283.83 & 0.00 & 283.83 & 86.51 & 3064.69 & 934.12 & \\
\hline $\mathrm{H}-06 \mathrm{c}$ & MAG & 3348.52 & $8 / 7 / 01$ & $14: 11$ & 283.85 & 0.00 & 283.85 & 86.52 & 3064.67 & 934.11 & \\
\hline $\mathrm{H}-06 \mathrm{c}$ & MAG & 3348.52 & $9 / 4 / 01$ & 07:26 & 283.76 & 0.00 & 283.76 & 86.49 & 3064.76 & 934.14 & \\
\hline $\mathrm{H}-06 \mathrm{c}$ & MAG & 3348.52 & $10 / 10 / 01$ & 11:19 & 283.69 & 0.00 & 283.69 & 86.47 & 3064.83 & 934.16 & \\
\hline $\mathrm{H}-06 \mathrm{c}$ & MAG & 3348.52 & $11 / 14 / 01$ & $07: 25$ & 283.60 & 0.00 & 283.60 & 86.44 & 3064.92 & 934.19 & \\
\hline $\mathrm{H}-06 \mathrm{c}$ & MAG & 3348.52 & $12 / 5 / 01$ & 13:59 & 283.68 & 0.00 & 283.68 & 86.47 & 3064.84 & 934.16 & \\
\hline $\mathrm{H}-07 \mathrm{~b} 1$ & CUL & 3164.17 & $3 / 5 / 01$ & 11:44 & 166.30 & 0.00 & 166.30 & 50.69 & 2997.87 & 913.75 & 2998.32 \\
\hline $\mathrm{H}-07 \mathrm{~b} 1$ & CUL & 3164.17 & $6 / 4 / 01$ & 11:44 & 165.99 & 0.00 & 165.99 & 50.59 & 2998.18 & 913.85 & 2998.63 \\
\hline $\mathrm{H}-07 \mathrm{~b} 1$ & CUL & 3164.17 & $9 / 5 / 01$ & 08:05 & 166.44 & 0.00 & 166.44 & 50.73 & 2997.73 & 913.71 & 2998.18 \\
\hline $\mathrm{H}-07 \mathrm{~b} 1$ & CUL & 3164.17 & $12 / 3 / 01$ & $08: 33$ & 166.48 & 0.00 & 166.48 & 50.74 & 2997.69 & 913.70 & 2998.14 \\
\hline $\mathrm{H}-07 \mathrm{~b} 2$ & CUL & 3164.40 & $1 / 10 / 01$ & 09:11 & 166.48 & 0.00 & 166.48 & 50.74 & 2997.92 & 913.77 & 2997.83 \\
\hline $\mathrm{H}-07 \mathrm{~b} 2$ & CUL & 3164.40 & $2 / 7 / 01$ & $08: 16$ & 166.38 & 0.00 & 166.38 & 50.71 & 2998.02 & 913.80 & 2997.93 \\
\hline $\mathrm{H}-07 \mathrm{~b} 2$ & CUL & 3164.40 & $3 / 5 / 01$ & $11: 40$ & 166.79 & 0.00 & 166.79 & 50.84 & 2997.61 & 913.67 & 2997.52 \\
\hline $\mathrm{H}-07 \mathrm{~b} 2$ & CUL & 3164.40 & $4 / 3 / 01$ & $12: 34$ & 166.40 & 0.00 & 166.40 & 50.72 & 2998.00 & 913.79 & 2997.91 \\
\hline $\mathrm{H}-07 \mathrm{~b} 2$ & CUL & 3164.40 & $5 / 7 / 01$ & $10: 32$ & 166.66 & 0.00 & 166.66 & 50.80 & 2997.74 & 913.71 & 2997.65 \\
\hline $\mathrm{H}-07 \mathrm{~b} 2$ & CUL & 3164.40 & $6 / 4 / 01$ & 11:40 & 166.36 & 0.00 & 166.36 & 50.71 & 2998.04 & 913.80 & 2997.95 \\
\hline $\mathrm{H}-07 \mathrm{~b} 2$ & CUL & 3164.40 & $7 / 9 / 01$ & 09:49 & 166.68 & 0.00 & 166.68 & 50.80 & 2997.72 & 913.71 & 2997.63 \\
\hline $\mathrm{H}-07 \mathrm{~b} 2$ & CUL & 3164.40 & $8 / 6 / 01$ & $11: 28$ & 166.84 & 0.00 & 166.84 & 50.85 & 2997.56 & 913.66 & 2997.47 \\
\hline $\mathrm{H}-07 \mathrm{~b} 2$ & CUL & 3164.40 & 9/5/01 & $07: 53$ & 166.80 & 0.00 & 166.80 & 50.84 & 2997.60 & 913.67 & 2997.51 \\
\hline $\mathrm{H}-07 \mathrm{~b} 2$ & CUL & 3164.40 & $10 / 8 / 01$ & $10: 21$ & 166.80 & 0.00 & 166.80 & 50.84 & 2997.60 & 913.67 & 2997.51 \\
\hline $\mathrm{H}-07 \mathrm{~b} 2$ & CUL & 3164.40 & $11 / 12 / 01$ & $15: 22$ & 166.80 & 0.00 & 166.80 & 50.84 & 2997.60 & 913.67 & 2997.51 \\
\hline $\mathrm{H}-07 \mathrm{~b} 2$ & CUL & 3164.40 & $12 / 3 / 01$ & $08: 24$ & 166.86 & 0.00 & 166.86 & 50.86 & 2997.54 & 913.65 & 2997.45 \\
\hline $\mathrm{H}-08 \mathrm{a}$ & MAG & 3432.99 & 1/10/01 & 09:45 & 405.95 & 0.00 & 405.95 & 123.73 & 3027.04 & 922.64 & \\
\hline $\mathrm{H}-08 \mathrm{a}$ & MAG & 3432.99 & $2 / 7 / 01$ & $08: 53$ & 406.05 & 0.00 & 406.05 & 123.76 & 3026.94 & 922.61 & \\
\hline $\mathrm{H}-08 \mathrm{a}$ & MAG & 3432.99 & $3 / 5 / 01$ & 11:06 & 405.90 & 0.00 & 405.90 & 123.72 & 3027.09 & 922.66 & \\
\hline $\mathrm{H}-08 \mathrm{a}$ & MAG & 3432.99 & $4 / 3 / 01$ & 13:35 & 405.88 & 0.00 & 405.88 & 123.71 & 3027.11 & 922.66 & \\
\hline H-08a & MAG & 3432.99 & $5 / 7 / 01$ & 11:01 & 405.88 & 0.00 & 405.88 & 123.71 & 3027.11 & 922.66 & \\
\hline $\mathrm{H}-08 \mathrm{a}$ & MAG & 3432.99 & $6 / 7 / 01$ & 08:48 & 405.89 & 0.00 & 405.89 & 123.72 & 3027.10 & 922.66 & \\
\hline $\mathrm{H}-08 \mathrm{a}$ & MAG & 3432.99 & $7 / 10 / 01$ & $13: 15$ & 405.96 & 0.00 & 405.96 & 123.74 & 3027.03 & 922.64 & \\
\hline $\mathrm{H}-08 \mathrm{a}$ & MAG & 3432.99 & $8 / 6 / 01$ & 12:25 & 405.99 & 0.00 & 405.99 & 123.75 & 3027.00 & 922.63 & \\
\hline $\mathrm{H}-08 \mathrm{a}$ & MAG & 3432.99 & 9/5/01 & $08: 35$ & 406.04 & 0.00 & 406.04 & 123.76 & 3026.95 & 922.61 & \\
\hline $\mathrm{H}-08 \mathrm{a}$ & MAG & 3432.99 & 10/9/01 & 07:46 & 406.11 & 0.00 & 406.11 & 123.78 & 3026.88 & 922.59 & \\
\hline $\mathrm{H}-08 \mathrm{a}$ & MAG & 3432.99 & $11 / 13 / 01$ & $09: 55$ & 406.15 & 0.00 & 406.15 & 123.79 & 3026.84 & 922.58 & \\
\hline
\end{tabular}


Waste Isolation Pilot Plant 2001 Site Environmental Report DOE/WIPP 02-2225

Table 6.9 - Groundwater Level Measurement Results for 2001

\begin{tabular}{|c|c|c|c|c|c|c|c|c|c|c|c|}
\hline WELL_NO & ZONE & TOC_AMSL* & DATE & TIME & TP_FT_TOC & ADJ_FT & WL_FT & WL_METERS & WL_MSL_FT & WL_MSL_M & Adj_Fr_Hd_amsl \\
\hline $\mathrm{H}-08 \mathrm{a}$ & MAG & 3432.99 & $12 / 4 / 01$ & $08: 20$ & 406.16 & 0.00 & 406.16 & 123.80 & 3026.83 & 922.58 & \\
\hline $\mathrm{H}-08 \mathrm{c}$ & RUS/SAL & 3432.90 & $1 / 10 / 01$ & 09:50 & 453.79 & 0.00 & 453.79 & 138.32 & 2979.11 & 908.03 & \\
\hline $\mathrm{H}-08 \mathrm{c}$ & RUS/SAL & 3432.90 & $2 / 7 / 01$ & 09:00 & 453.88 & 0.00 & 453.88 & 138.34 & 2979.02 & 908.01 & \\
\hline $\mathrm{H}-08 \mathrm{c}$ & RUS/SAL & 3432.90 & $3 / 5 / 01$ & 11:11 & 453.73 & 0.00 & 453.73 & 138.30 & 2979.17 & 908.05 & \\
\hline $\mathrm{H}-08 \mathrm{c}$ & RUS/SAL & 3432.90 & $4 / 3 / 01$ & 13:45 & 453.79 & 0.00 & 453.79 & 138.32 & 2979.11 & 908.03 & \\
\hline $\mathrm{H}-08 \mathrm{c}$ & RUS/SAL & 3432.90 & $5 / 7 / 01$ & 11:06 & 453.65 & 0.00 & 453.65 & 138.27 & 2979.25 & 908.08 & \\
\hline $\mathrm{H}-08 \mathrm{c}$ & RUS/SAL & 3432.90 & $6 / 7 / 01$ & 09:05 & 453.62 & 0.00 & 453.62 & 138.26 & 2979.28 & 908.08 & \\
\hline $\mathrm{H}-08 \mathrm{c}$ & RUS/SAL & 3432.90 & $7 / 10 / 01$ & $13: 25$ & 453.60 & 0.00 & 453.60 & 138.26 & 2979.30 & 908.09 & \\
\hline $\mathrm{H}-08 \mathrm{c}$ & RUS/SAL & 3432.90 & $8 / 6 / 01$ & $12: 33$ & 453.61 & 0.00 & 453.61 & 138.26 & 2979.29 & 908.09 & \\
\hline $\mathrm{H}-08 \mathrm{c}$ & RUS/SAL & 3432.90 & 9/5/01 & $08: 45$ & 453.65 & 0.00 & 453.65 & 138.27 & 2979.25 & 908.08 & \\
\hline $\mathrm{H}-08 \mathrm{c}$ & RUS/SAL & 3432.90 & 10/9/01 & $08: 00$ & 453.55 & 0.00 & 453.55 & 138.24 & 2979.35 & 908.11 & \\
\hline $\mathrm{H}-08 \mathrm{c}$ & RUS/SAL & 3432.90 & $11 / 13 / 01$ & 10:01 & 453.67 & 0.00 & 453.67 & 138.28 & 2979.23 & 908.07 & \\
\hline $\mathrm{H}-08 \mathrm{c}$ & RUS/SAL & 3432.90 & $12 / 4 / 01$ & $08: 28$ & 453.68 & 0.00 & 453.68 & 138.28 & 2979.22 & 908.07 & \\
\hline $\mathrm{H}-09 \mathrm{a}$ & CUL & 3406.68 & $3 / 5 / 01$ & $10: 42$ & 415.35 & 0.54 & 414.81 & 126.43 & 2991.87 & 911.92 & 2992.12 \\
\hline $\mathrm{H}-09 \mathrm{a}$ & CUL & 3406.68 & 6/6/01 & $14: 38$ & 414.73 & 0.54 & 414.19 & 126.25 & 2992.49 & 912.11 & 2992.74 \\
\hline $\mathrm{H}-09 \mathrm{a}$ & CUL & 3406.68 & 9/5/01 & 09:55 & 416.08 & 0.54 & 415.54 & 126.66 & 2991.14 & 911.70 & 2991.39 \\
\hline $\mathrm{H}-09 \mathrm{a}$ & CUL & 3406.68 & $12 / 4 / 01$ & 07:57 & 414.23 & 0.00 & 414.23 & 126.26 & 2992.45 & 912.10 & 2992.70 \\
\hline $\mathrm{H}-09 \mathrm{~b}$ & CUL & 3406.86 & $1 / 10 / 01$ & 10:11 & 415.96 & 0.00 & 415.96 & 126.78 & 2990.90 & 911.63 & 2991.15 \\
\hline $\mathrm{H}-09 \mathrm{~b}$ & CUL & 3406.86 & $2 / 7 / 01$ & $09: 23$ & 415.05 & 0.00 & 415.05 & 126.51 & 2991.81 & 911.90 & 2992.06 \\
\hline $\mathrm{H}-09 \mathrm{~b}$ & CUL & 3406.86 & $3 / 5 / 01$ & $10: 28$ & 414.67 & 0.00 & 414.67 & 126.39 & 2992.19 & 912.02 & 2992.44 \\
\hline $\mathrm{H}-09 \mathrm{~b}$ & CUL & 3406.86 & $4 / 3 / 01$ & $14: 10$ & 413.91 & 0.00 & 413.91 & 126.16 & 2992.95 & 912.25 & 2993.20 \\
\hline $\mathrm{H}-09 \mathrm{~b}$ & CUL & 3406.86 & $5 / 7 / 01$ & $13: 25$ & 413.87 & 0.00 & 413.87 & 126.15 & 2992.99 & 912.26 & 2993.24 \\
\hline $\mathrm{H}-09 \mathrm{~b}$ & CUL & 3406.86 & 6/6/01 & $14: 26$ & 414.04 & 0.00 & 414.04 & 126.20 & 2992.82 & 912.21 & 2993.07 \\
\hline $\mathrm{H}-09 \mathrm{~b}$ & CUL & 3406.86 & $7 / 10 / 01$ & $13: 45$ & 415.47 & 0.00 & 415.47 & 126.64 & 2991.39 & 911.78 & 2991.64 \\
\hline $\mathrm{H}-09 \mathrm{~b}$ & CUL & 3406.86 & 8/6/01 & 13:11 & 415.75 & 0.00 & 415.75 & 126.72 & 2991.11 & 911.69 & 2991.36 \\
\hline $\mathrm{H}-09 \mathrm{~b}$ & CUL & 3406.86 & $9 / 5 / 01$ & $09: 45$ & 415.39 & 0.00 & 415.39 & 126.61 & 2991.47 & 911.80 & 2991.72 \\
\hline $\mathrm{H}-09 \mathrm{~b}$ & CUL & 3406.86 & $10 / 9 / 01$ & 08:35 & 414.83 & 0.00 & 414.83 & 126.44 & 2992.03 & 911.97 & 2992.28 \\
\hline $\mathrm{H}-09 \mathrm{~b}$ & CUL & 3406.86 & $11 / 13 / 01$ & $10: 27$ & 416.27 & 0.00 & 416.27 & 126.88 & 2990.59 & 911.53 & 2990.84 \\
\hline $\mathrm{H}-09 \mathrm{~b}$ & CUL & 3406.86 & $12 / 4 / 01$ & 07:49 & 415.55 & 0.00 & 415.55 & 126.66 & 2991.31 & 911.75 & 2991.56 \\
\hline $\mathrm{H}-09 \mathrm{c}$ & CUL & 3407.30 & $3 / 5 / 01$ & $10: 36$ & 415.57 & 0.00 & 415.57 & 126.67 & 2991.73 & 911.88 & 2991.98 \\
\hline $\mathrm{H}-09 \mathrm{c}$ & CUL & 3407.30 & $6 / 6 / 01$ & $14: 15$ & 414.96 & 0.00 & 414.96 & 126.48 & 2992.34 & 912.07 & 2992.59 \\
\hline $\mathrm{H}-09 \mathrm{c}$ & CUL & 3407.30 & 9/5/01 & 09:35 & 416.30 & 0.00 & 416.30 & 126.89 & 2991.00 & 911.66 & 2991.25 \\
\hline $\mathrm{H}-09 \mathrm{c}$ & CUL & 3407.30 & $12 / 4 / 01$ & $07: 36$ & 414.92 & 0.00 & 414.92 & 126.47 & 2992.38 & 912.08 & 2992.63 \\
\hline $\mathrm{H}-10 \mathrm{a}$ & MAG & 3688.67 & $1 / 10 / 01$ & 10:42 & 528.39 & 0.00 & 528.39 & 161.05 & 3160.28 & 963.25 & \\
\hline $\mathrm{H}-10 \mathrm{a}$ & MAG & 3688.67 & $2 / 7 / 01$ & 10:00 & 528.41 & 0.00 & 528.41 & 161.06 & 3160.26 & 963.25 & \\
\hline $\mathrm{H}-10 \mathrm{a}$ & MAG & 3688.67 & $3 / 7 / 01$ & 10:02 & 528.08 & 0.00 & 528.08 & 160.96 & 3160.59 & 963.35 & \\
\hline $\mathrm{H}-10 \mathrm{a}$ & MAG & 3688.67 & $4 / 4 / 01$ & 09:04 & 527.92 & 0.00 & 527.92 & 160.91 & 3160.75 & 963.40 & \\
\hline
\end{tabular}


Waste Isolation Pilot Plant 2001 Site Environmental Report DOE/WIPP 02-2225

Table 6.9 - Groundwater Level Measurement Results for 2001

\begin{tabular}{|c|c|c|c|c|c|c|c|c|c|c|c|}
\hline WELL_NO & ZONE & TOC_AMSL* & DATE & TIME & TP_FT_TOC & ADJ_FT & WL_FT & WL_METERS & WL_MSL_FT & WL_MSL_M & Adj_Fr_Hd_amsI \\
\hline $\mathrm{H}-10 \mathrm{a}$ & MAG & 3688.67 & $5 / 7 / 01$ & $14: 15$ & 527.85 & 0.00 & 527.85 & 160.89 & 3160.82 & 963.42 & \\
\hline $\mathrm{H}-10 \mathrm{a}$ & MAG & 3688.67 & $6 / 6 / 01$ & $13: 30$ & 527.49 & 0.00 & 527.49 & 160.78 & 3161.18 & 963.53 & \\
\hline $\mathrm{H}-10 \mathrm{a}$ & MAG & 3688.67 & $7 / 11 / 01$ & $13: 15$ & 526.91 & 0.00 & 526.91 & 160.60 & 3161.76 & 963.70 & \\
\hline $\mathrm{H}-10 \mathrm{a}$ & MAG & 3688.67 & $8 / 6 / 01$ & $14: 18$ & 526.63 & 0.00 & 526.63 & 160.52 & 3162.04 & 963.79 & \\
\hline $\mathrm{H}-10 \mathrm{a}$ & MAG & 3688.67 & 9/5/01 & $12: 20$ & 526.54 & 0.00 & 526.54 & 160.49 & 3162.13 & 963.82 & \\
\hline $\mathrm{H}-10 \mathrm{a}$ & MAG & 3688.67 & $10 / 9 / 01$ & 09:56 & 526.51 & 0.00 & 526.51 & 160.48 & 3162.16 & 963.83 & \\
\hline $\mathrm{H}-10 \mathrm{a}$ & MAG & 3688.67 & $11 / 13 / 01$ & $11: 10$ & 526.59 & 0.00 & 526.59 & 160.50 & 3162.08 & 963.80 & \\
\hline $\mathrm{H}-10 \mathrm{a}$ & MAG & 3688.67 & $12 / 4 / 01$ & 09:24 & 526.49 & 0.00 & 526.49 & 160.47 & 3162.18 & 963.83 & \\
\hline $\mathrm{H}-10 \mathrm{~b}$ & CUL & 3689.47 & $1 / 10 / 01$ & $10: 53$ & 694.60 & 0.00 & 694.60 & 211.71 & 2994.87 & 912.84 & 3026.99 \\
\hline $\mathrm{H}-10 \mathrm{~b}$ & CUL & 3689.47 & $2 / 7 / 01$ & $10: 12$ & 694.57 & 0.00 & 694.57 & 211.70 & 2994.90 & 912.85 & 3027.02 \\
\hline $\mathrm{H}-10 \mathrm{~b}$ & CUL & 3689.47 & $3 / 7 / 01$ & $10: 08$ & 694.64 & 0.00 & 694.64 & 211.73 & 2994.83 & 912.82 & 3026.95 \\
\hline $\mathrm{H}-10 \mathrm{~b}$ & CUL & 3689.47 & $4 / 4 / 01$ & $09: 20$ & 694.49 & 0.00 & 694.49 & 211.68 & 2994.98 & 912.87 & 3027.10 \\
\hline $\mathrm{H}-10 \mathrm{~b}$ & CUL & 3689.47 & $5 / 7 / 01$ & $14: 22$ & 694.44 & 0.00 & 694.44 & 211.67 & 2995.03 & 912.89 & 3027.16 \\
\hline $\mathrm{H}-10 \mathrm{~b}$ & CUL & 3689.47 & $6 / 6 / 01$ & $13: 37$ & 694.07 & 0.00 & 694.07 & 211.55 & 2995.40 & 913.00 & 3027.54 \\
\hline $\mathrm{H}-10 \mathrm{~b}$ & CUL & 3689.47 & $7 / 11 / 01$ & $13: 25$ & 694.22 & 0.00 & 694.22 & 211.60 & 2995.25 & 912.95 & 3027.39 \\
\hline $\mathrm{H}-10 \mathrm{~b}$ & CUL & 3689.47 & $8 / 6 / 01$ & 13:56 & 694.30 & 0.00 & 694.30 & 211.62 & 2995.17 & 912.93 & 3027.30 \\
\hline $\mathrm{H}-10 \mathrm{~b}$ & CUL & 3689.47 & 9/5/01 & $12: 30$ & 694.46 & 0.00 & 694.46 & 211.67 & 2995.01 & 912.88 & 3027.13 \\
\hline $\mathrm{H}-10 \mathrm{~b}$ & CUL & 3689.47 & $10 / 9 / 01$ & $10: 09$ & 694.60 & 0.00 & 694.60 & 211.71 & 2994.87 & 912.84 & 3026.99 \\
\hline $\mathrm{H}-10 \mathrm{~b}$ & CUL & 3689.47 & $11 / 13 / 01$ & $11: 18$ & 694.80 & 0.00 & 694.80 & 211.78 & 2994.67 & 912.78 & 3026.78 \\
\hline $\mathrm{H}-10 \mathrm{~b}$ & CUL & 3689.47 & $12 / 4 / 01$ & 09:33 & 694.77 & 0.00 & 694.77 & 211.77 & 2994.70 & 912.78 & 3026.81 \\
\hline $\mathrm{H}-11 \mathrm{~b} 1$ & CUL & 3411.62 & $3 / 7 / 01$ & $10: 56$ & 431.05 & 0.00 & 431.05 & 131.38 & 2980.57 & 908.48 & 3003.70 \\
\hline $\mathrm{H}-11 \mathrm{~b} 1$ & CUL & 3411.62 & $6 / 6 / 01$ & $10: 43$ & 430.42 & 0.00 & 430.42 & 131.19 & 2981.20 & 908.67 & 3004.38 \\
\hline $\mathrm{H}-11 \mathrm{~b} 1$ & CUL & 3411.62 & 9/5/01 & $13: 42$ & 430.30 & 0.00 & 430.30 & 131.16 & 2981.32 & 908.71 & 3004.50 \\
\hline $\mathrm{H}-11 \mathrm{~b} 1$ & CUL & 3411.62 & $12 / 3 / 01$ & $10: 38$ & 430.39 & 0.00 & 430.39 & 131.18 & 2981.23 & 908.68 & 3004.41 \\
\hline $\mathrm{H}-11 \mathrm{~b} 2$ & CUL & 3411.64 & $3 / 5 / 01$ & 13:09 & 431.59 & 0.00 & 431.59 & 131.55 & 2980.05 & 908.32 & 3003.90 \\
\hline $\mathrm{H}-11 \mathrm{~b} 2$ & MAG & 3411.64 & $6 / 6 / 01$ & $10: 55$ & 284.24 & 0.00 & 284.24 & 86.64 & 3127.40 & 953.23 & \\
\hline $\mathrm{H}-11 \mathrm{~b} 2$ & MAG & 3411.64 & $7 / 10 / 01$ & 10:24 & 284.16 & 0.00 & 284.16 & 86.61 & 3127.48 & 953.26 & \\
\hline $\mathrm{H}-11 \mathrm{~b} 2$ & MAG & 3411.64 & $9 / 11 / 01$ & $09: 20$ & 284.30 & 0.00 & 284.30 & 86.65 & 3127.34 & 953.21 & \\
\hline $\mathrm{H}-11 \mathrm{~b} 2$ & MAG & 3411.64 & $10 / 3 / 01$ & $13: 10$ & 284.12 & 0.00 & 284.12 & 86.60 & 3127.52 & 953.27 & \\
\hline $\mathrm{H}-11 \mathrm{~b} 2$ & MAG & 3411.64 & $11 / 12 / 01$ & $10: 10$ & 284.16 & 0.00 & 284.16 & 86.61 & 3127.48 & 953.26 & \\
\hline $\mathrm{H}-11 \mathrm{~b} 2$ & MAG & 3411.64 & $12 / 3 / 01$ & $10: 22$ & 284.05 & 0.00 & 284.05 & 86.58 & 3127.59 & 953.29 & \\
\hline $\mathrm{H}-11 \mathrm{~b} 3$ & CUL & 3412.42 & $3 / 7 / 01$ & 11:01 & 432.21 & 0.00 & 432.21 & 131.74 & 2980.21 & 908.37 & 3005.07 \\
\hline $\mathrm{H}-11 \mathrm{~b} 3$ & CUL & 3412.42 & $6 / 6 / 01$ & $11: 00$ & 431.56 & 0.00 & 431.56 & 131.54 & 2980.86 & 908.57 & 3005.77 \\
\hline $\mathrm{H}-11 \mathrm{~b} 3$ & CUL & 3412.42 & 9/5/01 & 13:50 & 431.73 & 0.00 & 431.73 & 131.59 & 2980.69 & 908.51 & 3005.59 \\
\hline $\mathrm{H}-11 \mathrm{~b} 3$ & CUL & 3412.42 & $12 / 3 / 01$ & $10: 44$ & 431.55 & 0.00 & 431.55 & 131.54 & 2980.87 & 908.57 & 3005.78 \\
\hline $\mathrm{H}-11 \mathrm{~b} 4$ & CUL & 3410.89 & $1 / 10 / 01$ & 13:03 & 427.12 & 0.00 & 427.12 & 130.19 & 2983.77 & 909.45 & 3003.82 \\
\hline $\mathrm{H}-11 \mathrm{~b} 4$ & CUL & 3410.89 & 2/5/01 & $13: 13$ & 427.07 & 0.00 & 427.07 & 130.17 & 2983.82 & 909.47 & 3003.87 \\
\hline
\end{tabular}


Waste Isolation Pilot Plant 2001 Site Environmental Report DOE/WIPP 02-2225

Table 6.9 - Groundwater Level Measurement Results for 2001

\begin{tabular}{|c|c|c|c|c|c|c|c|c|c|c|c|}
\hline WELL_NO & ZONE & TOC_AMSL* & DATE & TIME & TP_FT_TOC & ADJ_FT & WL_FT & WL_METERS & WL_MSL_FT & WL_MSL_M & Adj_Fr_Hd_amsI \\
\hline $\mathrm{H}-11 \mathrm{~b} 4$ & CUL & 3410.89 & $3 / 7 / 01$ & 10:51 & 426.91 & 0.00 & 426.91 & 130.12 & 2983.98 & 909.52 & 3004.04 \\
\hline $\mathrm{H}-11 \mathrm{~b} 4$ & CUL & 3410.89 & $4 / 5 / 01$ & $08: 49$ & 426.56 & 0.00 & 426.56 & 130.02 & 2984.33 & 909.62 & 3004.41 \\
\hline $\mathrm{H}-11 \mathrm{~b} 4$ & CUL & 3410.89 & $5 / 9 / 01$ & $10: 42$ & 426.46 & 0.00 & 426.46 & 129.99 & 2984.43 & 909.65 & 3004.52 \\
\hline $\mathrm{H}-11 \mathrm{~b} 4$ & CUL & 3410.89 & $6 / 6 / 01$ & $10: 38$ & 426.25 & 0.00 & 426.25 & 129.92 & 2984.64 & 909.72 & 3004.74 \\
\hline $\mathrm{H}-11 \mathrm{~b} 4$ & CUL & 3410.89 & $7 / 10 / 01$ & $10: 15$ & 426.22 & 0.00 & 426.22 & 129.91 & 2984.67 & 909.73 & 3004.78 \\
\hline $\mathrm{H}-11 \mathrm{~b} 4$ & CUL & 3410.89 & $8 / 7 / 01$ & $08: 14$ & 426.50 & 0.00 & 426.50 & 130.00 & 2984.39 & 909.64 & 3004.48 \\
\hline $\mathrm{H}-11 \mathrm{~b} 4$ & CUL & 3410.89 & 9/5/01 & $13: 40$ & 426.42 & 0.00 & 426.42 & 129.97 & 2984.47 & 909.67 & 3004.56 \\
\hline $\mathrm{H}-11 \mathrm{~b} 4$ & CUL & 3410.89 & $10 / 9 / 01$ & $11: 37$ & 426.25 & 0.00 & 426.25 & 129.92 & 2984.64 & 909.72 & 3004.74 \\
\hline $\mathrm{H}-11 \mathrm{~b} 4$ & CUL & 3410.89 & $11 / 12 / 01$ & $10: 22$ & 426.41 & 0.00 & 426.41 & 129.97 & 2984.48 & 909.67 & 3004.57 \\
\hline $\mathrm{H}-11 \mathrm{~b} 4$ & CUL & 3410.89 & $12 / 3 / 01$ & $10: 32$ & 426.24 & 0.00 & 426.24 & 129.92 & 2984.65 & 909.72 & 3004.75 \\
\hline $\mathrm{H}-12$ & CUL & 3427.19 & $1 / 10 / 01$ & $11: 32$ & 458.05 & 0.00 & 458.05 & 139.61 & 2969.14 & 904.99 & 3006.35 \\
\hline $\mathrm{H}-12$ & CUL & 3427.19 & $2 / 7 / 01$ & $10: 40$ & 458.03 & 0.00 & 458.03 & 139.61 & 2969.16 & 905.00 & 3006.37 \\
\hline $\mathrm{H}-12$ & CUL & 3427.19 & $3 / 7 / 01$ & 09:26 & 458.02 & 0.00 & 458.02 & 139.60 & 2969.17 & 905.00 & 3006.38 \\
\hline $\mathrm{H}-12$ & CUL & 3427.19 & $4 / 4 / 01$ & $10: 19$ & 457.80 & 0.00 & 457.80 & 139.54 & 2969.39 & 905.07 & 3006.62 \\
\hline $\mathrm{H}-12$ & CUL & 3427.19 & $5 / 7 / 01$ & $15: 03$ & 457.81 & 0.00 & 457.81 & 139.54 & 2969.38 & 905.07 & 3006.61 \\
\hline $\mathrm{H}-12$ & CUL & 3427.19 & $6 / 6 / 01$ & $12: 54$ & 457.56 & 0.00 & 457.56 & 139.46 & 2969.63 & 905.14 & 3006.88 \\
\hline $\mathrm{H}-12$ & CUL & 3427.19 & $7 / 10 / 01$ & $09: 45$ & 457.63 & 0.00 & 457.63 & 139.49 & 2969.56 & 905.12 & 3006.81 \\
\hline $\mathrm{H}-12$ & CUL & 3427.19 & $8 / 7 / 01$ & $07: 47$ & 457.70 & 0.00 & 457.70 & 139.51 & 2969.49 & 905.10 & 3006.73 \\
\hline $\mathrm{H}-12$ & CUL & 3427.19 & 9/5/01 & 13:05 & 456.64 & 0.00 & 456.64 & 139.18 & 2970.55 & 905.42 & 3007.89 \\
\hline $\mathrm{H}-12$ & CUL & 3427.19 & $10 / 9 / 01$ & 11:03 & 457.61 & 0.00 & 457.61 & 139.48 & 2969.58 & 905.13 & 3006.83 \\
\hline $\mathrm{H}-12$ & CUL & 3427.19 & $11 / 13 / 01$ & $13: 46$ & 457.64 & 0.00 & 457.64 & 139.49 & 2969.55 & 905.12 & 3006.80 \\
\hline $\mathrm{H}-12$ & CUL & 3427.19 & $12 / 4 / 01$ & $10: 13$ & 457.56 & 0.00 & 457.56 & 139.46 & 2969.63 & 905.14 & 3006.88 \\
\hline $\mathrm{H}-14$ & CUL & 3347.11 & $1 / 10 / 01$ & $14: 31$ & 337.58 & 0.00 & 337.58 & 102.89 & 3009.53 & 917.30 & 3012.41 \\
\hline $\mathrm{H}-14$ & CUL & 3347.11 & $2 / 5 / 01$ & $10: 56$ & 337.71 & 0.00 & 337.71 & 102.93 & 3009.40 & 917.27 & 3012.28 \\
\hline $\mathrm{H}-14$ & CUL & 3347.11 & $3 / 8 / 01$ & $08: 25$ & 337.48 & 0.00 & 337.48 & 102.86 & 3009.63 & 917.34 & 3012.51 \\
\hline $\mathrm{H}-14$ & MAG & 3347.11 & $4 / 5 / 01$ & $14: 07$ & 240.12 & 0.00 & 240.12 & 73.19 & 3106.99 & 947.01 & \\
\hline $\mathrm{H}-14$ & MAG & 3347.11 & $5 / 9 / 01$ & $08: 13$ & 312.04 & 0.00 & 312.04 & 95.11 & 3035.07 & 925.09 & \\
\hline $\mathrm{H}-14$ & MAG & 3347.11 & $6 / 6 / 01$ & 09:10 & 297.80 & 0.00 & 297.80 & 90.77 & 3049.31 & 929.43 & \\
\hline $\mathrm{H}-14$ & MAG & 3347.11 & $7 / 11 / 01$ & $08: 37$ & 281.79 & 0.00 & 281.79 & 85.89 & 3065.32 & 934.31 & \\
\hline $\mathrm{H}-14$ & MAG & 3347.11 & $9 / 12 / 01$ & 07:15 & 256.72 & 0.00 & 256.72 & 78.25 & 3090.39 & 941.95 & \\
\hline $\mathrm{H}-14$ & MAG & 3347.11 & $10 / 3 / 01$ & $13: 00$ & 251.11 & 0.00 & 251.11 & 76.54 & 3096.00 & 943.66 & \\
\hline $\mathrm{H}-14$ & MAG & 3347.11 & $11 / 12 / 01$ & 13:53 & 245.25 & 0.00 & 245.25 & 74.75 & 3101.86 & 945.45 & \\
\hline $\mathrm{H}-14$ & MAG & 3347.11 & $12 / 3 / 01$ & $12: 29$ & 244.64 & 0.00 & 244.64 & 74.57 & 3102.47 & 945.63 & \\
\hline $\mathrm{H}-15$ & CUL & 3481.63 & $1 / 9 / 01$ & $12: 53$ & 519.62 & 0.00 & 519.62 & 158.38 & 2962.01 & 902.82 & 3015.22 \\
\hline $\mathrm{H}-15$ & CUL & 3481.63 & $2 / 5 / 01$ & $10: 20$ & 519.73 & 0.00 & 519.73 & 158.41 & 2961.90 & 902.79 & 3015.10 \\
\hline $\mathrm{H}-15$ & CUL & 3481.63 & $3 / 5 / 01$ & 09:53 & 519.41 & 0.00 & 519.41 & 158.32 & 2962.22 & 902.88 & 3015.47 \\
\hline $\mathrm{H}-15$ & MAG & 3481.63 & 4/6/01 & $07: 50$ & 382.94 & 0.00 & 382.94 & 116.72 & 3098.69 & 944.48 & \\
\hline
\end{tabular}


Waste Isolation Pilot Plant 2001 Site Environmental Report DOE/WIPP 02-2225

Table 6.9 - Groundwater Level Measurement Results for 2001

\begin{tabular}{|c|c|c|c|c|c|c|c|c|c|c|c|}
\hline WELL_NO & ZONE & TOC_AMSL* & DATE & TIME & TP_FT_TOC & ADJ_FT & WL_FT & WL_METERS & WL_MSL_FT & WL_MSL_M & Adj_Fr_Hd_amsI \\
\hline $\mathrm{H}-15$ & MAG & 3481.63 & $5 / 8 / 01$ & 07:07 & 369.42 & 0.00 & 369.42 & 112.60 & 3112.21 & 948.60 & \\
\hline $\mathrm{H}-15$ & MAG & 3481.63 & $6 / 7 / 01$ & $11: 21$ & 369.04 & 0.00 & 369.04 & 112.48 & 3112.59 & 948.72 & \\
\hline $\mathrm{H}-15$ & MAG & 3481.63 & $7 / 11 / 01$ & 07:45 & 368.59 & 0.00 & 368.59 & 112.35 & 3113.04 & 948.85 & \\
\hline $\mathrm{H}-15$ & MAG & 3481.63 & $9 / 12 / 01$ & $06: 45$ & 368.77 & 0.00 & 368.77 & 112.40 & 3112.86 & 948.80 & \\
\hline $\mathrm{H}-15$ & MAG & 3481.63 & $10 / 3 / 01$ & 11:05 & 368.10 & 0.00 & 368.10 & 112.20 & 3113.53 & 949.00 & \\
\hline $\mathrm{H}-15$ & MAG & 3481.63 & $11 / 12 / 01$ & $13: 20$ & 368.68 & 0.00 & 368.68 & 112.37 & 3112.95 & 948.83 & \\
\hline $\mathrm{H}-15$ & MAG & 3481.63 & $12 / 3 / 01$ & 07:54 & 368.63 & 0.00 & 368.63 & 112.36 & 3113.00 & 948.84 & \\
\hline $\mathrm{H}-17$ & CUL & 3385.31 & $1 / 10 / 01$ & $12: 14$ & 424.46 & 0.00 & 424.46 & 129.38 & 2960.85 & 902.47 & 3009.89 \\
\hline $\mathrm{H}-17$ & CUL & 3385.31 & $2 / 5 / 01$ & $12: 30$ & 424.52 & 0.00 & 424.52 & 129.39 & 2960.79 & 902.45 & 3009.82 \\
\hline $\mathrm{H}-17$ & CUL & 3385.31 & $3 / 7 / 01$ & 11:19 & 424.19 & 0.00 & 424.19 & 129.29 & 2961.12 & 902.55 & 3010.21 \\
\hline $\mathrm{H}-17$ & CUL & 3385.31 & $4 / 5 / 01$ & 07:49 & 423.85 & 0.00 & 423.85 & 129.19 & 2961.46 & 902.65 & 3010.60 \\
\hline $\mathrm{H}-17$ & CUL & 3385.31 & $5 / 9 / 01$ & 09:55 & 423.79 & 0.00 & 423.79 & 129.17 & 2961.52 & 902.67 & 3010.67 \\
\hline $\mathrm{H}-17$ & CUL & 3385.31 & $6 / 6 / 01$ & $11: 40$ & 423.41 & 0.00 & 423.41 & 129.06 & 2961.90 & 902.79 & 3011.12 \\
\hline $\mathrm{H}-17$ & CUL & 3385.31 & $7 / 11 / 01$ & 09:44 & 423.41 & 0.00 & 423.41 & 129.06 & 2961.90 & 902.79 & 3011.12 \\
\hline $\mathrm{H}-17$ & CUL & 3385.31 & $8 / 7 / 01$ & $08: 28$ & 423.57 & 0.00 & 423.57 & 129.10 & 2961.74 & 902.74 & 3010.93 \\
\hline $\mathrm{H}-17$ & CUL & 3385.31 & 9/5/01 & 13:58 & 423.54 & 0.00 & 423.54 & 129.09 & 2961.77 & 902.75 & 3010.96 \\
\hline $\mathrm{H}-17$ & CUL & 3385.31 & $10 / 9 / 01$ & $11: 53$ & 423.59 & 0.00 & 423.59 & 129.11 & 2961.72 & 902.73 & 3010.91 \\
\hline $\mathrm{H}-17$ & CUL & 3385.31 & $11 / 13 / 01$ & $14: 16$ & 423.44 & 0.00 & 423.44 & 129.06 & 2961.87 & 902.78 & 3011.08 \\
\hline $\mathrm{H}-17$ & CUL & 3385.31 & $12 / 4 / 01$ & $10: 48$ & 423.34 & 0.00 & 423.34 & 129.03 & 2961.97 & 902.81 & 3011.20 \\
\hline $\mathrm{H}-18$ & CUL & 3414.21 & $1 / 9 / 01$ & 09:32 & 354.55 & 0.00 & 354.55 & 108.07 & 3059.66 & 932.58 & 3074.93 \\
\hline $\mathrm{H}-18$ & CUL & 3414.21 & 2/5/01 & $08: 45$ & 354.51 & 0.00 & 354.51 & 108.05 & 3059.70 & 932.60 & 3074.97 \\
\hline $\mathrm{H}-18$ & CUL & 3414.21 & $3 / 6 / 01$ & $11: 10$ & 354.60 & 0.00 & 354.60 & 108.08 & 3059.61 & 932.57 & 3074.88 \\
\hline $\mathrm{H}-18$ & MAG & 3414.21 & $4 / 4 / 01$ & $14: 40$ & 474.48 & 0.00 & 474.48 & 144.62 & 2939.73 & 896.03 & \\
\hline $\mathrm{H}-18$ & MAG & 3414.21 & $5 / 8 / 01$ & $11: 30$ & 335.62 & 0.00 & 335.62 & 102.30 & 3078.59 & 938.35 & \\
\hline $\mathrm{H}-18$ & MAG & 3414.21 & $6 / 5 / 01$ & $12: 00$ & 335.79 & 0.00 & 335.79 & 102.35 & 3078.42 & 938.30 & \\
\hline $\mathrm{H}-18$ & MAG & 3414.21 & $7 / 9 / 01$ & $08: 29$ & 336.09 & 0.00 & 336.09 & 102.44 & 3078.12 & 938.21 & \\
\hline $\mathrm{H}-18$ & MAG & 3414.21 & $9 / 12 / 01$ & $08: 10$ & 336.87 & 0.00 & 336.87 & 102.68 & 3077.34 & 937.97 & \\
\hline $\mathrm{H}-18$ & MAG & 3414.21 & $10 / 3 / 01$ & 09:10 & 336.85 & 0.00 & 336.85 & 102.67 & 3077.36 & 937.98 & \\
\hline $\mathrm{H}-18$ & MAG & 3414.21 & $11 / 12 / 01$ & $14: 10$ & 337.04 & 0.00 & 337.04 & 102.73 & 3077.17 & 937.92 & \\
\hline $\mathrm{H}-18$ & MAG & 3414.21 & $12 / 3 / 01$ & $12: 29$ & 336.96 & 0.00 & 336.96 & 102.71 & 3077.25 & 937.95 & \\
\hline $\mathrm{H}-19 \mathrm{~b} 0$ & CUL & 3418.38 & $1 / 10 / 01$ & $13: 49$ & 429.38 & 0.00 & 429.38 & 130.88 & 2989.00 & 911.05 & 3010.72 \\
\hline $\mathrm{H}-19 \mathrm{~b} 0$ & CUL & 3418.38 & $2 / 6 / 01$ & $14: 45$ & 429.35 & 0.00 & 429.35 & 130.87 & 2989.03 & 911.06 & 3010.75 \\
\hline $\mathrm{H}-19 \mathrm{~b} 0$ & CUL & 3418.38 & $3 / 8 / 01$ & $07: 56$ & 429.04 & 0.00 & 429.04 & 130.77 & 2989.34 & 911.15 & 3011.08 \\
\hline $\mathrm{H}-19 \mathrm{~b} 0$ & CUL & 3418.38 & $4 / 5 / 01$ & 09:16 & 428.98 & 0.00 & 428.98 & 130.75 & 2989.40 & 911.17 & 3011.14 \\
\hline $\mathrm{H}-19 \mathrm{~b} 0$ & CUL & 3418.38 & $5 / 9 / 01$ & $09: 17$ & 429.40 & 0.00 & 429.40 & 130.88 & 2988.98 & 911.04 & 3010.70 \\
\hline $\mathrm{H}-19 \mathrm{~b} 0$ & CUL & 3418.38 & $6 / 6 / 01$ & $08: 20$ & 428.90 & 0.00 & 428.90 & 130.73 & 2989.48 & 911.19 & 3011.23 \\
\hline $\mathrm{H}-19 \mathrm{~b} 0$ & CUL & 3418.38 & $7 / 11 / 01$ & 08:05 & 428.67 & 0.00 & 428.67 & 130.66 & 2989.71 & 911.26 & 3011.48 \\
\hline
\end{tabular}


Waste Isolation Pilot Plant 2001 Site Environmental Report DOE/WIPP 02-2225

Table 6.9 - Groundwater Level Measurement Results for 2001

\begin{tabular}{|c|c|c|c|c|c|c|c|c|c|c|c|}
\hline WELL_NO & ZONE & TOC_AMSL* & DATE & TIME & TP_FT_TOC & ADJ_FT & WL_FT & WL_METERS & WL_MSL_FT & WL_MSL_M & Adj_Fr_Hd_amsI \\
\hline $\mathrm{H}-19 \mathrm{~b} 0$ & CUL & 3418.38 & $8 / 7 / 01$ & 10:06 & 428.64 & 0.00 & 428.64 & 130.65 & 2989.74 & 911.27 & 3011.51 \\
\hline $\mathrm{H}-19 \mathrm{~b} 0$ & CUL & 3418.38 & $9 / 7 / 01$ & $08: 20$ & 428.33 & 0.00 & 428.33 & 130.55 & 2990.05 & 911.37 & 3011.84 \\
\hline $\mathrm{H}-19 \mathrm{~b} 0$ & CUL & 3418.38 & $10 / 9 / 01$ & $13: 17$ & 428.30 & 0.00 & 428.30 & 130.55 & 2990.08 & 911.38 & 3011.87 \\
\hline $\mathrm{H}-19 \mathrm{~b} 0$ & CUL & 3418.38 & $11 / 13 / 01$ & $14: 59$ & 428.66 & 0.00 & 428.66 & 130.66 & 2989.72 & 911.27 & 3011.49 \\
\hline $\mathrm{H}-19 \mathrm{~b} 0$ & CUL & 3418.38 & $12 / 5 / 01$ & $11: 40$ & 428.65 & 0.00 & 428.65 & 130.65 & 2989.73 & 911.27 & 3011.50 \\
\hline $\mathrm{H}-19 \mathrm{~b} 2$ & CUL & 3419.01 & $3 / 8 / 01$ & $08: 16$ & 430.33 & 0.00 & 430.33 & 131.16 & 2988.68 & 910.95 & 3010.48 \\
\hline $\mathrm{H}-19 \mathrm{~b} 2$ & CUL & 3419.01 & $6 / 6 / 01$ & 08:06 & 430.23 & 0.00 & 430.23 & 131.13 & 2988.78 & 910.98 & 3010.59 \\
\hline $\mathrm{H}-19 \mathrm{~b} 2$ & CUL & 3419.01 & 9/7/01 & $08: 03$ & 429.63 & 0.00 & 429.63 & 130.95 & 2989.38 & 911.16 & 3011.23 \\
\hline $\mathrm{H}-19 \mathrm{~b} 2$ & CUL & 3419.01 & $12 / 5 / 01$ & $11: 22$ & 429.93 & 0.00 & 429.93 & 131.04 & 2989.08 & 911.07 & 3010.91 \\
\hline $\mathrm{H}-19 \mathrm{~b} 3$ & CUL & 3419.09 & $3 / 8 / 01$ & $08: 37$ & 430.55 & 0.00 & 430.55 & 131.23 & 2988.54 & 910.91 & 3010.23 \\
\hline $\mathrm{H}-19 \mathrm{~b} 3$ & CUL & 3419.09 & $6 / 6 / 01$ & $08: 26$ & 430.38 & 0.00 & 430.38 & 131.18 & 2988.71 & 910.96 & 3010.41 \\
\hline $\mathrm{H}-19 \mathrm{~b} 3$ & CUL & 3419.09 & $9 / 7 / 01$ & $12: 55$ & 429.83 & 0.00 & 429.83 & 131.01 & 2989.26 & 911.13 & 3011.00 \\
\hline $\mathrm{H}-19 \mathrm{~b} 3$ & CUL & 3419.09 & $12 / 5 / 01$ & $12: 00$ & 430.14 & 0.00 & 430.14 & 131.11 & 2988.95 & 911.03 & 3010.67 \\
\hline $\mathrm{H}-19 \mathrm{~b} 4$ & CUL & 3419.03 & $3 / 8 / 01$ & $08: 21$ & 429.78 & 0.00 & 429.78 & 131.00 & 2989.25 & 911.12 & 3010.84 \\
\hline $\mathrm{H}-19 \mathrm{~b} 4$ & CUL & 3419.03 & $6 / 6 / 01$ & $08: 34$ & 429.40 & 0.00 & 429.40 & 130.88 & 2989.63 & 911.24 & 3011.24 \\
\hline $\mathrm{H}-19 \mathrm{~b} 4$ & CUL & 3419.03 & 9/7/01 & $08: 26$ & 429.08 & 0.00 & 429.08 & 130.78 & 2989.95 & 911.34 & 3011.58 \\
\hline $\mathrm{H}-19 \mathrm{~b} 4$ & CUL & 3419.03 & $12 / 5 / 01$ & $11: 49$ & 429.49 & 0.00 & 429.49 & 130.91 & 2989.54 & 911.21 & 3011.15 \\
\hline $\mathrm{H}-19 \mathrm{~b} 5$ & CUL & 3418.63 & $3 / 8 / 01$ & $08: 11$ & 429.94 & 0.00 & 429.94 & 131.05 & 2988.69 & 910.95 & 3010.18 \\
\hline $\mathrm{H}-19 \mathrm{~b} 5$ & CUL & 3418.63 & $6 / 6 / 01$ & $08: 10$ & 429.75 & 0.00 & 429.75 & 130.99 & 2988.88 & 911.01 & 3010.38 \\
\hline $\mathrm{H}-19 \mathrm{~b} 5$ & CUL & 3418.63 & $9 / 7 / 01$ & $08: 15$ & 429.24 & 0.00 & 429.24 & 130.83 & 2989.39 & 911.17 & 3010.93 \\
\hline $\mathrm{H}-19 \mathrm{~b} 5$ & CUL & 3418.63 & $12 / 5 / 01$ & $11: 33$ & 429.51 & 0.00 & 429.51 & 130.91 & 2989.12 & 911.08 & 3010.64 \\
\hline $\mathrm{H}-19 \mathrm{~b} 6$ & CUL & 3419.07 & $3 / 8 / 01$ & $08: 28$ & 430.43 & 0.00 & 430.43 & 131.20 & 2988.64 & 910.94 & 3010.27 \\
\hline $\mathrm{H}-19 \mathrm{~b} 6$ & CUL & 3419.07 & $6 / 6 / 01$ & $08: 39$ & 430.29 & 0.00 & 430.29 & 131.15 & 2988.78 & 910.98 & 3010.42 \\
\hline $\mathrm{H}-19 \mathrm{~b} 6$ & CUL & 3419.07 & $9 / 7 / 01$ & $13: 02$ & 429.71 & 0.00 & 429.71 & 130.98 & 2989.36 & 911.16 & 3011.04 \\
\hline $\mathrm{H}-19 \mathrm{~b} 6$ & CUL & 3419.07 & $12 / 5 / 01$ & 12:06 & 430.04 & 0.00 & 430.04 & 131.08 & 2989.03 & 911.06 & 3010.69 \\
\hline $\mathrm{H}-19 \mathrm{~b} 7$ & CUL & 3418.99 & $3 / 8 / 01$ & 08:06 & 430.57 & 0.00 & 430.57 & 131.24 & 2988.42 & 910.87 & 3010.08 \\
\hline $\mathrm{H}-19 \mathrm{~b} 7$ & CUL & 3418.99 & $6 / 6 / 01$ & 08:03 & 430.42 & 0.00 & 430.42 & 131.19 & 2988.57 & 910.92 & 3010.24 \\
\hline $\mathrm{H}-19 \mathrm{~b} 7$ & CUL & 3418.99 & $9 / 7 / 01$ & 08:05 & 429.89 & 0.00 & 429.89 & 131.03 & 2989.10 & 911.08 & 3010.80 \\
\hline $\mathrm{H}-19 \mathrm{~b} 7$ & CUL & 3418.99 & $12 / 5 / 01$ & 11:28 & 430.18 & 0.00 & 430.18 & 131.12 & 2988.81 & 910.99 & 3010.50 \\
\hline $\mathrm{P}-15$ & CUL & 3311.38 & $1 / 8 / 01$ & $12: 14$ & 295.55 & 0.00 & 295.55 & 90.08 & 3015.83 & 919.22 & 3016.61 \\
\hline P-15 & CUL & 3311.38 & $2 / 5 / 01$ & $10: 42$ & 295.80 & 0.00 & 295.80 & 90.16 & 3015.58 & 919.15 & 3016.36 \\
\hline$P-15$ & CUL & 3311.38 & $3 / 8 / 01$ & 09:42 & 295.35 & 0.00 & 295.35 & 90.02 & 3016.03 & 919.29 & 3016.81 \\
\hline P-15 & CUL & 3311.38 & $4 / 5 / 01$ & $14: 32$ & 295.56 & 0.00 & 295.56 & 90.09 & 3015.82 & 919.22 & 3016.60 \\
\hline$P-15$ & CUL & 3311.38 & $5 / 8 / 01$ & $14: 24$ & 295.79 & 0.00 & 295.79 & 90.16 & 3015.59 & 919.15 & 3016.37 \\
\hline P-15 & CUL & 3311.38 & $6 / 4 / 01$ & $12: 10$ & 295.45 & 0.00 & 295.45 & 90.05 & 3015.93 & 919.26 & 3016.71 \\
\hline$P-15$ & CUL & 3311.38 & $7 / 11 / 01$ & 09:20 & 295.69 & 0.00 & 295.69 & 90.13 & 3015.69 & 919.18 & 3016.47 \\
\hline P-15 & CUL & 3311.38 & $8 / 7 / 01$ & $12: 34$ & 295.77 & 0.00 & 295.77 & 90.15 & 3015.61 & 919.16 & 3016.39 \\
\hline
\end{tabular}


Waste Isolation Pilot Plant 2001 Site Environmental Report DOE/WIPP 02-2225

Table 6.9 - Groundwater Level Measurement Results for 2001

\begin{tabular}{|c|c|c|c|c|c|c|c|c|c|c|c|}
\hline WELL_NO & ZONE & TOC_AMSL* & DATE & TIME & TP_FT_TOC & ADJ_FT & WL_FT & WL_METERS & WL_MSL_FT & WL_MSL_M & Adj_Fr_Hd_amsl \\
\hline P-15 & CUL & 3311.38 & 9/5/01 & $11: 20$ & 295.78 & 0.00 & 295.78 & 90.15 & 3015.60 & 919.15 & 3016.38 \\
\hline P-15 & CUL & 3311.38 & $10 / 8 / 01$ & $10: 43$ & 295.78 & 0.00 & 295.78 & 90.15 & 3015.60 & 919.15 & 3016.38 \\
\hline P-15 & CUL & 3311.38 & $11 / 12 / 01$ & 08:57 & 295.90 & 0.00 & 295.90 & 90.19 & 3015.48 & 919.12 & 3016.26 \\
\hline P-15 & CUL & 3311.38 & $12 / 5 / 01$ & 09:40 & 295.78 & 0.00 & 295.78 & 90.15 & 3015.60 & 919.15 & 3016.38 \\
\hline $\mathrm{P}-17$ & CUL & 3337.24 & $1 / 10 / 01$ & $12: 29$ & 355.06 & 0.54 & 354.52 & 108.06 & 2982.72 & 909.13 & 2996.85 \\
\hline P-17 & CUL & 3337.24 & $2 / 5 / 01$ & $12: 25$ & 355.18 & 0.54 & 354.64 & 108.09 & 2982.60 & 909.10 & 2996.73 \\
\hline P-17 & CUL & 3337.24 & $3 / 7 / 01$ & $11: 36$ & 354.94 & 0.54 & 354.40 & 108.02 & 2982.84 & 909.17 & 2996.98 \\
\hline P-17 & CUL & 3337.24 & $4 / 5 / 01$ & 07:11 & 354.68 & 0.54 & 354.14 & 107.94 & 2983.10 & 909.25 & 2997.26 \\
\hline P-17 & CUL & 3337.24 & $5 / 9 / 01$ & 10:09 & 354.61 & 0.54 & 354.07 & 107.92 & 2983.17 & 909.27 & 2997.33 \\
\hline P-17 & CUL & 3337.24 & $6 / 6 / 01$ & 11:55 & 354.32 & 0.54 & 353.78 & 107.83 & 2983.46 & 909.36 & 2997.64 \\
\hline P-17 & CUL & 3337.24 & $7 / 11 / 01$ & 10:05 & 354.31 & 0.54 & 353.77 & 107.83 & 2983.47 & 909.36 & 2997.65 \\
\hline P-17 & CUL & 3337.24 & $8 / 7 / 01$ & $08: 46$ & 354.48 & 0.54 & 353.94 & 107.88 & 2983.30 & 909.31 & 2997.47 \\
\hline P-17 & CUL & 3337.24 & $9 / 5 / 01$ & $14: 15$ & 354.54 & 0.54 & 354.00 & 107.90 & 2983.24 & 909.29 & 2997.41 \\
\hline P-17 & CUL & 3337.24 & $10 / 9 / 01$ & $12: 10$ & 354.47 & 0.54 & 353.93 & 107.88 & 2983.31 & 909.31 & 2997.48 \\
\hline P-17 & CUL & 3337.24 & $11 / 12 / 01$ & $09: 40$ & 354.53 & 0.54 & 353.99 & 107.90 & 2983.25 & 909.29 & 2997.42 \\
\hline P-17 & CUL & 3337.24 & $12 / 3 / 01$ & 09:43 & 354.43 & 0.54 & 353.89 & 107.87 & 2983.35 & 909.33 & 2997.53 \\
\hline P-18 & CUL & 3478.42 & $1 / 10 / 01$ & 11:51 & 316.48 & 0.68 & 315.80 & 96.26 & 3162.62 & 963.97 & 3234.14 \\
\hline P-18 & CUL & 3478.42 & $2 / 7 / 01$ & $11: 15$ & 316.37 & 0.68 & 315.69 & 96.22 & 3162.73 & 964.00 & 3234.27 \\
\hline P-18 & CUL & 3478.42 & $3 / 7 / 01$ & 09:11 & 316.17 & 0.68 & 315.49 & 96.16 & 3162.93 & 964.06 & 3234.49 \\
\hline P-18 & CUL & 3478.42 & $4 / 4 / 01$ & $10: 55$ & 316.02 & 0.68 & 315.34 & 96.12 & 3163.08 & 964.11 & 3234.66 \\
\hline $\mathrm{P}-18$ & CUL & 3478.42 & $5 / 7 / 01$ & $15: 24$ & 315.86 & 0.68 & 315.18 & 96.07 & 3163.24 & 964.16 & 3234.84 \\
\hline P-18 & CUL & 3478.42 & $6 / 6 / 01$ & $12: 32$ & 315.72 & 0.68 & 315.04 & 96.02 & 3163.38 & 964.20 & 3234.99 \\
\hline P-18 & CUL & 3478.42 & $7 / 10 / 01$ & 10:03 & 315.60 & 0.68 & 314.92 & 95.99 & 3163.50 & 964.23 & 3235.13 \\
\hline P-18 & CUL & 3478.42 & $8 / 7 / 01$ & 07:32 & 315.52 & 0.68 & 314.84 & 95.96 & 3163.58 & 964.26 & 3235.22 \\
\hline P-18 & CUL & 3478.42 & 9/5/01 & 13:25 & 315.38 & 0.68 & 314.70 & 95.92 & 3163.72 & 964.30 & 3235.37 \\
\hline P-18 & CUL & 3478.42 & $10 / 9 / 01$ & $11: 22$ & 315.28 & 0.68 & 314.60 & 95.89 & 3163.82 & 964.33 & 3235.48 \\
\hline $\mathrm{P}-18$ & CUL & 3478.42 & $11 / 13 / 01$ & $14: 02$ & 315.15 & 0.68 & 314.47 & 95.85 & 3163.95 & 964.37 & 3235.63 \\
\hline P-18 & CUL & 3478.42 & $12 / 4 / 01$ & $10: 30$ & 315.05 & 0.68 & 314.37 & 95.82 & 3164.05 & 964.40 & 3235.74 \\
\hline WIPP-12 & CUL & 3472.06 & $1 / 9 / 01$ & $10: 39$ & 440.47 & 0.00 & 440.47 & 134.26 & 3031.59 & 924.03 & 3068.34 \\
\hline WIPP-12 & CUL & 3472.06 & $2 / 5 / 01$ & 09:35 & 440.53 & 0.00 & 440.53 & 134.27 & 3031.53 & 924.01 & 3068.27 \\
\hline WIPP-12 & CUL & 3472.06 & $3 / 7 / 01$ & $14: 02$ & 440.37 & 0.00 & 440.37 & 134.22 & 3031.69 & 924.06 & 3068.45 \\
\hline WIPP-12 & CUL & 3472.06 & $4 / 5 / 01$ & $12: 30$ & 440.22 & 0.00 & 440.22 & 134.18 & 3031.84 & 924.10 & 3068.61 \\
\hline WIPP-12 & CUL & 3472.06 & $5 / 8 / 01$ & 13:02 & 440.30 & 0.00 & 440.30 & 134.20 & 3031.76 & 924.08 & 3068.52 \\
\hline WIPP-12 & CUL & 3472.06 & 6/5/01 & 13:45 & 439.97 & 0.00 & 439.97 & 134.10 & 3032.09 & 924.18 & 3068.89 \\
\hline WIPP-12 & CUL & 3472.06 & $7 / 11 / 01$ & $06: 45$ & 440.05 & 0.00 & 440.05 & 134.13 & 3032.01 & 924.16 & 3068.80 \\
\hline WIPP-12 & CUL & 3472.06 & 8/8/01 & $13: 28$ & 440.08 & 0.00 & 440.08 & 134.14 & 3031.98 & 924.15 & 3068.77 \\
\hline WIPP-12 & CUL & 3472.06 & $9 / 6 / 01$ & $06: 55$ & 440.13 & 0.00 & 440.13 & 134.15 & 3031.93 & 924.13 & 3068.71 \\
\hline
\end{tabular}


Waste Isolation Pilot Plant 2001 Site Environmental Report DOE/WIPP 02-2225

Table 6.9 - Groundwater Level Measurement Results for 2001

\begin{tabular}{|c|c|c|c|c|c|c|c|c|c|c|c|}
\hline WELL_NO & ZONE & TOC_AMSL* & DATE & TIME & TP_FT_TOC & ADJ_FT & WL_FT & WL_METERS & WL_MSL_FT & WL_MSL_M & Adj_Fr_Hd_amsI \\
\hline WIPP-12 & CUL & 3472.06 & 10/10/01 & $13: 12$ & 440.09 & 0.00 & 440.09 & 134.14 & 3031.97 & 924.14 & 3068.75 \\
\hline WIPP-12 & CUL & 3472.06 & $11 / 14 / 01$ & $08: 49$ & 440.13 & 0.00 & 440.13 & 134.15 & 3031.93 & 924.13 & 3068.71 \\
\hline WIPP-12 & CUL & 3472.06 & $12 / 5 / 01$ & $14: 53$ & 439.91 & 0.00 & 439.91 & 134.08 & 3032.15 & 924.20 & 3068.95 \\
\hline WIPP-13 & CUL & 3405.71 & $1 / 8 / 01$ & $14: 11$ & 348.85 & 0.64 & 348.21 & 106.13 & 3057.50 & 931.93 & 3068.07 \\
\hline WIPP-13 & CUL & 3405.71 & $2 / 5 / 01$ & $14: 09$ & 348.81 & 0.64 & 348.17 & 106.12 & 3057.54 & 931.94 & 3068.12 \\
\hline WIPP-13 & CUL & 3405.71 & $3 / 6 / 01$ & $12: 36$ & 348.89 & 0.64 & 348.25 & 106.15 & 3057.46 & 931.91 & 3068.03 \\
\hline WIPP-13 & CUL & 3405.71 & $4 / 4 / 01$ & 13:55 & 348.38 & 0.00 & 348.38 & 106.19 & 3057.33 & 931.87 & 3067.90 \\
\hline WIPP-13 & CUL & 3405.71 & $5 / 7 / 01$ & $09: 52$ & 348.28 & 0.00 & 348.28 & 106.16 & 3057.43 & 931.90 & 3068.00 \\
\hline WIPP-13 & CUL & 3405.71 & $6 / 5 / 01$ & $13: 00$ & 348.09 & 0.00 & 348.09 & 106.10 & 3057.62 & 931.96 & 3068.20 \\
\hline WIPP-13 & CUL & 3405.71 & $7 / 9 / 01$ & 07:55 & 348.23 & 0.00 & 348.23 & 106.14 & 3057.48 & 931.92 & 3068.05 \\
\hline WIPP-13 & CUL & 3405.71 & $8 / 8 / 01$ & $10: 54$ & 348.40 & 0.00 & 348.40 & 106.19 & 3057.31 & 931.87 & 3067.88 \\
\hline WIPP-13 & CUL & 3405.71 & $9 / 4 / 01$ & $12: 51$ & 348.67 & 0.00 & 348.67 & 106.27 & 3057.04 & 931.79 & 3067.60 \\
\hline WIPP-13 & CUL & 3405.71 & 10/10/01 & $10: 30$ & 348.52 & 0.00 & 348.52 & 106.23 & 3057.19 & 931.83 & 3067.76 \\
\hline WIPP-13 & CUL & 3405.71 & $11 / 14 / 01$ & $08: 13$ & 348.45 & 0.00 & 348.45 & 106.21 & 3057.26 & 931.85 & 3067.83 \\
\hline WIPP-13 & CUL & 3405.71 & $12 / 5 / 01$ & $15: 12$ & 348.63 & 0.00 & 348.63 & 106.26 & 3057.08 & 931.80 & 3067.64 \\
\hline WIPP-18 & CUL & 3458.76 & $1 / 9 / 01$ & 10:58 & 425.11 & 0.00 & 425.11 & 129.57 & 3033.65 & 924.66 & 3071.12 \\
\hline WIPP-18 & CUL & 3458.76 & $2 / 5 / 01$ & $09: 45$ & 425.23 & 0.00 & 425.23 & 129.61 & 3033.53 & 924.62 & 3070.99 \\
\hline WIPP-18 & CUL & 3458.76 & $3 / 5 / 01$ & $09: 29$ & 425.07 & 0.00 & 425.07 & 129.56 & 3033.69 & 924.67 & 3071.17 \\
\hline WIPP-18 & MAG & 3458.76 & $4 / 5 / 01$ & $12: 37$ & 522.65 & 0.00 & 522.65 & 159.30 & 2936.11 & 894.93 & \\
\hline WIPP-18 & MAG & 3458.76 & $5 / 8 / 01$ & $12: 43$ & 319.19 & 0.00 & 319.19 & 97.29 & 3139.57 & 956.94 & \\
\hline WIPP-18 & MAG & 3458.76 & $6 / 5 / 01$ & 13:54 & 318.08 & 0.00 & 318.08 & 96.95 & 3140.68 & 957.28 & \\
\hline WIPP-18 & MAG & 3458.76 & $7 / 11 / 01$ & $06: 50$ & 318.61 & 0.00 & 318.61 & 97.11 & 3140.15 & 957.12 & \\
\hline WIPP-18 & MAG & 3458.76 & 9/12/01 & 10:22:05 & 326.62 & 0.00 & 326.62 & 99.55 & 3132.14 & 954.68 & \\
\hline WIPP-18 & MAG & 3458.76 & $10 / 3 / 01$ & 10:22:05 & 332.88 & 0.00 & 332.88 & 101.46 & 3125.88 & 952.77 & \\
\hline WIPP-18 & MAG & 3458.76 & $11 / 12 / 01$ & 10:22:05 & 342.33 & 0.00 & 342.33 & 104.34 & 3116.43 & 949.89 & \\
\hline WIPP-18 & MAG & 3458.76 & $12 / 3 / 01$ & 10:22:05 & 345.90 & 0.00 & 345.90 & 105.43 & 3112.86 & 948.80 & \\
\hline WIPP-19 & CUL & 3435.14 & $1 / 9 / 01$ & 11:05 & 396.15 & 0.00 & 396.15 & 120.75 & 3038.99 & 926.28 & 3076.70 \\
\hline WIPP-19 & CUL & 3435.14 & $2 / 5 / 01$ & 09:53 & 396.32 & 0.00 & 396.32 & 120.80 & 3038.82 & 926.23 & 3076.51 \\
\hline WIPP-19 & CUL & 3435.14 & $3 / 7 / 01$ & $13: 54$ & 396.16 & 0.00 & 396.16 & 120.75 & 3038.98 & 926.28 & 3076.69 \\
\hline WIPP-19 & CUL & 3435.14 & $4 / 5 / 01$ & $12: 50$ & 396.01 & 0.00 & 396.01 & 120.70 & 3039.13 & 926.33 & 3076.85 \\
\hline WIPP-19 & CUL & 3435.14 & $5 / 8 / 01$ & $12: 30$ & 396.10 & 0.00 & 396.10 & 120.73 & 3039.04 & 926.30 & 3076.75 \\
\hline WIPP-19 & CUL & 3435.14 & 6/5/01 & 14:04 & 395.69 & 0.00 & 395.69 & 120.61 & 3039.45 & 926.42 & 3077.21 \\
\hline WIPP-19 & CUL & 3435.14 & $7 / 11 / 01$ & 07:00 & 395.58 & 0.00 & 395.58 & 120.57 & 3039.56 & 926.46 & 3077.33 \\
\hline WIPP-19 & CUL & 3435.14 & 8/8/01 & $13: 37$ & 395.51 & 0.00 & 395.51 & 120.55 & 3039.63 & 926.48 & 3077.40 \\
\hline WIPP-19 & CUL & 3435.14 & 9/6/01 & $07: 10$ & 395.40 & 0.00 & 395.40 & 120.52 & 3039.74 & 926.51 & 3077.53 \\
\hline WIPP-19 & CUL & 3435.14 & 10/10/01 & 13:24 & 395.30 & 0.00 & 395.30 & 120.49 & 3039.84 & 926.54 & 3077.64 \\
\hline WIPP-19 & CUL & 3435.14 & $11 / 14 / 01$ & $08: 55$ & 395.18 & 0.00 & 395.18 & 120.45 & 3039.96 & 926.58 & 3077.77 \\
\hline
\end{tabular}


Waste Isolation Pilot Plant 2001 Site Environmental Report DOE/WIPP 02-2225

Table 6.9 - Groundwater Level Measurement Results for 2001

\begin{tabular}{|c|c|c|c|c|c|c|c|c|c|c|c|}
\hline WELL_NO & ZONE & TOC_AMSL* & DATE & TIME & TP_FT_TOC & ADJ_FT & WL_FT & WL_METERS & WL_MSL_FT & WL_MSL_M & Adj_Fr_Hd_amsI \\
\hline WIPP-19 & CUL & 3435.14 & $12 / 5 / 01$ & $14: 58$ & 395.31 & 0.00 & 395.31 & 120.49 & 3039.83 & 926.54 & 3077.62 \\
\hline WIPP-21 & CUL & 3418.96 & $1 / 9 / 01$ & $12: 39$ & 404.03 & 0.00 & 404.03 & 123.15 & 3014.93 & 918.95 & 3038.99 \\
\hline WIPP-21 & CUL & 3418.96 & $2 / 5 / 01$ & $10: 00$ & 404.53 & 0.00 & 404.53 & 123.30 & 3014.43 & 918.80 & 3038.46 \\
\hline WIPP-21 & CUL & 3418.96 & $3 / 7 / 01$ & 13:39 & 404.08 & 0.00 & 404.08 & 123.16 & 3014.88 & 918.94 & 3038.94 \\
\hline WIPP-21 & CUL & 3418.96 & $4 / 5 / 01$ & 13:03 & 403.64 & 0.00 & 403.64 & 123.03 & 3015.32 & 919.07 & 3039.41 \\
\hline WIPP-21 & CUL & 3418.96 & $5 / 8 / 01$ & $12: 11$ & 403.54 & 0.00 & 403.54 & 123.00 & 3015.42 & 919.10 & 3039.52 \\
\hline WIPP-21 & CUL & 3418.96 & $6 / 5 / 01$ & $14: 26$ & 403.03 & 0.00 & 403.03 & 122.84 & 3015.93 & 919.26 & 3040.07 \\
\hline WIPP-21 & CUL & 3418.96 & $7 / 11 / 01$ & $07: 25$ & 402.91 & 0.00 & 402.91 & 122.81 & 3016.05 & 919.29 & 3040.19 \\
\hline WIPP-21 & CUL & 3418.96 & $8 / 8 / 01$ & $13: 50$ & 402.80 & 0.00 & 402.80 & 122.77 & 3016.16 & 919.33 & 3040.31 \\
\hline WIPP-21 & CUL & 3418.96 & 9/6/01 & $07: 45$ & 402.69 & 0.00 & 402.69 & 122.74 & 3016.27 & 919.36 & 3040.43 \\
\hline WIPP-21 & CUL & 3418.96 & $10 / 10 / 01$ & 13:51 & 402.60 & 0.00 & 402.60 & 122.71 & 3016.36 & 919.39 & 3040.53 \\
\hline WIPP-21 & CUL & 3418.96 & $11 / 14 / 01$ & 09:08 & 402.65 & 0.00 & 402.65 & 122.73 & 3016.31 & 919.37 & 3040.47 \\
\hline WIPP-21 & CUL & 3418.96 & $12 / 5 / 01$ & $15: 02$ & 402.86 & 0.00 & 402.86 & 122.79 & 3016.10 & 919.31 & 3040.25 \\
\hline WIPP-22 & CUL & 3428.12 & $1 / 9 / 01$ & $12: 29$ & 398.99 & 0.00 & 398.99 & 121.61 & 3029.13 & 923.28 & 3060.11 \\
\hline WIPP-22 & CUL & 3428.12 & $2 / 5 / 01$ & 09:56 & 399.28 & 0.00 & 399.28 & 121.70 & 3028.84 & 923.19 & 3059.80 \\
\hline WIPP-22 & CUL & 3428.12 & $3 / 7 / 01$ & $13: 43$ & 399.04 & 0.00 & 399.04 & 121.63 & 3029.08 & 923.26 & 3060.06 \\
\hline WIPP-22 & CUL & 3428.12 & $4 / 5 / 01$ & $12: 58$ & 398.80 & 0.00 & 398.80 & 121.55 & 3029.32 & 923.34 & 3060.32 \\
\hline WIPP-22 & CUL & 3428.12 & $5 / 8 / 01$ & $12: 22$ & 398.80 & 0.00 & 398.80 & 121.55 & 3029.32 & 923.34 & 3060.32 \\
\hline WIPP-22 & CUL & 3428.12 & $6 / 5 / 01$ & $14: 15$ & 398.35 & 0.00 & 398.35 & 121.42 & 3029.77 & 923.47 & 3060.81 \\
\hline WIPP-22 & CUL & 3428.12 & $7 / 11 / 01$ & 07:09 & 398.27 & 0.00 & 398.27 & 121.39 & 3029.85 & 923.50 & 3060.90 \\
\hline WIPP-22 & CUL & 3428.12 & $8 / 8 / 01$ & $13: 43$ & 398.20 & 0.00 & 398.20 & 121.37 & 3029.92 & 923.52 & 3060.97 \\
\hline WIPP-22 & CUL & 3428.12 & 9/6/01 & $07: 34$ & 398.07 & 0.00 & 398.07 & 121.33 & 3030.05 & 923.56 & 3061.11 \\
\hline WIPP-22 & CUL & 3428.12 & $10 / 10 / 01$ & $13: 36$ & 397.96 & 0.00 & 397.96 & 121.30 & 3030.16 & 923.59 & 3061.23 \\
\hline WIPP-22 & CUL & 3428.12 & $11 / 14 / 01$ & 09:01 & 397.90 & 0.00 & 397.90 & 121.28 & 3030.22 & 923.61 & 3061.30 \\
\hline WIPP-22 & CUL & 3428.12 & $12 / 5 / 01$ & $15: 07$ & 398.00 & 0.00 & 398.00 & 121.31 & 3030.12 & 923.58 & 3061.19 \\
\hline WIPP-25 (ANNULUS) & MAG & 3214.39 & $1 / 8 / 01$ & $12: 59$ & 165.62 & 0.00 & 165.62 & 50.48 & 3048.77 & 929.27 & \\
\hline WIPP-25 (ANNULUS) & MAG & 3214.39 & $2 / 5 / 01$ & $09: 46$ & 165.69 & 0.00 & 165.69 & 50.50 & 3048.70 & 929.24 & \\
\hline WIPP-25 (ANNULUS) & MAG & 3214.39 & $3 / 6 / 01$ & 10:12 & 164.79 & 0.00 & 164.79 & 50.23 & 3049.60 & 929.52 & \\
\hline WIPP-25 (ANNULUS) & MAG & 3214.39 & $4 / 3 / 01$ & 11:33 & 164.37 & 0.00 & 164.37 & 50.10 & 3050.02 & 929.65 & \\
\hline WIPP-25 (ANNULUS) & MAG & 3214.39 & $5 / 7 / 01$ & $08: 56$ & 164.11 & 0.00 & 164.11 & 50.02 & 3050.28 & 929.73 & \\
\hline WIPP-25 (ANNULUS) & MAG & 3214.39 & $6 / 5 / 01$ & $11: 00$ & 163.87 & 0.00 & 163.87 & 49.95 & 3050.52 & 929.80 & \\
\hline WIPP-25 (ANNULUS) & MAG & 3214.39 & $7 / 9 / 01$ & $14: 15$ & 163.70 & 0.00 & 163.70 & 49.90 & 3050.69 & 929.85 & \\
\hline WIPP-25 (ANNULUS) & MAG & 3214.39 & $8 / 8 / 01$ & 09:21 & 163.60 & 0.00 & 163.60 & 49.87 & 3050.79 & 929.88 & \\
\hline WIPP-25 (ANNULUS) & MAG & 3214.39 & $9 / 4 / 01$ & 11:45 & 163.54 & 0.00 & 163.54 & 49.85 & 3050.85 & 929.90 & \\
\hline WIPP-25 (ANNULUS) & MAG & 3214.39 & $10 / 8 / 01$ & 09:04 & 163.62 & 0.00 & 163.62 & 49.87 & 3050.77 & 929.87 & \\
\hline WIPP-25 (ANNULUS) & MAG & 3214.39 & $11 / 13 / 01$ & $08: 13$ & 163.84 & 0.00 & 163.84 & 49.94 & 3050.55 & 929.81 & \\
\hline WIPP-25 (ANNULUS) & MAG & 3214.39 & $12 / 4 / 01$ & $14: 00$ & 163.85 & 0.00 & 163.85 & 49.94 & 3050.54 & 929.80 & \\
\hline
\end{tabular}


Waste Isolation Pilot Plant 2001 Site Environmental Report DOE/WIPP 02-2225

Table 6.9 - Groundwater Level Measurement Results for 2001

\begin{tabular}{|c|c|c|c|c|c|c|c|c|c|c|c|}
\hline WELL_NO & ZONE & TOC_AMSL* & DATE & TIME & TP_FT_TOC & ADJ_FT & WL_FT & WL_METERS & WL_MSL_FT & WL_MSL_M & Adj_Fr_Hd_amsI \\
\hline WIPP-25 (PIP) & CUL & 3214.39 & $1 / 8 / 01$ & $12: 55$ & 156.75 & 0.42 & 156.33 & 47.65 & 3058.06 & 932.10 & 3055.01 \\
\hline WIPP-25 (PIP) & CUL & 3214.39 & $2 / 5 / 01$ & $09: 37$ & 156.18 & 0.42 & 155.76 & 47.48 & 3058.63 & 932.27 & 3055.57 \\
\hline WIPP-25 (PIP) & CUL & 3214.39 & $3 / 6 / 01$ & 10:09 & 155.85 & 0.42 & 155.43 & 47.38 & 3058.96 & 932.37 & 3055.90 \\
\hline WIPP-25 (PIP) & CUL & 3214.39 & $4 / 3 / 01$ & $11: 30$ & 155.44 & 0.42 & 155.02 & 47.25 & 3059.37 & 932.50 & 3056.31 \\
\hline WIPP-25 (PIP) & CUL & 3214.39 & $5 / 7 / 01$ & $08: 53$ & 155.35 & 0.42 & 154.93 & 47.22 & 3059.46 & 932.52 & 3056.40 \\
\hline WIPP-25 (PIP) & CUL & 3214.39 & $6 / 5 / 01$ & $10: 55$ & 155.21 & 0.42 & 154.79 & 47.18 & 3059.60 & 932.57 & 3056.53 \\
\hline WIPP-25 (PIP) & CUL & 3214.39 & $7 / 9 / 01$ & $14: 10$ & 154.96 & 0.42 & 154.54 & 47.10 & 3059.85 & 932.64 & 3056.78 \\
\hline WIPP-25 (PIP) & CUL & 3214.39 & $8 / 8 / 01$ & $09: 16$ & 154.90 & 0.42 & 154.48 & 47.09 & 3059.91 & 932.66 & 3056.84 \\
\hline WIPP-25 (PIP) & CUL & 3214.39 & $9 / 4 / 01$ & $11: 40$ & 154.95 & 0.42 & 154.53 & 47.10 & 3059.86 & 932.65 & 3056.79 \\
\hline WIPP-25 (PIP) & CUL & 3214.39 & $10 / 8 / 01$ & 09:02 & 154.79 & 0.42 & 154.37 & 47.05 & 3060.02 & 932.69 & 3056.95 \\
\hline WIPP-25 (PIP) & CUL & 3214.39 & $11 / 13 / 01$ & $08: 10$ & 154.70 & 0.42 & 154.28 & 47.02 & 3060.11 & 932.72 & 3057.04 \\
\hline WIPP-25 (PIP) & CUL & 3214.39 & $12 / 4 / 01$ & $13: 53$ & 154.38 & 0.42 & 153.96 & 46.93 & 3060.43 & 932.82 & 3057.36 \\
\hline WIPP-26 & CUL & 3153.20 & $1 / 8 / 01$ & $10: 52$ & 131.45 & 0.00 & 131.45 & 40.07 & 3021.75 & 921.03 & 3021.89 \\
\hline WIPP-26 & CUL & 3153.20 & $2 / 7 / 01$ & $07: 43$ & 131.37 & 0.00 & 131.37 & 40.04 & 3021.83 & 921.05 & 3021.97 \\
\hline WIPP-26 & CUL & 3153.20 & $3 / 6 / 01$ & $09: 35$ & 131.56 & 0.00 & 131.56 & 40.10 & 3021.64 & 921.00 & 3021.77 \\
\hline WIPP-26 & CUL & 3153.20 & $4 / 3 / 01$ & $12: 08$ & 131.15 & 0.00 & 131.15 & 39.97 & 3022.05 & 921.12 & 3022.19 \\
\hline WIPP-26 & CUL & 3153.20 & $5 / 7 / 01$ & 09:39 & 131.25 & 0.00 & 131.25 & 40.01 & 3021.95 & 921.09 & 3022.09 \\
\hline WIPP-26 & CUL & 3153.20 & $6 / 4 / 01$ & $11: 11$ & 132.00 & 0.00 & 132.00 & 40.23 & 3021.20 & 920.86 & 3021.33 \\
\hline WIPP-26 & CUL & 3153.20 & $7 / 9 / 01$ & $10: 20$ & 131.41 & 0.00 & 131.41 & 40.05 & 3021.79 & 921.04 & 3021.93 \\
\hline WIPP-26 & CUL & 3153.20 & $8 / 6 / 01$ & $11: 06$ & 131.80 & 0.00 & 131.80 & 40.17 & 3021.40 & 920.92 & 3021.53 \\
\hline WIPP-26 & CUL & 3153.20 & 9/5/01 & $07: 15$ & 132.63 & 0.00 & 132.63 & 40.43 & 3020.57 & 920.67 & 3020.70 \\
\hline WIPP-26 & CUL & 3153.20 & $10 / 8 / 01$ & 09:39 & 131.79 & 0.00 & 131.79 & 40.17 & 3021.41 & 920.93 & 3021.54 \\
\hline WIPP-26 & CUL & 3153.20 & $11 / 13 / 01$ & $08: 48$ & 131.06 & 0.00 & 131.06 & 39.95 & 3022.14 & 921.15 & 3022.28 \\
\hline WIPP-26 & CUL & 3153.20 & $12 / 5 / 01$ & 09:02 & 131.80 & 0.00 & 131.80 & 40.17 & 3021.40 & 920.92 & 3021.53 \\
\hline WIPP-27 (PIP) & CUL & 3178.98 & $1 / 8 / 01$ & $09: 44$ & 98.26 & 0.42 & 97.84 & 29.82 & 3081.14 & 939.13 & 3087.20 \\
\hline WIPP-27 (PIP) & CUL & 3178.98 & $2 / 6 / 01$ & $10: 28$ & 98.38 & 0.42 & 97.96 & 29.86 & 3081.02 & 939.09 & 3087.08 \\
\hline WIPP-27 (PIP) & CUL & 3178.98 & $3 / 6 / 01$ & $07: 36$ & 98.53 & 0.42 & 98.11 & 29.90 & 3080.87 & 939.05 & 3086.92 \\
\hline WIPP-27 (PIP) & CUL & 3178.98 & $4 / 3 / 01$ & $10: 25$ & 98.57 & 0.42 & 98.15 & 29.92 & 3080.83 & 939.04 & 3086.88 \\
\hline WIPP-27 (PIP) & CUL & 3178.98 & $5 / 7 / 01$ & $07: 49$ & 98.75 & 0.42 & 98.33 & 29.97 & 3080.65 & 938.98 & 3086.70 \\
\hline WIPP-27 (PIP) & CUL & 3178.98 & $6 / 4 / 01$ & 09:05 & 98.60 & 0.42 & 98.18 & 29.93 & 3080.80 & 939.03 & 3086.85 \\
\hline WIPP-27 (PIP) & CUL & 3178.98 & $7 / 9 / 01$ & $13: 25$ & 98.96 & 0.42 & 98.54 & 30.03 & 3080.44 & 938.92 & 3086.48 \\
\hline WIPP-27 (PIP) & CUL & 3178.98 & $8 / 6 / 01$ & 10:02 & 99.27 & 0.42 & 98.85 & 30.13 & 3080.13 & 938.82 & 3086.16 \\
\hline WIPP-27 (PIP) & CUL & 3178.98 & $9 / 4 / 01$ & $10: 35$ & 99.23 & 0.42 & 98.81 & 30.12 & 3080.17 & 938.84 & 3086.20 \\
\hline WIPP-27 (PIP) & CUL & 3178.98 & 10/8/01 & 08:05 & 98.59 & 0.42 & 98.17 & 29.92 & 3080.81 & 939.03 & 3086.86 \\
\hline WIPP-27 (PIP) & CUL & 3178.98 & $11 / 13 / 01$ & $07: 27$ & 97.95 & 0.42 & 97.53 & 29.73 & 3081.45 & 939.23 & 3087.52 \\
\hline WIPP-27 (PIP) & CUL & 3178.98 & $12 / 4 / 01$ & 13:19 & 97.30 & 0.42 & 96.88 & 29.53 & 3082.10 & 939.42 & 3088.19 \\
\hline WIPP-29 & CUL & 2978.26 & $1 / 8 / 01$ & $10: 29$ & 11.09 & 0.00 & 11.09 & 3.38 & 2967.17 & 904.39 & 2970.36 \\
\hline
\end{tabular}


Waste Isolation Pilot Plant 2001 Site Environmental Report DOE/WIPP 02-2225

Table 6.9 - Groundwater Level Measurement Results for 2001

\begin{tabular}{|c|c|c|c|c|c|c|c|c|c|c|c|}
\hline WELL_NO & ZONE & TOC_AMSL* & DATE & TIME & TP_FT_TOC & ADJ_FT & WL_FT & WL_METERS & WL_MSL_FT & WL_MSL_M & Adj_Fr_Hd_amsI \\
\hline WIPP-29 & CUL & 2978.26 & $2 / 7 / 01$ & $07: 20$ & 11.00 & 0.00 & 11.00 & 3.35 & 2967.26 & 904.42 & 2970.46 \\
\hline WIPP-29 & CUL & 2978.26 & $3 / 6 / 01$ & 09:11 & 11.03 & 0.00 & 11.03 & 3.36 & 2967.23 & 904.41 & 2970.43 \\
\hline WIPP-29 & CUL & 2978.26 & $4 / 4 / 01$ & 07:02 & 11.15 & 0.00 & 11.15 & 3.40 & 2967.11 & 904.38 & 2970.28 \\
\hline WIPP-29 & CUL & 2978.26 & $5 / 7 / 01$ & 10:05 & 11.20 & 0.00 & 11.20 & 3.41 & 2967.06 & 904.36 & 2970.23 \\
\hline WIPP-29 & CUL & 2978.26 & $6 / 4 / 01$ & $10: 47$ & 11.35 & 0.00 & 11.35 & 3.46 & 2966.91 & 904.31 & 2970.05 \\
\hline WIPP-29 & CUL & 2978.26 & 7/9/01 & $10: 45$ & 11.66 & 0.00 & 11.66 & 3.55 & 2966.60 & 904.22 & 2969.68 \\
\hline WIPP-29 & CUL & 2978.26 & $8 / 6 / 01$ & $10: 42$ & 11.25 & 0.00 & 11.25 & 3.43 & 2967.01 & 904.34 & 2970.17 \\
\hline WIPP-29 & CUL & 2978.26 & 9/4/01 & $09: 45$ & 11.40 & 0.00 & 11.40 & 3.47 & 2966.86 & 904.30 & 2969.99 \\
\hline WIPP-29 & CUL & 2978.26 & 10/8/01 & 07:09 & 11.33 & 0.00 & 11.33 & 3.45 & 2966.93 & 904.32 & 2970.07 \\
\hline WIPP-29 & CUL & 2978.26 & $11 / 13 / 01$ & $09: 19$ & 11.51 & 0.00 & 11.51 & 3.51 & 2966.75 & 904.27 & 2969.86 \\
\hline WIPP-29 & CUL & 2978.26 & $12 / 4 / 01$ & $14: 36$ & 11.20 & 0.00 & 11.20 & 3.41 & 2967.06 & 904.36 & 2970.23 \\
\hline WIPP-30 (ANNULUS) & MAG & 3429.05 & $1 / 8 / 01$ & 13:39 & 335.84 & 2.08 & 333.76 & 101.73 & 3095.29 & 943.44 & \\
\hline WIPP-30 (ANNULUS) & MAG & 3429.05 & $2 / 6 / 01$ & $11: 35$ & 333.44 & 2.08 & 331.36 & 101.00 & 3097.69 & 944.18 & \\
\hline WIPP-30 (ANNULUS) & MAG & 3429.05 & $3 / 6 / 01$ & $13: 35$ & 331.70 & 2.08 & 329.62 & 100.47 & 3099.43 & 944.71 & \\
\hline WIPP-30 (ANNULUS) & MAG & 3429.05 & $4 / 4 / 01$ & $13: 00$ & 330.80 & 2.08 & 328.72 & 100.19 & 3100.33 & 944.98 & \\
\hline WIPP-30 (ANNULUS) & MAG & 3429.05 & $5 / 8 / 01$ & $08: 48$ & 329.03 & 2.08 & 326.95 & 99.65 & 3102.10 & 945.52 & \\
\hline WIPP-30 (ANNULUS) & MAG & 3429.05 & $6 / 5 / 01$ & $09: 26$ & 326.86 & 2.08 & 324.78 & 98.99 & 3104.27 & 946.18 & \\
\hline WIPP-30 (ANNULUS) & MAG & 3429.05 & $7 / 10 / 01$ & 08:05 & 324.85 & 2.08 & 322.77 & 98.38 & 3106.28 & 946.79 & \\
\hline WIPP-30 (ANNULUS) & MAG & 3429.05 & $8 / 8 / 01$ & 10:36 & 321.90 & 0.00 & 321.90 & 98.12 & 3107.15 & 947.06 & \\
\hline WIPP-30 (ANNULUS) & MAG & 3429.05 & $9 / 4 / 01$ & $12: 25$ & 321.55 & 0.00 & 321.55 & 98.01 & 3107.50 & 947.17 & \\
\hline WIPP-30 (ANNULUS) & MAG & 3429.05 & 10/10/01 & $10: 00$ & 320.65 & 0.00 & 320.65 & 97.73 & 3108.40 & 947.44 & \\
\hline WIPP-30 (ANNULUS) & MAG & 3429.05 & $11 / 12 / 01$ & $11: 46$ & 319.91 & 0.00 & 319.91 & 97.51 & 3109.14 & 947.67 & \\
\hline WIPP-30 (ANNULUS) & MAG & 3429.05 & $12 / 3 / 01$ & $11: 56$ & 318.37 & 0.00 & 318.37 & 97.04 & 3110.68 & 948.14 & \\
\hline WIPP-30 (PIP) & CUL & 3429.05 & $1 / 8 / 01$ & 13:31 & 369.15 & 2.08 & 367.07 & 111.88 & 3061.98 & 933.29 & 3068.89 \\
\hline WIPP-30 (PIP) & CUL & 3429.05 & $2 / 6 / 01$ & $11: 30$ & 368.15 & 2.08 & 366.07 & 111.58 & 3062.98 & 933.60 & 3069.92 \\
\hline WIPP-30 (PIP) & CUL & 3429.05 & $3 / 6 / 01$ & 13:24 & 367.20 & 2.08 & 365.12 & 111.29 & 3063.93 & 933.89 & 3070.89 \\
\hline WIPP-30 (PIP) & CUL & 3429.05 & $4 / 4 / 01$ & $12: 50$ & 366.19 & 2.08 & 364.11 & 110.98 & 3064.94 & 934.19 & 3071.93 \\
\hline WIPP-30 (PIP) & CUL & 3429.05 & $5 / 8 / 01$ & $08: 54$ & 365.41 & 2.08 & 363.33 & 110.74 & 3065.72 & 934.43 & 3072.73 \\
\hline WIPP-30 (PIP) & CUL & 3429.05 & $6 / 5 / 01$ & 09:28 & 364.54 & 2.08 & 362.46 & 110.48 & 3066.59 & 934.70 & 3073.62 \\
\hline WIPP-30 (PIP) & CUL & 3429.05 & $7 / 10 / 01$ & 08:00 & 364.37 & 2.08 & 362.29 & 110.43 & 3066.76 & 934.75 & 3073.79 \\
\hline WIPP-30 (PIP) & CUL & 3429.05 & $8 / 8 / 01$ & $10: 19$ & 363.13 & 0.70 & 362.43 & 110.47 & 3066.62 & 934.71 & 3073.65 \\
\hline WIPP-30 (PIP) & CUL & 3429.05 & $9 / 4 / 01$ & $12: 30$ & 362.63 & 0.70 & 361.93 & 110.32 & 3067.12 & 934.86 & 3074.16 \\
\hline WIPP-30 (PIP) & CUL & 3429.05 & 10/10/01 & $09: 52$ & 362.34 & 0.70 & 361.64 & 110.23 & 3067.41 & 934.95 & 3074.46 \\
\hline WIPP-30 (PIP) & CUL & 3429.05 & $11 / 12 / 01$ & $11: 40$ & 362.18 & 0.70 & 361.48 & 110.18 & 3067.57 & 935.00 & 3074.62 \\
\hline WIPP-30 (PIP) & CUL & 3429.05 & $12 / 3 / 01$ & $11: 52$ & 361.90 & 0.70 & 361.20 & 110.09 & 3067.85 & 935.08 & 3074.91 \\
\hline WQSP-1 & CUL & 3419.20 & $1 / 9 / 01$ & 09:21 & 366.36 & 0.16 & 366.20 & 111.62 & 3053.00 & 930.55 & 3069.65 \\
\hline WQSP-1 & CUL & 3419.20 & 2/6/01 & $08: 37$ & 366.27 & 0.16 & 366.11 & 111.59 & 3053.09 & 930.58 & 3069.75 \\
\hline
\end{tabular}


Waste Isolation Pilot Plant 2001 Site Environmental Report DOE/WIPP 02-2225

Table 6.9 - Groundwater Level Measurement Results for 2001

\begin{tabular}{|c|c|c|c|c|c|c|c|c|c|c|c|}
\hline WELL_NO & ZONE & TOC_AMSL* & DATE & TIME & TP_FT_TOC & ADJ_FT & WL_FT & WL_METERS & WL_MSL_FT & WL_MSL_M & Adj_Fr_Hd_amsI \\
\hline WQSP-1 & CUL & 3419.20 & $3 / 6 / 01$ & $11: 20$ & 366.26 & 0.16 & 366.10 & 111.59 & 3053.10 & 930.58 & 3069.76 \\
\hline WQSP-1 & CUL & 3419.20 & $4 / 5 / 01$ & $11: 14$ & 366.27 & 0.16 & 366.11 & 111.59 & 3053.09 & 930.58 & 3069.75 \\
\hline WQSP-1 & CUL & 3419.20 & $5 / 8 / 01$ & 11:19 & 365.95 & 0.16 & 365.79 & 111.49 & 3053.41 & 930.68 & 3070.08 \\
\hline WQSP-1 & CUL & 3419.20 & $6 / 5 / 01$ & $12: 10$ & 365.68 & 0.16 & 365.52 & 111.41 & 3053.68 & 930.76 & 3070.36 \\
\hline WQSP-1 & CUL & 3419.20 & $7 / 9 / 01$ & $08: 20$ & 365.71 & 0.16 & 365.55 & 111.42 & 3053.65 & 930.75 & 3070.33 \\
\hline WQSP-1 & CUL & 3419.20 & $8 / 7 / 01$ & $14: 36$ & 365.88 & 0.16 & 365.72 & 111.47 & 3053.48 & 930.70 & 3070.15 \\
\hline WQSP-1 & CUL & 3419.20 & 9/4/01 & $06: 35$ & 365.82 & 0.16 & 365.66 & 111.45 & 3053.54 & 930.72 & 3070.22 \\
\hline WQSP-1 & CUL & 3419.20 & 10/10/01 & $10: 42$ & 365.78 & 0.16 & 365.62 & 111.44 & 3053.58 & 930.73 & 3070.26 \\
\hline WQSP-1 & CUL & 3419.20 & $11 / 14 / 01$ & $06: 53$ & 365.55 & 0.16 & 365.39 & 111.37 & 3053.81 & 930.80 & 3070.50 \\
\hline WQSP-1 & CUL & 3419.20 & $12 / 5 / 01$ & $14: 22$ & 365.75 & 0.16 & 365.59 & 111.43 & 3053.61 & 930.74 & 3070.29 \\
\hline WQSP-2 & CUL & 3463.90 & $1 / 9 / 01$ & $08: 48$ & 404.59 & 0.16 & 404.43 & 123.27 & 3059.47 & 932.53 & 3079.21 \\
\hline WQSP-2 & CUL & 3463.90 & 2/6/01 & $08: 24$ & 404.33 & 0.16 & 404.17 & 123.19 & 3059.73 & 932.61 & 3079.49 \\
\hline WQSP-2 & CUL & 3463.90 & $3 / 7 / 01$ & $08: 26$ & 404.09 & 0.16 & 403.93 & 123.12 & 3059.97 & 932.68 & 3079.74 \\
\hline WQSP-2 & CUL & 3463.90 & $4 / 4 / 01$ & $12: 26$ & 405.38 & 0.16 & 405.22 & 123.51 & 3058.68 & 932.29 & 3078.39 \\
\hline WQSP-2 & CUL & 3463.90 & $5 / 8 / 01$ & $10: 10$ & 405.14 & 0.16 & 404.98 & 123.44 & 3058.92 & 932.36 & 3078.64 \\
\hline WQSP-2 & CUL & 3463.90 & $6 / 5 / 01$ & $13: 12$ & 404.37 & 0.16 & 404.21 & 123.20 & 3059.69 & 932.59 & 3079.44 \\
\hline WQSP-2 & CUL & 3463.90 & $7 / 9 / 01$ & 08:06 & 404.16 & 0.16 & 404.00 & 123.14 & 3059.90 & 932.66 & 3079.66 \\
\hline WQSP-2 & CUL & 3463.90 & $8 / 8 / 01$ & $11: 10$ & 404.06 & 0.16 & 403.90 & 123.11 & 3060.00 & 932.69 & 3079.77 \\
\hline WQSP-2 & CUL & 3463.90 & 9/6/01 & 10:45 & 403.90 & 0.16 & 403.74 & 123.06 & 3060.16 & 932.74 & 3079.94 \\
\hline WQSP-2 & CUL & 3463.90 & 10/10/01 & $11: 49$ & 405.05 & 0.16 & 404.89 & 123.41 & 3059.01 & 932.39 & 3078.73 \\
\hline WQSP-2 & CUL & 3463.90 & $11 / 14 / 01$ & $08: 24$ & 404.64 & 0.16 & 404.48 & 123.29 & 3059.42 & 932.51 & 3079.16 \\
\hline WQSP-2 & CUL & 3463.90 & $12 / 5 / 01$ & $14: 35$ & 404.61 & 0.16 & 404.45 & 123.28 & 3059.45 & 932.52 & 3079.19 \\
\hline WQSP-3 & CUL & 3480.30 & $1 / 9 / 01$ & $10: 28$ & 470.11 & 0.16 & 469.95 & 143.24 & 3010.35 & 917.55 & 3067.27 \\
\hline WQSP-3 & CUL & 3480.30 & 2/5/01 & 09:10 & 469.68 & 0.16 & 469.52 & 143.11 & 3010.78 & 917.69 & 3067.76 \\
\hline WQSP-3 & CUL & 3480.30 & $3 / 7 / 01$ & $14: 11$ & 469.08 & 0.16 & 468.92 & 142.93 & 3011.38 & 917.87 & 3068.45 \\
\hline WQSP-3 & CUL & 3480.30 & $4 / 5 / 01$ & $11: 37$ & 473.11 & 0.16 & 472.95 & 144.16 & 3007.35 & 916.64 & 3063.83 \\
\hline WQSP-3 & CUL & 3480.30 & $5 / 8 / 01$ & 13:11 & 469.94 & 0.16 & 469.78 & 143.19 & 3010.52 & 917.61 & 3067.46 \\
\hline WQSP-3 & CUL & 3480.30 & $6 / 5 / 01$ & 13:31 & 469.16 & 0.16 & 469.00 & 142.95 & 3011.30 & 917.84 & 3068.36 \\
\hline WQSP-3 & CUL & 3480.30 & $7 / 11 / 01$ & $06: 35$ & 468.88 & 0.16 & 468.72 & 142.87 & 3011.58 & 917.93 & 3068.68 \\
\hline WQSP-3 & CUL & 3480.30 & $8 / 8 / 01$ & $13: 16$ & 468.63 & 0.16 & 468.47 & 142.79 & 3011.83 & 918.01 & 3068.96 \\
\hline WQSP-3 & CUL & 3480.30 & 9/6/01 & $06: 45$ & 468.40 & 0.16 & 468.24 & 142.72 & 3012.06 & 918.08 & 3069.23 \\
\hline WQSP-3 & CUL & 3480.30 & 10/10/01 & 12:56 & 472.87 & 0.16 & 472.71 & 144.08 & 3007.59 & 916.71 & 3064.11 \\
\hline WQSP-3 & CUL & 3480.30 & $11 / 14 / 01$ & $08: 40$ & 469.28 & 0.16 & 469.12 & 142.99 & 3011.18 & 917.81 & 3068.22 \\
\hline WQSP-3 & CUL & 3480.30 & $12 / 5 / 01$ & $14: 45$ & 469.04 & 0.16 & 468.88 & 142.91 & 3011.42 & 917.88 & 3068.49 \\
\hline WQSP-4 & CUL & 3433.00 & $1 / 10 / 01$ & $13: 39$ & 446.73 & 0.16 & 446.57 & 136.11 & 2986.43 & 910.26 & 3011.49 \\
\hline WQSP-4 & CUL & 3433.00 & $2 / 6 / 01$ & $14: 35$ & 447.66 & 0.16 & 447.50 & 136.40 & 2985.50 & 909.98 & 3010.49 \\
\hline WQSP-4 & CUL & 3433.00 & $3 / 8 / 01$ & $07: 49$ & 446.42 & 0.16 & 446.26 & 136.02 & 2986.74 & 910.36 & 3011.82 \\
\hline
\end{tabular}


Waste Isolation Pilot Plant 2001 Site Environmental Report DOE/WIPP 02-2225

Table 6.9 - Groundwater Level Measurement Results for 2001

\begin{tabular}{|c|c|c|c|c|c|c|c|c|c|c|c|}
\hline WELL_NO & ZONE & TOC_AMSL* & DATE & TIME & TP_FT_TOC & ADJ_FT & WL_FT & WL_METERS & WL_MSL_FT & WL_MSL_M & Adj_Fr_Hd_amsI \\
\hline WQSP-4 & CUL & 3433.00 & $4 / 5 / 01$ & 09:36 & 446.43 & 0.16 & 446.27 & 136.02 & 2986.73 & 910.36 & 3011.81 \\
\hline WQSP-4 & CUL & 3433.00 & $5 / 9 / 01$ & 09:07 & 446.71 & 0.16 & 446.55 & 136.11 & 2986.45 & 910.27 & 3011.51 \\
\hline WQSP-4 & CUL & 3433.00 & $6 / 6 / 01$ & $07: 45$ & 446.24 & 0.16 & 446.08 & 135.97 & 2986.92 & 910.41 & 3011.83 \\
\hline WQSP-4 & CUL & 3433.00 & $7 / 11 / 01$ & $07: 55$ & 446.03 & 0.16 & 445.87 & 135.90 & 2987.13 & 910.48 & 3012.05 \\
\hline WQSP-4 & CUL & 3433.00 & $8 / 7 / 01$ & 09:55 & 446.00 & 0.16 & 445.84 & 135.89 & 2987.16 & 910.49 & 3012.09 \\
\hline WQSP-4 & CUL & 3433.00 & $9 / 7 / 01$ & $07: 45$ & 445.71 & 0.16 & 445.55 & 135.80 & 2987.45 & 910.57 & 3012.40 \\
\hline WQSP-4 & CUL & 3433.00 & $10 / 9 / 01$ & 13:06 & 445.68 & 0.16 & 445.52 & 135.79 & 2987.48 & 910.58 & 3012.43 \\
\hline WQSP-4 & CUL & 3433.00 & $11 / 13 / 01$ & $14: 42$ & 445.95 & 0.16 & 445.79 & 135.88 & 2987.21 & 910.50 & 3012.14 \\
\hline WQSP-4 & CUL & 3433.00 & $12 / 5 / 01$ & $12: 15$ & 445.99 & 0.16 & 445.83 & 135.89 & 2987.17 & 910.49 & 3012.10 \\
\hline WQSP-5 & CUL & 3384.40 & $1 / 10 / 01$ & $13: 58$ & 382.59 & 0.16 & 382.43 & 116.56 & 3001.97 & 915.00 & 3009.00 \\
\hline WQSP-5 & CUL & 3384.40 & $2 / 7 / 01$ & $11: 30$ & 382.47 & 0.16 & 382.31 & 116.53 & 3002.09 & 915.04 & 3009.13 \\
\hline WQSP-5 & CUL & 3384.40 & $3 / 8 / 01$ & $08: 57$ & 382.20 & 0.16 & 382.04 & 116.45 & 3002.36 & 915.12 & 3009.40 \\
\hline WQSP-5 & CUL & 3384.40 & $4 / 5 / 01$ & 09:59 & 382.19 & 0.16 & 382.03 & 116.44 & 3002.37 & 915.12 & 3009.41 \\
\hline WQSP-5 & CUL & 3384.40 & $5 / 9 / 01$ & $08: 56$ & 383.37 & 0.16 & 383.21 & 116.80 & 3001.19 & 914.76 & 3008.20 \\
\hline WQSP-5 & CUL & 3384.40 & $6 / 6 / 01$ & $08: 45$ & 383.31 & 0.16 & 383.15 & 116.78 & 3001.25 & 914.78 & 3008.27 \\
\hline WQSP-5 & CUL & 3384.40 & $7 / 11 / 01$ & $08: 15$ & 382.04 & 0.16 & 381.88 & 116.40 & 3002.52 & 915.17 & 3009.57 \\
\hline WQSP-5 & CUL & 3384.40 & $8 / 7 / 01$ & $10: 14$ & 381.95 & 0.16 & 381.79 & 116.37 & 3002.61 & 915.20 & 3009.66 \\
\hline WQSP-5 & CUL & 3384.40 & $9 / 7 / 01$ & $12: 45$ & 381.54 & 0.16 & 381.38 & 116.24 & 3003.02 & 915.32 & 3010.08 \\
\hline WQSP-5 & CUL & 3384.40 & $10 / 9 / 01$ & $13: 26$ & 381.52 & 0.16 & 381.36 & 116.24 & 3003.04 & 915.33 & 3010.10 \\
\hline WQSP-5 & CUL & 3384.40 & $11 / 14 / 01$ & $09: 26$ & 382.16 & 0.16 & 382.00 & 116.43 & 3002.40 & 915.13 & 3009.44 \\
\hline WQSP-5 & CUL & 3384.40 & $12 / 5 / 01$ & $12: 48$ & 381.97 & 0.16 & 381.81 & 116.38 & 3002.59 & 915.19 & 3009.64 \\
\hline WQSP-6 & CUL & 3363.80 & $1 / 10 / 01$ & $14: 11$ & 348.70 & 0.16 & 348.54 & 106.23 & 3015.26 & 919.05 & 3018.98 \\
\hline WQSP-6 & CUL & 3363.80 & $2 / 7 / 01$ & $11: 43$ & 348.45 & 0.16 & 348.29 & 106.16 & 3015.51 & 919.13 & 3019.23 \\
\hline WQSP-6 & CUL & 3363.80 & $3 / 8 / 01$ & 09:01 & 348.22 & 0.16 & 348.06 & 106.09 & 3015.74 & 919.20 & 3019.47 \\
\hline WQSP-6 & CUL & 3363.80 & $4 / 5 / 01$ & $10: 16$ & 348.14 & 0.16 & 347.98 & 106.06 & 3015.82 & 919.22 & 3019.55 \\
\hline WQSP-6 & CUL & 3363.80 & $5 / 9 / 01$ & $08: 30$ & 348.23 & 0.16 & 348.07 & 106.09 & 3015.73 & 919.19 & 3019.46 \\
\hline WQSP-6 & CUL & 3363.80 & $6 / 6 / 01$ & 09:00 & 349.16 & 0.16 & 349.00 & 106.38 & 3014.80 & 918.91 & 3018.51 \\
\hline WQSP-6 & CUL & 3363.80 & $7 / 11 / 01$ & $08: 30$ & 348.36 & 0.16 & 348.20 & 106.13 & 3015.60 & 919.15 & 3019.32 \\
\hline WQSP-6 & CUL & 3363.80 & $8 / 7 / 01$ & $10: 25$ & 348.20 & 0.16 & 348.04 & 106.08 & 3015.76 & 919.20 & 3019.49 \\
\hline WQSP-6 & CUL & 3363.80 & 9/7/01 & $12: 30$ & 347.74 & 0.16 & 347.58 & 105.94 & 3016.22 & 919.34 & 3019.95 \\
\hline WQSP-6 & CUL & 3363.80 & $10 / 10 / 01$ & $09: 17$ & 347.74 & 0.16 & 347.58 & 105.94 & 3016.22 & 919.34 & 3019.95 \\
\hline WQSP-6 & CUL & 3363.80 & $11 / 14 / 01$ & 09:36 & 350.62 & 0.16 & 350.46 & 106.82 & 3013.34 & 918.47 & 3017.03 \\
\hline WQSP-6 & CUL & 3363.80 & $12 / 5 / 01$ & $12: 55$ & 348.45 & 0.16 & 348.29 & 106.16 & 3015.51 & 919.13 & 3019.23 \\
\hline WQSP-6a & $\mathrm{DL}$ & 3364.70 & $1 / 10 / 01$ & $14: 20$ & 166.35 & 0.25 & 166.10 & 50.63 & 3198.60 & 974.93 & \\
\hline WQSP-6a & $\mathrm{DL}$ & 3364.70 & $2 / 7 / 01$ & $11: 50$ & 166.32 & 0.25 & 166.07 & 50.62 & 3198.63 & 974.94 & \\
\hline WQSP-6a & $\mathrm{DL}$ & 3364.70 & $3 / 8 / 01$ & 09:10 & 166.38 & 0.25 & 166.13 & 50.64 & 3198.57 & 974.92 & \\
\hline WQSP-6a & $\mathrm{DL}$ & 3364.70 & 4/5/01 & $10: 24$ & 166.61 & 0.25 & 166.36 & 50.71 & 3198.34 & 974.85 & \\
\hline
\end{tabular}


Waste Isolation Pilot Plant 2001 Site Environmental Report

DOE/WIPP 02-2225

Table 6.9 - Groundwater Level Measurement Results for 2001

\begin{tabular}{|c|c|c|c|c|c|c|c|c|c|c|c|}
\hline WELL_NO & ZONE & TOC_AMSL* & DATE & TIME & TP_FT_TOC & ADJ_FT & WL_FT & WL_METERS & WL_MSL_FT & WL_MSL_M & Adj_Fr_Hd_amsI \\
\hline WQSP-6a & $\mathrm{DL}$ & 3364.70 & $5 / 9 / 01$ & $08: 25$ & 166.71 & 0.25 & 166.46 & 50.74 & 3198.24 & 974.82 & \\
\hline WQSP-6a & $\mathrm{DL}$ & 3364.70 & $6 / 4 / 01$ & $06: 42$ & 166.44 & 0.25 & 166.19 & 50.65 & 3198.51 & 974.91 & \\
\hline WQSP-6a & $\mathrm{DL}$ & 3364.70 & 7/11/01 & $08: 35$ & 166.62 & 0.25 & 166.37 & 50.71 & 3198.33 & 974.85 & \\
\hline WQSP-6a & $\mathrm{DL}$ & 3364.70 & $8 / 7 / 01$ & 10:31 & 166.79 & 0.25 & 166.54 & 50.76 & 3198.16 & 974.80 & \\
\hline WQSP-6a & $\mathrm{DL}$ & 3364.70 & 9/7/01 & $12: 35$ & 166.50 & 0.25 & 166.25 & 50.67 & 3198.45 & 974.89 & \\
\hline WQSP-6a & $\mathrm{DL}$ & 3364.70 & 10/10/01 & $09: 26$ & 166.64 & 0.25 & 166.39 & 50.72 & 3198.31 & 974.84 & \\
\hline WQSP-6a & $\mathrm{DL}$ & 3364.70 & $11 / 12 / 01$ & $05: 00$ & 166.69 & 0.25 & 166.44 & 50.73 & 3198.26 & 974.83 & \\
\hline WQSP-6a & $\mathrm{DL}$ & 3364.70 & $12 / 5 / 01$ & 13:01 & 166.84 & 0.25 & 166.59 & 50.78 & 3198.11 & 974.78 & \\
\hline
\end{tabular}




\section{Waste Isolation Pilot Plant 2001 Site Environmental Report DOE/WIPP 02-2225}

Table 6.10 - Analytical Results for Shallow Groundwater Program

\begin{tabular}{|c|c|c|c|c|c|c|c|}
\hline Parameter & Units & C-2505 & C-2506 & C-2507 & Dup. & C-2811 & $\mathrm{PZ}-1$ \\
\hline Ammonium & $\mathrm{mg} / \mathrm{l}$ & 0.097 & 0.0967 & $<0.0042$ & 0.0075 & $<0.0042$ & 0.0699 \\
\hline Arsenic & $\mathrm{mg} / \mathrm{l}$ & $<0.003$ & $<0.003$ & 0.0015 & 0.0017 & 0.0014 & $<0.003$ \\
\hline Barium & $\mathrm{mg} / \mathrm{l}$ & 0.103 & 0.0914 & 0.0377 & 0.0386 & 0.0934 & 0.125 \\
\hline Boron & $\mathrm{mg} / \mathrm{l}$ & 0.17 & 0.12 & 0.27 & 0.25 & 0.17 & 0.079 \\
\hline Bromide & $\mathrm{mg} / \mathrm{l}$ & 9.9 & 9.5 & 5.3 & 5.6 & 2.8 & 19.2 \\
\hline Cadmium & $\mathrm{mg} / \mathrm{l}$ & $<0.001$ & $<0.001$ & $<0.0001$ & $<0.0001$ & $<0.0001$ & $<0.001$ \\
\hline Calcium & $\mathrm{mg} / \mathrm{l}$ & 943 & 1250 & 418 & 431 & 283 & 4250 \\
\hline Chloride & $\mathrm{mg} / \mathrm{l}$ & 6230 & 9240 & 1300 & 1330 & 956 & 33100 \\
\hline Chromium & $\mathrm{mg} / \mathrm{l}$ & 0.0141 & 0.0099 & 0.0491 & 0.0535 & 0.0017 & 0.0108 \\
\hline Iron & $\mathrm{mg} / \mathrm{l}$ & $<0.008$ & $<0.008$ & $<0.0008$ & $<0.0008$ & $<0.0008$ & $<0.008$ \\
\hline Lead & $\mathrm{mg} / \mathrm{l}$ & 0.0048 & $<0.001$ & 0.00012 & $<0.0001$ & $<0.0001$ & $<0.001$ \\
\hline Magnesium & $\mathrm{mg} / \mathrm{l}$ & 646 & 820 & 337 & 331 & 207 & 2310 \\
\hline Mercury & $\mathrm{mg} / \mathrm{l}$ & $<0.0002$ & $<0.0002$ & $<0.0002$ & $<0.0002$ & $<0.0002$ & 0.0016 \\
\hline Nitrate & $\mathrm{mg} / \mathrm{l}$ & 23.2 & 23.2 & 26 & 25.7 & 27.9 & 4.9 \\
\hline Nitrite & $\mathrm{mg} / \mathrm{l}$ & 0.0165 & $<0.0082$ & 0.0139 & 0.0156 & 0.0147 & $<0.0082$ \\
\hline $\mathrm{pH}$ & & 7.28 & 7.2 & 7.61 & 7.42 & 7.56 & 6.94 \\
\hline Potassium & $\mathrm{mg} / \mathrm{l}$ & 11.3 & 14.5 & 6.5 & 6.5 & 4.6 & 32 \\
\hline Selenium & $\mathrm{mg} / \mathrm{l}$ & 0.112 & 0.0447 & 0.075 & 0.0698 & 0.0243 & 0.0753 \\
\hline Silicon & $\mathrm{mg} / \mathrm{l}$ & 22.7 & 22.3 & 25 & 25 & 22.3 & 19.4 \\
\hline Silver & $\mathrm{mg} / \mathrm{l}$ & $<0.001$ & $<0.001$ & $<0.0001$ & 0.00012 & $<0.0001$ & $<0.001$ \\
\hline Sodium & $\mathrm{mg} / \mathrm{l}$ & 2030 & 3230 & 328 & 329 & 163 & 12700 \\
\hline Specific Gravity & $\mathrm{mg} / \mathrm{g}$ & 1.01 & 1.01 & 1 & 1 & 1 & 1.04 \\
\hline Sulfate & $\mathrm{mg} / \mathrm{l}$ & 1290 & 1300 & 940 & 970 & 379 & 1610 \\
\hline Total Dissolved Solids & $\mathrm{mg} / \mathrm{l}$ & 13000 & 18000 & 4170 & 4180 & 2630 & 62200 \\
\hline Total Inorganic Carbon & $\mathrm{mg} / \mathrm{l}$ & & & 75.1 & 75.8 & 49.5 & \\
\hline Total Organic Carbon & $\mathrm{mg} / \mathrm{l}$ & & & 3 & 2.9 & 1.4 & \\
\hline Total Suspended Solids & $\mathrm{mg} / \mathrm{l}$ & $<20$ & $<20$ & $<20$ & $<20$ & $<20$ & $<20$ \\
\hline Zinc & $\mathrm{mg} / \mathrm{l}$ & $<0.05$ & $<0.05$ & 0.0438 & 0.0386 & 0.0357 & $<0.05$ \\
\hline Parameter & Units & PZ-2 & PZ-3 & PZ-4 & Dup. & PZ-5 & PZ-6 \\
\hline Ammonium & $\mathrm{mg} / \mathrm{l}$ & 0.129 & 0.101 & 0.112 & 0.123 & 0.0578 & 0.0345 \\
\hline Arsenic & $\mathrm{mg} / \mathrm{l}$ & $<0.003$ & $<0.003$ & $<0.003$ & $<0.003$ & $<0.003$ & $<0.003$ \\
\hline Barium & $\mathrm{mg} / \mathrm{l}$ & 0.0588 & 0.0816 & 0.149 & 0.151 & 0.0977 & 0.0931 \\
\hline Boron & $\mathrm{mg} / \mathrm{l}$ & 0.13 & 0.16 & 0.15 & 0.15 & 0.1 & 0.11 \\
\hline Bromide & $\mathrm{mg} / \mathrm{l}$ & 7.6 & 7.5 & 12.1 & 7.1 & 23.1 & 16.6 \\
\hline Cadmium & $\mathrm{mg} / \mathrm{l}$ & $<0.001$ & $<0.001$ & $<0.001$ & $<0.001$ & $<0.001$ & $<0.001$ \\
\hline Calcium & $\mathrm{mg} / \mathrm{l}$ & 997 & 1230 & 2110 & 2110 & 3070 & 2240 \\
\hline Chloride & $\mathrm{mg} / \mathrm{l}$ & 9160 & 23500 & 32900 & 34200 & 37500 & 36200 \\
\hline Chromium & $\mathrm{mg} / \mathrm{l}$ & 0.0115 & 0.0119 & 0.0134 & 0.0129 & 0.0117 & 0.0156 \\
\hline Iron & $\mathrm{mg} / \mathrm{l}$ & $<0.008$ & $<0.008$ & $<0.008$ & $<0.008$ & $<0.008$ & $<0.008$ \\
\hline Lead & $\mathrm{mg} / \mathrm{l}$ & $<0.001$ & $<0.001$ & $<0.001$ & $<0.001$ & 0.0018 & 0.0048 \\
\hline Magnesium & $\mathrm{mg} / \mathrm{l}$ & 626 & 839 & 1090 & 1090 & 1760 & 1330 \\
\hline Mercury & $\mathrm{mg} / \mathrm{l}$ & $<0.0002$ & $<0.0002$ & 0.0017 & 0.0016 & 0.0014 & 0.00021 \\
\hline Nitrate & $\mathrm{mg} / \mathrm{l}$ & 6.79 & 16.3 & 17.2 & 17.1 & 14.4 & 25.2 \\
\hline Nitrite & $\mathrm{mg} / \mathrm{l}$ & 0.0169 & $<0.0082$ & 0.0147 & 0.0145 & 0.0177 & 0.0153 \\
\hline $\mathrm{pH}$ & & 7.3 & 7.23 & 7.22 & 7.33 & 7.04 & 6.94 \\
\hline Potassium & $\mathrm{mg} / \mathrm{l}$ & 13.7 & 95 & 39.8 & 39.6 & 68.8 & 170 \\
\hline Selenium & $\mathrm{mg} / \mathrm{l}$ & 0.102 & 0.102 & 0.0431 & 0.0429 & 0.069 & 0.0607 \\
\hline Silicon & $\mathrm{mg} / \mathrm{l}$ & 20.4 & 18.3 & 20.5 & 20.4 & 18.7 & 20.3 \\
\hline Silver & $\mathrm{mg} / \mathrm{l}$ & $<0.001$ & $<0.001$ & $<0.001$ & $<0.001$ & $<0.001$ & 2.4 \\
\hline Sodium & $\mathrm{mg} / \mathrm{l}$ & 3880 & 11800 & 16000 & 16000 & 16200 & 17700 \\
\hline Specific Gravity & $\mathrm{mg} / \mathrm{g}$ & 1.01 & 1.03 & 1.04 & 1.04 & 1.05 & 1.04 \\
\hline Sulfate & $\mathrm{mg} / \mathrm{l}$ & 1660 & 1660 & 1300 & 1290 & 1510 & 2040 \\
\hline Total Dissolved Solids & $\mathrm{mg} / \mathrm{l}$ & 18000 & 41800 & 58600 & 59400 & 65200 & 65700 \\
\hline Total Inorganic Carbon & $\mathrm{mg} / \mathrm{l}$ & & & & & & \\
\hline Total Organic Carbon & $\mathrm{mg} / \mathrm{l}$ & & & & & & \\
\hline
\end{tabular}


Waste Isolation Pilot Plant 2001 Site Environmental Report DOE/WIPP 02-2225

Table 6.10 - Analytical Results for Shallow Groundwater Program

\begin{tabular}{|c|c|c|c|c|c|c|c|}
\hline Total Suspended Solids & $\mathrm{mg} / \mathrm{l}$ & $<20$ & $<20$ & $<20$ & $<20$ & $<20$ & $<20$ \\
\hline Zinc & $\mathrm{mg} / \mathrm{l}$ & $<0.05$ & $<0.05$ & $<0.05$ & $<0.05$ & $<0.05$ & $<0.05$ \\
\hline Parameter & Units & PZ-7 & PZ-9 & PZ-10 & PZ-11 & PZ-12 & Dup. \\
\hline Ammonium & $\mathrm{mg} / \mathrm{l}$ & 0.0466 & 0.267 & $<0.0042$ & 0.142 & 0.124 & 0.154 \\
\hline Arsenic & $\mathrm{mg} / \mathrm{l}$ & $<0.003$ & $<0.003$ & 0.0014 & $<0.003$ & $<0.003$ & $<0.003$ \\
\hline Barium & $\mathrm{mg} / \mathrm{l}$ & 0.0598 & 0.185 & 0.0479 & 0.246 & 0.116 & 0.115 \\
\hline Boron & $\mathrm{mg} / \mathrm{l}$ & 0.064 & 0.17 & 0.28 & 0.062 & 0.21 & 0.2 \\
\hline Bromide & $\mathrm{mg} / \mathrm{l}$ & 18 & 57.1 & 2.2 & 21.4 & 5.6 & 4.9 \\
\hline Cadmium & $\mathrm{mg} / \mathrm{l}$ & $<0.001$ & $<0.001$ & $<0.0001$ & $<0.001$ & $<0.001$ & $<0.001$ \\
\hline Calcium & $\mathrm{mg} / \mathrm{l}$ & 3340 & 3550 & 254 & 3980 & 868 & 867 \\
\hline Chloride & $\mathrm{mg} / \mathrm{l}$ & 38900 & 72400 & 468 & 56700 & 6530 & 6560 \\
\hline Chromium & $\mathrm{mg} / \mathrm{l}$ & 0.0126 & 0.0181 & 0.00083 & 0.0112 & 0.0114 & 0.0121 \\
\hline Iron & $\mathrm{mg} / \mathrm{l}$ & $<0.008$ & 49.2 & $<0.0008$ & $<0.008$ & $<0.008$ & $<0.008$ \\
\hline Lead & $\mathrm{mg} / \mathrm{l}$ & $<0.001$ & $<0.001$ & $<0.0001$ & $<0.001$ & $<0.001$ & $<0.001$ \\
\hline Magnesium & $\mathrm{mg} / \mathrm{l}$ & 2010 & 3550 & 177 & 2950 & 613 & 608 \\
\hline Mercury & $\mathrm{mg} / \mathrm{l}$ & 0.0016 & 0.00079 & $<0.0002$ & 0.0022 & $<0.0002$ & $<0.0002$ \\
\hline Nitrate & $\mathrm{mg} / \mathrm{l}$ & 20.2 & 14.4 & 18.3 & 28.2 & 29.5 & 30.8 \\
\hline Nitrite & $\mathrm{mg} / \mathrm{l}$ & 0.0209 & $<0.0082$ & 0.0089 & $<0.0082$ & 0.0083 & 0.0082 \\
\hline $\mathrm{pH}$ & & 6.75 & 5.99 & 7.45 & 6.62 & 7.28 & 7.19 \\
\hline Potassium & $\mathrm{mg} / \mathrm{l}$ & 61 & 499 & 4.2 & 62.9 & 24.7 & 24.5 \\
\hline Selenium & $\mathrm{mg} / \mathrm{l}$ & 0.0916 & 0.0516 & 0.031 & 0.0289 & 0.0378 & 0.0367 \\
\hline Silicon & $\mathrm{mg} / \mathrm{l}$ & 20 & 10.6 & 22.3 & 12.5 & 20.2 & 20.2 \\
\hline Silver & $\mathrm{mg} / \mathrm{l}$ & $<0.001$ & $<0.001$ & $<0.0001$ & $<0.001$ & $<0.001$ & $<0.001$ \\
\hline Sodium & $\mathrm{mg} / \mathrm{l}$ & 17000 & 36100 & 188 & 24300 & 2290 & 2290 \\
\hline Specific Gravity & $\mathrm{mg} / \mathrm{g}$ & 1.05 & 1.09 & 1.01 & 1.07 & 1.05 & 1.06 \\
\hline Sulfate & $\mathrm{mg} / \mathrm{l}$ & 2180 & 3470 & 730 & 2380 & 829 & 843 \\
\hline Total Dissolved Solids & $\mathrm{mg} / \mathrm{l}$ & 70200 & 134000 & 2320 & 99000 & 12900 & 12800 \\
\hline Total Inorganic Carbon & $\mathrm{mg} / \mathrm{l}$ & & & 93.1 & & & \\
\hline Total Organic Carbon & $\mathrm{mg} / \mathrm{l}$ & & & 2.5 & & & \\
\hline Total Suspended Solids & $\mathrm{mg} / \mathrm{l}$ & $<20$ & 71 & 39 & 59 & $<20$ & $<20$ \\
\hline Zinc & $\mathrm{mg} / \mathrm{l}$ & $<0.05$ & $<0.05$ & 0.0409 & $<0.05$ & $<0.05$ & $<0.05$ \\
\hline
\end{tabular}




\section{CHAPTER 7 - RADIOLOGICAL DOSE ASSESSMENT}

It is the policy of DOE ". . to conduct its operations in an environmentally safe and sound manner. Protection of the environment and the public are responsibilities of paramount importance and concern to DOE" (DOE Order 5400.1). "It is also a DOE objective that potential exposures to members of the public be as far below the limits as is reasonably achievable. .." (DOE Order 5400.5).

Chapter 4 of this report summarized the amount of radioactivity in air emissions and other media sampled in the WIPP environment in 2001. It is the purpose of this chapter to summarize the air emission levels in regard to the potential dose from WIPP operations.

Specifically, this chapter summarizes:

- Regulatory requirements on emissions of radionuclides, effective dose equivalents, and use of CAP88-PC computer model;

- The national average dose from naturally occurring sources of radiation;

- $\quad$ The estimated dose from air emissions from WIPP;

- The total potential dose from WIPP operations; and

- $\quad$ Potential doses to nonhuman biota from radioactivity measured near WIPP.

\subsection{Introduction and Dose Limits}

Title 40 CFR Part 61, Subpart H-National Emission Standards for Emissions of Radionuclides Other than Radon From Department of Energy Facilities, Section 61.92 Standard state "Emissions of radionuclides to the ambient air from Department of Energy facilities shall not exceed those amounts that would cause any member of the public to receive in any year an effective dose equivalent of $10 \mathrm{mrem} / \mathrm{year} . "$

Compliance with the above regulatory compliance is determine by measuring effluent flow rate, monitoring, extracting, collecting, and measuring radionuclides, and calculating the effective dose equivalent (EDE). The EDE is the weighted sum of the doses to the individual organs of the body. The dose to each organ is weighted according to the risk that dose represents. These organ doses are then added together, and that total is the effective dose equivalent. In this manner, the risk from different sources of radiation can be controlled by a single standard.

To calculate the EDE to members of the public, require the use of CAP88-PC or other EPA approved computer models and procedures. The WIPP Effluent Monitoring Program generally uses CAP88-PC. CAP88-PC is a set of computer programs, datasets and associated utility programs for estimation of dose and risk from radionuclide air emissions. CAP88-PC uses a Gaussian Plume dispersion model, which 
predicts air concentrations, deposition rates, concentrations in food, and intake rates for people. CAP88-PC estimates dose and risk to individuals and populations from multiple pathways. Dose and risk is calculated for ingestion, inhalation, ground level air immersion and ground surface irradiation exposure pathways.

Environmental radiation protection standards for the management and disposal of TRU wastes set limits on the total annual radiation dose to members of the public at $0.25 \mathrm{mSv}$ (25 mrem) to the whole body and $0.75 \mathrm{mSv}(75 \mathrm{mrem})$ to any critical organ (40 CFR §191.03). National standards for emissions of radionuclides from DOE facilities state that the maximum annual dose to any member of the public from air emissions must be no greater than $0.1 \mathrm{mSv}(10 \mathrm{mrem})$ (40 CFR §61.92). The SDWA (40 CFR §141.16) states that average annual concentrations of beta- and gamma-emitting human-made radionuclides in drinking water shall not result in an annual dose greater than $0.04 \mathrm{mSv}(4 \mathrm{mrem})$. It is important to note that all of these dose limits are set for radionuclides released to the environment from DOE operations. They do not include, but are limits in addition to, doses from natural background radiation or from medical procedures.

\subsection{Background Radiation}

Radiation is a naturally-occurring phenomenon that has been in the environment since the beginning of time. There are several sources of natural radiation: cosmic and cosmogenic radiation (from outer space and the earth's atmosphere), terrestrial radiation (from the earth's crust), and internal radiation (naturally-occurring radiation in our bodies, such as ${ }^{40} \mathrm{~K}$ ). The most common sources of terrestrial radiation are uranium, thorium, and their decay products. Potassium-40 is another source of terrestrial radiation. While not a major radiation source, ${ }^{40} \mathrm{~K}$ may be enhanced in the southeastern New Mexico environment due to local potash mining. Radon gas, a decay product of uranium, is the most widely known naturally-occurring terrestrial radionuclide. In addition to natural radioactivity, small amounts of radioactivity from above-ground nuclear weapons tests that occurred from 1945 through 1980 and the 1986 Chernobyl nuclear accident are also present in the environment. Together, these sources of radiation are called "background" radiation. Every human is constantly exposed to background radiation. Exposure to radioactivity from weapons testing fallout is quite small compared to natural radioactivity and continually gets smaller as radionuclides decay.

Naturally occurring radiation in our environment can deliver both internal and external doses. Internal dose is received as a result of the intake of radionuclides. The major routes of intake of radionuclides for members of the public are ingestion and inhalation. Ingestion includes the intake of the radionuclides from eating and drinking contaminated food or drink. Inhalation includes the intake of radionuclides through breathing dust particles containing radioactive materials or radon gas. External dose can occur from submersion in contaminated air or deposition of contaminants on surfaces. The average annual dose received by a member of the public from naturally-occurring radionuclides is about $3 \mathrm{mSv}$ (300 mrem) (Table 7.1). 
Table 7.1 - Annual Estimated Average Radiation Dose Received by a Member of the Population of the United States from Naturally Occurring Radiation Sources (adapted from NCRP, 1987)

\begin{tabular}{lcc}
\hline \multicolumn{1}{c}{ Source } & \multicolumn{2}{c}{ Average Annual Effective Dose Equivalent } \\
\cline { 2 - 3 } & $(\mathbf{m S v})$ & (mrem) \\
\hline Inhaled (Radon and Decay Products) & 2 & 200 \\
Internal Radionuclides & 0.39 & 39 \\
Terrestrial Radiation & 0.28 & 28 \\
Cosmic Radiation & 0.27 & 27 \\
Cosmogenic Radioactivity & 0.01 & 1 \\
& & \\
Rounded Total from Natural Sources & 3 & 300 \\
\hline
\end{tabular}

\subsection{Dose from Air Emissions}

The NESHAP issued by the EPA set limits for radionuclide emissions to air (40 CFR Part 61). Compliance procedures for DOE facilities (40 CFR §61.93[a]) require the use of CAP88-PC or AIRDOS-PC computer models, or an equivalent, to calculate dose to members of the public. For the determination of the radiation dose received by members of the public, WIPP used the computer model CAP88-PC, version 2.0. Source term input for the program was determined by radiochemical analyses of periodic air samples taken from the effluent Stations A, B, and C (see Section 4.1). Air samples were analyzed for ${ }^{241} \mathrm{Am},{ }^{239+240} \mathrm{Pu}$, and ${ }^{238} \mathrm{Pu}$ because they constitute over 98 percent of the dose potential from contact-handled waste. Measured activity values greater than the MDC were used as a part of the source term for the air emission pathway and, for measured results less than the MDC, the MDC value was used as part of the source term (see Table 4.1). CAP88-PC dose calculations are based on the assumption that exposed persons remain at home during the entire year and all vegetables, milk, and meat consumed are home produced. Thus, this dose calculation is a maximum potential dose which encompasses dose from inhalation, submersion, deposition, and ingestion of air emitted radionuclides.

For 2001, the CAP88-PC model predicted the highest dose to someone residing near WIPP to be at the Smith Ranch approximately $8 \mathrm{~km}(5 \mathrm{mi})$ northwest of WIPP. Results showed the whole body dose potentially received by someone residing at this location to be about $4.96 \times 10^{-8} \mathrm{mSv}\left(4.96 \times 10^{-6} \mathrm{mrem}\right)$ per year.

\subsection{Total Potential Dose from WIPP Operations}

The radiation dose received by members of the public as a result of the management and storage of TRU radioactive wastes at any disposal facility operated by the DOE is regulated under 40 CFR Part 191, Subpart A. Specific standards state that the combined annual dose to any member of the public in the general environment shall not exceed $0.25 \mathrm{mSv}(25 \mathrm{mrem})$ to the whole body and $0.75 \mathrm{mSv}(75 \mathrm{mrem})$ to any critical 


\section{Waste Isolation Pilot Plant 2001 Site Environmental Report DOE/WIPP 02-2225}

organ. Section 7.3 discussed the potential dose received from radionuclides released to the air from WIPP. The following sections discuss the potential dose through other pathways and the total potential dose a member of the public may have received from WIPP operations during 2001.

\subsubsection{Potential Dose from Water Ingestion Pathway}

The potential dose to individuals from the ingestion of WIPP-related radionuclides transported in water is estimated to be nonexistent for several reasons. Drinking water for communities near WIPP comes from groundwater sources which are not expected to be affected by potential WIPP contaminants (based on current radionuclide transport scenarios summarized in the WIPP Safety Analysis Report (DOE/WIPP 95-2065). The only credible pathway for contaminants from WIPP to accessible groundwater is through the Culebra member of the Rustler Formation and the Dewey Lake Formation (DOE/CAO 96-2184). Water from the Culebra is naturally not potable due to high levels of TDS. Water from the Dewey Lake Formation is suitable for livestock consumption having TDS values below 10,000 mg/l. Groundwater and surface water samples collected around WIPP during 2001 did not contain radionuclide concentrations discernable from those in samples collected prior to WIPP receiving waste.

\subsubsection{Potential Dose from Wild Game Ingestion}

Game animals sampled during 2000 were mule deer, quail, rabbit, and fish. The only radionuclides detected were not different from background levels measured prior to commencement of waste shipments to WIPP. Therefore, no dose from WIPP-related radionuclides is estimated to have been received by any individual from this pathway during 2001.

\subsubsection{Total Potential Dose from All Pathways}

The only pathway for which a dose could be estimated was that of air emissions. Air emissions from WIPP were not above background ambient air levels. Estimated concentrations of radionuclides in air emissions accounted for the calculable dose from WIPP operations during 2001. The effective dose equivalent potentially received by the maximally exposed individual residing $8 \mathrm{~km}(5 \mathrm{mi})$ northwest of WIPP was calculated to be $4.96 \times 10^{-8} \mathrm{mSv}\left(4.96 \times 10^{-6} \mathrm{mrem}\right)$ per year whole body. This value is in compliance with the requirements of $0.1 \mathrm{mSv}(10 \mathrm{mrem})$ per year as specified in 40 CFR $\$ 61.92$.

In compliance with 40 CFR Part 191, Subpart A, the receptor selected resides yearround at the WIPP fence line located 350 meters in the NW sector. The dose to this receptor is estimated to be $8.99 \times 10^{-7} \mathrm{mSv}\left(8.99 \times 10^{-5} \mathrm{mrem}\right)$ per year whole body and $1.56 \times 10^{-5} \mathrm{mSv}\left(1.56 \times 10^{-3} \mathrm{mrem}\right)$ per year to the critical organ. These values are in compliance with the requirements of $0.25 \mathrm{mSv}(25 \mathrm{mrem})$ and $0.75 \mathrm{mSv}$ (75mrem) per year to the critical organ as specified in 40 CFR $\$ 191.03(b)$. 


\subsection{Dose to Nonhuman Biota}

DOE Order 5400.5 lists the environmental radiation protection requirements that WIPP must meet to protect aquatic animals. In addition, dose limits below which no deleterious effects on populations of aquatic and terrestrial organisms have been observed have been discussed by the National Council on Radiation Protection and Measurements (NCRP-109) and the International Atomic Energy Agency (IAEA Technical Report Series No. 332). Those dose limits are:

- Aquatic animals - $10 \mathrm{mGy} / \mathrm{d}(1 \mathrm{rad} / \mathrm{d})$

- Terrestrial plants $-10 \mathrm{mGy} / \mathrm{d}(1 \mathrm{rad} / \mathrm{d})$

- Terrestrial animals $-1 \mathrm{mGy} / \mathrm{d}(0.1 \mathrm{rad} / \mathrm{d})$

The DOE has considered proposing these dose standards for aquatic and terrestrial biota under proposed rule 10 CFR Part 834 , "Radiation protection of the public and the environment" but has delayed until guidance for demonstrating compliance was developed. The DOE-STD-XXXX-YR, A Graded Approach for Evaluating Radiation Doses to Aquatic and Terrestrial Biota, was developed to meet this need. Although the proposed rule has not been implemented, the DOE requires reporting of radiation doses to non-human biota in the Annual Site Environmental Report using the Interim Technical Standard.

The Interim Technical Standard uses a multi-phase approach, including an initial screening phase with conservative assumptions. Software is provided with the Interim Technical Standard to conduct the screening evaluation. In the initial screen, Biota Concentration Guides (BCG) are derived using very conservative assumptions for a variety of generic organisms. Maximum concentrations of radionuclides detected in soil, sediment, and water during environmental monitoring are divided by the BCGs and the results are summed for each organism (DOE-STD-XXXX-YR). If the sum of these fractions is less than 1 , the site is deemed to have passed the screen and no further action is required. This screening evaluation is intended to provide a very conservative evaluation of whether the site is in compliance with the recommended limits.

This guidance was used to screen radionuclide concentrations observed around WIPP during 2001 using the maximum radionuclide concentrations listed in Table 7.2. The sum of fractions was less than one for all media, demonstrating compliance with the proposed rule. Radiation in the environment surrounding WIPP does not have a deleterious effect on populations of plants and animals. 


\section{Waste Isolation Pilot Plant 2001 Site Environmental Report DOE/WIPP 02-2225}

Table 7.2 - General Screening Results for Potential Radiation Dose to Nonhuman Biota from Radionuclide Concentrations in Surface Water (Bq/l), Sediment $(\mathrm{Bq} / \mathrm{g})$, and Soil $(\mathrm{Bq} / \mathrm{g})$ near the WIPP Site. Maximum detected concentrations were compared with $\mathrm{BCG}^{\mathrm{a}}$ values to assess potential dose to biota. As long as the sum of the ratios between observed maximum concentrations and the associated BCG is below 1.0, no adverse effects on plant or animal populations are expected (DOE-STD-XXXX-YR).

\begin{tabular}{|c|c|c|c|c|}
\hline Medium & Radionuclide & $\begin{array}{c}\text { Maximum } \\
\text { Observed } \\
\text { Concentration }\end{array}$ & BCG & Concentration/BCG \\
\hline \multicolumn{5}{|c|}{ Aquatic System Evaluation } \\
\hline \multirow[t]{6}{*}{ Sediment $(\mathrm{Bq} / \mathrm{g})$} & ${ }^{60} \mathrm{Co}$ & $6.85 \times 10^{-4}$ & $5.00 \times 10^{1}$ & $1.37 \times 10^{-5}$ \\
\hline & ${ }^{137} \mathrm{Cs}$ & $4.59 \times 10^{-2}$ & $1.00 \times 10^{2}$ & $4.59 \times 10^{-4}$ \\
\hline & ${ }^{234} U$ & $4.96 \times 10^{-2}$ & $2.00 \times 10^{2}$ & $2.48 \times 10^{-4}$ \\
\hline & ${ }^{235} \mathrm{U}$ & $2.12 \times 10^{-3}$ & $1.00 \times 10^{2}$ & $2.12 \times 10^{-5}$ \\
\hline & ${ }^{238} \mathrm{U}$ & $3.35 \times 10^{-2}$ & $9.00 \times 10^{1}$ & $3.72 \times 10^{-4}$ \\
\hline & ${ }^{241} \mathrm{Am}$ & $7.10 \times 10^{-4}$ & $2.00 \times 10^{2}$ & $3.55 \times 10^{-6}$ \\
\hline \multirow[t]{7}{*}{ Water $^{\mathrm{b}}(\mathrm{Bq} / \mathrm{l})$} & ${ }^{60} \mathrm{Co}$ & $4.66 \times 10^{-1}$ & $1.00 \times 10^{2}$ & $4.66 \times 10^{-3}$ \\
\hline & ${ }^{137} \mathrm{Cs}$ & $3.23 \times 10^{-1}$ & $2.00 \times 10^{0}$ & $1.62 \times 10^{-1}$ \\
\hline & ${ }^{234} U$ & $2.18 \times 10^{-1}$ & $7.00 \times 10^{0}$ & $3.11 \times 10^{-2}$ \\
\hline & ${ }^{235} U$ & $6.51 \times 10^{-3}$ & $8.00 \times 10^{0}$ & $8.14 \times 10^{-3}$ \\
\hline & ${ }^{238} \mathrm{U}$ & $1.08 \times 10^{-1}$ & $8.00 \times 10^{0}$ & $1.35 \times 10^{-2}$ \\
\hline & ${ }^{241} \mathrm{Am}$ & $6.51 \times 10^{-4}$ & $2.00 \times 10^{1}$ & $3.26 \times 10^{-5}$ \\
\hline & & & $\begin{array}{c}\text { Sum of } \\
\text { Fractions }\end{array}$ & $2.21 \times 10^{-1}$ \\
\hline \multicolumn{5}{|c|}{ Terrestrial System Evaluation } \\
\hline \multirow[t]{6}{*}{ Soil $(\mathrm{Bq} / \mathrm{g})$} & ${ }^{60} \mathrm{Co}$ & $3.66 \times 10^{-4}$ & $3.00 \times 10^{1}$ & $1.22 \times 10^{-5}$ \\
\hline & ${ }^{137} \mathrm{Cs}$ & $1.65 \times 10^{-2}$ & $8.00 \times 10^{-1}$ & $2.06 \times 10^{-2}$ \\
\hline & ${ }^{234} \mathrm{U}$ & $2.09 \times 10^{-2}$ & $2.00 \times 10^{2}$ & $1.05 \times 10^{-4}$ \\
\hline & ${ }^{235} \mathrm{U}$ & $2.32 \times 10^{-3}$ & $1.00 \times 10^{2}$ & $2.32 \times 10^{-5}$ \\
\hline & ${ }^{238} U$ & $2.27 \times 10^{-2}$ & $6.00 \times 10^{1}$ & $3.78 \times 10^{-4}$ \\
\hline & ${ }^{241} \mathrm{Am}$ & $4.18 \times 10^{-4}$ & $1.00 \times 10^{2}$ & $4.18 \times 10^{-6}$ \\
\hline \multirow[t]{7}{*}{ Water $(\mathrm{Bq} / \mathrm{l})$} & ${ }^{60} \mathrm{Co}$ & $4.66 \times 10^{-1}$ & $4.00 \times 10^{4}$ & $1.17 \times 10^{-5}$ \\
\hline & ${ }^{137} \mathrm{Cs}$ & $3.23 \times 10^{-1}$ & $2.00 \times 10^{4}$ & $1.62 \times 10^{-5}$ \\
\hline & ${ }^{234} U$ & $2.18 \times 10^{-1}$ & $1.00 \times 10^{4}$ & $2.18 \times 10^{-5}$ \\
\hline & ${ }^{235} U$ & $6.51 \times 10^{-3}$ & $2.00 \times 10^{4}$ & $3.26 \times 10^{-7}$ \\
\hline & ${ }^{238} \mathrm{U}$ & $1.08 \times 10^{-1}$ & $2.00 \times 10^{4}$ & $5.40 \times 10^{-6}$ \\
\hline & ${ }^{241} \mathrm{Am}$ & $6.51 \times 10^{-4}$ & $7.00 \times 10^{3}$ & $9.30 \times 10^{-8}$ \\
\hline & & & $\begin{array}{c}\text { Sum of } \\
\text { Fractions }\end{array}$ & $2.12 \times 10^{-2}$ \\
\hline
\end{tabular}

a The radionuclide concentration in the medium that would produce a radiation dose in the organism equal to the dose limit under the conservative assumptions in the model.

b Sediment and water samples were assumed to be co-located. 


\section{CHAPTER 8 - QUALITY ASSURANCE}

The fundamental objective of a QA program is to ensure high-quality measurements are produced and reported from the analytical laboratory. The defensibility of data generated by laboratories must be based on sound scientific principles, method evaluations, and data verification and validation. WIPP Laboratories, Wastren, in Grand Junction, Colorado; Air Toxics, Ltd., in Folsom, California; and Trace Analysis, in Lubbock, Texas, were the contract laboratories that performed the radiological and nonradiological analyses for WIPP environmental samples.

All laboratories were required to have documented QA programs, standard procedures to perform the work, and to participate in some intercomparison programs with the National Institute of Standards and Technology Radiochemistry Intercomparison Program (NRIP), the Environmental Monitoring Laboratory of the DOE Environmental Measurements Laboratory Quality Assurance Program (QAP), the Environmental Resource Associates ${ }^{\circledR}$ (ERA) interlaboratory assessment, and/or any other reputable intercomparison program.

The contract laboratories used one or more of these accepted protocols in their QA program.

- $\quad$ American Society of Mechanical Engineers NQA-1-1994, Quality Assurance Program Requirements for Nuclear Facilities.

- $\quad$ Title 10 CFR Part 50, Appendix B, "Quality Assurance Criteria for Nuclear Power Plants and Fuel Reprocessing Plants."

- $\quad$ EPA/600 14-83-004, QAMS-005/80, Interim Guidelines and Specification for Preparing Quality Assurance Project Plans.

- $\quad$ NRC Regulatory Guide 4.15, Rev. 1, Quality Assurance for Radiological Monitoring Program-Effluent Streams and the Environment.

- HPS N13.30 ANSI, Performance Criteria for Radiobioassay.

- $\quad$ Proposed ANSI/ASQC-E4, Quality Assurance Program Requirements for Environmental Programs.

The WIPP Environmental Monitoring Section performed assessments and audits to ensure the quality of the systems, processes, and deliverables were maintained or improved. Along with these regulatory requirements, the Environmental Monitoring Section also implements DOE Order 414.1A, Quality Assurance. The parameters for performance evaluations are completeness, reproducibility, accuracy, comparability, and representativeness. 


\subsection{Completeness}

The completeness parameter was calculated as the ratio of the number of valid results to the total number of samples collected and analyzed. The gross alpha/beta analyses were 96 percent complete for 2001. Samples for air particulates were 95.6 percent complete. Samples and measurements for all other media (groundwater, surface water, soil, sediment, and animal and plant tissues) were 100 percent complete. The data quality objective established for the environmental program is 98 percent complete. The Environmental Monitoring Program exceeded the objective in 2001 for environmental samples.

\subsection{Reproducibility}

The reproducibility of the measurements was validated through analyses of duplicate samples. A low-volume air sampler was rotated in each quarter from location to location, and sampled along with routine samples. The results of these duplicate comparisons are shown in Tables 8.1, 8.2, 8.3, and 8.4 for the four quarters of 2001. The duplicate samples for other matrices were collected at the same time, same place, and under similar conditions as routine samples. These samples were analyzed in the same analytical batch and/or sample delivery group using similar methods for radiochemical separation and counting as the original samples.

Reproducibility is partially influenced by statistical counting uncertainty, so variances were expected between samples with very low activities (environmental levels). As a part of data validation all radiochemical duplicate samples are evaluated for the RER and on analytical chemistry the relative percent difference (RPD).

Where:

$$
R E R=\frac{\mid(\text { Mean Activity })_{o r i}-(\text { Mean Activity })_{\text {dup }} \mid}{\sqrt{(2 \times S D)_{o r i}^{2}+(2 \times S D)_{d u p}^{2}}}
$$

(Mean Activity $)_{\text {ori }} \quad=\quad$ Mean Activity of Original Sample $(\text { Mean Activity })_{\text {dup }} \quad=\quad$ Mean Activity of Duplicate Sample SD $\quad=\quad$ Standard Deviation of Original and Duplicate Samples

Relative error ratio results equal to or less than one are acceptable and considered to demonstrate reproducibility. A gross alpha result for the week of January 10, 2001, RER is greater than one, 1.03 (Table 8.1).

$$
R P D=\left[\frac{S-D}{\frac{S+D}{2}}\right] * 100
$$


Where:

$S=$ Sample concentration

$\mathrm{D}=$ Duplicate sample concentration

An acceptable range for RPD is $<25$ percent for the analytical methods. The duplicate results, RER, and RPD for all required analysis passed the required criteria. WIPP's requirement is to reanalyze the batch of samples associated with the duplicate that failed to meet criteria.

\subsection{Accuracy and Comparability}

The accuracy of the analyses were assured/controlled by using NIST-traceable standards for instrument calibration. Internal QC is performed by using NIST-traceable spiked laboratory control samples. Samples having analysis recoveries outside the range of 50 to 120 percent were reanalyzed. Intercomparisons were performed with the DOE Environmental Measurements Laboratory (EML), NRIP, and ERA to ensure the reliability of radiochemical separation methods and counting instruments. Accuracy, expressed as percent bias, was calculated by:

$$
\% B I A S=\left[\frac{A_{m}-A_{k}}{A_{k}}\right] * 100
$$

Where:

$\begin{array}{lll}\% \text { BIAS } & = & \text { Percent Bias } \\ A_{m} & = & \text { Measured Sample Activity } \\ A_{k} & = & \text { Known Sample Activity }\end{array}$

The DOE EML QAP, NRIP, and ERA prepare QC samples containing various alpha-, beta-, and gamma-emitting nuclides in water, soil, air filter, vegetation, synthetic urine, and tissue media and distributes them to numerous laboratories. The programs are an interlaboratory comparison in that results from the participants are compared with the experimentally determined results of QAP, NRIP, and ERA. Also, the administering programs EML, NIST, and ERA assess the results as acceptable or not within a range of bias from the EML, NIST, and ERA known result.

Wastren Laboratory participated in the QAP and ERA programs and WIPP Laboratories participated in the QAP and NRIP programs. The results for Wastren Laboratory are provided in Tables 8.5, 8.6, 8.7, and 8.8 for QAP air, soil, vegetation, and water, respectively. Table 8.9 displays the results for ERA water. Table 8.10 contains the NRIP results for WIPP Laboratories and Tables 8.11, 8.12, 8.13, and 8.14 contain the results for the QAP air, soil, vegetation, and water, respectively. WIPP Laboratories percent bias was acceptable for all radionuclides and all media with two exceptions. Strontium-90 in vegetation during the June intercomparison (QAP 54) and ${ }^{90} \mathrm{Sr}$ in air during the December intercomparison (QAP 55). The percent bias exceeded the acceptable level for the vegetation sample (QAP 54) for ${ }^{90} \mathrm{Sr}$ in June; however, 


\section{Waste Isolation Pilot Plant 2001 Site Environmental Report DOE/WIPP 02-2225}

according to QAP's evaluation, the result is acceptable with a warning. WIPP Laboratories did not analyze the Environmental Monitoring vegetation samples during the June time frame and the laboratory did have acceptable results in the next intercomparison round. The stable carrier addition, as prescribed by the strontium method, was not added correctly during the chemical process for the air filter QAP 55 sample. The weight of the carrier was not recorded properly; therefore, the activity of the sample was calculated with an incorrect weight. In the December intercomparison (QAP 55), the amount of stable strontium carrier added to the air filter sample was recorded incorrectly. This caused an error in the activity calculation that resulted in the reported number being not acceptable.

Wastren Laboratory's percent bias in evaluating soil was acceptable for all radionuclides and all media except for ${ }^{212} \mathrm{Bi}$ in soil during the June intercomparison (QAP 54). The percent bias exceeds the acceptable level of -25 percent; however, the result is acceptable with warning by QAP's evaluation. WIPP does not require the analysis of ${ }^{212} \mathrm{Bi}$ in any media.

DOE EML QAP participant's analytical performance is evaluated based on the historical analytical capabilities for individual analyte/matrix pairs. The criteria for acceptable performance has been chosen to be between the $15^{\text {th }}$ and $85^{\text {th }}$ percentile of the cumulative normalized distribution, which can be viewed as the 70 percent of all historic measurements. The acceptable with warning criteria is between the $5^{\text {th }}$ and $15^{\text {th }}$ percentile and between the $85^{\text {th }}$ and $95^{\text {th }}$ percentile. In other words, the middle 90 percent of all reported values are acceptable, while the outer $5^{\text {th }}$ through $15^{\text {th }}$ (10 percent) and $85^{\text {th }}$ through $95^{\text {th }}$ (10 percent) percentiles are in the warning area. The not acceptable criteria is established at less than the $5^{\text {th }}$ percentile and greater than the $95^{\text {th }}$ percentile, that is, the outer 10 percent of historical data.

The ERA ${ }^{226} \mathrm{Ra}$ also failed to meet the acceptable percent bias due to a calculation problem at the laboratory. Wastren Laboratory assumed equilibrium with ${ }^{224} \mathrm{Ra}$ in the calculation spreadsheet which caused the ${ }^{226} \mathrm{Ra}$ result to be understated. This problem has been corrected by issuing a nonconformance internally, which instructs analysts to not make an assumption of equilibrium on intercomparison samples. The ERA acceptance criteria for ${ }^{226} \mathrm{Ra}$ was 3.44 to $5.86 \mathrm{pCi} / \mathrm{l}$ and the reported result was $3.21 \mathrm{pCi} / \mathrm{l}$.

Air Toxics, Ltd., participated in the ERA, for 49 VOCs in non-potable water. Results were 96 percent satisfactory (Table 8.15). Two volatiles results: bromodichloromethane and bromoform have a performance evaluation of "Check for Error" which indicates that the result is above the warning limit, but within the acceptance limit.

Trace Analysis, Inc., participated in several ERA interlaboratory assessments. For the ERA (July 19, 2001) run of WP-76 response performance standards (Table 8.16), 11 of 193 (5.7 percent) parameters were not acceptable. Subsequently, blind samples were analyzed for all analytes missed. When reevaluated, all were acceptable. 


\section{Waste Isolation Pilot Plant 2001 Site Environmental Report DOE/WIPP 02-2225}

The cyanide analysis failed to meet the acceptance criteria due to a problem with the extraction process in the laboratory. The instrument calibration verification passed the QC requirements. The laboratory control sample, however, had low recovery, indicating a loss of cyanide during the extraction process. The corrective action was to retrain the analyst extracting the cyanide samples. The laboratory QA officer also submitted a blind sample to verify the effectiveness of the corrective action. The blind sample had a 99 percent recovery.

The total organic carbon did not meet the acceptance criteria because of deteriorated standards. The standards used had not expired; however, when a new curve was analyzed with new standards, the sample was within acceptable range.

The thallium result in the metals analysis was also not acceptable. The instrument was adjusted to read at a more sensitive range. The blind sample submitted for analysis passed with the adjusted instrument line.

The polychlorinated biphenyl (PCB) Aroclor 1260 in water failed to meet acceptance criteria because of the analyst not following the procedure properly. The analyst has been retrained and blind samples submitted passed acceptance criteria.

Four compounds were out of the acceptable range in the semivolatile analysis. Anthracene and benzo(a)anthracene were misidentified on the instrument raw printout. The laboratory implemented a step in reviewing instrument printouts by a second person to avoid misidentifying peaks. Chrysene and di-n-octylphthalate were missed due to a bad stock standard which has been corrected by replacing the standard and running a new curve. Blind samples for the semi-volatile analysis also passed for the compounds missed.

The ERA UST-34 (Table 8.17) and QuiK ${ }^{\mathrm{TM}}$ Response (Table 8.18) both had excellent results; all compounds were within acceptable range.

Wastren Laboratory, participated in several methods within the ERA assessment, WP-74, May 17, 2001. Results were 99 percent satisfactory (Table 8.19). Of the volatile analysis, trichloroethylene was not acceptable due to a reporting problem. The laboratory discovered that the raw data did not match the reported result. To correct the problem internally, the laboratory QA officer now performs a final review prior to reporting results. Bromide and orthophosphate as $P$ also did not pass the acceptable criteria. The laboratory investigated all obvious possibilities such as dilution error, calculation error, calibration problems and was not able to resolve the problem until the ion chromatograph was replaced. The samples were analyzed on the new instrument and the results fell within the acceptable range.

\subsection{Representativeness}

The primary objective of environmental monitoring has been to protect the health and safety of the population surrounding the WIPP facility. The quality objective of representativeness was based on potential radiation exposure of the population through 
inhalation and ingestion. Samples of ambient air, surface water, sediment, groundwater, and biota were collected from areas representative of potential pathways for intake.

The samples were collected using generally accepted methodologies for environmental sampling and approved procedures, ensuring they were representative of the media sampled. These samples were analyzed for natural radioactivity, fallout radioactivity from nuclear weapons tests, and other anthropogenic radionuclides. The reported concentrations at various locations were representative of the baseline information for radionuclides of interest at the WIPP facility. 
Waste Isolation Pilot Plant 2001 Site Environmental Report DOE/WIPP 02-2225

Table 8.1 - Comparison of Duplicate Air Monitoring Results

(First Quarter of 2001) from WIPP Laboratories Data from WIPP East (WEE) Sampling Location

\begin{tabular}{|c|c|c|c|c|c|c|c|c|c|c|}
\hline \multirow{2}{*}{$\begin{array}{c}\text { Week } \\
\text { Beginning }\end{array}$} & \multicolumn{5}{|c|}{ Gross Alpha $\left(\mathrm{Bq} / \mathrm{m}^{3}\right)$} & \multicolumn{5}{|c|}{ Gross Beta $\left(\mathrm{Bq} / \mathrm{m}^{3}\right)$} \\
\hline & Sample & $2 \times$ TPU $^{a}$ & Duplicate & $2 \times$ TPU & $\mathbf{R E R}^{\mathbf{b}}$ & Sample & $2 \times$ TPU & Duplicate & $2 \times \mathrm{TPU}$ & RER \\
\hline $01 / 03$ & $4.19 \times 10^{-5}$ & $2.29 \times 10^{-5}$ & $4.74 \times 10^{-5}$ & $2.23 \times 10^{-5}$ & 0.17 & $1.12 \times 10^{-3}$ & $1.49 \times 10^{-4}$ & $1.23 \times 10^{-3}$ & $1.55 \times 10^{-4}$ & 0.51 \\
\hline $01 / 10$ & $2.94 \times 10^{-5}$ & $1.85 \times 10^{-5}$ & $6.17 \times 10^{-5}$ & $2.55 \times 10^{-5}$ & 1.03 & $7.95 \times 10^{-4}$ & $1.10 \times 10^{-4}$ & $7.78 \times 10^{-4}$ & $1.07 \times 10^{-4}$ & 0.11 \\
\hline $01 / 17$ & $6.18 \times 10^{-5}$ & $2.62 \times 10^{-5}$ & $3.07 \times 10^{-5}$ & $1.86 \times 10^{-5}$ & 0.97 & $1.21 \times 10^{-3}$ & $1.53 \times 10^{-4}$ & $1.21 \times 10^{-3}$ & $1.52 \times 10^{-4}$ & 0.00 \\
\hline $01 / 24$ & $3.22 \times 10^{-5}$ & $1.93 \times 10^{-5}$ & $5.77 \times 10^{-5}$ & $2.54 \times 10^{-5}$ & 0.80 & $7.73 \times 10^{-4}$ & $1.08 \times 10^{-4}$ & $8.34 \times 10^{-4}$ & $1.15 \times 10^{-4}$ & 0.39 \\
\hline $01 / 31$ & $9.76 \times 10^{-5}$ & $3.28 \times 10^{-5}$ & $1.07 \times 10^{-5}$ & $3.52 \times 10^{-5}$ & 0.20 & $1.31 \times 10^{-3}$ & $1.64 \times 10^{-4}$ & $1.32 \times 10^{-3}$ & $1.66 \times 10^{-4}$ & 0.04 \\
\hline $02 / 07$ & $4.93 \times 10^{-5}$ & $2.36 \times 10^{-5}$ & $4.19 \times 10^{-5}$ & $2.13 \times 10^{-5}$ & 0.23 & $8.69 \times 10^{-4}$ & $1.20 \times 10^{-4}$ & $9.19 \times 10^{-4}$ & $1.24 \times 10^{-4}$ & 0.29 \\
\hline $02 / 14$ & $4.59 \times 10^{-5}$ & $2.28 \times 10^{-5}$ & $4.08 \times 10^{-5}$ & $2.15 \times 10^{-5}$ & 0.16 & $1.30 \times 10^{-3}$ & $1.64 \times 10^{-4}$ & $1.17 \times 10^{-3}$ & $1.50 \times 10^{-4}$ & 0.58 \\
\hline $02 / 21$ & $4.27 \times 10^{-5}$ & $2.19 \times 10^{-5}$ & $3.75 \times 10^{-5}$ & $2.13 \times 10^{-5}$ & 0.17 & $7.20 \times 10^{-4}$ & $1.03 \times 10^{-4}$ & $7.49 \times 10^{-4}$ & $1.08 \times 10^{-4}$ & 0.19 \\
\hline $02 / 28$ & $5.57 \times 10^{-5}$ & $2.37 \times 10^{-5}$ & $5.63 \times 10^{-5}$ & $2.39 \times 10^{-5}$ & 0.02 & $9.12 \times 10^{-4}$ & $1.21 \times 10^{-4}$ & $8.63 \times 10^{-4}$ & $1.16 \times 10^{-4}$ & 0.29 \\
\hline 03/07 & $2.99 \times 10^{-5}$ & $1.81 \times 10^{-5}$ & $1.67 \times 10^{-5}$ & $1.37 \times 10^{-5}$ & 0.58 & $5.54 \times 10^{-4}$ & $8.61 \times 10^{-5}$ & $5.77 \times 10^{-4}$ & $8.80 \times 10^{-5}$ & 0.19 \\
\hline $03 / 14$ & $4.69 \times 10^{-5}$ & $2.19 \times 10^{-5}$ & $5.14 \times 10^{-5}$ & $2.40 \times 10^{-5}$ & 0.14 & $6.84 \times 10^{-4}$ & $9.86 \times 10^{-5}$ & $7.17 \times 10^{-4}$ & $1.05 \times 10^{-4}$ & 0.23 \\
\hline $03 / 21$ & $3.56 \times 10^{-5}$ & $2.08 \times 10^{-5}$ & $3.95 \times 10^{-5}$ & $2.13 \times 10^{-5}$ & 0.13 & $7.69 \times 10^{-4}$ & $1.10 \times 10^{-4}$ & $6.97 \times 10^{-4}$ & $1.02 \times 10^{-4}$ & 0.48 \\
\hline $03 / 28$ & $4.73 \times 10^{-5}$ & $2.27 \times 10^{-5}$ & $6.21 \times 10^{-5}$ & $2.59 \times 10^{-5}$ & 0.43 & $8.39 \times 10^{-4}$ & $1.15 \times 10^{-4}$ & $8.67 \times 10^{-4}$ & $1.18 \times 10^{-4}$ & 0.17 \\
\hline
\end{tabular}

a Total propagated uncertainty

${ }^{\mathrm{b}}$ Relative error ratio 
Waste Isolation Pilot Plant 2001 Site Environmental Report DOE/WIPP 02-2225

Table 8.2 - Comparison of Duplicate Air Monitoring Results

(Second Quarter of 2001) from WIPP Laboratories Data from WIPP South (WSS) Sampling Location

\begin{tabular}{|c|c|c|c|c|c|c|c|c|c|c|}
\hline \multirow[b]{2}{*}{ Week Beginning } & \multicolumn{5}{|c|}{ Gross Alpha $\left(\mathrm{Bq} / \mathrm{m}^{3}\right)$} & \multicolumn{5}{|c|}{ Gross Beta $\left(\mathrm{Bq} / \mathrm{m}^{3}\right)$} \\
\hline & Sample & $2 \times$ TPU $^{\mathrm{a}}$ & Duplicate & $2 \times$ TPU & $\mathbf{R E R}^{\mathbf{b}}$ & Sample & $2 \times$ TPU & Duplicate & $2 \times$ TPU & RER \\
\hline $04 / 04$ & $8.69 \times 10^{-5}$ & $3.15 \times 10^{-5}$ & $7.63 \times 10^{-5}$ & $2.94 \times 10^{-5}$ & 0.25 & $7.40 \times 10^{-4}$ & $1.06 \times 10^{-4}$ & $7.01 \times 10^{-4}$ & $1.02 \times 10^{-4}$ & 0.27 \\
\hline $04 / 11$ & $5.36 \times 10^{-5}$ & $2.38 \times 10^{-5}$ & $5.64 \times 10^{-5}$ & $2.50 \times 10^{-5}$ & 0.08 & $8.57 \times 10^{-4}$ & $1.16 \times 10^{-4}$ & $9.49 \times 10^{-4}$ & $1.27 \times 10^{-4}$ & 0.53 \\
\hline $04 / 18$ & $7.32 \times 10^{-5}$ & $2.87 \times 10^{-5}$ & $7.40 \times 10^{-5}$ & $2.90 \times 10^{-5}$ & 0.02 & $7.83 \times 10^{-4}$ & $1.10 \times 10^{-4}$ & $7.68 \times 10^{-4}$ & $1.09 \times 10^{-4}$ & 0.10 \\
\hline $04 / 25$ & $7.80 \times 10^{-5}$ & $2.96 \times 10^{-5}$ & $5.83 \times 10^{-5}$ & $2.57 \times 10^{-5}$ & 0.50 & $1.06 \times 10^{-3}$ & $1.39 \times 10^{-4}$ & $9.50 \times 10^{-4}$ & $1.27 \times 10^{-4}$ & 0.58 \\
\hline $05 / 02$ & $7.54 \times 10^{-5}$ & $2.92 \times 10^{-5}$ & $6.39 \times 10^{-5}$ & $2.66 \times 10^{-5}$ & 0.29 & $7.88 \times 10^{-4}$ & $1.12 \times 10^{-4}$ & $7.35 \times 10^{-4}$ & $1.06 \times 10^{-4}$ & 0.34 \\
\hline 05/09 & $6.05 \times 10^{-5}$ & $2.62 \times 10^{-5}$ & $5.82 \times 10^{-5}$ & $2.52 \times 10^{-5}$ & 0.06 & $7.86 \times 10^{-4}$ & $1.12 \times 10^{-4}$ & $9.11 \times 10^{-4}$ & $1.24 \times 10^{-4}$ & 0.75 \\
\hline $05 / 16$ & $4.32 \times 10^{-5}$ & $2.18 \times 10^{-5}$ & $3.80 \times 10^{-5}$ & $2.04 \times 10^{-5}$ & 0.17 & $6.44 \times 10^{-4}$ & $9.62 \times 10^{-5}$ & $6.32 \times 10^{-4}$ & $9.51 \times 10^{-5}$ & 0.09 \\
\hline $05 / 23$ & $5.91 \times 10^{-5}$ & $2.75 \times 10^{-5}$ & $6.81 \times 10^{-5}$ & $2.89 \times 10^{-5}$ & 0.23 & $8.98 \times 10^{-4}$ & $1.23 \times 10^{-4}$ & $8.15 \times 10^{-4}$ & $1.13 \times 10^{-4}$ & 0.50 \\
\hline $05 / 30$ & $8.27 \times 10^{-5}$ & $3.15 \times 10^{-5}$ & $6.98 \times 10^{-5}$ & $2.91 \times 10^{-5}$ & 0.30 & $8.72 \times 10^{-4}$ & $1.19 \times 10^{-4}$ & $8.65 \times 10^{-4}$ & $1.18 \times 10^{-4}$ & 0.04 \\
\hline 06/06 & $6.82 \times 10^{-5}$ & $2.87 \times 10^{-5}$ & $7.27 \times 10^{-5}$ & $2.94 \times 10^{-5}$ & 0.11 & $8.90 \times 10^{-4}$ & $1.23 \times 10^{-4}$ & $7.55 \times 10^{-4}$ & $1.09 \times 10^{-4}$ & 0.82 \\
\hline $06 / 13$ & $5.27 \times 10^{-5}$ & $2.43 \times 10^{-5}$ & $5.83 \times 10^{-5}$ & $2.56 \times 10^{-5}$ & 0.16 & $6.68 \times 10^{-4}$ & $9.81 \times 10^{-5}$ & $6.37 \times 10^{-4}$ & $9.50 \times 10^{-5}$ & 0.23 \\
\hline $06 / 20$ & $9.79 \times 10^{-5}$ & $3.39 \times 10^{-5}$ & $9.08 \times 10^{-5}$ & $3.18 \times 10^{-5}$ & 0.15 & $8.56 \times 10^{-4}$ & $1.20 \times 10^{-4}$ & $9.21 \times 10^{-4}$ & $1.25 \times 10^{-4}$ & 0.38 \\
\hline $06 / 27$ & $7.38 \times 10^{-5}$ & $3.04 \times 10^{-5}$ & $7.27 \times 10^{-5}$ & $3.06 \times 10^{-5}$ & 0.03 & $7.49 \times 10^{-4}$ & $1.11 \times 10^{-4}$ & $7.75 \times 10^{-4}$ & $1.15 \times 10^{-4}$ & 0.16 \\
\hline
\end{tabular}

a Total propagated uncertainty

${ }^{\mathrm{b}}$ Relative error ratio 
Waste Isolation Pilot Plant 2001 Site Environmental Report DOE/WIPP 02-2225

Table 8.3 - Comparison of Duplicate Air Monitoring Results (Third Quarter of 2001) from WIPP Laboratories Data from Mills Ranch (MLR) Sampling Location

\begin{tabular}{|c|c|c|c|c|c|c|c|c|c|c|}
\hline \multirow[b]{2}{*}{ Week Beginning } & \multicolumn{5}{|c|}{ Gross Alpha $\left(\mathrm{Bq} / \mathrm{m}^{3}\right)$} & \multicolumn{5}{|c|}{ Gross Beta $\left(\mathrm{Bq} / \mathrm{m}^{3}\right)$} \\
\hline & Sample & $2 \times \mathrm{TPU}^{\mathrm{a}}$ & Duplicate & $2 \times$ TPU & $\mathbf{R E R}^{\mathbf{b}}$ & Sample & $2 \times$ TPU & Duplicate & $2 \times$ TPU & RER \\
\hline $07 / 04$ & $2.50 \times 10^{-5}$ & $1.63 \times 10^{-5}$ & $4.17 \times 10^{-5}$ & $2.08 \times 10^{-5}$ & 0.63 & $6.34 \times 10^{-4}$ & $9.07 \times 10^{-5}$ & $6.82 \times 10^{-4}$ & $9.61 \times 10^{-5}$ & 0.36 \\
\hline $07 / 11$ & $6.25 \times 10^{-5}$ & $2.73 \times 10^{-5}$ & $5.70 \times 10^{-5}$ & $2.61 \times 10^{-5}$ & 0.15 & $8.97 \times 10^{-4}$ & $1.23 \times 10^{-4}$ & $9.08 \times 10^{-4}$ & $1.24 \times 10^{-4}$ & 0.06 \\
\hline $07 / 18$ & $N^{c}$ & NR & $6.90 \times 10^{-5}$ & $2.79 \times 10^{-5}$ & $N / A^{d}$ & NR & NR & $7.06 \times 10^{-4}$ & $1.03 \times 10^{-4}$ & $\mathrm{~N} / \mathrm{A}$ \\
\hline $07 / 25$ & $5.34 \times 10^{-5}$ & $2.46 \times 10^{-5}$ & $3.39 \times 10^{-5}$ & $1.95 \times 10^{-5}$ & 0.62 & $6.60 \times 10^{-4}$ & $9.83 \times 10^{-5}$ & $7.24 \times 10^{-4}$ & $1.04 \times 10^{-4}$ & 0.45 \\
\hline $08 / 01$ & $3.96 \times 10^{-5}$ & $2.11 \times 10^{-5}$ & $2.36 \times 10^{-5}$ & $1.65 \times 10^{-5}$ & 0.60 & $6.86 \times 10^{-4}$ & $1.01 \times 10^{-4}$ & $8.08 \times 10^{-4}$ & $1.13 \times 10^{-4}$ & 0.80 \\
\hline 08/08 & $7.59 \times 10^{-5}$ & $2.96 \times 10^{-5}$ & $9.41 \times 10^{-5}$ & $3.25 \times 10^{-5}$ & 0.41 & $7.82 \times 10^{-4}$ & $1.10 \times 10^{-4}$ & $7.73 \times 10^{-4}$ & $1.08 \times 10^{-4}$ & 0.06 \\
\hline $08 / 15$ & $8.28 \times 10^{-5}$ & $3.07 \times 10^{-5}$ & $4.44 \times 10^{-5}$ & $2.28 \times 10^{-5}$ & 1.00 & $8.34 \times 10^{-4}$ & $1.15 \times 10^{-4}$ & $8.22 \times 10^{-4}$ & $1.14 \times 10^{-4}$ & 0.07 \\
\hline $08 / 22$ & $3.28 \times 10^{-5}$ & $2.17 \times 10^{-5}$ & $2.75 \times 10^{-5}$ & $2.04 \times 10^{-5}$ & 0.18 & $6.88 \times 10^{-4}$ & $1.03 \times 10^{-4}$ & $7.00 \times 10^{-4}$ & $1.04 \times 10^{-4}$ & 0.08 \\
\hline $08 / 29$ & $4.36 \times 10^{-5}$ & $2.27 \times 10^{-5}$ & $5.57 \times 10^{-5}$ & $2.53 \times 10^{-5}$ & 0.36 & $6.04 \times 10^{-4}$ & $9.04 \times 10^{-5}$ & $6.85 \times 10^{-4}$ & $9.87 \times 10^{-5}$ & 0.61 \\
\hline $09 / 05$ & $4.70 \times 10^{-5}$ & $2.53 \times 10^{-5}$ & $5.23 \times 10^{-5}$ & $2.64 \times 10^{-5}$ & 0.14 & $7.25 \times 10^{-4}$ & $1.07 \times 10^{-4}$ & $7.80 \times 10^{-4}$ & $1.12 \times 10^{-4}$ & 0.36 \\
\hline $09 / 12$ & $2.50 \times 10^{-5}$ & $1.79 \times 10^{-5}$ & $3.74 \times 10^{-5}$ & $2.11 \times 10^{-5}$ & 0.45 & $7.50 \times 10^{-4}$ & $1.06 \times 10^{-4}$ & $8.31 \times 10^{-4}$ & $1.14 \times 10^{-4}$ & 0.52 \\
\hline $09 / 19$ & $5.99 \times 10^{-5}$ & $2.59 \times 10^{-5}$ & $3.65 \times 10^{-5}$ & $1.84 \times 10^{-5}$ & 0.74 & $8.80 \times 10^{-4}$ & $1.22 \times 10^{-4}$ & $7.23 \times 10^{-4}$ & $1.01 \times 10^{-4}$ & 0.99 \\
\hline $09 / 26$ & $5.92 \times 10^{-5}$ & $2.56 \times 10^{-5}$ & $6.35 \times 10^{-5}$ & $2.64 \times 10^{-5}$ & 0.12 & $1.25 \times 10^{-3}$ & $1.60 \times 10^{-4}$ & $1.42 \times 10^{-3}$ & $1.76 \times 10^{-4}$ & 0.71 \\
\hline
\end{tabular}

a Total propagated uncertainty

${ }^{\mathrm{b}}$ Relative error ratio

${ }^{c}$ Not Reported

d Not Applicable since sample or duplicate value is not reported. 
Waste Isolation Pilot Plant 2001 Site Environmental Report DOE/WIPP 02-2225

Table 8.4 - Comparison of Duplicate Air Monitoring Results

(Fourth Quarter of 2001) from WIPP Laboratories Data from Smith Ranch (SMR) Sampling Location

\begin{tabular}{|c|c|c|c|c|c|c|c|c|c|c|}
\hline \multirow{2}{*}{ Week Beginning } & \multicolumn{5}{|c|}{ Gross Alpha $\left(\mathrm{Bq} / \mathrm{m}^{3}\right)$} & \multicolumn{5}{|c|}{ Gross Beta $\left(\mathrm{Bq} / \mathrm{m}^{3}\right)$} \\
\hline & Sample & $2 \times$ TPU $^{\mathrm{a}}$ & Duplicate & $2 \times$ TPU & $\mathbf{R E R}^{\mathbf{b}}$ & Sample & $2 \times$ TPU & Duplicate & $2 \times$ TPU & RER \\
\hline $10 / 03$ & $4.23 \times 10^{-5}$ & $2.21 \times 10^{-5}$ & $2.52 \times 10^{-5}$ & $1.70 \times 10^{-5}$ & 0.61 & $1.02 \times 10^{-3}$ & $1.37 \times 10^{-4}$ & $1.17 \times 10^{-3}$ & $1.51 \times 10^{-4}$ & 0.74 \\
\hline $10 / 10$ & $7.41 \times 10^{-5}$ & $3.05 \times 10^{-5}$ & $N^{c}$ & NR & $N / A^{d}$ & $8.20 \times 10^{-4}$ & $1.16 \times 10^{-4}$ & NR & NR & $\mathrm{N} / \mathrm{A}$ \\
\hline $10 / 17$ & $3.66 \times 10^{-5}$ & $2.18 \times 10^{-5}$ & $5.75 \times 10^{-5}$ & $2.71 \times 10^{-5}$ & 0.60 & $1.39 \times 10^{-3}$ & $1.73 \times 10^{-4}$ & $1.19 \times 10^{-3}$ & $1.53 \times 10^{-4}$ & 0.87 \\
\hline $10 / 24$ & $1.08 \times 10^{-4}$ & $3.63 \times 10^{-5}$ & $1.18 \times 10^{-4}$ & $3.87 \times 10^{-5}$ & 0.19 & $1.19 \times 10^{-3}$ & $1.53 \times 10^{-4}$ & $1.12 \times 10^{-3}$ & $1.47 \times 10^{-4}$ & 0.33 \\
\hline $10 / 31$ & NR & NR & $1.22 \times 10^{-4}$ & $3.86 \times 10^{-5}$ & $\mathrm{~N} / \mathrm{A}$ & NR & NR & $8.51 \times 10^{-4}$ & $1.18 \times 10^{-4}$ & $\mathrm{~N} / \mathrm{A}$ \\
\hline $11 / 07$ & NR & NR & $1.63 \times 10^{-4}$ & $4.59 \times 10^{-5}$ & $\mathrm{~N} / \mathrm{A}$ & NR & NR & $1.75 \times 10^{-3}$ & $2.11 \times 10^{-4}$ & $\mathrm{~N} / \mathrm{A}$ \\
\hline $11 / 14$ & NR & NR & $4.18 \times 10^{-5}$ & $2.33 \times 10^{-5}$ & $\mathrm{~N} / \mathrm{A}$ & NR & NR & $7.64 \times 10^{-4}$ & $1.12 \times 10^{-4}$ & $\mathrm{~N} / \mathrm{A}$ \\
\hline $11 / 21$ & NR & NR & $8.81 \times 10^{-5}$ & $3.01 \times 10^{-5}$ & $\mathrm{~N} / \mathrm{A}$ & NR & NR & $8.12 \times 10^{-4}$ & $1.09 \times 10^{-4}$ & $\mathrm{~N} / \mathrm{A}$ \\
\hline $11 / 28$ & $9.20 \times 10^{-5}$ & $3.23 \times 10^{-5}$ & $1.25 \times 10^{-4}$ & $3.89 \times 10^{-5}$ & 0.65 & $9.38 \times 10^{-4}$ & $1.25 \times 10^{-4}$ & $1.00 \times 10^{-3}$ & $1.33 \times 10^{-4}$ & 0.35 \\
\hline $12 / 05$ & $4.27 \times 10^{-5}$ & $1.98 \times 10^{-5}$ & $6.04 \times 10^{-5}$ & $2.41 \times 10^{-5}$ & 0.57 & $6.89 \times 10^{-4}$ & $9.55 \times 10^{-5}$ & $7.34 \times 10^{-4}$ & $1.01 \times 10^{-4}$ & 0.32 \\
\hline $12 / 12$ & $7.72 \times 10^{-5}$ & $3.07 \times 10^{-5}$ & $1.19 \times 10^{-4}$ & $4.08 \times 10^{-5}$ & 0.82 & $1.13 \times 10^{-3}$ & $1.50 \times 10^{-4}$ & $1.08 \times 10^{-3}$ & $1.49 \times 10^{-4}$ & 0.24 \\
\hline $12 / 19$ & $4.28 \times 10^{-5}$ & $2.16 \times 10^{-5}$ & $4.10 \times 10^{-5}$ & $2.13 \times 10^{-5}$ & 0.06 & $1.09 \times 10^{-3}$ & $1.41 \times 10^{-4}$ & $1.04 \times 10^{-3}$ & $1.36 \times 10^{-4}$ & 0.26 \\
\hline $12 / 26$ & $6.77 \times 10^{-5}$ & $2.68 \times 10^{-5}$ & $9.63 \times 10^{-5}$ & $3.30 \times 10^{-5}$ & 0.67 & $1.16 \times 10^{-3}$ & $1.49 \times 10^{-4}$ & $1.20 \times 10^{-3}$ & $1.54 \times 10^{-4}$ & 0.19 \\
\hline
\end{tabular}

a Total propagated uncertainty

${ }^{\mathrm{b}}$ Relative error ratio

c Not Reported

d Not Applicable since sample or duplicate value is not reported. 


\section{Waste Isolation Pilot Plant 2001 Site Environmental Report DOE/WIPP 02-2225}

Table 8.5 - Environmental Measurements Laboratory Assessments for Wastren, 2001 MATRIX: Air Filter (Bq/Filter)

\begin{tabular}{|c|c|c|c|c|c|c|c|c|c|c|}
\hline \multirow[b]{3}{*}{$\mathbf{R N}^{\mathrm{c}}$} & \multicolumn{5}{|c|}{ QAP $^{\mathrm{a}} 54$ June 2001} & \multicolumn{4}{|c|}{ QAP 55 December 2001} & \multirow{3}{*}{$\begin{array}{c}\% \\
\text { Bias }\end{array}$} \\
\hline & \multicolumn{2}{|c|}{ Reported } & \multicolumn{2}{|c|}{$\mathrm{EML}^{\mathrm{b}}$} & \multirow{2}{*}{$\begin{array}{c}\% \\
\text { Bias }\end{array}$} & \multicolumn{2}{|c|}{ Reported } & \multicolumn{2}{|c|}{ EML } & \\
\hline & Value & Error & Value & Error & & Value & Error & Value & Error & \\
\hline${ }^{241} \mathrm{Am}$ & 0.49 & 0.02 & 0.486 & 0.016 & 0.82 & 0.094 & 0.005 & 0.088 & 0.01 & 6.82 \\
\hline${ }^{60} \mathrm{Co}$ & 21 & 2 & 19.44 & 0.5 & 8.02 & 19 & 2 & 17.5 & 0.47 & 8.57 \\
\hline${ }^{137} \mathrm{Cs}$ & 9.8 & 2 & 8.76 & 0.34 & 11.87 & 18 & 2 & 17.1 & 0.58 & 5.26 \\
\hline Gross $\alpha$ & 3.57 & 0.34 & 3.97 & 0.3 & -10.08 & 5.54 & 0.67 & 5.362 & 0.536 & 3.32 \\
\hline Gross $\beta$ & 2.51 & 0.29 & 2.58 & 0.15 & -2.71 & 11.98 & 1.34 & 12.77 & 1.277 & -6.19 \\
\hline${ }^{54} \mathrm{Mn}$ & 7.4 & 1 & 6.52 & 0.28 & 13.5 & 88 & 14 & 81.15 & 4.76 & 8.44 \\
\hline${ }^{238} \mathrm{Pu}$ & 0.21 & 0.008 & 0.215 & 0.009 & -2.32 & 0.069 & 0.004 & 0.071 & 0 & -2.82 \\
\hline${ }^{239} \mathrm{Pu}$ & 0.14 & 0.006 & 0.136 & 0.012 & 2.94 & 0.23 & 0.009 & 0.2291 & 0.017 & 0.39 \\
\hline${ }^{90} \mathrm{Sr}$ & 7.34 & 0.39 & 7.1 & 0.22 & 3.38 & 3.31 & 0.19 & 3.481 & 0.233 & -4.91 \\
\hline${ }^{234} U$ & 0.043 & 0.004 & 0.046 & 0.002 & -6.52 & 0.099 & 0.005 & 0.1082 & 0.01 & -8.5 \\
\hline${ }^{238} \mathrm{U}$ & 0.046 & 0.004 & 0.046 & 0.002 & 0 & 0.104 & 0.005 & 0.1093 & 0.01 & -4.85 \\
\hline TOT U( $\mu \mathrm{g})$ & 3.6 & $N / A^{d}$ & 3.7 & 0.16 & -2.7 & 8.1 & $\mathrm{~N} / \mathrm{A}$ & 8.844 & 0.581 & -8.41 \\
\hline
\end{tabular}

Table 8.6 - Environmental Measurements Laboratory Assessments for Wastren, 2001 MATRIX: Soil (Bq/kg)

\begin{tabular}{|c|c|c|c|c|c|c|c|c|c|c|}
\hline \multirow[b]{3}{*}{$\mathbf{R N}^{\mathrm{c}}$} & \multicolumn{5}{|c|}{ QAP $^{\mathrm{a}} 54$ June 2001} & \multicolumn{4}{|c|}{ QAP 55 December 2001} & \multirow{3}{*}{$\begin{array}{c}\% \\
\text { Bias }\end{array}$} \\
\hline & \multicolumn{2}{|c|}{ Reported } & \multicolumn{2}{|c|}{$\mathrm{EML}^{\mathrm{b}}$} & \multirow{2}{*}{$\begin{array}{c}\% \\
\text { Bias }\end{array}$} & \multicolumn{2}{|c|}{ Reported } & \multicolumn{2}{|c|}{ EML } & \\
\hline & Value & Error & Value & Error & & Value & Error & Value & Error & \\
\hline${ }^{228} \mathrm{Ac}$ & 42.4 & 10 & 42.7 & 1.7 & -0.7 & 56.3 & 8 & 59.57 & 2.09 & -5.49 \\
\hline${ }^{241} \mathrm{Am}$ & 14.53 & 0.76 & 14.8 & 0.51 & -1.82 & 4.98 & 0.31 & 4.432 & 0.312 & 12.36 \\
\hline${ }^{212} \mathrm{Bi}$ & 25.4 & 20 & 42 & 4.1 & $-39.52^{d}$ & 54.2 & 18 & 62.0667 & 5.152 & -12.67 \\
\hline${ }^{137} \mathrm{Cs}$ & 1624 & 162 & 1740 & 90 & -6.67 & 542 & 70 & 612.33 & 30.62 & -11.48 \\
\hline${ }^{40} \mathrm{~K}$ & 462 & 56 & 468 & 25 & -1.28 & 617 & 206 & 623.33 & 33.04 & -1.02 \\
\hline${ }^{212} \mathrm{~Pb}$ & 45.8 & 16 & 41.5 & 2.2 & 10.36 & 59.7 & 11 & 58.33 & 3.13 & 2.35 \\
\hline${ }^{214} \mathrm{~Pb}$ & 29.5 & 10 & 34.3 & 1.6 & -13.99 & 41.9 & 6 & 39.67 & 1.72 & 5.62 \\
\hline${ }^{239} \mathrm{Pu}$ & 24.83 & 1.11 & 25.6 & 0.34 & -3.01 & 9.32 & 0.49 & 8.948 & 0.323 & 4.16 \\
\hline${ }^{90} \mathrm{Sr}$ & 66.6 & 5.1 & 69 & 5.7 & -3.48 & 29.1 & 2.4 & 30.596 & 1.065 & -4.89 \\
\hline${ }^{234} \mathrm{Th}$ & 59.3 & 24 & 46.6 & 3.5 & 27.25 & $N / A^{e}$ & N/A & $\mathrm{N} / \mathrm{A}$ & N/A & $N / A$ \\
\hline${ }^{234} U$ & 40.46 & 2.41 & 43.6 & 1.8 & -7.2 & 87 & 4.81 & 92.23 & 1.3 & -5.67 \\
\hline${ }^{238} \mathrm{U}$ & 42.27 & 2.46 & 46.1 & 1.3 & -8.31 & 92.87 & 5.08 & 98.33 & 3.2 & -5.55 \\
\hline TOTU $(\mu \mathrm{g})$ & 3.6 & $\mathrm{~N} / \mathrm{A}$ & 3.73 & 0.02 & -3.48 & 8 & N/A & 7.948 & 0.125 & 0.65 \\
\hline
\end{tabular}

${ }^{a}$ Quality Assurance Program

${ }^{b}$ Environmental Measurements Laboratory

${ }^{c}$ Radionuclide

d Not Acceptable

${ }^{\text {e }}$ Not Applicable 


\section{Waste Isolation Pilot Plant 2001 Site Environmental Report DOE/WIPP 02-2225}

Table 8.7 - Environmental Measurements Laboratory Assessments for Wastren, 2001 MATRIX: Vegetation $(\mathrm{Bq} / \mathrm{kg})$

\begin{tabular}{|c|c|c|c|c|c|c|c|c|c|c|}
\hline \multirow[b]{3}{*}{$\mathrm{RN}^{\mathrm{c}}$} & \multicolumn{5}{|c|}{ QAP $^{a} 54$ June 2001} & \multicolumn{4}{|c|}{ QAP 55 December 2001} & \multirow{3}{*}{$\begin{array}{c}\% \\
\text { Bias }\end{array}$} \\
\hline & \multicolumn{2}{|c|}{ Reported } & \multicolumn{2}{|c|}{$\mathrm{EML}^{\mathrm{b}}$} & \multirow{2}{*}{$\begin{array}{c}\% \\
\text { Bias }\end{array}$} & \multicolumn{2}{|c|}{ Reported } & \multicolumn{2}{|c|}{ EML } & \\
\hline & Value & Error & Value & Error & & Value & Error & Value & Error & \\
\hline${ }^{241} \mathrm{Am}$ & 6.19 & 0.34 & 6.17 & 0.32 & 0.32 & 7.62 & 0.4 & 6.915 & 0.419 & 10.2 \\
\hline${ }^{244} \mathrm{Cm}$ & 3.65 & 0.24 & 3.69 & 0.29 & -1.08 & 4.27 & 0.26 & 4.308 & 1.021 & -0.88 \\
\hline${ }^{60} \mathrm{Co}$ & 32.4 & 6 & 30.4 & 1.2 & 6.58 & 37.4 & 4 & 35.3 & 1.436 & 5.95 \\
\hline${ }^{137} \mathrm{Cs}$ & 835 & 168 & 842 & 42 & -0.83 & 993 & 130 & 1030 & 51.8 & -3.59 \\
\hline${ }^{40} \mathrm{~K}$ & 691 & 166 & 603 & 32 & 14.59 & 1200 & 400 & 898.67 & 48.23 & 33.53 \\
\hline${ }^{239} \mathrm{Pu}$ & 9.18 & 0.48 & 9.58 & 1.3 & -4.18 & 11.54 & 0.48 & 11.022 & 0.43 & 4.7 \\
\hline${ }^{90} \mathrm{Sr}$ & 1224 & 65 & 1330 & 70 & -7.97 & 1541 & 84 & 1612.8 & 48.6 & -4.45 \\
\hline
\end{tabular}

${ }^{a}$ Quality Assurance Program

${ }^{\mathrm{b}}$ Environmental Measurements Laboratory

${ }^{\mathrm{c}}$ Radionuclide

Table 8.8 - Environmental Measurements Laboratory Assessments for Wastren, 2001 MATRIX: Water (Bq/l)

\begin{tabular}{|c|c|c|c|c|c|c|c|c|c|c|}
\hline \multirow[b]{3}{*}{$\mathbf{R N}^{\mathrm{c}}$} & \multicolumn{5}{|c|}{ QAP $^{a} 54$ June 2001} & \multicolumn{4}{|c|}{ QAP 55 December 2001} & \multirow{3}{*}{$\begin{array}{c}\% \\
\text { Bias }\end{array}$} \\
\hline & \multicolumn{2}{|c|}{ Reported } & \multicolumn{2}{|c|}{$\mathrm{EML}^{\mathrm{b}}$} & \multirow{2}{*}{$\begin{array}{c}\% \\
\text { Bias }\end{array}$} & \multicolumn{2}{|c|}{ Reported } & \multicolumn{2}{|c|}{ EML } & \\
\hline & Value & Error & Value & Error & & Value & Error & Value & Error & \\
\hline${ }^{241} \mathrm{Am}$ & 1.62 & 0.07 & 1.67 & 0.08 & -2.99 & 0.77 & 0.04 & 0.7597 & 0.04 & 1.36 \\
\hline${ }^{60} \mathrm{Co}$ & 104 & 8 & 98.2 & 3.6 & 5.91 & 218 & 20 & 209 & 7.59 & 4.31 \\
\hline${ }^{137} \mathrm{Cs}$ & 77 & 14 & 73 & 3.7 & 5.48 & 44 & 5 & 45.133 & 2.467 & -2.51 \\
\hline Gross $\alpha$ & 1918 & 165 & 1900 & 190 & 0.95 & 1224 & 118 & 1150 & 115 & 6.43 \\
\hline Gross $\beta$ & 1272 & 140 & 1297 & 100 & -1.93 & 8005 & 731 & 7970 & 800 & 0.44 \\
\hline${ }^{3} \mathrm{H}$ & 86.1 & 8.4 & 79.3 & 2 & 8.58 & 214 & 17 & 207 & 2.69 & 3.38 \\
\hline${ }^{238} \mathrm{Pu}$ & 1.58 & 0.07 & 1.58 & 0.09 & 0 & 1.13 & 0.05 & 1.0882 & 0.058 & 3.84 \\
\hline${ }^{239} \mathrm{Pu}$ & 1.65 & 0.07 & 1.64 & 0.09 & 0.61 & 1.78 & 0.07 & 1.628 & 0.114 & 9.33 \\
\hline${ }^{90} \mathrm{Sr}$ & 4.08 & 0.26 & 4.4 & 0.2 & -7.27 & 3.82 & 0.25 & 3.729 & 0.364 & 2.44 \\
\hline${ }^{234} U$ & 0.95 & 0.05 & 1.04 & 0.05 & -8.65 & 1.15 & 0.07 & 1.166 & 0.062 & -1.37 \\
\hline${ }^{238} \mathrm{U}$ & 0.97 & 0.05 & 1.04 & 0.04 & -6.73 & 1.12 & 0.07 & 1.169 & 0.056 & 4.19 \\
\hline TOTU $(\mu \mathrm{g})$ & 0.078 & $N / A^{d}$ & 0.08 & 0.003 & -2.5 & 0.091 & $\mathrm{~N} / \mathrm{A}$ & 0.0944 & 0 & -3.6 \\
\hline
\end{tabular}




\section{Waste Isolation Pilot Plant 2001 Site Environmental Report DOE/WIPP 02-2225}

Table 8.9 - Environmental Resource Associates $®$ for Wastren, 2001 MATRIX: Water (pCi/l)

\begin{tabular}{|c|c|c|c|c|c|c|c|c|c|c|}
\hline \multirow[b]{3}{*}{$\mathbf{R N}^{\mathrm{b}}$} & \multicolumn{5}{|c|}{37007} & \multicolumn{4}{|c|}{37129} & \multirow{3}{*}{$\begin{array}{c}\% \\
\text { Bias }\end{array}$} \\
\hline & \multicolumn{2}{|c|}{ Reported } & \multicolumn{2}{|c|}{$\mathrm{ERA}^{\mathrm{a}}$} & \multirow{2}{*}{$\begin{array}{c}\% \\
\text { Bias }\end{array}$} & \multicolumn{2}{|c|}{ Reported } & \multicolumn{2}{|c|}{ ERA } & \\
\hline & Value & Error & Value & Error & & Value & Error & Value & Error & \\
\hline U(NAT) & 19.8 & $N / A^{c}$ & 20.4 & 3 & -2.94 & $\mathrm{~N} / \mathrm{A}$ & $\mathrm{N} / \mathrm{A}$ & $\mathrm{N} / \mathrm{A}$ & $\mathrm{N} / \mathrm{A}$ & $\mathrm{N} / \mathrm{A}$ \\
\hline${ }^{226} \mathrm{Ra}$ & 3.21 & 0.122 & 4.65 & 0.698 & $-30.97^{d}$ & $\mathrm{~N} / \mathrm{A}$ & N/A & $N / A$ & $N / A$ & $\mathrm{~N} / \mathrm{A}$ \\
\hline${ }^{228} \mathrm{Ra}$ & 13.4 & 0.458 & 14.4 & 3.6 & -6.94 & $\mathrm{~N} / \mathrm{A}$ & $\mathrm{N} / \mathrm{A}$ & $\mathrm{N} / \mathrm{A}$ & N/A & $\mathrm{N} / \mathrm{A}$ \\
\hline Gross $\alpha$ & $N / A$ & $\mathrm{~N} / \mathrm{A}$ & $\mathrm{N} / \mathrm{A}$ & $N / A$ & $\mathrm{~N} / \mathrm{A}$ & 16.3 & 1.42 & 17.8 & 5 & -8.42 \\
\hline Gross $\beta$ & $\mathrm{N} / \mathrm{A}$ & $\mathrm{N} / \mathrm{A}$ & $\mathrm{N} / \mathrm{A}$ & $\mathrm{N} / \mathrm{A}$ & $\mathrm{N} / \mathrm{A}$ & 45.1 & 0.833 & 53 & 10 & -14.9 \\
\hline
\end{tabular}

${ }^{a}$ Environmental Resource Associates ${ }^{\circledR}$

${ }^{\mathrm{b}}$ Radionuclide

${ }^{\mathrm{c}}$ Not Applicable

${ }^{\mathrm{d}}$ Not Acceptable

Table 8.10 - NRIP for WIPP Laboratories, 2001

\begin{tabular}{|c|c|c|c|c|c|c|c|c|c|c|}
\hline \multirow[b]{3}{*}{$\mathbf{R N}^{\mathrm{b}}$} & \multicolumn{5}{|c|}{ Synthetic Urine (mBq/g) } & \multicolumn{4}{|c|}{ Soil (Bq/g) } & \multirow[b]{3}{*}{$\begin{array}{c}\% \\
\text { Bias }\end{array}$} \\
\hline & \multicolumn{2}{|c|}{ Reported } & \multicolumn{2}{|c|}{ NIST $^{\mathrm{a}}$} & \multirow[b]{2}{*}{$\begin{array}{c}\% \\
\text { Bias }\end{array}$} & \multicolumn{2}{|c|}{ Reported } & \multicolumn{2}{|c|}{ NIST } & \\
\hline & Value & $\begin{array}{l}\% 1 \sigma \\
\text { Error }\end{array}$ & Value & $\begin{array}{l}\% 1 \sigma \\
\text { Error }\end{array}$ & & Value & $\begin{array}{l}\% 1 \sigma \\
\text { Error }\end{array}$ & Value & $\begin{array}{l}\% 1 \sigma \\
\text { Error }\end{array}$ & \\
\hline${ }^{241} \mathrm{Am}$ & 0.0608 & 19.24 & 0.061 & 0.32 & -0.3 & 0.6364 & 21.4 & 0.715 & 0.32 & -10.9 \\
\hline${ }^{238} \mathrm{Pu}$ & 0.0584 & 17.59 & 0.0623 & 0.55 & -6.3 & 0.7465 & 14.4 & 0.73 & 0.55 & 2.3 \\
\hline${ }^{239} \mathrm{Pu}$ & 0.0582 & 17.58 & 0.0609 & 0.38 & -4.4 & 0.7701 & 14.7 & 0.713 & 0.39 & 8 \\
\hline${ }^{90} \mathrm{Sr}$ & 0.0573 & 10.81 & 0.0637 & 0.37 & -10 & 0.6191 & 3.5 & 0.747 & 0.37 & -17.1 \\
\hline${ }^{238} \mathrm{U}$ & 0.0597 & 18.34 & 0.06 & 0.03 & -0.5 & 0.7665 & 30.2 & 0.703 & 0.3 & 9.1 \\
\hline
\end{tabular}

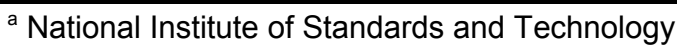

${ }^{\mathrm{b}}$ Radionuclide

Table 8.11 - Environmental Measurements Laboratory Assessments for WIPP Laboratories, 2001 MATRIX: Air Filter (Bq/Filter)

\begin{tabular}{|c|c|c|c|c|c|c|c|c|c|c|}
\hline \multirow[b]{3}{*}{$\mathbf{R N}^{\mathrm{c}}$} & \multicolumn{5}{|c|}{ QAP $^{a} 54$ June 2001} & \multicolumn{4}{|c|}{ QAP 55 December 2001} & \multirow{3}{*}{$\begin{array}{c}\% \\
\text { Bias }\end{array}$} \\
\hline & \multicolumn{2}{|c|}{ Reported } & \multicolumn{2}{|c|}{$\mathrm{EML}^{\mathrm{b}}$} & \multirow{2}{*}{$\begin{array}{c}\% \\
\text { Bias }\end{array}$} & \multicolumn{2}{|c|}{ Reported } & \multicolumn{2}{|c|}{ EML } & \\
\hline & Value & Error & Value & Error & & Value & Error & Value & Error & \\
\hline${ }^{241} \mathrm{Am}$ & 0.462 & 0.096 & 0.486 & 0.016 & -4.94 & 0.099 & 0.016 & 0.088 & 0.01 & 12.5 \\
\hline${ }^{60} \mathrm{Co}$ & 19.13 & 2.57 & 19.44 & 0.5 & -1.59 & 17.433 & 2.373 & 17.5 & 0.47 & -0.38 \\
\hline${ }^{137} \mathrm{Cs}$ & 8.377 & 1.167 & 8.76 & 0.34 & -4.37 & 17.4 & 2.423 & 17.1 & 0.58 & 1.75 \\
\hline Gross $\alpha$ & 3.26 & 0.332 & 3.97 & 0.3 & -17.88 & 5.14 & 0.519 & 5.362 & 0.536 & -4.14 \\
\hline Gross $\beta$ & 2.523 & 0.256 & 2.58 & 0.15 & -2.21 & 11 & 1.097 & 12.77 & 1.277 & -13.86 \\
\hline${ }^{54} \mathrm{Mn}$ & 6.593 & 0.948 & 6.52 & 0.28 & 1.12 & 84.733 & 11.5 & 81.15 & 4.76 & 4.42 \\
\hline${ }^{238} \mathrm{Pu}$ & 0.2 & 0.042 & 0.215 & 0.009 & -6.98 & 0.065 & 0.013 & 0.071 & 0 & -8.45 \\
\hline${ }^{239} \mathrm{Pu}$ & 0.129 & 0.028 & 0.136 & 0.012 & -5.15 & 0.232 & 0.038 & 0.2291 & 0.017 & 1.26 \\
\hline${ }^{90} \mathrm{Sr}$ & 5.41 & 0.298 & 7.1 & 0.22 & -23.8 & 1.86 & 0.141 & 3.481 & 0.233 & $-46.57^{d}$ \\
\hline $\mathrm{Bq} \mathrm{U}$ & 0.105 & 0.016 & 0.093 & 0 & 12.9 & 0.21 & 0.023 & 0.2225 & 0.014 & -5.62 \\
\hline
\end{tabular}




\section{Waste Isolation Pilot Plant 2001 Site Environmental Report DOE/WIPP 02-2225}

Table 8.12 - Environmental Measurements Laboratory Assessments for WIPP Laboratories, 2001 MATRIX: Soil (Bq/Filter)

\begin{tabular}{|c|c|c|c|c|c|c|c|c|c|c|}
\hline \multirow[b]{3}{*}{$\mathbf{R N}^{\mathrm{c}}$} & \multicolumn{5}{|c|}{ QAP $^{a} 54$ June 2001} & \multicolumn{4}{|c|}{ QAP 55 December 2001} & \multirow{3}{*}{$\begin{array}{c}\% \\
\text { Bias }\end{array}$} \\
\hline & \multicolumn{2}{|c|}{ Reported } & \multicolumn{2}{|c|}{$\mathrm{EML}^{\mathrm{b}}$} & \multirow{2}{*}{$\begin{array}{c}\% \\
\text { Bias }\end{array}$} & \multicolumn{2}{|c|}{ Reported } & \multicolumn{2}{|c|}{ EML } & \\
\hline & Value & Error & Value & Error & & Value & Error & Value & Error & \\
\hline${ }^{228} \mathrm{Ac}$ & 37.667 & 6.623 & 42.7 & 1.7 & -11.79 & 53.033 & 8.547 & 59.57 & 2.09 & -10.97 \\
\hline${ }^{241} \mathrm{Am}$ & 17.05 & 2.549 & 14.8 & 0.51 & 15.2 & 5.523 & 1.103 & 4.432 & 0.312 & 24.62 \\
\hline${ }^{212} \mathrm{Bi}$ & 47.6 & 11.5 & 42 & 4.1 & 13.33 & 56.633 & 12.267 & 62.0667 & 5.152 & -8.75 \\
\hline${ }^{214} \mathrm{Bi}$ & 27 & 4.713 & 32.6 & 1.4 & -17.18 & 32.633 & 4.967 & 36.9 & 1.53 & -11.56 \\
\hline $\mathrm{Bq} \mathrm{U}$ & 83.41 & 8.247 & 91.8 & 2.3 & -9.14 & 205.75 & 21.145 & 194.23 & 3.76 & 5.93 \\
\hline${ }^{137} \mathrm{Cs}$ & 1633.3 & 205.67 & 1740 & 90 & -6.13 & 576.667 & 72.733 & 612.33 & 30.62 & -5.82 \\
\hline${ }^{40} \mathrm{~K}$ & 531.67 & 71.67 & 468 & 25 & 13.6 & 716.333 & 94.967 & 623.33 & 33.04 & 14.92 \\
\hline${ }^{212} \mathrm{~Pb}$ & 51.33 & 7.607 & 41.5 & 2.2 & 23.69 & 71.9 & 10.15 & 58.33 & 3.13 & 23.26 \\
\hline${ }^{214} \mathrm{~Pb}$ & 34.667 & 5.837 & 34.3 & 1.6 & 1.07 & 42.533 & 6.127 & 39.67 & 1.72 & 7.22 \\
\hline${ }^{239} \mathrm{Pu}$ & 30.057 & 4.631 & 25.6 & 0.67 & 17.41 & 10.62 & 2.037 & 8.948 & 0.323 & 18.68 \\
\hline${ }^{90} \mathrm{Sr}$ & 61.64 & 7.363 & 69 & 5.7 & -10.67 & 28.733 & 3.66 & 30.596 & 1.065 & -6.09 \\
\hline
\end{tabular}

${ }^{\text {a }}$ Quality Assurance Program

${ }^{\mathrm{b}}$ Environmental Measurements Laboratory

${ }^{\mathrm{c}}$ Radionuclide

Table 8.13 - Environmental Measurements Laboratory Assessments for WIPP Laboratories, 2001 MATRIX: Vegetation $(\mathrm{Bq} / \mathrm{kg})$

\begin{tabular}{|c|c|c|c|c|c|c|c|c|c|c|}
\hline \multirow[b]{3}{*}{$\mathbf{R N}^{\mathrm{c}}$} & \multicolumn{5}{|c|}{ QAP $^{a} 54$ June 2001} & \multicolumn{4}{|c|}{ QAP 55 December 2001} & \multirow{3}{*}{$\begin{array}{c}\% \\
\text { Bias }\end{array}$} \\
\hline & \multicolumn{2}{|c|}{ Reported } & \multicolumn{2}{|c|}{$\mathrm{EML}^{\mathrm{b}}$} & \multirow{2}{*}{$\begin{array}{c}\% \\
\text { Bias }\end{array}$} & \multicolumn{2}{|c|}{ Reported } & \multicolumn{2}{|c|}{ EML } & \\
\hline & Value & Error & Value & Error & & Value & Error & Value & Error & \\
\hline${ }^{241} \mathrm{Am}$ & 6.283 & 1.14 & 6.17 & 0.32 & 1.83 & 8.21 & 1.63 & 6.915 & 0.419 & 18.73 \\
\hline${ }^{244} \mathrm{Cm}$ & 3.82 & 0.769 & 3.69 & 0.29 & 3.52 & $\mathrm{NR}^{\mathrm{d}}$ & NR & 4.308 & 1.021 & $N / A^{e}$ \\
\hline${ }^{60} \mathrm{Co}$ & 29.967 & 3.97 & 30.4 & 1.2 & -1.42 & 33.967 & 4.48 & 35.3 & 1.436 & -3.78 \\
\hline${ }^{137} \mathrm{Cs}$ & 761 & 95.8 & 842 & 42 & -9.62 & 899 & 113 & 1030 & 51.8 & -12.72 \\
\hline${ }^{40} \mathrm{~K}$ & 661 & 88.167 & 603 & 32 & 9.62 & 973.667 & 128 & 898.67 & 48.23 & 8.34 \\
\hline${ }^{239} \mathrm{Pu}$ & 9.27 & 1.437 & 9.58 & 1.3 & -3.24 & 11.27 & 1.65 & 11.022 & 0.43 & 2.25 \\
\hline${ }^{90} \mathrm{Sr}$ & 877.333 & 70.367 & 1330 & 70 & $-34.04^{f}$ & 1601.67 & 126.667 & 1612.8 & 48.6 & -0.69 \\
\hline
\end{tabular}

${ }^{a}$ Quality Assurance Program

${ }^{b}$ Environmental Measurements Laboratory

${ }^{\mathrm{c}}$ Radionuclide

${ }^{\mathrm{d}}$ Not Reported

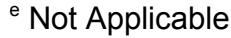

${ }^{f}$ Not Acceptable according to the percent bias acceptable limits, but acceptable with warning according to EML 


\section{Waste Isolation Pilot Plant 2001 Site Environmental Report DOE/WIPP 02-2225}

Table 8.14 - Environmental Measurements Laboratory Assessments for WIPP Laboratories, 2001 MATRIX: Water (Bq/l)

\begin{tabular}{|c|c|c|c|c|c|c|c|c|c|c|}
\hline \multirow[b]{3}{*}{$\mathbf{R N}^{\mathbf{c}}$} & \multicolumn{5}{|c|}{ QAP $^{\mathrm{a}} 54$ June 2001} & \multicolumn{4}{|c|}{ QAP 55 December 2001} & \multirow{3}{*}{$\begin{array}{c}\% \\
\text { Bias }\end{array}$} \\
\hline & \multicolumn{2}{|c|}{ Reported } & \multicolumn{2}{|c|}{$E M L^{b}$} & \multirow{2}{*}{$\begin{array}{c}\% \\
\text { Bias }\end{array}$} & \multicolumn{2}{|c|}{ Reported } & \multicolumn{2}{|c|}{ EML } & \\
\hline & Value & Error & Value & Error & & Value & Error & Value & Error & \\
\hline${ }^{241} \mathrm{Am}$ & 1.66 & 0.277 & 1.67 & 0.08 & -0.599 & 0.742 & 0.163 & 0.7597 & 0.04 & -2.33 \\
\hline $\mathrm{Bq} \mathrm{U}$ & 1.947 & 0.223 & 2.12 & 0.09 & -8.16 & 2.227 & 0.241 & 2.372 & 0.118 & -6.11 \\
\hline${ }^{60} \mathrm{Co}$ & 102.667 & 13.633 & 98.2 & 3.6 & 4.55 & 211.333 & 28.3 & 209 & 7.59 & 1.12 \\
\hline${ }^{137} \mathrm{Cs}$ & 75.03 & 10.167 & 73 & 3.7 & 2.78 & 45.533 & 6.343 & 45.133 & 2.467 & 0.89 \\
\hline${ }^{238} \mathrm{Pu}$ & 1.507 & 0.298 & 1.58 & 0.09 & -4.62 & 1.031 & 0.168 & 1.0882 & 0.058 & -5.26 \\
\hline${ }^{239} \mathrm{Pu}$ & 1.597 & 0.315 & 1.64 & 0.09 & -2.62 & 1.653 & 0.258 & 1.628 & 0.114 & 1.54 \\
\hline${ }^{90} \mathrm{Sr}$ & 4.105 & 0.289 & 4.4 & 0.2 & -6.7 & 4.22 & 0.338 & 3.729 & 0.364 & 13.17 \\
\hline
\end{tabular}

${ }^{a}$ Quality Assurance Program

${ }^{\mathrm{b}}$ Environmental Measurements Laboratory

${ }^{\mathrm{c}}$ Radionuclide

Table 8.15 - Environmental Resource Associates ${ }^{\circledR}$ Assessment of Air Toxics, Ltd., WP-75, June 14, 2001, for Volatile Organic Compounds

\begin{tabular}{|c|c|c|c|c|c|}
\hline Analyte & Units & $\begin{array}{c}\text { Reported } \\
\text { Value }\end{array}$ & $\begin{array}{c}\text { Assigned } \\
\text { Value }\end{array}$ & $\begin{array}{l}\text { Acceptance } \\
\text { Limits }\end{array}$ & $\begin{array}{c}\text { Performance } \\
\text { Evaluation }\end{array}$ \\
\hline Acetone & $\mu g / l$ & $<10.00$ & 0 & $\mathrm{NR}^{\mathrm{a}}$ & Acceptable \\
\hline Acetonitrile & $\mu \mathrm{g} / \mathrm{l}$ & $<10.00$ & 0 & NR & Acceptable \\
\hline Acrylonitrile & $\mu \mathrm{g} / \mathrm{l}$ & $<2.00$ & 0 & NR & Acceptable \\
\hline Acrolein & $\mu g / l$ & $<10.00$ & 0 & NR & Acceptable \\
\hline Benzene & $\mu g / l$ & 59.1 & 51.7 & $37.3-66.5$ & Acceptable \\
\hline Bromodichloromethane & $\mu g / l$ & 43.4 & 34.6 & $24.4-45.1$ & Check for Error ${ }^{b}$ \\
\hline Bromoform & $\mu \mathrm{g} / \mathrm{l}$ & 49.4 & 37.4 & $24.0-51.3$ & Check for Error \\
\hline Bromomethane & $\mu \mathrm{g} / \mathrm{l}$ & $<2.00$ & 0 & NR & Acceptable \\
\hline 2-Butanone (MEK) & $\mu g / l$ & $<10.0$ & 0 & NR & Acceptable \\
\hline Carbon disulfide & $\mu g / l$ & $<2.00$ & 0 & NR & Acceptable \\
\hline Carbon tetrachloride & $\mu \mathrm{g} / \mathrm{l}$ & 59.3 & 55.4 & $34.2-78.1$ & Acceptable \\
\hline Chlorobenzene & $\mu \mathrm{g} / \mathrm{l}$ & 36.5 & 31.7 & $22.7-40.3$ & Acceptable \\
\hline Chlorodibromomethane & $\mu \mathrm{g} / \mathrm{l}$ & 61.6 & 51.4 & $34.0-68.3$ & Acceptable \\
\hline Chloroethane & $\mu g / l$ & $<2.00$ & 0 & NR & Acceptable \\
\hline 2-Chloroethylvinylether & $\mu g / l$ & $<10.0$ & 0 & NR & Acceptable \\
\hline Chloroform & $\mu \mathrm{g} / \mathrm{l}$ & 26.9 & 23.3 & $16.4-30.1$ & Acceptable \\
\hline Chloromethane & $\mu \mathrm{g} / \mathrm{l}$ & $<2.00$ & 0 & NR & Acceptable \\
\hline DBCP & $\mu g / l$ & $<10.0$ & 0 & NR & Acceptable \\
\hline 1,2-Dibromoethane (EDB) & $\mu g / l$ & $<2.00$ & 0 & NR & Acceptable \\
\hline Dibromomethane & $\mu g / l$ & $<2.00$ & 0 & NR & Acceptable \\
\hline 1,2-Dichlorobenzene & $\mu \mathrm{g} / \mathrm{l}$ & 21.3 & 18.4 & $12.7-23.8$ & Acceptable \\
\hline 1,3-Dichlorobenzene & $\mu g / l$ & 43.2 & 38.5 & $27.1-48.1$ & Acceptable \\
\hline 1,4-Dichlorobenzene & $\mu g / l$ & 14.1 & 11.6 & $7.81-15.5$ & Acceptable \\
\hline Dichlorodifluoromethane & $\mu g / l$ & $<2.00$ & 0 & NR & Acceptable \\
\hline 1,1-Dichloroethane & $\mu g / l$ & $<2.00$ & 0 & NR & Acceptable \\
\hline 1,2-Dichloroethane & $\mu \mathrm{g} / \mathrm{l}$ & 47.4 & 39.9 & $27.6-53.3$ & Acceptable \\
\hline 1,1-Dichloroethylene & $\mu \mathrm{g} / \mathrm{l}$ & 69.8 & 64.4 & $35.2-98.5$ & Acceptable \\
\hline cis-1,2-Dichloroethylene & $\mu \mathrm{g} / \mathrm{l}$ & $<2.00$ & 0 & NR & Acceptable \\
\hline
\end{tabular}




\section{Waste Isolation Pilot Plant 2001 Site Environmental Report DOE/WIPP 02-2225}

Table 8.15 - Environmental Resource Associates ${ }^{\circledR}$ Assessment of Air Toxics, Ltd., WP-75, June 14, 2001, for Volatile Organic Compounds

\begin{tabular}{|c|c|c|c|c|c|}
\hline Analyte & Units & $\begin{array}{c}\text { Reported } \\
\text { Value }\end{array}$ & $\begin{array}{c}\text { Assigned } \\
\text { Value }\end{array}$ & $\begin{array}{l}\text { Acceptance } \\
\text { Limits }\end{array}$ & $\begin{array}{c}\text { Performance } \\
\text { Evaluation }\end{array}$ \\
\hline trans-1,2-Dichloroethylene & $\mu \mathrm{g} / \mathrm{l}$ & 32.1 & 28.6 & $16.5-40.6$ & Acceptable \\
\hline 1,2-Dichloropropane & $\mu \mathrm{g} / \mathrm{l}$ & 16 & 14.3 & $10.8-17.7$ & Acceptable \\
\hline cis-1,3-Dichloropropylene & $\mu \mathrm{g} / \mathrm{l}$ & $<2.00$ & 0 & NR & Acceptable \\
\hline trans-1,3-Dichloropropylene & $\mu \mathrm{g} / \mathrm{l}$ & $<2.00$ & 0 & NR & Acceptable \\
\hline Ethylbenzene & $\mu g / l$ & 29.1 & 24.3 & $16.4-31.6$ & Acceptable \\
\hline 2-Hexanone & $\mu g / l$ & $<10.0$ & 0 & NR & Acceptable \\
\hline Methylene chloride & $\mu \mathrm{g} / \mathrm{l}$ & 12.7 & 12.2 & $7.75-17.6$ & Acceptable \\
\hline 4-Methyl-2-pentanone (MIBK) & $\mu g / l$ & $<10.0$ & 0 & NR & Acceptable \\
\hline Styrene & $\mu g / l$ & $<2.00$ & 0 & NR & Acceptable \\
\hline 1,1,1,2-Tetrachloroethane & $\mu \mathrm{g} / \mathrm{l}$ & $<2.00$ & 0 & NR & Acceptable \\
\hline 1,1,2,2-Tetrachloroethane & $\mu \mathrm{g} / \mathrm{l}$ & 109 & 84.7 & $49.6-118$ & Acceptable \\
\hline Tetrachloroethylene & $\mu g / l$ & 44.8 & 41.7 & $27.6-53.5$ & Acceptable \\
\hline Toluene & $\mu g / l$ & 18.5 & 16.1 & $11.3-20.6$ & Acceptable \\
\hline 1,1,1-Trichloroethane & $\mu g / l$ & 28.7 & 26.2 & $17.1-34.5$ & Acceptable \\
\hline 1,1,2-Trichloroethane & $\mu g / l$ & 47.8 & 39.3 & $27.2-50.9$ & Acceptable \\
\hline Trichloroethylene & $\mu g / l$ & 54.9 & 50.9 & $33.0-65.8$ & Acceptable \\
\hline Trichlorofluoromethane & $\mu g / l$ & 49.8 & 44 & $11.6-75.5$ & Acceptable \\
\hline 1,2,3-Trichloropropane & $\mu g / l$ & $<2.00$ & 0 & NR & Acceptable \\
\hline Vinyl acetate & $\mu \mathrm{g} / \mathrm{l}$ & $<10.0$ & 0 & NR & Acceptable \\
\hline Vinyl chloride & $\mu g / l$ & $<2.00$ & 0 & NR & Acceptable \\
\hline Xylenes, total & $\mu \mathrm{g} / \mathrm{l}$ & 147 & 127 & $72.7-171$ & Acceptable \\
\hline
\end{tabular}

${ }^{a}$ Not Reported

${ }^{\mathrm{b}}$ Check for Error indicates result is above the warning limit, but within the acceptance limit.

Table 8.16 - Environmental Resource Associates $®$ Assessment of Trace Analysis, Inc., WP-76, July 19, 2001

\begin{tabular}{lccccc}
\hline \multicolumn{1}{c}{ Parameter } & Units & $\begin{array}{c}\text { Reported } \\
\text { Value }\end{array}$ & $\begin{array}{c}\text { Assigned } \\
\text { Value }\end{array}$ & $\begin{array}{c}\text { Acceptance } \\
\text { Limits }\end{array}$ & $\begin{array}{c}\text { Performance } \\
\text { Evaluation }\end{array}$ \\
\hline $\mathrm{pH}$ & $\mathrm{S} . \mathrm{U}$. & 5.91 & 5.9 & $5.77-6.04$ & Acceptable \\
Cyanide & $\mathrm{mg} / \mathrm{l}$ & 0.333 & 0.556 & $0.384-0.717$ & Not Acceptable \\
Phenolics, total & $\mathrm{mg} / \mathrm{l}$ & 0.182 & 0.175 & $0.0886-0.261$ & Acceptable \\
Grease \& Oil (Gravimeteric) & $\mathrm{mg} / \mathrm{l}$ & 20.8 & 21 & $12.3-25.9$ & Acceptable \\
Total Residual Chlorine & $\mathrm{mg} / \mathrm{l}$ & 3.58 & 3.44 & $2.83-4.05$ & Acceptable \\
Mercury & $\mu \mathrm{g} / \mathrm{l}$ & 3.73 & 4.27 & $3.11-5.42$ & Acceptable \\
Hexavalent Chromium & $\mu \mathrm{g} / \mathrm{l}$ & 191 & 187 & $152-215$ & Acceptable \\
Minerals & & & & & \\
\hline Total solids at $105^{\circ} \mathrm{C}$ & $\mathrm{mg} / \mathrm{l}$ & 224 & 255 & $217-291$ & Acceptable \\
Total Dissolved Solids & $\mathrm{mg} / \mathrm{l}$ & 225 & 240 & $178-302$ & Acceptable \\
Conductivity at $25^{\circ} \mathrm{C}$ & $\mu \mathrm{mhos}$ & 336 & 338 & $312-364$ & Acceptable \\
Alkalinity as CaCO3 & $\mathrm{mg} / \mathrm{l}$ & 60 & 56.9 & $50.7-63.4$ & Acceptable \\
Chloride & $\mathrm{mg} / \mathrm{l}$ & 51.4 & 54.7 & $48.9-60.1$ & Acceptable \\
Fluoride & $\mathrm{mg} / \mathrm{l}$ & 2.7 & 2.95 & $2.57-3.29$ & Acceptable \\
Potassium & $\mathrm{mg} / \mathrm{l}$ & 15.1 & 15.1 & $12.9-17.4$ & Acceptable \\
Sodium & $\mathrm{mg} / \mathrm{l}$ & 49.4 & 61.6 & $55.6-67.7$ & Not Acceptable
\end{tabular}


Table 8.16 - Environmental Resource Associates ${ }^{\circledR}$ Assessment of Trace Analysis, Inc., WP-76, July 19, 2001

\begin{tabular}{|c|c|c|c|c|c|}
\hline Parameter & Units & $\begin{array}{c}\text { Reported } \\
\text { Value }\end{array}$ & $\begin{array}{l}\text { Assigned } \\
\text { Value }\end{array}$ & $\begin{array}{c}\text { Acceptance } \\
\text { Limits }\end{array}$ & $\begin{array}{c}\text { Performance } \\
\text { Evaluation }\end{array}$ \\
\hline Sulfate & $\mathrm{mg} / \mathrm{l}$ & 10.1 & 11.1 & $8.03-13.9$ & Acceptable \\
\hline \multicolumn{6}{|l|}{ Hardness } \\
\hline Total suspended solids & $\mathrm{mg} / \mathrm{l}$ & 41 & 45 & $33.7-48.2$ & Acceptable \\
\hline Calcium & $\mathrm{mg} / \mathrm{l}$ & 27.1 & 27.2 & $24.1-31.0$ & Acceptable \\
\hline Magnesium & $\mathrm{mg} / \mathrm{l}$ & 21.5 & 20.9 & $18.3-23.4$ & Acceptable \\
\hline Calcium hardness as $\mathrm{CaCO}_{3}$ & $\mathrm{mg} / \mathrm{l}$ & $N R^{a}$ & 67.9 & $48.8-90.5$ & \\
\hline Total hardness as $\mathrm{CaCO}_{3}$ & $\mathrm{mg} / \mathrm{l}$ & 156 & 154 & $140-169$ & Acceptable \\
\hline \multicolumn{6}{|l|}{ Demand } \\
\hline BOD & $\mathrm{mg} / \mathrm{l}$ & 108 & 107 & $54.3-161$ & Acceptable \\
\hline CBOD & $\mathrm{mg} / \mathrm{l}$ & 67 & 92.4 & $41.5-143$ & Acceptable \\
\hline COD & $\mathrm{mg} / \mathrm{l}$ & 185 & 174 & $134-198$ & Acceptable \\
\hline TOC & $\mathrm{mg} / \mathrm{l}$ & 84.8 & 68.7 & $57.4-79.0$ & Not Acceptable \\
\hline \multicolumn{6}{|l|}{ Nutrients } \\
\hline Ammonia as $\mathrm{N}$ & $\mathrm{mg} / \mathrm{l}$ & 3.53 & 3.78 & $2.87-4.67$ & Acceptable \\
\hline Nitrate as $\mathrm{N}$ & $\mathrm{mg} / \mathrm{l}$ & 11.8 & 11.9 & $9.42-14.1$ & Acceptable \\
\hline Ortho-phosphate as $\mathrm{P}$ & $\mathrm{mg} / \mathrm{l}$ & 1.24 & 1.27 & $1.07-1.48$ & Acceptable \\
\hline Total phosphorus as $\mathrm{P}$ & $\mathrm{mg} / \mathrm{l}$ & 1.51 & 1.43 & $1.08-1.71$ & Acceptable \\
\hline Total kjeldahl nitrogen as $\mathrm{N}$ & $\mathrm{mg} / \mathrm{l}$ & 17.9 & 23.7 & $17.4-29.2$ & Check for Error \\
\hline \multicolumn{6}{|l|}{ Trace Metals } \\
\hline Aluminum & $\mu g / l$ & 1240 & 1190 & $1020-1360$ & Acceptable \\
\hline Antimony & $\mu \mathrm{g} / \mathrm{l}$ & 804 & 733 & $518-880$ & Acceptable \\
\hline Arsenic & $\mu g / l$ & 693 & 621 & $521-727$ & Acceptable \\
\hline Barium & $\mu g / l$ & 2080 & 2070 & $1760-2340$ & Acceptable \\
\hline Beryllium & $\mu g / l$ & 46 & 47 & $38.6-53.3$ & Acceptable \\
\hline Boron & $\mu g / l$ & 630 & 724 & $517-931$ & Acceptable \\
\hline Cadmium & $\mu \mathrm{g} / \mathrm{l}$ & 628 & 658 & $562-747$ & Acceptable \\
\hline Chromium & $\mu \mathrm{g} / \mathrm{l}$ & 287 & 286 & $248-325$ & Acceptable \\
\hline Cobalt & $\mu g / l$ & 530 & 519 & $456-582$ & Acceptable \\
\hline Copper & $\mu g / l$ & 660 & 652 & $592-716$ & Acceptable \\
\hline Iron & $\mu g / l$ & 2890 & 2930 & $2600-3300$ & Acceptable \\
\hline Lead & $\mu g / l$ & 1450 & 1450 & $1270-1620$ & Acceptable \\
\hline Manganese & $\mu g / l$ & 2740 & 2690 & $2420-2990$ & Acceptable \\
\hline Molybdenum & $\mu g / l$ & 270 & 279 & $238-320$ & Acceptable \\
\hline Nickel & $\mu \mathrm{g} / \mathrm{l}$ & 1000 & 988 & $894-1100$ & Acceptable \\
\hline Selenium & $\mu \mathrm{g} / \mathrm{l}$ & 1210 & 1210 & $963-1400$ & Acceptable \\
\hline Silver & $\mu g / l$ & 214 & 213 & $182-244$ & Acceptable \\
\hline Strontium & $\mu g / l$ & NR & 161 & $137-185$ & NR \\
\hline Thallium & $\mu g / l$ & 101 & 191 & $152-224$ & Not Acceptable \\
\hline Vanadium & $\mu \mathrm{g} / \mathrm{l}$ & 1860 & 1850 & $1670-2030$ & Acceptable \\
\hline Zinc & $\mu g / l$ & 624 & 614 & $543-692$ & Acceptable \\
\hline \multicolumn{6}{|l|}{ PCBs in $\mathrm{H}_{2} \mathrm{O}$ (Standard \#1) } \\
\hline Aroclor $1016 / 1242$ & $\mu g / l$ & 2.7 & 5.79 & $1.84-7.99$ & Check for Error \\
\hline Aroclor 1221 & $\mu \mathrm{g} / \mathrm{l}$ & NR & 0 & NR & Acceptable \\
\hline Aroclor 1232 & $\mu g / l$ & NR & 0 & NR & Acceptable \\
\hline Aroclor 1248 & $\mu g / l$ & NR & 0 & NR & Acceptable \\
\hline
\end{tabular}


Table 8.16 - Environmental Resource Associates ${ }^{\circledR}$ Assessment of Trace Analysis, Inc., WP-76, July 19, 2001

\begin{tabular}{|c|c|c|c|c|c|}
\hline Parameter & Units & $\begin{array}{l}\text { Reported } \\
\text { Value }\end{array}$ & $\begin{array}{l}\text { Assigned } \\
\text { Value }\end{array}$ & $\begin{array}{l}\text { Acceptance } \\
\text { Limits }\end{array}$ & $\begin{array}{l}\text { Performance } \\
\text { Evaluation }\end{array}$ \\
\hline Aroclor 1254 & $\mu \mathrm{g} / \mathrm{l}$ & NR & 0 & NR & Acceptable \\
\hline Aroclor 1260 & $\mu g / l$ & NR & 0 & NR & Acceptable \\
\hline \multicolumn{6}{|l|}{ PCBs in $\mathrm{H}_{2} \mathrm{O}$ (Standard \#2) } \\
\hline Aroclor $1016 / 1242$ & $\mu \mathrm{g} / \mathrm{l}$ & NR & 0 & NR & Acceptable \\
\hline Aroclor 1221 & $\mu g / l$ & NR & 0 & NR & Acceptable \\
\hline Aroclor 1232 & $\mu g / l$ & NR & 0 & NR & Acceptable \\
\hline Aroclor 1248 & $\mu \mathrm{g} / \mathrm{l}$ & NR & 0 & NR & Acceptable \\
\hline Aroclor 1254 & $\mu g / l$ & NR & 0 & NR & Acceptable \\
\hline Aroclor 1260 & $\mu g / l$ & 0.8 & 3.52 & $1.82-4.62$ & Not Acceptable \\
\hline \multicolumn{6}{|l|}{ PCBs in Oil (Standard \#1) } \\
\hline Aroclor 1016/1242 & $\mathrm{mg} / \mathrm{Kg}$ & NR & 0 & NR & Acceptable \\
\hline Aroclor 1254 & $\mathrm{mg} / \mathrm{Kg}$ & 9.29 & 29.9 & $3.67-44.9$ & Check for Error \\
\hline Aroclor 1260 & $\mathrm{mg} / \mathrm{Kg}$ & NR & 0 & NR & Acceptable \\
\hline \multicolumn{6}{|l|}{ PCBs in Oil (Standard \#2) } \\
\hline Aroclor 1016/1242 & $\mathrm{mg} / \mathrm{Kg}$ & 20.1 & 41.7 & $7.72-55.8$ & Acceptable \\
\hline Aroclor 1254 & $\mathrm{mg} / \mathrm{Kg}$ & NR & 0 & NR & Acceptable \\
\hline Aroclor 1260 & $\mathrm{mg} / \mathrm{Kg}$ & NR & 0 & NR & Acceptable \\
\hline \multicolumn{6}{|l|}{$\underline{\text { Volatiles }}$} \\
\hline Acetone & $\mu g / l$ & $<10.0$ & 0 & NR & Acceptable \\
\hline Acetonitrile & $\mu g / l$ & NR & 0 & NR & No Evaluation \\
\hline Acrylonitrile & $\mu g / l$ & $<1.00$ & 0 & NR & Acceptable \\
\hline Acrolein & $\mu g / l$ & NR & 0 & NR & No Evaluation \\
\hline Benzene & $\mu g / l$ & 35.1 & 30.8 & $22.0-39.9$ & Acceptable \\
\hline Bromodichloromethane & $\mu \mathrm{g} / \mathrm{l}$ & 17.6 & 15.7 & $10.9-20.6$ & Acceptable \\
\hline Bromoform & $\mu g / l$ & 50.6 & 44.9 & $29.1-61.5$ & Acceptable \\
\hline Bromomethane & $\mu g / l$ & $<1.00$ & 0 & NR & Acceptable \\
\hline 2-Butanone (MEK) & $\mu \mathrm{g} / \mathrm{l}$ & $<5.00$ & 0 & NR & Acceptable \\
\hline Carbon disulfide & $\mu g / l$ & $<1.00$ & 0 & NR & Acceptable \\
\hline Carbon tetrachloride & $\mu g / l$ & 50.9 & 44.3 & $27.4-62.5$ & Acceptable \\
\hline Chlorobenzene & $\mu \mathrm{g} / \mathrm{l}$ & 17 & 16.2 & $12.0-20.4$ & Acceptable \\
\hline Chlorodibromomethane & $\mu g / l$ & 22.1 & 21.5 & $14.2-28.5$ & Acceptable \\
\hline Chloroethane & $\mu g / l$ & $<1.00$ & 0 & NR & Acceptable \\
\hline 2-Chloroethylvinylether & $\mu \mathrm{g} / \mathrm{l}$ & $<5.00$ & 0 & NR & Acceptable \\
\hline Chloroform & $\mu g / l$ & 61.7 & 53.7 & $37.3-68.8$ & Acceptable \\
\hline Chloromethane & $\mu g / l$ & $<1.00$ & 0 & NR & Acceptable \\
\hline DBCP & $\mu g / l$ & $<5.00$ & 0 & NR & Acceptable \\
\hline 1,2-Dibromoethane (EDB) & $\mu g / l$ & $<1.00$ & 0 & NR & Acceptable \\
\hline Dibromomethane & $\mu g / l$ & $<1.00$ & 0 & NR & Acceptable \\
\hline 1,2-Dichlorobenzene & $\mu g / l$ & 36.6 & 33.9 & $23.8-43.1$ & Acceptable \\
\hline 1,3-Dichlorobenzene & $\mu g / l$ & 16.2 & 16.3 & $11.2-20.7$ & Acceptable \\
\hline 1,4-Dichlorobenzene & $\mu g / l$ & 55.9 & 48.4 & $33.3-62.4$ & Acceptable \\
\hline Dichlorodifluoromethane & $\mu g / l$ & $<1.00$ & 0 & NR & Acceptable \\
\hline 1,1-Dichloroethane & $\mu g / l$ & $<1.00$ & 0 & NR & Acceptable \\
\hline 1,2-Dichloroethane & $\mu g / l$ & 49.5 & 44.7 & $30.9-59.6$ & Acceptable \\
\hline 1,1-Dichloroethylene & $\mu g / l$ & 100 & 86.9 & $48.3-132$ & Acceptable \\
\hline
\end{tabular}




\section{Waste Isolation Pilot Plant 2001 Site Environmental Report DOE/WIPP 02-2225}

Table 8.16 - Environmental Resource Associates ${ }^{\circledR}$ Assessment of Trace Analysis, Inc., WP-76, July 19, 2001

\begin{tabular}{|c|c|c|c|c|c|}
\hline Parameter & Units & $\begin{array}{c}\text { Reported } \\
\text { Value }\end{array}$ & $\begin{array}{l}\text { Assigned } \\
\text { Value }\end{array}$ & $\begin{array}{l}\text { Acceptance } \\
\text { Limits }\end{array}$ & $\begin{array}{l}\text { Performance } \\
\text { Evaluation }\end{array}$ \\
\hline cis-1,2-Dichloroethylene & $\mu g / l$ & 2.01 & 0 & NR & Not Acceptable \\
\hline trans-1,2-Dichloroethylene & $\mu g / l$ & 110 & 94.1 & $59.5-129$ & Acceptable \\
\hline 1,2-Dichloropropane & $\mu \mathrm{g} / \mathrm{l}$ & 54.2 & 49.7 & $34.2-62.9$ & Acceptable \\
\hline cis-1,3-Dichloropropylene & $\mu \mathrm{g} / \mathrm{l}$ & 2.82 & 0.911 & $0.00-2.59$ & Not Acceptable \\
\hline trans-1,3-Dichloropropylene & $\mu g / l$ & 32.3 & 41.4 & $14.9-61.2$ & Acceptable \\
\hline Ethylbenzene & $\mu g / l$ & 52.9 & 47.3 & $31.6-61.8$ & Acceptable \\
\hline 2-Hexanone & $\mu \mathrm{g} / \mathrm{l}$ & $<5.00$ & 0 & NR & Acceptable \\
\hline Methylene chloride & $\mu g / l$ & 19.5 & 19.1 & $12.1-26.9$ & Acceptable \\
\hline 4-Methyl-2-pentanone (MIBK) & $\mu g / l$ & $<5.00$ & 0 & NR & Acceptable \\
\hline Styrene & $\mu \mathrm{g} / \mathrm{l}$ & $<1.00$ & 0 & NR & Acceptable \\
\hline 1,1,1,2-Tetrachloroethane & $\mu g / l$ & $<1.00$ & 0 & NR & Acceptable \\
\hline 1,1,2,2-Tetrachloroethane & $\mu \mathrm{g} / \mathrm{l}$ & 67.5 & 62.4 & $36.4-87.2$ & Acceptable \\
\hline Tetrachloroethylene & $\mu g / l$ & 53.1 & 66.1 & $43.8-84.5$ & Acceptable \\
\hline Toluene & $\mu g / l$ & 57.7 & 50.5 & $36.3-63.0$ & Acceptable \\
\hline 1,1,1-Trichloroethane & $\mu \mathrm{g} / \mathrm{l}$ & 27.5 & 26.9 & $17.6-35.5$ & Acceptable \\
\hline 1,1,2-Trichloroethane & $\mu g / l$ & 63.9 & 58.2 & $39.9-75.5$ & Acceptable \\
\hline Trichloroethylene & $\mu g / l$ & 29.9 & 29 & $18.9-37.6$ & Acceptable \\
\hline Trichlorofluoromethane & $\mu g / l$ & 69.8 & 65.3 & $14.0-114$ & Acceptable \\
\hline 1,2,3-Trichloropropane & $\mu \mathrm{g} / \mathrm{l}$ & $<1.00$ & 0 & NR & Acceptable \\
\hline Vinyl acetate & $\mu g / l$ & NR & 0 & NR & No Evaluation \\
\hline Vinyl chloride & $\mu g / l$ & $<1.00$ & 0 & NR & Acceptable \\
\hline Xylenes, total & $\mu g / l$ & 133 & 116 & $66.3-156$ & Acceptable \\
\hline \multicolumn{6}{|l|}{$\underline{\text { Acids }}$} \\
\hline Benzoic acid & $\mu g / l$ & $<5.00$ & 0 & NR & Acceptable \\
\hline 4-Chloro-3-methylphenol & $\mu \mathrm{g} / \mathrm{l}$ & 128 & 114 & $44.4-147$ & Acceptable \\
\hline 2-Chlorophenol. & $\mu g / l$ & 56 & 65.4 & $20.1-82.9$ & Acceptable \\
\hline 2,4-Dichlorophenol & $\mu g / l$ & 122 & 112 & $40.4-135$ & Acceptable \\
\hline 2,6-Dichlorophenol & $\mu \mathrm{g} / \mathrm{l}$ & $<5.00$ & 0 & NR & Acceptable \\
\hline 2,4-Dimethylphenol & $\mu g / l$ & 63.7 & 64.9 & $12.2-86.2$ & Acceptable \\
\hline 4,6-Dinitro-2-methylphenol & $\mu g / l$ & $<5.00$ & 0 & NR & Acceptable \\
\hline 2,4-Dinitrophenol & $\mu g / l$ & 78.9 & 92.1 & $0.00-127$ & Acceptable \\
\hline 2-Methlyphenol & $\mu g / l$ & $<5.00$ & 0 & NR & Acceptable \\
\hline 3-Methylphenol & $\mu g / l$ & NR & 0 & NR & No Evaluation \\
\hline 4-Methylphenol & $\mu g / l$ & $<5.00$ & 0 & NR & Acceptable \\
\hline 2-Nitrophenol & $\mu \mathrm{g} / \mathrm{l}$ & 27 & 27.6 & $9.16-35.3$ & Acceptable \\
\hline 3-Nitrophenol & $\mu g / l$ & NR & 0 & $N R$ & No Evaluation \\
\hline 4-Nitrophenol & $\mu g / l$ & $<5.00$ & 33.1 & $0.00-52.5$ & Acceptable \\
\hline Pentachlorophenol & $\mu g / l$ & 102 & 112 & $29.1-155$ & Acceptable \\
\hline Phenol & $\mu g / l$ & 34.3 & 95.1 & $0.00-129$ & Acceptable \\
\hline 2,4,5-Trichlorophenol & $\mu \mathrm{g} / \mathrm{l}$ & 101 & 87.3 & $35.1-111$ & Acceptable \\
\hline 2,4,6-Trichlorophenol & $\mu g / l$ & 94.5 & 88.3 & $29.4-117$ & Acceptable \\
\hline \multicolumn{6}{|l|}{ Base Neturals } \\
\hline Acenaphthene & $\mu g / l$ & 97.5 & 106 & $39.6-135$ & Acceptable \\
\hline Acenaphthylene & $\mu \mathrm{g} / \mathrm{l}$ & 32.2 & 30.6 & $11.4-38.9$ & Acceptable \\
\hline Aniline & $\mu \mathrm{g} / \mathrm{l}$ & $<5.00$ & 0 & NR & Acceptable \\
\hline
\end{tabular}


Table 8.16 - Environmental Resource Associates ${ }^{\circledR}$ Assessment of Trace Analysis, Inc., WP-76, July 19, 2001

\begin{tabular}{|c|c|c|c|c|c|}
\hline Parameter & Units & $\begin{array}{l}\text { Reported } \\
\text { Value }\end{array}$ & $\begin{array}{l}\text { Assigned } \\
\text { Value }\end{array}$ & $\begin{array}{c}\text { Acceptance } \\
\text { Limits }\end{array}$ & $\begin{array}{c}\text { Performance } \\
\text { Evaluation }\end{array}$ \\
\hline Anthracene & $\mu g / l$ & 89 & 0 & NR & Not Acceptable \\
\hline Benzidine & $\mu g / l$ & $<5.00$ & 0 & NR & Acceptable \\
\hline Benzo(a)anthracene & $\mu \mathrm{g} / \mathrm{l}$ & 131 & 96.5 & $49.2-119$ & Not Acceptable \\
\hline Benzo(b)fluoranthene & $\mu g / l$ & 26.2 & 26.2 & $11.9-34.5$ & Acceptable \\
\hline Benzo(k)fluoranthene & $\mu g / l$ & 30.7 & 30.3 & $6.61-47.2$ & Acceptable \\
\hline Benzo(g,h,i)perylene & $\mu g / l$ & $<5.00$ & 0 & NR & Acceptable \\
\hline Benzo(a)pyrene & $\mu g / l$ & 32.3 & 33.8 & $5.22-45.0$ & Acceptable \\
\hline Benzyl alcohol & $\mu g / l$ & $<5.00$ & 0 & NR & Acceptable \\
\hline 4-Bromophenyl-phenylether & $\mu g / l$ & 124 & 111 & $47.5-142$ & Acceptable \\
\hline Butylbenzylphthalate & $\mu g / l$ & 144 & 134 & $0.00-212$ & Acceptable \\
\hline Carbazole & $\mu \mathrm{g} / \mathrm{l}$ & NR & 0 & NR & No Evaluation \\
\hline 4-Chloroaniline & $\mu g / l$ & $<5.00$ & 0 & NR & Acceptable \\
\hline bis(2-Chloroethoxy)methane & $\mu g / l$ & $<5.00$ & 0 & NR & Acceptable \\
\hline bis(2-Chloroethyl)ether & $\mu g / l$ & 94.5 & 113 & $30.5-138$ & Acceptable \\
\hline bis(2-Chloroisopropyl)ether & $\mu \mathrm{g} / \mathrm{l}$ & $<5.00$ & 0 & NR & Acceptable \\
\hline 1-Chloronaphthalene & $\mu g / l$ & $<5.00$ & 0 & NR & Acceptable \\
\hline 2-Chloronaphthalene & $\mu g / l$ & 38.6 & 45.6 & $17.7-55.5$ & Acceptable \\
\hline 4-Chlorophenyl-phenylether & $\mu g / l$ & 155 & 145 & $51.2-185$ & Acceptable \\
\hline Chrysene & $\mu g / l$ & 52.8 & 36.7 & $16.6-47.2$ & Not Acceptable \\
\hline Dibenz(a,h)anthracene & $\mu g / l$ & $<5.00$ & 0 & NR & Acceptable \\
\hline Dibenzofuran & $\mu g / l$ & $<5.00$ & 0 & NR & Acceptable \\
\hline Di-n-butylphthalate & $\mu g / l$ & 85.7 & 78.3 & $14.8-111$ & Acceptable \\
\hline 1,2-Dichlorobenzene & $\mu g / l$ & $<5.00$ & 0 & NR & Acceptable \\
\hline 1,3-Dichlorobenzene & $\mu g / l$ & $<5.00$ & 0 & NR & Acceptable \\
\hline 1,4-Dichlorobenzene & $\mu g / l$ & $<5.00$ & 0 & NR & Acceptable \\
\hline 3,3'-Dichlorobenzidine & $\mu g / l$ & $<5.00$ & 0 & NR & Acceptable \\
\hline Diethylphthalate & $\mu g / l$ & 119 & 108 & $0.00-165$ & Acceptable \\
\hline Dimethlyphthalate & $\mu \mathrm{g} / \mathrm{l}$ & 111 & 101 & $0.00-155$ & Acceptable \\
\hline 2,4-Dinitrotoluene & $\mu g / l$ & 34 & 27.7 & $7.23-35.9$ & Acceptable \\
\hline 2,6-Dinitrotoulene & $\mu g / l$ & 85.5 & 70.8 & $27.1-91.7$ & Acceptable \\
\hline Di-n-octylphthalate & $\mu \mathrm{g} / \mathrm{l}$ & $<5.00$ & 80.8 & $13.4-118$ & Not Acceptable \\
\hline bis(2-ethylhexyl)phthalate & $\mu g / l$ & 59.1 & 46.6 & $16.4-67.2$ & Acceptable \\
\hline Fluoranthene & $\mu g / l$ & 27.3 & 23.5 & $12.8-29.8$ & Acceptable \\
\hline Fluorene & $\mu g / l$ & 20.3 & 17.6 & $7.65-23.7$ & Acceptable \\
\hline Hexachlorobenzene & $\mu g / l$ & 22 & 19.1 & $8.24-25.1$ & Acceptable \\
\hline Hexachlorobutadiene & $\mu g / l$ & $<5.00$ & 0 & NR & Acceptable \\
\hline Hexachlorocyclopentadiene & $\mu g / l$ & $<5.00$ & 0 & NR & Acceptable \\
\hline Hexachloroethane & $\mu g / l$ & 25.9 & 46.6 & $6.28-57.5$ & Acceptable \\
\hline Indeno(1,2,3-cd)pyrene & $\mu g / l$ & $<5.00$ & 0 & NR & Acceptable \\
\hline Isophorone & $\mu g / l$ & 49.3 & 46.2 & $18.2-60.4$ & Acceptable \\
\hline 1-Methylnaphthalene & $\mu g / l$ & $<5.00$ & 0 & NR & Acceptable \\
\hline 2-Methylnaphthalene & $\mu g / l$ & $<5.00$ & 0 & NR & Acceptable \\
\hline Naphthalene & $\mu g / l$ & 71.2 & 84.4 & $22.2-110$ & Acceptable \\
\hline 2-Nitroaniline & $\mu g / l$ & $<5.00$ & 0 & NR & Acceptable \\
\hline 3-Nitroaniline & $\mu g / l$ & $<5.00$ & 0 & NR & Acceptable \\
\hline
\end{tabular}




\section{Waste Isolation Pilot Plant 2001 Site Environmental Report DOE/WIPP 02-2225}

Table 8.16 - Environmental Resource Associates ${ }^{\circledR}$ Assessment of Trace Analysis, Inc., WP-76, July 19, 2001

\begin{tabular}{lccccc}
\hline \multicolumn{1}{c}{ Parameter } & Units & $\begin{array}{c}\text { Reported } \\
\text { Value }\end{array}$ & $\begin{array}{c}\text { Assigned } \\
\text { Value }\end{array}$ & $\begin{array}{c}\text { Acceptance } \\
\text { Limits }\end{array}$ & $\begin{array}{c}\text { Performance } \\
\text { Evaluation }\end{array}$ \\
\hline 4-Nitroaniline & $\mu \mathrm{g} / \mathrm{l}$ & $<5.00$ & 0 & $\mathrm{NR}$ & Acceptable \\
Nitrobenzene & $\mu \mathrm{g} / \mathrm{l}$ & $<5.00$ & 0 & $\mathrm{NR}$ & Acceptable \\
N-Nitrosodiethylamine & $\mu \mathrm{g} / \mathrm{l}$ & $\mathrm{NR}$ & 0 & $\mathrm{NR}$ & No Evaluation \\
N-Nitrosodimethylamine & $\mu \mathrm{g} / \mathrm{l}$ & $<5.00$ & 59.8 & $0.00-73.2$ & Acceptable \\
N-Nitrosodiphenylamine & $\mu \mathrm{g} / \mathrm{l}$ & $<5.00$ & 0 & $\mathrm{NR}$ & Acceptable \\
N-Nitroso-di-n-propylamine & $\mu \mathrm{g} / \mathrm{l}$ & $<5.00$ & 0 & $\mathrm{NR}$ & Acceptable \\
Phenanthrene & $\mu \mathrm{g} / \mathrm{l}$ & 89 & 81.3 & $32.6-105$ & Acceptable \\
Pyrene & $\mu \mathrm{g} / \mathrm{l}$ & $<5.00$ & 0 & $\mathrm{NR}$ & Acceptable \\
Pyridine & $\mu \mathrm{g} / \mathrm{l}$ & $<5.00$ & 0 & $\mathrm{NR}$ & Acceptable \\
1,2,4-Trichlorobenzene & $\mu \mathrm{g} / \mathrm{l}$ & 38.8 & 51.6 & $14.8-63.7$ & Acceptable \\
\hline
\end{tabular}

${ }^{\text {a }}$ Not Reported

${ }^{\mathrm{b}}$ Check for Error indicates result is above the warning limit, but within the acceptance limit.

Table 8.17 - Environmental Resource Associates ${ }^{\circledR}$ Assessment of Trace Analysis, Inc., UST-34, June 15, 2001

\begin{tabular}{|c|c|c|c|c|c|}
\hline Parameter & Units & $\begin{array}{c}\text { Reported } \\
\text { Value }\end{array}$ & $\begin{array}{c}\text { Assigned } \\
\text { Value }\end{array}$ & $\begin{array}{c}\text { Acceptance } \\
\text { Limits }\end{array}$ & $\begin{array}{c}\text { Performance } \\
\text { Evaluation }\end{array}$ \\
\hline \multicolumn{6}{|l|}{ Gasoline in Water } \\
\hline Unleaded Gasoline & $\mu \mathrm{g} / \mathrm{l}$ & 3530 & 3910 & $1140-7260$ & Acceptable \\
\hline Benzene & $\mu g / l$ & 23.6 & 18.5 & $4.67-34.1$ & Acceptable \\
\hline Ethylbenzene & $\mu \mathrm{g} / \mathrm{l}$ & 87 & 91.5 & $18.7-148$ & Acceptable \\
\hline Toluene & $\mu \mathrm{g} / \mathrm{l}$ & 236 & 249 & $74.8-365$ & Acceptable \\
\hline Xylenes, total & $\mu \mathrm{g} / \mathrm{l}$ & 446 & 528 & $226-655$ & Acceptable \\
\hline \multicolumn{6}{|l|}{ Diesel in Water } \\
\hline No. 2 Diesel & $\mu g / l$ & 4200 & 3410 & $0.00-5440$ & Acceptable \\
\hline \multicolumn{6}{|l|}{$\underline{\mathrm{TPH}}$ in Water } \\
\hline TPH (gravimetric) & $\mathrm{mg} / \mathrm{bttl}$ & $\mathrm{NR}^{\mathrm{a}}$ & 120 & $28.8-175$ & NR \\
\hline $\mathrm{TPH}(\mathrm{IR})$ & $\mathrm{mg} / \mathrm{bttl}$ & 184 & 144 & $17.5-309$ & Acceptable \\
\hline \multicolumn{6}{|l|}{ BTEX in Water } \\
\hline Benzene & $\mathrm{mg} / \mathrm{l}$ & 59.2 & 58.6 & $34.6-79.6$ & Acceptable \\
\hline Ethylbenzene & $\mathrm{mg} / \mathrm{l}$ & 9.8 & 10 & $4.63-14.1$ & Acceptable \\
\hline Toluene & $\mathrm{mg} / \mathrm{l}$ & 74.9 & 73.9 & $36.1-106$ & Acceptable \\
\hline Xylenes, total & $\mathrm{mg} / \mathrm{l}$ & 197 & 225 & $99.6-332$ & Acceptable \\
\hline
\end{tabular}

${ }^{a}$ Not Reported 
Table 8.18 - Environmental Resource Associates ${ }^{\circledR}$ Pesticides assessment Trace Analysis, Inc., QuiK $^{\text {T M }}$ Response, March 8, 2001

\begin{tabular}{lccccc}
\hline \multicolumn{1}{c}{ Parameter } & Units & $\begin{array}{c}\text { Reported } \\
\text { Value }\end{array}$ & $\begin{array}{c}\text { Assigned } \\
\text { Value }\end{array}$ & $\begin{array}{c}\text { Acceptance } \\
\text { Limits }\end{array}$ & $\begin{array}{c}\text { Performance } \\
\text { Evaluation }\end{array}$ \\
\hline Aldrin & $\mu \mathrm{g} / \mathrm{l}$ & 0.92 & 1.16 & $0.295-1.57$ & Acceptable \\
alpha-BHC & $\mu \mathrm{g} / \mathrm{l}$ & 2.5 & 5.24 & $2.00-7.22$ & Acceptable \\
beta-BHC & $\mu \mathrm{g} / \mathrm{l}$ & 2.5 & 3.01 & $0.983-4.51$ & Acceptable \\
delta-BHC & $\mu \mathrm{g} / \mathrm{l}$ & $<0.0001$ & $<0.100$ & $\mathrm{NR}^{\mathrm{a}}$ & Acceptable \\
gamma-BHC (Lindane) & $\mu \mathrm{g} / \mathrm{l}$ & 2.8 & 6.32 & $2.14-9.10$ & Acceptable \\
alpha-Chlordane & $\mu \mathrm{g} / \mathrm{l}$ & $<0.0001$ & $<0.100$ & $\mathrm{NR}$ & Acceptable \\
gamma-Chlordane & $\mu \mathrm{g} / \mathrm{l}$ & 1.9 & 2.7 & $0.744-4.78$ & Acceptable \\
Chlordane, technical & $\mu \mathrm{g} / \mathrm{l}$ & $\mathrm{NR}$ & $<0.100$ & $\mathrm{NR}$ & Acceptable \\
4,4'-DDD & $\mu \mathrm{g} / \mathrm{l}$ & 1.9 & 2.04 & $0.995-2.85$ & Acceptable \\
4,4'-DDE & $\mu \mathrm{g} / \mathrm{l}$ & 1.1 & 1.05 & $0.490-1.43$ & Acceptable \\
4,4'-DDT & $\mu \mathrm{g} / \mathrm{l}$ & 4 & 5.52 & $2.53-7.46$ & Acceptable \\
Dieldrin & $\mu \mathrm{g} / \mathrm{l}$ & 2.1 & 2.88 & $1.49-3.98$ & Acceptable \\
Endrin & $\mu \mathrm{g} / \mathrm{l}$ & 0.93 & 1.09 & $0.577-1.21$ & Acceptable \\
Endrin aldehyde & $\mu \mathrm{g} / \mathrm{l}$ & $<0.0001$ & $<0.100$ & $\mathrm{NR}$ & Acceptable \\
Endrin ketone & $\mu \mathrm{g} / \mathrm{l}$ & $<0.0001$ & $<0.100$ & $\mathrm{NR}$ & Acceptable \\
Endosulfan I & $\mu \mathrm{g} / \mathrm{l}$ & 1.5 & 2.19 & $0.886-2.95$ & Acceptable \\
Endosulfan II & $\mu \mathrm{g} / \mathrm{l}$ & 2.4 & 3.83 & $0.823-6.09$ & Acceptable \\
Endosulfan sulfate & $\mu \mathrm{g} / \mathrm{l}$ & 6 & 7.77 & $2.02-12.3$ & Acceptable \\
Heptachlor & $\mu \mathrm{g} / \mathrm{l}$ & 1.7 & 2.6 & $0.686-3.62$ & Acceptable \\
Heptachlor epoxide & $\mu \mathrm{g} / \mathrm{l}$ & 1.7 & 2.14 & $1.09-2.75$ & Acceptable \\
Methoxychlor & $\mu \mathrm{g} / \mathrm{l}$ & 5 & 6.39 & $2.42-9.64$ & Acceptable \\
Toxaphene & $\mu \mathrm{g} / \mathrm{l}$ & $\mathrm{NR}$ & $<0.100$ & $\mathrm{NR}$ & Acceptable \\
\hline Not & & & & &
\end{tabular}

${ }^{\text {a }}$ Not Reported

Table 8.19 - Environmental Resource Associates ${ }^{\circledR}$ Assessment of Wastren, May 17, 2001

\begin{tabular}{|c|c|c|c|c|c|}
\hline Parameter & Units & $\begin{array}{l}\text { Reported } \\
\text { Value }\end{array}$ & $\begin{array}{l}\text { Assigned } \\
\text { Value }\end{array}$ & $\begin{array}{l}\text { Acceptance } \\
\text { Limits }\end{array}$ & $\begin{array}{c}\text { Performance } \\
\text { Evaluation }\end{array}$ \\
\hline $\mathrm{pH}$ & S.U. & 8.19 & 8.1 & $7.87-8.33$ & Acceptable \\
\hline \multicolumn{6}{|l|}{ Minerals } \\
\hline Total Dissolved Solids & $\mathrm{mg} / \mathrm{l}$ & 333 & 329 & $248-410$ & Acceptable \\
\hline Chloride & $\mathrm{mg} / \mathrm{l}$ & 103 & 104 & $94.5-113$ & Acceptable \\
\hline Fluoride & mg/l & 2.57 & 2.63 & $2.29-2.94$ & Acceptable \\
\hline Potassium & $\mathrm{mg} / \mathrm{l}$ & 14.1 & 14.3 & $12.2-16.5$ & Acceptable \\
\hline Sodium & $\mathrm{mg} / \mathrm{l}$ & 93.9 & 94.6 & $85.5-103$ & Acceptable \\
\hline Sulfate & $\mathrm{mg} / \mathrm{l}$ & 10.5 & 10.9 & $7.86-13.7$ & Acceptable \\
\hline \multicolumn{6}{|l|}{ Hardness } \\
\hline Total suspended solids & mg/l & 82 & 79.9 & $61.8-86.2$ & Acceptable \\
\hline Calcium & $\mathrm{mg} / \mathrm{l}$ & 90.9 & 86.4 & $77.4-97.7$ & Acceptable \\
\hline Magnesium & $\mathrm{mg} / \mathrm{l}$ & 12.7 & 12.5 & $10.9-14.1$ & Acceptable \\
\hline \multicolumn{6}{|l|}{ Nutrients } \\
\hline Ammonia as $\mathrm{N}$ & $\mathrm{mg} / \mathrm{l}$ & 14.2 & 13 & $10.1-15.8$ & Acceptable \\
\hline Nitrate as $\mathrm{N}$ & $\mathrm{mg} / \mathrm{l}$ & 7.15 & 7.78 & $6.14-9.26$ & Acceptable \\
\hline Ortho-phosphate as $\mathrm{P}$ & mg/l & 5.16 & 3.73 & $3.18-4.31$ & Not Acceptable \\
\hline
\end{tabular}


Table 8.19 - Environmental Resource Associates ${ }^{\circledR}$ Assessment of Wastren, May 17, 2001

\begin{tabular}{|c|c|c|c|c|c|}
\hline Parameter & Units & $\begin{array}{l}\text { Reported } \\
\text { Value }\end{array}$ & $\begin{array}{l}\text { Assigned } \\
\text { Value }\end{array}$ & $\begin{array}{c}\text { Acceptance } \\
\text { Limits }\end{array}$ & $\begin{array}{c}\text { Performance } \\
\text { Evaluation }\end{array}$ \\
\hline \multicolumn{6}{|l|}{ PCBs In Water (Standard \#1) } \\
\hline Aroclor $1016 / 1242$ & $\mu g / l$ & 4.24 & 4.28 & $1.53-5.77$ & Acceptable \\
\hline Aroclor 1221 & $\mu g / l$ & $<1.0$ & 0 & $N R^{a}$ & Acceptable \\
\hline Aroclor 1232 & $\mu g / l$ & $<1.0$ & 0 & NR & Acceptable \\
\hline Aroclor 1248 & $\mu g / l$ & $<1.0$ & 0 & NR & Acceptable \\
\hline Aroclor 1254 & $\mu \mathrm{g} / \mathrm{l}$ & $<1.0$ & 0 & NR & Acceptable \\
\hline Aroclor 1260 & $\mu g / l$ & $<1.0$ & 0 & NR & Acceptable \\
\hline \multicolumn{6}{|l|}{ PCBs In Water (Standard \#2) } \\
\hline Aroclor $1016 / 1242$ & $\mu g / l$ & $<1.0$ & 0 & NR & Acceptable \\
\hline Aroclor 1221 & $\mu g / l$ & $<1.0$ & 0 & NR & Acceptable \\
\hline Aroclor 1232 & $\mu \mathrm{g} / \mathrm{l}$ & $<1.0$ & 0 & NR & Acceptable \\
\hline Aroclor 1248 & $\mu g / l$ & 4.63 & 4.99 & $2.07-7.05$ & Acceptable \\
\hline Aroclor 1254 & $\mu g / l$ & $<1.0$ & 0 & NR & Acceptable \\
\hline Aroclor 1260 & $\mu \mathrm{g} / \mathrm{l}$ & $<1.0$ & 0 & NR & Acceptable \\
\hline \multicolumn{6}{|l|}{ PCBs In Oil (Standard \#1) } \\
\hline Aroclor $1016 / 1242$ & $\mathrm{mg} / \mathrm{Kg}$ & $<9.9$ & 0 & NR & Acceptable \\
\hline Aroclor 1254 & $\mathrm{mg} / \mathrm{Kg}$ & 29.8 & 40.6 & $6.51-59.0$ & Acceptable \\
\hline Aroclor 1260 & $\mathrm{mg} / \mathrm{Kg}$ & $<9.9$ & 0 & NR & Acceptable \\
\hline \multicolumn{6}{|l|}{ PCBs In Oil (Standard \#2) } \\
\hline Aroclor $1016 / 1242$ & $\mathrm{mg} / \mathrm{Kg}$ & $<9.9$ & 0 & NR & Acceptable \\
\hline Aroclor 1254 & $\mathrm{mg} / \mathrm{Kg}$ & $<9.9$ & 0 & NR & Acceptable \\
\hline Aroclor 1260 & $\mathrm{mg} / \mathrm{Kg}$ & 22.1 & 32 & $5.87-45.3$ & Acceptable \\
\hline \multicolumn{6}{|l|}{$\underline{\text { Volatiles }}$} \\
\hline Acetone & $\mu \mathrm{g} / \mathrm{l}$ & 0 & 0 & NR & Acceptable \\
\hline Acetonitrile & $\mu g / l$ & 0 & 0 & NR & Acceptable \\
\hline Acrylonitrile & $\mu g / l$ & 0 & 0 & NR & Acceptable \\
\hline Acrolein & $\mu \mathrm{g} / \mathrm{l}$ & 0 & 0 & NR & Acceptable \\
\hline Benzene & $\mu g / l$ & 47.1 & 44.3 & $31.9-57.1$ & Acceptable \\
\hline Bromodichloromethane & $\mu g / l$ & 48.5 & 45.4 & $32.2-59.1$ & Acceptable \\
\hline Bromoform & $\mu g / l$ & 33.4 & 29.9 & $19.0-41.1$ & Acceptable \\
\hline Bromomethane & $\mu g / l$ & 0 & 0 & NR & Acceptable \\
\hline 2-Butanone (MEK) & $\mu \mathrm{g} / \mathrm{l}$ & 0 & 0 & NR & Acceptable \\
\hline Carbon disulfide & $\mu g / l$ & 0 & 0 & NR & Acceptable \\
\hline Carbon tetrachloride & $\mu g / l$ & 27.8 & 29.1 & $18.2-41.1$ & Acceptable \\
\hline Chlorobenzene & $\mu g / l$ & 65.5 & 60.5 & $42.5-77.1$ & Acceptable \\
\hline Chlorodibromomethane & $\mu \mathrm{g} / \mathrm{l}$ & 12.2 & 11.9 & $7.79-15.7$ & Acceptable \\
\hline Chloroethane & $\mu g / l$ & 0 & 0 & NR & Acceptable \\
\hline 2-Chloroethylvinylether & $\mu g / l$ & 0 & 0 & NR & Acceptable \\
\hline Chloroform & $\mu g / l$ & 37.5 & 36.7 & $25.6-47.2$ & Acceptable \\
\hline Chloromethane & $\mu \mathrm{g} / \mathrm{l}$ & 0 & 0 & NR & Acceptable \\
\hline $\mathrm{DBCP}$ & $\mu g / l$ & 0 & 0 & NR & Acceptable \\
\hline 1,2-Dibromoethane (EDB) & $\mu g / l$ & 0 & 0 & NR & Acceptable \\
\hline Dibromomethane & $\mu g / l$ & 0 & 0 & NR & Acceptable \\
\hline 1,2-Dichlorobenzene & $\mu g / l$ & 58.7 & 53.1 & $37.5-67.0$ & Acceptable \\
\hline 1,3-Dichlorobenzene & $\mu \mathrm{g} / \mathrm{l}$ & 26.5 & 27.4 & $19.2-34.4$ & Acceptable \\
\hline
\end{tabular}


Table 8.19 - Environmental Resource Associates ${ }^{\circledR}$ Assessment of Wastren, May 17, 2001

\begin{tabular}{|c|c|c|c|c|c|}
\hline Parameter & Units & $\begin{array}{c}\text { Reported } \\
\text { Value }\end{array}$ & $\begin{array}{c}\text { Assigned } \\
\text { Value }\end{array}$ & $\begin{array}{c}\text { Acceptance } \\
\text { Limits }\end{array}$ & $\begin{array}{c}\text { Performance } \\
\text { Evaluation }\end{array}$ \\
\hline 1,4-Dichlorobenzene & $\mu \mathrm{g} / \mathrm{l}$ & 62.9 & 58 & $39.9-74.6$ & Acceptable \\
\hline Dichlorodifluoromethane & $\mu \mathrm{g} / \mathrm{l}$ & 0 & 0 & NR & Acceptable \\
\hline 1,1-Dichloroethane & $\mu g / l$ & 0 & 0 & NR & Acceptable \\
\hline 1,2-Dichloroethane & $\mu g / l$ & 13.7 & 13.7 & $9.67-18.8$ & Acceptable \\
\hline 1,1-Dichloroethylene & $\mu g / l$ & 79.6 & 78.8 & $43.6-120$ & Acceptable \\
\hline cis-1,2-Dichloroethylene & $\mu g / l$ & 0 & 0 & NR & Acceptable \\
\hline trans-1,2-Dichloroethylene & $\mu g / l$ & 21.2 & 20.3 & $11.0-29.4$ & Acceptable \\
\hline 1,2-Dichloropropane & $\mu g / l$ & 69.9 & 67.2 & $45.7-85.3$ & Acceptable \\
\hline cis-1,3-Dichloropropylene & $\mu g / l$ & 0 & 1.54 & $0.00-9.46$ & Acceptable \\
\hline trans-1,3-Dichloropropylene & $\mu g / l$ & 90.8 & 70.2 & $23.3-106$ & Acceptable \\
\hline Ethylbenzene & $\mu g / l$ & 27.3 & 26.5 & $17.8-34.5$ & Acceptable \\
\hline 2-Hexanone & $\mu g / l$ & 0 & 0 & NR & Acceptable \\
\hline Methylene chloride & $\mu g / l$ & 65.4 & 63.8 & $40.3-87.6$ & Acceptable \\
\hline 4-Methyl-2-pentanone (MIBK) & $\mu g / l$ & 0 & 0 & NR & Acceptable \\
\hline Styrene & $\mu g / l$ & 0 & 0 & NR & Acceptable \\
\hline 1,1,1,2-Tetrachloroethane & $\mu g / l$ & 0 & 0 & NR & Acceptable \\
\hline 1,1,2,2-Tetrachloroethane & $\mu g / l$ & 63.2 & 53 & $30.8-74.1$ & Acceptable \\
\hline Tetrachloroethylene & $\mu g / l$ & 58.2 & 54.6 & $36.1-69.9$ & Acceptable \\
\hline Toluene & $\mu g / l$ & 41.4 & 37.9 & $27.1-47.5$ & Acceptable \\
\hline 1,1,1-Trichloroethane & $\mu g / l$ & 15.8 & 16.3 & $10.8-21.5$ & Acceptable \\
\hline 1,1,2-Trichloroethane & $\mu g / l$ & 33.4 & 29.1 & $20.4-37.6$ & Acceptable \\
\hline Trichloroethylene & $\mu g / l$ & 18.8 & 14.1 & $9.29-18.4$ & Acceptable \\
\hline Trichlorofluoromethane & $\mu g / l$ & 77.4 & 69.6 & $14.4-121$ & Acceptable \\
\hline 1,2,3-Trichloropropane & $\mu g / l$ & 0 & 0 & NR & Acceptable \\
\hline Vinyl acetate & $\mu g / l$ & 0 & 0 & NR & Acceptable \\
\hline Vinyl chloride & $\mu g / l$ & 0 & 0 & NR & Acceptable \\
\hline Xylenes, total & $\mu g / l$ & 235 & 210 & $121-280$ & Acceptable \\
\hline \multicolumn{6}{|l|}{ Acids } \\
\hline Benzoic acid & $\mu g / l$ & $<10.0$ & 0 & NR & Acceptable \\
\hline 4-Chloro-3-methylphenol & $\mu g / l$ & 137 & 132 & $51.7-170$ & Acceptable \\
\hline 2-Chlorophenol & $\mu g / l$ & 74 & 78.4 & $23.5-99.1$ & Acceptable \\
\hline 2,4-Dichlorophenol & $\mu \mathrm{g} / \mathrm{l}$ & 75.2 & 80.4 & $29.0-98.0$ & Acceptable \\
\hline 2,6-Dichlorophenol & $\mu g / l$ & NR & 0 & NR & Acceptable \\
\hline 2,4-Dimethylphenol & $\mu g / l$ & 82.8 & 99 & $20.6-130$ & Acceptable \\
\hline 4,6-Dinitro-2-methylphenol & $\mu g / l$ & 81.6 & 88.7 & $16.5-121$ & Acceptable \\
\hline 2,4-Dinitrophenol & $\mu g / l$ & 99.1 & 118 & $0.00-156$ & Acceptable \\
\hline 2-Methlyphenol & $\mu \mathrm{g} / \mathrm{l}$ & $<10$ & 0 & NR & Acceptable \\
\hline 3-Methylphenol & $\mu g / l$ & NR & 0 & NR & Acceptable \\
\hline 4-Methylphenol & $\mu g / l$ & $<10$ & 0 & NR & Acceptable \\
\hline 2-Nitrophenol & $\mu g / l$ & 40.4 & 55.2 & $17.1-71.9$ & Acceptable \\
\hline 3-Nitrophenol & $\mu g / l$ & NR & 0 & NR & Acceptable \\
\hline 4-Nitrophenol & $\mu g / l$ & 10.3 & 27.1 & $0.00-44.8$ & Acceptable \\
\hline Pentachlorophenol & $\mu g / l$ & 59.4 & 67.4 & $15.1-93.2$ & Acceptable \\
\hline Phenol & $\mu g / l$ & 37.2 & 85.6 & $0.00-116$ & Acceptable \\
\hline
\end{tabular}


Table 8.19 - Environmental Resource Associates ${ }^{\circledR}$ Assessment of Wastren, May 17, 2001

\begin{tabular}{|c|c|c|c|c|c|}
\hline Parameter & Units & $\begin{array}{c}\text { Reported } \\
\text { Value }\end{array}$ & $\begin{array}{l}\text { Assigned } \\
\text { Value }\end{array}$ & $\begin{array}{c}\text { Acceptance } \\
\text { Limits }\end{array}$ & $\begin{array}{c}\text { Performance } \\
\text { Evaluation }\end{array}$ \\
\hline 2,4,5-Trichlorophenol & $\mu \mathrm{g} / \mathrm{l}$ & 100 & 112 & $42.6-142$ & Acceptable \\
\hline 2,4,6-Trichlorophenol & $\mu \mathrm{g} / \mathrm{l}$ & 40.2 & 48.7 & $17.2-63.6$ & Acceptable \\
\hline \multicolumn{6}{|l|}{ Base Neturals } \\
\hline Acenaphthene & $\mu \mathrm{g} / \mathrm{l}$ & 15 & 18.5 & $8.24-23.7$ & Acceptable \\
\hline Acenaphthylene & $\mu \mathrm{g} / \mathrm{l}$ & $<10.0$ & 0 & NR & Acceptable \\
\hline Aniline & $\mu \mathrm{g} / \mathrm{l}$ & $<10.0$ & 0 & NR & Acceptable \\
\hline Anthracene & $\mu \mathrm{g} / \mathrm{l}$ & 91.5 & 92.6 & $33.6-120$ & Acceptable \\
\hline Benzidine & $\mu \mathrm{g} / \mathrm{l}$ & NR & 0 & NR & Acceptable \\
\hline Benzo(a)anthracene & $\mu \mathrm{g} / \mathrm{l}$ & 98.6 & 91.7 & $46.9-113$ & Acceptable \\
\hline Benzo(b)fluoranthene & $\mu \mathrm{g} / \mathrm{l}$ & 43.2 & 43.7 & $14.5-60.3$ & Acceptable \\
\hline Benzo(k)fluoranthene & $\mu \mathrm{g} / \mathrm{l}$ & $<10.0$ & 0 & NR & Acceptable \\
\hline Benzo(g,h,i)perylene & $\mu \mathrm{g} / \mathrm{l}$ & 27.6 & 27 & $2.14-40.7$ & Acceptable \\
\hline Benzo(a)pyrene & $\mu \mathrm{g} / \mathrm{l}$ & 64.5 & 60.9 & $14.1-79.6$ & Acceptable \\
\hline Benzyl alcohol & $\mu \mathrm{g} / \mathrm{l}$ & $<10.0$ & 0 & NR & Acceptable \\
\hline 4-Bromophenyl-phenylether & $\mu \mathrm{g} / \mathrm{l}$ & 87.7 & 86.8 & $37.8-111$ & Acceptable \\
\hline Butylbenzylphthalate & $\mu \mathrm{g} / \mathrm{l}$ & 138 & 149 & $0.00-235$ & Acceptable \\
\hline Carbazole & $\mu \mathrm{g} / \mathrm{l}$ & $<10.0$ & 0 & NR & Acceptable \\
\hline 4-Chloroaniline & $\mu \mathrm{g} / \mathrm{l}$ & $<10.0$ & 0 & NR & Acceptable \\
\hline bis(2-Chloroethoxy)methane & $\mu \mathrm{g} / \mathrm{l}$ & 38 & 45.2 & $17.6-54.9$ & Acceptable \\
\hline bis(2-Chloroethyl)ether & $\mu \mathrm{g} / \mathrm{l}$ & 138 & 157 & $41.5-189$ & Acceptable \\
\hline bis(2-Chloroisopropyl)ether & $\mu \mathrm{g} / \mathrm{l}$ & $<10.0$ & 0 & NR & Acceptable \\
\hline 1-Chloronaphthalene & $\mu \mathrm{g} / \mathrm{l}$ & NR & 0 & NR & Acceptable \\
\hline 2-Chloronaphthalene & $\mu g / l$ & 107 & 120 & $48.2-136$ & Acceptable \\
\hline 4-Chlorophenyl-phenylether & $\mu \mathrm{g} / \mathrm{l}$ & $<10.0$ & 0 & NR & Acceptable \\
\hline Chrysene & $\mu \mathrm{g} / \mathrm{l}$ & $<10.0$ & 0 & NR & Acceptable \\
\hline Dibenz(a,h)anthracene & $\mu \mathrm{g} / \mathrm{l}$ & 14.1 & 13.9 & $3.41-18.4$ & Acceptable \\
\hline Dibenzofuran & $\mu \mathrm{g} / \mathrm{l}$ & $<10.0$ & 0 & NR & Acceptable \\
\hline Di-n-butylphthalate & $\mu \mathrm{g} / \mathrm{l}$ & 118 & 102 & $15.4-143$ & Acceptable \\
\hline 1,2-Dichlorobenzene & $\mu g / l$ & $<10.0$ & 0 & NR & Acceptable \\
\hline 1,3-Dichlorobenzene & $\mu \mathrm{g} / \mathrm{l}$ & $<10.0$ & 0 & NR & Acceptable \\
\hline 1,4-Dichlorobenzene & $\mu \mathrm{g} / \mathrm{l}$ & $<10.0$ & 0 & NR & Acceptable \\
\hline 3,3'-Dichlorobenzidine & $\mu \mathrm{g} / \mathrm{l}$ & $<10.0$ & 0 & NR & Acceptable \\
\hline Diethylphthalate & $\mu \mathrm{g} / \mathrm{l}$ & 42 & 40.5 & $10.3-61.1$ & Acceptable \\
\hline Dimethlyphthalate & $\mu g / l$ & 54.4 & 53.6 & $2.70-81.8$ & Acceptable \\
\hline 2,4-Dinitrotoluene & $\mu \mathrm{g} / \mathrm{l}$ & 49.1 & 48.9 & $17.1-64.4$ & Acceptable \\
\hline 2,6-Dinitrotoluene & $\mu \mathrm{g} / \mathrm{l}$ & $<10.0$ & 0 & NR & Acceptable \\
\hline Di-n-octylphthalate & $\mu \mathrm{g} / \mathrm{l}$ & 113 & 97 & $14.9-142$ & Acceptable \\
\hline bis(2-ethylhexyl)phthalate & $\mu \mathrm{g} / \mathrm{l}$ & 57.4 & 57.2 & $16.8-82.9$ & Acceptable \\
\hline Fluoranthene & $\mu \mathrm{g} / \mathrm{l}$ & 64.6 & 61 & $27.7-78.5$ & Acceptable \\
\hline Fluorene & $\mu \mathrm{g} / \mathrm{l}$ & $<10.0$ & 0 & NR & Acceptable \\
\hline Hexachlorobenzene & $\mu \mathrm{g} / \mathrm{l}$ & 38.8 & 47.7 & $20.8-61.8$ & Acceptable \\
\hline Hexachlorobutadiene & $\mu \mathrm{g} / \mathrm{l}$ & $<10.0$ & 0 & NR & Acceptable \\
\hline Hexachlorocyclopentadiene & $\mu \mathrm{g} / \mathrm{l}$ & 75.9 & 110 & $0.00-141$ & Acceptable \\
\hline Hexachloroethane & $\mu \mathrm{g} / \mathrm{l}$ & 69.9 & 85.4 & $8.41-108$ & Acceptable \\
\hline Indeno(1,2,3-cd)pyrene & $\mu \mathrm{g} / \mathrm{l}$ & $<10.0$ & 0 & NR & Acceptable \\
\hline
\end{tabular}


Table 8.19 - Environmental Resource Associates $₫$ Assessment of Wastren, May 17, 2001

\begin{tabular}{lccccc}
\hline \multicolumn{1}{c}{ Parameter } & Units & $\begin{array}{c}\text { Reported } \\
\text { Value }\end{array}$ & $\begin{array}{c}\text { Assigned } \\
\text { Value }\end{array}$ & $\begin{array}{c}\text { Acceptance } \\
\text { Limits }\end{array}$ & $\begin{array}{c}\text { Performance } \\
\text { Evaluation }\end{array}$ \\
\hline Isophorone & $\mu \mathrm{g} / \mathrm{l}$ & 115 & 123 & $41.9-164$ & Acceptable \\
1-Methylnaphthalene & $\mu \mathrm{g} / \mathrm{l}$ & $\mathrm{NR}$ & 0 & $\mathrm{NR}$ & Acceptable \\
2-Methylnaphthalene & $\mu \mathrm{g} / \mathrm{l}$ & $<10.0$ & 0 & $\mathrm{NR}$ & Acceptable \\
Naphthalene & $\mu \mathrm{g} / \mathrm{l}$ & 36.8 & 44.9 & $14.0-59.1$ & Acceptable \\
2-Nitroaniline & $\mu \mathrm{g} / \mathrm{l}$ & $<10.0$ & 0 & $\mathrm{NR}$ & Acceptable \\
3-Nitroaniline & $\mu \mathrm{g} / \mathrm{l}$ & $<10.0$ & 0 & $\mathrm{NR}$ & Acceptable \\
4-Nitroaniline & $\mu \mathrm{g} / \mathrm{l}$ & $<10.0$ & 0 & $\mathrm{NR}$ & Acceptable \\
Nitrobenzene & $\mu \mathrm{g} / \mathrm{l}$ & 65.2 & 88.2 & $29.1-115$ & Acceptable \\
N-Nitrosodiethylamine & $\mu \mathrm{g} / \mathrm{l}$ & $\mathrm{NR}$ & 0 & $\mathrm{NR}$ & Acceptable \\
N-Nitrosodimethylamine & $\mu \mathrm{g} / \mathrm{l}$ & $<10.0$ & 0 & $\mathrm{NR}$ & Acceptable \\
N-Nitrosodiphenylamine & $\mu \mathrm{g} / \mathrm{l}$ & $<10.0$ & 0 & $\mathrm{NR}$ & Acceptable \\
N-Nitroso-di-n-propylamine & $\mu \mathrm{g} / \mathrm{l}$ & $<10.0$ & 0 & $\mathrm{NR}$ & Acceptable \\
Phenanthrene & $\mu \mathrm{g} / \mathrm{l}$ & 41.2 & 46.4 & $23.7-58.2$ & Acceptable \\
Pyrene & $\mu \mathrm{g} / \mathrm{l}$ & 22.7 & 26.9 & $8.55-40.9$ & Acceptable \\
Pyridine & $\mu \mathrm{g} / \mathrm{l}$ & $<10.0$ & 0 & $\mathrm{NR}$ & Acceptable \\
1,2,4-Trichlorobenzene & $\mu \mathrm{g} / \mathrm{l}$ & 45.8 & 61.9 & $17.9-75.5$ & Acceptable \\
Bromide & & & & & \\
Bromide & $\mu \mathrm{g} / \mathrm{l}$ & 677 & 352 & $302-408$ & Not Acceptable \\
\hline a Not Reported & & & & &
\end{tabular}




\section{REFERENCES}

10 CFR Part 50, Appendix B. "Quality Assurance Criteria for Nuclear Power Plants and Fuel Reprocessing Plants." Code of Federal Regulations. Office of the Federal Register, National Archives and Records Administration, Washington D.C.

10 CFR Part 61. "Licensing Requirements for Land Disposal of Radioactive Waste. Code of Federal Regulations." Office of the Federal Register, National Archives and Records Administration, Washington D.C.

10 CFR Part 71. "Packaging and Transportation of Radioactive Material." Code of Federal Regulations. Office of the Federal Register, National Archives and Records Administration, Washington D.C.

10 CFR Part 834. "Radiation Protection of the Public and the Environment; Proposed Rule." Code of Federal Regulations. Office of the Federal Register, National Archives and Records Administration, Washington D.C.

10 CFR Part 835. "Occupational Radiation Protection." Code of Federal Regulations. Office of the Federal Register, National Archives and Records Administration, Washington D.C.

10 CFR Part 1021. "National Environmental Policy Act Implementing Procedures." Code of Federal Regulations. Office of the Federal Register, National Archives and Records Administration, Washington D.C.

10 CFR §1021.331. "National Environmental Policy Act Implementing Procedures, Mitigation Action Plans." Code of Federal Regulations. Office of the Federal Register, National Archives and Records Administration, Washington D.C.

40 CFR Part 61. "National Emission Standards for Hazardous Air Pollutants." Code of Federal Regulations. Office of the Federal Register, National Archives and Records Administration, Washington D.C.

40 CFR §61.92. "National Emission Standards for Hazardous Air Pollutants, Standard." Code of Federal Regulations. Office of the Federal Register, National Archives and Records Administration, Washington D.C.

40 CFR §61.93(a). "National Emission Standards for Hazardous Air Pollutants, Emission monitoring and test procedures." Code of Federal Regulations. Office of the Federal Register, National Archives and Records Administration, Washington D.C.

40 CFR Part 112. "Oil Pollution Prevention." Code of Federal Regulations. Office of the Federal Register, National Archives and Records Administration, Washington D.C. 
40 CFR Part 122. "EPA Administered Permit Programs: the National Pollutant Discharge Elimination System." Code of Federal Regulations. Office of the Federal Register, National Archives and Records Administration, Washington D.C.

40 CFR Part 191. "Environmental Radiation Protection Standards for the Management and Disposal of Spent Nuclear Fuel, High-level and Transuranic Radioactive Wastes." Code of Federal Regulations. Office of the Federal Register, National Archives and Records Administration, Washington D.C.

40 CFR Part 194. "Criteria for the Certification and Re-certification of the Waste Isolation Pilot Plant's Compliance with the 40 CFR Part 191 Disposal Regulations." Code of Federal Regulations. Office of the Federal Register, National Archives and Records Administration, Washington D.C.

40 CFR Part 247. "Comprehensive Procurement Guideline for Products Containing Recovered Materials." Code of Federal Regulations. Office of the Federal Register, National Archives and Records Administration, Washington D.C.

40 CFR Part 262. "Standards Applicable to Generators of Hazardous Waste." Code of Federal Regulations. Office of the Federal Register, National Archives and Records Administration, Washington D.C.

40 CFR Part 264. "Standards for Owners and Operators of Hazardous Waste Treatment, Storage, and Disposal Facilities." Code of Federal Regulations. Office of the Federal Register, National Archives and Records Administration, Washington D.C.

40 CFR Part 300. "National Oil and Hazardous Substances Pollution Contingency Plan." Code of Federal Regulations. Office of the Federal Register, National Archives and Records Administration, Washington D.C.

40 CFR Part 302. "Designation, Reportable Quantities, and Notification." Code of Federal Regulations. Office of the Federal Register, National Archives and Records Administration, Washington D.C.

40 CFR Part 503. "Standards for the Use or Disposal of Sewage Sludge." Code of Federal Regulations. Office of the Federal Register, National Archives and Records Administration, Washington D.C.

40 CFR Parts 1500-1517. "Council on Environmental Quality." Office of the Federal Register, National Archives and Records Administration, Washington D.C.

49 CFR. Transportation. Code of Federal Regulations. Office of the Federal Register, National Archives and Records Administration, Washington D.C. 
49 CFR Parts 106-178. "Research and Special Programs Administration, Department of Transportation." Code of Federal Regulations. Office of the Federal Register, National Archives and Records Administration, Washington D.C.

20.2 NMAC. "Air Quality." Title 20, New Mexico Administrative Code, Chapter 2. Sante Fe, NM.

20.2.72 NMAC. "Construction Permits." Title 20, New Mexico Administrative Code, Chapter 2, Part 72. (Air Quality Control Regulation 702). Santa Fe, NM.

20.4.1 NMAC. "Hazardous Waste Management." Title 20, New Mexico Administrative Code, Chapter 4, Part 1. Santa Fe, NM.

20.6.2.3 NMAC. "Ground and Surface Water Protection." Title 20, New Mexico Administrative Code, Chapter 6, Part 2, Section 3. Santa Fe, NM.

7 U.S.C. 136-136y. Federal Insecticide, Fungicide, and Rodenticide Act, as amended. U.S. Government Printing Office. Washington, D.C.

15 U.S.C. 2301 et seq. Toxic Substances Control Act. U.S. Government Printing Office. Washington, D.C.

16 U.S.C. 1531-1544, 87 Stat. 884. Endangered Species Act of 1973.

U.S. Government Printing Office. Washington, D.C.

16 U.S.C. 470 et seq. National Historic Preservation Act. U.S. Government Printing Office. Washington, D.C.

33 U.S.C. 1251-1376; Chapter 758; Pub. L. 845; 62 Stat. 1155. Federal Water Pollution Control Act of 1948 (Clean Water Act), Section 402. U.S. Government Printing Office. Washington, D.C.

42 U.S.C. 2278a. Atomic Energy Act of 1954. U.S. Government Printing Office. Washington, D.C.

42 U.S.C. $300 f$ et seq. Safe Drinking Water Act. U.S. Government Printing Office. Washington, D.C.

42 U.S.C. 321 et seq. Resource Conservation and Recovery Act. U.S. Government Printing Office. Washington, D.C.

42 U.S.C. 4321-4345. National Environmental Policy Act. U.S. Government Printing Office. Washington, D.C.

42 U.S.C. 7112. Department of Energy Organization Act. U.S. Government Printing Office. Washington, D.C. 
42 U.S.C. 7401 et seq. Clean Air Act. U.S. Government Printing Office. Washington, D.C.

42 U.S.C. 9601 et seq. Comprehensive Environmental Response, Compensation, and Liability Act (including the Superfund Amendments and Reauthorization Act of 1986). U.S. Government Printing Office. Washington, D.C.

42 U.S.C. 10101 et seq. Nuclear Waste Policy Act of 1982. U.S. Government Printing Office. Washington, D.C.

43 U.S.C. 1751 et seq. Federal Land Policy and Management Act, 1976.

U.S. Government Printing Office. Washington, D.C.

49 App. U.S.C.A. 1801 et seq.; 49 CFR Parts 106-179. Hazardous Materials Transportation Act. U.S. Government Printing Office. Washington, D.C.

310-M-2. 1993. Air Quality Permit. New Mexico Environment Department, Santa Fe, NM.

ANSI/ASQC - E4. Proposed. Quality Assurance Program Requirements for Environmental Programs. American National Standards Institute/American Society for Quality Control, Washington, D.C.

HPS N13.30. 1996. Performance Criteria for Radiobioassay. Health Physics Society, Washington, D.C.

NQA-1-1994. 1994. Quality Assurance Program Requirements for Nuclear Facilities. American National Standards Institute, Washington, D.C.

DOE/CAO 96-2184. 1996. Compliance Certification Application, October 1996. U.S. Department of Energy, Carlsbad Field Office. Carlsbad, NM.

DOE/EH-0173T. 1991. Environmental Regulatory Guide for Radiological Effluent Monitoring and Environmental Surveillance. U.S. Department of Energy, Washington, D.C.

DOE/EIS-0026. 1980. Final Environmental Impact Statement (FEIS), Waste Isolation Pilot Plant, Volumes 1 and 2. U.S. Department of Energy, Washington, D.C.

DOE/EIS-0026-FS. 1990. Final Supplemental Environmental Impact Statement (SEIS-I), Volumes 1-3. U.S. Department of Energy, Washington, D.C.

DOE/EIS-0026-S-2. 1997. Waste Isolation Pilot Plant Disposal Phase Final Supplemental Environmental Impact Statement (SEIS-II), Volumes 1-3. U.S. Department of Energy, Washington, D.C. 
DOE Order 151.1. 1996. Comprehensive Emergency Management System. U.S. Department of Energy, Washington, D.C.

DOE Order 225.1A. 1997. Accident Investigation. U.S. Department of Energy, Washington, D.C.

DOE Order 231.1. 1996. Environmental, Safety, and Health Reporting.

U.S. Department of Energy, Washington, D.C.

DOE Order 414.1. 1998. Quality Assurance. U.S. Department of Energy, Washington, D.C.

DOE Order 430.1A. 1995. Life-Cycle Assessment Management. U.S. Department of Energy, Washington, D.C.

DOE Order 435.1. 1999. Radioactive Waste Management. U.S. Department of Energy, Washington, D.C.

DOE Order 451.1B. 1995. National Environmental Compliance Policy Act Compliance Program. U.S. Department of Energy, Washington, D.C.

DOE Order 460.1A. 1996. Packaging and Transportation Safety. U.S. Department of Energy, Washington, D.C.

DOE Order 5400.1. 1990. General Environmental Protection Programs.

U.S. Department of Energy, Washington, D.C.

DOE Order 5400.5. 1988. Radiation Protection of the Public and the Environment. U.S. Department of Energy, Washington, D.C.

DOE Order 5480.23. 1994. Nuclear Safety Analysis Reports. U.S. Department of Energy, Washington, D.C.

DOE-STD-XXXX-YR (Proposed). 2000. A Graded Approach for Evaluating Radiation Doses to Aquatic and Terrestrial Biota. National Technical Information Service, Washington, D.C.

DOE/WIPP 93-004. Waste Isolation Pilot Plant Land Management Plan. Waste Isolation Pilot Plant, Carlsbad, NM.

DOE/WIPP 95-2065. WIPP Safety Analysis Report. Waste Isolation Pilot Plant, Carlsbad, NM.

DOE/WIPP 96-2199. 1996. Environmental Protection Implementation Plan for the Waste Isolation Pilot Plant. Waste Isolation Pilot Plant, Carlsbad, NM. 
DOE/WIPP 97-2219. 1997. Exhaust Shaft Hydraulic Assessment Data Report. Waste Isolation Pilot Plant, Carlsbad, NM.

DOE/WIPP 97-2278. 1997. Exhaust Shaft: Phase 2 Hydraulic Assessment Data Report Involving Drilling, Installation, Water-quality Sampling, and Testing of Piezometers 1-12. Waste Isolation Pilot Plant, Carlsbad, NM.

DOE/WIPP 98-2285. 1998. Waste Isolation Pilot Plant RCRA Background Groundwater Quality Baseline Report. Waste Isolation Pilot Plant, Carlsbad, NM.

DOE/WIPP 99-2171. 2000. WIPP Biennial Environmental Compliance Report. Waste Isolation Pilot Plant, Carlsbad, NM.

DOE/WIPP 99-2194. 1999. WIPP Environmental Monitoring Plan. Waste Isolation Pilot Plant, Carlsbad, NM.

DOE/WIPP 99-2302. 1999. Exhaust Shaft: Phase lii Hydraulic Assessment Data Report October 1997 - October 1998. Waste Isolation Pilot Plant, Carlsbad, NM.

DOE/WIPP 99-3120. 1999. 1998 Water Quality Report for Perched Ground Water. Waste Isolation Pilot Plant, Carlsbad, NM.

DOE/WIPP 01-2225. 2002. 2000 Annual Site Environmental Report. Waste Isolation Pilot Plant, Carlsbad, NM.

DOE/WIPP 01-3177. 2001. Geotechnical Analysis Report for July 1999 - June 2000. Waste Isolation Pilot Plant, Carlsbad, NM.

DOE/WIPP 01-3210. 2001. Basic Data Report for Drillhole C-2737. Waste Isolation Pilot Plant, Carlsbad, NM.

DP-831. 1997. WIPP Discharge Plan. New Mexico Environment Department. Santa $\mathrm{Fe}, \mathrm{NM}$.

Executive Order 13101, Greening the Government Through Waste Prevention, Recycling, and Federal Acquisition. Office of the President. Washington, D.C.

IAEA Technical Report Series No. 332. 1992. Effects of lonizing Radiation on Plants and Animals at Levels Implied by Current Radiation Protection Standards. International Atomic Energy Agency. Vienna, Austria.

ISO 14001. Environmental Management System Standards. International Organizations for Standardization. Geneva, Switzerland.

NCRP-109. 1991. Effects of lonizing Radiation on Aquatic Organisms. National Council on Radiation Protection and Measurements. Bethesda, MD. 
NEPA ID \# WIP:00:001. 2000. 1999 Annual Mitigation Report for the Waste Isolation Pilot Plant. Waste Isolation Pilot Plant, Carlsbad, NM.

NM4890139088-TSDF. 1999. Waste Isolation Pilot Plant Hazardous Waste Facility Permit. New Mexico Environment Department, Santa Fe, NM.

NMED/DOE/AIP 94/1. 1994. Resource Conservation and Recovery Act Facility Assessment. New Mexico Environment Department, Santa Fe, NM.

NMR05A823. 2001. New Mexico NPDES Multi-Sector General Permit. New Mexico Environment Department, Santa Fe, NM.

NMSA 1978 §74-2. New Mexico Air Quality Control Act. New Mexico Statutes Annotated 1978. State of New Mexico, Santa Fe, NM.

NMSA 1978 §74-6. New Mexico Water Quality Act. New Mexico Statutes Annotated 1978. State of New Mexico, Santa Fe, NM.

Public Law 96-164. National Security and Military Applications of Nuclear Energy Authorization Act of 1980.

Public Law 102-579, 106 Stat. 4777. Waste Isolation Pilot Plant Land Withdrawal Act. October 1992, as amended October 1996 by Public Law 104-201.

PPOA 99-02. 1999. Pollution Prevention Opportunity Assessment, CRC Lectra Motive Replacement. Waste Isolation Pilot Plant, Carlsbad, NM.

QAMS-005/80. 1980. Interim Guidelines and Specifications for Preparing Quality Assurance Project Plans. U.S. Environmental Protection Agency, Washington, D.C.

Regulatory Guide 4.15, Rev. 1. 1979. Quality Assurance for Radiological Monitoring Programs-Effluent Streams and the Environment. U.S. Nuclear Regulatory Commission, Washington, D.C.

Restani, M. 2001. WIPP Raptor Program 2001 Annual Report. Waste Isolation Pilot Plant, Carlsbad, NM.

TO-14A. 1997. Compendium of Methods for the Determination of Toxic Organic Compounds in Ambient Air. U.S. Environmental Protection Agency, Washington, D.C.

U.S. Department of Energy. 1986. Environmental Policy Statement, Secretary Herrington. U.S. Department of Energy. Washington, D.C.

WP 02-EC.07. Affirmative Procurement Program Plan. Waste Isolation Pilot Plant, Carlsbad, NM. 
This page intentionally left blank 


\title{
Appendix A \\ Acronyms, Abbreviations, and Symbols
}

\author{
A \\ ACAA \\ AMSL \\ ANOVA \\ Accelerated Corrective Action Approach \\ above mean sea level \\ ANSI \\ Analysis of Variance \\ AOC \\ APP \\ American National Standards Institute \\ Area of Concern \\ affirmative procurement plan \\ ASTM \\ American Society for Testing and Materials \\ B \\ BCG \\ BLM \\ BLS \\ $\mathrm{Bq}$ \\ $\mathrm{Bq} / \mathrm{l}$ \\ $\mathrm{Bq} / \mathrm{m}^{3}$ \\ Biota Concentration Guides \\ United States Department of the Interior, Bureau of Land Management \\ below land surface \\ becquerel \\ becquerels per liter \\ becquerels per cubic meter \\ C \\ $\mathrm{C}$ of $\mathrm{C}$ \\ CAP88 \\ Certificate of Compliance \\ computer code for calculating both dose and risk from radionuclide \\ emissions \\ CBFO Carlsbad Field Office \\ CCA Compliance Certification Application \\ CERCLA Comprehensive Environmental Response, Compensation and Liability \\ Act \\ CFR Code of Federal Regulations \\ $\mathrm{Ci} \quad$ curie \\ $\mathrm{cm} \quad$ centimeter \\ CMS Corrective Measures Study \\ $\mathrm{CY} \quad$ calendar year \\ D \\ DOE United States Department of Energy \\ DOT United States Department of Transportation \\ E \\ EA Environmental Assessment \\ EEG Environmental Evaluation Group \\ Eh Intensity Factor \\ EIS Environmental Impact Statement \\ EML Environmental Measurements Laboratory \\ EMP WIPP Environmental Monitoring Plan \\ EMS Environmental Management System \\ EPA United States Environmental Protection Agency
}




\begin{tabular}{|c|c|}
\hline $\mathbf{F}$ & \\
\hline $\mathrm{ft}$ & foot \\
\hline $\mathrm{ft}^{3}$ & cubic foot \\
\hline FEIS & Final Environmental Impact Statement \\
\hline $\mathrm{FR}$ & Federal Register \\
\hline FY & fiscal year \\
\hline G & \\
\hline $\mathrm{g}$ & gram \\
\hline gal & gallon \\
\hline Gy & Gray \\
\hline $\mathbf{H}$ & \\
\hline HalfPACT & Short Transuranic Package Transporter \\
\hline HEPA & high efficiency particulate arresting \\
\hline HWFP & Hazardous Waste Facility Permit \\
\hline $\mathbf{I}$ & \\
\hline ISO & International Organization for Standardization \\
\hline $\mathbf{K}$ & \\
\hline $\mathrm{kg}$ & kilogram \\
\hline $\mathrm{km}$ & kilometer \\
\hline $\mathrm{km}^{2}$ & square kilometers \\
\hline $\mathbf{L}$ & \\
\hline I & liter \\
\hline LMP & Land Management Plan \\
\hline LUR & Land Use Request \\
\hline $\mathbf{M}$ & \\
\hline $\mathrm{m}^{3}$ & cubic meters \\
\hline $\mathrm{mBq}$ & millibecquerel \\
\hline MDC & Minimum Detectable Concentration \\
\hline MDL & Method Detection Limit \\
\hline $\mathrm{mg}$ & milligram \\
\hline $\mathrm{mg} / \mathrm{l}$ & milligram per liter \\
\hline $\mathrm{mi}$ & mile \\
\hline $\mathrm{mi}^{2}$ & square miles \\
\hline $\mathrm{ml}$ & milliliter \\
\hline MOU & Memorandum of Understanding \\
\hline mrem & millirem \\
\hline $\mathrm{mrem} / \mathrm{yr}$ & millirem per year \\
\hline MSDS & material safety data sheet \\
\hline $\mathrm{mSv}$ & millisievert \\
\hline $\mathrm{mSv} / \mathrm{yr}$ & millisievert per year \\
\hline & metric tons \\
\hline
\end{tabular}




\begin{tabular}{|c|c|}
\hline \multicolumn{2}{|l|}{$\mathbf{N}$} \\
\hline N/A & not applicable \\
\hline NCRP & National Council for Radiation Protection and Measurements \\
\hline NEPA & National Environmental Policy Act \\
\hline NESHAP & National Emission Standards for Hazardous Air Pollutants \\
\hline NHPA & National Historic Preservation Act \\
\hline NIST & National Institute of Standards and Technology \\
\hline NMAC & New Mexico Administrative Code \\
\hline NMDG\&F & New Mexico Department of Game and Fish \\
\hline NMED & New Mexico Environment Department \\
\hline NMIMT & New Mexico Institute of Mining Technology \\
\hline $\mathrm{NOI}$ & Notice of Intent \\
\hline NPDES & National Pollutant Discharge Elimination System \\
\hline NQA & Nuclear Quality Assurance \\
\hline NR & not reported \\
\hline NRC & Nuclear Regulatory Commission \\
\hline \multicolumn{2}{|l|}{$\mathbf{0}$} \\
\hline $\mathrm{OZ}$ & ounce \\
\hline \multicolumn{2}{|l|}{$\mathbf{P}$} \\
\hline P2 & pollution prevention \\
\hline Pub. L. & Public Law \\
\hline PCB & polychlorinated biphenyl \\
\hline $\mathrm{pCi}$ & picoCuries \\
\hline $\mathrm{pCi} / \mathrm{l}$ & picoCuries per liter \\
\hline ppbv & parts per billion by volume \\
\hline PPOA & Pollution Prevention Opportunity Assessment \\
\hline \multicolumn{2}{|l|}{$\mathbf{Q}$} \\
\hline QA & quality assurance \\
\hline QAP & Quality Assurance Program \\
\hline QC & quality control \\
\hline \multicolumn{2}{|l|}{$\mathbf{R}$} \\
\hline RCRA & Resource Conservation and Recovery Act \\
\hline rem & Roentgen equivalent man \\
\hline RER & Relative Error Ratio \\
\hline RFI & RCRA Facility Investigation \\
\hline $\mathrm{RFI} / \mathrm{CMS}$ & RCRA Facility Investigation/Corrective Measures Study \\
\hline RL & Reporting Limit \\
\hline ROD & Record of Decision \\
\hline RN & Radionuclide \\
\hline \\
\hline SARA & Superfund Amendments and Reauthorization Act \\
\hline SD & soil deep \\
\hline
\end{tabular}




$\begin{array}{ll}\text { SD } & \text { Standard Deviation } \\ \text { SDWA } & \text { Safe Drinking Water Act } \\ \text { SEIS-I } & \text { First Supplemental Environmental Impact Statement } \\ \text { SEIS-II } & \text { Second Supplemental Environmental Impact Statement } \\ \text { SI } & \text { Soil Intermediate } \\ \text { SMA } & \text { Special Management Area } \\ \text { SNL } & \text { Sandia National Laboratories } \\ \text { SPDV } & \text { Site Preliminary Design and Validation } \\ \text { SS } & \text { Soil Surface } \\ \text { SU } & \text { Standard Unit } \\ \text { SWMU } & \text { Solid Waste Management Unit } \\ \text { T } & \\ \text { TCLP } & \text { Toxicity Characteristic Leaching Procedure } \\ \text { TDS } & \text { Total Dissolved Solid } \\ \text { TOC } & \text { Top of Casing } \\ \text { TPU } & \text { Total Propagated Uncertainty } \\ \text { TRANSCOM } & \text { Transportation Tracking and Communications (system) } \\ \text { TRU } & \text { Transuranic (waste) } \\ \text { TRUPACT-II } & \text { Transuranic Package Transporter Model II } \\ \text { U } & \\ \text { U.S.C. } & \text { United States Code } \\ \text { USF\&WS } & \text { United States Department of the Interior, Fish and Wildlife Service } \\ \text { UTLV } & \text { Upper Tolerance Limit Value } \\ \text { V } & \\ \text { VOC } & \text { Volatile Organic Compound } \\ \text { W } & \\ \text { WIPP } & \text { Waste Isolation Pilot Plant } \\ \text { WQSP } & \text { WIPP Groundwater Quality Sampling Program } \\ \text { WRP } & \text { WIPP Raptor Program } \\ \text { WTS } & \text { Westinghouse TRU Solutions LLC } \\ & \end{array}$


$\sigma$

${ }^{\circ} \mathrm{C}$

${ }^{\circ} \mathrm{F}$

$\mu \mathrm{Ci}$

$\mu \mathrm{g}$

umhos

$\%$

[RN]
Symbols

sigma

Degrees Celsius

Degrees Fahrenheit

microcurie

microgram

micromhos

Percent

Radionuclide concentration 
This page intentionally left blank 


\section{Appendix B \\ Location Codes}

Table B.1 - Codes Used to Identify the Sites from Which Samples Were Collected

\begin{tabular}{llll}
\hline Code & \multicolumn{1}{c}{ Location } & Code & \multicolumn{1}{c}{ Location } \\
\hline BHT & Bottom of the Hill Tank & RCP & Rainwater Catchment Pond \\
BRA & Brantley Lake & RED & Red Tank \\
CBD & Carlsbad & RNS & Rinse Aid Blank \\
COW & Coyote Well (deionized water blank) & SE1 & South East 1 \\
COY & Coyote (surface water duplicate) & SE2 & South East 2 \\
CT1 & Control 1 & SEC & South East Control \\
CT2 & Control 2 & SMR & Smith Ranch \\
FWT & Fresh Water Tank & SOO & Sample Of Opportunity \\
HIL & Hill Tank & SWL & Sewage Lagoons \\
IDN & Indian Tank & TUT & Tut Tank \\
LAG & Laguna Grande del Sol & UPR & Upper Pecos River \\
LST & Lost Tank & WAB & WIPP Air Blank \\
MLR & Mills Ranch & WE1 & WIPP East 1 \\
NOY & Noya Tank & WEE & WIPP East \\
NW1 & NorthWest1 & WIP & WIPP 16 Sections \\
NW2 & NorthWest2 & WFF & WIPP Far Field \\
PCN & Pierce Canyon & WQSP & Water Quality Sample Program \\
PEC & Pecos River & WSS & WIPP South \\
PKT & Poker Trap & & \\
\hline & & & \\
\hline
\end{tabular}


This page intentionally left blank 


\section{Appendix C Equations}

\section{Minimum Detectable Concentration (MDC)}

MDC is equal to the mean of a distribution such that 95 percent of the measurements of the distribution will produce analytical results that have the activity above that of a blank. It is possible to achieve a very low level of detection by analyzing a large sample size and counting for a very long time.

The laboratory used the following equation for calculating the MDCs for each radionuclide in various sample matrices:

$$
M D C=\frac{4.65 S_{b}}{K T}+\frac{3}{K T}
$$

Where:

$$
\begin{array}{lll}
S_{b} \quad= & \begin{array}{l}
\text { Standard deviation of the background } \\
K
\end{array} \quad \begin{array}{l}
\text { A correction factor that includes items such as unit } \\
\text { conversions, sample volume/weight, decay correction, } \\
\text { detector efficiency, chemical recovery and abundance }
\end{array} \\
T \quad & \begin{array}{l}
\text { correction, etc. } \\
\text { Counting time }
\end{array}
\end{array}
$$

For further evaluation of MDC, refer to HPS N13.30-1996, Performance Criteria for Bioassay.

\section{Total Propagated Uncertainty (TPU)}

Total propagated uncertainty for each data point must be reported at $2 \sigma$ level. The TPU was calculated by using the following equation:

$$
T P U_{1 \sigma}=\sigma_{A C T}=\frac{\sqrt{\sigma_{N C R}^{2}+(N C R)^{2} *\left(R E_{E F F}^{2}+R E_{A L I}^{2}+R E_{R}^{2}+\Sigma R E_{C F}^{2}\right)}}{2.22 * E F F * A L I * R * A B N_{S} * e^{-\lambda t} * C F}
$$

Where:

$\begin{array}{lll}\mathrm{EFF} & = & \text { Detector Efficiency } \\ \mathrm{ALI} & = & \text { Sample Aliquot Volume or Mass } \\ \mathrm{R} & = & \text { Sample Tracer/Carrier Recovery } \\ \mathrm{ABN}_{\mathrm{S}} & = & \text { Abundance Fraction of the Emissions Used for } \\ & & \text { Identification/Quantification } \\ \sigma_{\mathrm{NCR}}^{2} & = & \text { Variance of the Net Sample Count Rate } \\ \mathrm{NCR} & = & \text { Net Sample Count Rate }\end{array}$




$\begin{array}{lll}\mathrm{RE}^{2} & = & \text { Square of the Relative Error of the Efficiency Term } \\ \mathrm{RE}^{2}{ }^{\mathrm{ALI}} & = & \text { Square of the Relative Error of the Aliquot } \\ \mathrm{RE}^{2}{ }_{\mathrm{R}} & = & \text { Square of the Relative Error of the Sample Recovery } \\ \mathrm{RE}^{2}{ }_{\mathrm{CF}} & = & \text { Square of the Relative Error of Other Correction Factors } \\ \lambda & = & \begin{array}{l}\text { Analyte Decay Constant = In 2/(half-life) [Same units as the half-life } \\ \text { used to compute } \lambda]\end{array} \\ \mathrm{t} & =\begin{array}{l}\text { Time from Sample Collection to Radionuclide Separation or Mid-Point } \\ \text { of Count Time (Same units as half-life) }\end{array} \\ \mathrm{CF} & =\begin{array}{l}\text { Other Correction Factors as Appropriate (i.e., Ingrowth factor, self- } \\ \text { absorption factor, etc.). }\end{array}\end{array}$

\section{Relative Error Ratio (RER)}

The Relative Error Ratio is a method, similar to a t-test, with which to compare duplicate results (see Chapters 4 and 8; WP 02-EM 3004).

Where:

$$
R E R=\frac{\left|x_{A}-x_{B}\right|}{\sqrt{\left(2 \sigma_{A}\right)^{2}+\left(2 \sigma_{R}\right)^{2}}}
$$

$\begin{array}{lll}X_{A} & = & \\ X_{B} & = & \text { Mean Activity of Population A } \\ \sigma_{A} & = & \text { Standard Deviation of Population A } \\ \sigma_{B} & = & \text { Standard Deviation of Population B. }\end{array}$

\section{Percent Bias (\% Bias)}

A measure of the accuracy of radiochemical separation methods and counting instruments; that is, a measure of how reliable the results of analyses are when compared to the actual values.

$$
\% B I A S=\left[\frac{A_{m}-A_{k}}{A_{k}}\right] * 100
$$

Where:

$\begin{array}{lll}\% \text { BIAS } & = & \text { Percent Bias } \\ A_{m} & = & \text { Measured Sample Activity } \\ A_{k} & = & \text { Known Sample Activity. }\end{array}$


Waste Isolation Pilot Plant 2001 Site Environmental Report DOE/WIPP 02-2225

\section{Appendix D \\ Concentrations of Alpha and Beta Activities in Air Particulate}

Table D.1 - Results of Gross Alpha and Gross Beta Analyses in Air Particulates (Bq/m $\left.{ }^{3}\right)$

\begin{tabular}{|c|c|c|c|c|c|}
\hline \multirow[b]{2}{*}{ Week } & \multirow[b]{2}{*}{ Sample ID } & \multicolumn{2}{|c|}{ Gross Alpha } & \multicolumn{2}{|c|}{ Gross Beta } \\
\hline & & Concentration & $2 \times$ TPU $^{a}$ & Concentration & $2 \times$ TPU \\
\hline \multicolumn{6}{|c|}{ Carlsbad } \\
\hline 1 & AL-CBD-20010103 1.1 & $5.07 \times 10^{-5}$ & $2.44 \times 10^{-5}$ & $1.12 \times 10^{-3}$ & $1.48 \times 10^{-4}$ \\
\hline 2 & AL-CBD-200101101.1 & $4.88 \times 10^{-5}$ & $2.32 \times 10^{-5}$ & $7.66 \times 10^{-4}$ & $1.07 \times 10^{-4}$ \\
\hline 3 & AL-CBD-20010117 1.1 & $3.31 \times 10^{-5}$ & $1.92 \times 10^{-5}$ & $1.02 \times 10^{-3}$ & $1.33 \times 10^{-4}$ \\
\hline 4 & AL-CBD-20010124 1.1 & $3.35 \times 10^{-5}$ & $1.93 \times 10^{-5}$ & $8.45 \times 10^{-4}$ & $1.15 \times 10^{-4}$ \\
\hline 5 & AL-CBD-20010131 1.1 & $7.60 \times 10^{-5}$ & $2.95 \times 10^{-5}$ & $1.24 \times 10^{-3}$ & $1.58 \times 10^{-4}$ \\
\hline 6 & AL-CBD-20010207 1.1 & $2.31 \times 10^{-5}$ & $1.57 \times 10^{-5}$ & $1.01 \times 10^{-3}$ & $1.32 \times 10^{-4}$ \\
\hline 7 & AL-CBD-20010214 1.1 & $3.65 \times 10^{-5}$ & $1.92 \times 10^{-5}$ & $1.00 \times 10^{-3}$ & $1.30 \times 10^{-4}$ \\
\hline 8 & AL-CBD-20010221 1.1 & $5.77 \times 10^{-5}$ & $2.47 \times 10^{-5}$ & $6.47 \times 10^{-4}$ & $9.46 \times 10^{-5}$ \\
\hline 9 & AL-CBD-20010228 1.1 & $3.82 \times 10^{-5}$ & $2.07 \times 10^{-5}$ & $8.94 \times 10^{-4}$ & $1.22 \times 10^{-4}$ \\
\hline 10 & AL-CBD-20010307 1.1 & $3.80 \times 10^{-5}$ & $2.05 \times 10^{-5}$ & $5.59 \times 10^{-4}$ & $8.70 \times 10^{-5}$ \\
\hline 11 & AL-CBD-20010314 1.1 & $6.41 \times 10^{-5}$ & $2.57 \times 10^{-5}$ & $6.50 \times 10^{-4}$ & $9.51 \times 10^{-5}$ \\
\hline 12 & AL-CBD-20010321 1.1 & $6.04 \times 10^{-5}$ & $2.68 \times 10^{-5}$ & $7.14 \times 10^{-4}$ & $1.05 \times 10^{-4}$ \\
\hline 13 & AL-CBD-20010328 1.1 & $3.44 \times 10^{-5}$ & $2.01 \times 10^{-5}$ & $8.07 \times 10^{-4}$ & $1.13 \times 10^{-4}$ \\
\hline 14 & AL-CBD-20010404 1.1 & $6.60 \times 10^{-5}$ & $2.64 \times 10^{-5}$ & $6.92 \times 10^{-4}$ & $9.94 \times 10^{-5}$ \\
\hline 15 & AL-CBD-20010411 1.1 & $5.77 \times 10^{-5}$ & $2.50 \times 10^{-5}$ & $8.41 \times 10^{-4}$ & $1.16 \times 10^{-4}$ \\
\hline 16 & AL-CBD-20010418 1.1 & $6.70 \times 10^{-5}$ & $2.82 \times 10^{-5}$ & $6.42 \times 10^{-4}$ & $9.72 \times 10^{-5}$ \\
\hline 17 & AL-CBD-20010425 1.1 & $6.83 \times 10^{-5}$ & $2.83 \times 10^{-5}$ & $9.48 \times 10^{-4}$ & $1.28 \times 10^{-4}$ \\
\hline 18 & AL-CBD-20010502 1.1 & $6.65 \times 10^{-5}$ & $2.72 \times 10^{-5}$ & $7.93 \times 10^{-4}$ & $1.12 \times 10^{-4}$ \\
\hline 19 & AL-CBD-20010509 1.1 & $4.55 \times 10^{-5}$ & $2.17 \times 10^{-5}$ & $8.04 \times 10^{-4}$ & $1.11 \times 10^{-4}$ \\
\hline 20 & AL-CBD-20010516 1.1 & $2.77 \times 10^{-5}$ & $1.76 \times 10^{-5}$ & $6.21 \times 10^{-4}$ & $9.39 \times 10^{-5}$ \\
\hline 21 & AL-CBD-20010523 1.1 & $8.87 \times 10^{-5}$ & $3.23 \times 10^{-5}$ & $8.55 \times 10^{-4}$ & $1.16 \times 10^{-4}$ \\
\hline 22 & AL-CBD-20010530 1.1 & $4.86 \times 10^{-5}$ & $2.39 \times 10^{-5}$ & $9.22 \times 10^{-4}$ & $1.22 \times 10^{-4}$ \\
\hline 23 & AL-CBD-20010606 1.1 & $5.96 \times 10^{-5}$ & $2.56 \times 10^{-5}$ & $7.37 \times 10^{-4}$ & $1.05 \times 10^{-4}$ \\
\hline 24 & AL-CBD-20010613 1.1 & $5.61 \times 10^{-5}$ & $2.46 \times 10^{-5}$ & $7.06 \times 10^{-4}$ & $1.01 \times 10^{-4}$ \\
\hline 25 & AL-CBD-20010620 1.1 & $4.48 \times 10^{-5}$ & $2.18 \times 10^{-5}$ & $7.90 \times 10^{-4}$ & $1.10 \times 10^{-4}$ \\
\hline 26 & AL-CBD-20010627 1.1 & $7.08 \times 10^{-5}$ & $2.98 \times 10^{-5}$ & $7.93 \times 10^{-4}$ & $1.16 \times 10^{-4}$ \\
\hline 27 & AL-CBD-20010704 1.1 & $4.45 \times 10^{-5}$ & $2.05 \times 10^{-5}$ & $5.84 \times 10^{-4}$ & $8.38 \times 10^{-5}$ \\
\hline 28 & AL-CBD-20010711 1.1 & $4.52 \times 10^{-5}$ & $2.31 \times 10^{-5}$ & $7.84 \times 10^{-4}$ & $1.10 \times 10^{-4}$ \\
\hline 29 & AL-CBD-20010718 1.1 & $6.17 \times 10^{-5}$ & $2.54 \times 10^{-5}$ & $6.88 \times 10^{-4}$ & $9.90 \times 10^{-5}$ \\
\hline 30 & AL-CBD-20010725 1.1 & $4.03 \times 10^{-5}$ & $2.02 \times 10^{-5}$ & $6.97 \times 10^{-4}$ & $9.88 \times 10^{-5}$ \\
\hline 31 & AL-CBD-20010801 1.1 & $4.79 \times 10^{-5}$ & $2.40 \times 10^{-5}$ & $7.49 \times 10^{-4}$ & $1.09 \times 10^{-4}$ \\
\hline 32 & AL-CBD-20010808 1.1 & $5.24 \times 10^{-5}$ & $2.46 \times 10^{-5}$ & $7.74 \times 10^{-4}$ & $1.09 \times 10^{-4}$ \\
\hline 33 & AL-CBD-20010815 1.1 & $7.16 \times 10^{-5}$ & $2.84 \times 10^{-5}$ & $8.78 \times 10^{-4}$ & $1.19 \times 10^{-4}$ \\
\hline 34 & AL-CBD-20010822 1.1 & $4.64 \times 10^{-5}$ & $2.42 \times 10^{-5}$ & $6.19 \times 10^{-4}$ & $9.37 \times 10^{-5}$ \\
\hline 35 & AL-CBD-20010829 1.1 & $\mathrm{~N} / \mathrm{C}^{\mathrm{b}}$ & $\mathrm{N} / \mathrm{C}$ & $\mathrm{N} / \mathrm{C}$ & $\mathrm{N} / \mathrm{C}$ \\
\hline 36 & AL-CBD-20010905 1.1 & $5.22 \times 10^{-5}$ & $2.64 \times 10^{-5}$ & $8.11 \times 10^{-4}$ & $1.15 \times 10^{-4}$ \\
\hline 37 & AL-CBD-20010912 1.1 & $2.11 \times 10^{-5}$ & $1.74 \times 10^{-5}$ & $8.14 \times 10^{-4}$ & $1.14 \times 10^{-4}$ \\
\hline 38 & AL-CBD-20010919 1.1 & $4.70 \times 10^{-5}$ & $2.18 \times 10^{-5}$ & $8.67 \times 10^{-4}$ & $1.18 \times 10^{-4}$ \\
\hline 39 & AL-CBD-20010926 1.1 & $6.31 \times 10^{-5}$ & $2.62 \times 10^{-5}$ & $1.29 \times 10^{-3}$ & $1.63 \times 10^{-4}$ \\
\hline 40 & AL-CBD-20011003 1.1 & $7.18 \times 10^{-5}$ & $2.82 \times 10^{-5}$ & $1.06 \times 10^{-3}$ & $1.40 \times 10^{-4}$ \\
\hline
\end{tabular}


Waste Isolation Pilot Plant 2001 Site Environmental Report DOE/WIPP 02-2225

Table D.1 - Results of Gross Alpha and Gross Beta Analyses in Air Particulates $\left(\mathrm{Bq} / \mathrm{m}^{3}\right)$

\begin{tabular}{|c|c|c|c|c|c|}
\hline \multirow[b]{2}{*}{ Week } & \multirow[b]{2}{*}{ Sample ID } & \multicolumn{2}{|c|}{ Gross Alpha } & \multicolumn{2}{|c|}{ Gross Beta } \\
\hline & & Concentration & $2 \times$ TPU $^{a}$ & Concentration & $2 \times$ TPU \\
\hline 41 & AL-CBD-20011010 1.1 & $\mathrm{~N} / \mathrm{C}$ & $\mathrm{N} / \mathrm{C}$ & $\mathrm{N} / \mathrm{C}$ & $\mathrm{N} / \mathrm{C}$ \\
\hline 42 & AL-CBD-20011017 1.1 & $6.45 \times 10^{-5}$ & $3.05 \times 10^{-5}$ & $1.49 \times 10^{-3}$ & $1.89 \times 10^{-4}$ \\
\hline 43 & AL-CBD-20011024 1.1 & $1.30 \times 10^{-4}$ & $3.87 \times 10^{-5}$ & $1.16 \times 10^{-3}$ & $1.48 \times 10^{-4}$ \\
\hline 44 & AL-CBD-20011031 1.1 & $9.90 \times 10^{-5}$ & $3.35 \times 10^{-5}$ & $7.72 \times 10^{-4}$ & $1.08 \times 10^{-4}$ \\
\hline 45 & AL-CBD-20011107 1.1 & $1.16 \times 10^{-4}$ & $3.77 \times 10^{-5}$ & $1.70 \times 10^{-3}$ & $2.04 \times 10^{-4}$ \\
\hline 46 & AL-CBD-20011114 1.1 & $2.52 \times 10^{-5}$ & $1.79 \times 10^{-5}$ & $9.18 \times 10^{-4}$ & $1.27 \times 10^{-4}$ \\
\hline 47 & AL-CBD-20011121 1.1 & $1.23 \times 10^{-4}$ & $3.51 \times 10^{-5}$ & $9.02 \times 10^{-4}$ & $1.17 \times 10^{-4}$ \\
\hline 48 & AL-CBD-20011128 1.1 & $1.01 \times 10^{-4}$ & $3.46 \times 10^{-5}$ & $1.10 \times 10^{-3}$ & $1.43 \times 10^{-4}$ \\
\hline 49 & AL-CBD-20011205 1.1 & $7.69 \times 10^{-5}$ & $2.63 \times 10^{-5}$ & $6.83 \times 10^{-3}$ & $9.41 \times 10^{-5}$ \\
\hline 50 & AL-CBD-20011212 1.1 & $9.55 \times 10^{-5}$ & $3.45 \times 10^{-5}$ & $1.13 \times 10^{-3}$ & $1.50 \times 10^{-4}$ \\
\hline 51 & AL-CBD-20011219 1.1 & $6.02 \times 10^{-5}$ & $2.60 \times 10^{-5}$ & $1.05 \times 10^{-3}$ & $1.38 \times 10^{-4}$ \\
\hline 52 & AL-CBD-20011226 1.1 & $7.39 \times 10^{-5}$ & $2.84 \times 10^{-5}$ & $1.19 \times 10^{-3}$ & $1.53 \times 10^{-4}$ \\
\hline \multicolumn{6}{|c|}{ Mills Ranch } \\
\hline 1 & AL-MLR-20010103 1.1 & $5.42 \times 10^{-5}$ & $2.48 \times 10^{-5}$ & $1.12 \times 10^{-3}$ & $1.46 \times 10^{-4}$ \\
\hline 2 & AL-MLR-20010110 1.1 & $3.58 \times 10^{-5}$ & $1.98 \times 10^{-5}$ & $7.48 \times 10^{-4}$ & $1.05 \times 10^{-4}$ \\
\hline 3 & AL-MLR-20010117 1.1 & $5.07 \times 10^{-5}$ & $2.35 \times 10^{-5}$ & $1.19 \times 10^{-3}$ & $1.50 \times 10^{-4}$ \\
\hline 4 & AL-MLR-20010124 1.1 & $2.30 \times 10^{-5}$ & $1.71 \times 10^{-5}$ & $8.05 \times 10^{-4}$ & $1.13 \times 10^{-4}$ \\
\hline 5 & AL-MLR-20010131 1.1 & $6.29 \times 10^{-5}$ & $2.68 \times 10^{-5}$ & $1.24 \times 10^{-3}$ & $1.58 \times 10^{-4}$ \\
\hline 6 & AL-MLR-20010207 1.1 & $4.92 \times 10^{-5}$ & $2.36 \times 10^{-5}$ & $8.93 \times 10^{-4}$ & $1.22 \times 10^{-4}$ \\
\hline 7 & AL-MLR-20010214 1.1 & $3.38 \times 10^{-5}$ & $1.85 \times 10^{-5}$ & $1.21 \times 10^{-3}$ & $1.51 \times 10^{-4}$ \\
\hline 8 & AL-MLR-20010221 1.1 & $5.03 \times 10^{-5}$ & $2.42 \times 10^{-5}$ & $5.77 \times 10^{-4}$ & $8.99 \times 10^{-5}$ \\
\hline 9 & AL-MLR-20010228 1.1 & $3.74 \times 10^{-5}$ & $1.95 \times 10^{-5}$ & $8.11 \times 10^{-4}$ & $1.11 \times 10^{-4}$ \\
\hline 10 & AL-MLR-20010307 1.1 & $1.77 \times 10^{-5}$ & $1.45 \times 10^{-5}$ & $6.24 \times 10^{-4}$ & $9.46 \times 10^{-5}$ \\
\hline 11 & AL-MLR-20010314 1.1 & $5.23 \times 10^{-5}$ & $2.38 \times 10^{-5}$ & $7.09 \times 10^{-4}$ & $1.03 \times 10^{-4}$ \\
\hline 12 & AL-MLR-20010321 1.1 & $4.45 \times 10^{-5}$ & $2.19 \times 10^{-5}$ & $7.15 \times 10^{-4}$ & $1.02 \times 10^{-4}$ \\
\hline 13 & AL-MLR-20010328 1.1 & $2.65 \times 10^{-5}$ & $1.70 \times 10^{-5}$ & $8.26 \times 10^{-4}$ & $1.13 \times 10^{-4}$ \\
\hline 14 & AL-MLR-20010404 1.1 & $3.52 \times 10^{-5}$ & $1.97 \times 10^{-5}$ & $7.38 \times 10^{-4}$ & $1.05 \times 10^{-4}$ \\
\hline 15 & AL-MLR-20010411 1.1 & $7.32 \times 10^{-5}$ & $2.48 \times 10^{-5}$ & $9.68 \times 10^{-4}$ & $1.28 \times 10^{-4}$ \\
\hline 16 & AL-MLR-20010418 1.1 & $9.17 \times 10^{-5}$ & $3.31 \times 10^{-5}$ & $7.05 \times 10^{-4}$ & $1.04 \times 10^{-4}$ \\
\hline 17 & AL-MLR-20010425 1.1 & $9.43 \times 10^{-5}$ & $3.37 \times 10^{-5}$ & $1.07 \times 10^{-3}$ & $1.42 \times 10^{-4}$ \\
\hline 18 & AL-MLR-20010502 1.1 & $5.39 \times 10^{-5}$ & $2.45 \times 10^{-5}$ & $8.41 \times 10^{-4}$ & $1.17 \times 10^{-4}$ \\
\hline 19 & AL-MLR-20010509 1.1 & $6.21 \times 10^{-5}$ & $2.53 \times 10^{-5}$ & $8.44 \times 10^{-4}$ & $1.15 \times 10^{-4}$ \\
\hline 20 & AL-MLR-20010516 1.1 & $4.70 \times 10^{-5}$ & $2.30 \times 10^{-5}$ & $7.15 \times 10^{-4}$ & $1.04 \times 10^{-4}$ \\
\hline 21 & AL-MLR-20010523 1.1 & $7.45 \times 10^{-5}$ & $2.94 \times 10^{-5}$ & $9.20 \times 10^{-4}$ & $1.23 \times 10^{-4}$ \\
\hline 22 & AL-MLR-20010530 1.1 & $6.69 \times 10^{-5}$ & $2.84 \times 10^{-5}$ & $8.23 \times 10^{-4}$ & $1.14 \times 10^{-4}$ \\
\hline 23 & AL-MLR-20010606 1.1 & $5.40 \times 10^{-5}$ & $2.49 \times 10^{-5}$ & $7.99 \times 10^{-4}$ & $1.12 \times 10^{-4}$ \\
\hline 24 & AL-MLR-20010613 1.1 & $5.19 \times 10^{-5}$ & $2.39 \times 10^{-5}$ & $6.91 \times 10^{-4}$ & $1.00 \times 10^{-4}$ \\
\hline 25 & AL-MLR-20010620 1.1 & $7.96 \times 10^{-5}$ & $2.96 \times 10^{-5}$ & $7.90 \times 10^{-4}$ & $1.11 \times 10^{-4}$ \\
\hline 26 & AL-MLR-20010627 1.1 & $3.94 \times 10^{-5}$ & $2.26 \times 10^{-5}$ & $8.24 \times 10^{-4}$ & $1.20 \times 10^{-4}$ \\
\hline 27 & AL-MLR-20010704 1.2 & $2.50 \times 10^{-5}$ & $1.63 \times 10^{-5}$ & $6.34 \times 10^{-4}$ & $9.07 \times 10^{-5}$ \\
\hline 28 & AL-MLR-20010711 1.2 & $6.25 \times 10^{-5}$ & $2.73 \times 10^{-5}$ & $8.97 \times 10^{-4}$ & $1.23 \times 10^{-4}$ \\
\hline 29 & AL-MLR-20010718 1.2 & $6.90 \times 10^{-5}$ & $2.79 \times 10^{-5}$ & $7.06 \times 10^{-4}$ & $1.03 \times 10^{-4}$ \\
\hline 30 & AL-MLR-20010725 1.2 & $5.34 \times 10^{-5}$ & $2.46 \times 10^{-5}$ & $6.60 \times 10^{-4}$ & $9.83 \times 10^{-5}$ \\
\hline
\end{tabular}


Waste Isolation Pilot Plant 2001 Site Environmental Report DOE/WIPP 02-2225

Table D.1 - Results of Gross Alpha and Gross Beta Analyses in Air Particulates $\left(\mathrm{Bq} / \mathrm{m}^{3}\right)$

\begin{tabular}{|c|c|c|c|c|c|}
\hline \multirow[b]{2}{*}{ Week } & \multirow[b]{2}{*}{ Sample ID } & \multicolumn{2}{|c|}{ Gross Alpha } & \multicolumn{2}{|c|}{ Gross Beta } \\
\hline & & Concentration & $2 \times \mathrm{TPU}^{\mathrm{a}}$ & Concentration & $2 \times$ TPU \\
\hline 31 & AL-MLR-20010801 1.2 & $3.96 \times 10^{-5}$ & $2.11 \times 10^{-5}$ & $6.86 \times 10^{-4}$ & $1.01 \times 10^{-4}$ \\
\hline 32 & AL-MLR-20010808 1.2 & $7.59 \times 10^{-5}$ & $2.96 \times 10^{-5}$ & $7.82 \times 10^{-4}$ & $1.10 \times 10^{-4}$ \\
\hline 33 & AL-MLR-20010815 1.2 & $8.28 \times 10^{-5}$ & $3.07 \times 10^{-5}$ & $8.34 \times 10^{-4}$ & $1.15 \times 10^{-4}$ \\
\hline 34 & AL-MLR-20010822 1.2 & $3.28 \times 10^{-5}$ & $2.17 \times 10^{-5}$ & $6.88 \times 10^{-4}$ & $1.03 \times 10^{-4}$ \\
\hline 35 & AL-MLR-20010829 1.2 & $4.36 \times 10^{-5}$ & $2.27 \times 10^{-5}$ & $6.04 \times 10^{-4}$ & $9.04 \times 10^{-5}$ \\
\hline 36 & AL-MLR-20010905 1.2 & $4.70 \times 10^{-5}$ & $2.53 \times 10^{-5}$ & $7.25 \times 10^{-4}$ & $1.07 \times 10^{-4}$ \\
\hline 37 & AL-MLR-20010912 1.2 & $2.50 \times 10^{-5}$ & $1.79 \times 10^{-5}$ & $7.50 \times 10^{-4}$ & $1.06 \times 10^{-4}$ \\
\hline 38 & AL-MLR-20010919 1.2 & $5.99 \times 10^{-5}$ & $2.59 \times 10^{-5}$ & $8.80 \times 10^{-4}$ & $1.22 \times 10^{-4}$ \\
\hline 39 & AL-MLR-20010926 1.2 & $5.92 \times 10^{-5}$ & $2.56 \times 10^{-5}$ & $1.25 \times 10^{-3}$ & $1.60 \times 10^{-4}$ \\
\hline 40 & AL-MLR-20011003 1.1 & $3.09 \times 10^{-5}$ & $1.80 \times 10^{-5}$ & $1.08 \times 10^{-3}$ & $1.40 \times 10^{-4}$ \\
\hline 41 & AL-MLR-20011010 1.1 & $5.62 \times 10^{-5}$ & $2.64 \times 10^{-5}$ & $6.78 \times 10^{-4}$ & $1.00 \times 10^{-4}$ \\
\hline 42 & AL-MLR-20011017 1.1 & $5.50 \times 10^{-5}$ & $2.60 \times 10^{-5}$ & $1.42 \times 10^{-3}$ & $1.75 \times 10^{-4}$ \\
\hline 43 & AL-MLR-20011024 1.1 & $1.33 \times 10^{-4}$ & $4.03 \times 10^{-5}$ & $1.05 \times 10^{-3}$ & $1.39 \times 10^{-4}$ \\
\hline 44 & AL-MLR-20011031 1.1 & $8.82 \times 10^{-5}$ & $3.10 \times 10^{-5}$ & $8.32 \times 10^{-4}$ & $1.13 \times 10^{-4}$ \\
\hline 45 & AL-MLR-20011107 1.1 & $1.24 \times 10^{-4}$ & $3.89 \times 10^{-5}$ & $1.56 \times 10^{-3}$ & $1.91 \times 10^{-4}$ \\
\hline 46 & AL-MLR-20011114 1.1 & $2.75 \times 10^{-5}$ & $1.85 \times 10^{-5}$ & $8.29 \times 10^{-4}$ & $1.17 \times 10^{-4}$ \\
\hline 47 & AL-MLR-20011121 1.1 & $1.03 \times 10^{-4}$ & $3.17 \times 10^{-5}$ & $8.38 \times 10^{-4}$ & $1.11 \times 10^{-4}$ \\
\hline 48 & AL-MLR-20011128 1.1 & $9.91 \times 10^{-5}$ & $3.34 \times 10^{-5}$ & $9.58 \times 10^{-4}$ & $1.27 \times 10^{-4}$ \\
\hline 49 & AL-MLR-20011205 1.1 & NC & NC & $\mathrm{NC}$ & NC \\
\hline 50 & AL-MLR-20011212 1.1 & NC & NC & $\mathrm{NC}$ & NC \\
\hline 51 & AL-MLR-20011219 1.1 & $7.86 \times 10^{-5}$ & $2.98 \times 10^{-5}$ & $1.06 \times 10^{-3}$ & $1.39 \times 10^{-4}$ \\
\hline 52 & AL-MLR-20011226 1.1 & $8.32 \times 10^{-5}$ & $2.97 \times 10^{-5}$ & $1.18 \times 10^{-3}$ & $1.51 \times 10^{-4}$ \\
\hline \multicolumn{6}{|c|}{ Southeast Control } \\
\hline 1 & AL-SEC-20010103 1.1 & $5.52 \times 10^{-5}$ & $2.47 \times 10^{-5}$ & $1.21 \times 10^{-3}$ & $1.55 \times 10^{-4}$ \\
\hline 2 & AL-SEC-20010110 1.1 & $5.75 \times 10^{-5}$ & $2.48 \times 10^{-5}$ & $7.62 \times 10^{-4}$ & $1.06 \times 10^{-4}$ \\
\hline 3 & AL-SEC-20010117 1.1 & $3.10 \times 10^{-5}$ & $1.96 \times 10^{-5}$ & $1.12 \times 10^{-3}$ & $1.45 \times 10^{-4}$ \\
\hline 4 & AL-SEC-20010124 1.1 & $4.50 \times 10^{-5}$ & $2.26 \times 10^{-5}$ & $7.99 \times 10^{-4}$ & $1.11 \times 10^{-4}$ \\
\hline 5 & AL-SEC-20010131 1.1 & $8.11 \times 10^{-5}$ & $2.95 \times 10^{-5}$ & $1.12 \times 10^{-3}$ & $1.43 \times 10^{-4}$ \\
\hline 6 & AL-SEC-20010207 1.1 & $5.92 \times 10^{-5}$ & $2.57 \times 10^{-5}$ & $9.78 \times 10^{-4}$ & $1.31 \times 10^{-4}$ \\
\hline 7 & AL-SEC-20010214 1.1 & $4.14 \times 10^{-5}$ & $2.06 \times 10^{-5}$ & $1.26 \times 10^{-3}$ & $1.57 \times 10^{-4}$ \\
\hline 8 & AL-SEC-20010221 1.1 & $5.40 \times 10^{-5}$ & $2.47 \times 10^{-5}$ & $7.37 \times 10^{-4}$ & $1.06 \times 10^{-4}$ \\
\hline 9 & AL-SEC-20010228 1.1 & $5.84 \times 10^{-5}$ & $2.54 \times 10^{-5}$ & $8.61 \times 10^{-4}$ & $1.18 \times 10^{-4}$ \\
\hline 10 & AL-SEC-20010307 1.1 & $3.10 \times 10^{-5}$ & $1.80 \times 10^{-5}$ & $6.13 \times 10^{-4}$ & $9.12 \times 10^{-5}$ \\
\hline 11 & AL-SEC-20010314 1.1 & $4.61 \times 10^{-5}$ & $2.21 \times 10^{-5}$ & $7.31 \times 10^{-4}$ & $1.04 \times 10^{-4}$ \\
\hline 12 & AL-SEC-20010321 1.1 & $2.54 \times 10^{-5}$ & $1.71 \times 10^{-5}$ & $7.24 \times 10^{-4}$ & $1.03 \times 10^{-4}$ \\
\hline 13 & AL-SEC-20010328 1.1 & $4.71 \times 10^{-5}$ & $2.26 \times 10^{-5}$ & $8.37 \times 10^{-4}$ & $1.15 \times 10^{-4}$ \\
\hline 14 & AL-SEC-20010404 1.1 & $8.00 \times 10^{-5}$ & $2.94 \times 10^{-5}$ & $7.70 \times 10^{-4}$ & $1.08 \times 10^{-4}$ \\
\hline 15 & AL-SEC-20010411 1.1 & $5.61 \times 10^{-5}$ & $2.44 \times 10^{-5}$ & $9.60 \times 10^{-4}$ & $1.27 \times 10^{-4}$ \\
\hline 16 & AL-SEC-20010418 1.1 & $8.11 \times 10^{-5}$ & $3.02 \times 10^{-5}$ & $7.56 \times 10^{-4}$ & $1.08 \times 10^{-4}$ \\
\hline 17 & AL-SEC-20010425 1.1 & $4.34 \times 10^{-5}$ & $2.32 \times 10^{-5}$ & $9.68 \times 10^{-4}$ & $1.31 \times 10^{-4}$ \\
\hline 18 & AL-SEC-20010502 1.1 & $3.99 \times 10^{-5}$ & $2.03 \times 10^{-5}$ & $8.58 \times 10^{-4}$ & $1.17 \times 10^{-4}$ \\
\hline 19 & AL-SEC-20010509 1.1 & $4.60 \times 10^{-5}$ & $2.14 \times 10^{-5}$ & $8.04 \times 10^{-4}$ & $1.10 \times 10^{-4}$ \\
\hline 20 & AL-SEC-20010516 1.1 & $4.83 \times 10^{-5}$ & $2.36 \times 10^{-5}$ & $7.06 \times 10^{-4}$ & $1.04 \times 10^{-4}$ \\
\hline
\end{tabular}


Waste Isolation Pilot Plant 2001 Site Environmental Report DOE/WIPP 02-2225

Table D.1 - Results of Gross Alpha and Gross Beta Analyses in Air Particulates $\left(\mathrm{Bq} / \mathrm{m}^{3}\right)$

\begin{tabular}{|c|c|c|c|c|c|}
\hline \multirow[b]{2}{*}{ Week } & \multirow[b]{2}{*}{ Sample ID } & \multicolumn{2}{|c|}{ Gross Alpha } & \multicolumn{2}{|c|}{ Gross Beta } \\
\hline & & Concentration & $2 \times$ TPU $^{a}$ & Concentration & $2 \times$ TPU \\
\hline 21 & AL-SEC-20010523 1.1 & $8.14 \times 10^{-5}$ & $3.05 \times 10^{-5}$ & $9.18 \times 10^{-4}$ & $1.22 \times 10^{-4}$ \\
\hline 22 & AL-SEC-200105301.1 & $6.51 \times 10^{-5}$ & $2.77 \times 10^{-5}$ & $8.63 \times 10^{-4}$ & $1.17 \times 10^{-4}$ \\
\hline 23 & AL-SEC-20010606 1.1 & $1.01 \times 10^{-4}$ & $3.35 \times 10^{-5}$ & $8.01 \times 10^{-4}$ & $1.11 \times 10^{-4}$ \\
\hline 24 & AL-SEC-20010613 1.1 & $6.44 \times 10^{-5}$ & $2.43 \times 10^{-5}$ & $7.05 \times 10^{-4}$ & $9.66 \times 10^{-5}$ \\
\hline 25 & AL-SEC-20010620 1.1 & $7.67 \times 10^{-5}$ & $3.16 \times 10^{-5}$ & $8.89 \times 10^{-4}$ & $1.27 \times 10^{-4}$ \\
\hline 26 & AL-SEC-20010627 1.1 & $4.80 \times 10^{-5}$ & $2.40 \times 10^{-5}$ & $8.47 \times 10^{-4}$ & $1.20 \times 10^{-4}$ \\
\hline 27 & AL-SEC-20010704 1.2 & $3.82 \times 10^{-5}$ & $1.96 \times 10^{-5}$ & $7.14 \times 10^{-4}$ & $9.88 \times 10^{-5}$ \\
\hline 28 & AL-SEC-20010711 1.2 & $4.56 \times 10^{-5}$ & $2.32 \times 10^{-5}$ & $9.08 \times 10^{-4}$ & $1.23 \times 10^{-4}$ \\
\hline 29 & AL-SEC-20010718 1.2 & $5.02 \times 10^{-5}$ & $2.37 \times 10^{-5}$ & $8.10 \times 10^{-4}$ & $1.14 \times 10^{-4}$ \\
\hline 30 & AL-SEC-20010725 1.2 & $3.54 \times 10^{-5}$ & $1.89 \times 10^{-5}$ & $6.64 \times 10^{-4}$ & $9.52 \times 10^{-5}$ \\
\hline 31 & AL-SEC-20010801 1.2 & $2.95 \times 10^{-5}$ & $1.77 \times 10^{-5}$ & $8.06 \times 10^{-4}$ & $1.11 \times 10^{-4}$ \\
\hline 32 & AL-SEC-20010808 1.2 & $7.14 \times 10^{-5}$ & $2.78 \times 10^{-5}$ & $7.72 \times 10^{-4}$ & $1.07 \times 10^{-4}$ \\
\hline 33 & AL-SEC-20010815 1.2 & $5.41 \times 10^{-5}$ & $2.48 \times 10^{-5}$ & $8.54 \times 10^{-4}$ & $1.17 \times 10^{-4}$ \\
\hline 34 & AL-SEC-20010822 1.2 & $5.22 \times 10^{-5}$ & $2.56 \times 10^{-5}$ & $6.41 \times 10^{-4}$ & $9.64 \times 10^{-5}$ \\
\hline 35 & AL-SEC-20010829 1.2 & $5.76 \times 10^{-5}$ & $2.61 \times 10^{-5}$ & $6.68 \times 10^{-4}$ & $9.78 \times 10^{-5}$ \\
\hline 36 & AL-SEC-20010905 1.2 & $4.38 \times 10^{-5}$ & $2.44 \times 10^{-5}$ & $7.77 \times 10^{-4}$ & $1.12 \times 10^{-4}$ \\
\hline 37 & AL-SEC-20010912 1.2 & $2.46 \times 10^{-5}$ & $1.77 \times 10^{-5}$ & $8.25 \times 10^{-4}$ & $1.13 \times 10^{-4}$ \\
\hline 38 & AL-SEC-20010919 1.2 & $4.19 \times 10^{-5}$ & $2.11 \times 10^{-5}$ & $8.89 \times 10^{-4}$ & $1.22 \times 10^{-4}$ \\
\hline 39 & AL-SEC-20010926 1.2 & $5.96 \times 10^{-5}$ & $2.52 \times 10^{-5}$ & $1.24 \times 10^{-3}$ & $1.57 \times 10^{-4}$ \\
\hline 40 & AL-SEC-200110031.1 & $3.13 \times 10^{-5}$ & $1.83 \times 10^{-5}$ & $9.65 \times 10^{-4}$ & $1.29 \times 10^{-4}$ \\
\hline 41 & AL-SEC-20011010 1.1 & $7.74 \times 10^{-5}$ & $3.07 \times 10^{-5}$ & $8.48 \times 10^{-4}$ & $1.18 \times 10^{-4}$ \\
\hline 42 & AL-SEC-20011017 1.1 & $4.96 \times 10^{-5}$ & $2.41 \times 10^{-5}$ & $1.43 \times 10^{-3}$ & $1.75 \times 10^{-4}$ \\
\hline 43 & AL-SEC-20011024 1.1 & $1.40 \times 10^{-4}$ & $4.11 \times 10^{-5}$ & $1.23 \times 10^{-3}$ & $1.56 \times 10^{-4}$ \\
\hline 44 & AL-SEC-20011031 1.1 & $7.72 \times 10^{-5}$ & $2.93 \times 10^{-5}$ & $8.68 \times 10^{-4}$ & $1.17 \times 10^{-4}$ \\
\hline 45 & AL-SEC-20011107 1.1 & $1.16 \times 10^{-4}$ & $3.61 \times 10^{-5}$ & $1.62 \times 10^{-3}$ & $1.93 \times 10^{-4}$ \\
\hline 46 & AL-SEC-20011114 1.1 & $2.58 \times 10^{-5}$ & $1.83 \times 10^{-5}$ & $8.37 \times 10^{-4}$ & $1.19 \times 10^{-4}$ \\
\hline 47 & AL-SEC-20011121 1.1 & $\mathrm{~N} / \mathrm{C}$ & $\mathrm{N} / \mathrm{C}$ & $\mathrm{N} / \mathrm{C}$ & $\mathrm{N} / \mathrm{C}$ \\
\hline 48 & AL-SEC-20011128 1.1 & $9.01 \times 10^{-5}$ & $3.20 \times 10^{-5}$ & $1.02 \times 10^{-3}$ & $1.34 \times 10^{-4}$ \\
\hline 49 & AL-SEC-20011205 1.1 & $\mathrm{NC}$ & NC & NC & $\mathrm{NC}$ \\
\hline 50 & AL-SEC-20011212 1.1 & $1.25 \times 10^{-4}$ & $4.07 \times 10^{-5}$ & $9.93 \times 10^{-4}$ & $1.38 \times 10^{-4}$ \\
\hline 51 & AL-SEC-20011219 1.1 & $8.65 \times 10^{-5}$ & $3.08 \times 10^{-5}$ & $1.09 \times 10^{-3}$ & $1.41 \times 10^{-4}$ \\
\hline 52 & AL-SEC-20011226 1.1 & $7.64 \times 10^{-5}$ & $2.76 \times 10^{-5}$ & $1.12 \times 10^{-3}$ & $1.43 \times 10^{-4}$ \\
\hline \multicolumn{6}{|c|}{ Smith Ranch } \\
\hline 1 & AL-SMR-200101031.2 & $\mathrm{N} / \mathrm{C}^{\mathrm{b}}$ & $\mathrm{N} / \mathrm{C}$ & $\mathrm{N} / \mathrm{C}$ & $\mathrm{N} / \mathrm{C}$ \\
\hline 2 & AL-SMR-200101101.2 & $6.77 \times 10^{-5}$ & $2.70 \times 10^{-5}$ & $7.75 \times 10^{-4}$ & $1.08 \times 10^{-4}$ \\
\hline 3 & AL-SMR-20010117 1.2 & $3.70 \times 10^{-5}$ & $2.06 \times 10^{-5}$ & $1.18 \times 10^{-3}$ & $1.50 \times 10^{-4}$ \\
\hline 4 & AL-SMR-20010124 1.2 & $2.49 \times 10^{-5}$ & $1.74 \times 10^{-5}$ & $8.26 \times 10^{-4}$ & $1.14 \times 10^{-4}$ \\
\hline 5 & AL-SMR-20010131 1.2 & $6.79 \times 10^{-5}$ & $2.78 \times 10^{-5}$ & $1.18 \times 10^{-3}$ & $1.52 \times 10^{-4}$ \\
\hline 6 & AL-SMR-20010207 1.2 & $3.22 \times 10^{-5}$ & $1.81 \times 10^{-5}$ & $8.07 \times 10^{-4}$ & $1.10 \times 10^{-4}$ \\
\hline 7 & AL-SMR-20010214 1.2 & $5.50 \times 10^{-5}$ & $2.45 \times 10^{-5}$ & $1.17 \times 10^{-3}$ & $1.50 \times 10^{-4}$ \\
\hline 8 & AL-SMR-20010221 1.2 & $4.15 \times 10^{-5}$ & $2.19 \times 10^{-5}$ & $6.01 \times 10^{-4}$ & $9.19 \times 10^{-5}$ \\
\hline 9 & AL-SMR-20010228 1.2 & $4.30 \times 10^{-5}$ & $2.12 \times 10^{-5}$ & $8.71 \times 10^{-4}$ & $1.18 \times 10^{-4}$ \\
\hline 10 & AL-SMR-20010307 1.2 & $1.52 \times 10^{-5}$ & $1.37 \times 10^{-5}$ & $5.68 \times 10^{-4}$ & $8.89 \times 10^{-5}$ \\
\hline
\end{tabular}


Waste Isolation Pilot Plant 2001 Site Environmental Report DOE/WIPP 02-2225

Table D.1 - Results of Gross Alpha and Gross Beta Analyses in Air Particulates $\left(\mathrm{Bq} / \mathrm{m}^{3}\right)$

\begin{tabular}{|c|c|c|c|c|c|}
\hline \multirow[b]{2}{*}{ Week } & \multirow[b]{2}{*}{ Sample ID } & \multicolumn{2}{|c|}{ Gross Alpha } & \multicolumn{2}{|c|}{ Gross Beta } \\
\hline & & Concentration & $2 \times$ TPU $^{a}$ & Concentration & $2 \times$ TPU \\
\hline 11 & AL-SMR-20010314 1.2 & $2.81 \times 10^{-5}$ & $1.73 \times 10^{-5}$ & $7.37 \times 10^{-4}$ & $1.05 \times 10^{-4}$ \\
\hline 12 & AL-SMR-20010321 1.2 & $2.77 \times 10^{-5}$ & $1.85 \times 10^{-5}$ & $6.36 \times 10^{-4}$ & $9.62 \times 10^{-5}$ \\
\hline 13 & AL-SMR-20010328 1.2 & $3.09 \times 10^{-5}$ & $1.89 \times 10^{-5}$ & $7.60 \times 10^{-4}$ & $1.08 \times 10^{-4}$ \\
\hline 14 & AL-SMR-20010404 1.1 & $6.46 \times 10^{-5}$ & $2.68 \times 10^{-5}$ & $7.91 \times 10^{-4}$ & $1.11 \times 10^{-4}$ \\
\hline 15 & AL-SMR-20010411 1.1 & $6.43 \times 10^{-5}$ & $2.84 \times 10^{-5}$ & $6.82 \times 10^{-4}$ & $1.04 \times 10^{-4}$ \\
\hline 16 & AL-SMR-20010418 1.1 & $7.02 \times 10^{-5}$ & $2.96 \times 10^{-5}$ & $6.92 \times 10^{-4}$ & $1.04 \times 10^{-4}$ \\
\hline 17 & AL-SMR-20010425 1.1 & $6.25 \times 10^{-5}$ & $2.76 \times 10^{-5}$ & $9.32 \times 10^{-4}$ & $1.28 \times 10^{-4}$ \\
\hline 18 & AL-SMR-20010502 1.1 & $4.58 \times 10^{-5}$ & $2.26 \times 10^{-5}$ & $7.78 \times 10^{-4}$ & $1.11 \times 10^{-4}$ \\
\hline 19 & AL-SMR-20010509 1.1 & $5.63 \times 10^{-5}$ & $2.49 \times 10^{-5}$ & $8.09 \times 10^{-4}$ & $1.14 \times 10^{-4}$ \\
\hline 20 & AL-SMR-20010516 1.1 & $3.32 \times 10^{-5}$ & $1.92 \times 10^{-5}$ & $6.31 \times 10^{-4}$ & $9.52 \times 10^{-5}$ \\
\hline 21 & AL-SMR-20010523 1.1 & $9.96 \times 10^{-5}$ & $3.68 \times 10^{-5}$ & $9.75 \times 10^{-4}$ & $1.33 \times 10^{-4}$ \\
\hline 22 & AL-SMR-200105301.1 & $5.26 \times 10^{-5}$ & $2.58 \times 10^{-5}$ & $8.29 \times 10^{-4}$ & $1.15 \times 10^{-4}$ \\
\hline 23 & AL-SMR-20010606 1.1 & $8.24 \times 10^{-5}$ & $2.97 \times 10^{-5}$ & $6.91 \times 10^{-4}$ & $9.89 \times 10^{-5}$ \\
\hline 24 & AL-SMR-20010613 1.1 & $4.28 \times 10^{-5}$ & $2.14 \times 10^{-5}$ & $6.33 \times 10^{-4}$ & $9.31 \times 10^{-5}$ \\
\hline 25 & AL-SMR-200106201.1 & $5.96 \times 10^{-5}$ & $2.62 \times 10^{-5}$ & $8.19 \times 10^{-4}$ & $1.16 \times 10^{-4}$ \\
\hline 26 & AL-SMR-20010627 1.1 & $\mathrm{~N} / \mathrm{C}$ & $\mathrm{N} / \mathrm{C}$ & $\mathrm{N} / \mathrm{C}$ & $\mathrm{N} / \mathrm{C}$ \\
\hline 27 & AL-SMR-20010704 1.1 & $6.20 \times 10^{-5}$ & $2.51 \times 10^{-5}$ & $6.14 \times 10^{-4}$ & $8.88 \times 10^{-5}$ \\
\hline 28 & AL-SMR-20010711 1.1 & $6.47 \times 10^{-5}$ & $2.71 \times 10^{-5}$ & $8.11 \times 10^{-4}$ & $1.12 \times 10^{-4}$ \\
\hline 29 & AL-SMR-20010718 1.1 & $5.71 \times 10^{-5}$ & $2.57 \times 10^{-5}$ & $4.71 \times 10^{-4}$ & $7.88 \times 10^{-5}$ \\
\hline 30 & AL-SMR-20010725 1.1 & $4.11 \times 10^{-5}$ & $2.12 \times 10^{-5}$ & $6.89 \times 10^{-4}$ & $1.00 \times 10^{-4}$ \\
\hline 31 & AL-SMR-20010801 1.1 & $5.26 \times 10^{-5}$ & $2.31 \times 10^{-5}$ & $7.62 \times 10^{-4}$ & $1.06 \times 10^{-4}$ \\
\hline 32 & AL-SMR-20010808 1.1 & $6.68 \times 10^{-5}$ & $2.80 \times 10^{-5}$ & $7.42 \times 10^{-4}$ & $1.07 \times 10^{-4}$ \\
\hline 33 & AL-SMR-20010815 1.1 & $3.98 \times 10^{-5}$ & $2.18 \times 10^{-5}$ & $8.29 \times 10^{-4}$ & $1.16 \times 10^{-4}$ \\
\hline 34 & AL-SMR-20010822 1.1 & $4.70 \times 10^{-5}$ & $2.53 \times 10^{-5}$ & $5.70 \times 10^{-4}$ & $9.07 \times 10^{-5}$ \\
\hline 35 & AL-SMR-20010829 1.1 & $3.52 \times 10^{-5}$ & $2.12 \times 10^{-5}$ & $6.34 \times 10^{-4}$ & $9.45 \times 10^{-5}$ \\
\hline 36 & AL-SMR-20010905 1.1 & $4.47 \times 10^{-5}$ & $2.49 \times 10^{-5}$ & $7.23 \times 10^{-4}$ & $1.07 \times 10^{-4}$ \\
\hline 37 & AL-SMR-20010912 1.1 & $3.54 \times 10^{-5}$ & $2.17 \times 10^{-5}$ & $8.09 \times 10^{-4}$ & $1.14 \times 10^{-4}$ \\
\hline 38 & AL-SMR-20010919 1.1 & $3.78 \times 10^{-5}$ & $1.97 \times 10^{-5}$ & $8.54 \times 10^{-4}$ & $1.17 \times 10^{-4}$ \\
\hline 39 & AL-SMR-20010926 1.1 & $4.80 \times 10^{-5}$ & $2.29 \times 10^{-5}$ & $1.20 \times 10^{-3}$ & $1.54 \times 10^{-4}$ \\
\hline 40 & AL-SMR-200110031.2 & $4.23 \times 10^{-5}$ & $2.21 \times 10^{-5}$ & $1.02 \times 10^{-3}$ & $1.37 \times 10^{-4}$ \\
\hline 41 & AL-SMR-20011010 1.2 & $7.41 \times 10^{-5}$ & $3.05 \times 10^{-5}$ & $8.20 \times 10^{-4}$ & $1.16 \times 10^{-4}$ \\
\hline 42 & AL-SMR-20011017 1.2 & $3.66 \times 10^{-5}$ & $2.18 \times 10^{-5}$ & $1.39 \times 10^{-3}$ & $1.73 \times 10^{-4}$ \\
\hline 43 & AL-SMR-20011024 1.2 & $1.08 \times 10^{-4}$ & $3.63 \times 10^{-5}$ & $1.19 \times 10^{-3}$ & $1.53 \times 10^{-4}$ \\
\hline 44 & AL-SMR-20011031 1.2 & $\mathrm{~N} / \mathrm{C}$ & $\mathrm{N} / \mathrm{C}$ & $\mathrm{N} / \mathrm{C}$ & $\mathrm{N} / \mathrm{C}$ \\
\hline 45 & AL-SMR-20011107 1.2 & $\mathrm{~N} / \mathrm{C}$ & $\mathrm{N} / \mathrm{C}$ & $\mathrm{N} / \mathrm{C}$ & $\mathrm{N} / \mathrm{C}$ \\
\hline 46 & AL-SMR-20011114 1.2 & $\mathrm{~N} / \mathrm{C}$ & $\mathrm{N} / \mathrm{C}$ & $\mathrm{N} / \mathrm{C}$ & $\mathrm{N} / \mathrm{C}$ \\
\hline 47 & AL-SMR-20011121 1.2 & $\mathrm{~N} / \mathrm{C}$ & $\mathrm{N} / \mathrm{C}$ & $\mathrm{N} / \mathrm{C}$ & $\mathrm{N} / \mathrm{C}$ \\
\hline 48 & AL-SMR-20011128 1.2 & $9.20 \times 10^{-5}$ & $3.23 \times 10^{-5}$ & $9.38 \times 10^{-4}$ & $1.25 \times 10^{-4}$ \\
\hline 49 & AL-SMR-20011205 1.2 & $4.27 \times 10^{-5}$ & $1.98 \times 10^{-5}$ & $6.89 \times 10^{-4}$ & $9.55 \times 10^{-5}$ \\
\hline 50 & AL-SMR-20011212 1.2 & $7.72 \times 10^{-5}$ & $3.07 \times 10^{-5}$ & $1.13 \times 10^{-3}$ & $1.50 \times 10^{-4}$ \\
\hline 51 & AL-SMR-20011219 1.2 & $4.28 \times 10^{-5}$ & $2.16 \times 10^{-5}$ & $1.09 \times 10^{-3}$ & $1.41 \times 10^{-4}$ \\
\hline 52 & AL-SMR-20011226 1.2 & $6.77 \times 10^{-5}$ & $2.68 \times 10^{-5}$ & $1.16 \times 10^{-3}$ & $1.49 \times 10^{-4}$ \\
\hline
\end{tabular}


Waste Isolation Pilot Plant 2001 Site Environmental Report DOE/WIPP 02-2225

Table D.1 - Results of Gross Alpha and Gross Beta Analyses in Air Particulates $\left(\mathrm{Bg} / \mathrm{m}^{3}\right)$

\begin{tabular}{|c|c|c|c|c|c|}
\hline \multirow[b]{2}{*}{ Week } & \multirow[b]{2}{*}{ Sample ID } & \multicolumn{2}{|c|}{ Gross Alpha } & \multicolumn{2}{|c|}{ Gross Beta } \\
\hline & & Concentration & $2 \times$ TPU $^{a}$ & Concentration & $2 \times$ TPU \\
\hline \multicolumn{6}{|c|}{ WIPP Air Blank } \\
\hline 1 & AL-WAB-200101031.1 & $2.62 \times 10^{-3}$ & $5.00 \times 10^{-3}$ & $4.48 \times 10^{-2}$ & $1.77 \times 10^{-2}$ \\
\hline 2 & AL-WAB-20010110 1.1 & $1.49 \times 10^{-3}$ & $5.13 \times 10^{-3}$ & $2.76 \times 10^{-2}$ & $1.66 \times 10^{-2}$ \\
\hline 3 & AL-WAB-20010117 1.1 & $-1.54 \times 10^{-3}$ & $5.16 \times 10^{-3}$ & $2.34 \times 10^{-2}$ & $1.60 \times 10^{-2}$ \\
\hline 4 & AL-WAB-20010124 1.1 & $-1.80 \times 10^{-5}$ & $4.21 \times 10^{-3}$ & $1.77 \times 10^{-2}$ & $1.51 \times 10^{-2}$ \\
\hline 5 & AL-WAB-20010131 1.1 & $4.30 \times 10^{-3}$ & $5.75 \times 10^{-3}$ & $8.08 \times 10^{-2}$ & $2.23 \times 10^{-2}$ \\
\hline 6 & AL-WAB-20010207 1.1 & $7.31 \times 10^{-3}$ & $7.10 \times 10^{-3}$ & $5.06 \times 10^{-2}$ & $1.82 \times 10^{-2}$ \\
\hline 7 & AL-WAB-20010214 1.1 & $-1.57 \times 10^{-3}$ & $4.16 \times 10^{-3}$ & $5.35 \times 10^{-2}$ & $1.86 \times 10^{-2}$ \\
\hline 8 & AL-WAB-20010221 1.1 & $1.74 \times 10^{-3}$ & $5.02 \times 10^{-3}$ & $3.82 \times 10^{-2}$ & $1.73 \times 10^{-2}$ \\
\hline 9 & AL-WAB-20010228 1.1 & $1.40 \times 10^{-3}$ & $4.04 \times 10^{-3}$ & $5.27 \times 10^{-2}$ & $1.93 \times 10^{-2}$ \\
\hline 10 & AL-WAB-20010307 1.1 & $2.88 \times 10^{-3}$ & $4.98 \times 10^{-3}$ & $5.15 \times 10^{-2}$ & $1.91 \times 10^{-2}$ \\
\hline 11 & AL-WAB-20010314 1.1 & $2.88 \times 10^{-3}$ & $4.99 \times 10^{-3}$ & $3.68 \times 10^{-2}$ & $1.73 \times 10^{-2}$ \\
\hline 12 & AL-WAB-20010321 1.1 & $2.84 \times 10^{-3}$ & $5.70 \times 10^{-3}$ & $3.77 \times 10^{-2}$ & $1.72 \times 10^{-2}$ \\
\hline 13 & AL-WAB-20010328 1.1 & $2.83 \times 10^{-3}$ & $5.69 \times 10^{-3}$ & $4.55 \times 10^{-2}$ & $1.83 \times 10^{-2}$ \\
\hline 14 & AL-WAB-20010404 1.1 & $1.44 \times 10^{-3}$ & $4.14 \times 10^{-3}$ & $5.44 \times 10^{-2}$ & $1.99 \times 10^{-2}$ \\
\hline 15 & AL-WAB-20010411 1.1 & $9.01 \times 10^{-3}$ & $7.87 \times 10^{-3}$ & $5.16 \times 10^{-2}$ & $1.95 \times 10^{-2}$ \\
\hline 16 & AL-WAB-20010418 1.1 & $7.29 \times 10^{-3}$ & $8.17 \times 10^{-3}$ & $5.27 \times 10^{-2}$ & $2.02 \times 10^{-2}$ \\
\hline 17 & AL-WAB-20010425 1.1 & $5.83 \times 10^{-3}$ & $7.64 \times 10^{-3}$ & $4.48 \times 10^{-2}$ & $1.91 \times 10^{-2}$ \\
\hline 18 & AL-WAB-20010502 1.1 & $7.34 \times 10^{-3}$ & $7.14 \times 10^{-3}$ & $5.09 \times 10^{-2}$ & $1.98 \times 10^{-2}$ \\
\hline 19 & AL-WAB-20010509 1.1 & $1.33 \times 10^{-2}$ & $9.26 \times 10^{-3}$ & $4.57 \times 10^{-2}$ & $1.89 \times 10^{-2}$ \\
\hline 20 & AL-WAB-20010516 1.1 & $1.44 \times 10^{-3}$ & $4.08 \times 10^{-3}$ & $3.54 \times 10^{-2}$ & $1.75 \times 10^{-2}$ \\
\hline 21 & AL-WAB-20010523 1.1 & $1.48 \times 10^{-3}$ & $6.52 \times 10^{-3}$ & $5.49 \times 10^{-2}$ & $1.88 \times 10^{-2}$ \\
\hline 22 & AL-WAB-200105301.1 & $-1.50 \times 10^{-3}$ & $6.53 \times 10^{-3}$ & $6.94 \times 10^{-2}$ & $2.08 \times 10^{-2}$ \\
\hline 23 & AL-WAB-20010606 1.1 & $2.95 \times 10^{-3}$ & $5.04 \times 10^{-3}$ & $6.71 \times 10^{-2}$ & $2.00 \times 10^{-2}$ \\
\hline 24 & AL-WAB-20010613 1.1 & $1.04 \times 10^{-2}$ & $8.30 \times 10^{-3}$ & $6.87 \times 10^{-2}$ & $2.02 \times 10^{-2}$ \\
\hline 25 & AL-WAB-20010620 1.1 & $2.94 \times 10^{-3}$ & $5.01 \times 10^{-3}$ & $5.99 \times 10^{-2}$ & $2.02 \times 10^{-2}$ \\
\hline 26 & AL-WAB-20010627 1.1 & $4.41 \times 10^{-3}$ & $5.79 \times 10^{-3}$ & $4.64 \times 10^{-2}$ & $1.84 \times 10^{-2}$ \\
\hline 27 & AL-WAB-20010704 1.1 & $-3.02 \times 10^{-3}$ & $5.90 \times 10^{-3}$ & $4.67 \times 10^{-2}$ & $1.73 \times 10^{-2}$ \\
\hline 28 & AL-WAB-20010711 1.1 & $1.47 \times 10^{-3}$ & $5.78 \times 10^{-3}$ & $3.11 \times 10^{-2}$ & $1.63 \times 10^{-2}$ \\
\hline 29 & AL-WAB-20010718 1.1 & $5.90 \times 10^{-3}$ & $6.50 \times 10^{-3}$ & $4.65 \times 10^{-2}$ & $1.83 \times 10^{-2}$ \\
\hline 30 & AL-WAB-20010725 1.1 & $4.43 \times 10^{-3}$ & $5.81 \times 10^{-3}$ & $3.68 \times 10^{-2}$ & $1.69 \times 10^{-2}$ \\
\hline 31 & AL-WAB-20010801 1.1 & $1.47 \times 10^{-3}$ & $4.09 \times 10^{-3}$ & $3.70 \times 10^{-2}$ & $1.70 \times 10^{-2}$ \\
\hline 32 & AL-WAB-20010808 1.1 & $8.93 \times 10^{-3}$ & $8.30 \times 10^{-3}$ & $5.61 \times 10^{-2}$ & $1.91 \times 10^{-2}$ \\
\hline 33 & AL-WAB-20010815 1.1 & $1.48 \times 10^{-3}$ & $5.05 \times 10^{-3}$ & $6.00 \times 10^{-2}$ & $1.97 \times 10^{-2}$ \\
\hline 34 & AL-WAB-20010822 1.1 & $1.50 \times 10^{-3}$ & $6.60 \times 10^{-3}$ & $2.20 \times 10^{-2}$ & $1.66 \times 10^{-2}$ \\
\hline 35 & AL-WAB-20010829 1.1 & $-3.01 \times 10^{-3}$ & $7.23 \times 10^{-3}$ & $2.45 \times 10^{-2}$ & $1.70 \times 10^{-2}$ \\
\hline 36 & AL-WAB-20010905 1.1 & $-3.01 \times 10^{-3}$ & $7.23 \times 10^{-3}$ & $1.68 \times 10^{-2}$ & $1.59 \times 10^{-2}$ \\
\hline 37 & AL-WAB-20010912 1.1 & $1.49 \times 10^{-3}$ & $5.89 \times 10^{-3}$ & $6.06 \times 10^{-2}$ & $1.98 \times 10^{-2}$ \\
\hline 38 & AL-WAB-20010919 1.1 & $7.54 \times 10^{-3}$ & $6.67 \times 10^{-3}$ & $3.87 \times 10^{-2}$ & $1.82 \times 10^{-2}$ \\
\hline 39 & AL-WAB-20010926 1.1 & $4.53 \times 10^{-3}$ & $5.15 \times 10^{-3}$ & $2.32 \times 10^{-2}$ & $1.60 \times 10^{-2}$ \\
\hline 40 & AL-WAB-20011003 1.1 & $2.88 \times 10^{-3}$ & $4.99 \times 10^{-3}$ & $6.92 \times 10^{-2}$ & $2.15 \times 10^{-2}$ \\
\hline 41 & AL-WAB-200110101.1 & $-2.78 \times 10^{-5}$ & $5.11 \times 10^{-3}$ & $3.53 \times 10^{-2}$ & $1.71 \times 10^{-2}$ \\
\hline 42 & AL-WAB-20011017 1.1 & $4.49 \times 10^{-3}$ & $7.22 \times 10^{-3}$ & $2.50 \times 10^{-2}$ & $1.56 \times 10^{-2}$ \\
\hline 43 & AL-WAB-20011024 1.1 & $4.54 \times 10^{-3}$ & $6.00 \times 10^{-3}$ & $5.28 \times 10^{-2}$ & $1.91 \times 10^{-2}$ \\
\hline
\end{tabular}


Waste Isolation Pilot Plant 2001 Site Environmental Report DOE/WIPP 02-2225

Table D.1 - Results of Gross Alpha and Gross Beta Analyses in Air Particulates $\left(\mathrm{Bq} / \mathrm{m}^{3}\right)$

\begin{tabular}{|c|c|c|c|c|c|}
\hline \multirow[b]{2}{*}{ Week } & \multirow[b]{2}{*}{ Sample ID } & \multicolumn{2}{|c|}{ Gross Alpha } & \multicolumn{2}{|c|}{ Gross Beta } \\
\hline & & Concentration & $2 \times \mathrm{TPU}^{\mathrm{a}}$ & Concentration & $2 \times$ TPU \\
\hline 44 & AL-WAB-20011031 1.1 & $-6.97 \times 10^{-4}$ & $5.02 \times 10^{-3}$ & $4.61 \times 10^{-2}$ & $1.83 \times 10^{-2}$ \\
\hline 45 & AL-WAB-20011107 1.1 & $6.08 \times 10^{-3}$ & $6.73 \times 10^{-3}$ & $4.83 \times 10^{-2}$ & $1.85 \times 10^{-2}$ \\
\hline 46 & AL-WAB-20011114 1.1 & $7.62 \times 10^{-3}$ & $7.39 \times 10^{-3}$ & $4.37 \times 10^{-2}$ & $1.78 \times 10^{-2}$ \\
\hline 47 & AL-WAB-20011121 1.1 & $3.08 \times 10^{-3}$ & $6.06 \times 10^{-3}$ & $3.77 \times 10^{-2}$ & $1.77 \times 10^{-2}$ \\
\hline 48 & AL-WAB-20011128 1.1 & $1.53 \times 10^{-3}$ & $5.24 \times 10^{-3}$ & $3.45 \times 10^{-2}$ & $1.73 \times 10^{-2}$ \\
\hline 49 & AL-WAB-20011205 1.1 & $6.03 \times 10^{-3}$ & $6.66 \times 10^{-3}$ & $4.60 \times 10^{-2}$ & $1.81 \times 10^{-2}$ \\
\hline 50 & AL-WAB-20011212 1.1 & $1.50 \times 10^{-3}$ & $4.21 \times 10^{-3}$ & $3.48 \times 10^{-2}$ & $1.82 \times 10^{-2}$ \\
\hline 51 & AL-WAB-20011219 1.1 & $3.00 \times 10^{-3}$ & $5.14 \times 10^{-3}$ & $4.96 \times 10^{-2}$ & $1.86 \times 10^{-2}$ \\
\hline 52 & AL-WAB-20011226 1.1 & $1.49 \times 10^{-3}$ & $2.95 \times 10^{-3}$ & $4.12 \times 10^{-2}$ & $1.84 \times 10^{-2}$ \\
\hline \multicolumn{6}{|c|}{ WIPP East } \\
\hline 1 & AL-WEE-20010103 1.2 & $4.19 \times 10^{-5}$ & $2.29 \times 10^{-5}$ & $1.12 \times 10^{-3}$ & $1.49 \times 10^{-4}$ \\
\hline 2 & AL-WEE-20010110 1.2 & $2.94 \times 10^{-5}$ & $1.85 \times 10^{-5}$ & $7.95 \times 10^{-4}$ & $1.10 \times 10^{-4}$ \\
\hline 3 & AL-WEE-20010117 1.2 & $6.18 \times 10^{-5}$ & $2.62 \times 10^{-5}$ & $1.21 \times 10^{-3}$ & $1.53 \times 10^{-4}$ \\
\hline 4 & AL-WEE-20010124 1.2 & $3.22 \times 10^{-5}$ & $1.93 \times 10^{-5}$ & $7.73 \times 10^{-4}$ & $1.08 \times 10^{-4}$ \\
\hline 5 & AL-WEE-20010131 1.2 & $9.76 \times 10^{-5}$ & $3.28 \times 10^{-5}$ & $1.31 \times 10^{-3}$ & $1.64 \times 10^{-4}$ \\
\hline 6 & AL-WEE-20010207 1.2 & $4.93 \times 10^{-5}$ & $2.36 \times 10^{-5}$ & $8.69 \times 10^{-4}$ & $1.20 \times 10^{-4}$ \\
\hline 7 & AL-WEE-20010214 1.2 & $4.59 \times 10^{-5}$ & $2.28 \times 10^{-5}$ & $1.30 \times 10^{-3}$ & $1.64 \times 10^{-4}$ \\
\hline 8 & AL-WEE-20010221 1.2 & $4.27 \times 10^{-5}$ & $2.19 \times 10^{-5}$ & $7.20 \times 10^{-4}$ & $1.03 \times 10^{-4}$ \\
\hline 9 & AL-WEE-20010228 1.2 & $5.57 \times 10^{-5}$ & $2.37 \times 10^{-5}$ & $9.12 \times 10^{-4}$ & $1.21 \times 10^{-4}$ \\
\hline 10 & AL-WEE-20010307 1.2 & $2.99 \times 10^{-5}$ & $1.81 \times 10^{-5}$ & $5.54 \times 10^{-4}$ & $8.61 \times 10^{-5}$ \\
\hline 11 & AL-WEE-20010314 1.2 & $4.69 \times 10^{-5}$ & $2.19 \times 10^{-5}$ & $6.84 \times 10^{-4}$ & $9.86 \times 10^{-5}$ \\
\hline 12 & AL-WEE-20010321 1.2 & $3.56 \times 10^{-5}$ & $2.08 \times 10^{-5}$ & $7.69 \times 10^{-4}$ & $1.10 \times 10^{-4}$ \\
\hline 13 & AL-WEE-20010328 1.2 & $4.73 \times 10^{-5}$ & $2.27 \times 10^{-5}$ & $8.39 \times 10^{-4}$ & $1.15 \times 10^{-4}$ \\
\hline 14 & AL-WEE-20010404 1.1 & $8.49 \times 10^{-5}$ & $3.13 \times 10^{-5}$ & $8.36 \times 10^{-4}$ & $1.17 \times 10^{-4}$ \\
\hline 15 & AL-WEE-20010411 1.1 & $7.09 \times 10^{-5}$ & $2.74 \times 10^{-5}$ & $9.04 \times 10^{-4}$ & $1.21 \times 10^{-4}$ \\
\hline 16 & AL-WEE-20010418 1.1 & $6.64 \times 10^{-5}$ & $2.74 \times 10^{-5}$ & $6.44 \times 10^{-4}$ & $9.61 \times 10^{-5}$ \\
\hline 17 & AL-WEE-20010425 1.1 & $4.28 \times 10^{-4}$ & $2.37 \times 10^{-5}$ & $9.64 \times 10^{-4}$ & $1.32 \times 10^{-4}$ \\
\hline 18 & AL-WEE-20010502 1.1 & $7.04 \times 10^{-5}$ & $2.68 \times 10^{-5}$ & $8.16 \times 10^{-4}$ & $1.12 \times 10^{-4}$ \\
\hline 19 & AL-WEE-20010509 1.1 & $7.14 \times 10^{-5}$ & $2.85 \times 10^{-5}$ & $8.18 \times 10^{-4}$ & $1.15 \times 10^{-4}$ \\
\hline 20 & AL-WEE-20010516 1.1 & $2.71 \times 10^{-5}$ & $1.72 \times 10^{-5}$ & $5.80 \times 10^{-4}$ & $8.89 \times 10^{-5}$ \\
\hline 21 & AL-WEE-20010523 1.1 & $6.85 \times 10^{-5}$ & $2.91 \times 10^{-5}$ & $9.18 \times 10^{-4}$ & $1.24 \times 10^{-4}$ \\
\hline 22 & AL-WEE-20010530 1.1 & $6.95 \times 10^{-5}$ & $2.95 \times 10^{-5}$ & $8.10 \times 10^{-4}$ & $1.13 \times 10^{-4}$ \\
\hline 23 & AL-WEE-20010606 1.1 & $6.87 \times 10^{-5}$ & $2.89 \times 10^{-5}$ & $8.50 \times 10^{-4}$ & $1.20 \times 10^{-4}$ \\
\hline 24 & AL-WEE-20010613 1.1 & $4.96 \times 10^{-5}$ & $2.35 \times 10^{-5}$ & $7.21 \times 10^{-4}$ & $1.03 \times 10^{-4}$ \\
\hline 25 & AL-WEE-20010620 1.1 & $1.22 \times 10^{-4}$ & $3.76 \times 10^{-5}$ & $8.85 \times 10^{-4}$ & $1.22 \times 10^{-4}$ \\
\hline 26 & AL-WEE-20010627 1.1 & $6.70 \times 10^{-5}$ & $2.88 \times 10^{-5}$ & $7.85 \times 10^{-4}$ & $1.15 \times 10^{-4}$ \\
\hline 27 & AL-WEE-20010704 1.1 & $4.29 \times 10^{-5}$ & $2.14 \times 10^{-5}$ & $6.48 \times 10^{-4}$ & $9.34 \times 10^{-5}$ \\
\hline 28 & AL-WEE-20010711 1.1 & $1.03 \times 10^{-4}$ & $3.52 \times 10^{-5}$ & $8.37 \times 10^{-4}$ & $1.17 \times 10^{-4}$ \\
\hline 29 & AL-WEE-20010718 1.1 & $6.10 \times 10^{-5}$ & $2.68 \times 10^{-5}$ & $7.72 \times 10^{-4}$ & $1.11 \times 10^{-4}$ \\
\hline 30 & AL-WEE-20010725 1.1 & $5.84 \times 10^{-5}$ & $2.57 \times 10^{-5}$ & $6.73 \times 10^{-4}$ & $9.94 \times 10^{-5}$ \\
\hline 31 & AL-WEE-20010801 1.1 & $5.49 \times 10^{-5}$ & $2.41 \times 10^{-5}$ & $7.61 \times 10^{-4}$ & $1.07 \times 10^{-4}$ \\
\hline 32 & AL-WEE-20010808 1.1 & $9.02 \times 10^{-5}$ & $3.25 \times 10^{-5}$ & $6.94 \times 10^{-4}$ & $1.01 \times 10^{-4}$ \\
\hline 33 & AL-WEE-20010815 1.1 & $4.14 \times 10^{-5}$ & $2.27 \times 10^{-5}$ & $8.68 \times 10^{-4}$ & $1.21 \times 10^{-4}$ \\
\hline
\end{tabular}


Waste Isolation Pilot Plant 2001 Site Environmental Report DOE/WIPP 02-2225

Table D.1 - Results of Gross Alpha and Gross Beta Analyses in Air Particulates $\left(\mathrm{Bq} / \mathrm{m}^{3}\right)$

\begin{tabular}{|c|c|c|c|c|c|}
\hline \multirow[b]{2}{*}{ Week } & \multirow[b]{2}{*}{ Sample ID } & \multicolumn{2}{|c|}{ Gross Alpha } & \multicolumn{2}{|c|}{ Gross Beta } \\
\hline & & Concentration & $2 \times$ TPU $^{a}$ & Concentration & $2 \times$ TPU \\
\hline 34 & AL-WEE-20010822 1.1 & $4.08 \times 10^{-5}$ & $2.36 \times 10^{-5}$ & $5.80 \times 10^{-4}$ & $9.12 \times 10^{-5}$ \\
\hline 35 & AL-WEE-20010829 1.1 & $4.07 \times 10^{-5}$ & $2.27 \times 10^{-5}$ & $6.64 \times 10^{-4}$ & $9.80 \times 10^{-5}$ \\
\hline 36 & AL-WEE-20010905 1.1 & $5.71 \times 10^{-5}$ & $2.72 \times 10^{-5}$ & $7.46 \times 10^{-4}$ & $1.08 \times 10^{-4}$ \\
\hline 37 & AL-WEE-20010912 1.1 & $2.41 \times 10^{-5}$ & $1.84 \times 10^{-5}$ & $8.71 \times 10^{-4}$ & $1.20 \times 10^{-4}$ \\
\hline 38 & AL-WEE-20010919 1.1 & $7.01 \times 10^{-5}$ & $2.75 \times 10^{-5}$ & $8.51 \times 10^{-4}$ & $1.18 \times 10^{-4}$ \\
\hline 39 & AL-WEE-20010926 1.1 & $5.28 \times 10^{-5}$ & $2.39 \times 10^{-5}$ & $1.31 \times 10^{-3}$ & $1.65 \times 10^{-4}$ \\
\hline 40 & AL-WEE-20011003 1.1 & $4.69 \times 10^{-5}$ & $2.30 \times 10^{-5}$ & $1.05 \times 10^{-3}$ & $1.39 \times 10^{-4}$ \\
\hline 41 & AL-WEE-20011010 1.1 & $5.23 \times 10^{-5}$ & $2.76 \times 10^{-5}$ & $8.33 \times 10^{-4}$ & $1.21 \times 10^{-4}$ \\
\hline 42 & AL-WEE-20011017 1.1 & $5.89 \times 10^{-5}$ & $2.65 \times 10^{-5}$ & $1.45 \times 10^{-3}$ & $1.78 \times 10^{-4}$ \\
\hline 43 & AL-WEE-20011024 1.1 & $1.26 \times 10^{-4}$ & $3.92 \times 10^{-5}$ & $1.14 \times 10^{-3}$ & $1.48 \times 10^{-4}$ \\
\hline 44 & AL-WEE-20011031 1.1 & $6.89 \times 10^{-5}$ & $2.85 \times 10^{-5}$ & $8.15 \times 10^{-4}$ & $1.14 \times 10^{-4}$ \\
\hline 45 & AL-WEE-20011107 1.1 & $1.12 \times 10^{-4}$ & $3.51 \times 10^{-5}$ & $1.64 \times 10^{-3}$ & $1.95 \times 10^{-4}$ \\
\hline 46 & AL-WEE-20011114 1.1 & $4.59 \times 10^{-5}$ & $2.47 \times 10^{-5}$ & $7.66 \times 10^{-4}$ & $1.13 \times 10^{-4}$ \\
\hline 47 & AL-WEE-20011121 1.1 & $1.15 \times 10^{-4}$ & $3.35 \times 10^{-5}$ & $8.23 \times 10^{-4}$ & $1.09 \times 10^{-4}$ \\
\hline 48 & AL-WEE-20011128 1.1 & $8.50 \times 10^{-5}$ & $3.11 \times 10^{-5}$ & $1.01 \times 10^{-3}$ & $1.33 \times 10^{-4}$ \\
\hline 49 & AL-WEE-20011205 1.1 & $7.98 \times 10^{-5}$ & $2.73 \times 10^{-5}$ & $6.89 \times 10^{-4}$ & $9.56 \times 10^{-5}$ \\
\hline 50 & AL-WEE-20011212 1.1 & $1.07 \times 10^{-4}$ & $3.65 \times 10^{-5}$ & $1.19 \times 10^{-3}$ & $1.55 \times 10^{-4}$ \\
\hline 51 & AL-WEE-20011219 1.1 & $8.37 \times 10^{-5}$ & $2.99 \times 10^{-5}$ & $1.02 \times 10^{-3}$ & $1.33 \times 10^{-4}$ \\
\hline 52 & AL-WEE-20011226 1.1 & $1.02 \times 10^{-4}$ & $3.35 \times 10^{-5}$ & $1.11 \times 10^{-3}$ & $1.44 \times 10^{-4}$ \\
\hline
\end{tabular}

WIPP Far Field

\begin{tabular}{|c|c|c|c|c|c|}
\hline 1 & AL-WFF-20010103 1.1 & $\mathrm{~N} / \mathrm{C}$ & $\mathrm{N} / \mathrm{C}$ & $\mathrm{N} / \mathrm{C}$ & $\mathrm{N} / \mathrm{C}$ \\
\hline 2 & AL-WFF-20010110 1.1 & $2.71 \times 10^{-5}$ & $1.79 \times 10^{-5}$ & $7.62 \times 10^{-4}$ & $1.07 \times 10^{-4}$ \\
\hline 3 & AL-WFF-20010117 1.1 & $4.55 \times 10^{-5}$ & $2.22 \times 10^{-5}$ & $1.10 \times 10^{-3}$ & $1.41 \times 10^{-4}$ \\
\hline 4 & AL-WFF-20010124 1.1 & $1.99 \times 10^{-5}$ & $1.60 \times 10^{-5}$ & $8.58 \times 10^{-4}$ & $1.18 \times 10^{-4}$ \\
\hline 5 & AL-WFF-20010131 1.1 & $1.07 \times 10^{-4}$ & $3.51 \times 10^{-5}$ & $1.36 \times 10^{-3}$ & $1.70 \times 10^{-4}$ \\
\hline 6 & AL-WFF-20010207 1.1 & $5.65 \times 10^{-5}$ & $2.46 \times 10^{-5}$ & $9.04 \times 10^{-4}$ & $1.22 \times 10^{-4}$ \\
\hline 7 & AL-WFF-20010214 1.1 & $3.20 \times 10^{-5}$ & $1.90 \times 10^{-5}$ & $1.29 \times 10^{-3}$ & $1.63 \times 10^{-4}$ \\
\hline 8 & AL-WFF-20010221 1.1 & $5.33 \times 10^{-5}$ & $2.44 \times 10^{-5}$ & $6.49 \times 10^{-4}$ & $9.63 \times 10^{-5}$ \\
\hline 9 & AL-WFF-20010228 1.1 & $4.41 \times 10^{-5}$ & $2.17 \times 10^{-5}$ & $9.10 \times 10^{-4}$ & $1.23 \times 10^{-4}$ \\
\hline 10 & AL-WFF-20010307 1.1 & $2.18 \times 10^{-5}$ & $1.55 \times 10^{-5}$ & $5.87 \times 10^{-4}$ & $8.92 \times 10^{-5}$ \\
\hline 11 & AL-WFF-20010314 1.1 & $3.47 \times 10^{-5}$ & $1.90 \times 10^{-5}$ & $9.13 \times 10^{-4}$ & $1.22 \times 10^{-4}$ \\
\hline 12 & AL-WFF-20010321 1.1 & $3.62 \times 10^{-5}$ & $2.03 \times 10^{-5}$ & $7.04 \times 10^{-4}$ & $1.02 \times 10^{-4}$ \\
\hline 13 & AL-WFF-20010328 1.1 & $3.86 \times 10^{-5}$ & $2.03 \times 10^{-5}$ & $9.33 \times 10^{-4}$ & $1.24 \times 10^{-4}$ \\
\hline 14 & AL-WFF-20010404 1.1 & $5.07 \times 10^{-5}$ & $2.42 \times 10^{-5}$ & $8.41 \times 10^{-4}$ & $1.81 \times 10^{-4}$ \\
\hline 15 & AL-WFF-20010411 1.1 & $4.83 \times 10^{-5}$ & $2.25 \times 10^{-5}$ & $9.16 \times 10^{-4}$ & $1.22 \times 10^{-4}$ \\
\hline 16 & AL-WFF-20010418 1.1 & $8.04 \times 10^{-5}$ & $3.04 \times 10^{-5}$ & $7.79 \times 10^{-4}$ & $1.11 \times 10^{-4}$ \\
\hline 17 & AL-WFF-20010425 1.1 & $6.43 \times 10^{-5}$ & $2.72 \times 10^{-5}$ & $1.07 \times 10^{-3}$ & $1.40 \times 10^{-4}$ \\
\hline 18 & AL-WFF-20010502 1.1 & $7.00 \times 10^{-5}$ & $2.76 \times 10^{-5}$ & $8.78 \times 10^{-4}$ & $1.20 \times 10^{-4}$ \\
\hline 19 & AL-WFF-20010509 1.1 & $1.14 \times 10^{-4}$ & $4.07 \times 10^{-5}$ & $1.18 \times 10^{-3}$ & $1.61 \times 10^{-4}$ \\
\hline 20 & AL-WFF-20010516 1.1 & $5.03 \times 10^{-5}$ & $2.34 \times 10^{-5}$ & $7.19 \times 10^{-4}$ & $1.04 \times 10^{-4}$ \\
\hline 21 & AL-WFF-20010523 1.1 & $5.57 \times 10^{-5}$ & $2.59 \times 10^{-5}$ & $8.38 \times 10^{-4}$ & $1.15 \times 10^{-4}$ \\
\hline 22 & AL-WFF-20010530 1.1 & $\mathrm{~N} / \mathrm{C}$ & $\mathrm{N} / \mathrm{C}$ & $\mathrm{N} / \mathrm{C}$ & $\mathrm{N} / \mathrm{C}$ \\
\hline 23 & AL-WFF-20010606 1.1 & $6.57 \times 10^{-5}$ & $3.11 \times 10^{-5}$ & $9.80 \times 10^{-4}$ & $1.39 \times 10^{-4}$ \\
\hline
\end{tabular}


Waste Isolation Pilot Plant 2001 Site Environmental Report DOE/WIPP 02-2225

Table D.1 - Results of Gross Alpha and Gross Beta Analyses in Air Particulates $\left(\mathrm{Bq} / \mathrm{m}^{3}\right)$

\begin{tabular}{|c|c|c|c|c|c|}
\hline \multirow[b]{2}{*}{ Week } & \multirow[b]{2}{*}{ Sample ID } & \multicolumn{2}{|c|}{ Gross Alpha } & \multicolumn{2}{|c|}{ Gross Beta } \\
\hline & & Concentration & $2 \times \mathrm{TPU}^{\mathrm{a}}$ & Concentration & $2 \times$ TPU \\
\hline 24 & AL-WFF-20010613 1.1 & $3.48 \times 10^{-5}$ & $1.92 \times 10^{-5}$ & $6.83 \times 10^{-4}$ & $9.81 \times 10^{-5}$ \\
\hline 25 & AL-WFF-20010620 1.1 & $9.22 \times 10^{-5}$ & $3.23 \times 10^{-5}$ & $9.67 \times 10^{-4}$ & $1.30 \times 10^{-4}$ \\
\hline 26 & AL-WFF-20010627 1.1 & $6.69 \times 10^{-5}$ & $2.94 \times 10^{-5}$ & $8.62 \times 10^{-4}$ & $1.24 \times 10^{-4}$ \\
\hline 27 & AL-WFF-20010704 1.1 & $4.76 \times 10^{-5}$ & $2.25 \times 10^{-5}$ & $6.41 \times 10^{-4}$ & $9.25 \times 10^{-5}$ \\
\hline 28 & AL-WFF-20010711 1.1 & $5.41 \times 10^{-5}$ & $2.54 \times 10^{-5}$ & $9.84 \times 10^{-4}$ & $1.31 \times 10^{-4}$ \\
\hline 29 & AL-WFF-20010718 1.1 & $7.50 \times 10^{-5}$ & $2.92 \times 10^{-5}$ & $7.14 \times 10^{-4}$ & $1.04 \times 10^{-4}$ \\
\hline 30 & AL-WFF-20010725 1.1 & $5.87 \times 10^{-5}$ & $2.47 \times 10^{-5}$ & $6.64 \times 10^{-4}$ & $9.62 \times 10^{-5}$ \\
\hline 31 & AL-WFF-20010801 1.1 & $3.51 \times 10^{-5}$ & $2.02 \times 10^{-5}$ & $8.29 \times 10^{-4}$ & $1.16 \times 10^{-4}$ \\
\hline 32 & AL-WFF-20010808 1.1 & $8.32 \times 10^{-5}$ & $3.09 \times 10^{-5}$ & $8.03 \times 10^{-4}$ & $1.12 \times 10^{-4}$ \\
\hline 33 & AL-WFF-20010815 1.1 & $4.77 \times 10^{-5}$ & $2.44 \times 10^{-5}$ & $8.00 \times 10^{-4}$ & $1.14 \times 10^{-4}$ \\
\hline 34 & AL-WFF-20010822 1.1 & $7.08 \times 10^{-5}$ & $3.01 \times 10^{-5}$ & $6.20 \times 10^{-4}$ & $9.54 \times 10^{-5}$ \\
\hline 35 & AL-WFF-20010829 1.1 & $3.14 \times 10^{-5}$ & $1.98 \times 10^{-5}$ & $7.20 \times 10^{-4}$ & $1.02 \times 10^{-4}$ \\
\hline 36 & AL-WFF-20010905 1.1 & $3.83 \times 10^{-5}$ & $2.31 \times 10^{-5}$ & $8.08 \times 10^{-4}$ & $1.15 \times 10^{-4}$ \\
\hline 37 & AL-WFF-20010912 1.1 & $3.87 \times 10^{-5}$ & $2.19 \times 10^{-5}$ & $8.24 \times 10^{-4}$ & $1.14 \times 10^{-4}$ \\
\hline 38 & AL-WFF-20010919 1.1 & $5.20 \times 10^{-5}$ & $2.35 \times 10^{-5}$ & $9.17 \times 10^{-4}$ & $1.25 \times 10^{-4}$ \\
\hline 39 & AL-WFF-20010926 1.1 & $4.31 \times 10^{-5}$ & $2.12 \times 10^{-5}$ & $1.26 \times 10^{-3}$ & $1.58 \times 10^{-4}$ \\
\hline 40 & AL-WFF-20011003 1.2 & $3.54 \times 10^{-5}$ & $1.99 \times 10^{-5}$ & $1.05 \times 10^{-3}$ & $1.39 \times 10^{-4}$ \\
\hline 41 & AL-WFF-20011010 1.2 & $4.76 \times 10^{-5}$ & $2.61 \times 10^{-5}$ & $7.94 \times 10^{-4}$ & $1.16 \times 10^{-4}$ \\
\hline 42 & AL-WFF-20011017 1.2 & $6.02 \times 10^{-5}$ & $2.65 \times 10^{-5}$ & $1.50 \times 10^{-3}$ & $1.82 \times 10^{-4}$ \\
\hline 43 & AL-WFF-20011024 1.2 & $1.52 \times 10^{-4}$ & $4.27 \times 10^{-5}$ & $1.30 \times 10^{-3}$ & $1.63 \times 10^{-4}$ \\
\hline 44 & AL-WFF-20011031 1.2 & $7.22 \times 10^{-5}$ & $2.88 \times 10^{-5}$ & $8.93 \times 10^{-4}$ & $1.21 \times 10^{-4}$ \\
\hline 45 & AL-WFF-20011107 1.2 & $9.91 \times 10^{-5}$ & $3.33 \times 10^{-5}$ & $1.66 \times 10^{-3}$ & $1.98 \times 10^{-4}$ \\
\hline 46 & AL-WFF-20011114 1.2 & $3.63 \times 10^{-5}$ & $2.11 \times 10^{-5}$ & $7.56 \times 10^{-4}$ & $1.09 \times 10^{-4}$ \\
\hline 47 & AL-WFF-20011121 1.2 & $\mathrm{~N} / \mathrm{C}$ & $\mathrm{N} / \mathrm{C}$ & $\mathrm{N} / \mathrm{C}$ & $\mathrm{N} / \mathrm{C}$ \\
\hline 48 & AL-WFF-20011128 1.2 & $8.45 \times 10^{-5}$ & $3.05 \times 10^{-5}$ & $1.00 \times 10^{-3}$ & $1.31 \times 10^{-4}$ \\
\hline 49 & AL-WFF-20011205 1.2 & $7.10 \times 10^{-5}$ & $2.57 \times 10^{-5}$ & $6.46 \times 10^{-4}$ & $9.11 \times 10^{-5}$ \\
\hline 50 & AL-WFF-20011212 1.2 & $1.08 \times 10^{-4}$ & $3.70 \times 10^{-5}$ & $1.33 \times 10^{-3}$ & $1.71 \times 10^{-4}$ \\
\hline 51 & AL-WFF-20011219 1.2 & $7.79 \times 10^{-5}$ & $2.86 \times 10^{-5}$ & $1.15 \times 10^{-3}$ & $1.46 \times 10^{-4}$ \\
\hline 52 & AL-WFF-20011226 1.2 & $6.25 \times 10^{-5}$ & $2.49 \times 10^{-5}$ & $1.12 \times 10^{-3}$ & $1.43 \times 10^{-4}$ \\
\hline \multicolumn{6}{|c|}{ WIPP South } \\
\hline 1 & AL-WSS-200101031.1 & $8.46 \times 10^{-5}$ & $3.08 \times 10^{-5}$ & $1.22 \times 10^{-3}$ & $1.56 \times 10^{-4}$ \\
\hline 2 & AL-WSS-200101101.1 & $3.52 \times 10^{-5}$ & $1.95 \times 10^{-5}$ & $7.95 \times 10^{-4}$ & $1.09 \times 10^{-4}$ \\
\hline 3 & AL-WSS-20010117 1.1 & $5.93 \times 10^{-5}$ & $2.51 \times 10^{-5}$ & $1.13 \times 10^{-3}$ & $1.43 \times 10^{-4}$ \\
\hline 4 & AL-WSS-20010124 1.1 & $2.79 \times 10^{-5}$ & $1.84 \times 10^{-5}$ & $8.74 \times 10^{-4}$ & $1.20 \times 10^{-4}$ \\
\hline 5 & AL-WSS-20010131 1.1 & $7.82 \times 10^{-5}$ & $2.94 \times 10^{-5}$ & $1.17 \times 10^{-3}$ & $1.50 \times 10^{-4}$ \\
\hline 6 & AL-WSS-20010207 1.1 & $5.17 \times 10^{-5}$ & $2.41 \times 10^{-5}$ & $8.28 \times 10^{-4}$ & $1.15 \times 10^{-4}$ \\
\hline 7 & AL-WSS-20010214 1.1 & $2.73 \times 10^{-5}$ & $1.69 \times 10^{-5}$ & $1.16 \times 10^{-3}$ & $1.47 \times 10^{-4}$ \\
\hline 8 & AL-WSS-20010221 1.1 & $5.38 \times 10^{-5}$ & $2.52 \times 10^{-5}$ & $6.05 \times 10^{-4}$ & $9.34 \times 10^{-5}$ \\
\hline 9 & AL-WSS-20010228 1.1 & $5.57 \times 10^{-5}$ & $2.37 \times 10^{-5}$ & $7.81 \times 10^{-4}$ & $1.08 \times 10^{-4}$ \\
\hline 10 & AL-WSS-20010307 1.1 & $3.23 \times 10^{-5}$ & $1.88 \times 10^{-5}$ & $6.68 \times 10^{-4}$ & $9.81 \times 10^{-5}$ \\
\hline 11 & AL-WSS-20010314 1.1 & $5.36 \times 10^{-5}$ & $2.38 \times 10^{-5}$ & $6.39 \times 10^{-4}$ & $9.49 \times 10^{-5}$ \\
\hline 12 & AL-WSS-20010321 1.1 & $4.29 \times 10^{-5}$ & $2.17 \times 10^{-5}$ & $7.43 \times 10^{-4}$ & $1.05 \times 10^{-4}$ \\
\hline 13 & AL-WSS-20010328 1.1 & $5.19 \times 10^{-5}$ & $2.37 \times 10^{-5}$ & $8.61 \times 10^{-4}$ & $1.17 \times 10^{-4}$ \\
\hline
\end{tabular}


Table D.1 - Results of Gross Alpha and Gross Beta Analyses in Air Particulates $\left(\mathrm{Bq} / \mathrm{m}^{3}\right)$

\begin{tabular}{|c|c|c|c|c|c|}
\hline \multirow[b]{2}{*}{ Week } & \multirow[b]{2}{*}{ Sample ID } & \multicolumn{2}{|c|}{ Gross Alpha } & \multicolumn{2}{|c|}{ Gross Beta } \\
\hline & & Concentration & $2 \times$ TPU $^{a}$ & Concentration & $2 \times$ TPU \\
\hline 14 & AL-WSS-20010404 1.2 & $8.69 \times 10^{-5}$ & $3.15 \times 10^{-5}$ & $7.40 \times 10^{-4}$ & $1.06 \times 10^{-4}$ \\
\hline 15 & AL-WSS-20010411 1.2 & $5.36 \times 10^{-5}$ & $2.38 \times 10^{-5}$ & $8.57 \times 10^{-4}$ & $1.16 \times 10^{-4}$ \\
\hline 16 & AL-WSS-20010418 1.2 & $7.32 \times 10^{-5}$ & $2.87 \times 10^{-5}$ & $7.83 \times 10^{-4}$ & $1.10 \times 10^{-4}$ \\
\hline 17 & AL-WSS-20010425 1.2 & $7.80 \times 10^{-5}$ & $2.96 \times 10^{-5}$ & $1.06 \times 10^{-3}$ & $1.39 \times 10^{-4}$ \\
\hline 18 & AL-WSS-20010502 1.2 & $7.54 \times 10^{-5}$ & $2.92 \times 10^{-5}$ & $7.88 \times 10^{-4}$ & $1.12 \times 10^{-4}$ \\
\hline 19 & AL-WSS-20010509 1.2 & $6.05 \times 10^{-5}$ & $2.62 \times 10^{-5}$ & $7.86 \times 10^{-4}$ & $1.12 \times 10^{-4}$ \\
\hline 20 & AL-WSS-20010516 1.2 & $4.32 \times 10^{-5}$ & $2.18 \times 10^{-5}$ & $6.44 \times 10^{-4}$ & $9.62 \times 10^{-5}$ \\
\hline 21 & AL-WSS-200105231.2 & $5.91 \times 10^{-5}$ & $2.75 \times 10^{-5}$ & $8.98 \times 10^{-4}$ & $1.23 \times 10^{-4}$ \\
\hline 22 & AL-WSS-200105301.2 & $8.27 \times 10^{-5}$ & $3.15 \times 10^{-5}$ & $8.72 \times 10^{-4}$ & $1.19 \times 10^{-4}$ \\
\hline 23 & AL-WSS-20010606 1.2 & $6.82 \times 10^{-5}$ & $2.87 \times 10^{-5}$ & $8.90 \times 10^{-4}$ & $1.23 \times 10^{-4}$ \\
\hline 24 & AL-WSS-20010613 1.2 & $5.27 \times 10^{-5}$ & $2.43 \times 10^{-5}$ & $6.68 \times 10^{-4}$ & $9.81 \times 10^{-5}$ \\
\hline 25 & AL-WSS-200106201.2 & $9.79 \times 10^{-5}$ & $3.39 \times 10^{-5}$ & $8.56 \times 10^{-4}$ & $1.20 \times 10^{-4}$ \\
\hline 26 & AL-WSS-20010627 1.2 & $7.38 \times 10^{-5}$ & $3.04 \times 10^{-5}$ & $7.49 \times 10^{-4}$ & $1.11 \times 10^{-4}$ \\
\hline 27 & AL-WSS-20010704 1.1 & $2.98 \times 10^{-5}$ & $1.78 \times 10^{-5}$ & $6.27 \times 10^{-4}$ & $9.03 \times 10^{-5}$ \\
\hline 28 & AL-WSS-20010711 1.1 & $6.42 \times 10^{-5}$ & $2.80 \times 10^{-5}$ & $7.86 \times 10^{-4}$ & $1.12 \times 10^{-4}$ \\
\hline 29 & AL-WSS-20010718 1.1 & $6.76 \times 10^{-5}$ & $2.73 \times 10^{-5}$ & $7.01 \times 10^{-4}$ & $1.02 \times 10^{-4}$ \\
\hline 30 & AL-WSS-20010725 1.1 & $4.10 \times 10^{-5}$ & $2.11 \times 10^{-5}$ & $6.93 \times 10^{-4}$ & $1.01 \times 10^{-4}$ \\
\hline 31 & AL-WSS-20010801 1.1 & $3.67 \times 10^{-5}$ & $2.03 \times 10^{-5}$ & $7.81 \times 10^{-4}$ & $1.10 \times 10^{-4}$ \\
\hline 32 & AL-WSS-20010808 1.1 & $5.44 \times 10^{-5}$ & $2.50 \times 10^{-5}$ & $6.90 \times 10^{-4}$ & $1.00 \times 10^{-4}$ \\
\hline 33 & AL-WSS-20010815 1.1 & $5.72 \times 10^{-5}$ & $2.69 \times 10^{-5}$ & $7.77 \times 10^{-4}$ & $1.12 \times 10^{-4}$ \\
\hline 34 & AL-WSS-20010822 1.1 & $3.21 \times 10^{-5}$ & $2.02 \times 10^{-5}$ & $6.05 \times 10^{-4}$ & $9.10 \times 10^{-5}$ \\
\hline 35 & AL-WSS-20010829 1.1 & $3.84 \times 10^{-5}$ & $2.14 \times 10^{-5}$ & $6.22 \times 10^{-4}$ & $9.19 \times 10^{-5}$ \\
\hline 36 & AL-WSS-20010905 1.1 & $4.57 \times 10^{-5}$ & $2.46 \times 10^{-5}$ & $7.70 \times 10^{-4}$ & $1.11 \times 10^{-4}$ \\
\hline 37 & AL-WSS-20010912 1.1 & $3.00 \times 10^{-5}$ & $2.03 \times 10^{-5}$ & $7.70 \times 10^{-4}$ & $1.10 \times 10^{-4}$ \\
\hline 38 & AL-WSS-20010919 1.1 & $6.50 \times 10^{-5}$ & $2.70 \times 10^{-5}$ & $9.65 \times 10^{-4}$ & $1.31 \times 10^{-4}$ \\
\hline 39 & AL-WSS-20010926 1.1 & $5.83 \times 10^{-5}$ & $2.52 \times 10^{-5}$ & $1.18 \times 10^{-3}$ & $1.52 \times 10^{-4}$ \\
\hline 40 & AL-WSS-20011003 1.1 & $4.55 \times 10^{-5}$ & $2.23 \times 10^{-5}$ & $1.03 \times 10^{-3}$ & $1.36 \times 10^{-4}$ \\
\hline 41 & AL-WSS-20011010 1.1 & $4.49 \times 10^{-5}$ & $2.55 \times 10^{-5}$ & $6.73 \times 10^{-4}$ & $1.03 \times 10^{-4}$ \\
\hline 42 & AL-WSS-20011017 1.1 & $7.05 \times 10^{-5}$ & $2.97 \times 10^{-5}$ & $1.44 \times 10^{-3}$ & $1.78 \times 10^{-4}$ \\
\hline 43 & AL-WSS-20011024 1.1 & $1.28 \times 10^{-4}$ & $3.78 \times 10^{-5}$ & $1.19 \times 10^{-3}$ & $1.52 \times 10^{-4}$ \\
\hline 44 & AL-WSS-20011031 1.1 & $6.62 \times 10^{-5}$ & $2.74 \times 10^{-5}$ & $7.95 \times 10^{-4}$ & $1.11 \times 10^{-4}$ \\
\hline 45 & AL-WSS-20011107 1.1 & $1.40 \times 10^{-4}$ & $4.08 \times 10^{-5}$ & $1.51 \times 10^{-3}$ & $1.83 \times 10^{-4}$ \\
\hline 46 & AL-WSS-20011114 1.1 & $2.47 \times 10^{-5}$ & $1.76 \times 10^{-5}$ & $8.25 \times 10^{-4}$ & $1.16 \times 10^{-4}$ \\
\hline 47 & AL-WSS-20011121 1.1 & $1.22 \times 10^{-4}$ & $3.50 \times 10^{-5}$ & $7.80 \times 10^{-4}$ & $1.05 \times 10^{-4}$ \\
\hline 48 & AL-WSS-20011128 1.1 & $1.23 \times 10^{-4}$ & $3.69 \times 10^{-5}$ & $1.17 \times 10^{-3}$ & $1.47 \times 10^{-4}$ \\
\hline 49 & AL-WSS-20011205 1.1 & $5.88 \times 10^{-5}$ & $2.30 \times 10^{-5}$ & $6.27 \times 10^{-4}$ & $8.86 \times 10^{-5}$ \\
\hline 50 & AL-WSS-20011212 1.1 & $\mathrm{~N} / \mathrm{C}$ & $\mathrm{N} / \mathrm{C}$ & $\mathrm{N} / \mathrm{C}$ & $\mathrm{N} / \mathrm{C}$ \\
\hline 51 & AL-WSS-20011219 1.1 & $4.97 \times 10^{-5}$ & $2.50 \times 10^{-5}$ & $1.05 \times 10^{-3}$ & $1.42 \times 10^{-4}$ \\
\hline 52 & AL-WSS-20011226 1.1 & $9.08 \times 10^{-5}$ & $3.07 \times 10^{-5}$ & $1.09 \times 10^{-3}$ & $1.40 \times 10^{-4}$ \\
\hline
\end{tabular}


Waste Isolation Pilot Plant 2001 Site Environmental Report DOE/WIPP 02-2225

Table D.1 - Results of Gross Alpha and Gross Beta Analyses in Air Particulates $\left(\mathrm{Bq} / \mathrm{m}^{3}\right)$

\begin{tabular}{|c|c|c|c|c|c|}
\hline \multirow[b]{2}{*}{ Week } & \multirow[b]{2}{*}{ Sample ID } & \multicolumn{2}{|c|}{ Gross Alpha } & \multicolumn{2}{|c|}{ Gross Beta } \\
\hline & & Concentration & $2 \times$ TPU $^{\mathrm{a}}$ & Concentration & $2 \times$ TPU \\
\hline \multicolumn{6}{|c|}{ Duplicate Samples } \\
\hline \multicolumn{6}{|c|}{ WIPP East (WEE) } \\
\hline 1 & AL-WEE-20010103 2.2 & $4.74 \times 10^{-5}$ & $2.23 \times 10^{-5}$ & $1.23 \times 10^{-3}$ & $1.55 \times 10^{-4}$ \\
\hline 2 & AL-WEE-20010110 2.2 & $6.17 \times 10^{-5}$ & $2.55 \times 10^{-5}$ & $7.78 \times 10^{-4}$ & $1.07 \times 10^{-4}$ \\
\hline 3 & AL-WEE-20010117 2.2 & $3.07 \times 10^{-5}$ & $1.86 \times 10^{-5}$ & $1.21 \times 10^{-3}$ & $1.52 \times 10^{-4}$ \\
\hline 4 & AL-WEE-20010124 2.2 & $5.77 \times 10^{-5}$ & $2.54 \times 10^{-5}$ & $8.34 \times 10^{-4}$ & $1.15 \times 10^{-4}$ \\
\hline 5 & AL-WEE-200101312.2 & $1.07 \times 10^{-5}$ & $3.52 \times 10^{-5}$ & $1.32 \times 10^{-3}$ & $1.66 \times 10^{-4}$ \\
\hline 6 & AL-WEE-20010207 2.2 & $4.19 \times 10^{-5}$ & $2.13 \times 10^{-5}$ & $9.19 \times 10^{-4}$ & $1.24 \times 10^{-4}$ \\
\hline 7 & AL-WEE-20010214 2.2 & $4.08 \times 10^{-5}$ & $2.15 \times 10^{-5}$ & $1.17 \times 10^{-3}$ & $1.50 \times 10^{-4}$ \\
\hline 8 & AL-WEE-20010221 2.2 & $3.75 \times 10^{-5}$ & $2.13 \times 10^{-5}$ & $7.49 \times 10^{-4}$ & $1.08 \times 10^{-4}$ \\
\hline 9 & AL-WEE-20010228 2.2 & $5.63 \times 10^{-5}$ & $2.39 \times 10^{-5}$ & $8.63 \times 10^{-4}$ & $1.16 \times 10^{-4}$ \\
\hline 10 & AL-WEE-20010307 2.2 & $1.67 \times 10^{-5}$ & $1.37 \times 10^{-5}$ & $5.77 \times 10^{-4}$ & $8.80 \times 10^{-5}$ \\
\hline 11 & AL-WEE-20010314 2.2 & $5.14 \times 10^{-5}$ & $2.40 \times 10^{-5}$ & $7.17 \times 10^{-4}$ & $1.05 \times 10^{-4}$ \\
\hline 12 & AL-WEE-20010321 2.2 & $3.95 \times 10^{-5}$ & $2.13 \times 10^{-5}$ & $6.97 \times 10^{-4}$ & $1.02 \times 10^{-4}$ \\
\hline 13 & AL-WEE-20010328 2.2 & $6.21 \times 10^{-5}$ & $2.59 \times 10^{-5}$ & $8.67 \times 10^{-4}$ & $1.18 \times 10^{-4}$ \\
\hline \multicolumn{6}{|c|}{ WIPP South (WSS) } \\
\hline 14 & AL-WSS-20010404 2.2 & $7.63 \times 10^{-5}$ & $2.94 \times 10^{-5}$ & $7.01 \times 10^{-4}$ & $1.02 \times 10^{-4}$ \\
\hline 15 & AL-WSS-200104112.2 & $5.64 \times 10^{-5}$ & $2.50 \times 10^{-5}$ & $9.49 \times 10^{-4}$ & $1.27 \times 10^{-4}$ \\
\hline 16 & AL-WSS-20010418 2.2 & $7.40 \times 10^{-5}$ & $2.90 \times 10^{-5}$ & $7.68 \times 10^{-4}$ & $1.09 \times 10^{-4}$ \\
\hline 17 & AL-WSS-20010425 2.2 & $5.83 \times 10^{-5}$ & $2.57 \times 10^{-5}$ & $9.50 \times 10^{-4}$ & $1.27 \times 10^{-4}$ \\
\hline 18 & AL-WSS-20010502 2.2 & $6.39 \times 10^{-5}$ & $2.66 \times 10^{-5}$ & $7.35 \times 10^{-4}$ & $1.06 \times 10^{-4}$ \\
\hline 19 & AL-WSS-20010509 2.2 & $5.82 \times 10^{-5}$ & $2.52 \times 10^{-5}$ & $9.11 \times 10^{-4}$ & $1.24 \times 10^{-4}$ \\
\hline 20 & AL-WSS-20010516 2.2 & $3.80 \times 10^{-5}$ & $2.04 \times 10^{-5}$ & $6.32 \times 10^{-4}$ & $9.51 \times 10^{-5}$ \\
\hline 21 & AL-WSS-20010523 2.2 & $6.81 \times 10^{-5}$ & $2.89 \times 10^{-5}$ & $8.15 \times 10^{-4}$ & $1.13 \times 10^{-4}$ \\
\hline 22 & AL-WSS-20010530 2.2 & $6.98 \times 10^{-5}$ & $2.91 \times 10^{-5}$ & $8.65 \times 10^{-4}$ & $1.18 \times 10^{-4}$ \\
\hline 23 & AL-WSS-20010606 2.2 & $7.27 \times 10^{-5}$ & $2.94 \times 10^{-5}$ & $7.55 \times 10^{-4}$ & $1.09 \times 10^{-4}$ \\
\hline 24 & AL-WSS-200106132.2 & $5.83 \times 10^{-5}$ & $2.56 \times 10^{-5}$ & $6.37 \times 10^{-4}$ & $9.50 \times 10^{-5}$ \\
\hline 25 & AL-WSS-20010620 2.2 & $9.08 \times 10^{-5}$ & $3.18 \times 10^{-5}$ & $9.21 \times 10^{-4}$ & $1.25 \times 10^{-4}$ \\
\hline 26 & AL-WSS-20010627 2.2 & $7.27 \times 10^{-5}$ & $3.06 \times 10^{-5}$ & $7.75 \times 10^{-4}$ & $1.15 \times 10^{-4}$ \\
\hline \multicolumn{6}{|c|}{ Mills Ranch (MLR) } \\
\hline 27 & AL-MLR-20010704 2.2 & $4.17 \times 10^{-5}$ & $2.08 \times 10^{-5}$ & $6.82 \times 10^{-4}$ & $9.61 \times 10^{-5}$ \\
\hline 28 & AL-MLR-200107112.2 & $5.70 \times 10^{-5}$ & $2.61 \times 10^{-5}$ & $9.08 \times 10^{-4}$ & $1.24 \times 10^{-4}$ \\
\hline 29 & AL-MLR-20010718 2.2 & $6.90 \times 10^{-5}$ & $2.79 \times 10^{-5}$ & $7.06 \times 10^{-4}$ & $1.03 \times 10^{-4}$ \\
\hline 30 & AL-MLR-20010725 2.2 & $3.39 \times 10^{-5}$ & $1.95 \times 10^{-5}$ & $7.24 \times 10^{-4}$ & $1.04 \times 10^{-4}$ \\
\hline 31 & AL-MLR-20010801 2.2 & $2.36 \times 10^{-5}$ & $1.65 \times 10^{-5}$ & $8.08 \times 10^{-4}$ & $1.13 \times 10^{-4}$ \\
\hline 32 & AL-MLR-20010808 2.2 & $9.41 \times 10^{-5}$ & $3.25 \times 10^{-5}$ & $7.73 \times 10^{-4}$ & $1.08 \times 10^{-4}$ \\
\hline 33 & AL-MLR-20010815 2.2 & $4.44 \times 10^{-5}$ & $2.28 \times 10^{-5}$ & $8.22 \times 10^{-4}$ & $1.14 \times 10^{-4}$ \\
\hline 34 & AL-MLR-20010822 2.2 & $2.75 \times 10^{-5}$ & $2.04 \times 10^{-5}$ & $7.00 \times 10^{-4}$ & $1.04 \times 10^{-4}$ \\
\hline 35 & AL-MLR-20010829 2.2 & $5.57 \times 10^{-5}$ & $2.53 \times 10^{-5}$ & $6.85 \times 10^{-4}$ & $9.87 \times 10^{-5}$ \\
\hline 36 & AL-MLR-20010905 2.2 & $5.23 \times 10^{-5}$ & $2.64 \times 10^{-5}$ & $7.80 \times 10^{-4}$ & $1.12 \times 10^{-4}$ \\
\hline 37 & AL-MLR-20010912 2.2 & $3.74 \times 10^{-5}$ & $2.11 \times 10^{-5}$ & $8.31 \times 10^{-4}$ & $1.14 \times 10^{-4}$ \\
\hline 38 & AL-MLR-20010919 2.2 & $3.65 \times 10^{-5}$ & $1.84 \times 10^{-5}$ & $7.23 \times 10^{-4}$ & $1.01 \times 10^{-4}$ \\
\hline 39 & AL-MLR-20010926 2.2 & $6.35 \times 10^{-5}$ & $2.64 \times 10^{-5}$ & $1.42 \times 10^{-3}$ & $1.76 \times 10^{-4}$ \\
\hline
\end{tabular}


Table D.1 - Results of Gross Alpha and Gross Beta Analyses in Air Particulates (Bq/m $\left.{ }^{3}\right)$

\begin{tabular}{|c|c|c|c|c|c|}
\hline \multirow[b]{2}{*}{ Week } & \multirow[b]{2}{*}{ Sample ID } & \multicolumn{2}{|c|}{ Gross Alpha } & \multicolumn{2}{|c|}{ Gross Beta } \\
\hline & & Concentration & $2 \times$ TPU $^{a}$ & Concentration & $2 \times$ TPU \\
\hline \multicolumn{6}{|c|}{ Smith Ranch (SMR) } \\
\hline 40 & AL-SMR-200110032.2 & $2.52 \times 10^{-5}$ & $1.70 \times 10^{-5}$ & $1.17 \times 10^{-3}$ & $1.51 \times 10^{-4}$ \\
\hline 41 & AL-SMR-20011010 2.2 & $\mathrm{~N} / \mathrm{C}$ & $\mathrm{N} / \mathrm{C}$ & $\mathrm{N} / \mathrm{C}$ & $\mathrm{N} / \mathrm{C}$ \\
\hline 42 & AL-SMR-20011017 2.2 & $5.75 \times 10^{-5}$ & $2.71 \times 10^{-5}$ & $1.19 \times 10^{-3}$ & $1.53 \times 10^{-4}$ \\
\hline 43 & AL-SMR-20011024 2.2 & $1.18 \times 10^{-4}$ & $3.87 \times 10^{-5}$ & $1.12 \times 10^{-3}$ & $1.47 \times 10^{-4}$ \\
\hline 44 & AL-SMR-200110312.2 & $1.22 \times 10^{-4}$ & $3.86 \times 10^{-5}$ & $8.51 \times 10^{-4}$ & $1.18 \times 10^{-4}$ \\
\hline 45 & AL-SMR-20011107 2.2 & $1.63 \times 10^{-4}$ & $4.59 \times 10^{-5}$ & $1.75 \times 10^{-3}$ & $2.11 \times 10^{-4}$ \\
\hline 46 & AL-SMR-20011114 2.2 & $4.18 \times 10^{-5}$ & $2.33 \times 10^{-5}$ & $7.64 \times 10^{-4}$ & $1.12 \times 10^{-4}$ \\
\hline 47 & AL-SMR-200111212.2 & $8.81 \times 10^{-5}$ & $3.01 \times 10^{-5}$ & $8.12 \times 10^{-4}$ & $1.09 \times 10^{-4}$ \\
\hline 48 & AL-SMR-20011128 2.2 & $1.25 \times 10^{-4}$ & $3.89 \times 10^{-5}$ & $1.00 \times 10^{-3}$ & $1.33 \times 10^{-4}$ \\
\hline 49 & AL-SMR-20011205 2.2 & $6.04 \times 10^{-5}$ & $2.41 \times 10^{-5}$ & $7.34 \times 10^{-4}$ & $1.01 \times 10^{-4}$ \\
\hline 50 & AL-SMR-20011212 2.2 & $1.19 \times 10^{-4}$ & $4.08 \times 10^{-5}$ & $1.08 \times 10^{-3}$ & $1.49 \times 10^{-4}$ \\
\hline 51 & AL-SMR-20011219 2.2 & $4.10 \times 10^{-5}$ & $2.13 \times 10^{-5}$ & $1.04 \times 10^{-3}$ & $1.36 \times 10^{-4}$ \\
\hline 52 & AL-SMR-20011226 2.2 & $9.63 \times 10^{-5}$ & $3.30 \times 10^{-5}$ & $1.20 \times 10^{-3}$ & $1.54 \times 10^{-4}$ \\
\hline
\end{tabular}

a Total propagated uncertainty

${ }^{\mathrm{b}}$ Not collected 
Waste Isolation Pilot Plant 2001 Site Environmental Report

DOE/WIPP 02-2225

\section{Appendix E \\ Air Sampling Data: Mass and Volume of Composite Air Samples}

\begin{tabular}{|c|c|c|c|c|c|c|c|c|}
\hline \multirow[t]{2}{*}{ Week } & Mass & Volume & Mass & Volume & Mass & Volume & Mass & Volume \\
\hline & \multicolumn{2}{|c|}{ WIPP Far Field (WFF) } & \multicolumn{2}{|c|}{ WIPP East (WEE) \#1 } & \multicolumn{2}{|c|}{ WIPP East (WEE) \#2 } & \multicolumn{2}{|c|}{ WIPP South (WSS) } \\
\hline 1 & $\mathrm{~N} / \mathrm{C}^{\mathrm{a}}$ & $\mathrm{N} / \mathrm{C}$ & 6 & 509.306 & 6.9 & 602.542 & 6.7 & 565.427 \\
\hline 2 & 4 & 596.879 & 5.2 & 602.262 & 6.2 & 630.567 & 6.1 & 630.941 \\
\hline 3 & 3.6 & 617.913 & 3.8 & 601.186 & 3.9 & 616.807 & 6.3 & 626.829 \\
\hline 4 & 8.8 & 582.974 & 9.5 & 596.908 & 9.5 & 595.133 & 14.8 & 579.772 \\
\hline 5 & 4.3 & 554.936 & 4.4 & 577.702 & 4.8 & 554.605 & 5.1 & 572.011 \\
\hline 6 & 9.4 & 586.325 & 12.2 & 554.068 & 12.9 & 578.841 & 10.7 & 557.364 \\
\hline 7 & 5 & 562.938 & 6 & 553.611 & 5.4 & 553.279 & 6.3 & 606.523 \\
\hline 8 & 10.5 & 582.281 & 14.2 & 586.529 & 14.1 & 549.008 & 11.8 & 550.228 \\
\hline 9 & 3.5 & 584.337 & 6.3 & 621.131 & 3.9 & 615.432 & 8.7 & 622.983 \\
\hline 10 & 5.5 & 585.484 & 5.2 & 576.229 & 6 & 589.789 & 5.5 & 576.229 \\
\hline 11 & 7.1 & 605.49 & 8.2 & 612.177 & 7.3 & 559.129 & 8.1 & 592.017 \\
\hline 12 & 8.1 & 580.854 & 7.9 & 548.774 & 8 & 570.15 & 8.9 & 591.685 \\
\hline 13 & 7.9 & 612.218 & 9.5 & 595.133 & 9.2 & 594.777 & 9.6 & 598.337 \\
\hline Total & 77.7 & 7052.6 & 98.4 & 7535 & 98.1 & 7610.1 & 108.6 & 7670.3 \\
\hline
\end{tabular}


Waste Isolation Pilot Plant 2001 Site Environmental Report DOE/WIPP 02-2225

\begin{tabular}{|c|c|c|c|c|c|c|c|c|}
\hline \multirow[t]{2}{*}{ Week } & Mass & Volume & Mass & Volume & Mass & Volume & Mass & Volume \\
\hline & \multicolumn{2}{|c|}{ Mills Ranch (MLR) } & \multicolumn{2}{|c|}{ Smith Ranch (SMR) } & \multicolumn{2}{|c|}{ Carlsbad (CBD) } & \multicolumn{2}{|c|}{ Southeast Control (SEC) } \\
\hline 1 & 6.8 & 555.96 & $\mathrm{~N} / \mathrm{C}^{\mathrm{a}}$ & $\mathrm{N} / \mathrm{C}$ & 10.9 & 536.51 & 6.3 & 572.24 \\
\hline 2 & 6.1 & 621.968 & 10 & 619.756 & 11 & 610.824 & 5.2 & 623.914 \\
\hline 3 & 5.1 & 612.948 & 7.6 & 594.759 & 7.2 & 620.862 & 4 & 565.828 \\
\hline 4 & 8.6 & 573.718 & 11.8 & 589.759 & 9.6 & 617.913 & 8.8 & 595.843 \\
\hline 5 & 5 & 546.725 & 8.3 & 550.228 & 10.5 & 549.394 & 4.6 & 588.34 \\
\hline 6 & 9.3 & 554.397 & 16.9 & 617.697 & 17.6 & 597.623 & 11.4 & 559.034 \\
\hline 7 & 7.1 & 619.756 & 10.6 & 571.328 & 10.9 & 619.649 & 6.4 & 612.177 \\
\hline 8 & 10.8 & 559.78 & 19.8 & 570.038 & 15 & 615.14 & 17.3 & 574.06 \\
\hline 9 & 4.5 & 612.948 & 4.6 & 599.752 & 7.8 & 559.958 & 4.4 & 568.825 \\
\hline 10 & 5 & 555.93 & 8.6 & 551.212 & 11.5 & 570.184 & 4.5 & 601.094 \\
\hline 11 & 7.3 & 577.702 & 20.3 & 598.328 & 17.9 & 610.519 & 7.9 & 590.073 \\
\hline 12 & 8.8 & 603.695 & 8.4 & 553.611 & 12.1 & 543.136 & 7.4 & 597.326 \\
\hline 13 & 10 & 620.636 & 13.2 & 583.394 & 21.3 & 565.643 & 7.5 & 597.98 \\
\hline Total & 94.4 & 7616.2 & 140 & 6999.9 & 163 & 7617.4 & 95.7 & 7646.7 \\
\hline
\end{tabular}


Waste Isolation Pilot Plant 2001 Site Environmental Report DOE/WIPP 02-2225

\begin{tabular}{|c|c|c|c|c|c|c|c|c|}
\hline \multicolumn{9}{|c|}{ Table E.2 - Mass (mg) of Air Particulates and Volume $\left(\mathrm{m}^{3}\right)$ of Air Sampled (Second Quarter of 2001) } \\
\hline Week & Mass & Volume & Mass & Volume & Mass & Volume & Mass & Volume \\
\hline & \multicolumn{2}{|c|}{ WIPP Far Field (WFF) } & \multicolumn{2}{|c|}{ WIPP East (WEE) } & \multicolumn{2}{|c|}{ WIPP South (WSS) \#1 } & \multicolumn{2}{|c|}{ WIPP South (WSS) \#2 } \\
\hline 14 & 33.1 & 554.273 & 43.7 & 562.464 & 42.3 & 568.04 & 36.2 & 568.04 \\
\hline 15 & 16.3 & 610.661 & 17.7 & 607.834 & 19 & 607.469 & 19.9 & 576.389 \\
\hline 16 & 19.6 & 577.796 & 22.7 & 590.793 & 23 & 594.076 & 22 & 588.194 \\
\hline 17 & 10.2 & 581.211 & 10 & 533.168 & 10.8 & 592.149 & 11.3 & 591.789 \\
\hline 18 & 11.1 & 581.151 & 11.9 & 620.493 & 11.9 & 560.779 & 11.7 & 569.362 \\
\hline 19 & 9 & 437.117 & 8.8 & 552.523 & 11.5 & 554.397 & 12 & 574.401 \\
\hline 20 & 11.1 & 578.469 & 11.6 & 586.624 & 14 & 572.797 & 13 & 572.797 \\
\hline 21 & 12.3 & 586.877 & 16 & 563.975 & 16.2 & 553.599 & 16 & 567.649 \\
\hline 22 & $N / C^{a}$ & $\mathrm{~N} / \mathrm{C}$ & 20.7 & 556.045 & 23 & 575.426 & 20.7 & 575.426 \\
\hline 23 & 8.2 & 427.985 & 11.9 & 517.152 & 12.9 & 521.044 & 12.4 & 529.476 \\
\hline 24 & 12.6 & 594.052 & 13.1 & 566.501 & 14.4 & 561.445 & 13.5 & 558.58 \\
\hline 25 & 12.3 & 558.631 & 13 & 556.592 & 15.9 & 541.352 & 15.4 & 567.333 \\
\hline 26 & 10.4 & 483.563 & 11.2 & 505.391 & 11.9 & 498.721 & 11.2 & 486.101 \\
\hline \multirow[t]{2}{*}{ Total } & 166.2 & 6571.8 & 212.3 & 7319.6 & 226.8 & 7301.3 & 215.3 & 6757.5 \\
\hline & \multicolumn{2}{|c|}{ Mills Ranch (MLR) } & \multicolumn{2}{|c|}{ Smith Ranch (SMR) } & \multicolumn{2}{|c|}{ Carlsbad (CBD) } & \multicolumn{2}{|c|}{ Southeast Control (SEC } \\
\hline 14 & 39.4 & 585.413 & 45.4 & 575.886 & 52.9 & 609.78 & 45.4 & 597.623 \\
\hline 15 & 17.2 & 608.894 & 12.3 & 510.103 & 16.6 & 591.196 & 18.2 & 605.836 \\
\hline 16 & 21.2 & 556.276 & 23.1 & 537.479 & 24.3 & 563.388 & 23.3 & 591.201 \\
\hline 17 & 12.3 & 553.264 & 15.4 & 553.179 & 16.3 & 571.053 & 9.3 & 559.012 \\
\hline 18 & 13.2 & 563.64 & 18.5 & 566.501 & 18.1 & 568.686 & 13.5 & 609.056 \\
\hline 19 & 12.5 & 610.401 & 12.9 & 568.686 & 14.5 & 605.473 & 9.9 & 630.305 \\
\hline 20 & 12.6 & 557.326 & 16.1 & 567.466 & 17.2 & 571.494 & 15.9 & 542.579 \\
\hline 21 & 17.3 & 598.328 & 19.5 & 507.59 & 24 & 586.529 & 17.7 & 602.595 \\
\hline 22 & 21 & 577.939 & 28.6 & 565.155 & 26.2 & 611.227 & 26.7 & 593.345 \\
\hline 23 & 14 & 548.244 & 16.9 & 593.699 & 24.7 & 570.986 & 16.3 & 574.743 \\
\hline 24 & 15.6 & 569.7 & 19.2 & 587.898 & 27.5 & 580.718 & 17.3 & 689.76 \\
\hline 25 & 16.4 & 573.035 & 18 & 542.861 & 21.7 & 590.431 & 13.2 & 479.798 \\
\hline 26 & 11 & 484.315 & $\mathrm{~N} / \mathrm{C}$ & $\mathrm{N} / \mathrm{C}$ & 16.7 & 499.098 & 12.8 & 520.472 \\
\hline Total & 223.7 & 7386.8 & 245.9 & 6676.5 & 300.7 & 7520.1 & 239.5 & 7596.3 \\
\hline
\end{tabular}


Waste Isolation Pilot Plant 2001 Site Environmental Report DOE/WIPP 02-2225

\begin{tabular}{|c|c|c|c|c|c|c|c|c|}
\hline \multicolumn{9}{|c|}{ Table E.3 - Mass (mg) of Air Particulates and Volume $\left(\mathrm{m}^{3}\right)$ of Air Sampled (Third Quarter of 2001). } \\
\hline Week & Mass & Volume & Mass & Volume & Mass & Volume & Mass & Volume \\
\hline & \multicolumn{2}{|c|}{ WIPP Far Field (WFF) } & \multicolumn{2}{|c|}{ WIPP East (WEE) } & \multicolumn{2}{|c|}{ WIPP South (WSS) } & \multicolumn{2}{|c|}{ Mills Ranch (MLR) \#1 } \\
\hline 27 & 11.5 & 625.667 & 12.6 & 625.341 & 13.5 & 647.463 & 12.5 & 653.288 \\
\hline 28 & 14.7 & 570.184 & 13.2 & 556.261 & 14 & 550.556 & 14.1 & 564.483 \\
\hline 29 & 9.7 & 550.884 & 9.7 & 531.393 & 12.7 & 567.333 & $\mathrm{~N} / \mathrm{C}^{\mathrm{a}}$ & $\mathrm{N} / \mathrm{C}$ \\
\hline 30 & 9.9 & 602.618 & 11.7 & 554.936 & 11.6 & 574.401 & 11.4 & 552.42 \\
\hline 31 & 11.4 & 544.699 & 13 & 590.844 & 12.8 & 561.297 & 13.2 & 557.918 \\
\hline 32 & 11.5 & 571.883 & 12.2 & 560.446 & 11.9 & 573.718 & 11.6 & 568.01 \\
\hline 33 & 7.5 & 530.17 & 8.2 & 538.885 & 9.5 & 519.733 & 10.5 & 574.743 \\
\hline 34 & 5.1 & 552.42 & 5.8 & 552.42 & 60.3 & 607.916 & 8.2 & 549.244 \\
\hline 35 & 7 & 621.501 & 7.7 & 590.141 & 7.8 & 626.829 & 9.1 & 620.76 \\
\hline 36 & 10.6 & 549.572 & 12.4 & 553.264 & 14.7 & 558.912 & 12 & 543.553 \\
\hline 37 & 8.5 & 579.772 & 8.5 & 556.924 & 7.8 & 547.605 & 8.7 & 597.263 \\
\hline 38 & 6.2 & 574.743 & 9 & 577.602 & 9.2 & 552.523 & 7.5 & 549.987 \\
\hline 39 & 9.5 & 583.321 & 9.9 & 562.97 & 11.2 & 562.301 & 11.1 & 553.738 \\
\hline \multirow[t]{2}{*}{ Total } & 123.1 & 7457.4 & 133.9 & 7351.4 & 197 & 7450.6 & 129.9 & 6885.4 \\
\hline & \multicolumn{2}{|c|}{ Mills Ranch (MLR) \#2 } & \multicolumn{2}{|c|}{ Smith Ranch (SMR) } & \multicolumn{2}{|c|}{ Carlsbad (CBD) } & \multicolumn{2}{|c|}{ Southeast Control (SEC } \\
\hline 27 & 13.4 & 643.201 & 17.5 & 650.017 & 22.8 & 703.539 & 14.3 & 662.202 \\
\hline 28 & 14.6 & 567.333 & 22.5 & 591.932 & 25.1 & 585.217 & 14.8 & 580.608 \\
\hline 29 & 9.9 & 555.598 & 8.5 & 542.321 & 15.5 & 597.232 & 11.9 & 556.924 \\
\hline 30 & 11.3 & 563.81 & 17 & 573.035 & 21 & 620.728 & 12.9 & 624.094 \\
\hline 31 & 13.7 & 558.249 & 22.6 & 616.166 & 17.4 & 522.318 & 12.3 & 597.266 \\
\hline 32 & 12.4 & 585.136 & 20.6 & 556.924 & 20.8 & 567.672 & 13.2 & 604.035 \\
\hline 33 & 9.5 & 569.024 & 11.2 & 560.113 & 16.5 & 581.721 & 9.8 & 576.792 \\
\hline 34 & 10.5 & 546.398 & 8.7 & 543.877 & 12.3 & 583.046 & 7.3 & 575.978 \\
\hline 35 & 9.9 & 620.76 & 17.1 & 597.98 & $\mathrm{~N} / \mathrm{C}$ & $\mathrm{N} / \mathrm{C}$ & 10.3 & 600.828 \\
\hline 36 & 13.6 & 546.398 & 14.8 & 537.57 & 19.5 & 546.725 & 13.9 & 548.578 \\
\hline 37 & 9.5 & 600.121 & 13.8 & 548.682 & 18.2 & 565.492 & 9 & 605.264 \\
\hline 38 & 8.7 & 552.851 & 13.2 & 590.09 & 16.2 & 602.975 & 9.5 & 569.315 \\
\hline 39 & 12.4 & 561.966 & 20.3 & 557.116 & 19.3 & 567.126 & 9.7 & 575.247 \\
\hline Total & 149.4 & 7470.8 & 207.8 & 7465.8 & 224.6 & 7043.8 & 148.9 & 7677.1 \\
\hline
\end{tabular}

\footnotetext{
${ }^{a}$ Not collected
} 
Waste Isolation Pilot Plant 2001 Site Environmental Report DOE/WIPP 02-2225

\begin{tabular}{|c|c|c|c|c|c|c|c|c|}
\hline \multicolumn{9}{|c|}{ Table E.4 - Mass (mg) of Air Particulates and Volume $\left(\mathrm{m}^{3}\right)$ of Air Sampled (Fourth Quarter of 2001) } \\
\hline & Mass & Volume & Mass & Volume & Mass & Volume & Mass & Volume \\
\hline Week & \multicolumn{2}{|c|}{ WIPP Far Field (WFF) } & \multicolumn{2}{|c|}{ WIPP East (WEE) } & \multicolumn{2}{|c|}{ WIPP South (WSS) } & \multicolumn{2}{|c|}{ Mills Ranch (MLR) } \\
\hline 40 & 8.3 & 566.501 & 9.5 & 554.727 & 10.5 & 571.883 & 11.1 & 600.121 \\
\hline 41 & 11.3 & 497.875 & 13.4 & 482.47 & 12.8 & 495.695 & 15 & 556.261 \\
\hline 42 & 14.4 & 586.877 & 17 & 575.426 & 16.5 & 545.5 & 16.4 & 561.966 \\
\hline 43 & 12 & 570.038 & 13.9 & 552.851 & 14.9 & 579.318 & 13.9 & 550.639 \\
\hline 44 & 8.5 & 585.54 & 11.7 & 571.204 & 11.1 & 593.699 & 14.2 & 616.9 \\
\hline 45 & 13.4 & 591.84 & 14.6 & 608.279 & 16.2 & 572.352 & 13.5 & 549.244 \\
\hline 46 & 4.9 & 535.627 & 4.7 & 491.691 & 4.6 & 537.657 & 5 & 537.744 \\
\hline 47 & N/A & $\mathrm{N} / \mathrm{A}$ & 11.8 & 712.245 & 10.3 & 695.547 & 12 & 705.323 \\
\hline 48 & 4.6 & 619.019 & 5.1 & 597.266 & 6.5 & 626.082 & 5.4 & 606.161 \\
\hline 49 & 14.2 & 700.267 & 16.3 & 698.812 & 17.1 & 717 & $\mathrm{~N} / \mathrm{C}^{\mathrm{a}}$ & $\mathrm{N} / \mathrm{C}$ \\
\hline 50 & 3.6 & 516.632 & 3.9 & 524.012 & $\mathrm{~N} / \mathrm{C}$ & $\mathrm{N} / \mathrm{C}$ & $\mathrm{N} / \mathrm{C}$ & $\mathrm{N} / \mathrm{C}$ \\
\hline 51 & 5.8 & 616.316 & 6 & 610.294 & 5.7 & 510.386 & 8.8 & 572.874 \\
\hline 52 & 5.4 & 622.864 & 5.7 & 576.777 & 5.4 & 612.218 & 8.5 & 595.133 \\
\hline \multirow[t]{2}{*}{ Total } & 106.4 & 7009.4 & 133.6 & 7556.1 & 131.6 & 7057.3 & 123.8 & 6452.4 \\
\hline & \multicolumn{2}{|c|}{ Smith Ranch (SMR) \#1 } & \multicolumn{2}{|c|}{ Smith Ranch (SMR) \#2 } & \multicolumn{2}{|c|}{ Carlsbad (CBD) } & \multicolumn{2}{|c|}{ Southeast Control (SEC) } \\
\hline 40 & 18.9 & 545.5 & 21.1 & 559.447 & 22.7 & 567.672 & 10.6 & 594.052 \\
\hline 41 & 45.1 & 542.579 & $\mathrm{~N} / \mathrm{C}$ & $\mathrm{N} / \mathrm{C}$ & $\mathrm{N} / \mathrm{C}$ & $\mathrm{N} / \mathrm{C}$ & 27.8 & 558.023 \\
\hline 42 & 32.7 & 558.115 & 26.1 & 540.061 & 27 & 480.442 & 17.2 & 592.647 \\
\hline 43 & 23.5 & 545.872 & 24.3 & 525.45 & 24.3 & 586.094 & 16.1 & 563.975 \\
\hline 44 & $\mathrm{~N} / \mathrm{C}$ & $\mathrm{N} / \mathrm{C}$ & 32.6 & 556.592 & 21.9 & 596.526 & 10.3 & 606.196 \\
\hline 45 & $\mathrm{~N} / \mathrm{C}$ & $\mathrm{N} / \mathrm{C}$ & 19.5 & 530.271 & 18.1 & 544.441 & 15.7 & 598.337 \\
\hline 46 & $\mathrm{~N} / \mathrm{C}$ & $\mathrm{N} / \mathrm{C}$ & 5.8 & 503.291 & 8.1 & 525.745 & 4.3 & 515.866 \\
\hline 47 & $\mathrm{~N} / \mathrm{C}$ & $\mathrm{N} / \mathrm{C}$ & 17.4 & 664.617 & 18.3 & 701.347 & $\mathrm{~N} / \mathrm{C}$ & $\mathrm{N} / \mathrm{C}$ \\
\hline 48 & 6.8 & 602.595 & 7.6 & 568.485 & 9.2 & 577.013 & 4.8 & 597.98 \\
\hline 49 & 21.5 & 701.286 & 22.1 & 671.514 & 21.9 & 724.759 & $\mathrm{~N} / \mathrm{C}$ & $\mathrm{N} / \mathrm{C}$ \\
\hline 50 & 8.3 & 527.723 & 8 & 469.087 & 8.6 & 522.473 & 3.2 & 496.866 \\
\hline 51 & 11.9 & 591.429 & 11.4 & 580.27 & 12.3 & 572.184 & 5.9 & 590.871 \\
\hline 52 & 12.3 & 584.439 & 10.8 & 561.297 & 10.5 & 568.01 & 6.7 & 627.95 \\
\hline Total & 181 & 5199.5 & 206.7 & 6730.4 & 202.9 & 6966.7 & 122.6 & 6343.8 \\
\hline
\end{tabular}


This page intentionally left blank 


\section{Appendix F}

\section{Time Trend Plots for Detectable Constituents in Groundwater}

The figures in this appendix show the concentrations of various groundwater constituents relative to a baseline concentration, and are in a form required by the NMED and the HWFP. Baseline concentrations were measured from 1995 through 2000. These plots indicate the maximum and minimum measurements, shown as whiskers, the $25^{\text {th }}$ and $75^{\text {th }}$ percentiles, shown as a box, and the median by a square point marker. Sampling round 12 occurred in March through May 2001 and sampling round 13 occurred in September through November 2001. See Chapter 6 for specific concentration information on the groundwater wells.

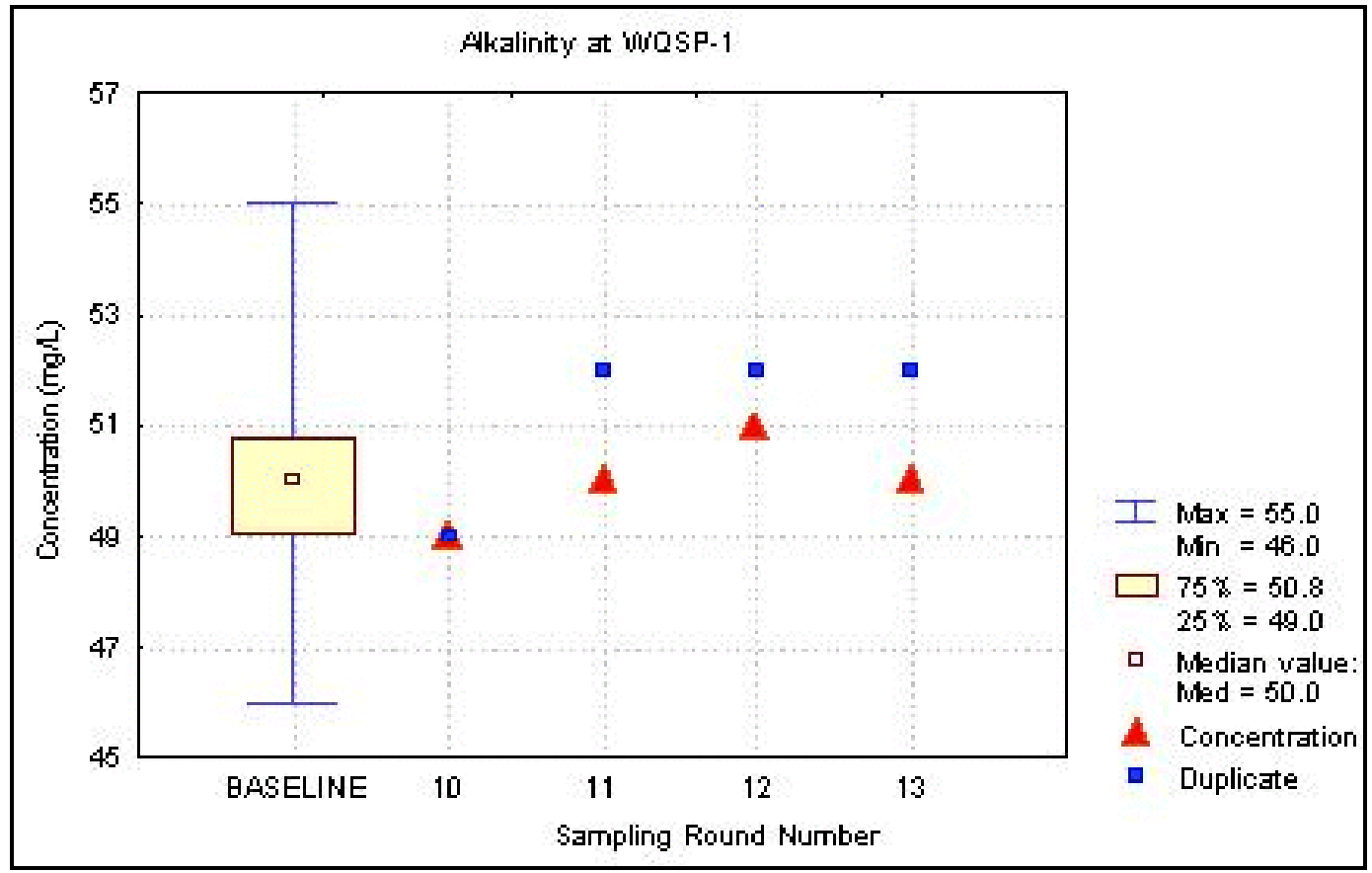

Figure F.1 - Time Trend Plot for Alkalinity at WQSP-1 


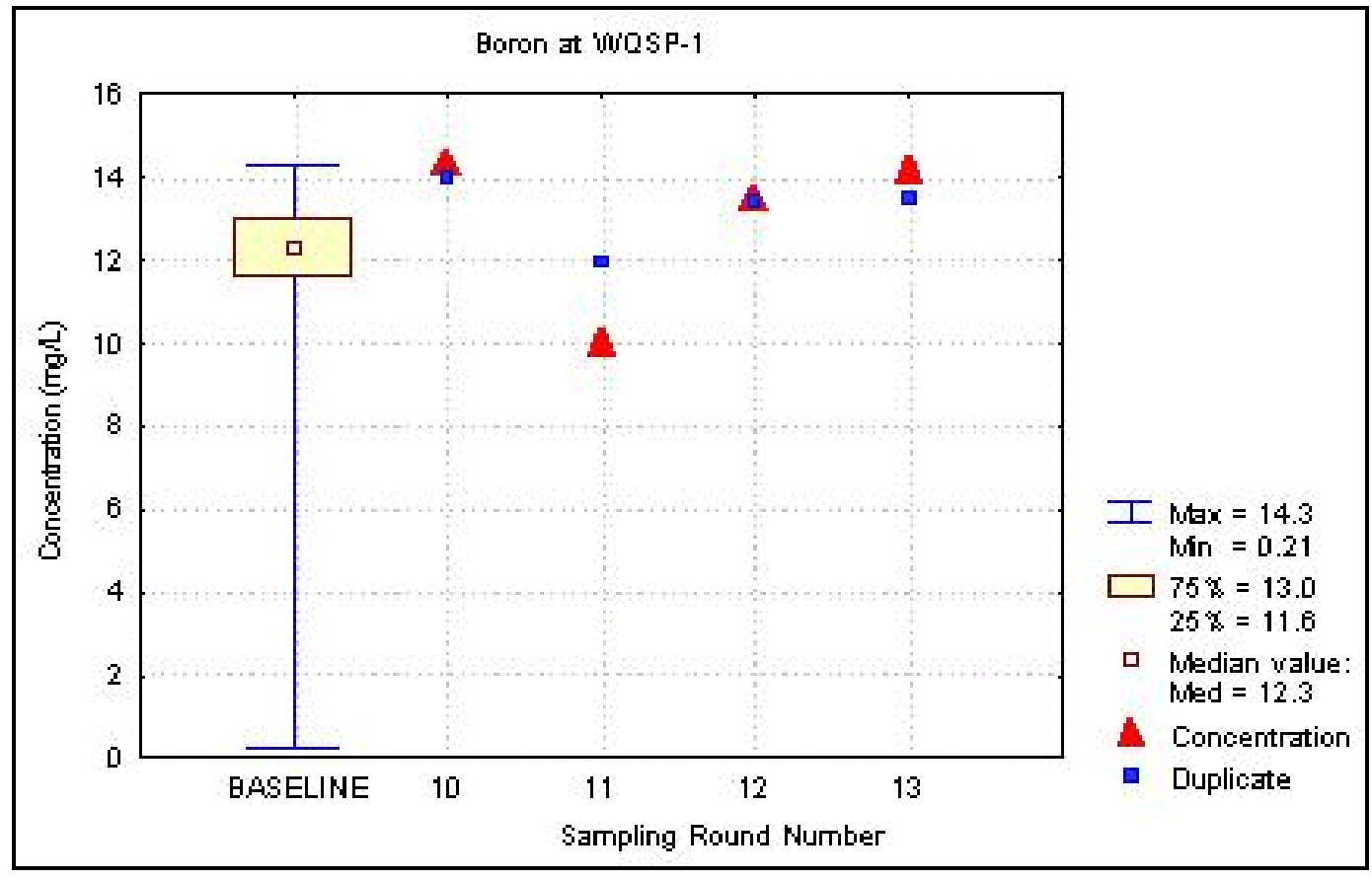

Figure F.2 - Time Trend Plot for Boron at WQSP-1

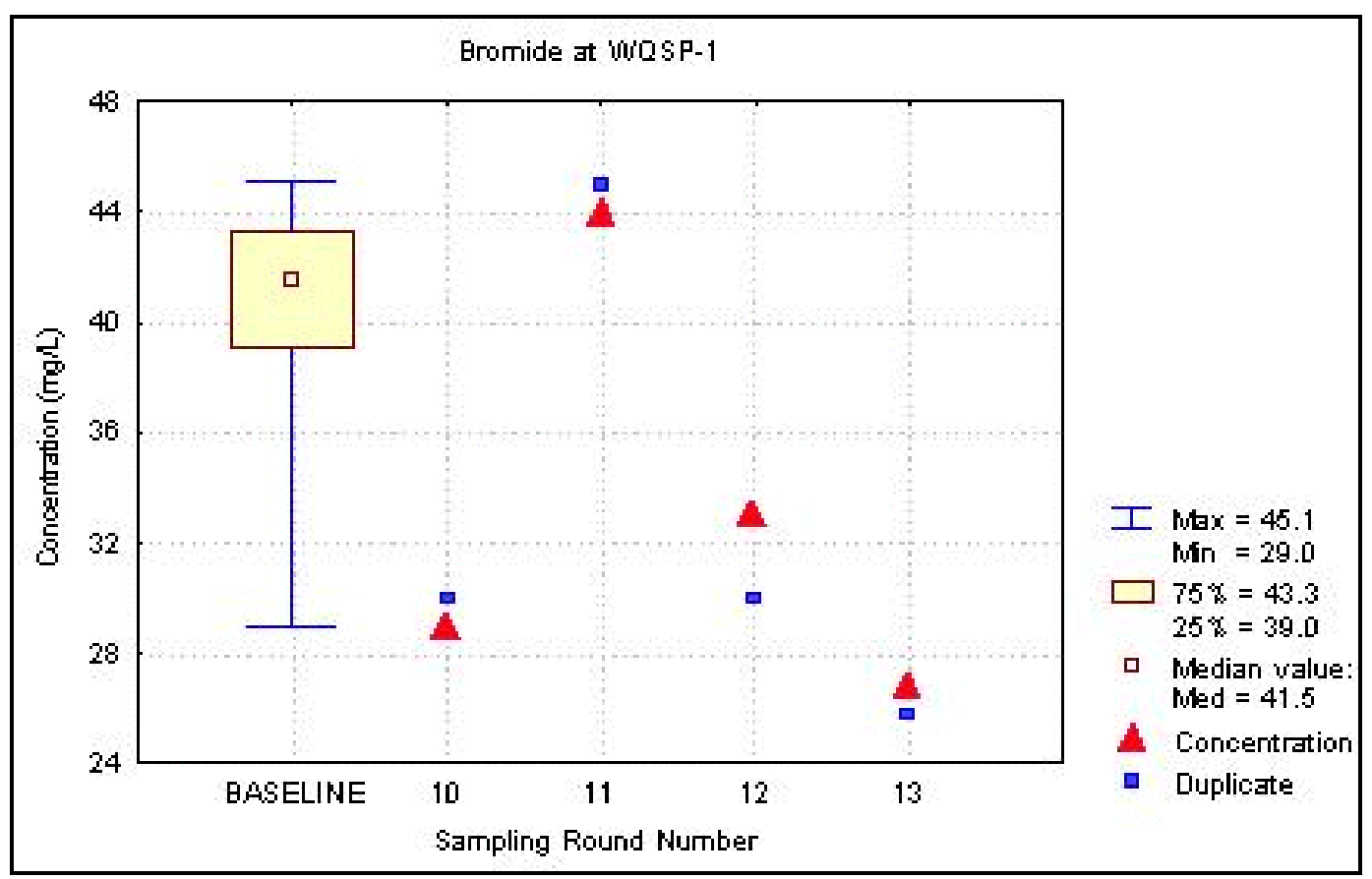

Figure F.3 - Time Trend Plot for Bromide at WQSP-1 


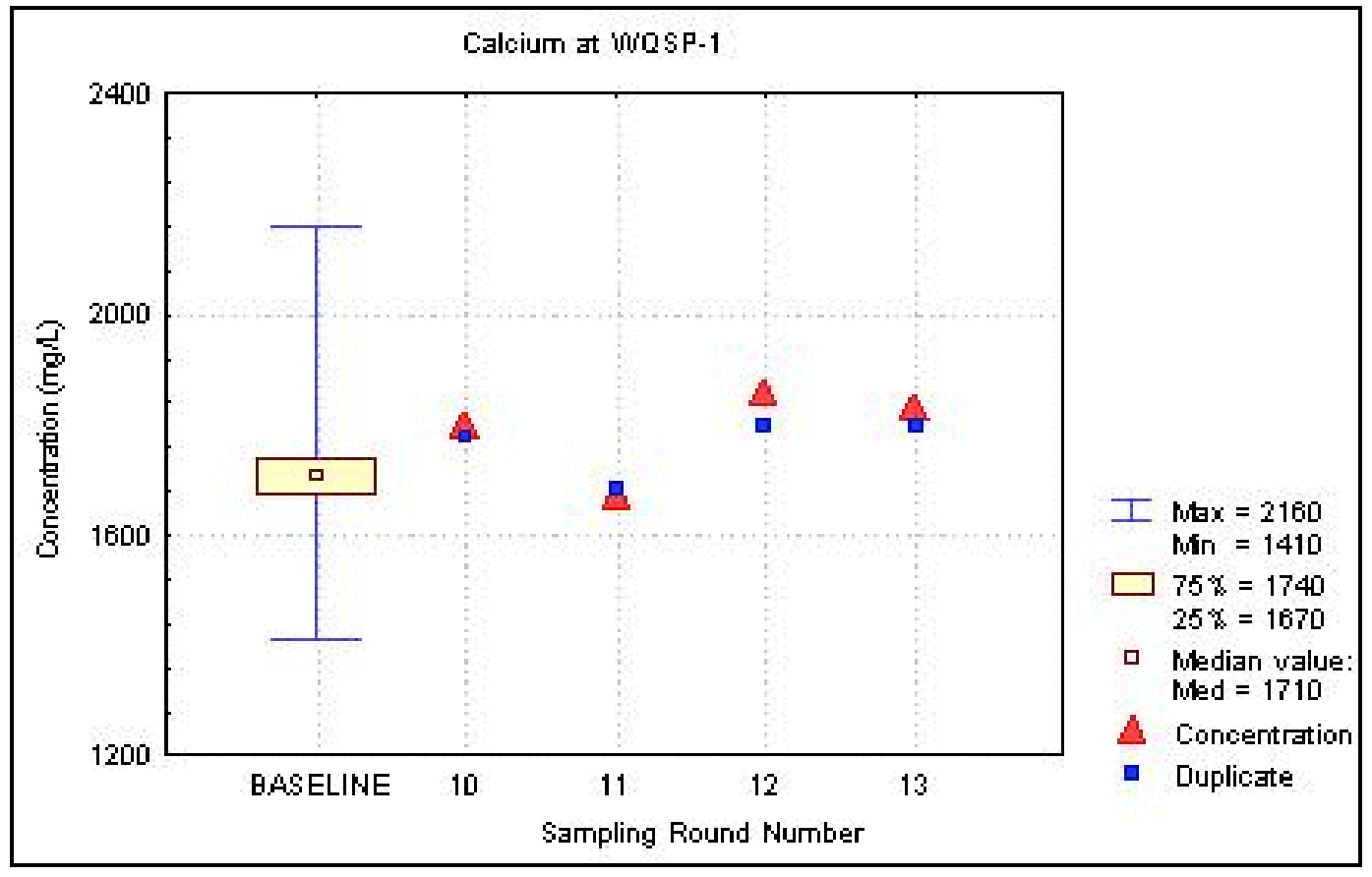

Figure F.4 - Time Trend Plot for Calcium at WQSP-1

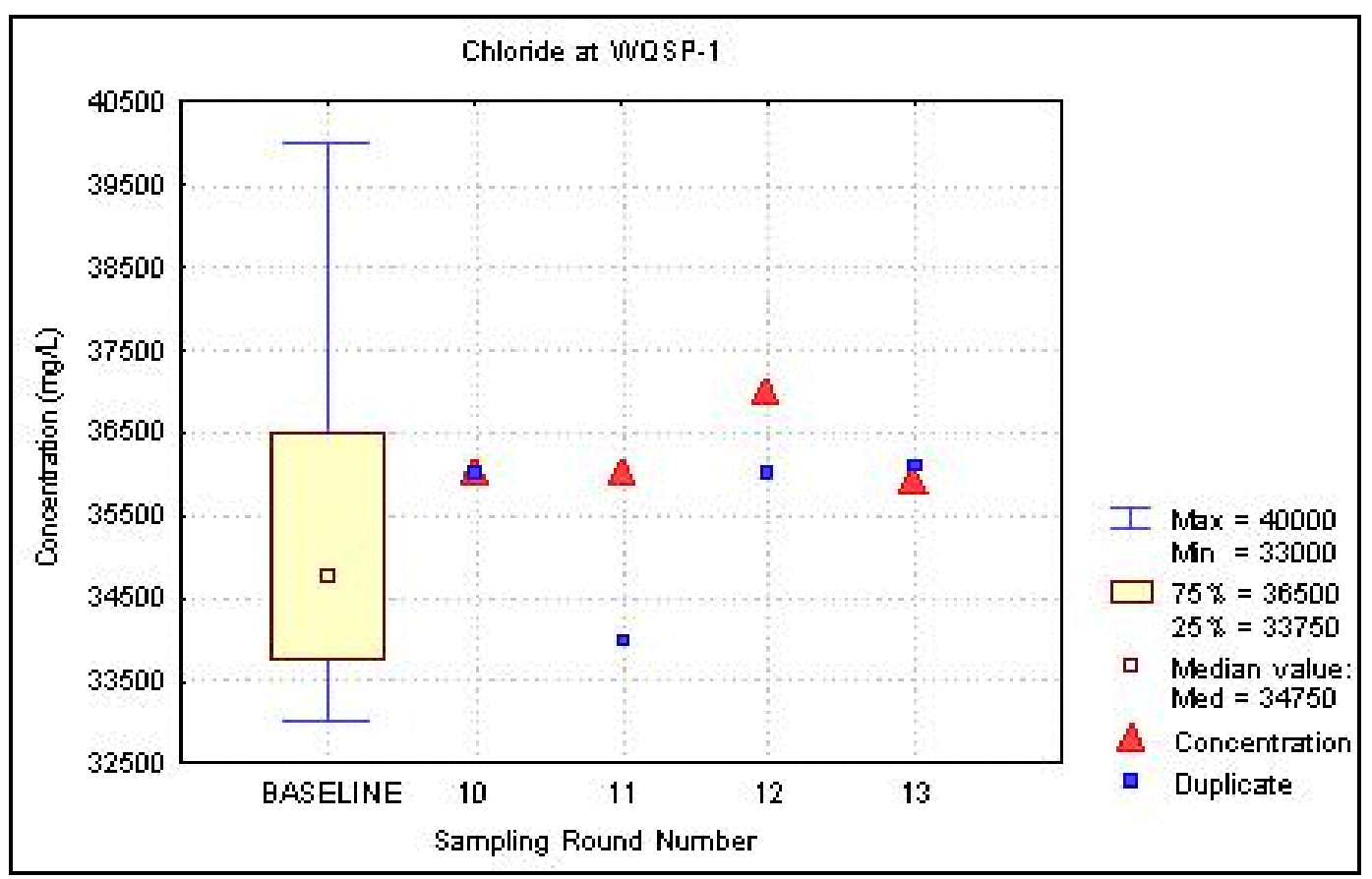

Figure F.5 - Time Trend Plot for Chloride at WQSP-1 


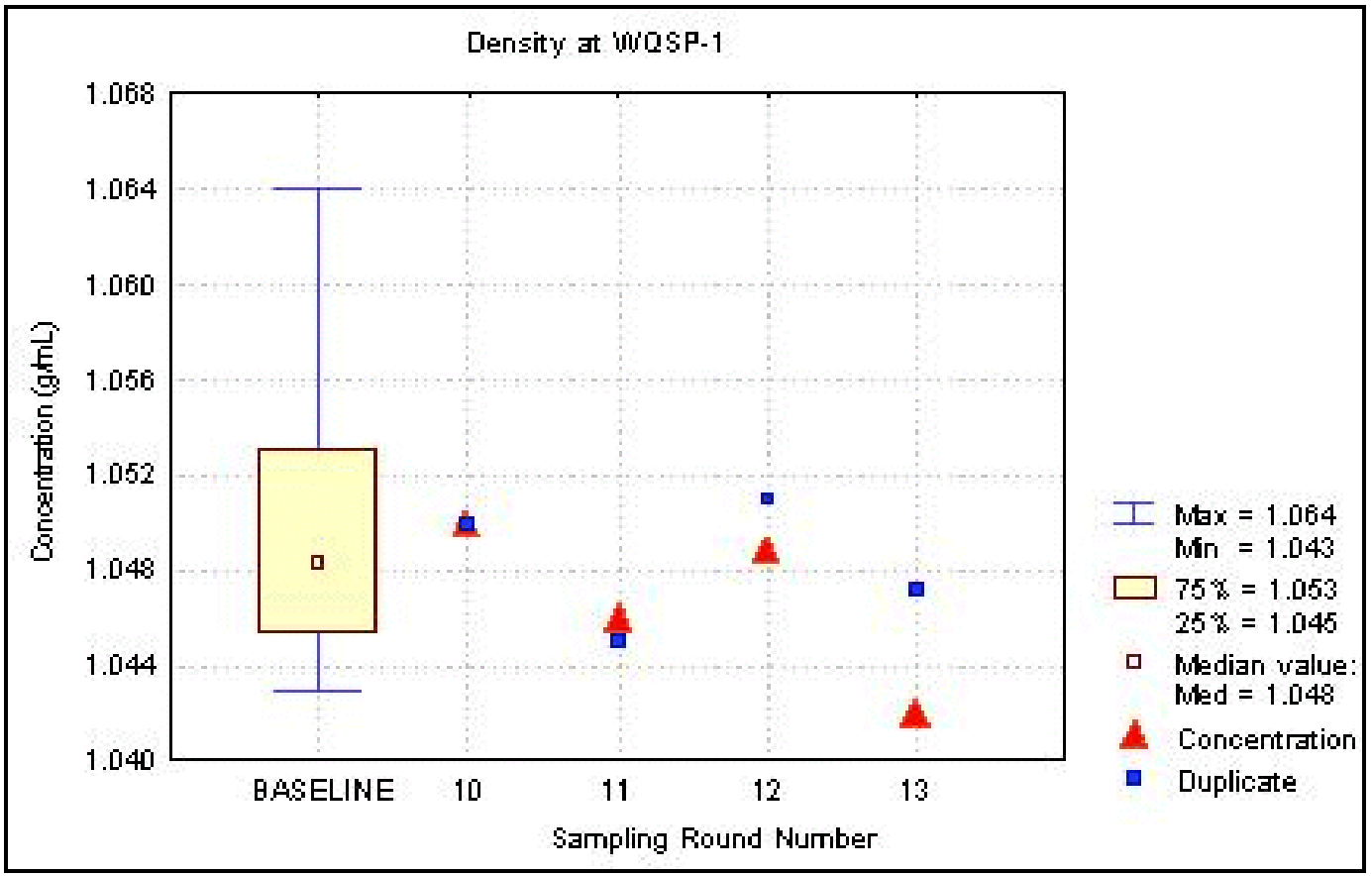

Figure F.6 - Time Trend Plot for Density at WQSP-1

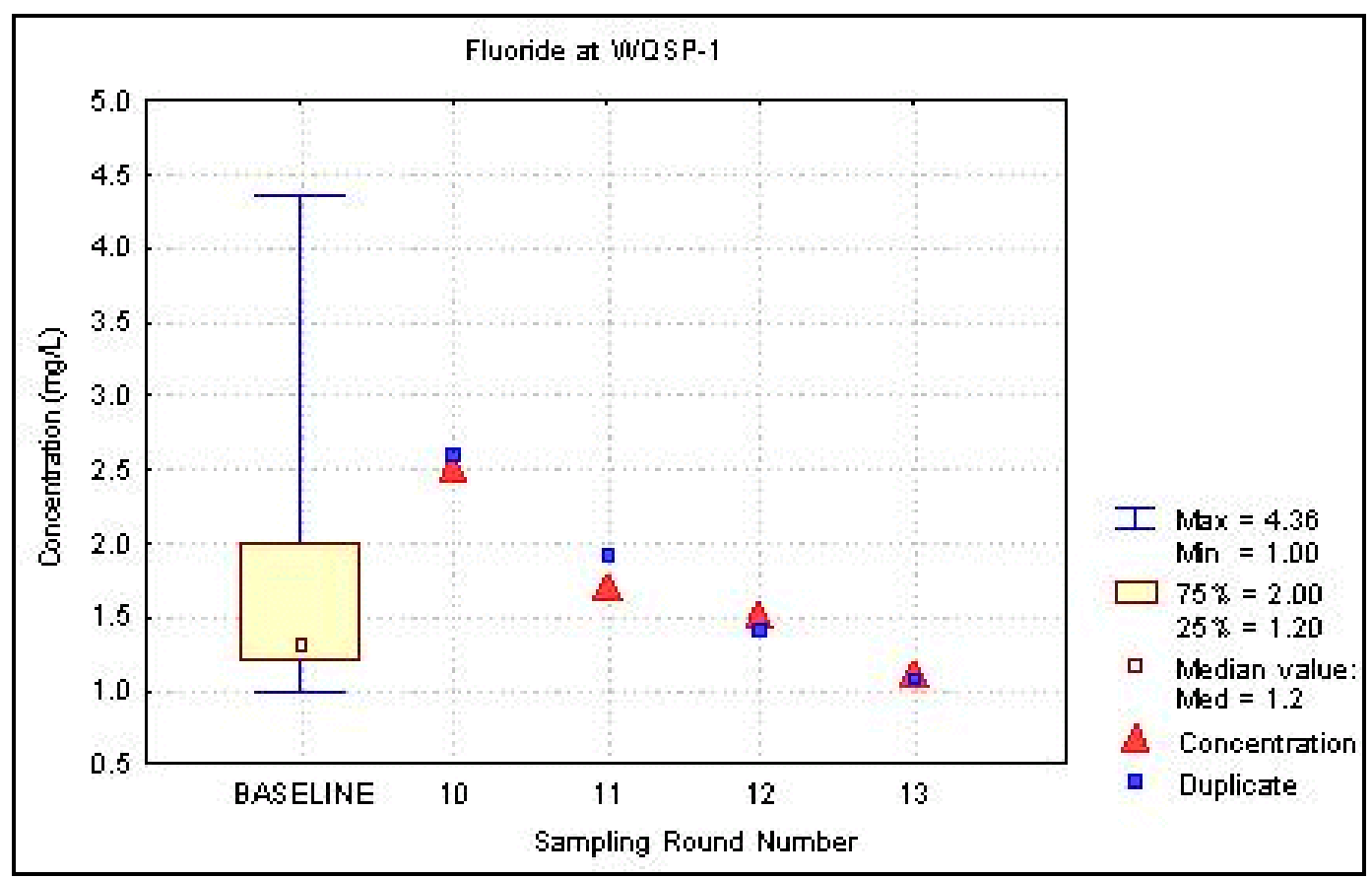

Figure F.7 - Time Trend Plot for Fluoride at WQSP-1 


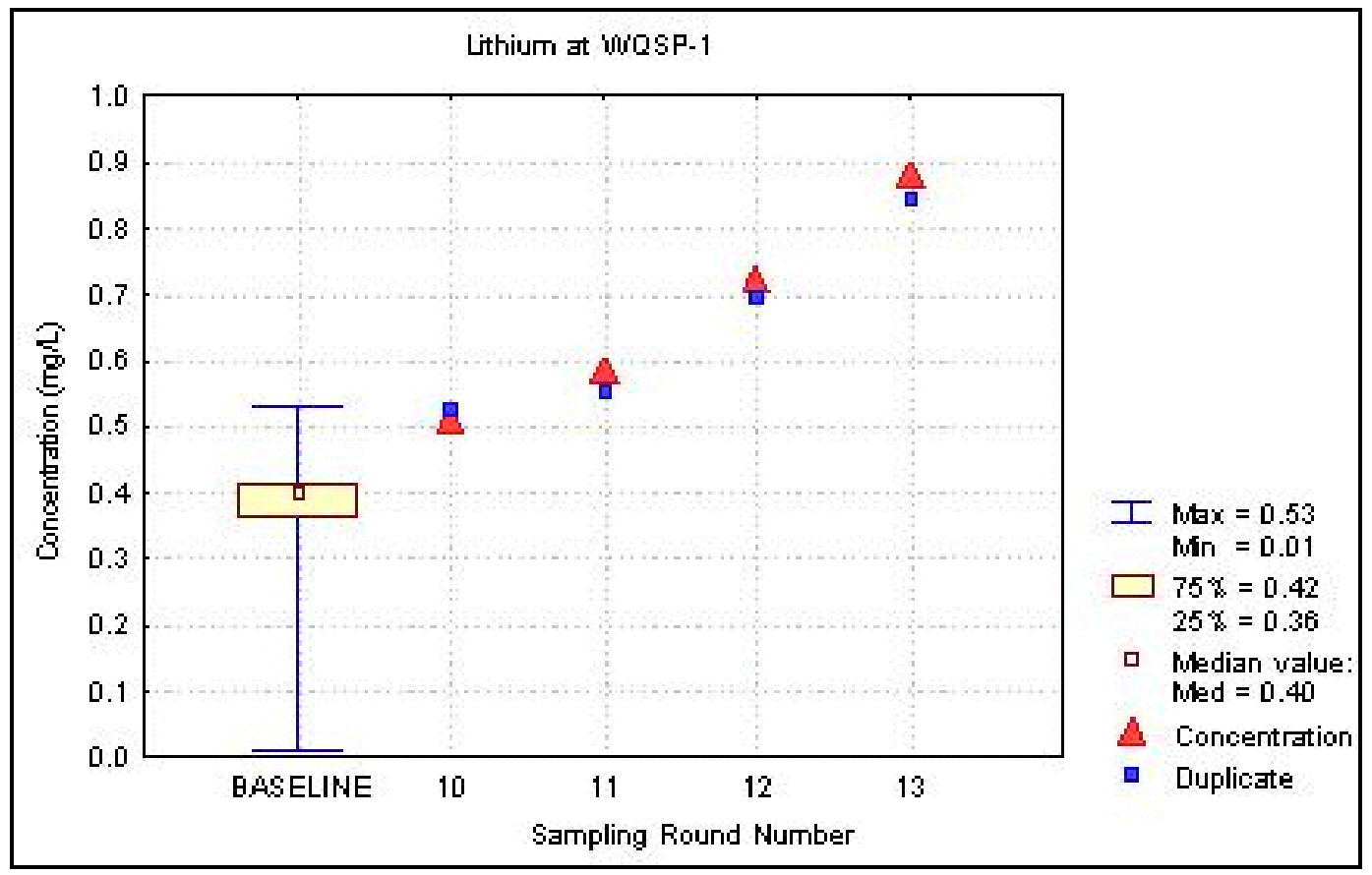

Figure F.8 - Time Trend Plot for Lithium at WQSP-1

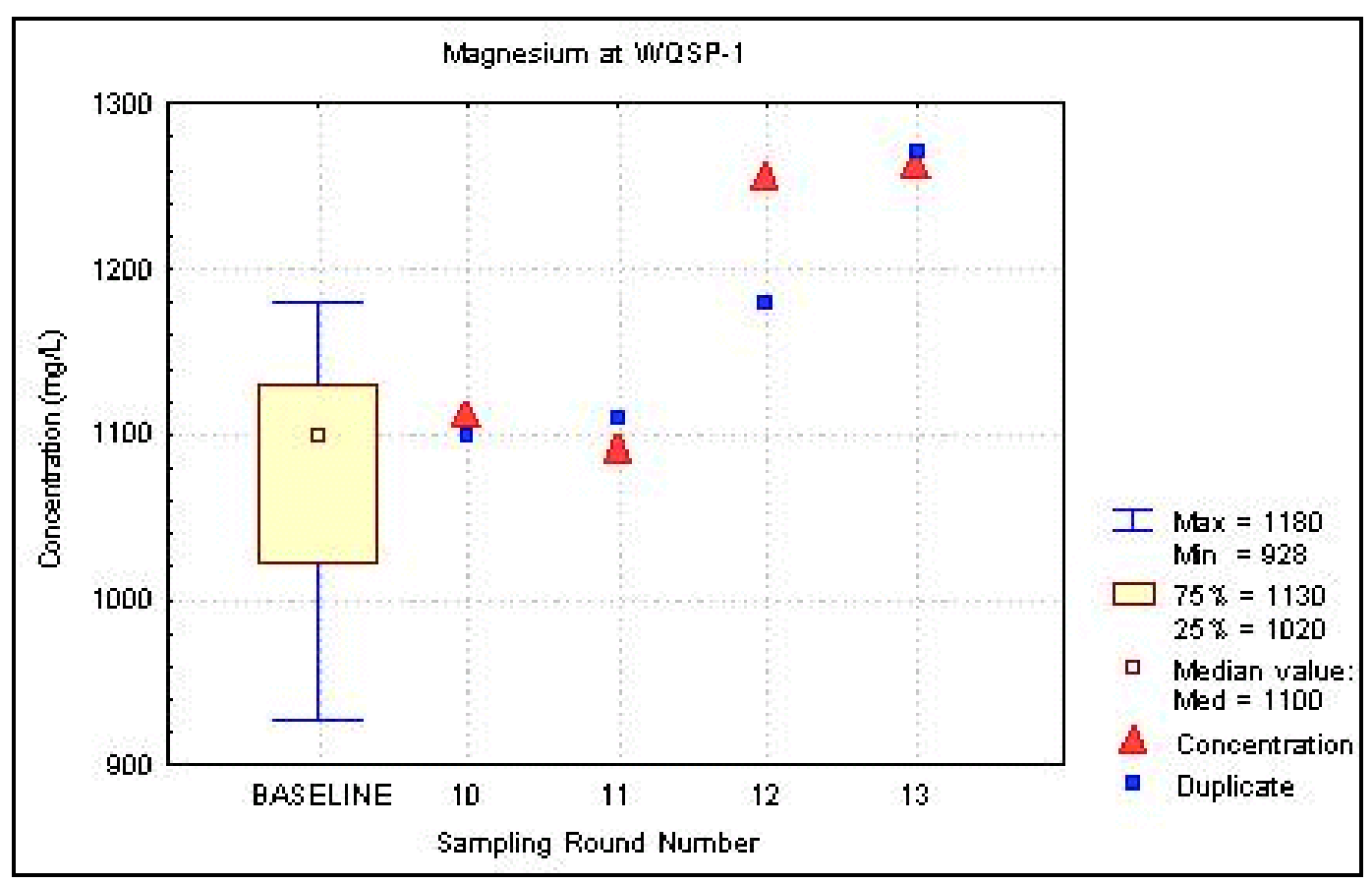

Figure F.9 - Time Trend Plot for Magnesium at WQSP-1 


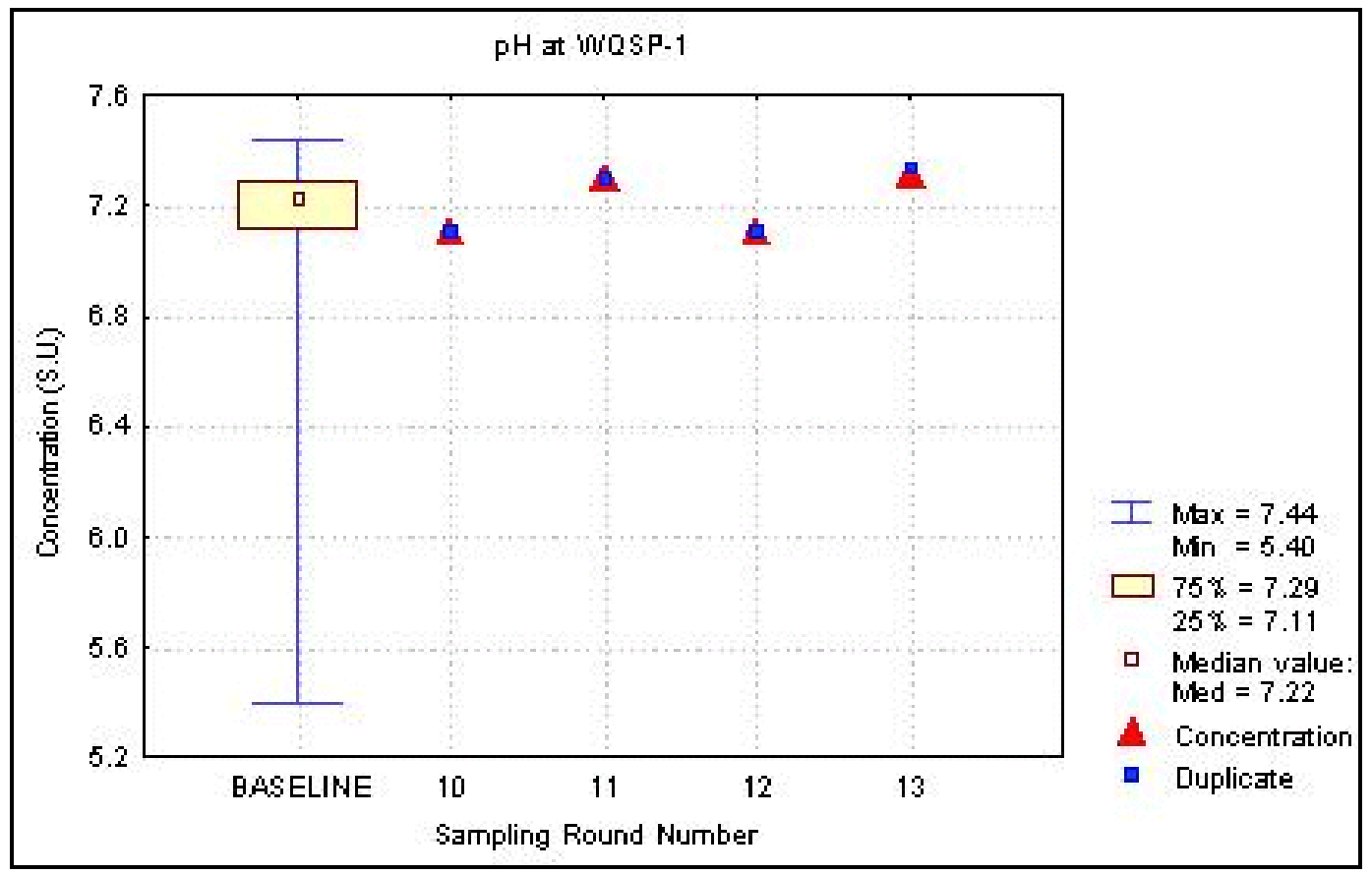

Figure F.10 - Time Trend Plot for pH at WQSP-1

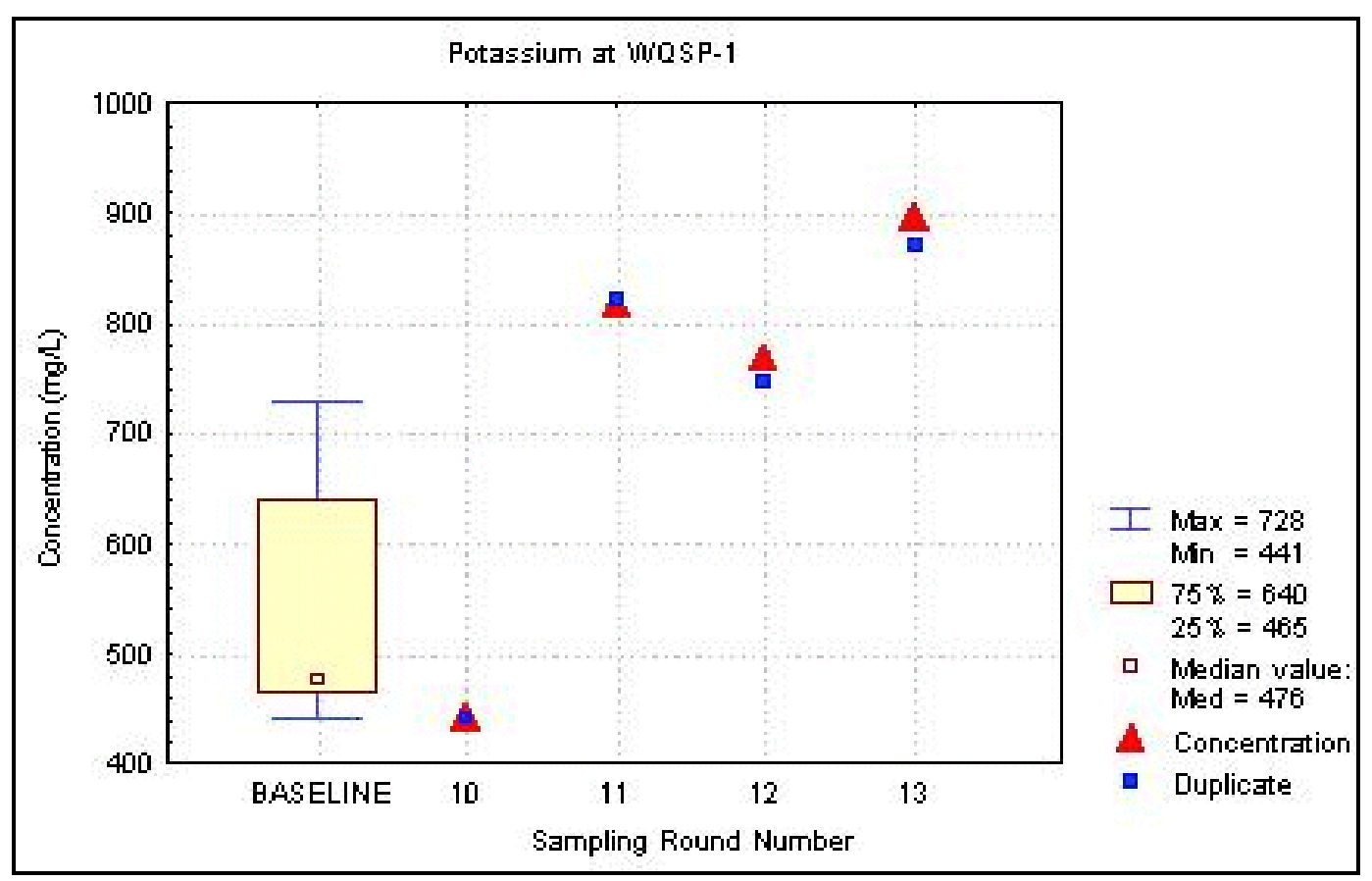

Figure F.11 - Time Trend Plot for Potassium at WQSP-1 


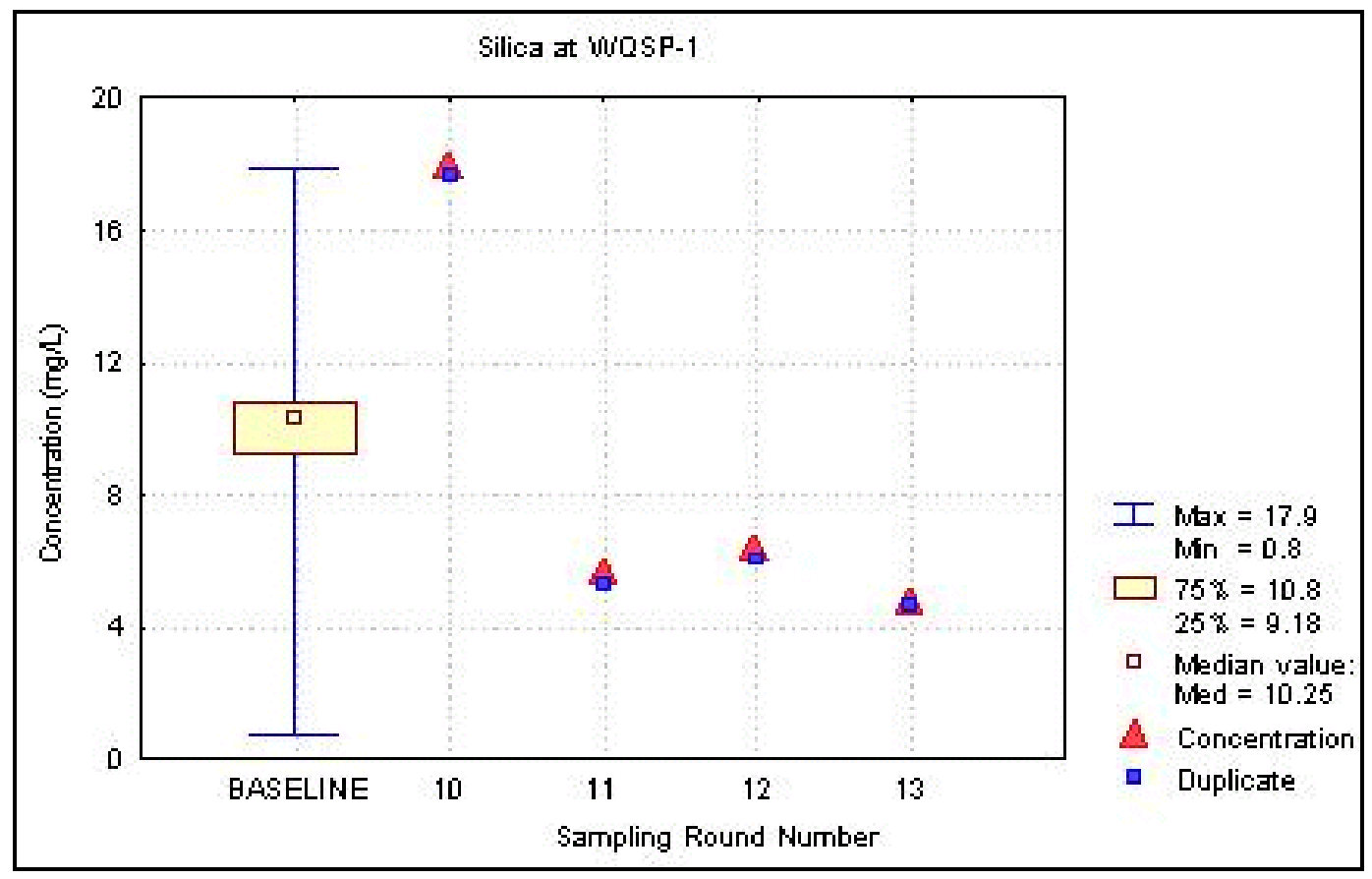

Figure F.12 - Time Trend Plot for Silica at WQSP-1

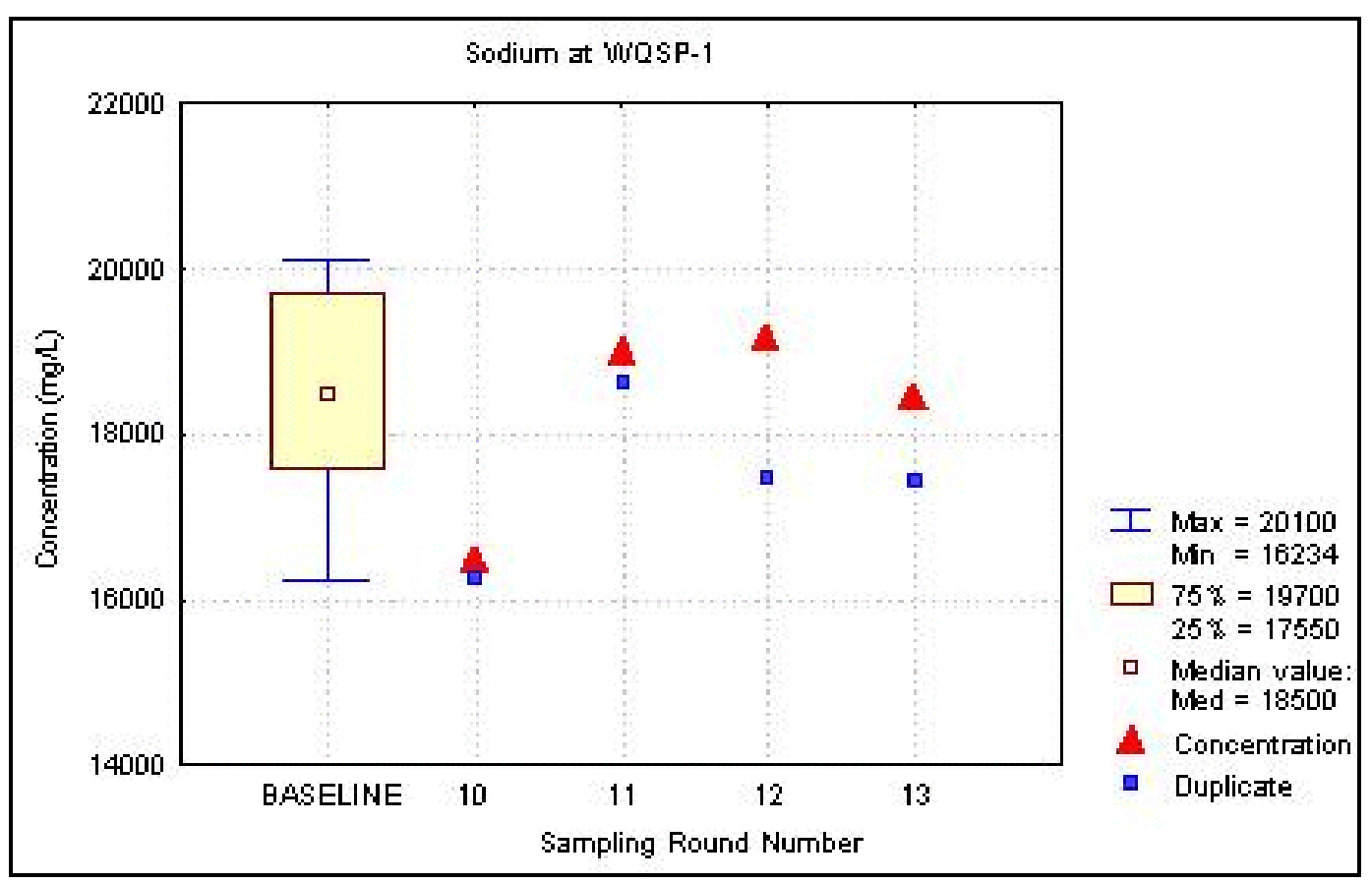

Figure F.13 - Time Trend Plot for Sodium at WQSP-1 


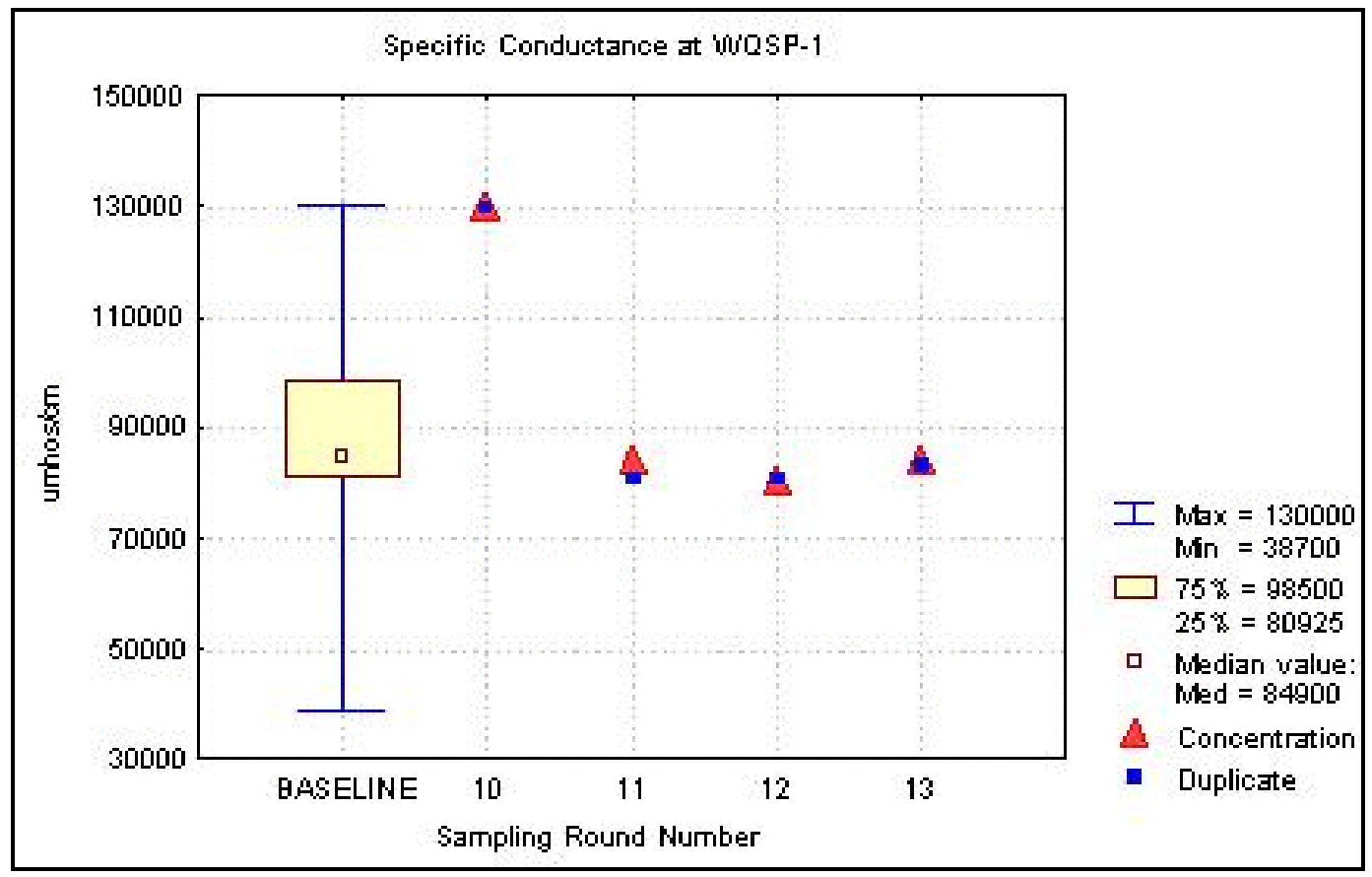

Figure F.14 - Time Trend Plot for Specific Conductance at WQSP-1

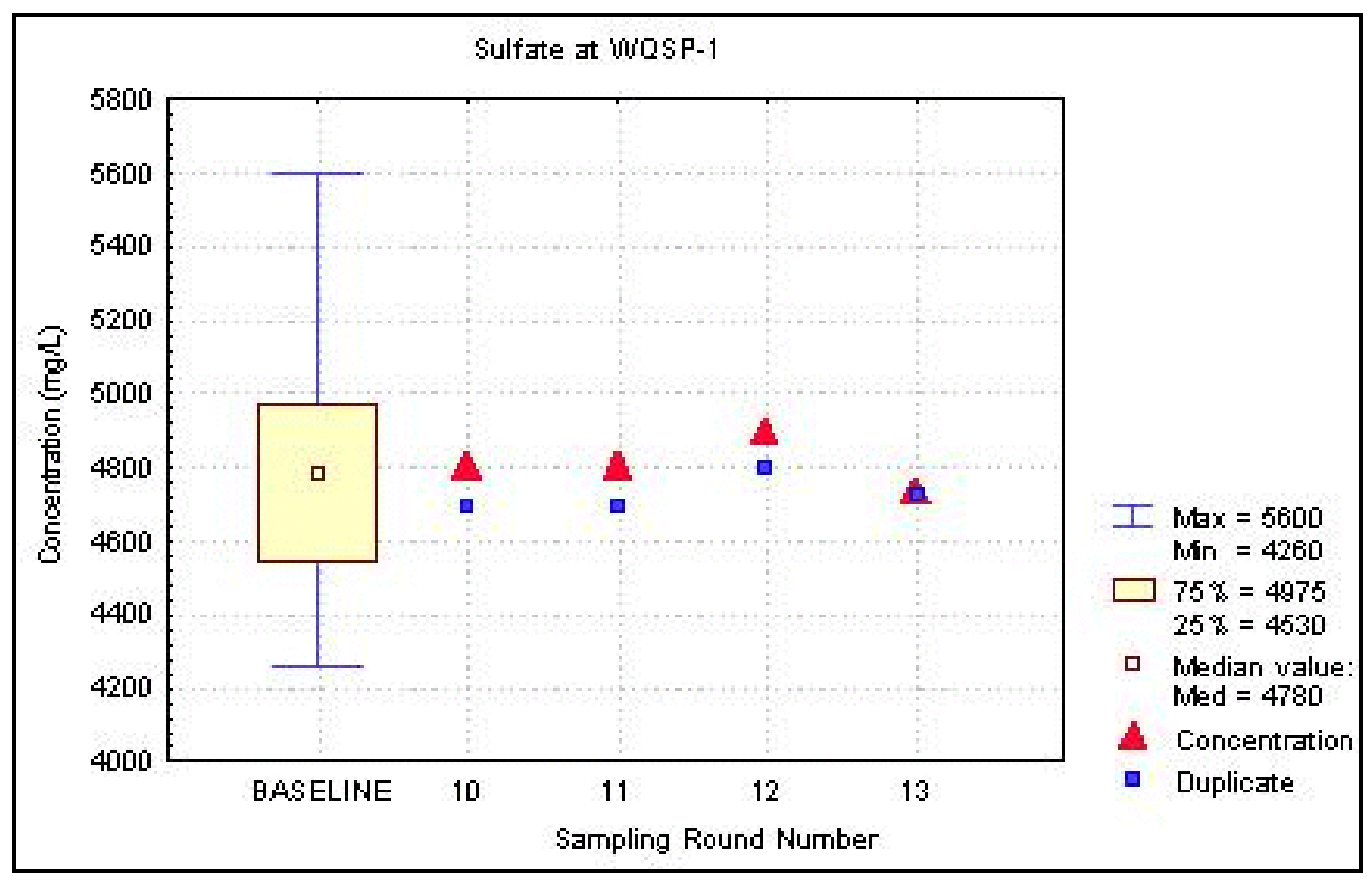

Figure F.15 - Time Trend Plot for Sulfate at WQSP-1 


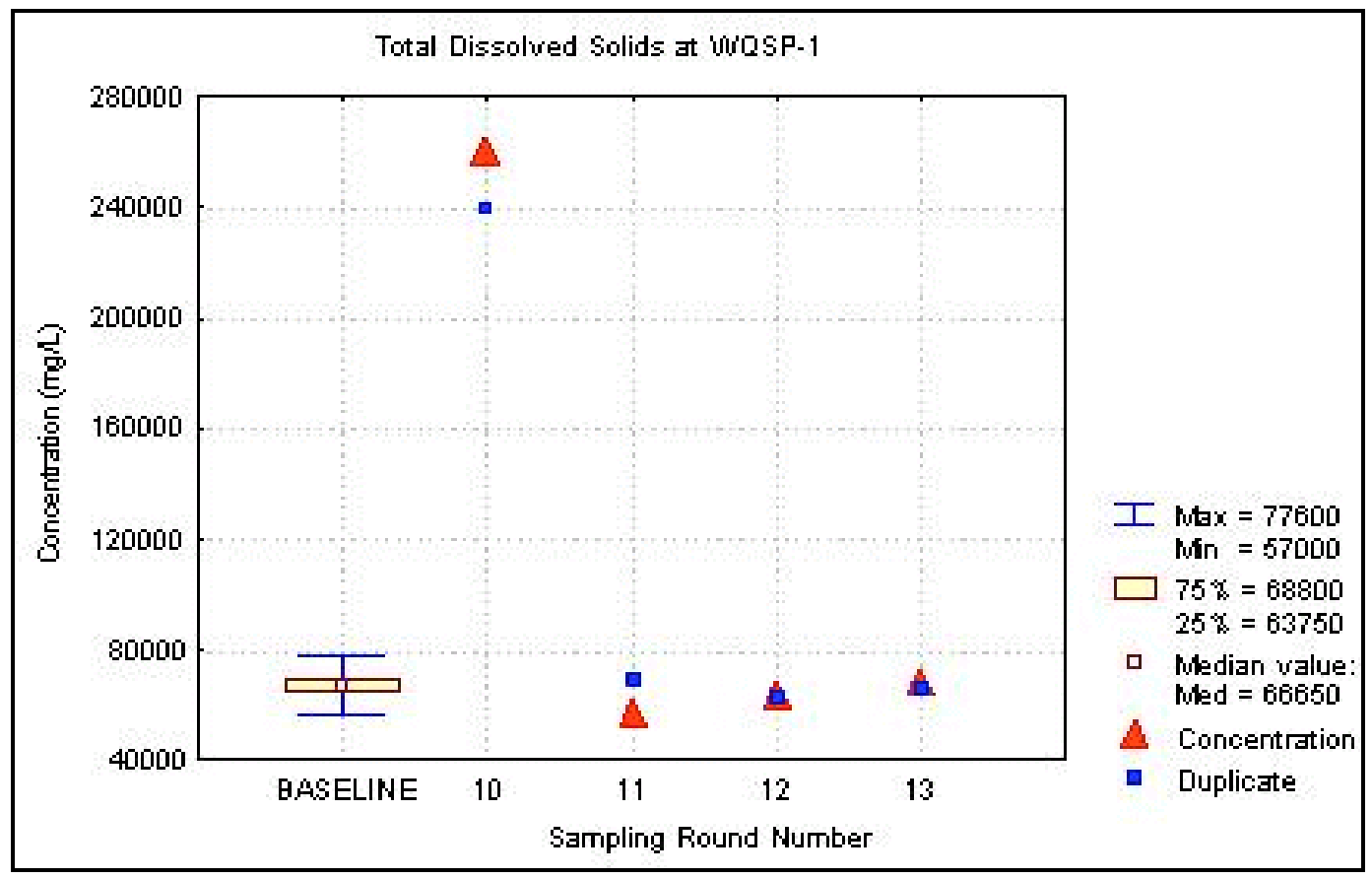

Figure F.16 - Time Trend Plot for Total Dissolved Solids at WQSP-1

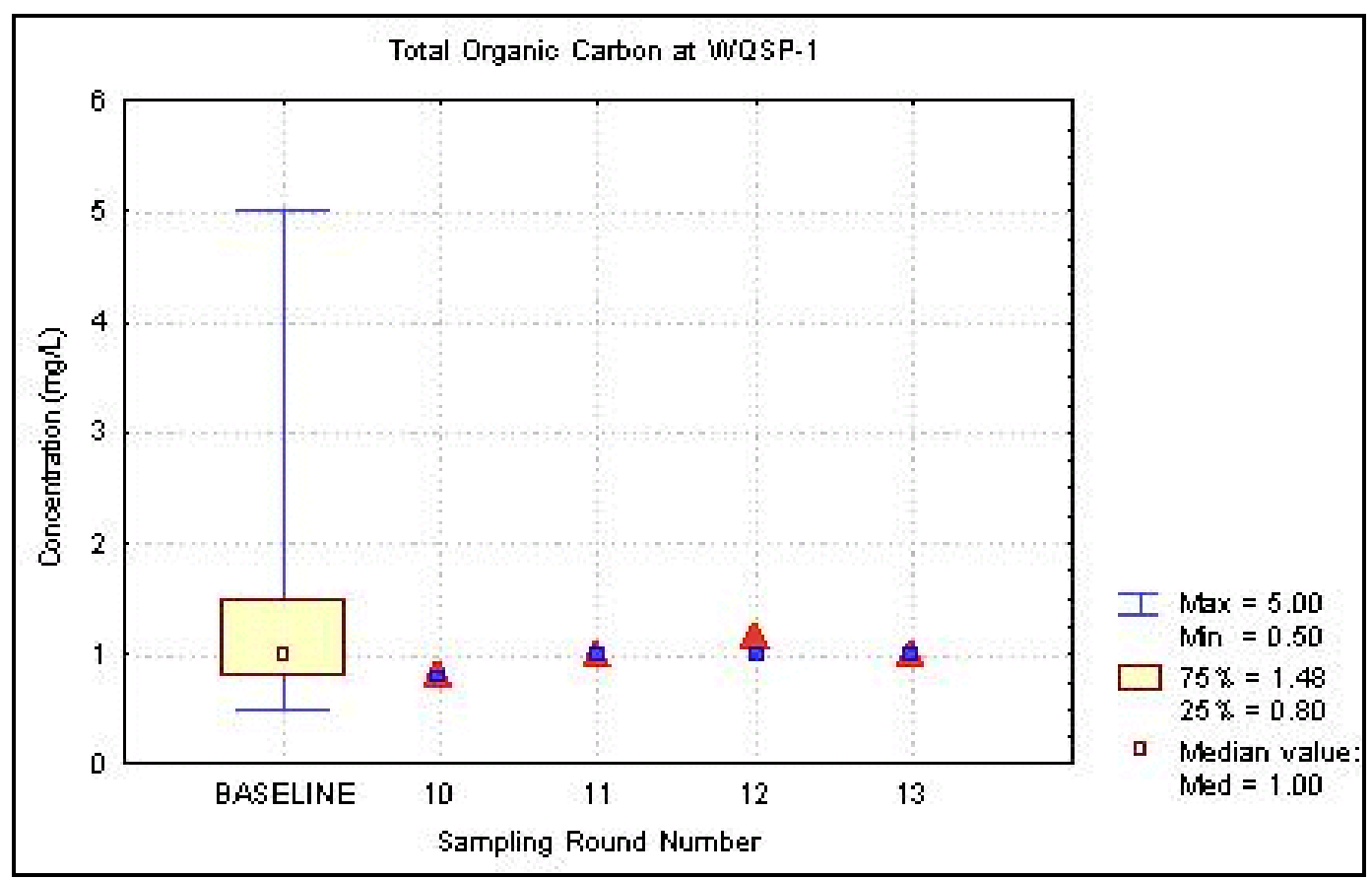

Figure F.17 - Time Trend Plot for Total Organic Carbon at WQSP-1 


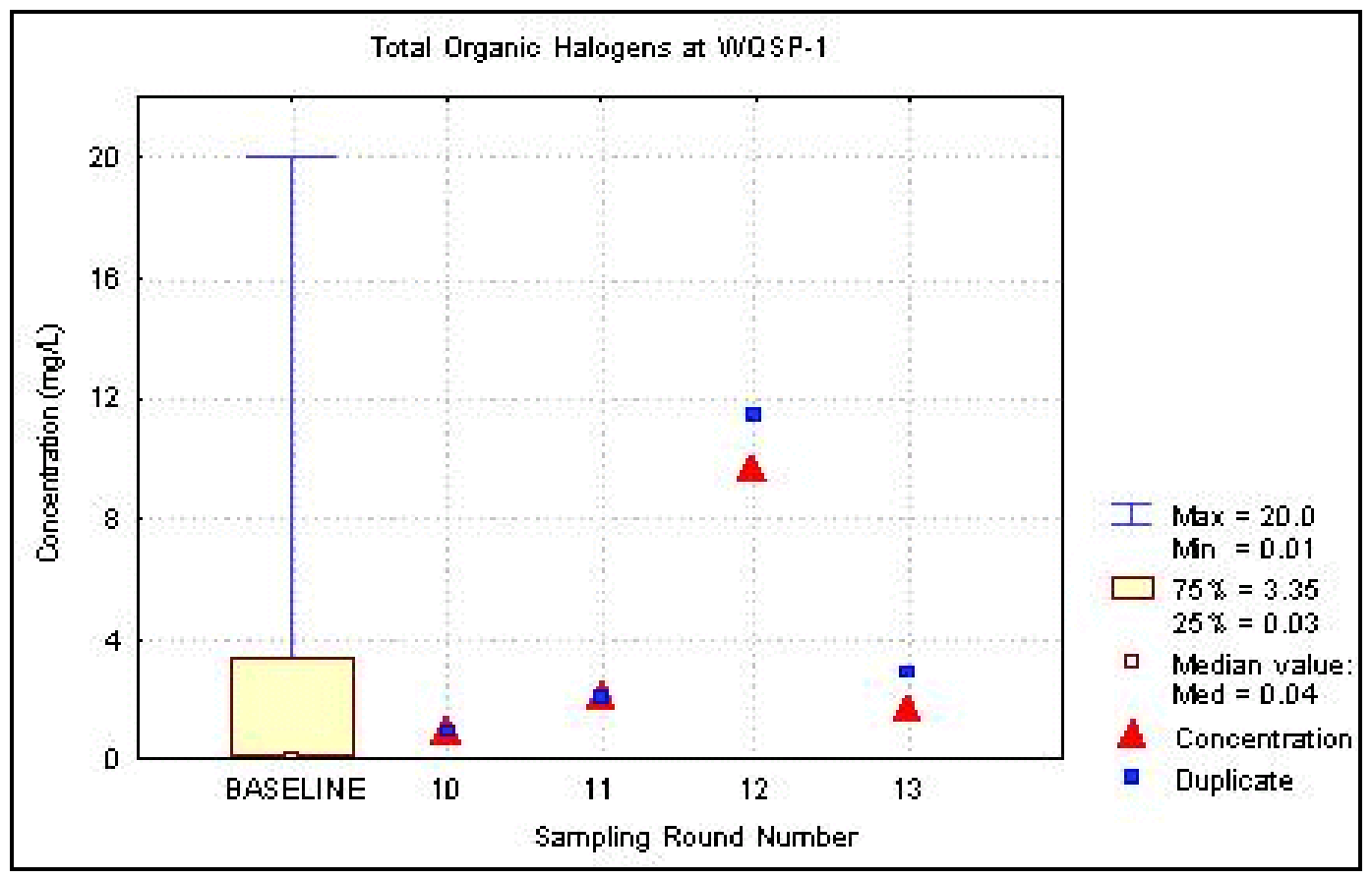

Figure F.18 - Time Trend Plot for Total Organic Halogens at WQSP-1

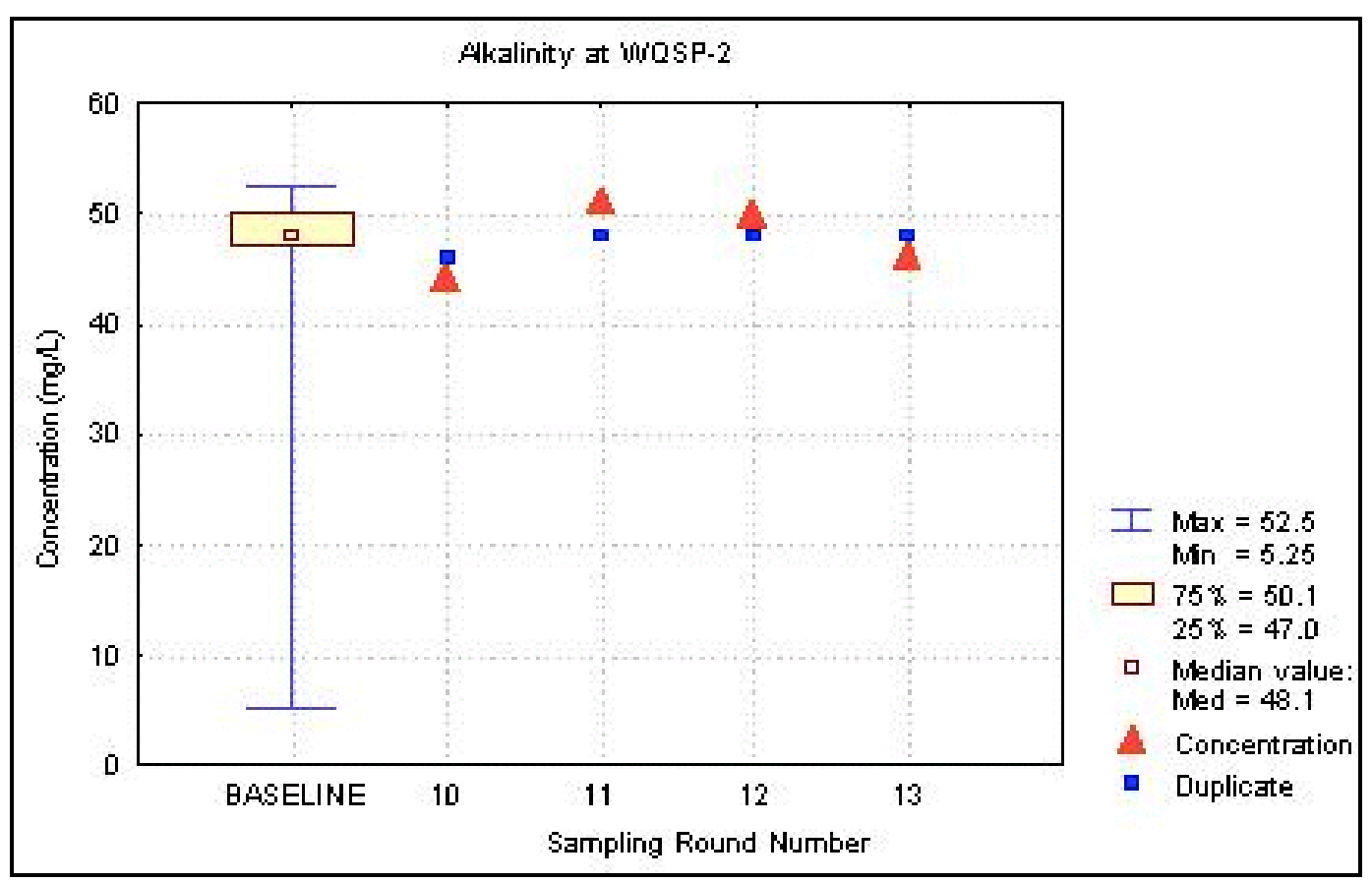

Figure F.19 - Time Trend Plot for Alkalinity at WQSP-2 


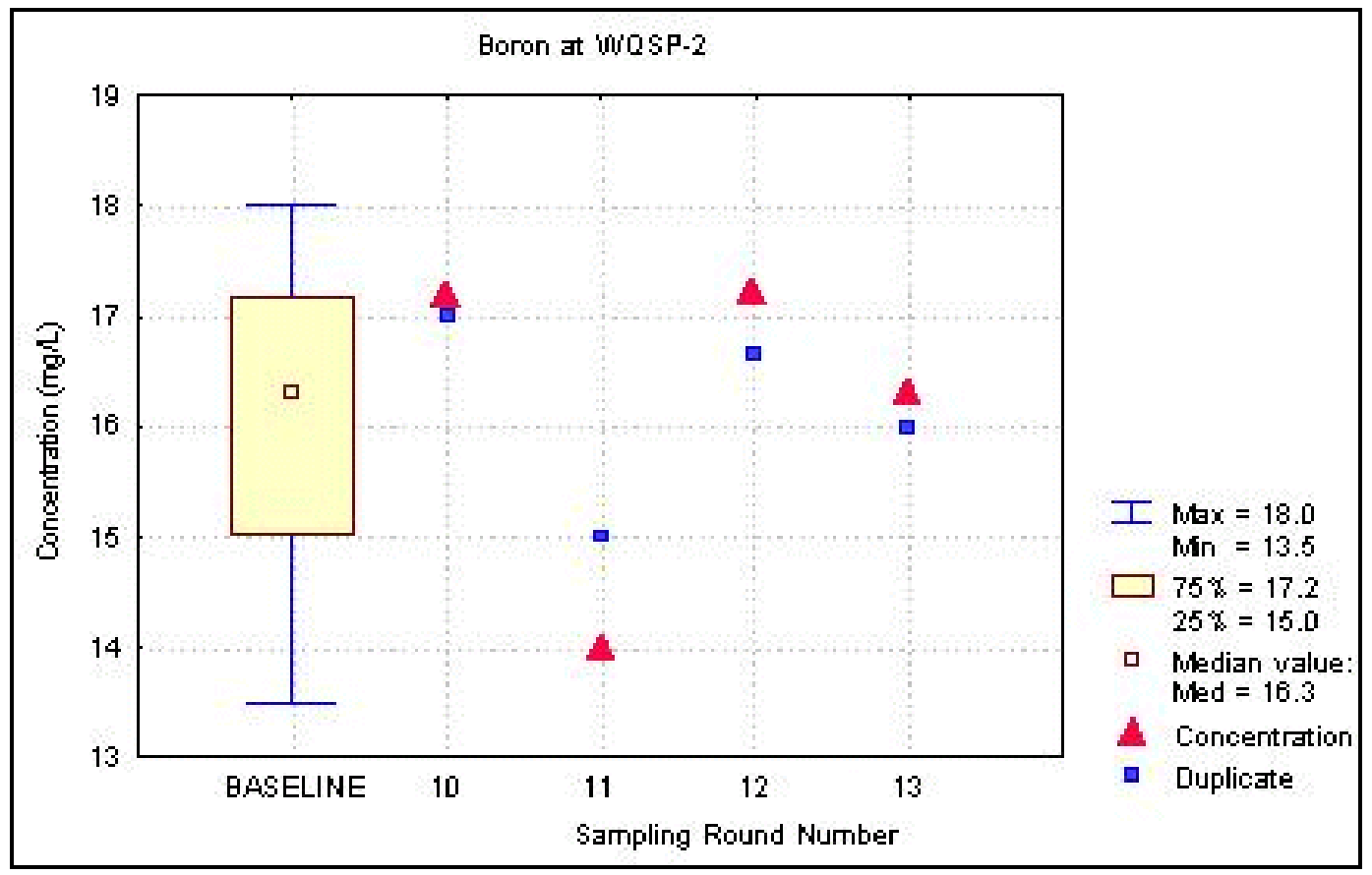

Figure F.20 - Time Trend Plot for Boron at WQSP-2

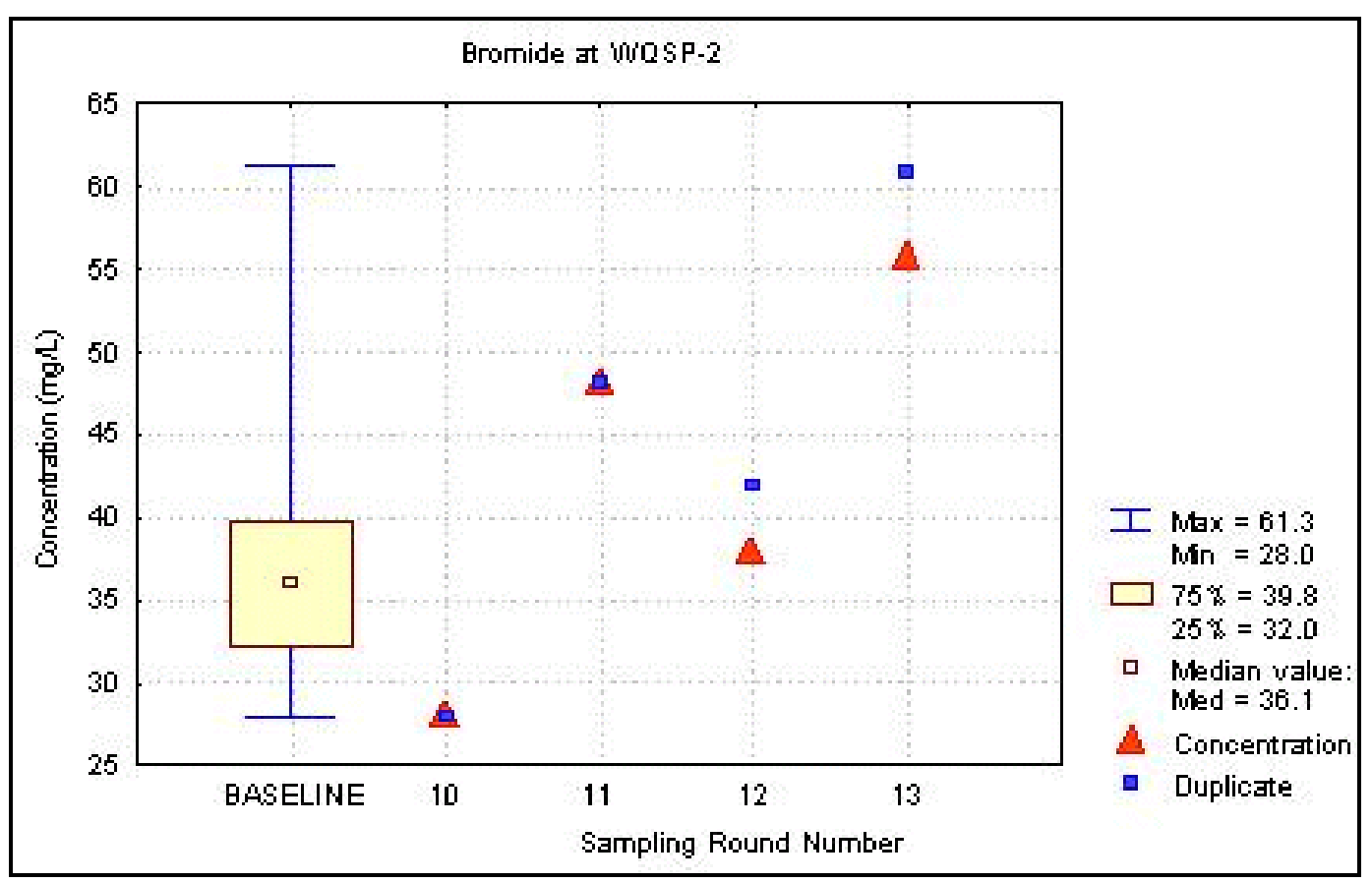

Figure F.21 - Time Trend Plot for Bromide at WQSP-1 


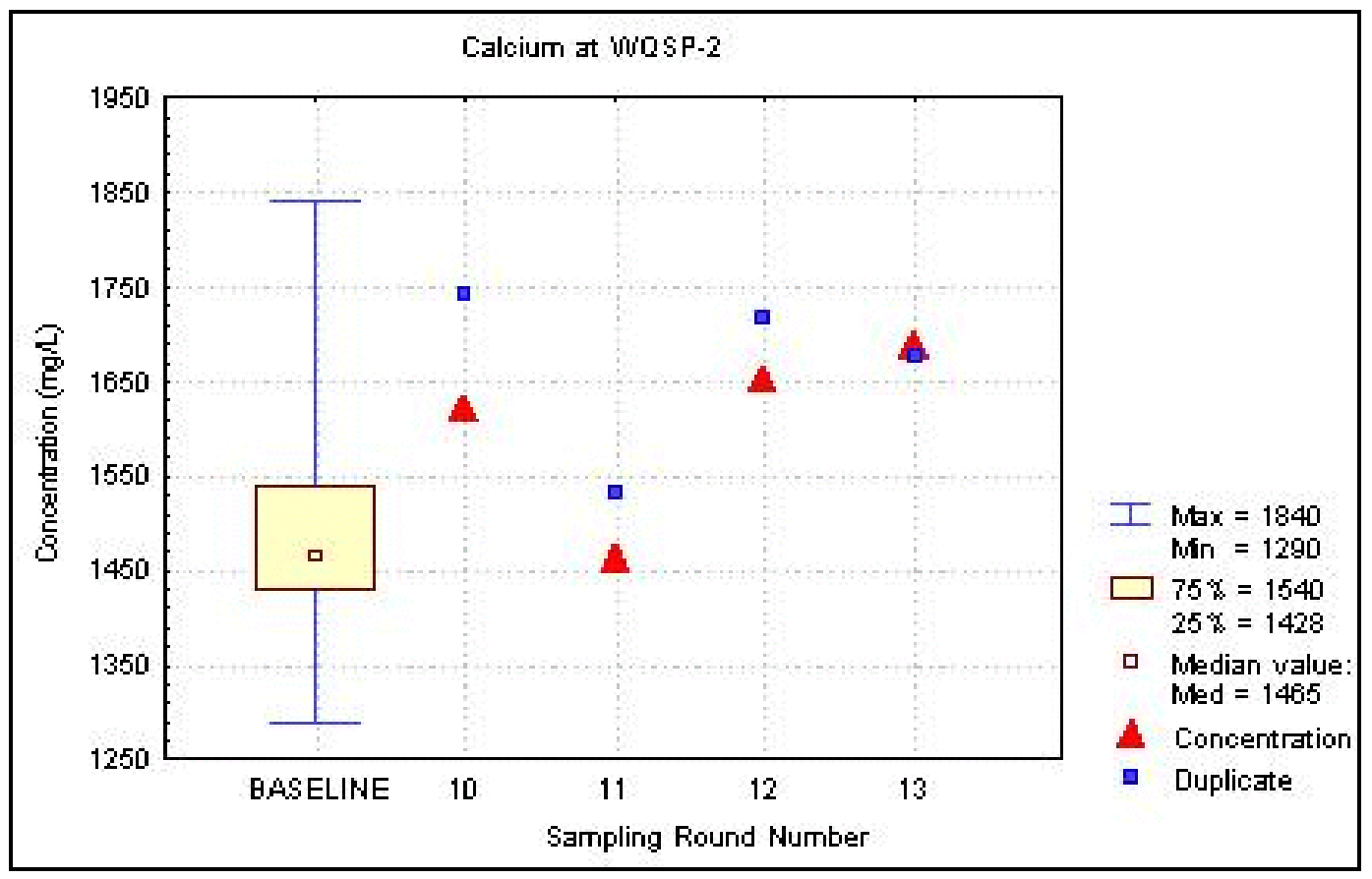

Figure F.22 - Time Trend Plot for Calcium at WQSP-2

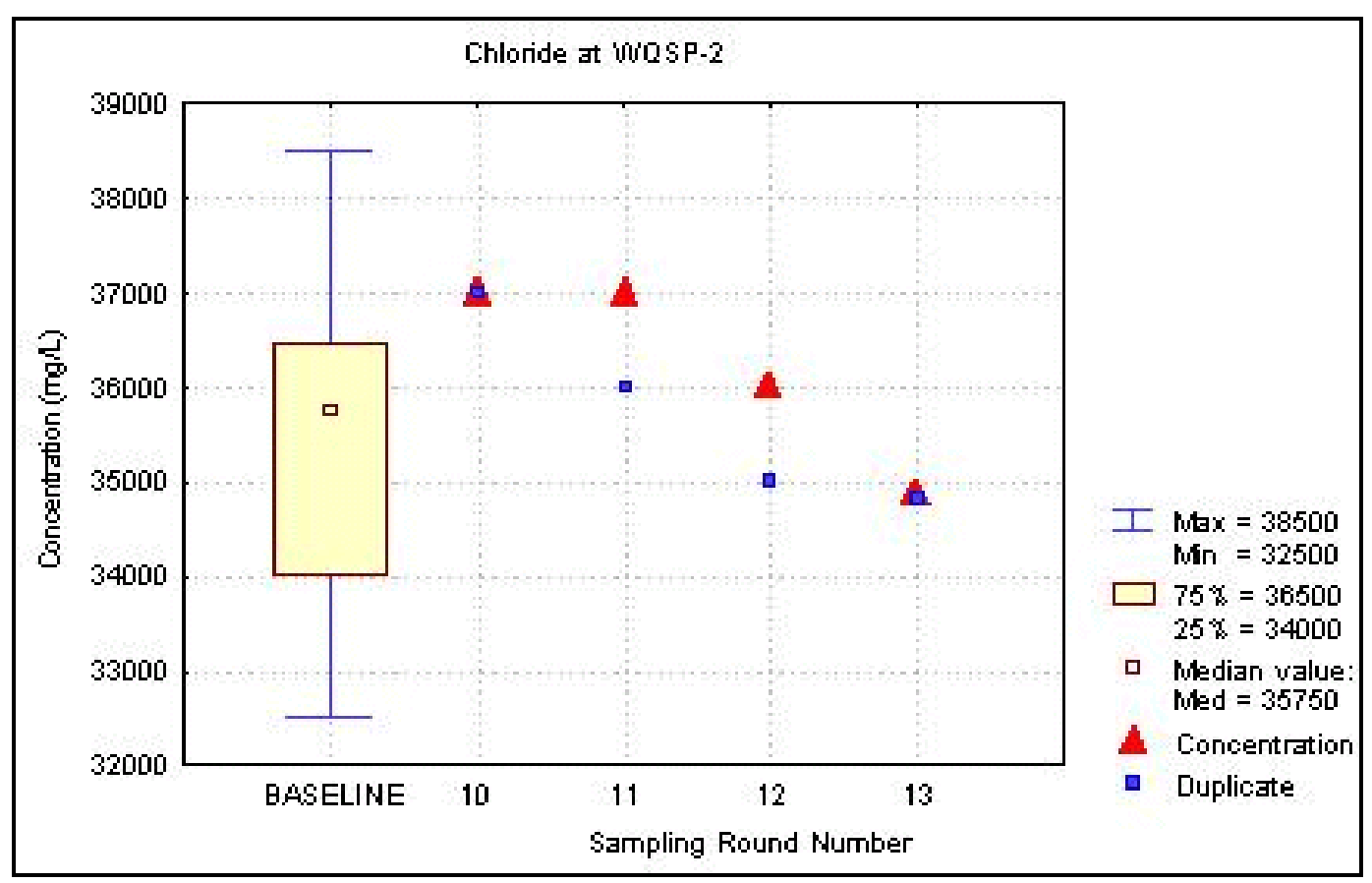

Figure F.23 - Time Trend Plot for Chloride at WQSP-2 


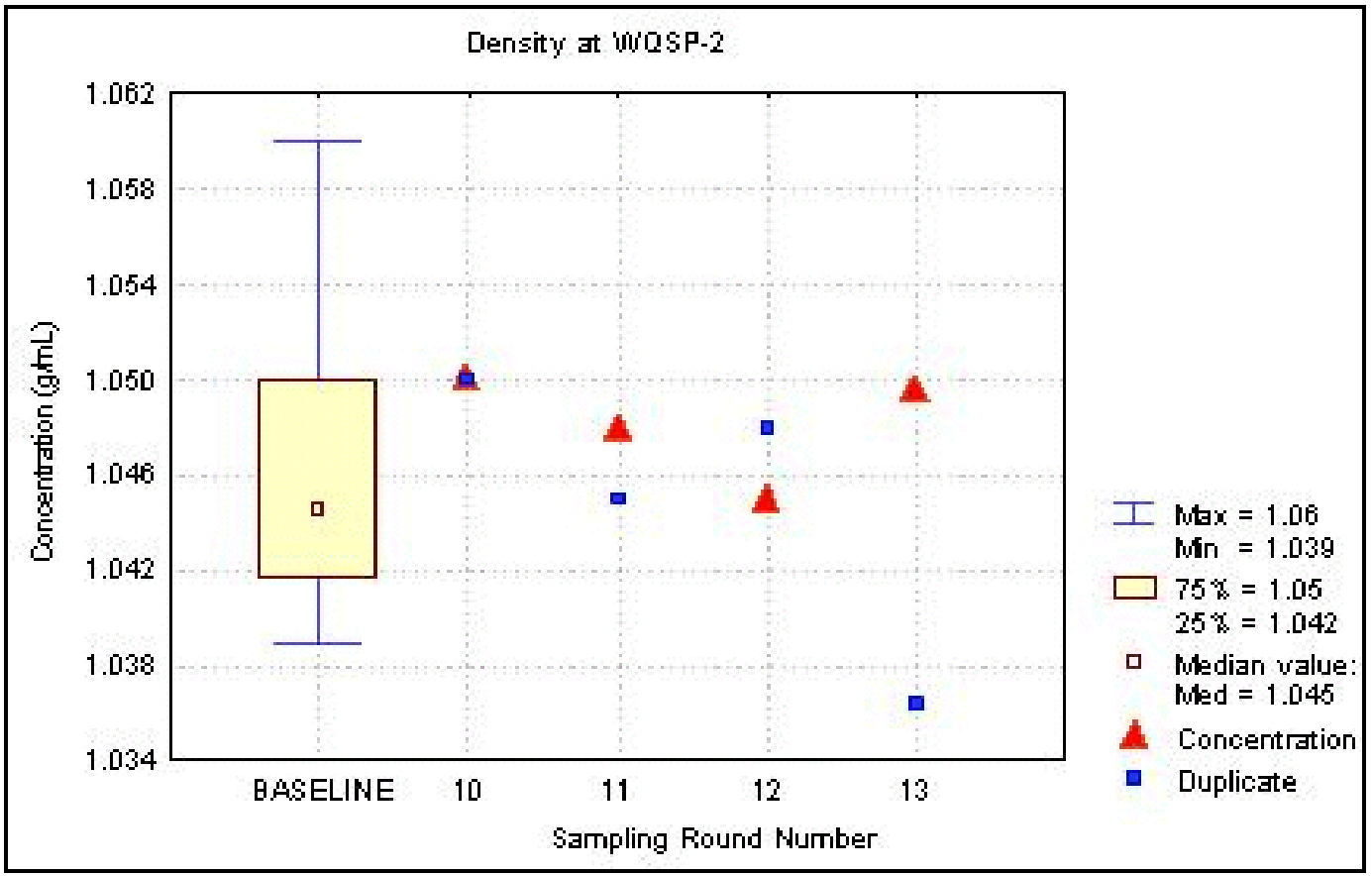

Figure F.24 - Time Trend Plot for Density at WQSP-1

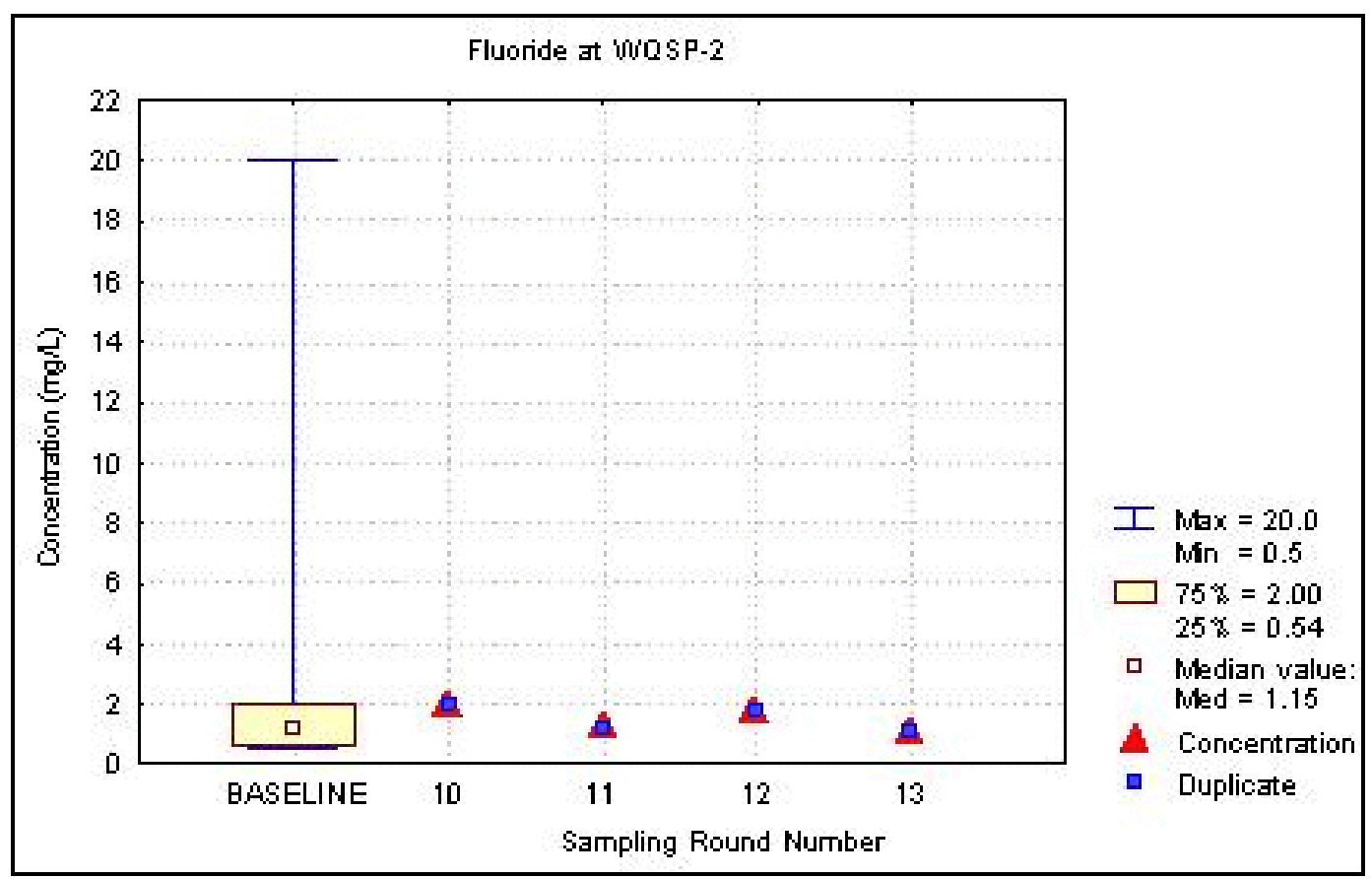

Figure F.25 - Time Trend Plot for Fluoride at WQSP-2 


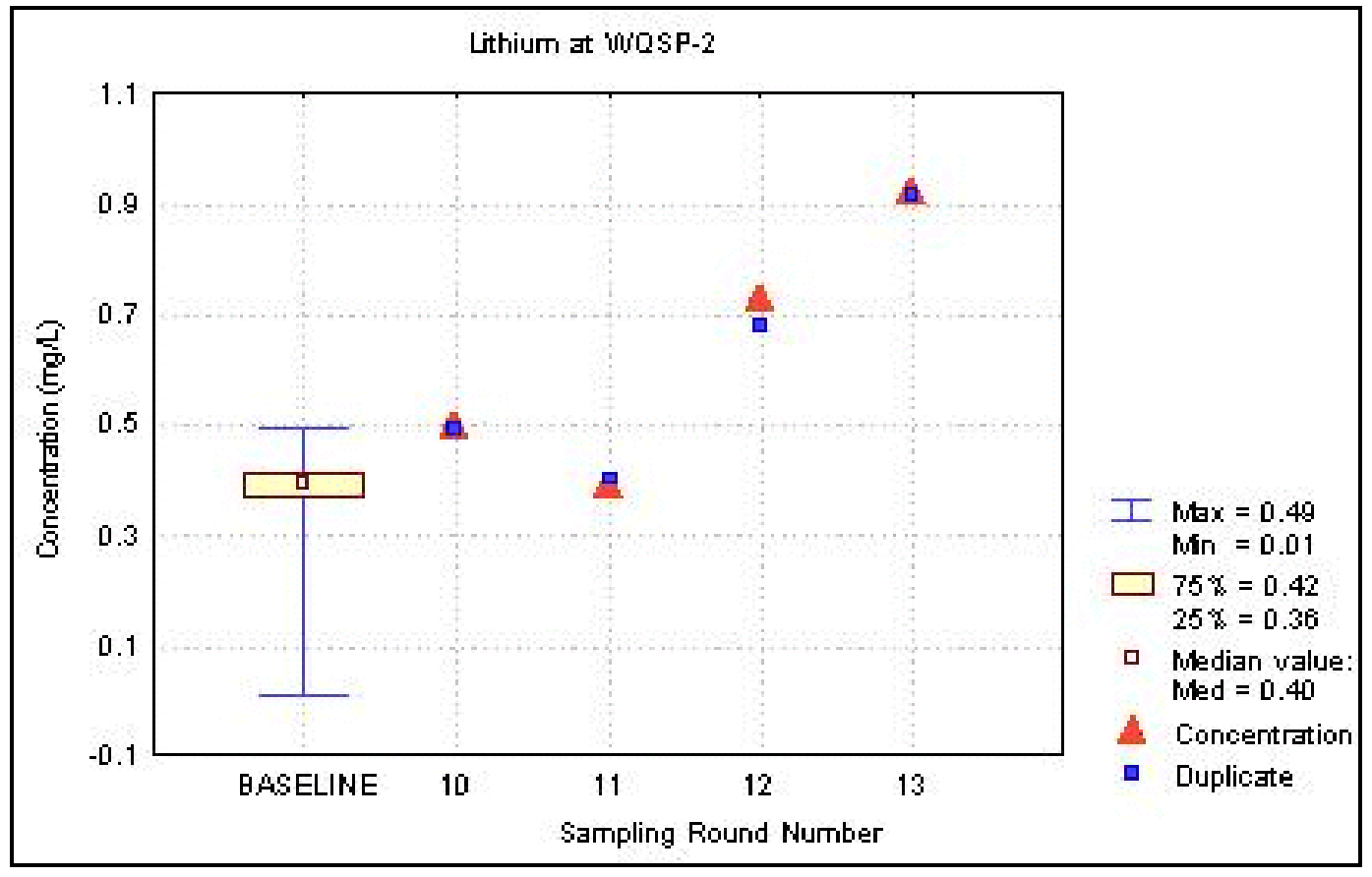

Figure F.26 - Time Trend Plot for Lithium at WQSP-2

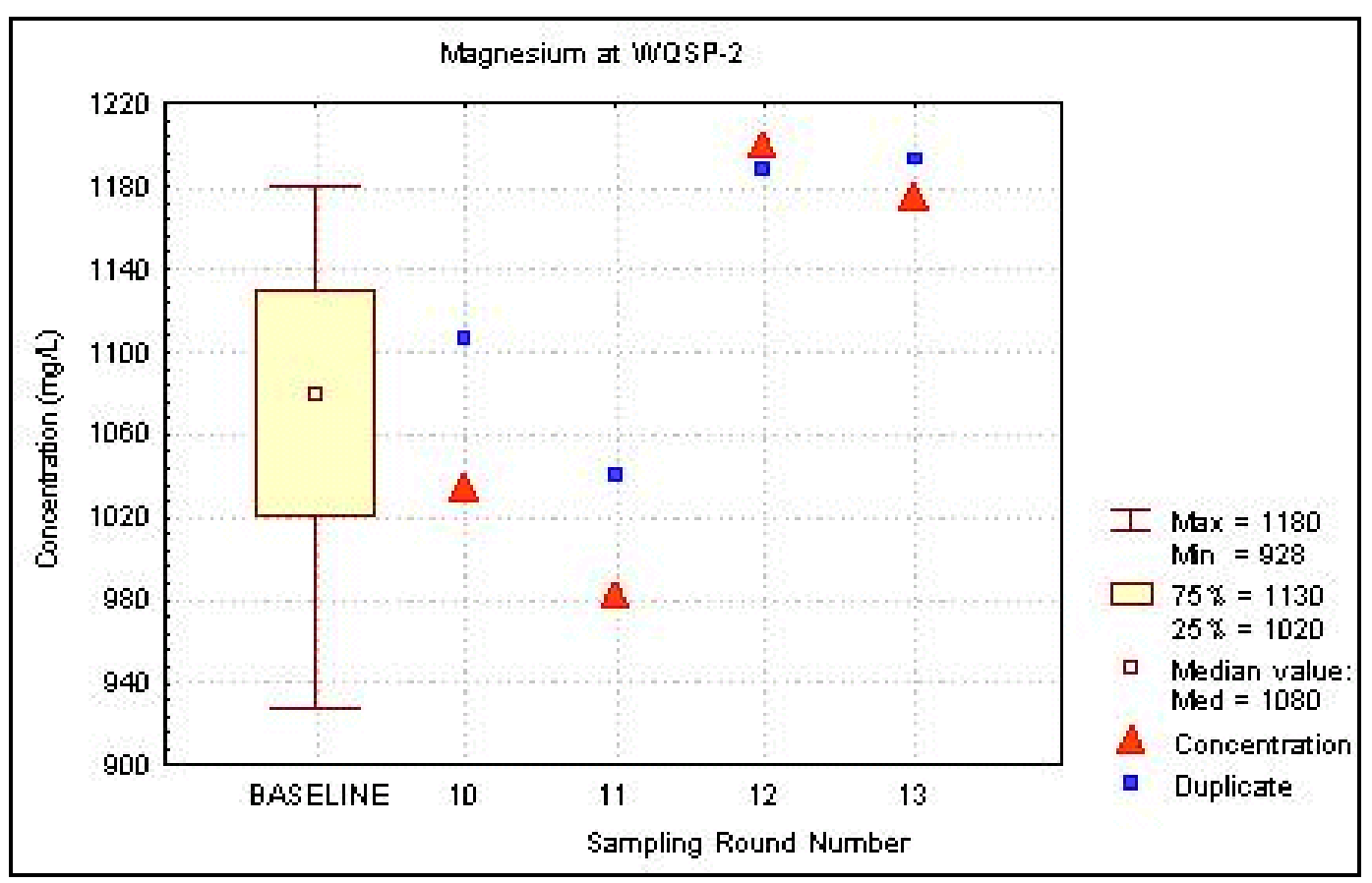

Figure F.27 - Time Trend Plot for Magnesium at WQSP-2 


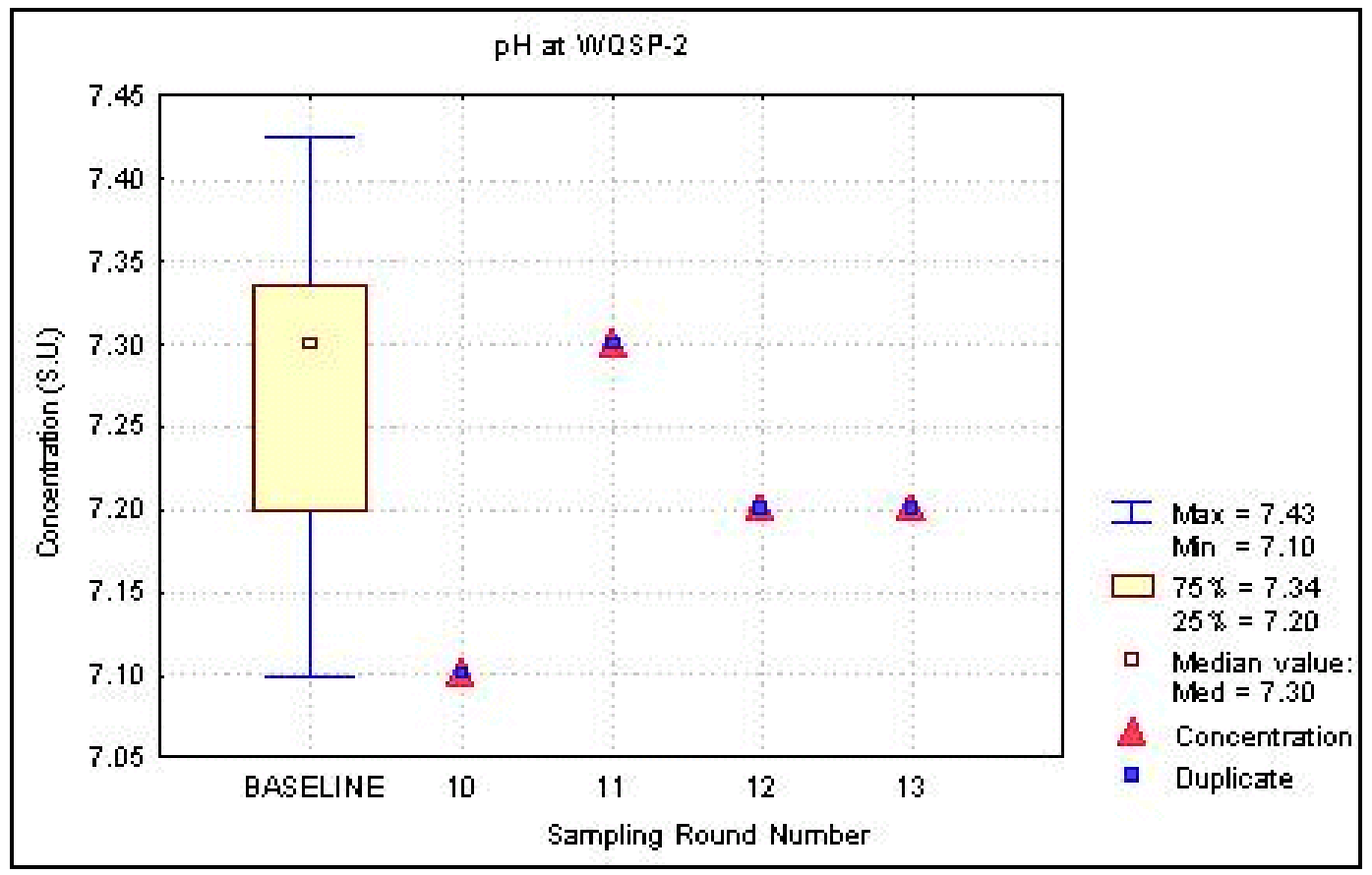

Figure F.28 - Time Trend Plot for $\mathrm{pH}$ at WQSP-2

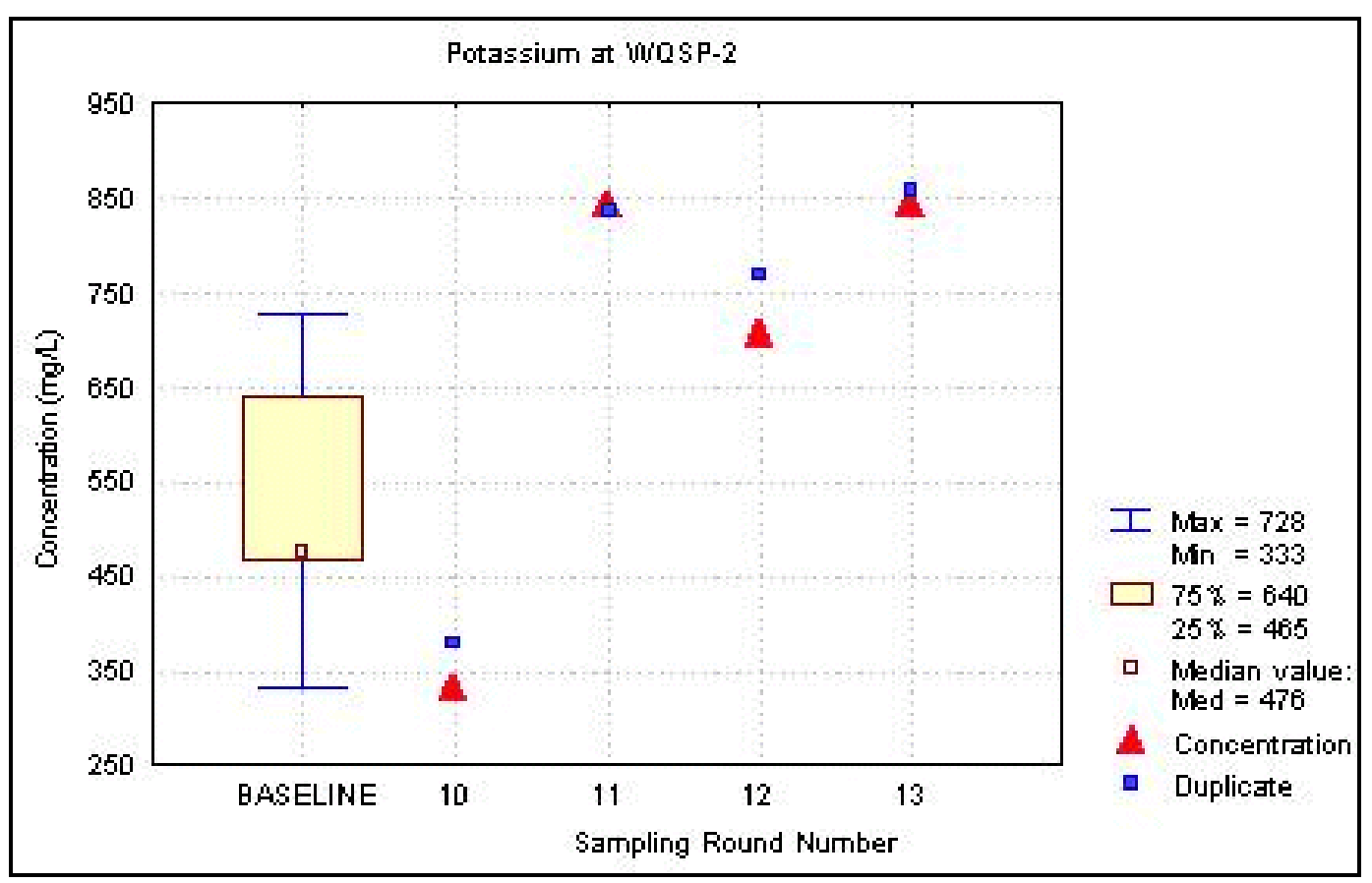

Figure F.29 - Time Trend Plot for Potassium at WQSP-2 


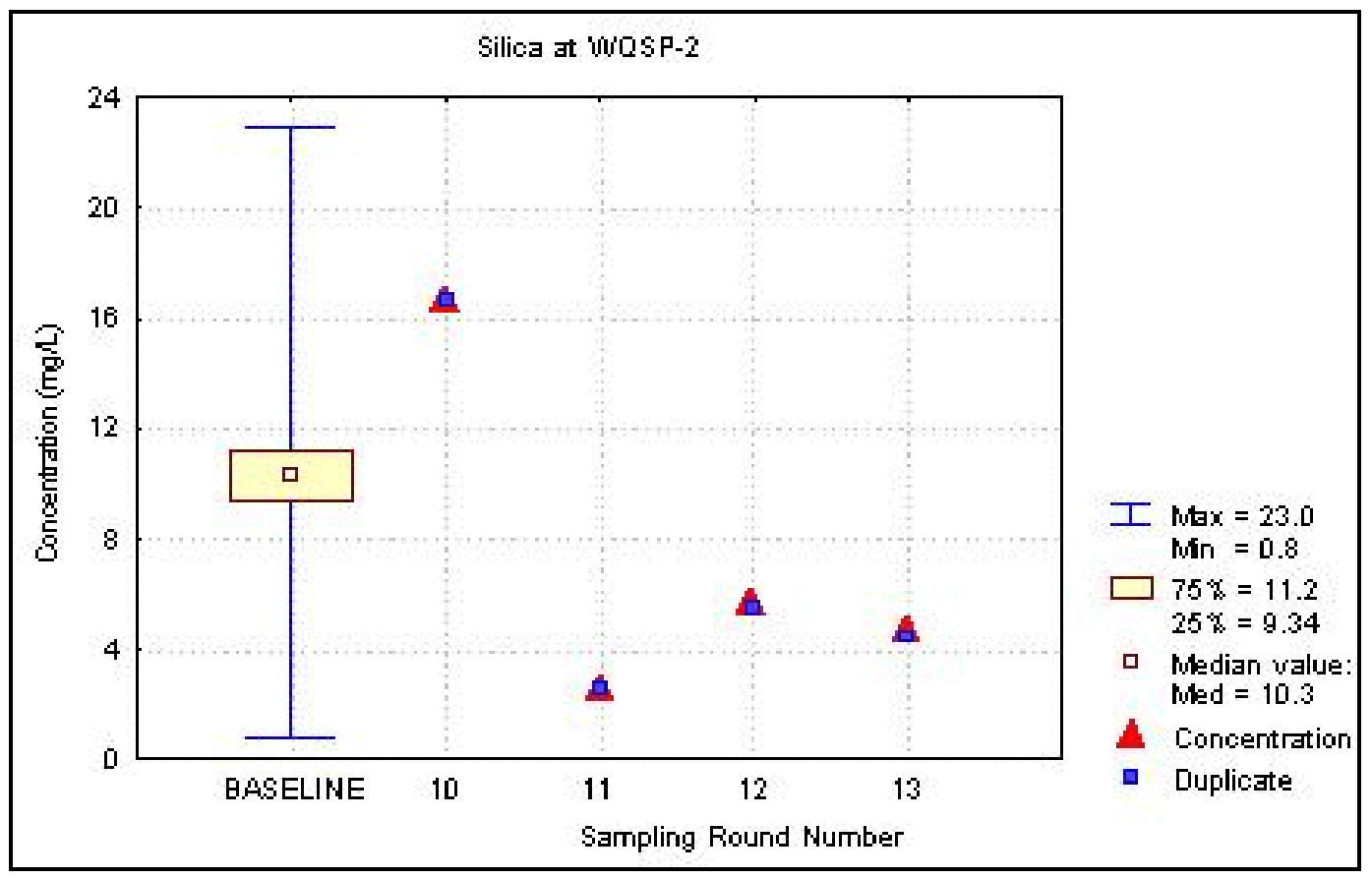

Figure F.30 - Time Trend Plot for Silica at WQSP-2

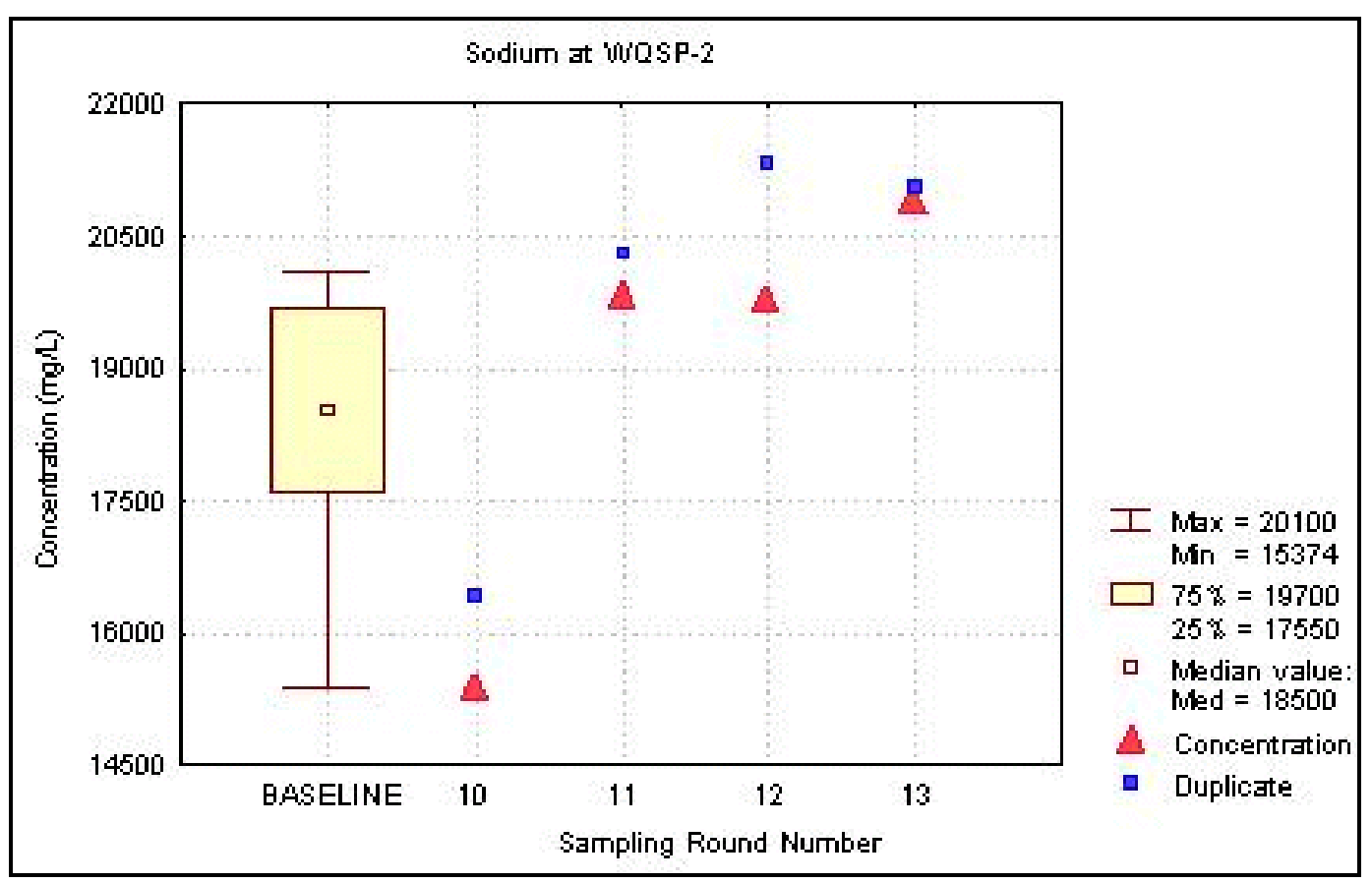

Figure F.31 - Time Trend Plot for Sodium at WQSP-2 


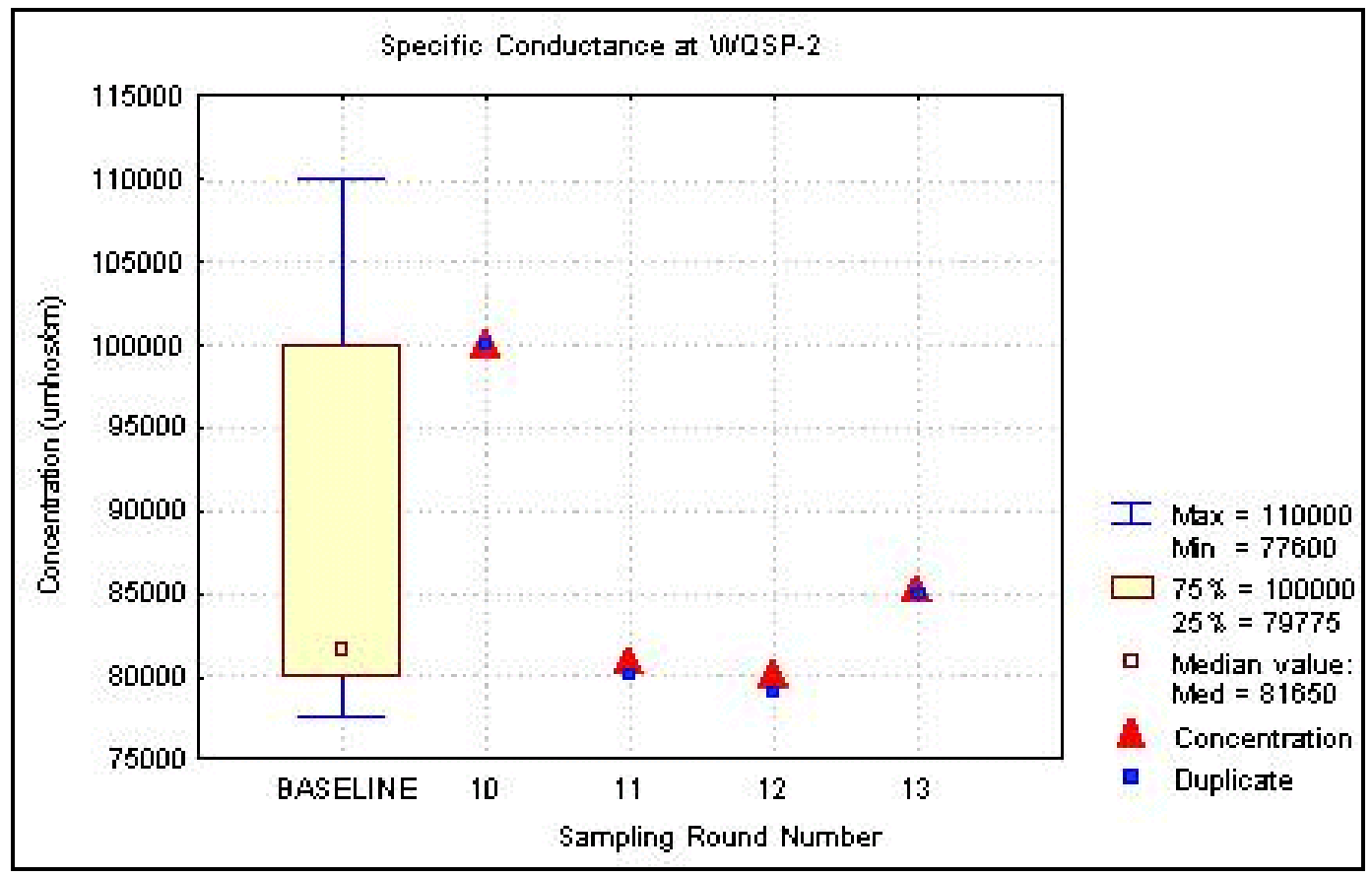

Figure F.32 - Time Trend Plot for Specific Conductance at WQSP-2

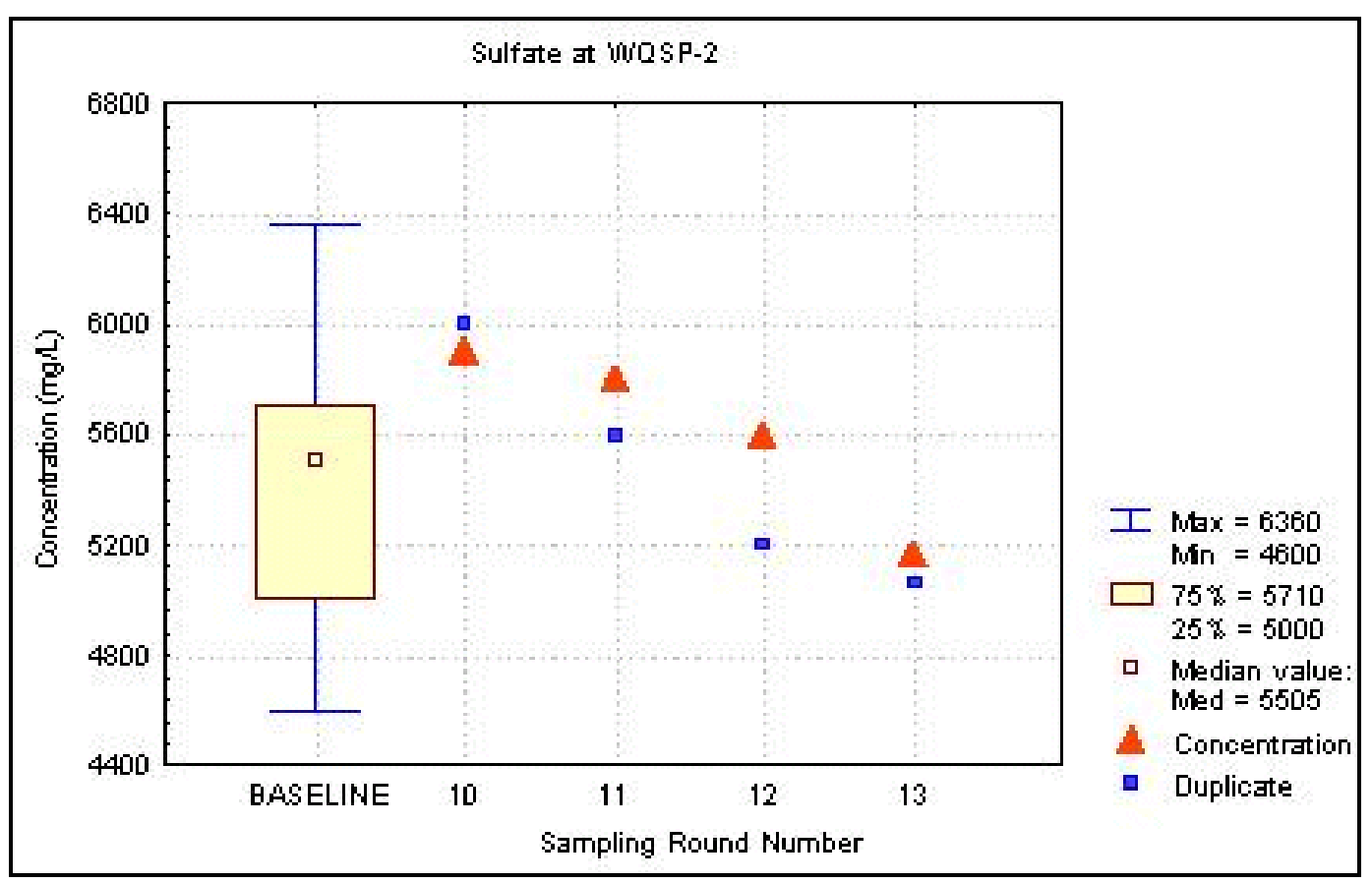

Figure F.33 - Time Trend Plot for Sulfate at WQSP-2 


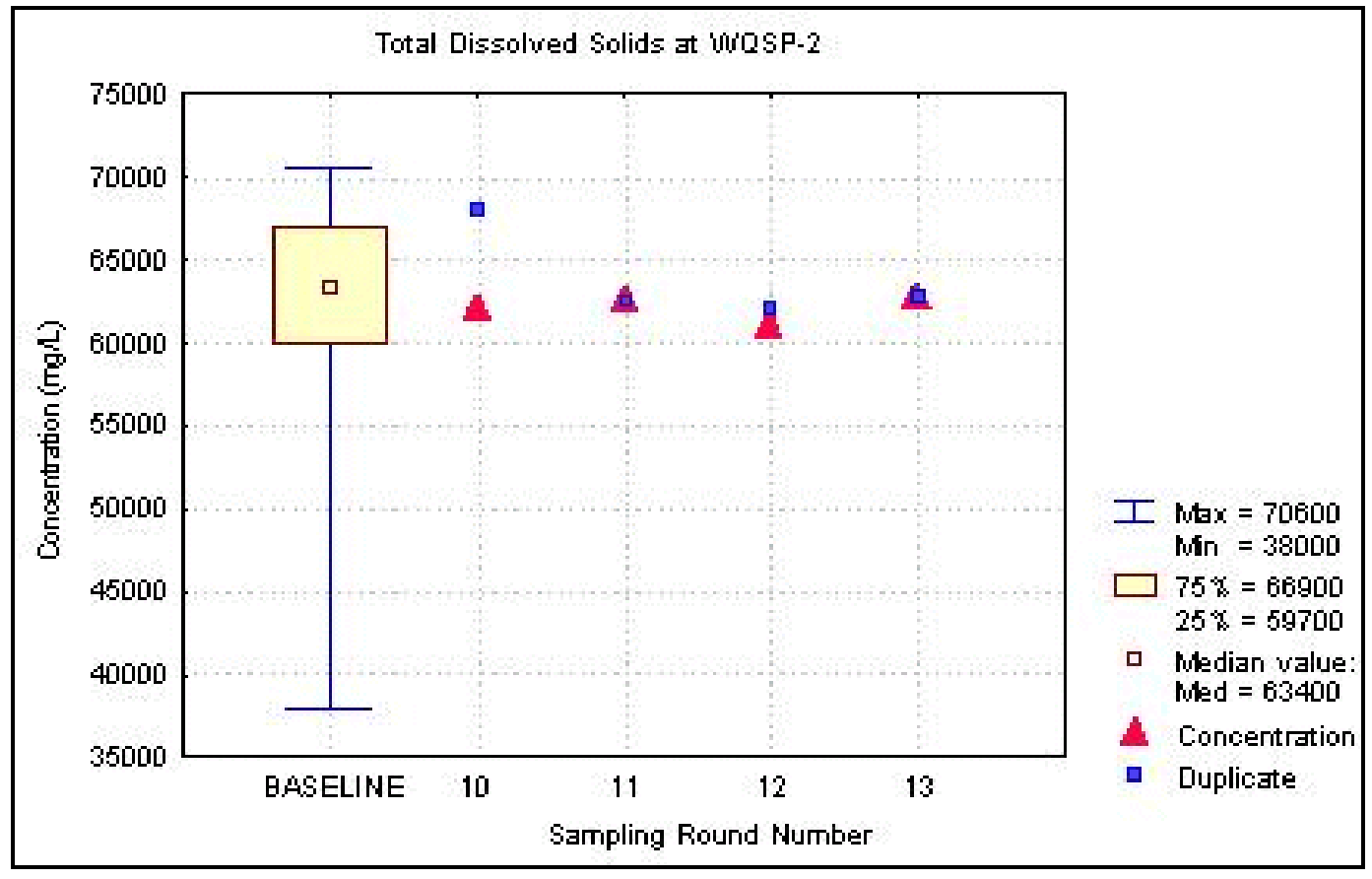

Figure F.34 - Time Trend Plot for Total Dissolved Solids at WQSP-2

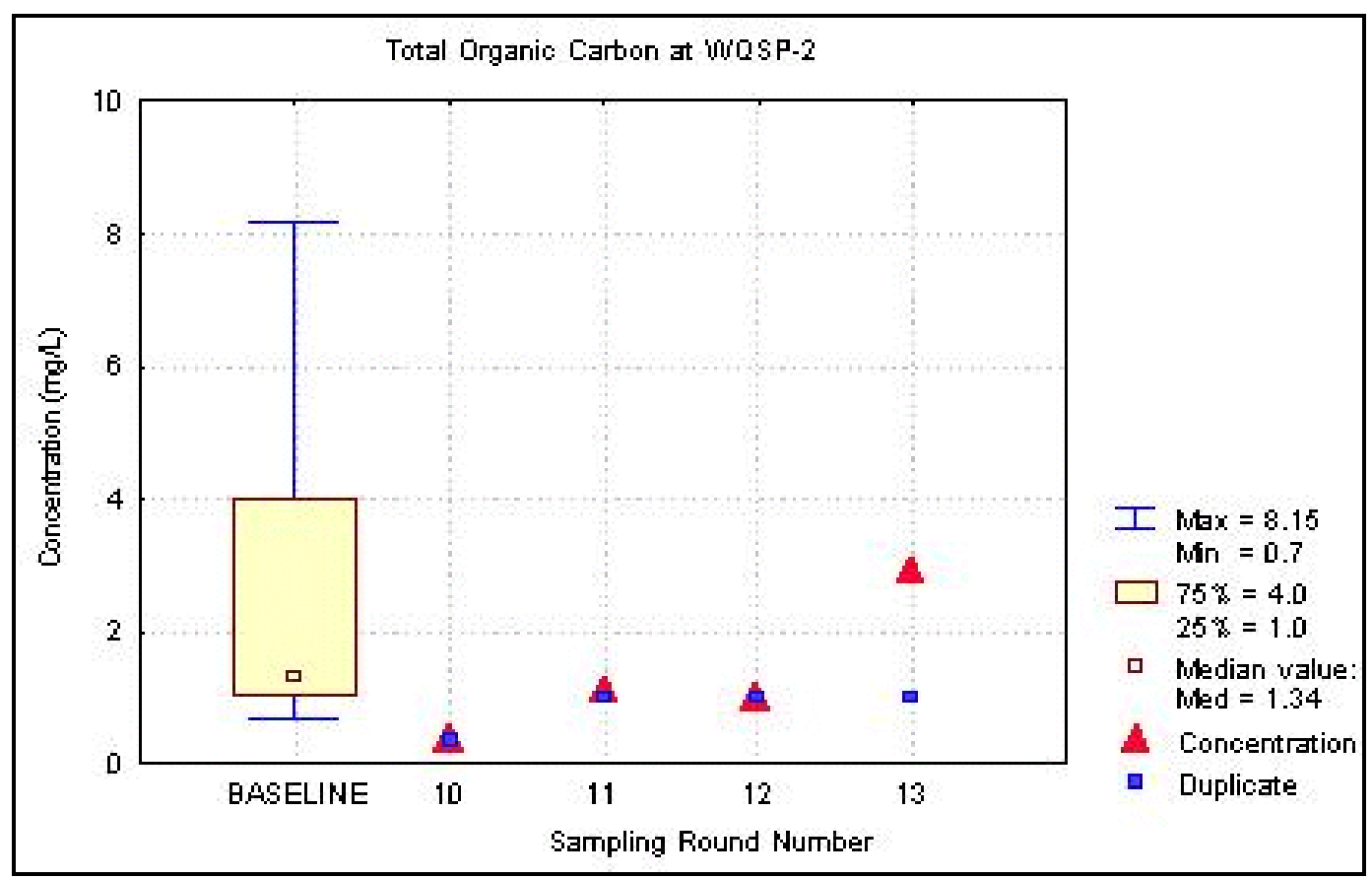

Figure F.35 - Time Trend Plot for Total Organic Carbon at WQSP-2 


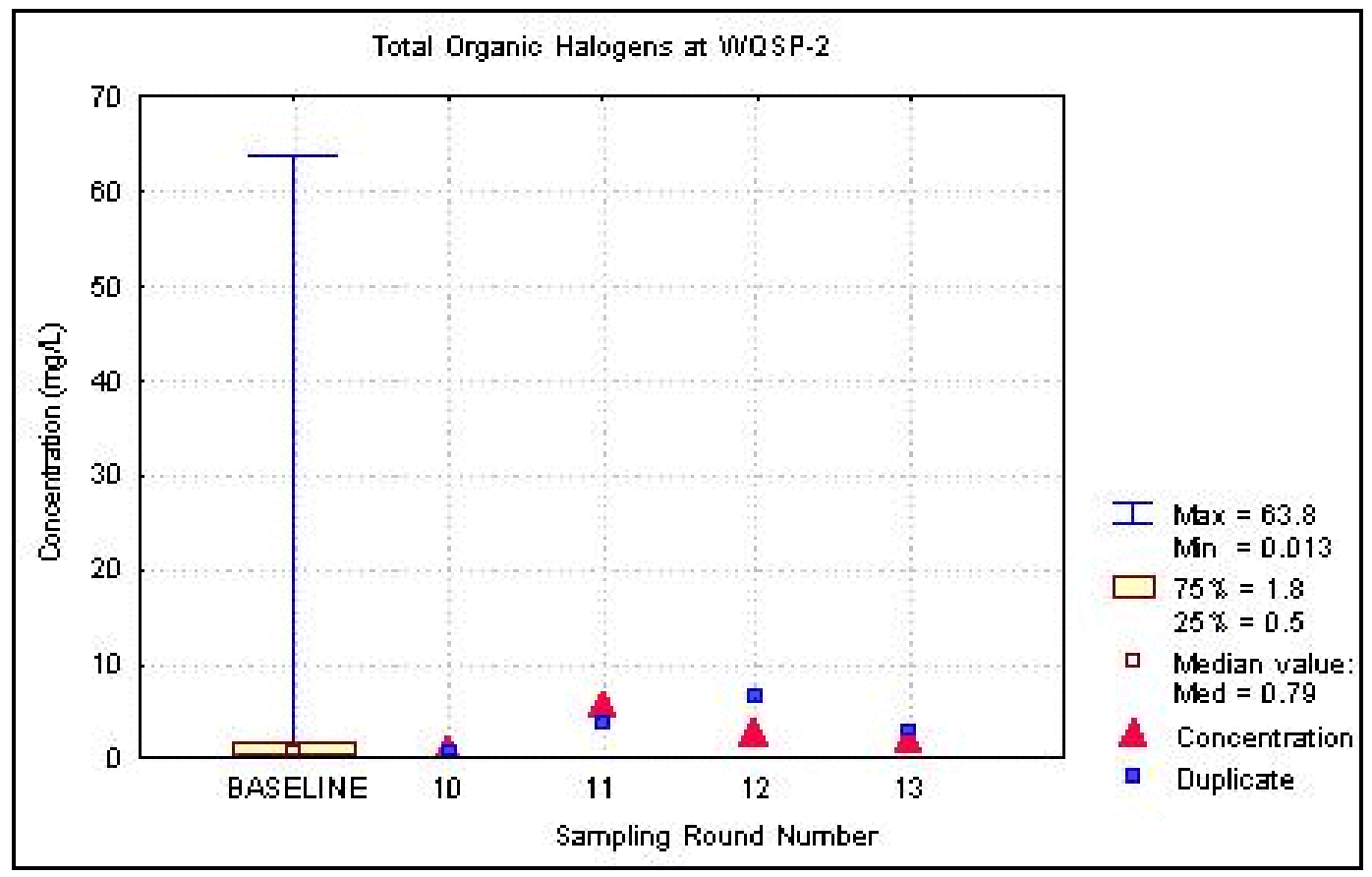

Figure F.36 - Time Trend Plot for Total Organic Halogens at WQSP-2

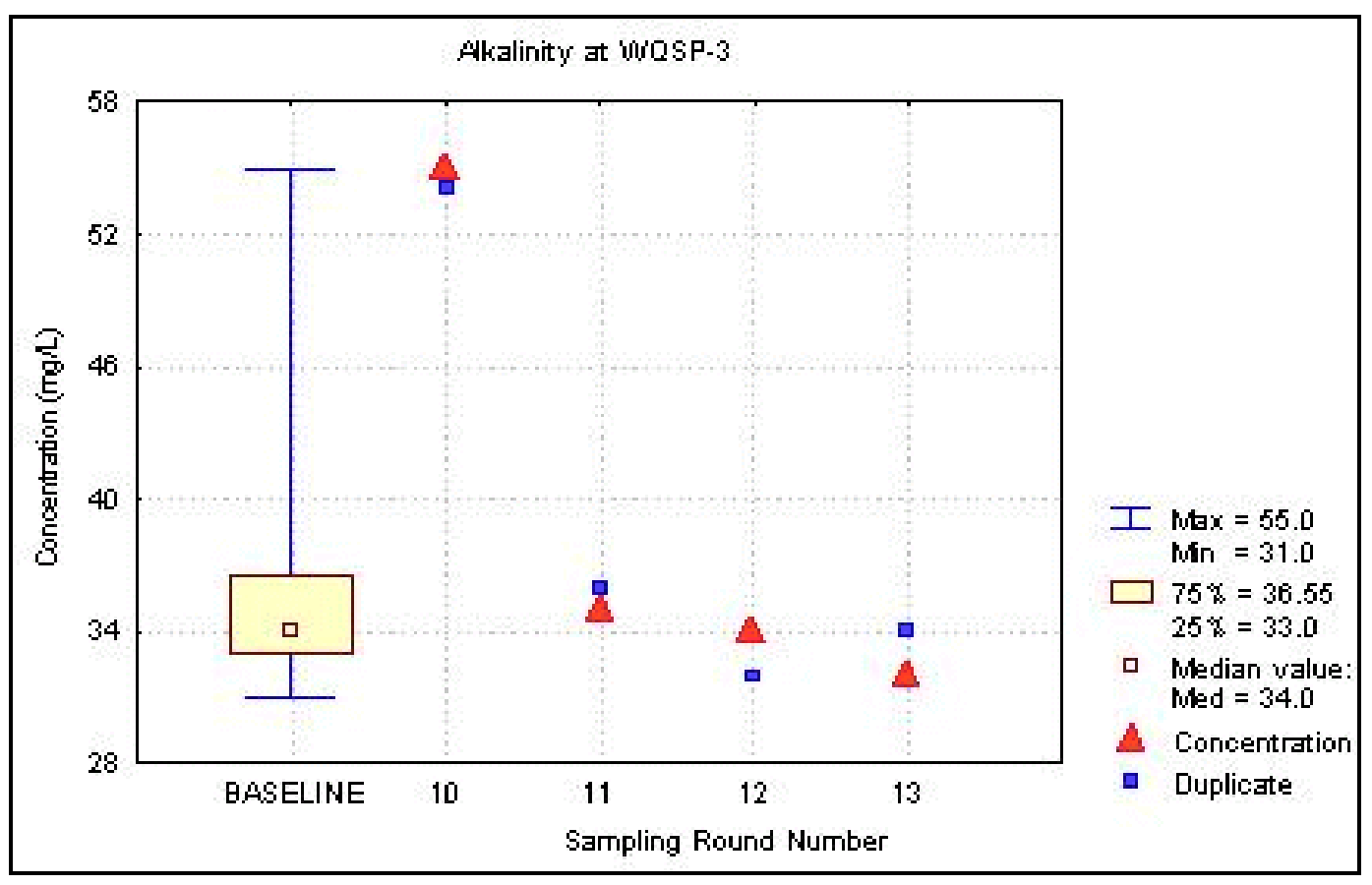

Figure F.37 - Time Trend Plot for Alkalinity at WQSP-2 


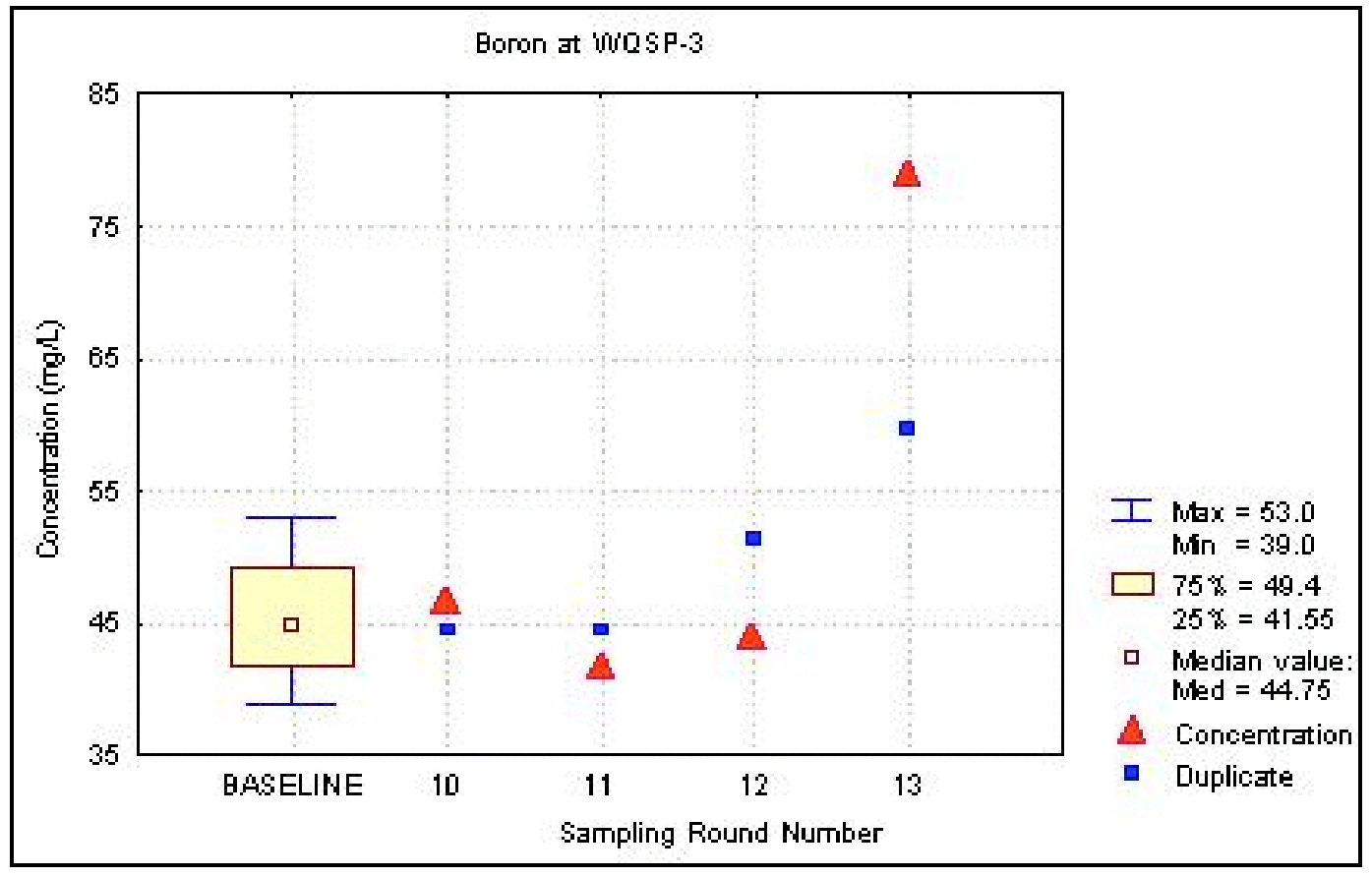

Figure F.38 - Time Trend Plot for Boron at WQSP-3

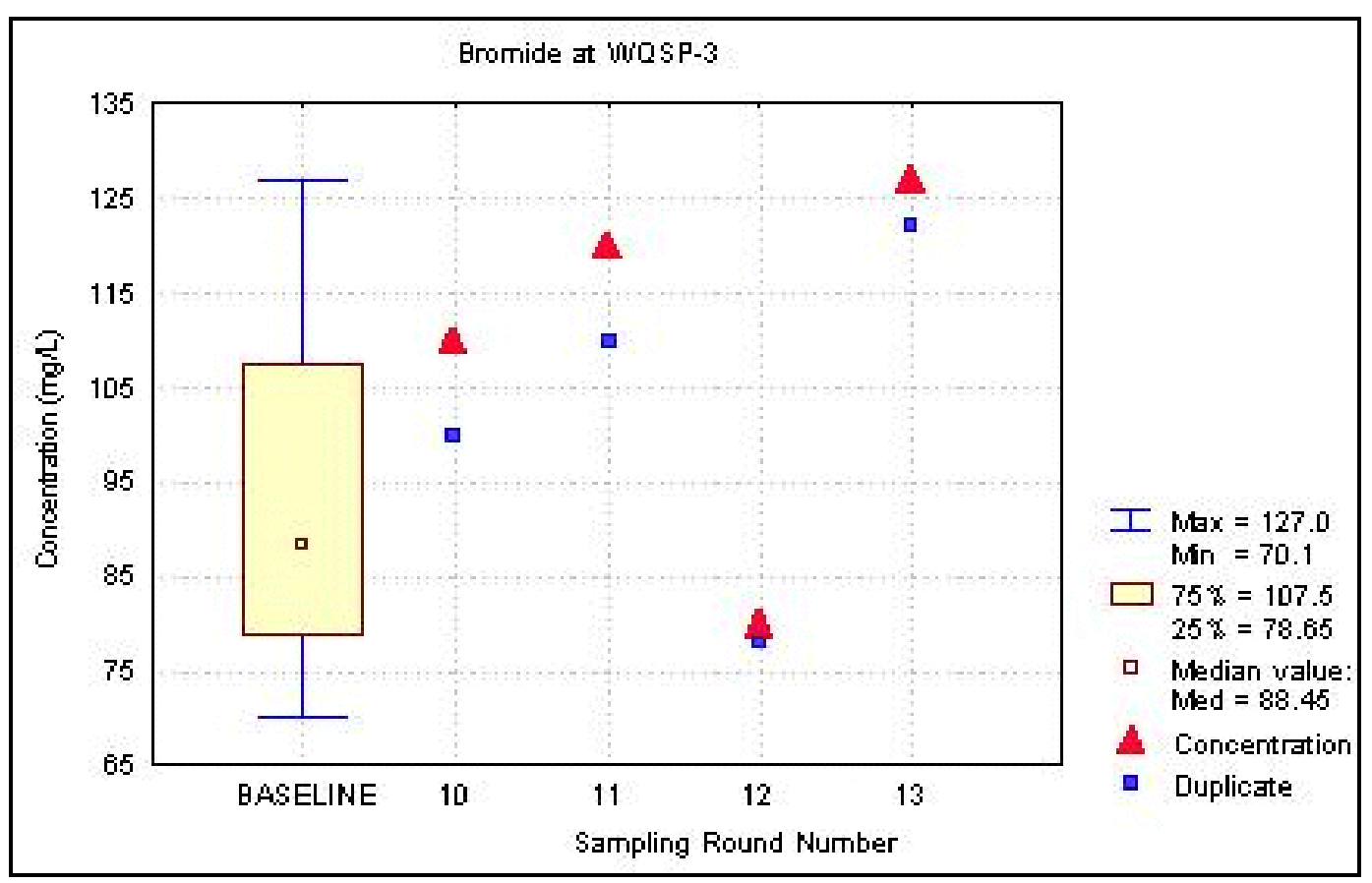

Figure F.39 - Time Trend Plot for Bromide at WQSP-3 


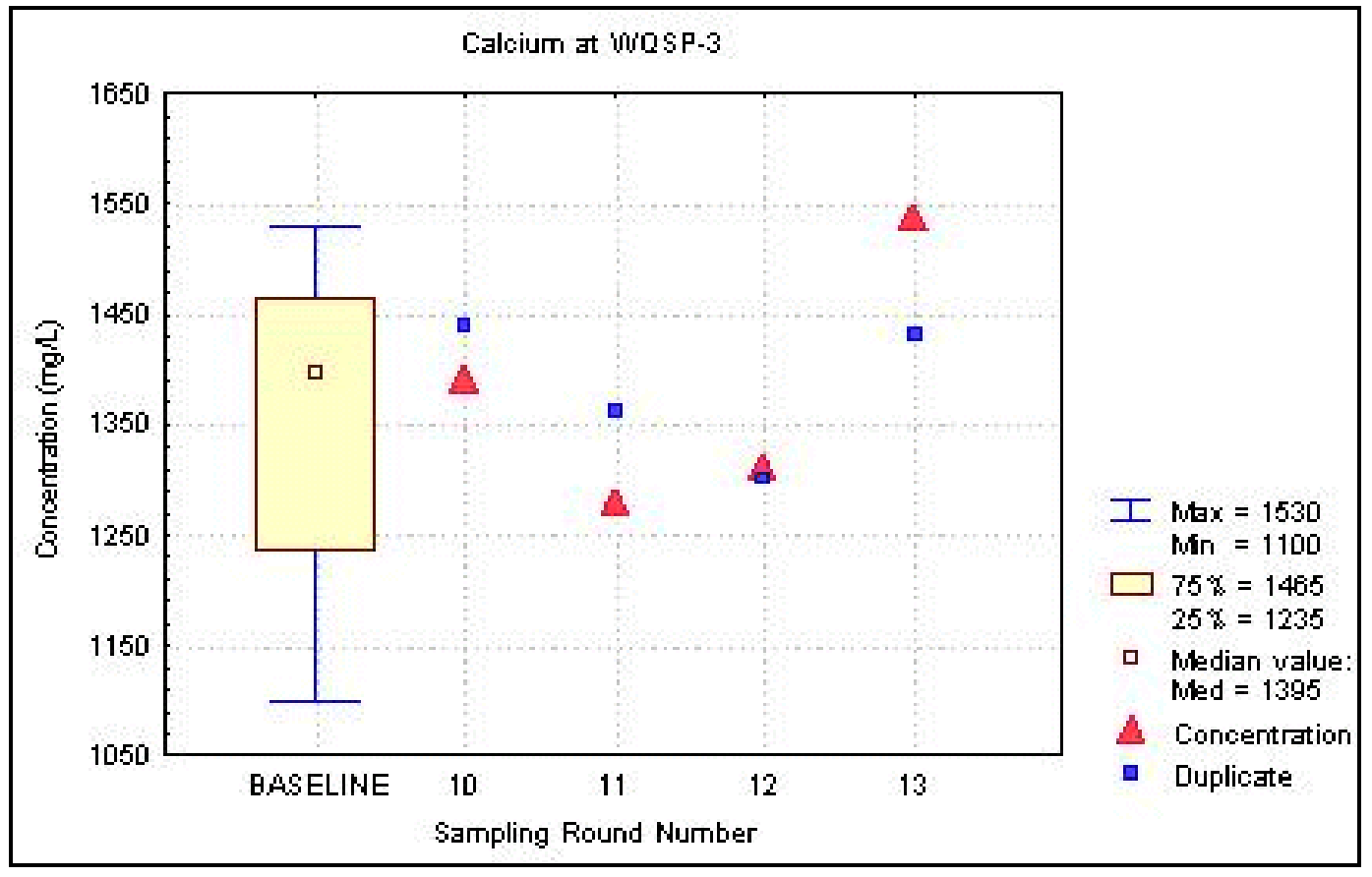

Figure F.40 - Time Trend Plot for Calcium at WQSP-3

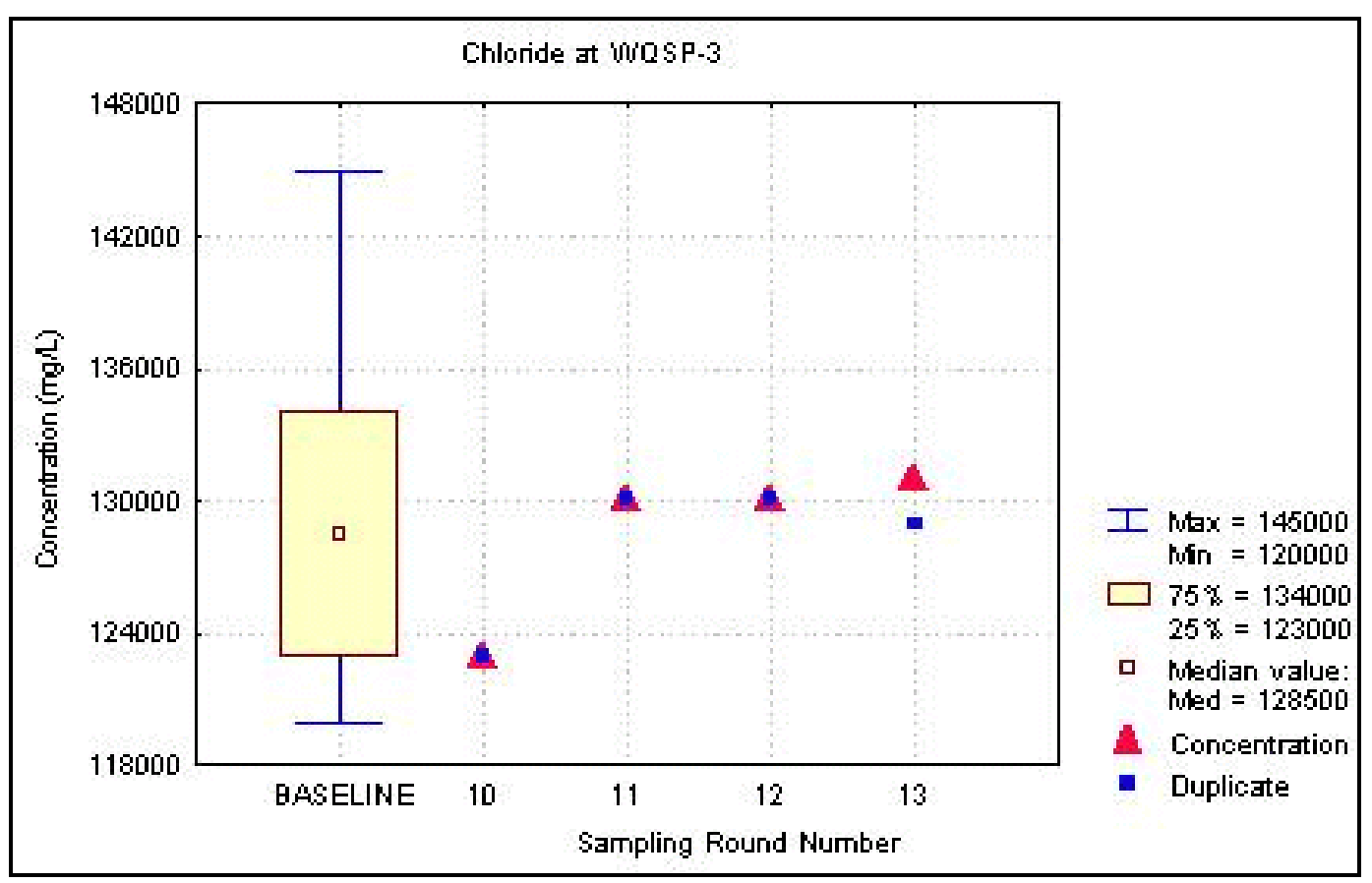

Figure F.41 - Time Trend Plot for Chloride at WQSP-3 


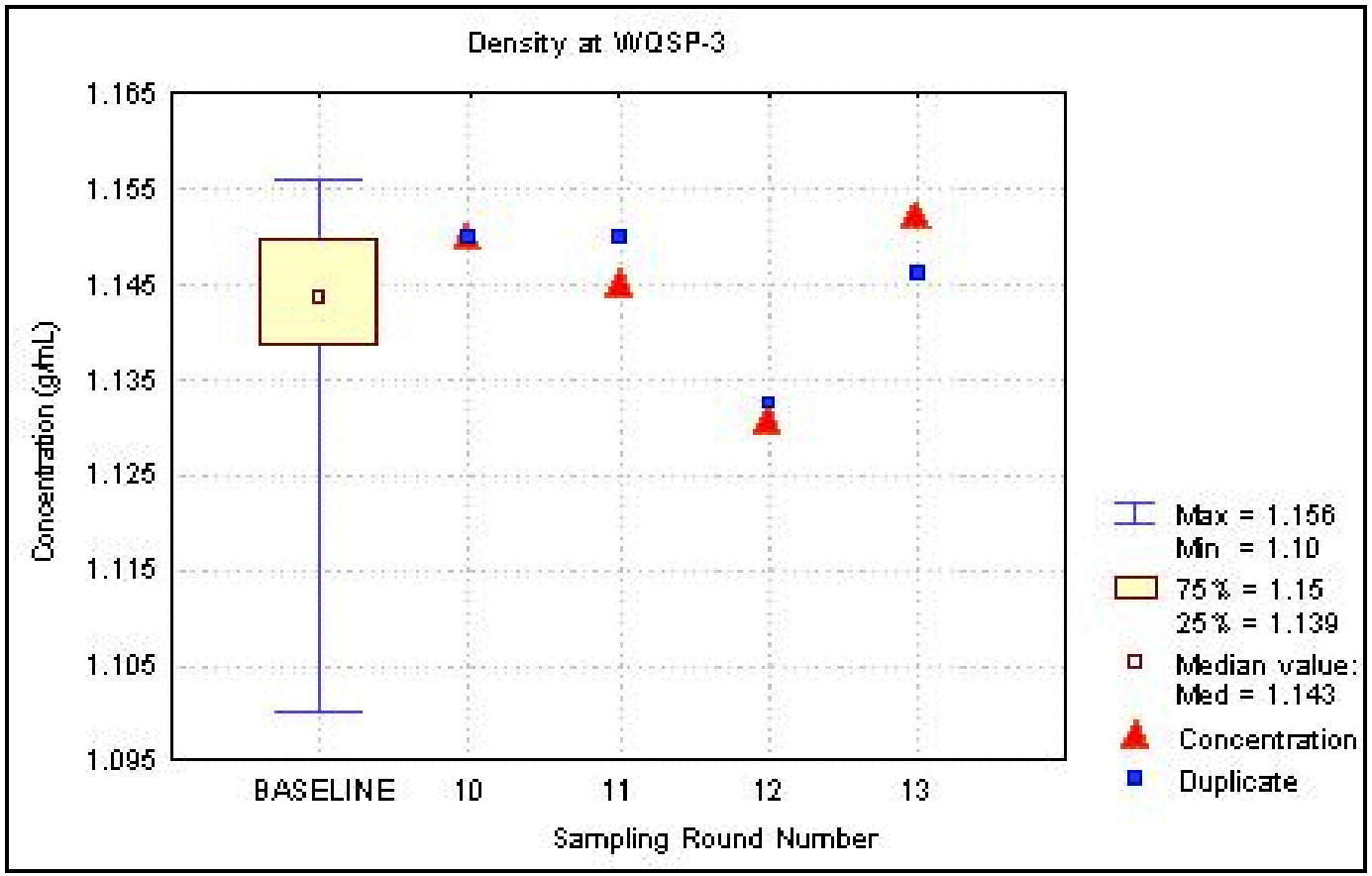

Figure F.42 - Time Trend Plot for Density at WQSP-3

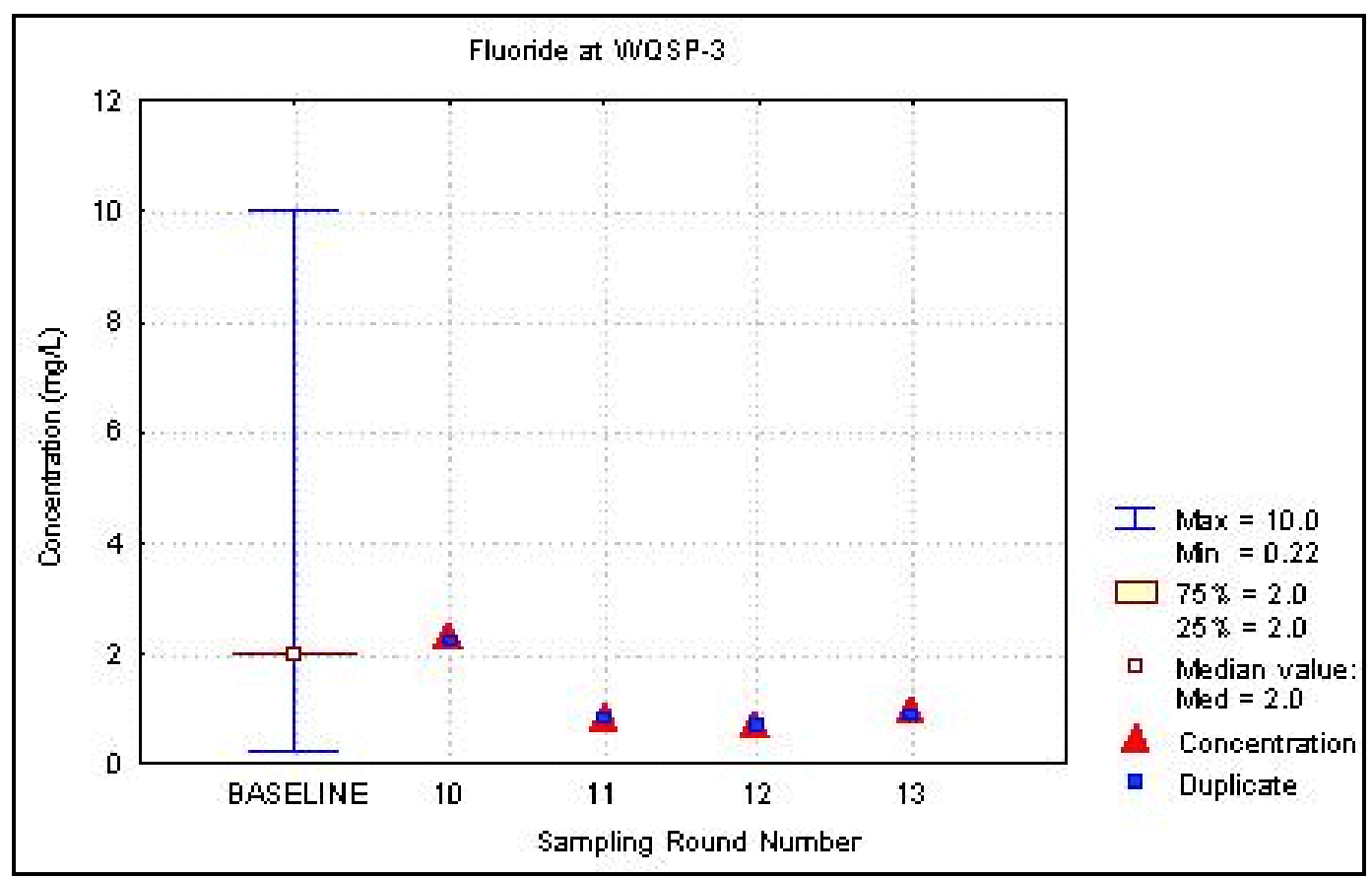

Figure F.43 - Time Trend Plot for Fluoride at WQSP-3 


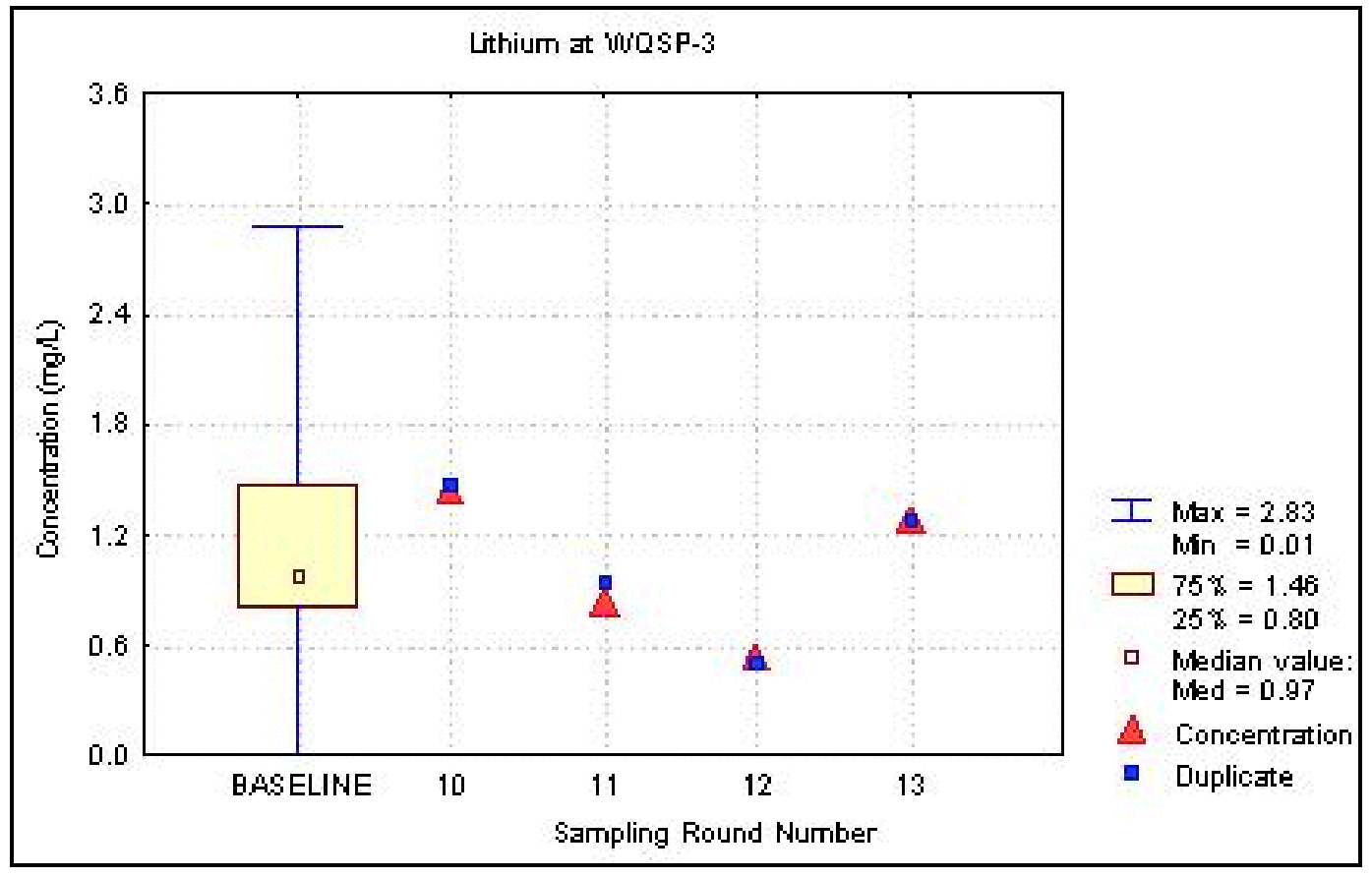

Figure F.44 - Time Trend Plot for Lithium at WQSP-3

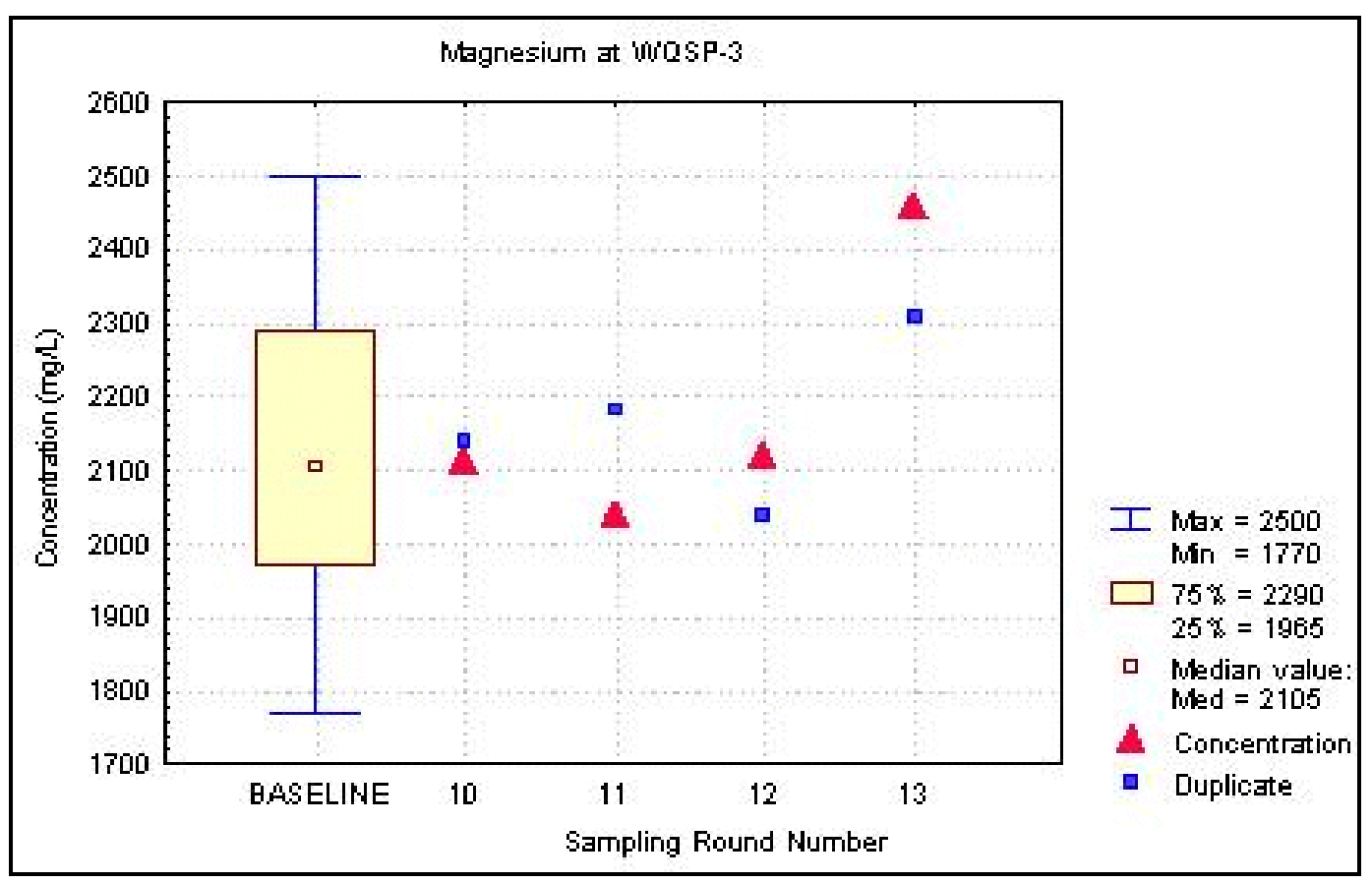

Figure F.45 - Time Trend Plot for Magnesium at WQSP-3 


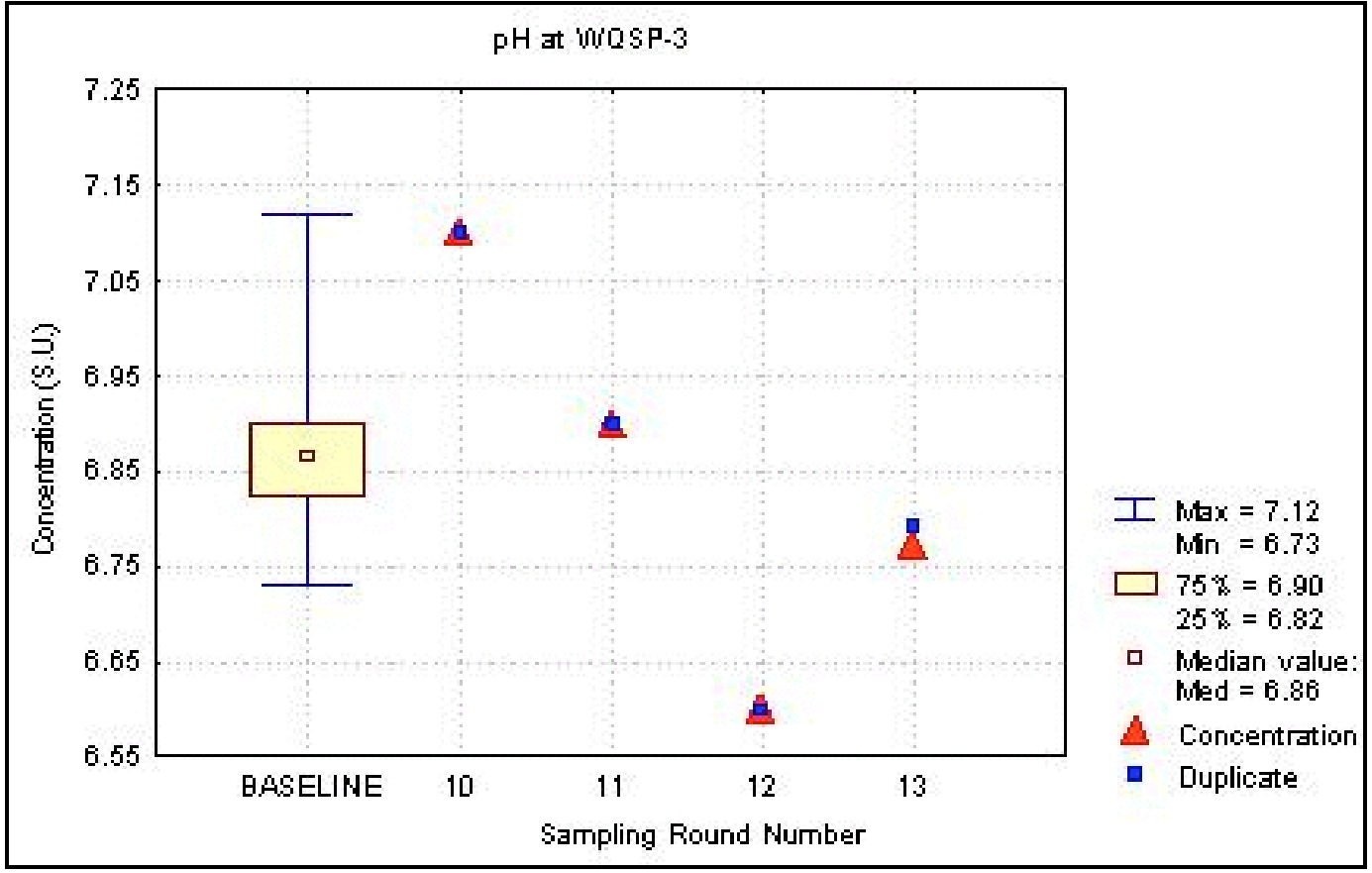

Figure F.46 - Time Trend Plot for $\mathrm{pH}$ at WQSP-3

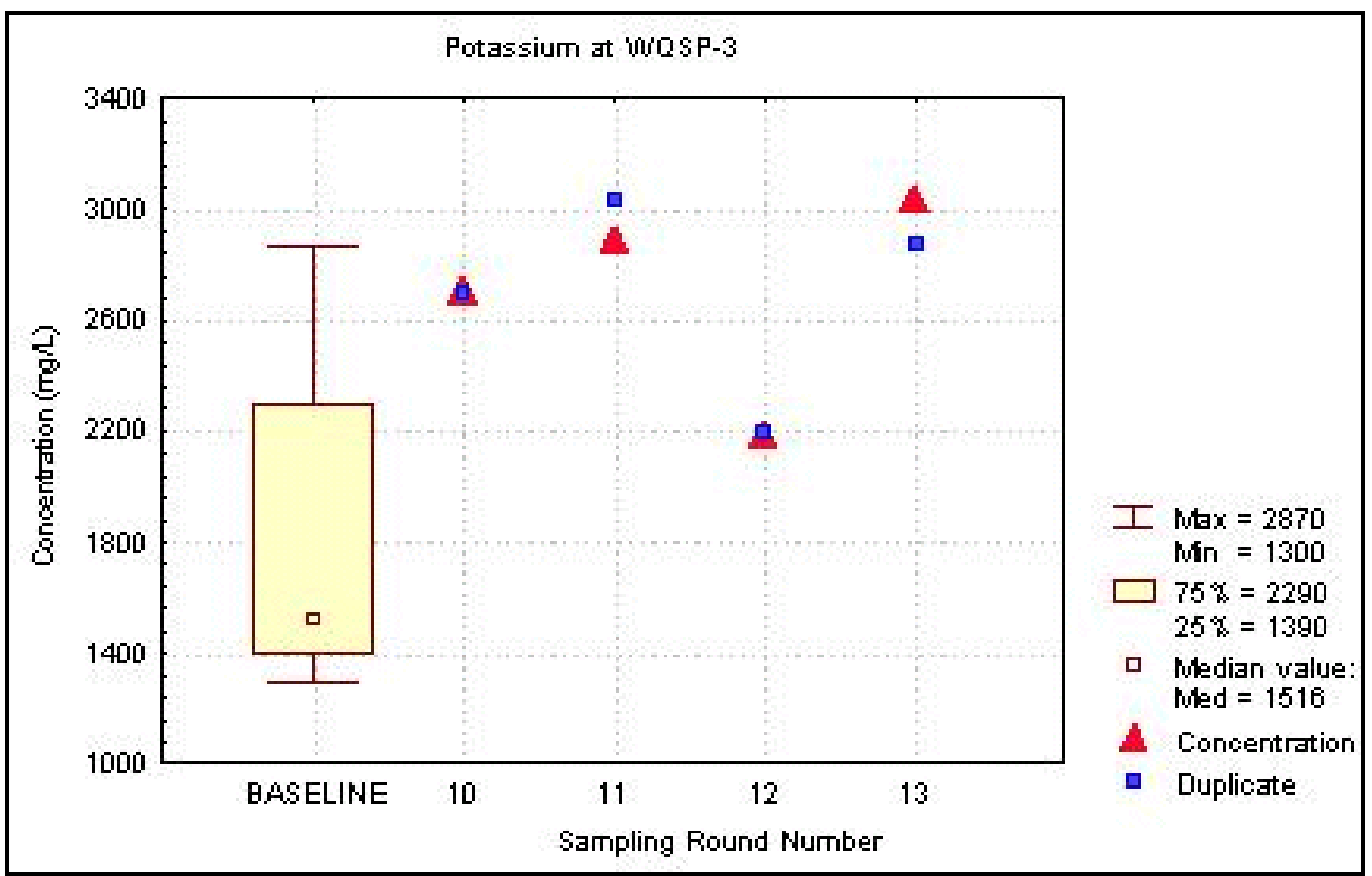

Figure F.47 - Time Trend Plot for Potassium at WQSP-3 


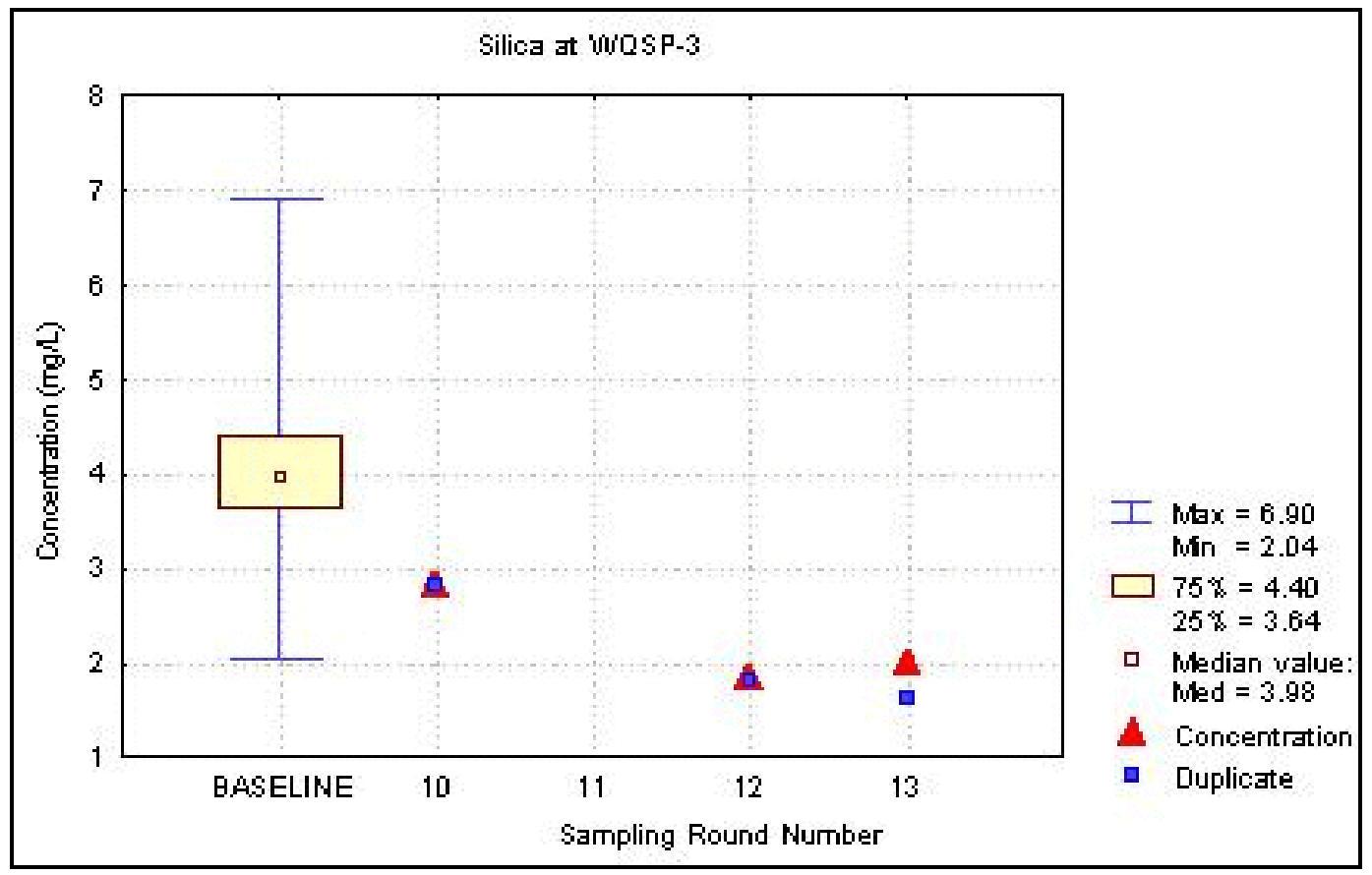

Figure F.48 - Time Trend Plot for Silica at WQSP-3

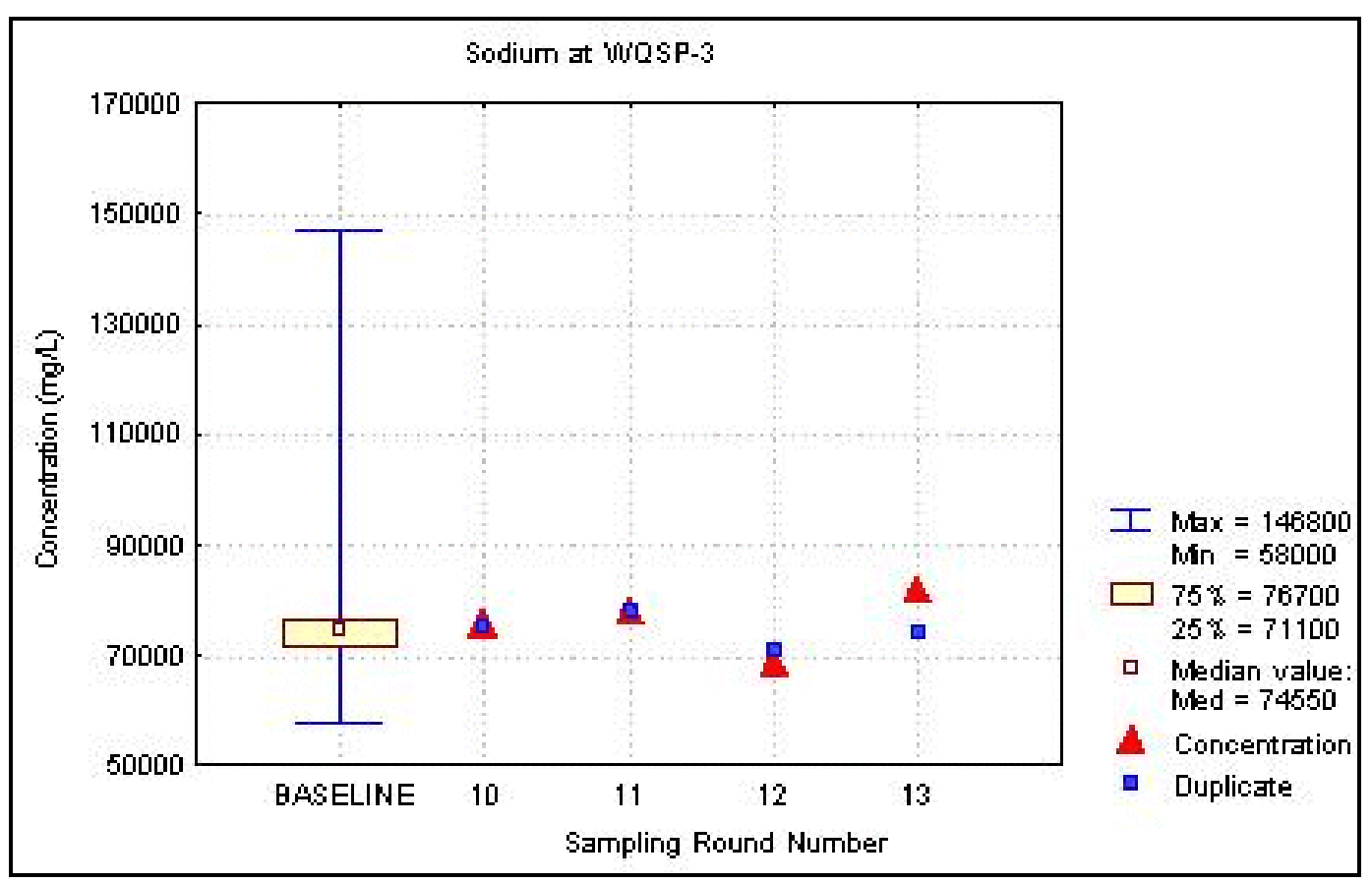

Figure F.49 - Time Trend Plot for Sodium at WQSP-3 


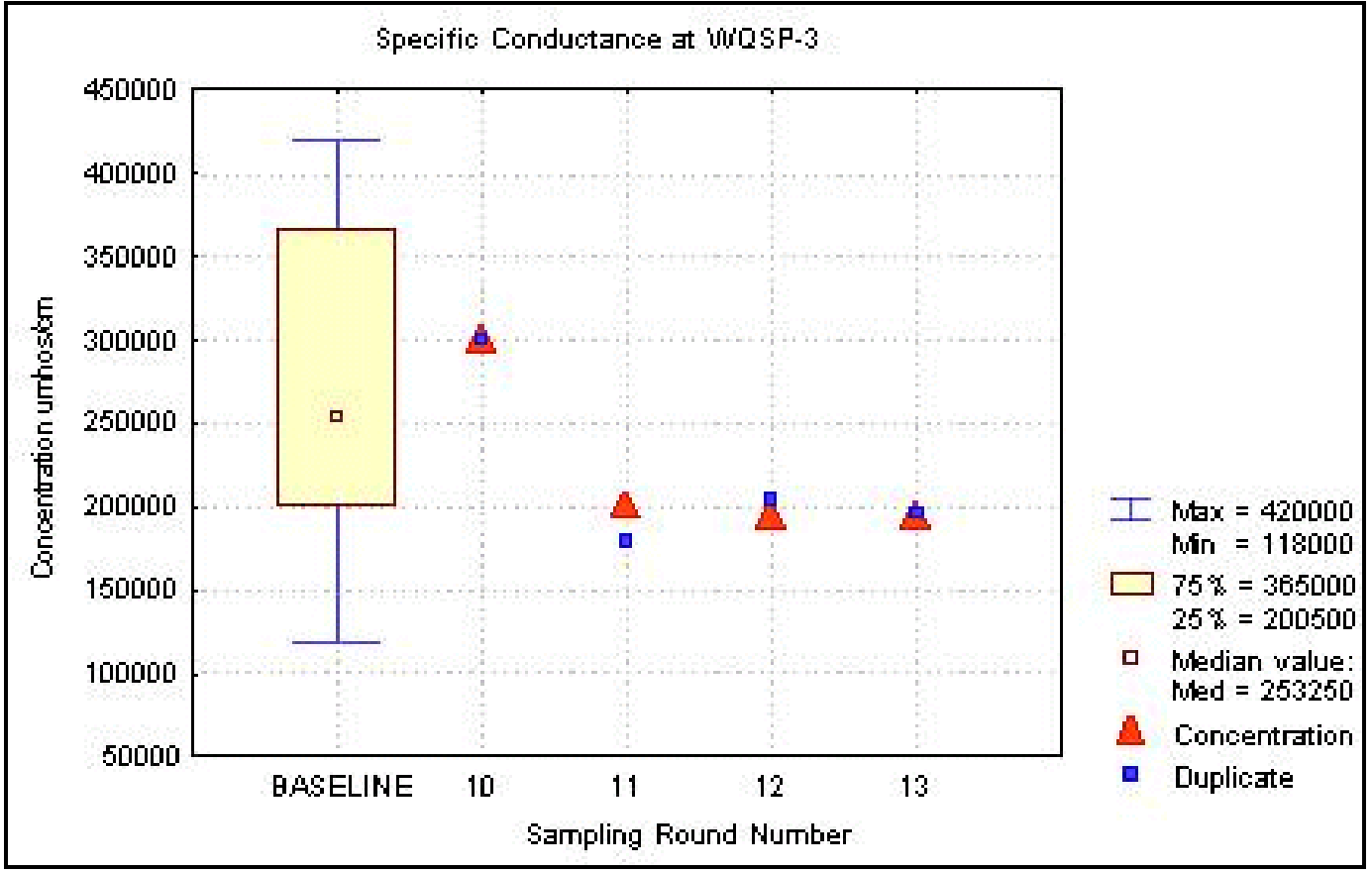

Figure F.50 - Time Trend Plot for Specific Conductance at WQSP-3

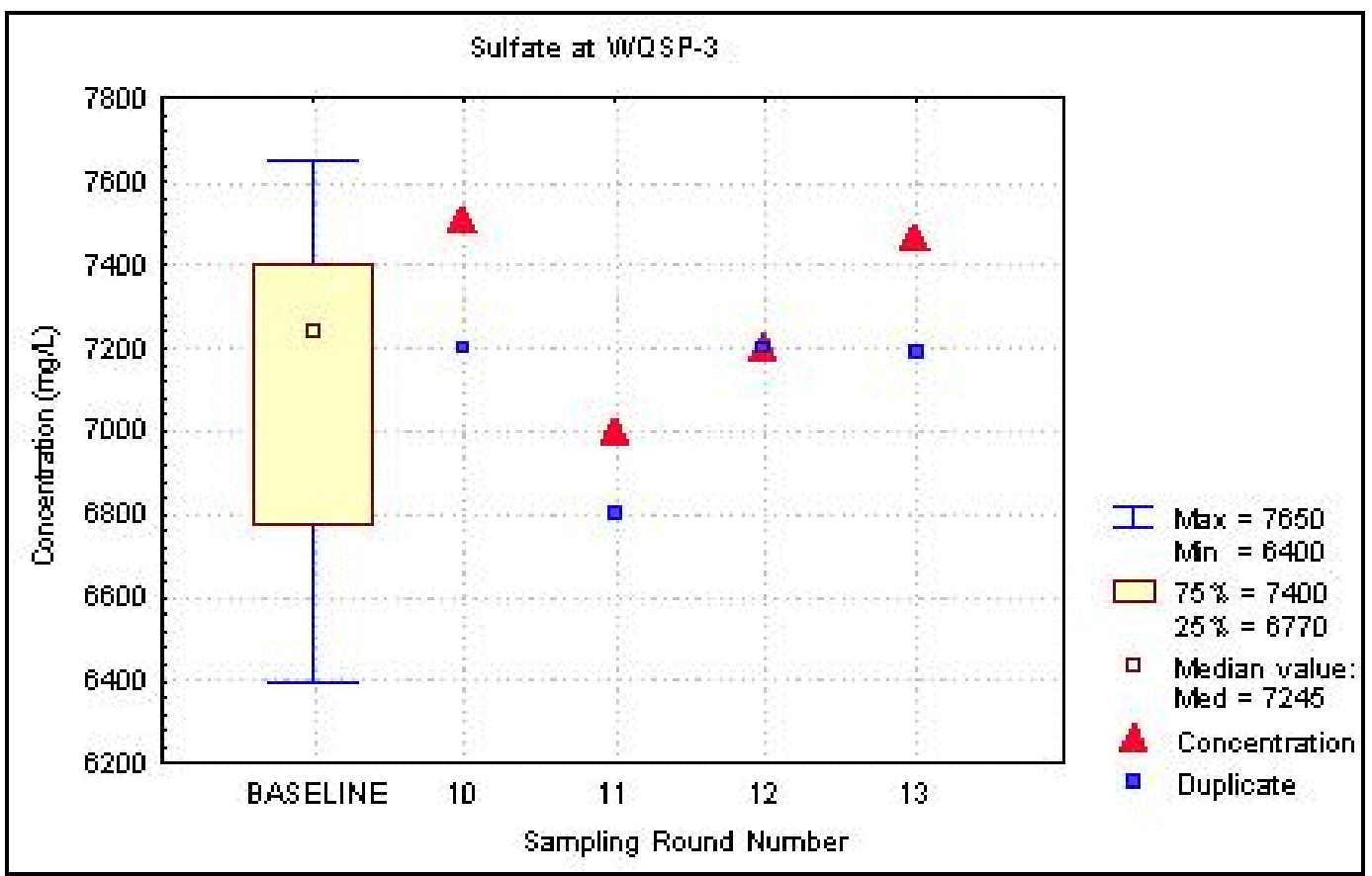

Figure F.51 - Time Trend Plot for Sulfate at WQSP-3 


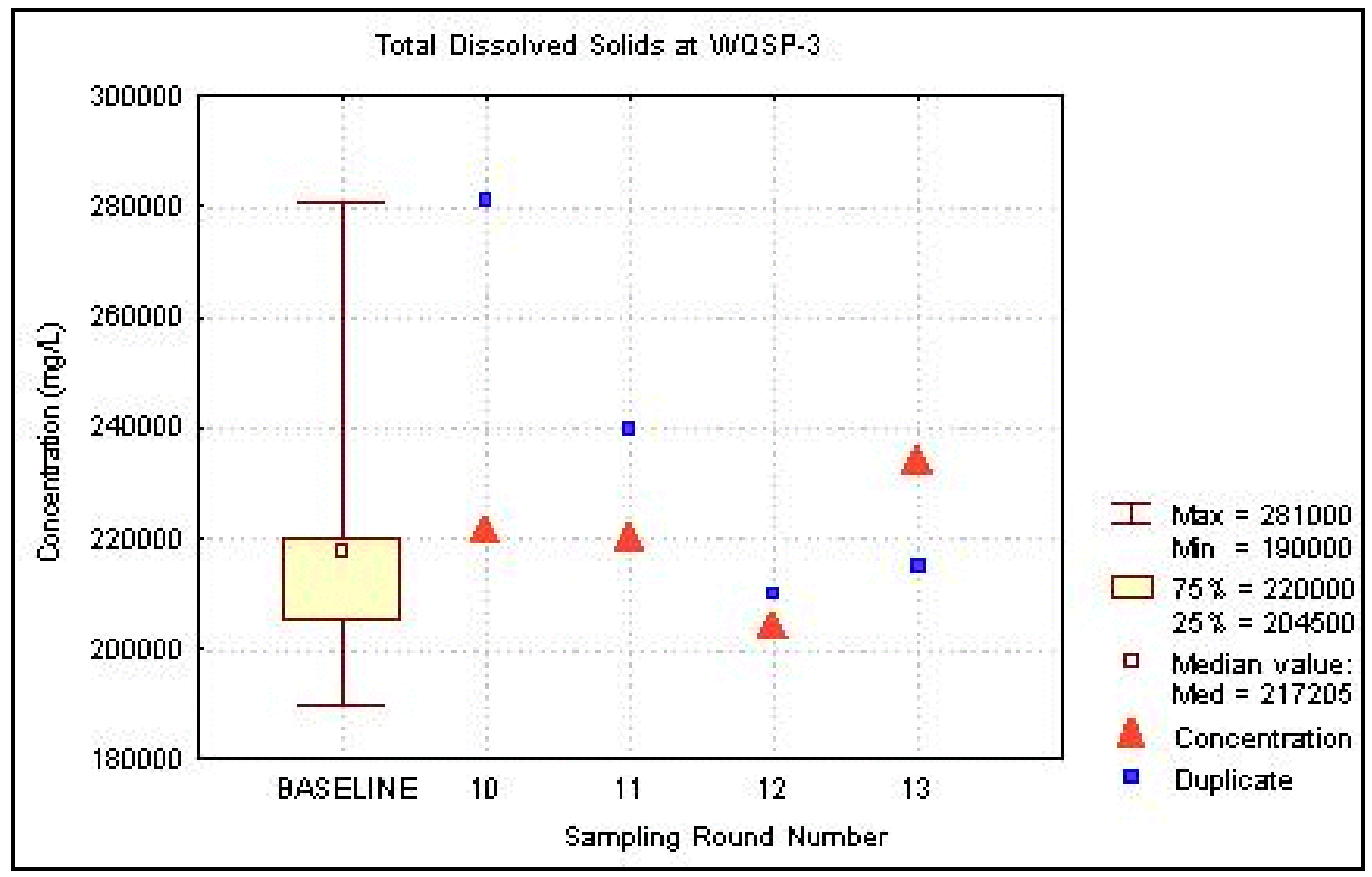

Figure F.52 - Time Trend Plot for Total Dissolved Solids at WQSP-3

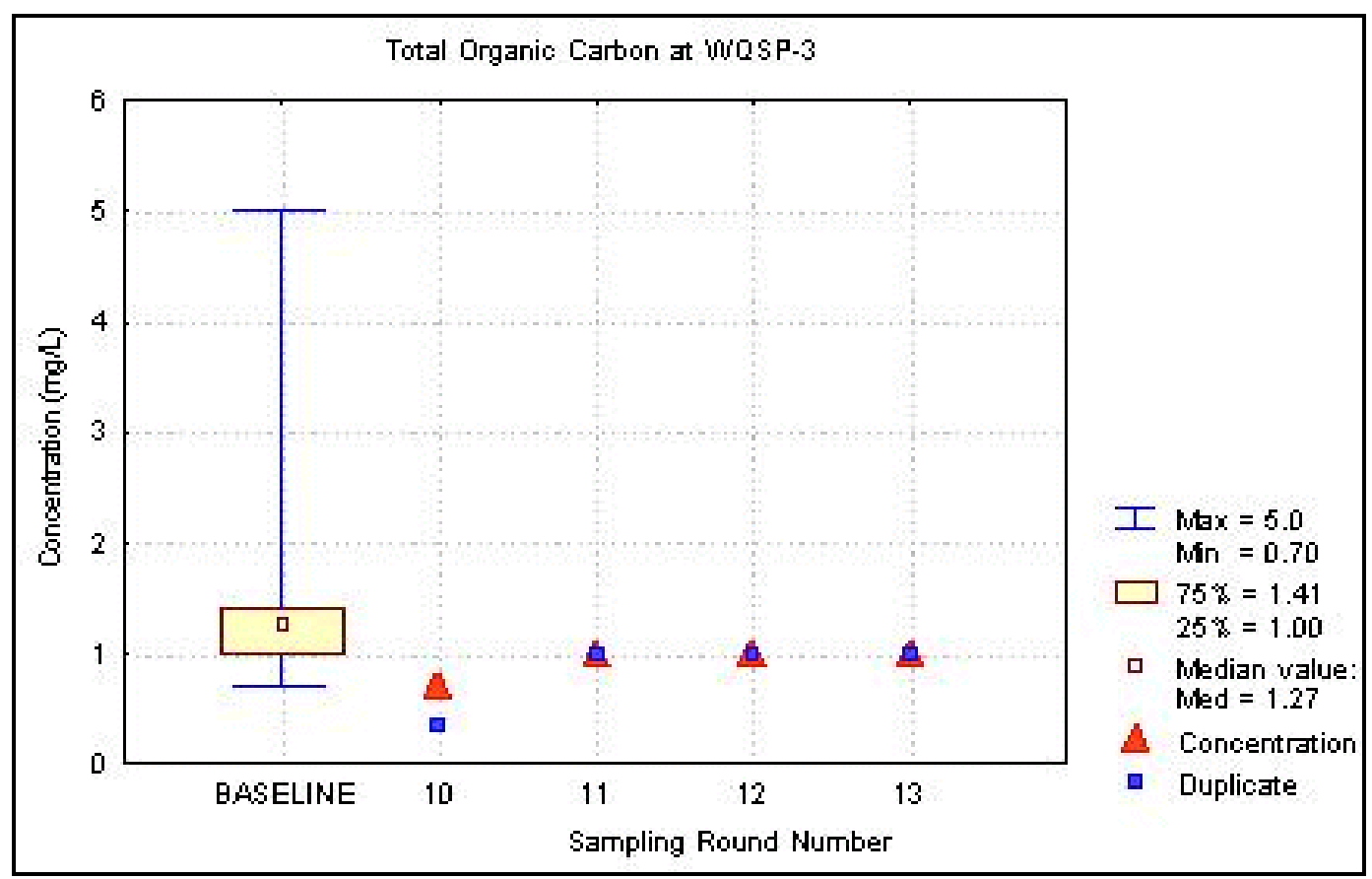

Figure F.53 - Time Trend Plot for Total Organic Carbon at WQSP-3 


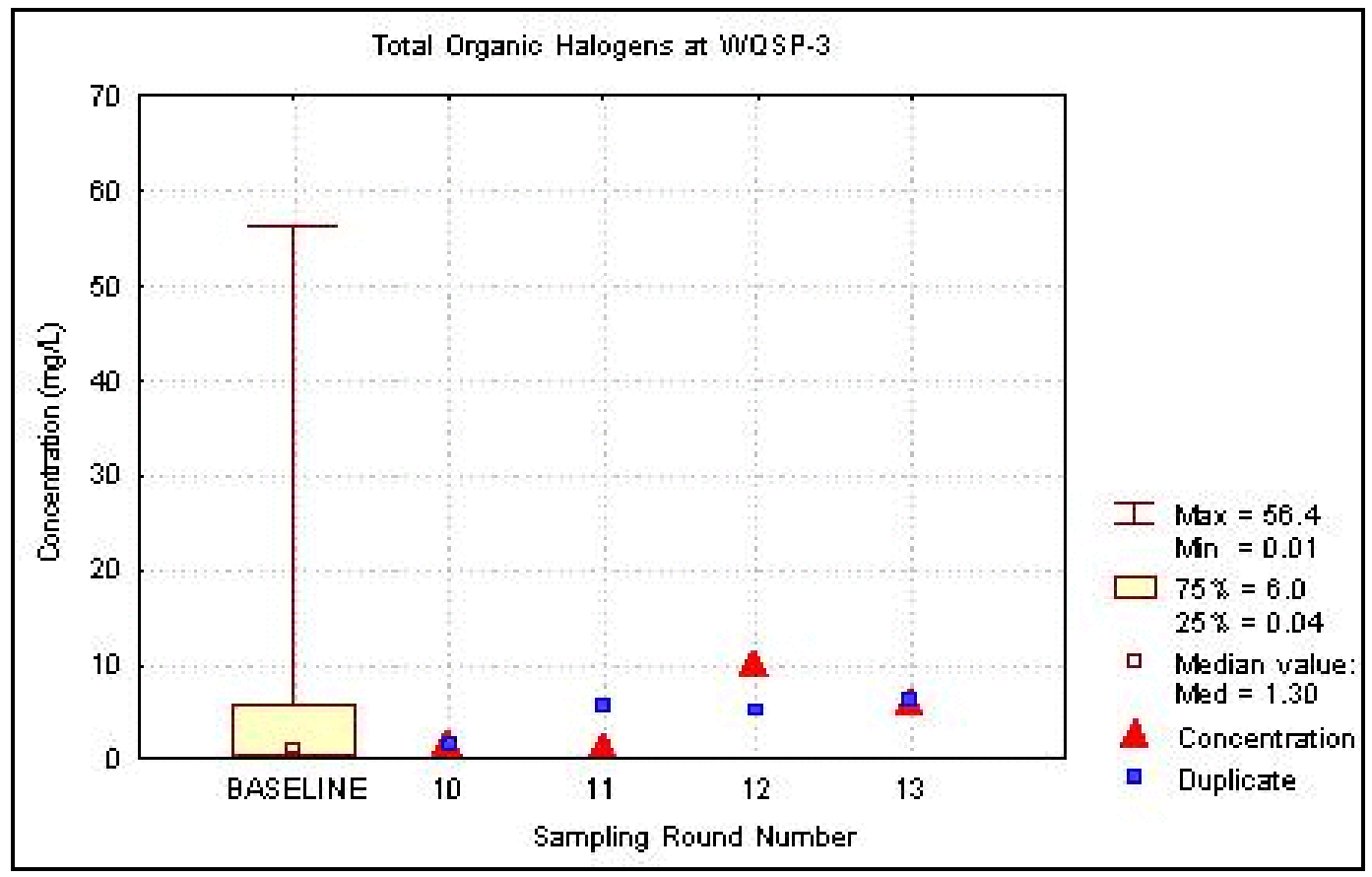

Figure F.54 - Time Trend Plot for Total Organic Halogens at WQSP-3

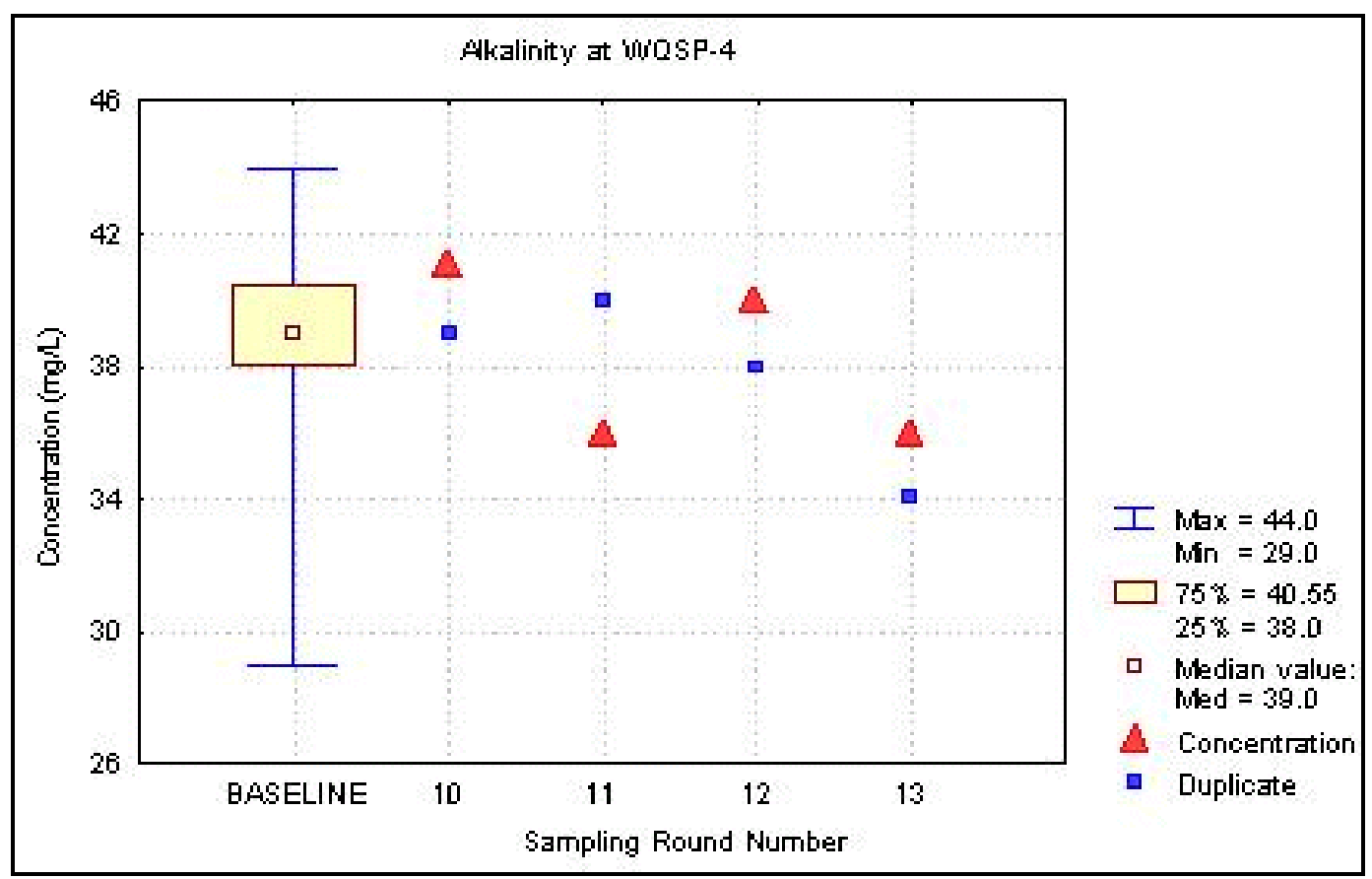

Figure F.55 - Time Trend Plot for Alkalinity at WQSP-4 


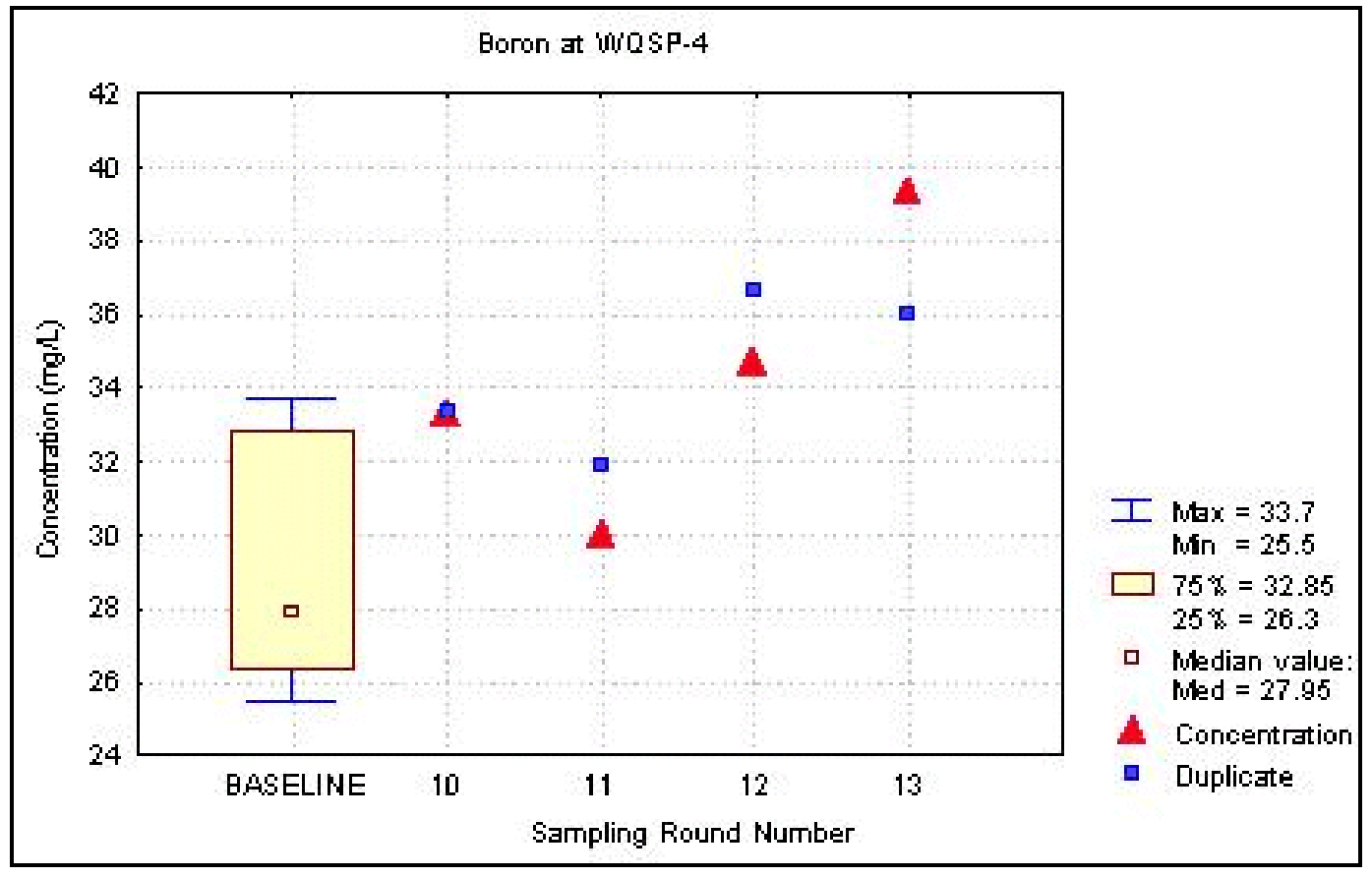

Figure F.56 - Time Trend Plot for Boron at WQSP-4

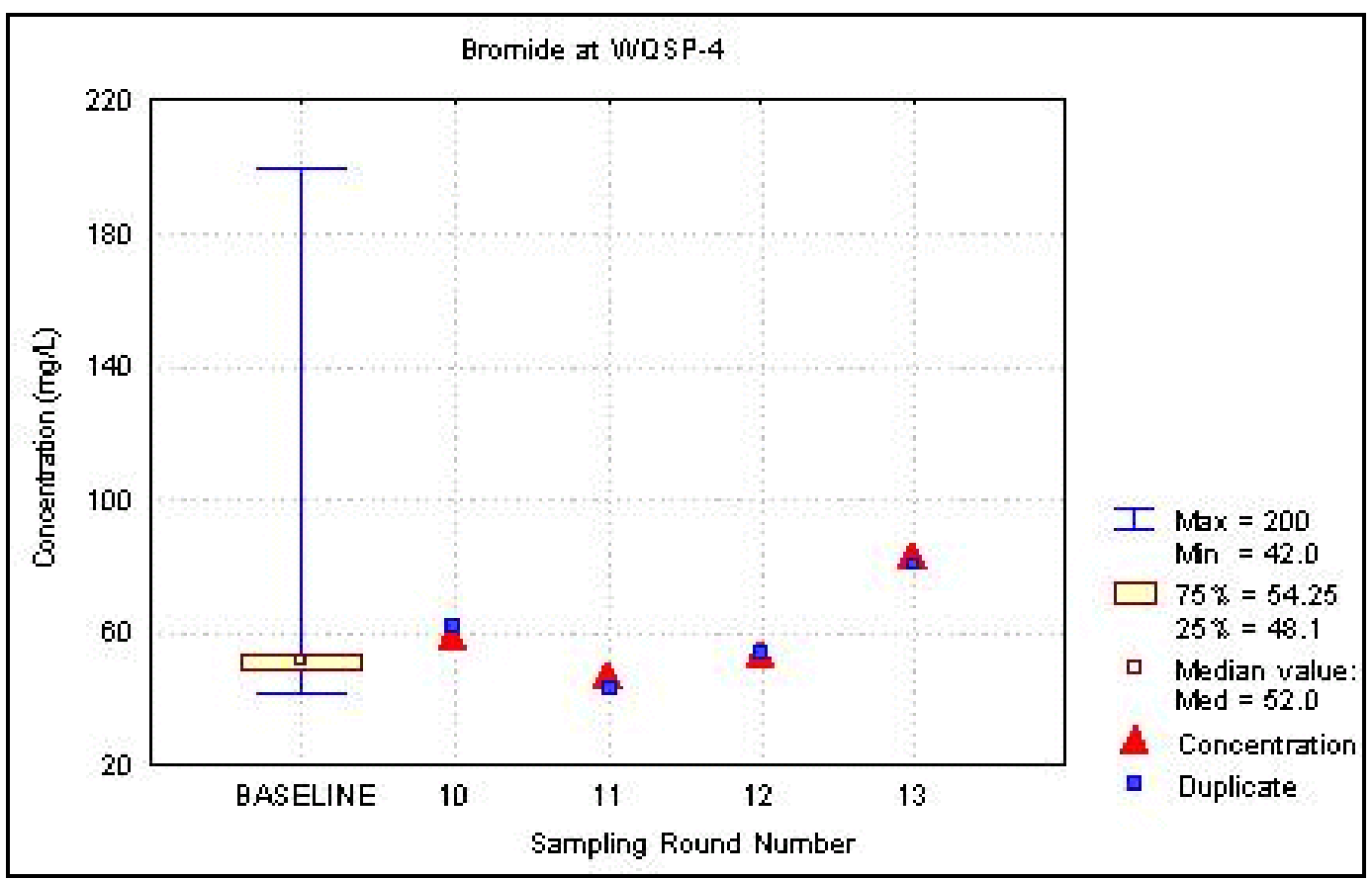

Figure F.57 - Time Trend Plot for Bromide at WQSP-4 


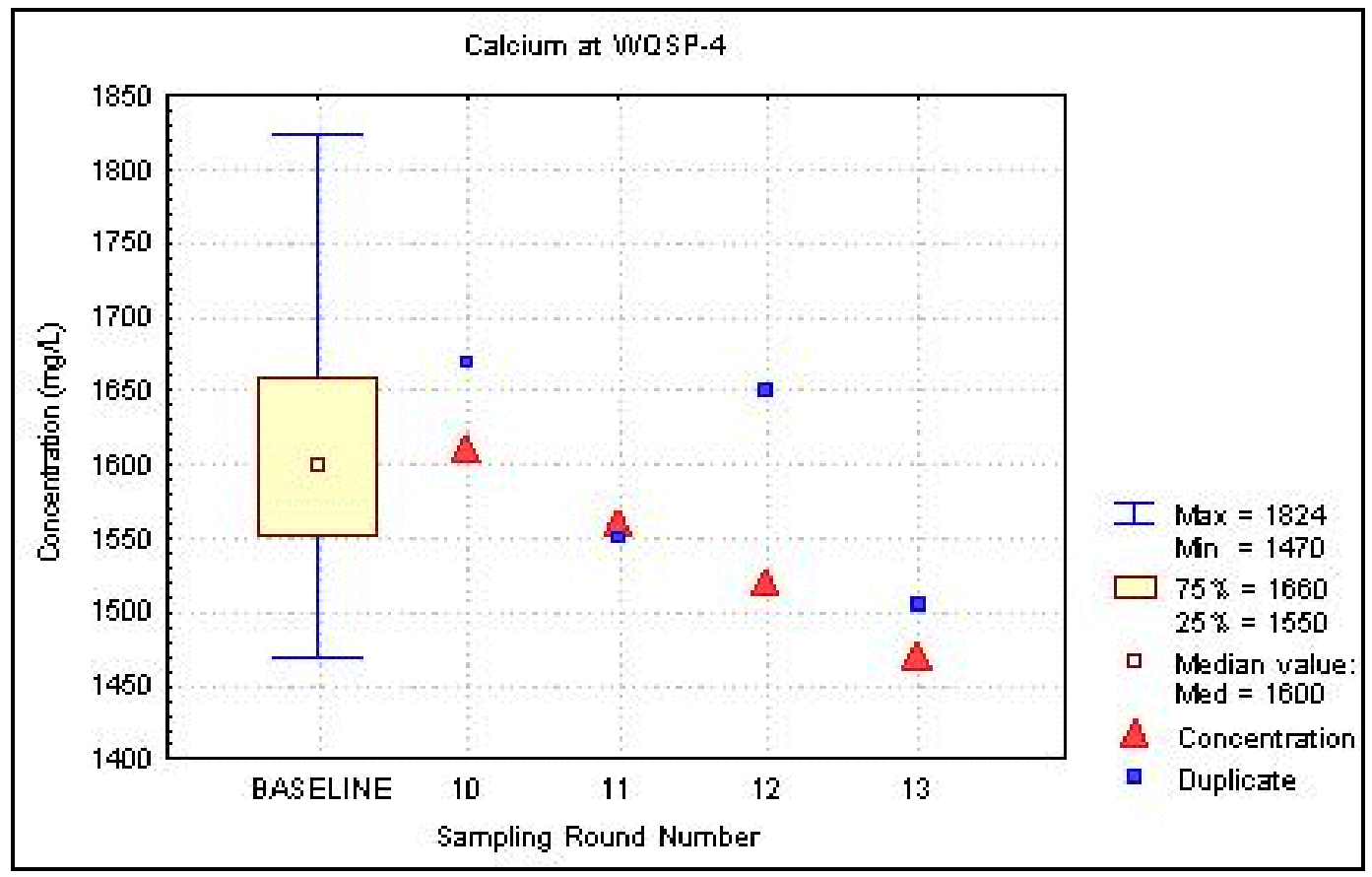

Figure F.58 - Time Trend Plot for Calcium at WQSP-4

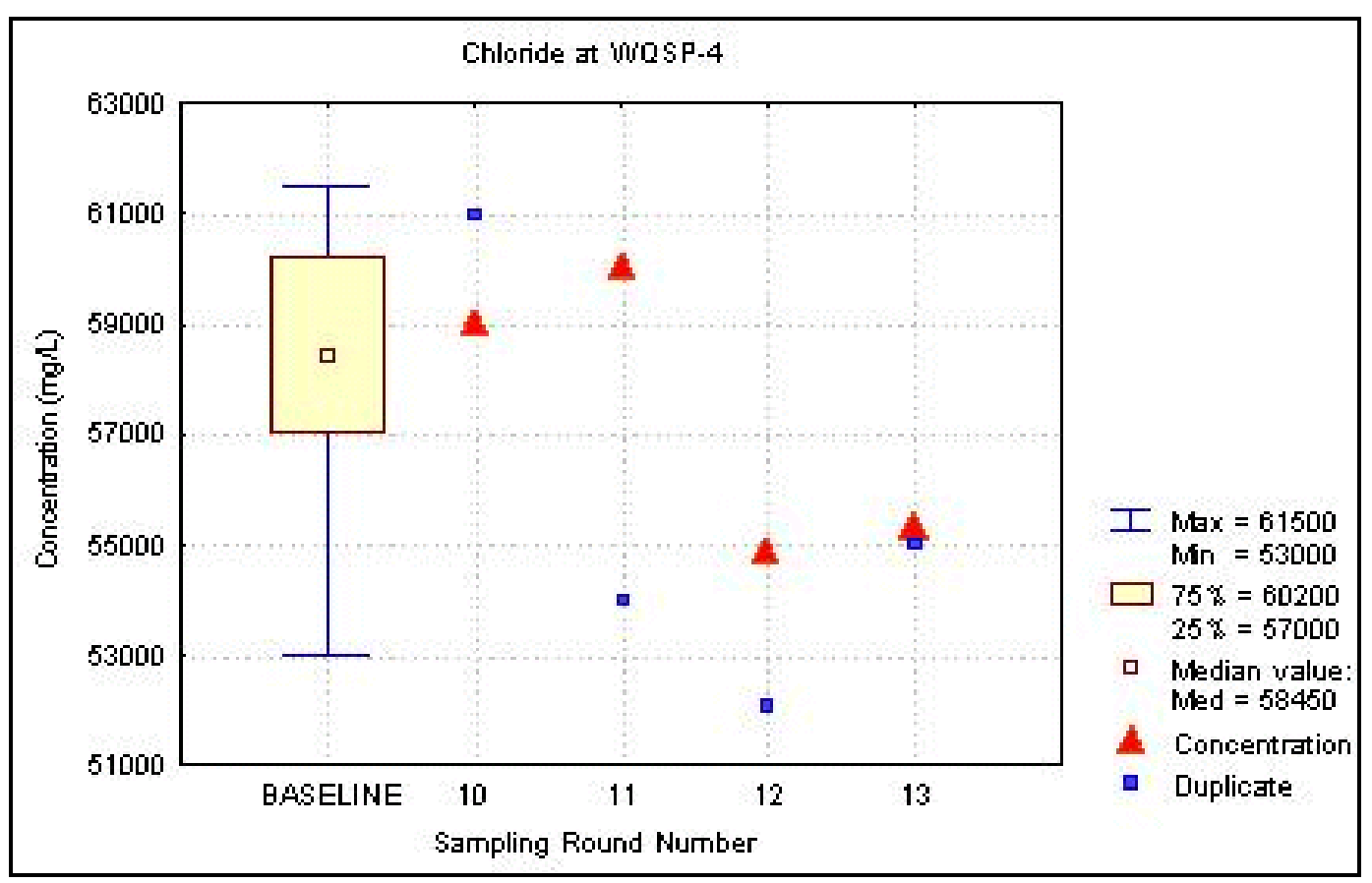

Figure F.59 - Time Trend Plot for Chloride at WQSP-4 


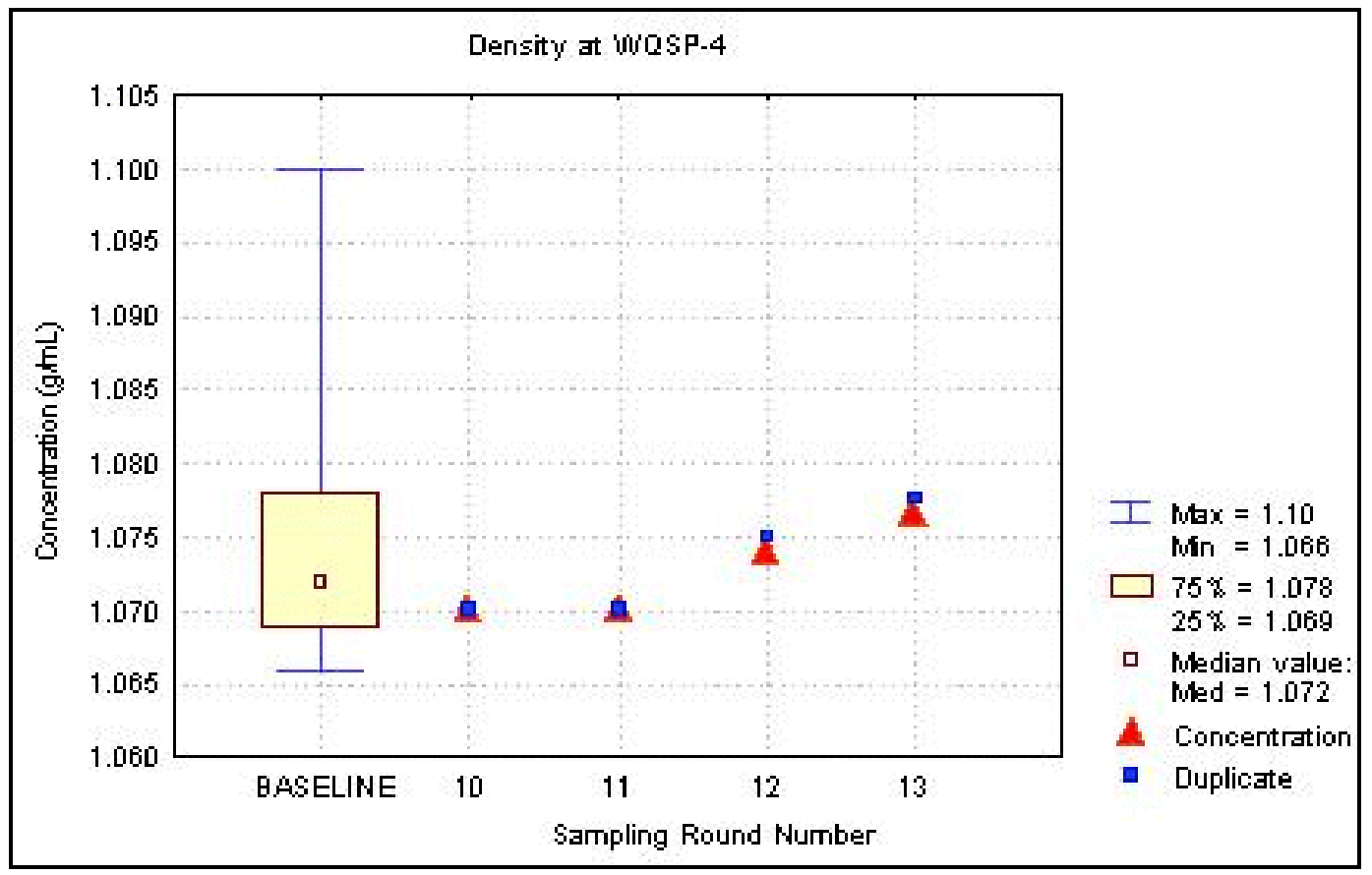

Figure F.60 - Time Trend Plot for Density at WQSP-4

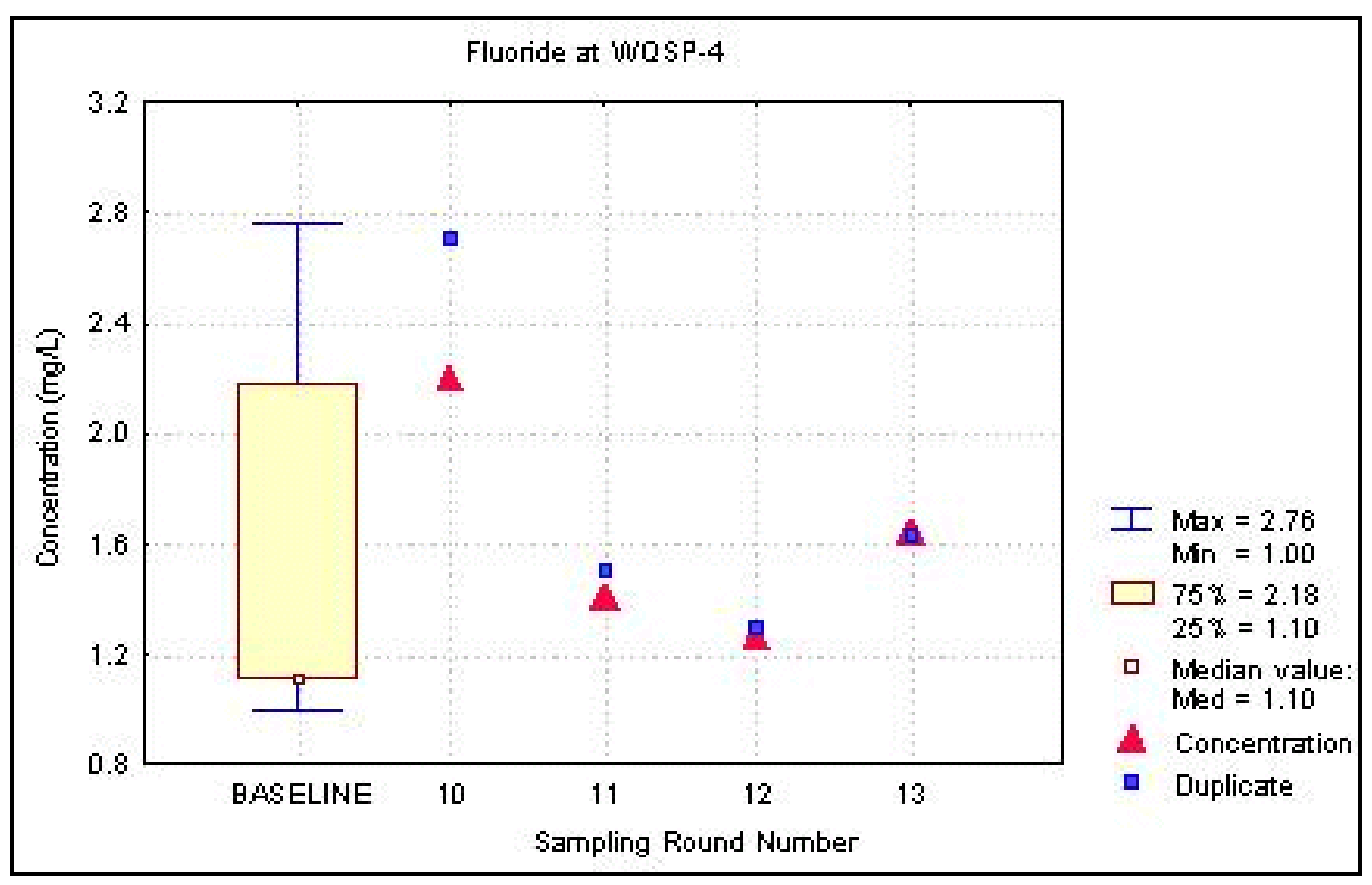

Figure F.61 - Time Trend Plot for Fluoride at WQSP-4 


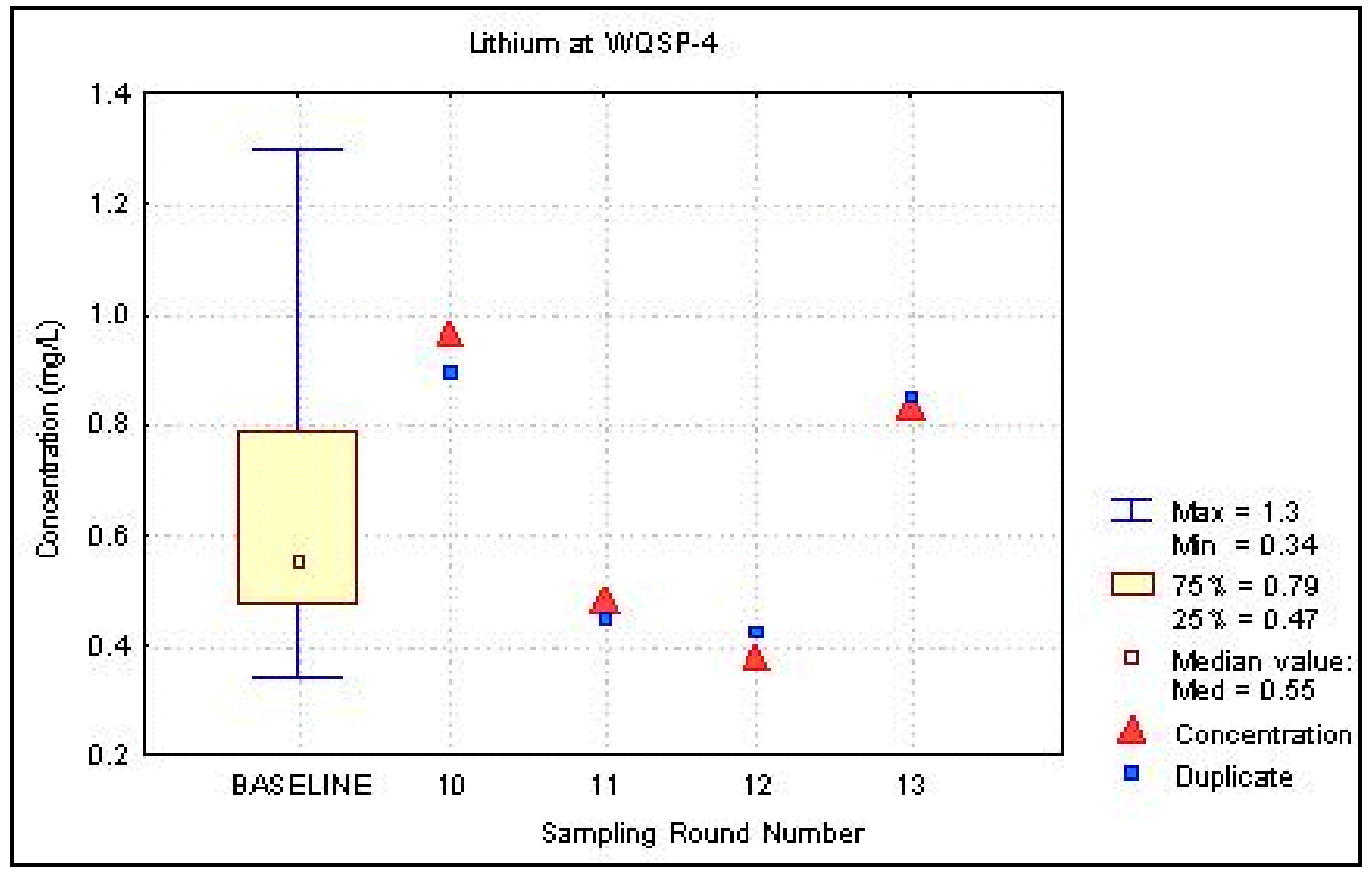

Figure F.62 - Time Trend Plot for Lithium at WQSP-4

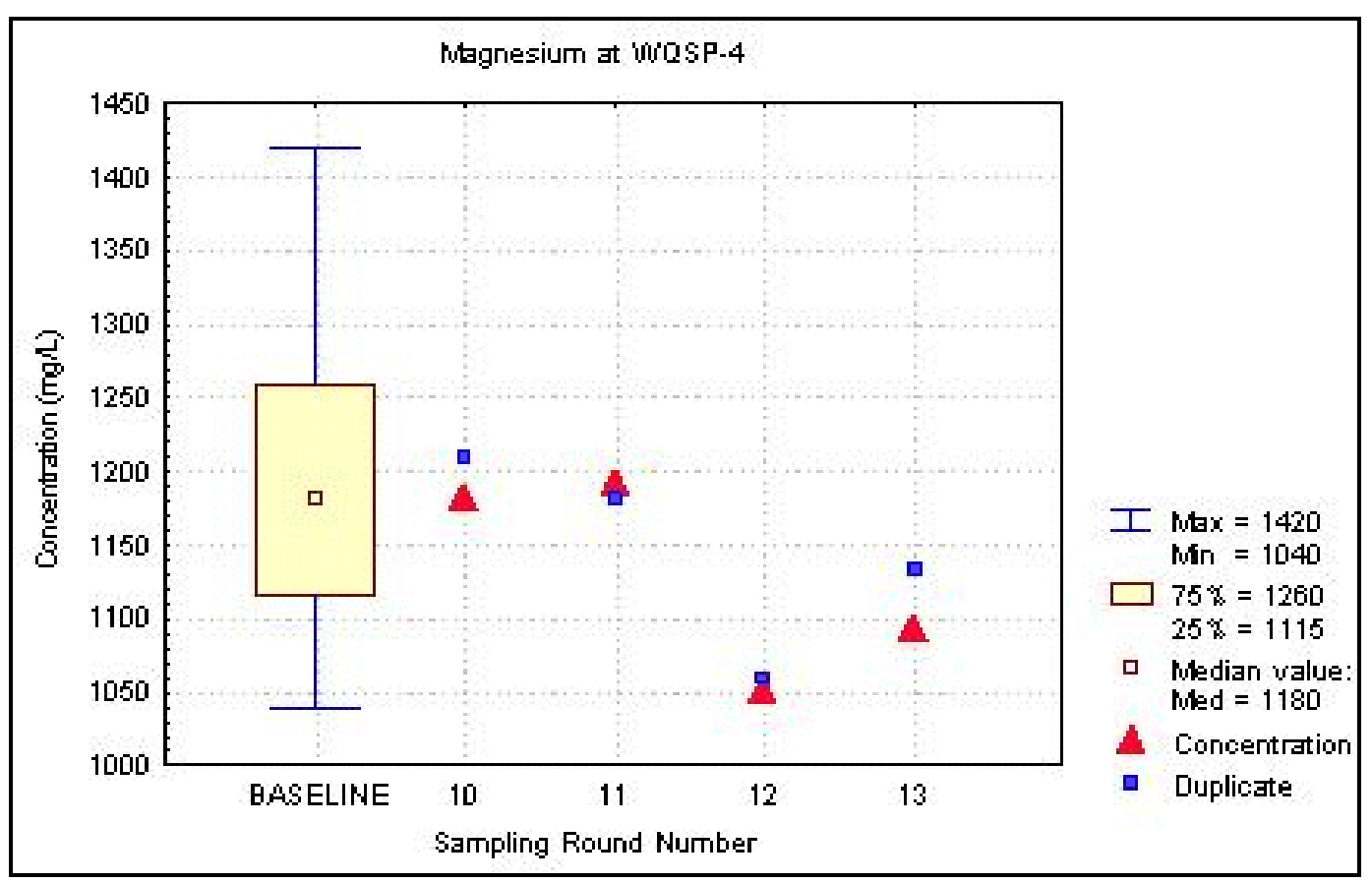

Figure F.63 - Time Trend Plot for Magnesium at WQSP-4 


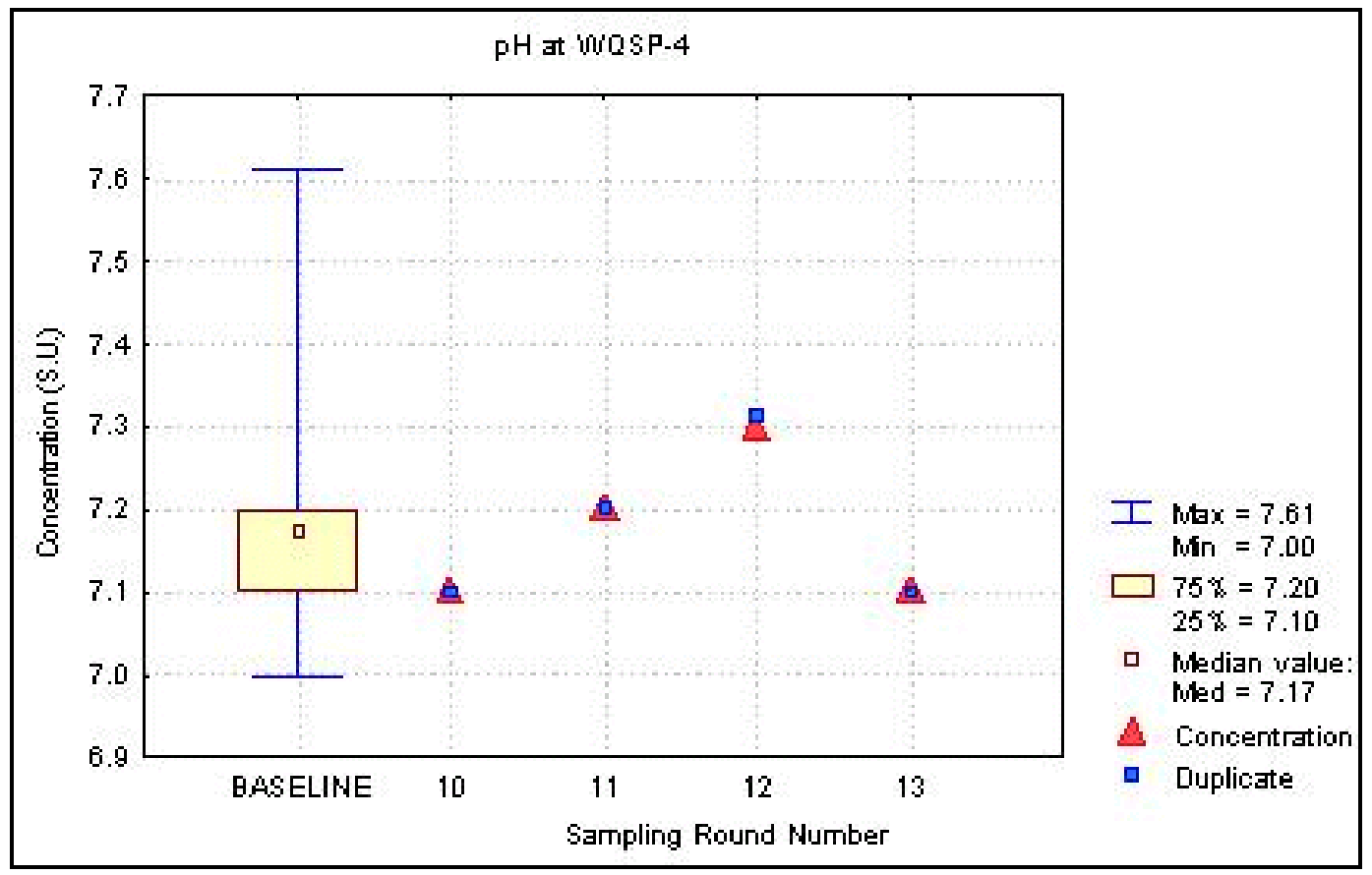

Figure F.64 - Time Trend Plot for $\mathrm{pH}$ at WQSP-4

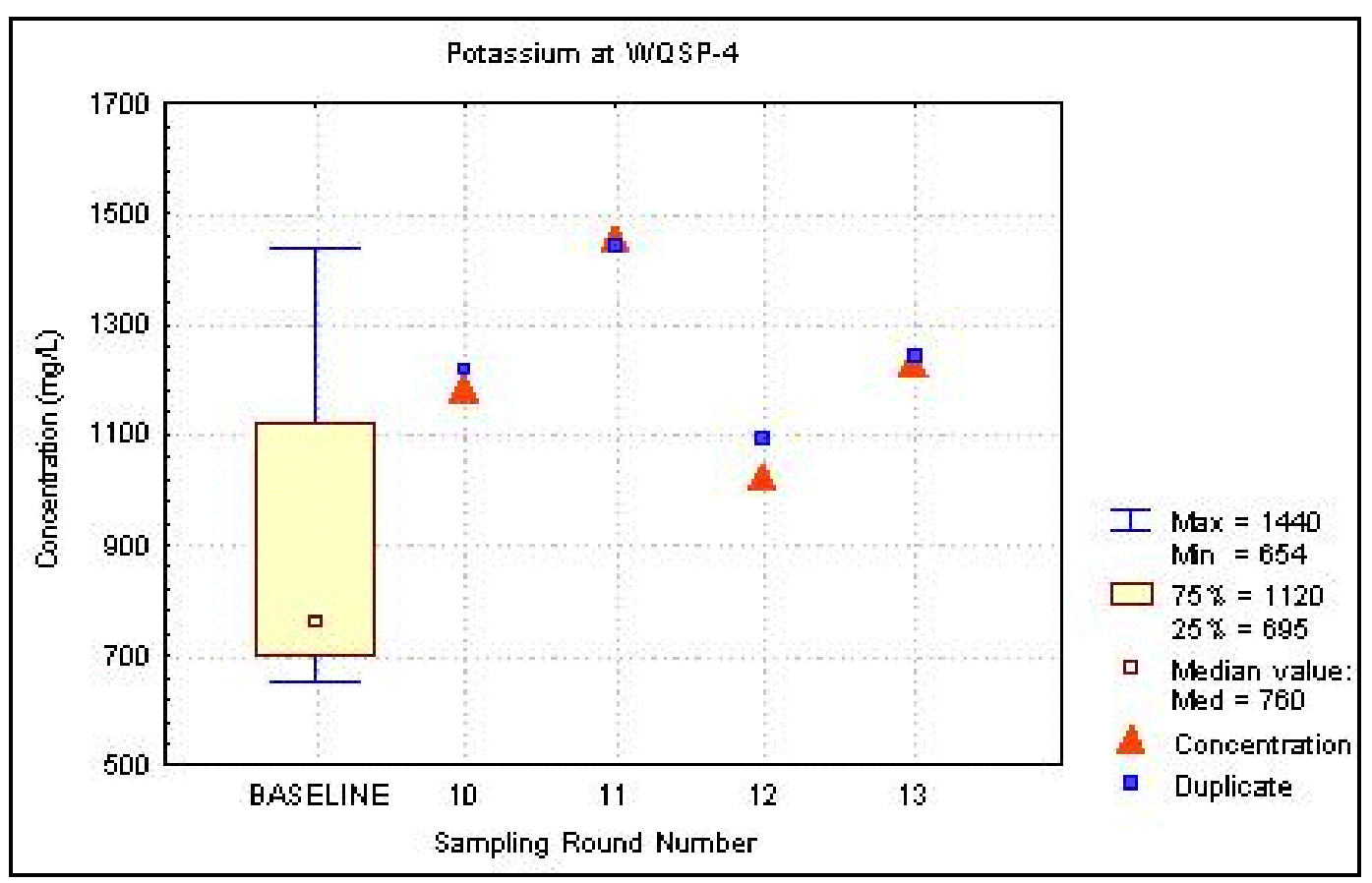

Figure F.65 - Time Trend Plot for Potassium at WQSP-4 


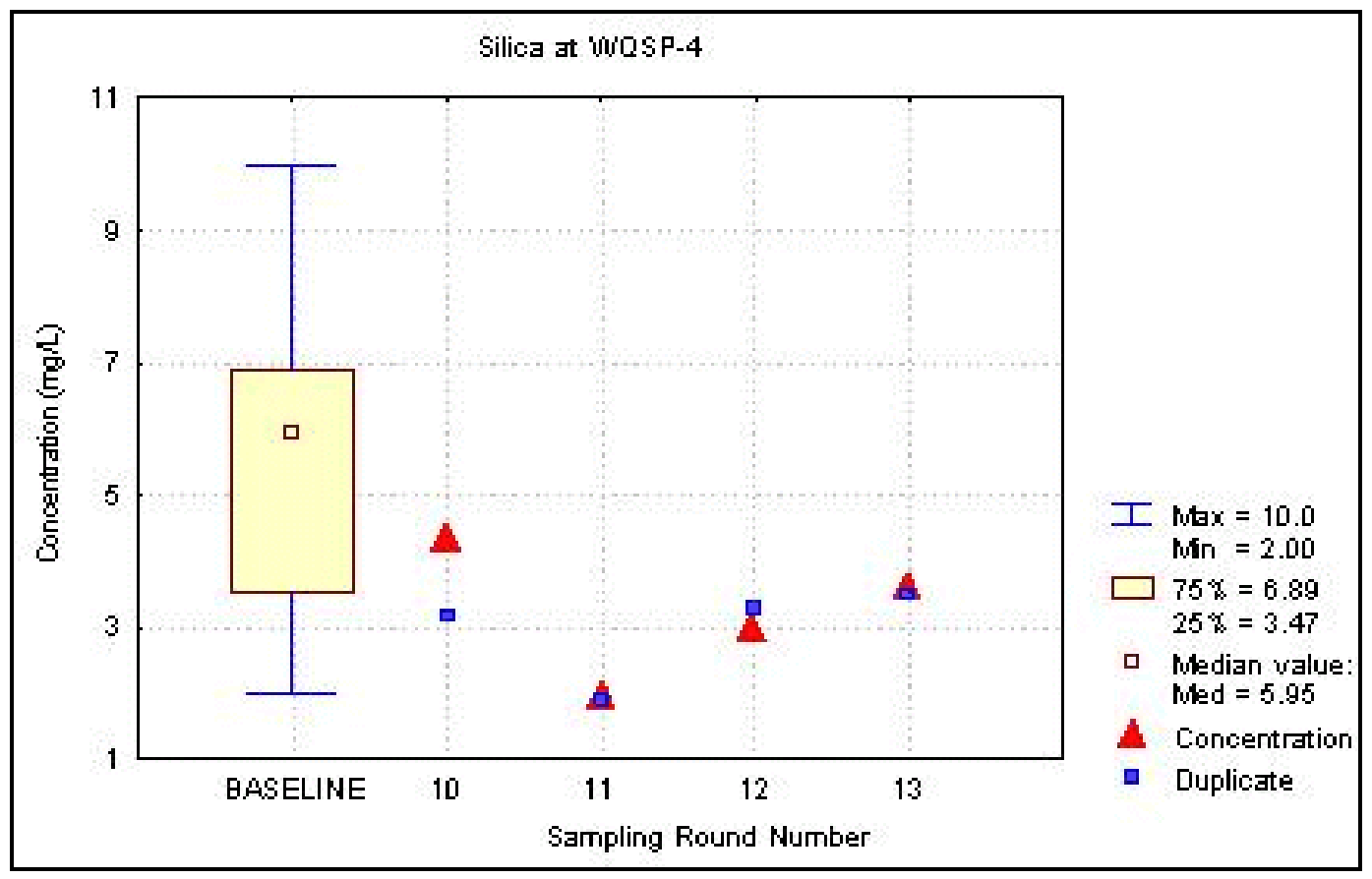

Figure F.66 - Time Trend Plot for Silica at WQSP-4

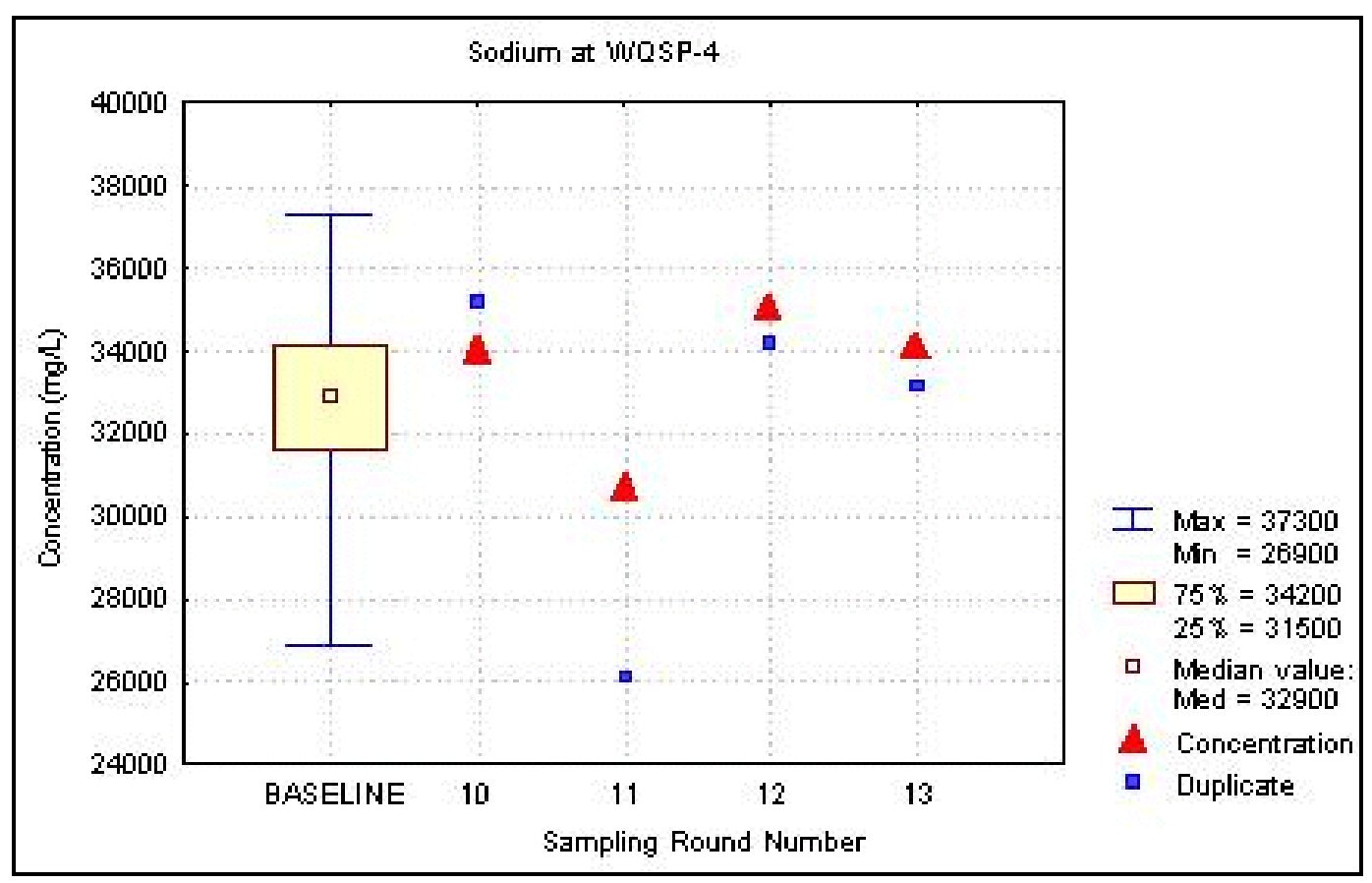

Figure F.67 - Time Trend Plot for Sodium at WQSP-4 


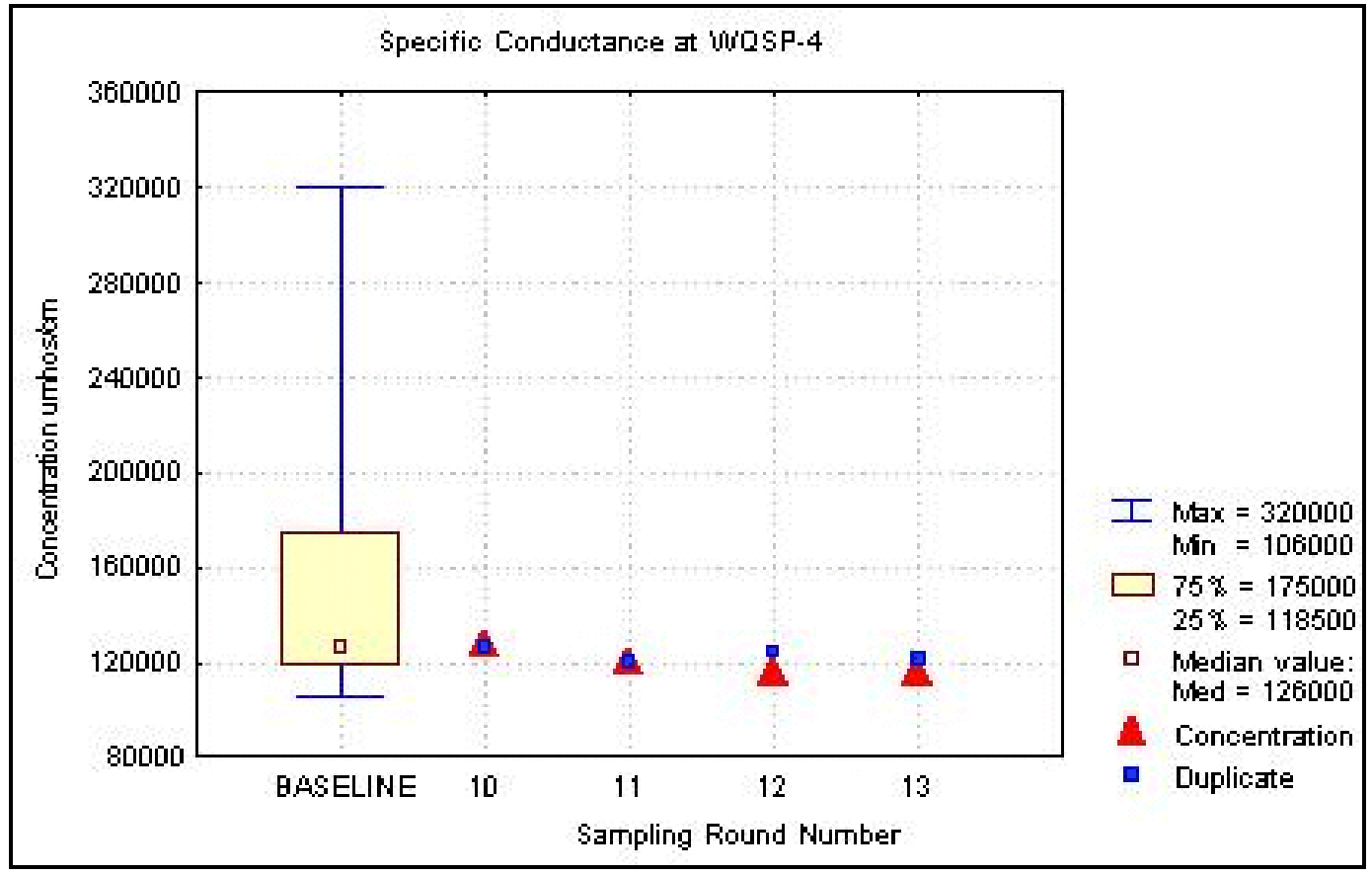

Figure F.68 - Time Trend Plot for Specific Conductance at WQSP-4

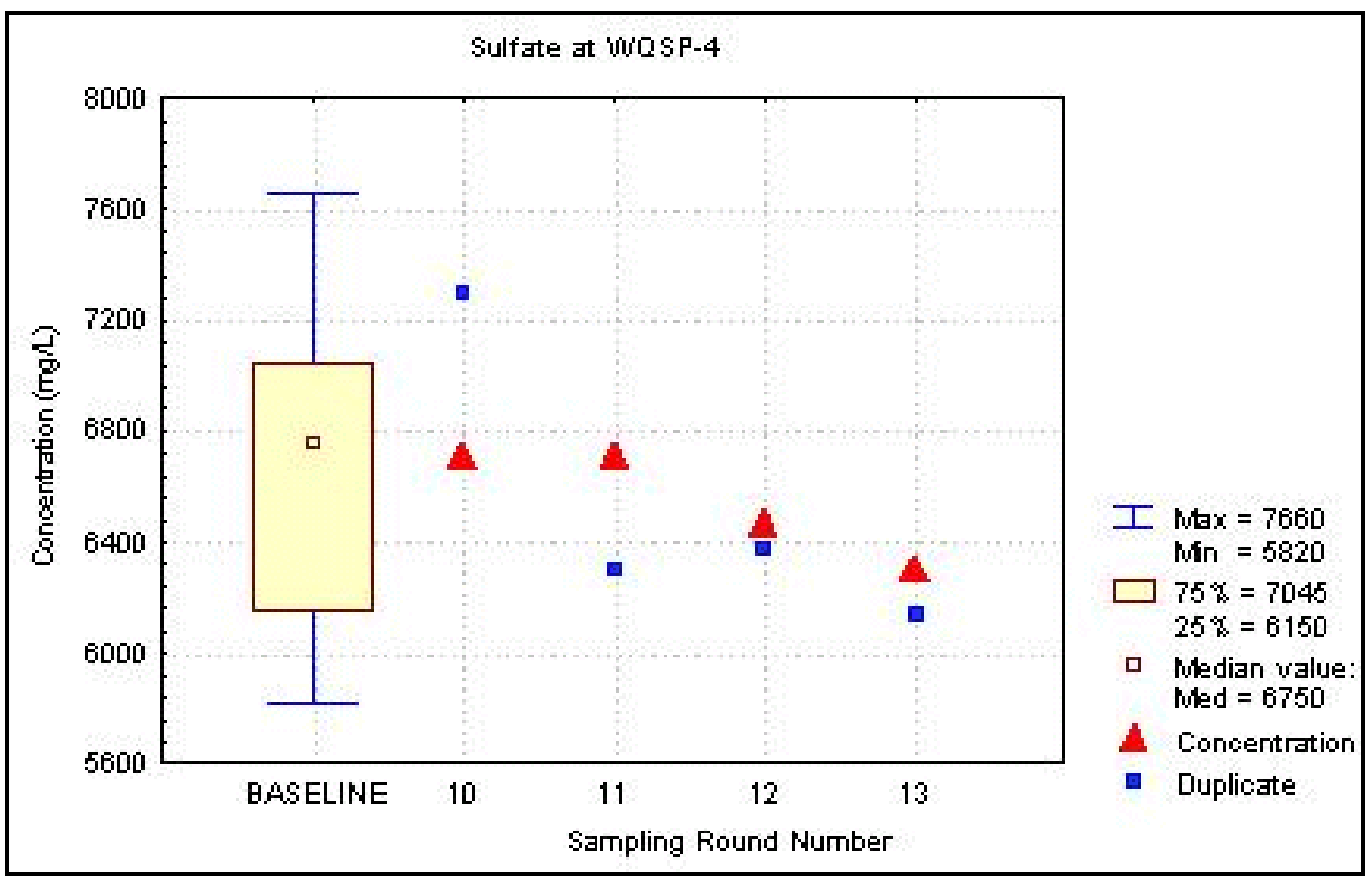

Figure F.69 - Time Trend Plot for Sulfate at WQSP-4 


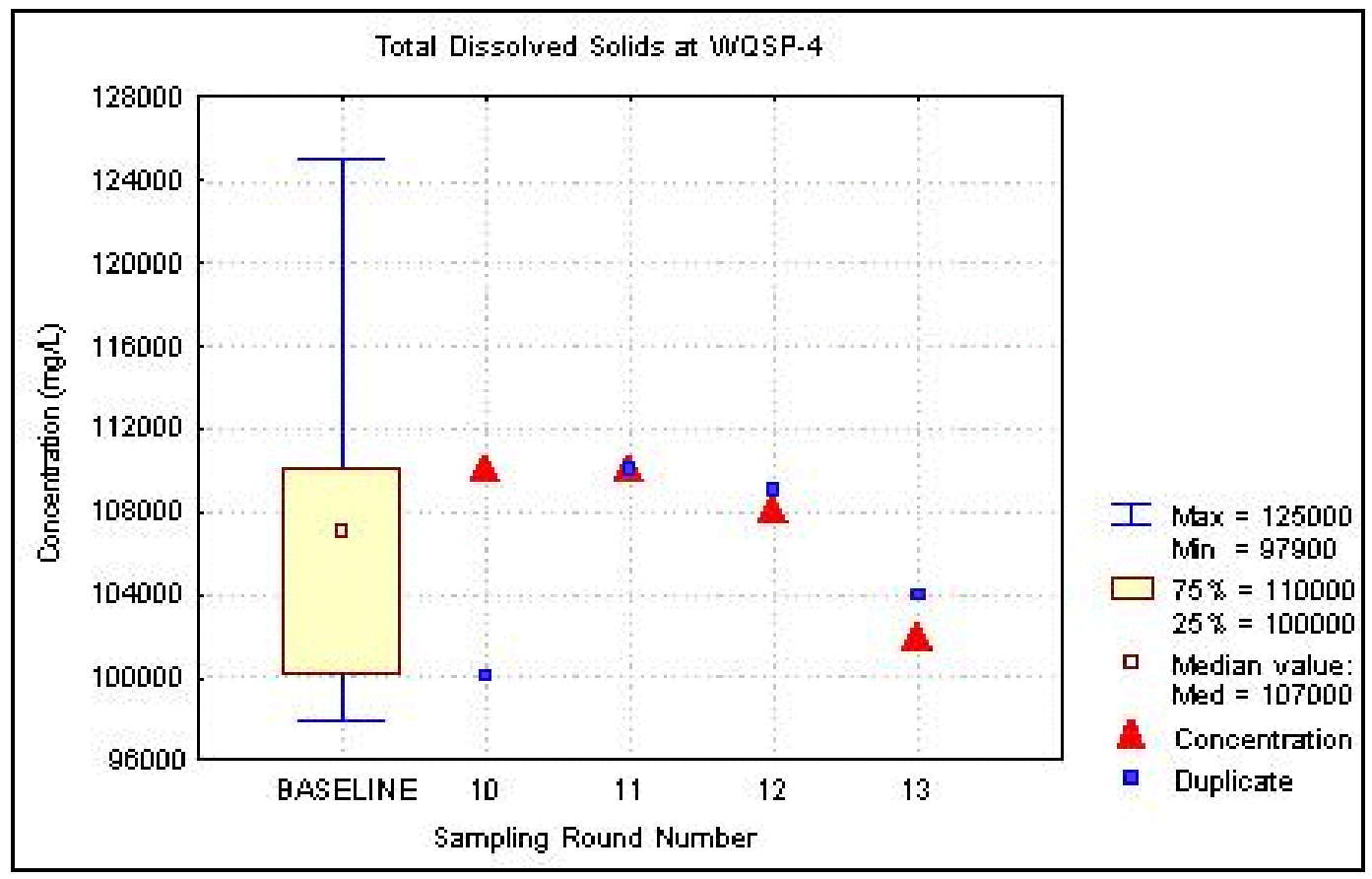

Figure F.70 - Time Trend Plot for Total Dissolved Solids at WQSP-4

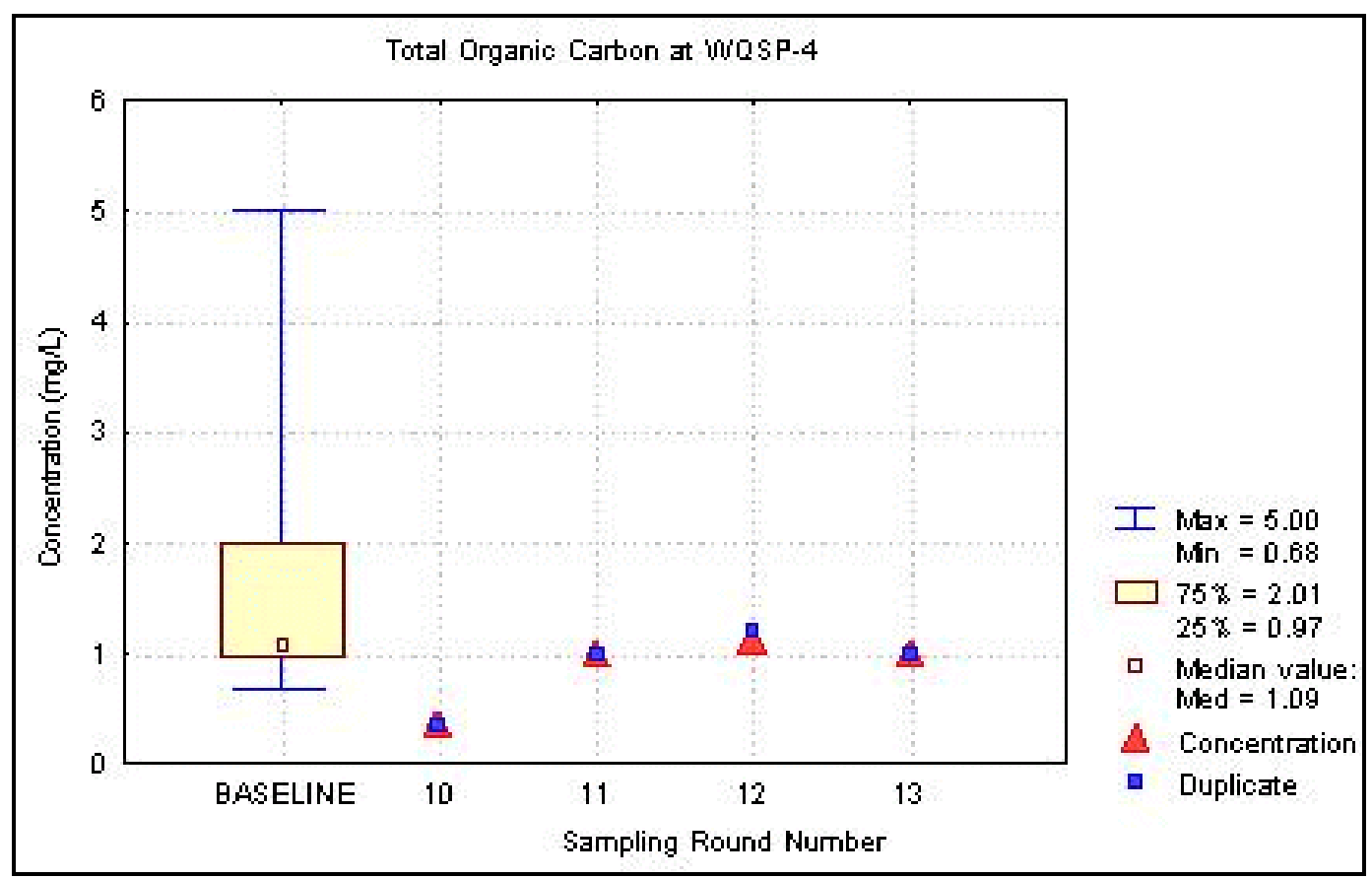

Figure F.71 - Time Trend Plot for Total Organic Carbon at WQSP-4 


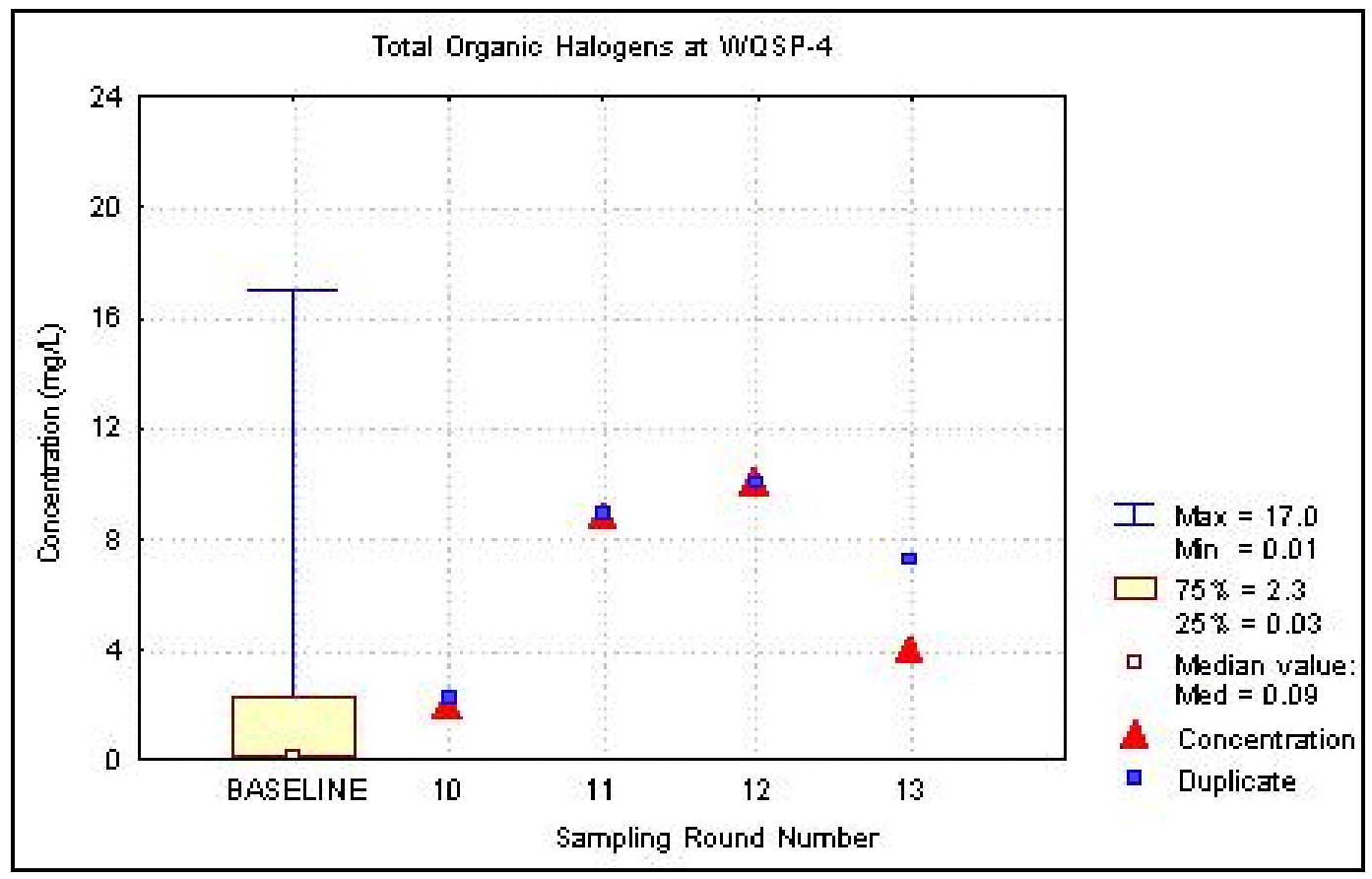

Figure F.72 - Time Trend Plot for Total Organic Halogens at WQSP-4

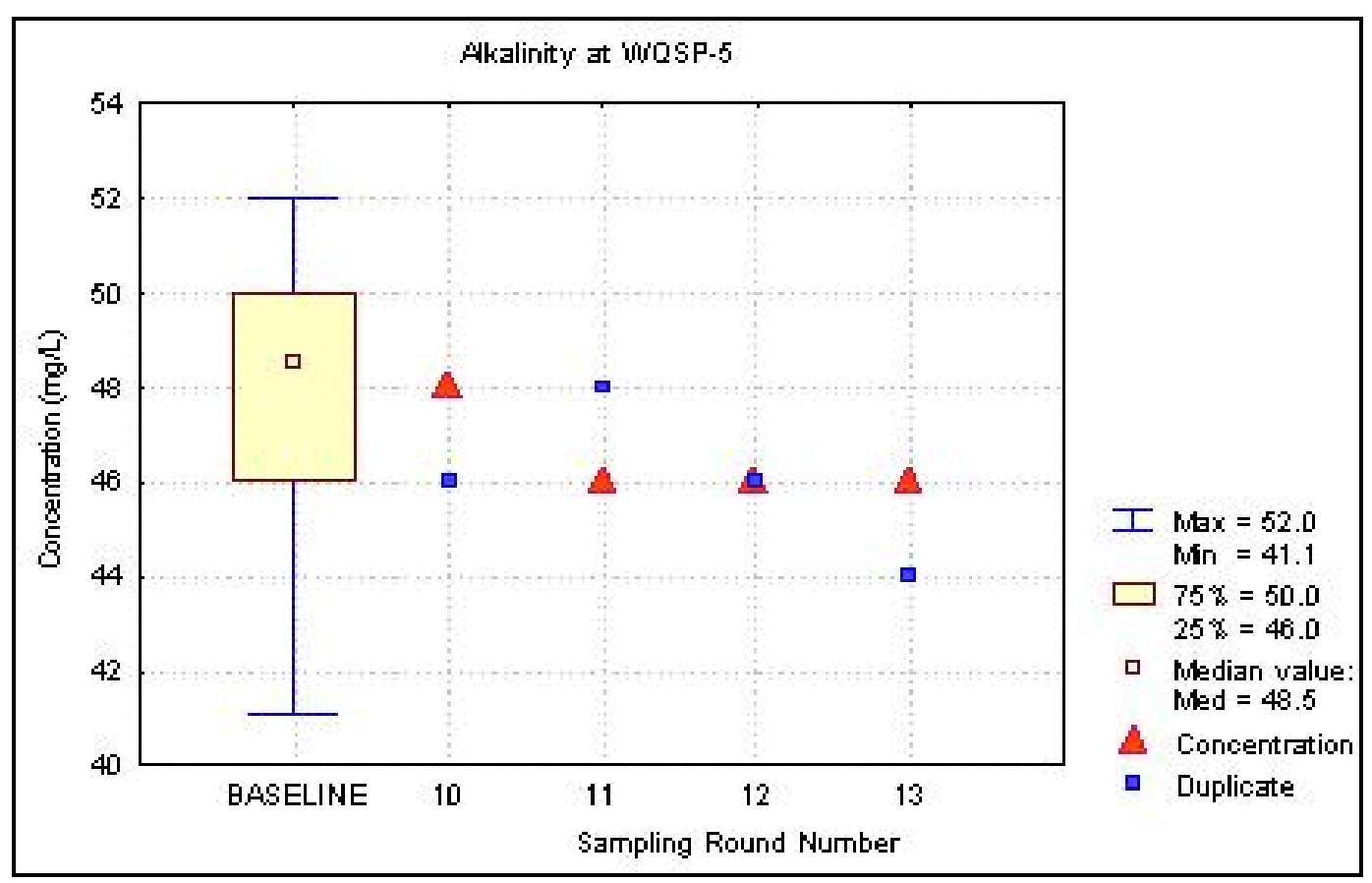

Figure F.73 - Alkalinity at WQSP-5 


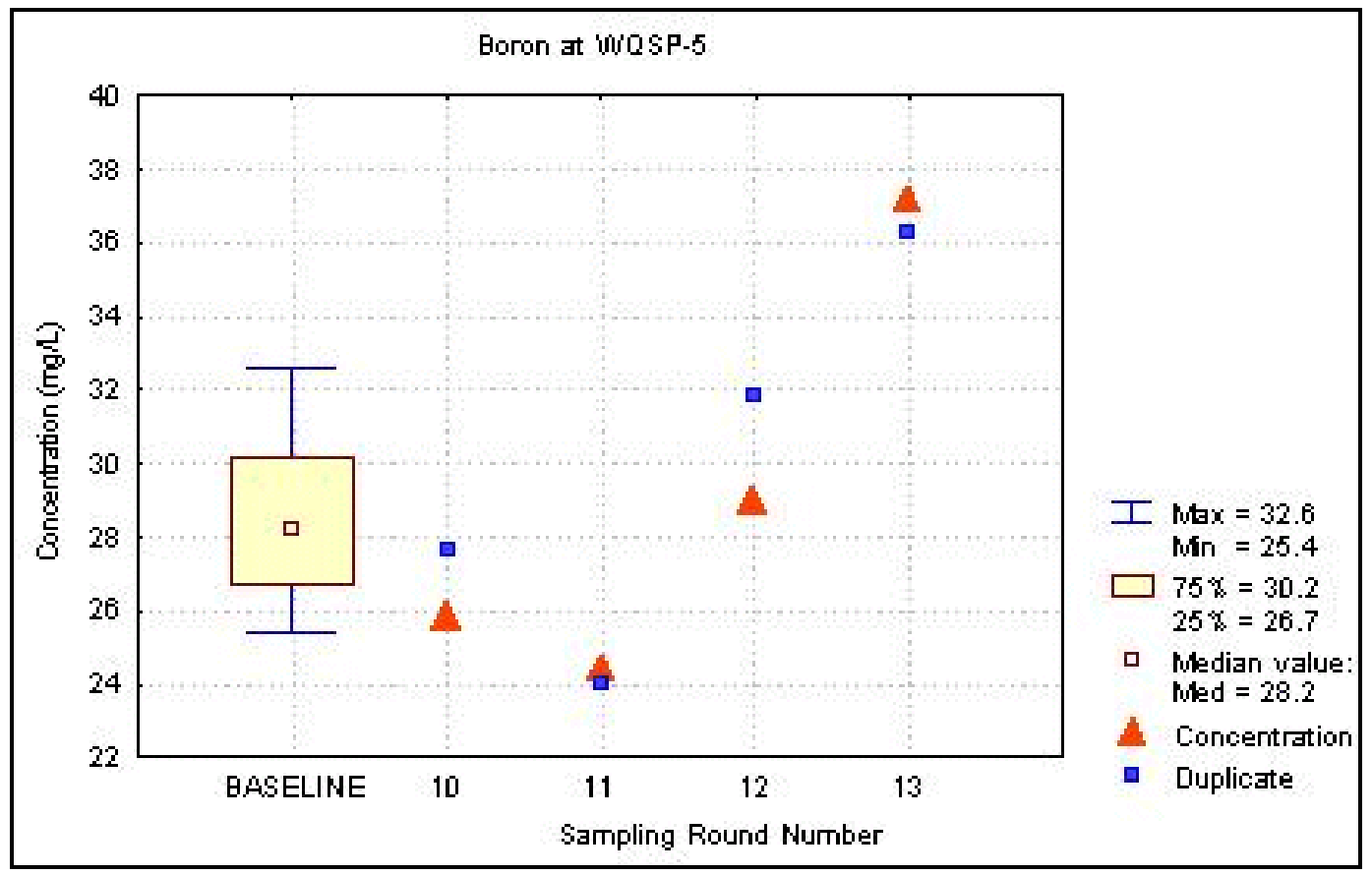

Figure F.74 - Time Trend Plot for Boron at WQSP-5

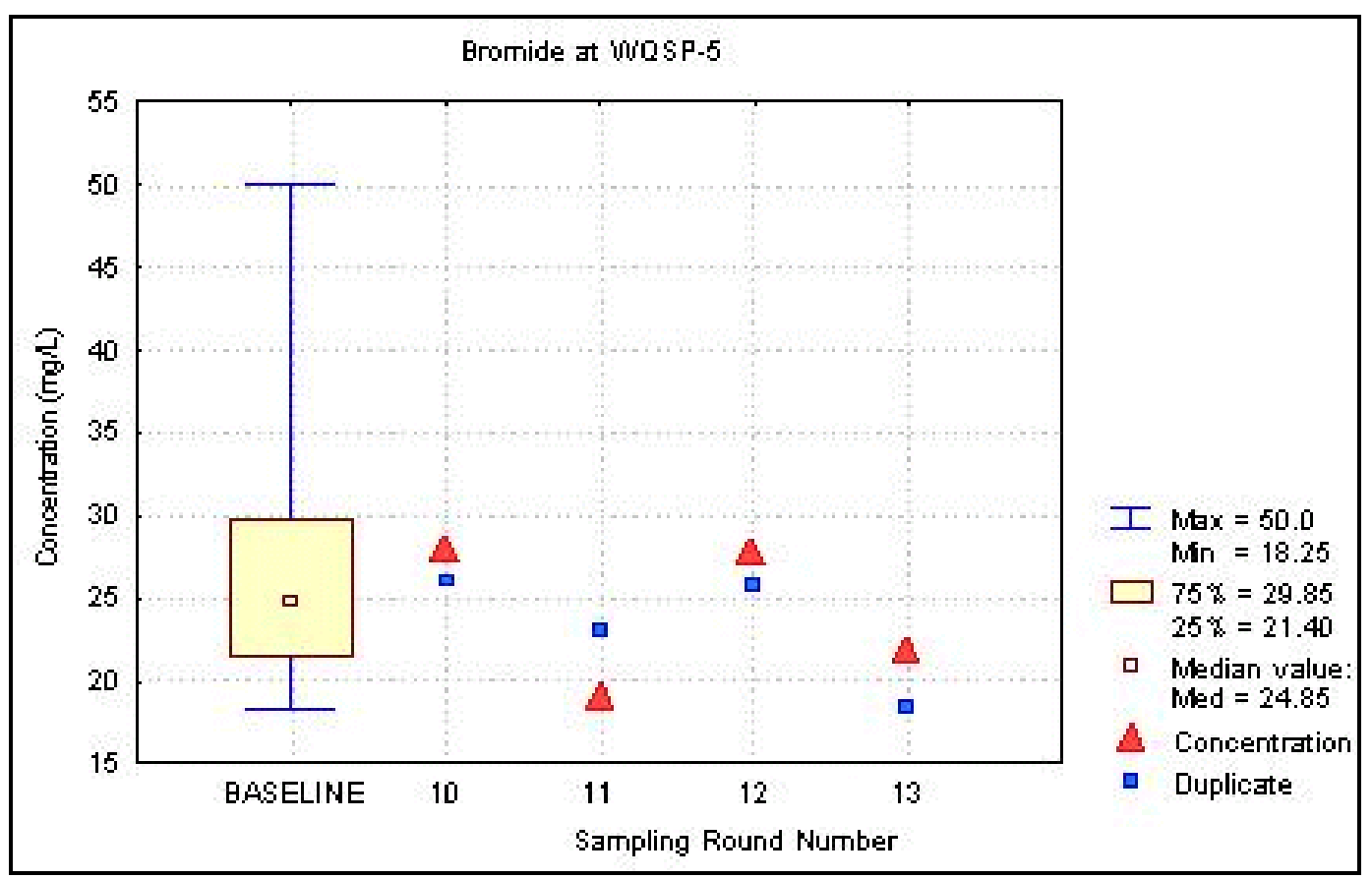

Figure F.75 - Time Trend Plot for Bromide at WQSP-5 


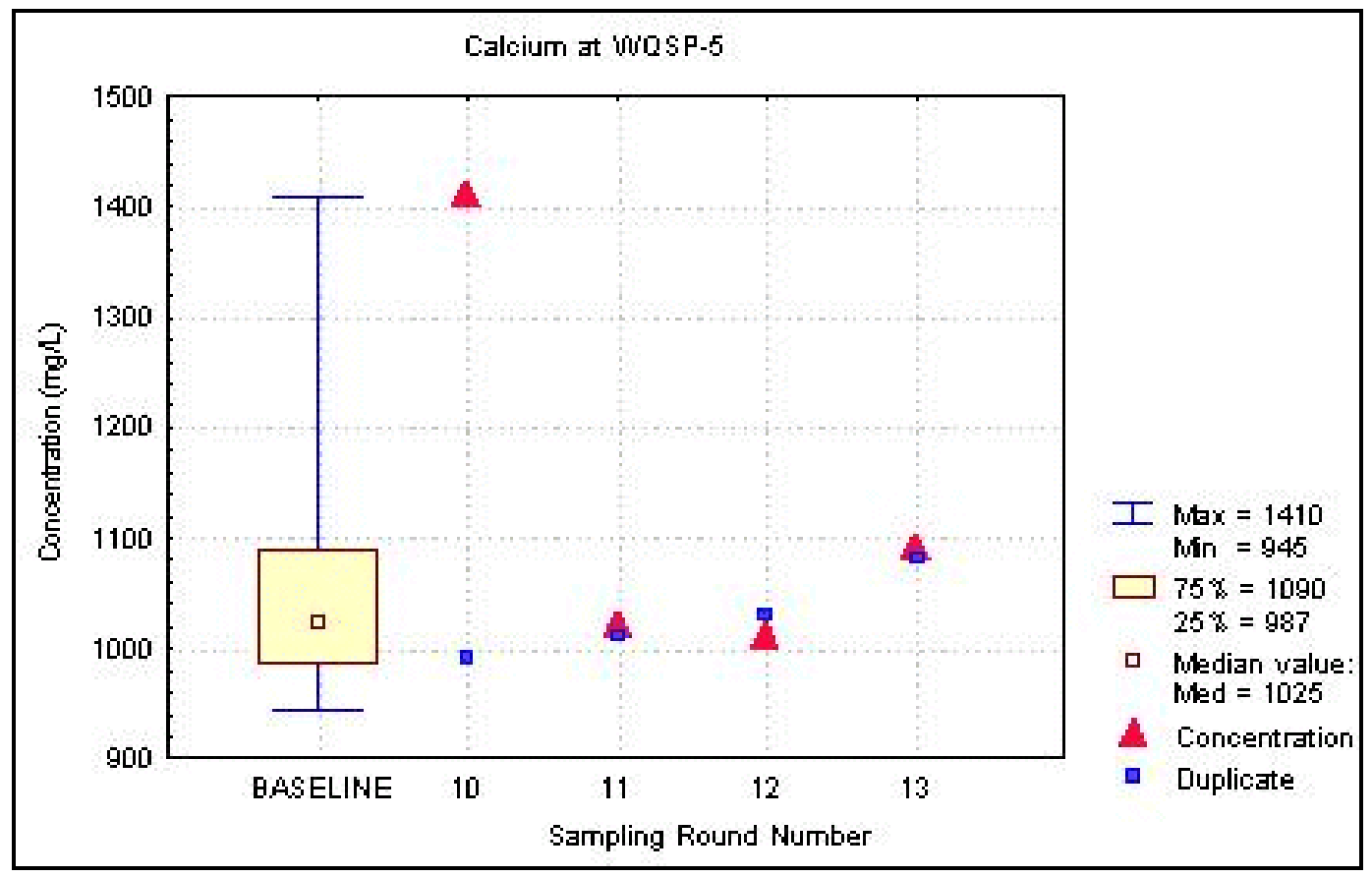

Figure F.76 - Time Trend Plot for Calcium at WQSP-5

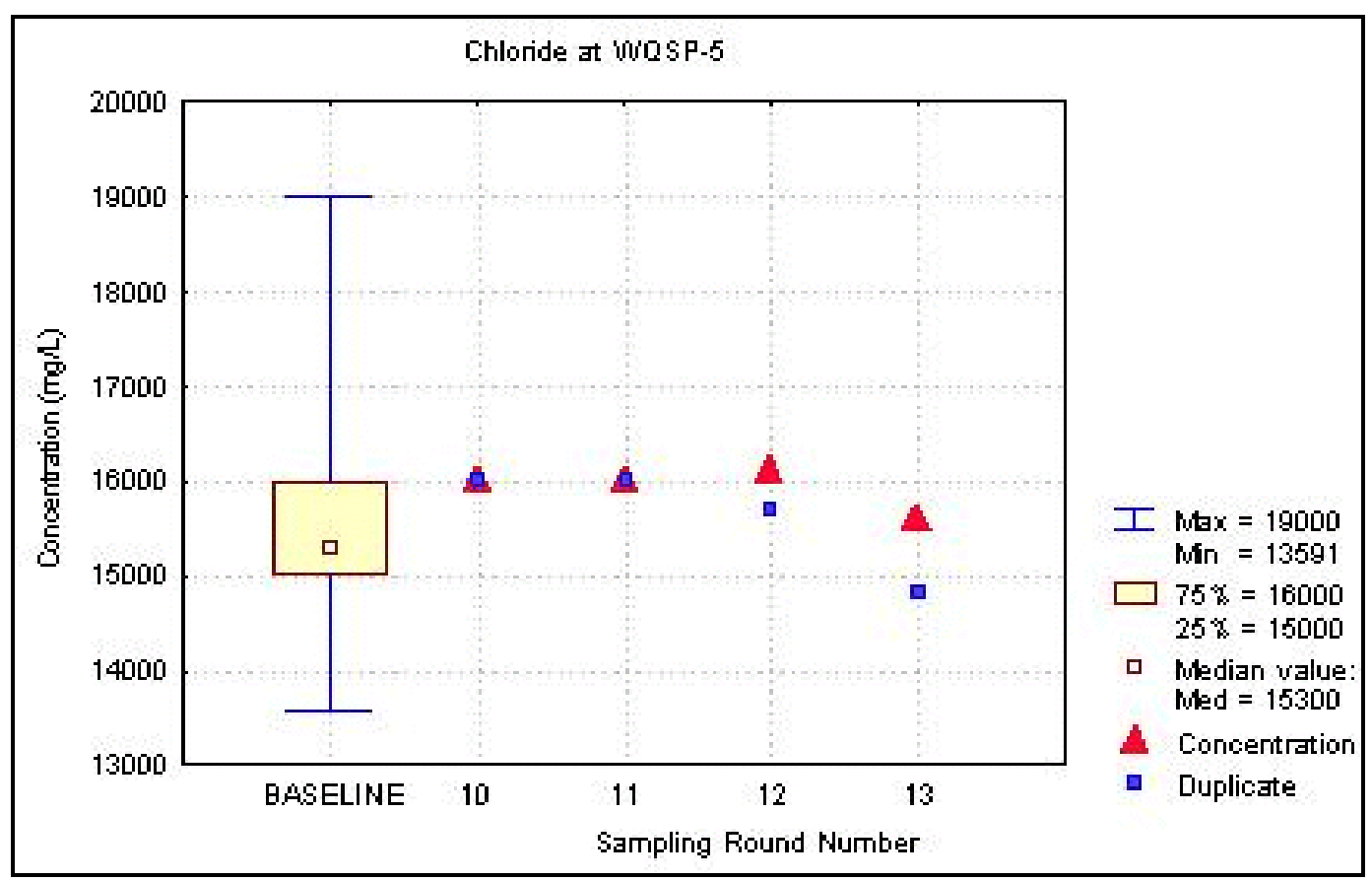

Figure F.77 - Time Trend Plot for Chloride at WQSP-5 


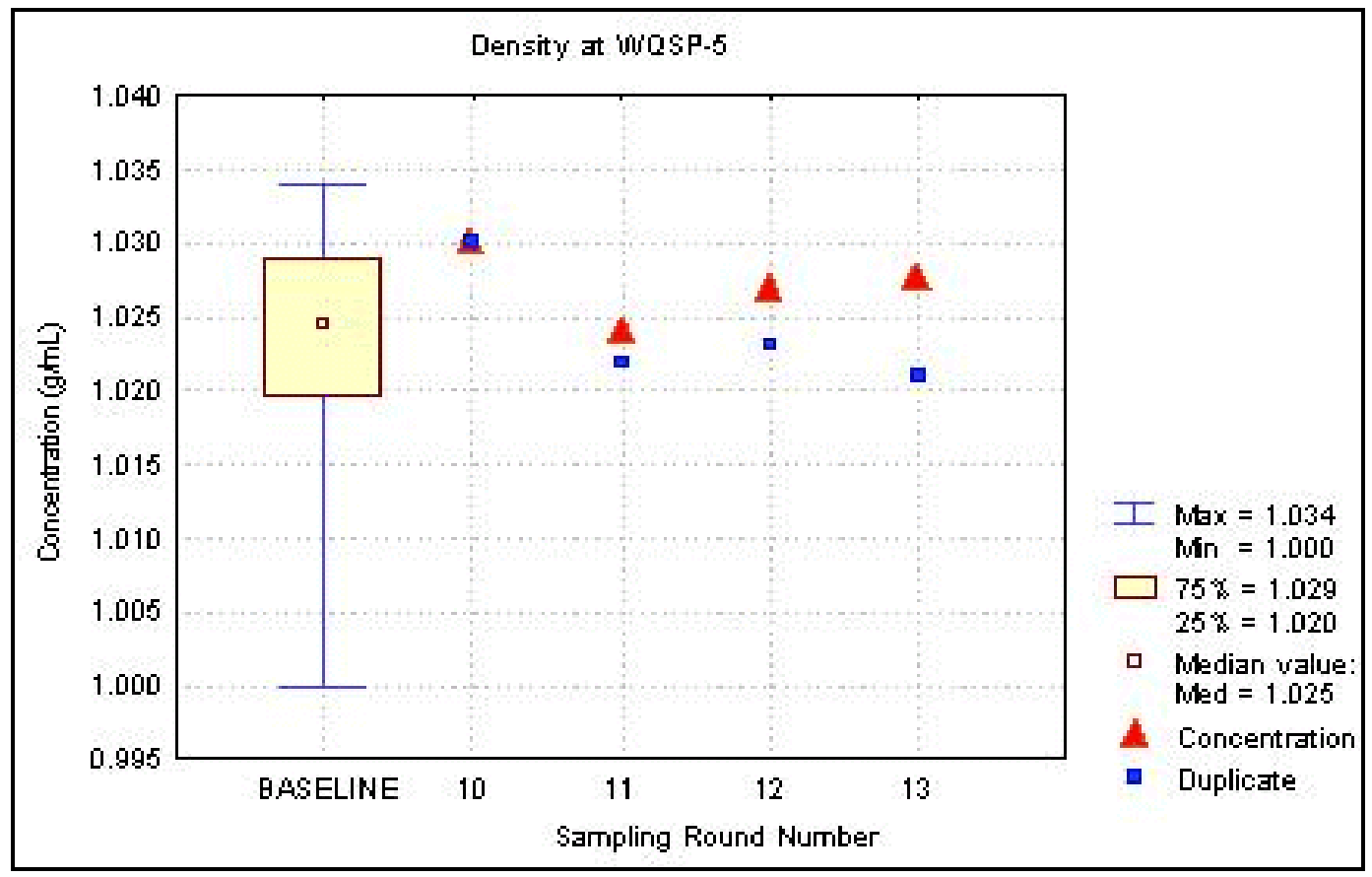

Figure F.78 - Time Trend Plot for Density at WQSP-5

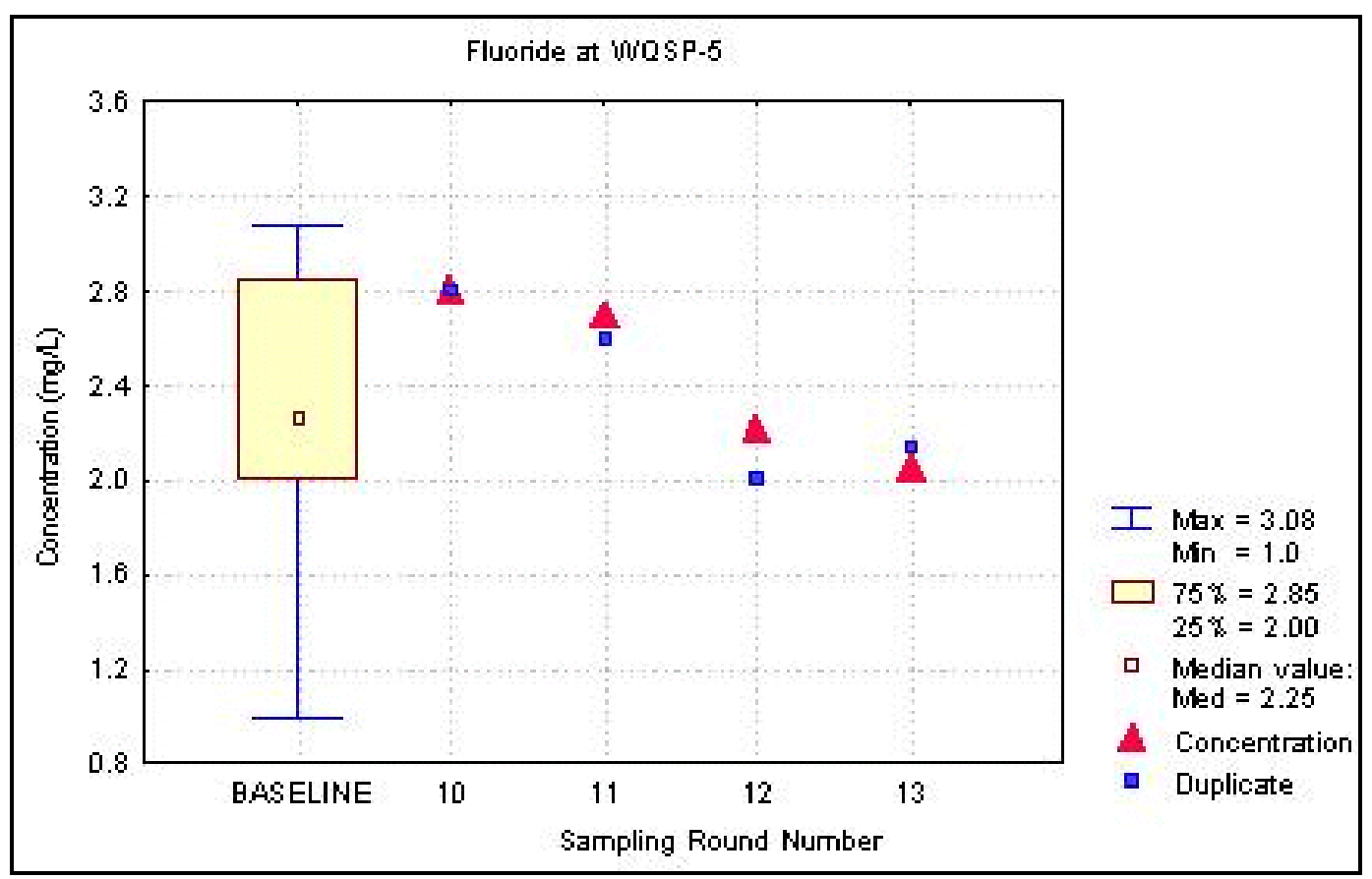

Figure F.79 - Time Trend Plot for Fluoride at WQSP-5 


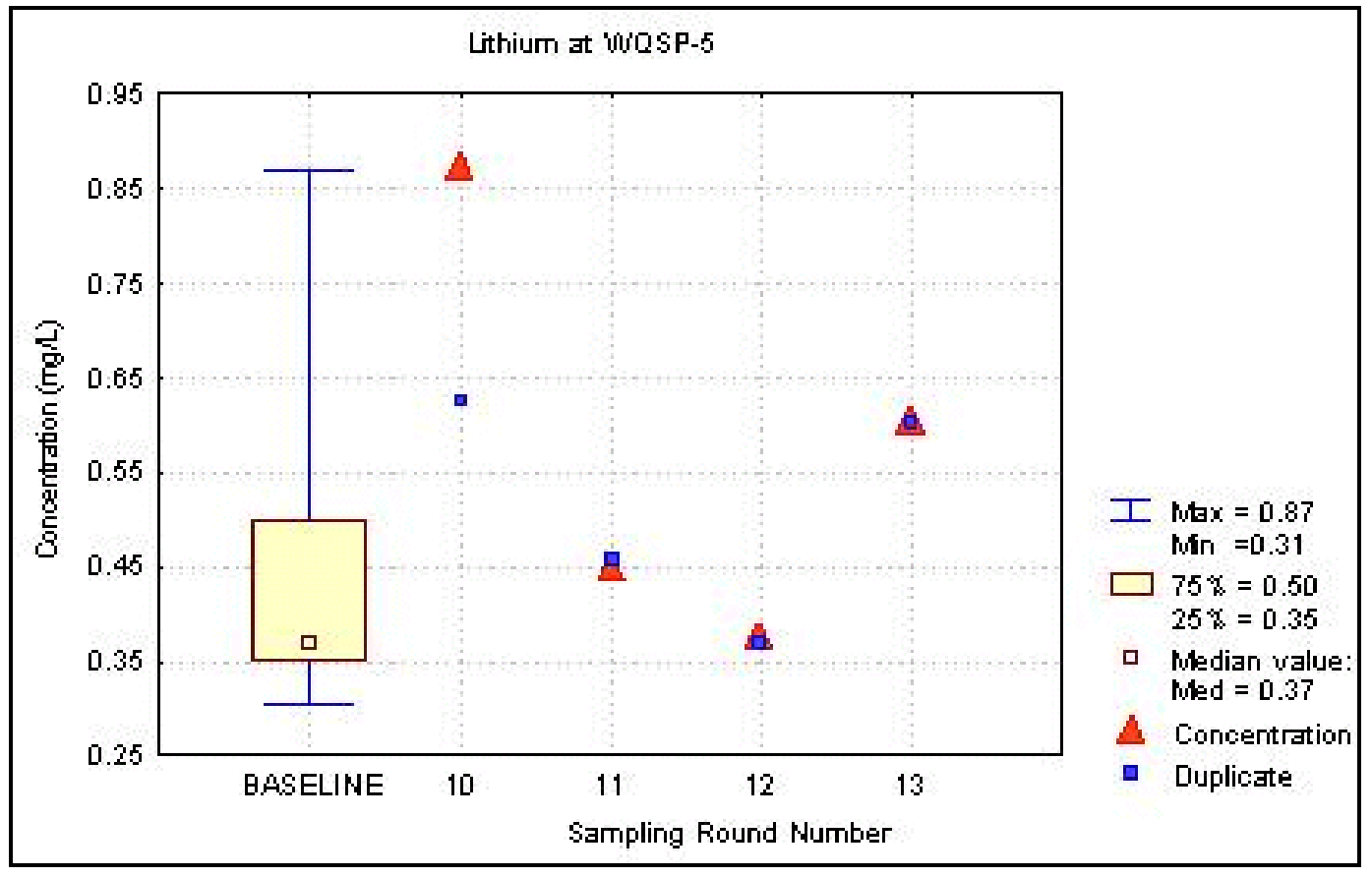

Figure F.80 - Time Trend Plot for Lithium at WQSP-5

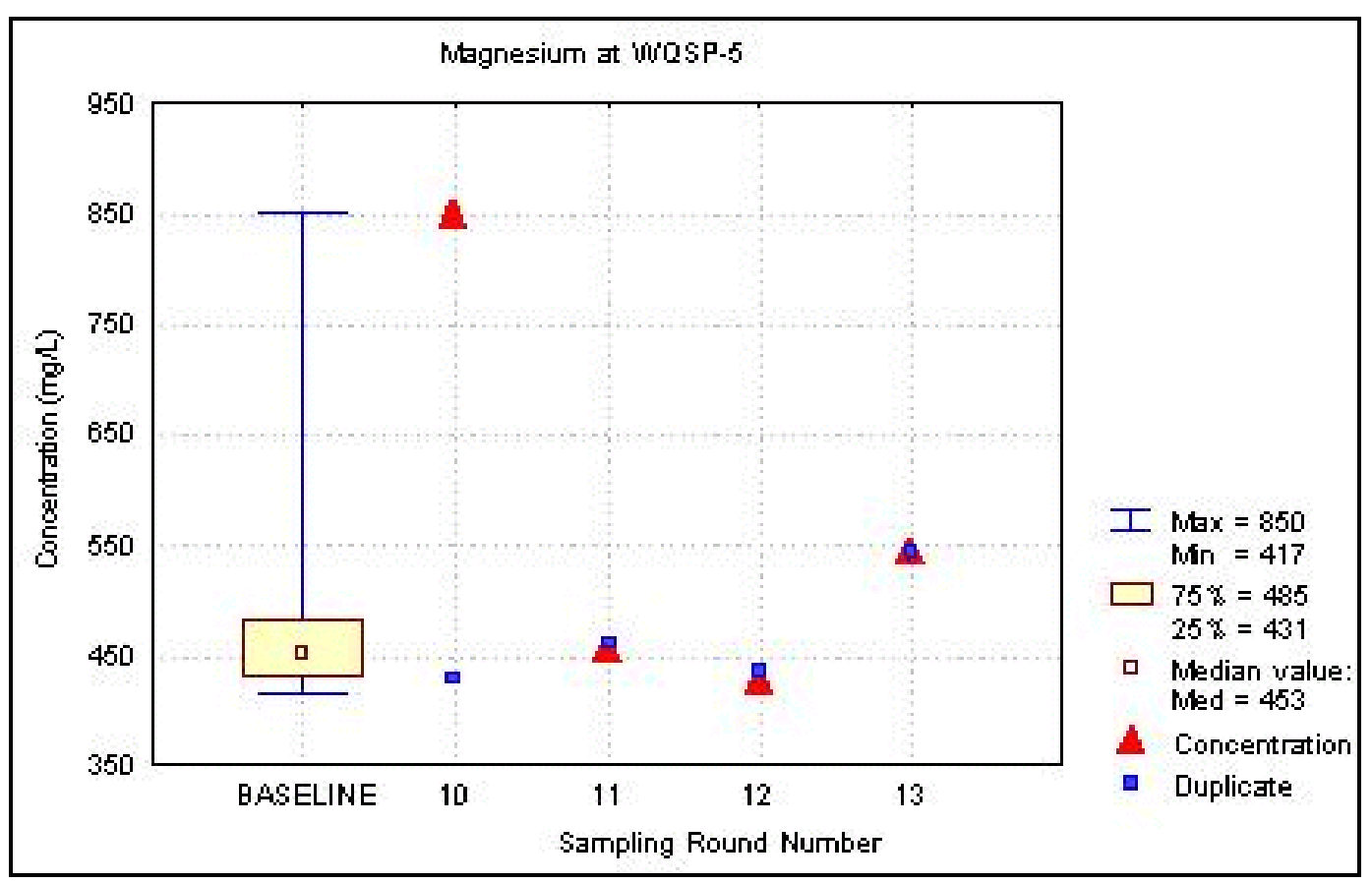

Figure F.81 - Time Trend Plot for Magnesium at WQSP-5 


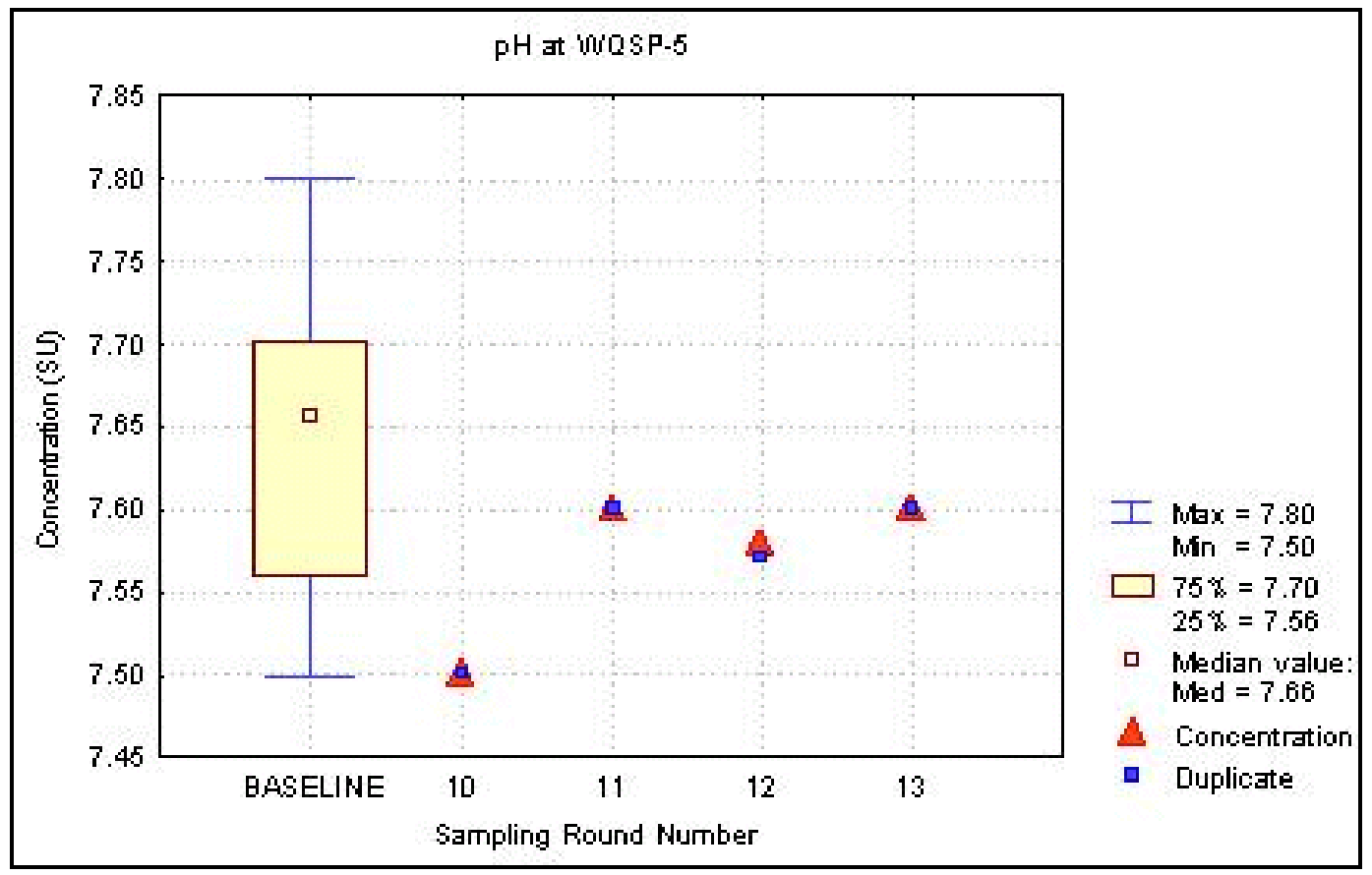

Figure F.82 - Time Trend Plot for pH at WQSP-5

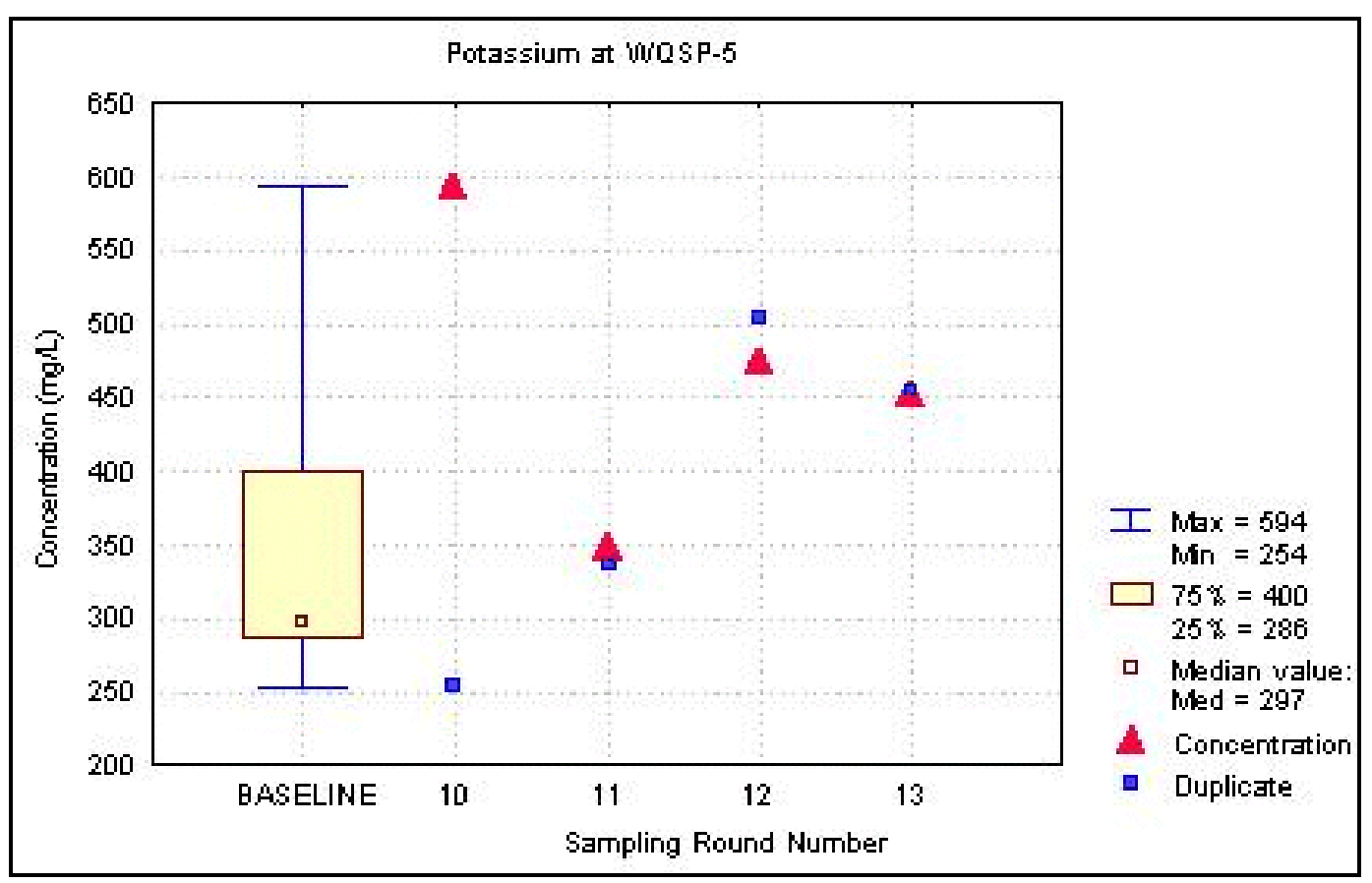

Figure F.83 - Time Trend Plot for Potassium at WQSP-5 


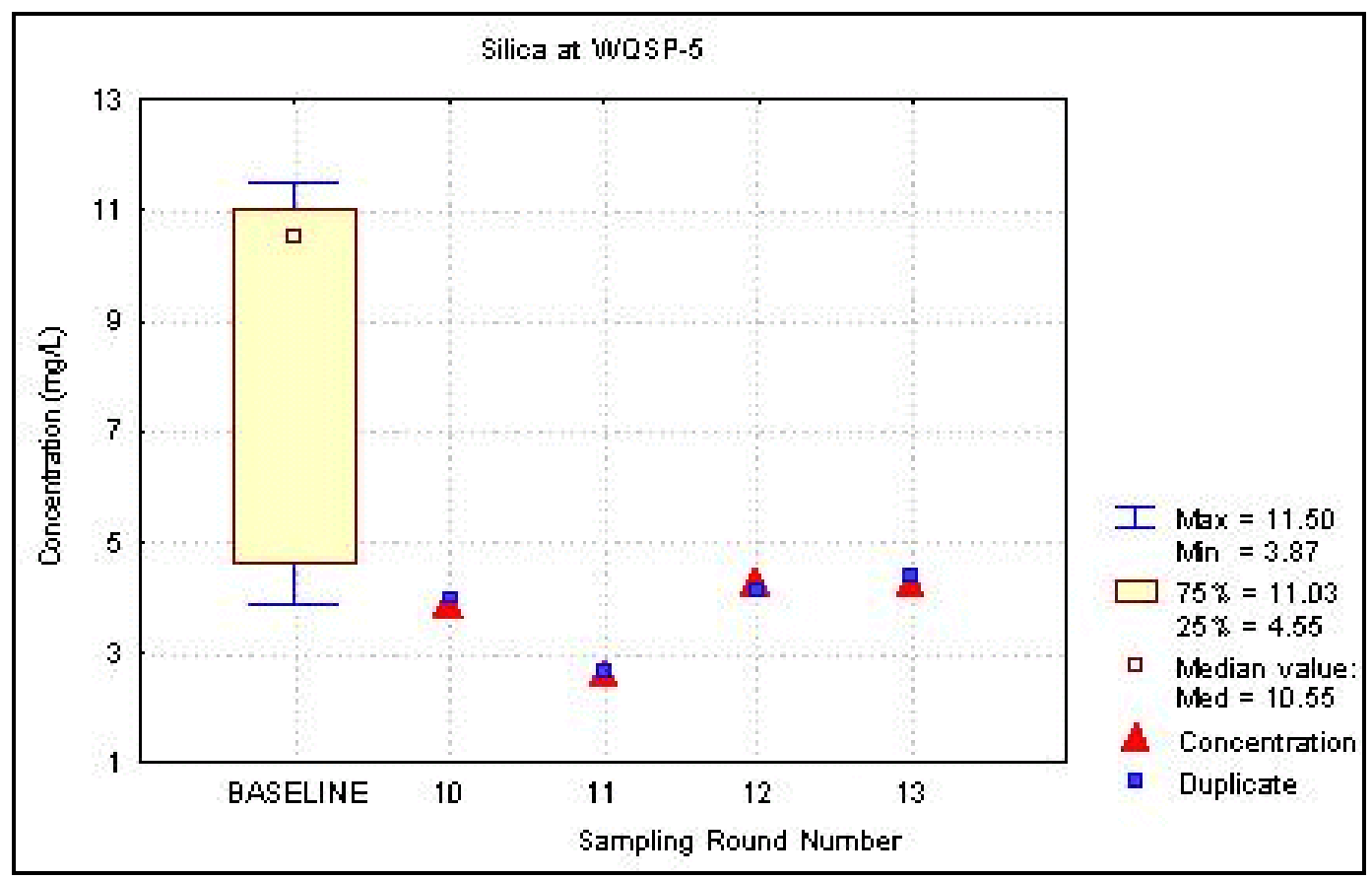

Figure F.84 - Time Trend Plot for Silica at WQSP-5

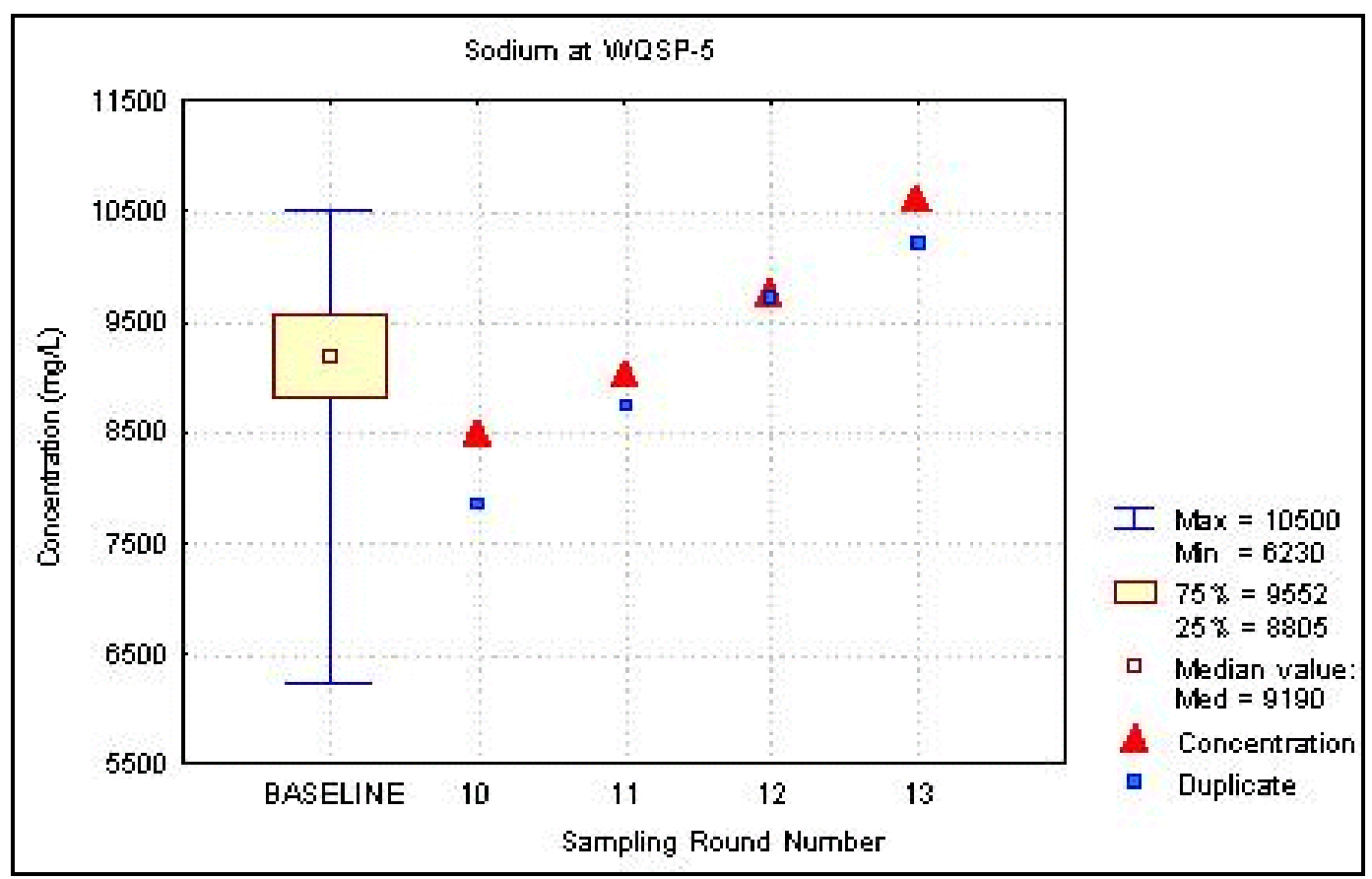

Figure F.85 - Time Trend Plot for Sodium at WQSP-5 


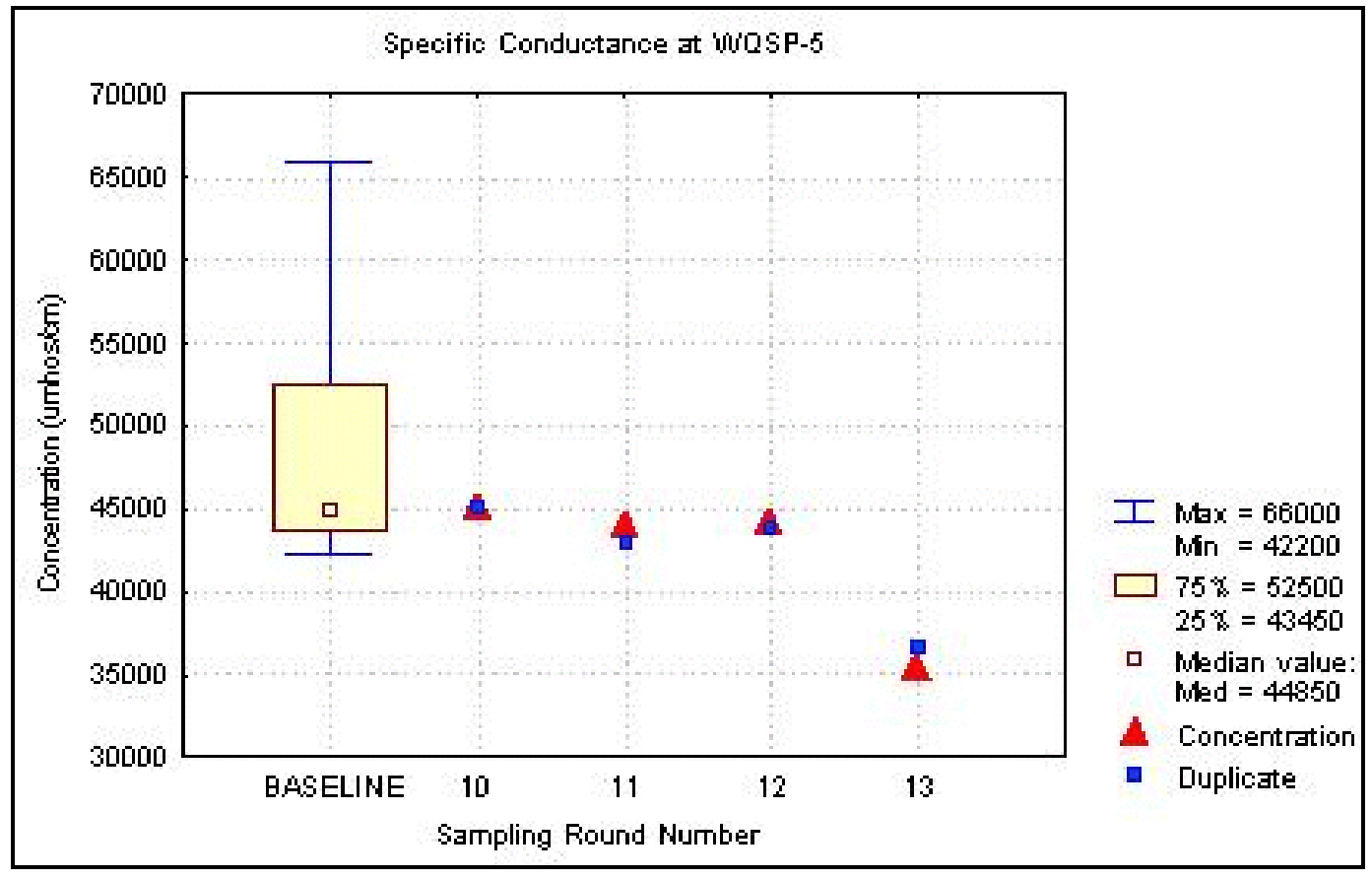

Figure F.86 - Time Trend Plot for Specific Conductance at WQSP-5

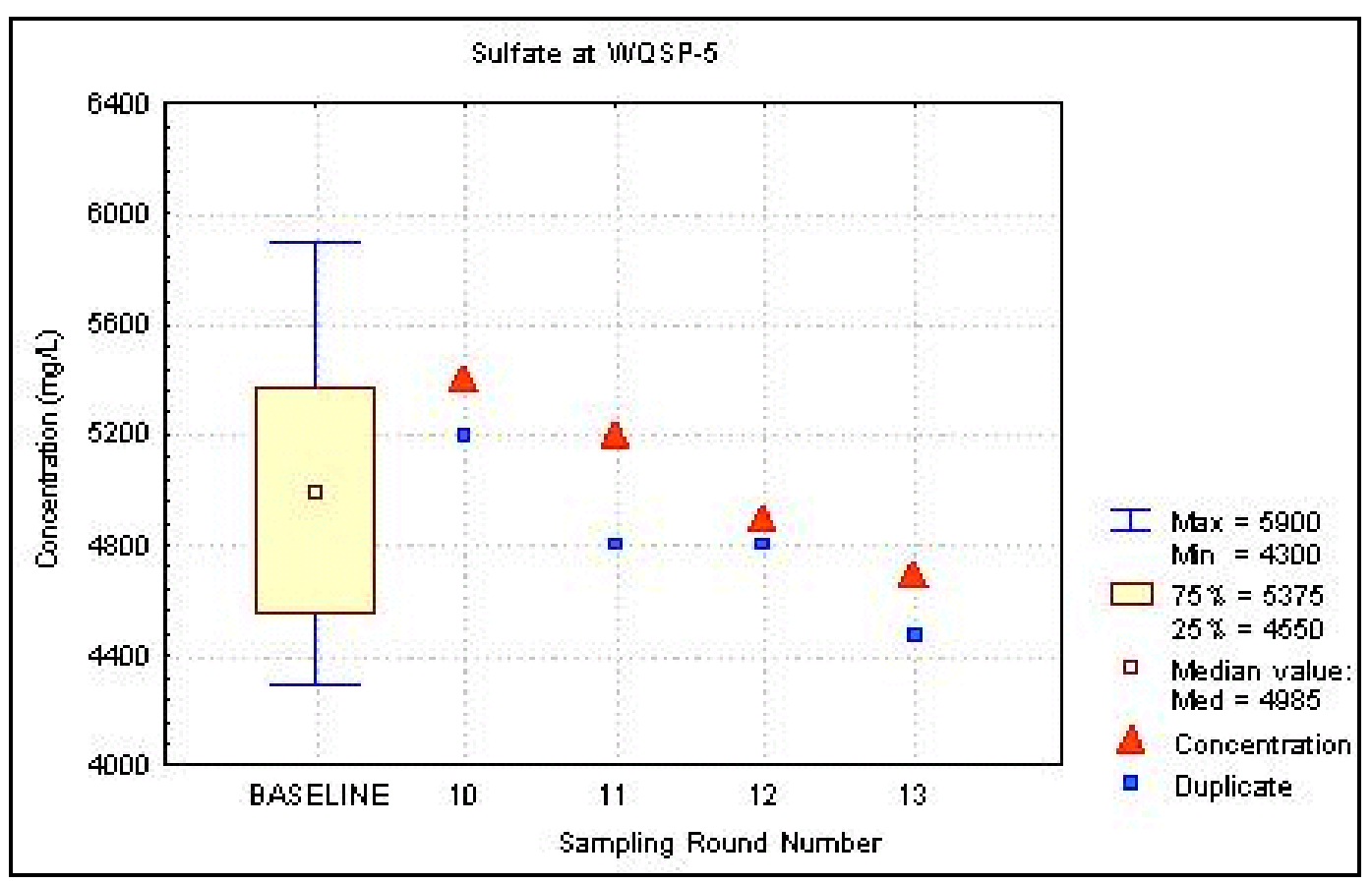

Figure F.87 - Time Trend Plot for Sulfate at WQSP-5 


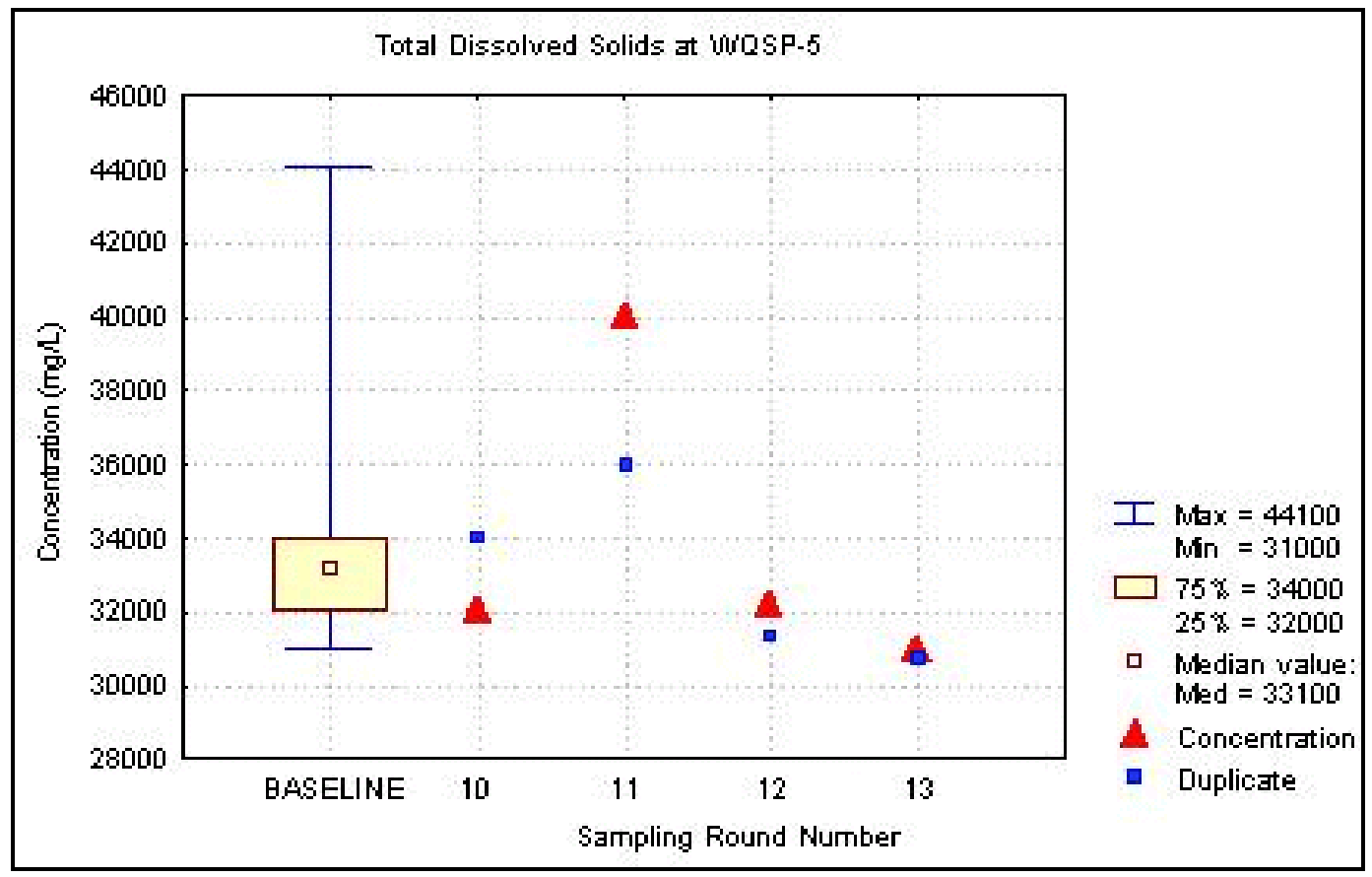

Figure F.88 - Time Trend Plot for Total Dissolved Solids at WQSP-5

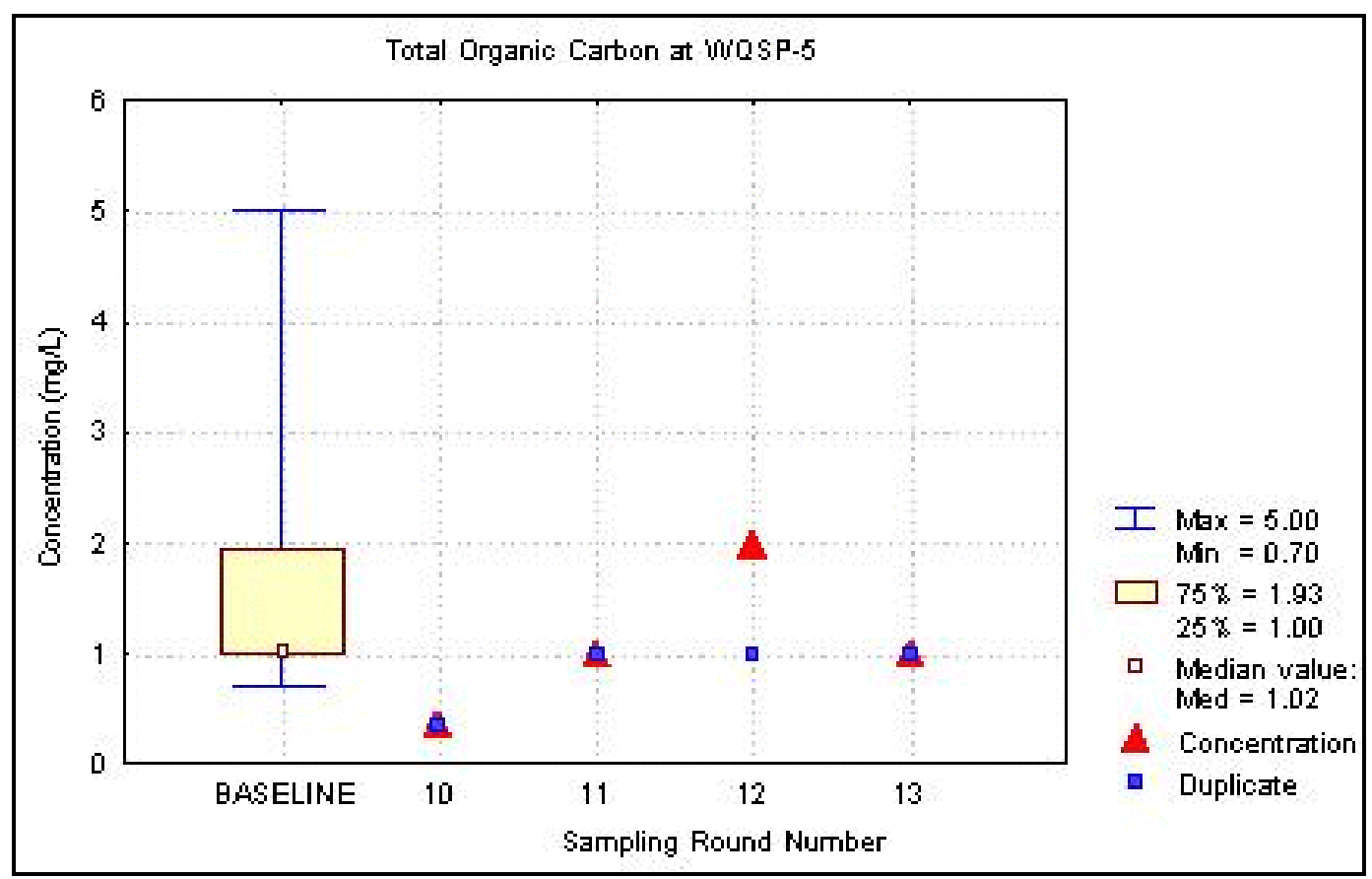

Figure F.89 - Time Trend Plot for Total Organic Carbon at WQSP-5 


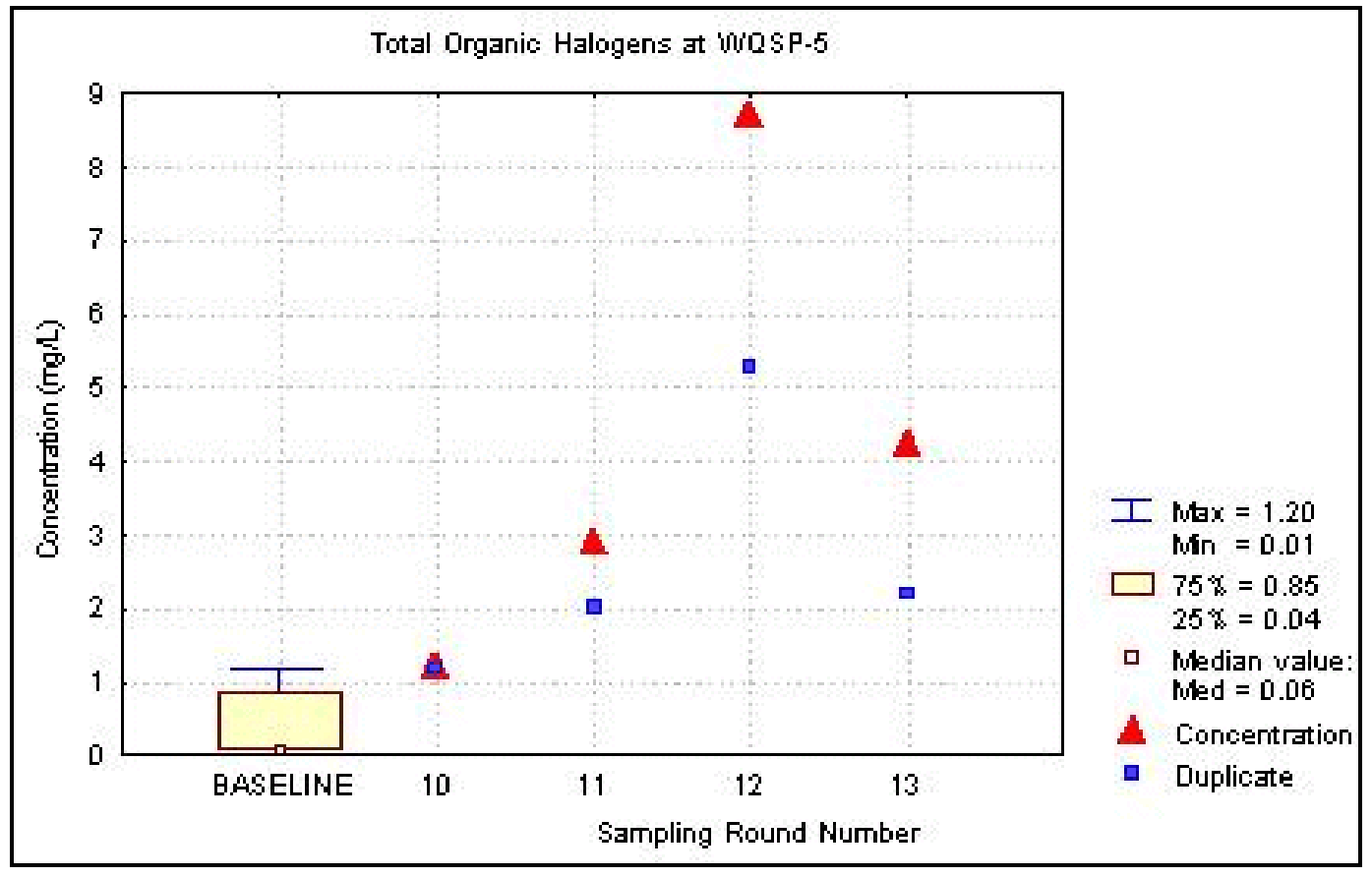

Figure F.90 - Time Trend Plot for Total Organic Halogens at WQSP-5

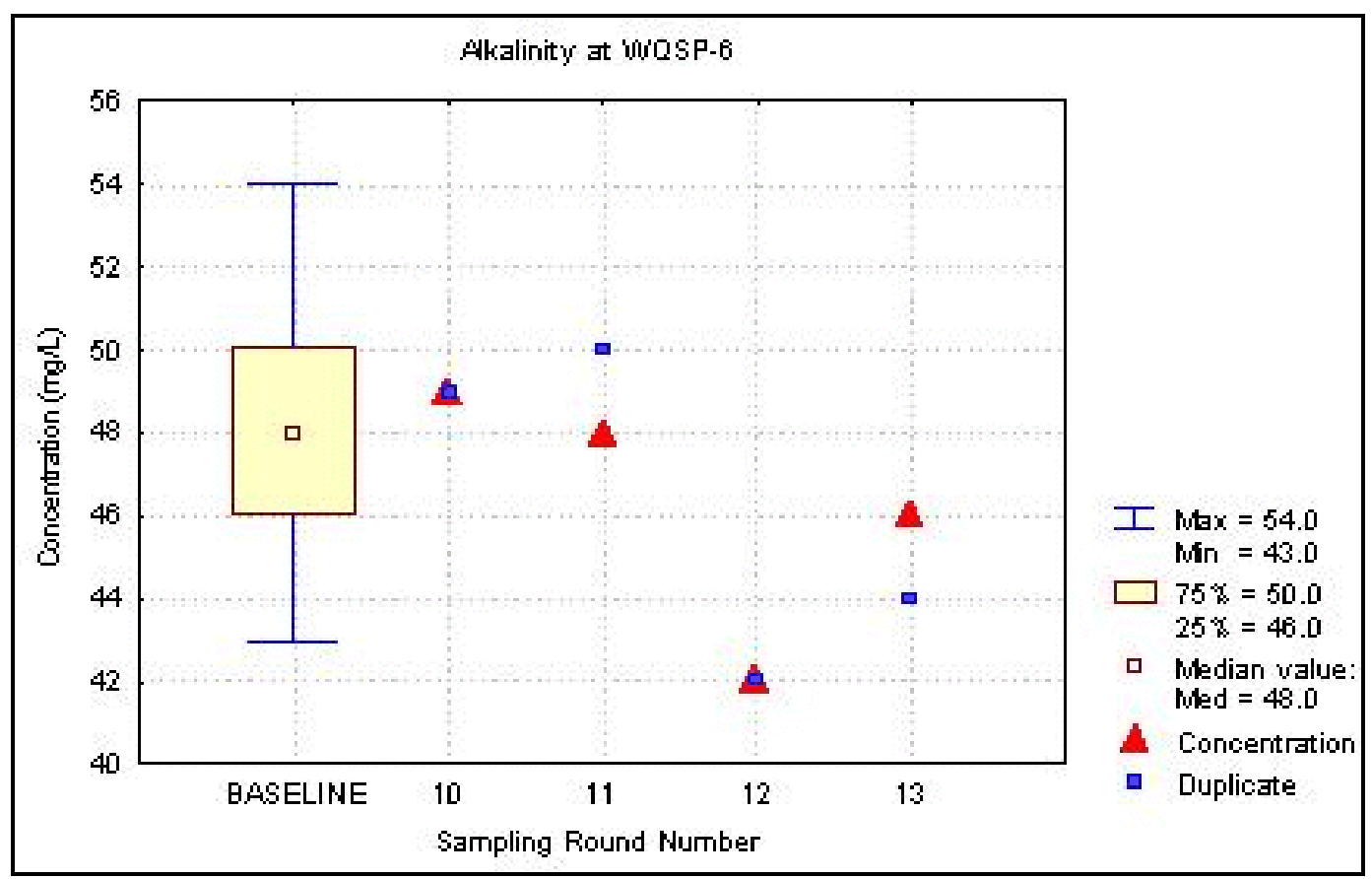

Figure F.91 - Time Trend Plot for Alkalinity at WQSP-6 


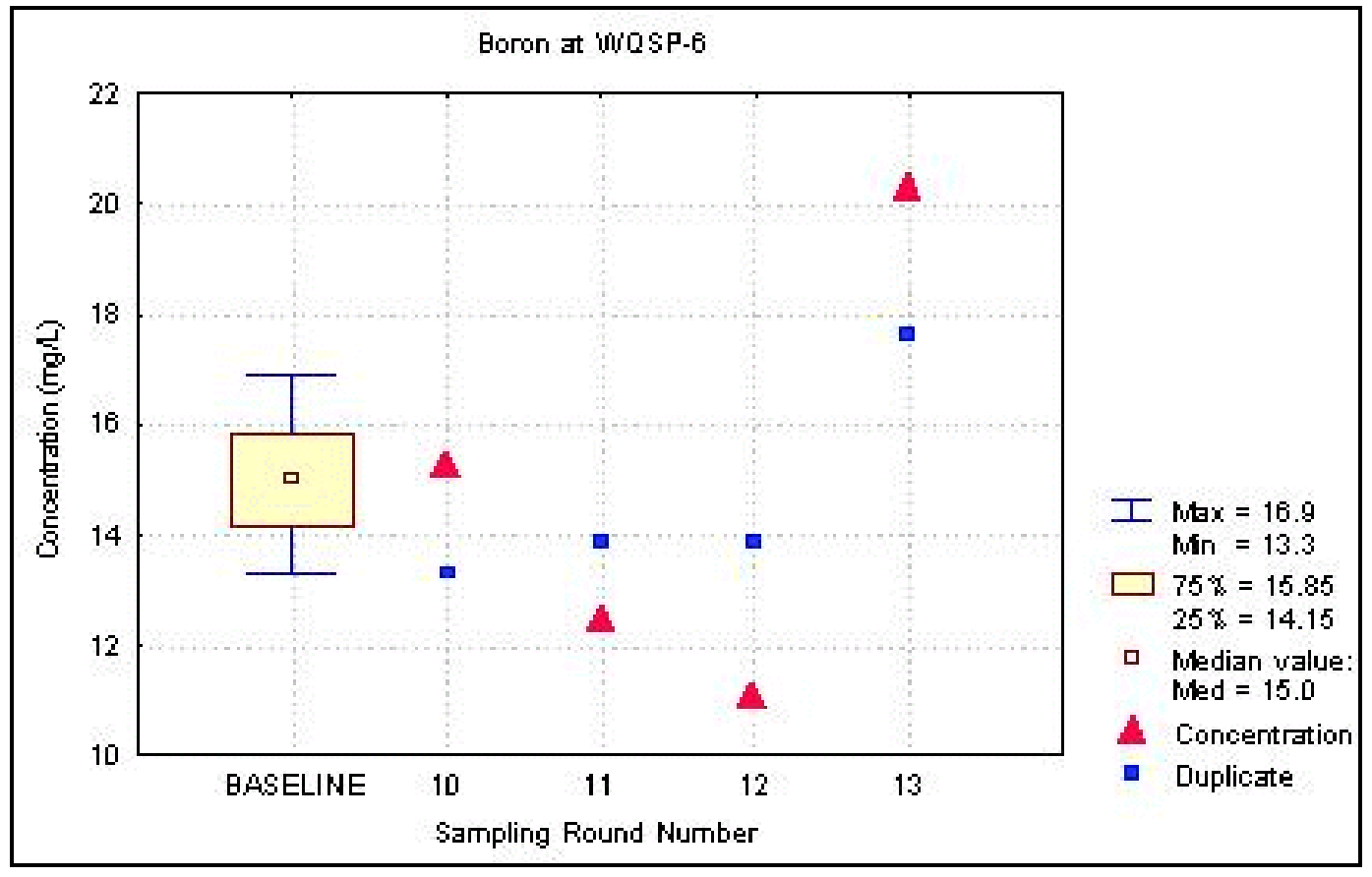

Figure F.92 - Time Trend Plot for Boron at WQSP-6

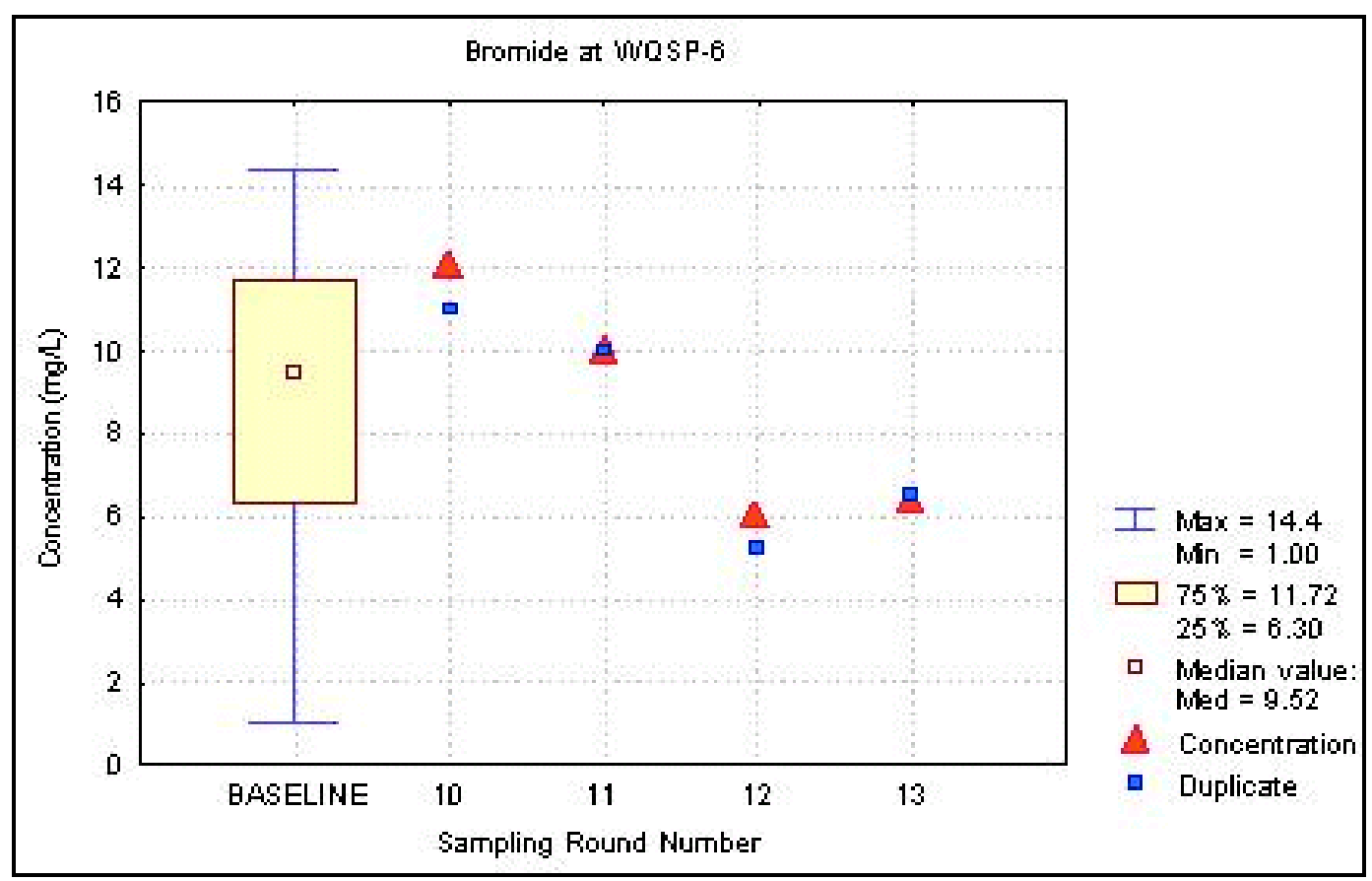

Figure F.93 - Time Trend Plot for Bromide at WQSP-6 


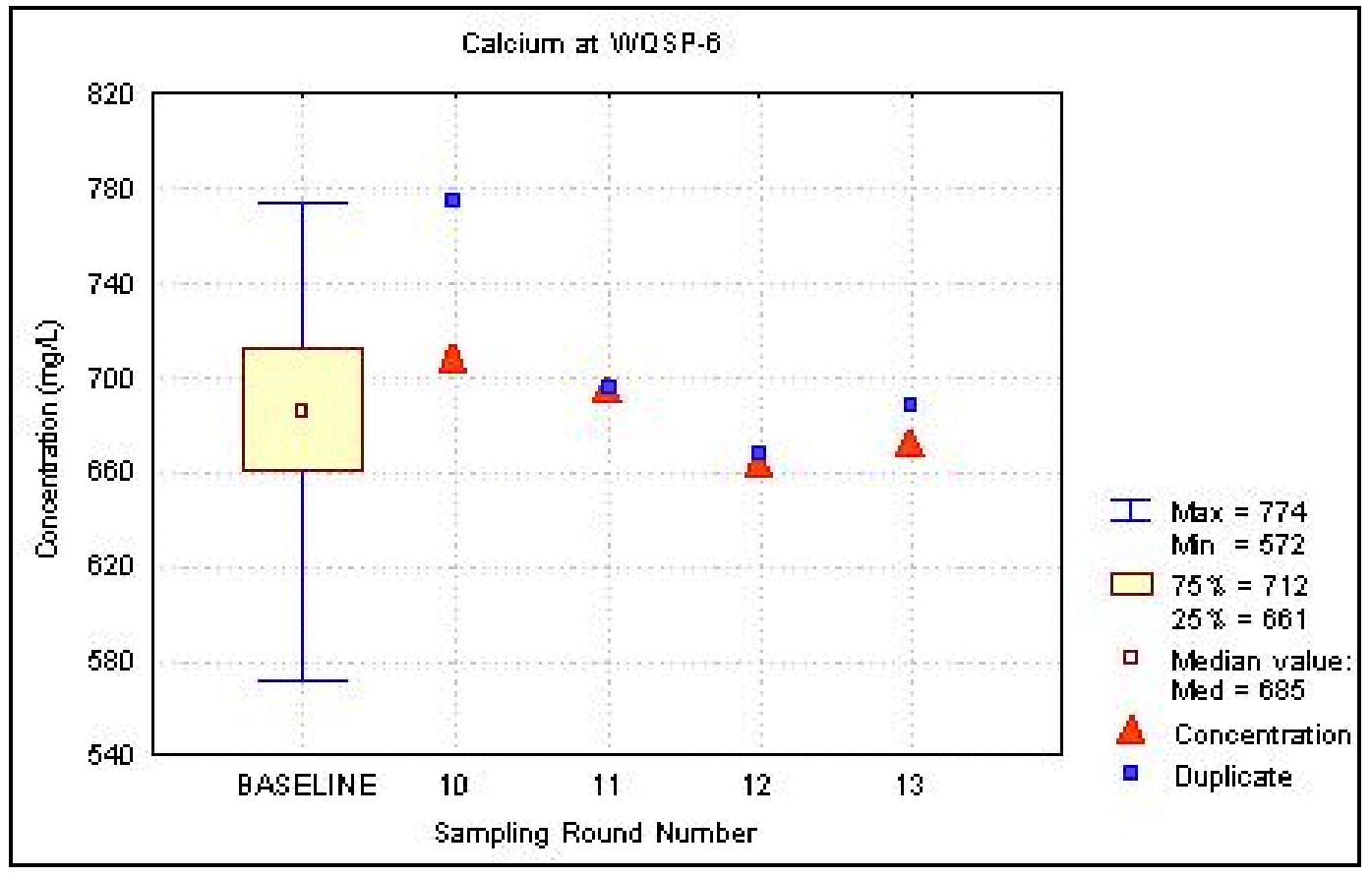

Figure F.94 - Time Trend Plot for Calcium at WQSP-6

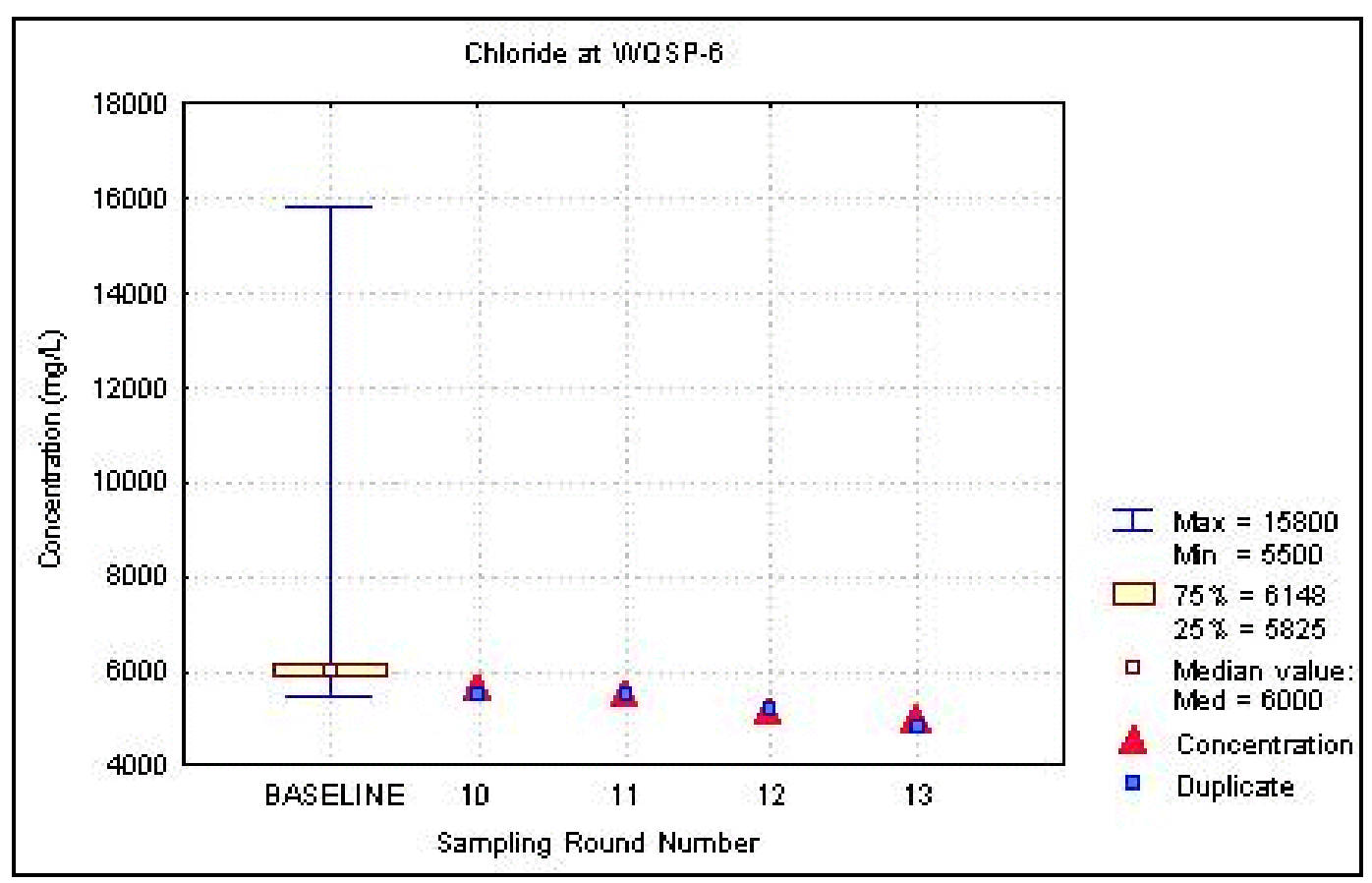

Figure F.95 - Time Trend Plot for Chloride at WQSP-6 


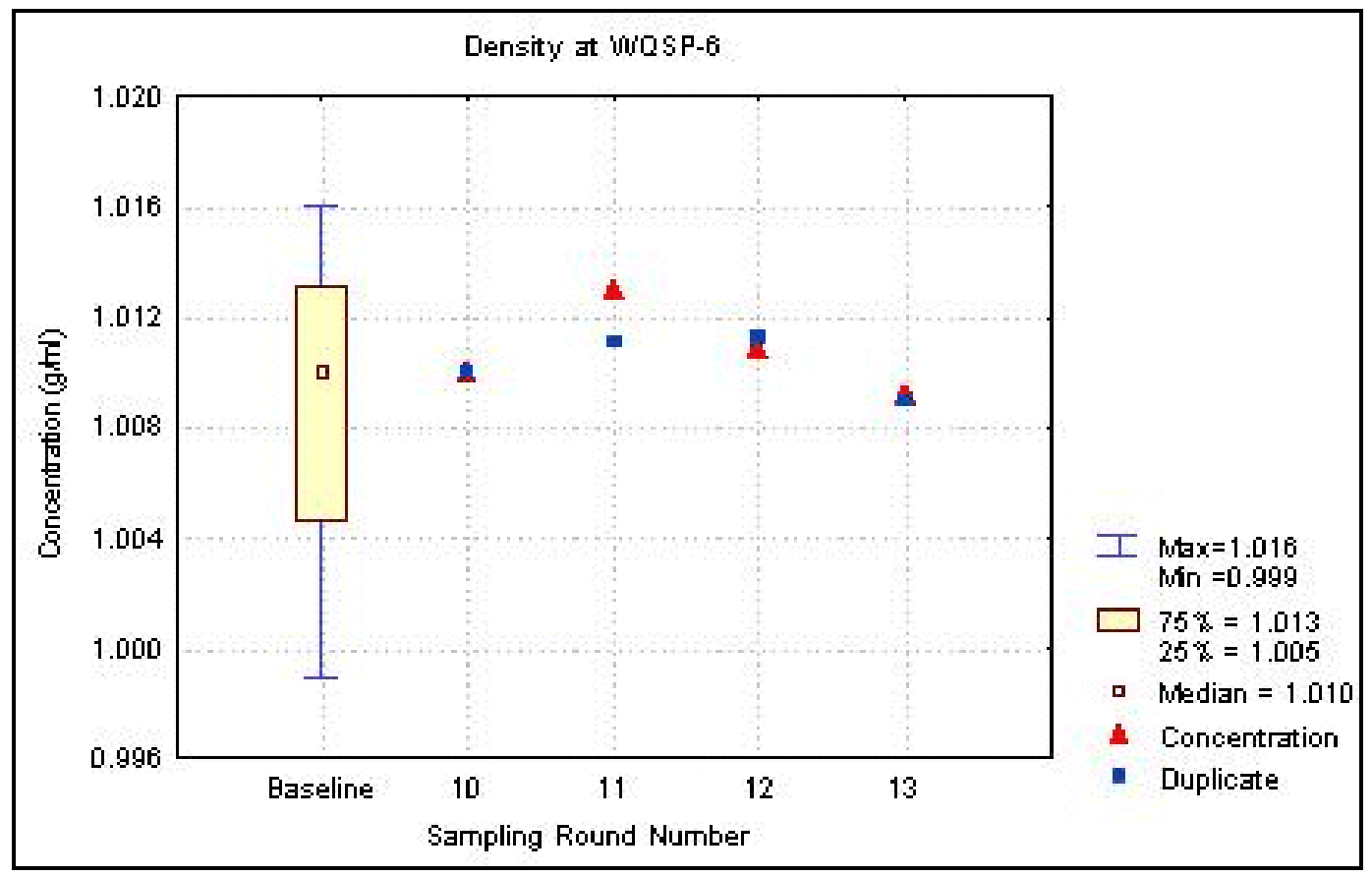

Figure F.96 - Time Trend Plot for Density at WQSP-6

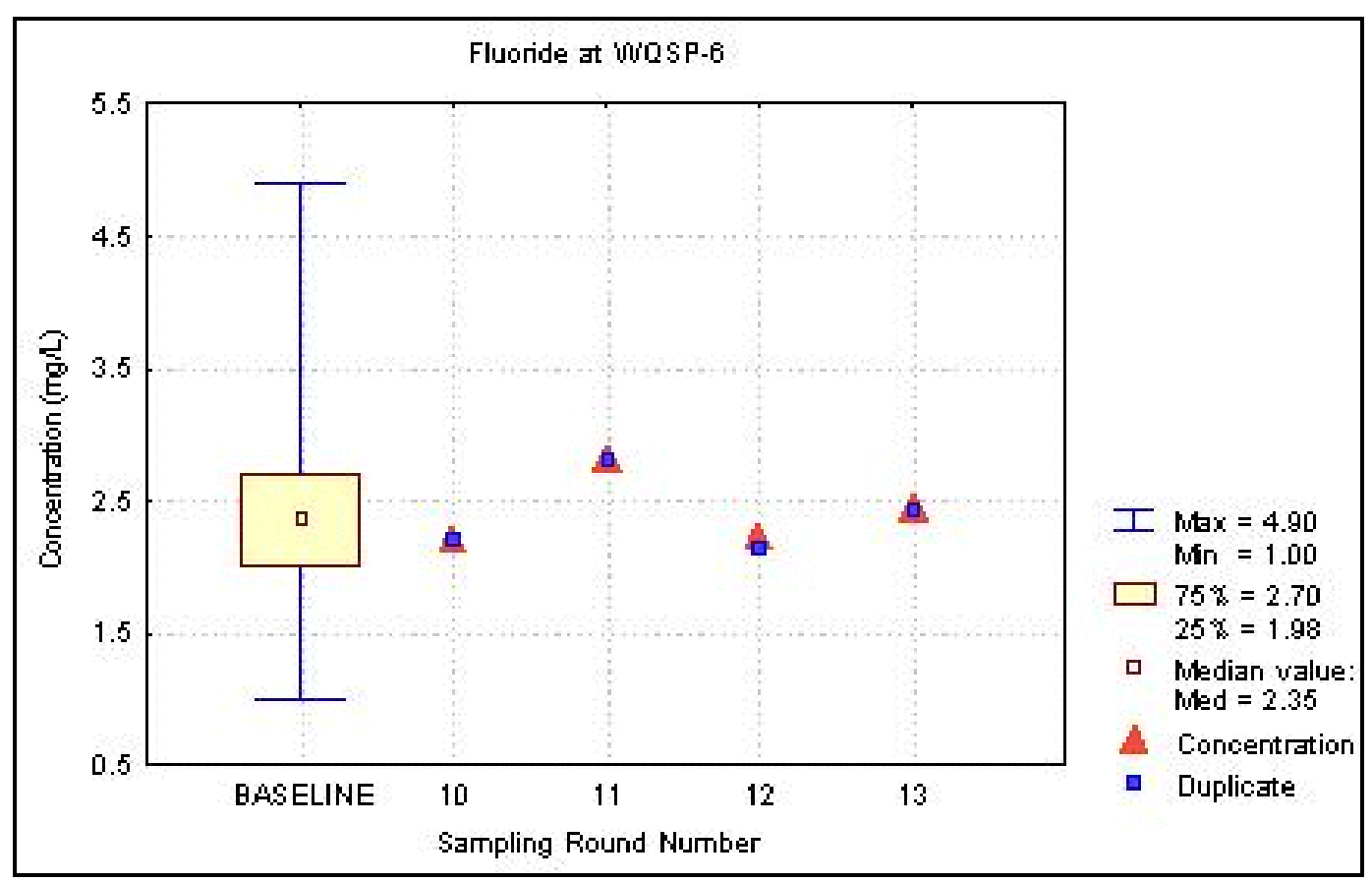

Figure F.97 - Time Trend Plot for Fluoride at WQSP-6 


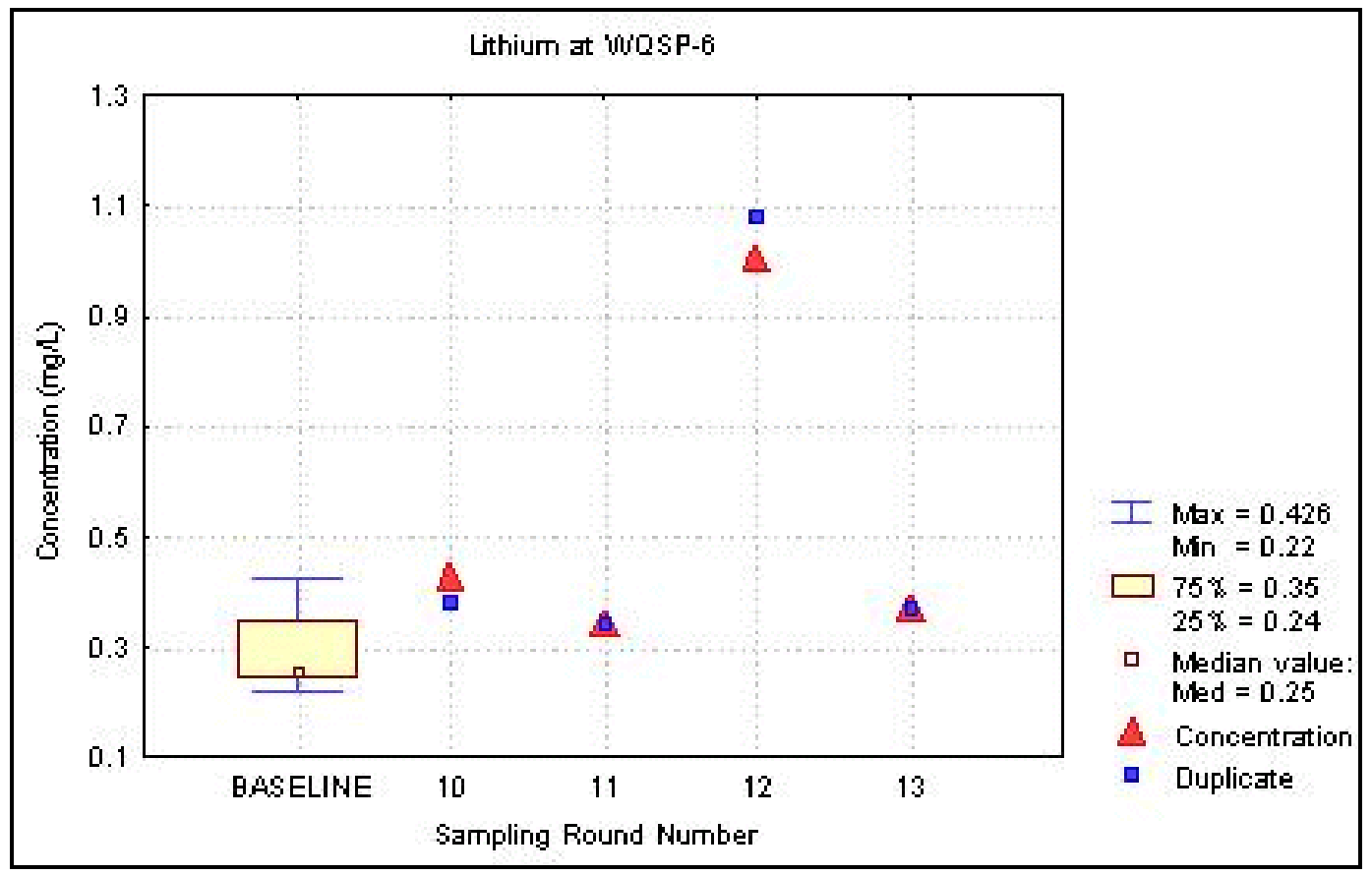

Figure F.98 - Time Trend Plot for Lithium at WQSP-6

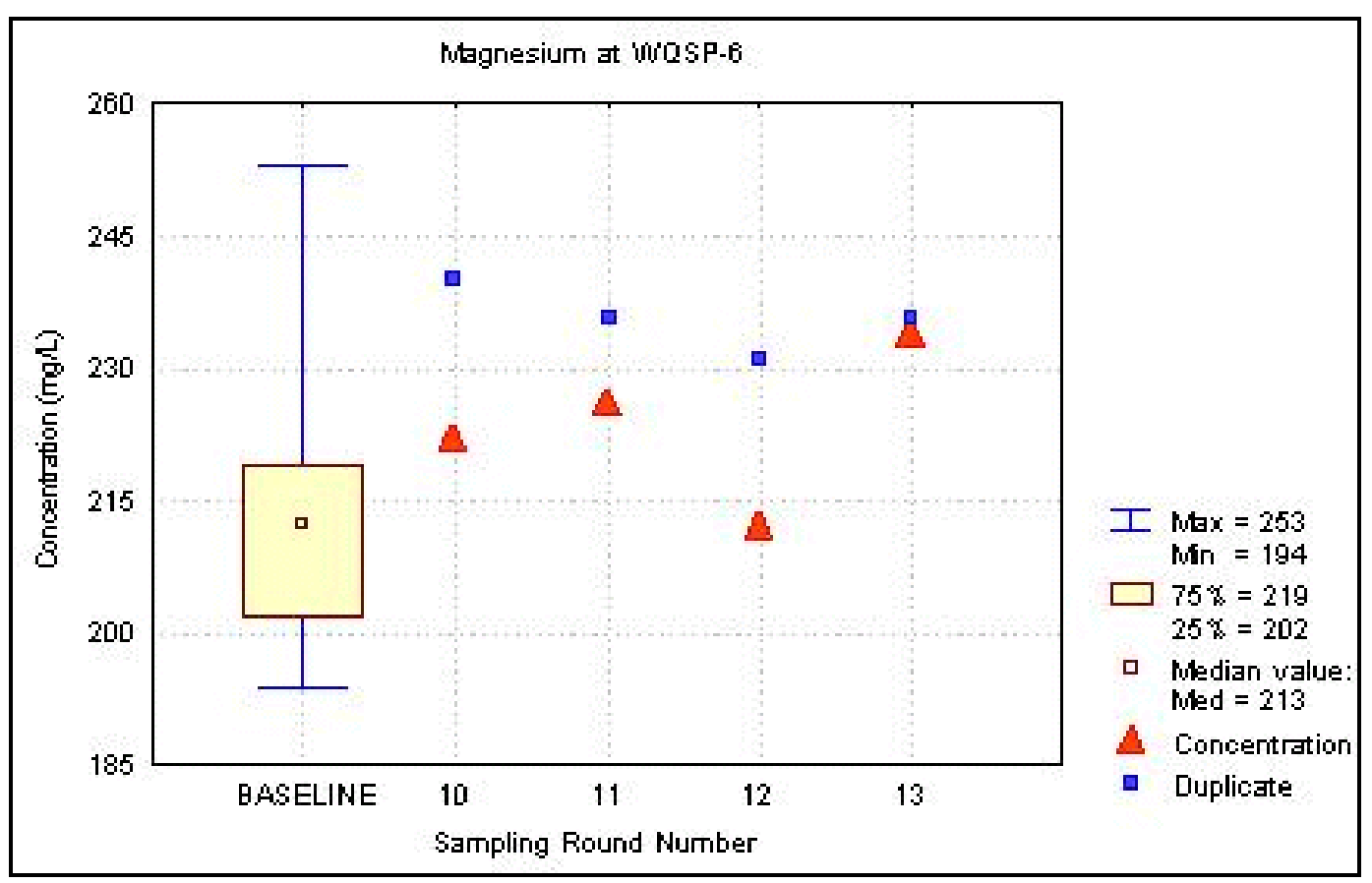

Figure F.99 - Time Trend Plot for Magnesium at WQSP-6 


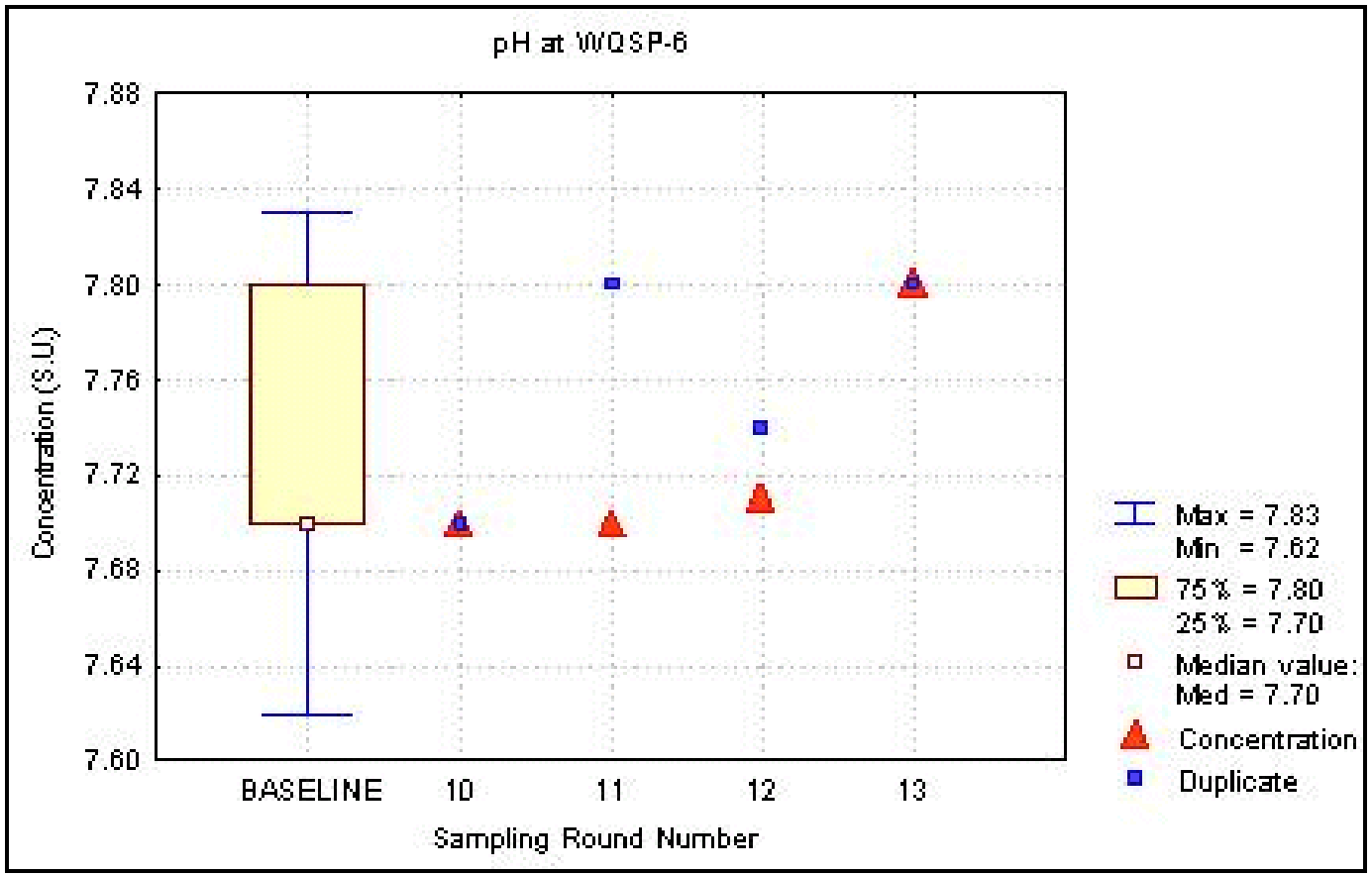

Figure F.100 - Time Trend Plot for pH at WQSP-6

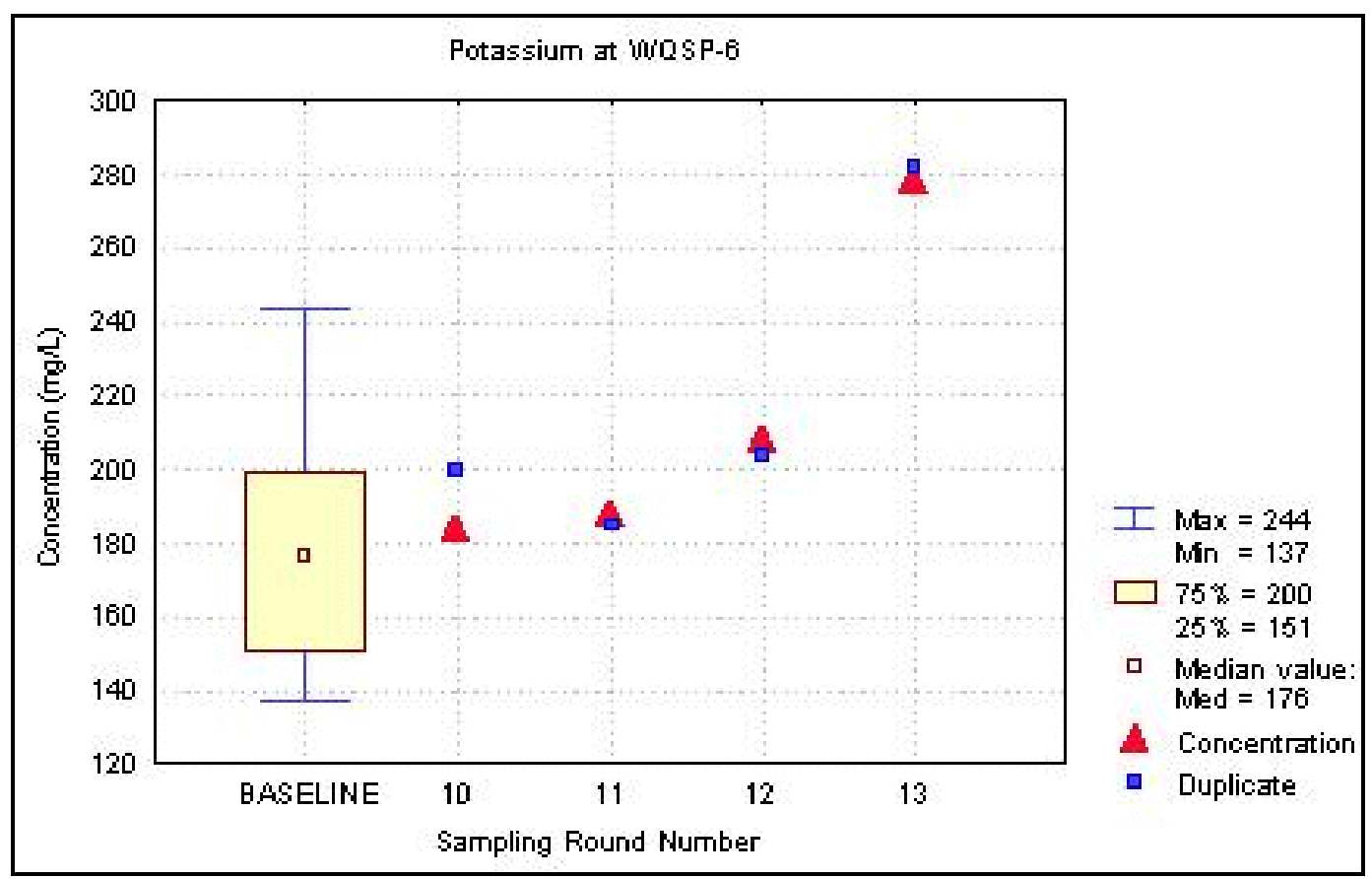

Figure F.101 - Time Trend Plot for Potassium at WQSP-6 


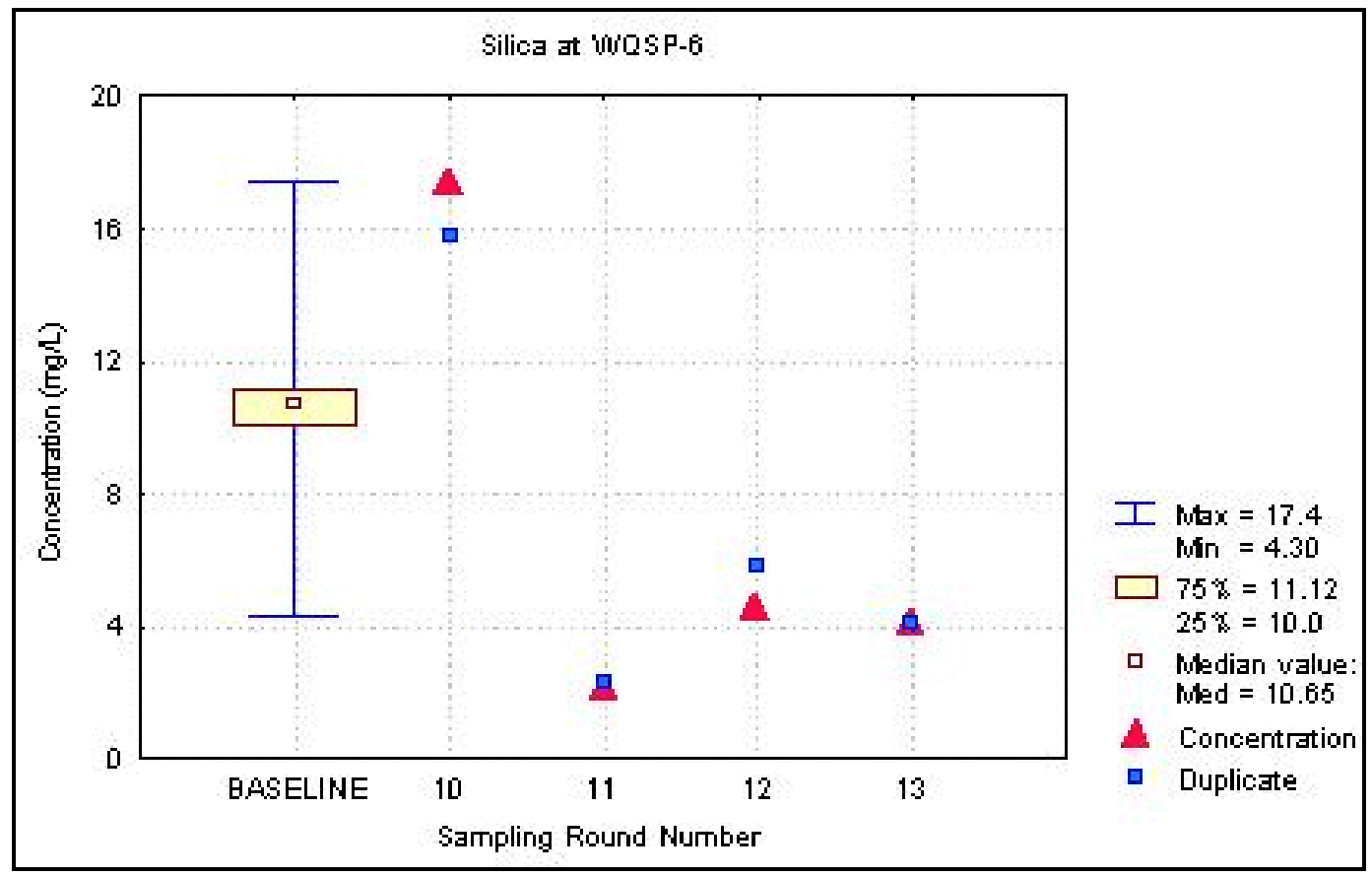

Figure F.102 - Time Trend Plot for Silica at WQSP-6

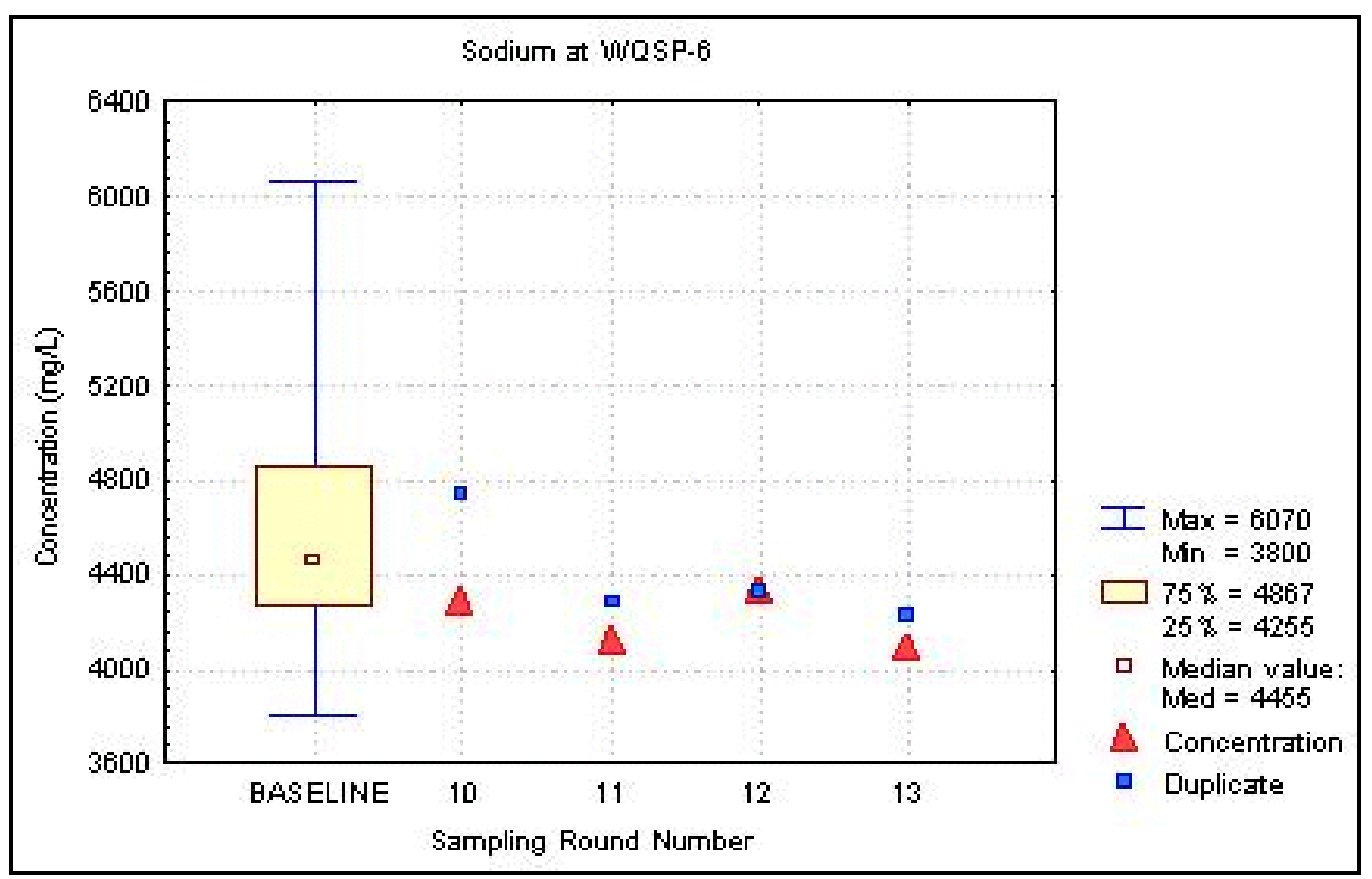

Figure F.103 - Time Trend Plot for Sodium at WQSP-6 


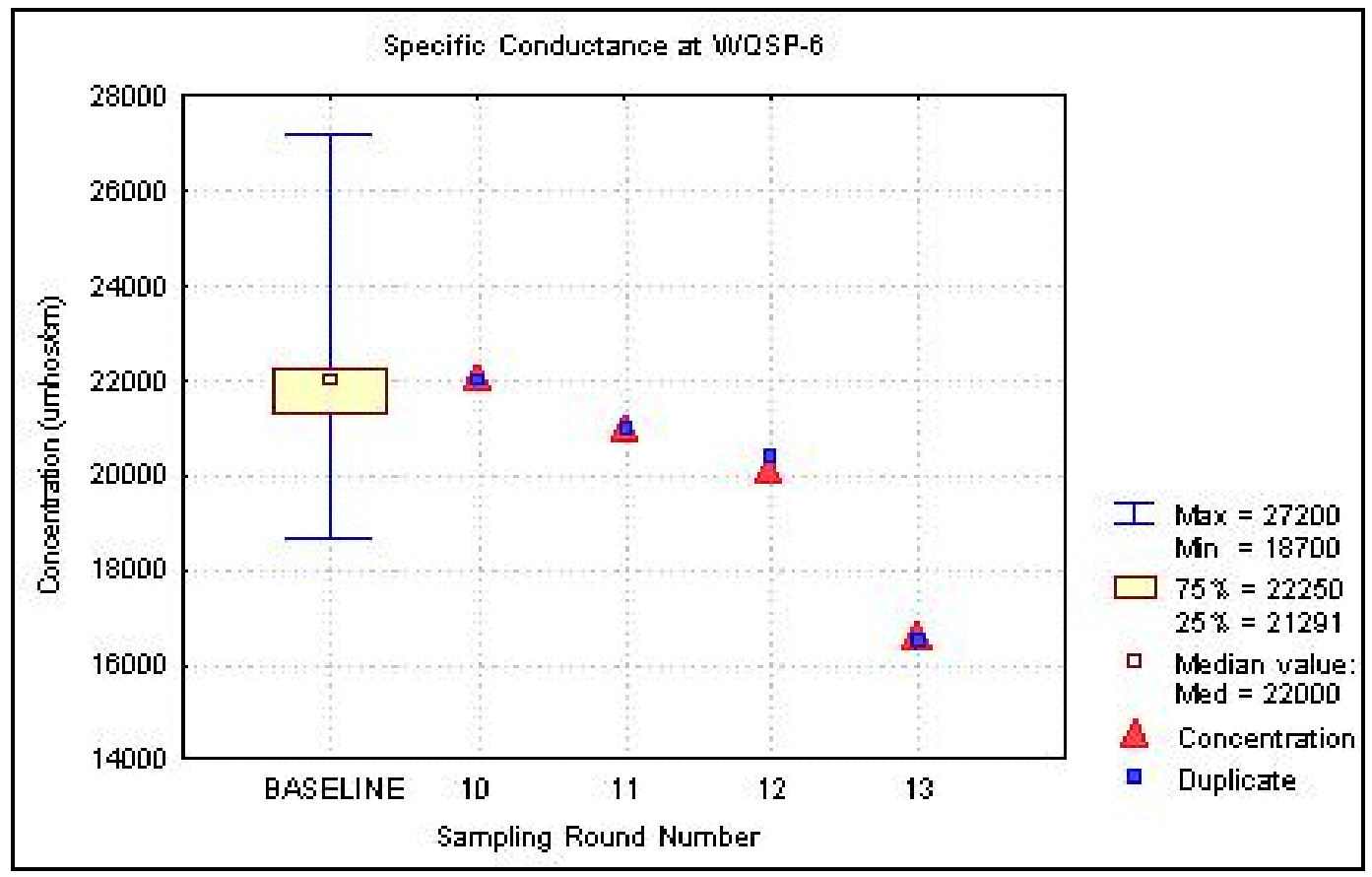

Figure F.104 - Time Trend for Specific Conductance at WQSP-6

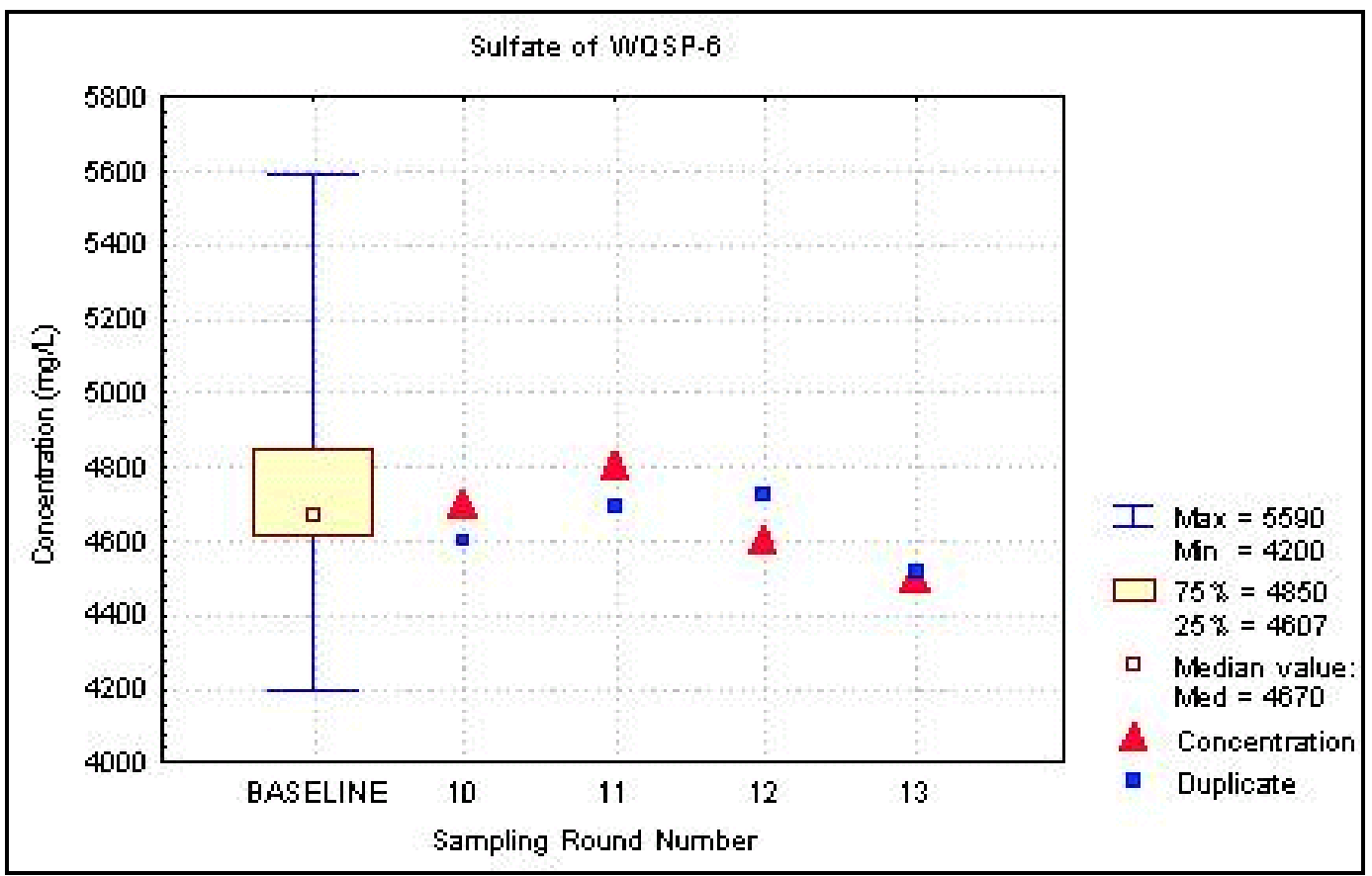

Figure F.105 - Time Trend Plot for Sulfate at WQSP-6 


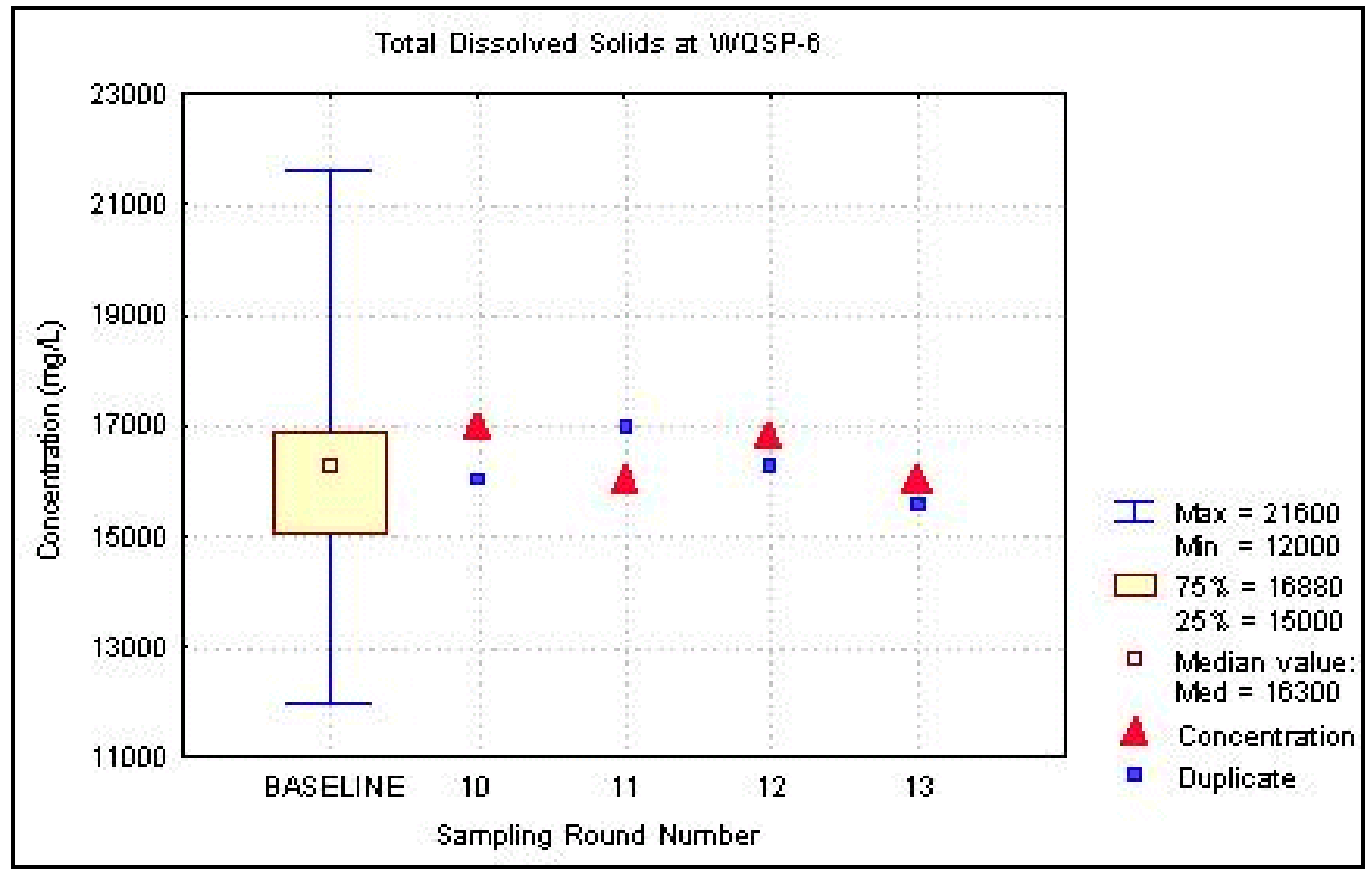

Figure F.106 - Time Trend Plot for Total Dissolved Solids at WQSP-6

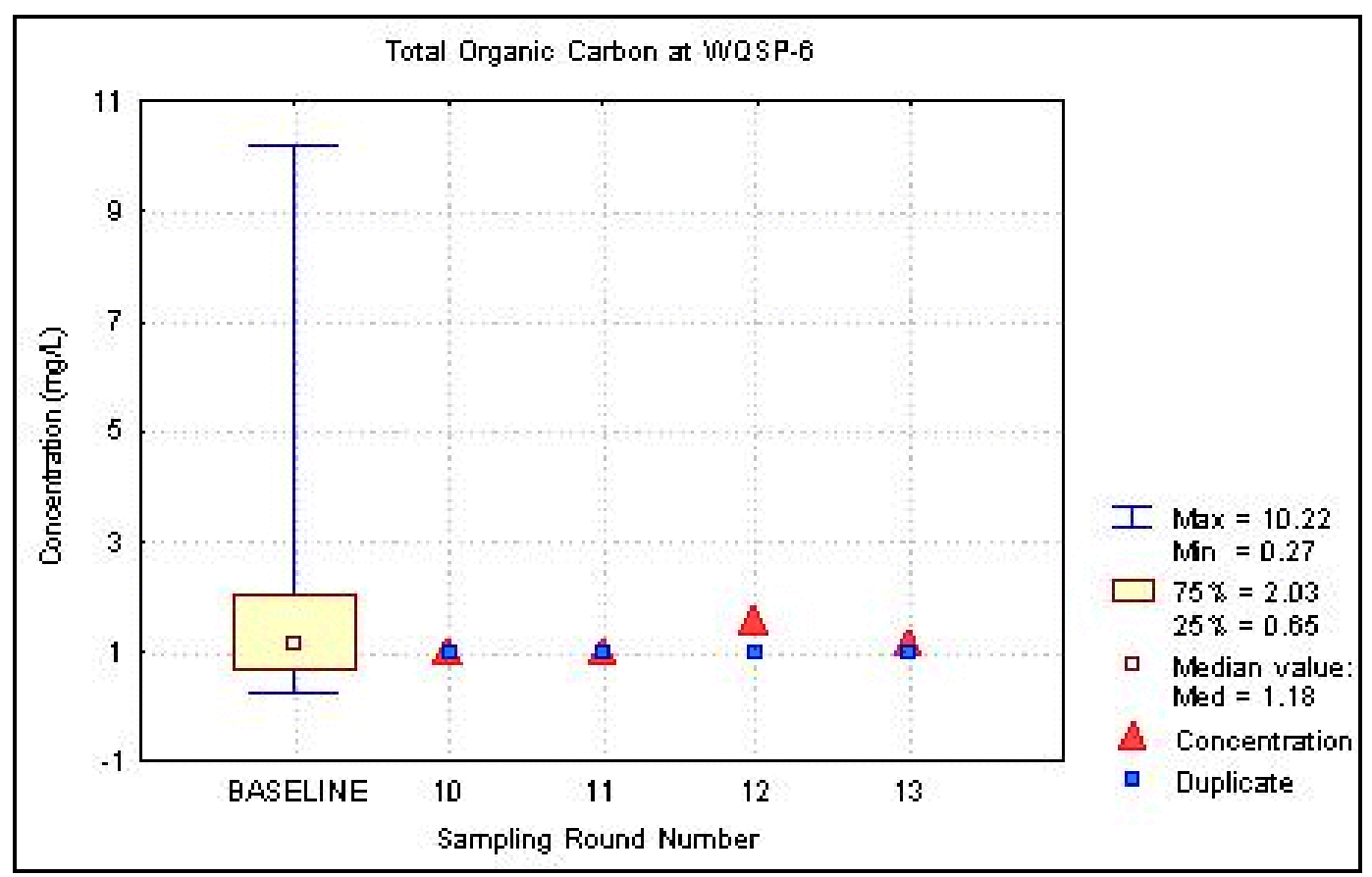

Figure F.107 - Time Trend Plot for Total Organic Carbon at WQSP-6 


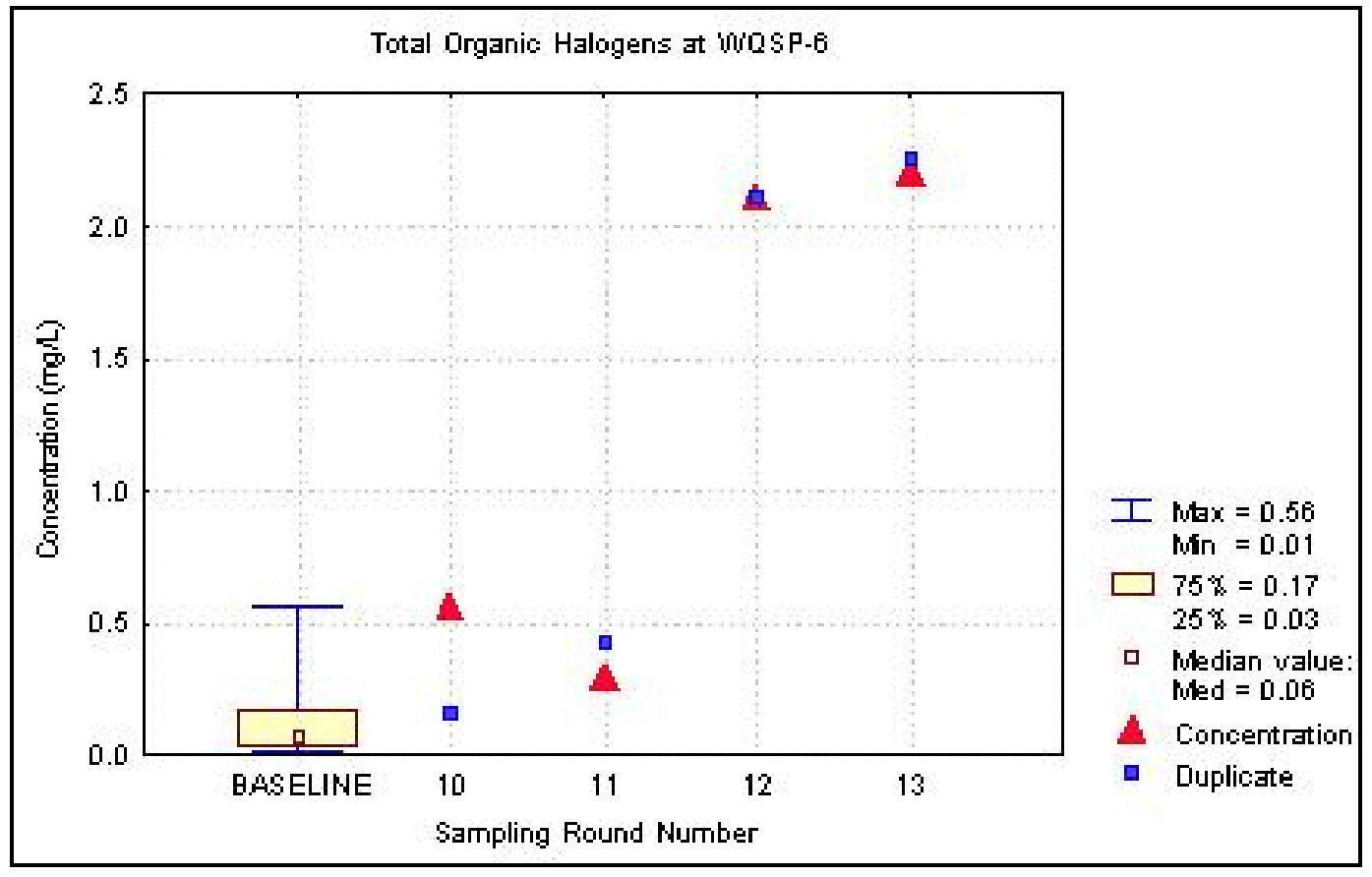

Figure F.108 - Time Trend Plot for Total Organic Halogens at WQSP-6

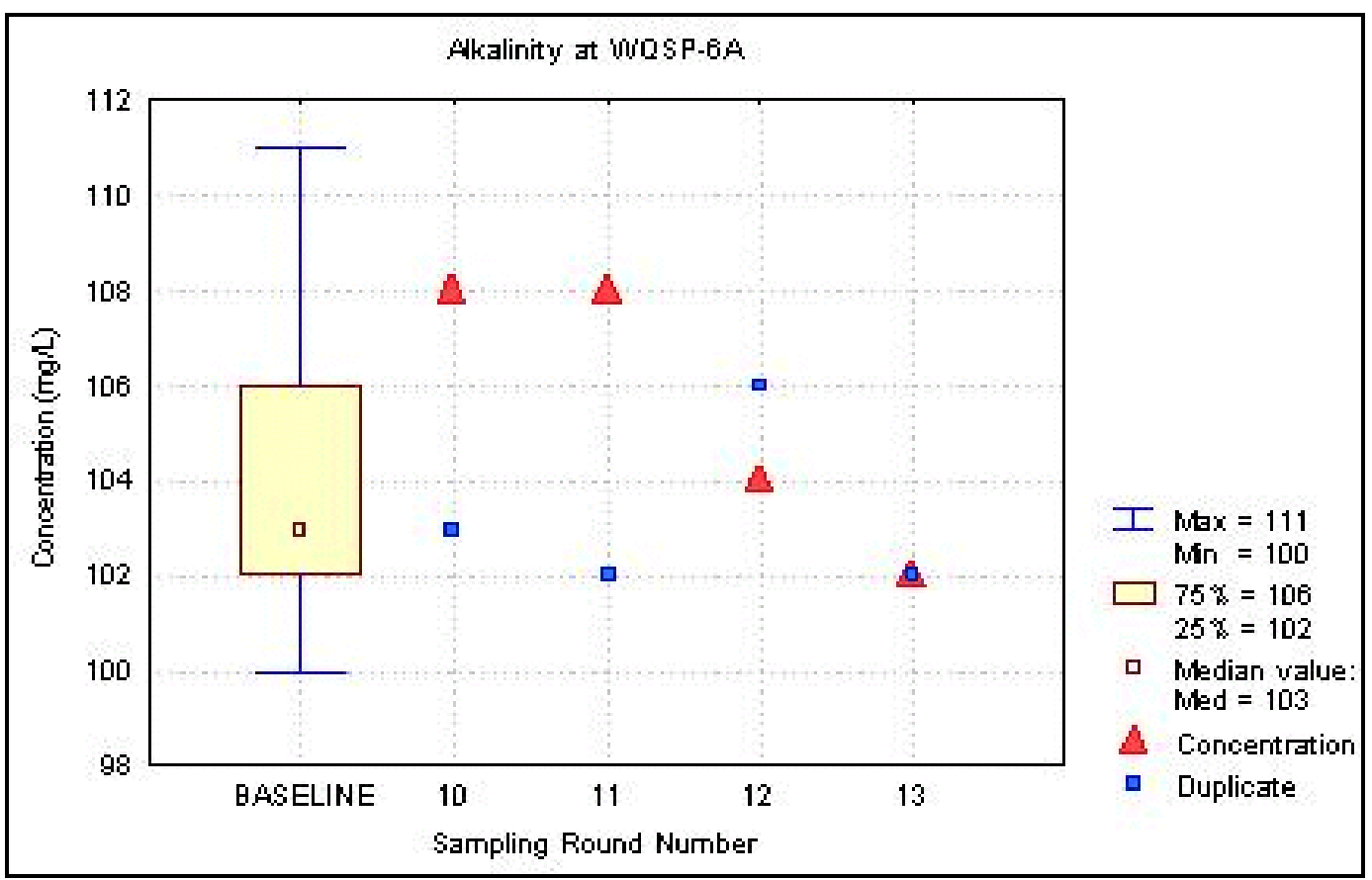

Figure F.109 - Time Trend Plot for Alkalinity at WQSP-6A 


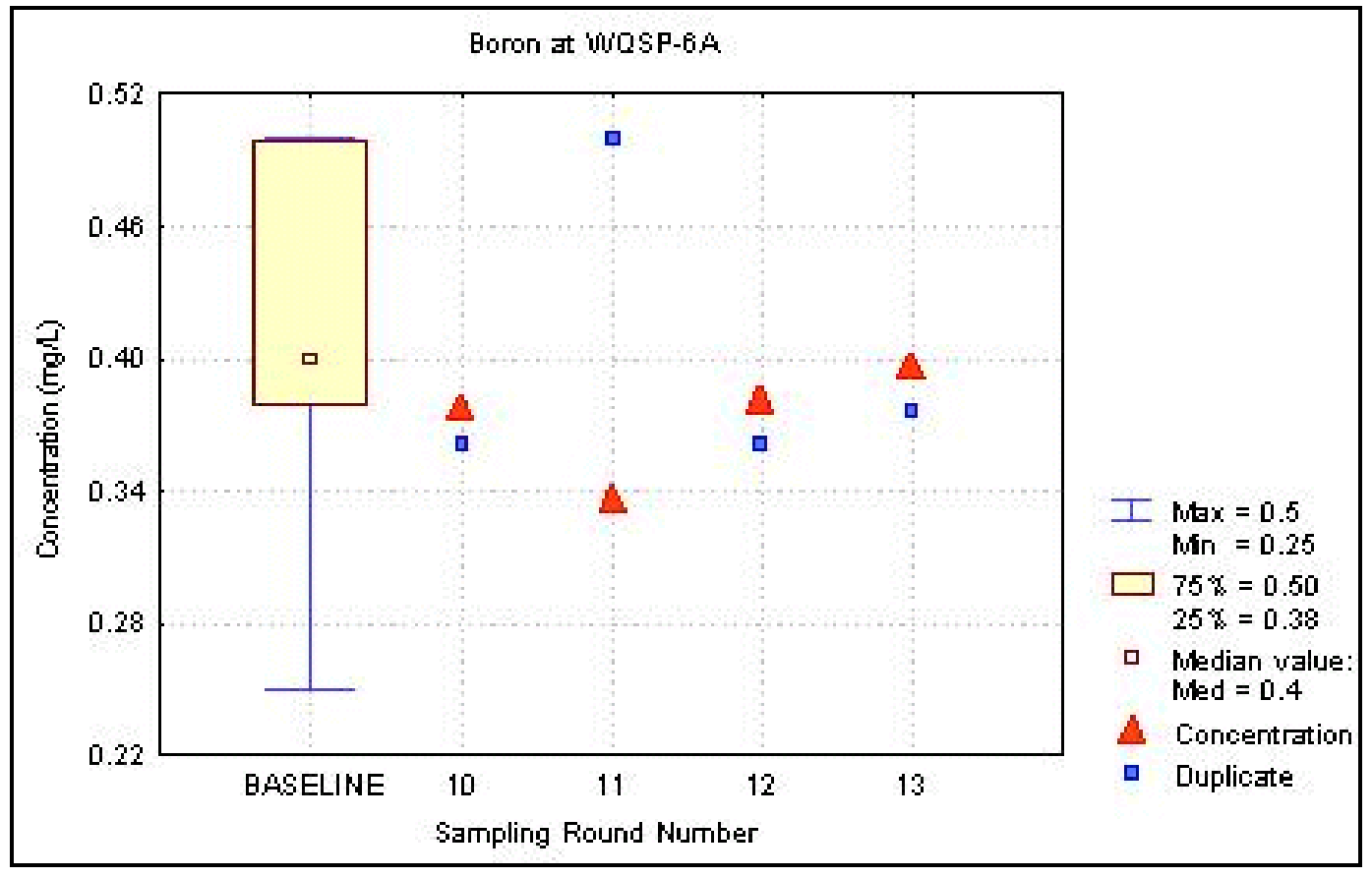

Figure F.110 - Time Trend Plot for Boron at WQSP-6A

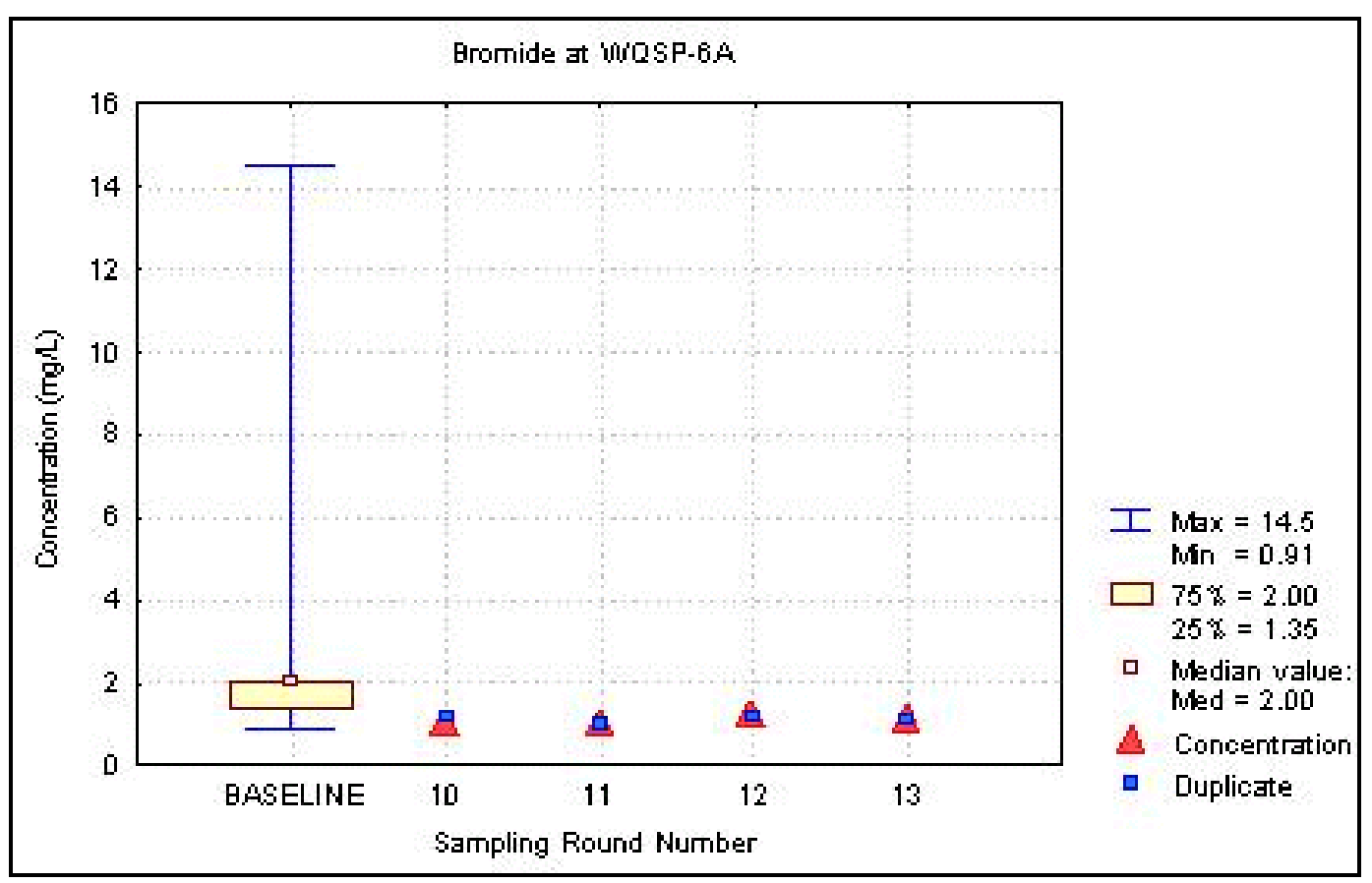

Figure F.111 - Time Trend Plot for Bromide at WQSP-6A 


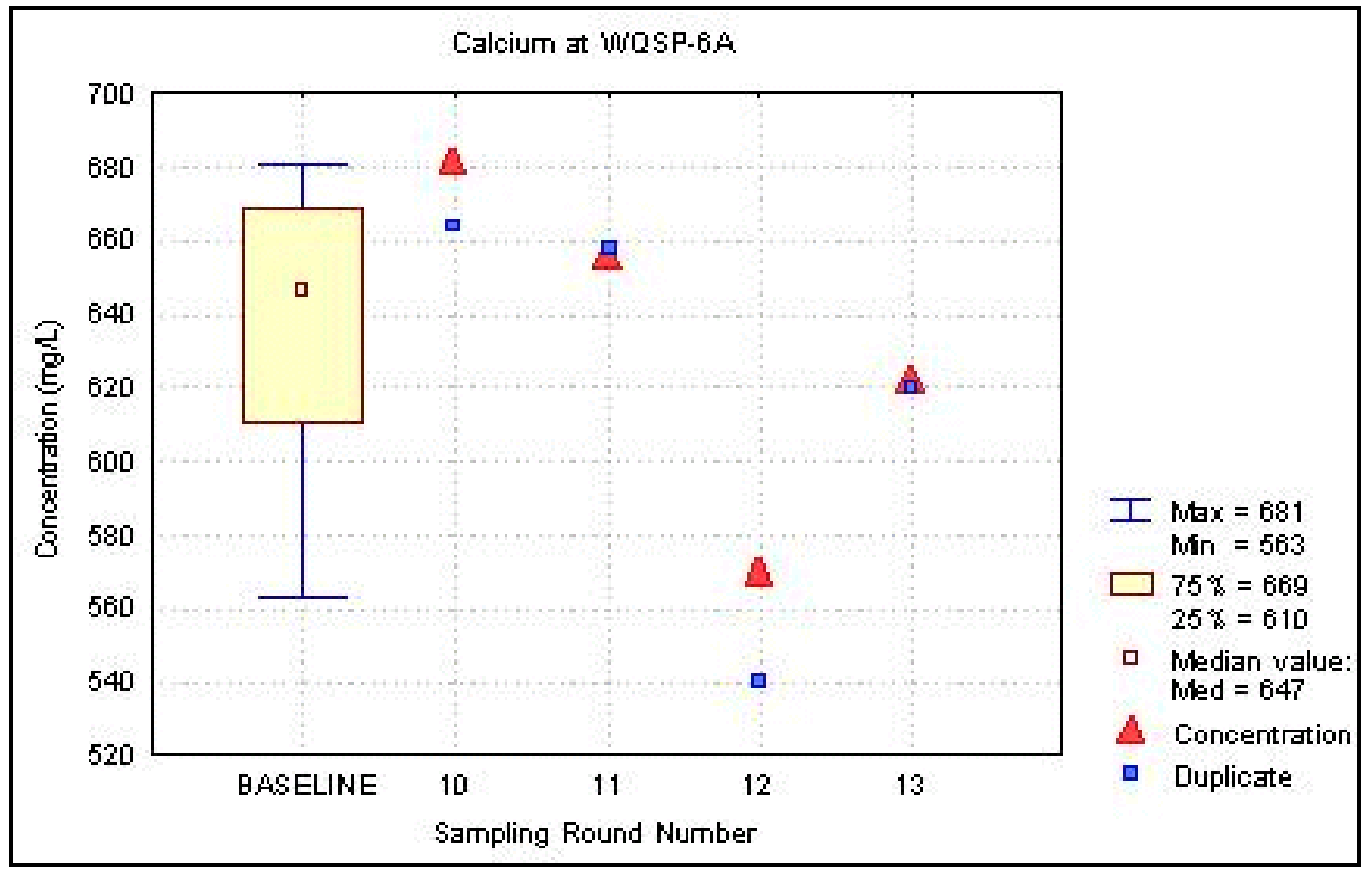

Figure F.112 - Time Trend Plot for Calcium at WQSP-6A

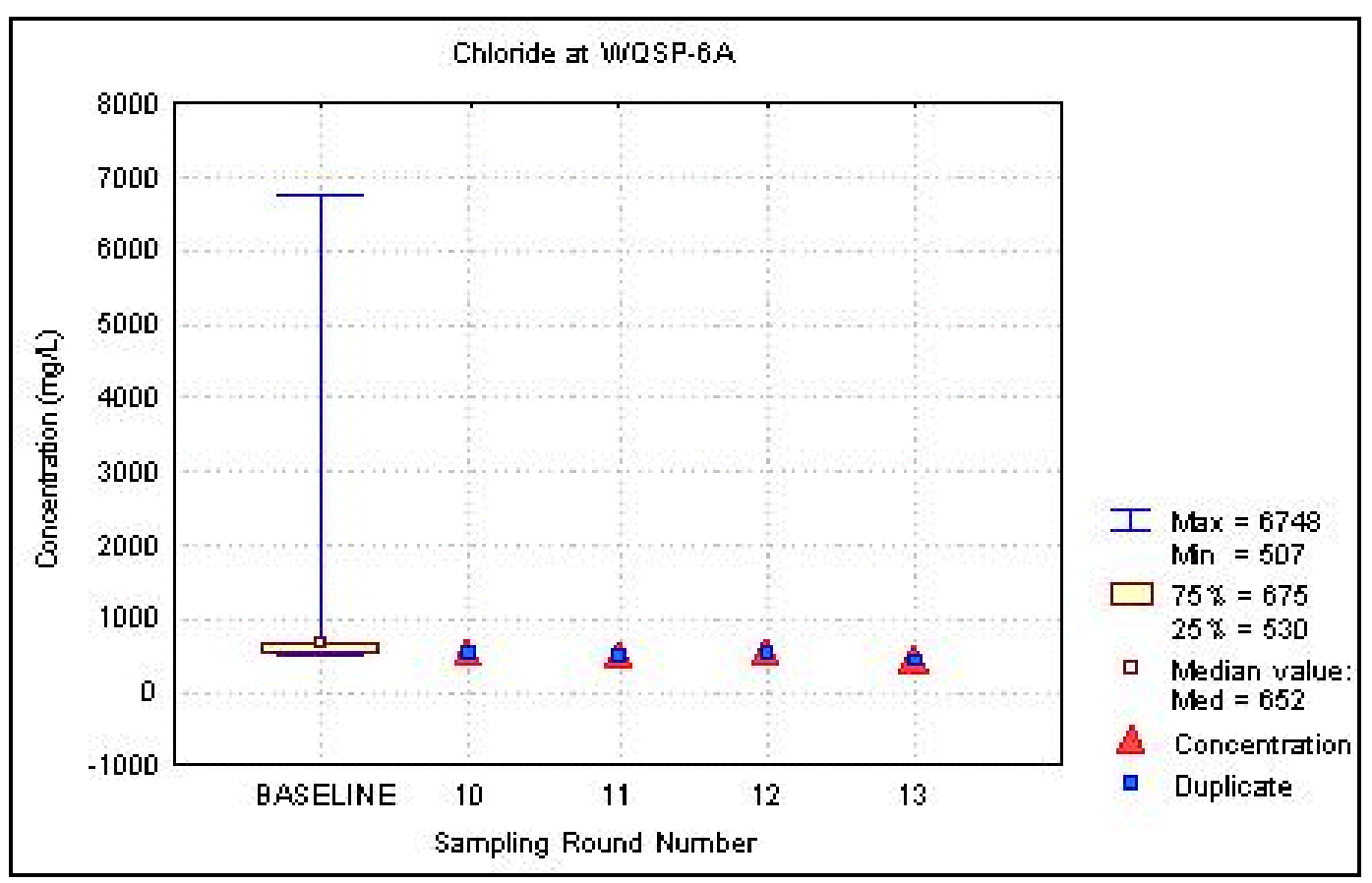

Figure F.113 - Time Trend Plot for Chloride at WQSP-6A 


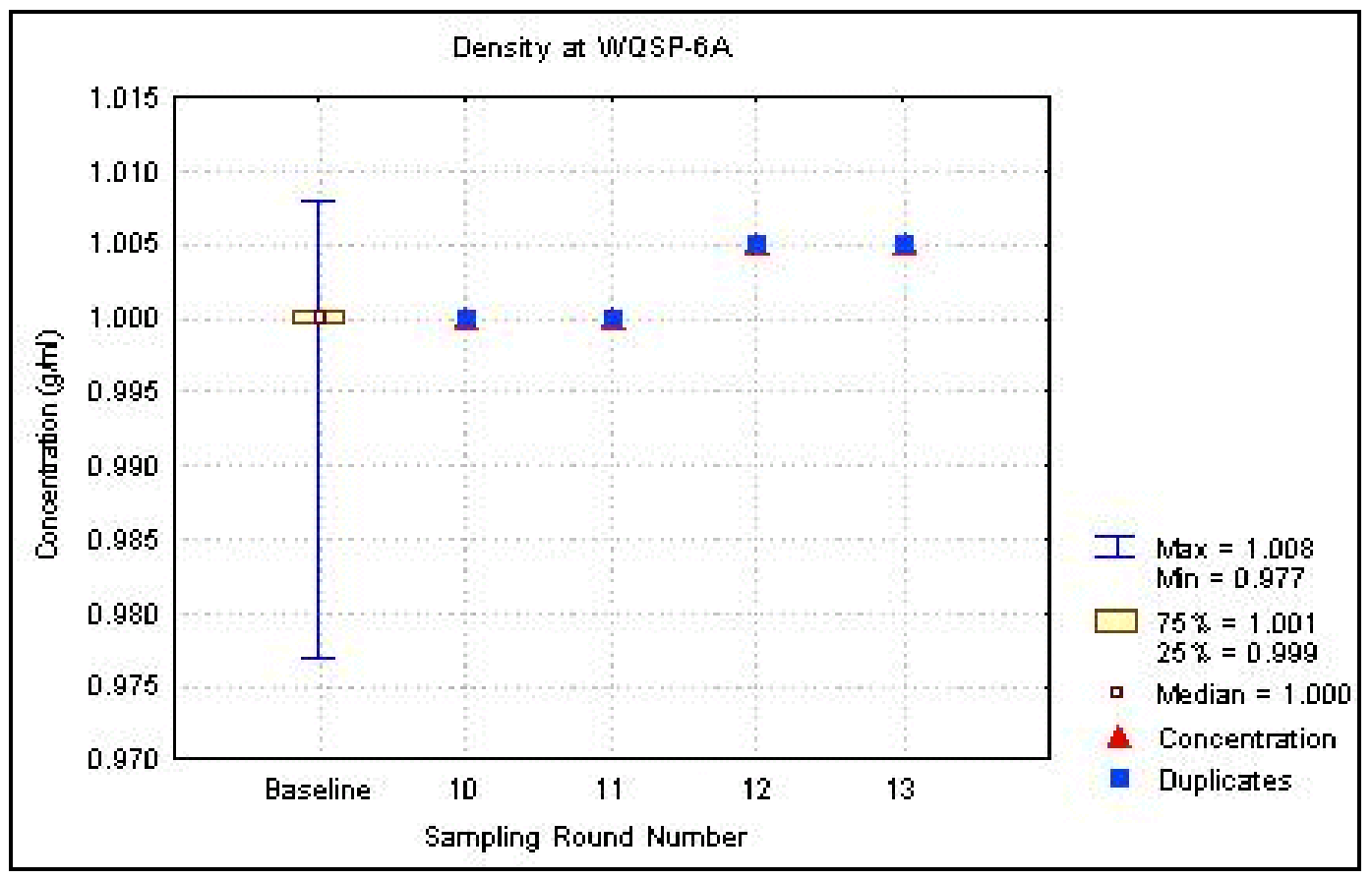

Figure F.114 - Time Trend Plot for Density at WQSP-6A

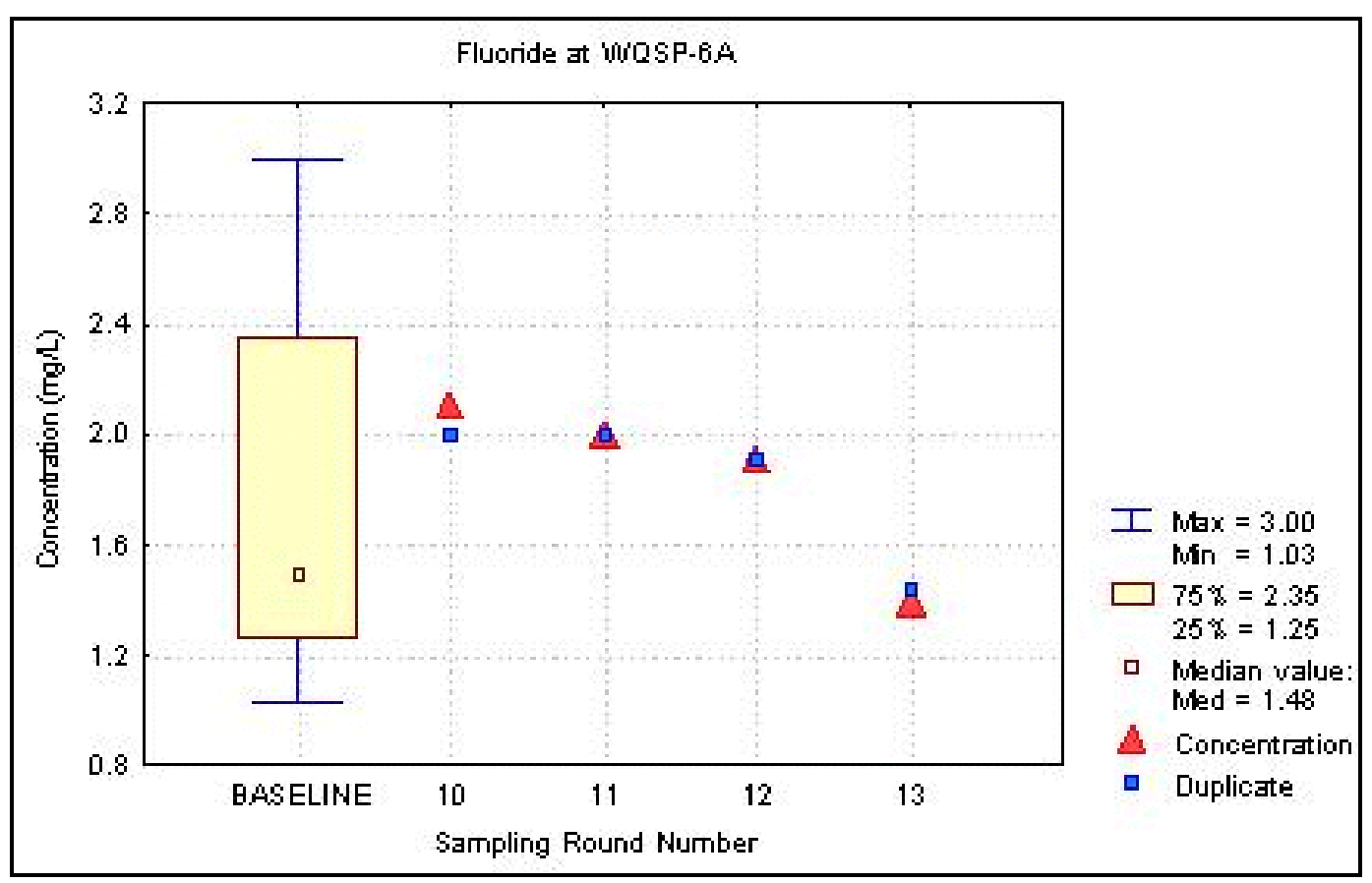

Figure F.115 - Time Trend Plot for Fluoride at WQSP-6A 


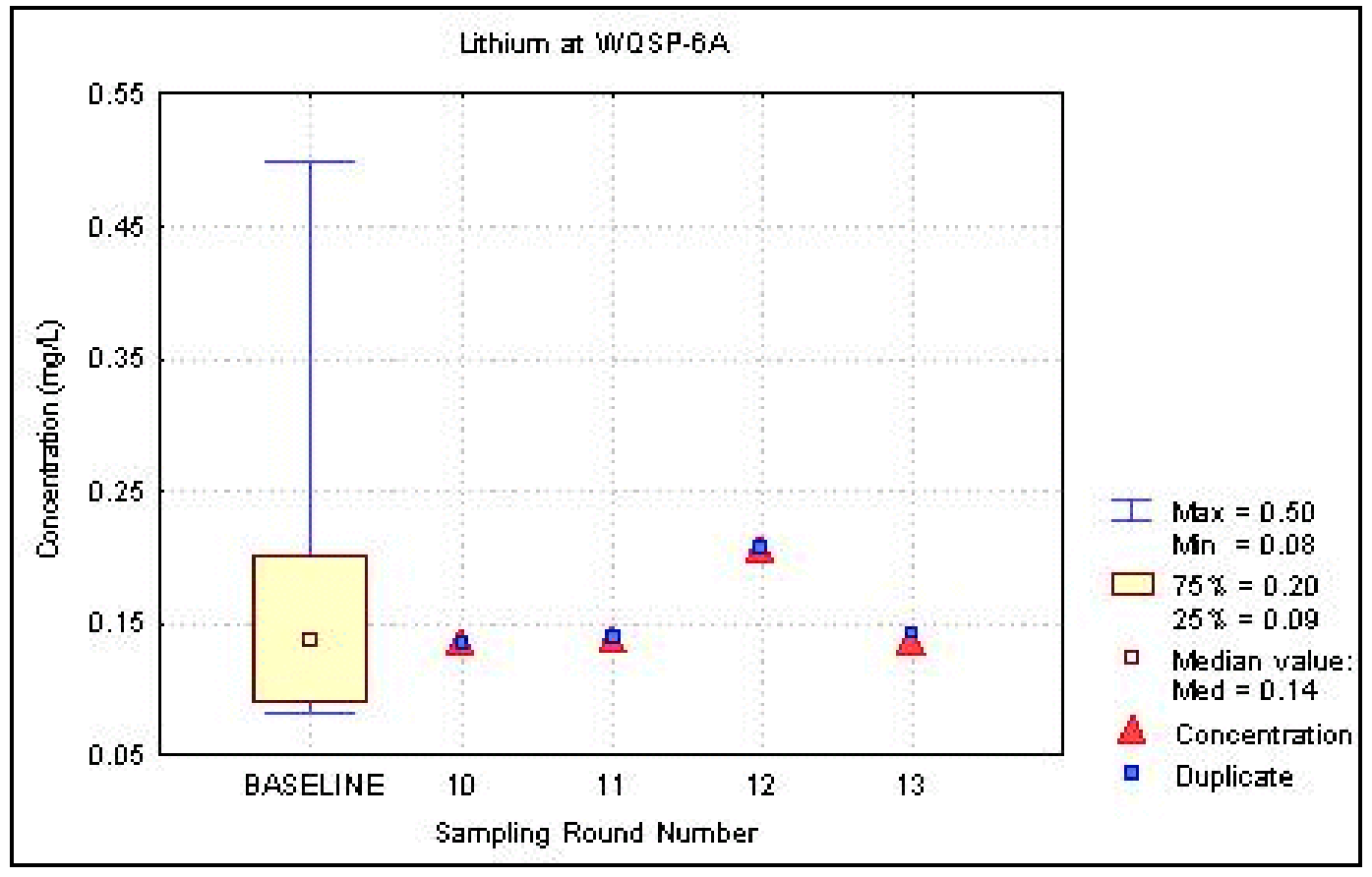

Figure F.116 - Time Trend Plot for Lithium at WQSP-6A

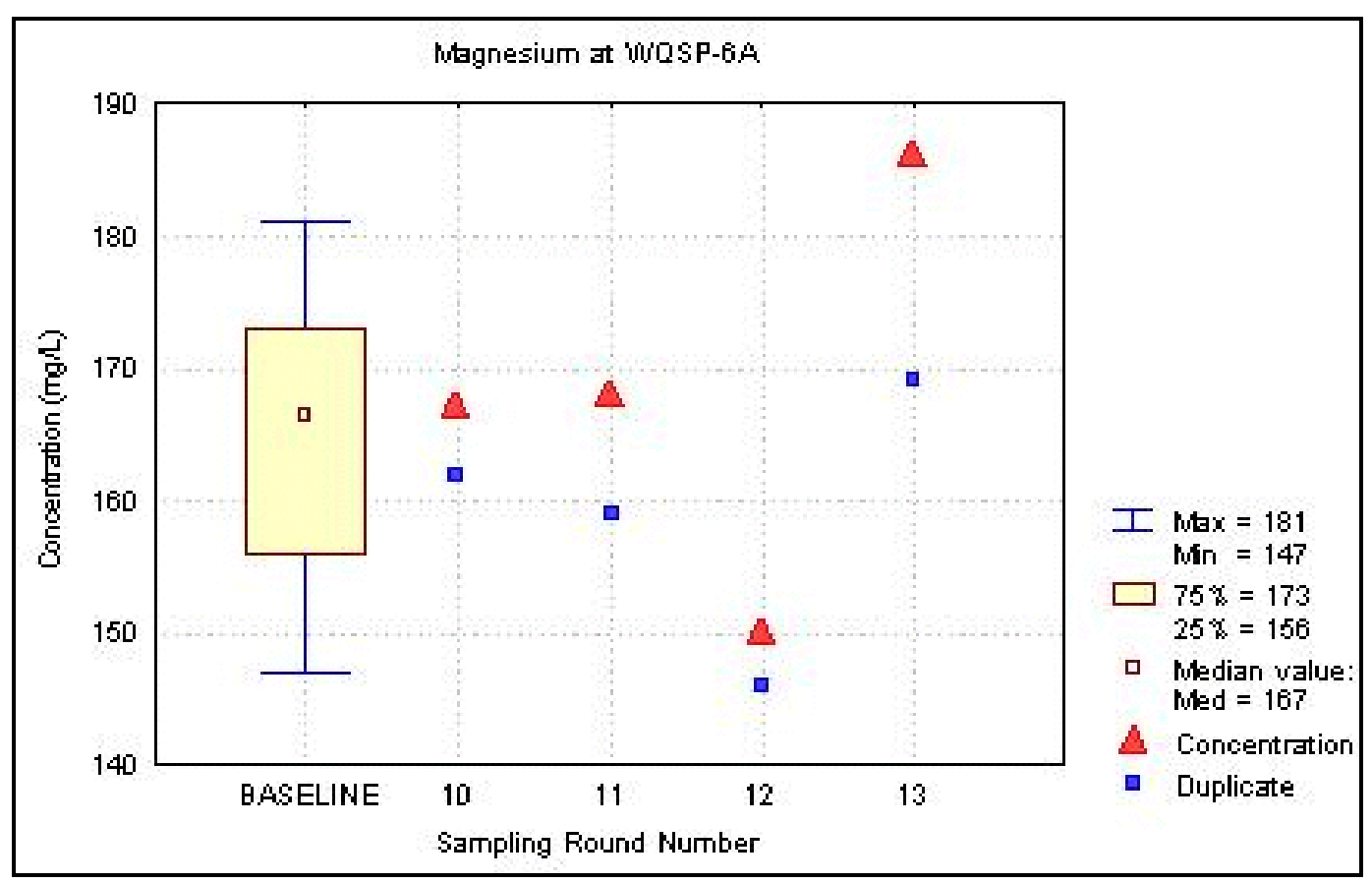

Figure F.117 - Time Trend Plot for Magnesium at WQSP-6A 


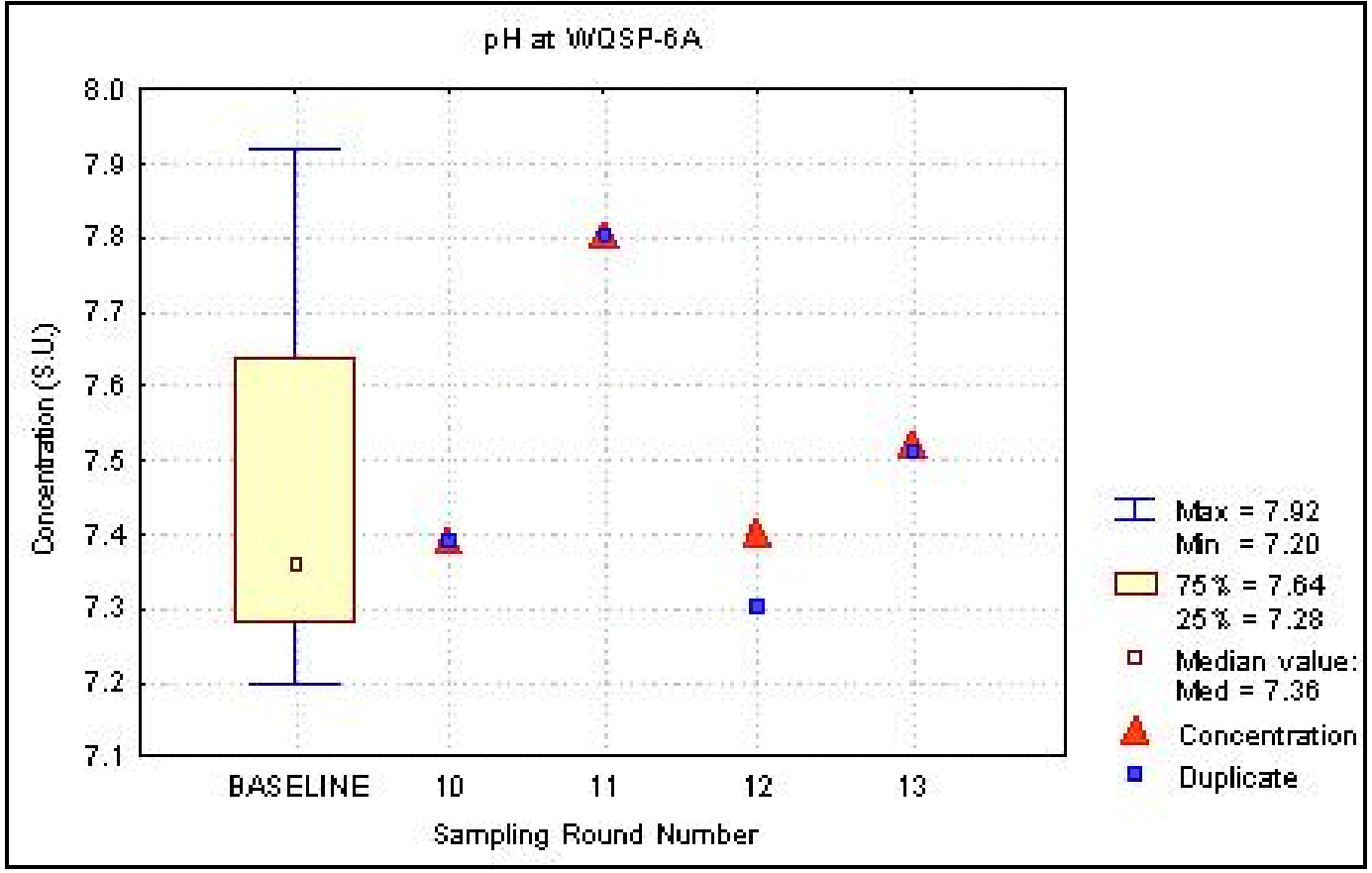

Figure F.118 - Time Trend Plot for $\mathrm{pH}$ at WQSP-6A

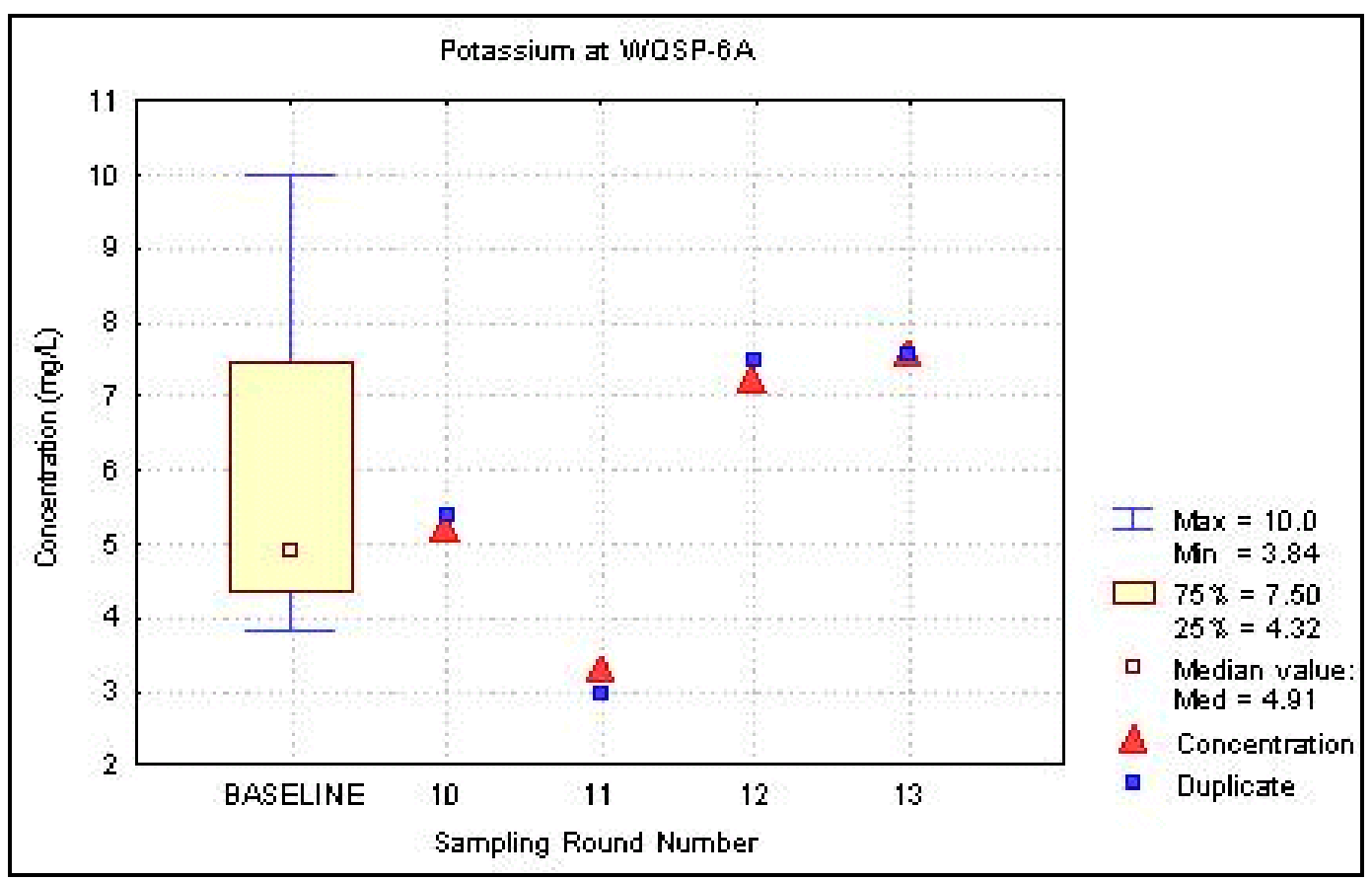

Figure F.119 - Time Trend Plot for Potassium at WQSP-6A 


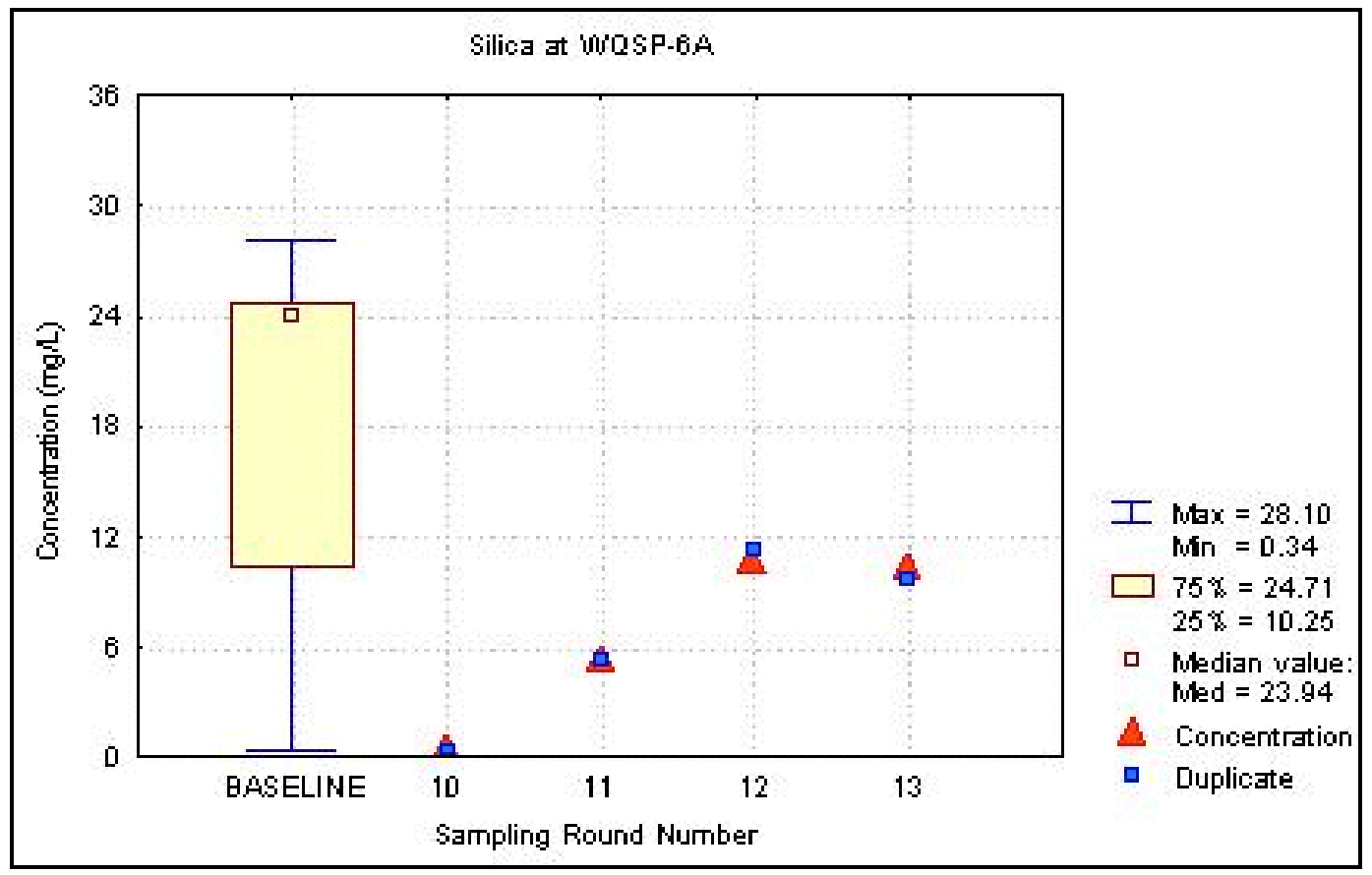

Figure F.120 - Time Trend Plot for Silica at WQSP-6A

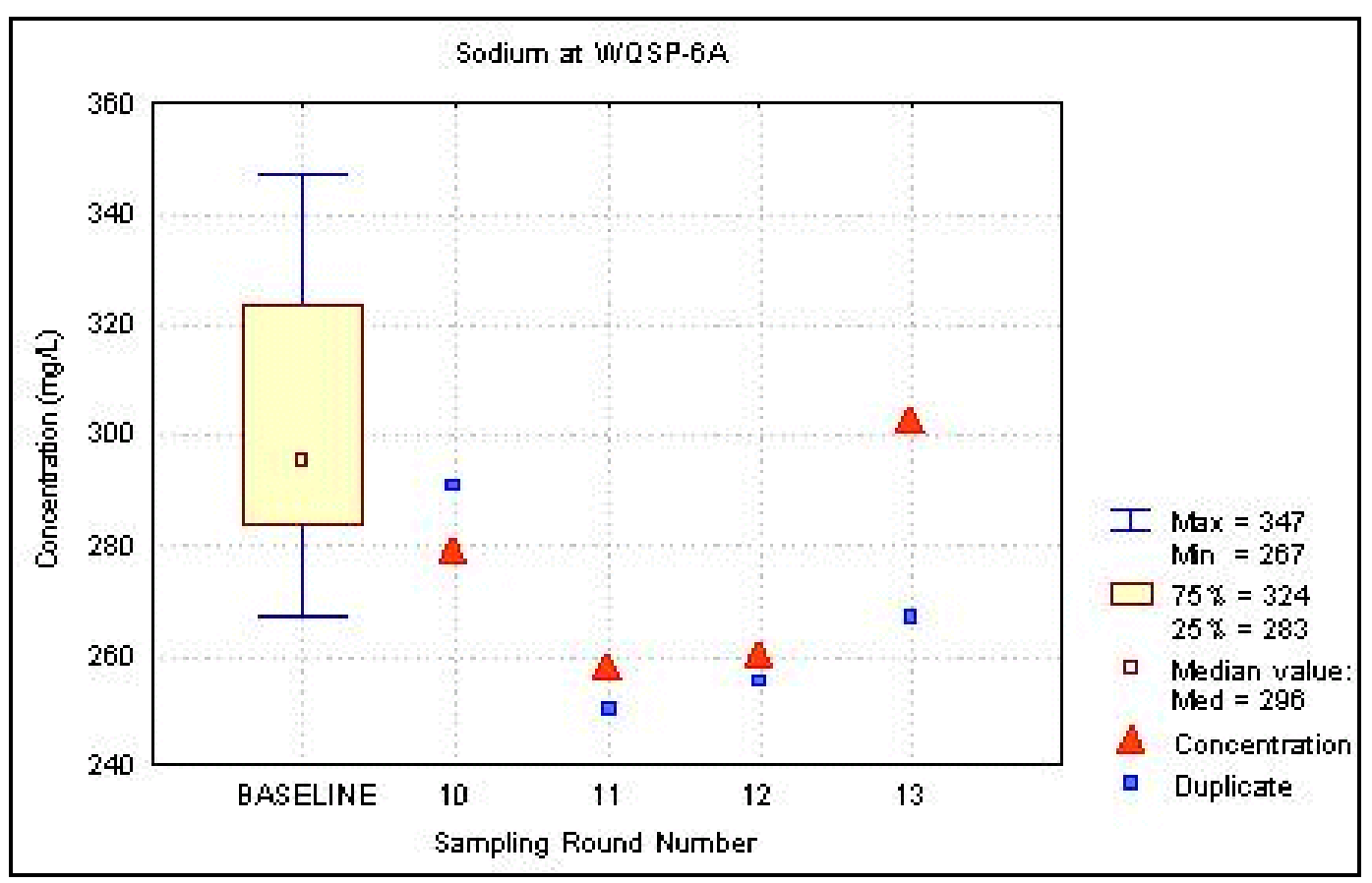

Figure F.121 - Time Trend Plot for Sodium at WQSP-6A 


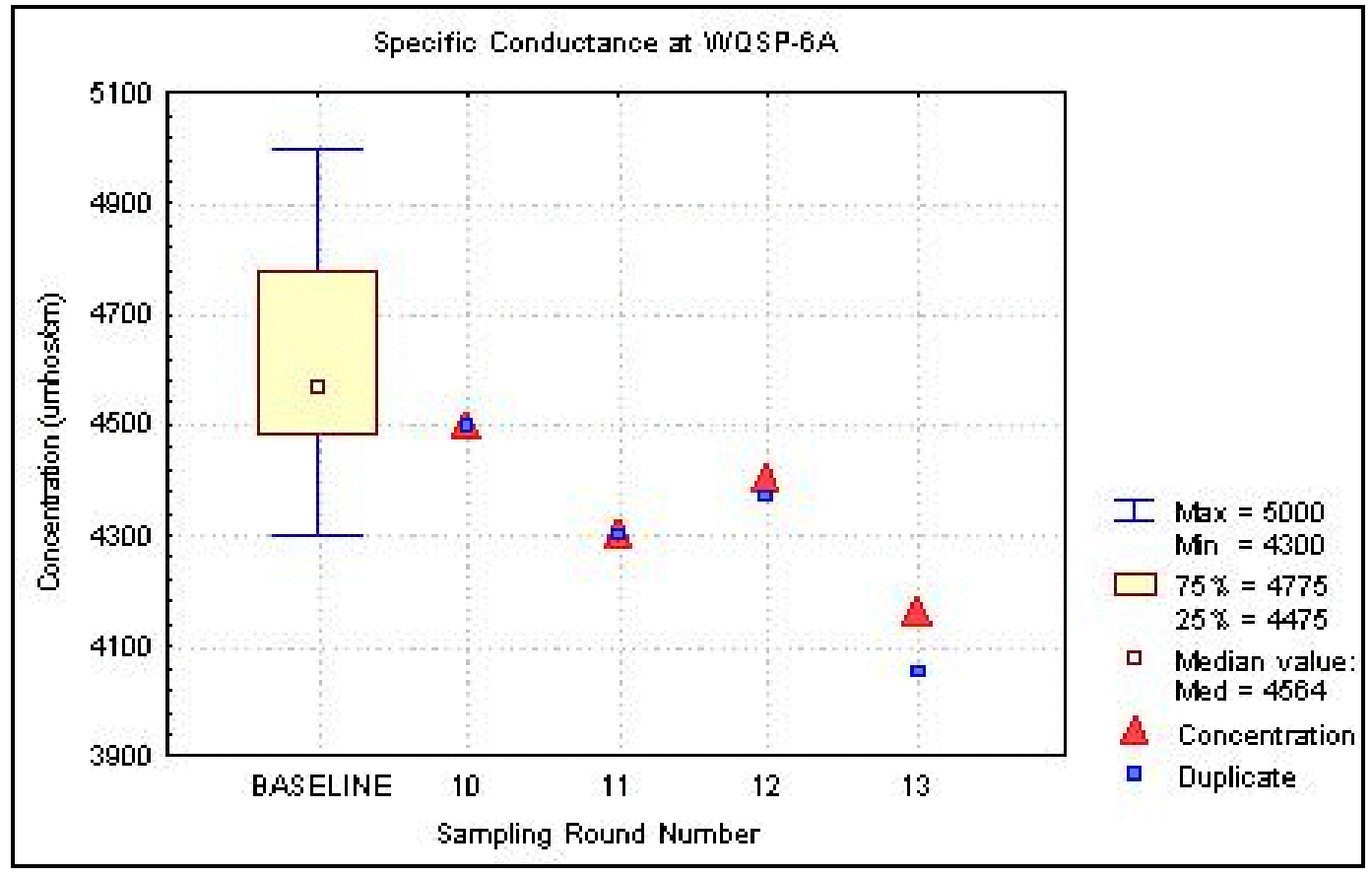

Figure F.122 - Time Trend Plot for Specific Conductance at WQSP-6A

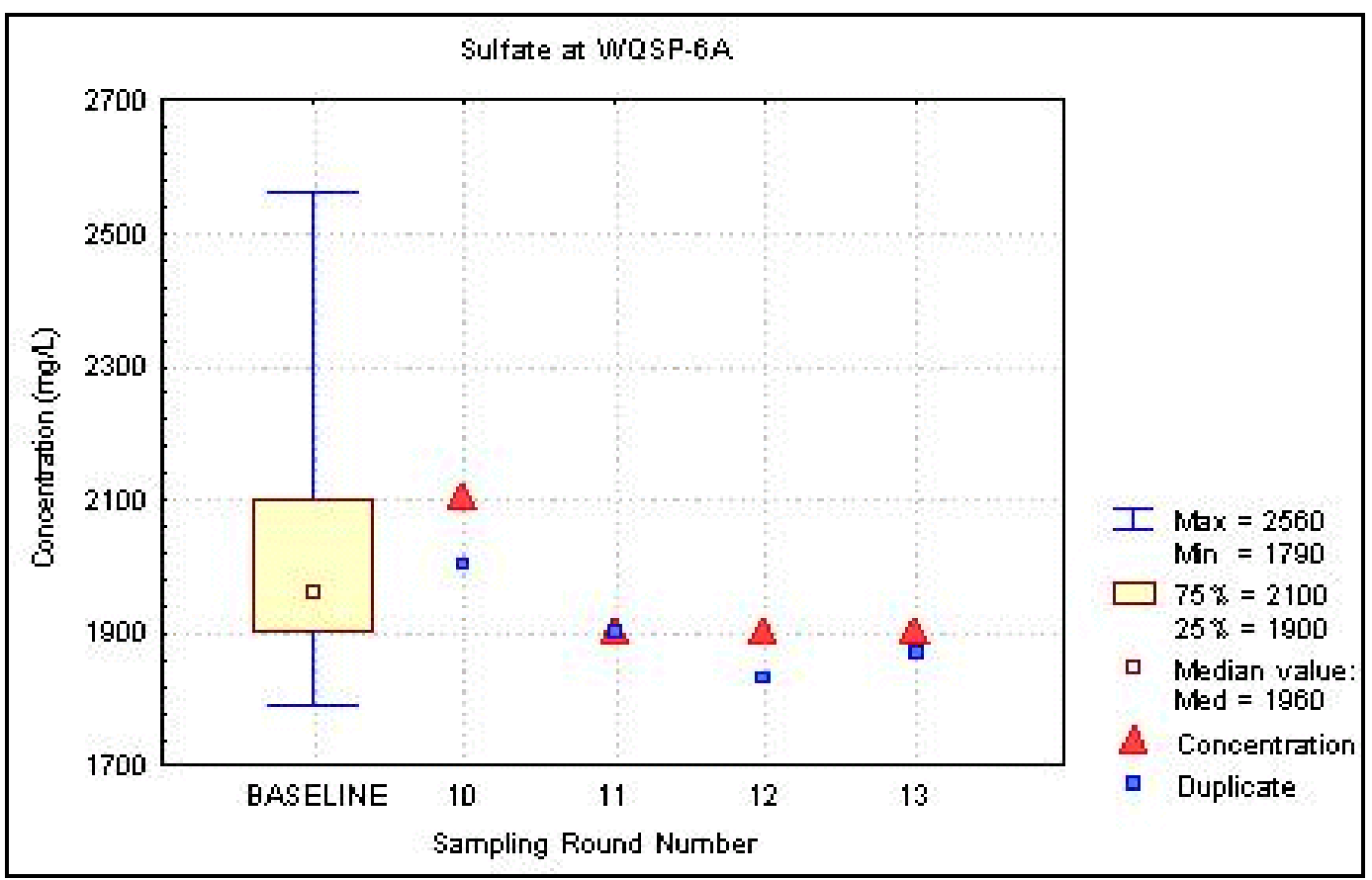

Figure F.123 - Time Trend Plot for Sulfate at WQSP-6A 


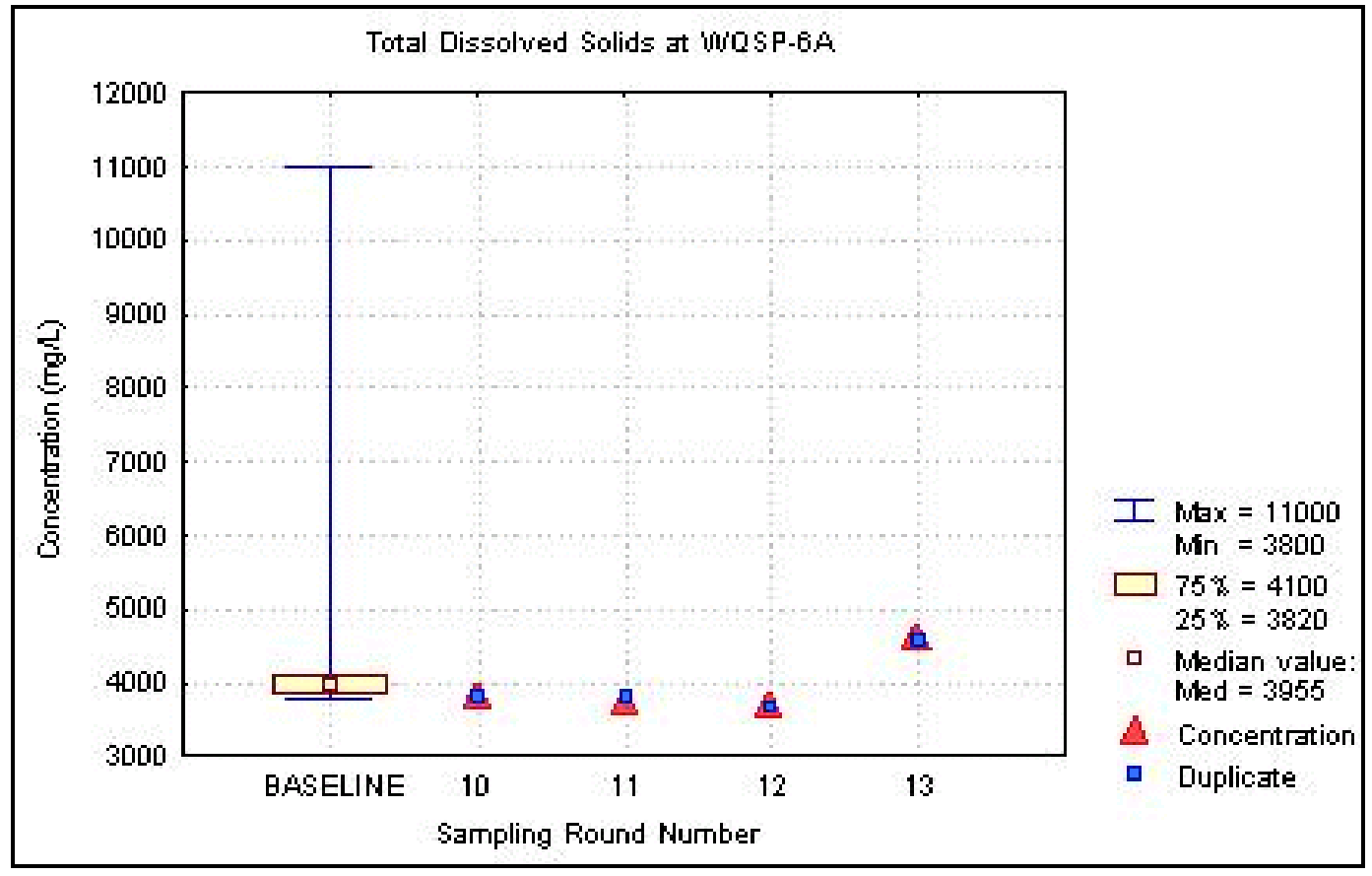

Figure F.124 - Time Trend Plot for Total Dissolved Solids at WQSP-6A

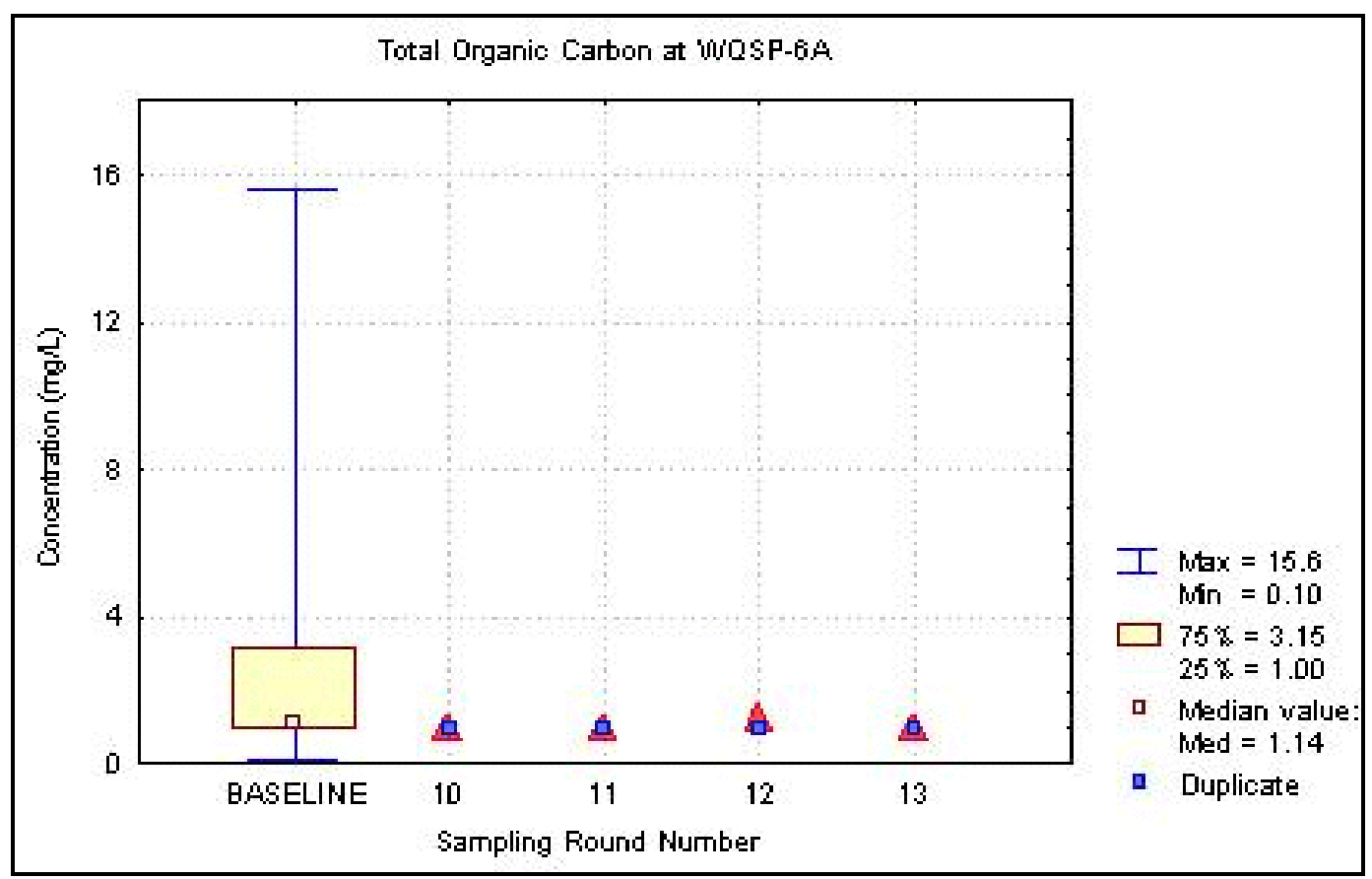

Figure F.125 - Time Trend Plot for Total Organic Carbon at WQSP-6A 
Waste Isolation Pilot Plant 2001 Site Environmental Report

DOE/WIPP 02-2225

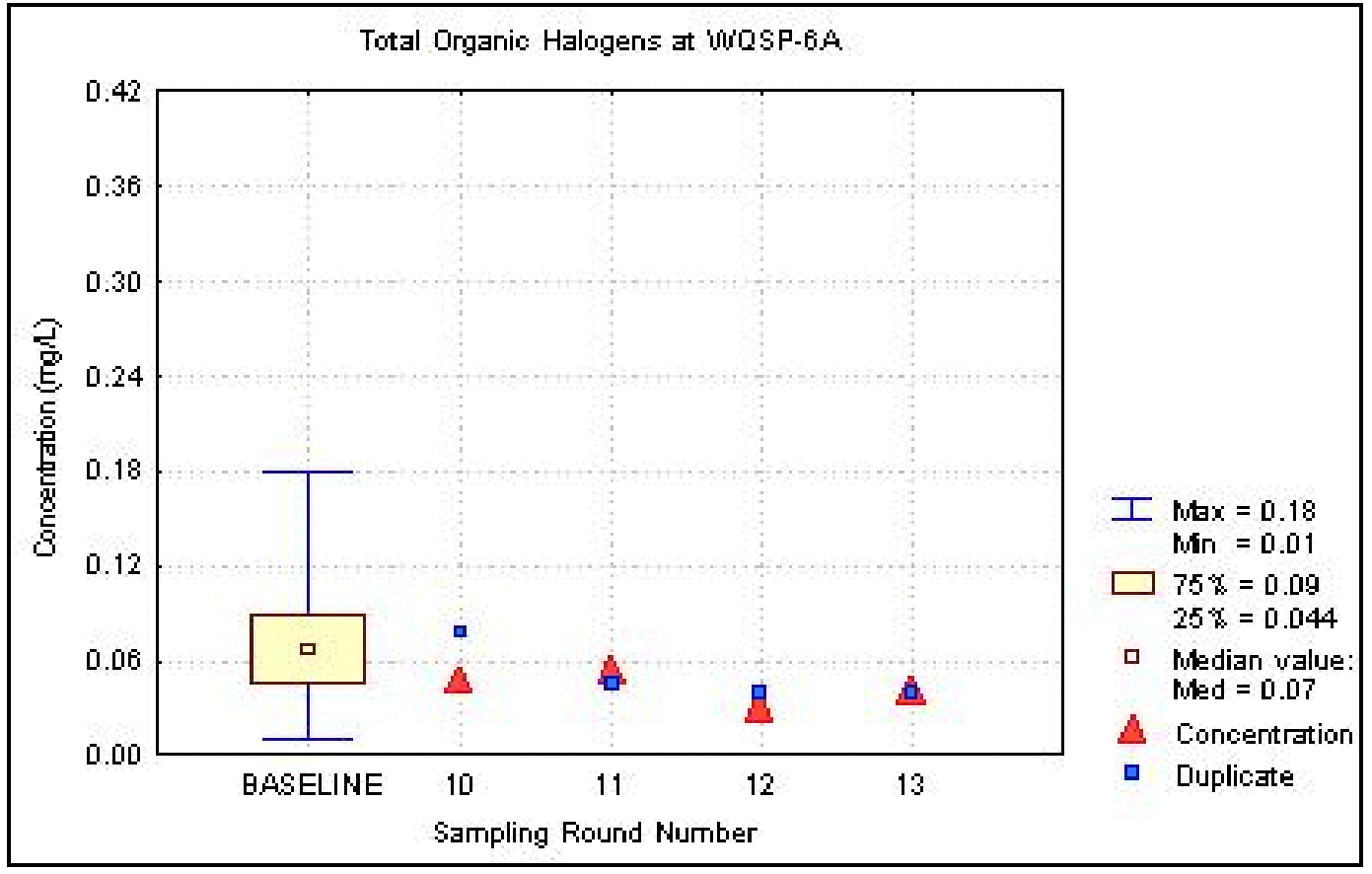

Figure F.126 - Time Trend Plot for Total Organic Halogens at WQSP-6A 


\section{Appendix G \\ Air Sampling Data: Concentrations of Radionuclides}

Table G.1 - Radionuclide Concentrations $\left(\mathrm{Bq} / \mathrm{m}^{3}\right)$ in Quarterly Composite Air Filters Collected from Locations Surrounding the WIPP Site. See Appendix $B$ for the sampling locations.

\begin{tabular}{|c|c|c|c|c|c|c|c|c|c|c|}
\hline Location & Quarter & {$[R N]^{a}$} & $2 x T^{\prime b}$ & $\mathrm{MDC}^{\mathrm{c}}$ & [RN] & 2xTPU & MDC & [RN] & 2xTPU & MDC \\
\hline & & & ${ }^{241} \mathrm{Am}$ & & & ${ }^{238} \mathrm{Pu}$ & & & ${ }^{239+240} \mathrm{Pu}$ & \\
\hline CBD & 1 & $0.00 \times 10^{0}$ & $0.00 \times 10^{0}$ & $3.89 \times 10^{-8}$ & $1.12 \times 10^{-8}$ & $5.70 \times 10^{-8}$ & $1.35 \times 10^{-7}$ & $0.00 \times 10^{0}$ & $0.00 \times 10^{0}$ & $4.51 \times 10^{-8}$ \\
\hline CBD & 2 & $1.51 \times 10^{-8}$ & $3.03 \times 10^{-8}$ & $4.11 \times 10^{-8}$ & $4.40 \times 10^{-8}$ & $5.14 \times 10^{-8}$ & $3.96 \times 10^{-8}$ & $0.00 \times 10^{0}$ & $0.00 \times 10^{0}$ & $3.96 \times 10^{-8}$ \\
\hline CBD & 3 & $4.55 \times 10^{-8}$ & $5.29 \times 10^{-8}$ & $4.11 \times 10^{-8}$ & $1.76 \times 10^{-8}$ & $6.11 \times 10^{-8}$ & $1.29 \times 10^{-7}$ & $3.50 \times 10^{-8}$ & $5.00 \times 10^{-8}$ & $4.74 \times 10^{-8}$ \\
\hline CBD & 4 & $6.03 \times 10^{-8}$ & $6.11 \times 10^{-8}$ & $4.07 \times 10^{-8}$ & $2.21 \times 10^{-8}$ & $1.17 \times 10^{-7}$ & $2.37 \times 10^{-7}$ & $0.00 \times 10^{0}$ & $0.00 \times 10^{0}$ & $5.96 \times 10^{-8}$ \\
\hline MLR & 1 & $1.47 \times 10^{-8}$ & $2.95 \times 10^{-8}$ & $4.00 \times 10^{-8}$ & $3.32 \times 10^{-8}$ & $4.74 \times 10^{-8}$ & $4.48 \times 10^{-8}$ & $2.21 \times 10^{-8}$ & $5.18 \times 10^{-8}$ & $1.08 \times 10^{-7}$ \\
\hline MLR & 2 & $0.00 \times 10^{0}$ & $0.00 \times 10^{0}$ & $1.53 \times 10^{-7}$ & $-3.36 \times 10^{-8}$ & $6.73 \times 10^{-8}$ & $1.81 \times 10^{-7}$ & $1.68 \times 10^{-8}$ & $3.36 \times 10^{-8}$ & $4.55 \times 10^{-8}$ \\
\hline MLR & 3 & $1.78 \times 10^{-8}$ & $7.99 \times 10^{-8}$ & $1.66 \times 10^{-7}$ & $4.85 \times 10^{-8}$ & $8.58 \times 10^{-8}$ & $1.50 \times 10^{-7}$ & $3.22 \times 10^{-8}$ & $6.48 \times 10^{-8}$ & $1.19 \times 10^{-7}$ \\
\hline MLR & 4 & $1.81 \times 10^{-8}$ & $3.62 \times 10^{-8}$ & $4.88 \times 10^{-8}$ & $8.07 \times 10^{-8}$ & $1.21 \times 10^{-7}$ & $1.97 \times 10^{-7}$ & $0.00 \times 10^{0}$ & $0.00 \times 10^{0}$ & $7.25 \times 10^{-8}$ \\
\hline SEC & 1 & $1.44 \times 10^{-8}$ & $2.87 \times 10^{-8}$ & $3.89 \times 10^{-8}$ & $-4.63 \times 10^{-9}$ & $3.81 \times 10^{-8}$ & $1.12 \times 10^{-7}$ & $1.39 \times 10^{-8}$ & $2.79 \times 10^{-8}$ & $3.77 \times 10^{-8}$ \\
\hline SEC & 2 & $4.22 \times 10^{-8}$ & $4.88 \times 10^{-8}$ & $3.81 \times 10^{-8}$ & $-2.60 \times 10^{-8}$ & $3.70 \times 10^{-8}$ & $1.21 \times 10^{-7}$ & $5.22 \times 10^{-8}$ & $5.25 \times 10^{-8}$ & $3.52 \times 10^{-8}$ \\
\hline SEC & 3 & $-1.43 \times 10^{-8}$ & $6.40 \times 10^{-8}$ & $1.54 \times 10^{-7}$ & $1.39 \times 10^{-8}$ & $4.81 \times 10^{-8}$ & $1.02 \times 10^{-7}$ & $1.38 \times 10^{-8}$ & $2.77 \times 10^{-8}$ & $3.74 \times 10^{-8}$ \\
\hline SEC & 4 & $5.25 \times 10^{-8}$ & $6.14 \times 10^{-8}$ & $4.74 \times 10^{-8}$ & $0.00 \times 10^{0}$ & $0.00 \times 10^{0}$ & $2.08 \times 10^{-7}$ & $-2.82 \times 10^{-8}$ & $5.66 \times 10^{-8}$ & $2.08 \times 10^{-7}$ \\
\hline SMR & 1 & $-9.99 \times 10^{-9}$ & $2.00 \times 10^{-8}$ & $9.73 \times 10^{-8}$ & $1.15 \times 10^{-8}$ & $5.85 \times 10^{-8}$ & $1.39 \times 10^{-7}$ & $2.29 \times 10^{-8}$ & $5.40 \times 10^{-8}$ & $1.12 \times 10^{-7}$ \\
\hline SMR & 2 & $1.62 \times 10^{-8}$ & $3.26 \times 10^{-8}$ & $4.40 \times 10^{-8}$ & $0.00 \times 10^{0}$ & $0.00 \times 10^{0}$ & $5.07 \times 10^{-8}$ & $3.74 \times 10^{-8}$ & $5.33 \times 10^{-8}$ & $5.07 \times 10^{-8}$ \\
\hline SMR & 3 & $4.07 \times 10^{-8}$ & $7.18 \times 10^{-8}$ & $1.26 \times 10^{-7}$ & $1.39 \times 10^{-8}$ & $4.81 \times 10^{-8}$ & $1.02 \times 10^{-7}$ & $-1.39 \times 10^{-8}$ & $2.78 \times 10^{-8}$ & $1.02 \times 10^{-7}$ \\
\hline SMR & 4 & $0.00 \times 10^{0}$ & $0.00 \times 10^{0}$ & $5.70 \times 10^{-8}$ & $2.07 \times 10^{-7}$ & $2.23 \times 10^{-7}$ & $3.05 \times 10^{-7}$ & $0.00 \times 10^{0}$ & $0.00 \times 10^{0}$ & $1.12 \times 10^{-7}$ \\
\hline WEE & 1 & $5.74 \times 10^{-8}$ & $5.81 \times 10^{-8}$ & $3.89 \times 10^{-8}$ & $-1.05 \times 10^{-8}$ & $2.11 \times 10^{-8}$ & $1.02 \times 10^{-7}$ & $1.57 \times 10^{-8}$ & $3.16 \times 10^{-8}$ & $4.26 \times 10^{-8}$ \\
\hline WEE & 2 & $-1.45 \times 10^{-8}$ & $5.00 \times 10^{-8}$ & $1.34 \times 10^{-7}$ & $5.62 \times 10^{-8}$ & $8.03 \times 10^{-8}$ & $1.31 \times 10^{-7}$ & $1.41 \times 10^{-8}$ & $2.82 \times 10^{-8}$ & $3.81 \times 10^{-8}$ \\
\hline WEE & 3 & $1.66 \times 10^{-8}$ & $1.10 \times 10^{-7}$ & $2.17 \times 10^{-7}$ & $-3.07 \times 10^{-8}$ & $7.55 \times 10^{-8}$ & $1.84 \times 10^{-7}$ & $3.06 \times 10^{-8}$ & $4.33 \times 10^{-8}$ & $4.14 \times 10^{-8}$ \\
\hline WEE & 4 & $4.81 \times 10^{-8}$ & $7.22 \times 10^{-8}$ & $1.18 \times 10^{-7}$ & $5.92 \times 10^{-8}$ & $1.46 \times 10^{-7}$ & $2.75 \times 10^{-7}$ & $-2.96 \times 10^{-8}$ & $5.96 \times 10^{-8}$ & $2.18 \times 10^{-7}$ \\
\hline WFF & 1 & $1.95 \times 10^{-8}$ & $4.59 \times 10^{-8}$ & $9.55 \times 10^{-8}$ & $3.89 \times 10^{-8}$ & $6.18 \times 10^{-8}$ & $1.08 \times 10^{-7}$ & $1.65 \times 10^{-8}$ & $3.32 \times 10^{-8}$ & $4.48 \times 10^{-8}$ \\
\hline WFF & 2 & $1.65 \times 10^{-8}$ & $5.74 \times 10^{-8}$ & $1.22 \times 10^{-7}$ & $-1.74 \times 10^{-8}$ & $3.48 \times 10^{-8}$ & $1.28 \times 10^{-7}$ & $5.18 \times 10^{-8}$ & $6.03 \times 10^{-8}$ & $4.70 \times 10^{-8}$ \\
\hline
\end{tabular}


Waste Isolation Pilot Plant 2001 Site Environmental Report DOE/WIPP 02-2225

Table G.1 - Radionuclide Concentrations $\left(\mathrm{Bq} / \mathrm{m}^{3}\right)$ in Quarterly Composite Air Filters Collected from Locations Surrounding the WIPP Site. See Appendix $B$ for the sampling locations.

\begin{tabular}{|c|c|c|c|c|c|c|c|c|c|c|}
\hline Location & Quarter & {$[R N]^{a}$} & $2 x T^{\prime b} U^{b}$ & $\mathrm{MDC}^{\mathrm{c}}$ & [RN] & 2xTPU & MDC & [RN] & 2xTPU & MDC \\
\hline$\overline{\text { WFF }}$ & 3 & $-4.26 \times 10^{-8}$ & $6.40 \times 10^{-8}$ & $1.71 \times 10^{-7}$ & $-1.80 \times 10^{-8}$ & $3.61 \times 10^{-8}$ & $1.32 \times 10^{-7}$ & $-1.79 \times 10^{-8}$ & $3.60 \times 10^{-8}$ & $1.32 \times 10^{-7}$ \\
\hline WFF & 4 & $1.59 \times 10^{-8}$ & $3.20 \times 10^{-8}$ & $4.33 \times 10^{-8}$ & $-2.71 \times 10^{-8}$ & $5.44 \times 10^{-8}$ & $7.33 \times 10^{-8}$ & $1.08 \times 10^{-7}$ & $1.34 \times 10^{-7}$ & $1.99 \times 10^{-7}$ \\
\hline WSS & 1 & $5.14 \times 10^{-9}$ & $3.70 \times 10^{-8}$ & $1.00 \times 10^{-7}$ & $0.00 \times 10^{0}$ & $0.00 \times 10^{0}$ & $3.92 \times 10^{-8}$ & $0.00 \times 10^{0}$ & $0.00 \times 10^{0}$ & $3.92 \times 10^{-8}$ \\
\hline WSS & 2 & $0.00 \times 10^{0}$ & $0.00 \times 10^{0}$ & $1.09 \times 10^{-7}$ & $1.64 \times 10^{-8}$ & $5.70 \times 10^{-8}$ & $1.21 \times 10^{-7}$ & $1.64 \times 10^{-8}$ & $3.29 \times 10^{-8}$ & $4.44 \times 10^{-8}$ \\
\hline WSS & 3 & $4.33 \times 10^{-8}$ & $5.03 \times 10^{-8}$ & $3.92 \times 10^{-8}$ & $-1.68 \times 10^{-8}$ & $7.51 \times 10^{-8}$ & $1.80 \times 10^{-7}$ & $1.67 \times 10^{-8}$ & $3.35 \times 10^{-8}$ & $4.51 \times 10^{-8}$ \\
\hline WSS & 4 & $4.59 \times 10^{-8}$ & $5.37 \times 10^{-8}$ & $4.14 \times 10^{-8}$ & $7.99 \times 10^{-8}$ & $1.61 \times 10^{-7}$ & $2.86 \times 10^{-7}$ & $2.66 \times 10^{-8}$ & $5.33 \times 10^{-8}$ & $7.22 \times 10^{-8}$ \\
\hline WAB & 1 & $1.14 \times 10^{-4}$ & $2.29 \times 10^{-4}$ & $3.10 \times 10^{-4}$ & $3.02 \times 10^{-4}$ & $3.52 \times 10^{-4}$ & $2.72 \times 10^{-4}$ & $-1.34 \times 10^{-4}$ & $1.91 \times 10^{-4}$ & $8.14 \times 10^{-4}$ \\
\hline WAB & 2 & $0.00 \times 10^{0}$ & $0.00 \times 10^{0}$ & $7.99 \times 10^{-4}$ & $2.83 \times 10^{-4}$ & $4.03 \times 10^{-4}$ & $3.85 \times 10^{-4}$ & $0.00 \times 10^{0}$ & $0.00 \times 10^{0}$ & $3.85 \times 10^{-4}$ \\
\hline WAB & 3 & $0.00 \times 10^{0}$ & $0.00 \times 10^{0}$ & $8.18 \times 10^{-4}$ & $-1.24 \times 10^{-4}$ & $6.55 \times 10^{-4}$ & $1.48 \times 10^{-3}$ & $0.00 \times 10^{0}$ & $0.00 \times 10^{0}$ & $9.07 \times 10^{-4}$ \\
\hline WAB & 4 & $-1.39 \times 10^{-4}$ & $2.80 \times 10^{-4}$ & $1.02 \times 10^{-3}$ & $3.70 \times 10^{-4}$ & $5.55 \times 10^{-4}$ & $9.07 \times 10^{-4}$ & $0.00 \times 10^{0}$ & $0.00 \times 10^{0}$ & $9.07 \times 10^{-4}$ \\
\hline Minimum & & $-4.26 \times 10^{-8}$ & $6.40 \times 10^{-8}$ & $3.81 \times 10^{-8}$ & $-3.36 \times 10^{-8}$ & $6.73 \times 10^{-8}$ & $3.92 \times 10^{-8}$ & $-2.96 \times 10^{-8}$ & $5.96 \times 10^{-8}$ & $3.52 \times 10^{-8}$ \\
\hline Maximum & & $6.03 \times 10^{-8}$ & $6.11 \times 10^{-8}$ & $2.17 \times 10^{-7}$ & $2.07 \times 10^{-7}$ & $2.23 \times 10^{-7}$ & $3.05 \times 10^{-7}$ & $1.08 \times 10^{-7}$ & $1.34 \times 10^{-7}$ & $2.18 \times 10^{-7}$ \\
\hline \multirow[t]{2}{*}{ Mean $^{c}$} & & $1.87 \times 10^{-8}$ & $4.88 \times 10^{-8}$ & $8.58 \times 10^{-8}$ & $2.23 \times 10^{-8}$ & $9.37 \times 10^{-8}$ & $1.43 \times 10^{-7}$ & $1.62 \times 10^{-8}$ & $5.36 \times 10^{-8}$ & $7.84 \times 10^{-8}$ \\
\hline & & & ${ }^{234} U$ & & & ${ }^{235} \mathrm{U}$ & & & ${ }^{238} \mathrm{U}$ & \\
\hline CBD & 1 & $2.51 \times 10^{-6}$ & $5.66 \times 10^{-7}$ & $4.11 \times 10^{-8}$ & $5.62 \times 10^{-8}$ & $6.55 \times 10^{-8}$ & $5.11 \times 10^{-8}$ & $2.44 \times 10^{-6}$ & $5.51 \times 10^{-7}$ & $4.11 \times 10^{-8}$ \\
\hline CBD & 2 & $4.29 \times 10^{-6}$ & $8.66 \times 10^{-7}$ & $4.18 \times 10^{-8}$ & $1.71 \times 10^{-7}$ & $1.17 \times 10^{-7}$ & $5.14 \times 10^{-8}$ & $4.81 \times 10^{-6}$ & $9.55 \times 10^{-7}$ & $4.14 \times 10^{-8}$ \\
\hline CBD & 3 & $3.10 \times 10^{-6}$ & $6.36 \times 10^{-7}$ & $3.92 \times 10^{-8}$ & $2.15 \times 10^{-7}$ & $1.28 \times 10^{-7}$ & $4.85 \times 10^{-8}$ & $3.00 \times 10^{-6}$ & $6.22 \times 10^{-7}$ & $1.07 \times 10^{-7}$ \\
\hline CBD & 4 & $2.08 \times 10^{-6}$ & $4.81 \times 10^{-7}$ & $4.07 \times 10^{-8}$ & $7.44 \times 10^{-8}$ & $1.06 \times 10^{-7}$ & $1.73 \times 10^{-7}$ & $2.80 \times 10^{-6}$ & $5.99 \times 10^{-7}$ & $4.07 \times 10^{-8}$ \\
\hline MLR & 1 & $2.07 \times 10^{-6}$ & $4.70 \times 10^{-7}$ & $1.15 \times 10^{-7}$ & $8.18 \times 10^{-7}$ & $9.29 \times 10^{-8}$ & $1.42 \times 10^{-7}$ & $2.16 \times 10^{-6}$ & $4.88 \times 10^{-7}$ & $1.31 \times 10^{-7}$ \\
\hline MLR & 2 & $4.44 \times 10^{-6}$ & $8.81 \times 10^{-7}$ & $4.11 \times 10^{-8}$ & $1.30 \times 10^{-7}$ & $1.01 \times 10^{-7}$ & $5.03 \times 10^{-8}$ & $4.22 \times 10^{-6}$ & $8.44 \times 10^{-7}$ & $4.07 \times 10^{-8}$ \\
\hline MLR & 3 & $2.91 \times 10^{-6}$ & $6.33 \times 10^{-7}$ & $4.26 \times 10^{-8}$ & $1.93 \times 10^{-7}$ & $1.26 \times 10^{-7}$ & $5.22 \times 10^{-8}$ & $2.53 \times 10^{-6}$ & $5.70 \times 10^{-7}$ & $1.15 \times 10^{-7}$ \\
\hline MLR & 4 & $2.63 \times 10^{-6}$ & $5.92 \times 10^{-7}$ & $1.27 \times 10^{-7}$ & $1.91 \times 10^{-7}$ & $1.31 \times 10^{-7}$ & $5.77 \times 10^{-8}$ & $2.43 \times 10^{-6}$ & $5.59 \times 10^{-7}$ & $4.66 \times 10^{-8}$ \\
\hline SEC & 1 & $2.42 \times 10^{-6}$ & $5.25 \times 10^{-7}$ & $3.74 \times 10^{-8}$ & $1.25 \times 10^{-7}$ & $1.01 \times 10^{-7}$ & $1.11 \times 10^{-7}$ & $2.39 \times 10^{-6}$ & $5.22 \times 10^{-7}$ & $3.74 \times 10^{-8}$ \\
\hline SEC & 2 & $3.81 \times 10^{-6}$ & $7.44 \times 10^{-7}$ & $1.23 \times 10^{-7}$ & $2.45 \times 10^{-7}$ & $1.32 \times 10^{-7}$ & $4.44 \times 10^{-8}$ & $3.85 \times 10^{-6}$ & $7.51 \times 10^{-7}$ & $3.58 \times 10^{-8}$ \\
\hline SEC & 3 & $2.64 \times 10^{-6}$ & $5.55 \times 10^{-7}$ & $3.52 \times 10^{-8}$ & $1.44 \times 10^{-7}$ & $1.09 \times 10^{-7}$ & $1.18 \times 10^{-7}$ & $2.54 \times 10^{-6}$ & $5.37 \times 10^{-7}$ & $3.51 \times 10^{-8}$ \\
\hline SEC & 4 & $2.05 \times 10^{-6}$ & $5.14 \times 10^{-7}$ & $5.18 \times 10^{-8}$ & $1.18 \times 10^{-7}$ & $1.07 \times 10^{-7}$ & $6.40 \times 10^{-8}$ & $2.59 \times 10^{-6}$ & $6.07 \times 10^{-7}$ & $5.18 \times 10^{-8}$ \\
\hline
\end{tabular}


Waste Isolation Pilot Plant 2001 Site Environmental Report DOE/WIPP 02-2225

Table G.1 - Radionuclide Concentrations $\left(\mathrm{Bq} / \mathrm{m}^{3}\right)$ in Quarterly Composite Air Filters Collected from Locations Surrounding the WIPP Site. See Appendix B for the sampling locations.

\begin{tabular}{|c|c|c|c|c|c|c|c|c|c|c|}
\hline Location & Quarter & [RN] $^{\mathrm{a}}$ & $2 x T^{\prime} U^{b}$ & MDC $^{c}$ & [RN] & $2 x T P U$ & MDC & [RN] & $2 x T P U$ & MDC \\
\hline$\overline{\text { SMR }}$ & 1 & $2.36 \times 10^{-6}$ & $5.33 \times 10^{-7}$ & $4.22 \times 10^{-8}$ & $2.31 \times 10^{-7}$ & $1.38 \times 10^{-7}$ & $5.22 \times 10^{-8}$ & $2.26 \times 10^{-6}$ & $5.22 \times 10^{-7}$ & $1.26 \times 10^{-7}$ \\
\hline SMR & 2 & $4.26 \times 10^{-6}$ & $8.44 \times 10^{-7}$ & $4.22 \times 10^{-8}$ & $1.91 \times 10^{-7}$ & $1.36 \times 10^{-7}$ & $1.41 \times 10^{-7}$ & $4.11 \times 10^{-6}$ & $8.21 \times 10^{-7}$ & $4.18 \times 10^{-8}$ \\
\hline SMR & 3 & $2.69 \times 10^{-6}$ & $5.59 \times 10^{-7}$ & $9.77 \times 10^{-8}$ & $1.47 \times 10^{-7}$ & $1.01 \times 10^{-7}$ & $4.44 \times 10^{-8}$ & $2.71 \times 10^{-6}$ & $5.59 \times 10^{-7}$ & $3.58 \times 10^{-8}$ \\
\hline SMR & 4 & $2.58 \times 10^{-6}$ & $5.99 \times 10^{-7}$ & $5.33 \times 10^{-8}$ & $4.85 \times 10^{-8}$ & $6.88 \times 10^{-8}$ & $6.59 \times 10^{-8}$ & $2.56 \times 10^{-6}$ & $6.03 \times 10^{-7}$ & $1.82 \times 10^{-7}$ \\
\hline WEE & 1 & $2.34 \times 10^{-6}$ & $5.40 \times 10^{-7}$ & $1.29 \times 10^{-7}$ & $7.88 \times 10^{-8}$ & $7.96 \times 10^{-8}$ & $5.33 \times 10^{-8}$ & $2.35 \times 10^{-6}$ & $5.40 \times 10^{-7}$ & $4.29 \times 10^{-8}$ \\
\hline WEE & 2 & $4.51 \times 10^{-6}$ & $8.84 \times 10^{-8}$ & $3.96 \times 10^{-8}$ & $1.62 \times 10^{-7}$ & $1.11 \times 10^{-7}$ & $4.88 \times 10^{-8}$ & $4.18 \times 10^{-6}$ & $8.29 \times 10^{-7}$ & $3.96 \times 10^{-8}$ \\
\hline WEE & 3 & $2.93 \times 10^{-6}$ & $6.44 \times 10^{-7}$ & $4.48 \times 10^{-8}$ & $1.84 \times 10^{-7}$ & $1.26 \times 10^{-7}$ & $5.55 \times 10^{-8}$ & $2.61 \times 10^{-6}$ & $5.88 \times 10^{-7}$ & $4.48 \times 10^{-8}$ \\
\hline WEE & 4 & $2.66 \times 10^{-6}$ & $5.99 \times 10^{-7}$ & $4.33 \times 10^{-8}$ & $1.77 \times 10^{-7}$ & $1.21 \times 10^{-7}$ & $5.33 \times 10^{-8}$ & $2.33 \times 10^{-6}$ & $5.44 \times 10^{-7}$ & $1.17 \times 10^{-7}$ \\
\hline WFF & 1 & $2.10 \times 10^{-6}$ & $4.74 \times 10^{-7}$ & $4.14 \times 10^{-8}$ & $1.20 \times 10^{-7}$ & $1.05 \times 10^{-7}$ & $1.23 \times 10^{-7}$ & $1.75 \times 10^{-6}$ & $4.18 \times 10^{-7}$ & $4.14 \times 10^{-8}$ \\
\hline WFF & 2 & $4.59 \times 10^{-6}$ & $8.51 \times 10^{-7}$ & $4.33 \times 10^{-8}$ & $2.95 \times 10^{-7}$ & $1.58 \times 10^{-7}$ & $5.33 \times 10^{-8}$ & $4.14 \times 10^{-6}$ & $7.84 \times 10^{-8}$ & $4.29 \times 10^{-8}$ \\
\hline WFF & 3 & $2.77 \times 10^{-6}$ & $5.92 \times 10^{-7}$ & $4.07 \times 10^{-8}$ & $2.03 \times 10^{-7}$ & $1.27 \times 10^{-7}$ & $5.00 \times 10^{-8}$ & $2.70 \times 10^{-6}$ & $5.81 \times 10^{-7}$ & $4.03 \times 10^{-8}$ \\
\hline WFF & 4 & $2.54 \times 10^{-6}$ & $5.55 \times 10^{-7}$ & $1.16 \times 10^{-7}$ & $0.00 \times 10^{-0}$ & $0.00 \times 10^{-0}$ & $2.10 \times 10^{-7}$ & $2.25 \times 10^{-6}$ & $5.07 \times 10^{-7}$ & $1.16 \times 10^{-7}$ \\
\hline WSS & 1 & $2.01 \times 10^{-6}$ & $4.48 \times 10^{-7}$ & $3.61 \times 10^{-8}$ & $1.04 \times 10^{-7}$ & $9.10 \times 10^{-8}$ & $1.07 \times 10^{-7}$ & $2.14 \times 10^{-6}$ & $4.70 \times 10^{-7}$ & $8.66 \times 10^{-8}$ \\
\hline WSS & 2 & $4.29 \times 10^{-6}$ & $8.62 \times 10^{-7}$ & $4.18 \times 10^{-8}$ & $7.59 \times 10^{-8}$ & $7.70 \times 10^{-8}$ & $5.14 \times 10^{-8}$ & $4.37 \times 10^{-6}$ & $8.73 \times 10^{-7}$ & $4.14 \times 10^{-8}$ \\
\hline WSS & 3 & $2.79 \times 10^{-6}$ & $5.85 \times 10^{-7}$ & $3.70 \times 10^{-8}$ & $1.85 \times 10^{-7}$ & $1.15 \times 10^{-7}$ & $4.55 \times 10^{-8}$ & $2.61 \times 10^{-6}$ & $5.55 \times 10^{-7}$ & $3.69 \times 10^{-8}$ \\
\hline WSS & 4 & $2.62 \times 10^{-6}$ & $5.74 \times 10^{-7}$ & $4.07 \times 10^{-8}$ & $5.55 \times 10^{-8}$ & $6.44 \times 10^{-8}$ & $5.00 \times 10^{-8}$ & $2.40 \times 10^{-6}$ & $5.37 \times 10^{-7}$ & $4.03 \times 10^{-8}$ \\
\hline WAB & 1 & $1.57 \times 10^{-2}$ & $3.74 \times 10^{-3}$ & $3.24 \times 10^{-4}$ & $1.18 \times 10^{-3}$ & $8.58 \times 10^{-4}$ & $4.00 \times 10^{-4}$ & $1.76 \times 10^{-2}$ & $4.11 \times 10^{-3}$ & $3.23 \times 10^{-4}$ \\
\hline WAB & 2 & $2.18 \times 10^{-2}$ & $4.74 \times 10^{-3}$ & $3.15 \times 10^{-4}$ & $8.58 \times 10^{-4}$ & $7.14 \times 10^{-4}$ & $3.89 \times 10^{-4}$ & $2.35 \times 10^{-2}$ & $5.03 \times 10^{-3}$ & $8.51 \times 10^{-4}$ \\
\hline WAB & 3 & $2.02 \times 10^{-2}$ & $4.29 \times 10^{-3}$ & $2.79 \times 10^{-4}$ & $1.14 \times 10^{-3}$ & $7.84 \times 10^{-4}$ & $3.45 \times 10^{-4}$ & $1.74 \times 10^{-2}$ & $3.85 \times 10^{-3}$ & $2.78 \times 10^{-4}$ \\
\hline WAB & 4 & $1.69 \times 10^{-2}$ & $3.77 \times 10^{-3}$ & $2.81 \times 10^{-4}$ & $6.40 \times 10^{-4}$ & $5.81 \times 10^{-4}$ & $3.47 \times 10^{-4}$ & $1.68 \times 10^{-2}$ & $3.77 \times 10^{-3}$ & $7.62 \times 10^{-4}$ \\
\hline Minimum & & $2.01 \times 10^{-6}$ & $4.48 \times 10^{-7}$ & $3.52 \times 10^{-8}$ & $0.00 \times 10^{-0}$ & $0.00 \times 10^{-0}$ & $4.44 \times 10^{-8}$ & $1.75 \times 10^{-6}$ & $4.18 \times 10^{-7}$ & $3.51 \times 10^{-8}$ \\
\hline Maximum & & $4.59 \times 10^{-6}$ & $8.51 \times 10^{-7}$ & $1.29 \times 10^{-7}$ & $8.18 \times 10^{-7}$ & $9.29 \times 10^{-8}$ & $2.10 \times 10^{-7}$ & $4.81 \times 10^{-6}$ & $9.55 \times 10^{-7}$ & $1.82 \times 10^{-7}$ \\
\hline Mean & & $2.96 \times 10^{-6}$ & $1.66 \times 10^{-6}$ & $5.80 \times 10^{-8}$ & $1.69 \times 10^{-7}$ & $2.82 \times 10^{-7}$ & $7.74 \times 10^{-8}$ & $2.90 \times 10^{-6}$ & $1.63 \times 10^{-6}$ & $6.42 \times 10^{-8}$ \\
\hline
\end{tabular}


Waste Isolation Pilot Plant 2001 Site Environmental Report DOE/WIPP 02-2225

Table G.1 - Radionuclide Concentrations $\left(\mathrm{Bq} / \mathrm{m}^{3}\right)$ in Quarterly Composite Air Filters Collected from Locations Surrounding the WIPP Site. See Appendix $B$ for the sampling locations.

\begin{tabular}{|c|c|c|c|c|c|c|c|c|c|c|}
\hline Location & Quarter & {$[\mathrm{RN}]^{\mathrm{a}}$} & $2 x T^{\prime b} U^{b}$ & $M^{\prime} C^{c}$ & [RN] & $2 x T P U$ & MDC & [RN] & $2 \times T P U$ & MDC \\
\hline & & & ${ }^{40} \mathrm{~K}$ & & & ${ }^{60} \mathrm{Co}$ & & & & \\
\hline CBD & 1 & $6.14 \times 10^{-3}$ & $9.40 \times 10^{-4}$ & $6.85 \times 10^{-4}$ & $7.47 \times 10^{-6}$ & $3.24 \times 10^{-5}$ & $3.69 \times 10^{-5}$ & & & \\
\hline CBD & 2 & $4.63 \times 10^{-4}$ & $3.06 \times 10^{-4}$ & $3.62 \times 10^{-4}$ & $3.92 \times 10^{-5}$ & $2.98 \times 10^{-5}$ & $3.57 \times 10^{-5}$ & & & \\
\hline CBD & 3 & $3.23 \times 10^{-4}$ & $2.41 \times 10^{-4}$ & $3.13 \times 10^{-4}$ & $5.96 \times 10^{-6}$ & $2.43 \times 10^{-5}$ & $2.95 \times 10^{-5}$ & & & \\
\hline CBD & 4 & $1.65 \times 10^{-4}$ & $1.92 \times 10^{-4}$ & $2.38 \times 10^{-4}$ & $-3.33 \times 10^{-6}$ & $2.13 \times 10^{-5}$ & $2.37 \times 10^{-5}$ & & & \\
\hline MLR & 1 & $2.10 \times 10^{-4}$ & $1.71 \times 10^{-4}$ & $2.19 \times 10^{-4}$ & $4.48 \times 10^{-6}$ & $1.64 \times 10^{-5}$ & $1.98 \times 10^{-5}$ & & & \\
\hline MLR & 2 & $2.78 \times 10^{-4}$ & $2.41 \times 10^{-4}$ & $3.08 \times 10^{-4}$ & $-1.64 \times 10^{-6}$ & $2.36 \times 10^{-5}$ & $2.73 \times 10^{-5}$ & & & \\
\hline MLR & 3 & $2.26 \times 10^{-4}$ & $1.04 \times 10^{-4}$ & $1.36 \times 10^{-4}$ & $-1.25 \times 10^{-6}$ & $2.20 \times 10^{-5}$ & $2.48 \times 10^{-5}$ & & & \\
\hline MLR & 4 & $3.92 \times 10^{-4}$ & $2.52 \times 10^{-4}$ & $3.36 \times 10^{-4}$ & $2.97 \times 10^{-5}$ & $2.40 \times 10^{-5}$ & $3.21 \times 10^{-5}$ & & & \\
\hline SEC & 1 & $6.44 \times 10^{-3}$ & $9.77 \times 10^{-4}$ & $6.99 \times 10^{-4}$ & $-1.28 \times 10^{-5}$ & $3.43 \times 10^{-5}$ & $3.77 \times 10^{-5}$ & & & \\
\hline SEC & 2 & $1.11 \times 10^{-4}$ & $1.35 \times 10^{-4}$ & $2.16 \times 10^{-4}$ & $-3.45 \times 10^{-6}$ & $1.86 \times 10^{-5}$ & $2.11 \times 10^{-5}$ & & & \\
\hline SEC & 3 & $2.82 \times 10^{-4}$ & $2.90 \times 10^{-4}$ & $3.39 \times 10^{-4}$ & $1.64 \times 10^{-5}$ & $3.06 \times 10^{-5}$ & $3.57 \times 10^{-5}$ & & & \\
\hline SEC & 4 & $3.29 \times 10^{-4}$ & $2.76 \times 10^{-4}$ & $3.54 \times 10^{-4}$ & $1.99 \times 10^{-6}$ & $2.71 \times 10^{-5}$ & $3.23 \times 10^{-5}$ & & & \\
\hline SMR & 1 & $2.57 \times 10^{-4}$ & $1.37 \times 10^{-4}$ & $1.89 \times 10^{-4}$ & $2.81 \times 10^{-6}$ & $2.50 \times 10^{-5}$ & $2.73 \times 10^{-5}$ & & & \\
\hline SMR & 2 & $6.03 \times 10^{-4}$ & $5.55 \times 10^{-4}$ & $8.84 \times 10^{-4}$ & $3.96 \times 10^{-5}$ & $4.00 \times 10^{-5}$ & $4.48 \times 10^{-5}$ & & & \\
\hline SMR & 3 & $4.92 \times 10^{-4}$ & $3.02 \times 10^{-4}$ & $3.59 \times 10^{-4}$ & $-1.32 \times 10^{-5}$ & $2.94 \times 10^{-5}$ & $3.22 \times 10^{-5}$ & & & \\
\hline SMR & 4 & $4.29 \times 10^{-4}$ & $3.64 \times 10^{-4}$ & $5.74 \times 10^{-4}$ & $9.99 \times 10^{-6}$ & $4.51 \times 10^{-5}$ & $5.07 \times 10^{-5}$ & & & \\
\hline WEE & 1 & $2.46 \times 10^{-4}$ & $2.43 \times 10^{-4}$ & $3.06 \times 10^{-4}$ & $3.92 \times 10^{-6}$ & $2.38 \times 10^{-5}$ & $2.79 \times 10^{-5}$ & & & \\
\hline WEE & 2 & $6.44 \times 10^{-5}$ & $2.46 \times 10^{-4}$ & $2.91 \times 10^{-4}$ & $1.58 \times 10^{-5}$ & $2.26 \times 10^{-5}$ & $2.85 \times 10^{-5}$ & & & \\
\hline WEE & 3 & $2.79 \times 10^{-4}$ & $2.32 \times 10^{-4}$ & $2.99 \times 10^{-4}$ & $2.52 \times 10^{-5}$ & $2.15 \times 10^{-5}$ & $2.86 \times 10^{-5}$ & & & \\
\hline WEE & 4 & $1.50 \times 10^{-4}$ & $8.92 \times 10^{-5}$ & $1.27 \times 10^{-4}$ & $9.32 \times 10^{-6}$ & $1.79 \times 10^{-5}$ & $2.14 \times 10^{-5}$ & & & \\
\hline WFF & 1 & $4.44 \times 10^{-5}$ & $2.56 \times 10^{-4}$ & $3.02 \times 10^{-4}$ & $-1.17 \times 10^{-5}$ & $2.60 \times 10^{-5}$ & $2.80 \times 10^{-5}$ & & & \\
\hline WFF & 2 & $-5.29 \times 10^{-5}$ & $2.37 \times 10^{-4}$ & $2.59 \times 10^{-4}$ & $1.48 \times 10^{-6}$ & $1.95 \times 10^{-5}$ & $2.31 \times 10^{-5}$ & & & \\
\hline WFF & 3 & $1.88 \times 10^{-4}$ & $1.82 \times 10^{-4}$ & $2.28 \times 10^{-4}$ & $7.84 \times 10^{-7}$ & $2.04 \times 10^{-5}$ & $2.31 \times 10^{-5}$ & & & \\
\hline WFF & 4 & $2.70 \times 10^{-4}$ & $1.86 \times 10^{-4}$ & $2.42 \times 10^{-4}$ & $-1.97 \times 10^{-6}$ & $1.99 \times 10^{-5}$ & $2.24 \times 10^{-5}$ & & & \\
\hline WSS & 1 & $1.93 \times 10^{-4}$ & $2.44 \times 10^{-4}$ & $3.01 \times 10^{-4}$ & $-6.25 \times 10^{-7}$ & $2.31 \times 10^{-5}$ & $2.65 \times 10^{-5}$ & & & \\
\hline
\end{tabular}


Waste Isolation Pilot Plant 2001 Site Environmental Report DOE/WIPP 02-2225

Table G.1 - Radionuclide Concentrations $\left(\mathrm{Bq} / \mathrm{m}^{3}\right)$ in Quarterly Composite Air Filters Collected from Locations Surrounding the WIPP Site. See Appendix B for the sampling locations.

\begin{tabular}{|c|c|c|c|c|c|c|c|c|c|c|}
\hline Location & Quarter & {$[R N]^{a}$} & $2 x \operatorname{TU}^{b}$ & $M^{\prime} C^{c}$ & [RN] & 2xTPU & MDC & [RN] & 2xTPU & MDC \\
\hline WSS & 2 & $2.93 \times 10^{-4}$ & $1.84 \times 10^{-4}$ & $2.41 \times 10^{-4}$ & $-3.56 \times 10^{-6}$ & $1.88 \times 10^{-5}$ & $2.13 \times 10^{-5}$ & & & \\
\hline WSS & 3 & $1.84 \times 10^{-4}$ & $2.39 \times 10^{-4}$ & $2.96 \times 10^{-4}$ & $1.85 \times 10^{-5}$ & $1.93 \times 10^{-5}$ & $2.49 \times 10^{-5}$ & & & \\
\hline WSS & 4 & $3.10 \times 10^{-4}$ & $1.24 \times 10^{-4}$ & $1.60 \times 10^{-4}$ & $-2.09 \times 10^{-6}$ & $2.05 \times 10^{-5}$ & $2.32 \times 10^{-5}$ & & & \\
\hline WAB & 1 & $3.07 \times 10^{0}$ & $1.32 \times 10^{0}$ & $1.81 \times 10^{0}$ & $6.70 \times 10^{-2}$ & $1.32 \times 10^{-1}$ & $1.62 \times 10^{-1}$ & & & \\
\hline WAB & 2 & $3.06 \times 10^{0}$ & $2.29 \times 10^{0}$ & $2.70 \times 10^{0}$ & $8.10 \times 10^{-3}$ & $2.28 \times 10^{-1}$ & $2.59 \times 10^{-1}$ & & & \\
\hline WAB & 3 & $3.24 \times 10^{0}$ & $1.57 \times 10^{0}$ & $2.13 \times 10^{0}$ & $-1.03 \times 10^{-1}$ & $2.94 \times 10^{-1}$ & $3.18 \times 10^{-1}$ & & & \\
\hline WAB & 4 & $3.25 \times 10^{0}$ & $2.35 \times 10^{0}$ & $2.77 \times 10^{0}$ & $2.06 \times 10^{-1}$ & $2.36 \times 10^{-1}$ & $2.76 \times 10^{-1}$ & & & \\
\hline Minimum & & $-5.29 \times 10^{-5}$ & $2.37 \times 10^{-4}$ & $1.27 \times 10^{-4}$ & $-1.32 \times 10^{-5}$ & $2.94 \times 10^{-5}$ & $1.98 \times 10^{-5}$ & & & \\
\hline Maximum & & $6.44 \times 10^{-3}$ & $2.46 \times 10^{-4}$ & $8.84 \times 10^{-4}$ & $3.96 \times 10^{-5}$ & $4.00 \times 10^{-5}$ & $5.07 \times 10^{-5}$ & & & \\
\hline \multirow[t]{2}{*}{ Mean } & & $6.90 \times 10^{-4}$ & $3.11 \times 10^{-3}$ & $3.31 \times 10^{-4}$ & $6.32 \times 10^{-6}$ & $2.72 \times 10^{-5}$ & $2.89 \times 10^{-5}$ & & & \\
\hline & & & ${ }^{90} \mathrm{Sr}$ & & & ${ }^{137} \mathrm{Cs}$ & & & & \\
\hline CBD & 1 & $2.55 \times 10^{-6}$ & $4.14 \times 10^{-6}$ & $6.99 \times 10^{-6}$ & $3.70 \times 10^{-5}$ & $3.70 \times 10^{-5}$ & $4.00 \times 10^{-5}$ & & & \\
\hline CBD & 2 & $-5.00 \times 10^{-6}$ & $5.11 \times 10^{-6}$ & $8.81 \times 10^{-6}$ & $-3.81 \times 10^{-5}$ & $3.28 \times 10^{-5}$ & $3.32 \times 10^{-5}$ & & & \\
\hline CBD & 3 & $8.03 \times 10^{-8}$ & $4.66 \times 10^{-6}$ & $7.77 \times 10^{-6}$ & $1.47 \times 10^{-5}$ & $2.13 \times 10^{-5}$ & $2.50 \times 10^{-5}$ & & & \\
\hline CBD & 4 & $5.88 \times 10^{-7}$ & $4.55 \times 10^{-6}$ & $7.81 \times 10^{-6}$ & $1.61 \times 10^{-6}$ & $1.61 \times 10^{-5}$ & $1.91 \times 10^{-5}$ & & & \\
\hline MLR & 1 & $5.33 \times 10^{-6}$ & $4.88 \times 10^{-6}$ & $8.03 \times 10^{-6}$ & $-9.66 \times 10^{-6}$ & $1.54 \times 10^{-5}$ & $1.69 \times 10^{-5}$ & & & \\
\hline MLR & 2 & $-3.23 \times 10^{-6}$ & $5.33 \times 10^{-6}$ & $9.03 \times 10^{-6}$ & $-1.28 \times 10^{-5}$ & $2.34 \times 10^{-5}$ & $2.49 \times 10^{-5}$ & & & \\
\hline MLR & 3 & $1.37 \times 10^{-7}$ & $4.88 \times 10^{-6}$ & $8.18 \times 10^{-6}$ & $-9.40 \times 10^{-6}$ & $1.75 \times 10^{-5}$ & $1.95 \times 10^{-5}$ & & & \\
\hline MLR & 4 & $3.43 \times 10^{-6}$ & $5.40 \times 10^{-6}$ & $9.10 \times 10^{-6}$ & $-5.59 \times 10^{-6}$ & $2.46 \times 10^{-5}$ & $2.81 \times 10^{-5}$ & & & \\
\hline SEC & 1 & $6.33 \times 10^{-6}$ & $4.40 \times 10^{-6}$ & $7.14 \times 10^{-6}$ & $1.44 \times 10^{-5}$ & $3.65 \times 10^{-5}$ & $3.92 \times 10^{-5}$ & & & \\
\hline SEC & 2 & $-4.70 \times 10^{-6}$ & $5.14 \times 10^{-6}$ & $8.81 \times 10^{-6}$ & $4.77 \times 10^{-6}$ & $1.42 \times 10^{-5}$ & $1.71 \times 10^{-5}$ & & & \\
\hline SEC & 3 & $-2.55 \times 10^{-6}$ & $4.29 \times 10^{-6}$ & $7.36 \times 10^{-6}$ & $-1.52 \times 10^{-5}$ & $2.97 \times 10^{-5}$ & $3.26 \times 10^{-5}$ & & & \\
\hline SEC & 4 & $3.92 \times 10^{-6}$ & $5.77 \times 10^{-6}$ & $9.69 \times 10^{-6}$ & $-4.70 \times 10^{-6}$ & $2.50 \times 10^{-5}$ & $2.76 \times 10^{-5}$ & & & \\
\hline SMR & 1 & $7.77 \times 10^{-7}$ & $4.96 \times 10^{-6}$ & $8.55 \times 10^{-6}$ & $-2.07 \times 10^{-6}$ & $2.29 \times 10^{-5}$ & $2.57 \times 10^{-5}$ & & & \\
\hline SMR & 2 & $-1.58 \times 10^{-6}$ & $8.47 \times 10^{-6}$ & $1.44 \times 10^{-5}$ & $3.66 \times 10^{-5}$ & $3.89 \times 10^{-5}$ & $4.55 \times 10^{-5}$ & & & \\
\hline SMR & 3 & $-3.02 \times 10^{-6}$ & $4.29 \times 10^{-6}$ & $7.40 \times 10^{-6}$ & $-2.91 \times 10^{-5}$ & $3.26 \times 10^{-5}$ & $3.39 \times 10^{-5}$ & & & \\
\hline
\end{tabular}


Waste Isolation Pilot Plant 2001 Site Environmental Report DOE/WIPP 02-2225

Table G.1 - Radionuclide Concentrations $\left(\mathrm{Bq} / \mathrm{m}^{3}\right)$ in Quarterly Composite Air Filters Collected from Locations Surrounding the WIPP Site. See Appendix B for the sampling locations.

\begin{tabular}{|c|c|c|c|c|c|c|c|c|c|c|}
\hline Location & Quarter & [RN] $^{\mathrm{a}}$ & $2 x T^{\prime b} U^{b}$ & $M^{\prime} C^{c}$ & [RN] & $2 x T P U$ & MDC & [RN] & $2 x T P U$ & MDC \\
\hline SMR & 4 & $2.21 \times 10^{-6}$ & $6.96 \times 10^{-6}$ & $1.19 \times 10^{-5}$ & $-3.28 \times 10^{-5}$ & $4.63 \times 10^{-5}$ & $4.88 \times 10^{-5}$ & & & \\
\hline WEE & 1 & $4.51 \times 10^{-6}$ & $4.51 \times 10^{-6}$ & $7.47 \times 10^{-6}$ & $5.00 \times 10^{-6}$ & $2.11 \times 10^{-5}$ & $2.41 \times 10^{-5}$ & & & \\
\hline WEE & 2 & $-7.47 \times 10^{-6}$ & $5.66 \times 10^{-6}$ & $9.84 \times 10^{-6}$ & $9.14 \times 10^{-6}$ & $2.16 \times 10^{-5}$ & $2.49 \times 10^{-5}$ & & & \\
\hline WEE & 3 & $7.92 \times 10^{-8}$ & $5.11 \times 10^{-6}$ & $8.55 \times 10^{-6}$ & $1.56 \times 10^{-5}$ & $2.21 \times 10^{-5}$ & $2.59 \times 10^{-5}$ & & & \\
\hline WEE & 4 & $-9.21 \times 10^{-7}$ & $4.44 \times 10^{-6}$ & $7.73 \times 10^{-6}$ & $9.10 \times 10^{-6}$ & $1.46 \times 10^{-5}$ & $1.78 \times 10^{-5}$ & & & \\
\hline WFF & 1 & $5.40 \times 10^{-6}$ & $5.03 \times 10^{-6}$ & $8.29 \times 10^{-6}$ & $-6.33 \times 10^{-6}$ & $2.32 \times 10^{-5}$ & $2.52 \times 10^{-5}$ & & & \\
\hline WFF & 2 & $-3.33 \times 10^{-6}$ & $6.70 \times 10^{-6}$ & $1.12 \times 10^{-5}$ & $-1.01 \times 10^{-5}$ & $1.85 \times 10^{-5}$ & $2.06 \times 10^{-5}$ & & & \\
\hline WFF & 3 & $-2.80 \times 10^{-7}$ & $5.40 \times 10^{-6}$ & $9.07 \times 10^{-6}$ & $-3.10 \times 10^{-6}$ & $1.52 \times 10^{-5}$ & $1.75 \times 10^{-5}$ & & & \\
\hline WFF & 4 & $-1.61 \times 10^{-7}$ & $4.59 \times 10^{-6}$ & $7.96 \times 10^{-6}$ & $7.59 \times 10^{-6}$ & $1.50 \times 10^{-5}$ & $1.82 \times 10^{-5}$ & & & \\
\hline WSS & 1 & $5.62 \times 10^{-6}$ & $4.51 \times 10^{-6}$ & $7.36 \times 10^{-6}$ & $-7.59 \times 10^{-6}$ & $2.13 \times 10^{-5}$ & $2.31 \times 10^{-5}$ & & & \\
\hline WSS & 2 & $-4.11 \times 10^{-6}$ & $5.74 \times 10^{-6}$ & $9.73 \times 10^{-6}$ & $8.10 \times 10^{-7}$ & $1.48 \times 10^{-5}$ & $1.76 \times 10^{-5}$ & & & \\
\hline WSS & 3 & $-8.36 \times 10^{-7}$ & $5.55 \times 10^{-6}$ & $9.40 \times 10^{-6}$ & $-4.74 \times 10^{-6}$ & $2.09 \times 10^{-5}$ & $2.31 \times 10^{-5}$ & & & \\
\hline WSS & 4 & $1.84 \times 10^{-6}$ & $4.66 \times 10^{-6}$ & $7.88 \times 10^{-6}$ & $2.36 \times 10^{-6}$ & $1.58 \times 10^{-5}$ & $1.88 \times 10^{-5}$ & & & \\
\hline WAB & 1 & $4.63 \times 10^{-3}$ & $3.27 \times 10^{-2}$ & $5.62 \times 10^{-2}$ & $-4.96 \times 10^{-2}$ & $1.15 \times 10^{-1}$ & $1.30 \times 10^{-1}$ & & & \\
\hline WAB & 2 & $-2.22 \times 10^{-2}$ & $3.74 \times 10^{-2}$ & $6.33 \times 10^{-2}$ & $-3.10 \times 10^{-2}$ & $2.24 \times 10^{-1}$ & $2.53 \times 10^{-1}$ & & & \\
\hline WAB & 3 & $-2.12 \times 10^{-2}$ & $3.35 \times 10^{-2}$ & $5.74 \times 10^{-2}$ & $5.62 \times 10^{-2}$ & $2.11 \times 10^{-1}$ & $2.53 \times 10^{-1}$ & & & \\
\hline WAB & 4 & $1.08 \times 10^{-2}$ & $3.16 \times 10^{-2}$ & $5.37 \times 10^{-2}$ & $-3.40 \times 10^{-1}$ & $2.51 \times 10^{-1}$ & $2.50 \times 10^{-1}$ & & & \\
\hline$\overline{\text { Minimum }}$ & & $-7.47 \times 10^{-6}$ & $5.66 \times 10^{-6}$ & $6.99 \times 10^{-6}$ & $-3.81 \times 10^{-5}$ & $3.28 \times 10^{-5}$ & $1.69 \times 10^{-5}$ & & & \\
\hline Maximum & & $6.33 \times 10^{-6}$ & $4.40 \times 10^{-6}$ & $1.44 \times 10^{-5}$ & $3.70 \times 10^{-5}$ & $3.70 \times 10^{-5}$ & $4.88 \times 10^{-5}$ & & & \\
\hline Mean & & $2.01 \times 10^{-7}$ & $7.08 \times 10^{-6}$ & $8.77 \times 10^{-6}$ & $-7.71 \times 10^{-7}$ & $3.35 \times 10^{-5}$ & $2.62 \times 10^{-5}$ & & & \\
\hline \multicolumn{11}{|c|}{ a Radionuclide Concentration } \\
\hline \multicolumn{11}{|c|}{ b Total Propagated Uncertainty } \\
\hline${ }^{\mathrm{C}}$ Minimum & Detectable & entration & & & & & & & & \\
\hline
\end{tabular}




\section{Appendix $\mathrm{H}$ \\ Authors and Contributors}

Executive Summary

Wesley Nance

Irene Quintana

Stewart Jones

Chapter 1 Introduction

Wesley Nance

Irene Quintana

Stewart Jones

Chapter 2 Environmental Program Information

Don Gilbert

Stewart Jones

Doug Lynn

Roger Simmons

Chapter 3 Environmental Compliance

Cindy Anderson

Rick Chavez

Koreen Guillermo

Jim Hollen

Patty Hollen

Steve Kouba

Doug Lynn

Irene Quintana

Cindy Woodin

Chapter 4 Environmental

Radiological Program Information

Mansour Akbarzadeh

Don Gilbert

Irene Quintana

Doug C. Lynn

Wesley Nance

Aurelio Rivas

Roger Simmons

Ginny Waymire
Chapter 5 Environmental

Nonradiological Program Information

Wesley Boatwright

Rey Carrasco

Mark Crawley

Oscar Garcia

Doug Lynn

Wesley Nance

Steve Offner

Roger Simmons

Chapter 6 Groundwater Monitoring

Melvin Balderrama

Mark Crawley

Butch Daszczyszak

William Foster

Irene Quintana

Doug Lynn

Ron Richardson

\section{Chapter 7 Radiological Dose}

Assessment

Marsha Beekman

Linda Frank-Supka

Chapter 8 Quality Assurance

Irene Quintana

Dave Weidenhoeft

\section{Appendices}

Wesley Nance

Irene Quintana

Administrative Support

Mak Walker

Luann Underwood

Text and Data Compilation

Vivian Allen 
This page intentionally left blank 